W

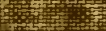
(1)

(x)

\title{
DEPTHS OF THE OCEAN
} C:-10

ye
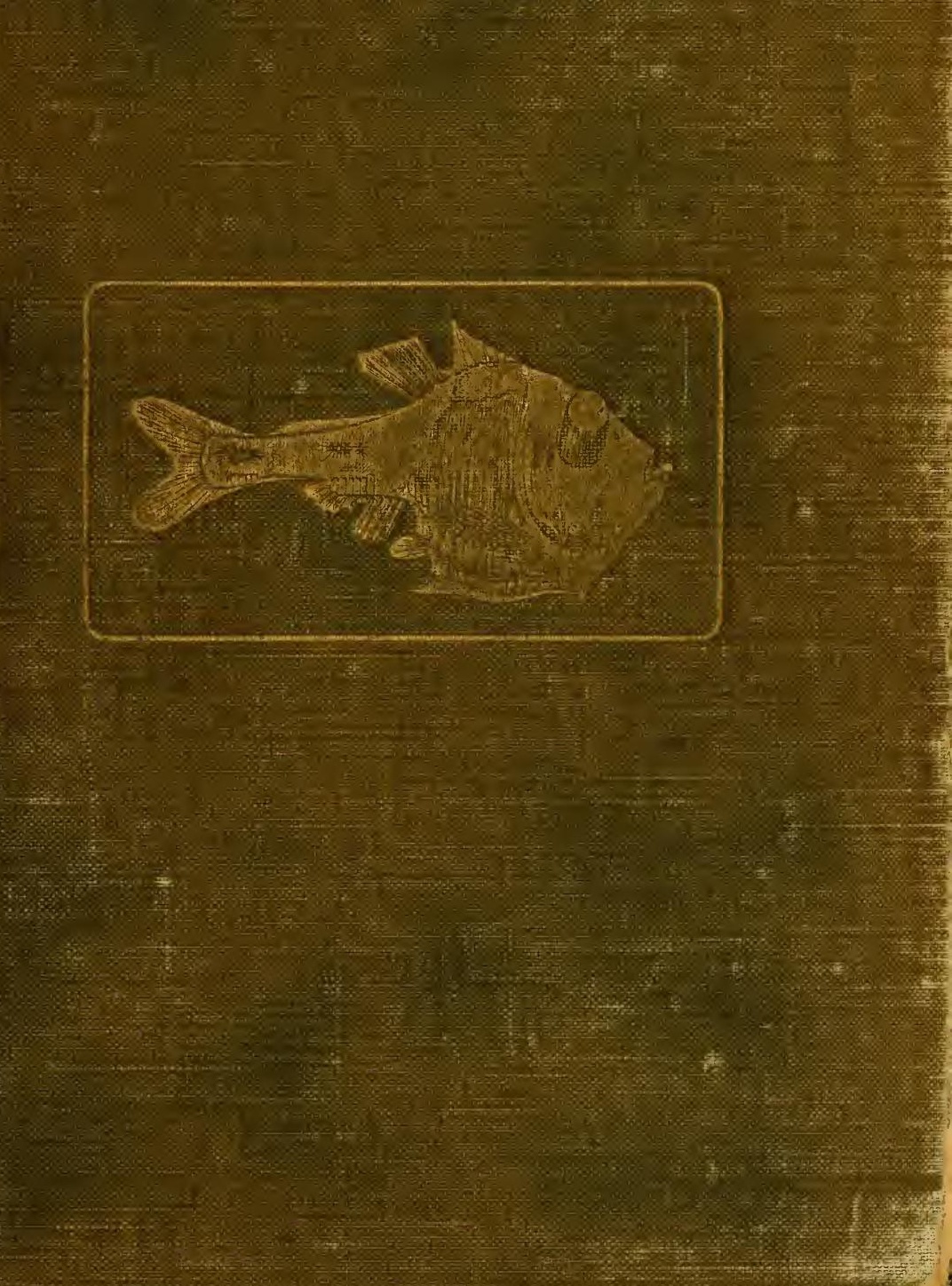


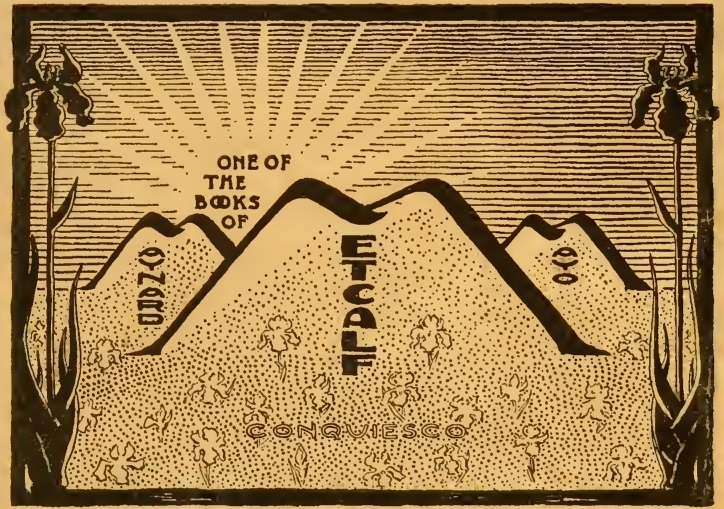


Maynard in. mutealf

furtin Q 



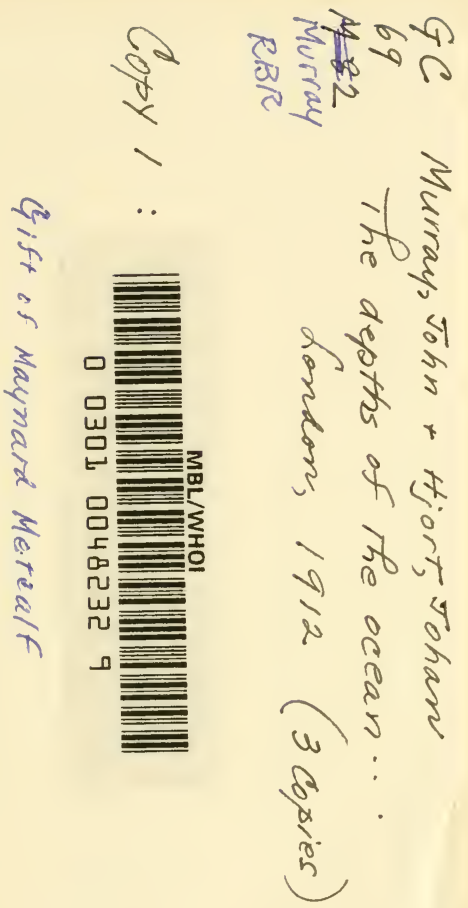




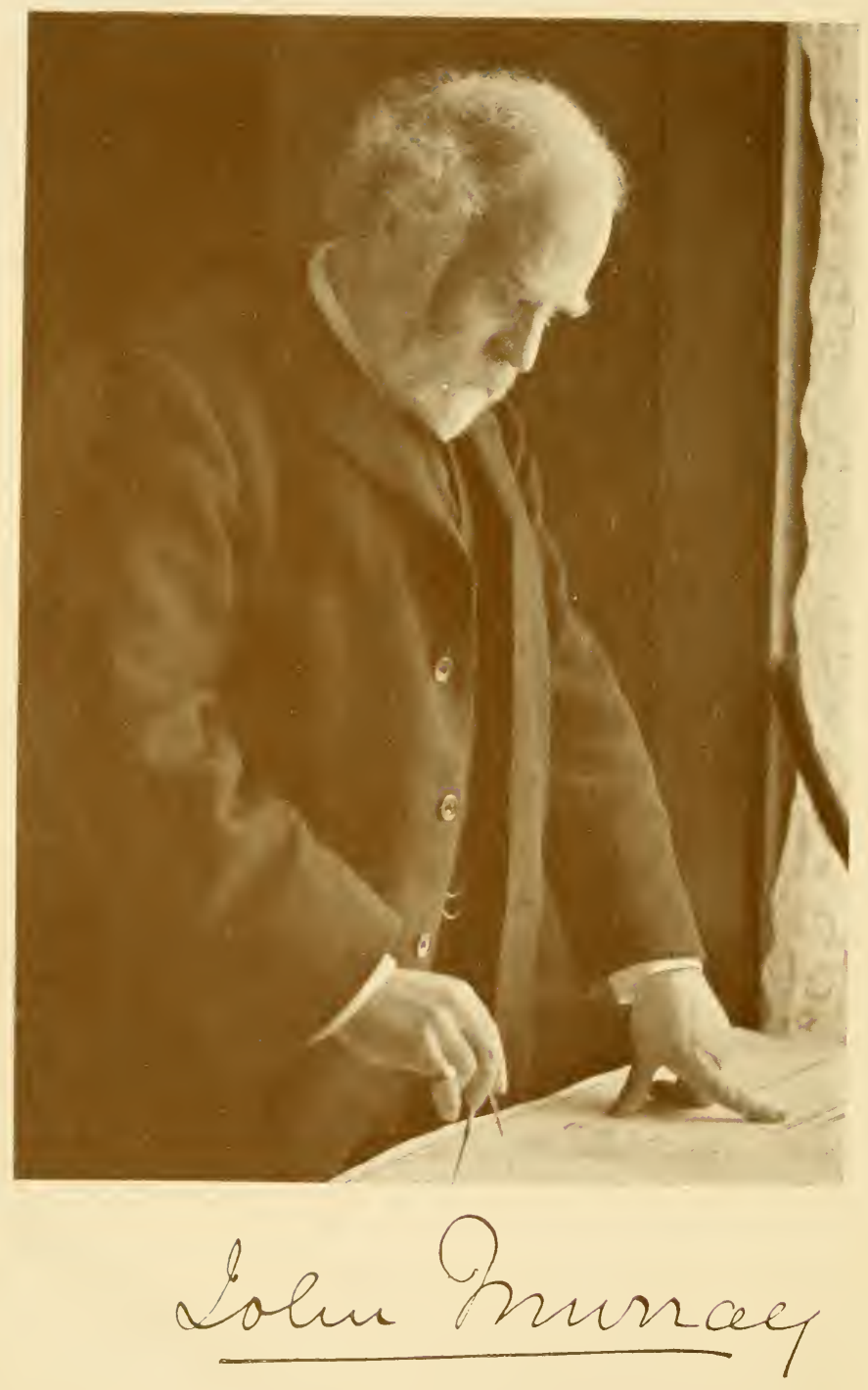


THE DEPTHS OF THE OCEAN 


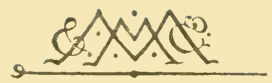
M.ACMILLAN AND CO., LIMITED LONDON - BOMBAY + CALCLTTA MELBOURNE

THE MACMILLAN CONPANY

NEW YORK - BOSTON - CHICAGO DALLAS - SAN FRANCISCO

THE MACMILLAN CO. OF CANADA, LTD. TORONTO 
THE

\section{LINARD IS. AETOLLF,}

\section{DEPTHS OF THE OCEAN}

A GENERAL ACCOUNT

OF THE MODERN SCIENCE OF OCEANOGRAPHY

BASED LARGELY ON THE SCIENTIFIC RESEARCHES

OF THE NORWEGIAN STEAMER

MICHAEL SARS

IN THE NORTH ATLANTIC

BY

Sir JOHN MURRAY, K.C.B., F.R.S., etc. of THE 'CHALLENGer' EXPEDition

AND

DR. JOHAN HJORT

DIRECTOR OF NORWEGIAN FISHERIES

WITH CONTRIBUTIONS FROM

Professor A. APPEllöf, Professor H. H. GRAN AND Dr. B. HELLAND-HANSEN

MACMILLAN AND CO,, LIMITED ST. MARTIN'S STREET, LONDON 
COPYRIGHT 


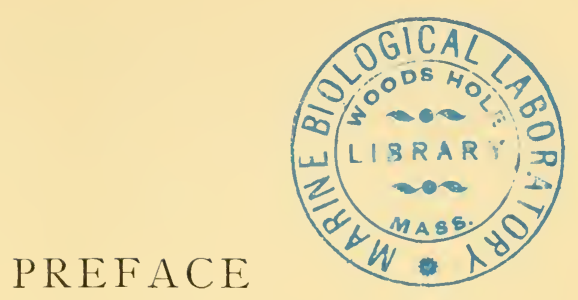

Aт the International Congress for the Exploration of the Sea held on the invitation of the Swedish Government in Stockholm in 1899 , Sir John Murray was the chief British delegate, and acted as president of the physical and chemical section, which drew up a programme of work for the proposed investigations in the North Sea and in the Norwegian Sea. Although his official connection with these marine researches came to an end with the close of the first Congress, it is well known that he has followed with great interest all the proceedings of the International Council during the past ten or twelve years.

In the year 1909 he chanced to visit Copenhagen at a time when one of the annual meetings of the Council was going on, and was invited by the members to take part in some of their deliberations. In the course of the conversations which followed he expressed the opinion that systematic observations in the Atlantic might throw much light on some of the problems then being studied in our more northern seas.

Subsequently Sir John Murray wrote to me that if the Norwegian Government would lend the "Michael Sars" and her scientific staff for a four months' summer cruise in the North Atlantic, he would pay all the other expenses.

When this proposal was laid before the Norwegian Government it was favourably received, and within a few weeks a satisfactory financial agreement was drawn up and adopted. My scientific colleagues, Professor Gran, Dr. Helland-Hansen, Mr. E. Koefoed, and Captain Thor Iversen, who had long been 
associated with me in oceanographical investigations in the Norwegian Sea, likewise received the proposal with enthusiasm. A large part of the winter of 1909-10 was spent in making the necessary rearrangements on board the ship, in the selection and installation of new apparatus and instruments, and in choosing the routes where we might expect to get the most interesting results.

By the Ist of April 1910 the ship was fully equipped and ready for sea. The first port of call was Plymouth, where Sir John Murray embarked, and the last piece of apparatusa large centrifuge-was installed on board. After being hospitably entertained by scientific men in London and Plymouth, we sailed on the 7 th of April for the south-west of Ireland, where it was arranged that we should occupy our first observing station. The ship worked down the western coasts of Europe as far as the Canaries, then proceeded across the Atlantic, by way of the Azores, to Newfoundland, afterwards re-crossing from Newfoundland to the coast of Ireland, and returned to Bergen by way of the Faroe Channel. About I 20 observing stations were established, and the expedition was in all respects successful.

It was agreed that the zoological and all other collections and observations made during the cruise should be sent to Bergen, Sir John Murray generously agreeing to provide $£_{5}$ oo to enable the collections to be sorted out and arranged for study by specialists.

It was further arranged that a general account of the cruise and of the results of the observations should be published as soon as possible after the return of the expedition, and this volume has accordingly been prepared. Its main object is to indicate the most important results of the voyage in so far as these can be stated at the present time, although the biological collections and the physical observations have as yet only been examined in a preliminary way. In preparing the various 
chapters the previous investigations of the "Michael Sars" in the North Sea and in the Norwegian Sea generally have been taken into consideration, in order to compare the physical and biological conditions prevailing in northern waters with those in the Atlantic. In this way it is hoped that the book as a whole will present the student with a fairly complete epitome of recent advances in the modern science of oceanography, even though it has proved impossible to give a complete review of the literature of the subject.

The historical chapter and the chapter on the Depths and Deposits of the Ocean have been prepared by Sir John Murray; that on Physical Oceanography by Dr. Helland-Hansen; that on Phytoplankton by Professor Gran ; and that on the Bottom Fauna by Professor Appellöf, while the chapters dealing with the equipment of the ship, the working of the gear, the narrative of the cruise, the fishes from the sea-bottom, the pelagic animals, and general biology have been written by myself.

In the examination of the zoological collections I have received most valuable assistance from Mr. James Grieg, Mr. Einar Koefoed (who took part in the expedition and also in the special examination of the fishes), Mr. Einar Lea, and Mr. Oscar Sund. All the original drawings have been made by Mr. Thorolv Rasmussen, who also took part in the cruise, and was continually engaged in making drawings and sketches on board ship. To all these gentlemen I acknowledge my indebtedness.

The biological collections have been distributed to specialists in different parts of the world, and the following have sent me preliminary reports on their results, which I have been able to use in this book:-

Mr. Paul Bjerkan, Bergen;

Dr. Kristine Bonnevie, Christiania ;

Dr. August Brinkmann, Bergen ;

Dr. Hjalmar Broch, Trondhjem ; 
Professor Carl Chun, Leipzig ;

Mr. C. Dons, Tromsö;

Dr. P. P. C. Hoek, Haarlem;

Dr. O. Nordgaard, Trondhjem ;

Professor G. O. Sars, Christiania ;

Professor R. Woltereck, Leipzig.

Sir John Murray's secretary, Mr. James Chumley, has given us most valuable assistance by correcting the English manuscript and taking care of all printing arrangements. Sir John Murray wishes also to acknowledge the co-operation of Dr. Caspari and the other assistants in the "Challenger" office in correcting proofs and preparing the indexes of this book.

The authorities of the Bergen Museum have undertaken to publish a detailed account of the voyage and of the physical and biological observations, in a series of quarto volumes which will be issued from the press at intervals during the next few years. These more detailed reports will undoubtedly form valuable contributions to the science of oceanography. I hope also that this general account will be of use to those engaged in the study of oceanography, and that it may lead to further investigations in the North Atlantic-that wonderful ocean bordered by nearly all the seafaring countries. As will be seen from several of the following chapters, Sir John Murray's well-known scientific views and his original ideas have been of great value to this expedition. I wish therefore to express my indebtedness to Sir John Murray, not only for the opportunity of engaging in this interesting Atlantic cruise, but also for his kindness in giving the benefit of his great experience to the advancement of the undertaking.

JOHAN HJORT. 


\section{CONTENTS}

TABLE I. FOR CONVERTING METRES INTO FATHOIS MaG

" II. For CONVerting Degrees Fahrenheit into Degrees

Centigrade . . . . . . . xiv

,. III. Showing Mean Temperature at Various Depths for the Whole Ocean . . . . . Xvi

" IV. Showing Positions of "Michael Sars" Stations , xvii

CHAPTER I

A Brief Historical Review of Oceanographical Investigations

\section{CHAPTER II}

The Ship and its Equiphent

CHAPTER III

The WORK ANd Cruises of The "Michael Sars"

\section{CHAPTER IV}

The Depths and Deposits of the Ocean .

CHAPTER V

Physical Oceanography

ix 


\section{CHAPTER VI}

Pelagic Plant Life

\section{CHAPTER VII}

FISHES FROM THE SEA-BOTTOM

\section{CHAPTER VIII}

Invertebrate Bottom Fauna of the Norwegian Sea ani North Atlantic .

\section{CHAPTER IX}

Pelagic Animal Life.

\section{CHAPTER X}

General Biologi

\section{INDEXES}

INdex OF Proper NAMES

Index of Genera AND Species

General Index 


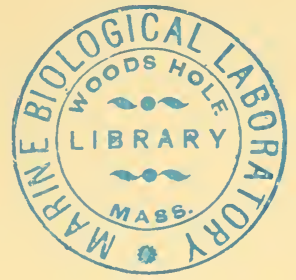

\section{MAPS AND PLATES}

Map I. Reproduction of Lieut. Maury's Map of the North Atlantic, I $S_{54}$

" II. Bathymetrical Chart of the Oceans showing the "Deeps," according to Sir John Nurray . . . . IV

" III. Depths of the North Atlantic compiled from the latest sources, IgII . . . . . . . IV

" IV. Deposits of the North Atlantic, after Sir John Murray . IV

Plate I. Cyclothone . . . . . . . . . $\mathrm{x}$

" II. Argyropelecus and Gonostoma . . . . . $\mathrm{x}$

" III. Red-coloured Shrimps . . . . . . $\mathrm{x}$

" IV. Flying-Fish and Pilot-Fish . . . . . . x

" V. Sargasso Fish . . . . . . . $\mathrm{x}$

"VI. Sargasso Crabs . . . . . . . . $\mathrm{x}$

" VII. Coast Fishes from the bottom . . . . . $\mathrm{x}$

"VIII. Deep-Sea Fishes from the bottom . . . . $\mathrm{x}$

" IX. Bathytroctes . . . . . . . X 

I. Table for Converting Metres into Fathoms

\begin{tabular}{|c|c|c|c|}
\hline Metres. & Fathoms. & Metres. & Fathons. \\
\hline I & 0.55 & 200 & 109.36 \\
\hline 2 & 1.09 & 300 & 164.04 \\
\hline 3 & 1.64 & 400 & 218.73 \\
\hline 4 & 2.19 & 500 & $273.4 \mathrm{I}$ \\
\hline 5 & 2.73 & 600 & 328.09 \\
\hline 6 & 3.28 & 700 & 382.77 \\
\hline 7 & $3.8_{3}$ & 800 & $437 \cdot 45$ \\
\hline 8 & $4 \cdot 37$ & 900 & $49^{2.1} 3$ \\
\hline 9 & 4.92 & $\mathrm{I}, \infty 00$ & 546.82 \\
\hline IO & $5 \cdot 47$ & 2,000 & $i, 093.63$ \\
\hline 20 & 10.94 & 3,000 & $1,640.45$ \\
\hline 30 & 16.40 & $4, \infty 00$ & $2,187.27$ \\
\hline 40 & $2 \mathrm{I} .87$ & $5, \infty 00$ & $2,734.08$ \\
\hline 50 & $27 \cdot 34$ & $6, \infty 00$ & $3,280.90$ \\
\hline 60 & 32.81 & $7, \infty 00$ & $3,827.72$ \\
\hline 70 & $3^{8.28}$ & 8,000 & $4,374.53$ \\
\hline So & +3.75 & $9, \infty 00$ & $4,92 \mathrm{I} \cdot 35$ \\
\hline 90 & $49.2 \mathrm{I}$ & 10,000 & $5,468.16$ \\
\hline 100 & 54.68 & & \\
\hline
\end{tabular}


II. Table for Converting Degrees of Fahrenheit into Degrees of Centigrade

\begin{tabular}{|c|c|c|c|c|c|c|c|c|c|}
\hline${ }^{\circ} \mathrm{F}$. & ${ }^{\circ} \mathrm{C}$. & ${ }^{\circ} \mathrm{F}$. & ${ }^{\circ} \mathrm{C}$. & ${ }^{\circ} \mathrm{F}$. & ${ }^{\circ} \mathrm{C}$. & ${ }^{\circ} \mathrm{F}$. & ${ }^{\circ} \mathrm{C}$. & ${ }^{\circ} \mathrm{F}$. & ${ }^{\circ} \mathrm{C}$. \\
\hline 80.0 & 26.67 & $75 \cdot 5$ & 24.17 & 71.0 & 21.67 & 66.5 & I9. I 7 & 62.0 & I 6.67 \\
\hline 79.9 & $26.6 \mathrm{I}$ & 75.4 & 24.1 I & 70.9 & $2 \mathrm{I} .6 \mathrm{I}$ & 66.4 & I9. I I & 61.9 & I6.6I \\
\hline 79.8 & $26.5^{6}$ & $75 \cdot 3$ & 24.05 & 70.8 & 21.56 & 66.3 & I 9.05 & 61.8 & I $6.5^{6}$ \\
\hline 79.7 & $26.5^{\circ}$ & 75.2 & 24.00 & 70.7 & 21.50 & 66.2 & 19.00 & 61.7 & 16.50 \\
\hline 79.6 & 26.44 & $75 . \mathrm{I}$ & 23.95 & 70.6 & $2 \mathrm{I} .44$ & 66. I & I 8.95 & 61.6 & I 6.44 \\
\hline $79 \cdot 5$ & 26.39 & 75.0 & 23.89 & 70.5 & 21.39 & 66.0 & I 8.89 & 61.5 & I 6.39 \\
\hline $79 \cdot 4$ & 26.33 & 74.9 & 23.83 & 70.4 & 21.33 & 65.9 & I 8.83 & $6 \mathrm{I} .4$ & 16.33 \\
\hline $79 \cdot 3$ & 26.28 & 74.8 & 23.78 & 70.3 & 21.28 & 65.8 & I 8.78 & $61 \cdot 3$ & 16.28 \\
\hline 79.2 & 26.22 & 74.7 & 23.72 & 70.2 & 21.22 & 65.7 & 18.72 & 61.2 & I6.22 \\
\hline 79. I & 26. I 7 & 74.6 & 23.67 & 70.1 & $2 \mathrm{I} . \mathrm{I} 7$ & 65.6 & I 8.67 & 6I.I & I6. I 7 \\
\hline 79.0 & 26. I I & 74.5 & $23.6 \mathrm{I}$ & 70.0 & 2 I. I I & 65.5 & I 8.6 I & 61.0 & I6. I I \\
\hline 78.9 & 26.05 & $74 \cdot 4$ & $23.5^{6}$ & 69.9 & 21.05 & 65.4 & I $8.5^{6}$ & 60.9 & I 6.05 \\
\hline 78.8 & 26.00 & $74 \cdot 3$ & 23.50 & 69.8 & 21.00 & 65.3 & $18.5^{\circ}$ & 60.8 & I 6.00 \\
\hline 78.7 & 25.95 & 74.2 & 23.44 & 69.7 & 20.95 & 65.2 & 18.44 & 60.7 & I 5.95 \\
\hline 78.6 & 25.89 & 74.1 & 23.39 & 69.6 & 20.89 & 65.1 & I 8.39 & 60.6 & 15.89 \\
\hline 78.5 & 25.83 & 74.0 & 23.33 & 69.5 & 20.83 & 65.0 & I 8.33 & 60.5 & 15.83 \\
\hline 78.4 & 25.78 & 73.9 & 23.28 & 69.4 & 20.78 & 64.9 & I 8.28 & 60.4 & I 5.78 \\
\hline 78.3 & 25.72 & 73.8 & 23.22 & 69.3 & 20.72 & 64.8 & 18.22 & 60.3 & 15.72 \\
\hline 78.2 & 25.67 & 73.7 & 23.17 & 69.2 & 20.67 & 64.7 & I 8.17 & 60.2 & 15.67 \\
\hline 78.1 & $25.6 \mathrm{I}$ & 73.6 & 23.1 I & 69.1 & $20.6 \mathrm{I}$ & 64.6 & I 8. I I & 6o. I & $15.6 \mathrm{I}$ \\
\hline 78.0 & $25 \cdot 5^{6}$ & $73 \cdot 5$ & 23.05 & 69.0 & $20.5^{6}$ & 64.5 & I 8.05 & 60.0 & I $5.5^{6}$ \\
\hline 77.9 & 25.50 & 73.4 & 23.00 & 68.9 & 20.50 & 64.4 & I 8.00 & 59.9 & I 5.50 \\
\hline 77.8 & 25.44 & $73 \cdot 3$ & 22.95 & 68.8 & 20.44 & $64 \cdot 3$ & 17.95 & 59.8 & I 5.44 \\
\hline 77.7 & $25 \cdot 39$ & 73.2 & 22.89 & 68.7 & 20.39 & 64.2 & I 7.89 & 59.7 & I 5.39 \\
\hline 77.6 & 25.33 & 73.1 & 22.83 & 68.6 & 20.33 & 64.1 & 17.83 & 59.6 & I 5.33 \\
\hline $77 \cdot 5$ & 25.28 & 73.0 & 22.78 & 68.5 & 20.28 & 64.0 & 17.78 & 59.5 & 15.28 \\
\hline $77 \cdot 4$ & 25.22 & 72.9 & 22.72 & 68.4 & 20.22 & 63.9 & $17.7^{2}$ & 59.4 & I 5.22 \\
\hline $77 \cdot 3$ & 25.17 & 72.8 & 22.67 & 68.3 & 20.17 & 63.8 & 17.67 & 59.3 & I 5.17 \\
\hline 77.2 & 25 . I I & 72.7 & $22.6 \mathrm{I}$ & 68.2 & 20. I I & 63.7 & I $7.6 \mathrm{I}$ & 59.2 & I $5 . \mathrm{I} \mathrm{I}$ \\
\hline 77.1 & 25.05 & 72.6 & 22.56 & 68. I & 20.05 & 63.6 & 17.56 & 59.1 & 15.05 \\
\hline 77.0 & 25.00 & 72.5 & 22.50 & 68.0 & 20.00 & 63.5 & 17.50 & 59.0 & I 5.00 \\
\hline 76.9 & 24.95 & 72.4 & 22.44 & 67.9 & 19.95 & $63 \cdot 4$ & I 7.44 & 58.9 & I 4.95 \\
\hline 76.8 & 24.89 & 72.3 & 22.39 & 67.8 & 19.89 & 63.3 & I 7.39 & 58.8 & I 4.89 \\
\hline 76.7 & 24.83 & 72.2 & 22.33 & 67.7 & 19.83 & 63.2 & 17.33 & 58.7 & I $4.8_{3}$ \\
\hline 76.6 & 24.78 & 72.1 & 22.28 & 67.6 & 19.78 & 63.1 & I 7.28 & $5^{8.6}$ & 14.78 \\
\hline 76.5 & $24 \cdot 72$ & 72.0 & 22.22 & $67 \cdot 5$ & 19.72 & 63.0 & 17.22 & 58.5 & 14.72 \\
\hline 76.4 & 24.67 & 71.9 & 22.17 & 67.4 & 19.67 & 62.9 & I 7.17 & $5^{8.4}$ & 14.67 \\
\hline 76.3 & $24.6 \mathrm{I}$ & 71.8 & 22. I I & $67 \cdot 3$ & $19.6 \mathrm{I}$ & 62.8 & I 7.11 & $5^{8.3}$ & $14.6 \mathrm{I}$ \\
\hline 76.2 & $24 \cdot 5^{6}$ & 71.7 & 22.05 & 67.2 & I9. $5^{6}$ & 62.7 & 17.05 & $5^{8.2}$ & I $4.5^{6}$ \\
\hline 76.1 & 24.50 & 71.6 & 22.00 & $67 \cdot 1$ & 19.50 & 62.6 & 17.00 & $58 . \mathrm{I}$ & 14.50 \\
\hline 76.0 & 24.44 & 71.5 & 21.95 & 67.0 & 19.44 & 62.5 & I 6.95 & 58.0 & I 4.44 \\
\hline 75.9 & $24 \cdot 39$ & 71.4 & 21.89 & 66.9 & I 9.39 & 62.4 & I 6.89 & 57.9 & I 4.39 \\
\hline 75.8 & 24.33 & 71.3 & $21.8_{3}$ & 66.8 & 19.33 & 62.3 & $16.8_{3}$ & 57.8 & 14.33 \\
\hline 75.7 & 24.28 & 71.2 & 21.78 & 66.7 & 19.28 & 62.2 & I 6.78 & 57.7 & I 4.28 \\
\hline 75.6 & 24.22 & 71.1 & 21.72 & 66.6 & 19.22 & 62.I & 16.72 & 57.6 & 14.22 \\
\hline
\end{tabular}


II. Table For Converting Degrees of Fahrenheit into Degrees of Centigrade-Continued

\begin{tabular}{|c|c|c|c|c|c|c|c|c|c|}
\hline${ }^{\circ} \mathrm{F}$. & ${ }^{\circ} \mathrm{C}$. & ${ }^{\circ} \mathrm{F}$. & ${ }^{\circ} \mathrm{C}$. & ${ }^{\circ} \mathrm{F}$. & ${ }^{\circ} \mathrm{C}$. & ${ }^{\circ} \mathrm{F}$. & ${ }^{\circ} \mathrm{C}$. & ${ }^{\circ} \mathrm{F}$. & ${ }^{\circ} \mathrm{C}$. \\
\hline 57.5 & I 4.17 & 52.9 & 11.61 & 48.3 & 9.05 & 43.7 & $6.5^{\circ}$ & $39 . \mathrm{I}$ & 3.95 \\
\hline $57 \cdot 4$ & I4. I I & 52.8 & I I. 56 & 48.2 & 9.00 & 43.6 & 6.44 & 39.0 & 3.89 \\
\hline $57 \cdot 3$ & 14.05 & 52.7 & II. $5^{\circ}$ & 48.1 & 8.95 & 43.5 & 6.39 & 38.9 & 3.83 \\
\hline 57.2 & I 4.00 & 52.6 & I I. 44 & 48.0 & 8.89 & 43.4 & 6.33 & 38.8 & 3.78 \\
\hline 57.1 & I 3.95 & $5^{2.5}$ & I I. 39 & 47.9 & $8.8_{3}$ & $43 \cdot 3$ & 6.28 & 38.7 & 3.72 \\
\hline 57.0 & 13.89 & $5^{2.4}$ & I 1.33 & 47.8 & 8.78 & 43.2 & 6.22 & 38.6 & 3.67 \\
\hline 56.9 & 13.83 & $5^{2} \cdot 3$ & 11.28 & $47 \cdot 7$ & 8.72 & $43 . I$ & 6.17 & $3^{8.5}$ & $3.6 \mathrm{I}$ \\
\hline 56.8 & 13.78 & 52.2 & I I. 22 & 47.6 & 8.67 & 43.0 & 6. I I & 38.4 & $3 \cdot 5^{6}$ \\
\hline $5^{6.7}$ & 13.72 & 52.1 & II.1 7 & $47 \cdot 5$ & 8.61 & 42.9 & 6.05 & 38.3 & 3.50 \\
\hline 56.6 & 13.67 & 52.0 & I I. I I & $47 \cdot 4$ & $8.5^{6}$ & 42.8 & 6.00 & 38.2 & 3.44 \\
\hline $5^{6.5}$ & 13.61 & 51.9 & 11.05 & $47 \cdot 3$ & 8.50 & 42.7 & $5 \cdot 95$ & 38.1 & 3.39 \\
\hline 56.4 & 13.56 & 51.8 & I I. 00 & 47.2 & 8.44 & 42.6 & 5.89 & 38.0 & 3.33 \\
\hline 56.3 & 13.50 & 51.7 & 10.95 & $47 \cdot 1$ & 8.39 & 42.5 & $5.8_{3}$ & 37.9 & 3.28 \\
\hline $5^{6.2}$ & I. 3.44 & 51.6 & 10.89 & 47.0 & 8.33 & 42.4 & 5.78 & 37.8 & 3.22 \\
\hline 56.1 & 13.39 & 51.5 & 10.83 & 46.9 & 8.28 & 42.3 & $5 \cdot 72$ & 37.7 & 3.17 \\
\hline $5^{6.0}$ & I 3.33 & $5^{1.4}$ & 10.78 & 46.8 & 8.22 & 42.2 & 5.67 & 37.6 & 3. I I \\
\hline 55.9 & 13.28 & 51.3 & 10.72 & 46.7 & S.I 7 & $4^{2 . I}$ & $5.6 \mathrm{I}$ & $37 \cdot 5$ & 3.05 \\
\hline 55.8 & 13.22 & 51.2 & 10.67 & 46.6 & 8. I I & 42.0 & $5 \cdot 5^{6}$ & $37 \cdot 4$ & 3.00 \\
\hline $55 \cdot 7$ & I 3.17 & $5 \mathrm{I} . \mathrm{I}$ & $10.6 \mathrm{I}$ & 46.5 & 8.05 & 41.9 & $5 \cdot 5^{\circ}$ & $37 \cdot 3$ & 2.95 \\
\hline 55.6 & I3. I I & 51.0 & $10.5^{6}$ & 46.4 & 8.00 & 41.8 & $5 \cdot 44$ & 37.2 & 2.89 \\
\hline 55.5 & 13.05 & 50.9 & $10.5^{\circ}$ & 46.3 & $7 \cdot 95$ & 41.7 & $5 \cdot 39$ & $37 \cdot 1$ & 2.83 \\
\hline 55.4 & 13.00 & 50.8 & 10.44 & 46.2 & 7.89 & 41.6 & $5 \cdot 33$ & 37.0 & 2.78 \\
\hline $55 \cdot 3$ & I 2.95 & 50.7 & I0.39 & 46.1 & 7.83 & $4 I .5$ & 5.28 & 36.9 & 2.72 \\
\hline 55.2 & 12.89 & 50.6 & 10.33 & 46.0 & $7 \cdot 78$ & 41.4 & 5.22 & 36.8 & 2.67 \\
\hline 55.1 & $12.8_{3}$ & 50.5 & 10.28 & 45.9 & $7 \cdot 72$ & $4 I \cdot 3$ & 5.17 & $3^{6.7}$ & $2.6 \mathrm{I}$ \\
\hline 55.0 & I 2.78 & 50.4 & 10.22 & 45.8 & 7.67 & 41.2 & 5.11 & 36.6 & $2.5^{6}$ \\
\hline 54.9 & I 2.72 & 50.3 & IO. I 7 & $45 \cdot 7$ & $7.6 \mathrm{I}$ & $4 \mathrm{I} . \mathrm{I}$ & 5.05 & 36.5 & 2.50 \\
\hline 54.8 & 12.67 & 50.2 & IO. I I & 45.6 & $7 \cdot 5^{6}$ & 41.0 & 5.00 & 36.4 & 2.44 \\
\hline 54.7 & I 2.61 & 50.1 & 10.05 & $45 \cdot 5$ & $7 \cdot 50$ & 40.9 & 4.95 & 36.3 & 2.39 \\
\hline 54.6 & I $2.5^{6}$ & 50.0 & 10.00 & $45 \cdot 4$ & $7 \cdot 44$ & 40.8 & 4.89 & 36.2 & 2.33 \\
\hline $54 \cdot 5$ & 12.50 & 49.9 & 9.95 & $+5 \cdot 3$ & $7 \cdot 39$ & 40.7 & 4.83 & 36.1 & 2.28 \\
\hline $54 \cdot 4$ & I 2.44 & 49.8 & 9.89 & $45 \cdot 2$ & $7 \cdot 33$ & 40.6 & 4.78 & 36.0 & 2.22 \\
\hline $5+\cdot 3$ & 12.39 & 49.7 & $9.8_{3}$ & 45.1 & 7.28 & 40.5 & 4.72 & 35.9 & 2. 17 \\
\hline 54.2 & I 2.33 & 49.6 & 9.78 & 45.0 & 7.22 & 40.4 & 4.67 & 35.8 & 2. I I \\
\hline $54 . I$ & 12.28 & $49 \cdot 5$ & 9.72 & 44.9 & 7.17 & 40.3 & $4.6 \mathrm{I}$ & 35.7 & 2.05 \\
\hline 54.0 & I 2.22 & $49 \cdot 4$ & 9.67 & 44.8 & $7.1 \mathrm{I}$ & 40.2 & $4 \cdot 5^{6}$ & 35.6 & 2.00 \\
\hline 53.9 & I 2.17 & $49 \cdot 3$ & $9.6 \mathrm{I}$ & 44.7 & 7.05 & 40.1 & $4 \cdot 5^{\circ}$ & $35 \cdot 5$ & I.95 \\
\hline 53.8 & I 2. I I & 49.2 & $9 \cdot 5^{6}$ & 44.6 & 7.00 & 40.0 & $4 \cdot 44$ & $35 \cdot 4$ & 1.89 \\
\hline 53.7 & 12.05 & 49.1 & $9 \cdot 50$ & 44.5 & 6.95 & 39.9 & $4 \cdot 39$ & $35 \cdot 3$ & I. 83 \\
\hline 53.6 & 12.00 & 49.0 & $9 \cdot 44$ & 44.4 & 6.89 & 39.8 & 4.33 & 35.2 & 1.78 \\
\hline $53 \cdot 5$ & I I. 95 & 48.9 & $9 \cdot 39$ & $44 \cdot 3$ & $6.8_{3}$ & 39.7 & 4.28 & $35 \cdot I$ & 1.72 \\
\hline 53.4 & I I. 89 & 48.8 & $9 \cdot 33$ & 44.2 & 6.78 & 39.6 & 4.22 & 35.0 & 1.67 \\
\hline $53 \cdot 3$ & I I. 83 & 48.7 & 9.28 & $44 \cdot \mathrm{I}$ & 6.72 & $39 \cdot 5$ & 4.17 & 34.9 & $1.6 \mathrm{I}$ \\
\hline 53.2 & II. 78 & 48.6 & 9.22 & 44.0 & 6.67 & $39 \cdot 4$ & 4. I I & 34.8 & I. 56 \\
\hline 53.1 & I I. 72 & 48.5 & 9. I 7 & 43.9 & $6.6 \mathrm{I}$ & $39 \cdot 3$ & 4.05 & $34 \cdot 7$ & 1.50 \\
\hline 53.0 & I 1.67 & 48.4 & 9. I I & 43.8 & 6.56 & 39.2 & 4.00 & 34.6 & 1.44 \\
\hline
\end{tabular}


II. TABle For Converting Degrees of FAHrenheit into Degrees of CENTIGRADE-Continued

\begin{tabular}{|c|c|c|c|c|c|c|c|c|c|}
\hline $\mathrm{F}$. & ${ }^{\circ} \mathrm{C}$. & ${ }^{\circ} \mathrm{F}$. & ${ }^{\circ} \mathrm{C}$. & ${ }^{\circ} \mathrm{F}$. & ${ }^{\circ} \mathrm{C}$. & ${ }^{\circ} \mathrm{F}$. & ${ }^{\circ} \mathrm{C}$. & ${ }^{\circ} \mathrm{F}$. & ${ }^{\circ} \mathrm{C}$. \\
\hline 34.5 & I. 39 & 33.1 & $0.6 \mathrm{I}$ & 31.8 & - O. I I & 30.5 & $-0.8_{3}$ & 29.2 & $-1.5^{6}$ \\
\hline $34 \cdot 4$ & 1.33 & 33.0 & $0.5^{6}$ & 31.7 & -0.17 & 30.4 & -0.89 & $29 . \mathrm{I}$ & $-\mathbf{I} .6 \mathrm{I}$ \\
\hline $3+3$ & I. 28 & 32.9 & 0.50 & 31.6 & -0.23 & 30.3 & -0.95 & 29.0 & -1.67 \\
\hline 34.2 & 1.22 & 32.8 & 0.44 & 31.5 & -0.28 & 30.2 & -1.00 & 28.9 & -1.72 \\
\hline $3+1$ & I. 17 & 32.7 & 0.39 & 31.4 & -0.33 & 30. I & -1.05 & 28.8 & -1.78 \\
\hline 34.0 & I. I I & 32.6 & 0.33 & $3 \mathrm{I} \cdot 3$ & -0.39 & 30.0 & - I.I I & 28.7 & $-\mathrm{I}_{3} S_{3}$ \\
\hline 33.9 & I.O5 & 32.5 & 0.28 & $3 \mathrm{I} .2$ & -0.44 & 29.9 & $-\mathrm{I} .17$ & 28.6 & -1.89 \\
\hline 33.8 & 1.00 & 32.4 & 0.22 & $3 \mathrm{I} . \mathrm{I}$ & -0.50 & 29.8 & -1.22 & 28.5 & -1.95 \\
\hline 33.7 & 0.95 & $32 \cdot 3$ & ०. I 7 & 31.0 & $-0.5^{6}$ & 29.7 & $-\mathrm{I} .2 \mathrm{~S}$ & 28.4 & -2.00 \\
\hline 33.6 & 0.89 & 32.2 & O. I I & 30.9 & $-0.6 \mathrm{I}$ & 29.6 & $-\mathrm{I} \cdot 33$ & 28.3 & -2.05 \\
\hline $33 \cdot 5$ & $0.8_{3}$ & $32 . I$ & 0.05 & 30.8 & -0.67 & $29 \cdot 5$ & $-\mathbf{I} \cdot 39$ & 28.2 & -2. I I \\
\hline $33 \cdot 4$ & 0.78 & 32.0 & 0.00 & 30.7 & -0.72 & $29 \cdot 4$ & $-\mathbf{I} \cdot 44$ & 28. I & -2.17 \\
\hline $33 \cdot 3$ & 0.72 & 31.9 & -0.05 & 30.6 & $-0.7^{8}$ & $29 \cdot 3$ & $-I .50$ & 28.0 & -2.22 \\
\hline 33.2 & 0.67 & & & & & & & & \\
\hline
\end{tabular}

III. Table showing Decrease of Mean Temperature with INCREASE OF DEPTH FOR THE WHOLE OCEAN

Calculated from the "Challenger" and all other observations available up to the year iS95.

\begin{tabular}{|c|c|c|c|c|}
\hline \multicolumn{2}{|c|}{ Depth. } & \multicolumn{3}{|c|}{ Temperature. } \\
\hline Fathoms. & Metres. & ${ }^{\circ} \mathrm{F}$. & ${ }^{\circ} \mathrm{C}$. & \\
\hline 100 & $18_{3}$ & $60^{\circ} \cdot 7$ & $15^{\circ} .95$ & \\
\hline 200 & 366 & $50^{\circ} . \mathrm{I}$ & 10.05 & \\
\hline 300 & 549 & $44^{\circ} \cdot 7$ & $7^{\circ} .05$ & \\
\hline 400 & $73^{2}$ & $41^{\circ} \cdot \dot{S}$ & $5^{\circ} \cdot 44$ & \\
\hline 500 & 9I4 & $40^{\circ} . I$ & 4.50 & \\
\hline 600 & I 097 & $39^{\circ} .0$ & $3^{\circ} .89$ & \\
\hline 700 & I 280 & $38^{\circ} . I$ & $3 \cdot 39$ & \\
\hline 800 & $146_{3}$ & $37^{\circ} \cdot 3$ & 2.95 & \\
\hline 900 & I 646 & $36^{\circ} .8$ & $2^{\circ} .67$ & \\
\hline 1000 & 1829 & $3^{6} \cdot 5$ & $2^{\circ} \cdot 50$ & \\
\hline I 100 & 2012 & $3^{6} \cdot 1$ & $2.2 \mathrm{~S}$ & \\
\hline I 200 & 2195 & $35^{\circ} .8$ & $2^{\circ} . \mathrm{II}$ & - \\
\hline I 300 & 2377 & $35^{\circ} \cdot 6$ & $2^{\circ} .00$ & \\
\hline 1400 & 2560 & $35^{\circ} \cdot 4$ & $I^{\circ} \cdot S 9$ & \\
\hline I 500 & 2743 & $35^{\circ} \cdot 3$ & $I^{\circ} \cdot S_{3}$ & \\
\hline 2200 & 4023 & $35^{\circ} \cdot 2$ & $I^{\circ} \cdot 78$ & \\
\hline
\end{tabular}

Except in the Norwegian Sea and in the North-West Atlantic to the south-east of Greenland, the temperatures in the North Atlantic at all depths down to the bottom are above the means for the whole ocean as given in this table. On the other hand, the temperatures in the North I'acific in the same latitudes and depths are, for the most part, below these means. 
IV. Table showing the Positions of the "Michael Sars"

Observing Stations, igio

Night Stations where the nets were towed between midnight and dawn are distinguished by asterisks.

Station.

Date.

Position.

Depth in

Depth in

Metres.

Fathoms.

\section{From Plymouth to Gibraltar.}

\begin{tabular}{|c|c|c|c|c|c|c|}
\hline I & April & 9 & $\begin{array}{c}\text { N. } \\
49^{\circ}\end{array}$ & $\begin{array}{l}\text { W. } \\
8^{\circ} 36^{\prime}\end{array}$ & 146 & 80 \\
\hline 2 & , & 10 & $49^{\circ} 30^{\prime}$ & $9^{\circ} 4^{\prime}$ & I 49 & 82 \\
\hline 3 & , & ro & $49^{\circ} 32^{\prime}$ & $10^{\circ} 49^{\prime}$ & 184 & IOI \\
\hline 4 & , & IO-II & $493^{8}$ & $11^{\circ} 35^{\prime}$ & 923 & 504 \\
\hline 5 & , & 16 & $5^{1^{\circ}} \quad 24^{\prime}$ & $9^{\circ} 27^{\prime}$ & 68 & 37 \\
\hline 6 & , & $16-17$ & $50^{\circ} 33^{\prime}$ & $10^{\circ} 4^{\prime}$ & r68 & $9^{2}$ \\
\hline 7 & , & 17 & $49^{\circ} 54^{\prime}$ & $12^{\circ} \mathrm{IO}$ & I 8 I 3 & $99 \mathrm{I}$ \\
\hline 8 & ", & I 8 & $48^{\circ} 53^{\prime}$ & I I $3 I^{\prime}$ & ... & $\cdots$ \\
\hline 9 & ", & I 8 & $47^{\circ} 49^{\prime}$ & $10^{\circ} 5^{\prime}$ & $\ldots$ & $\ldots$ \\
\hline 10 & , & $19^{-21}$ & $45^{\circ} 26^{\prime}$ & $9^{\circ} 20^{\prime}$ & 4700 & 2570 \\
\hline I I & , & $2 \mathrm{I}$ & $44^{\circ} 25^{\prime}$ & $9^{\circ}$ I $8^{\prime}$ & $\cdots$ & $\ldots$ \\
\hline 12 & , & $2 \mathrm{I}$ & $43^{\circ}$ I I & $9^{\circ} 26^{\prime}$ & I66 & \\
\hline I 3 & , & 22 & $41^{\circ} 32^{\prime}$ & $9^{\circ} \circ 5^{\prime}$ & 78 & 42 \\
\hline 14 & " & 22 & $41^{\circ} 15$ & $8^{\circ} 54^{\prime}$ & 69 & \\
\hline 15 & , & $22-23$ & $40^{\circ} 56^{\prime}$ & $9^{\circ} 28^{\prime}$ & $\ldots$ & \\
\hline I 6 & ", & 23 & $40^{\circ}$ I $5^{\prime}$ & $9^{\circ} 23^{\prime}$ & I 54 & \\
\hline I 7 & ", & 23 & $38^{\circ} \quad 20^{\prime}$ & $9^{\circ} 43^{\prime}$ & r 860 & 1017 \\
\hline I 8 & , & $29-30$ & $35^{\circ} 56^{\prime}$ & $5^{\circ} 43^{\prime}$ & About 400 & \\
\hline
\end{tabular}

From Gibraltar to Gran Canaria.

\begin{tabular}{|c|c|c|c|c|c|c|}
\hline 19 & May & $2-3$ & $36^{\circ} \quad 5^{\prime}$ & $4^{\circ} 42^{\prime}$ & $\cdots$ & $\cdots$ \\
\hline 20 & , & 5 & $35^{\circ} 25^{\prime}$ & $6^{\circ} 25^{\prime}$ & I $4 \mathrm{I}$ & 77 \\
\hline $2 \mathrm{I}$ & , & 5 & $35^{\circ} 3 \mathrm{I}^{\prime}$ & $6^{\circ} 35^{\prime}$ & 535 & 292 \\
\hline 22 & ", & 5 & $35^{\circ} 42^{\prime}$ & $6^{\circ} 5^{I^{\prime}}$ & 835 & $45^{6}$ \\
\hline${ }^{*} 23$ & , & $5^{-6}$ & $35^{\circ} 32^{\prime}$ & $7^{\circ} 7^{\prime}$ & 12 I 5 & 664 \\
\hline *24 & , & $6-7$ & $35^{\circ} 34^{\prime}$ & $7^{\circ} 35^{\prime}$ & 1615 & $88_{3}$ \\
\hline $25 \mathrm{~A}$ & , & 7 & $35^{\circ} 35^{\prime}$ & $8^{\circ} 25^{\prime}$ & 2300 & 1258 \\
\hline${ }^{*} 25 \mathrm{~B}$ & ", & 8 & $35^{\circ} 46^{\prime}$ & $8^{\circ}$ I $6^{\prime}$ & 2055 & I I 24 \\
\hline 26 & ," & 8 & $3^{6^{\circ}} 53^{\prime}$ & $6^{\circ} 48^{\prime}$ & 50 & 27 \\
\hline 27 & " & 9 & $3^{6^{\circ}} 3 I^{\prime}$ & $7^{\circ} \quad 1^{\prime}$ & $\ldots$ & $\cdots$ \\
\hline 28 & " & 9 & $36^{\circ} \quad o^{\prime}$ & $7^{\circ} 19^{\prime}$ & $\ldots$ & ... \\
\hline 29 & , & $9-10$ & $35^{\circ}$ I $0^{\prime}$ & $7^{\circ} 55^{\prime}$ & $\ldots$ & ... \\
\hline 30 & , & IO & $34^{\circ} 38^{\prime}$ & $8^{\circ} 22^{\prime}$ & $\ldots$ & $\cdots$ \\
\hline $3^{I}$ & , & Io & $33^{\circ}+7^{\prime}$ & $8^{\circ} 27^{\prime}$ & 184 & IOI \\
\hline 32 & " & IO & $33^{\circ} 27^{\prime}$ & $8^{\circ} 32^{\prime}$ & 105 & 57 \\
\hline 33 & , & I I & $3 I^{\circ} \quad I 7^{\prime}$ & $10^{\circ} 6^{\prime}$ & 100 & 55 \\
\hline * 34 & ," & $13-14$ & $28^{\circ} 5^{2}$ & $14^{\circ} 16^{\prime}$ & 2170 & II 87 \\
\hline
\end{tabular}


IV. TABle showing the Positions of the "Michael Sars" ObSERViNg Stations, 1910-Continued

\section{Between Gran Canaria and Cape Bojador (Africa).}

\begin{tabular}{|c|c|c|c|c|c|c|}
\hline 35 & May & IS-I 9 & $27^{\circ} 27^{\prime}$ & $\begin{array}{l}\text { W. } \\
14^{\circ} 52^{\prime}\end{array}$ & 2603 & $1+24$ \\
\hline $3^{6}$ & , & I 9-20 & $26^{\circ}$ I $2^{\prime}$ & $1+26^{\prime}$ & IO & 5 \\
\hline 37 & ", & 20 & $26^{\circ} \quad 6^{\prime}$ & $1433^{\prime}$ & 39 & 21 \\
\hline $3^{8}$ & ", & 20 & $26^{\circ}$ & $14^{\circ} 3^{\prime}$ & 77 & 42 \\
\hline $39 \mathrm{~A}$ & " & $20-2 I$ & $26^{\circ} \quad 3^{\prime}$ & I $5^{\circ} \mathrm{O}^{\prime}$ & $2 \mathrm{I} 4$ & I 6 \\
\hline *39 B & ", & $2 \mathrm{I}$ & $26^{\circ} \quad 3^{\prime}$ & I $5^{\circ} \quad O^{\prime}$ & $267-280$ & $146-153$ \\
\hline 40 & , & $22-23$ & $28^{\circ}$ I $5^{\prime}$ & I $329^{\prime}$ & I 197 & 655 \\
\hline $4^{I}$ & " & 23 & $2 S^{\circ} \quad 8^{\prime}$ & I3 $35^{\prime}$, & I 365 & 747 \\
\hline 12 & " & $23^{-24}$ & $28^{\circ}$ & $14 \quad 17^{\prime}$ & $\ldots$ & $\ldots$ \\
\hline
\end{tabular}

\section{From Gran Canaria to Fayal (the Azores).}

43

44

${ }^{*} 45$

46

47

48

$49 \mathrm{~A}$

$49 \mathrm{~B}$

* $49 \mathrm{C}$

50

* 5 I

52

* 53

54

55
$* 56$

57

${ }^{*} 58$

57

$$
\begin{array}{cl}
\text { May } & 27 \\
, & 28 \\
" & 28-29 \\
" & 29 \\
, & 30 \\
\text { June } & 3 \text { I } \\
, & \text { I } \\
", & \text { I-2 } \\
" & 4 \\
" & 5-6 \\
, & 6-7 \\
, & 8-9 \\
, & \text { I0 } \\
, & \text { I0 } \\
, & \text { I0-I I } \\
, & \text { I I }
\end{array}
$$

$\begin{array}{lr}28^{\circ} & 2^{\prime} \\ 28^{\circ} & 37^{\prime} \\ 28^{\circ} & 42^{\prime} \\ 28^{\circ} & 56^{\prime} \\ 29^{\circ} & 2^{\prime} \\ 28^{\circ} & 54^{\prime} \\ 29^{\circ} & 6^{\prime} \\ 29^{\circ} & 8^{\prime} \\ 29^{\circ} & 7^{\prime} \\ 30^{\circ} & 8^{\prime} \\ 31^{\circ} & 20^{\prime} \\ 31^{\circ} & 24^{\prime} \\ 34^{\circ} & 59^{\prime} \\ 35^{\circ} & 37^{\prime} \\ 36^{\circ} & 24^{\prime} \\ 36^{\circ} & 53^{\prime} \\ 37^{\circ} & 20^{\prime} \\ 37^{\circ} & 11^{\prime} \\ 37^{\circ} & 33^{\prime} \\ 37^{\circ} & 33^{\prime} \\ 37^{\circ} & 37^{\prime} \\ 37^{\circ} & 38^{\prime} \\ 37^{\circ} & 42^{\prime}\end{array}$

$17^{\circ} \mathrm{I} 8^{\prime}$

$198^{\prime}$

$20^{\circ} 0^{\prime}$

$21^{\circ} 45^{\circ}$

$22^{\circ} 53^{\prime}$

$24^{\circ} 14^{\prime}$

$25^{\circ} 2^{\prime}$

$25^{\circ}$ I $6^{\prime}$

$25^{\circ} 32^{\prime}$

$31^{\circ} 19^{\prime}$

$35^{\circ} 7^{\prime}$

$34^{\circ} 47^{\prime}$

$33^{\circ}$ I'

$30^{\circ}$ I $5^{\prime}$

$29^{\circ} 52^{\prime}$

$29^{\circ} 47^{\prime}$

$29^{\circ} 33^{\prime}$

$29^{\circ} 3 \mathrm{I}^{\prime}$

$29^{\circ} 29^{\prime}$

$29^{\circ} 20^{\prime}$,

$29^{\circ} 25^{\prime}$

$29^{\circ} 20^{\prime}$

$29^{\circ} \mathrm{I}^{\prime}$

\begin{tabular}{|c|c|}
$\ldots$ \\
$\ldots$ \\
$\ldots$ \\
$\ldots$ \\
2822 \\
$\ldots$ \\
$\ldots$ \\
$\ldots$ \\
$\ldots$ \\
$\cdots$ \\
2124 \\
$\ldots$ \\
I $430-1567$ \\
I 742 \\
I 770 \\
I 770 \\
$\ldots$ \\
930 \\
825 \\
949 \\
675 \\
518 \\
541 \\
\end{tabular}


IV. Table showing the Positions of the "Michael Sars OpSERVING Stations, I9IO-Contimed

\begin{tabular}{l|l|l|ll}
\hline Station. & Date. & Position. & $\begin{array}{c}\text { Depth in } \\
\text { Metres. }\end{array}$ & $\begin{array}{l}\text { Depth in } \\
\text { Fathoms. }\end{array}$ \\
\hline
\end{tabular}

\section{From the Azores to Newfoundland.}

\begin{tabular}{|c|c|c|c|c|c|c|}
\hline 59 & June & I 7 & $3^{8^{\circ}} 30^{\prime}$ & $\begin{array}{c}\text { w. } \\
28^{\circ} \\
\end{array}$ & 225 & I 23 \\
\hline 60 & , & 20 & $37^{\circ} \quad 9^{\prime}$ & $38^{\circ} \quad 5^{\prime}$ & ... & ... \\
\hline $6 I$ & , & 20 & $37^{\circ} 7^{\prime}$ & $38^{\circ} 34^{\prime}$ & ... & ... \\
\hline${ }^{*} 62$ & ", & $20-2 I$ & $3^{6} \quad 5^{\prime}$ & $39^{\circ} 55^{\prime}$ & $\ldots$ & $\cdots$ \\
\hline 63 & ", & 22 & $3^{6^{\circ}} \quad 5^{\prime}$ & $43^{\circ} \quad 5^{\prime}$ & 5035 & 2753 \\
\hline 64 & " & 24 & $34^{\circ} 44^{\prime}$ & $47^{\prime} \quad 5^{\prime}$ & ... & ... \\
\hline 65 & , & 25 & $37^{\circ}$ I $2^{\prime}$ & $48^{\circ} 30^{\prime}$ & ... & ... \\
\hline 66 & ", & 26 & $39^{\circ} 30^{\prime}$ & $49^{\circ} 42^{\prime}$ & ... & $\ldots$ \\
\hline 67 & , & 27 & $40^{\circ}$ I $7^{\prime}$ & $50^{\circ} 39^{\prime}$ & ... & $\ldots$ \\
\hline 68 & $"$ & 28 & $39^{\circ} 20^{\prime}$ & $50^{\circ} \quad 50^{\prime}$ & $\ldots$ & $\cdots$ \\
\hline 69 & ", & 29 & $41^{\circ} 39^{\prime}$ & $5 I^{\circ} \quad 4^{\prime}$ & $\ldots$ & $\cdots$ \\
\hline 70 & $"$ & 30 & $42^{\circ} 59^{\prime}$ & $5 \mathrm{I}^{\circ} \quad \mathrm{I} 5^{\prime}$ & I IOO & 602 \\
\hline $70 \mathrm{~A}$ & ", & 30 & $\ldots$ & $\cdots$ & $\ldots$ & $\ldots$ \\
\hline $7 \mathrm{I}$ & & 30 & $43^{\circ}$ I $8^{\prime}$ & $5 \mathrm{I}^{\circ} \mathrm{I} 7^{\prime}$ & I $47^{-1} 3^{8}$ & $80 \div 75$ \\
\hline $7^{2}$ & July & I & $44^{\circ} 35^{\prime}$ & $5^{I^{\circ}} \quad$ I $55^{\prime}$ & 75 & $4 \mathrm{I}$ \\
\hline 73 & $"$ & I & $45^{\circ} \quad 5^{8^{\prime}}$ & $5^{I^{3}} 25^{\prime}$ & 70 & 38 \\
\hline 74 & , & 2 & $47^{\circ} 25^{\prime}$ & $5^{2} \quad 20^{\prime}$ & I 56 & $8_{5}$ \\
\hline
\end{tabular}

\section{From Newfoundland to Glasgow.}

\begin{tabular}{|c|c|c|c|c|c|c|}
\hline 75 & July & 9 & $47^{\circ} 22^{\prime}$ & $49^{\circ}$ I $6^{\prime}$ & I 20 & 66 \\
\hline 76 & " & 9 & $47^{\circ}$ I I $^{\prime}$ & $47^{\circ} \quad 6^{\prime}$ & 380 & 208 \\
\hline 77 & $"$ & IO & $47^{\circ}$ I $8^{\prime}$ & $44^{\circ} 54^{\prime}$ & I $7 \mathrm{I}$ & 93 \\
\hline $\begin{array}{l}78 \\
70\end{array}$ & $"$ & IO & $47^{\circ}$ I $7^{\prime}$ & $44^{\circ} 32^{\prime}$ & 202 & I IO \\
\hline 79 & $"$ & IO & $47 \quad 16$ & $44^{\circ} \quad 17^{\prime}$ & $27 \mathrm{I}$ & I 47 \\
\hline 80 & $"$ & I I & $47^{\circ} 34^{\prime}$ & $43^{\prime \prime}$ I I $^{\prime}$ & 2000 & $\frac{\dot{1094}}{1094}$ \\
\hline 8 I & $"$ & I 2 & $4^{8^{\circ}} \quad 2^{\prime}$ & $39^{\circ} 55^{\prime}$ & $\ldots$ & ... \\
\hline & ," & I 2 & $8^{\circ}$ & $36^{\cdots}=3^{\prime}$ & $\cdots$ & $\cdots$ \\
\hline $8_{3}$ & ", & $\begin{array}{l}13 \\
14\end{array}$ & $48^{\circ} 30^{\prime}$ & $\begin{array}{l}30 \\
33 \\
33\end{array}$ & $\ldots$ & $\cdots$ \\
\hline 84 & ," & I 5 & $48^{\circ} \quad 4^{\prime}$ & $3^{2} 25^{\prime}$ & $\ldots$ & $\begin{array}{l}\cdots \\
\cdots\end{array}$ \\
\hline *85 & , & I $5-16$ & $47^{\circ} 5^{8^{\prime}}$ & $3 \mathrm{I}^{\circ} 4 \mathrm{I}^{\prime}$ & $\ldots$ & $\ldots$ \\
\hline 86 & , & 16 & $47^{\circ} 29^{\prime}$ & $30^{\circ} 20^{\prime}$ & $\ldots$ & $\ldots$ \\
\hline 87 & , & I 7 & $46^{\circ} \quad 8^{\prime}$ & $27^{\circ} 4^{6^{\prime}}$ & 2 I 57 & I I 80 \\
\hline $\begin{array}{l}88 \\
88\end{array}$ & , & I 8 & $45^{\circ} \quad 26^{\prime}$ & $25 \quad 45$ & 3120 & I 706 \\
\hline $\begin{array}{l}88 \mathrm{~A} \\
88 \mathrm{~B}\end{array}$ & $"$ & I 8 & $\cdots$ & $\cdots$ & $\cdots$ & $\cdots$ \\
\hline & ", & 19 & & $\cdots$ & $\ldots$ & \\
\hline
\end{tabular}


IV. Table showing the Positions of the "Michael Sars" ObServing Stations, rgio-Continued.

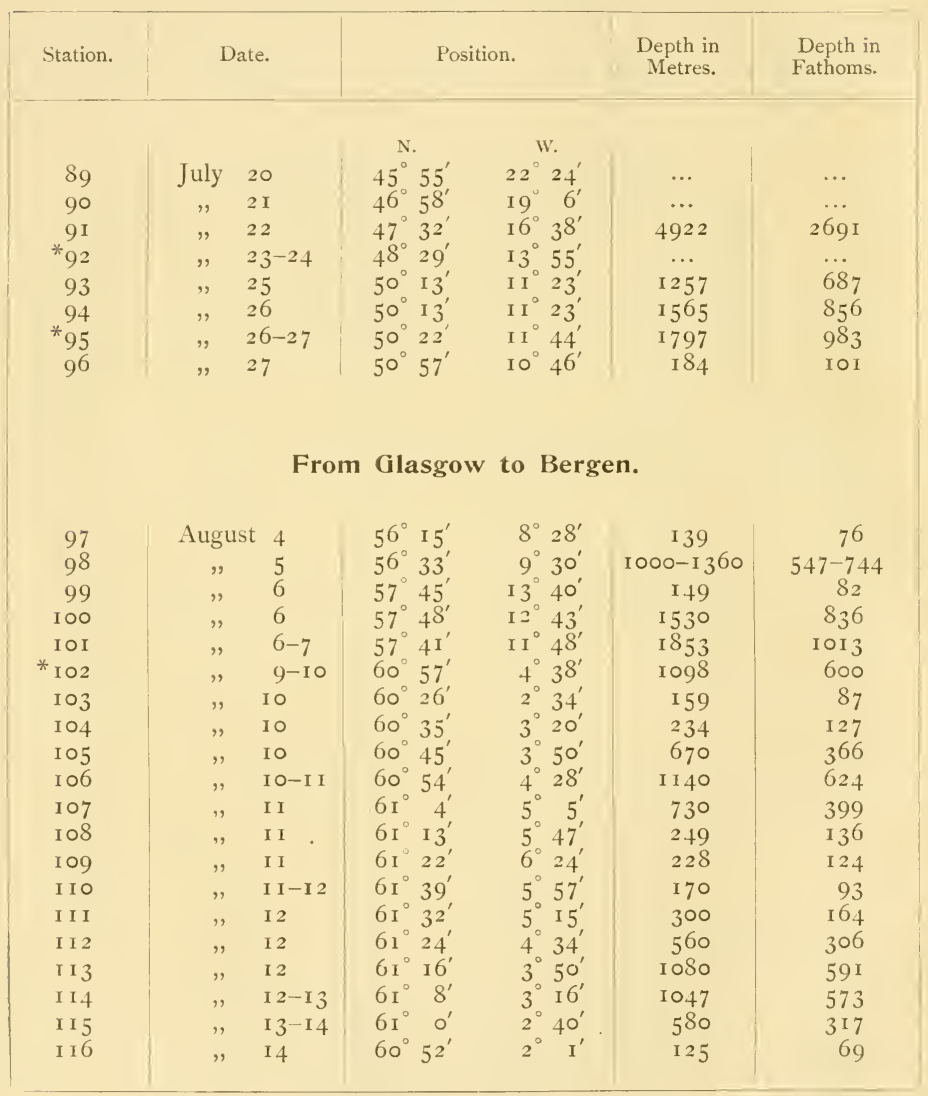




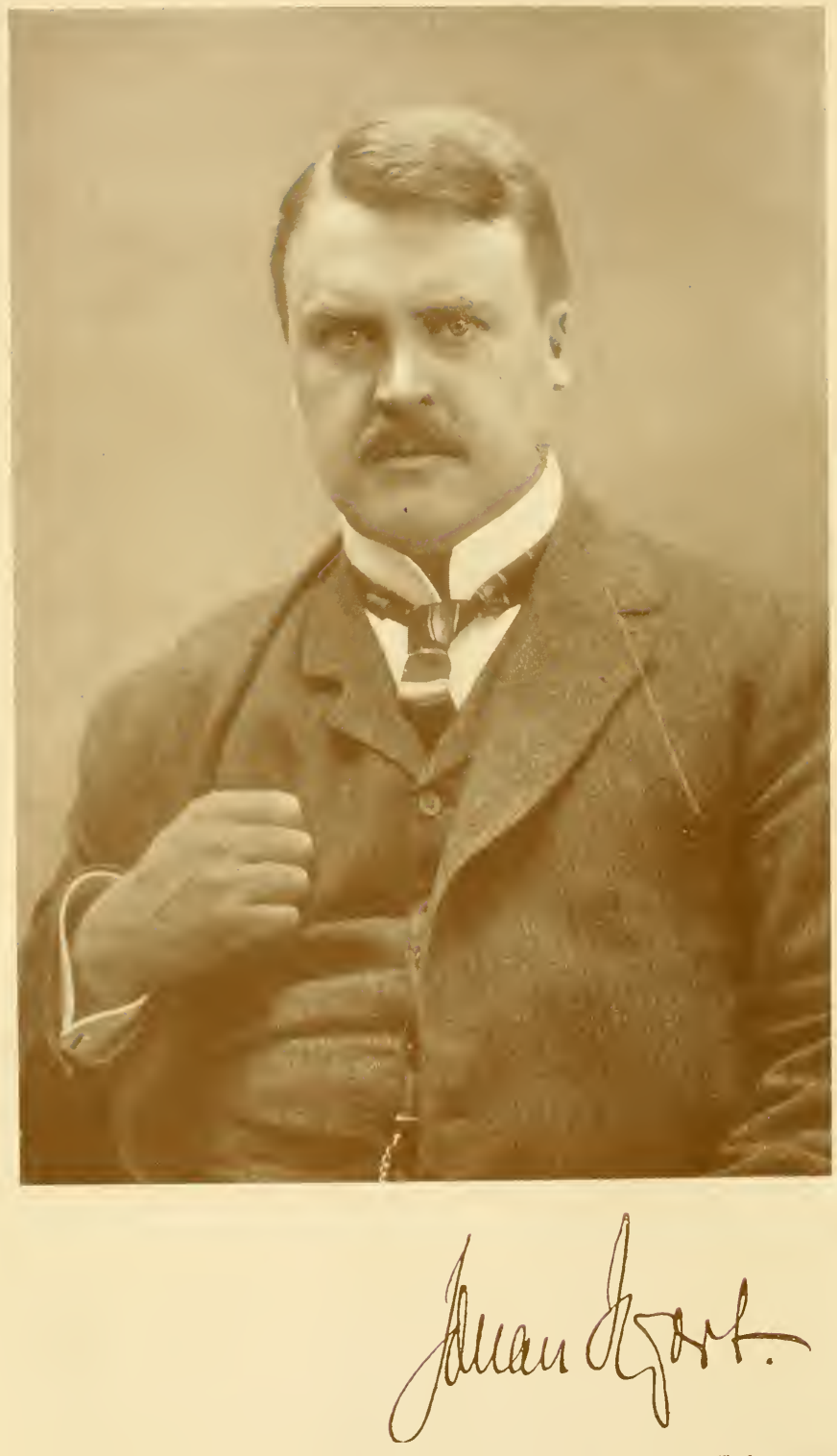


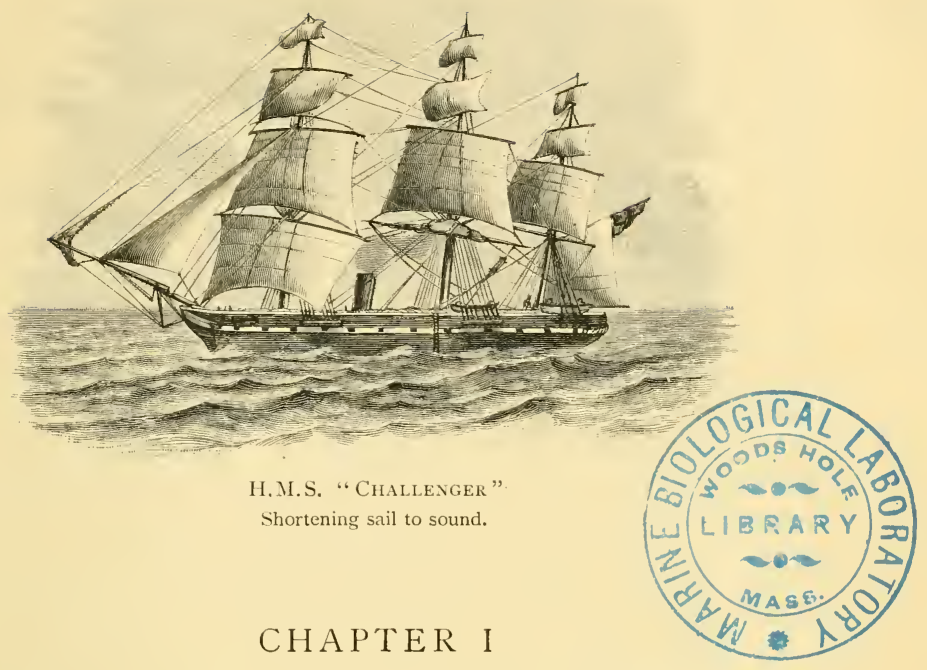

A BRIEF HISTORICAL REVIEW OF OCEANOGRAPHICAL

INVESTIGATIONS

THE phenomena displayed at the surface of the ocean have Development been the object of observation from the earliest ages,- - waves, $\begin{gathered}\text { of the modern } \\ \text { scien of }\end{gathered}$ currents, winds, tides, and the temperature of the water were oceanography. matters of very great importance and concern to the earliest navigators. It was not, however, till about the time of the famous "Challenger" Expedition, nearly forty years ago, that any systematic attempts were made to examine the deeper and more remote regions, or to explore the physical and biological conditions of the ocean as a whole.

It seems desirable to commence this book by indicating, as briefly as possible, the various steps by which the present development of the modern science of oceanography has been reached. This can best be accomplished by (I) pointing out some of the scientific observations made previous to the "Challenger" Expedition, (2) referring to the expeditions contemporaneous with and subsequent to that expedition, and (3) referring to the work carried out at marine biological laboratories, and in connection with international and other fishery investigations. 
Early: soundings.

Cusanus bathometer.

Puehler's apparatus.

Alberti:s apparatus.

Hooke's apparatus.

First soundings laid down on maps.

First attempt at deep-sea sounding.

Iagellan.

From time immemorial soundings were taken by hand with a plummet, always in shallow water near land, but attempts have not been wanting to sound the ocean without the aid of a line. Thus about the middle of the fifteenth century Cardinal Nicolaus Cusanus invented a bathometer, consisting of a hollow sphere with a heavy weight attached by means of a hook; on touching the bottom the weight was detached, and the sphere returned to the surface, the interval of time from the launching of the apparatus to the re-appearance of the sphere at the surface indicating the depth. A century later Puehler improved on Cusanus' bathometer by adding a piece of apparatus (clepsydra) to measure the time from the disappearance to the re-appearance of the float, using for this purpose a clay vase with a small orifice at the bottom, through which water was made to enter during the period of the experiment, the amount of water in the vase indicating the depth. Alberti subsequently replaced the sphere by a light, bent metal tube. In I667 Robert Hooke described in the Philosophical Transactions a similar apparatus, shown in the tailpiece to Chapter IV., with which experiments were made in the Indian Ocean, but there was always doubt as to the moment when the float returned to the surface, and to remedy this Hooke introduced first a clockwork odometer to register the descent, and then two odometers-one for the descent and the other for the ascent. These various forms of bathometers, though interesting historically, proved of little practical value.

Soundings in shallow water first appeared on a map by Juan de la Cosa in 1504, and soundings were laid down on maps by Gerard Mercator in 1585 and by Lucas Janszon Waghenaer in 1586.

Probably the first attempt at oceanographical research to which the term "scientific" may be applied is Magellan's unsuccessful effort to determine the depth of the Pacific Ocean during the first circumnavigation of the globe. In 1521 , we are told, Magellan tried to sound the ocean between the two coral islands, St. Paul and Los Tiburones in the Low Archipelago, making use of the sounding lines carried by explorers at that period, which were only 100 to 200 fathoms in length. He failed to touch bottom, and therefore concluded that he had reached the deepest part of the ocean. This first authentic attempt at deep-sea sounding ever made in the open sea is historically extremely interesting, though scientifically the result was negative. 
The expedition of Edmund Halley, Astronomer-Royal, in Halley's I699, to improve our knowledge concerning longitude and the expedition. variation of the compass, was a purely scientific voyage, though it may be said that scientific voyages were really initiated at the time of James Cook in the second half of the eighteenth century.

Cruquius introduced bathymetrical contours on a chart of the River Merwede published in 1728 . Thus contour lines were first used on maps to show the depths of the sea and not the heights of the land.

In a map published by Philippe Buache in 1737 we find the Buache. bottom of the sea again represented by isobathic curves, intended to show that certain elevations of the sea-floor correspond to the orography of the neighbouring land. He develops these ideas in his Essay on Physical Geography, published in 1752 , maintaining that the globe is sustained by chains of mountains crossing the sea as well as the land, forming as it were the framework of the globe-a view previously expressed by Father Athanasius Kircher. His kircher. conception of submarine mountains was a first step towards founding geography on the real form and relief of each region.

The dredge seems to have been first used by two Italians, First use of Marsigli and Donati, about the year 1750 , for obtaining marine organisms from shallow water, and a modification of this form Marsigli and Donati. was introduced by O. F. Müller in I799, which was known as O. F. Müller. the naturalist's dredge.

In the middle of the eighteenth century Dalrymple and Temperature Davy made observations on the temperature of the equatorial currents during a voyage to the East Indies.

In I 770 Benjamin Franklin published the first map of the Gulf Stream (see figure in Chapter V.), and in 1776 Charles Blagden was engaged in the study of temperature distribution observations. Dalrymple and Davy. on the North American coasts, reporting on his results to the Royal Society of London in $178 \mathrm{I}$.

During Cook's voyages ( $1772-73$ ), temperature observations James Cook. beneath the surface were taken by the Forsters, father and son, The Forsters. but the first use of self-registering thermometers for determining the temperature beneath the surface of the sea was during Lord Mulgraves' expedition to the Arctic in 1773 by Dr. Irvine, who Irvine. seems also to have constructed a water-bottle for bringing up water-samples from various depths, one sample giving a reading of $40^{\circ}$ Fahr., while the surface temperature was $55^{\circ}$ Fahr. 
Phipps' deep- During this expedition also some of the earliest attempts at sea soundings. deep-sea sounding were made by Captain Phipps, the deepest sounding being $68_{3}$ fathoms, from which depth he brought up a sample of Blue mud.

In I 780 Saussure determined the temperature of the Mediterranean at depths of 300 and 600 fathoms by protected thermometers, and in 1782 Six's maximum and minimum thermometer was invented, and subsequently made use of by

Krusenstern. Kotzebue.

John Ross and Sabine.

Parry.

d'Urville.

Péron.

Scoresby.

Lenz.

Thouars.

IIartins and Bravais.

James Clark Ross.

Maury.

l'ullen. Krusenstern in $\mathrm{I}_{80}$, by Kotzebue in 1815 , by Sir John Ross accompanied by Sir Edward Sabine in 1818 , by Parry in 1819 , and by Dumont d'Urville in 1826 . Slow-conducting water-bottles were used by Péron in 1800 , by Scoresby in I 81 I, who recorded warmer water beneath the colder surface layers in the Arctic regions, and by Kotzebue accompanied by Lenz in I 823. Protected thermometers were used for deep - sea temperatures by Thouars in 1832 , by Martins and Bravais in I 839 , and by Sir James Clark Ross during his Antarctic expedition from I 839 to I 843 , the lastmentioned making also many observations on

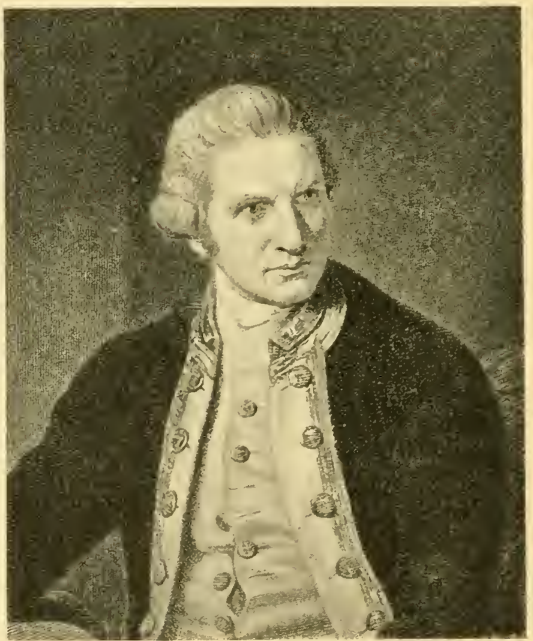

Captain James CoOK.

the density of the water at various depths. In I843 Aimé introduced reversible outflow thermometers, and about is $85 \mathrm{I}$ Maury used cylinders of non-conducting material for taking temperatures in deep water. But it was only when thermometers with bulbs properly protected from pressure came into use that oceanic temperatures could be recorded with precision. The first thermometer of this kind seems to have been used in I 857 by Captain Pullen of H.M.S. "Cyclops," and shortly thereafter improved forms of the Six pattern (Miller-Casella) and of Negretti and Zambra's reversing pattern were introduced, and have been largely used ever since, improvements and modifications being incorporated from time to time. 
Scoresby in ISI I recorded some soundings off the coast of Deep Greenland, and Sir John Ross during his voyage to Baffin's Bay in 1817-18 took some deep soundings by means of an apparatus, designed by him and made on board, called "deepsea clamms," in depths of 450,650, 1000, and 1050 fathoms, bringing up from the last-mentioned depth several pounds of greenish mud. With the deposit-samples worms and other Deep-sea animals were brought up, and when sounding in rooo fathoms animals. a star-fish was found entangled in the line a little distance above the mud, thus proving that animal life was present in deep water.

In I 8 I 7 Romme published in Paris a work on winds, tides, Romme. and currents, and Risso in 1826 , Lowe from I843 to I860, Risso. Johnson from I 862 to I 866 , and Günther from I 860 to I 870 , published important papers dealing with deep-sea and pelagic fishes. In 1832 James Rennell published an investigation of the currents of the Atlantic Ocean, based upon the observations recorded by sailors up to that time.

During the United States Exploring Expedition in I839- Wilkes and I 842 under Captain Wilkes, accompanied by Dana, several deep soundings were taken with the aid of a copper wire, and a few dredgings in shallow water were also made.

Important sounding and dredging work was carried out by Sir James Clark Ross, accompanied by Hooker, during the British Antarctic Expedition in I839 to 1843 , the first truly oceanic soundings in depths exceeding 2000 fathoms being taken. After many unsuccessful attempts to sound in deep water, due to the want of a proper line, Ross had a line 3600 fathoms in length specially constructed on board. It was fitted with swivels here and there, strong enough to carry a weight of 76 lbs., and was allowed to run out from an enormous reel in one of the ship's boats. With this line the first abysmal sounding on record was taken in 2425 fathoms on the 3 rd January $\mathrm{I} 840$, in lat. $27^{\circ} 26^{\prime}$ S., long. $17^{\circ} 29^{\prime} \mathrm{W}$., and frequently during the cruise similar and greater depths were sounded. Such deep soundings could only be attempted in calm weather, and a note was kept of the time each Ioo-fathoms mark left the reel, a lengthening of the time-interval indicating when the weight had reached the bottom. The dredge also was successfully used during this expedition in depths down to 400 Lowe. Tohnson. Guinther. Rennell. Dana. fathoms, abundant evidence of animal life being forthcoming, though unfortunately the deep-sea zoological collections were

British Antarctic Expedition. James Clark Ross and Hooker.

Sourdings in very deep water

Introduction of time intervals in sounding. Dredgings in deep water. 
subsequently lost to science. In April I 840 the dredge came up full of coral from a depth of 95 fathoms, and in the following January dredgings in 270 and 300 fathoms gave abundance of marine invertebrates in great variety, the deepest dredging in 400 fathoms in August I 84 I bringing up some beautiful specimens of coral, corallines, flustræ, and a few crustaceous animals.

Hooker on Antarctic diatoms. Hooker made known some of Ross's results, and drew attention to the great rôle played by diatoms in the seas of the far south.

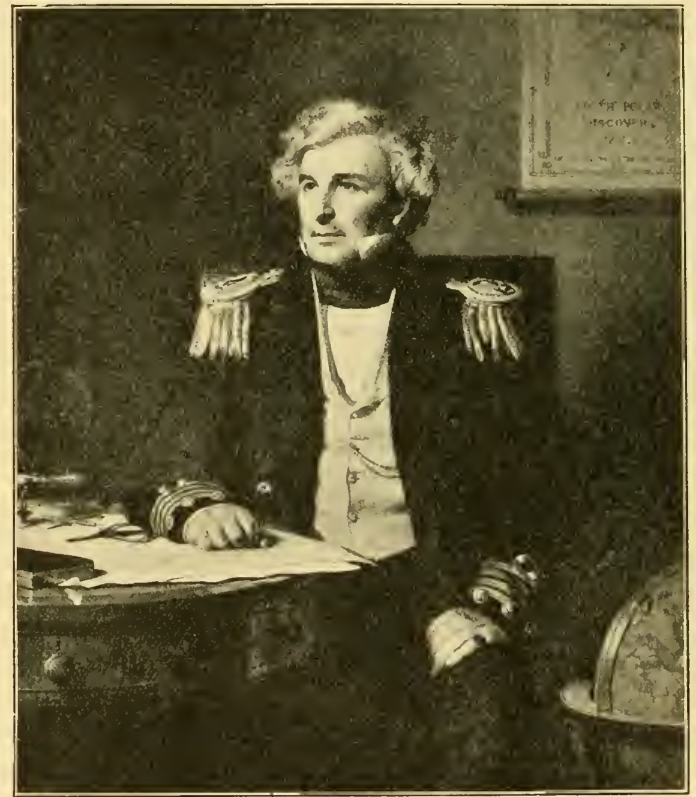

Sir James Clark Ross.

British Association Dredging Committee. Edward Forbes.

Audouin and MilneEdwards. Michael Sars.

In ${ }^{8} 39$ the British Association appointed a Committee to investigate the marine zoology of Great Britain by means of the dredge, the ruling spirit of this Committee being Edward Forbes, who made many observations on the bathymetrical distribution of life in various seas. Before this time, it is true, Audouin and Milne-Edwards in 1830 , and Michael Sars in I 835 , had published the results of dredgings in comparatively shallow waters within limited areas along the coasts of Europe.

In I840-4 I Forbes studied the fauna of the Egean Sea, 
taking a great many dredgings at different depths, and came to Forbes' the conclusion that marine animals were distributed in zones of observations depth, each characterised by a special assemblage of species. Marine He divided the area occupied by marine animals into eight animals zones, in which animal life gradually diminished with increase in zones of of depth, until a zero was reached at about 300 fathoms. He depth. supposed that plants, like animals, disappeared at a certain depth, the zero of vegetable life being at a less depth than that zero of life of animal life. In his Report on the Investigation of British in the sea.

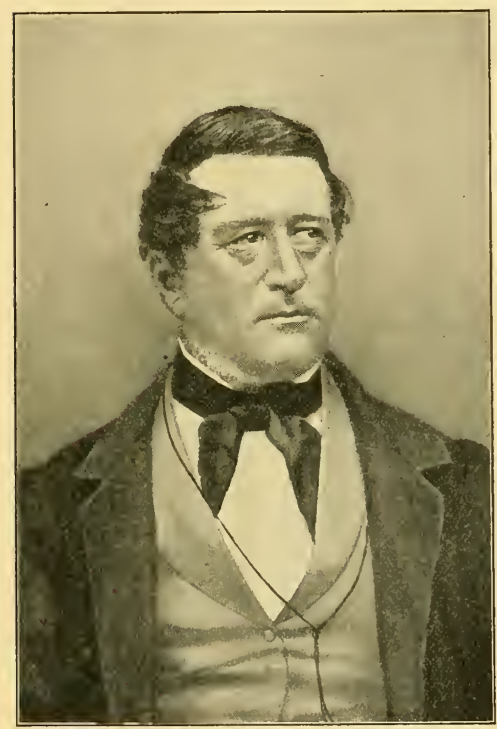

Professor Michael SARS.

Marine Zoology by means of the Dredge (i 850 ), Forbes suggested that dredgings off the Hebrides and the Shetlands, and between the Shetland and Faroe Islands, would throw much light on marine zoology, thus pointing to the scene of the subsequent important work carried on by Carpenter and Wyville Thomson, and Murray and Tizard.

In I 844 Lovèn carried Lovèn. on researches on the distribution of marine organisms along the Scandinavian coasts, confirming and extending the observations recorded by Forbes, and in I 845 Johannes Müller commenced to study the pelagic life of the sea by examining samples of sea-water and by means of the tow-net, thus giving a great impetus to the study of marine biology.

In I845 Sir John Franklin set sail on his ill-fated North John Franklin Polar Expedition, accompanied by Harry Goodsir, who recorded and Goodsir. the results of dredging in depths of 300 fathoms.

In 1846 Spratt took dredgings in the Mediterranean down spratt. to a depth of 3 IO fathoms; he afterwards brought up shellfragments from a depth of 1620 fathoms in the Mediterranean.

In 1850 Michael Sars published the results of his dredgings Michael Sars off the coast of Norway, giving a list of $\mathrm{I} 9$ species living at and $\mathrm{G}$. $\mathrm{O}$. 
depths greater than 300 fathoms. He was afterwards assisted by his son, G. O. Sars, in carrying on this work, and in I 864 they gave a list of 92 species living in depths between 200 and 300 fathoms, and showed a few years later that marine life was abundant down to depths of 450 fathoms.

Mac. Andrew.

In 1856 MacAndrew published the results of his observations on the marine Mollusca of the Atlantic coasts of Europe and northern Africa, giving a list of 750 species obtained in his dredgings, which covered 43 degrees of latitude.

United States Coast Survey.

Bailey.

Maury.

Brooke's sounding apparatus.

Maury's map of North Atlantic.
The oceanographical researches of the United States Coast Survey may be said to date back to 1844 , when the Director, Bache, issued instructions to his officers to preserve the deposit-samples brought up by the sounding-machine. J. W. Bailey studied these deposit-samples, and published the result of his examination in 1851 , followed in 1856 by other papers on deposits and on the formation of greensand in modern seas.

The name of M. F. Maury, of the United States Navy, was for a long period associated with the hydrographical work of the United States. He issued several editions of his Sailing Directions to accompany the wind and current charts published by the U.S. Hydrographic Office, the last edition appearing in I 859. About this time the need was felt for an improved and more trustworthy method of sounding in deep water, and various attempts were made to devise forms of apparatus to replace the heavy weight attached to a line which had to be let down and then drawn up to the surface again, the difficulty being to know when the weight touched the bottom. This problem was finally solved by Midshipman Brooke, who conceived the idea of detaching the weight used to carry down the sounding lead upon striking the bottom, the sounding tube, enclosing its deposit-sample, being alone drawn to the surface. He used a spherical weight (a bullet), with a hole passing through the centre to receive the sounding tube, suspended by a cord to the upper part of the sounding tube; on touching the bottom the cord was thrown off its support and remained at the bottom along with the weight. With the aid of Brooke's sounding apparatus, the records of deep-sea soundings rapidly accumulated, and enabled Maury to prepare the first bathymetrical map of the North Atlantic Ocean, with contour-lines drawn in at $1000,2000,3000$, and 4000 fathoms, which was published in 1854 and is reproduced in Map I. The deposit- 


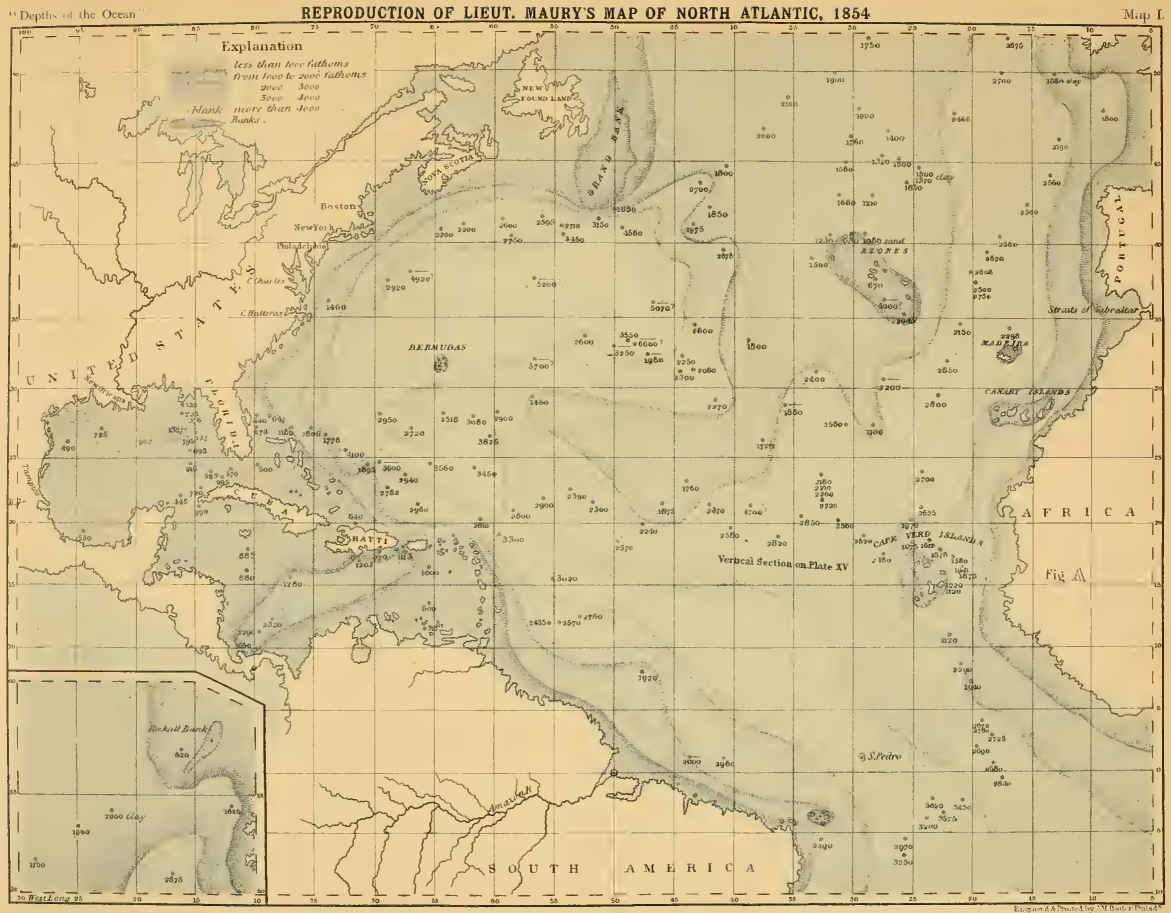



samples procured were examined and described by Bailey and Pourtalès. by Pourtalès, the results being of great importance and interest. Systematic soundings in the North Atlantic were commenced by Lee in the U.S.S. "Dolphin" in $\mathrm{I}_{5} \mathrm{I}-52$, and continued in the same vessel by Berryman in $18_{52-53}$. In 1856 Berryman on the U.S.S. "Arctic" sounded across the North Atlantic from Newfoundland to Ireland, with the object of verifying the existence of a submarine ridge, along which it was proposed to lay a telegraph cable; his deposit-samples were described by Bailey.

In 1857 Pullen and Dayman in H.M.S. "Cyclops" ran a Pullen and line of soundings along the great circle from Ireland to Newfoundland, a little to the north of Berryman's line. A modification of Brooke's sounding-machine was used, in which the spherical weight was replaced by a cylindrical one suspended by wire instead of cord, and with a different valve for collecting the deposit. The deposit-samples were examined and described by Huxley, who found in the bottles a viscous Huxley. substance, described by him as Bathybius, which was subse- Bathybius. quently shown by the "Challenger" observers to be a chemical precipitate thrown down from the sea-water associated with the deposits by the alcohol used in their preservation.

In 1858 Dayman in H.M.S. "Gorgon" sounded across the Dayman. North Atlantic from Newfoundland to the Azores, and thence to the south-west of England.

In 1860 Sir Leopold M'Clintock on board H.M.S. "Bulldog" surveyed the route for the telegraph cable between England and America, in the region previously sounded by Berryman and Dayman. He was accompanied by G. C. Wallich, who published in $\mathrm{I} 862$ an interesting account of the very important observations he made during the cruise on life in deep water and on the deposits covering the floor of the North Atlantic.

In I860 a telegraph cable laid along the bed of the Mediterranean gave way at a depth of 1200 fathoms, and was raised for repair by Fleeming Jenkin, who brought up to the surface portions of the cable about forty miles in length, to which living organisms were found attached. Corals were growing on the cable at the place where it broke in 1200 fathoms, and other forms were adhering to the cable where it had lain in lesser depths, including molluscs, worms, bryozoa, alcyonarians, and hydroids, thus establishing beyond all doubt 
the fact that members of the higher groups of animals really lived at great depths in the sea.

Since I86I Swedish and Norwegian expeditions to the Arctic regions and the North Atlantic have been numerous, and during one of these in I 864 many animals were dredged

Torell.

Bocage.

Perceval IVright.

Pourtalès.

Permanence of oceanic and continental areas.

Louis Agassiz. from depths of 1000 to I 400 fathoms by Otto Torell. In the same year Bocage published a paper on the occurrence of the glass-rope sponge (Hyalonema) at depths of 500 fathoms off the coast of Portugal, which was confirmed in I 868 by Perceval Wright, who went there for the purpose and dredged up specimens from 480 fathoms.

From the year I 867 dredgings as well as soundings were carried out under the auspices of the United States Coast Survey by Pourtalès and Louis Agassiz off the coast of Florida, and between Cuba and Florida. Pourtalès took up the examination of the deposit-samples after the death of Bailey, the number of samples collected up to 1870 being nine thousand. Louis Agassiz reported on the results of the dredgings, and compared some of the dredged forms with fossil types; he concluded by stating his conviction that the continental areas and the oceanic areas have occupied from the earliest times much the same positions as at the present day.

In 1868 were commenced a series of short cruises in the North Atlantic and Mediterranean, under the direction of British naturalists, which may be regarded as preliminary and leading up to the great "Challenger" Expedition. Thus in II.M.s. I 868 Wyville Thomson and W. B. Carpenter carried out "Lightning." oceanographical work on board H.M.S. "Lightning," taking Thomson and W. B. Carpenter. dredgings in depths down to 650 fathoms, and showing beyond question that animal life is there varied and abundant, represented by all the invertebrate groups, a large proportion of the forms belonging to species hitherto unknown, others being specifically identical with tertiary fossils hitherto believed to be extinct, or illustrating extinct groups of the fauna of more remote periods. The temperature observations seemed to 
disclose two adjacent regions in which the bottom tem-Peculiar peratures differed as much as $15^{\circ} \mathrm{Fahr}$. $\left(30^{\circ} \mathrm{Fahr}\right.$. in the comperature one region and $45^{\circ}$ Fahr. in the other), and it was con-the Faroe cluded that great masses of water at different temperatures were moving about, each in its particular course, maintaining a remarkable system of oceanic circulation, and yet keeping so distinct from one another that one hour's sail might be sufficient to pass from the extreme of heat to the extreme of cold.

In I 869 Gwyn Jeffreys was associated with Carpenter and H.M.s. Wyville Thomson in carrying on the work on board H.M.S. "Porcupine," which made three cruises: (I) to the west of Jeffreys, Ireland, where dredgings down to I 470 fathoms were taken; and Thomson. (2) to the Bay of Biscay, where dredgings were taken in depths exceeding 2000 fathoms; and (3) to the Faroe Channel to confirm and extend the "Lightning" observations. In 1870 the "Porcupine" carried on work in the Mediterranean and the Strait of Gibraltar, which was continued in 187 I on board H.M.S. "Shearwater."

About the same time Leigh Smith made several voyages Leigh smith. to the Arctic regions, and, like Scoresby, recorded warmer layers of water beneath the colder surface waters of the Arctic Ocean. ${ }^{1}$

The researches briefly noticed in the preceding paragraphs The paved the way for the special investigation of the physical, chemical, and biological conditions of the great ocean basins of the world carried out on board H.M.S. "Challenger" from December 1872 to May 1876 by a staff of scientific observers. During this period she circumnavigated the world, traversed the great oceans in many directions, made observations in nearly all departments of the physical and biological sciences, and laid down the broad general foundations of the recent science of oceanography. The results of the "Challenger" Expedition were published by the British Government in fifty quarto volumes, and became the starting-point for all subsequent observations.

Contemporaneous with the "Challenger" Expedition was that of the U.S.S. "Tuscarora," under Belknap, in the Pacific Ocean, which contributed greatly to our knowledge of the

"Challenger" Expedition.

${ }^{1}$ Leigh Smith's temperature observations were published in Proc. Roy. Soc. Lond., vol. xxi. pp. 94 and 97, 1873, and in Natural Science, vol. xi. p. 48, 1897. In the former paper IVells quotes a reading of $64^{\circ} \mathrm{F}$. in 600 fathoms and a reading of $42^{\circ} \mathrm{F}$. at 300 fathoms near Spitzbergen, and argues that they indicate the southward flow of a vast body of warm water from the circumpolar region, while in the latter paper Leigh Smith refers to a warm undercurrent running into the Arctic basin between Greenland and Spitzbergen. 
Piano wire used for sounding. Lord Kelvin.

The

"Gazelle."

The "Gettysburg.'

The

"Vöringen."

Alexander Agassiz. The "Blake."

The "Albatross."

distribution of temperature in that ocean and of the deep-sea deposits covering its floor. Piano wire was first used for oceanic sounding work on board the "Tuscarora," though for some years previously Sir William Thomson (Lord Kelvin) had been experimenting with it on board his yacht.

Also contemporaneous with the "Challenger" Expedition was the circumnavigating cruise of the German ship "Gazelle," during which many valuable oceanographical observations were recorded.

In 1876 the U.S.S. "Gettysburg" took a series of deep-sea soundings in the North Atlantic, and in the year's 1876 to 1878 the Norwegian North Atlantic Expedition on board the S.S. "Vöringen" made important physical and biological observations in the seas between Norway and Greenland, making thus the first survey of the Norwegian Sea; the scientific results were published in English and Norwegian.

From 1877 to 1880

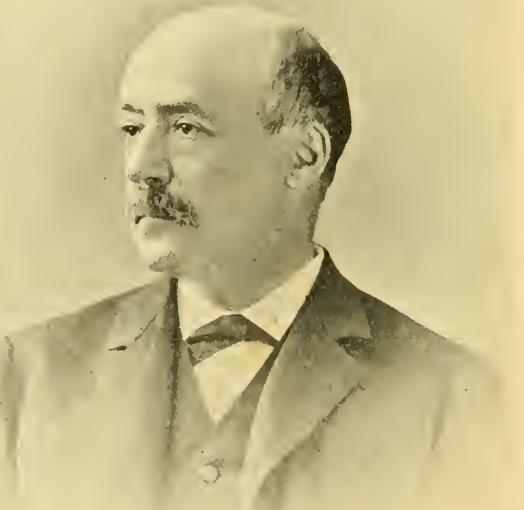

the United States Coast Survey steamer "Blake" explored the Caribbean Sea, the Gulf of Mexico, and the coasts of Florida, under the direction of Alexander Agassiz, who published in I 888 a general account of the results. At the same time the U.S. Fish Commission steamer "Albatross" was engaged in making observations along the Atlantic coast of the United States, and later, in I89I, explored the Panamic region of the Pacific under the direction of Alexander Agassiz.

During the "Challenger" Expedition the naturalists became convinced, as a result of their observations in different parts of the world, that a ridge must separate the bodies of cold and warm water found by the "Lightning" and "Porcupine" 
Expeditions to occupy the Faroe Channel. On the representations of Murray and Tizard, H.M.S. "Knight Errant" in 1880, Murray and and H.M.S. "Triton" in I882, were engaged in re-examining the Faroe Channel. The result was the discovery of the Tizard.

The "Knight Errant." Wyville Thomson Ridge, which separates the warm and cold areas, and accounts for the great difference in the marine faunas in the deep water on either side of this ridge. Detailed lists of the animals obtained by these four expeditions were published in a paper by Murray, ${ }^{1}$ who shows that 2 I 6 species and varieties were recorded from the warm area, and 2 I 7 species and varieties from the cold area, while only 48 species and varieties were found to be common to the two areas.

From I 880 to 1883 the French ships "Travailleur" and The "Talisman" investigated the eastern Atlantic, while from i88 I to ${ }^{8} 88_{5}$ the Italian ships "Washington " and "Vettor Pisani," the former in the Mediterranean and the latter during a circumnavigating cruise, were engaged in biological and other scientific work.

In $\mathrm{I}_{8} 8_{3} \mathrm{~J}$. Y. Buchanan took part in the sounding expedition of the S.S. "Dacia," belonging to the India-Rubber, Gutta-Percha, and Telegraph Works Company, of Silvertown, when surveying the route for a submarine cable from Cadiz to the Canary Islands, which resulted in the discovery of several oceanic shoals rising steeply from deep water; and again in I $885-86$ he joined the same company's S.S. "Buccaneer" while The exploring the Gulf of Guinea, accompanied by a trained naturalist, John Rattray, when valuable observations as to the depth, John Rattray. temperature, density, currents, and plankton were made.

During the years $188_{3}$ to I 886 the U.S.S. "Enterprise" The "Enterbrought together a most important collection of deposit-samples taken throughout a cruise embracing all the great oceans.

From I884 to 1892 Murray investigated the sea-lochs John Murray. along the west coast of Scotland on board his steam-yacht, the "Medusa," and discovered in the deeper waters of Loch Etive "Me "Musa." and Upper Loch Fyne remnants of an Arctic fauna. The physical results obtained were used by Mill in his Memoir on H. R. Mill. the Clyde Sea Area. ${ }^{2}$

Since the year I 885 the Prince of Monaco has carried on Prince of oceanographical work in a systematic manner in the MediterMonaco.

1 "The Physical and Biological Conditions of the Seas and Estuaries about North Britain," Proc. Phil: Soc. Glasgow, vol. xvii. p. 306, I886.

2 Trans. Roy. Soc. Edin., vols. xxxvi, and xxxviii., I891, I894. 
ranean and North Atlantic on board his yachts "Hirondelle," " Hirondelle II," "Princesse Alice," and "Princesse Alice II,"

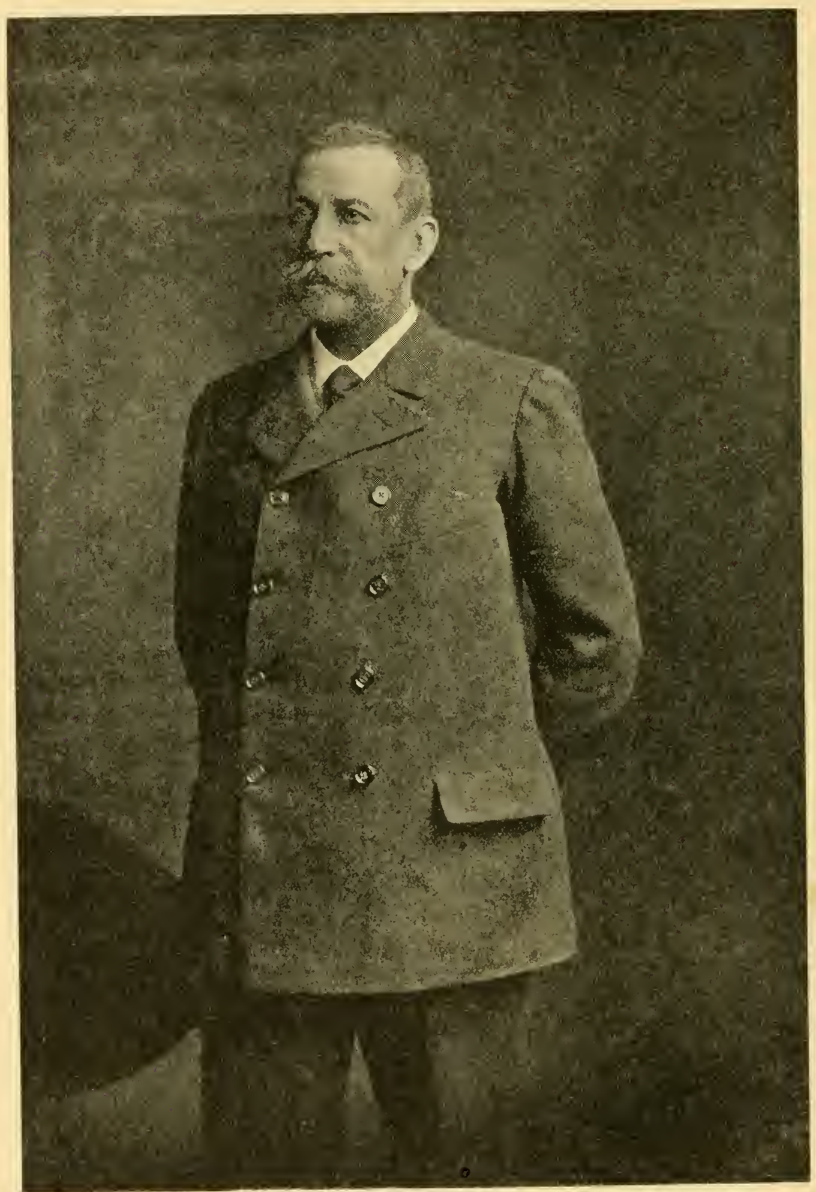

H.S.H. The Prince of Monaco.

and he has founded and endowed a magnificent oceanographical museum at Monaco and an oceanographical institute in Paris; many important memoirs have been issued from the Monaco press. 
From I 886 to I 889 the Russian steamer "Vitiaz," under The "Vitiaz." Makaroff, made a voyage round the world, during which Makaroff: valuable observations on the temperature and specific gravity of the waters of the North Pacific were made, and in 1890 Lebedinzeff Russian scientists, notably Lebedinzeff and Andrusoff, investigated the physical and biological conditions in the deep water of the Black Sea.

In 1889 a German expedition on board the S.S. "National" The was despatched to the

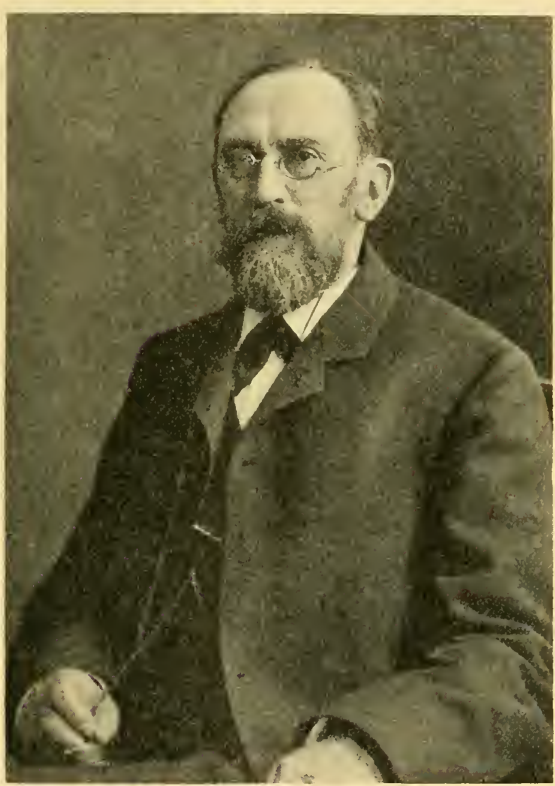

Professor Victor Hensen. North Atlantic, with the special object of studying the plankton (hence called the Plankton Ex- Plankton pedition) by improved Expedition. methods, under the direction of Victor v. Hensen. Hensen, who was accompanied by several other scientific men.

From I 890 till I 898 the Austrian steamer "Pola" made observa- The "Pola. tions in the Mediterranean and the Red Sea, the chemical work being in the hands of Natterer, whopublished Natterer. someinteresting results.

In 1890 systematic observations in the North Sea and adjacent waters were commenced by Swedish investigators under Otto Petters- o. Pettersson son and Gustav Ekman, important results as to temperature, and ${ }_{\text {G. Ekman. }}$ salinity, alkalinity, currents, gases, and plankton being achieved, a summary of which was published by Pettersson in English.

During the years 1893 to 1896 Nansen made his remarkable Nansen's drift drift on board the "Fram" across the North Polar Sea, during "in the which valuable oceanographical observations were taken, his soundings tending to prove that the position of the North Pole is occupied not by land but by a deep sea, as Murray had

$$
1 \text { Scott. Geogr. Mag., vol. x., } 1894 .
$$


previously indicated. His scientific results were published in the English language in six handsome volumes.

The "Ingolf." During I 895 and I 896 the Danish ship "Ingolf" was engaged in the investigation of the northerly portions of the Atlantic, the physical and biological results being published in English.

Survey of Scottish lakes.

John Murray. F. P. Pullar. Laurence Pullar.

Chrystal's observations on seiches.

Temperature seiche.

Vedderburn.

The

"Belgica.

The - Valdivia.

Chun.

The "Nero."

From I 897 to I 909 Sir John Murray, associated at first with F. P. Pullar and afterwards with Laurence Pullar, carried out a bathymetrical survey of the Scottish fresh-water lochs, including detailed physical and biological observations, and the report on the scientific results was published in six volumes in I9I0. During these investigations very careful observations were made by Chrystal on seiches, as a result of which our knowledge of these oscillations and their causes was widely extended. Another kind of oscillation was also discovered, which has been called the temperature seiche. This occurs at the discontinuity layer, where there is a rapid fall of temperature. This temperature oscillation in Loch Ness had a period of about three days, and a maximum rise and fall of about 200 feet. The period of these oscillations is dependent on the difference in density between the upper warm layer and the lower cold layer: the smaller the difference in density, i.e. the smaller the temperature differences in a lake, the longer does the period of the oscillation become. These observations in the Scottish lakes have recently been extended by further systematic work in Loch Earn under E. M. Wedderburn, and have already suggested explanations of phenomena in the ocean, where longperiod oscillations are observed in various depths, and the explanation is probably the same as that given for the lakes.

In the years 1897 to I 899 the Belgian Antarctic Expedition on board the "Belgica" carried on important work. This was the first vessel to winter in the Antarctic regions, and the scientific results are necessarily of great interest and value.

In $1898-99$ the German Deep-Sea Expedition on board the "Valdivia" investigated the physical and biological conditions of the Atlantic and Indian Oceans, penetrating into the Antarctic as far as the ice would permit. The extremely valuable scientific results are being issued in a series of magnificent memoirs under the editorship of Chun, the leader of the expedition.

In I 899 the U.S.S. "Nero" surveyed the route for a telegraph cable between the Sandwich and Philippine Islands by way of Midway and Ladrone Islands, many of the soundings 
being in very deep water, including the deepest cast hitherto recorded, viz. 5269 fathoms, in the vicinity of Guam Island in the Ladrone group. The deposit-samples brought home were examined by Flint, ${ }^{1}$ who records many distinct patches of Flint.

Diatom ooze within the tropics, but Murray has examined these samples, and declares them to be identical with what he has called Radiolarian ooze; the frustules of the large Coscinodiscus rex are, however, very numerous in these deposits.

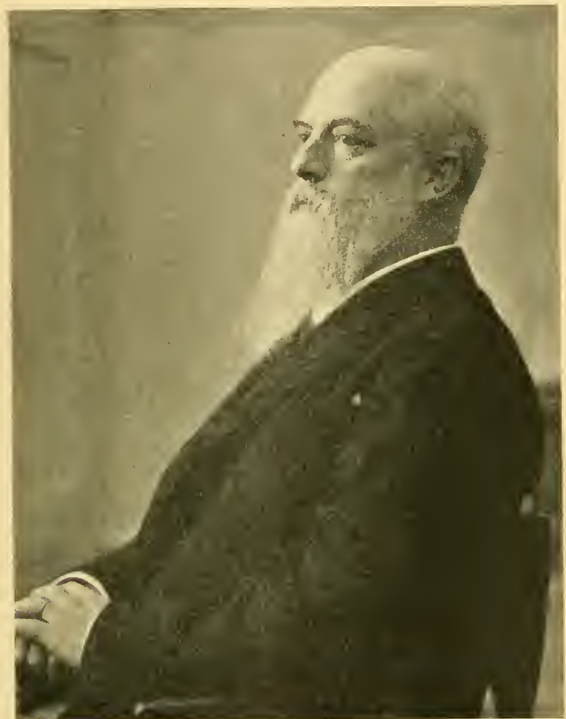

Professor CARL CHUN.

In I 899-I 900 the The U.S.S. "Albatross" "Albatross," carried on oceanographical observations throughout the tropical portions of the Pacific, under the personal direction of Alexander Alexander Agassiz, who issued the Agassiz. scientific results in a series of profusely illustrated memoirs, under the auspices of the Museum of Comparative Zoology, Cambridge, Mass.

In I 899-I 900 the The

Dutch steamer "Sib- "Siboga." oga" investigated the oceanographical conditions in the seas of the Dutch East Indies. Though limited to such a circumscribed area the observations are of great value, and the results are being issued in English, German, or French, under the editorship of the leader of the expedition, Max Weber of Amsterdam.

Max Weber.

During the years I90I to I903 the British National The Antarctic Expedition on board the "Discovery" under Scott, the German South Polar Expedition on board the "Gauss " The "Gauss." under von Drygalski, and the Swedish South Polar Expedition on board the "Antarctic" under Otto Nordenskjöld, were

"A Contribution to the Oceanography of the Pacific," Bull. U.S. Nat. Mus., No. 55, Washington, 1905 . 
simultaneously engaged in the exploration of different portions of the Antarctic regions, and in 1902-1904 the Scottish The "Scotia." National Antarctic Expedition on board the "Scotia" under Bruce. Bruce was likewise busy in the far south. The results of all these expeditions have added very largely to our knowledge of the oceanography of the Antarctic.

The "Edi." Between I9O3 and I9I I the German ships "Edi,"

The

"Stephan." The

"Planet."

The

"Albatross," I904.

Alexander Agassiz.

The

"Nimrod."

Shackleton.

gaged in making scientific observations and pushing south beyond "Stephan," and "Planet" took many soundings throughout the different ocean basins, the last-mentioned recording the greatest known depth in the Indian Ocean.

In IgO4 we find the U.S.S. "Albatross" again carrying on oceanographical work in the eastern Pacific under the personal direction of Alexander Agassiz, the published results constituting a great advance in our knowledge of the Pacific Ucean.

In 1907-1909 another British Antarctic Expedition on board the "Nimrod," under Shackleton, was enanything previously attained. The biological work was under James Murray. the direction of James Murray, formerly of the Scottish Lake Survey, and the results issued under his editorship are excellent in quality.

The

"Français."

The

"Pourquoi pas?"

The

"Deutschland."

Mention may also be made of the two French Antarctic Expeditions under Charcot, the first from 1903 to 1905 on board the "Français," and the second from I908 to I9I0 on board the "Pourquoi pas?" Still more recently the German Antarctic Expedition of IgI I on board the "Deutschland" has, during the outward voyage, taken valuable serial 
temperatures and salinities off the Atlantic coast of South America.

In addition to the specific expeditions referred to in the foregoing paragraphs, many British surveying and cable ships have been busily engaged during the past thirty years amassing valuable information regarding the depth of the ocean in various parts of the world. Temperature observations were also included in the work carried on by H.M. surveying ships, and by some of the cable ships when accompanied by scientific men like J. Y. Buchanan and R. E. Peake. The principal British surveying ships. ships and the oceans investigated by them may be here briefly enumerated :
H.M.S. "Egeria"
H.M.S. "Waterwitch"
H.M.S. "Rambler"
H.M.S. "Penguin"
H.M.S. "Stork"
H.M.S. "Investigator"
Atlantic, Indian, and Pacific
I 887 to I 899
I 894, , I 90 I
I 888 " 1904
Indian and Pacific
I 890 , I 906
Indian and Atlantic
I 888, , I 897
Indian Ocean
From 1886 to the
H.M.S. "Dart"
Pacific Ocean
present time
I 888 to 1902

Other ships were engaged in one or other of the great oceans for shorter periods, including H.M.Ss. "Myrmidon," " Marathon," “Flying Fish," "Goldfinch," "Sealark,” "Sylvia," "Fantome," and "Mutine."

Of British cable ships mention may be made of the British cable following :ships.

S.S. "Britannia"
S.S. "Great Northern"
S.S. "Chiltern"
S.S. "Amber"
S.S. "Scotia"
S.S. "Seine"
S.S. "Electra"
S.S. " Vohn Pender"
S.S. "Duplex"
S.S. "Silvertown"
S.S. "Retriever"
S.S. "Sherard Osborn"
S.S. "Recorder"
S.S. "Dacia"
S.S. "Ninia"
S.S. "Norseman"
S.S. "Buccaneer"

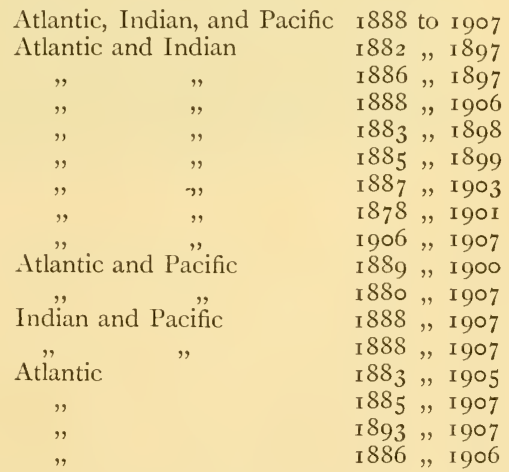

Many other ships were engaged for shorter periods, including 
S.Ss. "Westmeath," “ Roddam," “Volta," “ Mirror,” " Viking,' "Grappler," “Faraday," “Anglia," “Newington,” “ Henry Holmes," "Cambria," “International," "Clan McNeil," "Patrick Stewart," "Cruiser," "Colonia," "Magnet," etc.

It is quite impossible in this brief review even to mention the names of all the investigators and authors who have during the past thirty years made important original contribu-

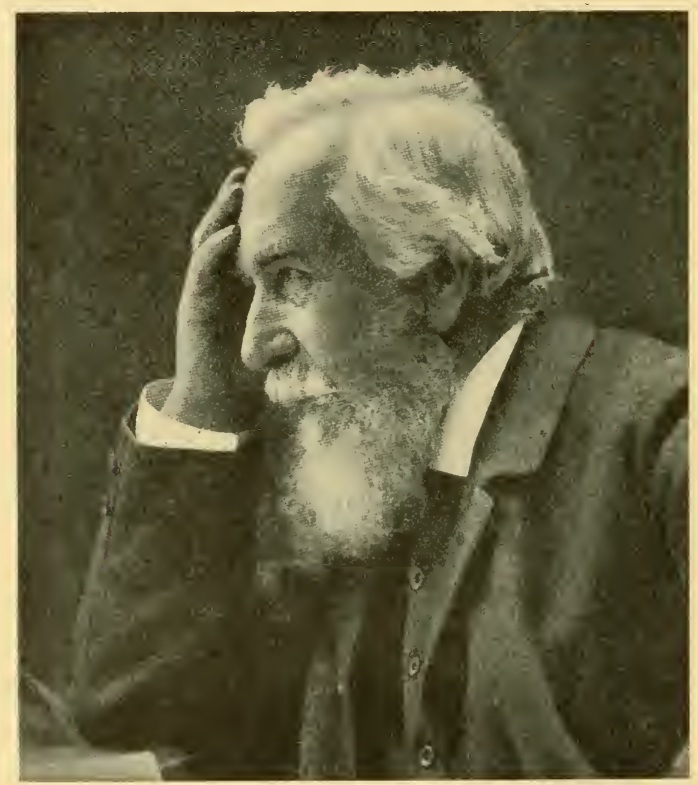

Professor ERnst Haeckel.

tions to the science of oceanography. Among those who have not taken an active part in extensive explorations and expeditions, but whose influence on the development of the Ernst science has been very great, the names of Ernst Haeckel 1 laeckel. and Anton Dohrn should be mentioned. Through his voluminous publications on the radiolaria and on other marine groups in the "Challenger" Reports, through his charming Plankton-Studien, and through his more popular writings, Haeckel has created a widespread interest in all marine 
investigations among the intelligent reading public of the whole world.

Although small and more or less permanent marine laboratories had been established on various parts of the European and American coasts previous to I88o, it must be acknowledged that the foundation of the Zoological Station at Naples in that year by Anton Dohrn marks an era in all that concerns the histology and embryology of marine organisms, and these studies have in turn given a great impetus to the systematic investigation of many purely oceanic problems.

Similar marine laboratories have since been founded in many parts of the world, some for researches of purely scientific

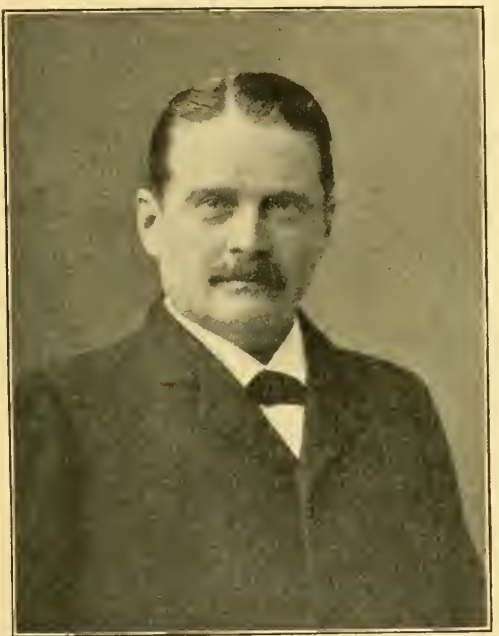

Professor Otto Pettersson. interest and others for the investigation of economic questions connected with the study of the habits and development of the food fishes.

By far the most important of these organisations was that resulting from an International Hydrographic Congress held in Stockholm in I 899, which was largely brought about by the exertions of Otto Pettersson. Pettersson. An International Commis- International

sion for the Scientific In- North Sea vestigation of the North Sea was established, the participating countries being Great Britain, Germany, Holland, Belgium, Russia, Denmark, Sweden, and Norway. Many important researches have been undertaken, and many elaborate reports have been issued by the scientific staffs of each of the countries concerned. This international work, which has been carried on for over ten years, and is still in operation, has given a great impulse to nearly all departments of oceanic science, one result among the many others being the organisation of the "Michael Sars "Expedition in the North Atlantic in I9ro, to an account of which this Hydrographic Congress, I899. volume is chiefly devoted. J. M.

The " Michael Sars" North Atlantic Expedition, 1910. 


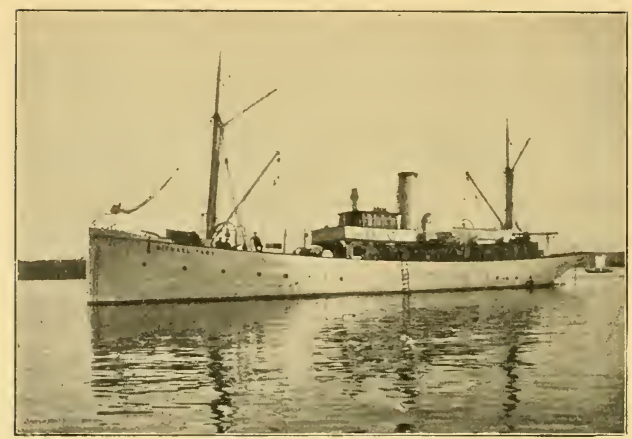

S.S. "Michael SaRs."

\section{CHAPTER II}

THE SHIP AND ITS EQUIPMENT

Difficulties experienced in making deep-sea observations.
Importance of development of mechanical aids in deepsea work.

Iт has often been said that studying the depths of the sea is like hovering in a balloon high above an unknown land which is hidden by clouds, for it is a peculiarity of oceanic research that direct observations of the abyss are impracticable. Instead of the complete picture which vision gives, we have to rely upon a patiently put together mosaic representation of the discoveries made from time to time by sinking instruments and appliances into the deep, and bringing to the surface material for examination and study. Our difficulties are greatly increased by the fact that it is impossible to watch our apparatus at work. A trawl, for instance, is lowered to a great depth, and a few fathoms below the surface it disappears from view; later on it is brought on board and found to be empty. Is this because there was nothing to catch where it was operating, or has it somehow or other got out of order, or failed to reach the bottom, or met with some similar mishap, and so been prevented from catching anything? These questions can only be answered by examining the trawl when once more on deck, and drawing one's conclusions accordingly.

Obviously, therefore, the progress of oceanography depends to a great extent upon the development of mechanical aids, by which we mean not only the scientific instruments employed, but also the whole arrangements of the ship itself. To be able 


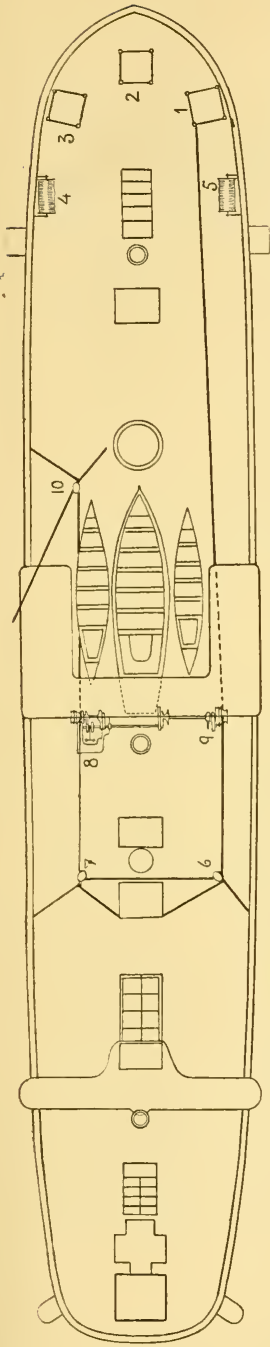

Fig. I.-DECK ARrangeMENT ON BOARD THE "Chai.LENGER."

to haul in some thousands of fathoms of line within reasonable time would be quite out of the question without a steam-winch, and it is precisely because the use of steam first made it possible to examine properly the vast marine areas of the world that oceanic research is such a comparatively new science. The cruise of the "Challenger," the first great expedition specially fitted out to investigate the ocean, took place during the years $1872-76$. Since then oceanography has made giant strides, and we have now many appliances at our disposal that were unknown to the pioneers of those days.

It is interesting to compare our modern methods with those of the "Challenger" Expedition, for we can then see what great advances have been made, and realise to what extent we have availed ourselves of the scientific inventions of our times. A critical examination of the mode of working adopted by the "Michael Sars" will be of use in this connection.

The "Challenger" was a spar-deck The " corvette of 2306 tons displacement, with an auxiliary engine of $\mathrm{I} 234$ indicated horsepower. The length of her deck was 226 feet, and her greatest breadth was 36 feet.

Almost amidships on her main deck, and just before the main mast, was a big steam-winch of i 8 horse-power, with a long axle that extended right across the ship and carried large end-drums (see Fig. I, 8). Hemp lines were used, which were hauled in by being passed round the end-drums.

The sounding-line was operated by two large reels on the forecastle, 5 feet long and $2 \frac{1}{2}$ feet in diameter (4 and 5), 3000 fathoms of line, one inch in circumference, Methods to each reel. The breaking strain was employed on about 700 kilos ( 44 cwt.), and the weight

"Challenger" Expedition. 
of 3000 fathoms of line in water was roughly io8 kilos. When heaving the lead the weight used was sometimes I5O and sometimes 200 kilos. During the whole of the voyage of the "Challenger" only two temperature lines with eight thermometers, and nine sounding-lines with thirteen thermometers, were lost; eleven thermometers collapsed under high pressure at great depths.

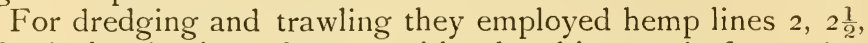
and 3 inches in circumference, with a breaking strain from 1600 to 2550 kilos, spliced together to form a length of 4000 fathoms, which was coiled on the forecastle (1, 2, and 3). An attempt was made to use swivels to keep the line from twisting, but this had to be abandoned owing to their being damaged in the blocks.

It is evident that in the arrangement and working of all the apparatus account had to be taken of these immense lengths of line. In the first place, they were extremely bulky, and required a large amount of deck space for coiling and handling, as the line had first to be led from the forecastle to the winch, and frequently from the end-drum on one side of the axle to its fellow on the other side, when the strain on the dredging rope was so great that the friction of the revolving drum was not sufficient to make it bite. This happened sometimes even when ten or twelve men were holding on abaft the winch. A second important consideration was the severe strain on the line every time the big heavy ship lurched, or when the lead or the dredge stuck fast on the bottom.

The weight of 3000 fathoms of sounding-line in water was, as already stated, over Ioo kilos, and the weights amounted to 200 kilos, so that there was not much margin left for friction in the water and accidental jerks, when we remember that the breaking strain was only 700 kilos. Accordingly, when sounding or trawling great care had to be taken to provide against such contingencies, and large accumulators were used, consisting of rubber bands 3 feet long and $\frac{3}{4}$-inch thick, which could be extended to 17 feet, and thus counteracted sudden jerks on the line. For sounding, forty of these were employed, while for trawling there were as many as eighty, which together could support $2 \frac{1}{2}$ tons, or the breaking strain of the line.

Fig. 2 shows the two accumulators, one for sounding and the other for trawling, attached to blocks high up on a yard, thus enabling them to expand and contract freely.

Before sounding all sail was taken in, and the ship was 
brought head to wind by means of her engine to keep her from Method of drifting off too much. With three or four heavy weights of sounding.

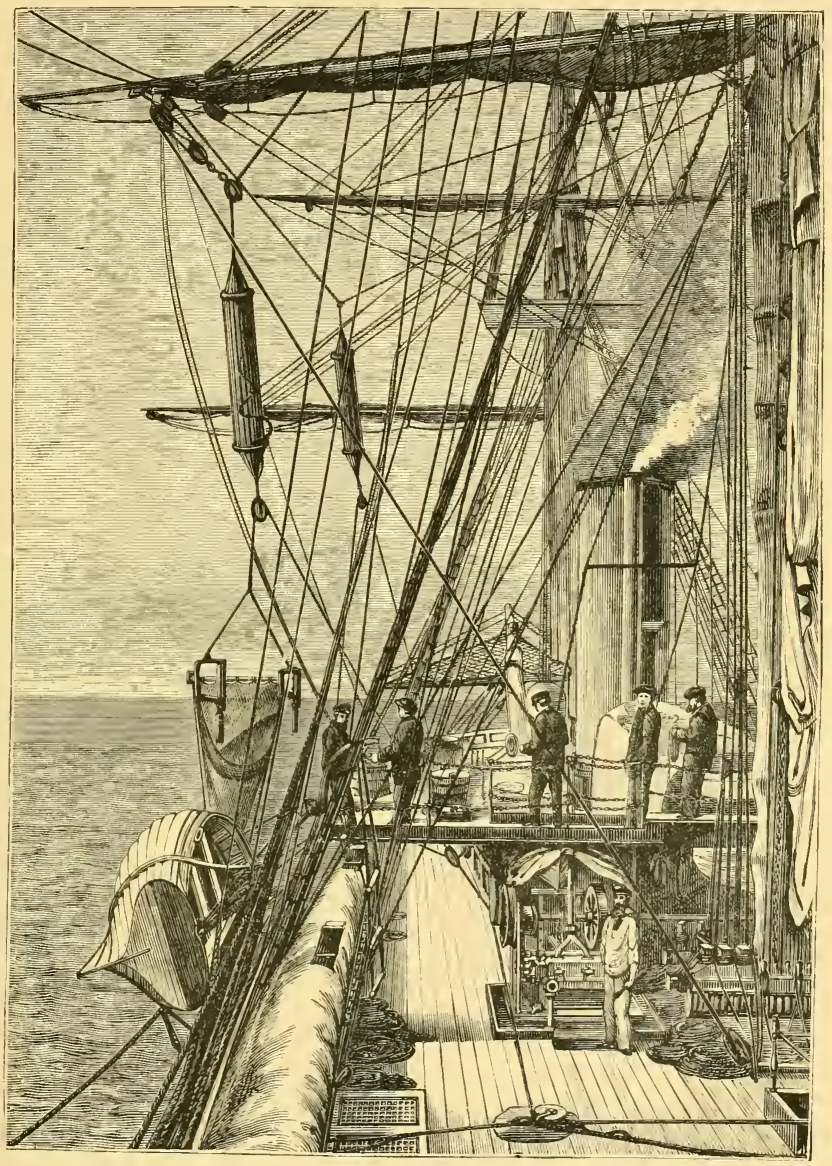

Fig. 2. -SOUNDING AND TRAWling ON BOARD THE "Challenger."

50 kilos each attached, the sounding-lead was heaved, and the apparatus was so constructed that the weights slipped off upon reaching the bottom, thus doing away with the necessity' of hauling the entire mass up again. The Baillie sounding 
Time required for sounding in deep water.

machine (Fig. 3) was the one in general use on board the "Challenger."

From the Narrative of the Cruise we get the following particulars regarding the time a required for sounding in deep water :-

Station 81. Began sounding 5 P.M. ; found bottom at 2675 fathoms; finished hauling in at 6.20 P.M.

Station 225. Began sounding I 2.3O P.M. ; found bottom at 4475 fathoms; finished sounding at 3 P.M.

We see, therefore, that sounding in about 3000 fathoms took nearly an hour and a half, whereas for about 4500 fathoms two and a half hours were required, which must be considered very quick work. On the same line and with the same arrangement as for sounding, series of temperatures were taken and deepwater samples obtained.

Method of dredging and trawling.

Heavy lines and strong accumulators were, however, necessary for the dredge and trawl, which were each fastened to a stout 2-inch line, paid out through a block attached to the big accumulator (see Fig. 2). From 300 to 500 fathoms first ran out, then a weight of about 8o kilos was allowed to slide down the line till it was stopped just a little in front of the appli-

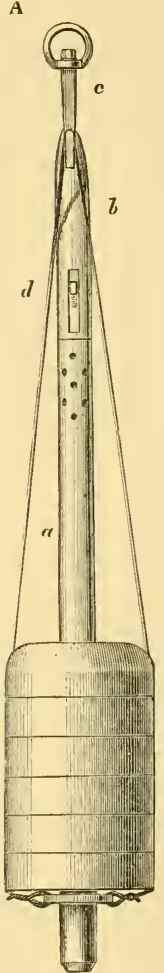
B

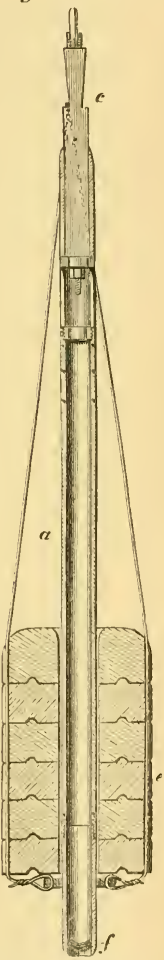

Fig. 3.-Baillie Sounding Machine. The tube $(f)$ was generally made to project 18 inches below the weights $(e)$. ance. The weight consequently reached the bottom before the appliance, with the result that this latter merely skimmed the ocean floor.

All this time the ship lay with her head to the wind to enable the appliance to reach the bottom, for which operation about three hours were required. When all was in readiness the ship was allowed to drift with the wind abeam, and thus towed the dredge or trawl along. 
Hauling in was done rapidly, as will be seen from the following extracts :-

Station 79, depth 2025 fathoms. The dredge was lowered at I I A.M., and 2800 fathoms of line paid out; at 4 P.M. commenced hauling in, and the dredge came up at 5.45 P.M.

Station 244, depth 2900 fathoms. The trawl was lowered at 4 A.M., and 3500 fathoms of line paid out; commenced hauling in at noon, and the trawl came up at 3.50 P.M.

Thus in the course of twelve hours it was possible to carry out a successful trawling at a depth of about 3000 fathoms.

With such means as they had then at their disposal-a sailing ship with auxiliary engine and hemp lines-it was scarcely possible to devise a more thorough system of working. During the whole three and a half years, when trawlings and dredgings were made at 354 stations, there were only eleven cases of the parting of the dredge or trawl line. But gear of this kind necessitated lavish space and a large number of hands, both of which were generally to be had on the old sailing ships. It entailed ample space on deck for the coils of line and high masts for the accumulators, while numbers of men were needed to coil the lines and to hold on abaft the end-drums of the winch. A sailing ship, however, required much less coal than a steamer, which is a great advantage on a voyage round the world.

In the Narrative of the "Challenger" Expedition it is mentioned that at the time the vessel was being got ready for her cruise, Sir William Thomson (Lord Kelvin) was engaged in trying once more to solve the problem of taking soundings with wire instead of with a hemp line, and that a sounding apparatus constructed by him was placed on board just before the ship sailed; the drum, however, collapsed when first used. Notwithstanding this Sir William Thomson continued with the utmost energy, and eventually with complete success, to develop his method, and it was employed by the American sounding vessels "Tuscarora" (Captain Belknap) and "Blake" (Captain Sigsbee). Wire has great advantages over a hemp line, firstly, because it enables soundings to be taken more quickly, since the steel wire meets with far less friction in the water; and secondly, because it requires much less space.

Fig. 4, which is taken from Sigsbee's excellent book, ${ }^{1}$ Advantages of represents sections of the hemp lines used by the "Challenger," wire over

1 Sigsbee, Deep-Sea Sounding and Dredging, Washington, I880. 
Thomson's sounding machine.

Precautions necessary in making soundings.

and of the steel line (piano wire) afterwards adopted for sounding. It will be obvious at once what a saving of space is obtained by the use of a steel line. This will be clear, too, if we look at Sir William Thomson's sounding machine, the principle of which is clearly illustrated by the following instructive figure from Sigsbee's book (Fig. 5).

The wire is wound in by a large wheel consisting of a drum 2 feet 6 inches in cir-

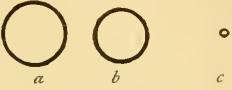

Fig. 4.-SOUNIING-LiNE A.ND WIRE.

$a$ and $b$, Circumference of the hemp sounding-line of the "Challenger" ; $c$, piano wire. (From Sigsbee.) cumference between two thin galvanised iron plates 6 feet in circumference, the object of making this wheel of such a size being to enable the line to be paid out and hauled in quickly.

In taking soundings the art consists in getting the wheel and line to stop the moment the plummet touches the bottom.

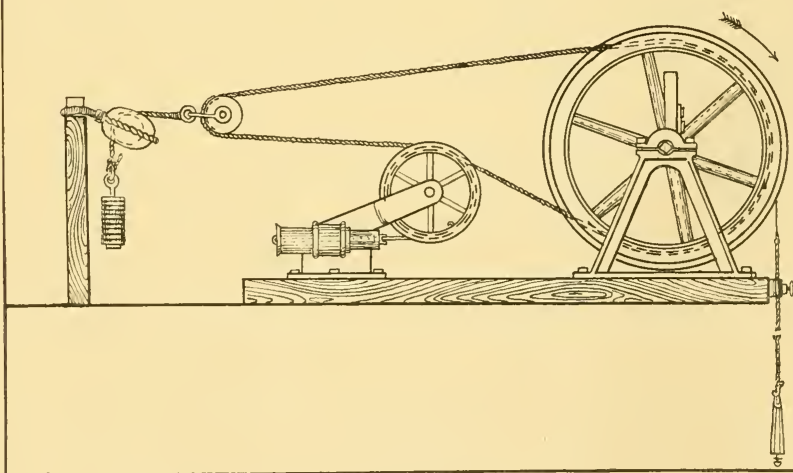

Fig. 5.-Thomson's Sounding Machine. (From Sigsbee.)

The line drifts when free of the lead, as it is, of course, relieved of the weight as soon as the bottom is reached, but there still remains the weight of the line itself, while the momentum of the wheel will cause it to continue revolving for a little while. The wheel must consequently be made as light as possible, and a resistance of some sort must be provided, rather stronger at 
any moment than what is necessary to counteract the weight of the length of line paid out. Thomson obtained this by means of a brake, a hemp line running in a separate groove at the side of the big wheel, and passing from there to a block, through which the brake could be tightened by means of weights.

Sir William Thomson used a plummet weigh-
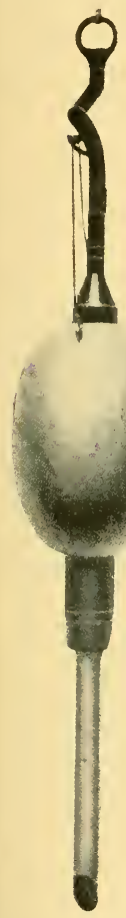

FIG. 6.-SIGSBEE'S SOUNDING - TuBE. (From Brennecke.) ing $34 \mathrm{lbs}$, and commenced his sounding with a counter-weight of ro lbs. on it. This was sufficient to run out the line at the rapid rate of 2000-3000 fathoms in thirty to fifty minutes. Gradually, as more line was paid out, the counter-weight was increased proportionately to the length of wire in the water ( 12 lbs. for each I 000 fathoms of wire), and this caused the wheel to stop almost instantaneously when the bottom was reached. The depth could be ascertained from the number of revolutions on the register. If the wheel did not stop instantaneously, an error would result in the determination of the depth, and if the steel line came into contact with the bottom, it easily kinked, and the plummet was likely to be lost. To obviate this a few fathoms of hemp rope were inserted between the plummet and the steel line.

Obviously this sounding machine is a great advance on the old hemp lines. ${ }^{1}$ Economy of space, smaller weights, greater speed, less friction in the water (and consequently a more perpendicular line, resulting in greater accuracy), are some of the advantages. For this reason Recent attempts have continually been made to improve Thomson's machine, and in the course of time sounding machines. a number of very good sounding machines have been constructed, amongst others those of Le Blanc, Sigsbee, and Lucas. Sigsbee's soundingtube is shown in Fig. 6. All of them are based on Thomson's model; thus Sigsbee says of his own admirable machine: "The modification or improvement made by me on the original Thomson sounding-machine lies chiefly in the employment of a peculiar kind of accumulator, and its adap-

I It is interesting here to observe that the "Challenger" hemp line could be used for sounding in depths down to 26,000 fathoms before reaching its breaking strain, whereas the wire could only be used down to a depth of 16,700 fathoms. Depths beyond 26,000 fathoms, should such depths exist, could not be explored by either method. 
tation to the various uses of accumulators, dynamometer, brake, correct register, and governor."

Lucas sounding machine.

On board the "Michael Sars" we employed the sounding machine constructed by Lucas. It was selected originally because it had been extensively used by the telegraph cable ships, and because it was the smallest and the cheapest. Weights used as brakes in Thomson's machine are replaced by spiral springs, which can be tightened or slackened with a screw, and can at the same time be relied upon in a high sea as accumulators (see Fig. 7, which explains the construction).

During the winter of $1877-78$ the United States Coast Survey steamer "Blake" undertook a cruise in the Gulf of

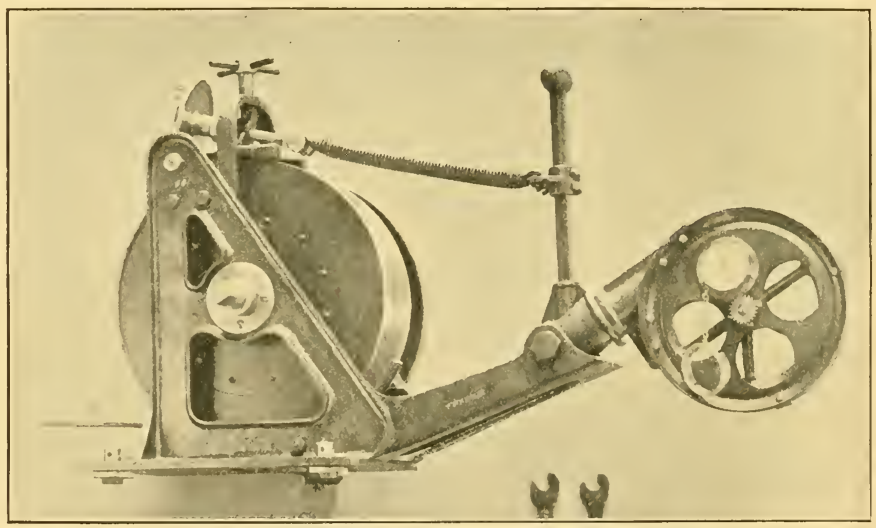

Fig. 7.-Lucas Sounding Machine.

Mexico, under the command of Captain Sigsbee and under the Wire rope for dredging.

personal supervision of the late Alexander Agassiz. As it was proposed to carry out investigations with the dredge and trawl along the bottom, Agassiz suggested the use of a wire rope instead of hemp ropes. Thanks to Sigsbee's inventive genius and practical methods, this plan was successfully adopted, and has since been adhered to by every expedition of any importance.

Fig. 8 shows sections of the "Challenger" hemp lines, 3 inches, $2 \frac{1}{2}$ inches, and 2 inches in circumference $(a, b, c)$, and of the wire rope, $\mathrm{I} \frac{1}{8}$ inch in circumference, used by the "Blake" $(d)$. 
The wire rope consisted of six strands, each made up of

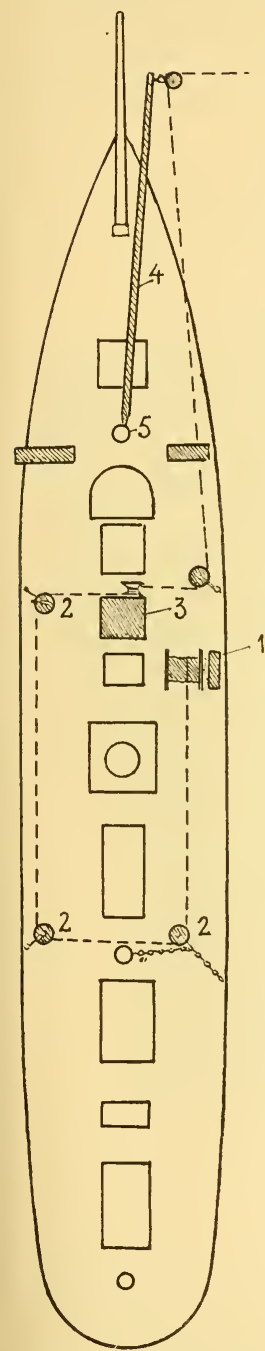

Fig. 9.-DECK ARrANGEMENT OF THE "BLAKE." (From Sigsbee.) seven wires (like piano wires about $1 \mathrm{~mm}$. in diameter), or altogether forty-two wires, with a tarred hemp line in the middle. The breaking strain of the whole was about 4 tons. Its weight per fathom was I.I 2 lbs.
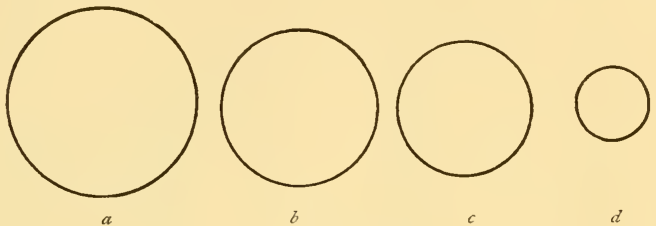

FIG. S.

$a, b, c$, Circumference of hemp lines used for trawling on board the "Challenger," and $d$, of wire rope used for trawling on board the "Blake." (From Sigsbee.)

in the air, and I $1 b$. in the water. We thus get a breaking strain of about 4000 kilos; weight in water of 5000 fathoms 2300 kilos; so that with 5000 fathoms out, there were about I 700 kilos over for resistance (friction) in the water, and for strains due to heavy seas or sticking fast on the bottom. The great strength of this line made it less necessary to use accumulators, and they were only employed occasionally during the "Blake" expedition.

Fig. 9 shows how Sigsbee worked the Method of wire rope on board the "Blake." It was using wire wound round a big drum (I), driven by a small steam-winch, and led from the drum over blocks of considerable diameter (2) to the large steam-winch (3), which had a large end-drum 55 centimetres (22.6 inches) in smallest diameter. From here the line went to a big boom (4) on the foremast (5).

When dredging or trawling the appliance was first lowered to near the bottom, while the ship was stationary, and afterwards the vessel went astern during the process of paying out and dredging. This manner of working was so successful, and conduced to 
such precision, that it may be considered quite the equal of any system adopted by subsequent expeditions. Sigsbee relates that he made one day, off Havana, between 7 A.M. and 5 P.M., as many as ten hauls with the dredge at depths varying from
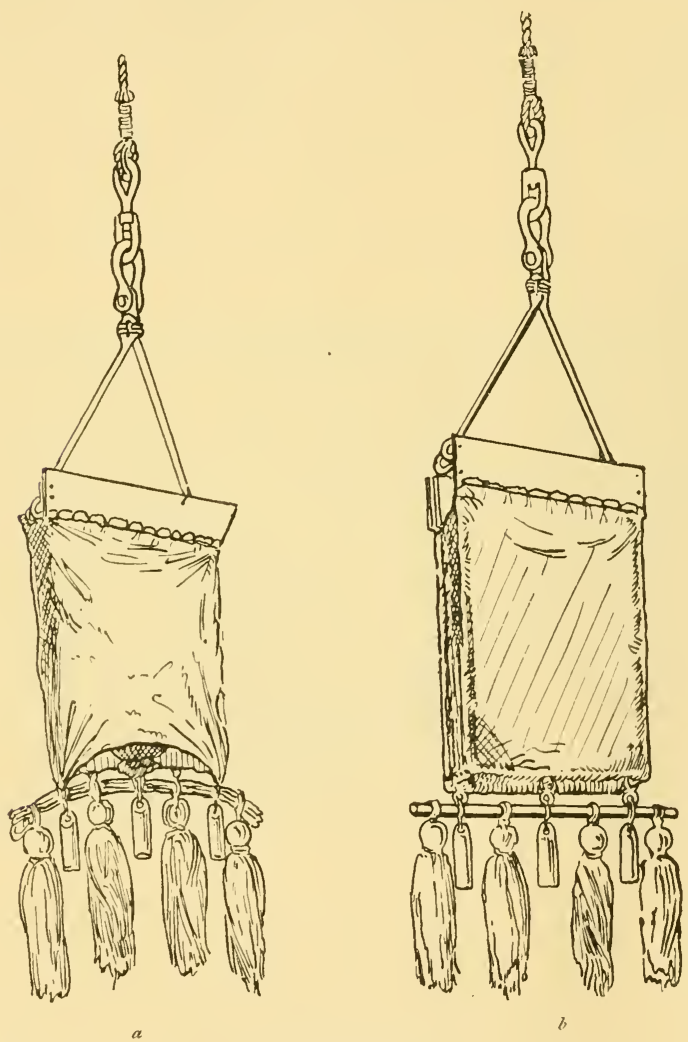

FIG. IO.-DREDGES.

$a$, Previous model ; $b$, Sigsbee's dredge. (From Sigsbee.)

50 to 400 fathoms. Although the bottom was unsatisfactory and the dredge stuck fast every time, he managed to avoid an accident and made very successful catches. He allowed from three to five minutes for lowering or for hauling in a line of a hundred fathoms, and from ten to thirty minutes for the actual 
dredging, the time required for dredging depending, of course, upon the nature of the bottom.

The joint labours of Agassiz and Sigsbee led to a great

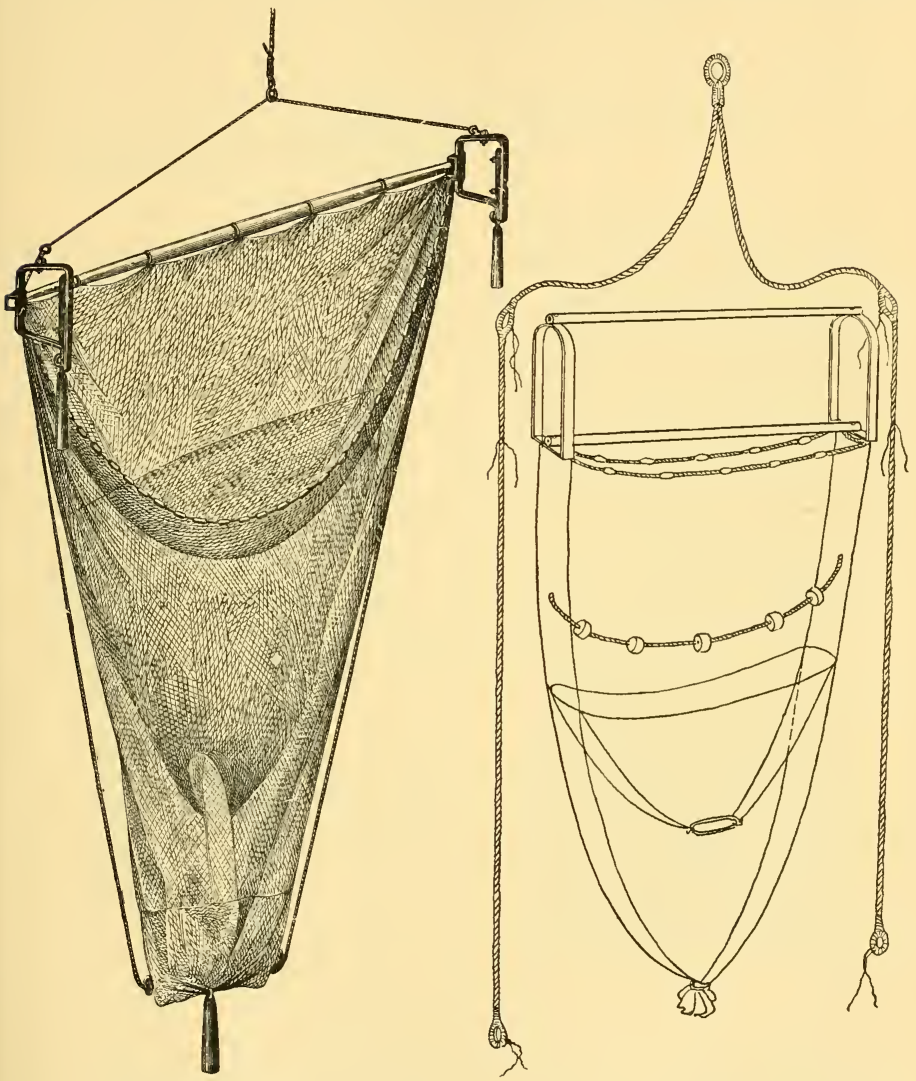

Fig. il.-The "Challenger" Traivl. Fig. I2,-Sigsbee's Trawl. (From Sigsbee.)

improvement in the appliances. Previously the dredges had ploughed into the ocean floor (Fig. Io, $a$ ), but the one employed by Sigsbee (Fig. IO, b) was believed to have skimmed over it, and so collected the animals which lived upon the surface, sweeping them up from a wide extent of ground. Both kinds 
of dredge have, however, their advantages, according to the animals it is desired to procure. "Challenger" The "Challenger" used a trawl (Fig. I I) constructed like the ordinary beam-trawl, which was employed particularly by

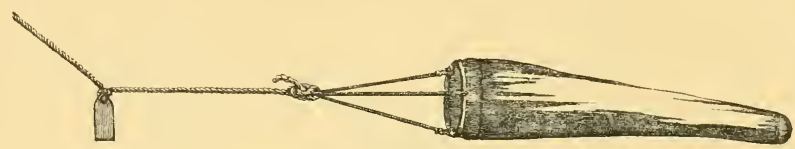

Fig. 13.-Tow-Net fixed AT ENd of Line ("Challenger").

the fishermen in the shallow waters off the flat English coasts. The beams were of different lengths, I7, I3, and ro feet, but the Io-feet length was found to be the best for deep water. It was, however, difficult to tell, when the depth was at all great, whether the trawl had reached the bottom right side up, and whether it was open while being towed. Sigsbee solved this difficulty by having tripping lines on both sides (Fig. I2); otherwise the size of his trawl was identical with that of the "Challenger," viz. Io feet between the runners.

Sigsbee's appliances and methods of working were adopted by the "Valdivia" and other recent expeditions.

Pelagic appliances of the

During the cruise of the "Challenger" the appliances used for making pelagic captures consisted of small nets resembling long nightcaps, of fine muslin or calico, and Io to 16 inches in diameter at the mouth. They were towed at various depths, even as far down as 800 fathoms, with a weight attached a little in front of the opening (Fig. I3), or they were sometimes made fast to the line (Fig. I 4) and lowered to a depth of about 2 miles (over 3600 metres), the object being to ascertain whether or not FIG. 14.-Tow-NET organisms lived in the deeper layers of water FIxED on THELINE different from those captured in the surface layers.

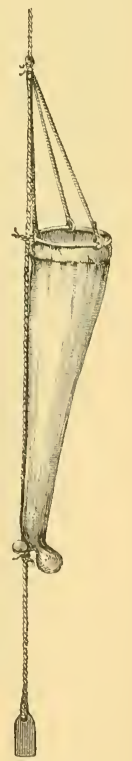

Since the time when the "Challenger" conclusively proved that life was present everywhere in the ocean, not only over the bottom at the profoundest depths, but also in the intermediate layers of water, much labour has been expended upon 
the investigation of the animal life of the sea. The appliances Closing nets for capturing animals at the bottom have undergone only slight for intermedi alterations, whereas many different kinds of contrivances for capturing the pelagic animals have been tried from time to time, some of them being of real practical value.

Chun has done more perhaps than any other naturalist in Chun and the way of studying the vertical distribution of organisms. Petersen Together with Petersen he constructed a vertical net that could

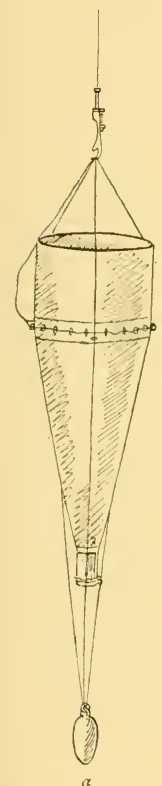

Fig. 15. -NANSen's Closing Net.

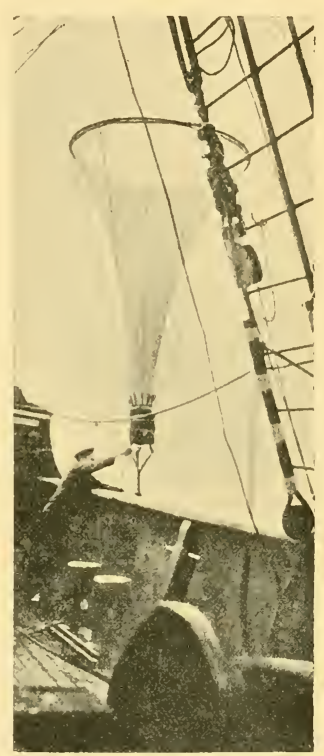

Fig. I6.-ChUN'S NET. (From Chun.)

be let down closed, then opened, and finally closed again, so as to catch the smaller organisms existing in a specified layer of water, say between 400 and 200 metres beneath the surface. Subsequently other closing nets were constructed on the principle of this invention. Fig. I 5 shows Nansen's closing Nansen net open $(a)$, and shut $(b)$, the construction of the net itself closing net. and the closing mechanism being easily understood from the illustrations. It is extremely simple and reliable, and we have tested it in various ways during the cruises of the "Michael 
Sars." We have found that if the appliance is sent down open to a considerable depth, immediately closed and hauled in again, it fails to capture anything, thus proving that vertical appliances need not be closed while being lowered.

For studying the vertical distribution of larger organisms Chun large Chun used during the "Valdivia" Expedition a large silk net, net. 4 metres in length (Fig. I6). By lowering it to different depths

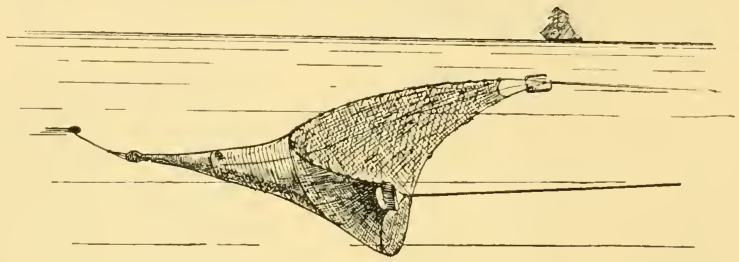

Fig. 17.-Monaco's Pelagic Trawl. (From Steuer.)

and comparing the catches so obtained, he could determine at what particular depths the animals lived, and he succeeded in collecting by this means valuable data as to pelagic deepwater forms.

The Prince of Monaco has also added largely to our

Prince of Mlonaco's pelagic trawl. knowledge of the habitats of the larger pelagic organisms by means of his pelagic trawl (Fig. I 7), which is designed for

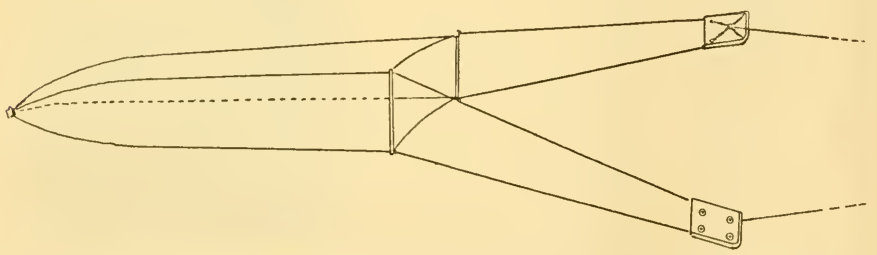

Fig. 18.-C. G. Joh. Petersen's Pelagic Young-Fish Trawl. (From Schmidt.)

being towed horizontally through the water. In addition he made some remarkable captures of large pelagic animals, chiefly cuttle-fish, by shooting whales and examining their stomach contents, for the whale is still far more capable of catching living marine creatures than any scientific appliance hitherto invented.

The young-fish trawl designed by C. G. Joh. Petersen (Fig. 18) is a considerable improvement on the Prince of Monaco's pelagic trawl. It is very easy to construct, and may be of any size or mesh. For catching young fish, etc.; 
he generally uses sackcloth, but a better fine-meshed material would undoubtedly be more desirable.

Hensen evolved various forms of apparatus for a quantitative study of the pelagic organisms, that is to say, for estimating the relative amounts of plankton organisms present in a given volume of water. He recommends vertical nets of the finest

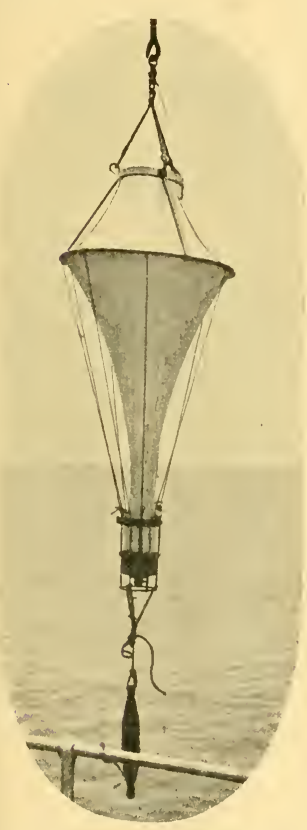

Fig, I9.-Hensen's LARGE Plankton Net. (From Chun.) the utmost value, for instance, in investigating certain uniformly distributed minute species in less extensive areas. The apparatus consists of a filtration net of miller-silk, with a brass cylinder at the lower end of the net, and a large conical part made of canvas, the object of which is to control the amount of water entering and so enable the silk net to filter it.

The steamer "Michael Sars" was built in 1900 by the The "Michael Norwegian Government to undertake researches in connection Sars." with the Norwegian fisheries, and to study the natural con- 
ditions on which they depend. It was therefore necessary to have a vessel capable of making investigations similar to those carried on by oceanic expeditions, and at the same time suitable for practical fishery experiments, which are every year becoming of more and more importance in the work of scientific research. A ship of this kind, however, had to be small, otherwise it was impossible to reckon on sufficient means for its upkeep. Accordingly the size we selected was that of a first-class fishing trawler. Her length is 125 feet between perpendiculars, and she is of 226 tons burden; her engines indicate 300 horse-power, and can give her a uniform speed of Io knots; her coal consumption is small, being about 5 tons per twenty-four hours when going at the rate of 9 knots, and she can carry in her bunkers about 80 tons. As will be seen from Fig. 20 there is plenty of space on deck forward of the engines. The big winch is placed here just abaft the hatch of the storeroom, in which there is cold storage for io tons of fish, and stowage for appliances, instruments, cases of glass bottles, etc. Forward of this storeroom are the cabins of the engineers and mates and the quarters of the crew. Abaft the engines there is a laboratory on deck, and below there are cabins and a messroom for the scientists. The deck is perfectly clear on either side of the deck-house, so that there is ample room for working with appliances and instruments.

Methods employed on board.

If we compare Figs. 20 and $2 \mathrm{I}$ we shall get a good idea of the appearance of the deck of the "Michael Sars." On the starboard side there are two small winches, the forward one of 3 horse-power and the aft one of I horse-power. The forward winch (2), by means of a long axle (see

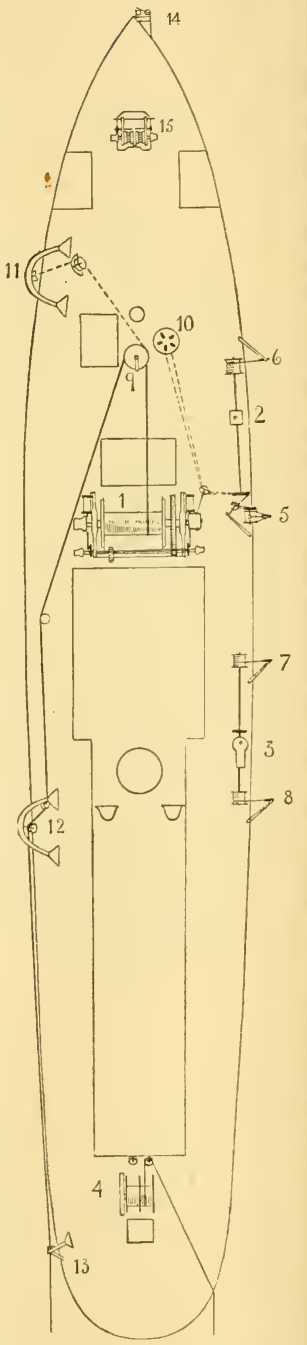

Fig. 20.-DECK ArRANgeMENT ON BOARD THE "MICHAEL SARS." 
also Fig. 22), drives a big reel with 6000 metres of wire, 3.5 $\mathrm{mm}$. in diameter, for the hydrographical instruments and the Lucas sounding machine ( 6 and 5 ), and it can also be used to drive the big centrifuge (Io) by means of a hemp line. By a similar arrangement the aft winch drives two drums with 2000 metres of wire, 3 and $4 \mathrm{~mm}$. in diameter, for the vertical nets and hydrographical work in moderate depths.

In calm weather and when the currents are slight all the appliances may be operated simultaneously, provided care be

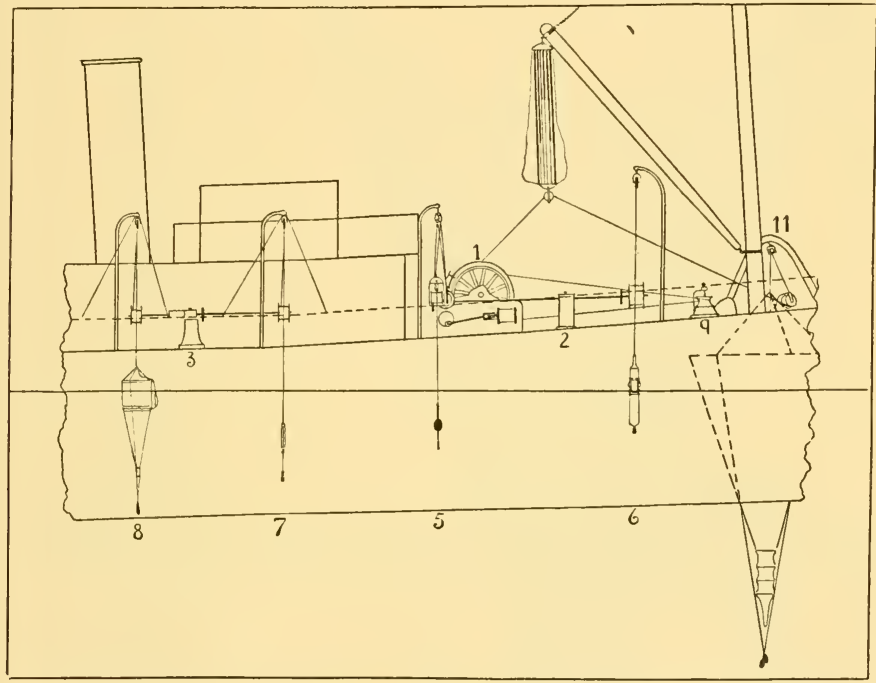

Fig. 21.-Side View of Arrangement of Gear ox board the "Michael Sars."

taken that one appliance, let us say, is lowered while others are being hauled in. But when there are strong currents there is always a danger of the appliances colliding, and it is best in that case to work one at a time from each winch.

For the larger nets and the trawl we use the big winch (I), which takes the long steel line, 9000 metres in length, increasing from $34 \mathrm{~mm}$. to $44 \mathrm{~mm}$. in diameter. When trawling the line passes round the big reel (9), on which there is a register, and from there it is led to the gallows ( 12 and I 3 ) and paid out astern. When operating the big vertical nets, the line is passed round a block in the accumulator, which hangs from 
the boom on the foremast, and is then led to the forward gallows (I I).

Pelagic appliances, to be towed horizontally, are either fastened to the trawl wire like the trawl itself, or else the wire is led round a smaller winch (4), situated abaft the deck-house, and then paid out over the stern.

The vessel may thus tow both steel lines at the same time,

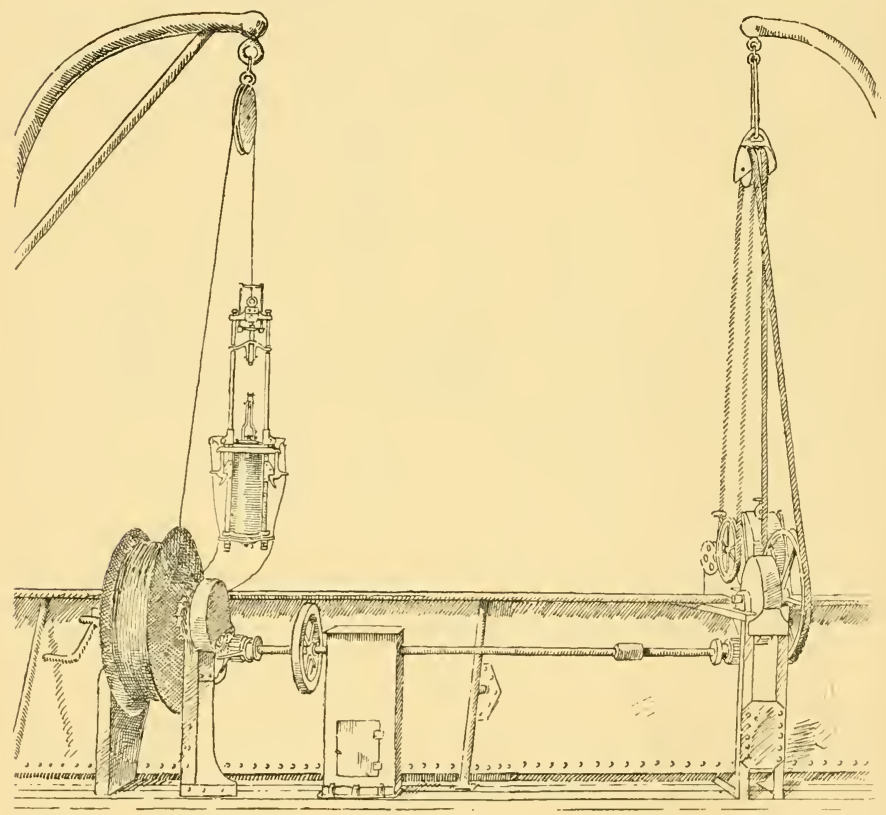

Fig. 22. - The Forward Starboard Winch.

and a number of appliances may be operated simultaneously. This mode of working differs in many ways from the system adopted in former expeditions.

Fig. 22 shows the forward starboard winch. The little Lucas sounding machine may also be seen, fastened quite simply to the rail of the ship, taking up very little space and requiring the attention of only one man. The large Pettersson-Nansen water-bottle, used for hydrographical observations at great depths, is also in a handy position. What simplifies matters 
very much, and enables us to dispense with the big projecting structures, or sounding platforms, that were formerly necessary, is the fact that in our little ship we are so near the surface of the sea that the person taking observations stands only a few feet above the water, and it is consequentl'y much easier to get the appliances on board as soon as they come up. It is much easier also to manœuvre with a little steamer, so as to humour the appliances and keep the lines perpendicular whilst being lowered or hauled in. Obviously these are great advantages, not merely at the moment of taking observations, but also in our whole system of working ; being able to operate a number of appliances simultaneously, for instance, means a great saving of men and time.

In the case of

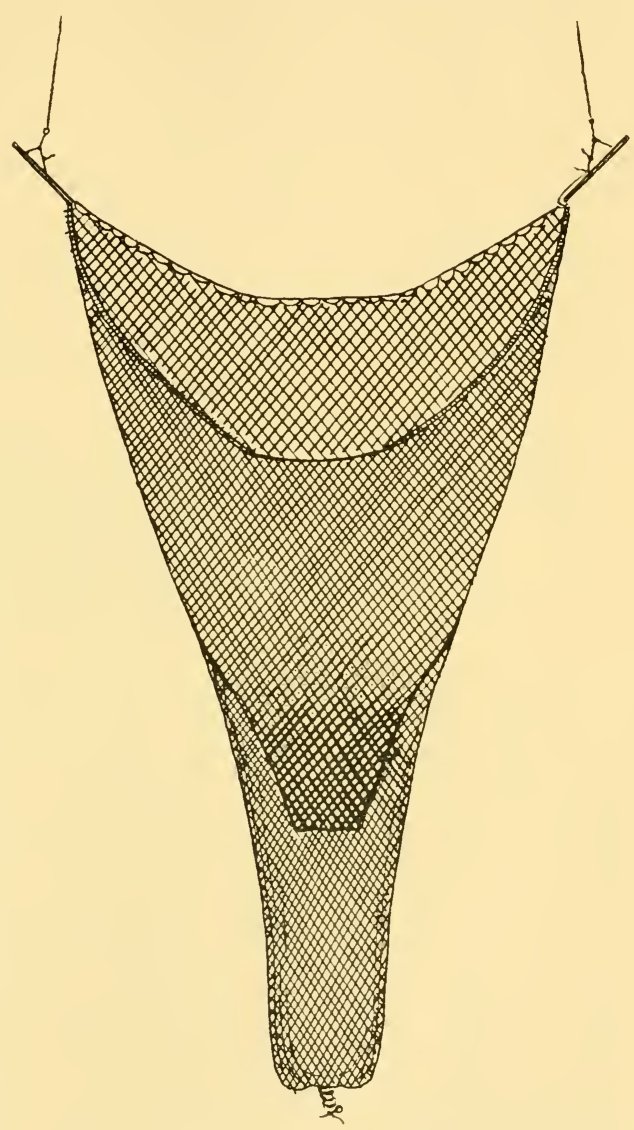

Fig. 23.-The Otter Trawl.

both sounding machine and hydrographical apparatus we are able to haul in the line at the rate of 120 metres per minute, or 6000 metres in fifty minutes. But the forward starboard winch was unfortunately too weak to keep up this 
speed when there was much line out and the weight was considerable.

For trawling, former expeditions employed the model designed by Sigsbee, Io feet in breadth. This appliance, notwithstanding all its good points, is too small for catching large animals. Modern fishing steamers, which are quite small compared with the expedition ships of former days, mostly operate trawls I 20 feet in length, having a span of about 60 to 80 feet, with a height at the entrance many times greater than that of the trawls employed for scientific purposes. Seeing then that a great many trials have been made in all oceans with the dredge and with Sigsbee's trawl, it was advisable to try whether a larger appliance would not yield different species and bigger catches, and it was natural to select as a model the appliance supposed to be best adapted for catching fish, namely, the Otter trawl. otter trawl in use among fishermen.

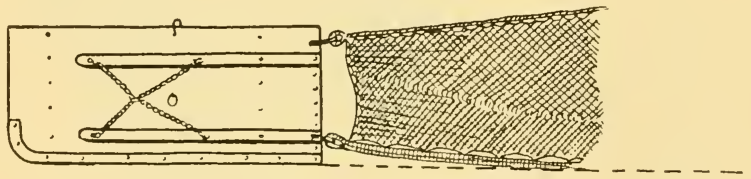

Fig. 24.-The OtTER BOARD.

The difference between the otter trawl (Fig. 23) and the beam trawl (see the "Challenger" trawl, Fig. I I) is that in the case of the former the appliance is kept distended by means of otter boards, working on the principle of an otter for trout fishing or a kite in the air. The otter boards (Fig. 24) are attached to the line by bridles, and thus have a tendency to spread when towed along through the water. The regular trawlers use two steel lines of colossal dimensions, up to 3 inches in circumference and with a breaking strain of 20 tons; these are wound round two large drums that are keyed on to the slow axle of the trawl-winch (see Fig. 25), from which each line passes to its gallows and then astern, being carefully fastened with chains during the time that the vessel goes ahead towing the trawl after it. Sigsbee, it will be remembered, went astern when trawling, and he had one winch for winding the wire round the drum and another for the actual hauling in.

It is quite evident that the system adopted by the regular trawlers economises labour, for it is simple, and space is saved by using only one winch. The otter trawl, again, has to be 
towed at a good speed to keep the boards in position, and the vessel skilfully steered, so that the lines must necessarily be towed from the stern. It was found very difficult, however, to adopt this plan to our requirements, the chief drawback being that everything must be of the very strongest materials. Sir William Thomson long ago, when working at his sounding machine, discovered that the drums were easily burst, and the trawlers too have had similar experiences, in spite of their using drums of cast metal several inches thick.

The "Michael Sars" could not, of course, use such large appliances, for if in addition to overcoming the resistance of two ponderous otter boards, 6 feet by ro feet, she had to tow a pair of wires each many thousands of metres long, she could obviously not have got over much ground; and besides, it would have been next to impossible to prevent such long lines from fouling one another. We were compelled therefore to trust to a smaller size of trawl, and to substitute a single warp, from the end of which we led a connecting line, 50 fathoms in length, to either otter board (see Fig. 26, line and bridle). A similar arrangement for small otter trawls had been already successfully tried by C. G. Joh. Petersen. During previous cruises of the "Michael Sars" we had operated a trawl with 50 feet of headrope at a depth of ${ }_{1} 8_{3} 0$ metres, and during our Atlantic expedition we succeeded in working the same appliance at a depth of 5 I60 metres. Our success must be ascribed to the solid construction of our gear. The drum of the winch which took the 9000 metres of wire was of the best cast steel, and the blocks were made as substantial as possible, though even then they had to be changed during the cruise, because the

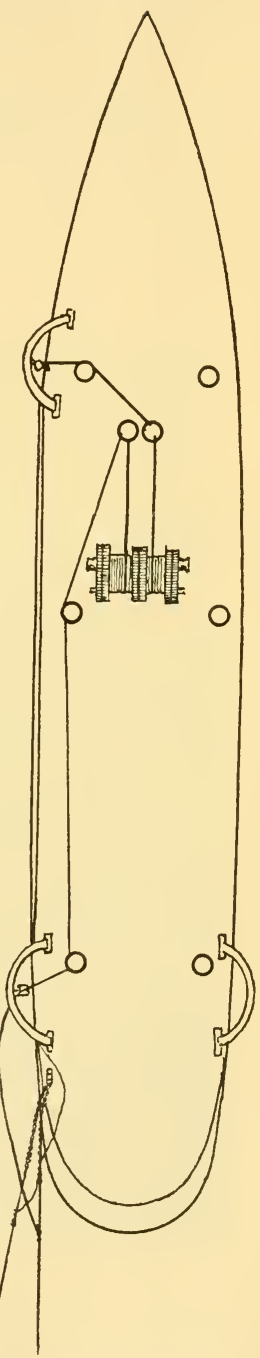

Fig. 25.-DECK ARrANGEMENTS OF A TRAWLER. 
steel wire soon wore deep grooves in them. Our trawlings, too, took a long time, for the 20 horse-power winch that wound in

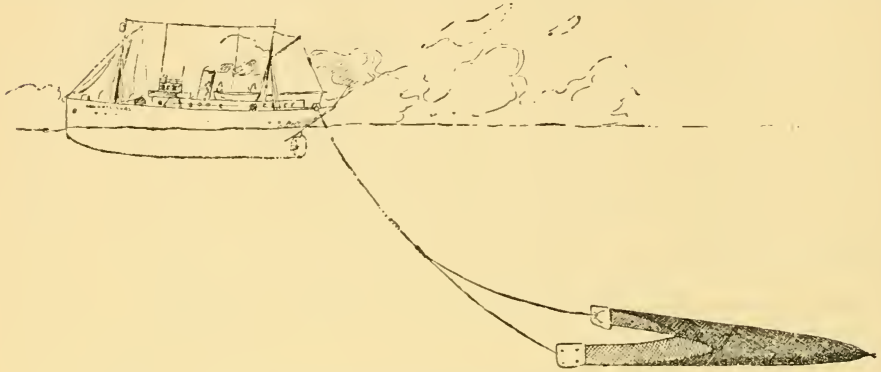

Fig. 26. -THE "MichaEl SARS" TRAWLiNg With ONE Wire Rope AND OTTER TRAIVL.

Time for trawling in deep water.

the wire directly on to the drum was unable to maintain its full speed when the load was unduly heavy.

On 3ist May, at Station 48, the trawl was shot at a depth of

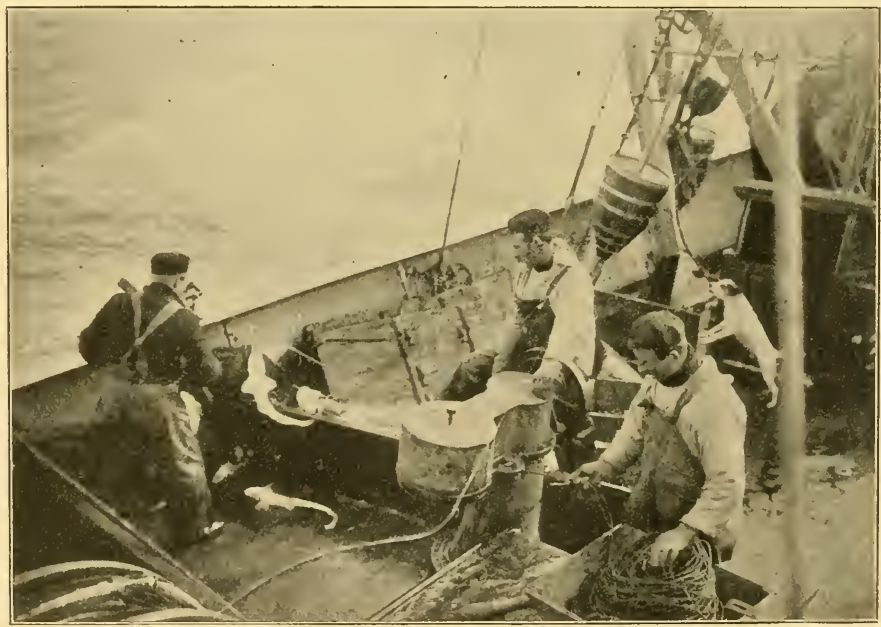

Fig. 27.-Hauling in Long Lines by means of Line Winch.

5160 metres with 8750 metres of wire; we commenced lowering at 5.45 A.M. and started trawling at II.2O A.M.; hauling in began at 2.50 P.M., and the trawl was once more on board at 
9 P.M. Hauling in took, therefore, six hours ten minutes, and the average rate was 24 metres per minute, or about a third of the speed at which Sigsbee hauled in his little trawl.

In addition to the trawl the "Michael Sars" can use lines Lines and and drift nets, in which respect she is equipped like an ordinary drift nets. fishing steamer. The lines are passed out over the stern and hauled in amidships by means of the little after starboard winch, which is really the same as the little winch used for the hydrographical instruments. This is moved forward on the deck, and the lines are hauled in as in Fig. 27. Herring drift nets are

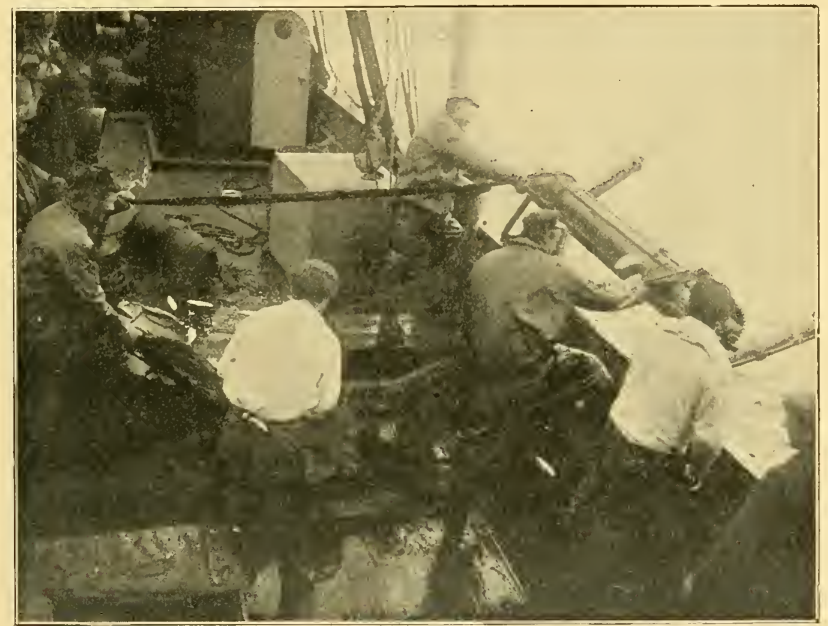

Fig. 28. - Hauling in Drift Nets.

set from the stern; when all the nets are out the vessel swings round on the warp. This warp is hauled in by means of the large end-drum on the big winch and over the reel in the bows, and the nets are hauled over the side on to the fore part of the deck (Fig. 28).

As regards the net constructed by Victor Hensen (Fig. I 9), a great deal of work has been devoted to studying its "coefficient of capture"; it is suitable for making quantitative studies of the occurrence of such plankton organisms as copepods, peridinii, etc., but for other purposes it has little practical value. Its upper part is furnished with a canvas cone, which allows no water to filter through, and therefore offers an effectual resist- 
ance to the water, both while being lowered and while being hauled in. It is, besides, quite useless for towing, for which purpose it was never intended.

"Michael Sars" townets for horizontal and vertical hauls.
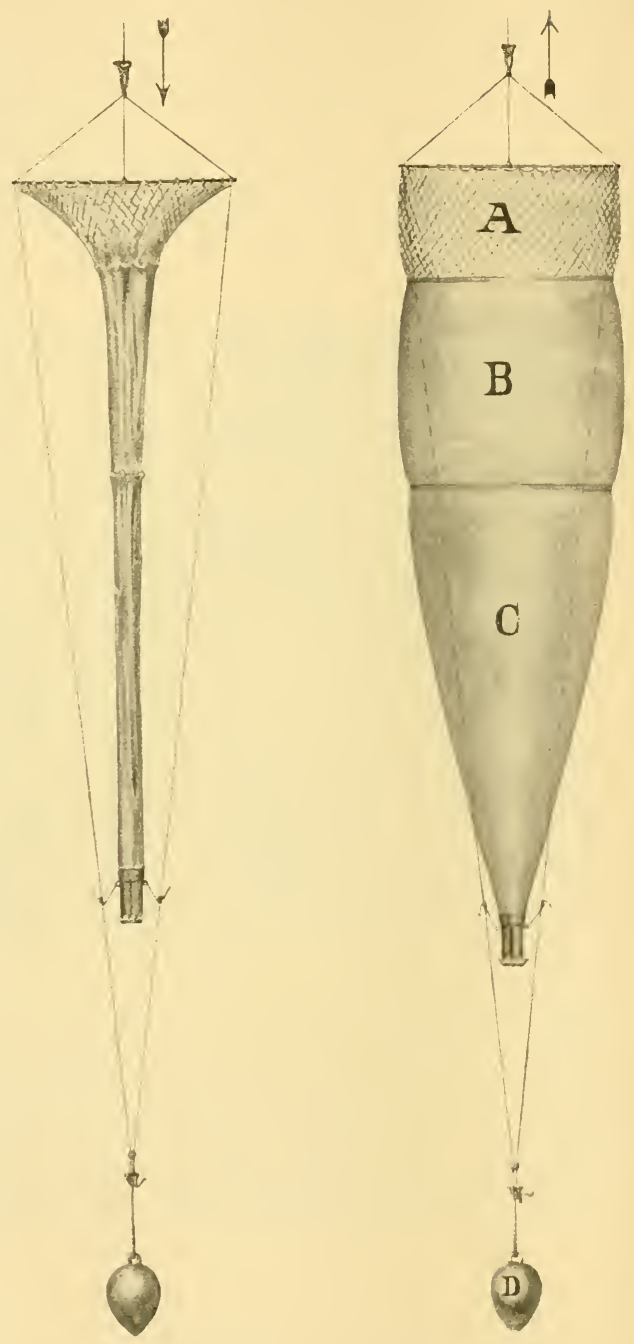

Fig 29 - The "Michael Sars" Tow-Net. $A$, net; B, coarse silk; $C$, finer silk; $D$, lead. 
fish almost as well as the trawl itself. The cylindrical fore part is largely responsible for this, as it retains within its walls the animals that do not pass immediately into the after part, which, owing to its great length, lets the water filter easily through. One great advantage of these tow-nets is that they can be lowered very rapidly when used as vertical nets. They then
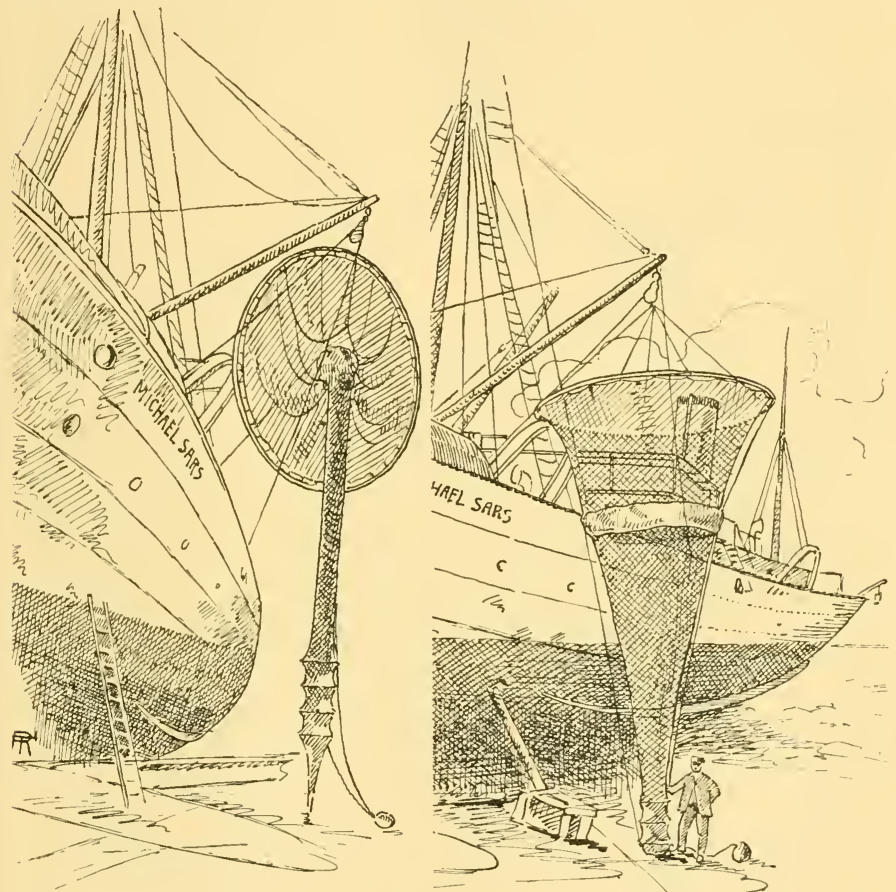

Fig. 30.-Large Vertical Closing Net.

assume the shape depicted on the left in Fig. 29. The net in the foremost portion of the cylinder is the only part that offers any resistance, and it too is wide meshed, so that the water easily passes through it; the rest descends like a thick rope. They can also be used as closing nets, and we have actually employed in that capacity nets $\frac{1}{2}, \frac{3}{4}$, and I metre in diameter at the entrance.

We further constructed two large closing nets, 3 metres in 
Large closing diameter at the mouth and 9 metres long, one of silk and the nets.

other of net; one of these is depicted open on the right and shut on the left in Fig. 30. They proved to be our most successful pelagic appliances. We used them sometimes as vertical nets and sometimes for towing. The closing mechanism

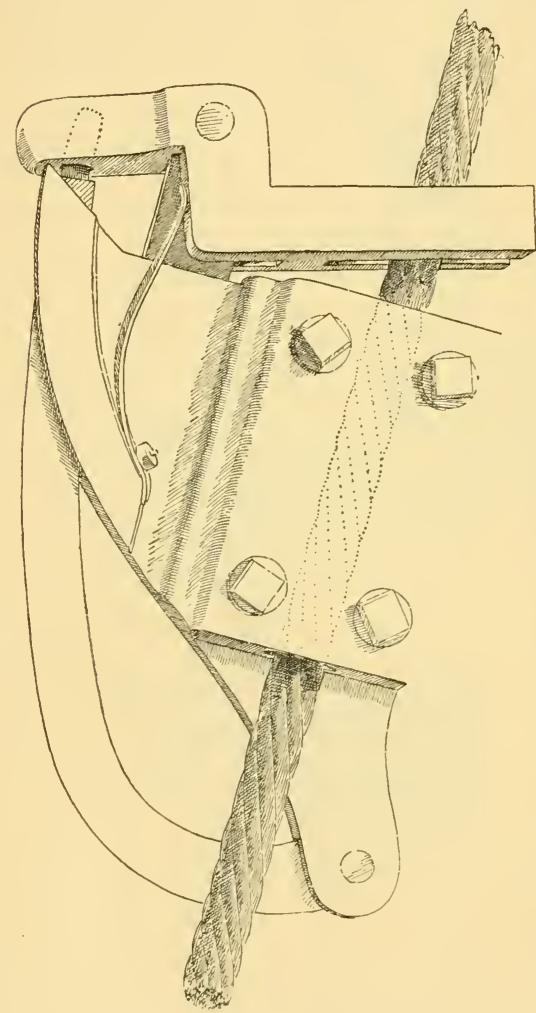

Fig. 31.-Closing Mechanism.

(Fig. 3I) was constructed on Nansen's principle. A slip-weight sets free the cords that support the ring, which falls down and leaves the whole hanging by a noose. This noose draws the net together so that nothing more can enter it. Two sizes of mesh are used in the construction of these nets; in the fore part a mesh of about I centimetre and in the after part one of almost $\frac{1}{2}$ centimetre from knot to knot.

In deep waters, however, and especially out in the open ocean, even these large appliances, if merely used as vertical closing nets, fail to furnish a representative picture of the animal life. The animals can only be captured by long horizontal hauls, and therefore to ascertain what exists at the different depths we must tow a large number of appliances simultaneously.

Method of using townets.
Fig. 32 shows the plan we generally adopted during the Atlantic cruise of the "Michael Sars." Two lines were used: a long line from the big winch for the deep-water appliances, and a shorter one from the after winch for lesser depths. Silk tow-nets either I metre or $\frac{3}{4}$ metre in diameter, and Petersen's young-fish trawls were alternately attached, and to 
the end of the longest line we fastened the large tow-net just described.

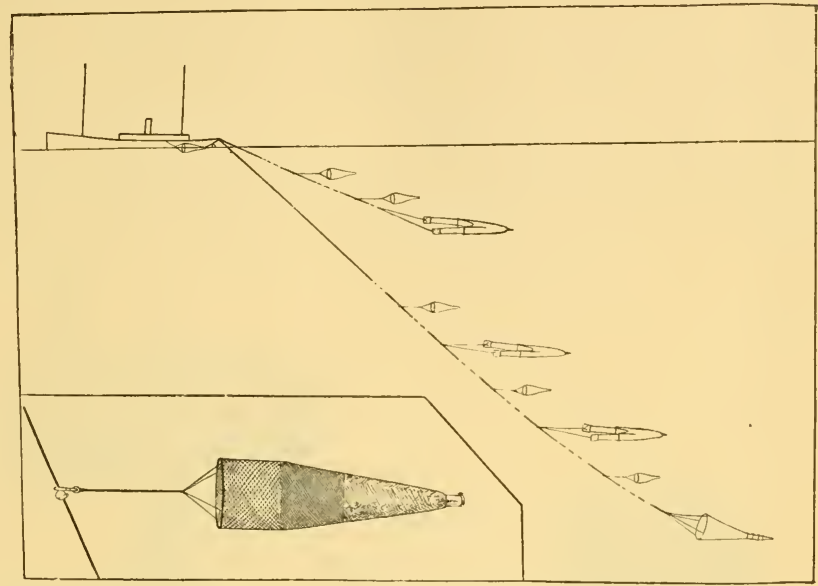

Fig. 32.-The "Michael Sars" towing Ten Nets and Pelagic Traivls. (Surface net not shown.)

A difficulty which arose when organising this system was that the cord by which a tow-net or trawl is attached to the wire becomes easily entangled, in which case the appliance is rolled round the wire or else torn off. To avoid this we screwed a brass knob (Fig. 33) on the wire and

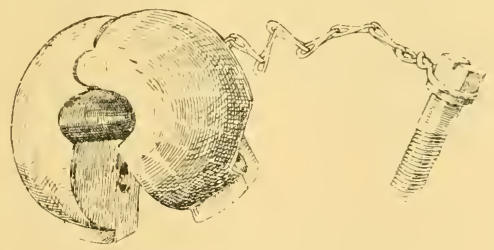

FIG. 33.-BRASS KNOB FOR TOW-NETS.

fastened the tow-net to a brass ring, which could be threaded on above the knob (Fig. 34). The appliance is thus kept from sliding down the wire, and is free to move in any direction (see also Fig. 32). This

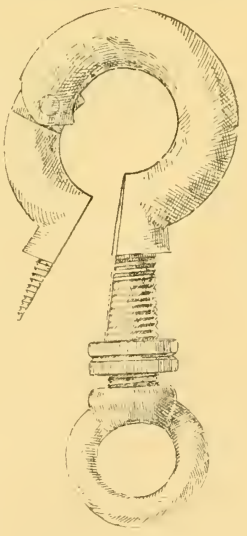

Fig. 34.-BRASS Ring FOR TOW-NETS. method of working enables one to operate as many appliances as 
the vessel is able to tow through the water, and by comparing the catches in the manner described in Chapter IX. one can ascertain the depths at which the animals lived. It is really a development of the plan adopted by the "Challenger," which towed its small nets along at different depths, or else attached them to the sounding-line (see above, p. 34).

Centrifuge. The pelagic investigations of recent years have shown that a great many marine organisms are so small that they pass through the meshes of all nets-even the finest silk nets (see

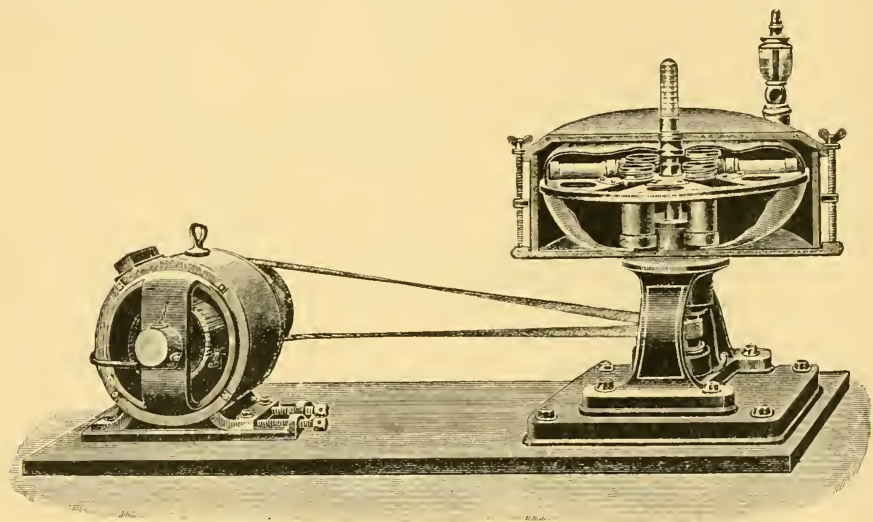

Fig. 35.-Centrifuge driven by Electric Motor. (From a catalogue.)

Chapter VI., where these organisms and their occurrence are described). To catch them in greater quantities we employed a large centrifuge (Fig. 35) as used by physiologists, which could centrifuge I 200 cubic centimetres at a time. The centrifuge was driven by one of the small steam-winches usually for a period of seven minutes and at a speed of 500 to 700 revolutions per minute.

This short description of the outfit of the "Michael Sars" does not claim to be exhaustive. During past years probably most kinds of fishing gear and scientific instruments available for the investigation of the sea have been made use of by us. When undertaking a definite limited cruise, however, a programme of the researches contemplated must ne̊cessarily be drawn up in advance and the gear selected accordingly.

Our Atlantic cruise proved that a greater number of appliances could hardly have been employed during a cruise 
of a few months' duration. But on the other hand a number of problems arose during the cruise, which we would fain have had the opportunity of investigating further.

It is especially our knowledge regarding the physical and biological conditions in the waters of the abyssal regions, and regarding the large pelagic organisms, that may still be considered as very imperfect. In order to study these problems more effectively, still more powerful winches, longer lengths of wire, and larger and better pelagic fishing gear are the principal things wanted. Future expeditions will thus have to face a serious task, not free from technical difficulties.

J. H.

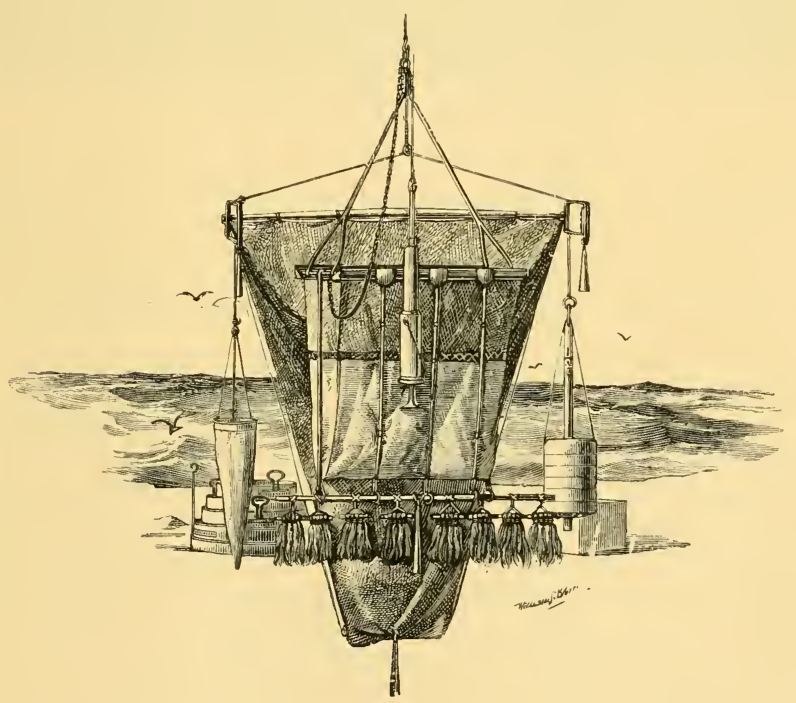

Group of Appliances used on board the "Challenger." 


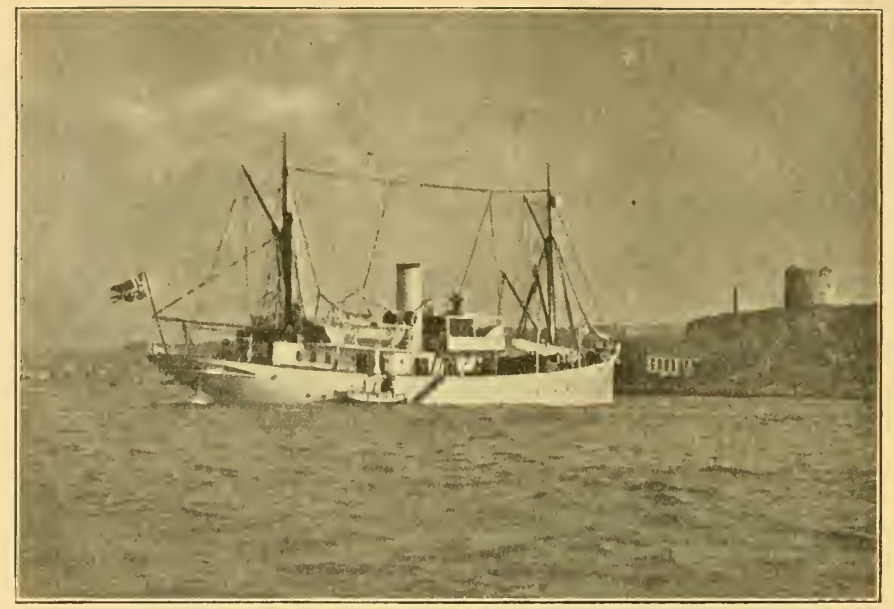

S.S. "Michael Sars" in Plymouth Harbour.

\section{CHAPTER III}

THE WORK AND CRUISES OF THE "MICHAEL SARS"

In this chapter it is proposed to point out briefly the nature and extent of the oceanographical work and fishery problems in which the S.S. "Michael Sars" has been engaged in the Norwegian Sea during the past ten years. Thereafter we will turn to the special cruise in the North Atlantic from April to August rgIo, and will recount the operations of the ship and the proceedings on board at the observing stations along the coasts of Europe, Africa, and Newfoundland, and during the voyages across the whole extent of the Atlantic.

Cruises of the "Michael Sars" since I900.

Since the summer of I 900 the "Michael Sars" has made a great number of cruises in the Norwegian Sea. Fig. 36 shows the location of the stations occupied during the years I900I 904, and a good deal more work has been done there subsequently. In the winter our task has been a particularly arduous one. We have found that stormy weather nearly always prevails at that season, and it is light for only a few hours each day. The temperature of the air is so low that all the water that falls on the deck and rigging freezes, and the 
quantity of ice thus formed is sometimes sufficient to weigh down the ship.

Captain Iversen has given an account of one of the cruises, Iversen's

account of a

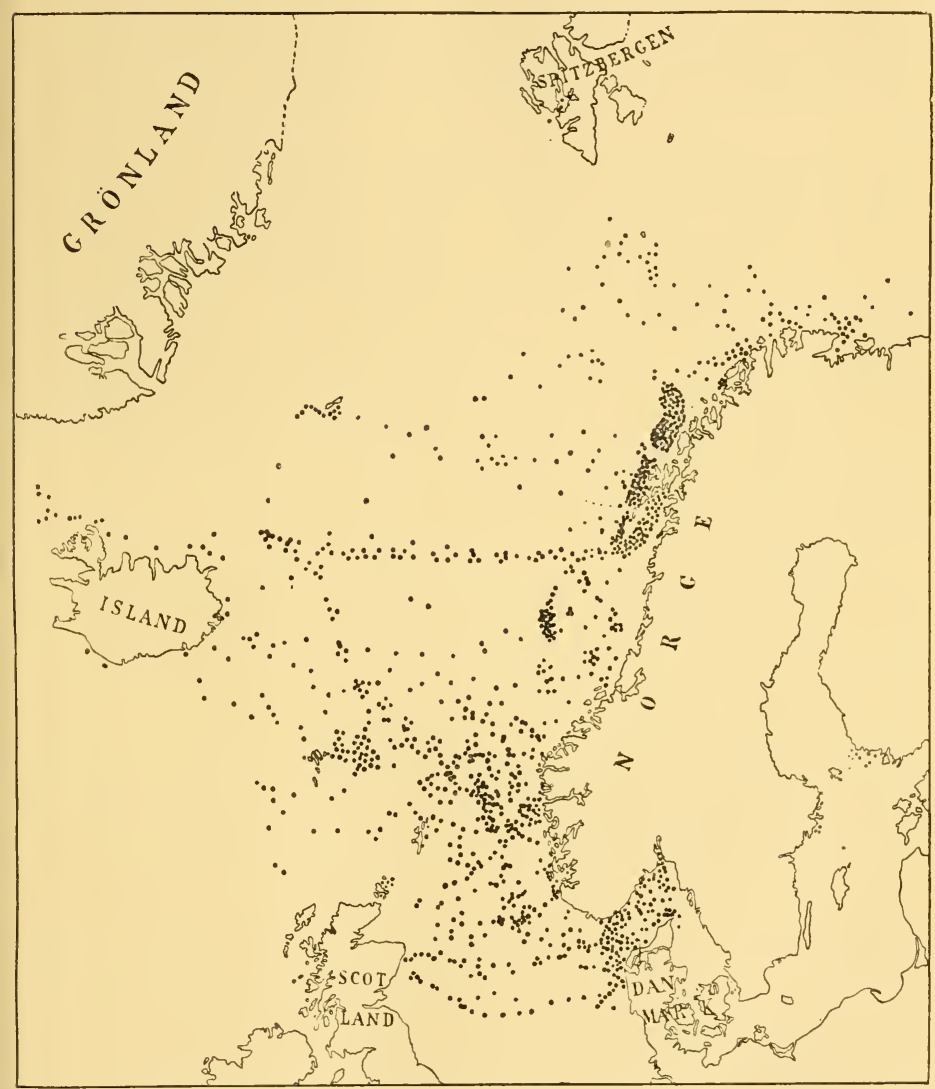

winter cruise.

Fig. 36.-The "Michael Sars" Observing Stations during the Years I900-1904.

that to Jan Mayen in February I903, and his description presents such a vivid picture of the difficulties to be encountered when studying the Norwegian Sea and its fisheries, that it may well be printed here:-

We came in here (i.e. Lofoten) yesterday with all well on board. 
We could not quite keep the course proposed, as the weather took charge of us a bit sometimes and no mistake. I will endeavour to give a few particulars of the trip.

We were pretty deep in the water when we left Bergen on the afternoon of the gth February, every available hole and corner being crammed full of coal ; consequently we got a bit of a washing that night. We had a hard gale dead ahead, but managed all the same to take up three stations before she refused to look at it about midnight of the Ioth. All the I Ith we lay hove-to, though we were able to take up one station; and on the I2th we stopped the engines to save coal, and got sail on her. Not till the afternoon of the I $3^{\text {th }}$ did the sea and wind go down enough for us to continue our course. During this storm we had frequent spits of snow and shipped a lot of water. To enable us to take up our stations we stretched a rope from davit to davit along the whole of the starboard side where we had to work. We did this to have something to hold on to, and so save us from being washed overboard. Koefoed was given a rope to tie round him, which fastened him like a dog to the davit where he worked. Otherwise everything was all right, except that the sheet of the mainsail parted so that the sail was damaged and a couple of thermometers were smashed. An interesting sight was a school of bottle-nose whales which we observed in lat. $63^{\circ} 3^{\prime} \mathrm{N}$., long. $2^{\circ} 44^{\prime} \mathrm{E}$. They were seven in number, most of them being males, "barrel hoops."

On the I4th and I5th we had good weather with little snow, so we made excellent progress northwards and took up a few stations. On the morning of the $I 6$ th we had clear weather and could see the iceblink, the water at the same time becoming cold. After taking up a station during the night just clear of the ice we steamed through icefloes all the next morning. We saw Jan Mayen in the distance, but the ice lay thick all round it. About midday we had to look sharp and get out again, as the wind increased to a gale, accompanied by severe frost and remarkable shrouds of mist, which assumed the most fantastic shapes and were constantly in motion. I have never seen anything like them before. We shaped our course for Vesteraalen, and got sail on her to steady her a bit. The whole of the afternoon we were pretty well cased with ice-hull, spars, and standing rigging-and on running suddenly into the middle of an ice-floe about nine oclock that evening we had a hard job to get the ship round against the wind, her sails being so stiff with ice that it was impossible to take them in. However, we managed gradually to get her bows up against a large cake of ice and brought her round with the help of the engines. There was just room to turn her and that was all. We then set our course back the way we had come, and so got clear.

The stations we took up during the severe frost were the reverse of easy, as the metre-wheels froze up, and we had to keep them warm with thick, red-hot iron bars that were brought from the engine-room and held close to the wheel-axles.

On the night of the 17 th we ran into another storm, which lasted till we arrived in port.

On the I9th, at midday, we saw land, but were unable to make it 
out, as the fog hid everything except a strip along the shore. All that day we tried to establish our whereabouts, but were compelled to lie to for the night in a hard south-westerly gale. Next day we found that we were off Gaukvaer Island and stood in for the land. After burning a little coal our vessel behaved splendidly, and after we had used up most of our coal and water, and so were very light, we could run before the sea in any direction without even having to keep the laboratory door closed. We wanted all our electricity this journey, for it was practically night the whole time.

The "Michael Sars" has carried out a great many different Investigations kinds of investigations in the Norwegian Sea, viz. : observa- "My the tions on the salinities, temperatures, and movements of the sars." water-layers ; observations on the floating organisms of various sizes and kinds; observations on the bottom fauna, especially bottom fishes. We have also made practical fishing experiments to discover what kinds of fish may be caught in the different areas of the sea.

To describe all the cruises that have been made would take too long and lead to much repetition. In the subsequent chapters of this book the most important results are summarised.

In order to study the movements of the water-layers and the distribution of floating organisms, cruises were undertaken at different seasons, as opportunity offered, from the coasts of Norway to Iceland, Jan Mayen, and Spitsbergen. To ascertain the fluctuations in the water-layers we have run a line of observations, nearly every year since I900, and always in the month of May, from the Sognefjord to the north of Iceland. This route lies exactly across the axis of the Atlantic water that streams through the Faroe-Shetland Channel into the Norwegian Sea, and we have consequently been able to obtain a section of this layer every year, and to compare its volume in different years. Besides a great many special studies, measurements of the velocity of the currents have been made out in the open sea and in the fjords.

At the time the "Michael Sars" commenced working there Investigations were hundreds of square miles of coast banks where no fishing to develop the had ever taken place, and there was therefore a real fascination industry. in experimenting in these virgin areas with the appliances in common use along the coast, more particularly with long lines. Expeditions were made for several years along the whole coast for capturing spawning cod on all the banks where the depth was 30-100 fathoms, and for halibut, tusk, and ling on the continental slope ; drift-net fishing was also undertaken for herring.

In these investigations we have chiefly aimed at ascertaining 
the geographical distribution, horizontal as well as vertical, of the most important species of fish, especially during the spawning period, when many of them are most sought after, and when each species may be supposed to congregate at localities where the natural conditions, such as depth, salinity, and temperature, are especially favourable and characteristic. These breeding places have been discovered partly by searching for the spawning fish, and partly by charting the distribution of the newlyspawned eggs, which float immediately above the shoals of spawning fish.

The development and growth of the fish, and the geographical distribution of the different stages, formed another important subject for our scientific studies. By various means it is now possible to ascertain the age of the different individuals in a shoal of fish, and we are in consequence able to study the growth of fishes in different areas.

Some of our fishing experiments have had an immediate influence on the development of the fishing industry, and have led to fish being found on hitherto unutilised banks, which have since turned out to be profitable fishing grounds. The study of the natural history of fishes may be said to have as its main object the widening of our knowledge regarding all the physical and biological phenomena on which depend the life of the fishes and the fishing industry.

The Atlantic ? cruise of 19 IO.

Depth of the North Atlantic.
During the winter of I 909-10 a great deal of time was spent in preparing the "Michael Sars" for an extended cruise in the North Atlantic, in selecting the route to be followed, and in preparing instruments and apparatus of the latest and most approved patterns.

A glance at the depth map is sufficient to make it clear that the greater part of the North Atlantic is deeper than 2000 fathoms. The coast plateaus off Africa, Spain, and the United States are very limited, and the continental slope is, as in the Norwegian Sea, very steep. The bathymetrical curves for 500 and I0oo fathoms lie in close proximity to one another. Only off Newfoundland and from the Bay of Biscay northwards along the western shores of Ireland and Great Britain do we find the continental shelf or coast banks widening out into tolerably broad plateaus. From the coast banks round Iceland a low ridge extends in a south-westerly direction, known as the Reykjanes Ridge. This is continued southwards as the Dolphin Rise, with deeper water on either side. From this low ridge 
rise the Azores and St. Paul's Rocks, and other volcanic cones

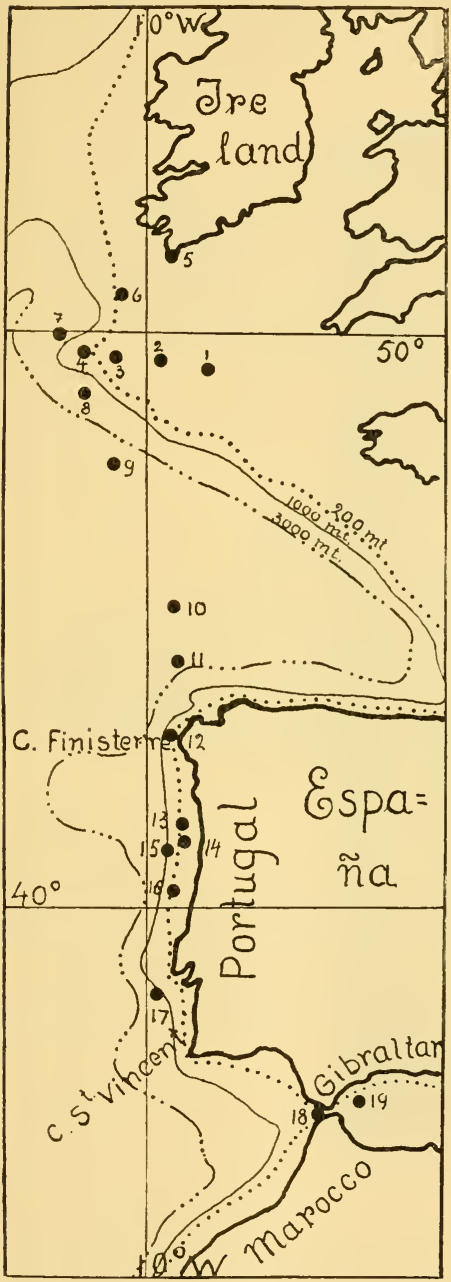

Fig. 37.-The " Michael Sars" Observing Stations from Plymouth to Gibraltar. and islands of small extent rise from the deeper water, like the Bermuda, Madeira, and Canary Islands, and the Dacia, Josephine, and other banks.

The route of the "Michael Route of the Sars" from Plymouth to Gib"Michael raltar (Fig. 37) was selected in order to find the most favourable localities for using the fishing gear, that is to say, where the continental slope is less steep than usual, and where accordingly the gear would be working on comparatively level ground. We expected to find the best ground where the coast banks are broadest ; for instance, off Ireland, in the Spanish Bay (Gulf of Cadiz), south of the Canaries, and off the Newfoundland Banks. In our crossings of the ocean we had particularly to take into consideration the distance between the coaling harbours.

All preparations being From complete the "Michael Sars" Plymouth to complete, the "Michael Sars Gibraltar. sailed from Bergen on the ist April, the first port made being Plymouth, where Sir John Murray joined the expedition. While at anchor at Plymouth the captains of trawlers informed us that the bottom on the coast banks and on the continental slope was very rough in some places, but that if we took a westerly direction we should have a good opportunity of using the trawl down to 
great depths. Our previous cruises had taught us what damage a rough bottom, especially coral, may do to the fishing tackle. Fig. 38 shows a piece of such coral brought up by the "Michael Sars" when fishing on the slope between the North Sea and

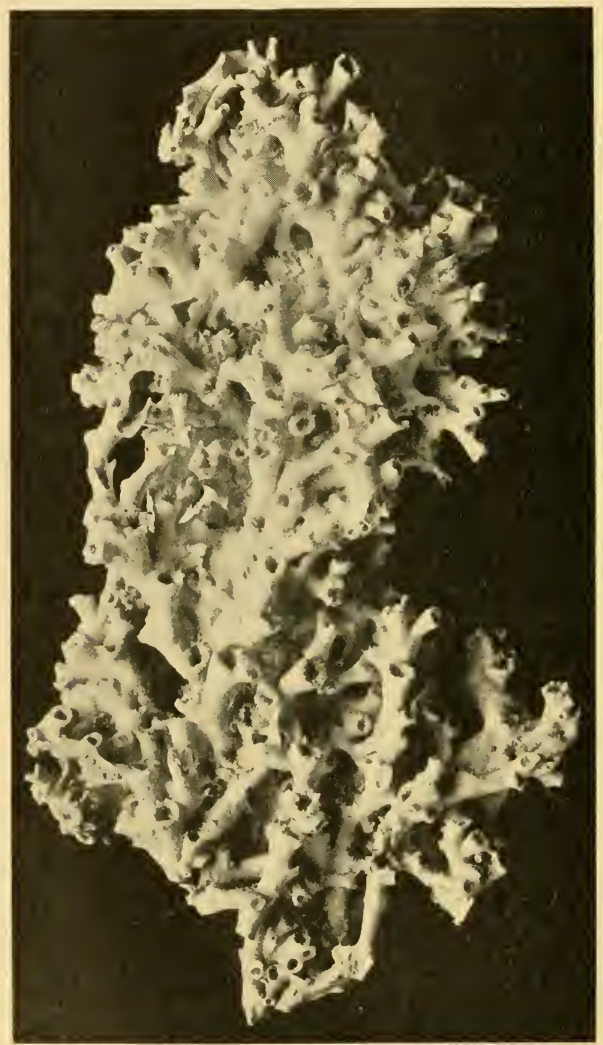

Fig. 38.-Piece of Coral (Lophohelia). About $\frac{1}{4}$ nat. size. the deep water of the Norwegian Sea. To avoid the corals we followed the advice given us and took a westerly course when we left Plymouth on the 9 th of April, and from the outermost westerly skerry, Bishop's Rock, we steered out over the coast banks to the continental slope. Everything was mean while got ready for trawling and for the hydrographical and plankton observations.

Before leaving the coast bank we made observations at our first three stations in depths of I 46, I 49, and I 84 metres, partly to test the winches and instruments and partly to get a section of the waters on the bank. All our arrangements for

hydrographical and pelagic work were found satisfactory. We secured a number of samples, and thoroughly tested the appliances. It was particularly important to see if the closing nets were to be relied on, so we lowered them to a depth of 50 metres, and closed them immediately. They came up empty, 
showing that they do not catch anything when sent down open. Successful trawlings at Stations I and 3 resulted in both cases in catches of over 300 fishes belonging to the ordinary coast-
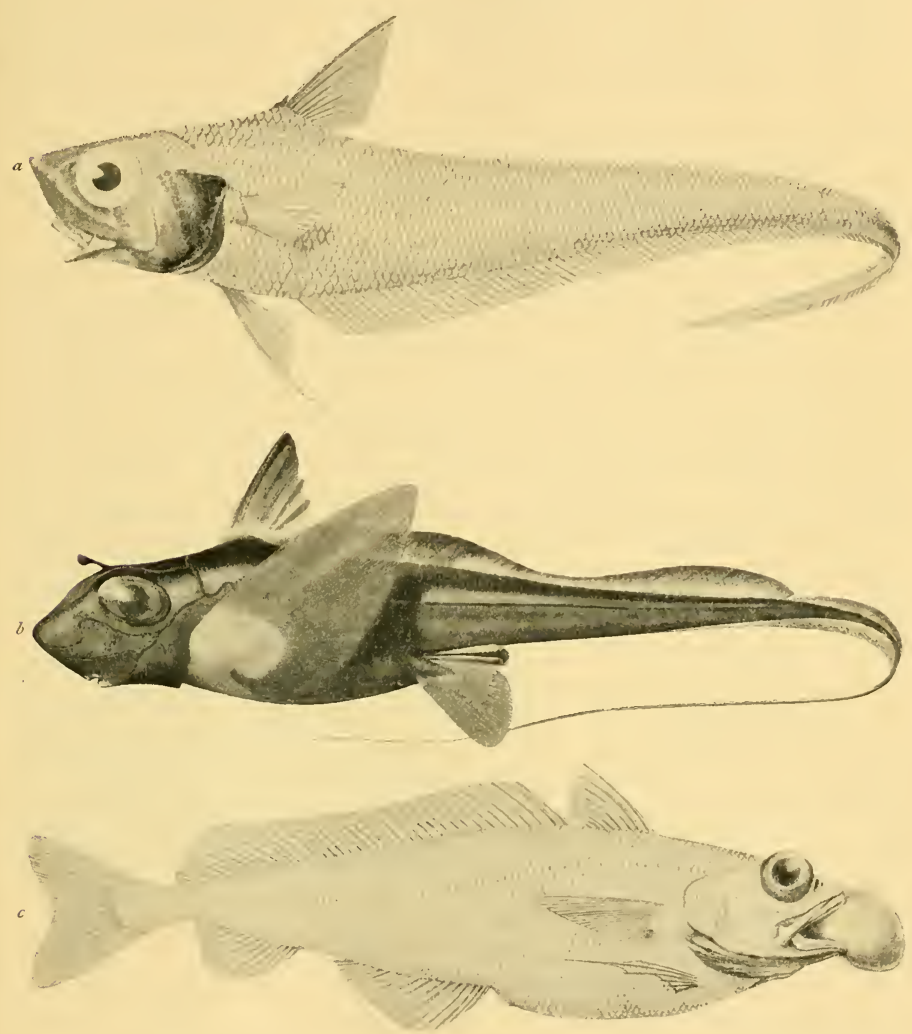

Fig. 39. - Three Deep-Sea Fishes from Station 4, 923 metres (about 500 fathoms).

a, Macrurus aqualis, Gthr. Nat. size, $23 \mathrm{~cm}$.

b. Chimara mirabilis, Collett. Nat. size, $71 \mathrm{~cm}$.

c, Mora mora, Risso. Nat. size, $45 \mathrm{~cm}$.

bank species. Even these first hauls, however, made it evident that the big winch did not run smoothly when paying out line.

On the morning of Monday, i I th April, a sounding at Station 4 gave us 923 metres. The big trawl was shot with 2360 metres of wire. At 3 P. 11. we assumed that it was on the bottom, and 
towed it for three hours till 6 P.M., when hauling in began. It came up at 7 P.M. with a catch of 330 large fishes (Macrurus,

Successful haul with the trawl.
Depth to which plant life extends. Mora, Lepidion, Chimara, etc. ; see Fig. 39). This haul was a thorough success. Perhaps never before had so large a draught of fish been made at such a depth. The trawl itself worked most satisfactorily, and considering its size hauling in was done rapidly (about 40 metres per minute). During the process of lowering, however, the big drum got jammed on the axle, and in spite of all our efforts we could not move it. There was nothing to be done, therefore, but to make for the nearest port to repair it, so we steamed into Cork and had it put right at the workshop on Wednesday morning (the $\mathrm{I} 3$ th). We found after finally getting the drum off the axle that a lot of sand from the foundry had been left in by mistake, which accounted for its not working properly. By Friday ( $15^{\text {th }}$ ) the sand had all been scraped off, and the drum was once more in its place. But in the meantime a strong north-easterly gale had set in, and it was not till Saturday (i 6 th) that we were able to steam westwards under the lee of the Irish coast. The wind continued strong and northerly, but for all that we steamed back to Station 4 , occupying a couple of small stations ( 5 and 6 ) on our way, and recommencing our interrupted section, proceeded out to still greater depths.

On Sunday, I7th April, a sounding at Station 7 gave us 1813 metres. The trawl was shot with 4000 metres of wire and towed for two hours. It came up all twisted and tangled, due to the fact that the swivels for keeping the wire and bridle from twisting had failed to act. The small steel balls in the bearings of the swivels had been crushed by the severe strain or the bend in the blocks. The trawl was got ready for a fresh attempt, but in the meantime the wind and sea rose to such an extent that we decided to give up further work in the deep water. To wait for good weather would have delayed us too long, so we set our course for the north-west point of Spain.

The pelagic life of the upper I50 metres was extremely uniform. Several series of hauls with fine-meshed closing nets revealed the fact that quantities of the same diatoms extended down to a depth of over 150 metres. This was particularly interesting evidence as to the depth at which plant life can exist, even as far north as about lat. $49^{\circ} 30^{\prime} \mathrm{N}$., under special conditions. From this and other experiments made later Gran is of opinion that the same vertical circulation which produces 
a uniform temperature throughout the deep layer also introduces materials, particularly nitrogenous matter from the surface-that is to say, indirectly from the coasts-which are favourable to the development of plant life. The plants were in consequence extraordinarily abundant. At Station 3 we found great quantities of diatoms, even in a haul with the closing net from i 60 metres up to Ioo metres.

On our way southwards from Station 7 we were prevented by the high sea from attempting any fishery experiments, so we had to content ourselves with making hydrographical

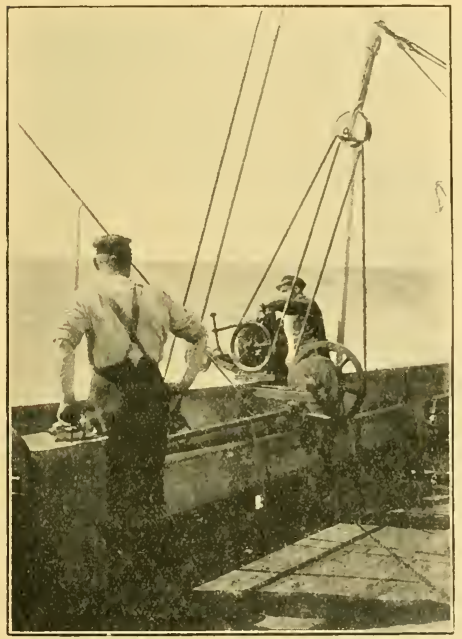

Fig. 40.--The Captain sounding in 4700 Metres. observations (at Stations 8 and 9), and it was not till we were well down in the Bay of Biscay at Station Io that the sea became calmer and the weather moderated. We sounded here and got 4700 metres, so that we now had an opportunity of trying our appliances in really deep water (see Fig. 40).

We commenced at this Vertical hauls. station, while the ship was still hove to, by taking a series of twelve water-samples as far down as 4500 metres, and made a number of vertical hauls with the closing nets down to IOoO metres. Everything was found to work splendidly, and all these operations took only about three hours.

Temperatures were recorded by means of the best kinds of reversible thermometers, which give readings exact to within a few hundredths of a degree even at the greatest depths. At this station we found the temperature at 3000 metres to be $2.40^{\circ} \mathrm{C}$. and at 4500 metres $2.56^{\circ} \mathrm{C}$. It was thus apparently warmer near the bottom than I700 metres (or nearly Iooo fathoms) above the bottom. It has often been thought that the water might derive a certain amount of heat from the sea-bottom, and this may have been the case here, but there is also another possibility, namely, that the water at 4500 metres had sunk from the upper layers and had been 
slightly warmed while sinking, just as happens with air that suddenly sinks from a great height towards the earth. This rise of temperature has also been attributed to decomposing organic matter and to radio-active matter in the deposits at the bottom. Whatever may have been the cause, we certainly found a similar slight rise in the temperature of the deepest layer on several subsequent occasions during our cruise.

Trawling in deep water.

We next resolved to try the big trawl, and to reach the bottom at 4700 metres we estimated that it would be necessary to allow 8000 metres of wire, that is to say, 8 kilometres (Fig.

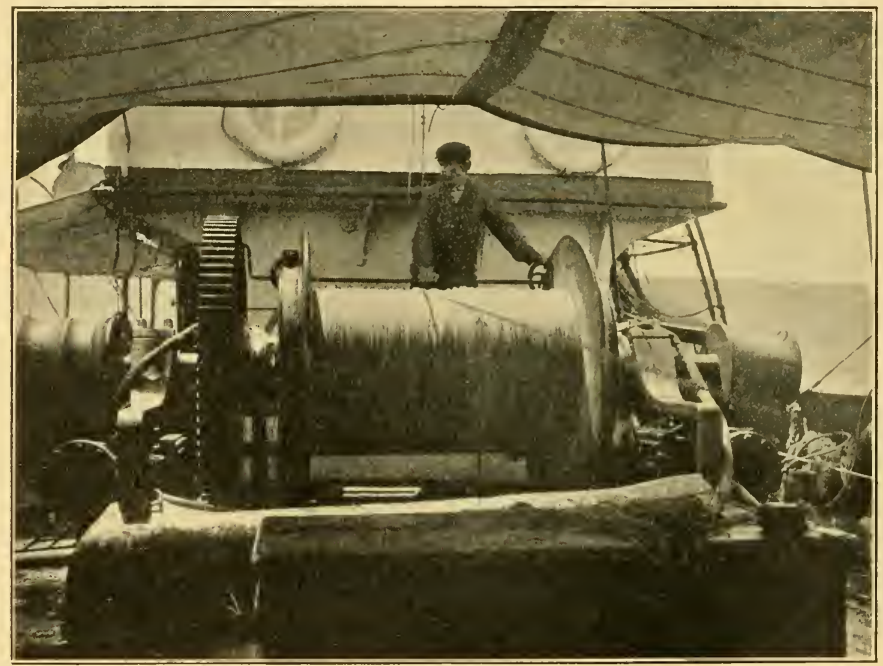

Fig. 4I.-ThE LARGE WINCH.

4I). We were engaged in paying out line from 5.30 P.M. to 7.I 5 P.M., and at midnight we commenced hauling in, which lasted for about six hours. The trawl contained only two fishes (Macrumus) and a number of lower forms of animals: holothurians, a few worms, a gasteropod, a chalk-coloured crab, some ascidians, and one or two other things (see Chapter VII.).

This seemed to us such a poor catch that we came to the conclusion that something had gone wrong. The trawl was therefore dropped again, and could be seen sinking down in perfect order. After being towed for three and a half hours, it suddenly stuck fast and stopped the ship. Hauling in took 
eight hours, and the trawl came up (Fig. 42) in perfect order, containing an enormous mass of perhaps a ton of clay-like Globigerina ooze, that was as stiff as dough, and looked as if it might have been dug out of a chalk pit. We carefully sifted and washed it all with the hose, and found only the following animals : four actinians, of which two were growing on hermit crabs, two cirripeds, a holothurian, some gasteropods, and a few worms. The question now presented itself - was animal life really so sparse down at those depths, or did our catch fail to represent it properly? Had the trawl perhaps, when dragged through the ooze, been rendered incapable of doing its work of capture? If so, how had we been able to go on towing for such a length of time? This was a problem that could only be solved by further experiment. A number of glass floats, about 3 inches in diameter, were sent down with the trawl, and were found to have been reduced to the finest powder by implosion through the immense pressure at this great depth.

One thing at any rate we had learned. The enormous weight of 8000 metres of wire, with a huge trawl at the end, had worn deep grooves in our blocks and rollers in a very

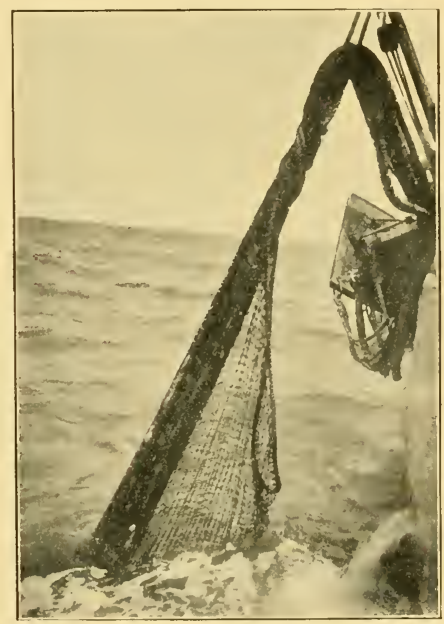

Fig. 42.-Otter Trawl coning UP. short space of time. It was necessary, therefore, to have rollers in reserve if much of this work was to be attempted.

After a few successful pelagic hauls we resumed our course on the morning of the 2 Ist April in the direction of Spain, our intention being to do some trawling at different depths on the continental slope, where the trawlers had told us the bottom was good. But when we made the coast of Spain at Cape Sisargas, an easterly gale sprang up and put a stop to all work, so after a few hydrographical observations (Stations I I and I 2) we steered southwards along the coast of Portugal. On the 22 nd the weather cleared up, and off the town of Vianna we saw the first line-buoys, and shortly afterwards the picturesque 
fishing-boats with their red lateen-sails came into view on the horizon.

Portuguese fishing industry.

One of these came close to us, and we had an opportunity of learning something of their industry. Their boats were flatbottomed, with a deep rudder that acted as a sort of keel. They were working with nets on a hard bottom, and, as a rule, in 30-40 fathoms of water. Their catches consisted of the lobster-like "languste" (Palimurus vulgaris), large crabs (Cancer, Lithodes), skates (Raia clavata, R. circularis), sharks (Centrina and Miustelus), and breams (Pagellus centrodontus). They also earned some money

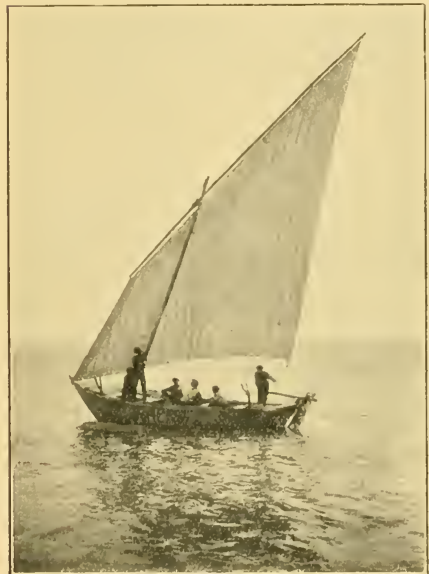

Fig. 43.-Portuguese Fishing-Boat. by going on board the trawlers and getting the small fish (small whitings, hake, etc.), which are generally thrown away. IVe came across the trawlers themselves not long afterwards, and boarded a boat belonging to Boston, England. They were trawling for soles (Solea vulgaris) and large hake; otherwise they got, as a rule, only skates and whitings. We shot our own trawl to see what there was on the bank, and captured the same fishes that the trawlers had spoken about (Station 14).

The fine weather tempted us to try to make a series of hauls at different depths along the edge of the coast banks. We accordingly lowered the following appliances in the evening: a tow-net at the surface and two more at 50 metres and IOO metres respectively, a young-fish trawl at I 50 metres, tow-nets at 300 metres and 500 metres, and another young-fish trawl at 750 metres.

We had, however, scarcely begun towing our nets before a northerly gale sprang up. Hauling in had therefore to be done in the dark, and the sea became high and broke over the stern, where the gear was being got in. The result was that the violent pitching of the ship tore the silk cloth of the nets and did considerable damage. We lost the tow-nets sent to 100 metres and 500 metres, as well as the young-fish trawl at 750 
metres, and a good deal of harm was also done to the others. All the same we managed to get some samples of interesting deep-sea forms, though such catches were of a more or less fortuitous nature.

Off Lisbon the sea became calm, and we took hydrographical observations at Station I7, obtaining water-samples from many depths. Here, out on the edge of the continental slope, and in the Spanish Bay, the weather was beautifully warm, and the sun shone brightly. IVe now met with some extremely interesting forms of animal life. Numerous dolphins swam round our bows, and when standing in the fore part of the ship we saw thousands of small pelagic crabs (Polybius; see Fig. 46), sometimes as many as fifty of them in three minutes. We also sighted a turtle.

While steam-

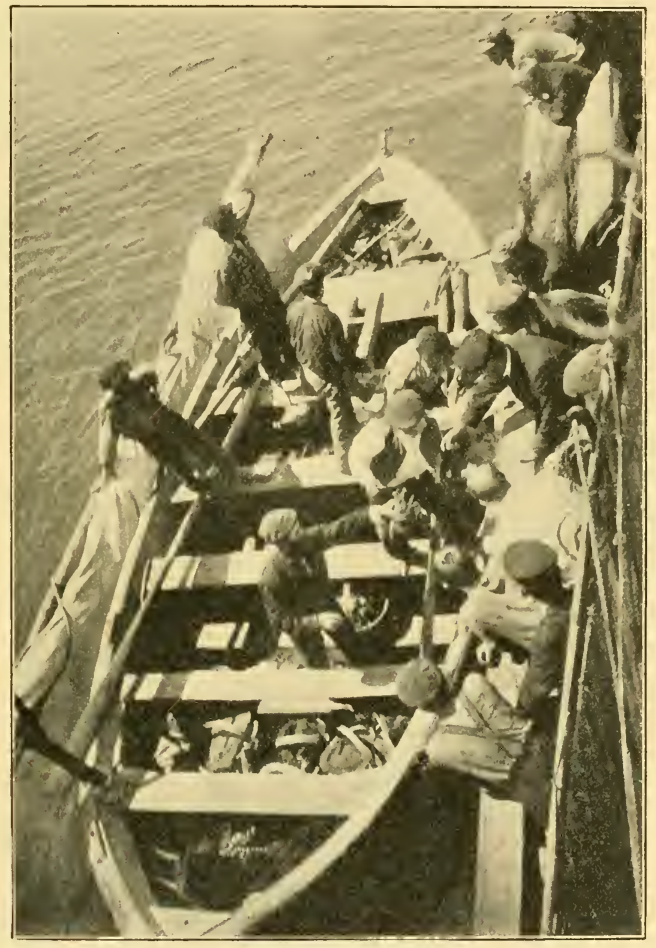

Fig. 44.-BARGAINING.

ing along Gran studied the plankton filtered from water Gran's invesobtained by a pump, and found in every sample more than tigations on forty species of diatoms and peridinii, whereas to the west of Ireland we had come across a diatom-plankton, rich in individuals but very poor in species, consisting of the ordinary North European coast diatoms. This showed that we had now reached a southern and warmer marine region, with a totally 
distinct assemblage of animal and plant life in the upper water-layers.

On the morning of Monday 25th April we anchored off Gibraltar, where we had our boilers overhauled, and procured reserve rollers and blocks, as well as new swivels for the trawl line.

Currents in the Strait of Gibraltar.

During our stay at Gibraltar we made two short trips: one to the Strait to study the currents, and the other to the Mediterranean to test our pelagic appliances. The Strait of Gibraltar has for a long time past attracted the attention of hydrographers. Through this narrow channel the exchange of water between

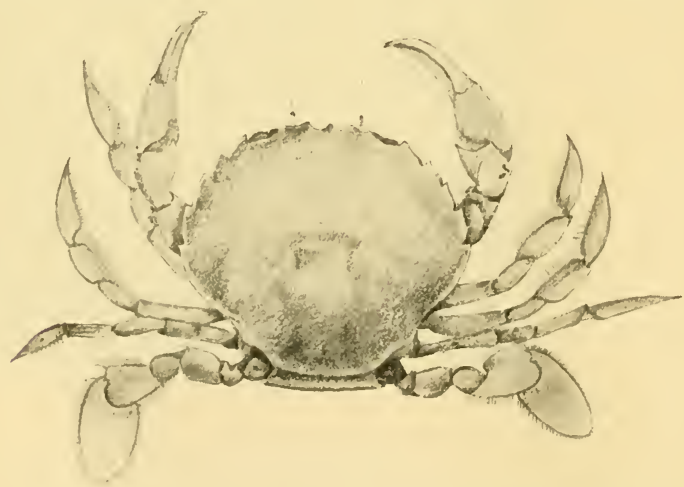

Fig. 46.-Pelagic Crab (Polybius henslowi, Leach). Nat. size.

the Atlantic and the Mediterranean takes place, and there are great fluctuations in the two streams. A knowledge of the laws that govern the currents of this marine thoroughfare 
is accordingly of the utmost importance, not merely because of the light it throws on the question of ocean circulation, but also because of its value to navigation. As early as i 87 I Nares and Carpenter made a study of these currents, and important investigations have been made in later days by the Danish research vessel "Thor" under the direction of Joh. Schmidt. No direct measurements of the actual velocities of the currents at different depths and their direction had previously been undertaken, but current-meters, especially the excellent one constructed by V. W. Ekman, put it in our power to make the attempt.

The "Michael Sars" had previously measured currents off the coast of Norway by anchoring a life-boat fore and aft with grapnels and a stout hemp line. We endeavoured to work on the same principle in the Strait of Gibraltar (Station I 8), but were unsuccessful at first ; one line after the other parted, owing to the velocity of the current. Finally we had to anchor the ship itself with $1 \frac{1}{2}$-inch steel line and a warp anchor, in 400 metres of water on a hard bottom. This held, and she lay at anchor from I.3O A.M. till 5 P.M. on the 3oth April. During this time Helland-Hansen worked unceasingly. One currentmeter was used continuously at a depth of io metres, and another was lowered to different depths right down to the bottom. In addition he took a series of water-samples and temperatures at different depths.

He found that there were two strong currents in the Strait, one going east from the Atlantic into the Mediterranean in the upper layers, and one going west at the greater depths. The limit between them was for the most part at a depth of about I 50 metres, but it varied so much that in the afternoon between 2 and 2.30 P.M. it was at a depth of 50 metres, while between 4 and 5 A.M. even at the very surface the current went westwards. These variations practically coincided with the tidal movements.

There were high velocities in the upper east-going current ; at 10 metres the velocity varied between $\mathrm{I}$ and $2 \frac{1}{2} \mathrm{knots}$, and at 25-30'metres between 1.7 and 3 knots. At a depth of 100-1 20 metres the current was always westerly, but the velocity was only between half a knot and a knot, whereas at I 50-200 metres, where the current was also westerly, the velocity varied from 0.3 knot to as much as 5 knots; close to the bottom a velocity of $\frac{1}{4}$ knot was measured. HellandHansen's interesting observations are the first reliable figures regarding the movements at the different depths, and they are 
of great assistance towards a proper understanding of the water circulation in the Strait of Gibraltar.

Pelagic inves. tigations in the Mediterranean.

Water strata in the Medi. terranean.

Noctiluia.

From the Spanish Bay southwards along the north-west coast of Africa.

At Station 19, a few hours' steaming from the entrance to the Mediterranean, we experimented with different appliances, to ascertain the best way of arranging our subsequent pelagic investigations. The big silk tow-net, 3 metres in diameter, was lowered to a depth of 900 metres and immediately hauled up again. It was found to work well, and captured a number of pelagic fish (eight specimens of Argyropelecus, a few scopelids, and some young fish), but our catch seemed to indicate that vertical hauls were not nearly so productive as horizontal hauls, and we therefore decided to make long horizontal hauls our principal mode of catching pelagic fish during the remainder of the cruise.

At this part of the Mediterranean there was a sharply defined limit between an upper water-layer, where the temperature was fairly high and the salinity almost identical with that of the upper layer in the Spanish Bay in the Atlantic, and a lower water-layer with "bottom-water" of uniform temperature (a little below $13^{\circ}$ C.) and salinity (over 38 per thousand). Several series of temperatures and water-samples were taken, and the limit between the two layers was found at a depth of I 50-200 metres, though subject to considerable variation, as in the Strait of Gibraltar but not to such an extent.

The surface water here was so full of phosphorescent Noctiluca as to be almost as thick as broth, and when the contents of the tow-net were emptied into a glass they formed a sediment a centimetre in thickness at the bottom of the glass. In the evening the sea resembled a star-spangled sky, and the wires following the vessel looked like gleaming stripes. During the day we now saw for the first time the beautiful surface organisms of the south, such as Velella and the Portuguese man-of-war (Physalia), with which zoologists and sailors in Mediterranean waters are so well acquainted.

The region from Spain along the coast of North Africa is well known to zoologists from the successful labours of the French "Travailleur" and "Talisman" Expeditions. Series of trawlings at various depths were undertaken by these two ships with only small beam trawls, so that we had every hope of accomplishing something with our large trawl. We were able besides to turn to good account the information acquired from the fishermen, large numbers of whom have shot their trawls 
along these shores in recent years. They had given us to understand that we could reckon on finding good trawling grounds as far down as 250 fathoms on many of the coast banks off Morocco, such as the stretch from Cape Spartel to Casa Blanca, from Mogador to the bay at Agadir, and south of Cape

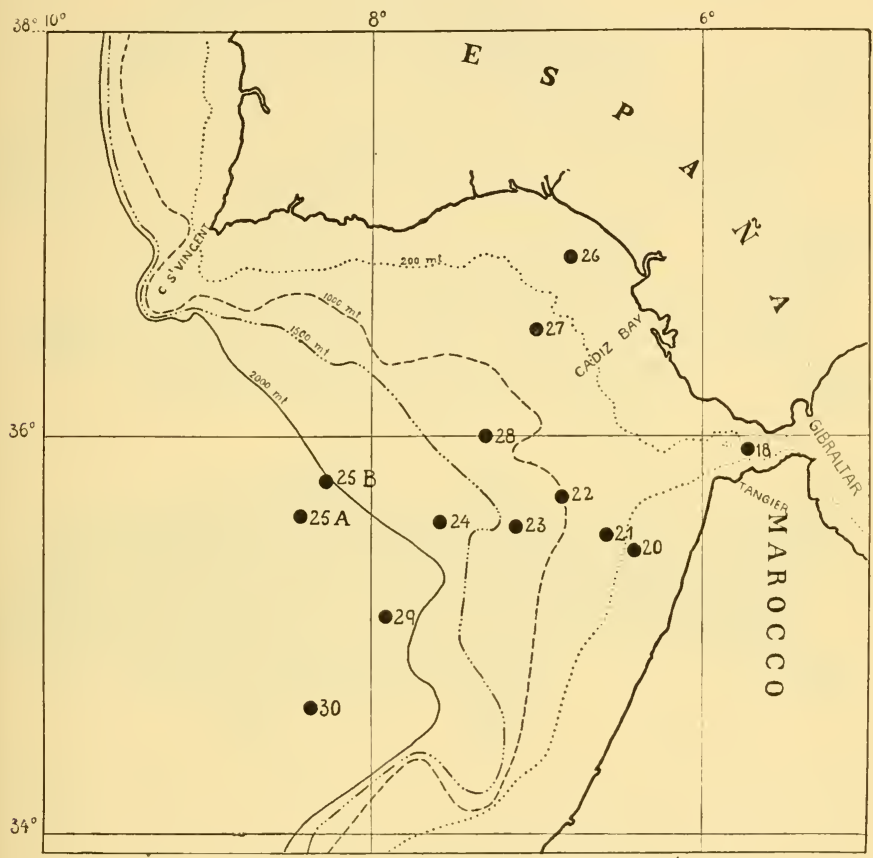

Fig, 47.-Depths and Stations in the Spanish Bay.

Juby on the inner side of the Canary Islands. We! also learned that their catches chiefly consisted of hake (Merluccius vulgaris), which, as a rule, made up two-thirds of the whole; soles (Solea vulgaris), and different kinds of silvery or brilliantlycoloured spiny-finned fish (mostly Sparidæ), which they call "salmon."

Our plan was to carry out two series of trawlings from the coast banks outwards to great depths, one in the Spanish Bay and one south of the Canary Islands, so as to have a general idea of the fauna at different depths in different latitudes. We 
wished also to take a thoroughly good hydrographic section right across the Spanish Bay, with water-samples and tempera-
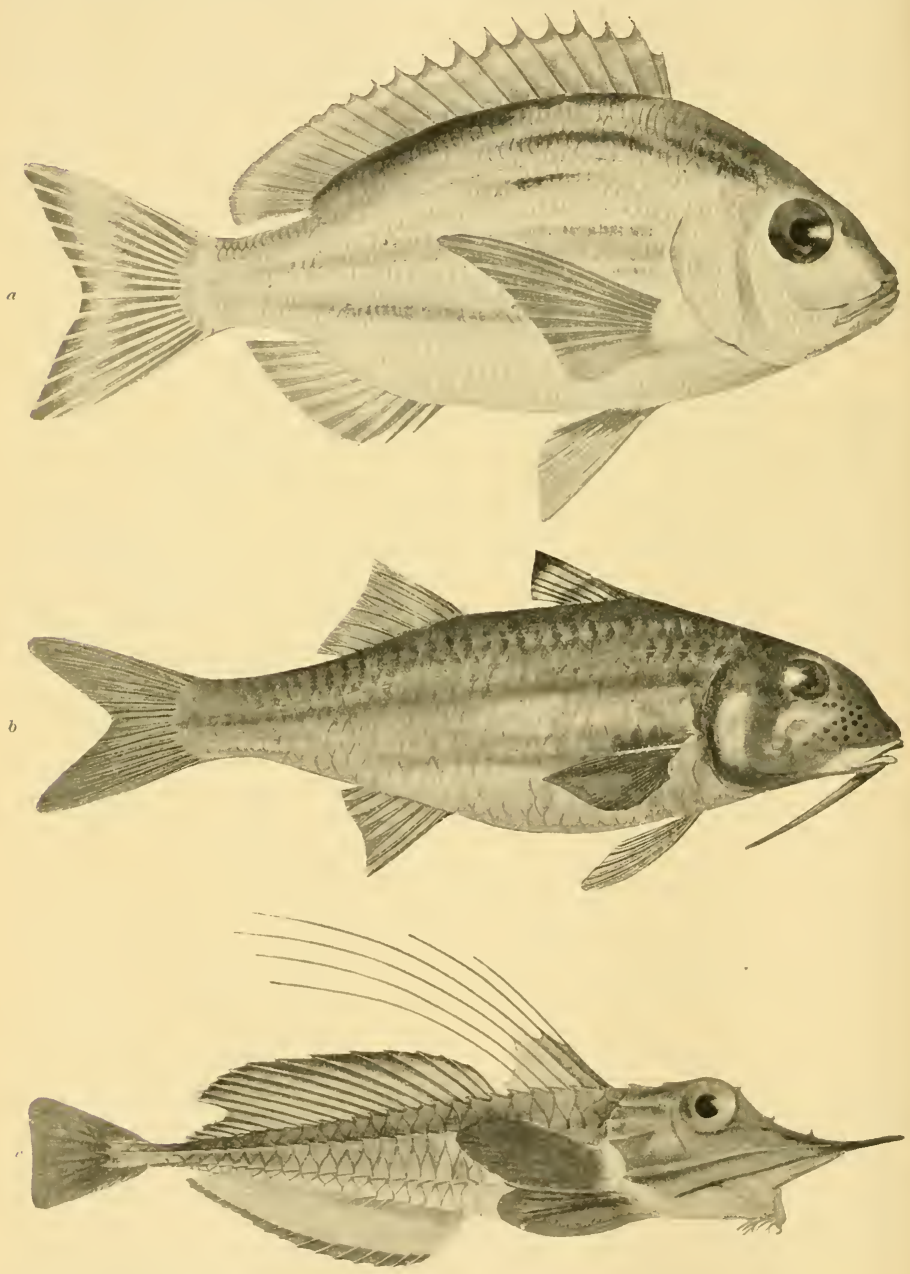

Fig. 48. - Three Shore Fishes from Station 20, 14 I metres (about 75 fathoms).

a. Dentex maroccanus, Cuv, et Val. Nat, size, $25 \mathrm{~cm}$.

b. Mullus surmuletus, L. Nat, size, $29 \mathrm{~cm}$.

c. Peristedion cataphractum, Cuv, et Val. Nat, size, $30 \mathrm{~cm}$. 
tures from all depths, and we hoped to trace the course of the salt-water layer that flows out from the Mediterranean to the Atlantic, which we felt would be interesting to all hydrographers.

We left Gibraltar on 4th May and steamed through the Trawlings in Strait and past Cape Spartel in perfect weather till we came to Spanish Bay. the coast bank, where at Station 20 (see Chart, Fig. 47) we saw seven trawlers at work. Our trawl was dropped in I 4 I metres, and towed for two and a half hours. The resulting catch of $16_{3}$ fishes was a good sample of the ordinary species to be found there, namely hake, different kinds of gurnard (Trigla sp.),
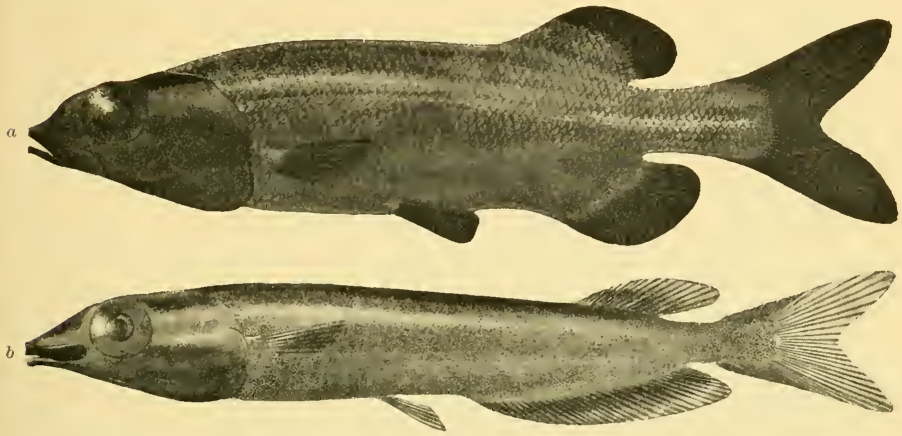

Fig. 49.-TWo Deep-Sea Fishes of the Family Alepocephalide.

a. Alepocephalus from Station 23 (1215 metres). Nat. size, $60 \mathrm{~cm}$.

b. Conocara from Station 25 (2055 metres). Nat, size, $20 \mathrm{~cm}$.

mullet (Mullus surmuletus), and silvery or brilliantly-coloured spiny-finned fishes (Capros, Pagellus, Dentex; see Fig. 48).

The next station (Station $2 \mathrm{I}$ ), in 535 metres, yielded I 7 fish, including hake, but all the beautifully-hued fish had disappeared. Instead we found the deep-sea fauna coming into evidence (Macrums, Chimara), and at the three following trawling stations our catches were made up entirely of true deep-sea fish (Fig. 49), namely :-

Station 23 at I 2 I 5 metres, 77 fishes.

Station 24 at 1615 metres, 32 fishes.

Station 25 at 2055 metres, 29 fishes.

From a technical point of view these hauls were in every way satisfactory, as our winch, trawl, and all connected with them worked perfectly smoothly. The new swivels (Fig. 50) 
procured at Gibraltar were a thorough success, and stopped the twisting in the trawl-warp and bridle. The bottom was everywhere well adapted for trawling.

At Station 23 we towed a small young-fish trawl at I 2 I 5 metres. It touched the bottom and brought up a quantity of empty pteropod shells which had been sifted out from the bottom deposit. It is extraordinary to find these deposits of shells belonging to plankton organisms only at certain relatively

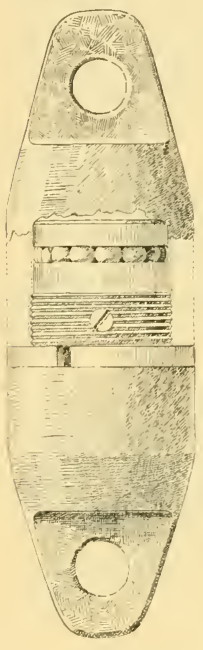

FIG. 50.-THE NEW SWIVEL.
Relation between Mediterranean and Atlantic waters. shallow and intermediate depths, for, when alive, the pteropods float over all depths.

Our trawlings further resulted in a fine collection of invertebrate animals; at Station 24, for instance, we found the trawl full of siliceous sponges.

These waters offer a good field for a thorough study of the distribution of animal life, for the nature of the bottom and the gentle slope permit of trawling at all depths. Our time unfortunately was too short to permit us to do more than obtain a general impression.

We next turned our attention to the hydrographical investigations, and steamed to the north side of the bay near Cadiz (Station 26), whence we ran a series of stations, at all of which careful hydrographical observations were made (Stations 26-30).

At the conclusion of the "Challenger" Expedition Buchan showed that it was possible to trace the course of the comparatively warm Mediterranean water out into the North Atlantic Ocean. In I 909 the Danish expedition in the "Thor" under Schmidt made some observations from the Strait of Gibraltar westwards, and secured extremely accurate determinations of temperature and salinity, showing that the Mediterranean water (in a very diluted state) makes its way out through the Spanish Bay, sinking down to a depth of I000-I 200 metres.

In our investigations we aimed at studying more closely the relation between Atlantic water and Mediterranean water, and we also endeavoured to become familiar with the currents on both the Spanish and Moroccan sides of the bay. Unfortunately we had to abandon our current measurements, but the variations of salinity and temperature from our many adjoining stations give a fairly good idea of the conditions. It is enough 
to mention here that in the neighbourhood of Spain the diluted Mediterranean water was found at far less depths (as near the surface, in fact, as 400 metres) than farther south in the bay. The surface current runs along the Spanish coast in an easterly or south-easterly direction, and off the Moroccan coast in a southerly or south-westerly direction (see Chapter V.).

Hydrographical investigations were continued all the way southwards along the continental edge to the Canary Islands. We were prevented from attempting any other kind of work, as near Mogador we encountered a stiff north-east trade-wind, before which we had to run. Every now and then a heavy sea broke over our quarter, sweeping the deck clean. Not till we reached the Canaries did the wind and sea go down. At Lanzarote we met with calm weather, so we did some pelagic work, taking vertical and horizontal hauls. The latter resulted in the capture of several in-

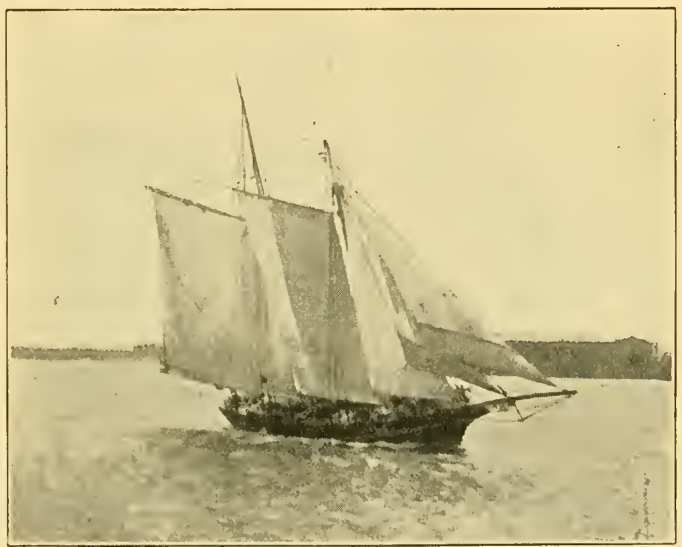

Fig. 51.-A Fishing Schooner sailing into Porta de la Luz. teresting deep-sea fish, a number of leptocephali, and the beautiful transparent Plagusia.

On Saturday, I4th May, we anchored at Porta de la Luz, the harbour of Grand Canary.

In Porta de la Luz we obtained a good deal of information regarding the fishing industry from a number of fishing schooners which work along the African coast, several being in port at the time of our visit.

Most of them are well-boats, which carry live fish in addition to the ones they salt. They employ partly hand lines and partly curious large basket-traps, baited with fish and placed on the bottom in the position shown in Fig. 52 . 
African 'coast fisheries.

When the boats arrive in port they transfer the live fish into big floating tanks, of which we saw many. We were able to examine the kinds they caught, and learned from the people the names in current use. This was a piece of good fortune for us, because the local guide-books give misleading information. The fish caught are spiny-finned and silvery, or of brilliant colours. The following are the commonest species :-

$\begin{array}{ll}\text { Chiacarone } & =\text { Dentex vulgaris. } \\ \text { Besugo } & =\text { Pagrus vulgaris. } \\ \text { Burr oor Chierne } & =\text { Diagramma mediterraneum. } \\ \text { Chopa } & =\text { Cantharus lineatus. } \\ \text { Saifia } & =\text { Sargus rondelettii. } \\ \text { Dorado } & =\text { Chrysophrys aurata. }\end{array}$

Most of them are at present sold alive and eaten fresh, but some are salted, being first split down the back and sliced.

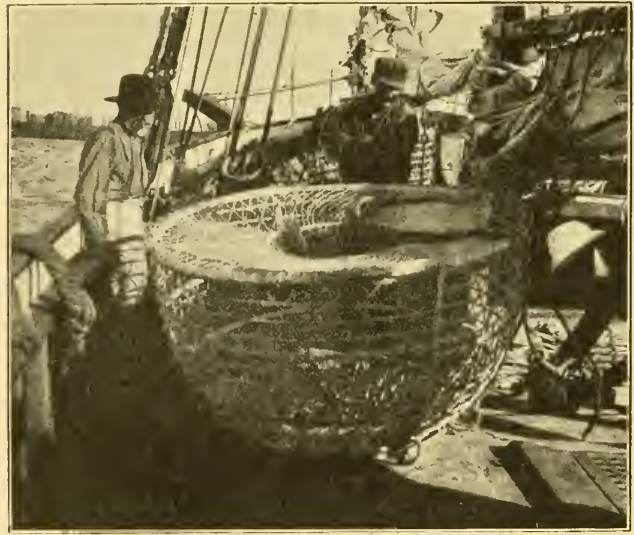

Fig. 52.-A Basket-Trap oN bOARD a FishiNg SchoONer.

They are also occasionally dried, though this kind of stock-fish does not keep long.

The harbour pilot was thoroughly acquainted with the industry. He himself owned one or two schooners, and had taken part in the fishing round the islands and off the African coast. According to him the best places were on the stretch from Cape Juby and beyond Cape Bojador to the River Ouro, and down near Cape Blanco. The trawlers found it too expensive to go so far. Only hand lines and traps are used at present, and most of the fishing is done on a hard bottom in about $16-30$ fathoms of water. He advised us to go as far as Cape Bojador, where there was a little bay sheltered from the trade-winds. We decided to follow his advice, partly because we hoped to see a little of the mode of fishing practised in the Canary Islands, and thus learn more about the animal life than we ourselves could expect to learn in the short 
time at our disposal, and partly with the idea of making a series of trawlings like those we had made in the Spanish Bay.

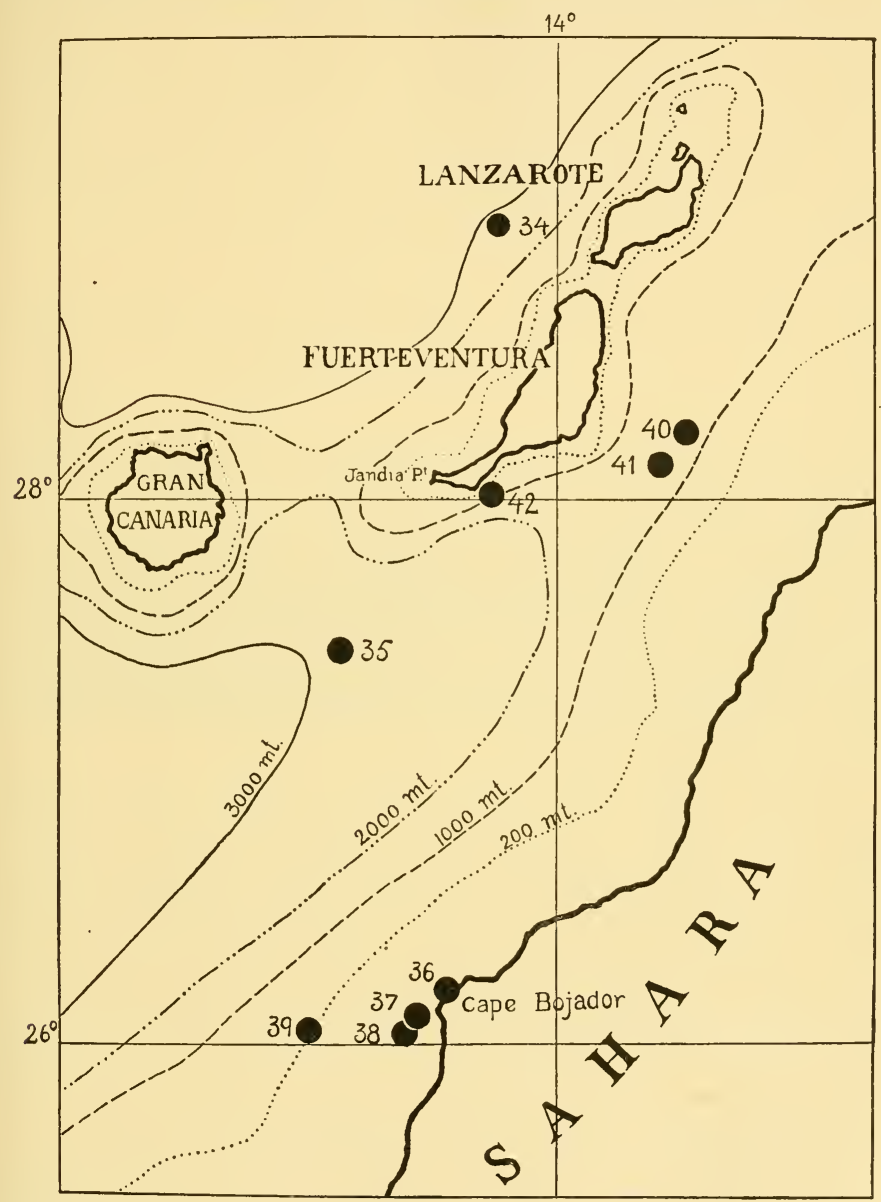

Fig. 53.-"Michael SARs" observing Stations ofF The CaNARy IsLands AND COAST OF AFRica.

Accordingly we left Gran Canaria on I 8th May, and steamed for Cape Bojador (see Chart, Fig. 53). On the way we resolved to try our trawl in deep water, as the weather was fine. 
We sounded, therefore, at Station 35 and got 2603 metres. The trawl was dropped with 5200 metres of wire and towed for about two hours till 6 P.M. At 9 P.M. it was on board again with an extremely interesting catch, including two baskets of holothurians and twenty fishes, several of which were remarkable bottom forms (Harriotta, Bathysaurus, Halosaums, Alepocephalus, and different species of Macrumus). There were also several pelagic fish, including the interesting Gastrostomus bairdii, with its huge gullet, which had previously only been found on the American side of the Atlantic.

At Bojador there were seven fishing schooners and two smacks at anchor. Some of the people were rowing about in boats setting traps, while others were jigging from the vessels themselves. We went on board the "Isabelita." Along the port-rail stood ten men with hand lines, each furnished with three hooks, by means of which they hauled up the big grey "burro" as fast as they could pull. Every now and then they captured "chiacarone" and smaller silvery fish with red fins and strong teeth. Their bait consisted of anchovies and sardines, Seine-net which they secured near the shore by means of a seine net. We fishing. were told that at daybreak next morning they were going close inshore to use their seine, and we obtained a promise to be allowed to accompany them. To our surprise we were asked to bring carbines and revolvers, as the fishermen were very much afraid of the Arabs.

Before daybreak we rowed towards the shore along with the fishermen to work the seine. The view was magnificent. For miles we could see the coast stretching away in a straight, clear-cut line like a mole, a hundred feet or so above the sea ; up beyond the cliffs the land apparently was quite flat, and the sun rose over this line as it does from the horizon at sea. Unfortunately the breakers prevented us from landing, and we had to lie a short distance out from the shore. On the heights above we could see the dreaded Arabs, with their long, thin firearms ready for use; but they sat as motionless as statues, and were probably only thinking of defending themselves.

The Spanish fishermen now made several casts with their seine (see Fig. 54), but were unsuccessful. They had expected to catch large quantities of sardines for bait. We got from them, however, some interesting samples of the small fish that live in quite shallow water, which it would otherwise have been difficult for us to obtain. Among them were young fish (sardines and anchovies), and a number of small spiny-finned 
fish (Sargus, Box, Pristipoma), besides fry of the horse-mackerel (Caranx trachurus), and hake. The fishermen gave us the whole of the catch and would take nothing for it. On parting from them we felt that we had made the acquaintance of capable energetic men, engaged in an interesting industry.

The guide-books sold on the islands state that the fishing industry is undeveloped, because the island population is apathetic, and the Spanish Government little interested in it. This is hardly correct; their African fishing seems to evince both enterprise and a power of adaptation to circumstances. It is no small matter to have to sail in the trade-winds, which are sometimes very violent off the coast of Africa, and there is besides an absence of harbours. The fish caught are best suited for selling alive in the local markets, and it is

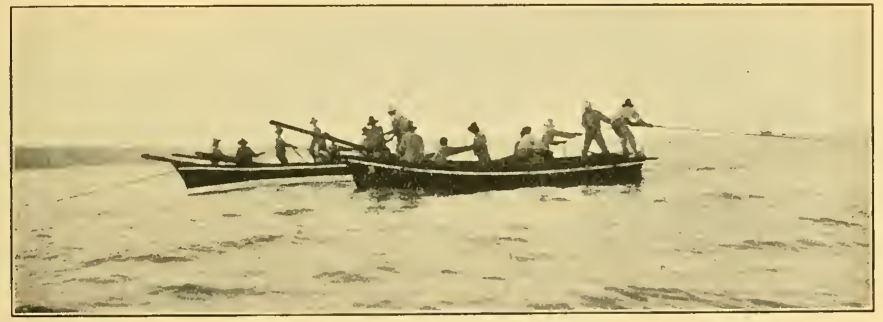

Fig. 54.-Hauling in the Seine.

extremely doubtful whether it would pay to start a fishery on a large scale, as has often been proposed, and commence salting and drying. The kinds of fish may possibly be unsuitable for curing, and the warm climate is very likely less favourable than that of northern lands. As long ago as the middle of the eighteenth century an enterprising man named George Glas made great efforts to establish a fishery, and maintained that the Spanish did not need to depend on Newfoundland for their fish, as they could make their African coast fishery the richest in the world. He did his utmost to prove the truth of his assertion, but failed, partly because of the natural difficulties, and partly owing to various tragic occurrences. Taking everything into account, the conditions under which it is carried on and the present state of the markets, the fishing industry of the Canary Islands is quite creditable, and the friendliness of the fishermen towards our expedition was much appreciated by all on board. 
Our plan after leaving Bojador was to undertake a series of trawlings over the coast banks and continental edge. This
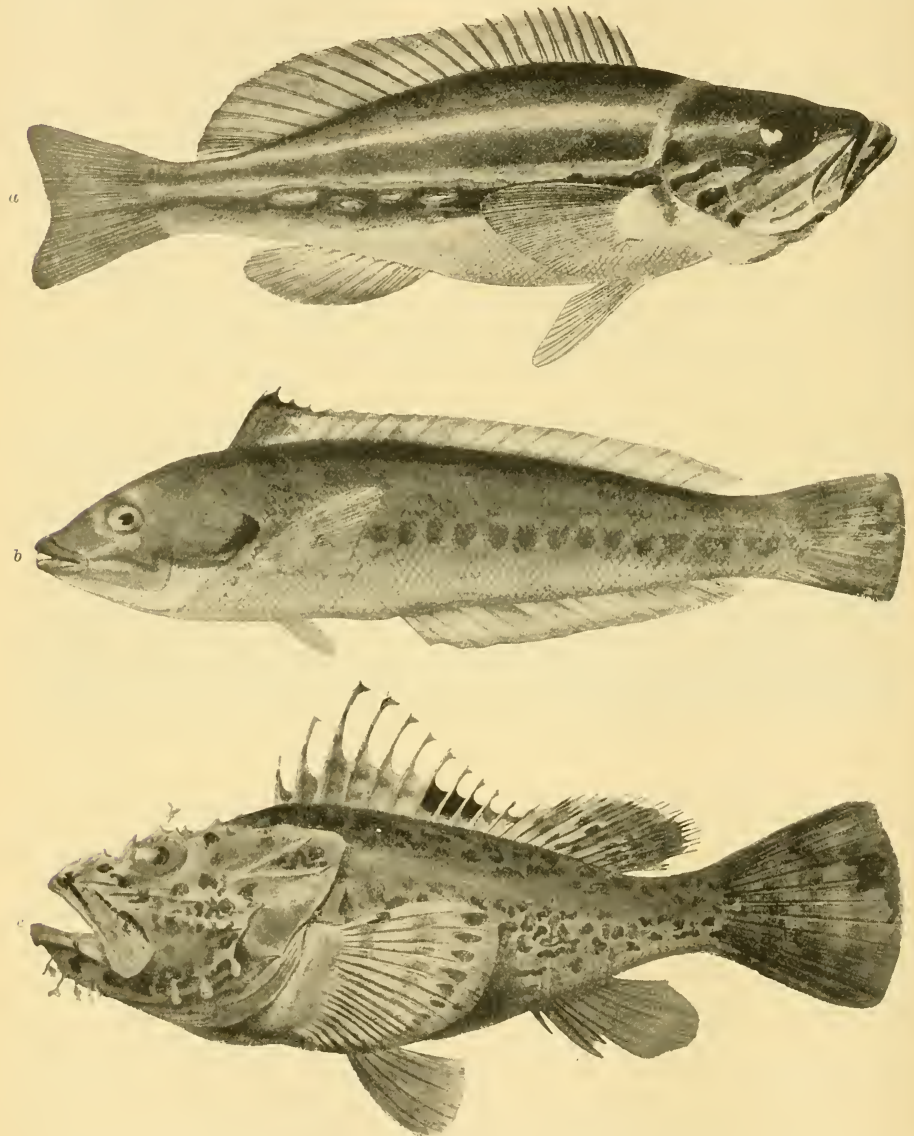

Fig. 55.-Three Coast Fishes from Station 37, 39 metres (about 20 fathoms).

a. Serranus cabrilla, L. Nat. size, $21 \mathrm{~cm}$.

b. Coris julis, L. Nat. size, $18 \mathrm{~cm}$.

c. Scorpana scrofa, L. Nat. size, $48 \mathrm{~cm}$.

proved, however, a matter of great difficulty. Both at Station 37 (see Fig. 55) in 39 metres of water, and at Station 38 (see Fig. 56) in 77 metres, the trawl stuck fast on the hard bottom. 
Still, we succeeded in making some small catches of the animals that live on the bank, including soles and megrims (Solea and Arnoglossus lophotes), gurnard, weevers, monkfish, a large
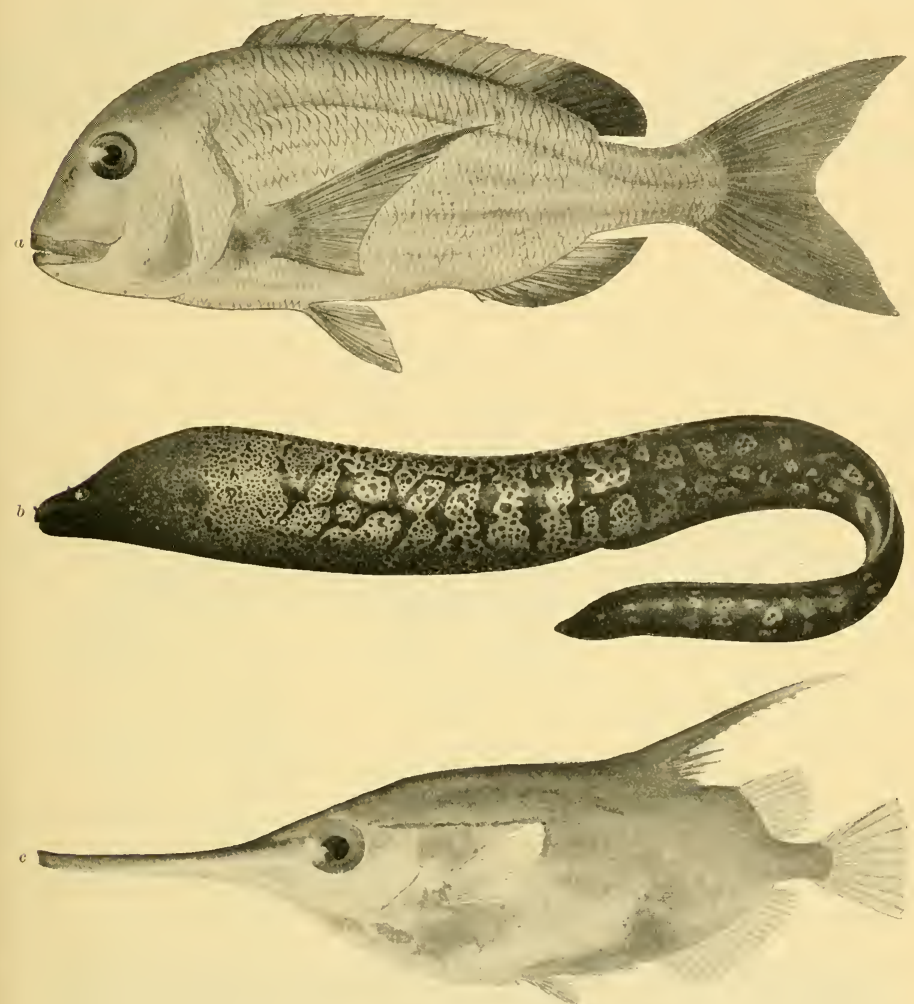

FIG. 56.

a. Pagrus vulgaris, Cuv. et Val. Nat. size, $50 \mathrm{~cm}$.

b. Murana helena, L. Nat. size, $102 \mathrm{~cm}$.

( $a$ and $b$ from Station 38,77 metres-about 40 fathoms.)

c. Centriscus scolopax, L. Station 39, 267-280 metres.

beautifully-coloured muræna (Murcena helena), and a number of skates. At Station 39 (see Fig. 56, c) in 267-28o metres of water, we were more successful, catching a quantity of spinyfinned fish (Dentex, Pagrus, Scorpana, Trigla), hake and skates, and quite a number of deep-water fish. A pelagic haul 
on the edge of the continental slope yielded some interesting captures, especially several spotted eel larvæ (leptocephali).

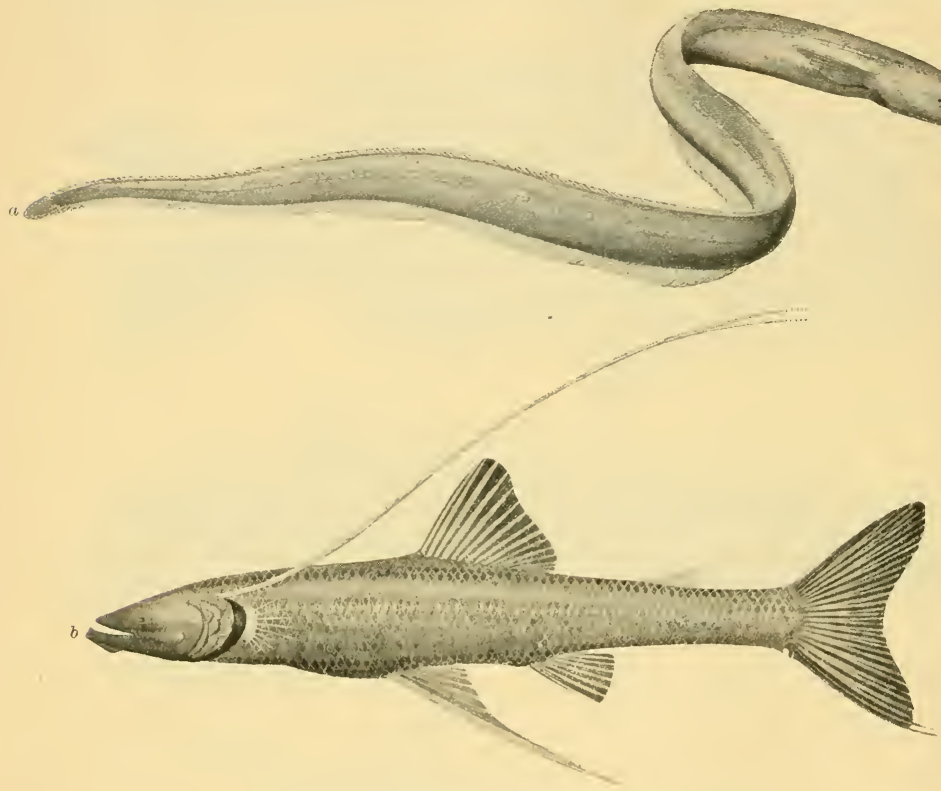

Fig. 57--Two Deep-Sea Fishes from Station $4 \mathrm{I}$.

a. Synaphobranchus pinnatus, Gron. Nat. size, $3 \mathrm{I} \mathrm{cm}$.

b. Bathypterois dubius, Vaill. Nat. size, $17 \mathrm{~cm}$.

Deeper trawlings were impracticable. The captain sounded in several places to try and find a spot where there was a chance of trawling along the slope at a fairly uniform depth, but the

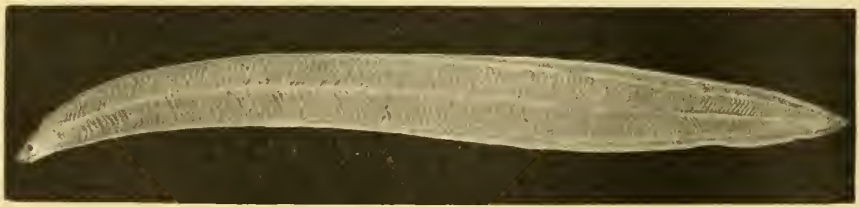

FIG. $5^{8}$.

Leptocephalus Congri vulgaris.

slope was too steep, and we had to abandon the idea. The only place where, according to the chart, there was any prospect of trawling at so great a depth as 1000 metres was between the 
coast of Africa and the island of Fuerte Ventura. Here we

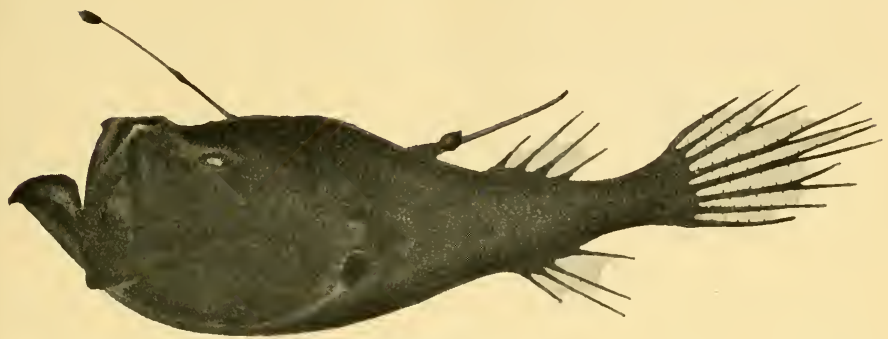

FIG. 59.

Ceratias, n.sp. Nat. size, $13 \mathrm{~cm}$. Station 42 .

sounded at Station 4 I and got I 365 metres. We shot our trawl with 3400 metres of wire, and towed it for three and a half hours. Hauling in took an hour and fifty minutes. Our catch consisted of about fifty deep-sea fishes (see Fig. 5i), several baskets of holothurians, and a number of interesting invertebrates, including some beautiful, large, red-coloured prawns, no less than 30 centimetres long. This catch was extremely interesting, as it yielded the same species of fish that we got in our hauls to the west of Ireland (Mora, Trachyrhyncus, Alepocephalus, Synaphobranchus).

The trade-winds had meanwhile freshened considerably, so we steamed under the lee of Fuerte Ventura, and at Station 42 used our pelagic appliances at various depths. The captures Eel larve. were particularly interesting, including as they did nineteen larvæ of eels (leptocephali). One individual among these (Fig. 58) belonged to the ordinary conger-eel FIG. 6o. - Spirula. (From Chun.) (Leptocephalus Congri vulgaris), but the other eighteen were all of another species closely resembling the conger larva, but 
differing from it in the number of muscle segments; some of them were only $4.2 \mathrm{~cm}$. long. There were further some remarkable deep-sea fish, including a curious Ceratias (Fig. 59), and the little rare cuttle-fish, Spirula (Fig. 6o), which is of such interest to zoologists.

During the night some flying-fish (Fig. 6I) with mature eggs came on board, and on our way back to Gran Canaria we saw a quantity of flying-fish near the island. We anchored once more at Porta de la Luz on Tuesday, 24th May.

From the Canaries to the Azores.

From Plymouth to the west coast of Africa we had been chiefly cruising over the coast banks and continental slopes.

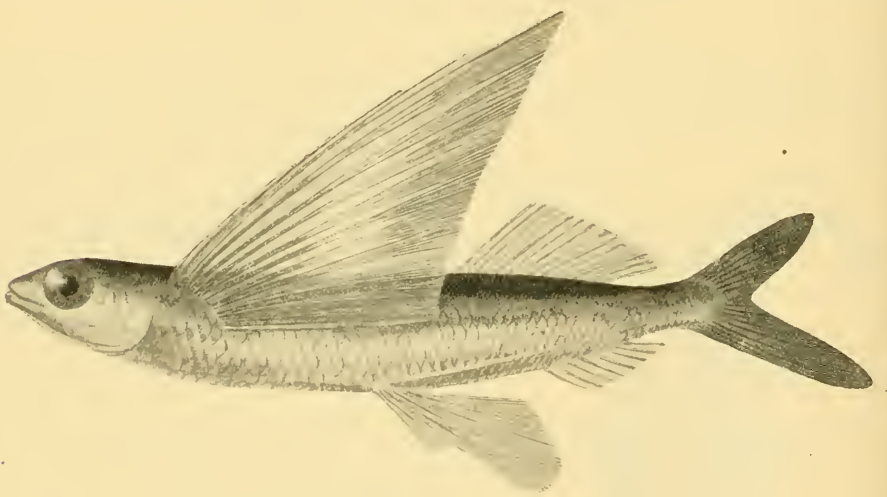

Fig. 61.-Flying-Fish (Exocatus spilopus, Val.). Nat. size, $32 \mathrm{~cm}$.

Now we were to begin a voyage across the Atlantic from the Canary Islands to the Azores and thence to Newfoundland. Our task henceforth was therefore to investigate a deep ocean, the average depth of which may roughly be put at 5000 metres. Everything accordingly had to be so arranged that we could lower our instruments and appliances to profound depths.

The experiences of previous expeditions had made it clear that the larger organisms, at any rate, are sparsely scattered over the vast ocean depths. We therefore prepared ourselves for long pelagic hauls of a day's or a night's duration, during the course of which it would be necessary to employ simultaneously as many appliances as we could at different depths, partly to 
accomplish as much as possible in a limited space of time, and partly to discover what creatures inhabit the various waterstrata.

While on our way to the Azores we hoped to be able to reach the Sargasso Sea and study its peculiar animal life. Accordingly before leaving Gran Canaria we interviewed some Norwegian skippers, who had spent many years in the waters lying between the Canary Islands and the West Indies, and were advised by them not to steer direct for the Azores, but to follow a westerly course as far as the longitude of those islands and then turn northwards. We followed their sugges-

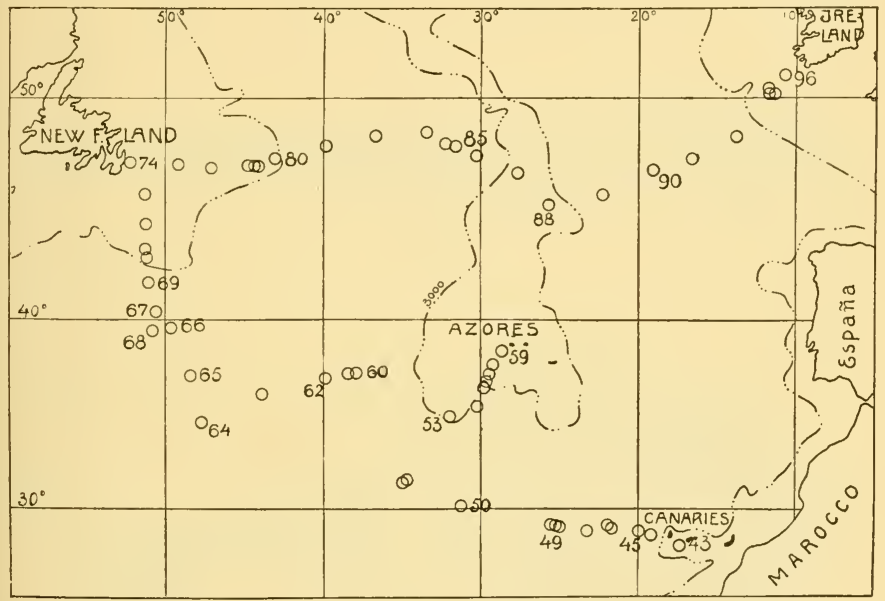

Fig. 62.- "Michael Sars" Stations From CaNary lslands to the Azores and Newfoundand and THENCE TO BRitaix.

tion, leaving Gran Canaria on $27^{\text {th }}$ May, and, as will be seen from the chart (Fig. 62), first steered westwards, making some investigations at Stations $43-52$, and then northwards to Fayal, one of the Azores, occupying Stations $53-58$, and arrived at Fayal on I 3 th June.

Hydrographical investigations were made all this time, and we took as many as fourteen water-samples at different depths at each station, from the surface down to 2000 metres, thus securing some excellent material from this area. Fig. 63 shows a section of the ocean on our westerly route. It is remarkable how uniform the hydrographical conditions proved to be. The

Uniformity of hydrographical conditions and of animal life. 
curves of salinity and temperature lie exactly parallel, both decreasing regularly as we descend in depth.

The animal life, too, showed everywhere great uniformity. While on this route we made seven long pelagic hauls, some at night, with a number of appliances working at different depths simultaneously. The weather was all that could be desired, and we had therefore a splendid opportunity of testing even the very finest of our appliances. As a result we succeeded in collecting a great variety of forms, a full description of which can only be given after thorough systematic examination. It

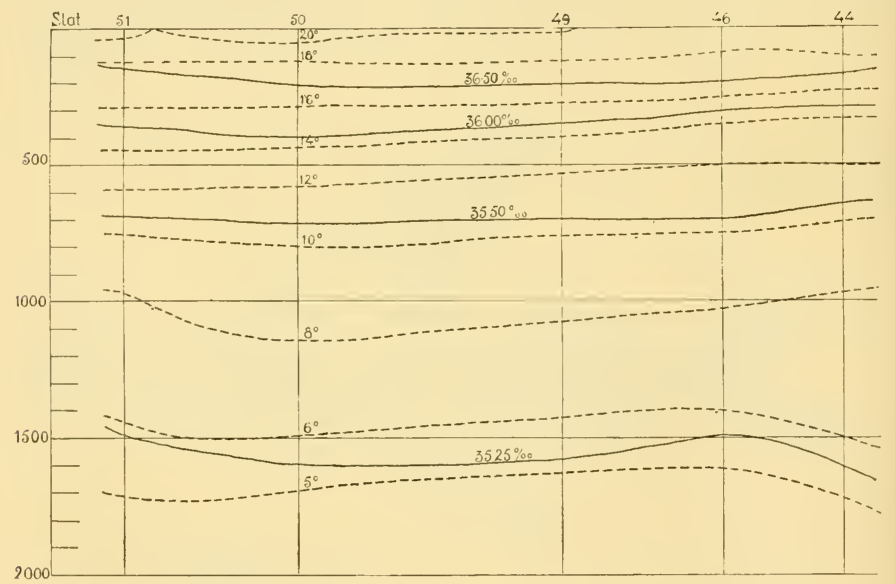

Fig. 63.-Hydrographical Section showing the Temperature and Salinity at StATIONS 44 TO 5 I.

will suffice here to mention the main features of the catches, and to describe one or two particularly remarkable forms (especially fishes) that attracted our attention at the time, or during our first cursory inspection in the laboratory. In the following chapters the material collected will be treated in a more systematic manner.

It was interesting to find that from the corresponding depths we always obtained catches practically identical in character. In the appliances towed at the surface and down to I 50 metres there were small colourless young fish of many species, and fisheggs of very different sizes, some even as small as $0.5 \mathrm{~mm}$. in diameter, and leptocephali occurred in considerable quantities. A profusion of crystal-clear pelagic forms, such as the large 
transparent amphipod (Cystosoma), Velella, Cestum veneris, Animal life Ianthina, Pterotrachea, Physalia, and Glaucus atlanticus, were at different also characteristic.

At depths of 300 metres down to 500 metres silvery fishes were much in evidence. The commonest of them were the flat-

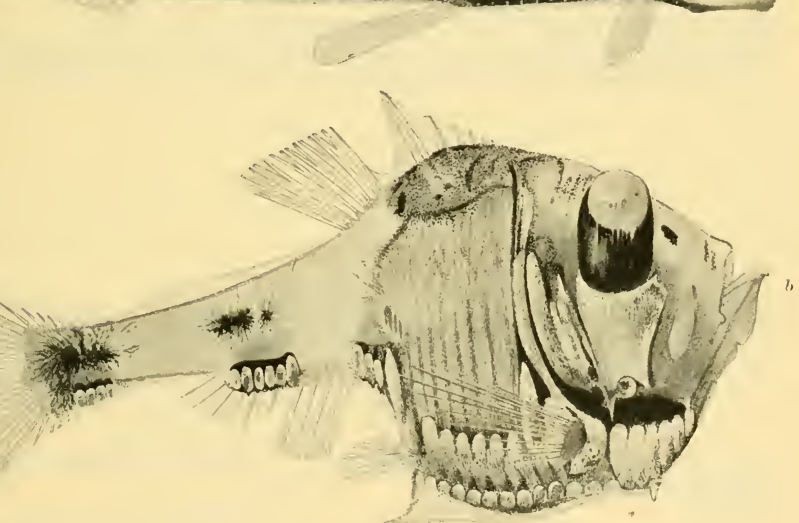

Fig. 64-Two Silvery Fishes from a Depth of About 300 Metres.

a. Chauliodus sloanei, Bl, and Schn. Nat. size, $6 \mathrm{~cm}$.

b. Argyropelecus hemigymnus, Cocco. Nat. size, $3.5 \mathrm{~cm}$.

shaped Argyropelecus (see Fig. 64, b) Stomias, Chauliodus (Fig. $64, a)$, and Serrivomer. The fish which we met with most frequently, however, was the grey-coloured Cyclothone signata, hundreds of which were sometimes taken in a single haul (see Plate I., Chapter X.). Several species of red prawns were also found here.

Our hauls from 1000 metres down to 2000 metres were 
equally interesting. They invariably contained black Cyclothone microdon (see Plate I., Chapter X.), and different species of red prawns in abundance. In addition there were many of the rarer sorts of black-coloured fish, Photostomias, etc., mentioned in the following pages, and dark brown medusæ. Atolla,

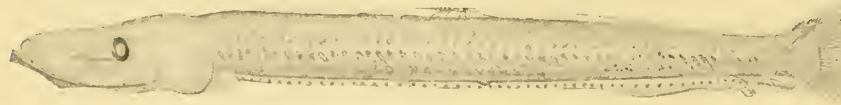

Fig. 65.-STALK-EYEd Fish-LARVA.

for instance, was especially characteristic, and so were red chætognaths, and at some stations red nemertines.

Besides the commonest forms which are almost always found

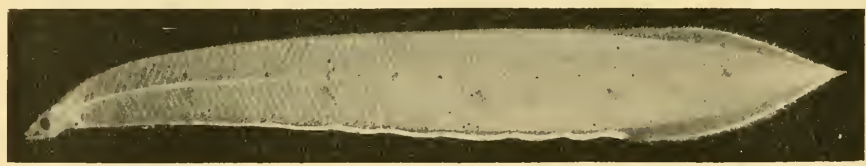

Fig. 66. - New Species of Leptocephalus.

occurring at the same depths, we obtained something of special interest at nearly every station. We can best illustrate this perhaps by a brief description of our most noticeable finds at
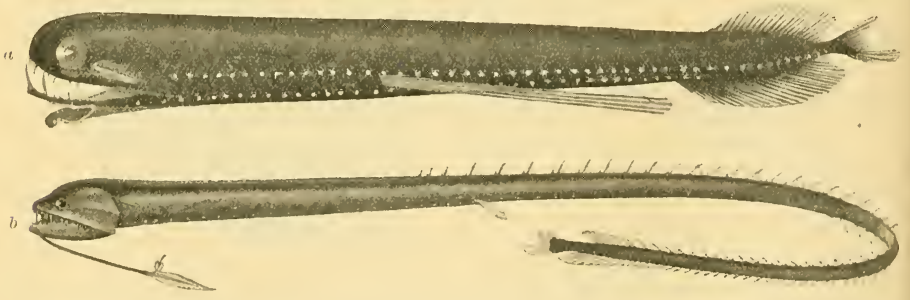

Fig. 67.-Two Black Fishes with many Phosphorescext Organs, sometimes found in THE UPPER LAYers at Night.

a. Photostomias guernei, Coll. Nat, size, $17 \mathrm{~cm}$.

b. Idiacanthus ferox, Gthr. Nat. size, $22 \mathrm{~cm}$.

the stations marked on the chart (Fig. 62), remarking only that in their selection we have been guided by what we consider the most interesting.

At Station 45 we made a haul with seven appliances during the night. In the upper I 50 metres there was a quantity of young fish (some of which were stalk-eyed; see Fig. 65), 
pteropods, leptocephali (one of which displayed remarkable pigment; see Fig. 66), and cuttle-fish. There were besides a few black fish (Idiacanthus ferox, Photostomias guernei; see Fig. 67).

In the deep hauls at 1000 metres and 1500 metres there were numerous very rare animals. For instance, we secured specimens of the cuttle-fish Spirula, and of the fish Melanocetus krechi, the type of which had been discovered by the "Valdivia" Expedition in the Indian Ocean, so far removed from the scene of its recapture. Again, Aceratias macrorhinus indicus, a small brown fish $(28 \mathrm{~mm}$. long; see Fig. 68), and Cyema atrum (Fig. 69), had hitherto only been met with in the Pacific and Indian Oceans, and off the coast of Morocco.

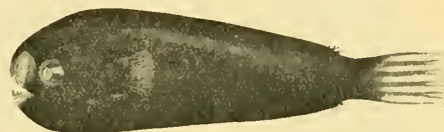

FIG. 68.

Aceratias macrorhinus indicus, $\mathrm{A} . \mathrm{Br}$ Nat. size, $2.8 \mathrm{~cm}$. It was extremely interesting to find at one spot all these proofs of the wide distribution of such "rare" pelagic fishes.

At Station 47 we sounded in 5160 metres. Trawling was tried, but was a failure, as the trawl got out of order and merely captured a sea-pen (Umbellula giinthern). During the night we sighted a turtle, which was thus about 250 nautical miles from the nearest land, the island of Palma.

At Station 48 we made another attempt at trawling. The big trawl was dropped with $875^{\circ}$ metres of wire at II.2O A.M.

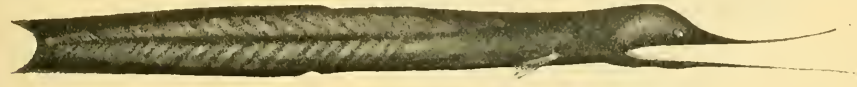

FIG. 69.

Cyema atrum, Gthr. Nat. size.

At 2.50 P. M. we commenced hauling in, and the trawl came up at 9 P.M. This time everything seemed to have gone right, for the trawl apparently went down and came up again in full working order. Strangely enough, the catch was meagre in the extreme, consisting of half a barrel of ooze, a number of pumice fragments, the earbone (bulla tympanica) of a whale, two sharks' teeth (Carcharodon and Oxyrhina), a fragment of a nautilus shell, two holothurians, about ten pteropod shells, an antipatharian, a sertularian, Umbellula, six fishes (Alepocephalus, Malacosteus indicus, Argyropelecus, leptocephalus in its transition stage from the larval form, a new form resembling Ipnops

Trawling in deep water. 
murrayi, for which Koefoed and I propose the name Bathymicrops regis, and an ophidiid not yet determined). All these fishes, if we except, perhaps, Bathymicrops regis, were probably captured while the trawl was being hauled in. There were thus no undoubted bottom-fish in this long haul with our large appliance, and taking everything into consideration,

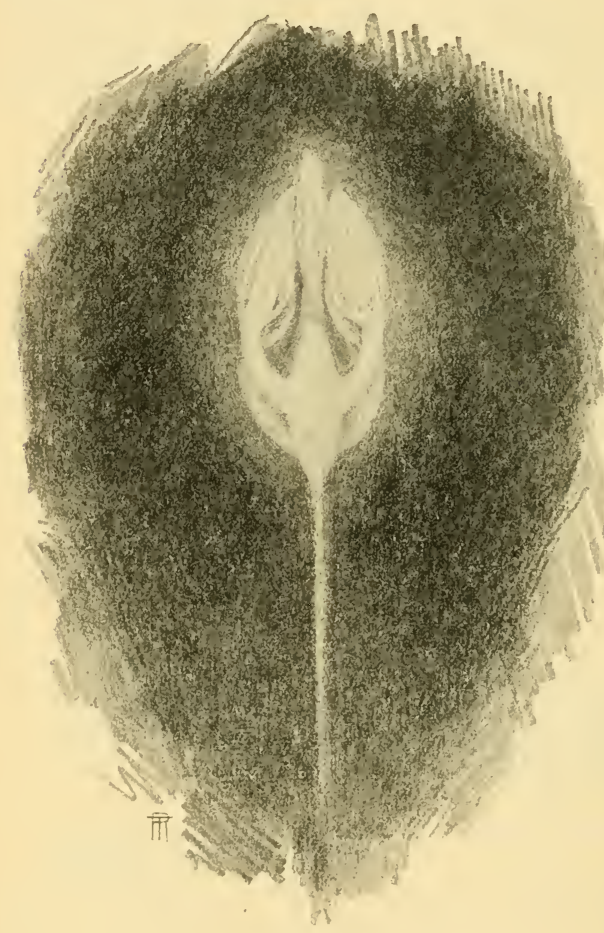

FIG. 70.

Umbellula gïntheri (phosphorescent). we had caught extremely little. Chapter VII. deals more fully with the significance of this result. We were interested to find a fragment of a sea-pen (Umbellula giuntheri, Fig. 70) which continued shining brightly on the deck, thus furnishing fresh proof of the well-known fact that some of the lower animals from the profoundest depths emit light.

While towing the trawl we made some interesting observations on the pelagic animal life, as we put two tow nets on the trawl wire, the one being towed at about 40 metres, and the other at about 2000 metres, and during the whole of the day we took samples from the surface.

The tow-net at 40 metres contained a mass of red copepods, which were not observed at the surface during the daytime, but suddenly appeared as soon as it grew dark, soon after 6 P.M. The surface plankton comprised Physalia, a great many molluscs, such as Ianthina and Pterotrachea, one of the remarkable little 
fishes called sea-horses (Hippocampus, Fig, 7 I), and the beautiful belt of Venus (Cestum veneris); very many pelagic foraminifera were present in the fine nets.

Our deep tow-net caught a large Alepocephalus, showing that this fish may be pelagic. So far as we know it had hitherto been taken only in the trawl, and this catch was all the more interesting, because our trawl at the end of the same wire also captured a specimen; previously one would have taken it for granted that this specimen must have been caught at the bottom.

At Station 49 B we towed seven appliances in daylight, and no black fish were captured in the upper layers. We observed a number of Portuguese men-of-war (Physalia), around which were a great many small fishes - probably horse-mackerel (Caranx),

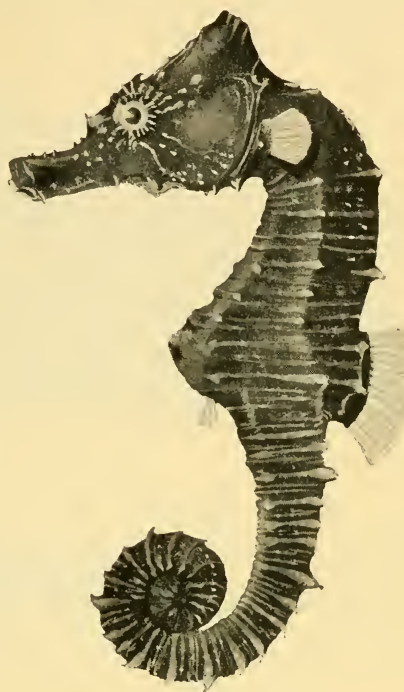

FIG. 71.-Hippocampus. which we caught in one of the young-fish trawls-and fry of Scombresox. A beautiful large transparent amphipod (Cystosoma)

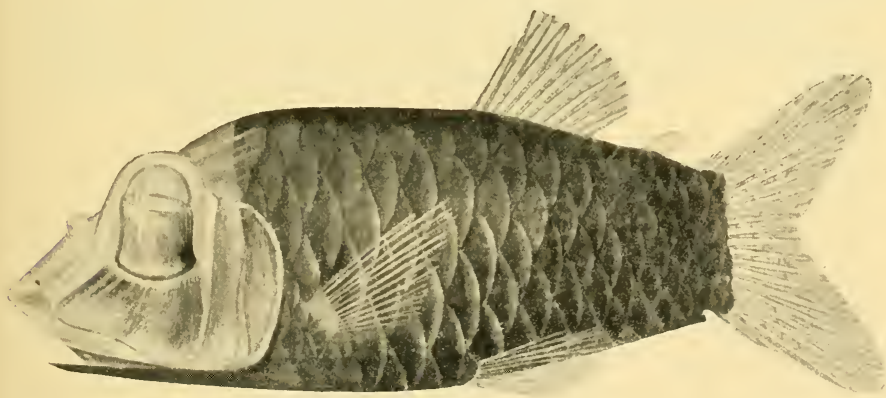

FIG. 72.

Opisthoproctus soleatus, Vaillant. Nat. size, $6.5 \mathrm{~cm}$.

was secured at 200 metres, and young Argyropelecus at 500 metres. In the deeper appliances we found large ostracods 
(Gigantocypris) with eggs, Opisthoproctus solcatus (a remarkable little fish, with large telescopic eyes, caught once or twice
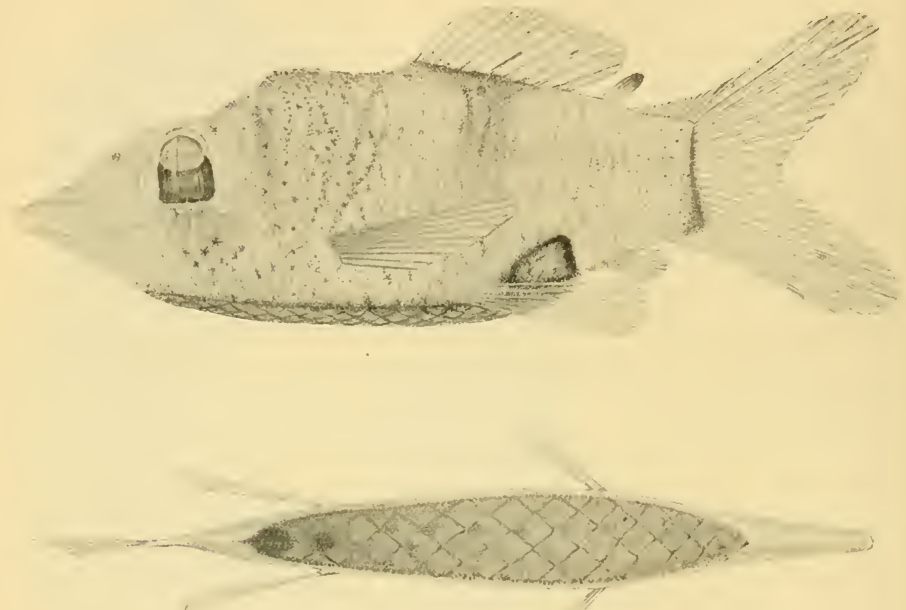

FIG. 73 .

Opisthoproctus grimaldii, Zugmayer. Nat. size, $2.6 \mathrm{~cm}$.

previously; see Fig. 72), and another species of the same genus, Opisthoproctus grimaldii (see Fig. 73), two specimens of which were taken by the Prince of Monaco off the coast of Portugal.

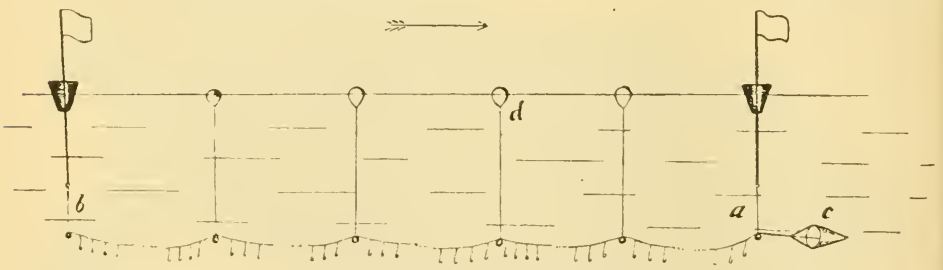

Fig. 74.-Flodting Loxg Lines.

$a, b$, Big buoys ; $c$, drift anchor ; $d$, leather buoy.

There were also some specimens of the little Aceratias macrorhinus indicus.

Drift nets We had all along intended to try drift nets and floating lines and lines. out in the ocean to see whether big fish were to be caught there, 
so we now made the experiment. A line was set perpendicularly with 1300 cod hooks, a fathom and a half apart (see Fig. 74), and we also put out six cod nets. Only one fish was caught on the line, at a depth of 550 metres, namely, Omosudis lowei (Fig. 75), which Lowe captured at Madeira, and is recorded by Guinther as having been found near the Philippines by the

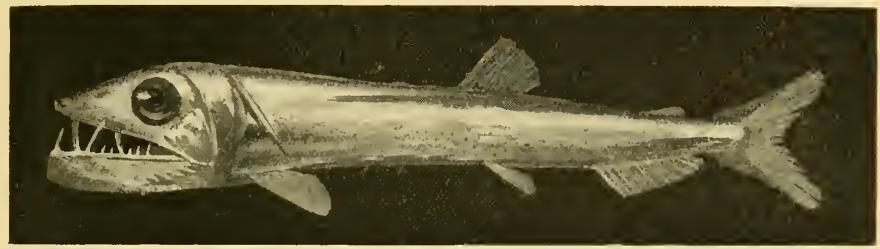

FIG. 75 .

Omosudis lowei, Gthr. Nat. size, $1+.5 \mathrm{~cm}$.

"Challenger." A large ossified spine springs from its gill-cover and extends right along the side of its body, and it has very large teeth; it has a beautiful silvery appearance. Our bait (sprats) was unfortunately several months old, so that this experiment cannot be regarded as in any way conclusive.

In the nets there were three pilot-fish (Naucrates ductor,

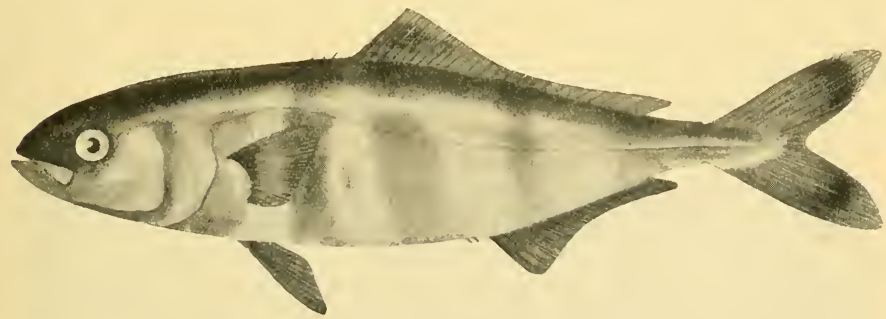

FIG. 76 .

Naucrates ductor, L. Nat. size, $23 \mathrm{~cm}$.

Fig. 76), and under the boat when hauling in the nets a number of fish were noticed, of which we saw a good many subsequently ; they seemed to be plentiful near the surface of the sea, and two species, Lirus maculatus (Fig. 77) and Lims ovalis, were eventually secured.

At Station 5 I we fell in with larger and smaller patches of drifting Sargasso weed with the ordinary gulf-weed animals clinging to it, such as small crabs, naked molluscs, and fishes 
(Syngnathus; see Plates V. and VI., Chapter X.), and in the open water between the patches were Portuguese men-of-war, invariably attended by small fishes. This seems to be a phenomenon corresponding to the association of the cod-fry with jelly-fishes in the Norwegian Sea.

At this station we made a very successful haul during the

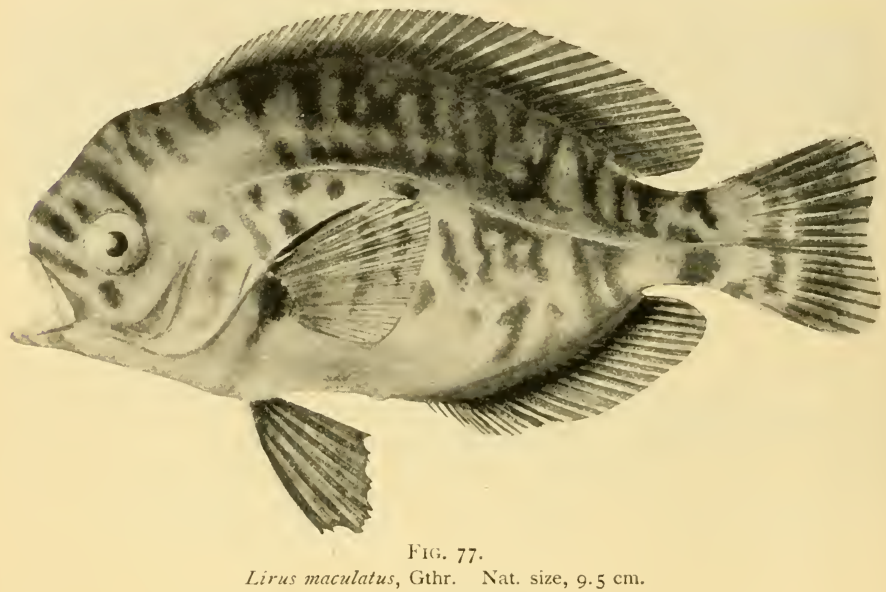

night of 5 th-6th June with nine appliances. In addition to the ordinary surface animals previously referred to, the tow-net at the surface secured as many as sixty-one leptocephali belonging

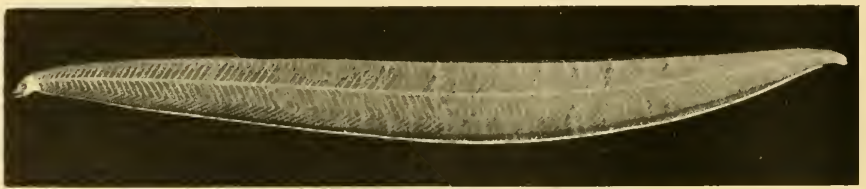

Fig. 78. - New Species of Leptocephalus.

to what we have since found to be a new species (Fig. 78), of which twenty-three specimens were captured at Station 52 . There was also an interesting high leaf-shaped leptocephalus (Fig. 79), another specimen of which was taken at Station 56.

In the upper appliances there were quantities of fish-eggs and young fish, another Cystosoma, and Ceratias conesii, which had previously been taken by the "Albatross" off the east 
coast of North America, by the "Challenger" near Japan, and by the "Valdivia" in the Indian Ocean at the bay of Aden. At this night-station, too, there were black fish in the upper layers, such as Astronesthes niger (Fig. 80), a dark Dactylostomias, and some black Cyclothone at 300 metres. An

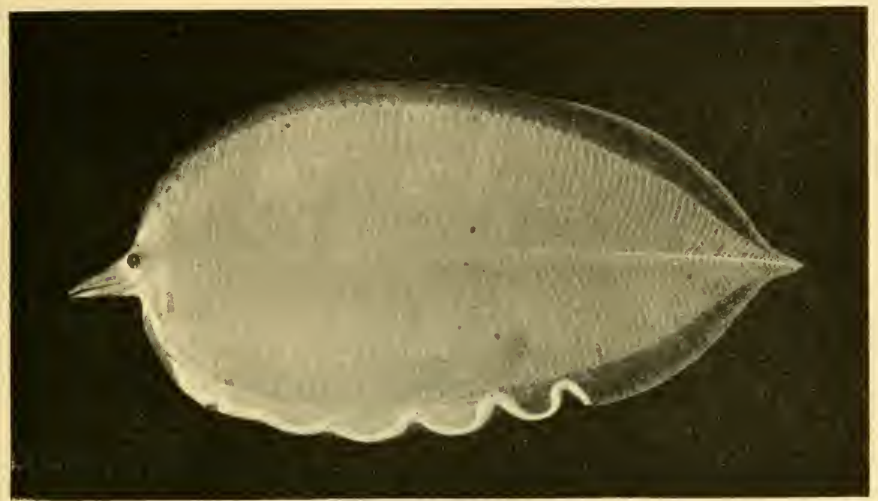

Fig. 79. -NEW SPECIES OF Leptocephalus.

interesting cuttle-fish with stalk-eyes was taken at 350 metres, and deeper down we got Servivomer, Nemichthys scolopaceus, Malacosteus niger, M. choristodactylus.

At this station we were able to try an apparatus for

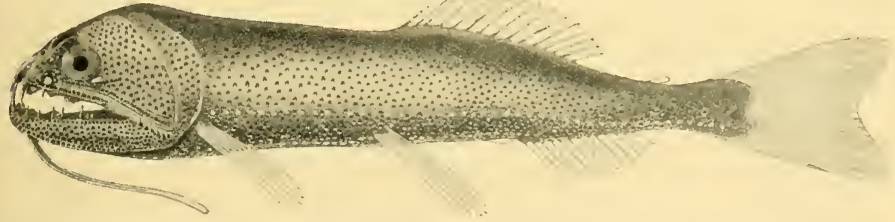

FIG. 8o.

Astronesthes niger, Rich. Nat. size, $3.5 \mathrm{~cm}$.

ascertaining the depth to which the rays of light penetrate. It was constructed by Helland-Hansen, and is likely to Helland prove useful in the study of the forms of life in deep water. Hansen's The apparatus shows the intensity of the light both from above and and from the sides. By means of panchromatic plates and photometric colour filters it is possible to tell, not merely whether there is 
light, but also the proportion of the different prismatic colours at different depths. At the very first attempts the apparatus acted perfectly, and as far down as 1000 metres at any rate showed light in considerable quantities, whereas at a depth of I 700 metres the plates were unaffected even after an exposure of two hours. We may assume accordingly that the amount of light at the latter depth is infinitesimal. The ultra-violet and blue rays are the ones that penetrate deepest. There were plenty of these rays at 500 metres, whereas the effect of the red and green rays there was imperceptible even after an exposure of forty minutes. At 100 metres the rays were of every colour, though red rays were least numerous, while there were rather more green rays, but even at this depth blue and ultra-violet rays predominated. These experiments are of great assistance in dealing with such problems as the growth of plants, for which light is essential, the colours of animals at different depths, and the remarkable modifications in the organs of sight and phosphorescent light-organs that are so characteristic of the higher animal groups in the ocean depths.

Another haul by night was made at Station 52, though only with four appliances, the deepest of which was at about 600 metres. The catches in the tow-nets at the surface and at 30 metres were particularly interesting, including a quantity of young fish, amongst which were young flying-fish and a number of young Scombresox, many leptocephali, one of which was afterwards found to be a small undeveloped larva of the common eel ; that is to say, a transition stage from the egg to the fully developed leptocephalic larva. It was extremely interesting, too, to find eggs of the deep-sea fish Trachypterus at the surface of this deep basin.

In our deepest appliance we found the beautiful Macrostomias longibarbatus, captured by us at Station 28 in the Spanish Bay, and previously recorded by the "Valdivia" Expedition from the Gulf of Guinea and the Indian Ocean. We also captured a specimen of Opisthoproctus soleatus, as well as a species of Oneirodes resembling megaceros (Fig. $8_{I}$ ). The haul with the trawl resulted in a take of at least two litres of large red prawns.

As we had now reached the Sargasso Sea, at Stations 5 I and 52 , we set our course northwards towards the island of Fayal, where we intended to coal before crossing over to Newfoundland. While steaming towards the bank which surrounds the Azores, we frequently saw sperm whales, sometimes swimming on the surface and easily recognisable by 
their abrupt heads, and sometimes with their flukes in the air. A school of other whales, probably the "caaing-whale," was also seen.

At Station 53 we reached a lesser depth of water, namely 26 I 5 to 2865 metres, and had, accordingly, arrived at the slope rising from the deep basin of the Atlantic to the plateau of the Azores. A sample from the bottom showed much pumice, pteropod shells, and a large percentage of carbonate of lime, with siliceous spicules of sponges and radiolaria.

We shot the big trawl with 6400 metres of wire, and towed it from ten in the morning till two o'clock in the afternoon. At 5. I 5 P.M. it came up with a most successful catch. The greater abundance of organisms here as compared with profound depths was surprising. There were at least 500 holothurians belonging

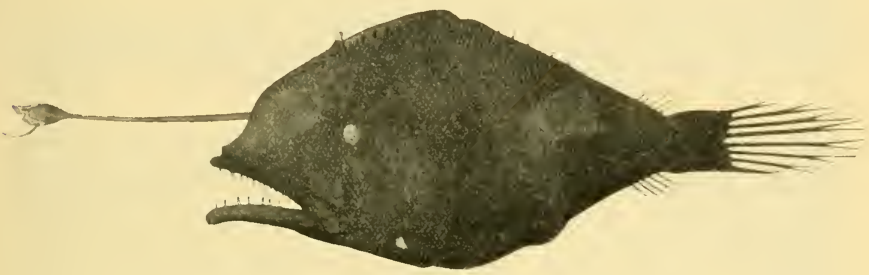

FIG. SI.

Oneirodes sp. Nat. size, $2.5 \mathrm{~cm}$.

to several species, large red crustaceans, fifteen Pagurus, a number of actinix, lamellibranchiates, and sponges, as well as thirty-nine fishes (different species of Macrumes, Alepocephahus, Halosauropsis, Bathysaurus, Benthosaums, and Synaphobranchus). This haul proved again that animal life was abundant at about 3000 metres ( 500 fathoms).

Our pelagic hauls were equally interesting. They were carried out during the night of 8 th June, and nine appliances were towed simultaneously. The surface tow-net contained a quantity of the large medusa (Pelagia atlantica), a number of what are sometimes called salmon-herrings (scopelids, most of them Myctophum coccoi or $M$. punctatum), and as many as thirteen black Astronesthes niger. This was the more remarkable because we had towed appliances on the trawl-wire at a depth of 30 metres the previous day, for at least four or five hours, and had not captured a single scopelid or Astronesthes. A better proof of the vertical wanderings of these animals seems 
hard to find. Young fish, too, were nearly absent during the day, if we except a few specimens taken in a tow-net at 60 metres, but at night we got masses of them at 50 metres. Among these young fish in the upper layers we found again five little eel larvæ of a size smaller than the grown larvæ, and there were besides a number of interesting young fish with telescopic eyes, young flying-fish, and different species of leptocephali. At I 50 metres we secured two remarkable leptocephali with long rostrums (see Fig. 82).

In the intermediate layers, that is to say, from 300 to 500
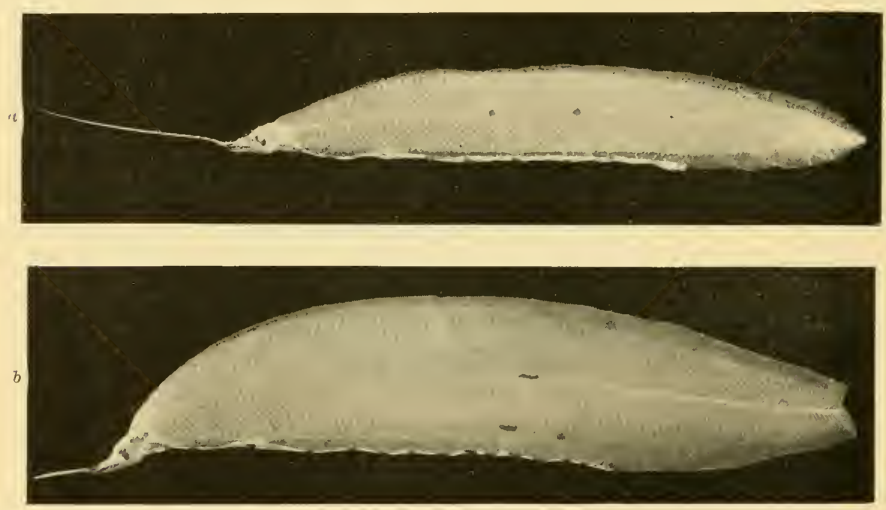

Fig. 82.-Two New Leptocephali with Rostrums.

metres, we found stomiatids, there being no fewer than fourteen specimens of Chauliodus sloanei in a little tow-net half a metre in diameter. At 800 to 1300 metres there were plenty of "rare" fishes; for instance, seven specimens of the large-mouthed Gastrostomus bairdii, a specimen belonging to a new genus of the Gastrostomidæ (Fig. 83), a small fish which has not yet been described (Fig. 84), one Cyema atmm, three Aceratias macrorhinus indicus, masses of black cyclothones, and several others of the more common forms. This station may well be called an El Dorado for collecting zoologists, and instead of a few days, months might profitably be spent to the south of the Azores, where we found so many new and interesting forms.

At Station 56, situated about 100 nautical miles from Fayal, the depth was 3239 metres. Here we lowered nine pelagic appliances on the evening of roth June, and hauled 
them in next morning between 2 A.M. and 4.3O A.M. Our catches resembled those at the preceding stations. At 50 to I 50 metres there were quantities of fish larvæ and young fish, including two small eel larvæ and also the young of Macrumes, a deep-sea fish, the young stages of which thus occur in the upper water-layers. Many of the young fish had telescopic

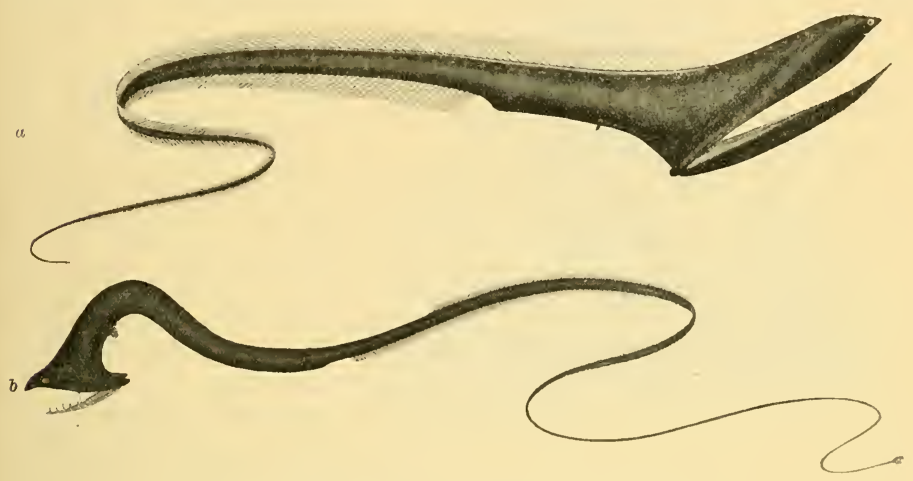

Fig. 83.-Two Gastrostomid.玉.

a. Gastrostomus bairdii, Gill and Ryder. Nat, size, $+7 \mathrm{~cm}$.

b. New genus. Nat, size, $20 \mathrm{~cm}$.

eyes. The fact that we obtained young flounders showed that we were nearing land. At greater depths we secured nothing of any particular note, merely the usual deep-sea forms.

While examining the material from our tow-nets in the morning, we noticed numbers of small silvery fishes near the

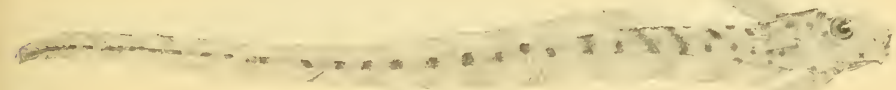

FIG. 84 .

A new species, not classified yet.

surface; and later on, when we commenced steaming towards Fayal, we came across one turtle after another. The boat was Great capture therefore lowered, and a regular turtle-hunt began. Our plan of turtles. was to row carefully up to the animals, which lay quite still on the glassy surface, seize them by the hind leg with our hands, and heave them into the boat; in this way we captured as many as fifteen turtles belonging to the species Thalassochelys 
corticata. Under the turtles there were often quite a number of the little silvery fish alluded to above, and we caught some of them in a net and found that they were horse mackerel (Caranx trachums, see Fig. 86). Some larger fish too were occasionally seen below the turtle near the mouth, just where the neck

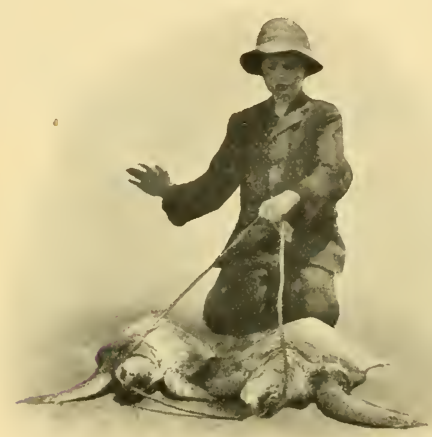

Fig. 85.-T. H. MURRAY ON BOARD THE "MichaEL SARS," IITH JUNE 19 IO. leaves the carapace. These swam under the boat as soon as the turtle was caught, but we captured three, and found them to be wreckfish (Polyprion americamus). Quantities of blue isopods were seen beneath one or two of the animals. Our meeting with turtles was extremely interesting, as we found that their stomach contents consisted entirely of medusæ and salpæ, immense quantities of which floated near the surface of the sea. In the transparent blue waters we could perceive thousands and thousands of beautifully-coloured and iridescent chains of salpæ, sometimes as much as 6 to 7

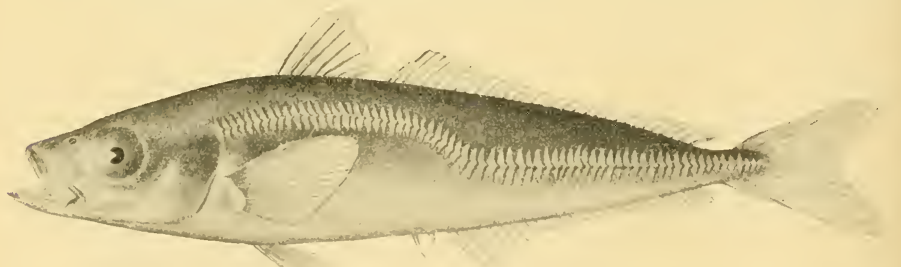

FIG. 86.

Caran $x$ trachurus, L. Nat. size, $10.5 \mathrm{~cm}$.

metres in length, besides siphonophores and floating aurelias, with little fish in attendance, - a fascinating pelagic animal life.

We made yet one more pelagic haul at Station 58 , and caught a splendid specimen of one of the most remarkable deepNemichthys. sea forms (Nemichthys scolopaceus). This is a long fish, with a long beak like that of a bird, large eyes, quite short body, and 
an immense tail. Our specimen was about I 25 centimetres long, of which the beak accounted for 8 centimetres, while the distance from the corner of the mouth to the anus was 4 centimetres, the remainder being thus over a metre long. This creature has been caught previously in both the Atlantic and Pacific.

After sounding at Station $5^{8}$ in 1235 metres, we decided to shoot our trawl. Hardly was it well out, however, before it stuck fast, and brought the ship completely to anchor. We availed ourselves of this circumstance to obtain some current measurements, hauled in on the trawl-wire, and passed it forward to the bow, being thus as it were riding on a warp.

We commenced measuring the currents at midnight, and went on till 3 P.M. next day, when we attempted to haul in the trawl. Unfortunately, however, the wire parted, so that we lost the trawl and I 500 metres of line as well. Still we had at any rate succeeded in taking some measurements, our mode of working being to have one current-meter constantly recording velocities at Io metres, while another current-meter was lowered to different depths. The movement of the water-masses at Io metres was a typically tidal one. In deep water, too, there Tidal currents were relatively strong currents as far down as 800 metres, and distinct indications of tidal movements. Generally speaking, the currents in deep water had an opposite motion to those of the surface layers, but a fuller account will be found in Chapter $\mathrm{V}$. It is sufficient to state here that our expedition succeeded in measuring currents out in the ocean at considerable depths, and that we found tidal movements even at profound depths. IVe anchored at Fayal on I $3^{\text {th }}$ June.

One of the most interesting tasks of our expedition was to From the take a section across the western basin of the North Atlantic Azores to from the Azores to North America. A section of the Gulf land. Stream as far south as we could manage would, we felt sure, be of value, and it would also be interesting to compare the animal life which we had found in the eastern basin between the Canaries and the Azores with that of the waters farther west. Unfortunately the accident by which we lost our trawl and I 500 metres of wire on the Azores plateau prevented us from sweeping the greatest depths, but we were still in a position to carry out pelagic experiments.

It would have been desirable to set our course from the Azores to the Bermudas, and then on to Boston, finishing with 
a series of short zig-zag sections between the land and the edge of the coast-banks, till we reached Newfoundland. We should in that case have been able to study the remarkable transition that occurs on passing from the almost tropical conditions of the Sargasso Sea to those of the icy Labrador Stream, which creeps southwards along the Labrador coast from Baffin's Bay to Newfoundland, and even farther south. The short time at our disposal made this impossible, and we were compelled to cross from the Azores to the nearest coaling station, namely Newfoundland, and then make for home.

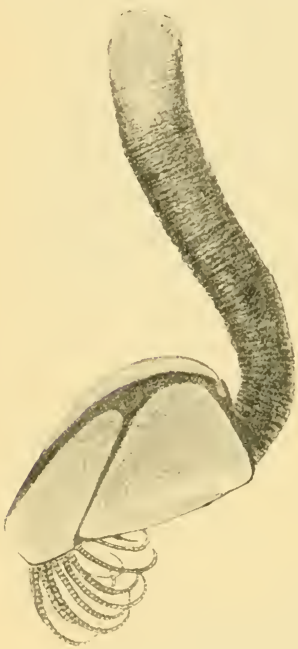

FIG. 87 .

Lepas anatifera. Nat. size.

The mere distance between the Azores and Newfoundland, between I 200 and I 300 nautical miles, was a serious consideration for our little vessel, for we had to count upon meeting headwinds and currents, especially when we reached the Gulf Stream off the Newfoundland Bank; and there was always the possibility of fog delaying us. We resolved accordingly to go westwards towards the eastern boundary of the Gulf Stream, and then turn northwards, which would increase the distance to I 800 miles, but would offer better conditions of wind and current. We should also be enabled to visit again the Sargasso Sea, the animal life of which we had found so interesting, and we should further be able to take a section right across the axis of the Gulf Stream. To prepare for all emergencies we not only filled our bunkers as full as they could hold with the best Welsh coal, but also piled our decks with as much as we could find room for. This done, we said farewell to Horta's little harbour on the afternoon of $\mathrm{I} 7$ th June.

During the first two or three days of our journey west we had wind and sea dead against us, so work was limited to hydrographical observations at Stations 59 and 60 (see Chart, Fig. 62). The weather afterwards cleared up, and at Station 6 I we met with certain fishes, hitherto regarded as extremely rare, swimming about on the surface of the Atlantic. On lowering a boat to examine a drifting log overgrown with barnacles (Fig. 87), we found it surrounded by fishes like those observed 
by us in the Sargasso Sea near Station 50, and we succeeded in capturing eleven specimens belonging to the species Pimelepterus boschii and Limus perciformis.

At Station 62 we tried nine pelagic appliances at different depths on the night of 2oth June. Our catches were very satisfactory at all depths, and much

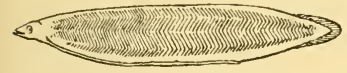

Fir. 8S. - THE SMALlEST LARVA OF THE COMNON EEL CAUGHT BY THE "MICHAEL SARS." 4. I cm. long. Nat. size. resembled those taken between the Canary Islands and the Azores.

In the upper layers there were some extremely interesting leptocephali, including no fewer than eleven specimens of the common eel larvæ Eel larw.

(Fig. 88), 5 to 5.7 centimetres long, showing that the little eel larvæ are to be met with west as well as south of the Azores. We also found two individuals, only 4.7 and 5 . I centimetres long, of leptocephali belonging to the deep-sea fish Synaphobranchus pimnatus. This had previously only been met with in sizes approximating to the full-grown larva (IO-I $3 \mathrm{~cm}$.), of which we found several at the different stations; but it was most interesting to come across such small (early) development stages of the species.

At depths from 300 metres to 50 metres there were again the same colourless Cyclothone signata as well as silvery Argyropelecus, Stomias, and Chauliodus. IVe got, too, a new species of Ceratias. In the deepest hauls, below 500 metres, the forms were the same as in previous hauls. There was the little black fish, Cyclothone microdon, once more, red prawns (particularly Acanthe-

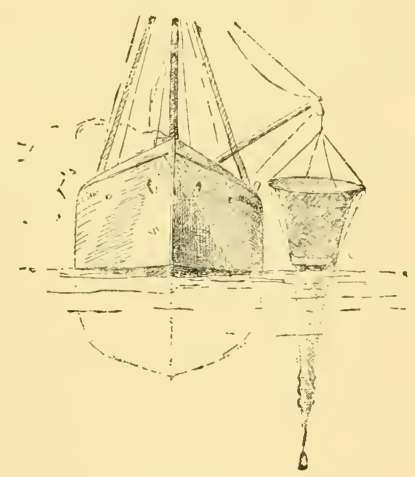

Fig. 89,-Large Closing Net. phyra), red sagittæ, dark-brown medusæ (Atolla), large ostracods (Gigantocypris), and the same kinds of "rare" fish: Gastrostomus bairdii, Cyema atrum, Gonostoma grande, Dactylostomias, and several others.

These numerous horizontal hauls accorded so closely with each other that we now began to feel that there must be a welldefined conformity in the vertical distribution of the different forms. Still, to avoid any uncertainty, we considered it desirable 
Vertical distribution of animals.

to try at the same time some vertical hauls with our closing nets. Accordingly, at Station 63 we made two series of hauls, one with a silk net I metre in diameter, and the other with the large 3-metre silk net (Fig. 89).

These experiments merely resulted in our capturing the species which occur most commonly, -a fresh proof that it is difficult to become acquainted with the fauna when only vertical hauls are made. A great many of the forms are too scarce to be caught by such means, and can only be taken by long: continued horizontal towing. In the case of the commonest species, however, these vertical hauls do give an indication of the vertical distribution as well as of the quantitative occurrence at different depths. It is advisable, therefore, to supply a few particulars of our experiments with the large net :-

Only Io fishes were taken in a haul from 4500 metres up to 1500 metres, where we closed the net. All of them belonged to the species Cyclothone microdon.

In a haul from 1350 metres up to 450 metres we got 44 fishes; 27 specimens of Cyclothone microdon, 3 of $C$. signata, and I4 young fish (stomiatids and others).

In a haul from, 500 metres up to 200 metres some small specimens of Cyclothone signata and a number of young fish were caught. From 200 metres to the surface there were only young fish.

This agrees with what we found when making horizontal hauls. The black Cyclothone microdon is only to be met with in deep water, where the light-coloured $C$. signata is absent, and $C$. signata occurs nearer the surface-from about 500 metres up to 200 metres-but has not been taken in depths less than 200 metres.

It is important to note how much fewer the individuals are in the deepest hauls. Though we drew the net through 3000 metres (from 4500 up to I 500 metres), we only caught Io fishes, while in the 900 metres of water from I 350 metres up to 450 metres we got 44 individuals, 27 of them belonging to the same species as the Io fishes from greater depths.

Similar conditions appear to prevail in the case of the red prawns, for in our deepest haul we caught only i I large red prawns, but in the haul immediately above it there were 35 individuals. This seems to indicate that the deepest waterlayers cannot at all compare in abundance of organisms with the intermediate layers.

At this station we also recorded a very large series of hydrographical observations, namely, twenty water-samples and 
temperature readings down to a depth of 4850 metres. We were interested to discover that the bottom temperature was only slightly under $2 \frac{1}{2}^{\circ} \mathrm{C}$., and thus exactly agreed with what we had previously found in the eastern basin.

During the night several flying-fish came on board, and in the morning we again saw small patches of the Sargasso weed. Sargasso Gran came to the conclusion that these patches must be much younger, or, rather, that they have drifted for a shorter time, than the ones found farther east. They had long vigorous shoots, which reached higher up above the water than the older growths, and it was easy to tell the top in every patch. In the older growths, which had been drifting about for a long time, the shoots in every direction were more stunted, and the patches became mere tangled masses of weed and lay deeper in the water. We found on them the ordinary small crabs (Planes minutus), needle-fish (Syngnathus pelagicus), frogfish (Antennarius), molluscs, compound ascidians, and hydroids (see Plates V. and VI., Chapter X.).

Station 64 was one of our most successful stations. The pelagic appliances were lowered in the morning between 6.30 A.M. and 9 A.м., and hauled in from 2.30 P.M. to 5 P.M., with excellent results. In the surface layers we secured a quantity of fish-eggs, including various stages of the eggs of scombresocids, tiny young fish with stalk-eyes, two small eel larvæ (4.I cm. and $4.8 \mathrm{~cm}$. long), a number of remarkable cuttle-fish, and three small leptocephali $(1.7 \mathrm{~cm}$. , I.7 cm., and $2.1 \mathrm{~cm}$. in length), all differing in appearance. They cannot belong to the larvæ of the common eel, because they have too many muscle segments (over I 30 ).

In deep water we got the same familiar forms in unusually large quantities. The following table shows the numbers of the species most commonly occurring, belonging to the genus Cyclothone:-

\section{Light-coloured, Dark-coloured, Cyclothone signata. C. microdon.}

\begin{tabular}{|c|c|c|c|c|c|}
\hline Young-fish & traw & at 500 & metres & . $\quad 1240$ & $2 \mathrm{I}_{4}$ (small individuals) \\
\hline ", & , & 1000 & " & 82 & $44^{8}$ \\
\hline , & ", & I 500 & " & 22 & 322 \\
\hline & & & & I 344 & 984 \\
\hline
\end{tabular}

Thus of the two species we were able to preserve more than 2000 individuals; we endeavoured to keep all that were brought on board, but a good many were damaged by the apparatus, and had to be thrown away. 
These results served to confirm the opinion we had formed at the previous station $\left(6_{3}\right)$ that the light-coloured species lives nearer the surface, while the dark-coloured species inhabits greater depths. Red prawns, sagittæ, and other creatures were found in large numbers in deep water, and we continued to meet with such forms as Gastrostomus and Opisthoproctus, and a new Oneirodes (Fig. 90).

IVe also discovered a curious little young fish, $4 \mathrm{~cm}$. long, which we can only suppose to be a transition stage from a Larval lestomus. Gastrostomus. so often met with). Its head shows clear indications of the

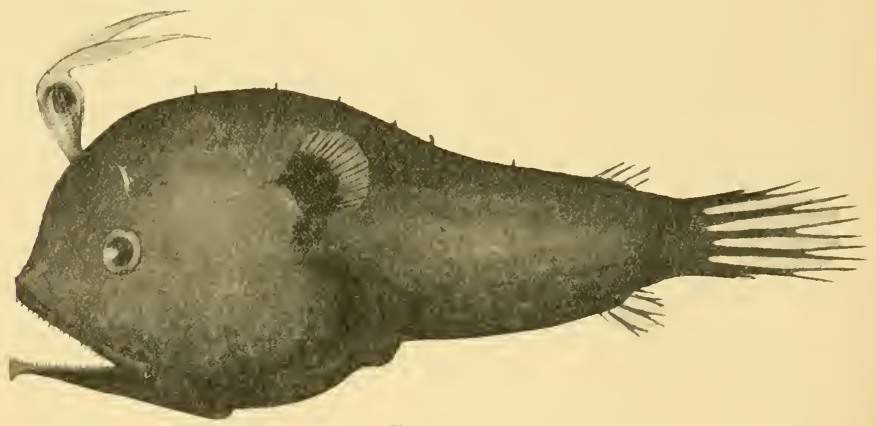

FIG. 90.

Oneirodes, n.sp. Nat. size, I. $4 \mathrm{~cm}$.

remarkable gullet, the tiny eyes far forward near the snout, and the small ventral fin. Posteriorly the body much resembles a leptocephalus, but here, too, there seems to be a commencement of the strange organ which is situated at the end of the long tail of Gastrostomus. What is chiefly interesting about this find is that it affords fresh proof of the relationship between the saccopharyngidxe and eels. When search is made, as it probably will be soon, for still younger stages of the common eel larvæ than the ones we found, it will probably be of zoological interest to seek in these teeming waters for transition stages between this strange form and the earlier leptocephalid stages.

Another deep-sea fish at this station that deserves mention was a form, as yet apparently undescribed, which resembles the Blind fish. undoubtedly blind fish (Cetomimus) found at Station 35; the eyes appear very much reduced, just as in the case of its relative. Both of them were taken in deep water, at 1000 metres. 
In addition to the silk nets Gran now commenced using his big steam centrifuge (Fig. 9I) for centrifuging the water

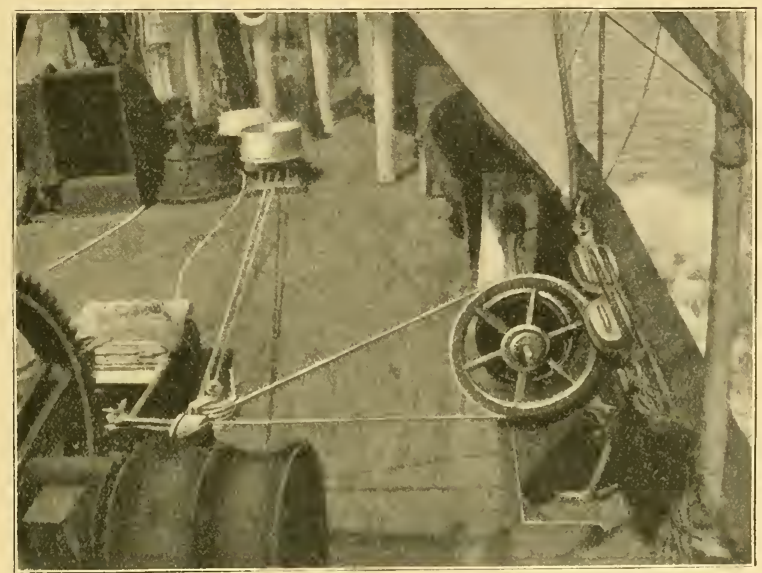

Fig. 91.-The Large Centrifuge.

samples from difterent depths. Several successful experiments Use of the had already been made centrifuge.

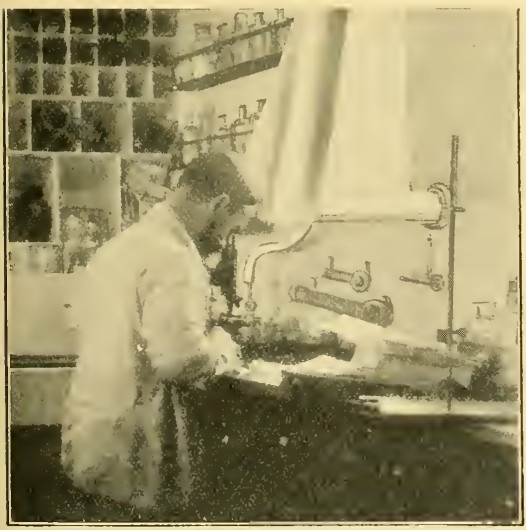

Fig. 92.-GRan COUNTiNg The Silallest Microscopic Pl.ANTS. with it, but it was at this station that he started to employ it systematically, and he continued to avail himself of its help until the end of the cruise. By means of it he was able to collect in a little drop below the microscope all the most minute organisms, and in spite of the movements of the little ship and the vibration from the propeller, he was able with his microscope to study the many hitherto unknown forms in their living state, to draw them, and to count the number of the different species (Fig. 92). A full description of these investigations will be 
found in Chapter VI. A few particulars may, however, be given here.

Among the exceedingly diminutive plants found in the open sea, calcareous flagellates or coccolithophoridæ are the most important, especially in the warmer waters. During the "Challenger" Expedition, Murray discovered that they were distributed everywhere over the surface of all warm seas, and he stated that they were plants. These small organisms occur in far greater abundance, both of species and individuals, than had hitherto been supposed. In reality they, together with

Great

abundance of coccolithophoridx in the Sargasso Sea. diatoms and other algæ, constitute the fundamental source of food for all animals in tropical and sub-tropical waters. In the Sargasso Sea there were in every litre 12 or 15 species and 2000 to 3000 individuals. In colder masses of water they decrease very greatly in quantity, yet even on the edge of the Newfoundland Bank, with a temperature of $2 \frac{1}{2}^{\circ} \mathrm{C}$., we still met with one or two species numbering 50 individuals to the litre. In the Arctic and Antarctic Oceans, on the other hand, they are not found at all.

After occupying Station 64 we were compelled to turn northwards and steer for our next coaling station, St. John's, Newfoundland. We had to abandon any idea of following up in a southerly direction the remarkable finds we had made, and probably thus lost the chance of making the most interesting discovery of all, namely, the earliest stages of eels, Gastrostomus, and other forms. Still there was the possibility of learning something about the currents off the coast of North America, as well as the connection between the different water-layers and the plants and animal forms existing in them.

Fig. 93 shows a temperature and salinity section from the Sargasso Sea to Newfoundland. At Stations 64 and 65 we see the vast layer, with a salinity of over 35 per thousand and high temperature down to considerable depths, the same as found by us over the whole distance from away beyond the Canary Islands.

On our way north from Station 64 on 28 th June we saw patches of Sargasso weed all the morning, and numbers of flying fish, about io centimetres long, started up in front of our bows. This led us to believe that we should capture the same forms as before, when we lowered our pelagic appliances in the evening at Station 66. Great was our astonishment, therefore, to discover next morning on hauling in our appliances that the catches 
mainly consisted of true "boreal" plankton, that is to say, animal forms which we were accustomed to get in the so-called extension of the Gulf Stream in the Norwegian Sea right up to the very shores of Spitsbergen. There was the amphipod Euthemisto, the copepod Eucheta, and "whale's food" (the pteropod Clione limacina), large quantities of which are met with from time to time in the waters between Spitsbergen and the north of Norway. This last is not an "arctic" form, that is, it is not associated with polar water in the Norwegian Sea, but on the contrary is found in Atlantic water to the south of Iceland,

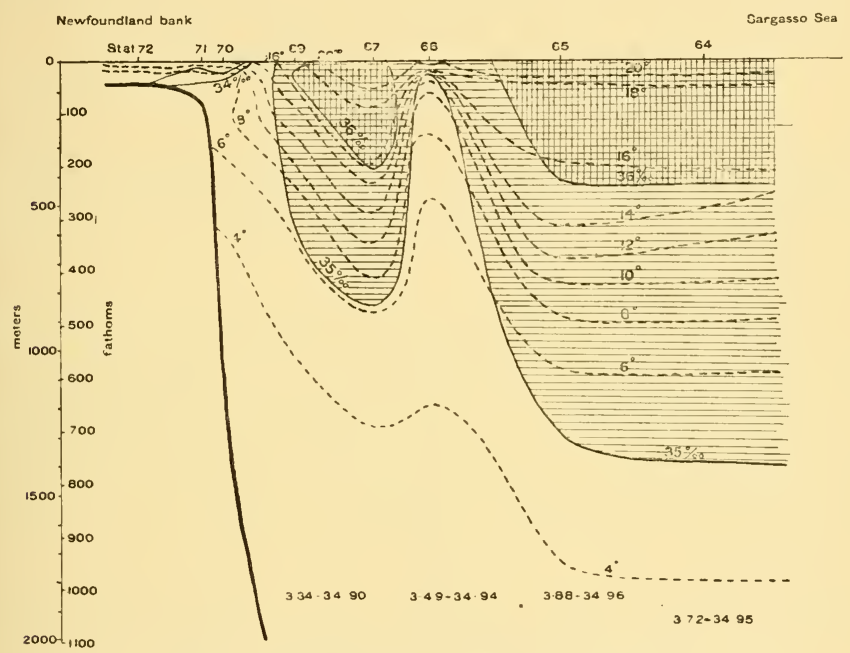

Fig. 93. - Hytrographical Section from the Sargasso Sea to the NEWFOUNDLAND BANK,

according to Danish observations. It seems, however, to be associated with the northern portion of the Atlantic and the Atlantic water that enters the Norwegian Sea. These animal forms were entirely absent during the whole of our cruise from the Canary Islands to Station 64, so that their occurrence at Station 66, where lower temperatures were recorded at no great depth beneath the surface, is very significant.

We fancied now that we had said farewell to the Sargasso Sea and its interesting animal life, but at Stations 67 and 69, in close accordance with the hydrographical conditions depicted in Fig. 93, we came once more across more southerly forms. 
In the upper layers there were the same young fish, many of them with stalk-eyes, and leptocephali, while flying fish, Sargasso weed, and the familiar Sargasso animals were all once more in evidence.

Ve found a large cluster of eggs, weighing approximately a kilo, drifting about at Station 69, belonging to the common angler-fish (Lophius piscatorius), the development of which was studied by Alexander Agassiz; we hatched out the eggs and obtained the stages depicted by him. Angler-fish only inhabit the coast banks, so that our find of slightly developed eggs, that could not have been drifting many days, indicated that we were now in the neighbourhood of the American coast bank.

In deep water we found once more at Stations 67 and 69 the deep-sea animals of the Sargasso Sea, that is to say, all the black fishes and red crustaceans which we have so often mentioned already. There were not merely the commonest kinds of small fish, but also large ones (such as three examples of Gastrostomus), and fishes which are caught in other oceans (Aceratias, Serrivomer).

While we were hauling in our appliances at Station 67, a storm got up, which gradually increased to a hurricane, worse than anything hitherto encountered by the "Michael Sars." It lasted for twenty-four hours, during which the ship was smothered in spray. Our engines were kept going full steam ahead, yet the vessel was driven a whole degree (6o nautical miles) astern. Still her buoyancy stood her in good stead, and she did not ship a single sea.

At Station 70, on the edge of the coast bank, where the depth was I IOo metres, we discovered that we had for the second time left purely oceanic conditions behind, and once more the true boreal plankton appeared in the surface layers. There was the little copepod Calamus finmarchicus, the commonest crustacean in the Norwegian Sea, and we also now met with Euthemisto, Nyctiphanes, Krohnia hamata, Limacina nelicina, ${ }^{1}$ and Clione limacina, all species that are regarded as specially characteristic of the Norwegian Sea. Still in the deep water from 350 metres down to I IOO metres we continued to get the familiar pelagic deep-sea fish $C y c l o t h o n e ~ s i g n a t a$ and $C$. microdon, as well as the medusa Atolla and other forms; so that the area of distribution of these animals extends from Africa to North America, that is to say, in all the water from the one continental slope to the other.

1 Limacina was taken in numbers by Haeckel and Murray off Scourie in Scotland. 
Our deepest young-fish trawl was unintentionally towed along the bottom, and came up full of most beautiful bottom-living organisms (Ophiura, asterids, Phormosoma, pennatulids, crinoids, pycnogonids, lycods, and Macrurus, as well as many other forms which need not be detailed here).

We had thus reached the Great Bank of Newfoundland, and had accomplished our task of taking a section right across the Atlantic from the shores of Africa. During the transit we had occupied twenty-nine hydrographical stations, and twenty stations

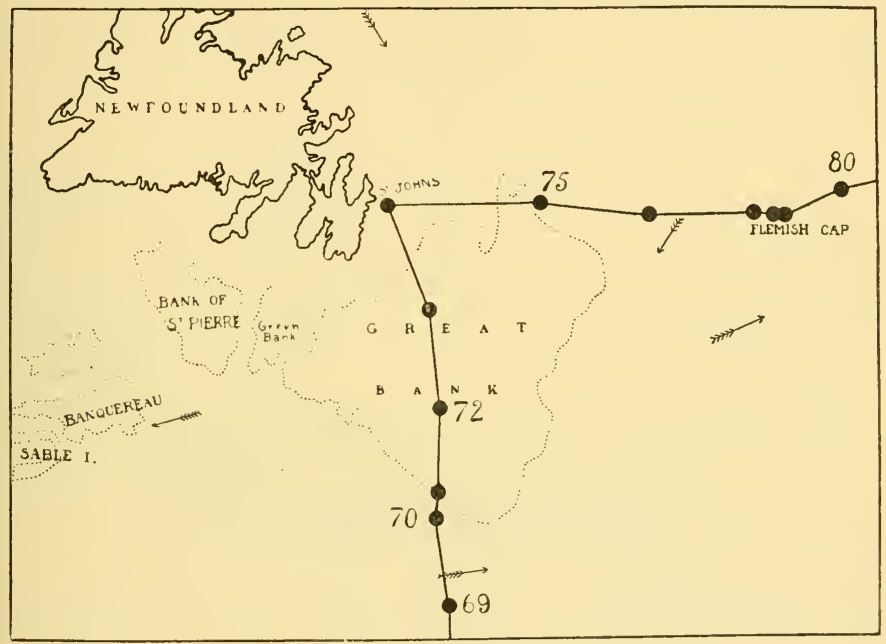

Fig. 94.- "Michael Sars" Stations 69 to So.

where we towed pelagic appliances, and had besides carried out many other investigations, so that we had every reason to be satisfied with the results of our venture.

The coast bank itself (Fig. 94) offered us a totally different Newfoundland field for study, which no doubt would have proved very interestBank. ing, but unfortunately our time was too short to attempt systematic researches ; we had to steam for our coaling station, contenting ourselves with one or two shallow stations on the way.

Fig. 95 shows the hydrographical conditions from our last true oceanic station (69) to a station (74) just off St. John's. It is extraordinary what a sudden change there is from the warm salt oceanic water to the cold coast water. The curves of 
temperature and salinity between Stations 69 and 70 go down straight like a wall-the well-known "cold wall" of oceanographers. Over the bank there is a surface layer, about 40 metres in depth, with a temperature of over $6^{\circ} \mathrm{C}$., similar to what we get in the boreal portion of the Norwegian Sea along the coast of Norway. Below that, however, the temperatures are under $2^{\circ} \mathrm{C}$., and even as low as $-1.5^{\circ} \mathrm{C}$., that is to say, the water may be as cold as what Nansen found near the North Pole. Probably at no other part of the globe are there such peculiar temperature conditions - conditions comparable with those in the Arctic regions, though the latitude is the same as that of Paris. It would have been an agreeable task to trace these conditions by following up the currents and animal life

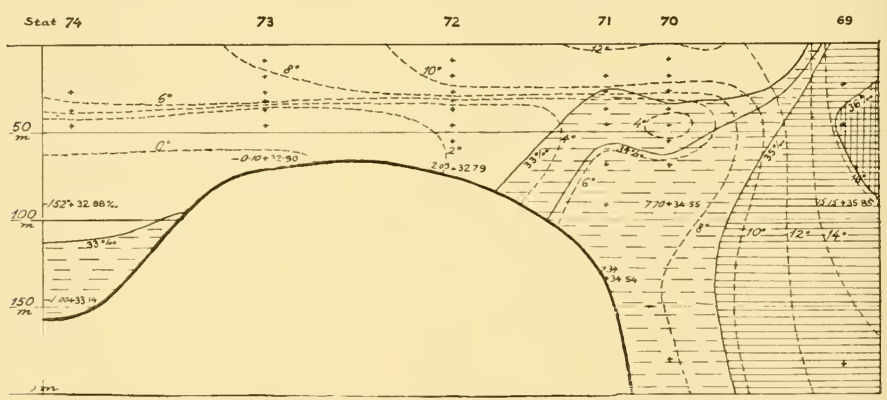

Fig. 95.-Hydrographical Section.across 2the?Great Newfoundaxd BaNk.

both northwards and southwards. Still even our random investigations furnished interesting results. Thus we discovered that from Station 70 to St. John's there was the same northerly plankton already mentioned, and an examination of the young fish showed that they accorded with what had previously been found by Norwegian naturalists off the coast of Norway, and by the Danes south of Iceland.

On the outer side of the coast bank, at Station 7 I, we met with larva of red-fish (Sebastes). At Station 72 there were codeggs and numbers of little cod-fry, besides fully developed eggs of

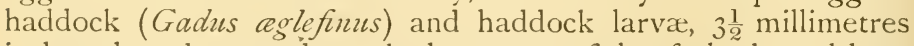
in length and upwards, and also young fish of the boreal long rough dab (Drepanopsetta). At Station 73 we came across eggs of this dab (besides a number of eggs that we have not yet determined), and the shallow-water form Ammodytes. At Station 74 there were neither eggs nor young fish. 
Similar catches are taken off the coasts of Norway and Iceland; near and just beyond the continental edge there are larvæ of red-fish, and on the bank in 30 or 40 fathoms of water there are larvæ and eggs of cod and haddock. It was interesting to find the eggs and larvæ of these fish at Station 72, where the bottom-temperature was between $2^{\circ} \mathrm{C}$. and $4.6^{\circ} \mathrm{C}$., whereas nearer land, where the bottom-temperature was $0^{\circ} \mathrm{C}$., or even less, they were absent.

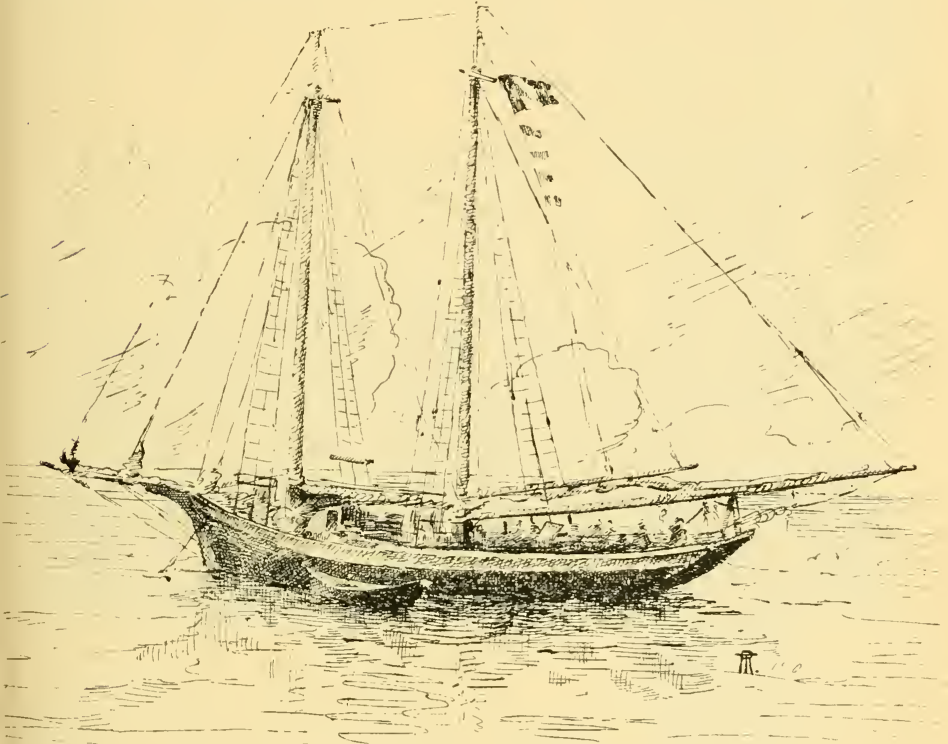

Fig. 96.-French Fishing Schooner.

At Station 72 we sighted the first fishing-boats (Fig. 96). Fishing They belonged to Frenchmen from the Island of Miquelon, indistry on south of Newfoundland, and as the weather was good, we paid land Bank. them a visit, spending a very pleasant time with these hospitable fishermen, who willingly gave us information about their industry (Fig. 97). They sail from Brittany and Normandy in April, and reach the Newfoundland Bank in May, at which time of the year there is ice over the whole northerly portion of the bank. They commence fishing in the south-eastern portion, which is probably the only part having warm bottom-water, and collect their bait by lowering nets with cod-heads in them. 
Quantities of gasteropods (most likely a species of Buccinum) creep into the nets, and form a very serviceable bait, just as on the eastern side of the Atlantic. Afterwards they remove to the southern portion of the bank, where they were when we met them. This was, according to the captain, lat. $44^{\circ} 30^{\prime} \mathrm{N}$., and long. $53^{\circ} 34^{\prime} \mathrm{W}$. The cod spawn here in July, and were just on the point of doing so. They were from 60 centimetres to over a metre long, and upon inspecting the catches of several dories (flat-bottomed boats used for cod-fishing in Norway also) we found the roes to be quite mature. The fishermen also catch squid (Gonatus fabricii ; see Fig. 98) with a grapnel

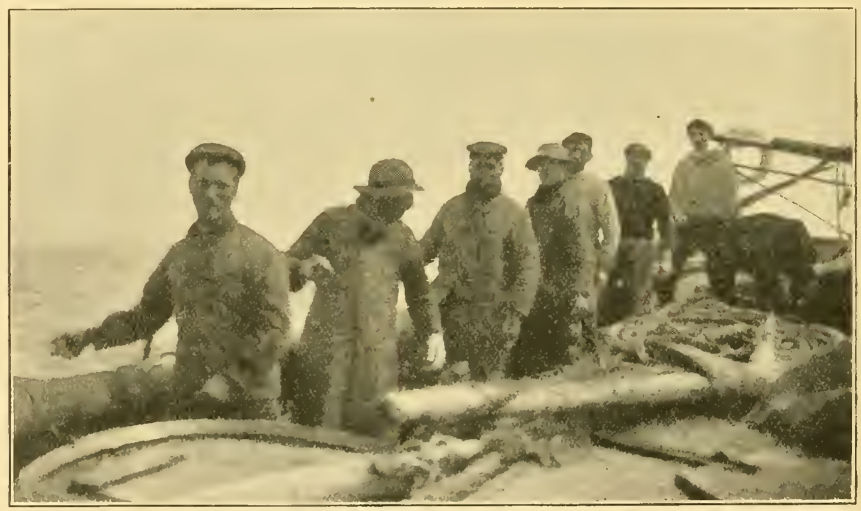

Fig. 97--Hand-Line Fishing.

- a red piece of metal with hooks all round it-exactly in the same way as they are caught on the north and west coasts of Norway.

After July the fishermen work their way northwards, probably because the cod move northwards along the bank as the cold water recedes during the course of the summer. According to their statements, which would justify a thorough investigation, there are for the most part only small-sized cod farther south and west on the banks off Nova Scotia and Cape Breton Island, or on what they call the "Banquereau." Is it perhaps the case here too, as in Norway and Iceland, that the larva and young fish drift with the current and grow into cod far away from the place where they were spawned?

On the Norwegian coast the cod chiefly spawn between 
Romsdal and Tromsoe, but the young fish are found in greatest quantity off Finmarken, that is to say, along the northernmost portion of the coast, to which they are carried by the current. Similarly in Iceland they spawn on the south and west coasts, but the young fish are chiefly found on the north and east coasts. The current there goes from the south to the west, and thence round the north and east coasts, making a circuit round the island.

The current off Newfoundland runs along the coast in a south - westerly direction, towards Nova Scotia and the United States. It is possible, therefore, that it is mostly young fish that are found down south, derived to some extent at any rate from eggs spawned on the Great Newfoundland Bank.

Cod spawn on the Norwegian coast banks as far north as lat. $70^{\circ} \mathrm{N}$., and chiefly during March and April. Here on the Newfoundland Bank, a little north of lat. $50^{\circ} \mathrm{N}$, and in the vicinity of the warm oceanic water their spawning season was in July.

The bottom-temperature on the bank was, as we have seen, very low-lower indeed than in the north of Norway during March-and it was interesting, therefore, to note

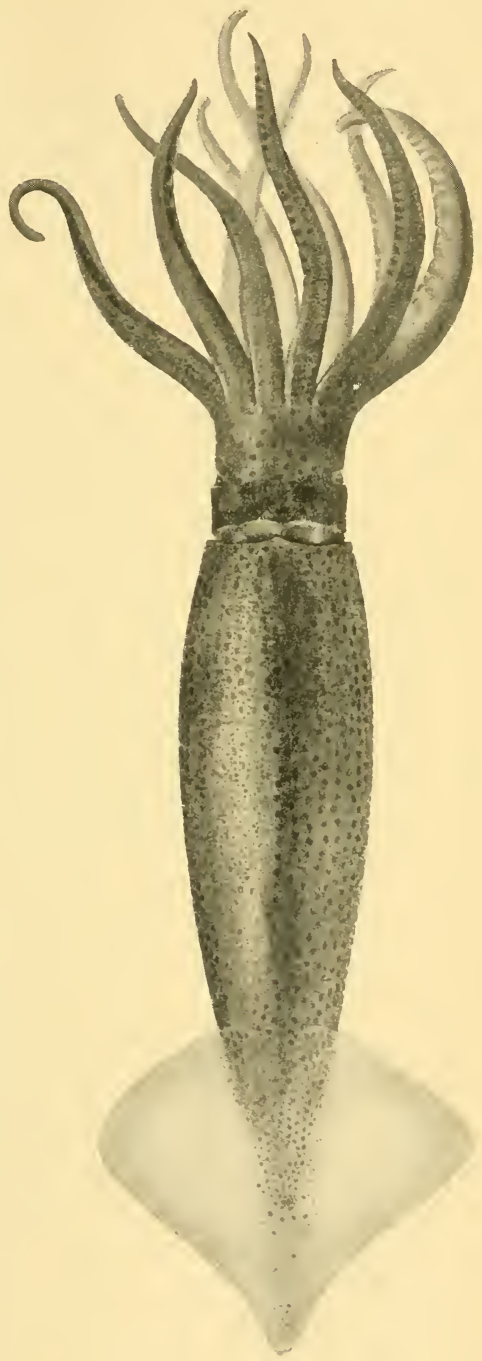

Fig. 98. - BaIt (Gonatus fubricii). Nat. size, $27 \mathrm{~cm}$. 
the summer growth periods and winter stagnation periods in the scales of cod which we procured from the French fishermen. Scales (see Chapter X.) illustrate the growth of the cod by means of "summer-belts" and "winter-rings." Those which we examined had extremely distinct winter-rings, and although it was already July, the summer-belt for the year had not yet commenced. It must therefore have been the winter season still down in the deep water where the cod were taken-and this though we were in the latitude of Paris and the month was July.

From Newfoundland to Glasgow.

On 3 rd July the "Michael Sars" anchored in the harbour of St. John's.

It was our original intention to go from Newfoundland to Reykjavik in Iceland, as this was the nearest coaling station on our way back to Europe, and we hardly expected when starting on our expedition that the little ship would be able to steam right across the Atlantic without having to put in anywhere for coal. We had now, however, formed such a favourable opinion of her seaworthiness, and her coal-consumption had been so small, especially on the voyage from the Azores to St. John's, that we decided to venture across the ocean without a stop. The distance from Fayal to St. John's by the way we had come was about I 800 nautical miles, and from St. John's to Ireland was roughly 2000 miles, so that the difference was not so very formidable.

As far as our scientific work was concerned, the direct route to Ireland was bound to be the more interesting. It is true that very little is known about the sea leading to Baffin's Bay, but the physical conditions, and therefore also the animal life, are presumably very uniform and not likely to differ much from the conditions prevailing to the eastward of the Newfoundland Bank. The direct route to Ireland, on the other hand, would give us a fresh section across the Atlantic, and enable us to study the varying conditions in the northerly portion of that ocean. Another reason for selecting this route was the possibility of again studying the remarkable conditions in the Gulf Stream observed on our southern section between Stations 64 and 70 (see Fig. 93). We therefore filled up our bunkers once more and piled the deck with the best coal we could procure, prepared ourselves for as long a cruise as the ship was able to accomplish, and left St. John's on the Sth July.

The water-masses of the North Atlantic may be roughly 
divided into four principal groups: (I) true Atlantic oceanic water, or Gulf Stream water, (2) Mediterranean water, (3) Arctic polar water, and (4) the so - called bottom-zuater, all of which we were able to study on our voyage across to Ireland. Fig. 99 shows the positions of Stations 79-93, and the vertical distribution of the different water-masses in their relation to one another on our route from the Newfoundland Bank to Ireland. Near America, on the actual coast bank and just outside the edge of the bank (Stations 75-79), we found only the cold Labrador Current, which descends from Baffin's Bay, follows the coast of Labrador, and sweeps south-west past Newfoundland. Immediately outside St. John's we met several icebergs of the kind so familiar to all who cross the North

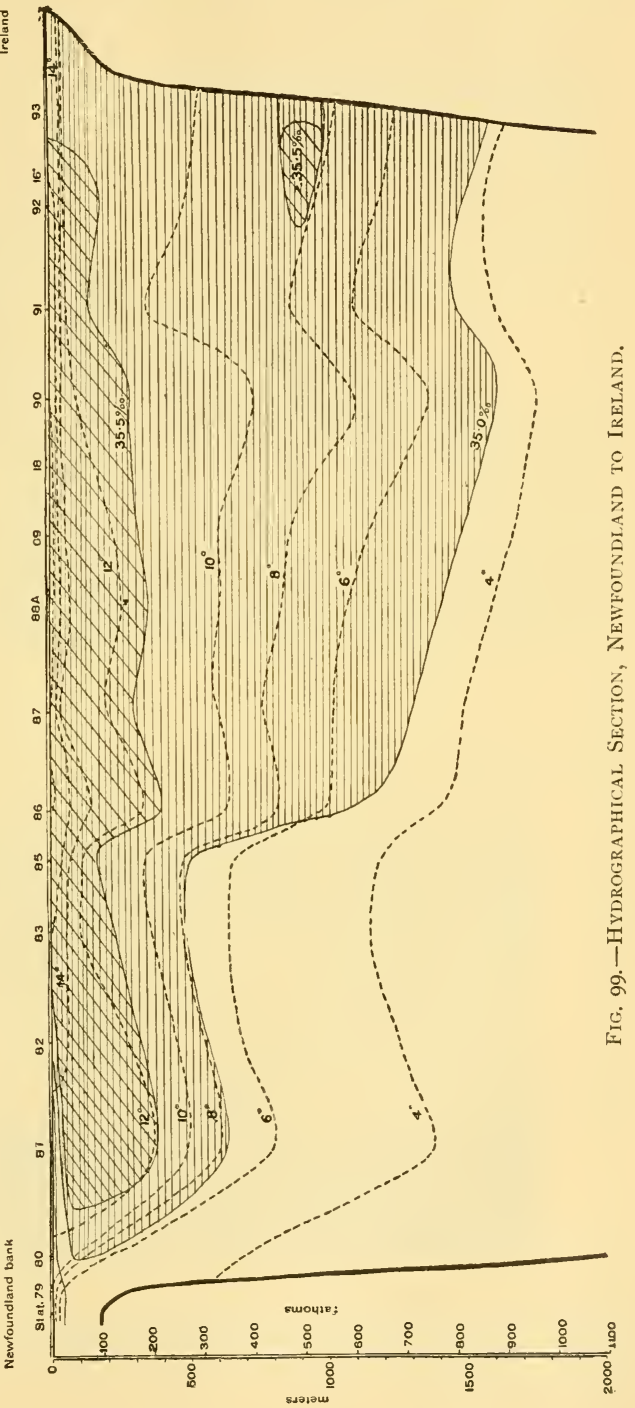


Atlantic (Figs. IOO and IOI), and we had thus an ocular demonstration of the origin of the cold water on the Great Bank, as

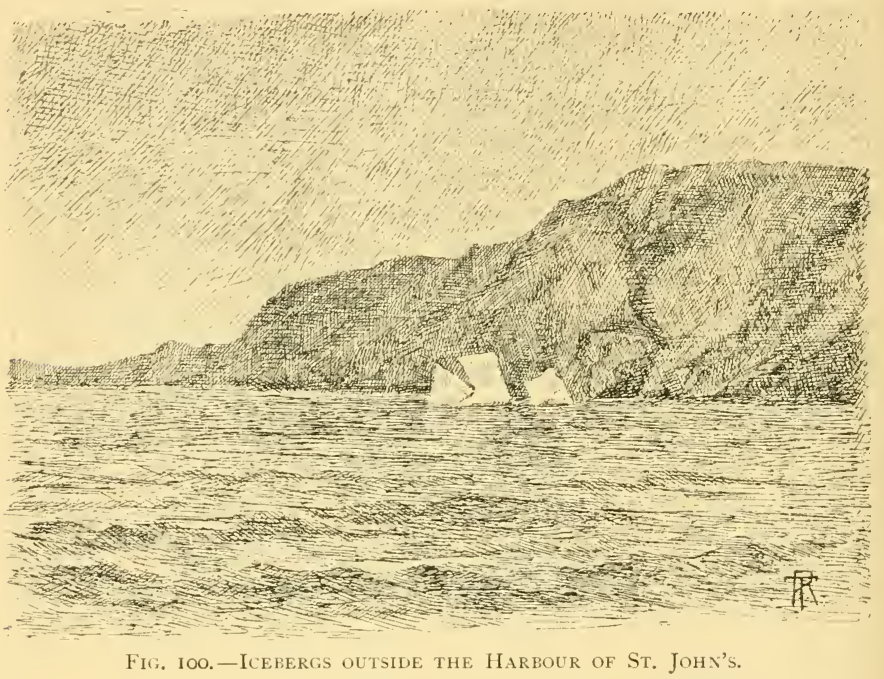

well as of the dangers which the bank-fishers have to face. Icebergs, fog, and the great ocean-steamers are the chief perils

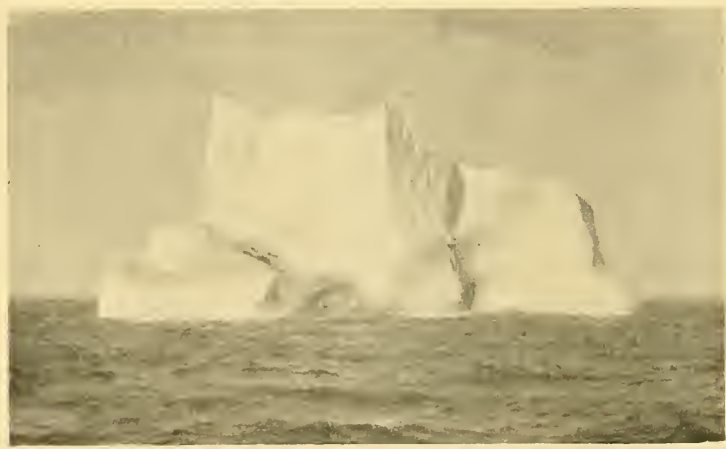

Fig. IOI.-ICEBerg OUtSIDE ST. JohN's.

these men have to reckon with, and it was an unpleasant sensation for us also to have to steam for three whole days over the bank in fog. 
At Station So we became aware of the influence of Atlantic water, and at the same time we got clear weather, but, as the figure will show, it was at Station 8 I that we first met with the real Atlantic or Gulf Stream water with a salinity of about 35.5 per thousand, which extended in a layer 100-200 metres deep right across to near the coast bank outside Ireland. Below this layer the salinity and temperature decrease till we come down to bottom-water, with a salinity of less than 35 per thousand; the temperature was the same as what we had found in bottom-water to the south of the Azores, namely, a little under $2 \frac{1}{2}^{\circ} \mathrm{C}$. Our investigations made it apparent that this bottom-water is in continuity with the surface water in the north-west corner of the Atlantic.

Our investigation of the plants of the sea was continued Plants. during this cruise; we made collections with silk nets, and centrifuged water-samples with the big steam centrifuge, with the result that, in spite of high seas and heavy rolling of the vessel on the eastern side of the ocean, Gran was able to proceed with his classification and enumeration of the minute living organisms that had hitherto eluded observation.

At almost every station he determined the number of extremely small organisms, chiefly coccolithophoridx, per litre of sea-water, and ascertained that here, too, on our northerly route they constituted the greater portion of the plant plankton. An exception must, however, be made in the case of the coast banks of Newfoundland and Ireland, where there was also a very abundant plankton of larger organisms, large enough to be retained by the tow-nets. One single species (a calcareous flagellate) at a station just outside the European coast bank numbered 200,000 per litre, and actually affected the transparency of the sea.

Gran succeeded in collecting abundant material for the study of these little-known forms (many of them new to science), and for a proper understanding of their significance in the total plant life of the sea. In Chapter VI. he has set down the chief results of his observations.

We found again a complete accordance between the distribution of the different water-masses and the occurrence of characteristic "societies" of pelagic animal life. At Stations Pelagic life of 75-79 on the Newfoundland Bank (see Fig. 94) the boreal Newfoundorganisms were mixed with arctic forms. Thus there were: 
Calanus finmarchicus and C. hyperboreus, Euchata, Euthemisto, Limacina, Aglantha, Berö̈, Pleurobrachia, Mertensia, Sagitta arctica, and Krohnia hamata-forms that in the Norwegian Sea are met with in "Gulf Stream water" or in "Polar water."

At Station 8o-just beyond the continental slope-this animal life was still typically represented at all depths examined, but in deep water we found co-existing with it our black fish and red crustaceans of the southern section. We made a few hauls here with the closing net, and obtained the following :-

In a haul from 525 metres to 235 metres we got calanids co-existing with Cyclothone signata.

In a haul from 950 metres to 525 metres we found Euchata norvegica, Calanus finmarchicus, Calanus hyperboreus and Clione limacina, together with Cyclothone microdon and the medusa Atolla.

Besides this, our horizontal hauls gave us Gastrostomus bairdii and large red prawns (Acanthephyra).

All the arctic forms had disappeared, however, at Station $8 \mathrm{I}$, and they did not occur again in our hauls during the rest of

Boreal pelagic life. our section to Ireland. In their place we found the boreal animals, such as we are familiar with in the Gulf Stream water of the Norwegian Sea right up to Spitsbergen, strongly represented, everywhere mingled with true oceanic Atlantic forms, like those that predominated in the southern section. At Station 8 I we secured at the surface a quantity of eggs and young of scopelids, as well as radiolaria, salpa, small Pelagia, and different kinds of leptocephali; of pteropods we got Clio pyramidata. In deep water there was the abundant oceanic fauna observed in the Sargasso Sea previously referred to. If we consider this short account of the animal life, together with the hydrographical section (Fig. 99), the accordance will become apparent. It is at Station 8I that the real oceanic "Atlantic water" or "Gulf Stream water" occurs, whereas at Station 80 the cold Labrador Current is still the controlling influence.

Generally speaking, the same pelagic fauna was noted from here across the Atlantic, though no doubt a closer investigation may reveal various differences in the different areas traversed. There is one feature that deserves particular mention, notwithstanding the incompleteness of our material, namely, the extraordinary abundance of forms met with from Stations 86 to 88. These stations lie exactly over the longitudinal ridge that stretches northwards from the Azores. Just as was the case on the plateau south of the Azores, so here too we made exceptionally big catches at all depths, and the surface contained millions 
of chains of salpæe the one day and of medusæ (Pelagia) the next.

We caught a large moonfish (Mola rotunda, Fig. IO2), Moonfish. which was moving along near the surface with its dorsal fin above water; we harpooned it from a boat, and got it on board with block and tackle and the steam winch. The length was 2. I metres, and the height of the body I.2 metres. A huge

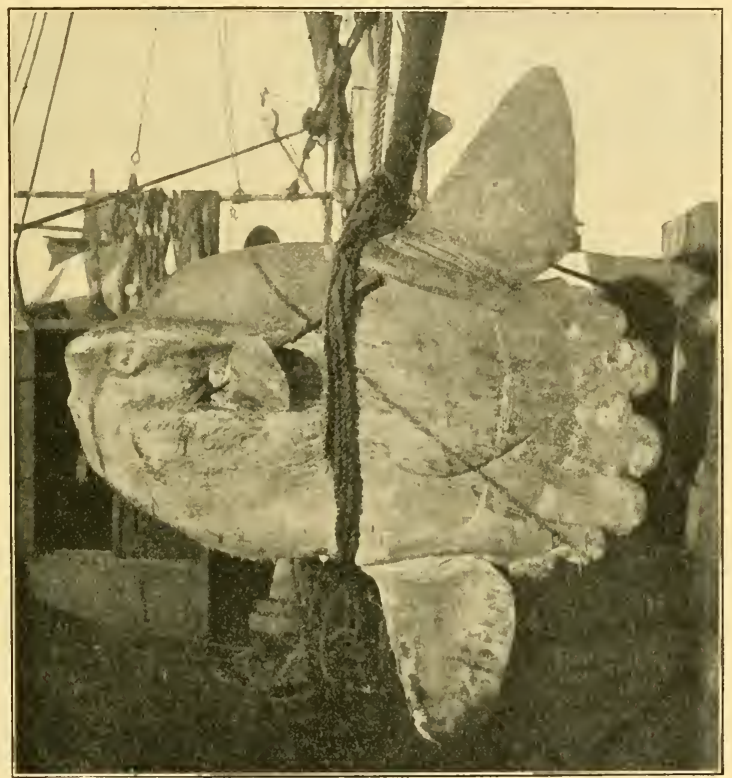

FIG. I02.-Mola rotunda, Cuv. Nat. size, $21 \mathrm{I} \mathrm{cm}$.

cuttle-fish, too, was found drifting about. Do these creatures, like the turtles farther south, feed on the abundant salpæ and medusæ, and was that the reason why we found them here? Is a richer pelagic life generally to be found just over the ridge, in the same way that we always find a richer plankton over the slope of the coast banks? These problems must be left for future solution.

On the eastern side of our section, towards the Irish coast bank, the conditions were again peculiar, especially at the surface. We found here increasing quantities of young of the 
needle-fish Nerophis, Fierasfer, Arachnactis and Lepas fascicularis, as well as young stages of coast-bank forms, stray specimens of which were also met with just off the slope (Stations 92 and 94).

It will be an interesting task to compare the western and eastern portions of this section, as well as the whole of this northerly section, with the section farther south from the Canary Islands past the Azores to the Gulf Stream. One thing which did strike us particularly was that the boreal plankton-the Gulf Stream forms of the Norwegian Sea-were entirely absent from the southern section (Stations 45-64), but were everywhere present in the northern section. It must be remembered, however, that our pelagic hauls did not reach the very deepest water-layers, which may have the same plankton in both sections, including the boreal species known from the Norwegian Sea. "We further noticed in the southern section more of the remarkable "rare" deep-sea fish that have been found in other oceans (the Indian Ocean, for instance) than in the northern section.

The distribution according to size of individuals belonging Eel larve. to the different larval forms was noteworthy. As previously mentioned, we came across very small larvæ-from $4 \mathrm{~cm}$. to $6 \mathrm{~cm}$. long-of the common eel to the south and west of the Azores; on the northern section also we found larvæ of the eel, but they were all full-grown leptocephali. This distribution does not seem to be specially characteristic of the eel, for on the southern section we came across many small larvæ and eggs belonging to other forms, none of which were met with farther north. Future investigations will doubtless make all this clear, and may lead to valuable discoveries.

The accident to our trawl on the Azores bank, already mentioned, prevented us from trawling in very deep water, but for all that we were able to carry out two successful trawlings at considerable depths. The first was at Station 88, on the longitudinal ridge north of the Azores, where we shot our trawl in 3 I 20 metres of water. There were numbers of echinoderms of all kinds (starfish, sand-stars, sea-urchins, and holothurians), as well as a score of bottom-fish (Macmurus, Synaphobranchus, Trawling on Bathysaurus). The haul was extremely interesting, as it gave Atlantic ridge. a fresh proof of the abundance of animal life as far down as 3000 metres - not in this case on a continental slope, but out on a ridge in the middle of the ocean. Off the coast of Ireland we succeeded in trawling at 1000 fathoms (1 797 metres, Station 95), 
which we had attempted in vain after leaving Plymouth, and we towed the big trawl for two and a half hours with very satisfactory results. There were quantities of echinoderms ( 300 Trawling off holothurians, 800 ophiuroidæ), molluscs, corals, crustaceans, and Ireland. $\mathrm{S}_{2}$ fishes (Macmurus, Antimora viola, Alepocephalus, Bathysaurus (Fig. Iо $3 a$ ), Notacanthus, Halosauropsis (Fig. Iо3 b),
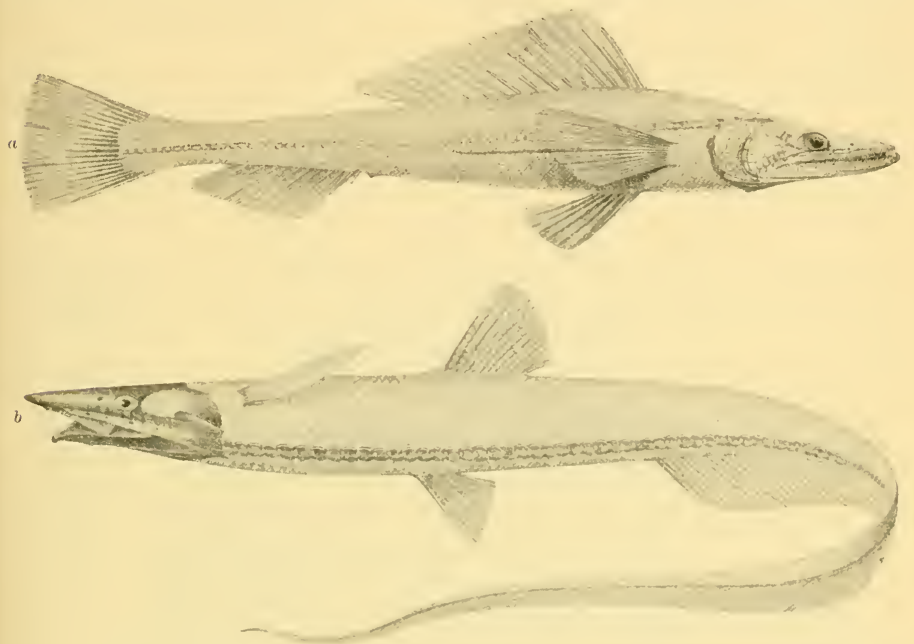

Fig. 103.-Two Deep-Sea Fishes from Station 95, 1797 metres (about 1000 fathoms).

a. Bathysaurus ferox, Gthr. Nat. size, $42 \mathrm{~cm}$.

b. Halosauropsis macrochir, Gthr. Nat. size, $60 \mathrm{~cm}$.

and Synaphobranchi). We also found in the trawl a basketful of stones, coal, and cinders.

The "Michael Sars" anchored at Glasgow on the 29th July after a passage from Newfoundland lasting three weeks. During this time we had worked at twenty-two stations, and had made investigations all the way across the Atlantic. In spite of having steamed about 2000 miles, and having been three weeks at sea, we had still nearly 37 tons of coal left, or enough for another week's work. We had thus proved that a little vessel may carry out investigations formerly attempted only with large ships, and this fact is certain to be taken into account when future expeditions are planned. Taking everything into consideration, we had made very satisfactory hydrographical 
and biological observations over a large part of the North Atlantic. As previously stated, one of the principal objects of the expedition was to carry out researches in the North Atlantic likely to increase our knowledge of the marine area explored by the "Michael Sars" during the past few years, namely, the Norwegian Sea lying between Norway, Greenland, Iceland, and the North Sea. It was important, therefore, to

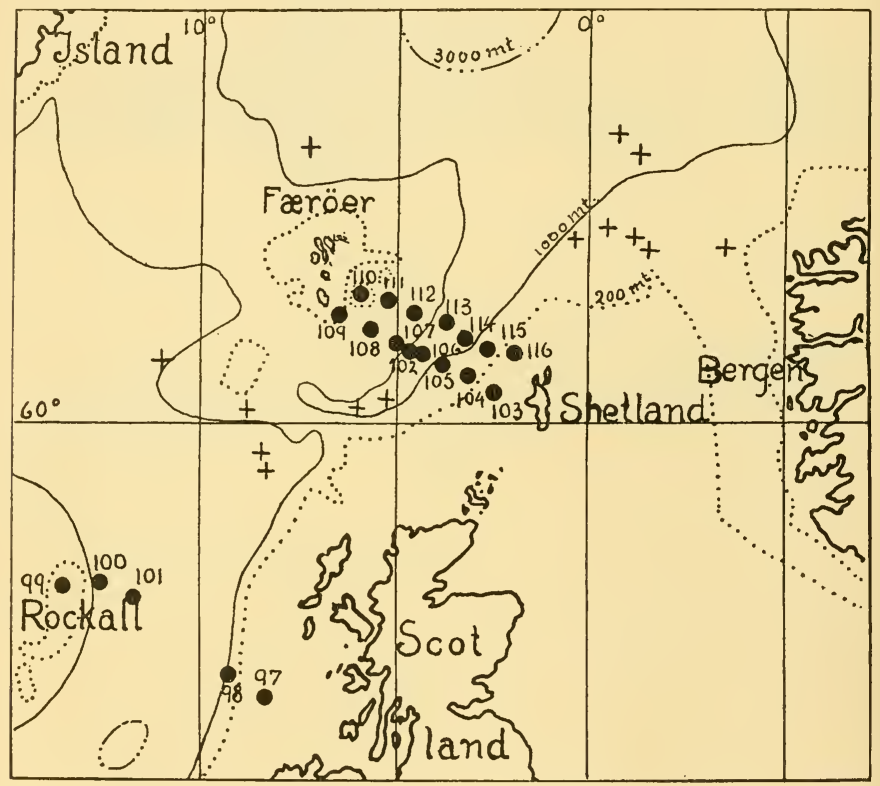

Fig. I04.- "Michael Sars" Stations from Glasgow to Bergen.

examine the adjoining portion of the Atlantic and to investigate the inflow of the Atlantic water.

After leaving the vicinity of the Newfoundland Bank, the Gulf Stream bends sharply eastwards and forms the surface layer examined by us between Stations 8I and 92 (see Fig. 99). Off the edge of the Irish coast bank a portion turns northwards towards the Norwegian Sea. The sea-bottom is here very complicated, for the deep basins of the Atlantic and Norwegian Sea are separated by a submarine ridge (see Fig. 104). To the north-west of Ireland the wide Atlantic plain narrows to a kind 
of valley, which is bounded on the west by the Rockall bank, and on the east by the coast bank of Scotland. Farther north this valley shallows towards the extensive ridge that stretches from Iceland past the Faroe Islands to Shetland, and separates the Atlantic Ocean from the Norwegian Sea at all depths beyond 400 to 500 metres. The part of this ridge between the Faroe Islands and Shetland is known as the Wyville Thomson Ridge, which has frequently been examined, first by British, afterwards by Danish, naturalists ; in fact, it may be regarded as a classical field for oceanic research (see Chapter I.). The

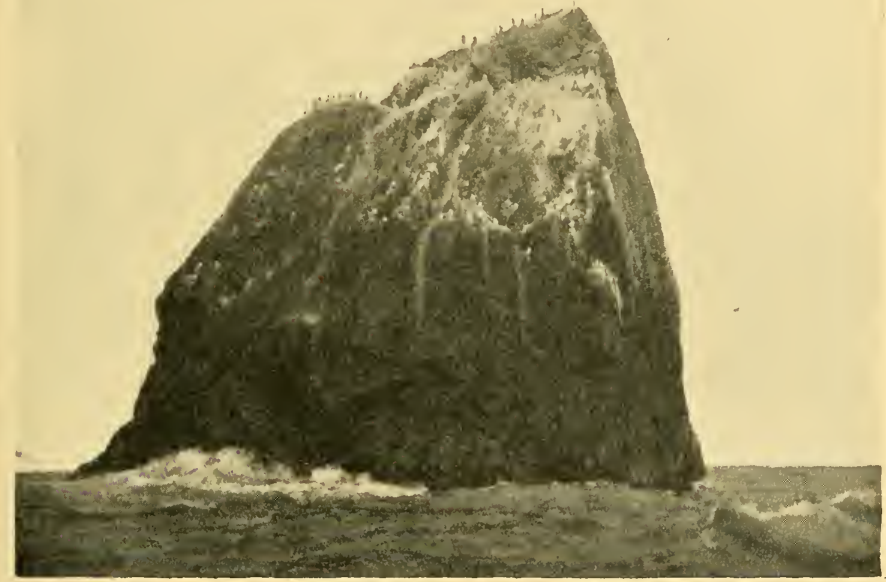

FIG. I05.-ROCKALL.

"Michael Sars" had made investigations there previously, both on the Atlantic side south of the ridge and in the Norwegian Sea to the north of it. In Fig. IO4 our former research-stations are marked with a cross.

It was desirable, however, to re-investigate this area, employing there the same methods of working as we had adopted in the North Atlantic, and we felt it necessary to have a section south of the IVyville Thomson Ridge and another one to the north of it. The valley between Britain on the one side and Rockall and the Faroes on the other is really the only connection between the two deep basins, for it is only through 
this channel that the water of the Atlantic streams into the Norwegian Sea; to the west of the Faroes, over the long ridge that extends to Iceland, the Atlantic water is checked by the East Iceland Polar current.

Glasgow to Bergen.

Our southern section was from Glasgow to Rockall, with stations on the British coast bank, on its seaward slope, and on the Rockall Bank. We had beautiful weather in which to make

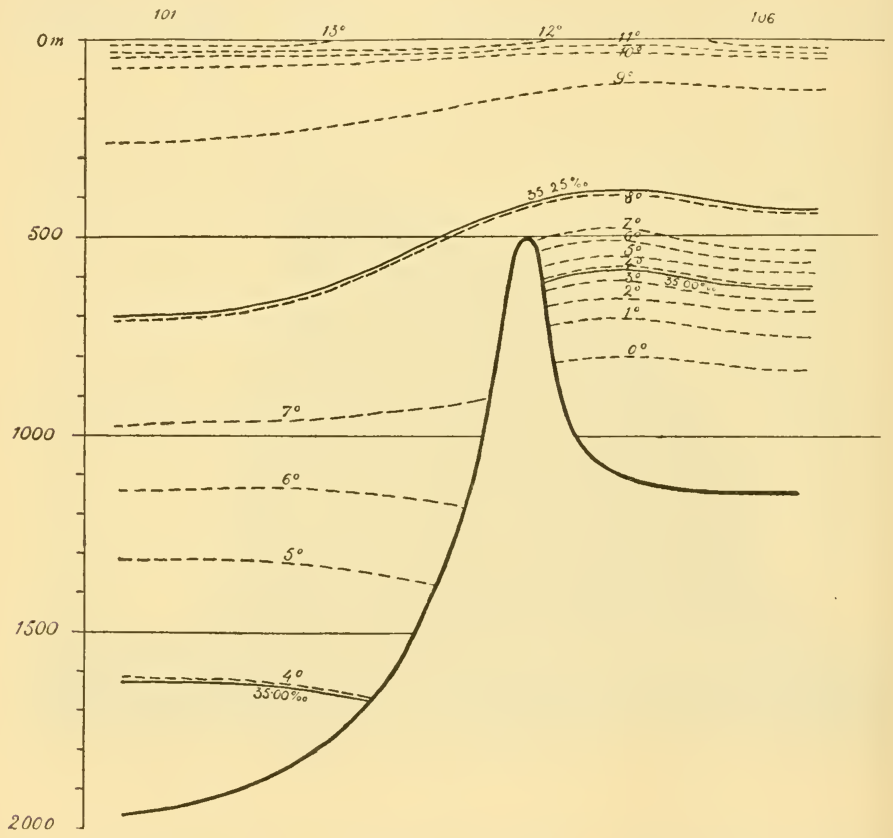

Fig. io6.-Section across the Wyville Thosison Ridge.

investigations, and approached close to the rocky little islet, which we photographed (Fig. I05). This rock is well known, Rockall. owing to many a sad disaster (only recently the transatlantic steamer "Norge" was wrecked there), and shows distinct traces of the power of the waves. All its brown granite-like sides are clad with small algæ (green-spored algæ), kept moist by the spray, and the top is covered with a thin layer of guano ; the rock and its surroundings swarm with auks and gulls. 
After completing this section, we proceeded towards the Wyville Wyville Thomson Ridge, and occupied a station (IOI) at a Thomson depth of Iooo fathoms, where we employed the trawl as well as a number of pelagic appliances, and then concluded our work by taking two sections on the northern side of the ridge (see stations in Fig. I04).

The hydrographical conditions here have often been described. Fig. Io6 gives a general idea of what we found at Station IOI south of the Wyville Thomson Ridge, and at Station 106 to the north of it. South of the ridge salinities and temperatures are rather lower than what we found in our northern Atlantic section, but the differences are not very considerable either in deep water or in the upper layers. The upper layers extend with little variation down to the level of the ridge in 500 metres, but the difference in the deep water on the two sides of the ridge is unmistakable, as the ice-cold bottomwater of the Norwegian Sea comes close to the northern margin of the ridge.

These conditions, however, are generally known, and our attention was chiefly turned in another direction. During our previous investigations in the Norwegian Sea we discovered that the hydrographical conditions often varied very considerably within a short distance or in the course of a short period of time. The variations were not always of the same character. A number of eddies, both large and small, occurred apparently during the movements of the water-layers, and there were up and down movements in the boundary-layers-possibly big submarine waves or something of that sort-as well as distinct pulsations in certain currents. We resolved, therefore, on our way over to Bergen to make a careful study of these phenomena in the Faroe-Shetland channel. To be able to do so, it was necessary to have our stations very close together and to occupy them in rapid succession, and also to lie stationary for at least twenty-four hours at one of them.

Altogether we had fourteen stations north of the ridge in the Investigations Faroe-Shetland channel (Nos. I03-1 I6; see Fig. I 04) along two in the Far nearly parallel sections, the distance from one station to another being about 20 nautical miles, and the distance between the sections a little over 25 miles. We found that the hydrographical conditions varied greatly in the different localities, and that there was an extraordinary difference between the two sections. At Station I I 5, on the continental edge to the west of Shetland, we anchored a buoy, and remained stationary there 
for twenty-four hours, taking continuous observations of temperature and salinity at different depths. It was quite evident that there were considerable vertical fluctuations, the intermediate layers showing up and down movements with an amplitude of as much as 35 metres during a period that corresponded practically with the tidal period.

Pelagic hauls. After leaving Glasgow we made pelagic hauls with our silk nets and young-fish trawls on the coast bank, on the slope, out in the deep channel, near the southern flank of the Wyville Thomson Ridge (Station IOI), and to the north of it (Station IO2). At every depth our catches to the south of the ridge closely resembled those we made in our northern Atlantic section between Newfoundland and Ireland, and particularly the catches made in the eastern portion of that section.

In the upper layers there were all the boreal animals characteristic of Atlantic water in the Norwegian Sea, as, for instance, Euthemisto and Clione limacina. But there was also a mass of Atlantic forms that do not occur all the year round in the Norwegian Sea, though they are known to wander in at certain seasons of the year, as at the end of the summer or during autumn. The tow-nets gave a mixture of Arachnactis, Salpa fusiformis, numbers of scopelids, leptocephali (fullgrown larvæ of the common eel), the young of Macrurus, and Nerophis equoreus.

At a depth of 300 metres we captured the silvery Argyropelecus, and in deep water, from 500 metres downwards, there was the characteristic fauna of black Cyclothone microdon, red crustaceans (Acanthephyra), and other forms, which thus occur right up to the southern slope of the Wyville Thomson Ridge.

On the northern side of the ridge we towed our appliances at $50,100,150,200,300,500,700$, and 750 metres (Station 102) without catching a single specimen of these Atlantic deep-sea forms; but in the upper layers there were not merely boreal forms, but also salpæ, the area of distribution of which is mainly Atlantic.

These results quite accord with our previous observations during the cruises of the "Michael Sars." Hauls in the deepest waters of the Norwegian Sea have not yielded any pelagic fish other than the black Paraliparis bathybii (Fig. IO7), which used to be considered a bottom-fish; it is interesting to note that it is black. There was a complete absence of Cyclothone and the red Atlantic crustaceans belonging to the genus Acan- 
thephyra, the only pelagic crustaceans found by us north of the ridge being Hymenodora glacialis and species of Pasiphaa.

In the upper layers, however, different scopelids have been found both by us and by others, and on the Norwegian coast the silvery species of Argyropelecus, which inhabit depths of about 300 metres in the Atlantic, have occasionally been met with. It seems tolerably certain, therefore, that the Wyville Thomson Ridge shuts out the whole of the Atlantic pelagic deepsea fauna from the Norwegian Sea, and that it is only in the superficial layers from the surface down to 400 or 500 metres that pelagic forms are able to wander in from the Atlantic.

That the bottom-fauna is different on either side of the Benthos of ridge is well known. Our trawlings, both on this occasion and the Faroe previously, have merely helped to confirm the fact; still we secured a very large amount of material, which in itself is of

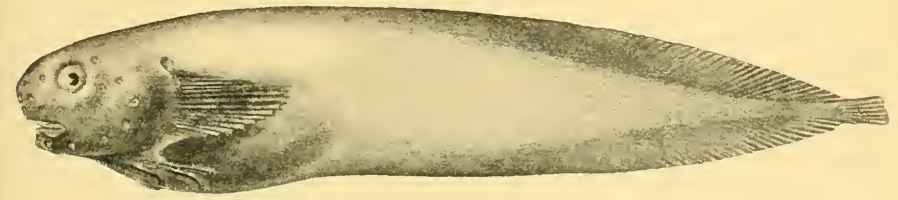

FiG. 107.

Paraliparis bathybii, Coll. Nat. size, $23 \mathrm{~cm}$.

(Taken in pelagic haul in Norwegian Sea, May rgi I.)

considerable interest. At Station IOI (south of the ridge), in I 000 fathoms (I853 metres) of water, a haul of two hours' duration yielded a barrel-full of lower animals, most of which were echinoderms, and ninety fishes (Macrurus, Antimora, Alepocephalus, Harriotta, and Synaphobranchi), representing a fauna that may be said to characterise the north-east Atlantic from the Wyville Thomson Ridge southwards, far along the coast of Africa. The remarkable fish, Harriotta raleighana, which we captured at Station IO I, a few miles from the deep water of the Norwegian Sea, had been previously taken by us at Station 35, to the south of the Canary Islands. On the other hand, fish that exist only a few miles farther north, on the northern side of the ridge, never enter the Atlantic, though in the deep water of the Norwegian Sea they may be met with as far north as Spitsbergen, and perhaps even still farther north.

The "Michael Sars" anchored at Bergen on I 5 th August. Extent of During her four and a half months' cruise she had traversed I I, 500 the cruise. 
miles, and occupied I 6 research stations; on a rough estimate we had lowered and hauled in about I 500 kilometres of wire with our four winches. Only the greatest attention and energy on the part of the crew could have made this possible. Thanks to them we have probably opened up a new way for ocean research, by showing what a little vessel can accomplish, which is by no means the least valuable result of our expedition. The following chapters aim at giving the results of our scientific observations from a more general and systematic point of view than was possible in this brief account of the actual cruise.

J. H.

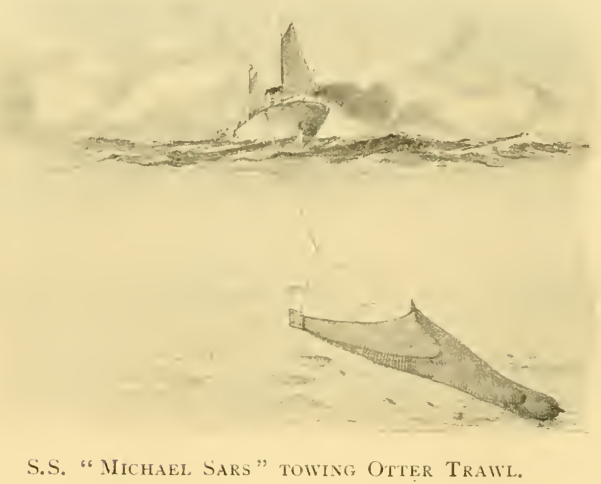





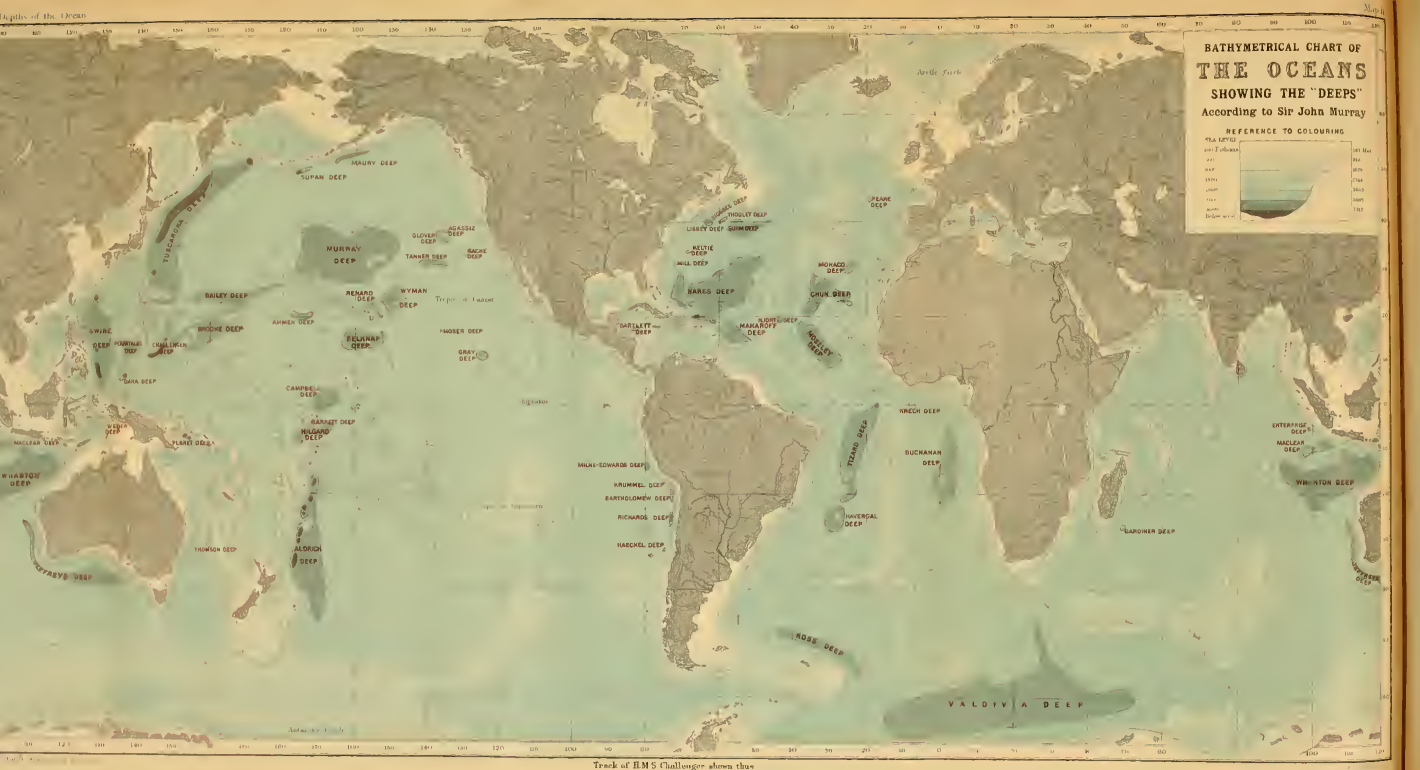






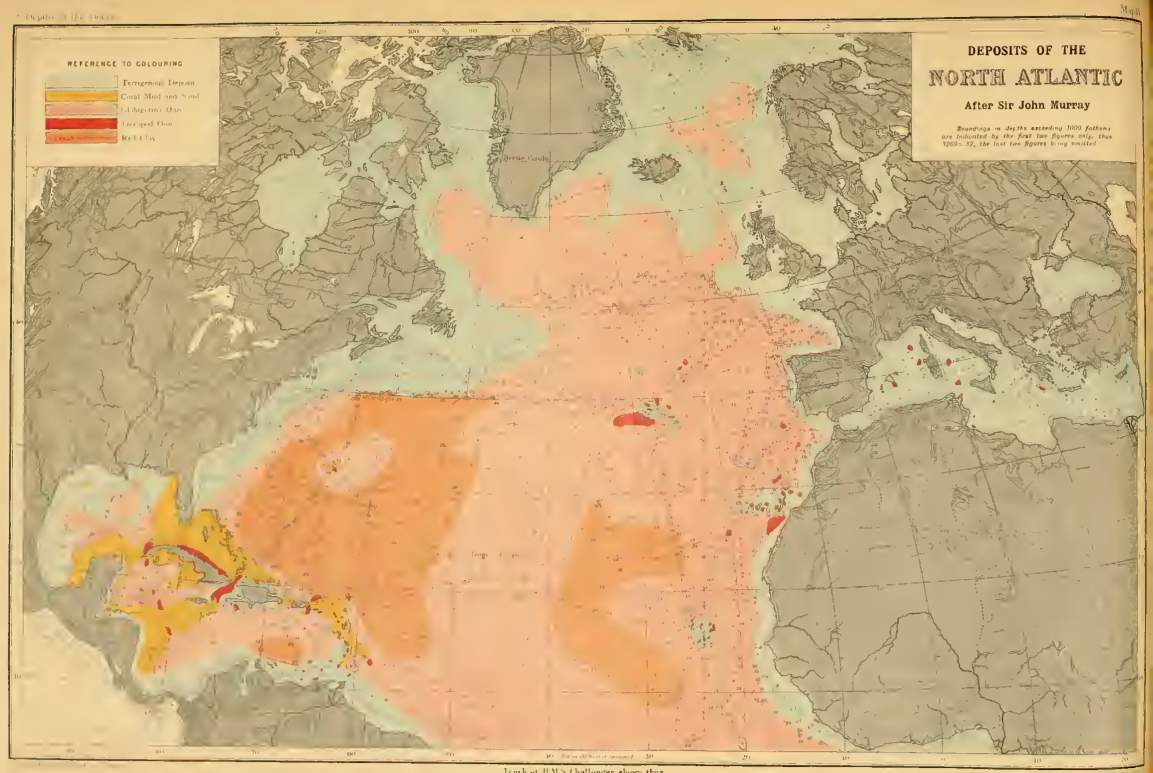




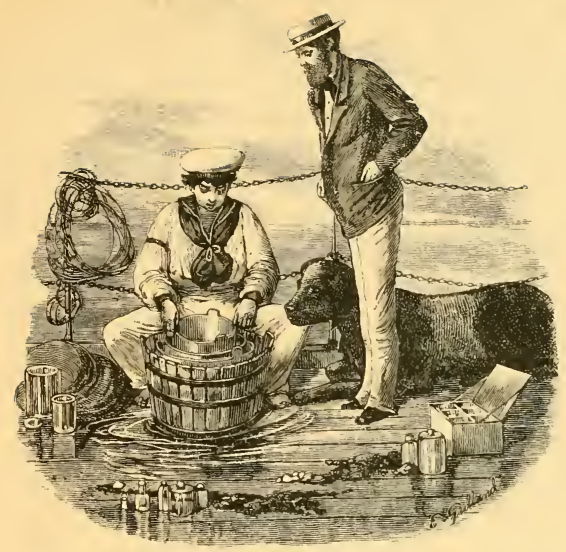

SiftiNg Deposits oN BOARD THE "ChALLENger."

\section{CHAPTER IV}

THE DEPTHS AND DEPOSITS OF THE OCEAN

\section{The Depths of the Ocean}

In the opinion of astronomers the earth is the only planet of The earth as our solar system which has oceans on its surface. If Mars and a planet. the moon once had oceans, these have apparently disappeared within their rocky crusts. Our earth is in what is called the terraqueous stage of a planet's development. The ocean is less than the hydrosphere, which is regarded as including all lakes and rivers, the water-vapour in the atmosphere, and the water which has penetrated deep into the lithosphere.

If the whole globe were covered with an ocean of uniform depth, and if there were no differences of density in the shells of the rocky crust, the surface of the ocean would be a perfect spheroid of revolution. But, as every one knows, the surface of the earth is made up of land and water, and at all events the superficial layers of the lithosphere are heterogeneous. The Figure of figure of the earth departs from a true spheroid of revolution, the earth. and is called a geoid. The surface of the ocean is, therefore, farther removed from the centre of the earth at some points 
Attraction of the

land-masses.

Measurements of depth.

Hand line.

Brooke's sounding machine.

Hemp line for sounding.

Wire for solinding.

Number of deep-sea soundings. than at others; the gravitational attraction of emerged land causes a heaping-up of the sea around continental and other coasts. The extent of this heaping-up near elevated continents, and consequent lowering of the sea-surface far from land, appear to have been much exaggerated. The difference of level due to this cause has sometimes been estimated at thousands of feet. Recent researches indicate that the differences of level at different points of the sea-surface do not depart more than 300 or 400 feet from a true spheroid of revolution.

The other causes which, in addition to the tides, may affect the level of the ocean are meteorologic, such as barometric pressure, temperature, the action of wind, evaporation, precipitation, the inflow of rivers, but in no cases do these affect the level of the ocean more than a few inches or a few feet.

All depths recorded by the sounding-line in the open sea are referred to the surface of the ocean, and near coasts to mean sealevel. The first method of ascertaining the depth of the ocean was by means of the hand line and lead, armed with tallow, used by ordinary sailors. A great advance was made when Lieutenant Brooke, of the United States Navy, devised the apparatus for detaching the weight or sinker when it struck the bottom, the line bringing up only a small tube with a sample of the bottomdeposit. During the "Challenger" Expedition the line used was a fine hempen rope, and the time when each roo-fathoms mark passed over the ship's side was carefully noted. When a great change of the rate was observed, the lead was known to have reached the bottom. It is believed that even the deepest soundings taken in this way are correct to within roo feet.

Another advance was made when fine wire was used for the soundings, and the machine recorded automatically the moment when the sinker struck the bottom. There are many types of wire deep-sea sounding machines now in use, but the most compact and practical of these is the Lucas sounding machine. Sounding instruments are referred to in greater detail in another chapter (see p. 30).

To give the total number of deep soundings recorded by British and other ships up to the present day, even in depths exceeding 1000 fathoms, would be difficult. An approximation has been made by counting the number of soundings in depths exceeding $\mathrm{I} 000$ fathoms laid down on the latest charts. It must be remembered that not all the recorded soundings can be laid down on small scale charts where they are at all numerous.

In 1886 Sir John Murray had three hemispheres drawn on 
Lambert's equal-surface projection, one to show the Atlantic Equal-surface Ocean, one the Pacific, and one the Indian Ocean, on which all projection the soundings recorded up to that time, in depths exceeding Iooo fathoms, were laid down in position, and contour-lines of depth drawn in. Since then these hemispheres have been kept up to date by Dr. Bartholomew by the inclusion from time to time of new soundings recorded in depths greater than 1000 fathoms, and the contour-lines have been redrawn. The North Atlantic from one of these hemispheres is shown on Map III., where practically all soundings recorded in depths greater than I 000 fathoms are placed in position, the two last figures being omitted.

The total number of soundings laid down on these charts is 5969 , of which 2500 are in the Atlantic ( 1873 in the North Atlantic and 627 in the South Atlantic), 2466 in the Pacific (I 266 in the North Pacific and I 200 in the South Pacific), and I003 in the Indian Ocean. These figures show that proportionately a great many more soundings have been taken in the Atlantic than in the Pacific, which covers an area so much larger. Of these 5969 soundings, 2516 were taken in depths between 1000 and 2000 fathoms, 2962 in depths between 2000 and 3000 fathoms, and only 491 are laid down in depths exceeding 3000 fathoms, of which 46 exceed 4000 fathoms, and only 4 exceed 5000 fathoms. It may be added that though only four soundings over 5000 fathoms have been laid down on the charts, in reality seven have been recorded, three in the South Pacific in the Aldrich Deep, and the other four taken by the U.S.S. "Nero" in the Challenger Deep in the North Pacific, near the island of Guam, but in such close proximity to one another that only the deepest, 5269 fathoms, could be laid down on the map.

The deepest sounding hitherto recorded is that of 5269 Deepest fathoms just mentioned. . This is equal to 9636 metres, or recorded $3 \mathrm{I}, 6$ I 4 feet, or 66 feet less than six English miles, and it exceeds the greatest known height above the level of the sea (Mount Everest in the Himalaya Mountains, 29,002 feet) by 261 2 feet. The known range of variation in the level of the earth's crust, from the greatest height above sea-level to the greatest depth below sea-level, is thus 60,616 feet, or about I I $\frac{1}{2}$ English miles, but this range is very small when we remember that the diameter of the earth is nearly 8000 miles ; in fact, on a six-feet globe a mere scratch one-tenth of an inch deep would represent the extreme variation in the irregularities of the earth's surface. 
Deepest soundings in the Atlantic and Indian Oceans.

Superficial area of the earth.

Area of Antarctic continent.

Area of land on the globe.

Area of water on the globe.

Areas of the ocean-floor at different depths.

The second deepest sounding on the ocean-floor is 5 I 55 fathoms in the Aldrich Deep in the South Pacific, depths exceeding 5000 fathoms being limited to the Pacific Ocean. The deepest sounding recorded in the Atlantic is 4662 fathoms in the Nares Deep to the north of the West Indies, and the deepest in the Indian Ocean 3828 fathoms in the Wharton Deep to the south of the East Indies.

In 1886 Professor Chrystal calculated for Sir John Murray the superficial area of the earth, regarded as a spheroid of revolution, as equal to $196,940,700$ square English miles, of which the land-surface was estimated at $55,697,000$ square miles, and the water-surface at I4I, 243,000 square miles. ${ }^{1}$ At that time the area of land surrounding the south pole was estimated at 3,565,000 square miles, but the results of all the recent south polar expeditions seem to indicate that the Antarctic continent covers a larger extent than was supposed. The latest measurements by Sir John Murray give a probable area of about 5,122,000 square miles for Antarctica, so that the total land-surface of the globe may now be estimated at $57,254,000$ square miles, which may be supposed to include all lakes and rivers, leaving about I 39,686,000 square miles for the waters of the ocean and seas directly connected therewith.

Planimeter measurements of the most recent depth hemispheres gave I39,295,000 square English miles for the area of the whole ocean, and this figure will be adopted throughout this publication.

The approximate areas between the consecutive contourlines drawn in at equal intervals of 1000 fathoms worked out as follows for the whole ocean :-

\begin{tabular}{|rr|r|}
\hline Fathoms. & Square English Miles. & Percentage. \\
\hline & & \\
$1000-1000$ & $21,725,000$ & 15.59 \\
$2000-3000$ & $26,915,000$ & 19.34 \\
$3000-4000$ & $81,381,000$ & 58.42 \\
Over 4000 & $9,058,000$ & 6.50 \\
& 216,000 & 0.15 \\
\hline & $139,295,000$ & 100.00 \\
\hline
\end{tabular}

1 Scottish Geographical Magazine, vol. ii. p. 550, IS86. 
This table shows at a glance that the greater portion of the ocean-floor is covered by deep water, i.e. by water exceeding IOoO fathoms in depth, equal to more than four-fifths of the entire superficies of the ocean, two-thirds being occupied by water exceeding 2000 fathoms in depth, while only one-fifteenth of the entire sea-floor is covered by water exceeding 3000 fathoms in depth.

Those parts of the ocean in which depths greater than 3000 fathoms have been recorded are called "deeps," and have had distinctive names conferred upon them, just as mountain ranges and peaks on the dry land (Mount Everest, for example) are distinguished by names. These deeps are shown on Map II., and will presently be dealt with in some detail.

The table also shows that a comparatively large area, about one-sixth of the ocean-floor, is covered by water less than 1000 fathoms in depth, of which by far the greater proportion is covered by still shallower water. Thus if we divide this area into two portions by the 500-fathoms line, we find that the area within that line is about $\mathrm{I} 7$ million square miles (or over I 2 per cent of the entire ocean) compared with only $4 \frac{1}{2}$ million square miles (or 3 per cent of the entire ocean) beyond that line, i.e. having depths between 500 and 1000 fathoms. Again, of the area covered by less than 500 fathoms of water, more than one-half is occupied by the continental shelf or continental plateau lying between the shore-line and the Ioo-fathoms line, which has elsewhere ${ }^{1}$ been estimated at 7 per cent of the whole ocean. The relatively large area covered by the gentle slopes of the continental shelf in depths less than Ioo fathoms, as compared with the relatively small area covered by the steeper gradients of the continental slope in depths greater than 100 fathoms, is strikingly shown by these figures, for while about 7 per cent of the ocean-floor lies within the Ioo-fathoms line, only about 5 per cent occurs within the next succeeding 400 fathoms (between the I00- and 500-fathoms lines), and only about 3 per cent within the next succeeding 500 fathoms (between the $500-$ and rooo-fathoms lines).

The position occupied by the junction of the continental shelf with the continental slope, as indicated by the change mud-line of gradient, has been called the continental edge (see Fig. I 44, p. I98), and varies in depth according to circumstances, but on the average all over the world is not far from the Ioo-fathoms

1 Sir John Murray, Presidential Address to the Geographical Section of the British Association, Dover, I899. 
line, coinciding generally with what we have designated the mud-line. ${ }^{1}$

Let us now consider the distribution of depth in the three great oceans (the Atlantic, the Pacific, and the Indian Oceans), regarding them as extending in each case as far south as the shores of the Antarctic continent.

Atlantic Ocean.-The Atlantic may be looked upon as including the Arctic Ocean and Norwegian Sea, the Mediterranean, Caribbean, and Gulf of Mexico, and as being separated from the Pacific in the south at the meridian of Cape

Area of the Atlantic sea-floor at different depths.
Continental shelf and slope in the Atlantic. Horn (long. $70^{\circ} \mathrm{W}$.) and from the Indian Ocean at the meridian of the Cape of Good Hope (long. $20^{\circ}$ E.). As thus defined the Atlantic Ocean covers an area of about 4I,32I,000 square English miles, the distribution of depth being shown in the following table :-

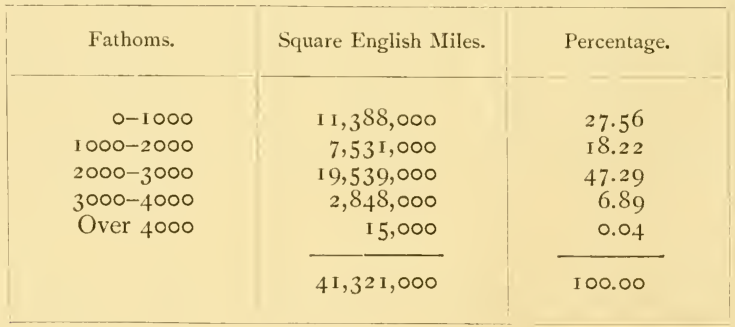

These figures show that nearly three-fourths of the Atlantic sea-floor are covered by water exceeding I000 fathoms in depth, and over one-hali by water exceeding 2000 fathoms in depth, but the most characteristic feature of this ocean when compared with the Pacific and Indian Oceans is the large proportion covered by water less than Iooo fathoms in depth. The table shows that this shallowest zone (from o-rooo fathoms, which includes both the continental shelf and the continental slope) covers about I I $\frac{1}{2}$ million square miles, while the succeeding zone ( $1000-2000$ fathoms) covers only $7 \frac{1}{2}$ million square miles. If again we divide the shallowest zone into two portions by the 500-fathoms line, the predominance of the area covered by shallow water is still more pronounced, the area less than 500 fathoms being nearly io million square miles as compared

1 Murray and Renard, Deep-Sea Deposits Chall. Exp. p. I85, I891; Murray, Summary of Results Chall. Exp. p. I433, I895. 
with $\mathrm{I} \frac{1}{2}$ million square miles between 500 and 1000 fathoms. This is due to the large expanses of shallow water in the Arctic regions and Hudson Bay, on the Banks of Newfoundland, off the east coasts of North and South America, between Greenland and the British Isles, around the British Isles, and in the Baltic.

The most striking feature of the Atlantic Ocean is certainly the low central ridge (dividing the ocean into eastern and western deep basins), which was until recently supposed to be continuous from Iceland through both the North and South Atlantic as far as lat. $40^{\circ} \mathrm{S}$., but is now known to be discontinuous in the neighbourhood of the equator; on the other hand, it has been extended farther south by the soundings taken on board the "Scotia" in 1904 by Dr. W. S. Bruce, so that the southern limit of the ridge now extends as far south as lat. $53^{\circ} \mathrm{S}$. At the position of the break in the ridge on the equator the floor of the ocean seems to be more than usually irregular, for depths less than 2000 fathoms alternate with depths exceeding 3000 and even 4000 fathoms. On this ridge, with the exception of the Azores group, the only islands are St. Paul's Rocks, Ascension, Tristan da Cunha, and Gough Island. The northern extremity of the ridge between lat. $50^{\circ}$ and $60^{\circ} \mathrm{N}$. is peculiar because of the number of isolated soundings exceeding 2000 fathoms apparently surrounded by shallower water.

Another point that strikes one in the Atlantic is the gentle slope off the American coasts and off the coasts of the British Isles, as compared with the slopes off Africa and off Spain and Portugal. This is still more remarkable when compared with the slopes off the Pacific coasts of America. The wide shore platform off the coast of the southern half of South America is especially noteworthy, as well as that off the coasts of the United States and Newfoundland. The shallow area surrounding Rockall Bank also attracts attention. The series of banks made known as a result of the work of telegraph ships, off the northwest coast of Africa to the north of the Canary Islands, is another striking instance of the irregularity of the floor of the Atlantic. In the same neighbourhood the area with depths less than 2000 fathoms surrounding Madeira and extending northwards towards the coast of Portugal is remarkable. In the South Atlantic, besides the central ridge, three smaller shallow areas should be noted, two neighbouring ones to the east of the South American coast in lat. $30^{\circ} \mathrm{S}$., and the third midway between the ridge and the Cape of Good Hope.

Mid-Atlantic ridge. 
Atlantic area exceeding 2000 fathoms in depth.

Irea of the Pacific seafloor at different depths.

The principal area exceeding 2000 fathoms in depth is continuous throughout the Atlantic, although much broken up by areas of shallower water ; there are besides in places isolated areas in which the depth exceeds 2000 fathoms, as in the Gulf of Guinea, near the Canary Islands, at the northern extremity of the Mid-Atlantic ridge (as already mentioned), as well as in the Norwegian Sea, the Mediterranean Sea, the Carribbean Sea, and the Gulf of Mexico.

The areas exceeding 3000 fathoms in depth ("deeps") will be referred to under a later heading.

Pacific Ocean.-The Pacific may be looked upon as extending southwards from the Arctic circle in Behring Strait to the Antarctic continent, including the fringe of partially enclosed seas along its western border, and as being separated from the Atlantic in the south at the meridian of Cape Horn (long. $70^{\circ} \mathrm{W}$.), and from the Indian Ocean at the meridian of Tasmania (long. $147^{\circ}$ E.). As thus defined the Pacific Ocean covers an area of about $68,634,000$ square English miles, the distribution of depth being shown in the following table:-

\begin{tabular}{|r|r|r|}
\hline Fathoms. & Square English Miles. & Percentage. \\
\hline & $7,174,000$ & 10.45 \\
\hline 1000-1000 & I $2,214,000$ & 17.80 \\
$2000-3000$ & $44,633,000$ & 65.03 \\
$3000-4000$ & $4,412,000$ & 6.43 \\
Over 4000 & 201,000 & 0.29 \\
\hline & $68,634,000$ & 100.00 \\
\hline
\end{tabular}

These figures show that nearly nine-tenths of the Pacific sea-floor are covered by water exceeding Iooo fathoms in depth, and nearly three-fourths by water exceeding 2000 fathoms in Continental depth. Unlike the Atlantic, the shallowest zone in the Pacific shelf and slope (O-IOOO fathoms) is smaller than the succeeding zone (IOOO-2000
in the Pacific. fathoms), indicating that the Pacific land-slopes are on the average steeper than those of the Atlantic, and this is strikingly shown by the near approach to the land of the deep contours in certain regions, as off the coasts of South America, North America, Japan, the Philippine Islands, and South-East Australia. The ratio between the two areas on either side of the 500-fathoms line is not so striking as in the case of the Atlantic, the area 
less than 500 fathoms in the Pacific being about 5 million square miles, as compared with 2 million square miles for the area between 500 and 1000 fathoms.

The Pacific Ocean differs from the Atlantic in having much more steeply sloping shores both on the east and west sides, greater depths, and very many small islands, chiefly of volcanic and coral formation. This gives a very irregular appearance to the depth-map of the Pacific, and shows sharper contrasts in rises and depressions of the ocean-floor than are found in either of the other great ocean basins. Along the west coasts of both North and South America the steep slopes are most remarkable, the land descending from the great heights of the Rocky Mountains and the Andes to depths of 2000 fathoms and more in a comparatively very short horizontal distance. This is particularly striking off the coast of South America between the latitudes of $10^{\circ}$ and $35^{\circ} \mathrm{S}$., where depths of over 3000 fathoms (in three cases over 4000 fathoms) are found within a very short distance from the shore-line. It is noteworthy that all the soundings recorded in depths of over 4000 fathoms are taken comparatively near land, viz. off South America (as just near land. mentioned), off the Aleutian Islands, the Kurile Islands and Japan, the Philippines, the Ladrone Islands, the Pelew Islands, between the Solomon Islands and New Pommerania, and to the north of New Zealand, east of the Kermadec and Friendly Islands.

The greater part of the area with depths less than Iooo fathoms lies in the western Pacific, in the fringe of partially enclosed seas which lie between the continents of Asia and Australia and the islands fringing their eastern shores, such as the Behring Sea, the Sea of Japan, the Yellow Sea, China Sea, Java and Arafura Seas, and around the New Zealand plateau.

The area covered by depths between I000 and 2000 fathoms lies mostly south of the equator, that part north of the equator consisting of detached areas in the Behring Sea, Sea of Okotsk, Sea of Japan, and China Sea, narrow bands round the various island groups and along the western shores of North America, widening greatly off the coast of Central America, and nine small areas where the floor of the ocean rises from surrounding depths of over 2000 fathoms. The area in the South Pacific with depths between $\mathrm{I} 000$ and 2000 fathoms was formerly supposed to extend from the Southern Ocean between Auckland Islands and the Antarctic continent in a wide band north-eastwards towards the coasts of Central America without a break, but recent investiga- 
Pacific area exceeding 2000 fathoms.

tions by the late Alexander Agassiz on board the U.S.S. "Albatross" showed that this rise from the general depth of over 2000 fathoms was not continuous. This has led to a great decrease in the figures given for the area with depths between I 000 and 2000 fathoms, and a corresponding increase in the area with depths between 2000 and 3000 fathoms.

The area exceeding 2000 fathoms in depth in the Pacific is connected with the corresponding area in the Atlantic by a comparatively narrow trench running to the south of Cape Horn between South Georgia and South Orkney, and is continuous throughout the Pacific except for detached areas in several of the fringing seas on the west, one in the Coral Sea, and one large and six small areas in the South-West Pacific, where the soundings are very numerous and the contour-lines of depth are very sinuous.

The areas exceeding 3000 fathoms in depth will be referred to under a later heading.

Area of the Indian Ocean sea-floor at different depths.

Indian Ocean. - The Indian Ocean may be looked upon as extending southwards from the Bay of Bengal and Arabian Sea to the Antarctic continent, including the Red Sea and Persian Gulf, and as being separated from the Atlantic in the south at the meridian of the Cape of Good Hope (long. $20^{\circ} \mathrm{E}$.) and from the Pacific at the meridian of Tasmania (long. $147^{\circ} \mathrm{E}$.). As thus defined the Indian Ocean covers an area of about 29,340,000 square English miles, the distribution of depth being shown in the following table:-

\begin{tabular}{|r|r|c|}
\hline Fathoms. & Square English Miles. & Percentage. \\
\hline & $3,163,000$ & 10.78 \\
\hline $0-1000$ & $7,170,000$ & 24.44 \\
$2000-2000$ & $17,209,000$ & 58.65 \\
Over 3000 & $1,798,000$ & 6.13 \\
\hline & $29,340,000$ & 100.00 \\
\hline
\end{tabular}

These figures show that, like the Pacific, nearly nine-tenths of the Indian Ocean sea-floor are covered by water exceeding IOOO fathoms in depth, while nearly two-thirds are covered by more than 2000 fathoms of water. The shallowest zone in the Indian Ocean (O-I00o fathoms) is much smaller than the succeeding zone (1000-2000 fathoms), indicating that the average 
land-slopes throughout the basin are, as in the Pacific, steeper than those of the Atlantic. The ratio between the two areas on either side of the 500-fathoms line is again much less than in the case of the Atlantic, the area less than 500 fathoms in the Indian Ocean being over 2 million square miles, as compared with less than I million square miles for the area between 500 and 1000 fathoms.

The Indian Ocean, unlike the other two, is completely landlocked to the north. The area with depths less than Iooo fathoms forms a zone of varying width along the main land-masses, a fairly wide zone round the various island groups, and extends into the Red Sea and Persian Gulf. The area with depths between 1000 and 2000 fathoms is made up of the greater part of the Bay of Bengal and the Arabian Sea, a fairly wide belt along the east coast of Africa, a much narrower one along the western shores of the Sunda Islands and Australia, a large expanse between Tasmania and the Antarctic continent which narrows considerably towards the west, and a large tract extending from lat. $30^{\circ}$ to $55^{\circ} \mathrm{S}$. and long. $35^{\circ}$ to $94^{\circ} \mathrm{E}$., forming a plateau on which are situated the islands of Prince Edward, Crozet, Kerguelen, M'Donald, Heard, St. Paul, and Amsterdam, as well as one or two small isolated areas.

With the exception of a comparatively small area in the Southern Ocean, about lat. $60^{\circ} \mathrm{S}$. to the south of Australia, the area with depths between 2000 and 3000 fathoms is a continuous one, though interrupted by areas of deeper and shallower water ; it is continuous with the corresponding area of the Atlantic, but distinct from that of the Pacific, being separated from it by the rise that runs southwards from Tasmania to the Antarctic continent.

The areas exceeding 3000 fathoms in depth are referred to under the next heading.

Deeps.-As already indicated, those areas of the ocean-floor covered by more than 3000 fathoms ( 5486 metres) of water have been called Deeps, and, though occupying a relatively Deeps. small proportion of the ocean-floor, estimated in the aggregate at about 9 million square miles, they are extremely interesting from an oceanographical point of view. Map II. shows the distribution of these deeps throughout the great ocean basins, according to the present state of our knowledge, and it will be seen that the total number is fifty-seven, of which thirty- Number of two occur in the Pacific, five in the Indian Ocean, nineteen in

Indian Ocean area with depths between 1000 and 2000 fathoms.

Indian Ocean area exceeding 2000 fathoms. 
the Atlantic, and one partly in the Atlantic and partly in the Indian Ocean. From the point of view of depth the Challenger Deepest Deep in the North Pacific and the Aldrich Deep in the South deeps.

Pacific are the most important, for only these two include depths exceeding 5000 fathoms, while in eight other deeps depths exceeding 4000 fathoms have been recorded. On the other hand, in some cases the deeps enclose low rises, on which the depth is less than 3000 fathoms. The deeps vary in form and size to a most extraordinary degree, and future soundings may show that some of them should be subdivided into two or more portions, or that two or more deeps as now laid down should be united into a single deep.

Largest deeps.

Valdivia Deep.

Murray Deep.

Tuscarora Deep.

From the point of view of superficial area, the most important deeps are the Valdivia, Murray, Tuscarora, Wharton, Nares, Aldrich, and Swire Deeps, which are estimated to cover in each case an area exceeding 500,000 square miles. In the following paragraphs the principal deeps of the world are briefly characterised, arranged in the order of magnitude :-

Valdivia Deep lies in the far south, partly in the Atlantic and partly in the Indian Ocean. It is based principally on soundings taken by the German Deep-Sea Expedition on board the "Valdivia," and has a maximum depth of 3 I 34 fathoms. It is estimated to cover a total area of $1,136,000$ square miles, nearly one-half of which $(523,000$ square miles $)$ lies to the west of long. $20^{\circ} \mathrm{E}$., i.e. within the Atlantic basin, while the remaining half $(613,000$ square miles) lies to the east of that meridian, and is therefore in the basin of the Indian Ocean. The outline of this deep, especially in its western portion, is largely hypothetical, and future soundings may modify the area assigned to it at present.

Murray Deep, situated in the Central North Pacific between lat. $25^{\circ}$ and $40^{\circ} \mathrm{N}$., is estimated to cover an area of about $\mathrm{I}, \mathrm{O} 33, \mathrm{OOO}$ square miles, and is founded on soundings taken partly by the "Challenger" Expedition. The maximum depth recorded in it is 3540 fathoms, and there is a small area within the deep in the vicinity of this deepest sounding where depths of only 2800 and 2900 fathoms are recorded.

Tuscarora Deep lies in the North-Western Pacific, and is of elongated form, extending from the Tropic of Cancer northeastwards to near the Aleutian Islands in lat. $52^{\circ} \mathrm{N}$., approaching to within a comparatively short distance of the shores of Japan and the Kurile Islands. Its area is estimated at 908,000 square miles, and the maximum depth is 4655 fathoms, recorded 
by the U.S.S. "Tuscarora" in 1874 . A considerable portion of this deep is covered by depths exceeding 4000 fathoms, including one large elongate area founded on eight soundings, and two small areas founded each on single soundings-one towards the southern end of the deep and the other in the extreme north.

Wharton Deep lies in the eastern Indian Ocean, extending from lat. Io S. to the Tropic of Capricorn, and is estimated to Wharton Deep. cover an area of $88_{3}, 000$ square miles; it includes the two deepest soundings yet recorded in the Indian Ocean, viz. 3828 and 3703 fathoms, taken in 1906 by the German ship "Planet" in what is called by the Germans the "Sunda Graben" at no great distance from the coast of Java.

Nares Deep is the largest deep lying wholly in the Atlantic Nares Deep. Ocean, and at the same time the deepest. Its outline is most irregular, extending from lat. $18^{\circ} \mathrm{N}$. to $34^{\circ} \mathrm{N}$., and in the neighbourhood of the West Indies the floor of the deep sinks to depths exceeding 4000 fathoms over a limited area, the maximum depth being 4662 fathoms, recorded by the U.S.S. "Dolphin" in 1902. This deep is estimated to cover an area of 697,000 square miles.

Aldrich Deep lies in the Central South Pacific, extending Aldrich Deep. from lat. $15^{\circ}$ to $47^{\circ} \mathrm{S}$., and is estimated to cover an area of about 6I3,000 square miles. It includes seven small areas lying along its western border in which the depth exceeds 4000 fathoms. In three of these the depth exceeds 5000 fathoms, viz. 5022, 5I47, and 5I55 fathoms, recorded by Commander Balfour on board H.M.S. "Penguin" in I 895. Numerous soundings have been taken round these seven deepest areas, and seem to prove that they are all separated from one another by ridges covered by water between 3000 and 3700 fathoms in depth. The outline of this deep is remarkable, and it is possible that future soundings will show it to be two distinct deeps, for a rise, on which soundings in 2000 to 2900 fathoms have been recorded, interrupts the sequence of great depths.

Swire Deep lies in the North-West Pacific in close proximity Swire Deep. to the Philippines, and extends from about lat. $4^{\circ} \mathrm{N}$. to lat. $25^{\circ} \mathrm{N}$., covering an area of about 550,000 square miles. It is broken up by several rises on the ocean-floor where depths of 2700,2800 , and 2900 fathoms have been recorded; on the other hand, at remarkably short distances from the coasts of Mindanao and Samar Islands in the Philippines are two areas with depths exceeding 4000 fathoms, a similar depth being 
recorded also at the northern end of the deep. The maximum depth, which occurs off Samar Island, is 4767 fathoms.

Tizard Deep in the South Atlantic is estimated to cover an area of about 468,000 square miles, extending southwards from the equator to lat. $22^{\circ} \mathrm{S}$. on the western side of the MidAtlantic ridge. The greatest depth recorded in it is 4030 fathoms, just south of the equator. In the southern portion of the deep two low rises occur, where depths rather less than 3000 fathoms have been recorded.

Buchanan Deep.

Brooke Peep.

Moseley

Deep.

Bailey Deep.

Jeffirey Deep.

Belknap Deep.

Buchanan Deep lies to the east of the Mid-Atlantic ridge in the South Atlantic, between lat. $6^{\circ}$ and $22^{\circ}$ S., and covers an estimated area of 298,000 square miles. This deep appears to be somewhat flat-bottomed, because the numerous soundings recorded within it do not reach 3100 fathoms though exceeding 3000 fathoms, the maximum depth being 3063 fathoms.

Brooke Deep lies in the North-West Pacific between the latitudes of $12^{\circ}$ and $19^{\circ} \mathrm{N}$., and covers an area estimated at about 282,000 square miles. Its greatest depth is 3429 fathoms. Several elevations of the ocean-floor, rising to within I400, I IOO, and even IOOO fathoms of the surface, are situated close to the western and northern borders of this deep, separating it from the Challenger Deep on the west, and from the Bailey Deep on the north.

Moseley Deep lies in the North Atlantic to the east of the Mid-Atlantic ridge between lat. $9^{\circ}$ and $\mathrm{I} 8^{\circ} \mathrm{N}$., and is estimated to cover an area of about 279,000 square miles; the deepest sounding recorded within it is 3309 fathoms.

Bailey Deep lies in the North-West Pacific, between the Brooke and the Murray Deeps, on the Tropic of Cancer. It is estimated to cover an area of about 24I,000 square miles, and the deepest sounding recorded in it is 3432 fathoms.

Jeffrey Deep, in the eastern Indian Ocean, extends in a narrow band round the southern and western coasts of Australia, and as laid down on the map at present is estimated to cover an area of about 228 , 000 square miles. It is based on nine widely scattered soundings in the southern portion and four soundings closer together at the northern end, leaving a long stretch where no soundings have been taken. Further investigation may show that what is now regarded as one continuous deep is really two distinct deeps.

Belknap Deep lies in the Central Pacific, extending from about lat. I 2 to $\mathrm{I} 7^{\circ} \mathrm{N}$., and covering an area estimated at about 165,000 square miles. Near the centre of the deep a 
rise based on a sounding in 2600 fathoms occurs between two soundings in 3100 fathoms, and the floor of the deep sinks from this rise towards the east to the maximum depth of 3337 fathoms.

Chun Deep lies in the North Atlantic between lat. $20^{\circ}$ and Chun Deep. $29^{\circ} \mathrm{N}$., and is very peculiar in outline; it is estimated to cover an area of about I 59,000 square miles, and the greatest depth is 33 I 8 fathoms.

Challenger Deep lies to the east of the Ladrone Islands in Challenger the western Pacific, and extends from lat. I I to nearly $20^{\circ} \mathrm{N}$., covering an area estimated at about I 29,000 square miles. In I875 the "Challenger" recorded a depth of 4575 fathoms between Guam and the Pelew Islands, and in I 899 the United States steamer "Nero" took a sounding in 5269 fathoms to the south-west of Guam, which is the deepest sounding hitherto recorded. The 4000-fathoms area extends in a narrow trench as far to the north-east of the "Nero" sounding as the "Challenger" sounding is south-west of it, and a small isolated area occurs still farther north, based on a single sounding in 4204 fathoms. At a comparatively very short distance from this deep trench is a pronounced rise within the deep based on three soundings: one in I 800 fathoms and two in Iooo fathoms; another slight rise is based on a sounding in 2900 fathoms.

The remaining deeps are smaller, and need not be referred to in detail, their position being clearly shown on the accompanying map (Map II.). Attention may be drawn, however, to the great depth of the Planet Deep, situated in the tropical Pacific between the Solomon Islands and New Pommerania, in which a sounding in 4998 fathoms was recorded in 19 IO by the German survey ship "Planet" a short distance to the west of Bougainville Island.

\section{Deep-Sea Deposits}

The systematic investigation of deep-sea deposits was first First undertaken by Sir John Murray during the "Challenger" Ex- systemati pedition, and the only standard work dealing with the whole marine subject is Murray and Renard's "Challenger" Report on DeepSea Deposits, published in I89I. That Report was not based merely on the deposit-samples brought home by H.M.S. "Challenger," though the detailed descriptions were limited to those samples, but included the results of the examination of samples collected by many other ships, received at the 
"Challenger" Office from the British Admiralty and from many other British and foreign sources. Since the publication of the "Challenger" Report, deposit-samples collected by H.M. surveying ships and by British cable ships, as well as by many ships belonging to other nations, have been forwarded to the "Challenger" Laboratory for study, so that nearly all the samples of deposits procured from deep water over the ocean's floor have passed through our hands, and are available for the preparation of maps showing the distribution of the different types of deposits, and for the determination of the various constituents entering into the composition of deep-sea deposits.

Number of depositsamples examined.
Composition of marine deposits.
How extensive this material is may be surmised from the fact that nearly 1 2,000 deposit-samples have been examined in the "Challenger" Office. Some of these samples were very small, in a few cases insufficient even to indicate the type of deposit; but the great majority sufficed for the determination of the deposit-type, and of the percentage of calcium carbonate, while a very large number were available for detailed study and description. The samples have all been dealt with in a uniform manner, the methods of examination and description fully explained in the "Challenger" Report having been adopted throughout, for, notwithstanding the large amount of soundingwork carried on since that Report was published, the general results, the classification, and the nomenclature given therein have been fully substantiated and found quite adequate in every respect, no new types having been discovered.

In this place we are dealing only with deep-sea deposits, i.e. those occurring in depths greater than Ioo fathoms, the littoral and shallow-water deposits found in depths less than 100 fathoms being excluded. It may be stated, however, that these shallow-water and shore deposits near land are principally made up of relatively gross materials directly derived from the adjacent coasts, and from rivers pouring their waters and detritus into the ocean. Coral sands prevail near coral reefs, Volcanic sands off volcanic islands, and continental detritus near the embouchures of great rivers. All these materials become finer in texture with increasing distance from land, and in the greater depths of the ocean.

The constituents entering into the composition of deep-sea deposits may conveniently be divided into two classes: (A) those of organic origin, precipitated by organisms from the dissolved constituents of sea-water, and (B) those of inorganic 

origin, derived from (I) the decomposition of terrestrial and

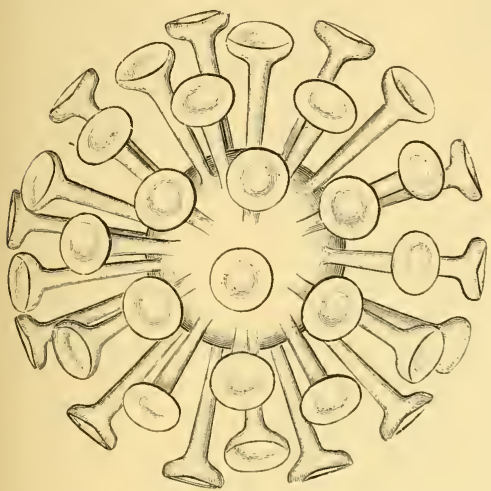

FIG, IOS.

Discosphara thomsoni, Ostenfeld. From the surface $\left(\frac{2000}{1}\right)$. submarine rocks, (2) extraterrestrial sources, (3) products synthesized at the bottom of the sea.

Organic remains belong- Materials of ing to the vegetable kingdom organic origin. are on the whole comparatively rare on the sea-floor, when compared with those belonging to the animal kingdom; still, in the neighbourhood of land, vegetable matter, branches of trees, Plant remains leaves, fruits, etc., may be in marine carried into deep water through the agency of large rivers, storms, off - shore winds, etc., along with the remains of sea-weeds growing in shallow water. Similarly in coral-reef regions, the remains of algæ which lived on the reefs, such as Lithothamnium and Corallina, occur in the deposits in the vicinity. But the most constant components of vegetable origin are the remains of algæ, which secreted either calcium carbonate or silica from the surface waters of the ocean to form their hard

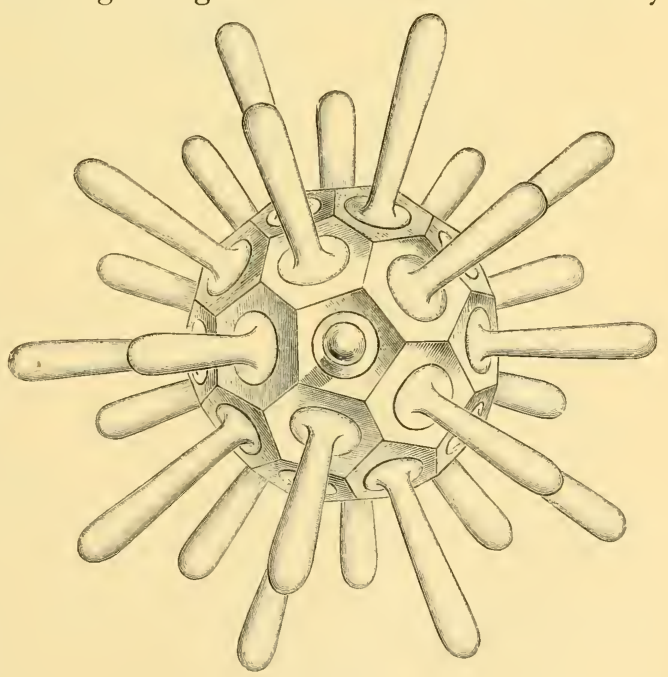

FIG. I09.

Rhabdosphera claviger, Murray and Blackman. From the surface $\left(\frac{2000}{1}\right)$. deposits.

parts, viz. the calcareous coccospheres and rhabdospheres (see 
Figs. I08 and I09) characteristic of tropical and sub-tropical regions, and the siliceous diatoms characteristic of extra-tropical regions. While the diatom remains are so abundant in the deposits of the Southern Ocean and of the North Pacific as to form a distinct deposit-type (Diatom ooze), the remains of the pelagic calcareous algæ are always overshadowed by the abundance of

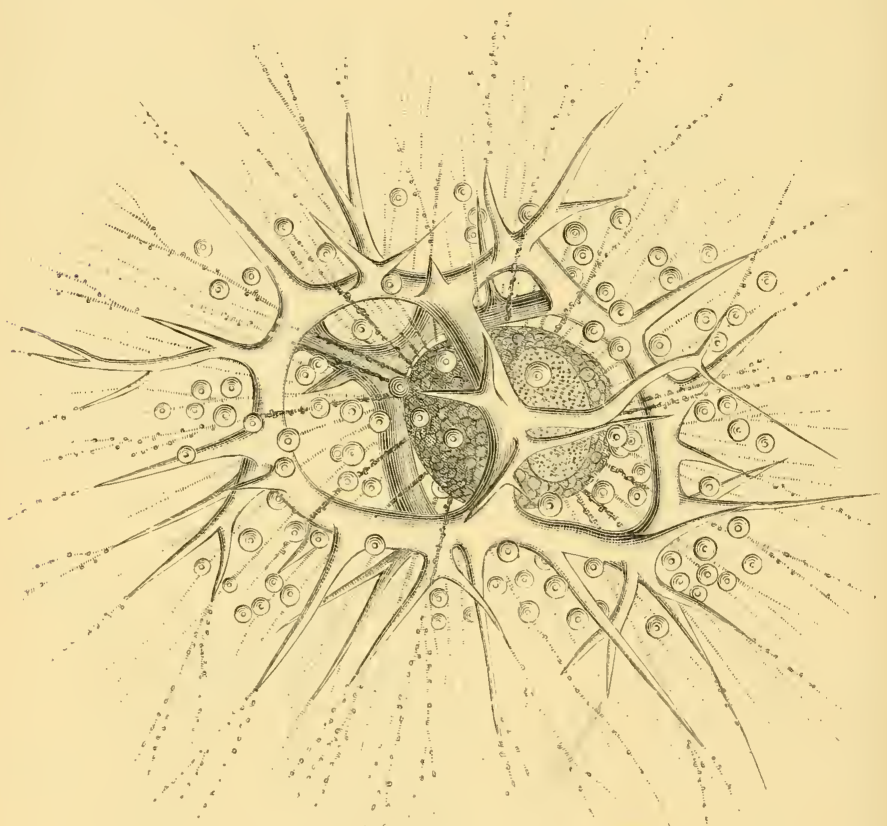

FIG. IIO.

Eucoronis challengeri, Haeckel. From the surface (magnified).

the remains of pelagic foraminifera and mollusca in the deposits of the warmer regions of the ocean. These pelagic calcareous algx are so fragile in texture, that it is principally their broken-down parts (coccoliths and rhabdoliths) that occur in the deposits; in certain favourable localities coccospheres of small size may be fairly numerous, but rhabdospheres are practically unknown in deep-sea deposits, being apparently easily dismembered, and the same remark seems to apply to the large-sized coccospheres. 
Traces of albuminoid organic matter may be found in most Albuminoid

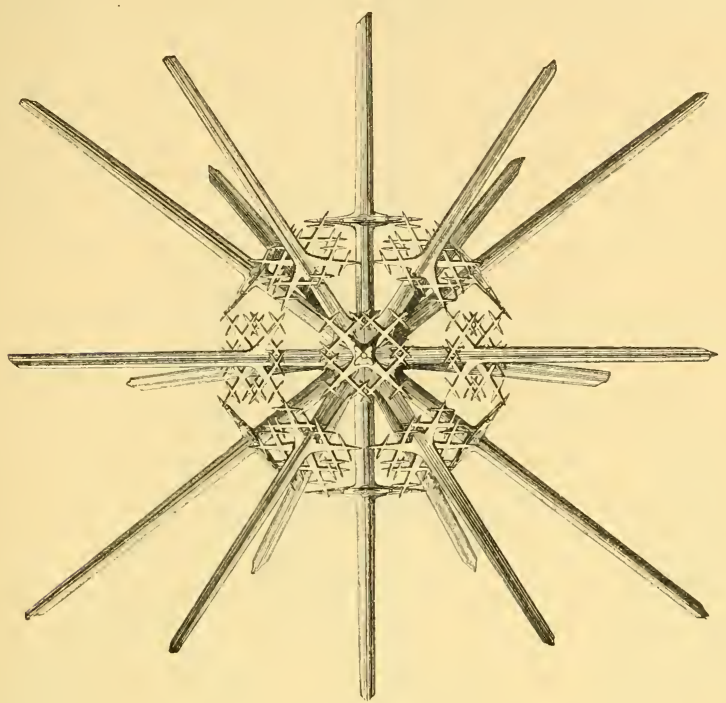

FIG. III.

Stauracantha murrayana, Haeckel. From the surface (magnified).

deep-sea deposits, especially in the neighbourhood of land, and

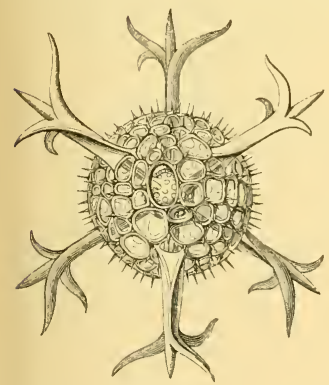

FIG. 112.

Hexancistra quadricuspis, Haeckel. From the surface (magnified).

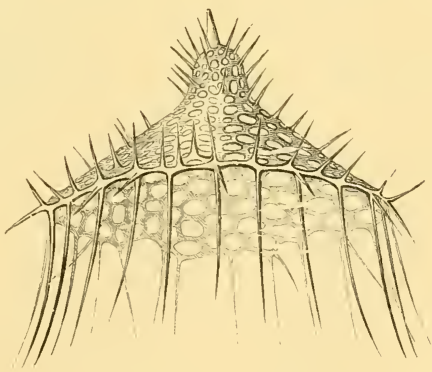

FIG. II3. Lampromitra huxleyi, Haeckel. From the surface (magnified).

may be either of animal or vegetable origin ; a greenish organic matter is generally associated with the glauconite in the Green 
sands. The benthonic deep-sea animals live by eating the mud or ooze covering the ocean-floor, and appear to find all the

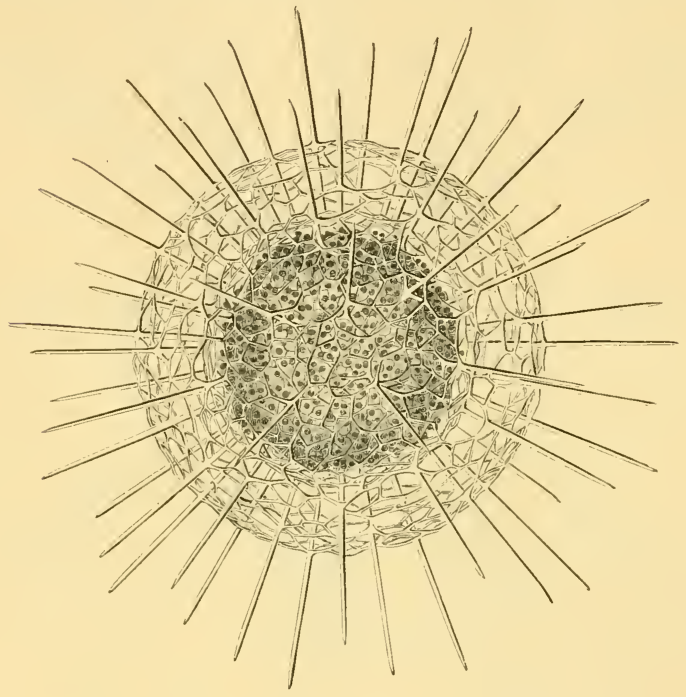

FIG. I 14.

Haliomma wyvillei, Haeckel. From the surface (magnified).

nourishment they require therein. The excreta of these animals are associated with a certain amount of slimy albuminoid matter, and in certain localities these excreta become so numerous that the term "coprolitic mud" has been proposed for the deposits containing them.

Animal remains in marine deposits.

Siliceous remains.
The animal remains found in deepsea deposits are either siliceous or calcareous, those of a chitinous character being extremely rare, if not entirely absent. The siliceous remains of radiolaria (see Figs. I Io to I I 7 ) and the spicules of siliceous sponges are widely distributed over the oceanfloor, the radiolarian skeletons being so abundant in certain regions as to make up a very large part of the deposit, which 
is then called Radiolarian ooze ; sponge spicules, though present in nearly every bottom-sample examined by us from deep and shallow water, very seldom take any considerable part in the formation of the deposits.

The calcareous remains of foraminifera, corals, alcyonaria, Calcareous annelids, crustacea, echinoderms, bryozoa, molluscs, tunicates, and fishes seem to bulk more largely in deep-sea deposits than the siliceous remains. The Globigerina and Pteropod oozes and

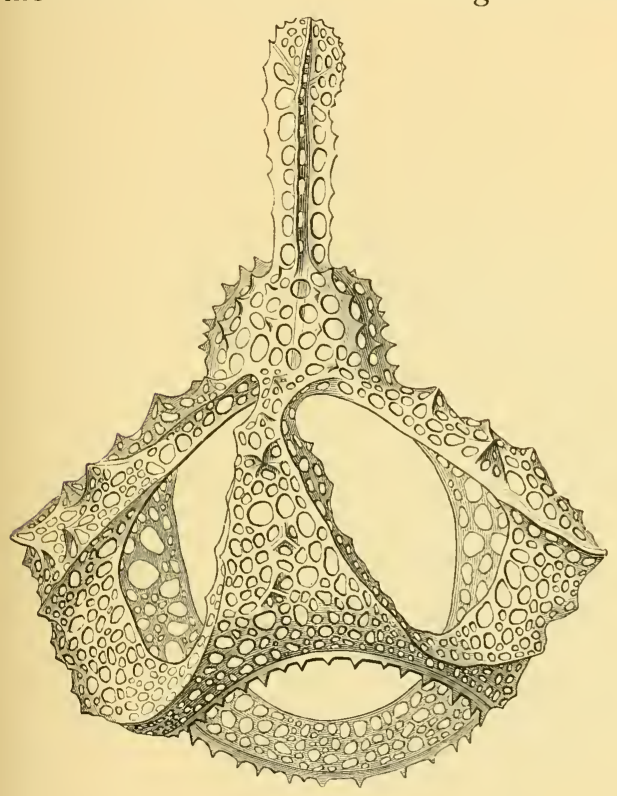

FiG, II6.

Clathrocanium regince, Haeckel. From the surface (magnified). the Coral muds and sands owe their names to the abundance in

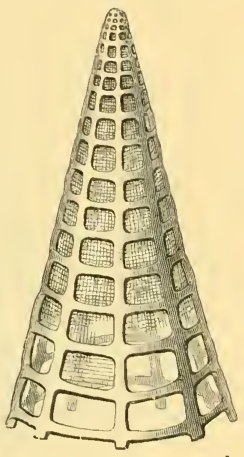

FIG. II7.

Cinclopyramis infundibulum, Haeckel. From the surface (magnified).

them of the remains of pelagic foraminifera (see Figs. I I 8 to I 2 I), of pelagic molluscs (Figs. I 22 and I 23), or of coral fragments, while the valves of ostracods (Figs. I 24 and I25), the spines of echinoids, the spicules of alcyonaria and tunicates, and the otoliths of fishes are among the most constant of the calcareous remains occurring in the deposits, though rarely found in any great abundance. Reference may also be made to the teeth of sharks (see Figs. I 26 and I 27) and the earbones of whales (see Figs. I 28 and I 29) found occasionally in all deposits, but characteristically in the Red clay areas especially of the 
Pacific Ocean, which have evidently lain there for a long period

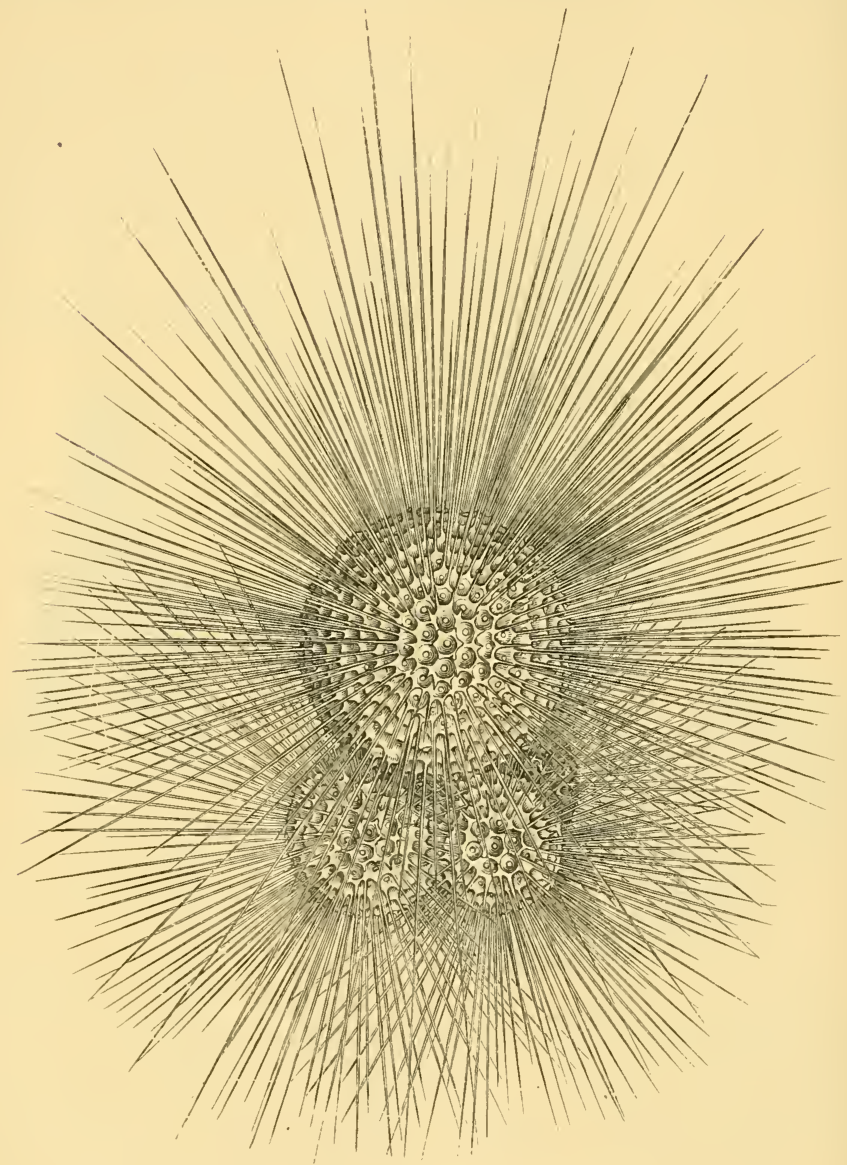

Fig. 118.

Globigerina bulloides, d'Orbigny. From the surface (magnified).

of time, having become much decomposed or deeply impregnated, and in many cases thickly coated, by the peroxides of manganese 
and iron. It is remarkable how very few fish bones other than teeth and otoliths occur in marine deposits.

The inorganic materials entering into the composition of Materials of deep-sea deposits may be conveniently considered under three $\begin{gathered}\text { inorganic } \\ \text { origin. }\end{gathered}$

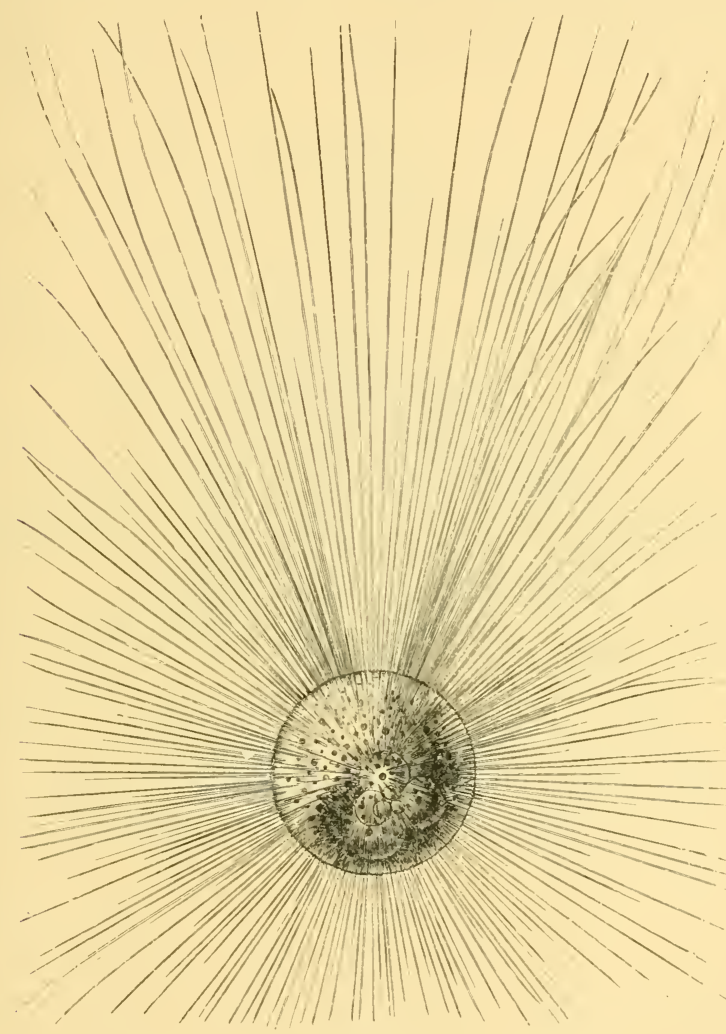

Fig. 119.

Orbulina universa, d'Orbigny. From the surface $\left(\frac{50}{1}\right)$.

heads: (I) terrestrial, (2) extra-terrestrial, and (3) secondary or chemical products.

The terrestrial materials are either of volcanic or continental Terrestrial origin, the former being derived from submarine and subaerial materials. eruptions, and, by reason of their areolar structure, widely 
CHAP.

distributed over the ocean-floor, the latter being derived from the disintegration of continental land through atmospheric and physical agencies and distributed in comparatively close proximity

Volcanic products.

to that land. Of volcanic products the most characteristic is pumice, which may float for a long time in the surface waters of

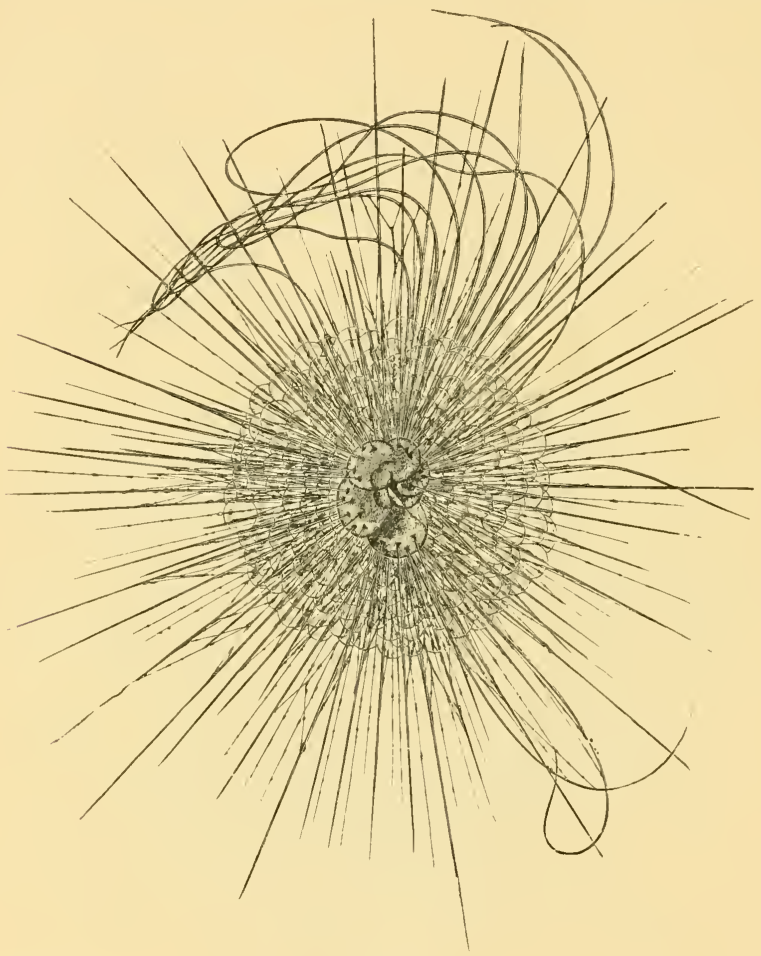

FIG. I 20.

Hastigerina pelagica, d'Orbigny. From the surface $\left(\begin{array}{c}10 \\ 1\end{array}\right)$.

the ocean and may be carried far from its original source before finally becoming water-logged and sinking to the bottom. While floating on the surface these stones are knocked against one another by the waves, and the broken-off fragments fall to the bottom. Three varieties of pumice have been recognised among the fragments from the sea-bottom: liparitic, basaltic 
or basic, and andesitic. After pumice, the most striking volcanic products are fragments of basic volcanic glass (sideromelan) nearly always partly, sometimes entirely, decomposed and altered into palagonite, together with palagonitic tufas, generally associated with the deposition of the peroxides of manganese and iron, besides basaltic and other lapilli and volcanic ashes. Great slabs have been dredged showing sometimes distinct

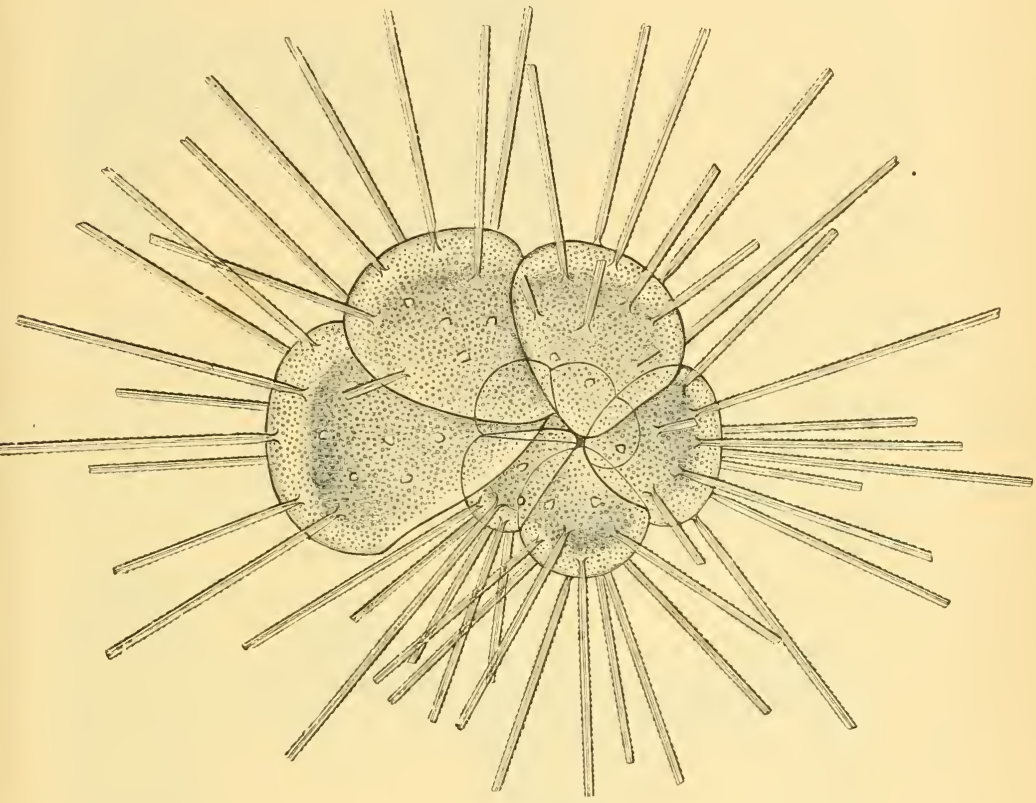

F1G. I21.

Hastigerina pelagica, d'Orbigny. From the surface $\left(\frac{50}{1}\right)$.

layers produced by showers of volcanic ashes. Minerals of volcanic origin (volcanic dusts) may be carried great distances by the winds, and ultimately find a resting-place on the bottom of the sea.

The continental products consist of fragments of continental Continental rocks and the minerals derived from their disintegration, the products. characteristic mineral species being quartz. The rock-fragments are usually found only in close proximity to the continental land-masses, though exceptionally found in deep water far from 
land in those regions of the ocean affected by floating icebergs. The dust from deserts, like volcanic dusts, may be carried by wind to great distances from land, and can be detected in deepsea deposits, for instance, off the west coast of Africa.

Extraterrestrial materials.

Cosmic spherules.

The materials of extra-terrestrial origin, though extremely interesting, do not bulk largely in marine deposits ; indeed they are rather of the nature of rarities, and are noticed most abundantly in Red clay areas where, for many reasons, it is believed the rate of deposition is

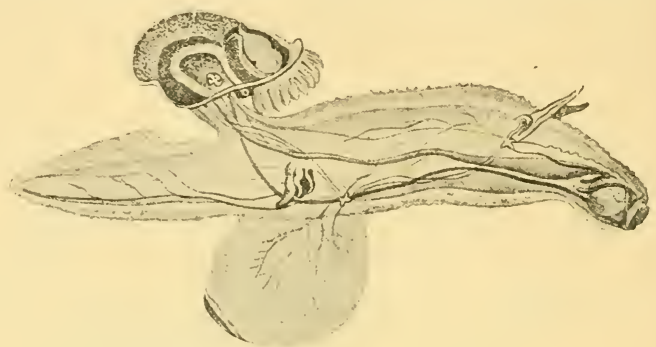

FIG. I 22.

Carinaria lamarkii, Pèr. and Les. (From Steuer.) The fragile shells of this species are occasionally met with in deep-sea deposits. at a minimum.

They consist of minute black metallic spherules and brown chondritic spherules, which may be extracted by the aid of a magnet when the Red clay deposit is reduced to a fluid condition by admixture of water. The black spherules (see Figs. I 30 and I3I) sometimes have a shining metallic

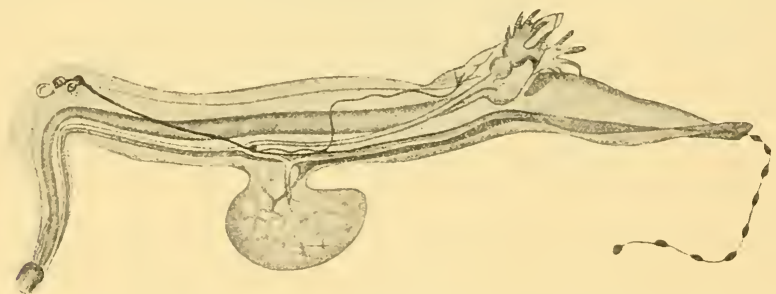

FIG. 123.

Pterotrachea coronata, Forsk. (From Leuckart, after Steuer.) This species has no shell, and therefore does not enter into the composition of deep-sea deposits.

nucleus of native iron (or an alloy of iron, cobalt, and nickel), surrounded by a shell of brilliant magnetic oxide of iron, to which the magnetic properties of the spherules are due. The brown spherules (see Figs. I 32 and I33) have the lustre of bronze externally, and have a finely lamellated crystalline structure, with blackish-brown inclusions of magnetic iron, which account for their extraction by the magnet. A cosmic 
origin is attributed to both forms of magnetic spherules, which are supposed to have been thrown off by meteorites, or falling stars, in their passage through our atmosphere.

The secondary products entering into the composition of Secondary deep-sea deposits are (I) clay, (2) manganese nodules, (3) barium products.
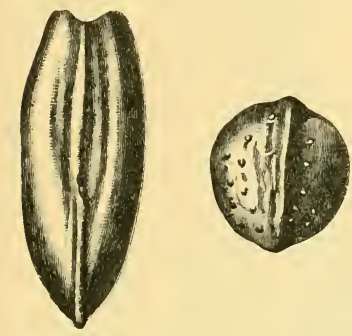

FIG. I24.

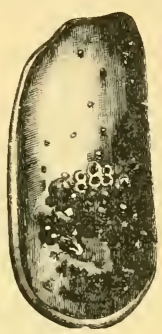

and barium nodules, (4) glauconite, (5) phosphatic concretions, and (6) zeolites.

The clayey matter in Clay.

the deposits near land may have been transported by rivers, etc., from the land, but most of the clayey matter present in the deposits far from land is believed to have been derived from (magnified).

Krithe producta, Brady. From the bottom-deposits

the decomposition under the action of water of eruptive and metamorphic rocks and minerals, especially pumice and volcanic glass. The deep-sea clays, some of which are mostly made up of these decomposing volcanic materials, are usually coloured a reddish-brown by the oxides of manganese and iron-
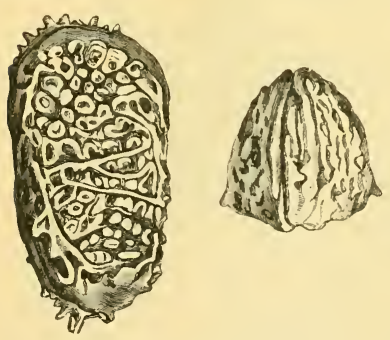

FIG. I25.

Cythere dictyon, Brady. From the bottom-deposits (magnified). products of the decomposition of the same rocks that gave rise to the clayey matter-and a comparatively small amount of clay may give a clayey character to the deposit.

The oxides of iron Manganese and manganese are nodules. widely distributed in marine deposits, and especially in deep-sea deposits. They occur in minute grains, and act as colouring matter in nearly all deep-sea clays, and in certain abyssal regions of the ocean they form concretions of larger or smaller size, which are among the most striking characteristics of the oceanic Red clay. Sometimes the oxides cover consolidated masses of tufa, fragments of rocks, portions of the deposit, branches of coral and other 
calcareous remains, or form irregular concretionary masses, though the commonest form is that of more or less rounded nodules (see Figs. I 34 and I 35), which at any one station have a general family resemblance and differ in form and size from those taken at another station, looking like marbles at one place, like potatoes or like cricket balls at other places. Generally the nodules are concretions formed around a nucleus, con-

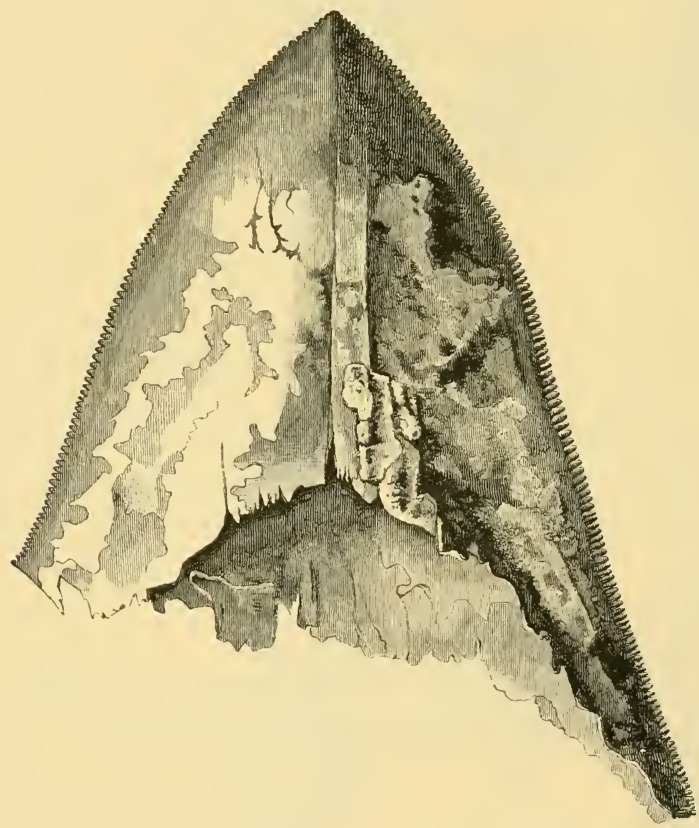

Fig. I26.-TOOTH OF CARCHARODON MEGALODON.

"Challenger" Station 28I, South Pacific, 2385 fathoms.

sisting of a shark's tooth or whale's earbone, or portions of teeth or bone, a piece of pumice or fragment of volcanic glass, etc., though sometimes no nucleus could be detected. These nodules of iron and manganese are classed with the impure variety of manganese known as wad or bog manganese ore, and the greater part of the manganese and iron is believed to have been derived directly, along with clay, from the alteration of the rockfragments and mineral particles containing manganese and iron, especially of those of volcanic origin, which are spread over the 
ocean-floor. Where basic volcanic rocks are in process of decomposition, manganese nodules may be relatively abundant

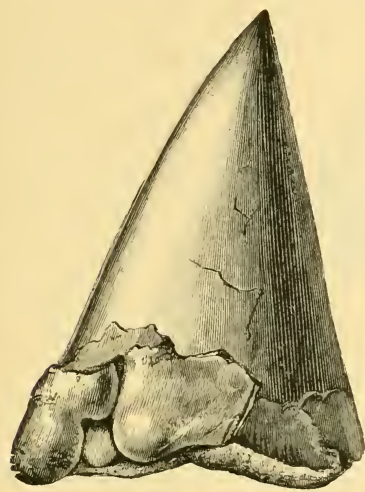

FIG. 127.-TOOTH OF OXYRHINA TRIGODON.

"Challenger" Station 276, Tropical Pacific, $235^{\circ}$ fathoms. in shallow water, and they are never numerous in Globigerina oozes, except where volcanic material is present in some abundance in the deposit.

Sulphate of barium has been Barium. found to be present in most marine deposits and in manganese nodules in small quantities; in terrigenous deposits up to about o. I per cent, in manganese nodules slightly more, and in Red clays up to about I per cent. Small round nodules have been trawled off Colombo, in 675 fathoms, containing 75 per cent of barium sulphate.

Glauconite occurs in the terri-Glauconite. genous deposits typically in the form of minute rounded grains of a greenish colour, usually associated with greenish or brownish casts of calcareous organisms (foraminifera, etc.); in fact, the rounded

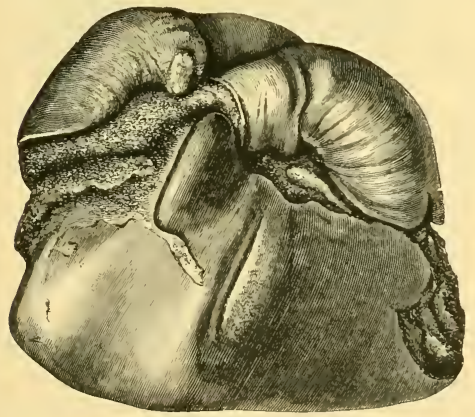

Fig. I28. - Petrous ANd Tympanic Bone OF ZIPHIUS CAVIROSTRIS.

"Challenger" Station 286, South Pacific, 2335 fathoms.

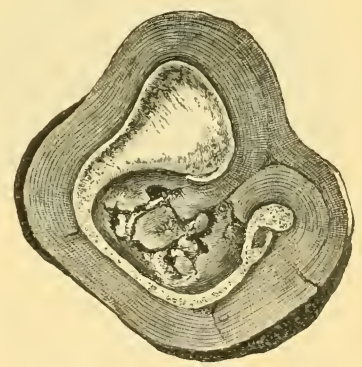

Fig. 129.-Section of a MaNgaNESE NODUle, SHOWING a TYMPANIC BONE OF MESOPLODON IN THE CENTRF.

"Challenger" Station I6o, Southern Ocean, 2600 fathoms.

green grains are supposed to be casts which have lost all trace of the enveloping calcareous chambers. The individual grains of glauconite do not exceed one millimetre in diameter; though 
occasionally they are cemented into nodules, several centimetres in diameter, by a phosphatic substance; the grains are always rounded, often mammillated, hard, dark green, or nearly black, with sometimes a dull and sometimes a shining surface. Mixed

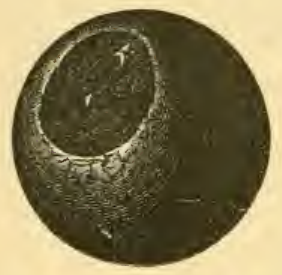

Fig. I30.-BLACK Spherule with Metallic Nucleus $\left(\frac{60}{1}\right)$.

"Challenger" Station 285 , South Pacific, 2375 fathoms.

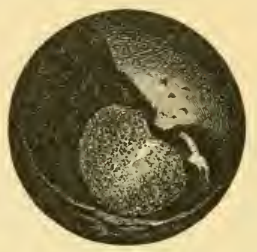

FIG. I3I.-BLACK SIHERULE with Metallic Nucleus $\left(\frac{60}{1}\right)$.

"Challenger" Station 9, North Atlantic, 3150 fathoms. with the rounded grains are pale green, pale grey, white, yellow and brownish internal casts of the cavities and chambers of calcareous organisms, often associated with an amorphous organic matter of a brownish-green colour. Glauconite is principally developed in the interior of foraminiferous shells and other calcareous structures, the initial stages in the formation of glauconite being probably due to the presence of organic matter in the interior of these shells. Glauconite is

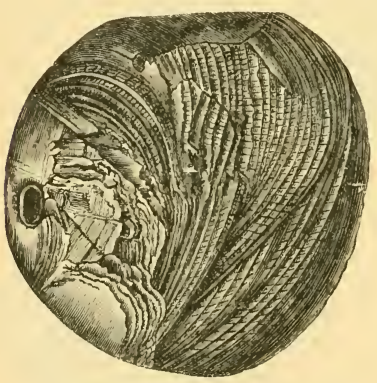

Fig. I32.-SPHERULE OF BRONZITE $\left(\begin{array}{c}2.5 \\ 1\end{array}\right)$.

"Challenger" Station $33^{8}$, South Atlantic, I 990 fathoms.

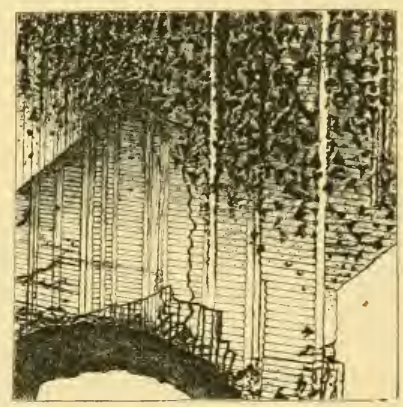

Fig. I33.-A LAMElla OF A SPHerule OF Bronzite (highly magnified).

"Challenger" Station 338, South Atlantic, I990 fathoms.

always associated with terrigenous mineral particles and rockfragments, the decomposition of which, under the action of seawater, would yield the chemical elements subsequently deposited in the form of glauconite in the chambers of foraminifera and other calcareous organisms. The excreta of echinoderms appear sometimes to be converted into glauconite. 
Associated with the glauconite in certain localities, more Phosphatic especially off the Cape of Good Hope and off the Atlantic coast concretions. of the United States, irregular concretions, largely made up of phosphate of lime, have been dredged. The concretions vary greatly in size and form, with a greenish or brownish glazed external surface, and are made up of heterogeneous fragments derived from the deposit containing the concretions (grains of glauconite and other minerals or remains of organisms), cemented by phosphatic material, which constitutes the principal part of the concretions. When the cemented particles are purely mineral, the phosphatic matter acts simply as a cement, but when the remains of calcareous organisms are included in the concretions, the phosphatic material plays a more important part, filling the internal chambers, and often the calcium carbonate of the shell is pseudomorphosed into calcium phosphate. When the filling up of a foraminifer, for example, and the pseudomorphism of its shell, are complete, the phosphate, attracted around this little centre continues to be added at the surface, and thus a phosphatic granule is formed, the external appearance of which no longer recalls that of the organism around which the phosphate has grouped itself. These phosphatic concretions occur chiefly along coasts bathed by waters subject at times to great and rapid changes of temperature, which cause the destruction on a

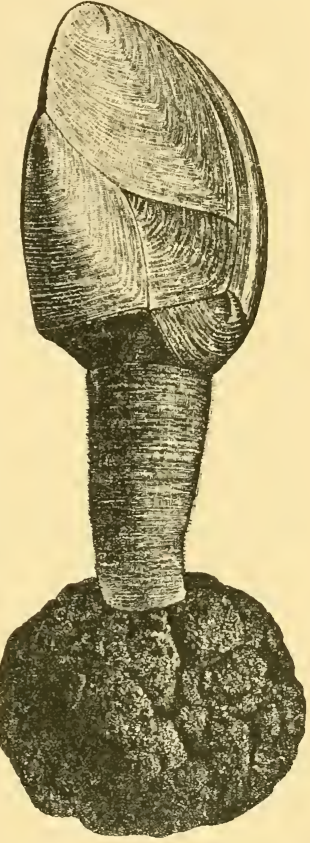

Fig. I34. - MaNgaNese Nodule WITH SCALPELLUM DARWINII GROWING ON IT.

" Challenger" Station 299, South Pacific, 2I60 fathoms. large scale of marine life, the decomposition of the organic remains, sometimes thickly covering the sea-floor in such localities, giving rise to the phosphate of lime to be permanently fixed in the phosphatic nodules.

Just as the silicate glauconite occurs in the terrigenous Phillipsite. deposits, and is supposed to be a secondary product derived from the decomposition of continental rock fragments, so the 
silicate phillipsite occurs in the pelagic deposits, and is supposed to be a secondary product derived from the decomposition of volcanic rock fragments. Phillipsite is found in the various kinds of deposits in the deep water of the Central Pacific and Central Indian Ocean far from land, and is most abundant in some Red clay areas. It occurs in crystalline form, either as simple isolated microliths, crossed twins, irregular groups, or aggregated into spherolithic groups in which these zeolitic crystals are entangled together so as to form crystalline globules of sufficient size to be distinguished by the naked eye. The distribution of these crystals of phillipsite coincides with that of basic volcanic glasses and basaltic lapilli over the ocean-floor, the decomposition of which, under the action of sea-water, would give rise to the materials afterwards deposited in a free state as zeolitic crystals and aggregates.

Professor Joly has examined for their radium contents a number of deposit-samples supplied by Sir John Murray. He finds that the deep-sea deposits are much richer in radium than the average terrestrial rocks. The Red clays and the Radiolarian oozes, which are laid down in deep water far from land, contain much more radium

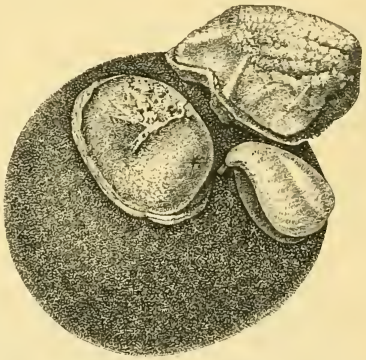

Fig. 135.-MAnganese Nodule With TWO TUNICATES AND A BRACHIOPOD ATTACHED.

"Challenger" Station I60, Southern Ocean, 2600 fathoms.

than the calcareous deposits like the Pteropod and Globigerina oozes. The radio-activity and percentage of calcium carbonate in the deposits stand in an inverse ratio to each other, and the Blue muds contain less than the calcareous oozes, though more than the continental rocks. It seems evident that the quantity of radio-active substances, of manganese nodules, with earbones of whales and sharks' teeth, of zeolitic crystals and cosmic spherules, is greatest where, for other reasons, we believe the rate of deposition to be least.

Deep-sea deposit types.
In the neighbourhood of emerged land the material derived from that land is spread over the sea-floor, becoming finer and finer in texture with greater distance and depth, whereas in the central regions of the great ocean basins land-detritus may be almost totally absent from the deposits, while the calcareous 
and siliceous shells and skeletons of pelagic or plankton organisms may greatly predominate. This fact affords a ready Classification. means of dividing marine deposits into two main classes, viz. Terrigenous Deposits, largely made up of detritus derived directly from emerged land, with the remains of benthonic organisms, and Pelagic Deposits, containing little if any landdetritus, but largely made up of the remains of pelagic organisms. The former class of deposits must therefore form a border, varying in extent according to circumstances, around all the land-masses and islands of the world, while the latter class of deposits occurs in those regions so far removed from the landmasses and islands that very little material derived directly from the land can reach the position where they are found. The dividing lines between these two classes of deposits, and between the various types included in them, are not sharply defined, but the different kinds of deposits merge gradually the one into the other, so that frequently two names, and in some cases even three names, might equally well be applied to the same sample. It is the terrigenous deposits laid down in close proximity to the land, and in enclosed seas like the Mediterranean, that are represented in the geological series of rocks, but it is extremely doubtful whether the pelagic deposits laid down in deep water far from land have any analogues among the geological strata.

After a careful study of all the available samples, Murray and Renard gave the following classification of marine deposits :-

MARINe Deposits

$\left.\begin{array}{l}\text { Red clay } \\ \text { Radiolarian ooze } \\ \text { Diatom ooze } \\ \text { Globigerina ooze } \\ \text { Pteropod ooze }\end{array}\right\}$

1. Deep-Sea Deposits, beyond roo fathoms.

$$
\begin{aligned}
& \text { Blue mud } \\
& \text { Red mud } \\
& \text { Green mud } \\
& \text { Volcanic mud } \\
& \text { Coral mud }
\end{aligned}
$$

2. Shallow-Water Deposits, between low water mark Sands, gravels, and $\mathrm{r} 00$ fathoms. muds, etc.
I. Pelagic Deposits formed in deep water removed from land.
II. Terrigenous Deposits, formed in deep and shallow water close to land-masses.

3. Littoral Deposits, between $\left.\left.\begin{array}{l}\text { high and low water } \\ \text { marks. }\end{array}\right\} \begin{array}{c}\text { Sands, gravels, } \\ \text { muds, etc. }\end{array}\right\}$ 
Terrigenous deposits.

Blue mud.

Green mud and sand.

Red mud.

Volcanic mud and sand.

Coral mud and sand.

Pelagic deposits.

The Terrigenous Deposits are characterised, as already stated, by the abundance of land-detritus, and are subdivided into the following types, viz. :-

Blue Mud.-This is the predominant type of deposit in the neighbourhood of continental land, and is principally made up of land-detritus (quartz being the characteristic mineral species), which becomes less and less abundant with increasing distance from the land, until the Blue mud passes gradually into one of the types of pelagic deposits.

Green Mud is a variety of Blue mud, distinguished by the abundance of grains of glauconite usually associated with phosphatic concretions, and is found most characteristically on the continental slopes off high and bold coasts where currents from different sources alternate with the season, as off the Cape of Good Hope, off the east coast of Australia, off Japan, and off the Atlantic coasts of the United States. In the lesser depths the amount of clayey and muddy matter decreases and the deposits are called Green Sands.

Red Mud is a local variety of Blue mud found in the Yellow Sea and off the coast of Brazil, where the great rivers bring down a large amount of ochreous matter, to which the deposit owes its colour and its name.

Volcanic Mud occurs off those coasts and islands where volcanic rocks prevail ; the volcanic mineral particles are larger and more abundant in the shallower water near the land, and the deposits there are called Volcanic Sands.

Coral Mud is found in the vicinity of coral reefs and islands ; fragments derived from the disintegration of the reefs are larger and intermixed with less fine material in the lesser depths, and the deposits are then called Coral Sands.

The Pelagic Deposits are characterised by the fact that, with the exception of Red clay, their composition is largely determined by the pelagic or plankton organisms, which secrete hard shells either of calcium carbonate or of silica, the predominance of the remains of one or other of these classes of organisms giving the names to the deposits. In fact, the deposits may be divided into those that are calcareous and those that are siliceous, the calcareous deposits (Globigerina ooze and Pteropod ooze) being characteristic of tropical and subtropical regions, where there is abundant secretion of calcium carbonate by plankton organisms, the siliceous deposits (Diatom ooze and Radiolarian ooze) being characteristic of polar and other regions, where there is a large admixture of clayey matter 
iv DEPTHS AND DEPOSITS OF THE OCEAN I63 in the surface waters, and where there is abundant secretion of

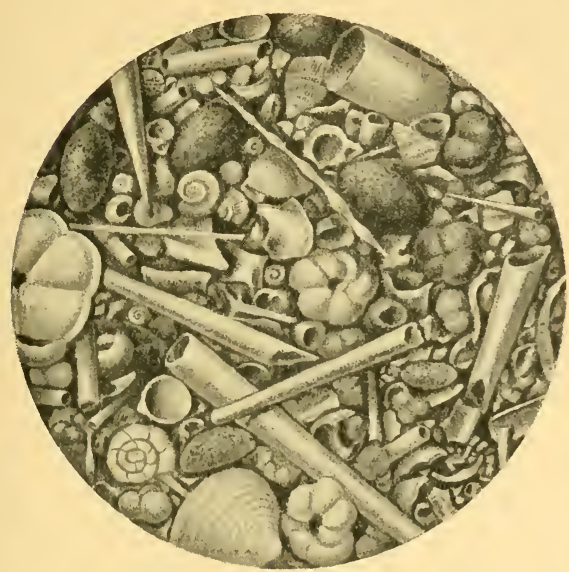

Fig, 136.-PTEROPOD OOZE.

"Valdivia" Station 208, Indian Ocean, lat. $6^{\circ} 54^{\prime} \mathrm{N}$., long. $93^{\circ} 28^{\prime} .8$ E., 162 fathonis (magnified). silica by the plankton organisms, Over wide areas invery deep water, however, neither calcareous nor siliceous remains predominate; the basis of the deposit then becomes Red clay, consisting of clayey matter derived from the decomposition of volcanic materials; quartz particles, so abundant in terrigenous deposits, are rare or absent.

The pelagic deposits are subdivided into the following types, viz. :-

Pteropod Ooze. - In Pteropod ooze. the shallower waters, usually far from continental land, on oceanic ridges and cones, especially within coral reef regions where warm water with small annual range occupies the surface, almost every surface organism which secretes a hard shell or skeleton is represented in the deposit, the dead shells of pteropods and heteropods being characteristic, and the deposit is hence called Pteropod ooze (see Fig. 136). About 35 species of pteropods and 32 species of heteropods, as well as pelagic gasteropods (see pp. I72-

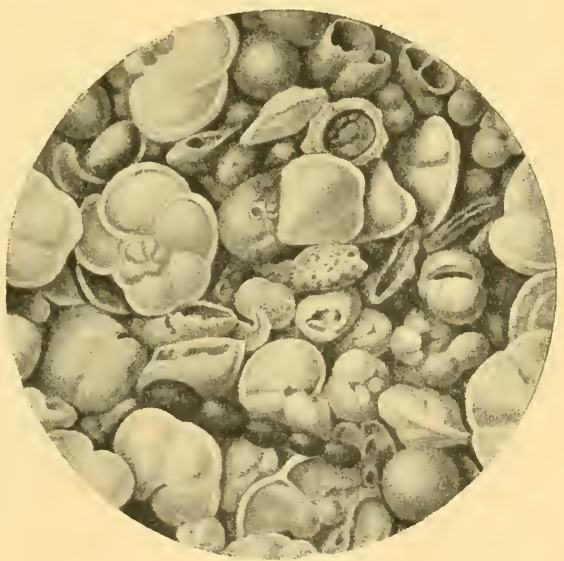

F19. 137-Globigerina OOZe. "Valdivia" Station 45 , Atlantic, lat. $2^{\circ} 5^{6} .4 \mathrm{~N}$., long. II $^{\circ} 40^{\prime} .5$ W., 2728 fathoms (magnified).

I73), are known to live in the surface waters of the tropics, and 
the shells of all these species may occur in the Pteropod ooze, but the extent of this type of deposit is not great. Shelled pteropods, except Limacina, are not found in the polar oceans.

Globigerina ooze.
Globigerina Ooze.The average depth of the ocean is about 2000 fathoms, and the most widely distributed of the deposits in these average depths is Globigerina ooze (see Figs. I 37 to I39), which is made up largeiy of the dead shells of surface foraminifera, the genus Globigerina often greatly predominating, hence the name. About twenty species of pelagic foraminifera (see p. I 72 ) inhabit the surface waters of the tropical oceans, and their dead shells are found in the Globigerina ooze ${ }^{1}$ and also in the Pteropod ooze, but towards the Arctic and Antarctic regions only one or two dwarfed species occur in the surface and subsurface waters. In very deep water, even within the tropics, the calcareous shells do not accumulate on the bottom,

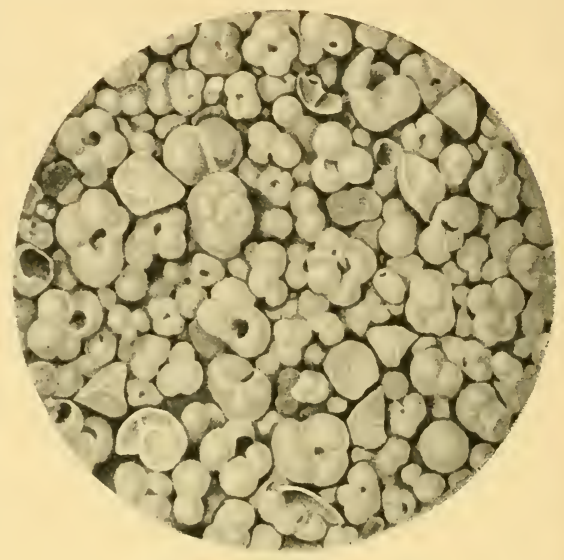

FIG. I38.-Globigerina OOZE.

"Valdivia " Station 162 , Southern Ocean, lat. $43^{\circ} 44^{\prime} \cdot 4 \mathrm{~S}$. long. $75^{\circ} 33^{\prime} .7$ E., 1878 fathoms (magnified).

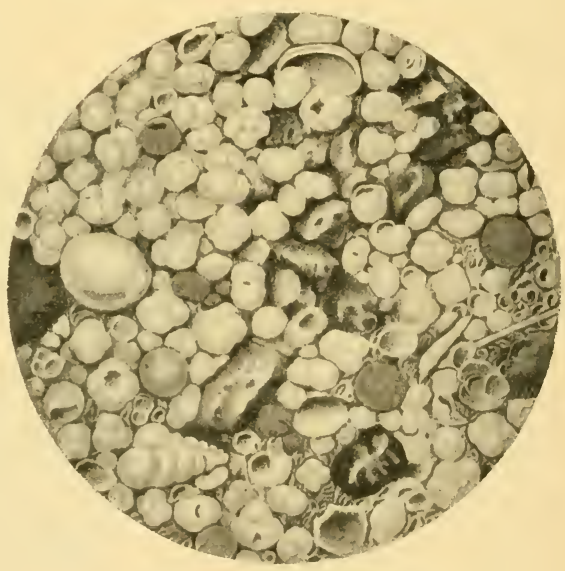

Fig. 139.-GLobigerisa OOZE.

"Valdivia "Station $15+$, Southern Ocean, lat. $6 \mathrm{I}^{\circ} 45^{\prime} .2 \mathrm{~S}$, long. $6 \mathrm{I}^{\circ} 15^{\prime} .9 \mathrm{E}$., 1940 fathoms (magnified).

1 The names "Biloculina ciay" and "Orbulina ooze" will be found in the literature of marine deposits, but these have been described from samples which had been passed through fine sieves, the larger shells having been retained while the smaller ones had passed through the meshes. 
iv DEPTHS AND DEPOSITS OF THE OCEAN I65 being apparently removed through the solvent action of seawater, and with increasing depth the Globigerina ooze passes gradually into another pelagic type, usually Red clay.

Diatom Ooze. - We Diatom ooze. have indicated that in the colder regions of the ocean, as in the great circumpolar Southern Ocean and along the northern border of the Pacific, diatoms flourish abundantly in the surface waters, and where detrital matters are not

Fig, 140.-Diatom OOZE.

"Valdivia " Station I 40 , Southern Ocean, lat. $54^{\circ} 2^{\prime} \mathrm{S}$. long. $22^{\circ} \mathrm{r}^{\prime} .2 \mathrm{E},{ }^{\prime} 2207$ fathoms (magnified).

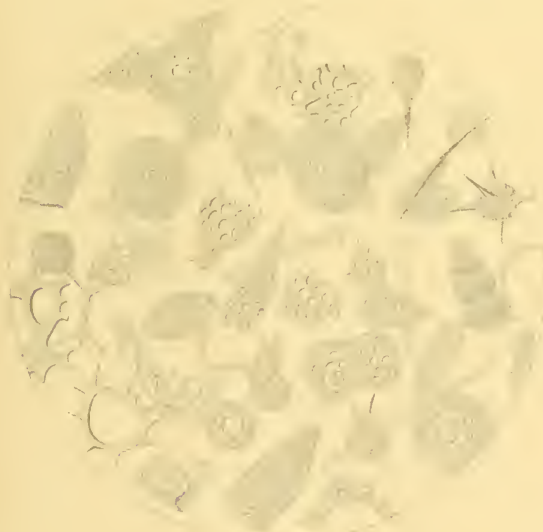

Fig, ifi. - Radiolariax OOze.

- Valdivia "Station 237, Indian Ocean, lat. $4+5^{\prime} \mathrm{S}$. long. $+8^{\circ} 58^{\prime} .6$ E., 2772 fathoms (magnified). very large in amount their dead frustules, falling to the bottom, make up a large part of the deposit called Diatom ooze (see Fig. I 40). ${ }^{1}$

Radiolarian Ooze Radiolarian (see Fig. I4I) has not been recorded from the Atlantic Ocean, but is characteristic of deep water in the tropical regions of the Pacific and Indian Oceans, where the surface waters have rather a low salinity and carry clayey matter in suspension. It may be regarded as a variety of Red clay containing

1 It may be noted that Flint has recorded Diatom ooze from the tropical Pacific, but his samples have since been examined and classed by us as Radiolarian ooze. 
many radiolarian skeletons. The frustules of diatoms and skeletons of radiolarians may occur in all deposits, but generally they do not become characteristic or predominant when calcareous shells are present in large numbers.

Red clay.

Red Clay is characteristic of great depths, say beyond 2700 fathoms (as Globigerina ooze is characteristic of moderate depths, between 1000 and 2500 fathoms), and is the most widely distributed of all the deep-sea deposits, covering a larger area of the sea-floor than any other deposit type. The basis of the deposit is the hydrated silicate of alumina, or clay, derived principally from the decomposition and disintegration of pumice and other volcanic products long exposed to the action of seawater, often associated with secondary products derived from the same source, such as manganese-iron nodules and phillipsite crystals. Calcareous remains may be totally absent in the greatest depths, while in lesser depths the percentage of calcium carbonate may approach 30 , and the deposit then passes gradually into Globigerina ooze. If the calcium carbonate in a Globigerina ooze or a Pteropod ooze be removed by weak acid, the residue resembles closely a Red clay. In other places the siliceous remains of radiolaria may increase to such an extent that the Red clay merges gradually into Radiolarian ooze. The rate of accumulation is evidently at a minimum in the Red clay areas, for the calcareous shells falling from the surface waters have been gradually removed in solution either before, or immediately after, reaching the bottom ; the ear-bones of whales and teeth of sharks (some of them belonging to extinct species) are there found in the greatest profusion, impregnated with and coated by the peroxides of manganese and iron; and there also occur in greatest abundance (though always rare) minute metallic and chondritic spherules supposed to have fallen from interstellar space, and found there more abundantly simply because of the sparse deposition of other materials. Radioactive substances are also found more abundantly in Red clay than in any other marine deposit, or in any continental rocks.

A few facts relating to the horizontal distribution of marine

deposits may now be indicated. The terrigenous deposits include a number of varieties, but as a whole they surround all continents and islands in all latitudes, and extend to varying distances from the shore. The Coral muds and sands included in this class are limited to the coral-reef regions of tropical and subtropical latitudes, and the presence of the calcareous shells 
of pteropods and heteropods and pelagic foraminifera in terrigenous deposits indicates approximately temperate or tropical latitudes; in the Arctic and Antarctic regions these shells are absent from the deposits. Green muds and sands appear to be limited to regions where there is a wide range of temperature in the surface waters of the ocean, while Red muds are limited to those localities where a large amount of ochreous matter is carried into the sea by rivers, and Volcanic muds and sands are limited to the neighbourhood of volcanic centres, both subaerial and submarine. But the most widely distributed of all the terrigenous types is Blue mud, which occurs in both the Arctic and Antarctic regions, and along the shores of continents and continental islands throughout the world, where not displaced by one or other of the varieties just mentioned.

Broadly speaking, the terrigenous deposits close to land in shallow water contain more and larger mineral fragments than those farther removed from the land and in deeper water. Where great rivers enter the sea the terrigenous deposits may extend very far seaward, and a Blue mud may occupy the whole of the continental slope, extending perhaps some distance out over the deep bed of the ocean. On the other hand, along high and steep coasts oceanic conditions may approach close to the shore, and a Blue mud may pass into a Green mud or into a Pteropod ooze, and finally into a Globigerina ooze along the continental slope.

Turning to the pelagic deposits, we find that Pteropod ooze is limited to the tropical and subtropical regions, usually in the neighbourhood of oceanic islands and on the summits and sides of submarine elevations; it is found in relatively shallow water, and covers a relatively small extent of the ocean-floor.

Globigerina ooze is much more widely distributed; in fact, it covers an area of the entire sea-floor second only to that occupied by Red clay, extending as far north as lat. $72^{\circ} \mathrm{N}$. in the Norwegian Sea and as far south as lat. $60^{\circ}$ S. in the South Atlantic. A Globigerina ooze from a tropical locality differs greatly from one taken towards the polar regions, for the tropical sample may contain the representatives of more than twenty species of pelagic foraminifera as well as many species of pelagic molluscs, whereas the polar sample would include only one or two species of pelagic foraminifera and no pelagic molluscs. Globigerina ooze is the predominant type of deposit in the North Atlantic, covering all the deeper parts of that ocean except for two areas of Red clay, and it is there found 
in much deeper water than in any other of the great ocean basins.

Diatom ooze occurs typically only in extra-tropical regions, forming a broad almost circumpolar band in the great Southern Ocean, outside the zone of Blue mud bordering the Antarctic continent, and a smaller band along the extreme northern border of the Pacific Ocean, along the Alaskan and British Columbian coasts of North America, and the Kamtchatkan and Japanese coasts of Asia and the intervening Aleutian Islands.

Radiolarian ooze covers the sea-floor in certain portions of the tropical regions of the Pacific and Indian Oceans, being apparently entirely unrepresented in the Atlantic; it occurs in a band of varying width in the equatorial eastern Pacific, approaching comparatively close to the shores of Central America, and in other smaller isolated areas.

Red clay is the most characteristic and most extensive of the pelagic deposits, occupying the deepest portions of the great ocean basins except in the polar regions, extending beyond lat. $50^{\circ} \mathrm{N}$. and S. in the Pacific, and between lat. $40^{\circ} \mathrm{N}$. and S. in the Atlantic. It is the typical deposit of the great Pacific Ocean, attaining there its maximum development, and being associated over wide areas with the characteristic manganese nodules; in the Indian Ocean it is also associated with much manganese, and therefore usually of a dark chocolate colour, while in the Atlantic it is generally intermixed with less manganese and usually of a light red-brown colour.

Vertical distribution.

As regards the vertical distribution of the deposits, we have already indicated how gradual is the transition between the various types and classes, so that frequently two or more names might be used to characterise samples from the border regions. It is therefore evident that no definite limits of depth can be assigned to the different types of deposits, but their general distribution may be broadly outlined.

The terrigenous deposits have for their upper limit the shore-line, while their lower limit varies according to local conditions. We have already pointed out that in certain localities Blue mud may be restricted to the continental slope within depths less than Iooo fathoms, while in other localities it may extend far into the abysmal area in depths exceeding 2000 fathoms, and in some places approaching 3000 fathoms. Coral mud may extend into depths approaching 2000 fathoms before passing gradually into a Globigerina ooze, but sometimes it merges into Pteropod ooze in depths less than Iooo fathoms, 
while in the lagoons of coral islands it may be found in a few feet of water. Volcanic mud may be found extending into very deep water-in fact, some of the deepest Red clays might be called Volcanic muds, so abundant are the minute fragments of pumice and volcanic glass - but in the neighbourhood of volcanic islands the material from the land is generally masked by the accumulation of pelagic shells, and the Volcanic mud may pass into Pteropod ooze in depths of about 1000 fathoms, or into Globigerina ooze in depths of I 500 or 2000 fathoms. Green mud and Red mud generally occur in depths less than Iooo fathoms, the seaward limit being about i 300 or I 400 fathoms.

Of the pelagic deposits, Pteropod ooze is found in shallower water than any of the other types-from about 400 fathoms to about I 500 fathoms, its seaward limit being reached in about I 700 or I 800 fathoms. Globigerina ooze may be found in all depths from about 400 fathoms to over 3000 fathoms, but occurs typically in depths between about 1200 and 2200 fathoms, its deeper limit in the Pacific and Indian Oceans occurring at about 2800 or 2900 fathoms, while in the North Atlantic it is known in depths approaching 3500 fathoms. Diatom ooze occurs usually in depths of about 600 to over 2000 fathoms, but in the North Pacific it is found in depths of 4000 fathoms. Radiolarian ooze is a characteristically deepwater deposit, hardly known in depths less than 2000 fathoms, and covers the bottom at the greatest depths recorded by the "Challenger" and "Nero" in 4500 to over 5000 fathoms. Radiolarian ooze may, however, be regarded as a mere variety of Red clay, containing a notable proportion of these siliceous remains as a result of the favourable conditions in the surface waters. Red clay is the typical deep-water deposit, and covers wide areas in depths exceeding 2000 fathoms, occupying the sea-floor in all the "deeps" except in one or two cases in the North Atlantic, being displaced in certain parts of the Pacific and Indian Ocean by its variety, Radiolarian ooze.

The rate of deposition of materials on the sea-floor is Rate of naturally beyond the range of direct measurement, at all events in deep water. The only observations bearing on this point have been recorded by Mr. Peake, who in 1903 on board the S.S. "Faraday" raised and repaired a telegraph cable lying in 2300 fathoms in lat. $50^{\circ} \mathrm{N}$. and long. $3 \mathrm{I}^{\circ} \mathrm{WW}$. in the North Atlantic. This same cable had been lifted from a depth of 2000 fathoms about 200 miles to the eastward in I $\$ 88$ by 
Mr. Lucas on board the S.S. "Scotia," and on portions of the cable recovered in 1903 being submitted to Mr. Lucas, he was quite convinced that no deterioration had taken place during the interval of fifteen years. This is ascribed to the fact that the cable when lifted in I 888 was covered by Globigerina ooze, which is believed to act as a preservative upon cables in contact with it. As in I 888 the cable had been submerged for thirteen years, this implies a rate of deposition of one inch of the deposit in some period less than thirteen years; but as the deterioration noted in the cable, especially in the hemp serving, had probably taken some years to effect, it is perhaps fair to assume a period of ten years for the accumulation of a layer of the deposit one inch in thickness, in the position referred to. Another cable lifted from the bed of the equatorial Atlantic (lat. $2^{\circ} 47^{\prime} \mathrm{N}$., long. $30^{\circ} 24^{\prime} \mathrm{W}$.) from a depth of 1900 fathoms in $188_{3}$, after having been submerged for nine years, was found to be in much better condition than the North Atlantic cables examined after having been laid for a similar period, and this is supposed to be due to the more rapid deposition of the Globigerina ooze in the warmer waters of the equatorial Atlantic than in the colder waters of the North Atlantic, so that the cable became more rapidly covered over by the Globigerina ooze. ${ }^{1}$

While, therefore, it may be assumed that the Globigerina ooze accumulates at the rate of about one inch in ten years in the central part of the North Atlantic in lat. $50^{\circ} \mathrm{N}$., and at a still more rapid rate in the central part of the equatorial Atlantic, it would appear from the recent observations of the "Michael Sars" Expedition that the rate of deposition of sediment may be almost nil even at depths of 1000 fathoms in certain parts of the North Atlantic, where glaciated stones have been dredged in considerable quantities. Possibly, however, these glaciated stones may have been deeply covered by the ooze since the close of the glacial period, and may have been subsequently exposed by the action of deep tidal currents sweeping away the Globigerina shells from the top of a low ridge perhaps recently elevated by earth-crust displacements in the deep sea. We now know that tidal currents prevent the formation of muddy deposits on the top of the Wyville Thomson Ridge in depths of 250 to 300 fathoms, while just below the summit of the ridge on both sides mud is deposited.

${ }^{1}$ See Murray and Peake, On Recent Contributions to our Kinowledge of the Floor of the North Atlantic Ocean, extra publication of the Royal Geographical Society, London, 1904, pp. 21 and 22. 
As to the relative rate of accumulation of the different types of deposits, it may be assumed that the terrigenous deposits accumulate at a much more rapid rate than the pelagic deposits. Of the terrigenous deposits, the Blue muds situated near the mouths of large rivers may be supposed to accumulate at a relatively very rapid rate, for the various constituents of the mud show little trace of alteration, while the rate of deposition in the case of Green muds and sands must be much slower, since the mineral particles are generally profoundly altered, and there is an extensive formation of secondary products, like glauconite and phosphate of lime; Coral muds and sands appear to accumulate rapidly under certain conditions, and the same may be said of Volcanic muds and sands in the neighbourhood of active volcanoes, where the volcanic minerals are fresh and unaltered, but most of the deep-sea volcanic deposits far from land appear to accumulate at a relatively slow rate, for the volcanic particles show abundant traces of alteration accompanied by the deposition of manganese peroxide.

Of the pelagic deposits, the Globigerina and Pteropod oozes of tropical regions probably accumulate the most rapidly, from the greater variety of tropical pelagic species of foraminifera and molluscs, and the larger and more massive shells secreted in tropical as compared, with extra-tropical regions. Diatom ooze appears to accumulate at a more rapid rate than Radiolarian ooze, since in addition to the siliceous remains it usually contains a considerable admixture of calcareous remains, but from all points of view it seems reasonable to suppose that the minimum rate of deposition of materials on the ocean-floor is reached in those characteristic Red clay areas farthest removed from continental land and in very deep water. The greater abundance of cosmic spherules, sharks' teeth, and ear-bones of whales, some of them belonging to extinct species, in the Red clays than in any other type of deposit, is ascribed to the fact that few other substances there fall to the bottom to cover them up. The state of profound alteration of the volcanic materials in the Red clay, accompanied by the secondary formation of clay, manganese nodules, and zeolitic crystals, is ascribed to the fact that these materials have lain for a long time exposed to the solvent action of sea-water. The presence of radio-active substances in this deposit, in much larger quantity than in other deposits, apparently also points to a very slow rate of deposition.

It may be stated generally, with reference to the horizontal 
Distribution of distribution of calcium carbonate organisms, that they are most calcareous remains in pelagic cleposits.

abundant both at the surface and at the bottom in warm tropical regions where the annual range of surface temperature is least. In the tropics the following genera and species of foraminifera are known to have a pelagic habitat, three or four of the species being rather doubtful :-

Pelagic species of foraminifera.
Globigerina sacculifera, Brady,

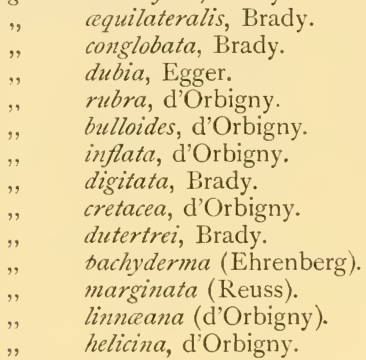

Orbulina universa, d'Orbigny.

Hastigerina pelagica (d'Orbigny).

Pullenia obliquiloculata, Parker and Jones.

Spharoidina dehiscens, Parker and Jones. Candeina nitida, d'Orbigny.

Cymbalopora (Tretomphalus) bulloides (d'Orbigny).

Pulvinulina menardii (d'Orbigny).

, tumida, Brady.

", canariensis (d'Orbigny).

", micheliniana (d'Orbigny).

, crassa (d'Orbigny).

, patagonica (d'Orbigny).

The following genera and species of shelled pteropods and heteropods are pelagic :-

Pteropons

Pelagic species Limacina inflata (d'Orbigny).

of pteropods. , , triacantha (Fischer).

, helicina (Phipps).

, antarctica, Woodward.

, helicoides, Jeffreys.

"lesueuri (d'Orbigny).

", austratis (Eydoux and Souleyet).

retroversa (Fleming).

" trochiformis (d'Orbigny).

" bulimoides (d'Orbigny).

Peraclis reticulata (d'Orbigny).

" bispinosa, Pelseneer.

Clio (Creseis) virgula (Rang).

", , conica (Eschscholtz).

, " $\quad$, acicula (Rang).

, , chierchice (Boas).

, (Hyalocylix) striata (Rang).
Clio (Styliola) subula (Quoy and Gaimard).

, andrea (Boas).

, polita (Craven).

," balantium (Rang).

,. chaptali (Souleyet).

, australis (d'Orbigny).

,'sulcata (Pfeffer).

"pyramidata, Linné.

" cuspidata (Bosc).

Cuvierina columnella (Rang).

Cavolinia trispinosa (Lesueur).

", quadridentata (Lesueur).

" longirostris (Lesueur).

," globulosa (Rang).

, gibbosa (Rang).

, tridentata (Forskål).

", uncinata (Rang).

, inflexa (Lesueur).

HETEROPODS

Pelagic species Carinaria cristata (Linné). of heteropods.
" fragilis, St. Vincent.

" lamarckii, Péron and Lesueur.
Carinaria depressa, Rang.

, australis, Quoy and Gaimard.

" galea, Benson. 
DEPTHS AND DEPOSITS OF THE OCEAN I73

Carinaria cithara, Benson.

$" \quad$ punctata, d'Orbigny.

" gaudichaudii, Eydoux and Souleyet.

atlantica, Adams and Reeve. cornucopia, Gould.

Atlanta peronii, Lesueur.

" turriculata, d'Orbigny.

" lesueurii, Eydoux and Souleyet. involuta, Eydoux and Souleyet. inflata, Eydoux and Souleyet. inclinata, Eydoux and Souleyet. helicinoides, Eydoux and Souleyet.

gibbosa, Eydoux and Souleyet.
Atlanta gaudichaudii, Eydoux and Souleyet.

" fusca, Eydoux and Souleyet.

" depressa, Eydoux and Souleyet. rosea, Eydoux and Souleyet. quoyana, Eydoux and Souleyet.

mediterranea, Costa.

violacea, Gould. tessellata, Gould.

primitia, Gould. cunicula, Gould. souleyeti, Smith.

Oxygyrus keraudrenii (Lesueur).

,$\quad$ rangii, Eydoux and Souleyet.

The gasteropod genus Ianthina is also pelagic, while the species of coccolithophoridæ are very numerous.

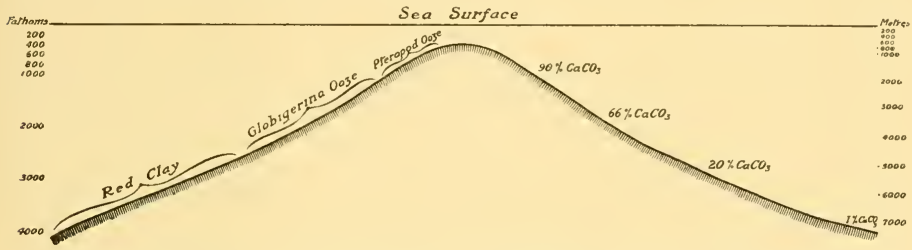

Fig. I42. - Diagram Shoining gradual disappearance of Calcium Carbonate WITH INCREASING DEPTH.

The distribution of the dead shells of these pelagic organisms in different depths is peculiar and remarkable. If we suppose a cone to rise from a depth of 4000 fathoms up to within half a mile of the surface far from land in the warmer regions of the ocean (see Fig. 142), we shall find on the upper surface of this cone, and down its sides to about 1000 fathoms, nearly every shell of pelagic organisms represented in the deposit, even the smallest and most delicate. At about I500 fathoms Disappearance many of the thinnest and smallest shells will have disappeared, and the Pteropod ooze passes gradually into Globigerina ooze. At 2000 fathoms there may not be a trace of pteropods, and of calcium carbonate with increase of some of the more delicate foraminifera will also have disappeared. At 2500 fathoms the larger and thicker foraminifera shells still remain, and the deposit becomes a Red clay with some carbonate of lime. At 4000 fathoms not a trace, or little more than a trace, of these shells can be found, and chemical analysis does not show I per cent of calcium carbonate.

Now it has been shown by hundreds of observations that 
in the surface waters the living animals are as abundant over the Red clay areas, where not a trace of their shells can be detected in the deposits, as over the Pteropod ooze areas, where every one of them may be found.

At about 2500 fathoms the percentage of calcium carbonate in the deposits apparently falls off more rapidly than at other depths. In some areas, as, for example, in the North Pacific, calcareous shells are not found in 2500 fathoms, while in the North Atlantic they are at the same depth sufficiently numerous for the deposit to be called a Globigerina ooze. Where the living organisms are most numerous in the surface waters, the dead shells are to be found at greater depths on the ocean's floor than elsewhere. Where cold and warm currents intermingle, shelled organisms are killed in large numbers, and the dead shells may be found in deeper water than in neighbouring regions.

Evidences of movements of the oceanfloor.

Stratification in marine deposits.
It must be remembered that while we know the crust of the earth on the continental areas to the depth of several thousands of feet, our knowledge of the crust under the oceanic areas is limited to one or two feet. Only in a few exceptional instances can we say that the sounding-tube has penetrated more than eighteen inches or two feet into the deposit. Sometimes, when the sounding-tube brings up a section over a foot in length, there are distinct indications of stratification. ${ }^{1}$ Even in great depths there may be a Globigerina ooze overlying a Red clay in the deeper part of the section. This arrangement may be explained by supposing that the calcareous shells have been slowly dissolved from the deeper layers, but this explanation will not suffice when a Red clay occupies the upper and a Globigerina ooze the deeper layer of the section. This latter arrangement appears to indicate that a large block of the earth's crust may have subsided to the extent of several hundreds of feet-from a depth at which a Globigerina ooze had been formed in normal circumstances to a depth at which a Red clay is laid down at the present time.

There are not many cases on record of one type of deposit being superposed upon another distinct type, examples being more numerous of differences in colour and in composition in the different layers of the same type of deposit. Thus, in Blue

${ }_{1}$ From his examination of the samples collected during the German South Polar Expedition on board the "Gauss," Philippi believed that stratification on the sea-floor of to-day is not the exception but the rule, and that, where it seems to be wanting, the upper layer is probably thicker than the depth to which the sounding-tube penetrated. 
muds it seems to be the rule that the upper portion should be thin and watery and reddish-brown in colour, in striking contrast with the stiff compact blue lower portion, and this is apparently due to the ferric oxide or ferric hydrate being transformed into sulphide and ferrous oxide in the deeper layers. Among our records there are seven cases of Red clay overlying Globigerina ooze, eight cases of Globigerina ooze overlying Red clay, three cases of Globigerina ooze overlying Blue mud, two cases of Globigerina ooze overlying Diatom ooze, and four cases of Diatom ooze overlying Blue mud; in twenty other cases the percentage of calcium carbonate was considerably higher in the upper portion of the deposit-samples than in the lower portion, while in six cases the lower portion was richer in calcareous remains than the upper portion.

The examples of Red clay overlying Globigerina ooze point to subsidence in the region where they occur, and, indeed, there are many reasons for believing that the great earth-blocks in the oceanic areas for the most part undergo subsidence, while similar earth-blocks on the continents are, on the whole, subject to elevation.

\section{Some Chemical Reactions in the Deep Sea}

In Dittmar's well-known analysis of ocean-water ${ }^{1}$ the acids and bases are arbitrarily combined, but it is now known that the dissolved substances in sea-water are not accurately represented by that table, inasmuch as they are present mainly as ions. The aggregate degree of ionic dissociation may be calculated from the freezing and boiling points of sea-water to be about 90 per cent. That is, only one-tenth of the total solids are present as salts pure and simple; but these must comprise not only those named by Dittmar but all the possible combinations of bases with acids, among which calcium and magnesium sulphates will be relatively in largest proportion. The bulk of the solutes, however, consists of ions, and it would be more rational to write the composition of sea-water thus :-

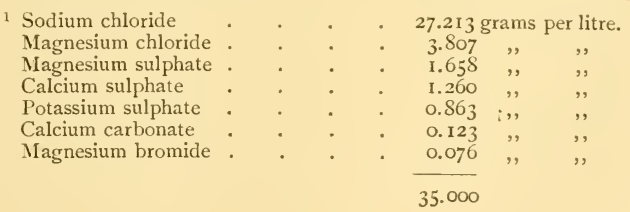


Dissolved solids in sea-water as ions.

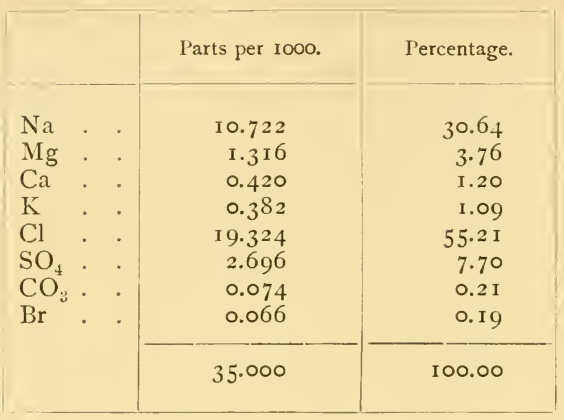

Dittmar's item $\mathrm{CaCO}_{3}$, which was presumably included in order to express the fact that there is on the whole an excess of bases over acids, is obviously incomplete as it stands. From the most recent measurements we gather that a 3 per cent sodium chloride solution, in equilibrium, as regards $\mathrm{CO}_{2}$-tension, with air (which holds good approximately for sea-water), dissolves at $25^{\circ}$ C. about $0.07 \mathrm{gr}$. of calcium carbonate per litre. Hence there cannot be as much as O. I 3 gr. per litre in sea-water. The surplus base should rather be regarded as a mixture of calcium and magnesium bicarbonates, existing in equilibrium with a certain amount of free $\mathrm{CO}_{2}$, and of the products of their hydrolytic dissociation, viz. calcium and magnesium hydroxides. It is the two latter which impart to sea-water its alkaline reaction.

On considering sea-water in its relation to submarine deposits we note that, of all possible combinations of cation with anion, there are three which are much less soluble than any others, and are therefore closest upon saturation and precipitation: these are calcium sulphate, calcium carbonate, and magnesium carbonate.

Calcium sulphate.

From what is known of the solubility of gypsum in brines, and allowing for the excess of $\mathrm{SO}_{4}$, one would suppose that sea-water is very nearly saturated for this salt, and that addition of, for instance, a sulphate would precipitate it. But gypsum is unknown as a constituent of deep-sea deposits (unless of extraneous origin), so that its solubility-limit is evidently never exceeded under submarine conditions.

Calcium carbonate.

Calcium carbonate, on the other hand, occurs, as already stated, in enormous quantities at the bottom of the sea over wide areas. All the lime in it has been derived, by the aid of organic agencies, from the calcium held in solution by sea-water, 
whilst the carbonic acid owes its origin more or less indirectly to the atmosphere and to infra-oceanic respiration.

In considering by what agencies calcium carbonate may be precipitated from the sea, we can at once set aside two which are of importance in terrestrial geology, viz. removal of solvent by evaporation and change of temperature; neither are operative in adequate degree in the hydrosphere. Turning to chemical processes we note, in the first place, that the solubility of calcium carbonate in water is nearly proportional to the cube root of the $\mathrm{CO}_{2}$-tension, ${ }^{1}$ i.e. the amount of free $\mathrm{CO}_{2}$ present in solution. Calcium carbonate as such is scarcely soluble at all, but in presence of $\mathrm{CO}_{2}$ the bicarbonate $\mathrm{Ca}\left(\mathrm{HCO}_{3}\right)_{2}$ is formed, and this is soluble to a considerable extent. Hence, if $\mathrm{CO}_{2}$ be abstracted, calcium carbonate will tend to come out of solution. Here we have what seems to be the modus operandi of calcareous algæ. The plant absorbs $\mathrm{CO}_{2}$ by way of nutrition, precipitates calcium carbonate, and thus builds its skeleton. That this process takes place in fresh water, where the bicarbonate is the chief salt of calcium present, may be considered as established. The mosses Hypunm, Eucladium, Trichostoma are cases in point, as also Chara. These plants deposit corallike growths, known to mineralogists as tufa and travertine. Many occurrences have been noted in the Yellowstone Park and other American localities. In some instances the calcium carbonate is aragonitic, as at Carlsbad. The calcareous algæ, which are well represented at the surface and at the bottom of the warmer oceans (coccolithophoridæ), no doubt secrete their skeletons in the same way as the fresh-water algæ enumerated.

But there is another far more important agency at work. Calcium carbonate must separate out if the product of the concentrations of its ions $\mathrm{Ca} \cdot$ and $\mathrm{CO}_{3}$ " happens to exceed a certain definite limit. Small increases in the concentration of $\mathrm{Ca}$. ions may be disregarded, since their concentration is already considerable ; but small local accessions of $\mathrm{CO}_{3}$ " ions, which, in the shape of alkaline carbonate, may and do occur, are more effective. Marine animals generate, as ultimate products of the metabolism of their proteid food, ammonia and carbon dioxide. These combine to form ammonium carbonate, which in aqueous solution is largely dissociated into $\mathrm{NH}_{4}{ }^{*}$ and $\mathrm{CO}_{3}$ " ions; thus calcium carbonate is precipitated with liberation of ammonia, and a shell or coral growth may be formed. The reaction here described,

1 Schloesing, Comptes Rendus Acad. Sci. Paris, vol. 1xxv. p. 70, 1872; Bodländer, Zeitschr. Phys. Chem., vol. xxxv. p. 23, 1900. 
which, according to the older chemical notions, was expressed by the equation

$$
\left(\mathrm{NH}_{4}\right)_{2} \mathrm{CO}_{3}+\mathrm{CaSO}_{4}=\mathrm{CaCO}_{3}+\left(\mathrm{NH}_{4}\right)_{2} \mathrm{SO}_{4} \text {, }
$$

seems to have been first suggested in this connection by Forchhammer, and was fully proved and worked out experimentally, with respect to marine organisms, by Murray and Irvine. ${ }^{1} \quad$ It accounts for the enormous amount of calcium carbonate at the bottom of the ocean, which once formed part of the tests or skeletons of living organisms. A limited amount of purely inorganic precipitation does, indeed, take place in coral reefs and some shallow-water deposits and in the Black Sea. In the Mediterranean, for instance, stone-like crusts are plentiful, consisting of clay cemented by calcium carbonate, which latter is produced by ammonium carbonate arising from the decay of organic matter in the mud below bottom-level meeting with fresh sea-water from above. We have further the lime-concretions of the Pourtales, Argus, and Seine banks, the "Challenger" casts of shells from the Great Barrier Reef, ${ }^{2}$ and so on. But all these must be regarded as rarities. A great many of the reactions here referred to are believed to be ruled by enzymes and catalytic substances.

Whilst a great deal of calcium is thus being taken out of solution throughout the ocean, conversely the carbonate is continually being redissolved. Calcium and magnesium carbonates are held in solution mainly as bicarbonates; but since these compounds are incapable of existence in the solid state, questions of precipitation and dissolution, so far as they can be approached on theoretical grounds, must be decided by the solubilities of the normal carbonates. The solubility of $\mathrm{CaCO}_{3}$ in water (foreign salts being absent), and the equilibrium of the various molecules and ions concerned, have been fairly thoroughly elucidated. ${ }^{3}$ When $\mathrm{MgCO}_{3}$ is also present and sea-water is the solvent, matters become so complicated that we cannot calculate, from first principles, how near sea-water is to saturation for calcium carbonate. There are, however, direct empirical data on this point. From the experiments of Anderson with natural, and of Cohen and Raken with artificial, sea-water, it would appear that with regard to $\mathrm{CaCO}_{3}$, in the final stable modification of calcite, sea-water is saturated and incapable of taking up more, under conditions of stable equilibrium. Nevertheless the ocean does unquestionably dis-

1 Proc. Roy. Soc. Edin., vol. xvii. p. 79, 1889.

2 Deep-Sea Deposits Chall. Exp., pp. 170, 172, 1891.

3 Bodländer, loc. cit. 
solve such calcium carbonate as it comes in contact with, especially dead shells and skeletons. Three reasons for this may be adduced :-

(I) There may be local accessions of $\mathrm{CO}_{2}$, the dissolving power of which has already been referred to. The sarcode of molluscs and the albuminous binding material of their shells are decomposed, on the death of the animal, to $\mathrm{CO}_{2}$ and ammonia, the former being much in excess. The solvent thus provided, in the case of any given shell-forming-organism, can only, however, be small relatively to the calcareous matter present.

(2) The carbonate may be in a less stable, and therefore more soluble, form than calcite. This is eminently true of corals, which are mainly aragonitic. Some shells also are wholly or partially aragonitic, and marine aragonitic algæ occur, such as Halimeda. Sea-water saturated for calcite would, needless to say, be unsaturated for aragonite.

(3) It is a familiar fact that freshly precipitated calcium carbonate is much more soluble than the stable macrocrystalline modification. The older theory, which supposed the former to be basic or hydrated $\mathrm{CaCO}_{3}$, seems open to doubt, since there is no sort of evidence that such compounds exist. More probably the abnormal solubility is due to the exceedingly small size of the particles. Above a certain limit of size, the concentration of saturated solutions of a solid is constant, whether the particles be large or small; below this limit the concentration becomes greater the smaller the particles, these stronger solutions being in perfectly stable equilibrium with solid particles of a definite magnitude. Experimental observations ' of this phenomenon, which may be an effect of surface-tension between solid and liquid, have in recent times been made on a variety of substances. ${ }^{1} \quad$ The limiting size for abnormal solubility is about $2 \mu$ diameter for gypsum, and will hardly be very different for calcium carbonate. It may be that what is called amorphous calcium carbonate is often merely calcite or aragonite in a state of extremely fine subdivision, whence the higher solubility. Abnormal solutions thus produced are of course supersaturated for larger particles, but there is evidence that they part with their surplus solute with extreme reluctance.

In all probability, then, the particles of calcium carbonate of organic origin in the sea, which are protected, during life, by albuminoid matter, go into solution, in the course of their postmortem descent, by virtue of their minute size, and leave trails 
of sea-water surcharged with lime. This lime, though in a metastable condition, finds no nuclei to deposit upon and remains in solution, being carried about until it reaches an area impoverished of lime by precipitation, when its condition becomes stable, or until it is itself reprecipitated by coming into the sphere of action of an ammonia-producing organism. Thus the ocean as a whole remains just about saturated for calcium carbonate.

Oceanic calcium undergoes extensive circulation between the dissolved and undissolved states. When calcareous fragments fall on a clayey or muddy bottom, they fall into water which can take up lime, and are dissolved as the water passes over them, while on falling on distinctively calcareous deposits like Pteropod ooze they fall into water-layers, immediately above the bottom, which can dissolve no more lime. In either case the lime depends for its redistribution on the slow processes of diffusion by convection and other currents. In those areas covered by Globigerina and Pteropod oozes lime is being steadily withdrawn from the ocean. Over Red clay areas, on the other hand, lime is being returned to the ocean. From the state of saturation of sea-water we may infer that the aggregate accessions of lime to the bottom exactly balance the aggregate supply from land and from the direct decomposition of submarine rocks. On the whole, lime at the present time appears to be accumulating towards the equator.

Magnesium carbonate.

Another element-present in the sea, magnesium, shares the vicissitudes of calcium, but in a very minor degree. Magnesium, in contrast with calcium, is very prone to form hydrated and basic carbonates, and when the carbonate is precipitated from solutions of magnesium salts, it comes down not in the anhydrous crystalline form, but mainly as a trihydrate. Now solubilitydeterminations in pure water and in salt-solutions indicate that $\mathrm{MgCO}_{3}$ as bicarbonate, in equilibrium with trihydrate, is of the order of ten times more soluble than $\mathrm{CaCO}_{3}$. Hence the former is far less likely to be precipitated than the latter, even though there is about three times as much magnesium in the sea as calcium. Moreover, it is well known that magnesium carbonate is not readily brought down in presence of ammonia. Thus we find that in living shells, corals, and algæ the proportion of $\mathrm{MgCO}_{3}$ to $\mathrm{CaCO}_{3}$ is usually below I per cent. It is observed, however, that in dead carbonates, e.g. Coral sands and muds and calcareous oozes which have been for a long time at the bottom, there are markedly greater admixtures of magnesium. 
This enrichment in magnesium is a familiar phenomenon at shallow depths, notably in and about coral reefs. It has also been shown on the basis of the "Challenger" analyses that bottomdeposits contain more $\mathrm{MgCO}_{3}$ in proportion to $\mathrm{CaCO}_{3}$ the less calcareous they are. Granted that accumulation of magnesium does take place, there are two explanations which have been offered, viz. (I) that deposited lime is dissolved away in preference to magnesia, and (2) that a kind of pseudomorphosis by the interaction of calcium carbonate and dissolved magnesium salts sets in. Both assume $\mathrm{MgCO}_{3}$ to be less soluble than $\mathrm{CaCO}_{3}$, and both may well hold good. Even if $\mathrm{MgCO}_{3}$ were precipitated as trihydrate, it would sooner or later change into the anhydrous form, or rather into dolomite, that being the most stable and final form. Perhaps this transformation has already been effected in the shell. But dolomite is well known to be less soluble in carbonated water than calcite. As regards enrichment by accession of magnesia, this could only take place if sea-water were nearly saturated for $\mathrm{MgCO}_{3}$, a matter which has not hitherto been put to the test ; sea-water is certainly not saturated for the trihydrate, but it is conceivable that anhydrous calcium carbonate would determine the deposition of magnesium carbonate in the anhydrous form, which is relatively very insoluble. Now when calcium carbonate goes into solution, the concentration of $\mathrm{CO}_{3}{ }^{\prime \prime}$ ions in its neighbourhood is increased, whereby the solubility of any other carbonate is lowered ; thus a precipitation of $\mathrm{MgCO}_{3}$ might ensue. However, if this action were capable of taking place generally, we should expect a far larger percentage of magnesia in the purer calcareous oozes. On the whole, therefore, the enrichment in magnesia in deepsea deposits proper is rather to be sought in preferential dissolution of lime.

The total magnesium carbonate at the bottom of the sea only amounts to a small percentage of the total calcium carbonate. Since the proportion of $\mathrm{Mg}$ to $\mathrm{Ca}$, primarily in rocks and secondarily in river-waters, is much larger than this, it is clear that dissolved magnesium is accumulating in the ocean.

Another of the more important constituents of sea-water, Sulphur. sulphur, suffers transference, on a modest scale, from the sea to the bottom. Nowhere in the deposits of the open ocean has sulphur been found to occur as sulphate, but in those very extensive landward areas where Blue muds form the deposit there is always a small percentage of ferrous sulphide and of free sulphur, which are directly or indirectly derived from 
sea-water sulphates. In all deep-sea muds there is a certain amount of decaying animal and vegetable matter fallen from the hydrosphere, the proteids of which leave their sulphur, so far as it escapes oxidation, combined with the iron of the surrounding mud. But apart from this rather insignificant item, there are bacteria which, whilst living on sarcodic matter, seize on the dissolved sulphates of sea-water and reduce them to sulphides; the latter react with whatever ferruginous material is present, and produce the highly insoluble compound ferrous sulphide. Free sulphur, when found, is to be accounted for by the partial oxidation of sulphides, either by dissolved oxygen or at the expense of ferric iron. The retention of sulphur in bottom-deposits can only occur where there is plenty of decaying organic matter, where the bottom-waters are stagnant, or nearly so, and not well aerated, and where there is not a copious hail of calcareous tests ; that is, mainly in the lower layers of muddy bottoms at shallow and medium depths. The sea-water imprisoned below the upper layer of mud becomes poorer in sulphate and richer in carbonic acid, ${ }^{1}$ whilst the mud is darkened in colour by very finely-divided and easily oxidizable ferrous sulphide. Under suitable conditions the ferrous sulphide may, as in Black Sea muds, ${ }^{2}$ combine with free sulphur and attain a condition of higher stability in the form of pyrites. The essential chemical factor which renders possible the retention of sulphur is the power of the colloidal ferric hydroxide in clay to react with sulphides. A small quantity of ammonium sulphide added, in the laboratory, to ordinary Red clay from the deep sea, at once goes into reaction: the clay is darkened to a tint resembling that of Blue mud; the original tawny colour is restored by atmospheric oxidation; the darkened clay evolves sulphuretted hydrogen with dilute acid. At the same time it is well to remember that many Blue muds owe their colour to quite other causes than the presence of sulphur.

The reduction of sulphates occurs only where there is a continuous deposition of detritus, and takes place, in the submarine muds, in the deeper layers. Consequently under normal conditions precipitated sulphur does not perform a cycle between bottom and sea, but remains irrevocably buried, accumulating as the deposit accumulates. No attempt seems hitherto to have been made to determine the ferrous sulphide in marine muds, but it is probably very minute in amount.

1 Murray and Irvine, Trans. Roy. Soc. Edin., vol. xxxvii. p. 48I, I893.

2 Murray, Scott. Geogr. Mlag., vol. xvi. p. 673, 1900. 
Free sulphur has been found in a maximum of 0.003 per cent in oceanic deposits, ${ }^{1}$ although inland and estuarine deposits may contain rather more. We may therefore take it that the aggregate influx of oxidized sulphur into the ocean greatly exceeds the fixation of reduced sulphur at the bottom.

The elements silicon (as hydrated silica) and phosphorus (as calcium phosphate) are transported by biological agencies from the sea to the bottom, the former in large, the latter in small, quantities. The compounds referred to are capable of existing in solution in sea-water only to an infinitesimal extent, so that all the silicic and phosphoric acids carried into the ocean must eventually find their way to the bottom.

The silica of organic origin in deep-sea deposits, which of silica. course represents but a tiny fraction of the total silica present, is peculiar in having been derived not only from dissolved, but also from suspended, silicates. ${ }^{2}$ It takes the form of tests and skeletons characterising the important Diatom ooze and Radiolarian ooze areas, and of sponge spicules, which are ubiquitous but nowhere concentrated enough to give rise to a definite deposit. Chemically, this silica is in the hydrated colloidal condition not unlike opal. By what process the siliceous organisms convert their intake of dissolved silica and floating clay into structural silica is not clearly known; as regards the former, it is evident that the organisms possess some means of coagulating to a hydrogel the silica which they receive either as $\mathrm{SiO}_{3}^{\prime \prime}$ ions or as a hydrosol of silicic acid; whilst their argillaceous food is probably decomposed by some acid juice with elimination of alumina in solution and eventual deposition of coagulated silica. During life, siliceous tests are protected from dissolution by an admixture of albuminoid matter, which rots away after death. The hydrogel of silica then undergoes peptisation (that is, so much of it as does not fall to the bottom), probably by virtue of the free alkali in sea-water, and returns to the dissolved state. The conditions of dissolution of silica and, for instance, calcium carbonate are very different. Silica, as being a colloid, has not a definite solubility; its existence as a hydrosol is limited only by the coagulating action of the electrolyte solutes of sea-water or by its precipitation in combination with a base. As to the former effect, we have no data except that sodium chloride is comparatively feeble as a coagulant. It is remarkable that no silica seems ever to reach the bottom as a chemical precipitate

1 Buchanan, Proc. Roy. Soc. Edin., vol. xviii. p. 17, I891.

2 Murray and Irvine, Proc. Roy. Soc. Edin., vol. xviii. p. 229, r\$gr. 
of calcium or magnesium silicate, although magnesium silicate is known to be soluble to only I part in I00,000 of sea-water. ${ }^{1}$ This perhaps indicates that the silica in solution in the sea is always below saturation-point, so that a local concentration large enough to determine precipitation never occurs. Or again, excess silica perhaps combines with what little alumina there is in sea-water and is deposited as clay; if that were the case, the limit of dissolved silica would be set by the solubility of this substance, which may well be less than that of magnesium silicate. At any rate, the quantity of silica really dissolved in sea-water is extremely small. According to the most recent and trustworthy determinations, ${ }^{2}$ there is on the average about one part, and never more than two parts, per million in North Sea and Baltic waters.

Although for obvious reasons vastly less silica is produced, by biological agencies, in the waters of the sea than calcium carbonate, the former, like the latter, is found in almost all submarine deposits. When siliceous remains fall into a calcareous deposit, the silica has little tendency to combine with lime, since silicic at low temperatures is an even weaker acid than carbonic; but, the process of peptisation being accelerated by the higher alkalinity of the superjacent waters, we should expect the predominance of lime to favour the dissolution of silica. This seems to be borne out by the fact that silica is least abundant in the most calcareous bottoms of the open sea, and also by the almost total absence of silica in coral reefs and muds. $^{3}$ Again, essentially siliceous accumulations (Radiolarian ooze) are characteristic of the very deepest parts of the ocean, where calcareous remains have such enormous columns of sea to fall through that they may fail to reach the bottom. There is thus a tendency for silica and calcium carbonate to be mutually exclusive. In terrestrial calcareous deposits (chalk) we find imprisoned silica going into solution, migrating to centres of coagulation and forming nodular segregations (flint). No such phenomenon is observed at the bottom of the sea, where the silica brought into solution has probably no difficulty in diffusing into the hydrosphere out of the comparatively loose deposit.

The soluble silica of the sea is derived ultimately from felspathic minerals, and the greater bulk is introduced from

1 Murray and Irvine, Proc. Koy. Soc. Edin., vol. xviii. p. 238, 1891.

2 Raben, Wissensch. Mleeresuntersuchungen, Kiel, vol. viii. pp. 99 and $277,1905$.

${ }^{3}$ The Atoll of Funafuti : Report of Coral Reef Committee of the Royal Society ; Chemical Examination of the Materials from Funafuti, by J. W. Judd, p. 370, 1904. 
land by means of rivers. Since the ocean cannot retain in solution more than a trace, all this silica must eventuate as organic deposits, especially Radiolarian and Diatom oozes. Furthermore, a certain quantity of suspended terrigenous clay is being continually converted into the hydrated silica of these deposits. Neglecting the latter source of biological silica and the comparatively inconsiderable radiolarian areas, we can say that the dissolved silica yielded by the continents is tending to accumulate on the frontiers of the temperate and polar zones, especially in the Antarctic Ocean.

The amount of phosphorus in sea-water is comparable in its Phosphorus. tenuity to that of silica. Raben's determinations for North Sea and Baltic waters show a seasonal variation ranging from O. 14 to $\mathrm{I} .46$ parts of $\mathrm{P}_{2} \mathrm{O}_{5}$ per million. Phosphorus originates as calcium phosphate in the form of apatite, passes through the ionized condition, and is deposited on the bottom of the sea as calcium phosphate. In the deposits this compound is of universal distribution; all samples of whatever character contain from a trace to about 3 per cent of tricalcium orthophosphate. The clays and muds no doubt retain traces of undecomposed mineral phosphate. On the other hand, calcium phosphate is secreted to a greater or less extent by the living denizens of the sea, whence its presence in calcareous and siliceous deposits; here we have the phosphorus withdrawn from aqueous solution and partly going through a cycle between the sea and the bottom, like lime and silica.

If there were no organic life in the ocean, the deposit everywhere would consist of a mud or clay, composed of mineral detritus. As it is, this detritus is nowhere wholly absent, and large areas consist of little else. Whether the mud be brought into the sea by rivers or through the agency of tidal erosion, or whether it be formed in situ at the bottom, it is always of a dual nature. The one ingredient is more or less finely powdered original mineral matter produced by mechanical comminution; the other is a mixture of substances resulting from the chemical decomposition of rocks. It has not been found possible to disentangle these components quite satisfactorily by chemical analysis, but it is safe to state that the proportion of one to the other ranges from one quarter to three quarters.

In chemically-produced mud we have the result of the action of water on crystalline silicates without the intervention of any solute except dissolved gases. Qualitatively, therefore, it is of 
the same composition whether formed in fresh water or in the sea. Quantitatively, it might be expected to show a difference for terrigenous and pelagic origin respectively, since the motherrocks are in general not the same. Nevertheless, a remarkably close similarity is revealed by analyses, such as the "Challenger" analyses of Blue muds and Red clays, or still better, of Clarke's ultimate analyses of averaged "Challenger" deposits. One notable point of difference is brought out, viz. the greater manganese-content of pelagic deposits.

The action of unlimited water, oxygen, and carbonic acid on the earth's crust tends to lead to certain definite end-products, the nature of which is dictated by the abundance and the affinities of the elements concerned, and by their habit as regards solubility. All minerals, given time, succumb to these agencies. Reviewing the chief elements, we find the final conditions of stability under subaqueous influences to be as follows. The alkalies, being of a highly soluble tendency, go into solution and accumulate in the hydrosphere. Calcium and magnesium are rendered soluble by the presence of carbonic acid and become sea-water constituents, the former being ultimately redeposited by organic processes. Phosphorus behaves similarly. Ferric iron is very feebly basic, and therefore tends to the condition not of a salt but of a hydrated oxide $\left(\mathrm{Fe}_{2} \mathrm{O}_{3} . \mathrm{Aq}\right)$ which, being very insoluble, remains in the residuum. Ferrous iron, which is a much stronger base, is leached out by the aid of carbonic acid, but is soon oxidized to ferric iron and rendered insoluble. Much the same holds good of manganese, which exists in minerals almost exclusively in the manganous state: it is dissolved as bicarbonate, undergoes oxidation, and comes to rest as hydrated peroxide $\left(\mathrm{MnO}_{2}\right.$. Aq) . Aluminium forms only one base, which is very weak, but has the property of combining with silica to form a highly insoluble substance, ideal clay $\left(\mathrm{Al}_{2} \mathrm{O}_{3} .2 \mathrm{SiO}_{2} .2 \mathrm{H}_{2} \mathrm{O}\right)$, which represents its final stable condition. Silicon exists as a weak acid $\left(\mathrm{SiO}_{2}\right)$ of insoluble tendencies, which, after having been brought into solution, partly joins the residuum as clay and is partly redeposited as hydrated silica through organic agency.

The ultimate mineral residuum, then, consists, if we pass over the rarer elements, of aluminous clay, hydrated ferric oxide, and hydrated manganese peroxide. In all probability the two former substances should be considered together and submarine clay regarded as an ill-defined colloidal compound in which

1 Proc. Roy. Soc. Edin., vol. xxxvii. pp. 167 and $269,1907$. 
silica and alumina play the chief part, but ferric hydroxide and even lime, magnesia, and alkalies are also represented. These minor constituents are, at any rate, so combined as to resist leaching out by dilute acids. Vast areas of the lowest depths of the sea are covered by such a clay in a state of considerable mechanical purity, a product of almost exclusively submarine disintegration, known as Red clay.

The chemical action by which pelagic clay is derived from its volcanic mother-rocks must proceed, as compared with subaerial weathering, with the utmost sluggishness. The fundamental question, indeed, whether fresh or salt water exerts the more powerful action upon rocks must be regarded as not yet answered. Great experimental difficulties are encountered, and we find the results of Thoulet, who concluded that fresh water is a better disintegrant than salt, diametrically opposed to those of Joly. ${ }^{1} \quad$ But several other considerations must be taken into account, and it cannot be doubted that rock silicates are degraded more slowly in the sea than on land. For instance, the clastic action of frost is never brought into play. There is no comminution of the minerals by moving water. The soluble by-products are removed, and the supply of oxygen and carbonic acid maintained, by diffusion only.

At this stage the state of rest of the deep-sea residuum is not even yet necessarily final, but is capable of being disturbed locally by organic agencies. Aluminous clay, indeed, is permanent once it is at the bottom, but, whilst floating, it is to some extent decomposed, as we have seen, by siliceous algæ for purposes of nutrition. Iron and manganese oxides are susceptible to reduction by purifying sarcodic matter, whence result the ferrous iron of the Blue muds, and also many of the concretionary forms of these oxides.

The Blue mud areas, which are of vast extent, afford a most important example of the reduction of submarine clay after deposition. We may indeed divide the floor of the sea, according to the relative abundance or paucity of dissolved oxygen in the bottom-waters, into oxidizing and reducing areas. Reducing conditions will prevail wherever there is a larger excess of putrefiable organic matter than can be coped with by whatever supply of oxygen (depending on the circulation of the area) may be available. In general, therefore, the coast-lines of continents are girdled by reducing areas, and it is here that

1 It may be mentioned that the methods of leaching adopted by these experimenters are somewhat different, and that Thoulet measures his effects by loss in weight, whereas Joly determined the amounts taken up in solution. 
Blue muds characteristically occur. Oxidation of the organic matter is here effected at the expense of ferric iron, probably by bacterial agency. A special case of this, viz. the bacterial production of ferrous sulphide and free sulphur, has already been referred to. It may be that sulphur plays an intermediate part in the formation of Blue muds, but the endproduct is simply a clay, in which some or most of the iron has been reduced to the ferrous state, containing I or 2 per cent of amorphous black organic substance. To these two factors the distinctive dark colour is due. The organic substance is associated with but little nitrogen and hydrogen, and it no doubt represents the final refuse of bacterial and higher forms of life. Blue muds are produced out of the deposit from the top downwards, as is evidenced by the reddish unreduced layer overlying the deeper Blue ones. Since Blue mud is of terrigenous origin, the undegraded silicate which it contains consists of continental minerals.

From the general conditions obtaining in reducing areas it follows that carbonic acid must be unusually plentiful in the mud-waters. A consequence of this is that calcium carbonate, if deposited, is readily redissolved. Hence the Blue muds are on the whole poor in lime. It further follows that lime is tending to accumulate in the deposits of the moderate depths of the ocean, between the reducing areas and the abysses where it is dissolved before reaching the bottom.

Doubtless the decay of minerals on the floor of the sea follows much the same course as subaerial weathering. Intermediate products, however, are comparatively rare, since the general conditions are not (as on land) subject to variation. The only substances of this category which form in any profusion are zeolites, especially the one known as phillipsite. Here and there intermediate products are arrested by being surrounded with concretions. A notable instance is the mineral Palagonite. palagonite, which is frequently found at the centre of ferromanganic nodules. Basic volcanic glass (an amorphous fused silicate of calcium, magnesium, and ferrous iron) has the property of combining with water continuously from the periphery inwards without crumbling, giving what is virtually a hydrated aluminium-iron silicate in a medium of opal. A coating of concretionary matter prevents the gelatinous silica from breaking away and dissolving, but offers no resistance to the diffusion of calcium and magnesium, which are leached out. Meanwhile the colloidal silica exerts its absorbing power on 
the potash and soda of sea-water, and these oxides enter to the extent of about 4 per cent each. The iron becomes ferric, and can no longer get away as bicarbonate. The resulting palagonite is a more or less homogeneous and transparent amorphous mineral. Exposed naked to the action of bottomwaters it rapidly breaks down to clay.

Deep-sea conditions are, on the whole, more favourable to synthetic the degradation of mineral matter than to the generation of new products. minerals. Nevertheless a few syntheses are being continually carried on in the muddy parts of the bottom and in the immediately superjacent layers of water; they fall into two groups, viz. true chemical syntheses of new classes of silicates, and mineralogical syntheses of concretionary minerals. The first group comprises glauconite and phillipsite, the second group ferromanganic and phosphatic concretions.

Glauconite is a hydrous double silicate of potassium and Glauconite. trivalent iron, occurring in rounded grains said to be composed of minute felted crystals. The ideal composition ( $\mathrm{KFe} \mathrm{Si}_{2} \mathrm{O}_{6}$. Aq) is claimed for it, but actually the purest marine glauconite hitherto analysed contains $\mathrm{I} .5$ per cent of $\mathrm{Al}_{2} \mathrm{O}_{3}$, 3. I per cent of $\mathrm{FeO}$, and $2.4 \mathrm{I}$ per cent of $\mathrm{MgO}$, with only 7.7 per cent of $\mathrm{K}_{2} \mathrm{O}^{1}$ The chemistry of its genesis is still a complete mystery ; all that can be said is that it appears to result from a metamorphosis of ferruginous clay, and that, in view of its frequent formation inside the shells of foraminifera (and of its absence in the Red clay and Red mud areas), decomposing organic matter probably plays a part in its formation. On the score of abundance glauconite is a mineral of considerable importance in bottom-deposits, being the characteristic component of the Green sands and Green muds. Glauconite is a mineral belonging essentially to the reducing areas of the deep sea.

The most notable geochemical change associated with glauconite is the withdrawal of potassium out of solution in the sea. This element has a remarkable tendency to be held in loose combination in amorphous and colloidal minerals (like palagonite), and all submarine muds and clays contain a small amount (less than I per cent) of absorbed potash; the quantities thus progressively entangled at the bottom will be roughly proportional to the aggregate accessions of clayey matter, and can only be a tiny fraction of the total potassium imported into the ocean. In glauconite-producing areas, on the other hand,

1 Collet and Lee, Proc. Roy. Soc. Edin,, vol. xxvi. p. 238, 1905. 
the fixation of potassium must reach formidable dimensions, since the purest Green sands may contain 7 to 8 per cent of $\mathrm{K}_{2} \mathrm{O}$. Nevertheless over the whole ocean it is hardly probable that deposition keeps pace with supply, and potassium may be regarded as one of those elements which are slowly concentrating in sea-water.

Phillipsite.

The zeolite phillipsite is the only substance produced in well-developed crystalline forms at the bottom of the sea, where it is peculiar to the deepest Red clay regions. Marine phillipsite is a hydrated calcium-aluminium silicate in which the principal minor bases are potash and soda ( 4 to 5 per cent each of $\mathrm{K}_{2} \mathrm{O}$ and $\mathrm{Na}_{2} \mathrm{O}$ ), with insignificant amounts of lime and magnesia. Like all zeolites, it must have been deposited out of a solution of its constituents, and it represents an intermediate stage in the degradation of rock-silicates to clay. Why should the process of degradation have been arrested at this stage? In all probability because solutions containing silica, alumina, and the other elements in just the right proportions were imprisoned in interstices of the Red clay, secure from diffusion, and therefore available for the slow process of crystallisation. It is worthy of note that in point of percentage quantity the minor bases of marine phillipsite differ widely from those of the terrestrial mineral, in which latter calcium plays the chief part. Taking into account the well-known faculty possessed by zeolites of exchanging bases with solutions with which they are in contact we have here (especially in the high percentage of $\mathrm{Na}_{2} \mathrm{O}$ ) an interesting effect of sea-water as a medium in the mineralogical world, comparable with its far-reaching biological effects. Why the crystallographical species phillipsite should be favoured rather than any other zeolite, we cannot in the present state of knowledge imagine.

The chief submarine concretionary substances are, in descending order of abundance, manganese and iron peroxides, calcium phosphate, calcium carbonate, and barium sulphate. A tendency to assume concretionary forms argues proneness to supersaturation and feebly crystalline habit on the part of the substance concerned. The former property is very characteristic of the peroxides and of calcium phosphate, and is evidently connected with the reluctance to come to equilibrium in solution which so often goes hand in hand with high valencies. ${ }^{1}$ Wherever concretions are found, we must suppose that there has at one time been a layer, or a chronological series of layers,

1 See Van t'Hoff, Sitzungsber. K. Akad. Wiss. Berlin, vol. xxxiv. p. 658, I907. 
of water surcharged with the substance, whence deposits have taken place on whatever nuclei offered, forming a hard radial aggregation, which would continue to grow until either the solution was exhausted or the supersaturation was relieved by external causes. The shape of the concretion must depend on the shape and number of its nuclei and the evenness of concentration in the surrounding solution; in the ideal case of a small single nucleus and a uniform supply of substance from all sides, the concretion becomes an almost perfect sphere, like the manganese nodules met with in certain localities.

Iron and manganese depend for the formation of supersaturated solutions in bottom-waters on the change of valency of which these elements are capable. Iron is brought into solution as ferrous bicarbonate by the decomposition of minerals; or again a solution of the bicarbonate may be produced locally by the action of decaying organic matter on ferric compounds. Now ferrous oxide is a base of strength comparable to, but rather less than, that of calcium oxide, and is subject to analogous conditions of solubility as bicarbonate. If oxygen were absent, and it the solubility were diminished, e.g. by withdrawal of carbonic acid, we should expect a deposition of ferrous monocarbonate (such as has often taken place on a large scale on land). As it is, the ferrous solution, diffusing out of the mud, meets with dissolved oxygen, and the change of valency to ferric iron rapidly supervenes. Ferric oxide, however, is a much weaker base, and the hydrolytic dissociation of its salts with a weak acid like carbonic is so complete as to render a ferric carbonate practically incapable of existence in presence of water. That is, the substance now in solution is ferric hydroxide. But this is a vastly less soluble body than ferrous bicarbonate; therefore the iron in solution is now supersaturated.

Non-manganiferous ferric concretions are comparatively rare, and have been reported only from the North Atlantic and the polar seas, ${ }^{1}$ where the terrigenous bottoms are poor in manganese. They attain no great size or hardness, contain much silica, and are rather balls of clay cemented with hydrated ferric oxide.

As for manganese, the manner in which supersaturated solutions come into being is the same, mutatis mutandis, as in the case of iron. The deposited peroxide has approximately the composition $\mathrm{MnO}_{2}$ in deep-sea nodules, but shows notable

I Schmelck, Norwegian North Atlantic Expedition, No. IX. p. 52, 1882; Böggild, Norwegian North Polar Expedition, Scientific Results, vol, v. No. XIV. p. 38 , 1906. 
admixtures of lower oxides of manganese when laid down in landward waters, ${ }^{1}$ where the supply of oxygen is competed for by much organic matter. The hydration $\mathrm{MnO}_{2} \cdot \frac{1}{2} \mathrm{H}_{2} \mathrm{O}$ is assumed by Murray and Renard, and $\mathrm{Fe}_{2} \mathrm{O}_{3}$. $\mathrm{I}_{2} \frac{1}{\mathrm{H}_{2}} \mathrm{O}$ (limonite) for the accompanying ferric oxide. Deep-sea nodules are never purely manganic, but contain inclusions of clayey and other matters, and always a considerable proportion of iron. The mean of forty "Challenger" analyses works out at 29.0 per cent of $\mathrm{MnO}_{2}$ and $2 \mathrm{I} .5$ per cent of $\mathrm{Fe}_{2} \mathrm{O}_{3}$, soluble in hydrochloric acid. As a rule, then, surcharged waters hold both iron and manganese ready to be deposited simultaneously. The mode of formation of these nodules and the origin of the manganese from volcanic minerals have been thoroughly elucidated by Murray and Irvine. ${ }^{2}$

It should be noted that these oxides need by no means necessarily assume a concretionary form. They are very commonly found as thin incrustations on granular and fragmentary objects. Furthermore many, if not most, of the pelagic clays contain intimate admixtures of finely-divided brown manganese and occasionally of limonitic iron. Here the supersaturation would seem to have been so high as to transgress the metastable limit, whereupon the oxides have precipitated themselves without the intervention of nuclei; they certainly must have been precipitated from solution.

Manganese originates in the form of silicates and comes to rest exclusively in the form of peroxide. It is imported, on the one hand, from land as detritus or in solution; but in the terrigenous areas of the bottom, where reducing conditions prevail, as a rule, it tends to exist in the suboxidized, i.e. soluble, form. Hence much of the terrigenous manganese will be carried on to the deeper oxidizing waters before it can deposit. There is thus a constant accession of manganese from land to the pelagic deposits. In the second place, manganese comes into the floor of the ocean from certain basic volcanic minerals of vitreous habit, and these are to be regarded as the principal source of ferromanganic nodules. These basic glasses are the only primary minerals in the deep sea which contain important amounts of manganese. It so happens that they are common in the Pacific, less common in the Indian Ocean, and rare in the Atlantic. Consequently the greatest abundance of manganese peroxide, pulverulent and nodular, is met with in mid-Pacific.

Phosphatic concretions are of very localised occurrence and

1 Buchanan, Trans. Roy. Soc. Edin., vol. xxxvi. p. 459, 1892.

2 Trans. Roy. Soc. Edin., vol. xxxvii. p. 721, 1894. 
are, in the last resort, of biological origin. The phosphoric Phosphatic acid in sea-water is derived chiefly from the skeletons and concretions. tissues of the marine fauna. At certain spots great masses of these skeletons are heaped up at the bottom, and here or hereabouts phosphatic nodules are presently formed. In order to explain why the phosphate of decaying bones goes into solution it is not necessary to postulate exceptional conditions in the surrounding sea-water. The solubility of tricalcium orthophosphate in water is a matter which bristles with complications, and experimental difficulties have hitherto proved too great for its exact measurement; but it seems to be of the order of decigrammes per litre. The solubility is much enhanced by the presence of $\mathrm{H}^{\circ}$ ions, i.e. of acids. The solvent action of carbonic acid which has been suggested seems, however, to be merely hypothetical. Carbonic acid is so weak that at best it can produce only a negligible concentration of $\mathrm{H}^{*}$ ions; moreover, there is experimental evidence that so long as excess of lime (as bicarbonate) is present, calcium phosphate is no more soluble in carbonated than in pure water. In all probability the rapid dissolution of the calcium phosphate and carbonate in fishbones is simply due to the fine state of division. This effect has already been discussed with reference to sea-shells. The extreme fineness of the inorganic particles disseminated in the gelatinous matter of fish-bones is attested by the translucency of the mass. Or it may even be that the carbonate and phosphate are present in a colloidal form. In either case they will readily yield supersaturated solutions when the enclosing ossein rots away, and as soon as a nucleus presents itself the formation of concretions is ready to begin. Since phosphatic concretions usually occur, as already indicated, in positions where organic remains accumulate on the bottom at a rapid rate, as in areas having a great range of surface temperature, the transference of matter from bones to nodules must have taken place without much delay. Consequently there has been little opportunity for differential diffusion of carbonate and phosphate, so that these calcium salts are invariably found to have been deposited simultaneously. The "Challenger" analyses show I $\frac{1}{2}$ to 3 parts of tricalcium orthophosphate to one of calcium carbonate. Magnesium phosphates being considerably more soluble than those of calcium, the phosphate of bones is redeposited unchanged after its passage through sea-water; only a trifling percentage of magnesium is shown by the analyses, and this is probably present as carbonate. 


\section{Depth and Deposits of the North Atlantic Ocean}

The North Atlantic may be called a circumscribed ocean, being practically land-locked except towards the south. Its superficial area is small compared with the other ocean basins, but the area draining into it is enormous, since the Arctic Ocean, the Mediterranean Sea, the Baltic Sea, the Gulf of Mexico, and the Caribbean Sea all communicate with it. Indeed, it has been estimated that nearly one-half of the entire world drains directly or indirectly into the Atlantic Ocean ${ }^{1}$ as a whole, or about four times the area draining into the great Pacific Ocean, and of this by far the larger portion drains into the North Atlantic as distinct from the South Atlantic; the largest river of South America, the Amazon, enters the Atlantic just on the equator, and its outflowing waters, with their burden of sediment, are carried mostly into the North Atlantic. It has further been estimated that more than one-half of the total rainfall of the globe falls on the Atlantic drainage area, equal to more than three times the amount-falling on either the Pacific or Indian Ocean drainage area. ${ }^{2}$ Remembering these facts, and the relatively large area occupied by the continental shelf and continental slope, it is easy to understand why the deposits covering the floor of the North Atlantic partake more of a terrigenous character than those of the other ocean basins, and this character is further emphasised by the floating icebergs met with in the northern part of the ocean, and by the proximity to the southern part of the ocean of the great desert of the Sahara, the sand grains from which are sometimes carried far out to sea by the wind. The North Atlantic is also remarkable for the relatively high temperature of its waters at all depths from surface to bottom, as compared with the other oceans, and this is due partly to the influence of the dense warm water flowing out from the Mediterranean at the Straits of Gibraltar, and partly to the downward movement of the dense surface water of the Sargasso Sea. Another characteristic of the North Atlantic is the permanent anticyclonic area in the Sargasso Sea region, which largely determines the direction of the prevailing winds over a large part of that ocean, and hence of the great surface currents like the Gulf Stream.

The bathymetry of the North Atlantic, according to the 1 Scott. Geogr. Mag., vol. ii. p. 554, is 86.

2 Ibid. vol. iii. p. 67, I 887 . 
present state of our knowledge, is shown in Map III. On this chart the soundings in depths greater than 1000 fathoms the North are indicated by the first two figures, and they show that the North Atlantic is now well sounded - in fact, probably the best sounded of all the ocean basins. The recent soundings by the "Michael Sars" did not bring to light many new facts as to depth, and it is not likely that any great changes in the contour-lines will be revealed by future soundings, though it is possible that further submarine cones, like the Seine Bank and Dacia Bank and the Coral Patch, may yet be discovered.

A comparison of this map with the depth map published by Maury in 1854 , which is reproduced in Map I., brings out at a glance the strides that have been made in our knowledge regarding the depth of the North Atlantic since that timea progress from comparative simplicity to great complexity. Maury's 4000 -fathoms area in the North-West Atlantic, based upon some doubtful soundings (two of them exceeding 5000 fathoms and another in 6600 fathoms), has disappeared, though the existence of very deep water in the neighbourhood is evidenced by the soundings in the Suhm Deep. These deep soundings laid down by Maury were among the early attempts at deep-sea sounding, and the records of such depths as 6600 fathoms, no bottom, were due to the uncertainty as to when the sounding-tube touched bottom. The only part of the North Atlantic where the depth is now known to exceed 4000 fathoms (in the Nares Deep north of the West Indies) is blank on Maury's map, but the northern portion of the midAtlantic ridge, on which the Azores plateau is situated, is correctly indicated, though since modified in outline; the continuation southward of this ridge was, however, unknown in Maury's time.

Reference has already been made to the relatively large area occupied throughout the world by the continental shelf, which is equal to about 7 per cent of the entire ocean-floor. The continental shelf apparently attains its maximum development in the North Atlantic basin, if we include the tributary seas shelf in the (Arctic Ocean, Mediterranean, etc.). The total area of this Atlantic. basin may be estimated at about 23 million square miles, and of this area no less than about 6 million square miles (or 26 per cent) lies between the shore-line and the roo-fathoms line. While the gentle gradients of the continental shelf cover such Continental an extensive area, the continental slope beyond the roo-fathoms slope in the line seems, on the other hand, to be relatively very steep, for Atlantic. 
the area between the Ioo-fathoms line and the 500-fathoms line is only a little over 2 million square miles (or 9 per cent), and the area between the 500-fathoms line and the Iooo-fathoms line is only about I million square miles (or 4 per cent of the total area). It thus appears that the area with depths less than IOOO fathoms within the North Atlantic basin, as already defined, is equal to about 9 million square miles (or 39 per cent of the total area), and of this the continental shelf covered by water less than 100 fathoms in depth occupies 6 million square miles (or 26 per cent).

Abyssal area of the North Atlantic.

Deeps of the North Atlantic.

The Norwegian Sea.

Proceeding into the abysmal region, we find that the area of the North.Atlantic sea-floor covered by water between Iooo and 2000 fathoms in depth is about 5 million square miles (or 22 per cent), the area covered by water between 2000 and 3000 fathoms in depth is about $7 \frac{1}{2}$ million square miles (or 33 per cent), and the area covered by more than 3000 fathoms of water ("deeps") is about $\mathrm{I} \frac{1}{2}$ million square miles (or 6 per cent of the total area). These figures show what a large proportion of the North Atlantic sea-floor is covered by shallow water less than 1000 fathoms (equal to two-fifths of the entire area), and by deep water between 2000 and 3000 fathoms (equal to onethird of the entire area).

The deeps of the North Atlantic number fourteen, and cover an area of about $\mathrm{I} \frac{1}{2}$ million square miles, as already indicated. The larger and more important of these, Nares Deep, Moseley Deep, and Chun Deep, have been briefly described on pages I 4I, I 42, and I43. The smaller ones are: Makaroff Deep in the West Indian seas; Bartlett Deep in the Caribbean Sea; Mill Deep and Keltie Deep in the sea between Bermuda and the American coast; Suhm Deep, Libbey Deep, Sigsbee Deep, and Thoulet Deep, to the south of Nova Scotia and Newfoundland; Peake Deep to the west of Cape Finisterre; Monaco Deep to the south of the Azores; and Hjort Deep immediately to the east of the mid-Atlantic ridge in lat. $20^{\circ} \mathrm{N}$.

The Norwegian Sea is bounded on the east by Spitsbergen, Bear Island, the banks of the Barents Sea and the Norwegian coast; on the south by the North Sea, the Shetland and Faroe Islands, and the submarine ridges between the Shetlands and Faroes and between the Faroes and Iceland; on the west by Iceland and Greenland; and on the north, about lat. $80^{\circ} \mathrm{N}$., by a submarine ridge supposed to separate the two deep basins called the Norwegian Sea and the Polar Sea. 
Iv DEPTHS AND DEPOSITS OF THE OCEAN 197

The Norwegian Sea has a superficial area of 2.58 million square kilometres, nearly two-thirds of which consists of a deep

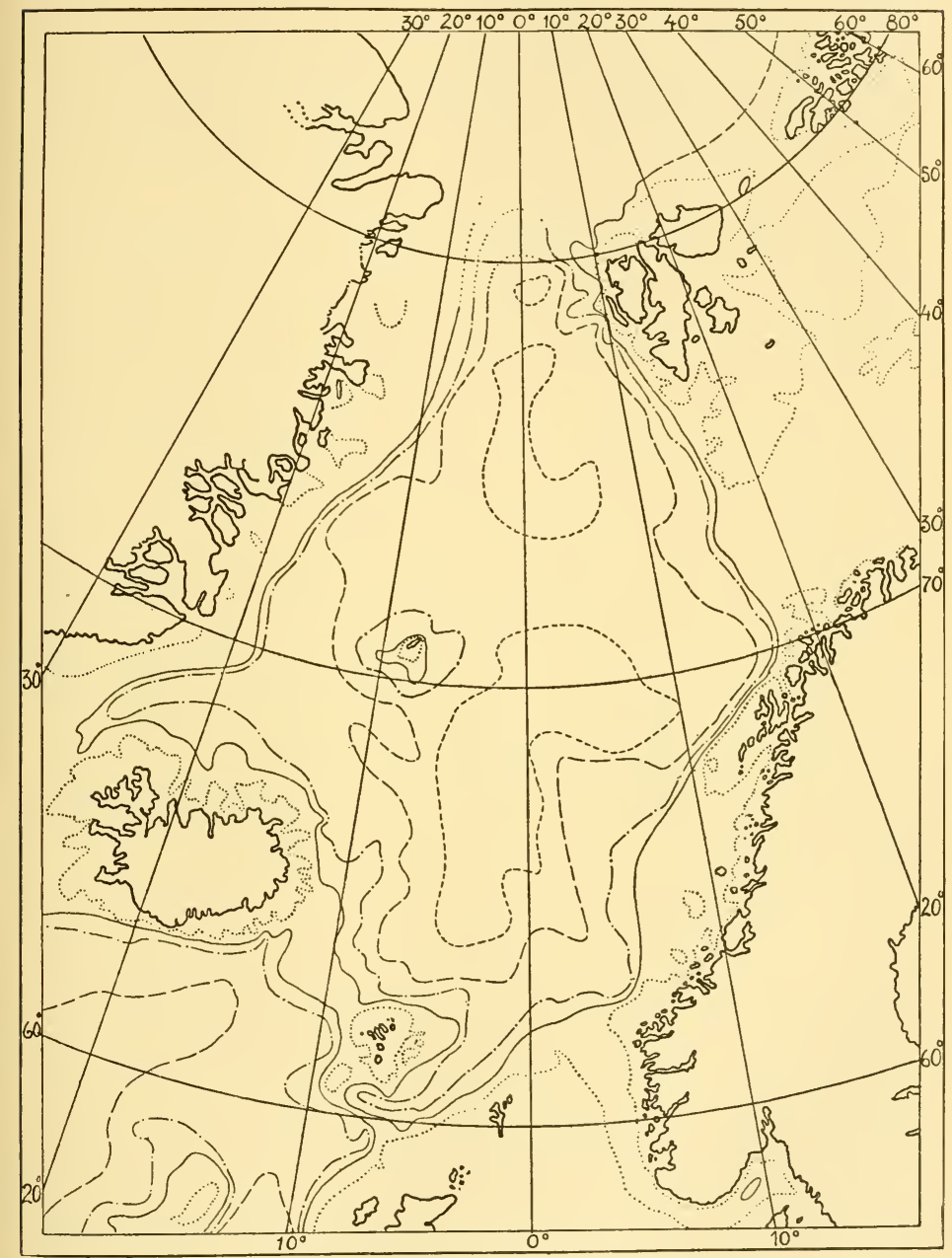

Fig. I43.-The Norwegian SEA, Showing Depths. 200 metres.

- - - - 1000 metres. 
basin (see Fig. I43), more than 3000 metres deep in the central portion. From this depth the floor rises gradually towards the continental slope on either side. The main features of the continental slope and shelf along the coast of Norway will be grasped by reference to the accompanying diagram (Fig. I 44). The term "coast banks" is usually applied to the higher parts of the submerged continental plateau or continental shelf, which are frequented by fishermen ; there is often a marked "edge" between the plateau and the continental slope.

The continental shelf fringes to a greater or less extent the whole of the coasts of the Norwegian Sea, and occupies altogether about a third of its entire superficial area. This shelf is covered by depths down to 200 metres with channels down to 600 metres. In water shallower than 200 metres there

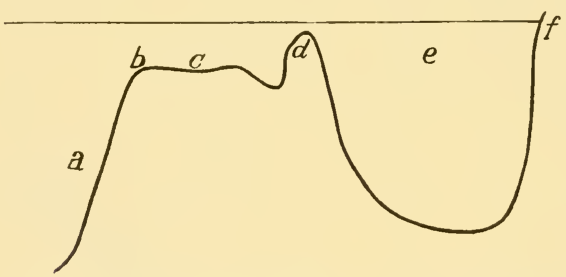

Fig, i44.-Diagrammatic Section off the Norwegian COAST.

$a$, Continental slope ; $b$, continental edge ; $c$, continental shelf or plateau ; $d$, coast bank ; $e$, fjord ; $f$, coast. are only comparatively small banks, the greatest being at Lofoten and Romsdal and round the Faroes and Iceland. Deeper than 600 metres the continental slope is steep; the bathymetrical curves for 600 and Iooo metres lie everywhere in close proximity to one another, and the area of the sea-bottom between them is no more than 5.4 per cent of the whole extent of the Norwegian Sea.

Deposits of the North Atlantic.

The distribution of the deposit-types over the floor of the North Atlantic is shown on Map IV., an examination of which bears out the statement that the terrigenous deposits are relatively more important in the North Atlantic than in the other oceans, in correlation with the relatively large area covered by shallow water. Thus of the total area of 23 million square miles, one-half, about I I $\frac{1}{2}$ million square miles (or 49 per cent), is covered by terrigenous deposits. This area is to a very large extent occupied by Blue mud, no attempt having been made to indicate on the map the small areas occupied by Green mud off the coast of the United States, off the Spanish and Portuguese coasts, and in the vicinity of the Wyville Thomson Ridge, nor the small areas occupied by Volcanic mud in the neighbourhood 
of the Azores, Madeira, etc. The position of the Coral mud deposits of the West Indies and Bermuda is, however, indicated on the map, and these deposits cover an area of about half a million square miles (or 2 per cent of the total area).

After the Blue mud, the principal type of deposit in the North Atlantic is Globigerina ooze, which covers an area of about 9 million square miles (or 39 per cent of the total area). A glance at the map shows what an extensive area is occupied by this type of deposit in the open ocean, where it is found in greater depths than is usually the case in the other ocean-basins (the "Michael Sars" deepest sounding in 2966 fathoms, for example, gave a Globigerina ooze with 64 per cent of calcium carbonate); it also occurs in the Caribbean Sea, in the Gulf of Mexico, and in the Norwegian Sea in lat. $63^{\circ} \mathrm{N}$. to $72^{\circ} \mathrm{N}$.

Red clay, which covers such an enormous area of the seafloor in the great Pacific Ocean, plays a subordinate part in the North Atlantic, being estimated to occupy about $2 \frac{1}{2}$ million square miles (or I I per cent of the total area); it occurs in two areas on either side of the mid-Atlantic ridge : the larger to the west of the ridge, surrounding Bermuda and extending from lat. $13^{\circ} \mathrm{N}$. to $40^{\circ} \mathrm{N}$., the smaller to the east of the ridge in lat. $8^{\circ} \mathrm{N}$. to $28^{\circ} \mathrm{N}$., with a subsidiary area in the Caribbean Sea in lat. $13^{\circ} \mathrm{N}$. to $15^{\circ} \mathrm{N}$.

Pteropod ooze, though widely distributed throughout the basin, covers in the aggregate a comparatively very small area, estimated at about 200,000 square miles (or I per cent of the total area); it occurs in the open ocean in the neighbourhood of the Azores, Canaries, Bermudas, and West Indies, as well as in the Mediterranean, Caribbean, and Gulf of Mexico. The other two types of pelagic deposits, Radiolarian ooze and Diatom ooze, are not represented in the North Atlantic.

Although the "Michael Sars" Expedition did not add "Michael greatly to our knowledge either of the depth or of the deposits of the North Atlantic, still both the soundings and the depositsamples are of value, many of the deposit-samples, indeed, being extremely interesting. A detailed description of all the samples will be reserved for a later publication, but in this place we may refer to the more interesting points brought out by a study of the material.

In the first place, reference may be made to the stones and rock fragments brought up from several stations, which form the subject of a report by Drs. Peach and Horne appended to Sars" deposit. samples. 
this chapter; from another station the ear-bone of a whale and two sharks' teeth were obtained.

Of the twenty-seven samples submitted to detailed examination, nineteen were Globigerina oozes, six were Blue muds, one a Pteropod ooze, and one a Globigerina ooze overlying Blue mud. The Globigerina oozes occur over the route followed by the "Michael Sars" as far west as long. $44^{\circ} \mathrm{W}$.; the Globigerina ooze overlying Blue mud occurred to the north of the Rockall Bank; the Pteropod ooze near the Canary Islands; and the Blue muds in the Eastern Atlantic from the Faroe Channel to the Straits of Gibraltar. The "Michael Sars" samples show that the Globigerina ooze approaches nearer to the coasts of the British Islands than was previously supposed, having been found at the following depths along the continental slope off the European and African coasts: 547 fathoms (Station 4), I 256 fathoms (Station 25 A), I I 22 fathoms (Station 25 B), I 422 fathoms (Station 35), 746 fathoms (Station 4I), 688 fathoms (Station 93), 98 I fathoms (Station 95), 742 fathoms (Station 98), and 835 fathoms (Station I00). Globigerina ooze and Pteropod ooze were found in the neighbourhood of the Canary Islands in positions where they were previously unrecorded.

An interesting point in connection with the "Michael Sars" deposits is the number of instances where the sounding-tube had plunged deeply into the sediment, bringing up sections varying from two to fourteen inches in length, and in some cases marks observed on the outside of the sounding-tube indicated that it had penetrated still farther into the deposit. Though in most cases the material was apparently uniform throughout, some of these long sections gave distinct evidences Stratification. of stratification. Thus at Station 10 in the Bay of Biscay, at a depth of 2567 fathoms, the sounding-tube brought up a section about five inches in length, of which the upper portion to the depth of about three inches was of a uniform fawn colour, representing apparently an ordinary Globigerina ooze with 66 per cent of calcium carbonate, while the lower inch or two had a mottled appearance, with light and dark brown patches, the dark brown material giving only 33 per cent of calcium carbonate when analysed. At Station $49 \mathrm{C}$, from a depth of 2966 fathoms, the sounding-tube brought up a section about fourteen inches in length, showing distinct traces of stratification, especially towards the upper end, although the lower end presented a mottled appearance with patches of lighter and darker brown; towards the upper end there were small patches 
of a dark brown colour which proved to be Red clay, with only 25 per cent of calcium carbonate, though the mass of the sample was a Globigerina ooze with 64 per cent of calcium carbonate. At Station roo, in 835 fathoms, the sounding-tube brought up a section about nine inches in length, which was extremely interesting because of the great difference between the upper and lower portions, the upper portion, to the extent of three or four inches, being a Globigerina ooze with $5^{8}$ per cent of calcium carbonate, while the lower portion was a Blue mud with only 26 per cent of calcium carbonate. At Station 88, in I703 fathoms, the sounding-tube brought up a section about fourteen inches in length, which showed little difference to the naked eye, although the colour was darker in the lower portion, the upper portion being rather lighter in colour, less coherent, and more granular ; the deposit was a Globigerina ooze, containing 83.79 per cent of calcium carbonate in the upper portion, 73.66 per cent of calcium carbonate in the middle portion, and 62.1 per cent of calcium carbonate in the lower portion. It is curious that at this station the trawl brought up a large quantity of empty pteropod shells (chiefly Cavolinia trispinosa), while in the samples from the sounding-tube submitted to examination no pteropods were observed. It is possible that the trawl may have worked over shallower depths than where the sounding was taken. Similarly, at Station 23, where the depth was 664 fathoms, the Petersen net sent down with 820 fathoms of line and towed throughout the night of $5^{\text {th }}$ and 6 th May brought up a large amount of empty pteropod shells (principally Cavolinia inflexa); indeed, the pteropod shells at this station differ strikingly in general appearance from those taken at Station 88, ten degrees farther north. At Station 34, in II 85 fathoms, the middle portion of the section from the sounding-tube, about six inches below the upper surface, showed dark-coloured patches containing a large proportion of volcanic glass splinters, to which the dark colour was due; the volcanic glass was quite fresh and unaltered, as though the products of a volcanic eruption (probably submarine, since the glassy fragments showed no trace of friction or decomposition but were perfectly angular) had been overlain by new material to the depth of six inches.

We append the detailed description of a typical Globigerina ooze taken by the "Michael Sars" to the south of the Azores:-

"Michael Sars" Station 55. Ioth June 1910. Lat. $36^{\circ} 24^{\prime}$ N., long. $29^{\circ} 52^{\prime}$ W. ; depth, $3239 \mathrm{~m}$. (I 768 fathoms). 
Description of GLOBIGERINA OOZE-dirty white colour, coherent, granular.

typical deposit sample collected by the "Michael Sars."

Rock fragments dredged by the "Michael Sars."

Calcium Carbonate- 78.59 per cent; pelagic and bottom-living foraminifera, ostracods, coccoliths, and rhabdoliths.

REsidue, 2I.4I per cent :-

Siliceous Organisms-2 per cent ; radiolaria, sponge spicules.

Minerals - 4 per cent, m. di. $0.09 \mathrm{~mm}$., one angular fragment of volcanic glass exceeded $2 \mathrm{~mm}$. in length; quartz, plagioclase, volcanic glass, augite (?), magnetite, mica.

Fine Washings-I 5.4I per cent; amorphous clayey matter with minute mineral particles.

Note.-The sounding-tube brought up a roll about 9 inches in length of a creamy white colour throughout.

All the rock fragments dredged during the "Michael Sars" Expedition, as well as those collected by H.M. ships "Knight Errant" and "Triton" in I 880 and I 882, have been carefully examined and studied by Dr. B. N. Peach. ${ }^{1}$ Drs. Peach and Horne have prepared the following note on the general results:-

The materials collected by the "Michael Sars" Expedition fall under two categories: (I) those whose presence on the sea-floor is due to natural agencies, and (2) those distributed by human agencies. The materials belonging to the first group consist chiefly of rock fragments, the remains of floating or swimming organisms that lived at or near the surface of the sea (such as barnacles and the ear-bone of a whale), and fragments of wood. The members of the second group are mainly furnace clinkers and pieces of coal, small pieces of glazed pottery, and oyster-shells, together with a cannon-bone of a small ox.

By far the most interesting collection of the "Michael Sars" series was obtained from Station 95, which lies about 230 miles south-west of Mizen Head, Ireland, at a depth of 5886 feet, or a little over a mile. The rock fragments, comprising over 200 specimens, included upwards of 100 of sedimentary origin, 58 of igneous origin, and 40 belonging to the metamorphic series. Some of the specimens were referred to the Cretaceous and Carboniferous periods by means of their fossil contents; the remainder were grouped with the Devonian or Old Red Sandstone and Silurian systems solely on lithological grounds.

The fragments regarded as of Silurian age include greywackesandstones, dark shales, and black lydian stone identical in lithological characters with rocks that floor a large part of the southern uplands of Scotland and the north of Ireland. Those referred to Devonian time resemble the Glengariff grits of the Dingle peninsula in the southwest of Ireland. The carboniferous specimens comprise encrinital limestones with chert, like those of Galway and Clare. One sandstone fragment was crowded with Schizodus and Edmondia similar to rocks occurring in places along the Solway shore in Scotland and in Londonderry and Tyrone in Ireland. The specimens of chalk and chalk-flints are like the rocks in the Antrim plateau.

1 See detailed report in Proc. Roy. Soc. Edin., I912. 


\section{iv DEPTHS AND DEPOSITS OF THE OCEAN 203}

Among the metamorphic series there are representatives of crystalline gneisses and schists which could be matched from the Lewisian gneiss

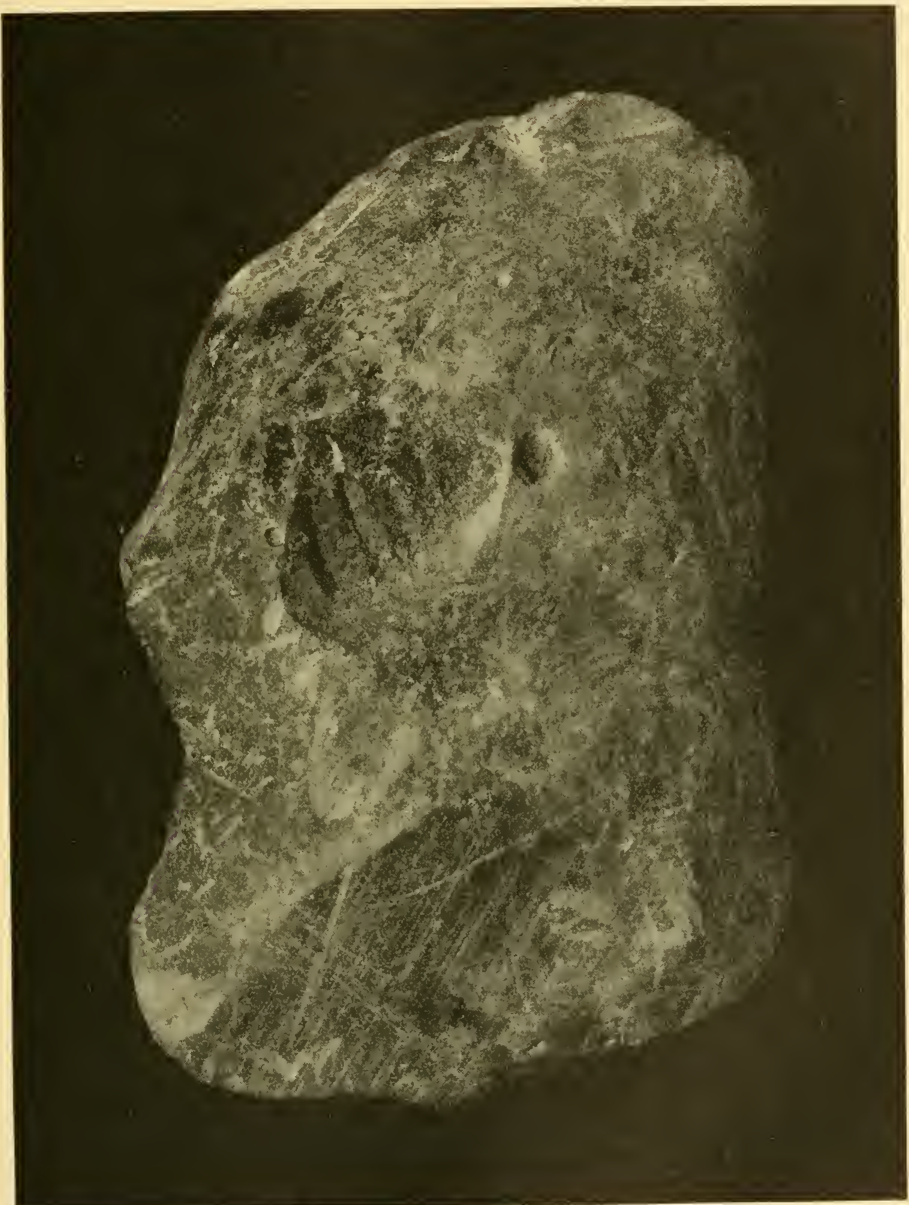

Fig. I45.-Glaciaten Stone from "Michael Sars" Station 95.

and Moine schist areas in the North-West Highlands of Scotland. Associated with these are specimens indicating a low grade of metamorphism, such as phyllites and sheared greywackes and igneous rocks, 
which resemble types to be found along the south-eastern border of the Highlands and the north of Ireland. Indeed, some may have been derived from the south of Ireland.

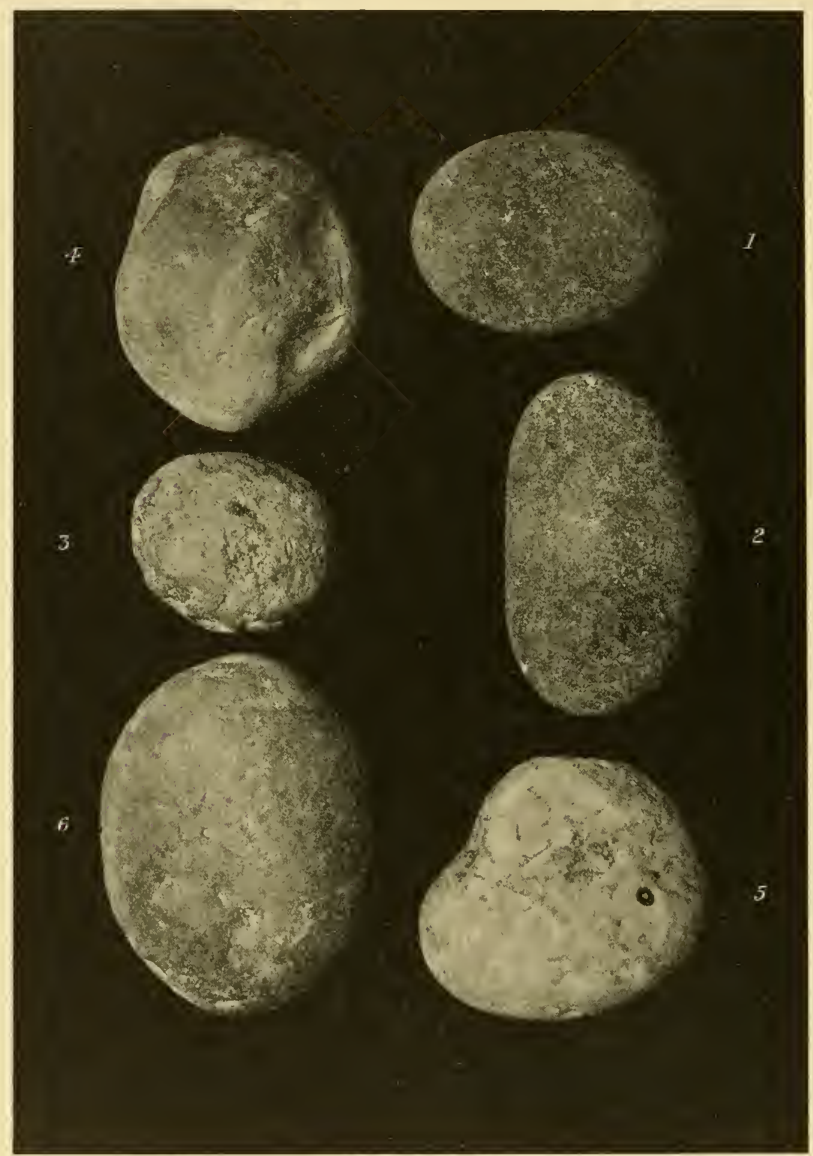

Fig. I46.-Rounded STONes From "Michael Sars" Station 95.

The evidence furnished by the igneous materials is no less remarkable. The plutonic rocks are represented by granites resembling those of Lower Old Red Sandstone age in Scotland and the north of Ireland, and also by a specimen of nepheline-syenite which cannot be matched 
with any known rock of this type in the North Atlantic basin. The lava-form and intrusive types of the basic materials have marked affinities with the tertiary volcanic rocks of the Inner Hebrides and the north of Ireland.

Of special interest is the evidence pointing to the conclusion that the rock fragments from this station must have been transported by floating ice during some phase of the glacial period. More than half of the specimens are glaciated, the larger part of the remainder are angular, and a number are well rounded. A typical example of one of the glaciated stones is shown in Fig. I45, which is a portion of a larger boulder broken off before being embedded. Irregular striæ appear on this specimen, but on one surface it is facetted and the striæ thereon are more or less parallel. It is noteworthy that the glaciated and ice-

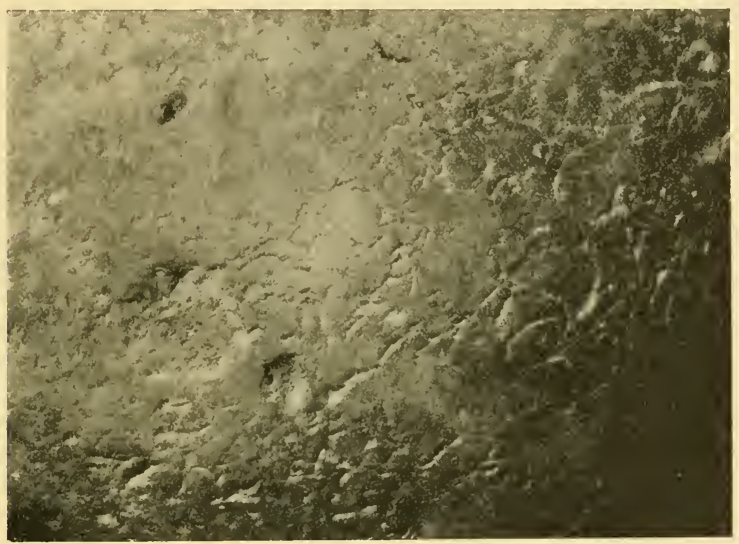

Fig. 147. - Surface of Specinen No. 4 IN Fig. I46, enlarged to show "CHATTER-MARKS."

moulded specimens include nearly every rock type represented in the collection from this particular station. The stones resemble those found in boulder clay or "moraine profonde," indeed in some instances the clayey matrix of this deposit has been cemented to some of them by calcareous matter.

Some of the rounded specimens, consisting of Silurian greywackes, carboniferous limestone, chalk-flint, dolomite, and vein-quartz, are shown in Fig. I46. These must have been rounded before they reached the position from which they were dredged.

An enlarged part of specimen No. 4 in Fig. 146 (chalk-flint) is represented in Fig. I 47, to illustrate the bulbs of percussion or "chatter-marks" which it displays. Such evidence indicates that the stones had originally been dashed against each other by torrent or wave action.

A careful examination of the specimens points to the conclusion that all had been partially embedded in a Globigerina ooze on the sea-floor, 
as shown by the attached marine organisms and by a slight coating of manganese oxide on the exposed parts. In Fig. I48, which represents a specimen composed of carboniferous limestone and chert, the arrow

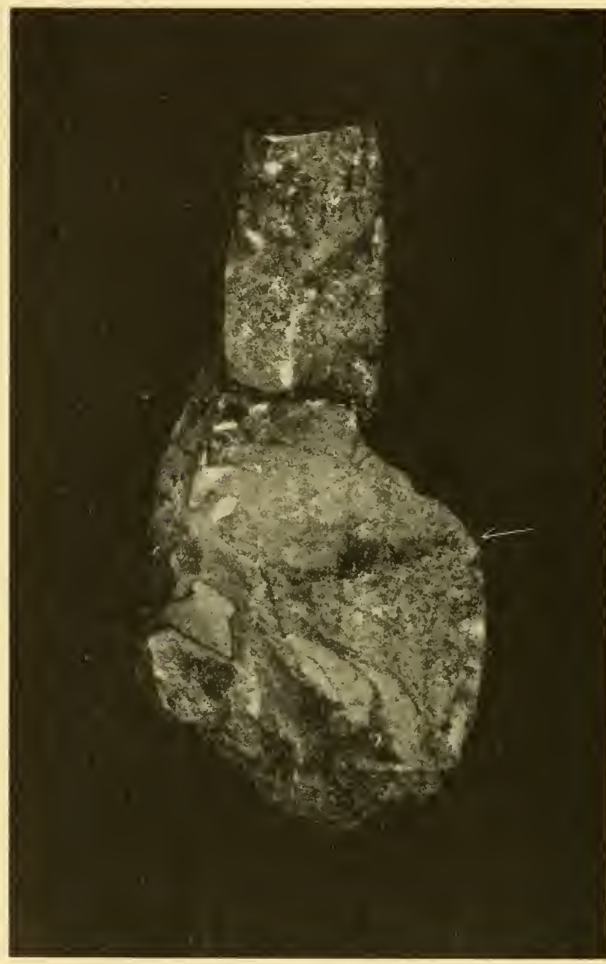

Fig. 148.-Stone With Staining of MANganese, The ARROW SHOWING THE POSITION OF THE SURFACE OF THE DEPOSIT IN WHICH THE SPECIMEN HAD BEEN EMBEDDED. in which they were completely buried. The stones would naturally be arranged along the lines of least resistance to friction, so that many would be entombed end on or edge on, like those illustrated in Figs. I49 and I5O. Subsequent current action has removed part of the material in which they were embedded, and has been powerful enough to prevent further accumulation of ooze at the spot where they were dredged. Since the ooze contains 37 per cent of insoluble material, the theory of the removal of the deposit by solution is improbable.

Among the materials distributed by human agency dredged from 
this station (95) about 200 specimens of furnace clinkers were found, Furnace together with fragments of unburnt coal, also a portion of an earthen- clinkers, coal, ware jar and a cannon-bone of an ox. This station lies along the route etc. of the Atlantic Liners, from which these specimens were probably dropped.

At Station IO, on the south side of the Bay of Biscay, and nearly 200 miles north of Cape Finisterre, at a depth of over I 5,000 feet, an assemblage of stones was obtained, numbering in all 339, most of which were glaciated and almost identical in lithological characters with those just described.

At Station 48 , lat. $28^{\circ} 54^{\prime} \mathrm{N}$., long. $24^{\circ} 14^{\prime} \mathrm{W}$., in about 2800 fathoms, chalk-flints and icemoulded metamorphic rocks were collected, showing that floating ice had dropped materials over that part of the sea-floor. They were associated with fragments of pumice carried thither by the descending branch of the Gulf Stream. An ear-bone of a finnerwhale was also found at this
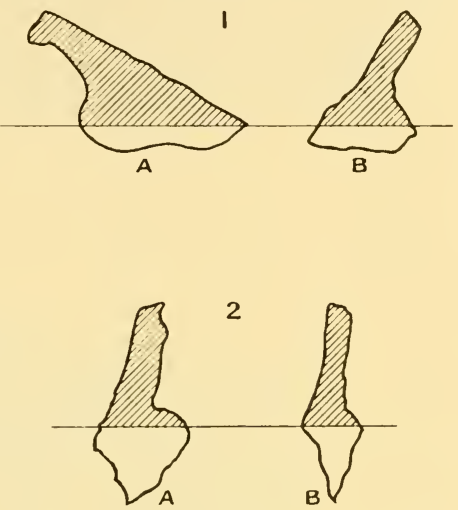
locality.

Just outside the Straits of Gibraltar, at Station 23, in 664 fathoms, a curious assortment of materials was dredged, comprising dead lamellibranch shells (some of them bored by gasteropods), barnacles dropped from whales, furnace clinkers, and an American blue point oyster that had fallen from a passing ship. The dead lamellibranch shells point to subsidence of that part of the sea-floor in recent geological times.

The materials dredged at Station 70, south of the Newfoundland Banks, in 600 fathoms, indicate that this part of the sea-floor is within the range of the present Arctic ice-drift.

The rock fragments obtained from Stations IOO and IOI, in 835 and IOI 3 fathoms, seem to point to the conclusion that they were transported thither by ice that passed over the Orkney and Shetland Isles.

Important evidence was gathered from the Wyville Thomson Ridge 
Rock fragments dredged by the "Knight Errant" and "Triton."

at depths ranging from 3 I 8 to 3420 feet during the expeditions of H.M. ships "Triton" and "Knight Errant." It suggests that the glaciated stones on the ridge are or have been embedded in a boulder clay. The stones are composed chiefly of Lewisian gneiss and the Moine schists lying to the east of the post-Cambrian displacements in the Highlands of Scotland. A large proportion consists of Caithness flagstones and other Old Red Sandstone rocks, like those occurring in place in the
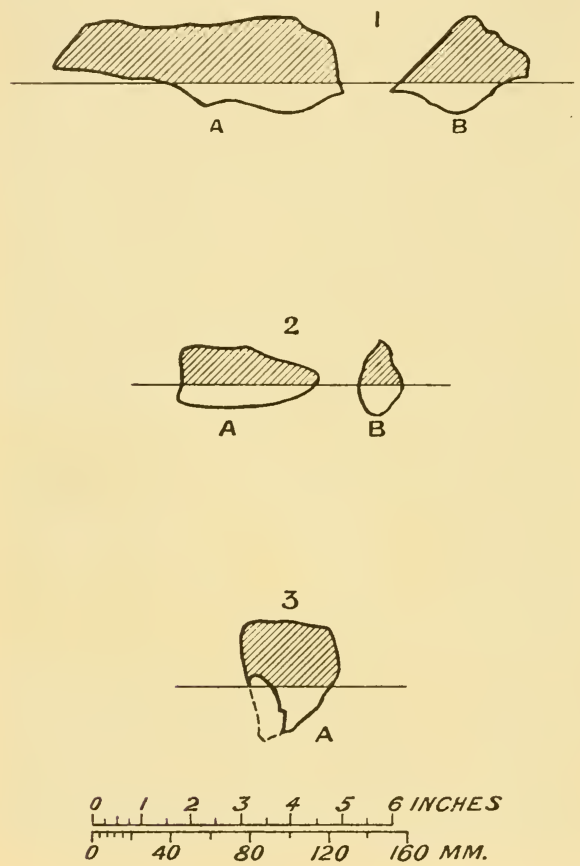

Fig. I 50. - DIAGRAMS DRAWN TO SCALE SHOWING POSITIONS OF STONES EMBEDLED IN THE DEPOSIT, THE SHADED PARTS INDICATING THE FORTIONS PROJECTING ABOVE THE DEPOSIT.

ooze are either red or green. The ooze also contained fragments of brown glass, resembling the slaggy volcanic rocks of Iceland. Such evidence suggests that some of the material found at this station was distributed by floating ice.

At Station 3 ("Knight Errant"), at a depth of $3 \mathrm{I} 8$ feet, many dead shells of shallow-water habitat were got, which clearly indicate a subsidence of the sea-floor since the glacial period. The absence of raised beaches in Orkney and Shetland, the submerged peat-mosses, 
the depth and steepness of the sounds between the Faroe Islands, the great depth at which the seaward extension of the fjords in Iceland cut the marine shelf, the submergence of shell banks between Iceland and Jan Mayen referred to by Nansen, all point to the same conclusion. In all probability there was either land connection with Greenland during the glacial period, or a confluent ice barrier which prevented the Gulf Stream from flowing into the Polar basin and deflected it towards the south.

J. M.

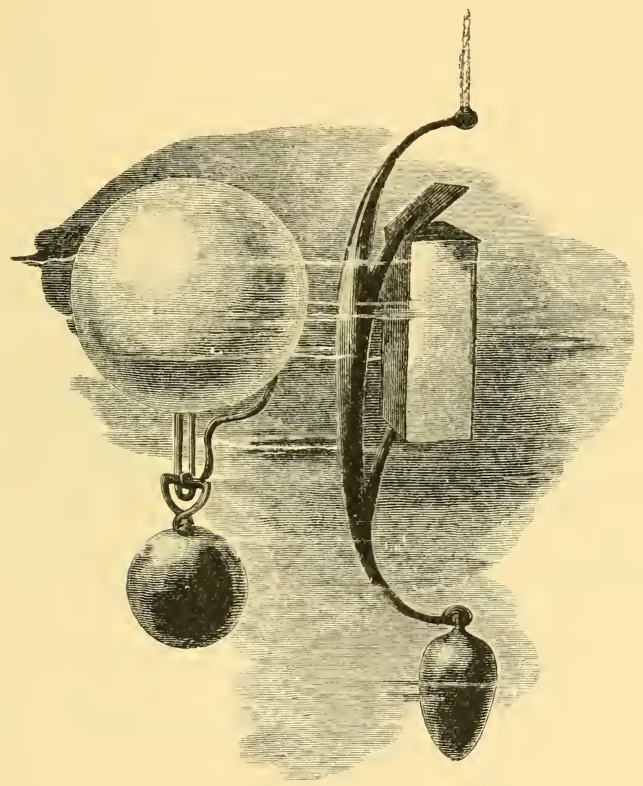

Hooke's Sounding Machine and Water-Bottle, 1667. (See page 2.) 


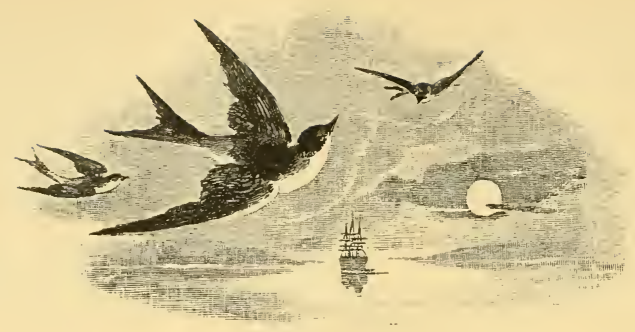

CHAPTER V

PHYSICAL OCEANOGRAPHY

In the middle of last century the idea of "physical oceanography" did not exist, but in the course of a few decades it has become a widespread branch of knowledge, with a copious literature and bulky text-books. A few figures may serve to show how important is the study of the sea. The waters of the globe cover more than two-thirds of its surface, and their volume is about $\mathrm{I} 300$ millions of cubic kilometres, or thirteen times that of all the land above sea-level. The mean height of the land is 700 metres, while the average depth of the sea is 3500 metres. Sea-water contains various salts in solution, the total weight of which is nine times that of the earth's atmosphere.

Difficulties in making oceanic observations.

Mechanical appliances necessary.

The reason why the ocean, which plays such an important part in the economy of the earth, has not been investigated until recently is because of the special difficulties which are encountered in making investigations. One great difficulty is, as has been previously mentioned, that it is impossible to observe directly what is going on beneath the surface, and it is necessary to have a special set of apparatus that can be relied upon. The methods have developed with phenomenal rapidity, but the observations are still few in proportion to the extent of the ocean, and consequently it is often difficult to obtain a complete and true image of the actual conditions. Many of the results obtained are therefore merely preliminary, and further study may alter our views on various points; for the solution of 
many important problems we have not yet sufficiently numerous observations. In a rapid sketch like this, only some of the principal facts can be dealt with; we shall first examine the methods employed in physical oceanography, and then endeavour to draw some conclusions from the observations available.

In the first place, one must have a line with which to send down the instruments and draw them up again. Formerly hemp lines were used, but they have now been superseded by wire; steel piano-wire is used for sounding, and wire rope for thermometers, water-bottles, etc. For general use the wire

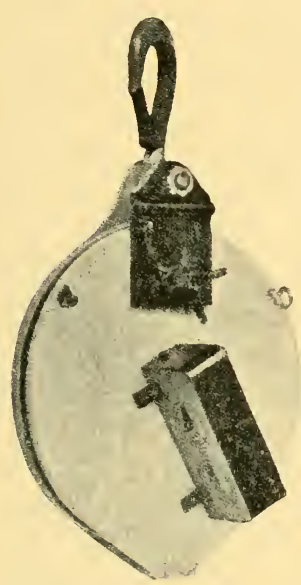

FIG. I5I.-METRE-WHEEL. need not be more than 2 to $3 \mathrm{~mm}$. in diameter, and it will, nevertheless, bear the weight of several hundred kilograms without breaking. The old hemp line was marked at regular intervals for the determination of the depth, but this cannot well be done with the wire, which is run out over the metre- or fathom-wheel Metre-wheel. (see Fig. I5I), and this is both a convenient and accurate method. The wheel communicates with a clock-work arrangement with dials and hands, by means of which the length of wire run out can always be read off correct to within a metre. When, however, an observation is to be taken at a depth of 1000 metres, it is not enough to run out Iooo metres of line. The line must be "up and down," and this is not always easily managed, especially in a wind or strong current, when the ship is drifting. Some manœuvring is then required, and the apparatus must either in itself be sufficiently heavy to straighten the line, or an extra weight must be added. Many of the instruments are so constructed that they may be attached to the side of the line as well as at the end, and thus several instruments may be used simultaneously. They are fastened at certain intervals on the line as it is being paid out, and a number of observations are made at the same time at different depths. By this method a comprehensive series of observations from the surface down to two or three thousand metres may be taken in a couple of hours. This method was employed during the "Challenger" Expedition. 


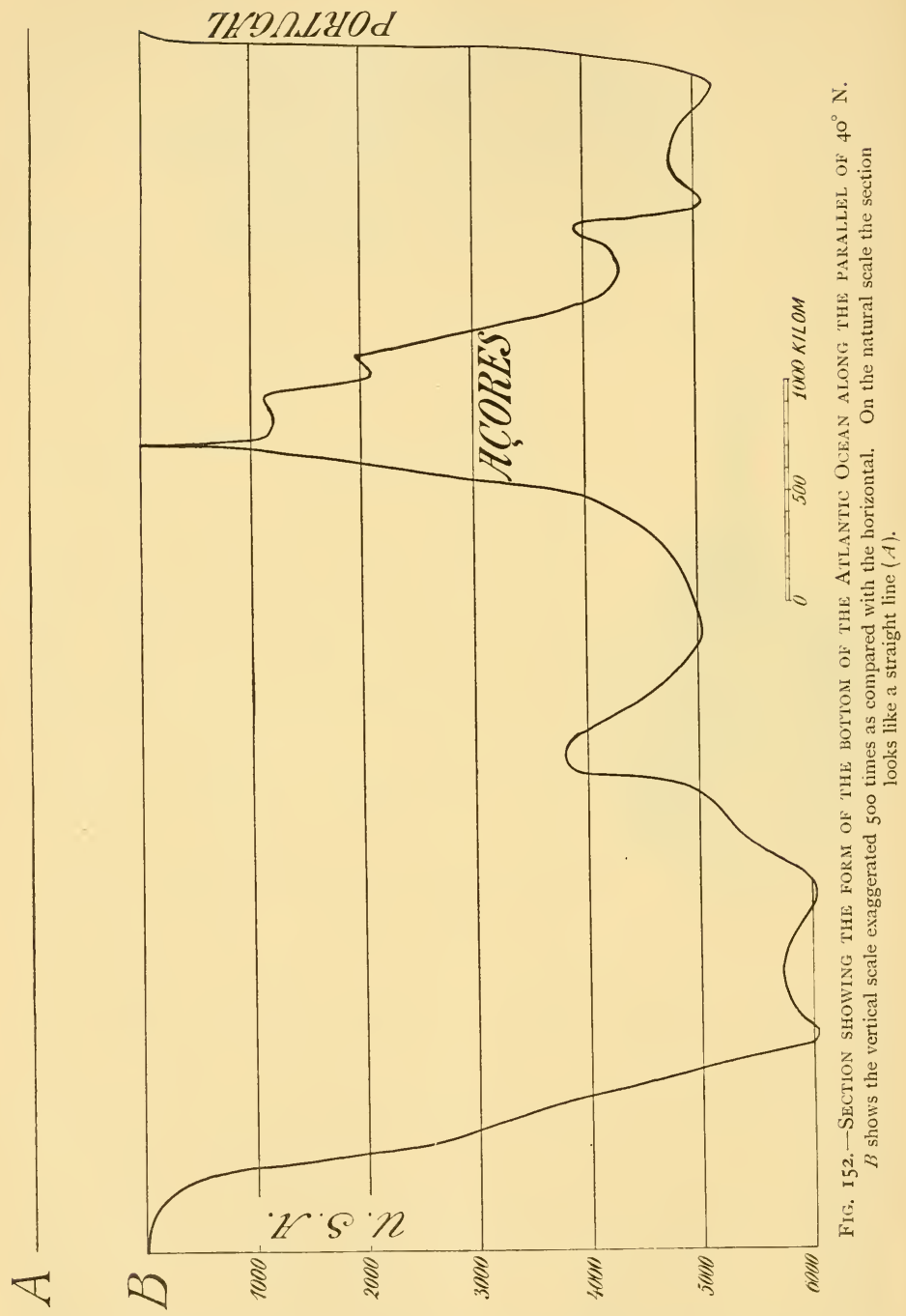

When several series of observations have been taken in a certain region, they are usually represented for diagrammatic 
purposes in horizontal plans and vertical sections. It is Toshow necessary, in order to be able to see anything in the sections, physical to exaggerate the scale of depth in comparison with the scale of horizontal distance. This is shown in Fig. 152 , which represents the floor of the Atlantic Ocean along the parallel of $40^{\circ} \mathrm{N}$. The upper line (A) shows the section drawn to the same scale for depths and horizontal distances; the variations in the depth are represented by a thin uneven line, indicating how relatively small is the depth of the Atlantic Ocean compared with horizontal distances on the earth's surface; the lower diagram (B) shows the section with the depths exaggerated 500 times. Drawing the depth on a larger scale brings out the details of the relief of the ocean-bed: thus off Portugal there is seen a narrow continental shelf, and then a rapid falling-off towards the deep water (the continental slope) ; farther west (about the middle of the figure) there is a corresponding slope, on the summit of which the Azores appear; then another fall towards the western basin of the North Atlantic, followed by the continental slope on the American side, where again a narrow continental shelf borders the coast. The continental shelf is seen to be wider on the American side than on the European side of the section. This exaggeration of the vertical scale allows of the representation of a number of details, but, of course, the lines look very much steeper than they really are. One must not imagine that the continental slopes are so marked as they appear in the figure, for the angle is usually not so much as two degrees, the slope being similar to that of our common roads and railways; real submarine precipices do occur, but mostly as rare exceptions.

At a comparatively early date it was known that the temperature of the sea-surface was strongly influenced by the currents. In the beginning of the seventeenth century, for instance, it was noticed that there was a sudden change of temperature on passing from the cold Labrador current south of the Newfoundland Banks to the adjacent warmer waters of the Gulf Stream. Benjamin Franklin, who made a careful study of the Gulf Stream (see Fig. 153), advised ships' officers to use the thermometer in order to find out when they entered the Gulf Stream, so that they might take advantage of the current when voyaging eastward, and steer clear of it when sailing westward.

The American naval officer M. F. Maury (1806-1873), Maury. 
one of the founders of physical oceanography, used the surface temperatures recorded from different places in the sea in his examination of the currents. He organised an extended collection of temperature-observations for the benefit of navigation; he studied the winds and the drift of vessels, and in the middle of the nineteenth century he published his $E x$ planations and Sailing Directions to accompany the Wind and Current Charts. He also wrote an extremely interesting book, The Physical Geography of the Sea and its Meteorology, which has appeared in many editions and in several translations. Maury's work had important consequences, for ship-masters following his directions shortened the voyage between North

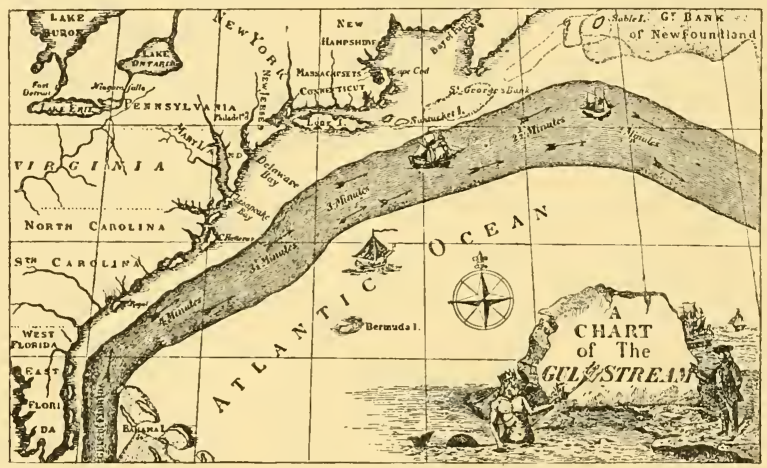

Fig. I53.-Benjamin Franklin's first chart of the Gulf Stream.

America and England by ten days, that from New York to California by about forty-five days, and that from England to Australia and back by more than sixty days. The profit derived from the use of Maury's charts by British ship-owners on the East India route alone amounted to ro million dollars yearly.

Log-books for recording observations at sea.

On Maury's suggestion it was decided, at an international congress at Brussels in 1853 , that numbers of log-books should be sent out with captains of ships for the purpose of entering observations of wind and weather, of currents, and of temperatures at the sea-surface. This plan has been followed ever since, the notes being as a rule entered once every watch, so that a formidable pile of material has now been amassed. Up to 1904 the Meteorological Office in London had collected 7 millions of these notes, the Deutsche Seewarte in Hamburg 
more than IO $\frac{1}{2}$ millions, the Dutch Meteorological Institute in De Bilt $3 \frac{1}{2}$ millions, the Hydrographical Bureau in Washington $5 \frac{1}{2}$ millions, and so on. Add to this the surface observations made by scientific and other expeditions, and it will be evident that in the course of the last sixty years a good deal of knowledge regarding the surface of the sea has been gained.

Making surface-temperature observations is very simple work. All that is necessary is to haul up a bucket of sea-water and measure the temperature by means of an ordinary thermometer. It is a far more difficult thing to record the actual temperature of the deeper layers. In I 749 Captain Ellis brought up water from I I 90 metres and from I 645 metres to the south of the Canaries, and, on measuring the temperature of the water inside the water-bottle after it had been hauled up, found it to be $17.2^{\circ} \mathrm{C}$. lower than the temperature at the surface. Some investigators coated their water-bottles with an insulating substance, so that the temperature might remain unaltered during the process of hauling up. This principle has recently been developed to a high degree of perfection in one of the water-bottles now most used, viz. the Pettersson-Nansen water-bottle, which will be described later.

Attempts were also made to insulate the thermometer itself by surrounding the bulb with a stout sheath of caoutchouc or wax. This insulated thermometer was lowered to the depth desired, where it was left for hours to assume the temperature of the water; it was then hauled up quickly and the temperature read off. In this manner de Saussure was able, in I780, to determine correctly the temperature in the Mediterranean at $5^{8} 5$ metres, finding it to be $13^{\circ} \mathrm{C}$. Thermometers made on this principle have been much used until our own times, but they have one serious drawback, for the operation takes a very long time, and this makes them unsuitable for use in expeditions, where the work must be done as quickly as possible; they may, however, do good service in cases where the very greatest accuracy is not required, and where there is unlimited time at disposal, as on light-ships.

Nearly a hundred years ago some one thought of employing Six's maximum and minimum thermometer for temperature observations in the sea, various modifications being introduced, until finally in 1868 it became quite serviceable as made by Casella under the direction of Dr. Miller. The Miller-Casella Nillerthermometer (see Fig. I 54) was the one principally used on board Casella. the "Challenger" and during other great expeditions. At the

Maximum and minimum thermometers. 
top there are two glass bulbs, united by a bent capillary tube ; the left-hand bulb is filled with creosote, the capillary tube contains some mercury, and the right-hand bulb constitutes a vacuum except for a little creosote. When the thermometer is heated, the creosote on the left side expands, driving the mercury through the tube so that it rises in the right-hand branch; the mercury lifts a small index, a pin

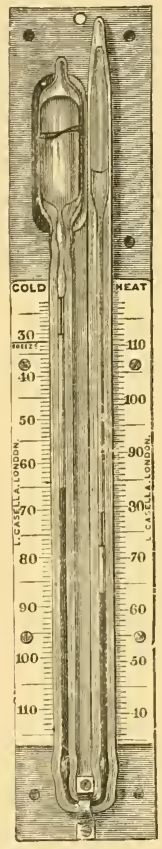

FIG. I54.

Miller-Casella THERMOMETER.
Reversing therinometers that is so constructed that it sticks at the place where the mercury leaves it. When the thermometer is cooled the creosote contracts, and the creosote-vapours in the right-hand bulb propel the mercury farther into the left-hand branch, where there is a similar index. In this way the index on the right shows the maximum temperature, and that on the left the minimum temperature. The thermometer is fastened to a rectangular plate carrying the temperature scale, and the whole instrument is put inside a protecting tube of copper. The maximum and minimum thermometer needs about twenty minutes for adjustment, and is slow enough not to change appreciably during a rapid hauling up from moderate depths, but if it has to be brought from great depths, erroneous results may be recorded, e.g. in waters where the temperature does not fall or rise uniformly towards the bottom. In Arctic and Antarctic seas, for instance, the temperature generally falls to a minimum at about 50 or 70 metres below the surface, rising to a secondary maximum at a depth of a few hundred metres, finally falling again towards the bottom, and this implies two maxima and two minima. In such a case Six's thermometer would show only the highest maximum and the lowest minimum encountered, and not the intervening values. This thermometer has, however, done very good service; it is, for instance, astonishing how correct the temperature determinations taken on board the "Challenger" have proved to be. In the great depths of the ocean the variations of temperature from year to year are so small that it is possible to verify now the observations of earlier expeditions.

The French physicist Aimé about seventy years ago introduced the reversing thermometer, which is caused-either by a 
sliding weight ("messenger") or by a propeller-release-to turn upside down at the depth where the temperature is to be determined. The temperature is thereby regis-

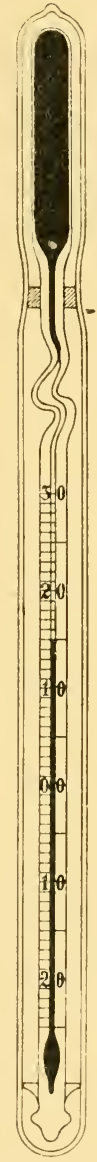

FIG. 155 .

NegretTI-ZAMBRA THERMOMETER, AFTER REVERSING. tered, and can be read off at any time after the instrument has been hauled up. Aimé's instru- Aimé. ment was, however, rather intricate. In 1878 Negretti and Zambra of London constructed a Negretti and reversing thermometer, which has played a Zambra. prominent part in physical oceanography. In this form there is a narrowing of the tube just above the bulb; the mercury fills the tube above the narrowing to a greater or lesser extent according to the temperature, and when the thermometer is tipped over, the mercury breaks off at the narrowing, the portion which was above that point sinking down to the end of the tube (Fig. I55); the scale on the tube indicates the temperature at the moment of inversion. The thermometer must be able to withstand the pressure of the ocean depths, and is therefore placed inside a strong glass tube, with some mercury round the bulb of the thermometer in order to secure a rapid conduction of heat.

The Negretti and Zambra reversing thermometer has latterly been widely used, but it has been found that occasionally the mercury broke off not exactly at the narrowing, but at some other place in the tube, while sometimes additional mercury might overflow during the process of hauling up. Certain improvements have therefore been introduced to remedy these defects, like the recent modifications by C. Richter of Berlin, who altered the breaking- Richter. off arrangement so as to render it quite trustworthy, and formed the tube in such a way that no superfluous mercury could enter it during the ascent (see Fig. I 56). The severed column naturally lengthens or shortens somewhat according to the temperature changes to which it is subjected: suppose, for instance, the thermometer to be reversed in water of $2.00^{\circ} \mathrm{C}$., and then hauled up through warmer water and read off in the air at a 
temperature of $20^{\circ} \mathrm{C}$., the mercury-thread would have expanded a little, giving a reading perhaps of $2.25^{\circ} \mathrm{C}$. instead of $2.00^{\circ} \mathrm{C}$. This secondary change is easily calculated when the temperature of the mercury at the readingoff is known, and so inside the protective tube Richter has placed a small auxiliary thermometer $(d)$, which gives the reading temperature, and thereby a correction for the reading.

In many cases it is necessary to have the temperature determined with the highest possible degree of accuracy, and Richter's reversing thermometer is very satisfactory in this respect. During the "Michael Sars" Atlantic Expedition the temperature series were taken almost exclusively by the aid of these thermometers, and in most instances two thermometers were used simultaneously, so as to make quite sure of the determinations. When the readings were corrected it was found that the mean difference between the values given by the two thermome-

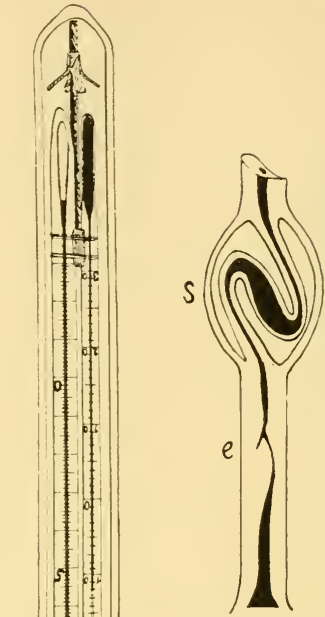

hermometer used simultaneously. 
ters in about 600 double determinations was only $\frac{1}{100^{\circ}} \mathrm{C}$., so that the temperature of the greatest ocean depths can now be determined with great accuracy.

A common form of reversing mechanism is a brass tube Reversing which can turn over within a frame. A pin retains the tube mechanism. (into which the thermometer is placed) in an upright position ; when the pin is withdrawn, the tube is tipped over by the aid of a steel spring. The pin is removed either by means of a propeller or by a messenger. The propeller is so adjusted that it does not move during the descent, but when the apparatus is pulled upwards it revolves, drawing out the pin along with it. Formerly this propeller-release was employed with many kinds of oceanographical apparatus, but it is not always reliable, especially in a rough sea, and the apparatus must be hauled up some distance before the propeller works. It is, therefore, gradually being superseded by the messenger, a small weight which is fixed on the line and let down after the apparatus has reached the desired depth. When the messenger reaches the reversing mechanism it knocks out the pin and the thermometer is turned upside down. One of the water-bottles used during the "Michael Sars" Expedition is reversed together with the thermometer; in other words, this water-bottle is a reversing mechanism for taking a temperature and a water-sample at the same time.

The Pettersson-Nansen water-bottle has a very high insulating capacity, and the temperature of the water-sample is not affected by conduction even when hauled up from a depth of several hundred metres, though the apparatus may be drawn through water-layers having very different temperatures. Pettersson originally used an ordinary thermometer, which was inserted into the water-bottle after it came up. Then Nansen thought of fixing a thermometer inside the water-bottle, and in this way the temperature at any depth was determined more easily as well as more exactly. The Nansen thermometer is very delicate, and is protected by a strong glass tube against the great pressure.

In making temperature-observations, however, one special precaution must be taken. When a liquid is exposed to great pressure its volume is slightly diminished, and, some heat being liberated, the temperature of the liquid rises. Lord Kelvin studied this question carefully, and arrived at a formula by which such changes of temperature may be calculated. Conversely, the volume of a liquid released from great pressure

PetterssonNansen water-bottle.

Effect of great pressure. 
increases, and by this process some heat is taken up which is drawn from the liquid, lowering its temperature. When, therefore, a water-sample is drawn up in an insulating water-bottle from a depth of 1000 metres, the temperature of the watersample sinks a little. Nansen first called attention to this fact, and has drawn up tables for the corrections according to Lord Kelvin's formula. The corrections prove to be quite considerable. When employing an insulating water-bottle, account must be taken, not only of the alteration of volume in the watersample, but also of that taking place in the solid parts of the water-bottle. A water-sample, for instance, brought up in an ordinary-sized Pettersson-Nansen water-bottle from a depth of 1000 metres in the Norwegian Sea, is cooled $0.06^{\circ} \mathrm{C}$. while being hauled up; a sample from the same depth in the Mediterranean is cooled o. 17 C. This difference is due to the fact that the amount of cooling depends on the temperature of the water, which at I000 metres in the Norwegian Sea is about $-\mathrm{I}^{\circ} \mathrm{C}$. and in the Mediterranean $+13^{\circ} \mathrm{C}$.

We are here confronted with a problem of considerable interest. When a body of water sinks from the surface down to great depths, its temperature rises a little because of the compression. The "bottom-water" of the Atlantic Ocean averages nearly $2 \frac{1}{2} \mathrm{C}$.; supposing that it has sunk from the surface to a depth of 3000 metres, it has been heated about $0.27^{\circ} \mathrm{C}$. in the course of its descent, by reason of the increasing pressure. If it should appear at the surface again, the reduction of pressure will have lowered the temperature by the same amount, $-0.27^{\circ} \mathrm{C}$. There are various other conditions which produce changes in the temperature, as, for instance, mixing with other bodies of water, in the upper layers absorption of solar heat, near the bottom possibly a very slight influence from the internal heat of the earth. It is, of course, difficult in such a combination of factors to single out the effects of one of them individually.

During the "Michael Sars" Expedition in the North Atlantic we made a certain number of observations in the deeper layers with a Richter reversing thermometer, which seemed to prove in several cases that the temperature increased slightly towards the bottom. The following extract from the "Michael Sars" tables shows the number of the station, the depth, the temperature (measured in situ), and the temperature that the water would acquire-on account of the reduction of pressure-if it were raised to the surface. The latter 
temperature has by the author of the present chapter been Potential called the potential temperature, a term used in meteorology.

\begin{tabular}{|c|c|c|c|}
\hline $\begin{array}{l}\text { Station. } \\
\text { Depth to the bottom. }\end{array}$ & $\begin{array}{l}\text { Depth of observa- } \\
\text { tion in metres. }\end{array}$ & $\begin{array}{l}\text { Temperature } \\
\text { in situ. }\end{array}$ & $\begin{array}{c}\text { Potential } \\
\text { Temperature. }\end{array}$ \\
\hline $\begin{array}{c}\text { I0 A } \\
4700 \mathrm{~m} \text {. }\end{array}$ & $\begin{array}{l}3000 \\
4500\end{array}$ & $\begin{array}{l}2.43^{\circ} \mathrm{C} . \\
2.55^{\circ}\end{array}$ & $\begin{array}{l}2.16^{\circ} \mathrm{C} . \\
2.08^{\circ}\end{array}$ \\
\hline $\begin{array}{c}49 \mathrm{C} \\
\text { about } 5400 \mathrm{~m} .\end{array}$ & $\begin{array}{l}395^{\circ} \\
495^{\circ}\end{array}$ & $\begin{array}{l}2.42^{\circ} \\
2.46^{\circ}\end{array}$ & $\begin{array}{l}2.03^{\circ} \\
1.92^{\circ}\end{array}$ \\
\hline $\begin{array}{c}63 \\
5 \circ 35 \mathrm{~m} .\end{array}$ & $\begin{array}{l}4000 \\
48_{50}\end{array}$ & $\begin{array}{l}2.35^{\circ} \\
2.37^{\circ}\end{array}$ & $\begin{array}{l}1.95^{\circ} \\
1.85^{\circ}\end{array}$ \\
\hline
\end{tabular}

From these and many similar observations it is seen that the temperature in the deepest strata of the North Atlantic is about $2 \frac{1}{2}^{\circ} \mathrm{C}$. (as a rule a little lower). The temperature of the deepest strata below 2000 fathoms appears to remain almost constant through long periods of time, the variations probably not amounting to more than a few hundredths of a degree. Very delicate instruments are necessary to detect them, and as yet we have insufficient observations to enable us to study the details.

It is apparent from the tables that the temperature would fall several tenths of a degree if the "deep-water" were raised to the surface without being heated by mixing on the way. This we have been able to prove in a direct way by means of the insulating water-bottle, which we used at Station 9 I at a depth of 4750 metres, the temperature inside the water-bottle after hauling up being only $2.00^{\circ} \mathrm{C}$., whereas the water at that depth was in reality several tenths of a degree warmer. When in situ the water has the temperature indicated by the reversing thermometer, but when brought to the surface it has the potential temperature nearly indicated by the thermometer inside the insulating water-bottle. Granted that no other change has taken place, the bottom-water must have had a temperature of about $2^{\circ} \mathrm{C}$. at the time when it began sinking down from the surface; as it sinks the temperature gradually rises, and at Station to $\mathrm{A}$, for instance, it was found to be O. I $2^{\circ}$ C. higher at 4500 metres than at 3000 metres. Some such increase of temperature towards the bottom has long been suspected as an effect of the internal heat of the earth; as early as about 1840 Aimé looked for it, but his methods 
were not sufficiently accurate. More recently several indications of a rise of temperature towards the bottom have been observed. The pressure and the internal heat having the same effect, it is difficult-at our present stage-to determine how much is due to the internal heat of the earth. In any case the bottom-water temperatures would be considerably lower but for the effect of pressure on the sinking waters.

It may be stated as a general rule that the temperature of

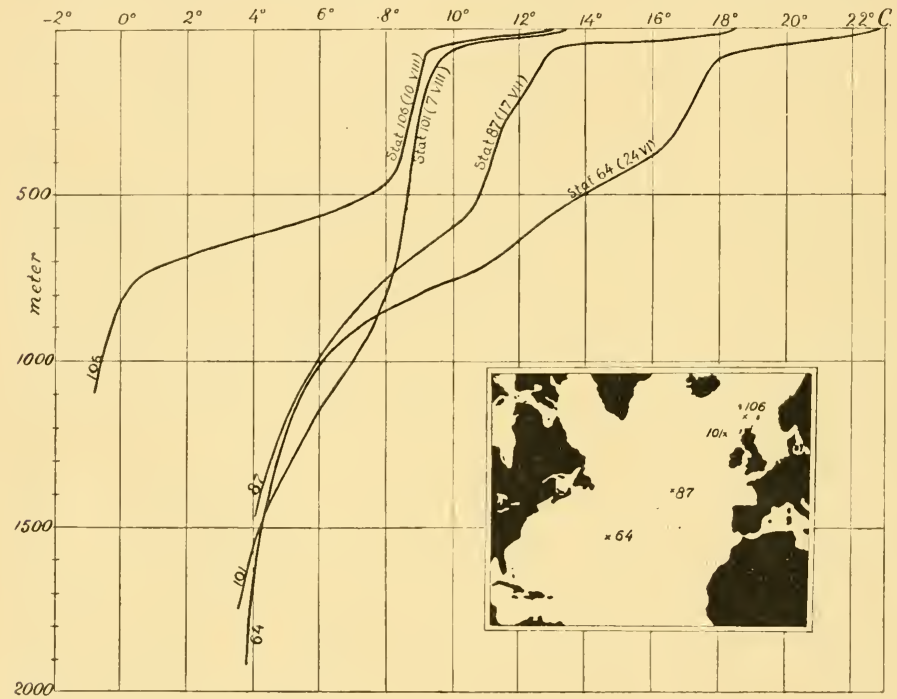

Fig. I57.-The Distribution OF Temperature at Four DifFerent Stations IN THE SUMMer OF I9IO.

The positions of the Stations are shown in the small inset map.

Decrease of temperature with increase of depth. ocean water is in summer highest at the surface, and decreases gradually towards the bottom. Fig. 157 shows the distribution of temperature as observed at four stations during the "Michael Sars" Atlantic Expedition, the position of the stations being indicated on the little inset map. Station 64 is situated in the Sargasso Sea westward of the Azores, Station 87 in mid-ocean between France and Newfoundland, Station ror between Scotland and Rockall, and Station 106 in the Faroe-Shetland Channel north of the Wyville Thomson Ridge. Station ro6 belongs to the region of the Norwegian Sea, whereas the other 
three belong to the Atlantic proper; Stations 87, Ior, and Io6 all lie within the precincts of the "Gulf Stream." At all four stations the temperature is highest at the surface: $22^{\circ}-23^{\circ} \mathrm{C}$. in the Sargasso Sea (24th June), over i $8^{\circ} \mathrm{C}$. at Station 87 (17th July), $13^{\circ}-14^{\circ} \mathrm{C}$. westward of Scotland ( 7 th August), and $13^{\circ} \mathrm{C}$. at the station west of Shetland (roth August). It is worthy of note that a temperature of about $13^{\circ} \mathrm{C}$. was observed at the surface near Scotland, while the same temperature occurred at a depth greater than 500 metres in the Sargasso Sea.

From the surface downwards the temperature falls very rapidly for the first 50 or 100 metres; at 100 metres it is from $4^{\circ}$ to $6^{\circ} \mathrm{C}$. colder than at the surface. Beyond 100 metres the temperature decreases at first much more slowly, then rapidly again, and then very slowly until the great depths are reached, where the temperature changes very little. The layers in which the temperature changes very rapidly are called "discontinuity-layers" (by the Americans "thermocline," and by the Germans "Sprungschicht"). They are particularly marked at Station 106, where there is such a layer immediately below the surface, and another extending from 450 to 750 metres. Between the two (from 50 to 450 metres) there is a fairly uniform stratum, and another one under the deeper layer, from 750 metres to the bottom. At the other three stations the upper discontinuity-layer is also very strongly marked, but the lower one is not so sharply distinguished from the adjoining water-strata.

It will be noticed that the temperatures in the deep strata (below 800 or 900 metres) were, at the same depths, nearly identical at the three stations in the Atlantic proper, the differences not exceeding $\mathrm{r}^{\circ} \mathrm{C}$., although these stations are situated far apart; but at Station 106 in the Norwegian Sea the temperature was $7^{\circ}-8^{\circ} \mathrm{C}$. colder. This is due to the form of the bottom, the Wyville Thomson Ridge separating the deep layers of the Atlantic from the deep layers of the Norwegian Sea, so that at a depth of 1000 metres the temperature is $6^{\circ}-7^{\circ} \mathrm{C}$. in the Atlantic Ocean, and below $0^{\circ} \mathrm{C}$. in the Norwegian Sea. That implies two widely different deep-sea regions: a warm one south of the ridge, and a cold one to the north of it, with great differences in the deep-sea fauna of the two regions. The influence of the Wyville Thomson Ridge is very clearly seen in a section across the ridge (see Fig. I06, p. I 24), from Station ror to Station 106; in the upper strata, down to 500 metres, there is little difference, but the deeper strata are like 
Decrease of surfacetemperature from equator to poles.

two different worlds, the Atlantic world south of the ridge, the Arctic world north of it.

The surface-temperature is naturally high in the equatorial regions, decreasing toward the poles, where it falls below $0^{\circ} \mathrm{C}$. Krümmel has calculated the mean surface-temperatures for each Io-degree zone throughout the great ocean basins, his figures for the North Atlantic being :-

\begin{tabular}{|c|c|c|c|c|c|c|c|}
\hline Zone & $0^{\circ}-10^{\circ}$ & $10^{\circ}-20^{\circ}$ & $20^{\circ}-30^{\circ}$ & $30^{\circ}-40^{\circ}$ & $40^{\circ}-50^{\circ}$ & $50^{\circ}-60^{\circ}$ & $60^{\circ}-70^{\circ} \mathrm{N}$. lat. \\
\hline Temp. . & 26.83 & 25.60 & 23.90 & 20.30 & 12.94 & 8.94 & $4.26{ }^{\circ} \mathrm{C}$ \\
\hline
\end{tabular}

It is interesting to compare this horizontal distribution of temperature with the vertical distribution in tropical waters. The following temperatures, for instance, were recorded by the German Antarctic Expedition in July I9I I, at a station in lat. $7 \frac{1}{2}^{\circ} \mathrm{N}$. in the middle of the Atlantic :-

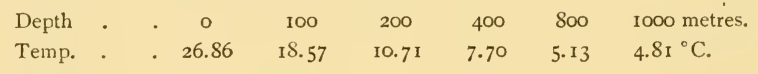

At a depth of Ioo metres the temperature is seen to be the same as the average surface-temperature in about $40^{\circ} \mathrm{N}$.; the mean surface-temperature at $50^{\circ} \mathrm{N}$. is the same as that found at 200 metres in the tropics, and the mean surface-temperature at $60^{\circ} \mathrm{N}$. corresponds to the temperature at a depth of $700-800$ metres in the tropics. In other words, we have a horizontal distribution of temperature from the equator towards the poles similar to what we have vertically from the surface towards the bottom in the tropics. Near the equator one need only send a thermometer down to 800 metres in order to find the same temperature that one would have to travel $60^{\circ}$ northwards to find at the surface, but the other physical conditions are widely different. In the deep water at the equator there is an enormous pressure and unchanging darkness, but at the surface far north and south there is a pressure of only one atmosphere and good light, at least in summer. Thus the physical conditions in the deep layers of the tropical waters are really very different from those at the surface towards the poles, and in consequence the conditions of life also differ; organisms living in the surface-layers of high latitudes are found in far deeper water in low latitudes, in so much as they are capable of adapting themselves to the excessive pressure and the infinitesimal quantity of light. Some organisms seem to be mainly dependent on the degree of light, the temperature being of less importance to them. We shall return to the questions of light 
and pressure, and the geographical distribution of animals, later on.

The high temperature at the surface evidenced by the curves in Fig. 157, is principally due to the absorption of heat-rays from the sun. In places the water is heated by contact with warm sea. air, but this source of heat is of less importance, the temperature of the surface-water being, as a rule, higher than the temperature of the air. The sun's rays penetrate into the water and are absorbed; the dark heat-rays are absorbed in the uppermost layers, while the light rays, which also convey a little heat, make their way down to a depth of several hundred metres before disappearing altogether. The action of the sun's rays is strongest in the tropics, declining towards the north and south, and this in a general way explains the distribution of the surfacetemperature.

A fine example of the heating action of the sun's rays is afforded by the Norwegian oyster-basins. Along the west coast of Norway there are in many places salt-water basins, separated from the outer fjord by a sill, which is covered only at high water. At the surface the water of the "poll"-as such a basin is called in Norway-is comparatively fresh, and consequently light; from a depth of about one metre to the bottom it is very salt and heavy. The sun's rays in summer penetrate into the water and heat it, mostly at the surface, but also to some extent down to a depth of a few metres. The surface-water is cooled during the night, but at a depth of one or two metres beneath the surface the heat will not be given off so readily, because the heavy water there does not reach the surface. When this has gone on for some time, the temperature at a depth of a few metres may be remarkably high, sometimes fully $35^{\circ} \mathrm{C}$., while the temperature at the surface might be about $20^{\circ} \mathrm{C}$. In these "polls" the surface-layer of relatively fresh water prevents the layers below from coming into contact with the cooling air, and such polls may indeed be compared to hot-houses, the fresh surface-layer corresponding to the fixed transparent roof, under which heat is stored. ${ }^{1}$ In these oyster-basins absolutely tropical conditions are developed in summer. It is significant that Gran once found in one of them a small crustacean, which according to G. O. Sars belongs to the Guinea Coast. Fig. I 58 shows the temperatures and salinities in an oyster-basin in the early part of the summer before

${ }^{1}$ Compare Murray and Pullar, Bathymetrical Survey of the Fresh-Water Lochs of Scotland, vol. i. pp. $5^{80}, 5^{8} \mathrm{I}$, and $5^{8} 7$, Edinburgh, I 910. 
Conduction of heat.

the maximum temperature has been reached, but already on the Ioth June (1903) the water of this poll is seen to be $5^{\circ} \mathrm{C}$. warmer at a depth of 2 metres than at the surface.

To understand how such a high temperature can be preserved for a length of time at a depth of 2 metres, one must bear in mind the fact that the conduction of heat plays an altogether subordinate part in the thermal conditions of the sea. Kelvin and Wegemann have made some calculations on the transmission of heat in water by conduction; Wegemann commences with a sea 5000 metres deep, with a temperature of $0^{\circ} \mathrm{C}$. throughout; the surface is supposed to be in contact with a

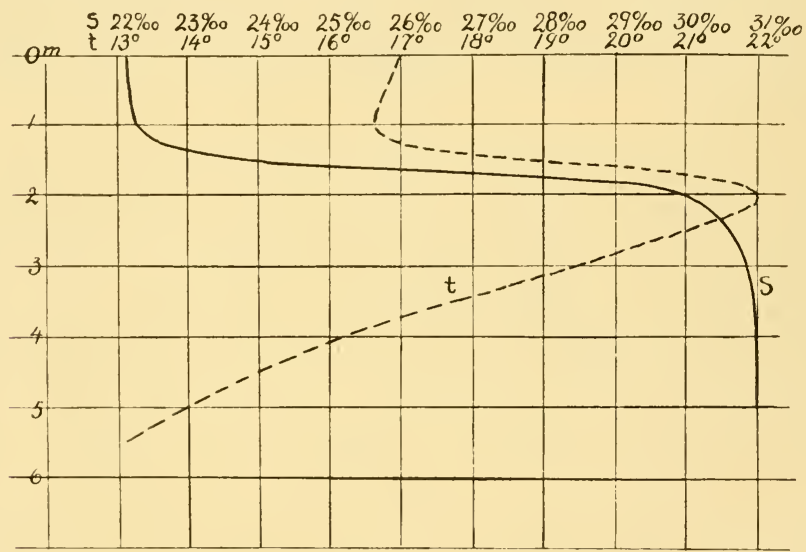

Fig. I58. - The Vertical Distribution of Temperature $(t)$ and Salinity $(s)$ IN THE KVERNE-POLL, IOTH JUNE I9O3.

source of heat at a temperature of $30^{\circ} \mathrm{C}$. No forces intervening other than conduction, no heating effect would be perceived at a depth of IOO metres after IoO years, and after 1000 years the temperature at 100 metres would only have reached $7.3^{\circ} \mathrm{C}$., and at 200 metres $0.6^{\circ} \mathrm{C}$. It is thus seen that transmission of heat by conduction is practically negligible in the sea. The heat conveyed by the sun to the uppermost water-layers cannot therefore be propagated into deep water by conduction, but only through movements of the water-waves, currents, convection "currents," etc. Where there is no such motion, and where the sun's rays cannot penetrate, heat cannot be transmitted by conduction, and hence we find temperatures as low as $2^{\circ} \mathrm{C}$. or less in deep water even under the equator. 
In winter, heat will be radiated from the sea-surface to the Radiation of colder air, and the temperature will be lowered. In Figs. I 59 heat from the and I 60 two maps of the North Atlantic, one for February and sea. one for August, are reproduced from Atlantischer Ozean, ein Atlas, published by the Deutsche Seewarte in Hamburg. In the February map the isotherm of $25^{\circ}$ C. runs from the Antilles towards the east and a little to the south, in the direction of Africa, whereas in August this line lies, in the western part of the ocean, as much as twenty degrees of latitude

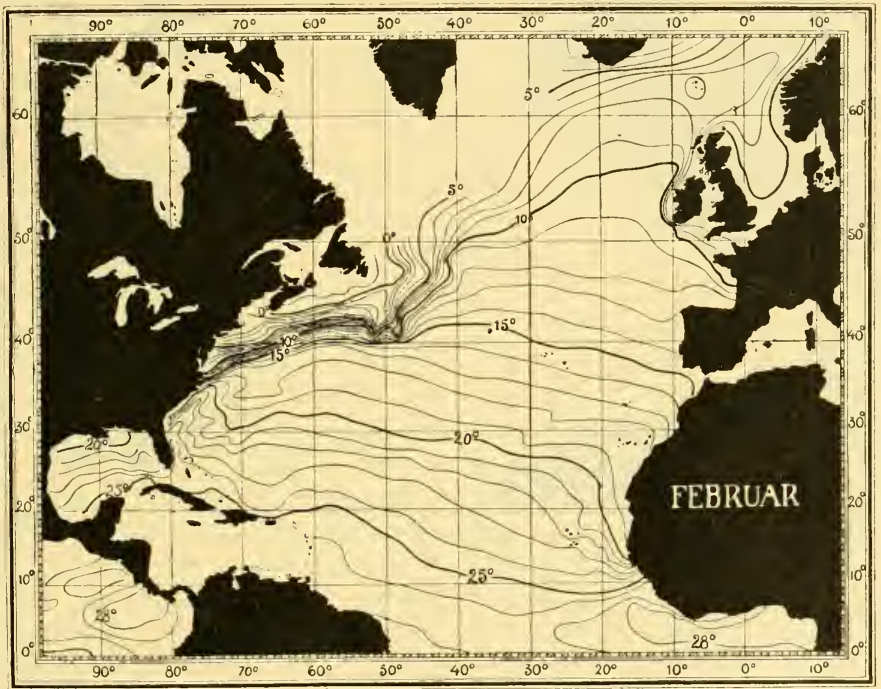

Fig. 159.-Surface Temperature of the North Atlantic in February.

farther north. In the same way the other isotherms have more northerly positions in summer than in winter. The difference between the surface-temperature in February and in August is about $5^{\circ} \mathrm{C}$., in some places less, in others considerably more. Near land the annual variations are much greater, as in the coast-water within the Norwegian skjærgaard ("skerryguard," literally: "fence of islands"), where the surfacetemperature in summer is $15^{\circ}-20^{\circ} \mathrm{C}$., and in winter only a few degrees above zero. Beneath the surface the variations gradually decrease, and at a depth of a few hundred metres no marked seasonal variations can be traced. 
At a certain depth a displacement of the seasons is often found. Repeated observations have been made by the "Michael Sars" at a station outside the entrance to the Sognefjord in different seasons and in different years. In I903. measurements were made at this station in the months of

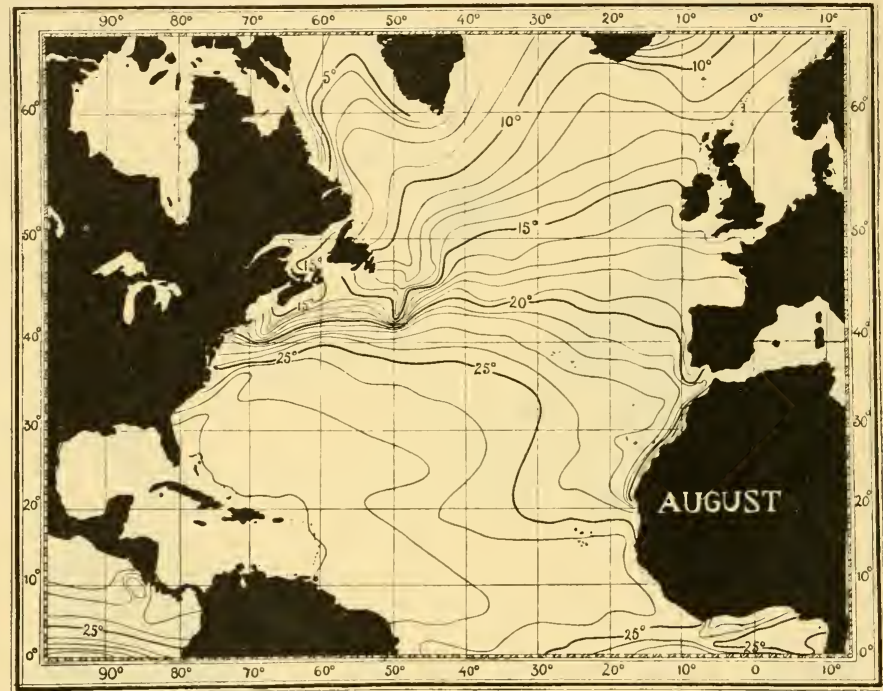

Fig. i6o. -Surface Temperature of the North Atlantic in August.

February, May, August, and November, and the following temperatures were found:-

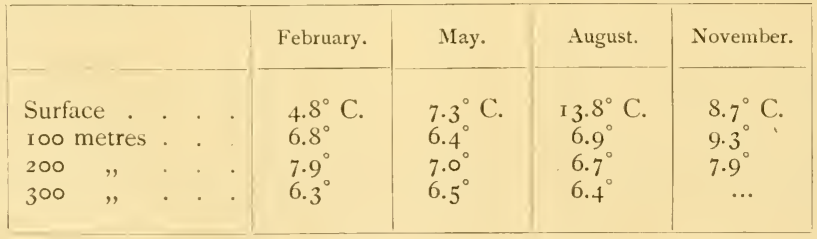

Reversal of seasons at a depth of 200 metres.

At the surface it was coldest in February and warmest in August - the difference being $9^{\circ} \mathrm{C}$. At 100 metres it was coldest in May and warmest in November, with a difference of $2.9^{\circ} \mathrm{C}$. At 200 metres it was coldest in August, warmest in February and November, the difference being $1.2^{\circ} \mathrm{C}$., so that 
at this depth the seasons were reversed: it was "winter" in the water in the middle of the summer, and "summer" in the middle of the winter. Murray's observations in Upper Loch Fyne in I 888 gave similar results. At 300 metres at the "Michael Sars" Station there were hardly any variations at all, the temperature being very much the same as the mean annual temperature of the air, as Nordgaard has shown to be the case with regard to the bottom-water of the Norwegian fjords.

When sea-water is cooled its density increases, and it often Vertical happens in winter that the surface-water becomes heavier than the water below. The surface-layer then sinks, and the undercirculation of ocean waters. lying water comes to the surface. By this vertical circulation the conditions are equalised, so that exactly the same salinities and temperatures are found as far down as the vertical circulation extends; wind and current aid in the process. This takes place especially from January to March; in April the weather again becomes warmer and the temperature begins to rise at the surface. A very good example of this phenomenon is afforded by the "Michael Sars" observations taken to the westward of Plymouth in April I910; at the very surface the temperature had risen slightly, but otherwise practically the same salinities and temperatures prevailed at every station down to a depth of I 50 metres or more. Later on in spring the surface temperature gradually rises, and a marked discontinuity-layer is formed. In many places near the coast, where the salinity is low at the surface and high beneath the surface, a brisk vertical circulation cannot be set up; the comparatively fresh water on top is so light that, even when considerably cooled, it does not change places with the salt and heavy water below. But farther out to sea the vertical circulation may extend down to a depth of 200-300 metres or more.

It is thus not only the surface-water that may give off heat Effect of heat to the air, but a great body of water extending to several hundred metres in depth, and hence the great influence of the sea on winter climates. The capacity for heat of water is very great compared with that of the air. Supposing that we have I cubic metre of water giving off enough heat to the air to lower the temperature of the water one degree, this heat would be sufficient to raise the temperature of more than 3000 cubic metres of air by one degree. An example will show the importance of this. Suppose a body of water, 700,000 square kilometres in extent and 200 metres deep, to give off enough heat to the air in winter to lower the water-temperature one 
degree, then the heat given off would be sufficient to raise the temperature of a stratum of air covering the whole of Europe to a height of 4000 metres on an average ten degrees. This Gulf Stream. explains how the Gulf Stream renders the climate of northern Europe so much milder in winter than would be expected from its northerly latitude. We shall see later on that the oceanographical researches of the last few years give reason to hope that it will even be possible to predict the winter temperature of northern Europe from the temperature of the sea some time in advance.

The salts of the sea.

Salinity determined from water. samples.

Obtaining samples from surface and shallow water
Obtaining samples from deep water.

Buchanan's stopcock water-bottle.
There are many different salts in the sea. Salinity means the total amount of salts in a given quantity of sea-water, and is usually stated in parts per thousand (per mille), indicating how many grams of salt are contained in one kilogram of sea-water. The salinity of the sea varies considerably both horizontally and vertically, and its distribution is determined by examining samples of water from different parts and different depths; these samples are secured by means of various water-bottles. From the surface a sample may be drawn with an ordinary bucket. For shallow waters down to 30 or 40 metres a common glass bottle is often employed; the line is bound to the neck of the bottle and a weight is suspended underneath. The stopper is fastened to the line a little way above the bottle, and is inserted when the bottle is lowered. When this simple water-bottle has arrived at the depth from which the sample is to be taken, the line is given a sharp pull, so that the stopper is drawn out and the bottle fills. In hauling up, a little water from the upper layers may, of course, enter the bottle, but this simple method does well enough for shallow water near land, where the variations are so great as to render extreme accuracy unnecessary.

Many varieties of water-bottles for investigations in deep water have been constructed. A few of those most in use, and most effective in working, may be described, and the different principles involved explained.

We will begin with an apparatus designed by J. Y. Buchanan for the "Challenger" Expedition, a so-called stopcock water-bottle (Fig. 16I). It consists of a brass tube (A), which can be closed at both ends by means of metal stopcocks $(B, B)$; the latter are, through two levers $(\mathrm{D}, \mathrm{D})$, connected with a rigid $\operatorname{rod}(\mathrm{O}, \mathrm{O})$. When the side-rod is in the upper position, as seen in the lefthand and central figures, the cocks are open. 
(E) is hinged on to the rod. In the left-hand figure the plate is tilted upwards, and it remains in that position while the

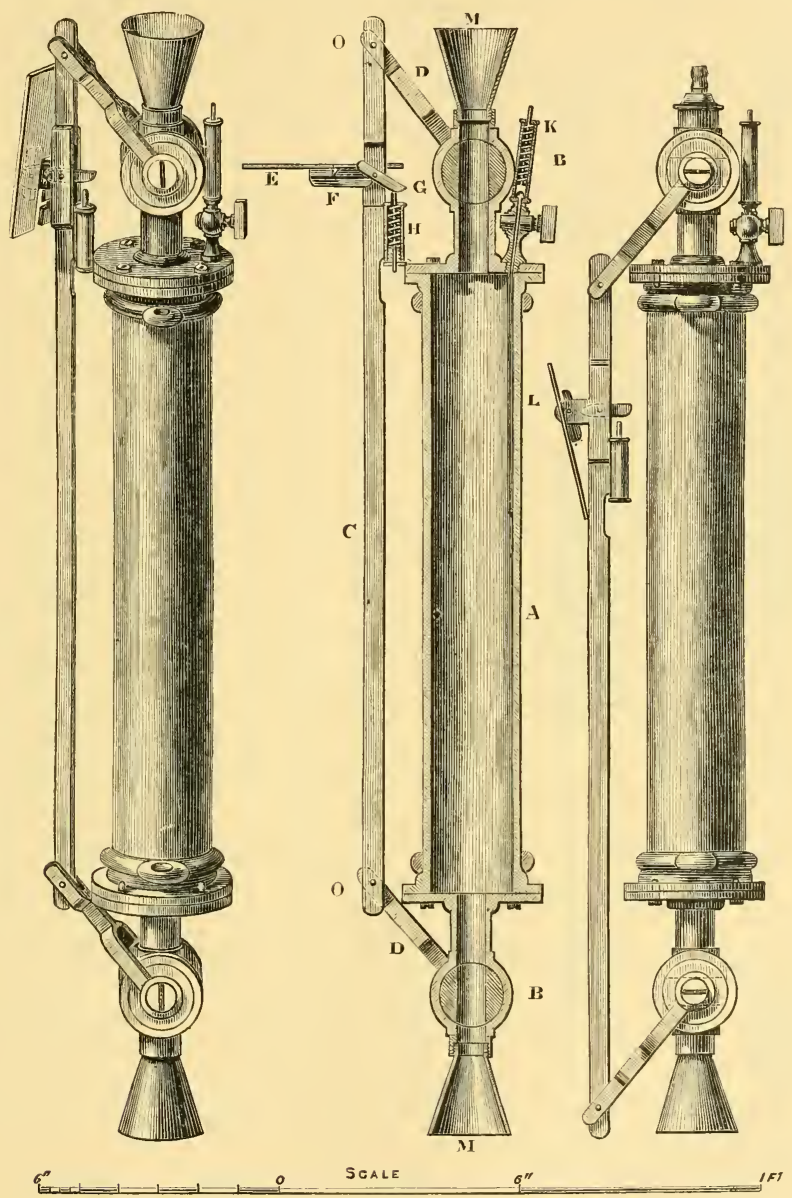

Fig. 16i.-Buchanan's Stopcock Water-Bottle.

apparatus is being lowered. But as soon as it is pulled upwards the water presses against the plate, tilting it into the position shown in the middle figure; the rod is then forced downwards, 
and along with it the levers, closing both stopcocks simultaneously. The plate then falls into the position seen in the right-hand figure. This simple arrangement allows of enclosing a water-sample at any depth required. This water-bottle has done very good service; it was much used on board the "Challenger," and has also-with a few small improvementsbeen employed a good deal in later times.

In a stopcock water-bottle of this construction the temperature of the water-sample may alter during the haulingup process, and it is impossible to get a record of the temperature in situ with the water-sample, without having a special apparatus for the thermometer. Buchanan himself, and later on Nansen, modified this water-bottle by adding an arrangement for a thermometer, which would be reversed the moment the cocks

Pettersson's insulating water-bottle.

PetterssonNansen water-bottle. were closed. In the meanwhile Otto Pettersson had adopted F. L. Ekman's old idea of making a water-bottle which should be insulating, so that the water-sample would retain its temperature unchanged, even when drawn up from a great depth. Pettersson availed himself of the circumstance that the water itself is an excellent insulator, its power of conduction being small and its capacity for heat very great. This waterbottle consisted of a bottom-piece, a cylinder, and a lid; these three parts could be separated by lifting up the cylinder and the lid along two brass rods forming the sides of the encompassing frame. The cylinder is a composite one; inside a strong cylinder of ebonite there are various other cylinders of celluloid and brass, one inside the other like a set of Chinese boxes. Between these concentric tubes are narrow cylindrical spaces which fill with water when the apparatus is lowered into the sea, and in this way a system of excellent water-insulators is formed. The outer cylinder may alter in temperature considerably in the course of hauling-up, the inner ones less and less, until in the central chamber the temperature will not change at all for some time, although the water-bottle be strongly heated from without. On the bottom and on the lid Pettersson attached a number of parallel plates, which likewise enclose insulating water-layers.

Nansen has introduced several improvements, and the latest model-the so-called Pettersson-Nansen water-bottle-is an excellent apparatus, which is now very widely used (see Fig. I62). On the left it is seen open, as it is let down into the water; the lid is suspended in the upper part of the frame, and supports the cylinders as well as a weight hanging below the 
apparatus. When a messenger is sent down the line and strikes the water-bottle, the lid is released, and the weight draws both lid and cylinders down, clasping the apparatus together and closing it hermetically. The right - hand figure shows the water-bottle closed and ready for hauling up. The Nansen thermometer is seen in the lefthand figure, and is - as mentioned above - a thin delicate instrument, fitted inside a strong protective glasstube in order to withstand the enormous pressure of the deep sea. The Pettersson-Nansen water-bottle is so well insulated that the temperature of the water-sample is not influenced from without, even when being hauled up from a depth of 1000 metres. But the temperature is lowered slightly, in consequence of the reduction of pressure during the process of hauling up, as has already been mentioned. This circumstance asserts itself quite appreciably in the case of the insulating water-bottle when used at great depths. The water-bottle is, however, fitted with a frame for carrying a reversing thermometer, so that a double determination may be made. During the "Michael Sars" Expedition we very often employed the insulating water-bottle, and took temperatures both with the Nansen thermometer and with the Richter reversing thermometer simultaneously. As an example, an observation made at Station IOI in I 400 metres may be mentioned: after correction the
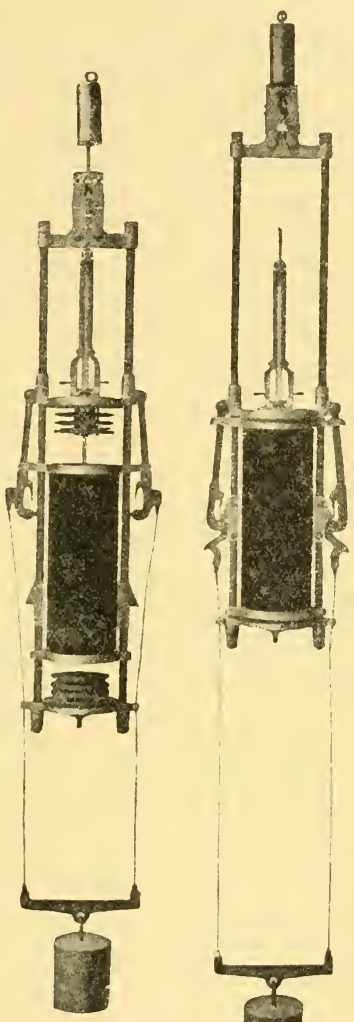
Nansen thermometer read $4.45^{\circ} \mathrm{C}$., the Richter thermometer $4.59^{\circ} \mathrm{C}$, that is $0.14^{\circ} \mathrm{C}$. lower in the first case than the second. The water in the water-bottle should, according to the calculation by Lord Kelvin's formula, have been cooled $0.12^{\circ} \mathrm{C}$; granting that the determinations 
Ekman reversing water-bottle. are absolutely correct, the cooling of the solid parts of the apparatus accounts for the difference of two-hundredths of a degree, which is a very probable value. This is an instance chosen at random from a vast number of observations, and proves how accurately deep-sea temperatures can now be determined.

V. W. Ekman has constructed an apparatus to serve as a reversing mechanism and a water-bottle at the same time. The apparatus is made of brass, and consists of a frame carrying inside a cylinder pivoted on an axle at the middle of the frame (see Fig. I63). At either end of the cylinder there is a lid, to which are attached two pairs of levers fastened to the frame near the axle of the cylinder. The cylinder can be placed in such a position that both lids are open, and it is kept in this position by means of a small pin, seen at the top of the frame on the right. Thus adjusted the water-bottle is let down into the sea. A messenger is sent down after it and knocks out the pin ; the cylinder is poised in such a way that it turns over in the frame. The levers gradually draw the lids closer, and when the cylinder is wholly reversed it is held fast by a catch and encloses the water-sample hermetically. To the side of the cylinder is attached a metal sheath for holding a reversing thermometer, which is consequently reversed along with the water-bottle. This apparatus may be fastened anywhere on the line, and a number of them may be used at the same time, in which case the messenger-release is arranged in the following manner: In the figure a messenger is seen hooked on to a small bar underneath the water-

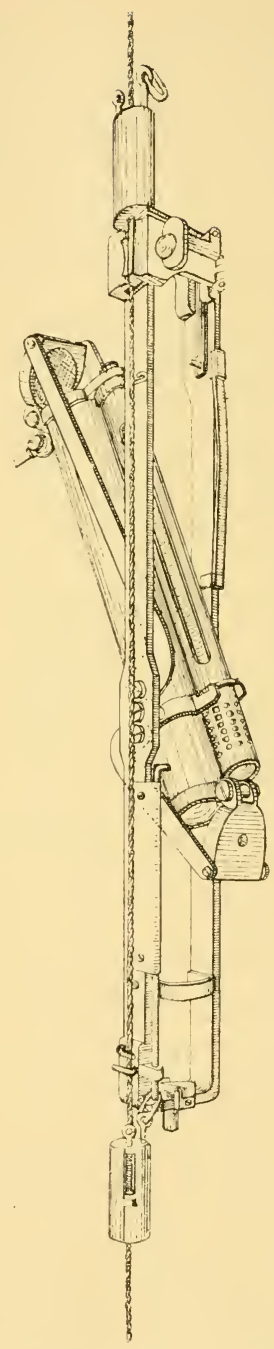

FIG. I63.-EKMAN's REvERSING

WATER-BOTTLE IN PROCESS OF BEING REVERSED, AND SHORTLY AFTER BEING RELEASED, 
bottle; when the water-bottle is reversed the bar is withdrawn, and the messenger is let go. The next water-bottle is knocked over, releasing in its turn the following messenger, and so on. It is indispensable with this, as with all other water-bottles, that when closed it should be absolutely water-tight, otherwise water might get in from the higher layers and vitiate the sample. ${ }^{1}$

The water-sample, when brought on board, may be dealt with at once, and its salinity, etc., determined, but it is generally the best plan to store the samples for examination in a shore laboratory. In this case the samples must be preserved absolutely air-tight, so that they shall not suffer any change in the interval. As a rule, the water may be kept in good glass bottles with lever stoppers, like those used in soda-water bottles. Cork stoppers will not do, unless capped with paraffin or wax, as it is difficult to avoid some degree of evaporation which would invalidate the results.

The chemical composition of sea-water has been very carefully determined. Wellnigh all known elements are found in Chemical composition solution in the sea, but most of them in such small quantities as to be detected only by the most delicate methods. A kilogram of sea-water contains about 35 grams of solid substances altogether; the quantity varies slightly in different places, but on an average there are about 35 weight-units of solids in 1000 weight-units of sea-water (35 per thousand). According to the results of Dittmar's analyses of the "Challenger" water-samples there are on an average in Iooo grams of seawater :-

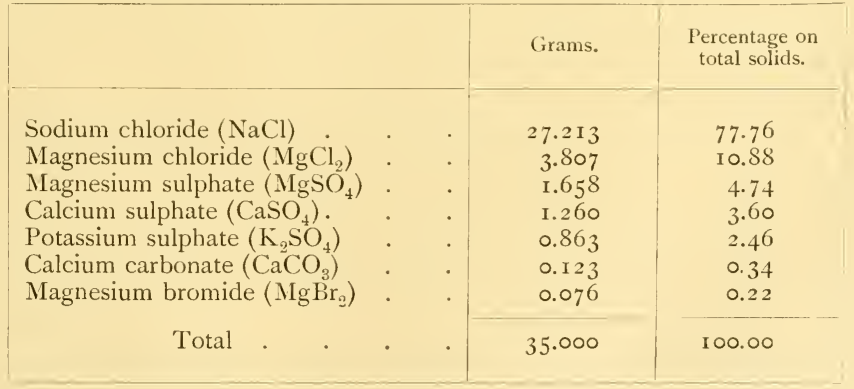

1 The highest perfection must be exacted with regard to this point. It formerly frequently occurred that the instruments leaked a little; as the knowledge of the sea has grown, many 
The numerous other substances in solution are present in such extremely small quantities that they may be disregarded. Although the total salinity may vary widely, the composition of the dissolved solids proves to be practically the same everywhere. Hence if in a sea-water the percentage of any one component, say chlorine, be known, the total salinity can be ascertained by calculation.

Determination

The direct determination of salinity by evaporating a known of salinity.

volume of water to dry ness does not give accurate results, unless the amount of chlorine is carefully determined before and after the evaporation, because in the last stages of evaporation and in drying the residual salt uncertain amounts of chlorine are disengaged in the form of hydrochloric acid. Such a determination is very circumstantial, and it is therefore necessary to resort to indirect methods, which may be physical or chemical.

An old-established physical method consists in determining the density by means of the hydrometer. This is a glass cylinder which floats in the water and has a graduated stem, on the scale of which densities are read off. The temperature of the water must be determined at the same time. Densities so found are recalculated by means of tables to a standard temperature, generally $17.5^{\circ} \mathrm{C}$. Now, owing to the uniform composition of sea-salts, a definite density at $17.5^{\circ}$ corresponds rigidly to a definite salinity. Hence by referring to tables the salinity of a sea-water can be found from its density at standard temperature.

The hydrometric method is easily applied on board ship, and may be made to give densities correct to four places of decimals. Densities can be determined to a yet higher degree of accuracy by means of the pycnometer, but this method is practicable only in a laboratory on land, and is not often employed.

Two other physical methods have been tried by way of

errors have been detected in earlier determinations referable to the leaky condition of the water-bottles.

When the forms of apparatus described above are to be used, the vessel must be stopped and hove to as long as the work goes on. Recently several investigators have studied the problem of constructing a , apparatus to be used while the ship is under way. Water-bottles have been made which can be let out when the ship is going at full speed, with the line running freely so as to allow them to sink. On checking the line the apparatus is closed by a mechanisin like that used by Buchanan in his water-bottle. The water-bottle being insulating, a temperaturereading is secured together with the water-sample. In such an experiment a metre-wheel showing how much line has run out is no use; one must have a special depth-gauge, usually one to measure the compression suffered by a certain volume of air from the weight of the water. These new instruments are not in common use as yet, being still in the experimental stage, but the time is not far off when we shall have automatic water-bottles working with absolute precision. That will mark an important step forward, as much time will then be saved in an expedition. 
experiment, but are not in general use. The one consists in measuring the refractivity of the water, i.e. the deflection undergone by a ray of monochromatic light when passing from air to water; this quantity, again, stands in definite relation to the salinity of the sample. The other method is based on the electrolytic conductivity of sea-water, and has the advantage that no sample need be brought up, a pair of electrodes being simply sent down to any required depth and the readings being taken on board. This method has been applied by Martin Knudsen with good results in shallow water.

The most convenient, and on the whole the most satis- Chemical factory, method of determining salinity is a chemical one, and is based on the fixed relation between the chlorine contained in a sea-water and its total salinity.

The amount of chlorine can be determined by a rapid and easy method. When a solution of silver nitrate is added to Chlorine sea-water, the chlorine is thrown down as a white precipitate of silver chloride. If a few drops of yellow chromate of potassium are added it is easy to see when all the chlorine is precipitated, for the silver nitrate will then act on the chromate so that the yellow colour is changed into red. When the chlorine content of a water-sample is to be determined, a certain quantity (e.g. I 5 c.c.) is measured off and poured into a glass; a few drops of the yellow chromate solution are added as an indicator, and then nitrate of silver from a burette, that is, a graduated glass tube with a stopcock (for discharge) at the lower end (see Fig. 164). When the red colour appears, the burette is read off to find out how much silver solution has been added, and it is easy from this value to calculate the amount of chlorine. From Knudsen's Hydrographical Tables the salinity or the specific gravity, corresponding to this chlorine-value found by titration, may be determined. All this can now be done quickly and accurately; in fact, the salinity of a water-sample is determined in less than five minutes to within about $\frac{1}{100}$ per mille, i.e. I centigram of salt per kilogram of sea-water. The modern method of chlorine titration is a great improvement on former methods, and it has been much used in recent oceanographical work, thousands of such determinations being now made yearly.

The density of sea-water depends both on the salinity and Density of on the temperature; the water is comparatively light when the salinity is low and the temperature high, and increases in density with a rise of salinity and a fall of temperature. 


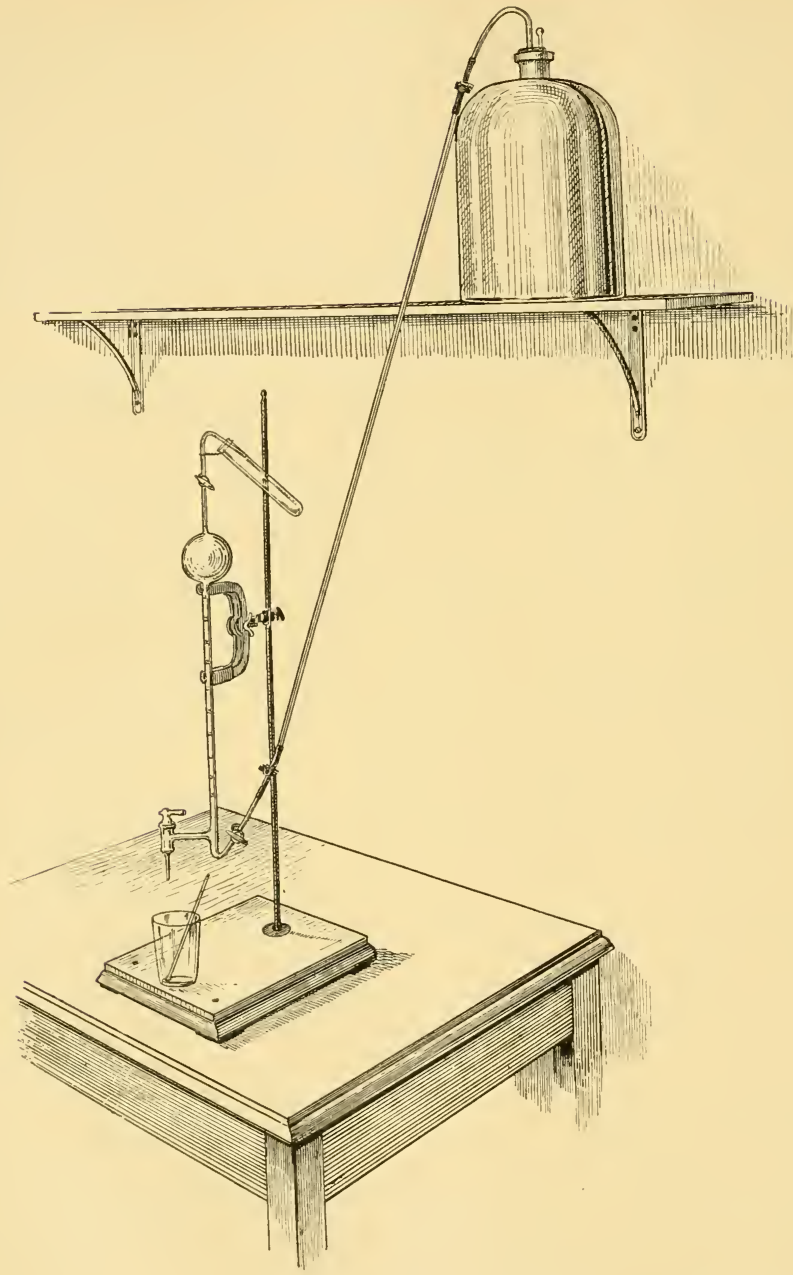

Fig, i64. - Titration Apparatus.

On a shelf there is a large bottle for the silver solution, which can flow through a glass tube into the burette; the latter is provided with cocks for regulating the inflow and the outflow of the solution.

Fresh water has its greatest density at $4^{\circ} \mathrm{C}$., which is taken as unity. Salt water becomes heavier the lower the temper- 
ature, the density of sea-water with a salinity of 35 per thousand and at a temperature of $0^{\circ} \mathrm{C}$. being 1.028 I3. By means of Knudsen's Tables the density is quickly found when both salinity and temperature are known. The value of most interest to us is the density at the potential temperature (see above, p. 22 I) corresponding to the temperature in situ. It has been found that this density always increases from the surface downwards to the bottom, even when the compression is left out of account. If this were not so, in order to attain equilibrium the heavier overlying water and the lighter underlying water would have to change places, and this is what actually takes place in winter, when the density at the surface exceeds that of the waters below. The layers will always arrange themselves in such a way that the lighter water is on the top and the heavier water underneath.

Salt water freezes at a lower temperature than fresh water; Freezingthus sea-water with a salinity of 35 per thousand freezes at point. $-1.9^{\circ} \mathrm{C}$., so that temperatures below zero are found in the sea, $-\mathrm{I} \frac{1}{2}^{\circ} \mathrm{C}$., for instance, being a common temperature in the polar currents. When the salinity exceeds 24.7 per thousand the water becomes heavier on being cooled, until the freezing-point (below zero) is reached. This implies an essential difference between salt water and fresh water. In the deep water of lakes temperatures below $4^{\circ} \mathrm{C}$. are never found, while in the bottomwater of the ocean considerably lower temperatures prevail, as, for instance, $-\mathrm{I}^{\circ} \mathrm{C}$. or still lower recorded in the Norwegian Sea, and about $+2^{\circ} \mathrm{C}$. recorded in the Atlantic. Thus it is, as a general rule, colder in the great depths of the ocean than it is at the bottom of deep lakes.

We shall now indicate in a general way the distribution of salinity. It must be remembered that the salinity is raised by evaporation, and lowered by dilution with fresh water either from rainfall or from rivers. Where the evaporation outweighs the supply of fresh water the salinity increases, as is the case, for instance, in the Mediterranean and in the Red Sea, where the air is dry and hot, and in the ocean north and south of the equator, where the warm trade-winds blow, producing a strong evaporation. In such places a high salinity will be found. There is a steady inflow of Atlantic surface-water with a salinity of about 36 per thousand into the Mediterranean Sea, where the water removed by evaporation is far greater than the supply of fresh water, so that the salinity rises to 38 per thousand, accompanied by an increase in density, which is accentuated by the

Distribution of salinity.

Mediterranean. 
cooling down in winter, and the surface-water becomes so heavy that it sinks and forms the bottom-water of the Mediterranean.

Coastal districts.

On the other hand, there are coastal districts where the many large rivers constantly carry more water into the sea than what is evaporated from it. In such places the salinity is decreased, as, for instance, off the coasts of Scandinavia. A great part of the rain falling in Northern and Central Europe, as far south as the Alps, is carried by rivers into the Baltic and the North Sea, where it is mixed with the salt water, producing the so-called "coast-water" of comparatively low salinity. The density of the coast-water is so low that it

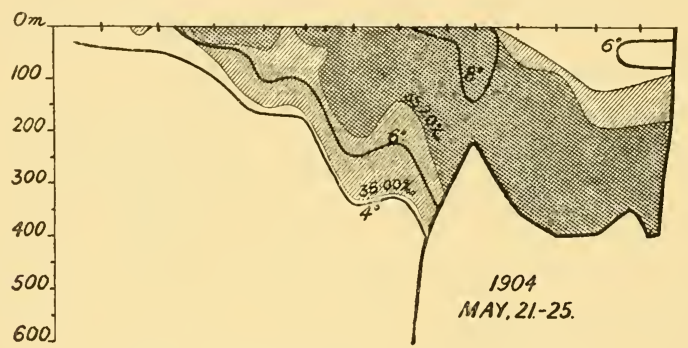

Fig. 165.-The Sognefjord Section, MAy 1904.

Salinities above 35.0 per thousand shown by single hatching; salinities above 35.20 per thousand shown by cross hatching.

always floats on the top, and often glides along a substratum of more saline water. Such coast-water forms the Baltic current, running out of the Baltic Sea through the Kattegat and Skagerrak, continuing on its way along the coast of Norway, above the salter and heavier Atlantic water carried north by the "Gulf Stream."

Fig. 165 represents a section from the mouth of the Sognefjord (near Feje) westwards to a little north of the Faroe Islands. The Atlantic water is marked by hatching, and we see the coast-water lying on the top, close to the land on the right. This section has been examined through a succession of years in the month of May, and we have measured the coastwater section in square kilometres. The top curve (I.) in Fig. 166 shows how this section has varied from year to year. Now it proves to be the case, as was to be expected, that these variations to a certain degree correspond to the variations in the rainfall. The other curves show the divergences 
(per cent) from the normal annual rainfall, (II.) for Christiania, (III.) for Bergen, (IV.) for Germany; (V.) shows the divergences in Norway during the months of October, November, and December. On the whole, the rainfall corresponds well with the transverse section of the coast-water some time afterwards. The rainfall was comparatively small in 1902 , and the coast-water had a small transverse section in May 1903; the rainfall was large in 1903 , and there was much coast-water in May I904, and so on. The effect of the rainfall on the land is not immediately felt in the coast-current off western Norway;
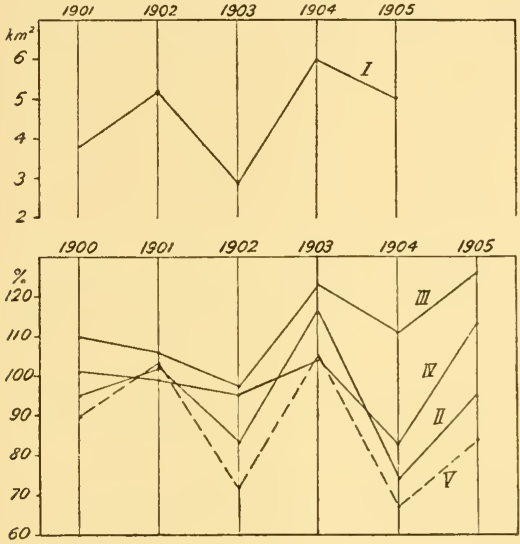

Fig. 166.-CuRves SHowiNg THE VARIATIONS IN

1. the transverse section of the coast-water off Feje (May); II., III., IV., the anmual rainfall for Christiania, Bergen, and Germany respectively; V., the rainfall in Norway during October, November, and December.

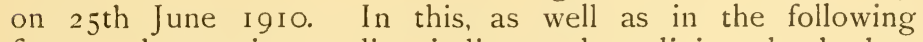
figures, the continuous line indicates the salinity, the broken line the temperature, and the dotted line the density. ${ }^{1}$ We see that the salinity is greatest at the surface, 36.43 per thousand; this is the result of the strong evaporation. It decreases downwards, at first rapidly, then more slowly, more rapidly again, and finally very slowly; in the deep layers below I 250 metres the salinity is less than 35 per thousand, and throughout the great body of the deep water 34.9 per thousand.

1 The density is given in abbreviated form, e.g. 25.56 instead of 1.02556 , and is indicated by the Greek letter $\sigma\left(\sigma_{t}\right.$ being the density at the temperature in situ disregarding the compression). 
The density increases from the surface to the bottom, but with varying rapidity;

Between

Scotland and Rockall. through the first roo metres it increases rapidly, and also in the discontinuity - layer between 600 and I 100 metres.

Fig. I 68 shows the conditions on the 7 th August I9I0, at Station IOI, between Scotland and Rockall, in that branch of the Gulf Stream which flows towards northern Europe. The salinity at the surface is here I

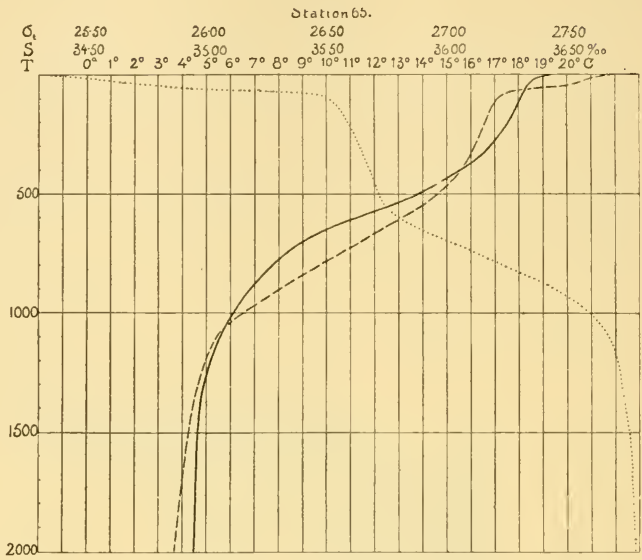

Fig. I67.-Temperature (BRoken line), Salinity (CONTINUous line), and Density (DOTted line) at Station 65, a little north of the Sargasso Sea (25th June I9Io). Depth in metres. per thousand lower than at Station 65 near the Sargasso Sea, Station 10 .

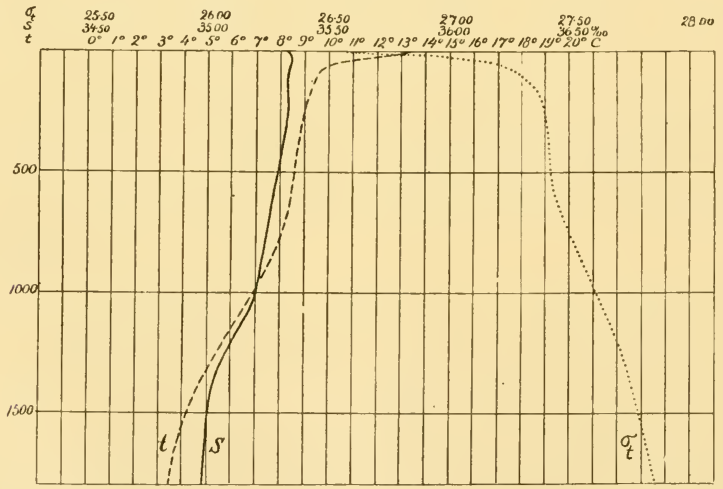

Fig. i68. - Temperature, Salinity, and Density at Station ioi, a little EAST OF Rockall (7th August 1910). Depth in metres.

due to admixture of fresh water; but from about 900 metres down to the bottom the salinity, temperature, and density 
are all very much alike in these two places, nearly 2000 nautical miles distant from each other. There is thus a marked difference as far as the upper layers are concerned, both salinity and temperature decreasing northwards, while in the deep layers below 500 fathoms the conditions are the same throughout the middle and north-eastern part of the North Atlantic. Northwards from Station $6_{5}$ to Station Ior the decrease of temperature in the upper layers is more marked than that of the salinity, so that the density of the surface-layer increases from I.O254 at Station 65 to I.O266 at Station IOI. As a general rule, the upper water-layers, on being cooled, become gradually heavier from the tropics toward the poles.

Fig. I69 shows the conditions at Station I06, Ioth August Faroe I9IO, in the Faroe-Shetland Channel to the north of the

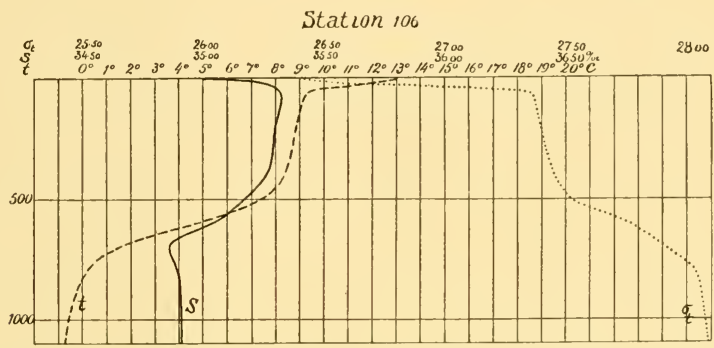

Fig. i69. - Temperature, Salinity, and Density at Station io6, in the Faroe-Shetland Channel (roth August 1910). Depth in metres.

Wyville Thomson Ridge, about 300 miles north-east of Station IOI. At Station I06 some fresher water was found at the surface, but otherwise the salinity, temperature, and density were the same at both stations as far down as 500 metres; the water had grown slightly colder and heavier in these 300 miles, but the difference was very small. Below 500 metres, however, there is a great contrast, the temperature of the deep water being, as already indicated, much lower north of the Wyville Thomson Ridge than south of it, and the density is therefore greater on the north side. The deep water of the Norwegian Sea is thus colder and heavier than that of the Atlantic, but, strange to say, there is no difference in the salinity of the deepest layers of the two regions.

At all three stations the surface-layers are occupied by a warm, comparatively saline, northerly current. On proceeding northwards, there is a fall of temperature and of salinity and 
an increase of density, but the differences are not so great as to forbid the inclusion of the three stations in one region with regard to the upper water-layers; it is a region with a southern character.

The conditions are widely different when we come to a northerly region, like that where the East Greenland Polar Current and the Labrador Current bring down great water-

Otf New foundland. masses from the Arctic seas. On our passage to and from St. John's we sailed across the Labrador Current and took a number of observations at different places in it. Fig. I 7o shows the conditions at Station 76, due east of St. John's, towards the eastern margin of the cold current. Here the temperature at the surface was about $6^{\circ} \mathrm{C}$., falling rapidly to $-0.35^{\circ} \mathrm{C}$. at 55 metres ( 30 fathoms), rising again, at first rapidly, to $3^{\circ} \mathrm{C}$. at a

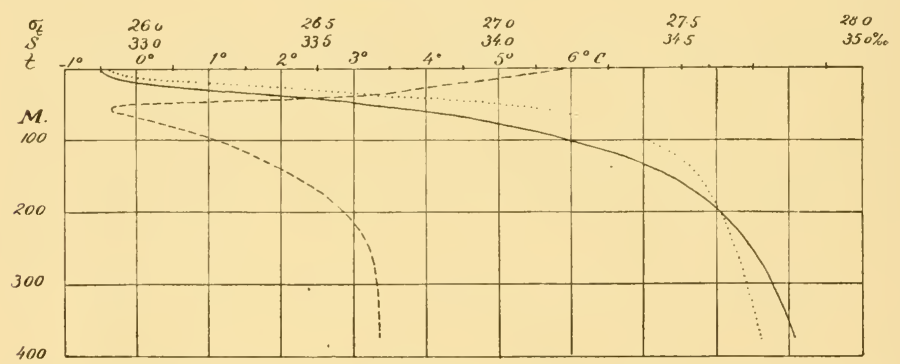

Fig. i7o.-Temperature, Salinity, and Density at Station 76, in the Eastern part of the Labrador CurReNt, OFF Newfoundland (9th July 1910). Depth in metres.

little more than 200 metres, and then slowly to $3.4^{\circ} \mathrm{C}$. towards the bottom in about 400 metres. If the depth had been greater, we should have found that the temperature fell again as we penetrated into the deep water. This is an example of the usual conditions in Arctic and Antarctic regions, where in summer the temperature decreases gradually from the surface to a minimum at 50 to 70 metres, then rises to a secondary maximum at 300 to 400 metres; falling again towards the bottom, and it is in a case like this that the ordinary maximum and minimum thermometer is inadequate (see p. 216). At Station 76 the water was warmer through the influence of the Gulf Stream ; it was much colder, for instance, at Station 75 farther west, where we found $-1.43^{\circ} \mathrm{C}$. at 55 metres, and at Station 74, just off St. John's, where the temperature was $-1.52^{\circ}$ at $9 \mathrm{I}$ metres. As a rule, it may be said that in a polar current 
in depths between 50 and 100 metres the temperature is below zero, and where there are banks at these depths they are covered with ice-cold water ; hence the great difference between such banks and those which lie within the region of the warm currents. Fig. 95,p. I I o, represents a section across the Newfoundland Banks from the Gulf Stream (Station 69) northwards to a point just outside St. John's (Station 74). On the northern part of the bank it is very cold, for there we are in the middle of the Labrador Current; on the southern slope it is much warmer, because of the vicinity of the Gulf Stream. There are accordingly great differences in temperature and salinity in different parts of the Newfoundland Banks, especially in the deeper parts.

From Fig. I 70 we see that the salinity was below 33 per thousand at the surface, that it increased rapidly downwards (to 34.6 per thousand at 200 metres), and afterwards more slowly, but it nowhere attained the salinity of the "Atlantic water," viz. more than 35.0 per thousand. This is characteristic of the Arctic and Antarctic regions, especially in summer. The water brought by the currents from the North Polar basin is a kind of coastwater. The great rivers of Siberia and of the north of America empty volumes of fresh water into the Polar Sea, where it mixes with the salt water, diminishing the surface salinity, which is further reduced by the melting of the drifting ice in summer. The low salinity at the surface renders the density comparatively small, but it increases rapidly downwards, so that the water at IOO metres is heavier than at any of the three stations within the warm water region just mentioned. We have not in any of these examples taken into consideration the fact that the density is slightly increased with increase of depth by the pressure due to the weight of the overlying water.

The pressure in the sea increases by about I atmosphere The pressure for every Io metres of depth. Thus there is a pressure of in the sea. about 100 atmospheres 1000 metres below the surface, and of 500 atmospheres at a depth of about 5000 metres. When differences in pressure occur in adjacent areas at the same level below the surface, various currents arise, just as air-currents are produceá by differences of barometric pressure. The circumstance that the water is not equally heavy everywhere is one of the main causes of the ocean currents, and, the water being easily moved, small differences of pressure will be sufficient to produce a sensible motion. By the great pressure the water 
itself, and all the materials carried into deep water, are compressed. Water is, however, only to a slight extent compressible, so the effect of pressure is not so great as is popularly supposed. Tait and Buchanan have shown conclusively that compressibility decreases slightly but sensibly with increase of pressure. V. W. Ekman has recently made a very careful investigation on the compression of sea-water, and has published Tables for-SeaWater under Pressure. From his tables we may easily compute the actual density with compression, when depth, salinity, and temperature are known.

Let us take, as an example, the conditions at Station 63 , near the Sargasso Sea, 22nd June 1910, as shown in the following table, giving for the depths specified: (I) the temperature, (2) the salinity, (3) the density disregarding the compression (calculated by means of Knudsen's Tables), and (4) the actual density with compression (calculated from Ekman's Tables):-

\begin{tabular}{|c|c|c|c|c|c|}
\hline \multicolumn{2}{|c|}{ Depth. } & \multirow{2}{*}{$\begin{array}{l}\text { Temp. } \\
{ }^{\circ} \mathrm{C} \text {. }\end{array}$} & \multirow{2}{*}{$\begin{array}{l}\text { Salinity } \\
\text { per } \\
\text { thousand. }\end{array}$} & \multicolumn{2}{|c|}{ Density. } \\
\hline Metres. & Fathoms. & & & $\begin{array}{c}\text { Without } \\
\text { compression S. }\end{array}$ & $\begin{array}{c}\text { Actual density } \\
\mathrm{S}_{1} \text {. }\end{array}$ \\
\hline ○ & $\circ$ & 22.30 & $3^{6.44}$ & 1.02525 & 1.02525 \\
\hline 183 & 100 & I $6.7 \mathrm{I}$ & 36.27 & 1.02658 & $\mathrm{I} .0274 \mathrm{I}$ \\
\hline 366 & 200 & 15.22 & 36.00 & 1.02671 & I.02835 \\
\hline 549 & 300 & 12.35 & $35 \cdot 54$ & 1.02696 & 1.02943 \\
\hline 732 & 400 & $8.4 \mathrm{I}$ & 35. I I & 1.02732 & 1.03067 \\
\hline 915 & 500 & $5 \cdot 97$ & 35.16 & 1.02770 & I.03190 \\
\hline 1830 & 1000 & 3.54 & 34.94 & I.0278I & I. 03631 \\
\hline 3000 & 1640 & 2.90 & 34.92 & I.02786 & 1.04171 \\
\hline 4000 & 2187 & 2.35 & 34.88 & 1.02787 & 1.04621 \\
\hline
\end{tabular}

Pressure and density.

It is seen that the density is practically identical, for instance, at 3000 metres and at 4000 metres when leaving compression out of account, whereas a considerable difference was actually produced by the compression. At 4000 metres the effect of the pressure of 400 atmospheres was so great that the density increased from 1.02787 to $\mathrm{I} .0462 \mathrm{I}$, equal to an increase of weight of $1 \frac{3}{4}$ per cent. As a matter of fact the water at 4000 metres has become only $1 \frac{3}{4}$ per cent heavier by reason of the compression; a fairly delicate weighing would have been necessary to detect this increase. The case may also be stated thus: 1 litre of water at 4000 metres weighs 1046 grams; if 
this litre were brought up to the surface, it would expand so that its volume would be increased by I 8 cubic centimetres; subtracting the 18 c.c. and weighing the remaining litre we find a weight of 1028 grams. Thus even at a depth of 4000 metres the difference caused by pressure is not great.

Now, what is the effect of this increase of density on a solid body lowered into the sea? Let us suppose a piece of solid Sinking of a iron, weighing 1000 grams in the air, to be sent down to 4000 metres at Station 63. When it is lowered just beneath the surface it becomes lighter by I 3 I grams, thus weighing 869 grams. When it has reached a depth of 4000 metres the buoyancy is 134 grams, so that the piece of iron there weighs 866 grams-a difference in weight of 3 grams for a piece of iron weighing 1000 grams in air. This is merely 0.3 per cent of the weight, and consequently quite insignificant. In other words, metals and other solid substances are practically just as heavy in deep water as they are at the surface, and will sink as rapidly there as in shallow water. This may be proved by direct observation, for if a messenger is sent down to close a water-bottle at a depth of 2000 metres it will be found to take four times as long as when sent down to 500 metres.

But suppose that, instead of a massive piece of iron, we take a perfectly tight capsule of thin iron filled with air, and lower it down to 4000 metres; in the course of the descent the pressure increases, forcing the walls of the capsule together. The volume of air within the capsule may be so large that it only just sinks at the surface, its total specific gravity being then very little greater than that of the water; but when it has reached a depth of 10 metres the air is compressed to half its original volume, granted that the capsule is collapsible, and the weight of the iron then acting more freely, the capsule will sink faster and faster; when it reaches a depth of 4000 metres it is exposed to a pressure of 400 atmospheres, and the compressed air having hardly any buoyancy left, the capsule will sink almost as fast as if it had been made of solid iron throughout. Collapsible solid bodies containing air will accordingly sink faster in deep water than at the surface. A piece of wood floats at the surface because it contains a large amount of air, but there is nothing to prevent it from sinking when it is sent down into deep water; therefore wood and cork are not suitable for floats at great depths. It is the same with the dead bodies of marine animals, etc., for when the air is compressed they will easily sink. 
The penetration of light into the sea.

Absorption of light rays.

Intensity of light at different depths.

Fol and Sarasin.

When the sun's rays fall on the surface of the sea, some of them are reflected, and the rest penetrate into the water, though in a somewhat altered direction. The direction is not much altered when the sun is high in the heavens, as at noon in the tropics. When the sun is just above the horizon its rays are most strongly deflected, the few rays penetrating into the water forming an angle of about $42^{\circ}$ with the surface. As the sun rises and the light becomes more intense, the deflection from the course in the air gradually decreases, so that the rays do not penetrate so deep as might be expected, even if the angle with the surface increases. When the sun is $60^{\circ}$ above the horizon, the refraction in the water is about $8^{\circ}$, the angle between the surface and the penetrating rays then being about $68^{\circ}$, and when the sun is at its zenith, the rays are not bent at all, but proceed perpendicularly into the water.

The rays making their way into the water are, however, gradually absorbed, some quickly, others more slowly, according to the wave-length of the ray and the limpidity of the water. The sun's light, of course, consists of many different kinds of rays: the dark heat-rays, imperceptible to the eye, lie beyond the red end of the spectrum, and are therefore called ultra-red rays; then comes the visible. spectrum with the colours in the well-known order-red, orange, yellow, green, blue, indigo, and violet; beyond the violet end are the ultra-violet rays, remarkable for their chemical action, but having no effect on our senses. These different rays are refracted and absorbed in different degrees. The red rays are refracted somewhat less than the blue and violet rays, and are much more quickly absorbed. The dark heat-rays are absorbed in the very uppermost water-layers. The light rays also convey some heat, and they penetrate deeper before disappearing-the deeper the nearer the blue end of the spectrum is approached. Light at a certain depth in the sea has not the same composition as on the surface of the earth, there being fewer of the red rays and more of the blue, which proportion becomes gradually more pronounced with increasing depth.

Attempts have been made to determine the intensity of the light at different depths, especially in the Mediterranean, by means of the action of the rays on photographic plates. Ordinary plates are most influenced by the rays at the blue end of the spectrum, and by the ultra-violet rays, and only slightly by the red. Fol and Sarasin, working off the Riviera, traced an effect on the plate as far down as between 465 and 480 
metres; Petersen found that in the neighbourhood of Capri a Petersen. plate was influenced by the rays at a depth of 550 metres. Luksch made some investigations in the eastern part of the luksch. Mediterranean, exposing his plate for fifteen minutes, and found that the limit of the light-rays must be drawn at 600 metres. In these experiments the influence of the collected rays on an ordinary photographic plate was studied.

In order to make some investigations on this subject in the

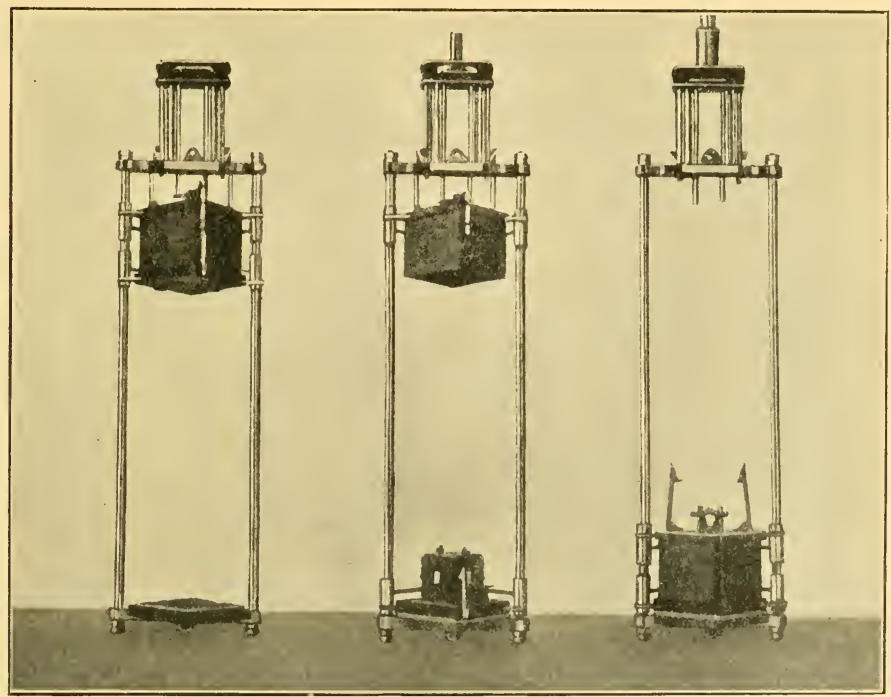

Fig. I7I.-Helland-Hansen's Photometer.

On the left, as it is sent down; in the middle, open for exposure; on the right, closed and ready for hauling up.

"Michael Sars" Atlantic Expedition, the author constructed a Hellandnew kind of photometer, which is represented in Fig. I 7 I. In Hansen's the centre figure-at the lower part-is seen a brass cube; the four sides and the top have square "windows," and on each of them a small square frame with a similar window $(2 \times 2 \mathrm{~cm}$.) can be screwed fast; the screws and openings are seen in the figure. The cube rests on a larger brass plate, or rather on an india-rubber mat covering the brass plate. The plate and cube are fastened inside a frame, along which they can be moved up and down. At the top of the central figure is seen a larger 
metal cube without any base; it is intended to cover tightly the lower cube to which the photographic plates are fastened. On the left the apparatus is seen closed, with the cubes suspended at the top of the frame, the smaller one inside the larger. In this position the apparatus is lowered into the water. A small messenger is sent down the line and releases the inner cube, which drops to the bottom of the frame (see the middle figure). The plates are thus exposed. After a certain time a larger messenger is sent down, releasing the large cube, which falls like a shutter over the plates, as seen in the figure on the right. The apparatus is then ready for hauling up, and the cubes are taken out of the frame into the dark-room for development and change of plates.

In all previous photometric apparatus for use in the sea the plates were hermetically closed behind a strong glass pane, in order to shield them against the great pressure, but in the photometer here described a totally different principle was applied. The gelatine-film was covered with a glass plate and inserted into a small envelope of thin caoutchouc, with a square opening in front through which the light is admitted. The envelope with the plate was then placed on one of the sides of the inner cube, and the corresponding brass frame was screwed on tightly. The water could penetrate both outside and inside the cube, so that there was the same pressure on both sides of the film and the glass cover. The rubber envelope would be pressed tightly on to the glass plate, so that no water could enter and spoil the film. By this arrangement the apparatus might be exposed to any pressure without any special protection, and it was used at various depths down to I 700 metres without a single plate being cracked or spoilt by water.

Highly sensitive pan-chromatic plates $(4 \times 4 \mathrm{~cm}$.) were employed in the experiments - the windows being, as mentioned above, $2 \times 2 \mathrm{~cm}$. In several experiments a gelatine colour filter was inserted between the photographic plate and the glass cover. Wratten and Wainwright's three-colour filters (red, green, and blue) admit respectively only a certain portion of the spectrum. This made it possible to study the rays present within the separate fields of the spectrum, as well as the total intensity of the rays. These investigations were carried out in the southern stretch of the cruise, and though time and weather did not allow of many experiments, those that were made gave interesting results.

Some of the plates exposed are represented in Fig. I 72. In 
the upper row are seen some results without a light-filter at Results at Station 5I. The plate on the left (No. IO), exposed for $40 \mathrm{different}$ depths with minutes at 500 metres, was strongly influenced by the rays. and without The next plate (in the middle of the upper row), exposed for colour-filters. So minutes at 1000 metres, was also blackened by the light-rays. The third plate was exposed for I 20 minutes at I 700 metres, and showed no effect whatever. These experiments were made at noon on the 6th June with a clear sky, and show that a good deal of light penetrates to a depth of 1000 metres-considerably deeper than was previously supposed. The limit of light

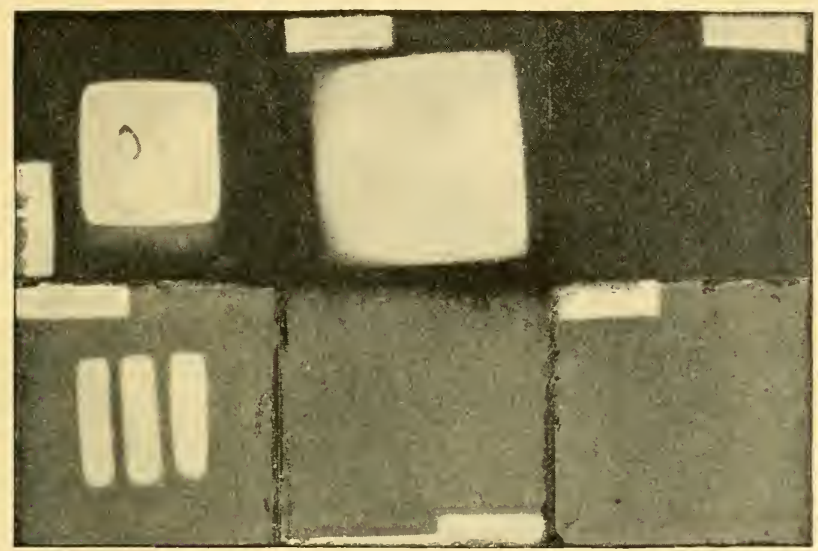

Fig. I72.-Photographic Plates exposed at Differenr Depths. The upper row from Station $5 \mathrm{I}$, the lower row from Station 55 .

sufficient to influence the plate in the course of two hours lies at a less depth than i 700 metres.

The lower row in Fig. I 72 shows some plates from Station 55 , all exposed for forty minutes at a depth of 500 metres. The plate on the left was used without filter, and shows the same strong effect as the corresponding plate from Station $5 \mathrm{I}$, in the upper row. The next plate (in the middle of the lower row) was exposed with the blue filter; an influence of the blue rays is visible on the original plate (a faint Roman V), but not so clearly in the reproduction given here. The right-hand plate in the figure was exposed with a green filter, and shows no effect. A plate with the blue filter needs an exposure six times, and one with the green filter eighteen times, as long as a plate 
CHAP.

with no filter. It is therefore difficult to compare the plates quantitatively, but it may at least be maintained that there must be many blue rays, though hardly any red ones, at a depth of 500 metres. Series of experiments with and without filters were also made at a depth of 100 metres ; in forty minutes all the plates were over-exposed, those with a red filter only a little, those with a blue one very much, so that there are many rays of all kinds at 100 metres, though fewest of the red. When plates without colour-filters were exposed on the top and on the sides of the cube simultaneously, the plate on the top proved to be more strongly influenced than the others. This fact is not without interest, as it shows that the rays in the clear tropical waters have a distinct direction at 500 metres, not having yet become altogether diffuse; shadows should, then, be thrown even at that depth.

Regnard's photometer.

Prince of Monaco's experiments.

Fol's diving dress experiments.

Regnard constructed an apparatus for determining the length of the day at different depths, in which a clockwork arrangement inside a cylinder causes a photographic film to pass before an aperture. At the end of March I889 the Prince of Monaco made some experiments with Regnard's apparatus in the harbour at Funchal, Madeira; the water was not so clear as in the open sea, so the times recorded may be rather short. At 20 metres the day lasted eleven hours; at 30 metres it began at $8.30 \mathrm{Am}$. and ended at I.3O P.M., the sky becoming overcast; at 40 metres, with the sun shining brightly, the film exhibited only a slight influence of light for a quarter of an hour about 2 P.M. These and a few other experiments show that the day becomes gradually shorter, and the intensity of light decreases, as the depth increases.

The Swiss naturalist, Hermann Fol, has several times gone down in diving dress off Nice to examine the bottom. At a depth of 10 metres the solar light disappeared quite suddenly in the afternoon a long time before sunset. At 30 metres the light was so bad that it was difficult to gather the animals on the bottom; he could see a stone only at a distance of 7 or 8 metres, whereas shining objects in favourable positions could be discerned at a distance of 25 metres. He also noticed that dark red animals (like Muricaa placornus) looked quite black, while the green and green-blue algx appeared lighter in colour. This is explained by the fact that the red light disappears much sooner than the blue. A coloured object will always look black when untouched by rays of its own colour. As the white sunlight contains all colours, objects display in it their proper tint, 
but when the red rays, for instance, are cut off, a piece of red paper will look black.

The usual method of studying the transparency of the water Transparency is to lower a large white disc, noting the depth at which it of sea-water. disappears from view. The degree of transparency is found to vary greatly, for in the clear dark-blue water in the middle of the ocean near the tropics the white disc can sometimes be seen as far down as 50 metres below the surface, or even more, while in those places where rivers bring down large quantities of detritus from the land the disc may occasionally be invisible a couple of metres beneath the surface. The enormous quantities of small plankton organisms inhabiting the upper layers may also render the water relatively opaque. The penetration of light thus varies according to circumstances, but few direct observations of the light-intensity have as yet been made. It would be of the greatest interest to know the amount of light at different depths in different seas, and thereby gain a better understanding of the conditions of life, for instance, as regards the development of the plankton, as the small plankton algæ need light for the processes of assimilation.

Sea-water normally contains oxygen, nitrogen (with argon), Gases in the and carbonic acid. These gases are absorbed at the surface sea. from the atmosphere, and are carried by currents even into the deepest parts of the ocean in varying amounts. A study of these variations is of considerable interest, and may be briefly dealt with here, although no gas-analyses were made during the "Michael Sars" Atlantic Expedition. There are several good methods of analysis. For the three gases named, the method introduced by Bunsen, and further developed by Pettersson and Fox, may be employed, the water-sample being boiled at a low pressure, and the escaping gas collected and analysed. The oxygen may be determined by a very simple titration, according to Winkler's method, or Krogh's method of examining the tension of the several gases in solution may be applied.

Oxygen is not so readily soluble in salt water as in fresh; Oxygen. the higher the salinity the less the absorption of oxygen by the water. It is also a well-known fact that cold water dissolves more air than warm. This is clearly seen in the following excerpt from Fox's tables, showing the cubic centimetres of oxygen in I litre of water at different temperatures and salinitices, when the water is saturated with this gas:- 


\begin{tabular}{|c|c|c|c|}
\hline \multirow{2}{*}{ Temperature. } & \multicolumn{3}{|c|}{ Salinity. } \\
\hline & o per thousand. & 20 per thousand. & 35 per thousand. \\
\hline $\begin{array}{r}0^{\circ} \mathrm{C} . \\
10^{\circ} \mathrm{C} . \\
20^{\circ} \mathrm{C} . \\
30^{\circ} \mathrm{C} .\end{array}$ & $\begin{array}{l}\text { O. in c.c. per litre. } \\
\begin{aligned} \text { I } 0.29 \\
8.02 \\
6.57 \\
5.57\end{aligned}\end{array}$ & $\begin{array}{c}\text { O. in c.c. per litre. } \\
9.0 \mathrm{I} \\
7.10 \\
5.88 \\
4.96\end{array}$ & $\begin{array}{l}\text { O. in c.c. per litre. } \\
8.03 \\
6.40 \\
5.35 \\
4.50\end{array}$ \\
\hline
\end{tabular}

At $30^{\circ} \mathrm{C}$. a litre of water which is saturated with oxygen contains little more than half as much as at $0^{\circ} \mathrm{C}$. There is therefore normally more oxygen in the cold water-masses of the Arctic and Antarctic regions than in the warm water-masses of the tropics. The salinity is not such an important factor in the solubility of oxygen as the temperature.

Marine animals need oxygen for respiration, and therefore consume some of that contained in the water. By the act of respiration carbonic acid is produced and dissolved in the water. The same thing goes on through the respiration of plants. These are some of the principal oxygen-consuming processes. But plants assimilate besides breathing; that is to say, they make use of the carbonic acid by dissociating it into oxygen and carbon ; they employ the carbon for building up cells, while the oxygen is again dissolved in the water. This is the chief oxygen-producing process, but it is carried on only through the influence of light-rays. It is doubtful what rays are the most important for marine plant life, and in what quantity they are necessary. Experiments have shown that many higher aquatic plants assimilate much better in yellow light than in blue or violet light; this is the case with most adherent green algæ, and hence they are found in the upper water-layers near the surface, where there is enough yellow light. The red algæ, on the other hand, assimilate better in blue light than in yellow, and therefore live in deeper water than the former. We know nothing of the assimilation by the plankton-algx of the various light-rays; we only know that they need light, and that they are found in the upper water-layers, but not in deep water. The production of oxygen in the sea is thus limited to the upper layers, while the consumption of oxygen takes place wherever there are living organisms (excepting certain bacteria). Now, supposing the processes of assimilation and of respiration 
are balanced, the quantity of oxygen in the water is not altered

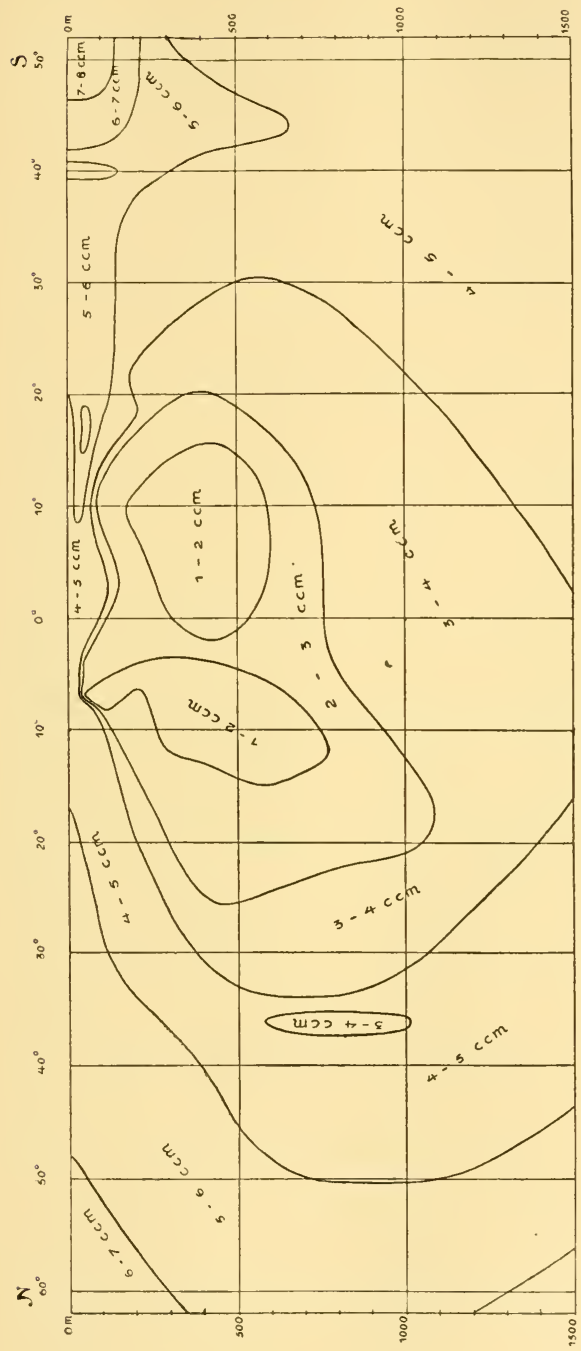
however many organisms are present. But if there is an excess of animal life the amount of oxygen decreases (as it always does in the dark); if there is an excess of plant life the amount of oxygen increases, provided there is light enough. Knudsen and Knudsen and Ostenfeld made Ostenfeld's some experiments experiments.

to prove this. They filled some bottles with a capacity of I litre with sea-water, and into one they put some living crustacea (copepods). After three hours there was 3.88 cubic centimetres less oxygen in this bottle than in the others, while the quantity of carbonic acid had increased. They filled two litrebottles with seawater, and introduced equal quantities of vegetable plankton (diatoms), covering one of them with tin-foil so as to shut out the light. After 
three hours it was found that the diatoms had consumed 2.34 cubic centi-

Brennecke's figures for oxygen in the Atlantic. metres of the oxygen in the dark bottle (the amount of carbonic acid being slightly increased), whereas in the uncovered bottle the quantity of oxygen had increased by I 1.00 c.c. (the amount of carbonic acid being decreased).

Brennecke has compared the results of a number of oxygen-determinations from the Atlantic Ocean, and in Figs. I 73 and I 74 his two sections showing the vertical distribution of oxygen in the Atlantic (from the surface to a depth of I 500 metres) between lat. $60^{\circ} \mathrm{N}$. and 50 $\mathrm{S}$. are reproduced. The first section shows the quantity in cubic centimetres per litre. A little north and south of the equator the value is only $I-2$ c.c. per litre in the water

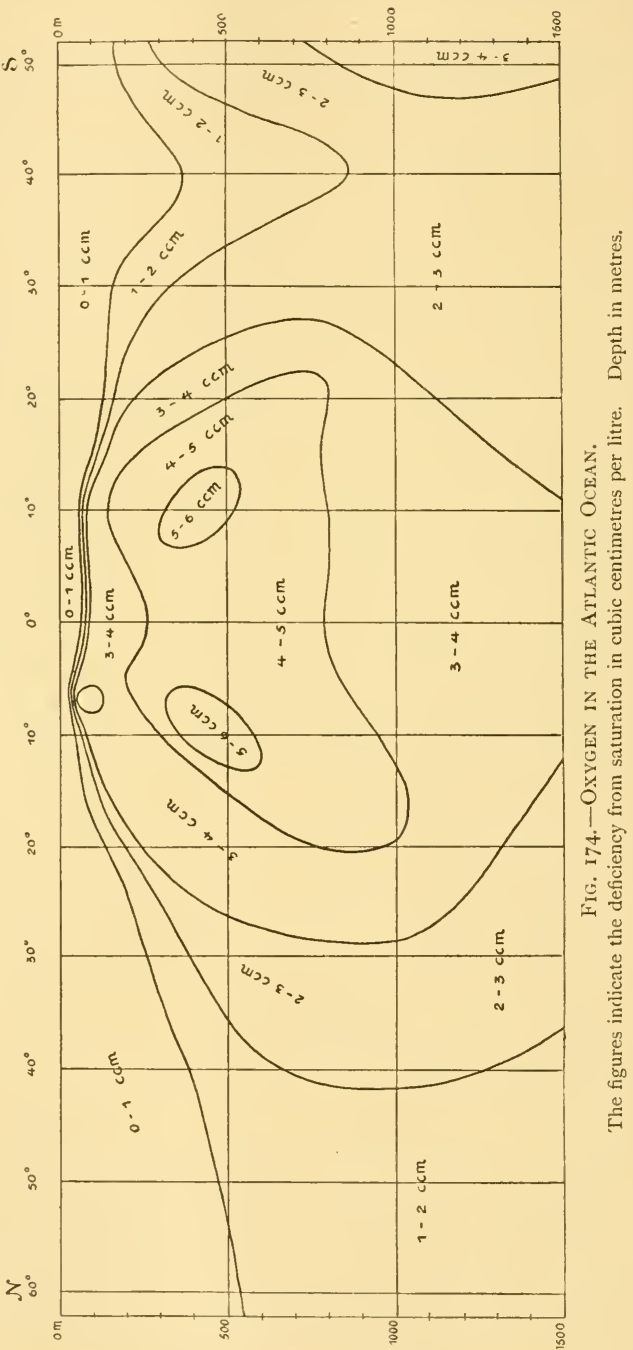
between 200 metres and 600 or 700 metres; on the equator, 
where the cold water from below comes comparatively near the surface, it is a little more; the highest value, over 6 c.c. per litre, is found in high northern and southern latitudes. The second section shows the deficiency from saturation in cubic centimetres per litre at the temperature and salinity in situ. In the upper 50-100 metres the water is nearly saturated all over the Atlantic, while in greater depths the oxygen is deficient, especially in tropical waters; at a depth of about 500 metres in lat. IO $\mathrm{N}$. and S. the deficit amounts to five or six cubic centimetres per litre. This is explained by the abundant supply of oxygen in the surface-layers, through absorption from the atmosphere, and through assimilation by the rich plant life, while the oxygen is being constantly consumed at greater depths, where plant life is scarce and animal life in excess. As a rule, where there is a great deficit of oxygen the water is characterised as "stale," a long time having elapsed since it was aerated at the surface or purified through the action of plants.

The disappearance of the oxygen is not, however, due only to the respiration of animals, but may also be caused by various hydro-chemical processes. In the Black Sea oxygen is found only in the upper $150-200$ metres (about 100 fathoms) of water; below this it has disappeared totally, whereas sulphuretted hydrogen is present in increasing quantities down towards the bottom. The Black Sea is separated from the Mediterranean Black Sea. by the Bosphorus ridge, so that the water in its deep basin lies stagnant, unrenewed by the influx of other water. Similar conditions prevail in several Norwegian "threshold fjords," or on a Norwegian smaller scale in the oyster-"polls." In such places the bottom is thickly covered with organic matter; a slimy black mud is formed, swarming with bacteria that produce sulphuretted threshold-
fjords and oysterhydrogen, which spreads through the water, combining with the oxygen to form various sulphates. This causes the oxygen to decrease and finally to disappear altogether, when the sulphuretted hydrogen begins to appear free in solution. It gradually spreads upwards, until the water is devoid of oxygen and contains free sulphuretted hydrogen, at a depth of only Ioo fathoms in the Black Sea, and in the oyster-basins in autumn often at merely a couple of metres below the surface. In summer the "bottom-water" of the oyster-"polls" lies stagnant, but in the course of the autumn and winter it is generally renewed by the supply of comparatively heavy water from without; then the sulphuretted hydrogen disappears and 
the oxygen returns, producing thus an annual change in the gaseous conditions of the deeper parts of the oyster-"polls." In autumn the state of things may become critical for the oysters, which are suspended in baskets at a depth of $\mathrm{I} \frac{1}{2}-2$ metres; it happens occasionally that the animals all die at this time by suffocation through want of oxygen or by sulphur poisoning.

The water may, on the other hand, become over-saturated with oxygen, as occurs sometimes in the Kattegat, or in spring in some parts of the oyster-" polls," where plant life is particularly luxuriant.

Carbonicacid. Carbonic acid occurs combined as carbonates and bicarbonates, and only in very small quantities as a free gas. The quantity varies considerably, among other things because of the activity of plants and animals, as above mentioned. Usually there is about 50 c.c. of carbonic acid in I litre of sea-water, but of this only a few tenths of a cubic centimetre is free gas in solution.

Carbonic acid has probably been present from the formation of the primitive ocean, together with the salts of the sea, but the quantity varies from place to place and from time to time, depending on the number of plants and animals, on the composition of the bottom, and more especially on atmospheric conditions. At times considerable quantities of carbonic acid gain access to the water through submarine volcanic activity, but this has probably less influence on the variations than the

Krogh's investigations. atmospheric conditions. August Krogh has made some very valuable investigations on this point, and has arrived at the conclusion that the sea is a sort of regulator for the amount of carbonic acid in the atmosphere. When there is much carbonic acid in the air, much will be absorbed by the sea; this is the case near land, and especially where there is a dense population and extensive industrial activity, or near active volcanoes. The tension of carbonic acid is everywhere small, but it is on the average greater over the land than over the sea. Now, if the tension in the air over a certain portion of the sea is smaller than it is in the sea, the latter will give off carbonic acid to the air. The sea thus has a regulating influence on the variations in the carbonic acid of the atmosphere. Many important questions arise with regard to these relations, but we cannot enter into further detail here; investigations on the subject are few.

Nitrogen is so inert a gas that it is of little importance in oceanography. It is absorbed from the atmosphere in con- 
siderable quantities, I litre of water at a temperature of $10^{\circ} \mathrm{C}$. and with a salinity of 35 per thousand, for instance, containing when saturated $\mathrm{I} 2$ c.c. of nitrogen. It is possible that marine bacteria partly dissociate nitric compounds so as to liberate nitrogen, and partly bind free nitrogen in various salts. These variations are always small, and not easily demonstrable. As a rule, though not without exception, the surface-water is saturated with nitrogen from the air, and when the water leaves the surface it carries down with it practically the same amount of nitrogen.

A vessel running a certain course at a speed measured by Currents in the log often proves to have arrived at another point than that which would be expected from the reckonings. This will be the case when there is a strong wind, but even in a calm a displacement is frequently experienced, which is then caused by a current, and when the calculated position is compared with that actually arrived at, the difference will indicate the effect of the current on the ship. In sailing across the Gulf Stream off the east coast of North America, for instance, the ship is carried north or north-east of its latitude according to the compass and the log. The deviation is then an expression of the direction and velocity of the current, and much information with regard to the set of the currents has been obtained in this way. But the method is not trustworthy when there is a wind acting on the ship. The drift of various objects floating on the sea, Drift of wreckage for example, has also been studied. When wreckage " belonging to the "Jeanette," which foundered in the Arctic Sea, was found in the North Atlantic, Nansen concluded that a current must run from the polar basin between Greenland and Spitzbergen into the Atlantic Ocean, and on this supposition he planned the "Fram" Expedition. In the Atlantic Ocean wrecks are often encountered drifting about with wind and current. These are reported, and from such reports one can follow the movements of wrecks for a long time. Fig. I 75 shows some such wreck-courses; many of the wrecks have drifted from North America towards Europe, thus showing the effect of the Gulf Stream; others have been carried eastward in the direction of the Azores, then south, and finally west back towards America again. But in these cases the wind always plays an important part, so that it is difficult to form a correct idea of the movements of the water. In the far north and far south we Floating can follow the drift of the icebergs; one, for instance, breaking icebergs. 
loose far north on the west coast of Greenland would float towards the south along the coasts of Labrador and Newfoundland, and even farther south, thus proving the existence of the Labrador Current. An iceberg lies deep in the water, a fraction only of its bulk rising into the air, so that the wind will have little influence on its motion, which will practically express the aggregate effect of the currents through which the foot of the iceberg stretches.

Drift of vessels in the ice.

It has occurred more than once that vessels have been locked up in the ice east of Greenland, and have been carried

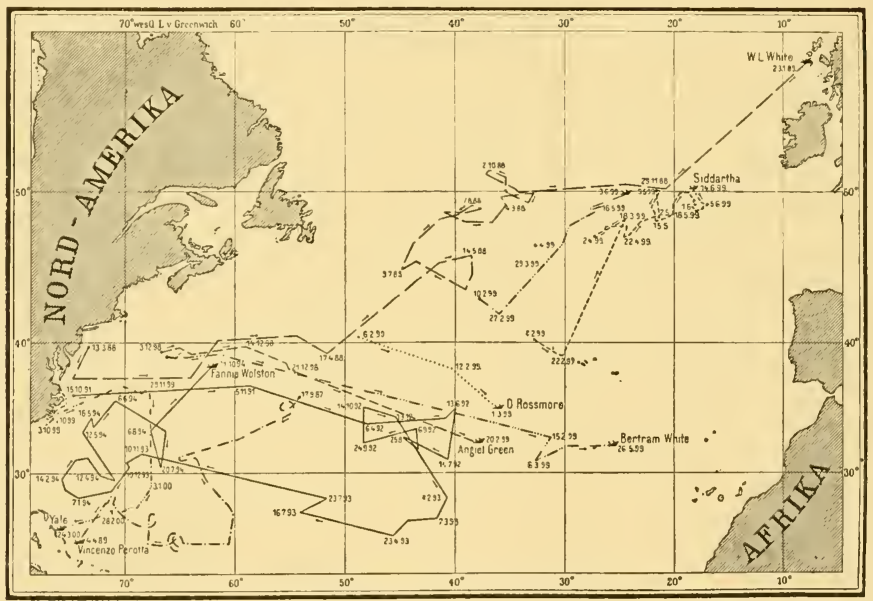

Fig. 175.-Drift of Wreckage in the North Atlantic. (After Krimmel.)

along with the drifting ice far towards the south. In the year I 777 a number of whalers were caught in the ice north of Jan Mayen, and all their efforts to free themselves were in vain, many of the ships being crushed, while most of the men perished; when the last ship was lost it had drifted I 100 nautical miles in IO7 days, or an average of ro miles per day. On the second German Arctic Expedition one of the ships, the "Hansa," was locked up in the ice in lat. $74^{\circ} 6^{\prime} \mathrm{N}$. and long. I $6 \frac{1}{2}^{\circ} \mathrm{W}$. on the 6 th September I 869 , and was carried southwards until it was crushed on the igth October. The crew took refuge on an ice-floe, and drifted on till the 7 th May 1870 , when they were able to land in Greenland in lat. $6 \mathrm{I}^{\circ}$ I $2^{\prime} \mathrm{N}$. 
They had been carried ro80 nautical miles in 246 days, that is, 4.4 miles per day on an average.

Information about the currents is also obtained from objects found drifting along with them. At Lofoten golf-balls have been found which must have come across from Scotland. In the Norwegian Sea drift-wood from Siberia is occasionally met with; once we came across the trunk of a Siberian tree thickly covered with littoral diatoms, which had thus travelled right through the polar sea, so that the log had come from the northern coast of Asia with the same current that carried the "Fram" through the northern waters.

In order to study the currents, drift-bottles have often been Drift-bottles. employed, in which are enclosed slips of paper with directions to the finder to send the note to the address given, with information about when and where it was found. Fig. I76 shows the results of some of the bottle-experiments made in the North Sea by Fulton, who has in this way been able to give a Fulton's more complete account of the currents of the North Sea than was previously possible. In this case the method gave quite trustworthy results, because there were shores all round where it was comparatively easy to recover the bottles within a short time. As regards the great oceans, the method often gives rather doubtful results. In the first place, one cannot know the route followed by the bottle from the time it was thrown overboard till the time it was found, and then it may lie for years on the shore before it is found, so that no one can tell how long it has been on its journey.

These methods give a certain amount of information about the motion of the superficial layers, but none about the deeper currents. We can also study the set of the water-masses by means of their physical or chemical qualities, especially temperature and salinity and gaseous contents. It is, for instance, known that the Gulf Stream carries much salt water (with a salinity above 35 per thousand) from the Atlantic into the Norwegian Sea, and the course of this salt water can be traced farther north; it forms a band along the coast of Norway, and branches off in several places. The position of this salt water indicates the course of the current itself, not at the surface only, but also in the deeper layers.

From a study of the distribution of salinity and temperature the average direction of the drift of the water-masses may be deduced, and an idea of the velocity obtained by calculation. Mohn. Mohn, and more recently especially Bjerknes, have greatly Bjerknes. 
aided oceanographical work by giving the mathematical basis

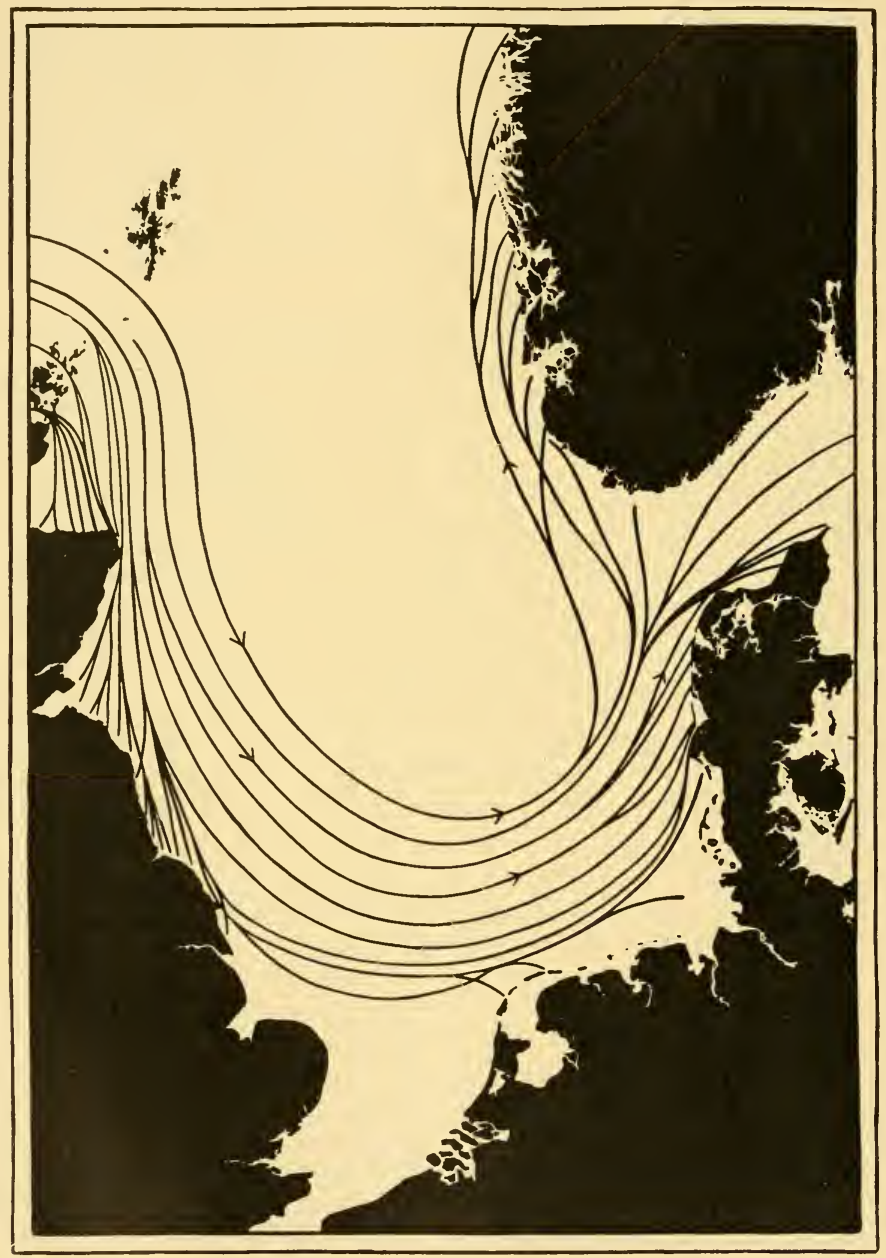

Fig. 176. - Results of Dr. Fulton's Drift-Bottle Experiments in the North Sea.

for these investigations. This method, however, is indirect, and is in many cases insufficient for obtaining an exact know- 
ledge of the motions of the sea, for which purpose direct current-measurements are necessary.

Measuring the currents at different depths in the sea is much more difficult than might appear at first sight, and re-

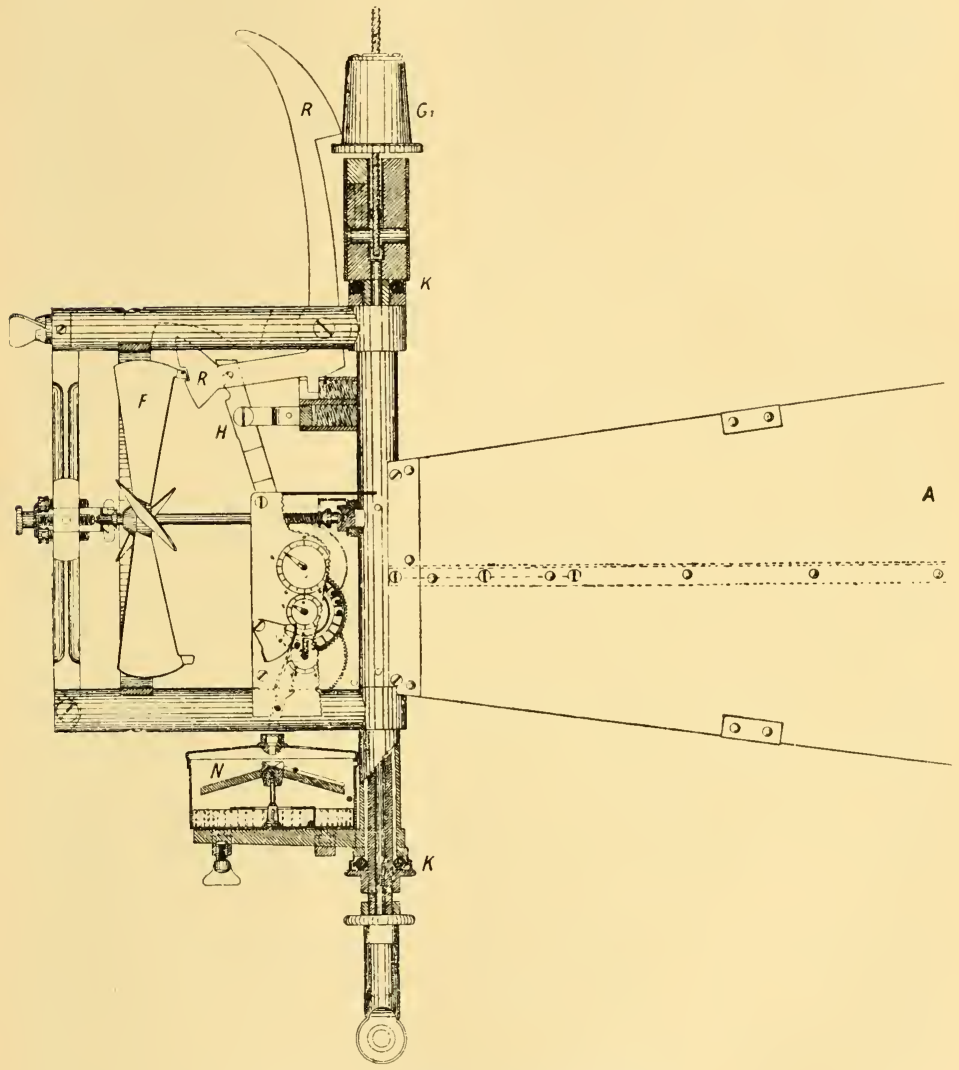

Fig. 177.-Ekman's CurRent-Mieter.

quires good apparatus. Many excellent current-meters have been constructed, the one made use of during the cruises of the "Michael Sars" being that invented by V. W. Ekman, Ekman's represented in Fig. I 77. The apparatus consists of a double current-meter. wing $(A)$, that points in the direction of the current. In front 
is a propeller which is moved by the current, the velocity determining the number of revolutions in a certain period. The propeller works some small cog-wheels connected with hands showing on a dial the number of revolutions. The mechanism for indicating the direction of the current is very ingenious. Some small shot are inserted into a tube leading to one of the cog-wheels, which is provided with notches each holding one little ball. The balls are carried round by the wheel, and after half a revolution are discharged through another tube into the centre of a metal box, in which is poised a magnetic needle with a groove along the top of one branch. As the shot fall, they roll along the needle and drop off its point into the box. Their path may be traced in the figure. The bottom of the box is divided into thirty-six small partitions, and the balls fall into one or other of these according to the position of the needle. The position of a ball in the box thus indicates the angle between the axis of the apparatus and the magnetic meridian, that is, the direction of the current. When the apparatus is lowered into the water, the propeller is set and fixed, and is subsequently released by a small messenger so as to spin with the current; when desired, a larger messenger is sent down to arrest the propeller before hauling up. With this current-meter a great number of observations have now been made, many of which have given very important results.

In order to obtain good results it is necessary that the apparatus should hang practically still, without being carried along by the ship or the water, or-if this be unavoidablethat the drift should be perfectly well known. The boat from which the work is done must be very firmly anchored. In the Norwegian investigations we have, as a rule, worked from a small boat with anchors fore and aft, and it was possible in this way to hold the boat, even when more than 500 metres over the bottom, the most exact bearings showing that the boat did not drift sufficiently to influence the current-meter; one anchor alone is usually not sufficient, for the boat may swing, thus affecting the apparatus. When measuring the currents in the Straits of Gibraltar, we tried double staying with the life-boat, using a strong hemp line about one inch in circumference, but the current was so strong that the line broke again and again, and we had to give it up. When the current (or the wind) is very strong, good results may be obtained by means of a single anchor forward, so we dropped one of the large anchors of the "Michael Sars," and the steamer lay so 
still that we could work with the current-meters from deck, but the strain on the wire was enormous. Double staying is much too difficult at great depths, although a single line may sometimes do. At Station 58, south of the Azores, we had the trawl out in about 900 metres of water, when it caught on something and stuck fast on the bottom, holding the ship practically still (the compass was carefully observed the whole time) ; we improved the occasion by making a series of currentobservations, and the results, which will be discussed farther on, prove the drift or the swing to have been insignificant, so that the observations are fairly reliable.

In the deep ocean, where current-measurements would be of special interest, it is impossible to anchor the ship on the bottom, but the drift of the vessel may, when exactly known, be allowed for, and measurements may be made at any depth. We tried this two or three times. At Station 19, in the Mediterranean, all the nets and young-fish trawls were towed at the same time. The speed of the vessel then just balanced the surface current; the motion appeared to be quite steady, and some observations were made at different depths to determine the deeper currents in comparison with the surface current. Again, at Station $49 \mathrm{C}$, west of the Canaries, we employed the large bag-net ( 3 metres in diameter) with the wire as a driftanchor. The net was lowered to a depth of 1000 metres and held there for many hours; the drift of the vessel was fairly steady, and the compass showed the swing to be trifling. The depth of water was about 5000 metres, and measurements were made at different depths down to 1830 metres (Iooo fathoms) with two Ekman current-meters, the results being indicated in Fig. I78. It may be interesting to see how an attempt at determining the currents above so great a depth turned out.

The cardinal points of the compass are shown by dotted crosses, and arrows are used to indicate the velocity and direction according to the current-meters sent to different depths, a broken line for $9 \mathrm{I}_{5}$ metres (500 fathoms) and $\mathrm{I}_{3} \mathrm{O}$ metres (rooo fathoms), and a thin line for io metres. Now, we know nothing directly about the currents in deep water in the open ocean between 500 and rooo fathoms, but we must suppose the movements to be comparatively insignificant when the depth to the bottom is very great, say more than 2000 fathoms. Supposing there were no current at these depths, the apparatus would act as a log, showing the velocity and direction of the drift of the vessel. Granting this to have been the case, the 
IO-metre arrow will represent the resultant of the two components: the actual current at io metres and the actual motion
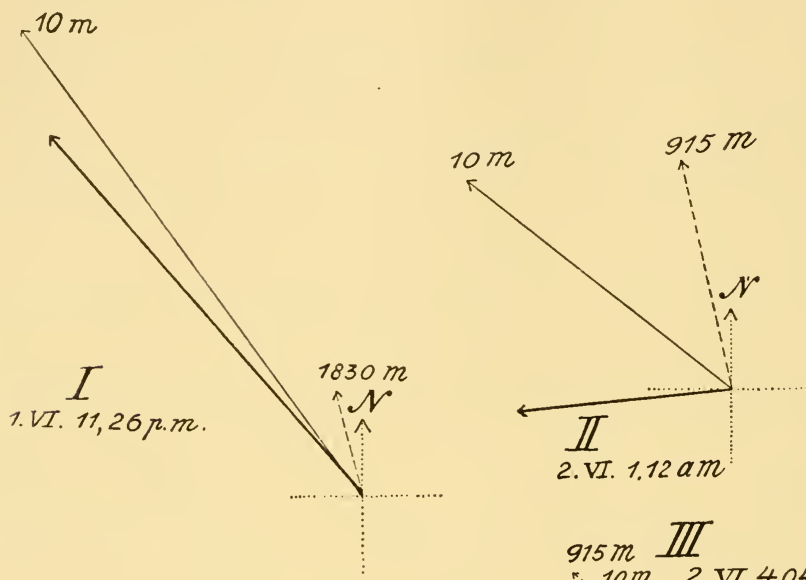

2. VI. $1.12 \mathrm{am}$

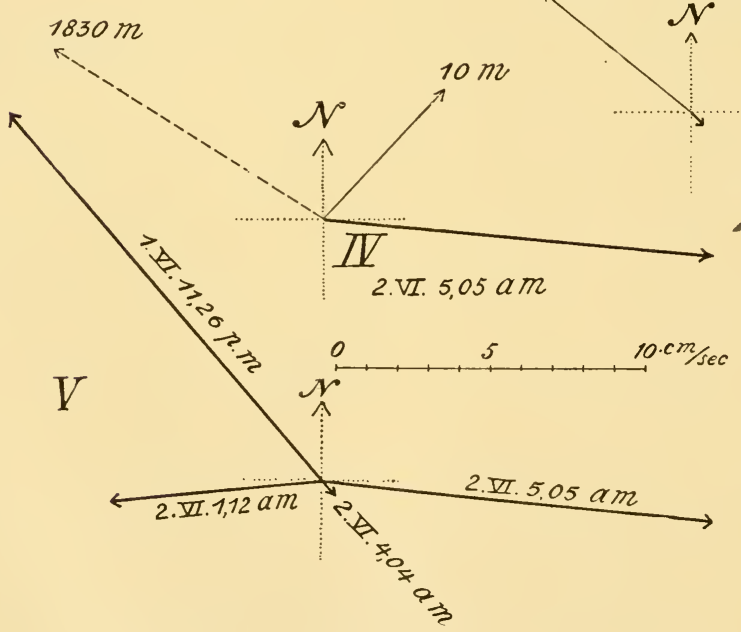

Fig. i78. -Current-Measurements at Station 49 C (ist-2nd June i9io).

of the ship, as indicated by the deep-water measurements. The actual current at Io metres is then easily determined; it 
is here indicated by the thick arrows. Two measurements were made at I830 metres (Nos. I. and IV. in the figure), and two at 9I5 metres (Nos. II. and III.), and at the same time observations were made at Io metres with another apparatus. The time by the watch is noted in the figure. The arrows in $\mathrm{V}$. show the currents thus found at ro metres after allowing for the assumed drift of the vessel, and it is seen that the variations both in velocity and in direction are large. This method is, however, uncertain so long as the currents in deep water are unknown; if these are considerable, the thick arrows in Fig. I $78, \mathrm{~V}$., do not give the actual currents at io metres, but only the relation between these currents and those in deep water. Still one thing is at least clear from the figure: the thick arrows alter their direction regularly, and the change is counter-clockwise. A continuous alteration of set is one of the characteristics of tidal currents, and the conclusion is in all probability admissible that our measurements at Station $49 \mathrm{C}$ prove the existence of tidal currents in the Atlantic Ocean, even where it is very deep.

Tidal motion in the sea is due to the attraction exercised by the sun and moon on the water-masses, which varies from place to place. It would take us too far to enter into the theories of the tides here, and besides, we have not yet a clear solution of the problem, because, among other reasons, we have no observations from the open sea, but only those from the coasts. The rise and fall of the surface, known as tides, are accompanied by currents, and the study of these currents in the open sea would be of great importance for the comprehension of tidal phenomena. In the "Michael Sars" Expedition, as mentioned above, we made a number of current-measurements, the principal object being to find out if it were possible to make trustworthy observations of the velocity and direction of tidal currents in the ocean. This has not been done before in deep water. Buchanan in 1883 made some interest- Buchanan. ing measurements on the Dacia Bank, off the west coast of Morocco, and found marked tidal currents during the couple of hours the observations lasted. Afterwards R. N. Wolfenden Wolfenden. discovered tidal currents on the Gettysburg Bank. Beyond these and a few other observations, we have no observations from the open ocean far from land and none at all in deep water.

We usually figure to ourselves the attraction of the moon Tidal waves. and the sun producing a tidal wave which can develop freely in the Southern Ocean, where a zone of water encircles the 
earth. This wave has a very great length, with high - water at the crest and low-water in the trough. Its form remains, fettered by the moon, while the earth revolves beneath it. Passing the opening between Africa and South America, it gives rise to a lateral wave moving from south to north through the Atlantic. This tide-wave reaches the coasts of northern

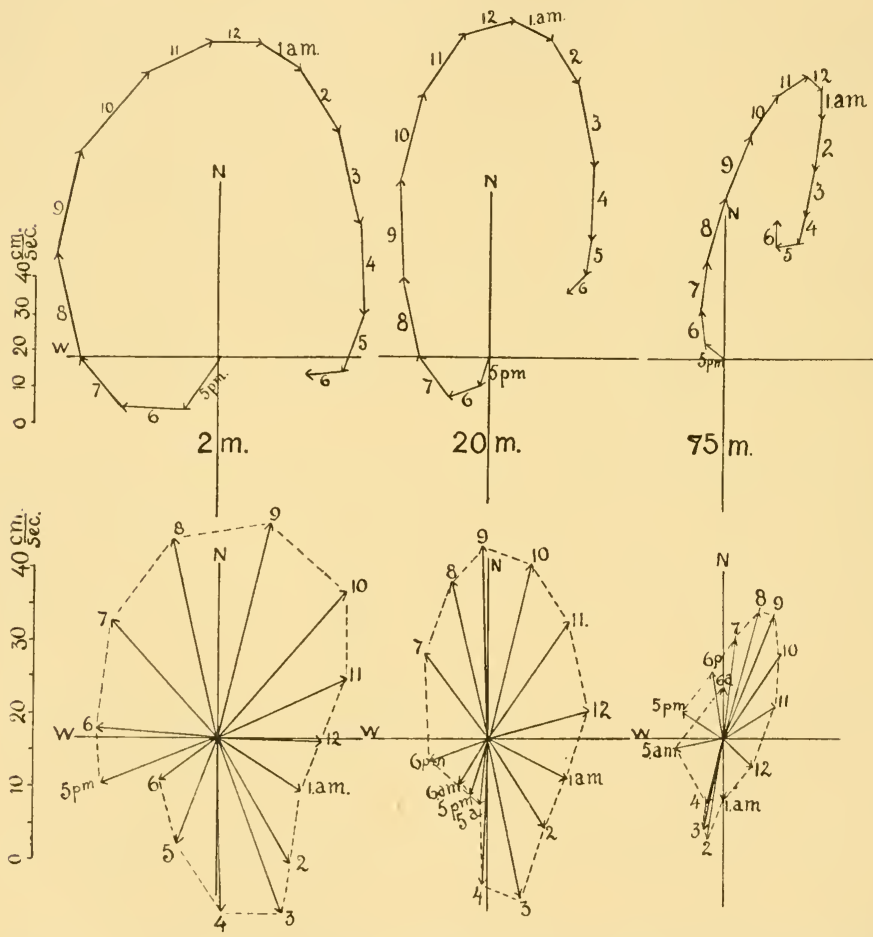

Fig. 179. - The Currents on the Ling Bank'in the Nor'th Sea (7th-8th August 1906).

Europe, producing tidal effects there. But besides this wave coming from the Southern Ocean there is formed an Atlantic tide-wave following the movement of the sun and moon from east to west. As already remarked, these things are somewhat enigmatical, but as there is a connection between tidal waves and tidal currents, we may hope that careful current-observations will contribute to the unravelling of these problems. 
In August 1906, a series of current-measurements was made Currentby the "Michael Sars" on measurements

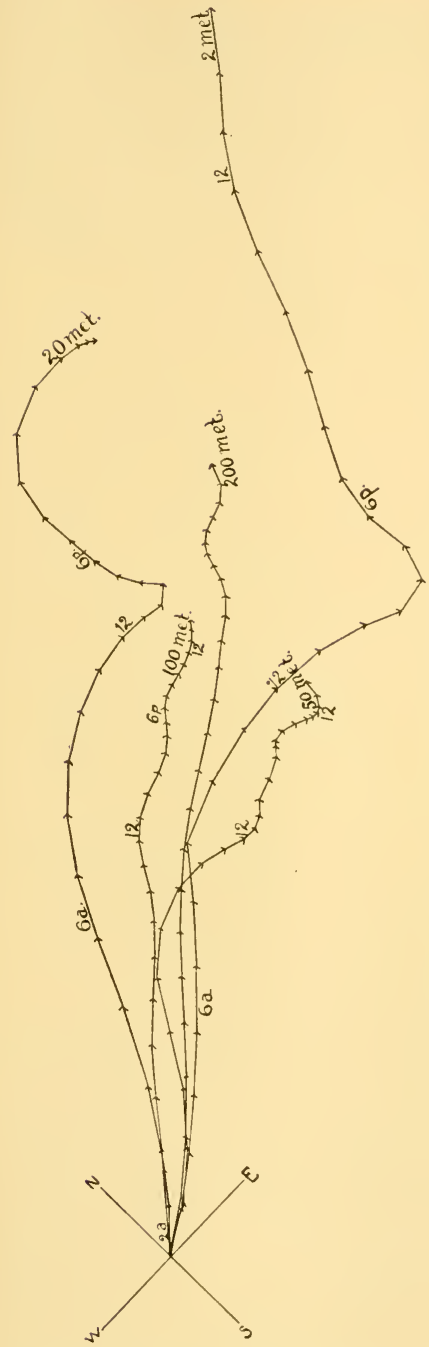
the Ling Bank in the North Sea. Sea. Fig. 179 shows the currents at depths of 2, 20, and 75 metres (the depth of water being 80 metres). In the lower row the direction $\rightarrow$ and velocity of the current : are indicated by arrows for every hour from 5 P.M. on the 7 th August to 6 A.M. on the 8th August. It is seen how the water moved at the different depths, varying in direction and velocity; in the course of twelve or thirteen hours the direction of the current had passed through all the points of the compass. In the top row all the arrows are joined, thus forming a line which shows roughly the motion of the water during the period of thirteen hours. The course proved to be somewhat elliptic, the water returning very nearly, but not quite, to its point of departure. This is a typical case, for tidal currents are, as 7 a rule, characterised by this $\therefore$ turning, the water arriving at \pm its starting-point again after 离 a period of about twelve and a half hours. The displacement in the course of this time, as exhibited by the current-lines, is attributable to a general motion of the water, towards the east at 2 metres, north-east at 20 metres, and north-north-east at 75 metres. But this 
Currentmeasurements on Storeggen.

general motion is quite insignificant compared with the tidal current.

In Fig. I 80 we see some current-lines of a totally different form, the results of a number of measurements made on Storeggen, westward of Aalesund, on the I 2 th and I $3^{\text {th }}$ July I 906. A line is drawn for each of the following depths below the surface: $2,20,50,100$, and 200 metres (the depth of water being 260 metres). It is seen that the current on the whole flowed in a north-easterly direction at all depths, but the

\section{Stat 5810 meters \\ 12 VI 1910}

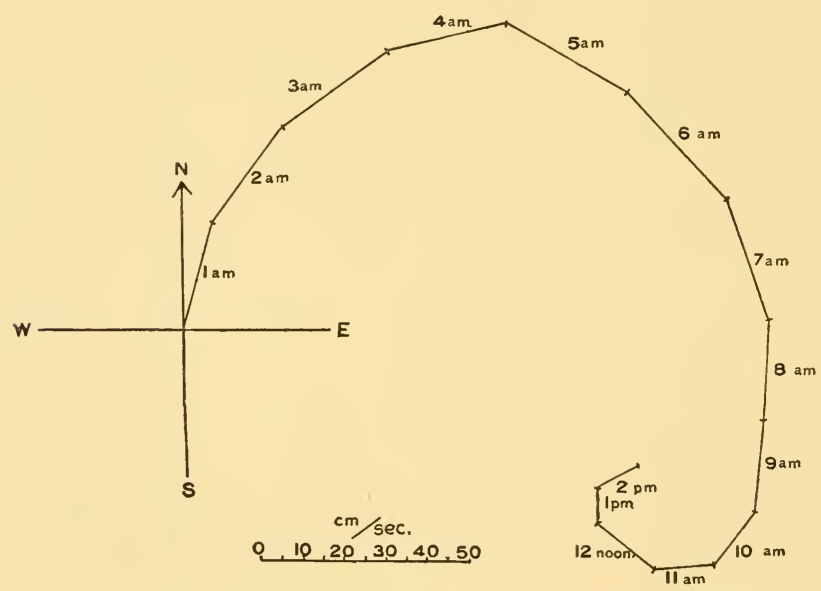

Fig. 181.-Result of Current-Mieasurements at io metres at Station 58, SOUTH OF THE AZORES (12th June 1910).

direction was not constant, as implied by the bends in the lines. The variations of direction were due to the tides, but here the tidal current was weak compared with the general motion of the water-masses. In this place the coast-current of the upper 75 or IOO metres, and that portion of the Gulf Stream which traversed the layers below, both ran towards the north-east; had there been no tide-motion on the bank, the lines would probably have been straight, not sinuous.

The measurements at these two stations give an idea of the movements of the water-masses in the sea, and show that current-lines may have very different courses, largely determined 
by the relation between the tidal current and the general drift of the water.

We have already mentioned that the observations made at

$$
\text { I } 46 \mathrm{~m}(25 f)
$$
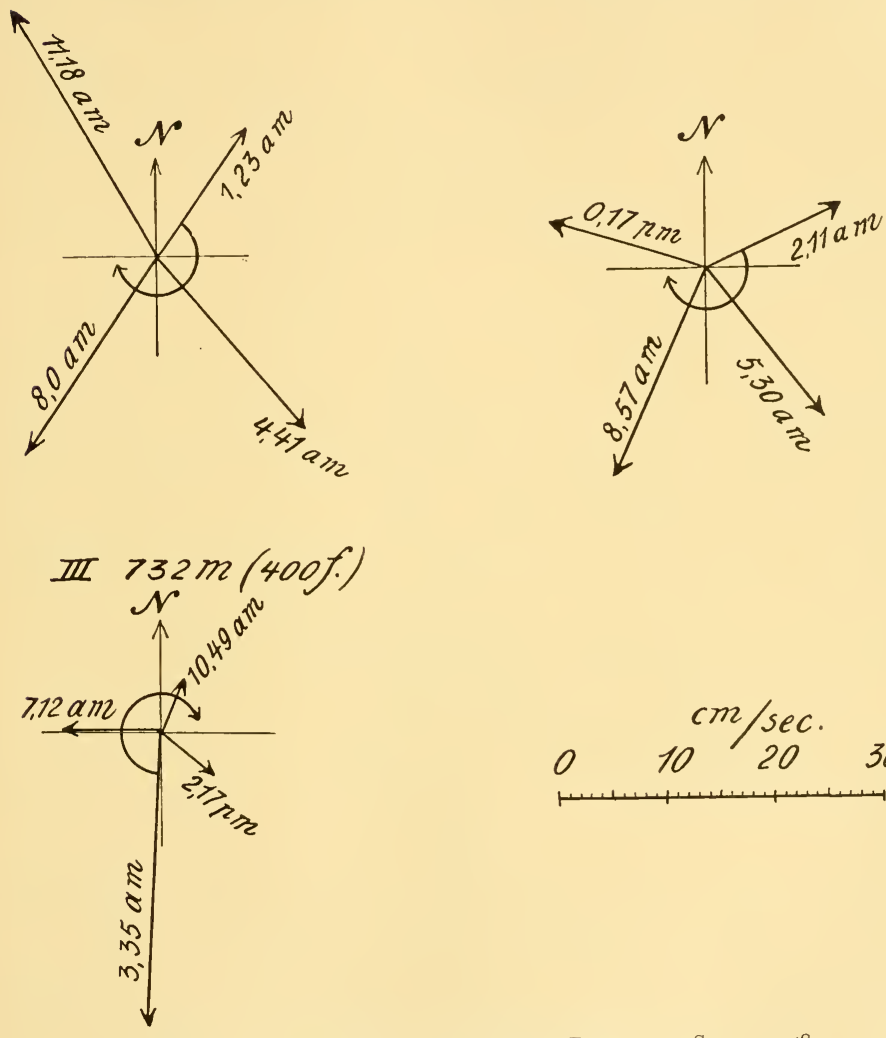

Fig. I82.-The Currents at Different Depths at Station 58 , SOUTH OF THE AZORES (12th June I9IO).

Station 49 C lead us to infer that tidal currents exist even in the deep sea. Again, at Station 58, south of the Azores, we made a number of current-measurements from the ship at anchor throughout one complete tide-period. With one of the 
Currentmeasurements to the south of the Azores.

current-meters we took regular observations at Io metres, 70 in all, from I A.M. till 2.45 P.M. on the I 2 th June. Fig. I 8 I shows the variations at this depth, which recall the current-lines on the Ling Bank. The tidal current predominated, attaining a maximum velocity of $38 \mathrm{~cm}$. per second ( 0.7 knot per hour); there was also a general drift of the water towards the south-east, with a mean velocity of $8-9 \mathrm{~cm}$. per second ( 0.2 knot per hour). Simultaneously another apparatus was employed to determine the current at different depths down to 732 metres ( 400 fathoms), the depth of water exceeding 900 metres. Some of the results are represented in Fig. I 82, which shows the current at different depths: I. at 46 metres ( 25 fathoms); II. at $8_{3}$ metres (IOO fathoms); and III. at 732 metres (400 fathoms). At all depths the velocity and direction varied constantly, the changes in direction being clockwise, and it is notable that the direction shifted about $I 80^{\circ}$ in the course of half a tide-period. In this case there is no doubt that tidal currents prevailed throughout the whole body of water from the surface to the bottom; they were unmistakable even at 732 metres; at this depth a velocity of more than $27 \mathrm{~cm}$. per second (more than $\frac{1}{2}$ knot.per hour) was once measured, showing that the tide can make its influence felt down to considerable depths. This is particularly the case where a plateau or ridge obstructs the passage of the tidal wave; in such places the current near the bottom is probably increased. This would explain the remarkable fact that on many submarine slopes and ridges no fine mud is deposited, because the strong current sweeps the bottom clean.

Another interesting result of these measurements is represented in Fig. I 83, where the arrows show the currents at several depths simultaneously: I. at 3.35 A.M., and II. at 7.12 A.M. on the same date. We see that the currents set in different directions at the different depths. In the upper layers the direction shifted more and more to the right with increasing depth, but from 100 fathoms ( ${ }_{1} 8_{3}$ metres) down to the bottom the direction was reversed. Thus the current at 500 metres ran in the opposite direction to that of the upper layers, which again approached that of the currents at the greatest depths. At a certain moment the currents are, then, arranged in the fashion of spiral staircases, the whole system turning in clockwise direction from top to bottom.

These observations in the Atlantic give rise to many interesting ideas about the currents in the sea, and show that there 
is still much to be done in this line. But the fluctuations of the ocean-currents are determined by more influences than tides, for many other forms of motion supervene, rendering the whole picture highly complicated. A careful analysis of the measurements made on Storeggen in 1906, led to the conclusion that there were certain regular variations which took the form of

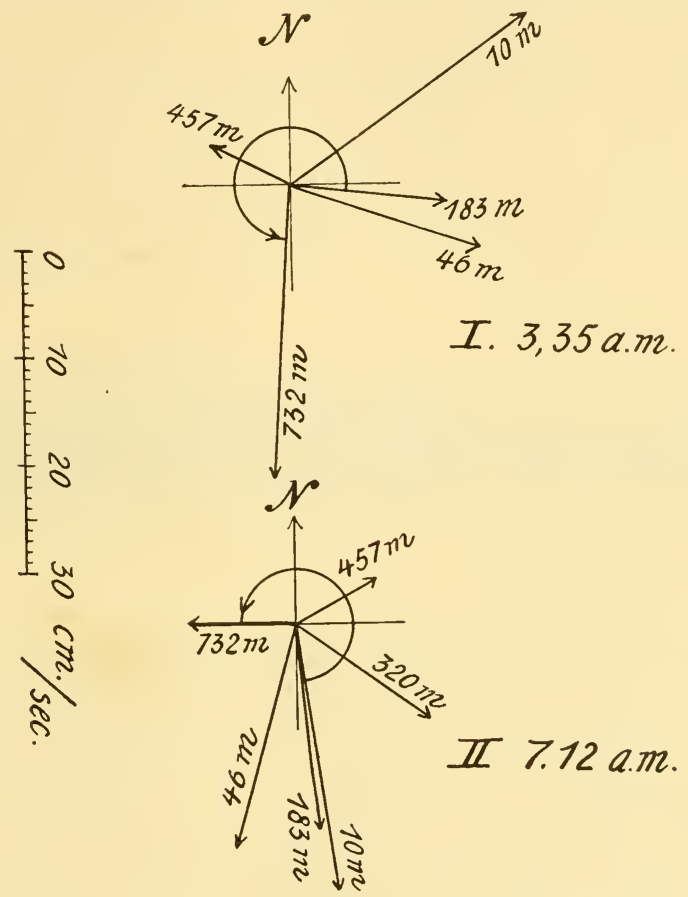

Fig. 183.-The Currents as Determined by simultaneous measurements (3.35 A.M. AND 7.12 A.M.) at DIfFereNt Depths at Station 58.

pulsations in the current. When the effect of the tide was Pulsations subtracted it appeared that the ordinary current at Io metres in currents. ran for some time with considerable velocity (up to $\frac{1}{2}$ metre per second) ; then the velocity decreased during seven or eight hours until it approached zero, increasing again during the next seven to eight hours, and so on. The fluctuations had thus a period of about fifteen hours, but we are as yet ignorant of the particular cause, though it may be a usual phenomenon in the 
sea. Supposing the coexistence of two different periodical variations, one with a period of about twelve and a half hours, the other with one of about fifteen hours, an infinite number of variations would ensue, to which might be added the more casual influence of the wind and other factors, causing among other things incessant dislocations of the boundaries between the different water-layers or currents.

Windproduced currents.
Boundarywaves.

The wind may produce a current, particularly in the surface layers, thus altering the direction and velocity of the existing current. WVe know very little, however, about the relation between wind and current, through lack of detailed observations, although the question is naturally of the first importance from an oceanographical point of view, as well as from its bearings on the conditions of everyday life. This is one of the principal tasks for the oceanographer of the future; such observations are difficult to make, no doubt, but with modern methods much can be done.

A wind blowing over the sea will carry the surface water along with it. In the open ocean

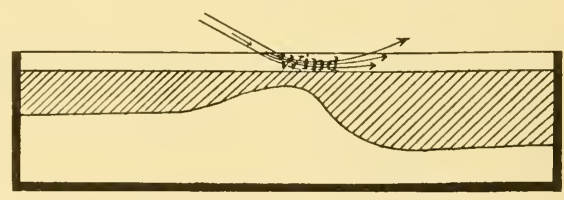

FIG. I84.-SANDSTRÖM'S EXPERIMENT FOR PRODUCING A SUBMarine WAVE BY a GUST OF WiND. the current thus produced is generally somewhat deflected from the direction of the wind itself. During the drift of the "Fram" over the North Polar Sea, Nansen found that the ship, as a rule, was carried to the right of the wind's course. V. W. Ekman has studied the question theoretically, arriving at the conclusion that such a deflection is a result of the earth's rotation. Later, Forch, by extracting the records from a number of ships' journals, found the same deflection to the right in the Mediterranean and in the North Atlantic, while, as might be expected, there is a deviation to the left in the southern hemisphere. Now, as the surface-water is carried along by the wind, the deeper layer will approach the surface at the place of origin of the wind-current. In Fig. I84, which represents one of Sandström's experiments, we see how the wind may raise the boundary between the upper and lower water-layers. When the wind ceases this rise again subsides, producing a boundary-wave which will proceed farther. A wave like this may attain a considerable height, without being perceptible at the surface; its dimensions will depend on the distribution of density. A boundary-wave in the Norwegian 
Sea Ioo metres in height would manifest itself as a surfacewave about $5 \mathrm{~cm}$. high, that is, practically imperceptible, as the wave is very long and proceeds slowly. Several of the "Michael Sars" investigations indicate such boundary-waves, but here also precise observations are lacking. They are, however, known in one particular form, viz. as the boundarywave producing "dead water." When a comparatively fresh and light water-layer, 2 or 3 metres thick, rests on a salt and heavy layer, a passing ship may give rise to a boundarywave between the two layers. This wave may stop the ship, so that it lies in dead water hardly able to move at all. Ekman, who has investigated these phenomena, has demonstrated the dead-water wave by the following experiment (see Fig. I 85 ). He put salt water, coloured dark, into a long basin, and on the top he poured a thinner layer of fresh water; when he slowly towed a small model of a ship through the upper layer, a

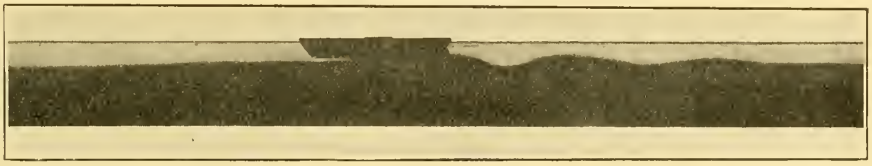

Fig. 185.-Ekman's Experiment to show the wave producing Dead-water.

boundary-wave arose, as seen in the figure, which, when strongly developed, checked the speed considerably.

Naturally when a wave like this passes a certain spot on the sea, the undulating boundary between the two water-layers will at one moment be vertically nearer to that spot, at another moment farther down. Similar vertical oscillations may arise in other ways, as we shall now briefly indicate before describing some observations made during the cruises of the "Michael Sars," which prove that such undulations do exist in the sea.

We may first mention one of the effects of the rotation of the earth. By reason of the earth's rotation a body moving freely in the northern hemisphere in any direction will be deflected to the right, and with great velocities this deflection is quite considerable. There are many examples of it: a swinging pendulum constantly turns; the wind does not blow straight towards a cyclonic area, but in a spiral direction, bending to the right in the northern, and to the left in the southern, hemisphere; the effect of the earth's rotation is also

Effect of the earth's rotation 
seen in the direction of the trade-winds, monsoons, etc. The rivers of Siberia flowing northwards to the Polar Sea, eat into their eastern beaches as an effect of the rotation of the earth. It is the same influence which directs the course of the great ocean-currents. In the North Atlantic the warm currents from the south bend in general to the right, that is to the east, and the cold currents from the north likewise bend to the right, that is to the west; thus the Gulf Stream flows across to Europe, and the polar currents to Greenland and Labrador. Let us now suppose that we take observations at a couple of stations right across a current. This may be represented roughly by a vertical section, as in Fig. I 86 ; we must here imagine that the motion takes place in the direction from the eye through the paper, that the motion is swiftest at the top, and that we are in the northern hemisphere. The rotation imparts to the water-

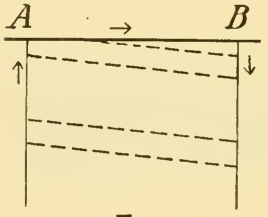

$I$

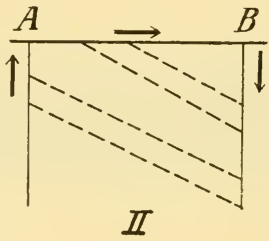

FIG. I 86.

By reason of the deflecting influence of the earth's rotation (represented by the horizontal arrows) the water-layers acquire a slanting position, determined by the difference of velocity and density in the different layers.

the broken lines, the incline being current is slow (I) and strong if the current is rapid (II.). Consequently the light water will go deep at $B$, the station situated to the right in the current, while at Station A, on the left, the heavy water from below will come nearer to the surface. Wherever there is a strong current in the upper water-layers the following rule will apply in the northern hemisphere: on the right-hand side the water is comparatively light, on the left-hand side comparatively heavy ; the conditions are reversed in the southern hemisphere. There are many examples illustrating this. Off the west coast of Norway the current runs north, and the water to the right, near the coast, is light, while that to the left, in the middle of the Norwegian Sea, is heavy. In the Gulf Stream off the east coast of North America the water is light (warm) on the right side of the current, and cold (heavy) on the left. The southern hemisphere 
affords many other examples; the distribution of temperature in the remarkable Agulhas Current, for instance, is explained in this way.

The Norwegian coast-current presents a good example of the effect of the earth's rotation on the inclination of the water-

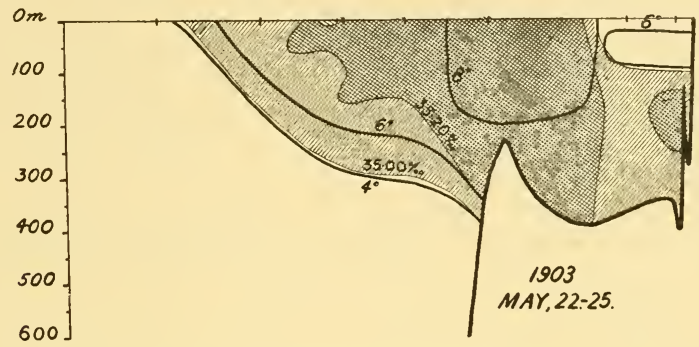

Fig, 187.-The Sognefjord Section in May 1903.

(Fig. I6 5 shows the same section in May 1904.)

layers. Fig. 187 shows the conditions in May 1903 along a section through the Norwegian Sea from the mouth of the Sognefjord to the west; on the right, close to the land, the coast-water attains a depth of about roo metres. By heating in the course of spring and summer this water becomes lighter

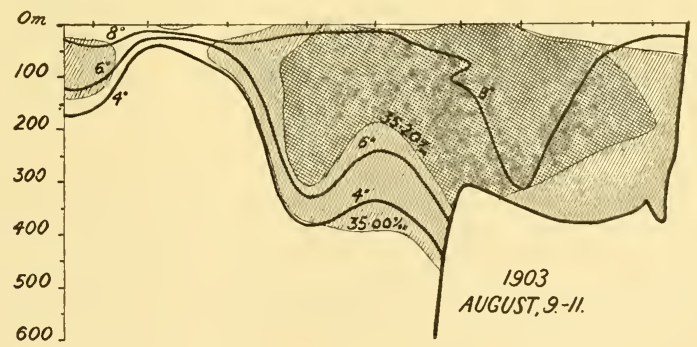

Fig. I88.-The Sognefjord Section in August 1903.

and acquires a greater tendency to spread over the surface. This tendency counteracts the deflecting force of the earth's rotation, and finally causes the surface-layers to extend towards the west, becoming less thick in proportion. Fig. 1 88 shows the conditions along the same section in August 1903, when we repeated the investigations. The coast-water now lay much farther from the land than in May, reaching only to a depth of 
60 metres near the coast, the water naturally having become lighter and its tendency to spread westwards having overcome the effect of rotation acting eastwards. When the coast-water is cooled down in autumn it becomes heavier again, is not then so much lighter than the Atlantic water, and has consequently not such a great tendency to spread westwards over the surface as in summer; it is then forced towards the land (to the right) again by the rotation of the earth. Thus there are in the course of the year periodic lateral movements of the coast-water, which are of importance, for instance, in their effect on the distribution of the young fish.

The water-layers, then, slant differently according to the strength of the surface-current and the vertical distribution of density. Supposing the surface-current to run sometimes fast and sometimes slow, the layers will respectively be lowered or raised. Again, regarding Fig. I 86, the layers that in I. are comparatively deep at Station A, by an increase of the surface-

Vertical oscillations.

Observations in the Faroe Channel. current (as in II.) will rise considerably higher. Thus vertical oscillations are set up as a consequence of the fluctuations of the current; at a certain fixed point the movement will be like that of a submarine wave. Such vertical oscillations may be imagined to arise in other ways. It is, for instance, highly probable that there exist in the sea standing waves with one or more nodes, similar to the undulations of a violin string. Forel, Chrystal, and others have found these standing waves in lakes, the Japanese have shown them to be present in their seas, and we have several indications of their existence in the Norwegian Sea.

We cannot dwell any longer upon this question, but will now examine some observations made during the "Michael Sars" Expedition, which show marked vertical oscillations of one kind or another. We made a number of careful measurements in the course of twenty-four hours at Station I I 5, in the eastern part of the Faroe-Shetland Channel, near the slope west of Shetland, in 570 metres of water. Here we anchored a buoy, near which the steamer kept as long as the observations lasted. We made continuous observations of temperature and salinity at the same depths, and were thus able to see whether or not the conditions at a certain depth varied. At the same time similar measurements were made by the Scottish research steamer, the "Grold-Seeker," on the Faroe side of the channel. By these simultaneous investigations we hoped to determine 
whether the variations were due to a progressive wave, or to fluctuations in the current, or to standing waves. The results have not yet been worked out, so we can only discuss some of the "Michael Sars" observations. Unfortunately it was impossible to make direct current-measurements, as the weather was too rough.

During the twenty-four hours we made 86 observations at the buoy, care being taken that the line was absolutely vertical. Surface-observations apart, most of the measurements were made at a depth of 300 metres (I 9 observations). The temperatures found at this depth are noted in Fig. 189 along the vertical scale, while the hours are put down along the horizontal scale. There were considerable variations: on the 13 th August at 5.8 P.M the temperature was $5.60^{\circ} \mathrm{C}$., and on the 14 th August at I 2.25 A.M.

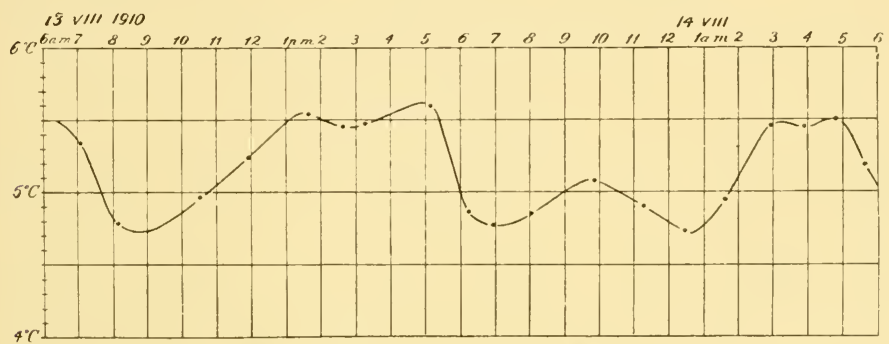

Fig. 189. - Temperature Variations at 300 metres at Station il5 (1 $3^{\text {th-14th }}$ August 1910).

it was $4.73^{\circ}$ C. - a difference of $0.87^{\circ}$ C. When the mean temperatures of the different water-layers are calculated and represented in curves, it is easy to see how much the temperature altered for each metre of depth. At about 300 metres the temperature decreased with increase of depth to such an extent that a difference in temperature of $0.87^{\circ} \mathrm{C}$. corresponded to a difference in depth of about 35 metres. In the other layers there were similar variations, indicating vertical oscillations of between 15 and 35 metres. These observations go far to prove the presence of such undulations of the water-layers, which is indicated also by the form of the curve in the figure, among other things. But these variations are not comprised in one single period, as if they were due to an ordinary progressive wave, or an ordinary standing wave alone. The shape of the curve points to complicated fluctuations of the velocity as the cause of the variations, but it is possible, nay probable, that we 
are here confronted with an inter-play of several different factors. It is, by the way, worthy of notice that there is an interval of twelve or thirteen hours between the two principal maxima of temperature; this agrees with the tide-period, and we know that the velocity of the current varies with the tide.

In previous investigations in the Norwegian Sea we have several times encountered variations which are most naturally explained by supposing that there are great undulatory movements of the water-layers, and the investigations just described strongly corroborate this supposition. The problem is one of the greatest importance, and its solution will, in more ways than one, lead to a fuller comprehension of the science of the sea, in the first place with regard to the dynamics of the water-masses, and in the second place with regard to certain biological questions. The discontinuity-layer is often a boundary between two different worlds of living organisms, and it is a point of interest for the study of these to know if this boundary is moving up and down, for this would probably imply that the organisms themselves (possibly even shoals of fish) were also being moved up and down. On the continental slope, just below the edge, there live multitudes of marine animals, the warm water having one characteristic fauna, and the deeper cold water another. Now, if the fairly definite boundary between the two water-masses swings up and down, one must expect that there is a comparatively broad transitional region, where the particularly hardy individuals of either of these characteristic domains would live together. Where the change of temperature is slow and regular the effect upon the organisms would be of little importance; not so, however, where there is a marked discontinuity-layer, as for instance in the Norwegian Sea. The proof that there are such oscillations would also be of very great importance for our methods of studying the sea. Let us look, for example, at Fig. I90, showing a section from Shetland to the Faroe Islands, taken during the "Michael Sars" Expedition on the Ioth and I Ith of August. The positions of the stations are shown in Fig. IO4, p. I22. Isotherms are drawn at intervals of two degrees Centigrade; single hatching indicates salinities between 35.00 and 35.25 per thousand, and cross-hatching salinities above 35.25 per thousand ; in the deep layers the salinity was below 35 per thousand. The lines both for temperature and salinity are strikingly wavelike in the intermediate water-layers. The saltest water has come from the Atlantic in the south, and the cold deep water 
from the Norwegian Sea; the boundary between these layers lies deeper at Station Io6 than at the neighbouring stations, the difference of level amounting to 200 metres. In order to get as true a picture of the conditions as possible the stations were placed at short intervals of only 20 nautical miles; there may be great differences within 20 miles, as from Station IO5 to Station I06, and fewer stations at longer intervals might have given a totally false representation. Knowing the distribution of salinity and temperature, we may now draw conclusions as

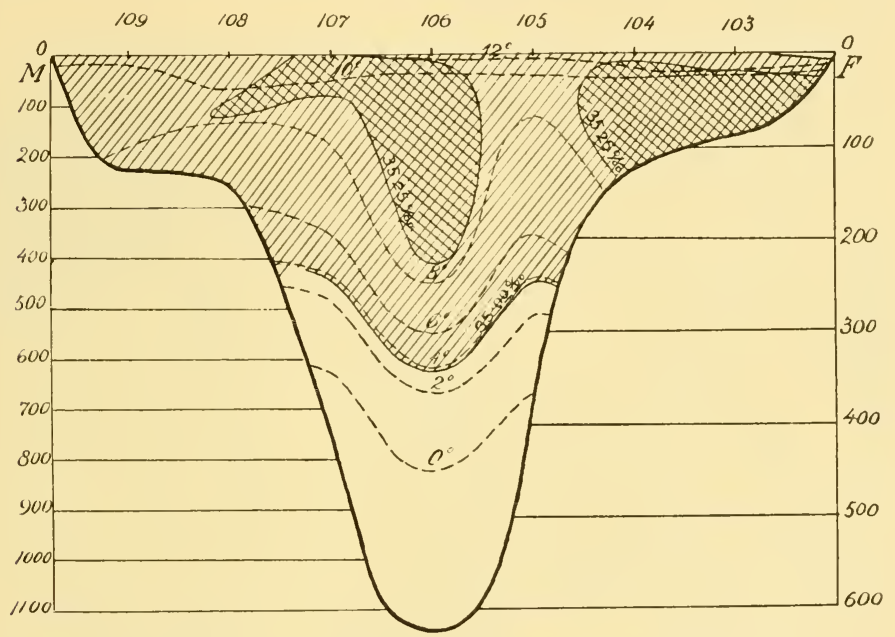

Fig. 190. - The Southern Section in the Faroe-Shetland Channel (IOth-1 ith August 1910).

to the nature of the currents, their direction, breadth, and depth. Our section has a rather irregular look, suggesting complicated conditions; it seems, for instance, as if the Gulf Stream were divided into two branches, one close to Shetland, and one in the middle of the channel. In the present case the variations from one station to another are probably in part caused by the vertical oscillations mentioned, but they are evidently in part due also to another important phenomenon, viz. vortex movements.

One of the objects of our joint-research with the Scottish Vortex investigators in the Faroe-Shetland Channel was to throw light movements. 
on possible vortex movements. Four parallel sections were made, the two in the middle by the "Michael Sars," the southerly one being represented in Fig. I90, and the northerly one in Fig. I9I. In the map of the stations (Fig. IO4, P. I 22) the position of the sections is seen, the distance between them being 20 to 25 nautical miles. Although the sections were so close together they differed greatly. In the northern section the lines are fairly regular; high salinities of more than 35.25 per thousand are found only in the neighbourhood of Shetland, not in

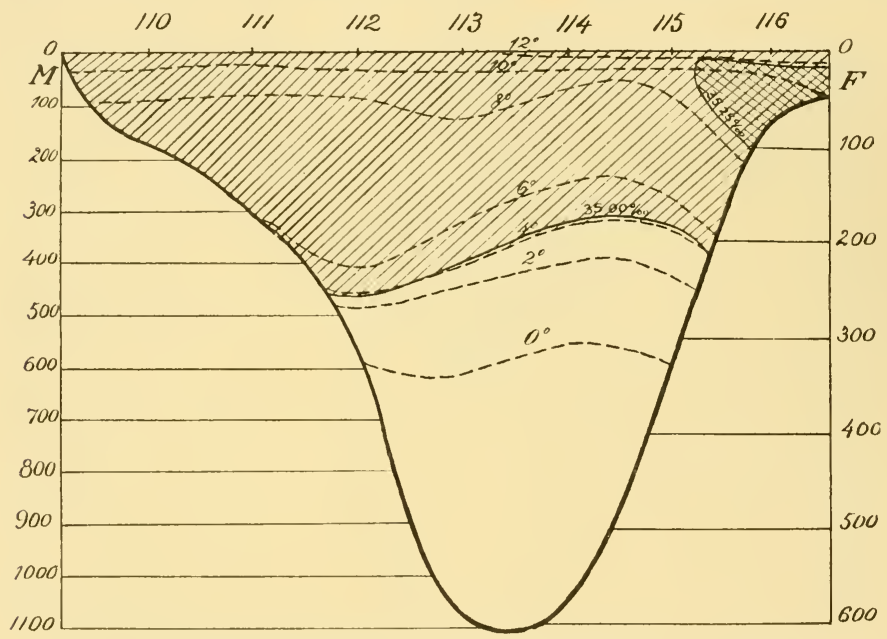

Fig. i9i.-The Northern Section in the Faroe-Shetland Channel

(I Ith-I4th August I9IO).

the middle of the channel. Vertical oscillations may have had great influence on the appearance of the section. The two sections might not have presented such great differences if the observations had been taken at other times, but in any case they point to other irregularities, in the first place to vortices with vertical axes, similar to those known in rivers, only very much larger. These vortices have rendered the motion of the water highly complicated. The "Atlantic water" has moved towards the north, having a breadth of 50 or 60 miles in the neighbourhood of Shetland; between Stations 105 and 106 the water of the upper layers has probably moved southwards, between Stations I06 and I07 to the north, and so on. Previous investigations 
have shown that there are great vortices in several places in the Norwegian Sea. Fig. 192 shows the distribution of salinity at a depth of Ioo metres in the southern part of the Norwegian Sea and the northern part of the Atlantic in May 1904. The arrows mark the probable direction of the movements. There are several vortices of different dimensions, one being drawn in

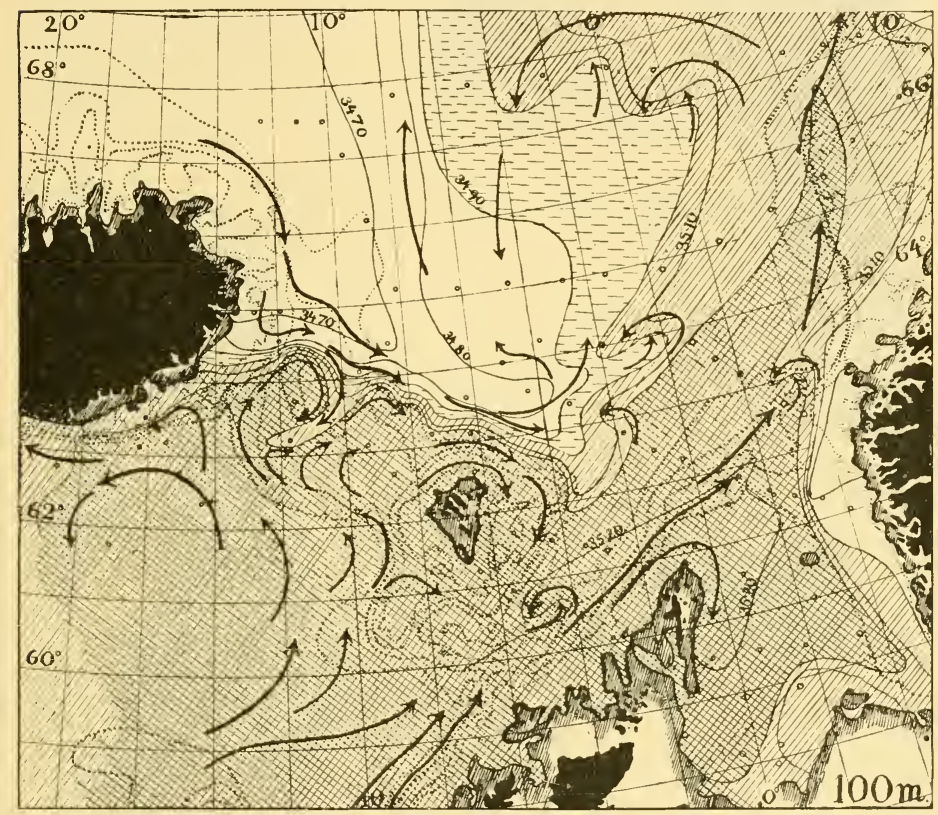

Fig. 192.-The Distribution of SAlinity in the Northern part of the Atlantic OCEAN AND THE SOUTHERN PART OF THE NoRWEgian SEA AT A DEPTH OF IOO METRES (May 1904).

the Faroe-Shetland Charinel; similar conditions prevailed in this place in August I9IO.

Nansen and the writer have discussed ${ }^{1}$ at some length the currents and oceanographical conditions of the Norwegian Sea on the basis vortices in the of earlier investigations. Fig. I93 shows the currents and Sea. vortices in the Norwegian Sea. We arrived at the conclusion that there must be many forms of motion of great and farreaching importance, though hitherto hardly known at all, 
among them vertical oscillations of the water-layers and vortex movements. Many things go to prove that these are phenomena of general occurrence. We must picture to ourselves great

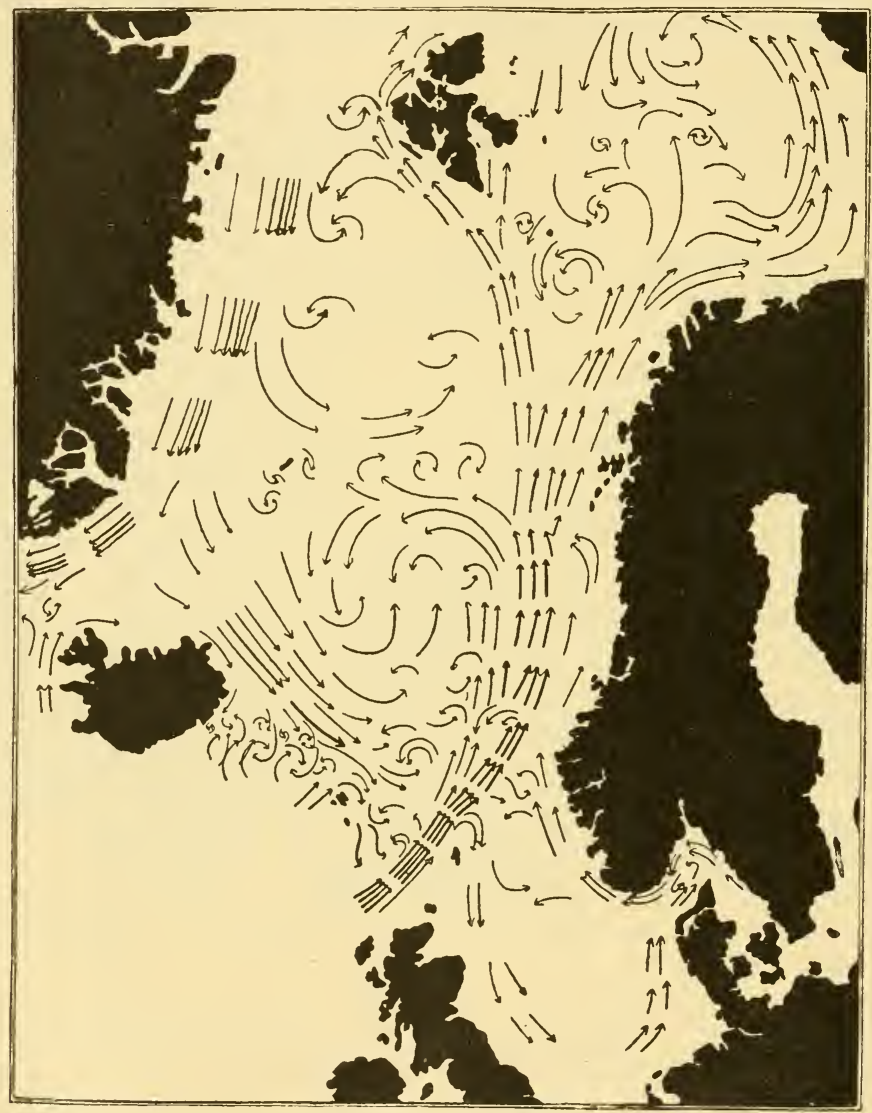

Fig. I93.-The Currents of the Norwegian Sea.

submarine waves moving through the water-masses, alterations of depth in the layers according to changes in the velocity of the currents, standing waves, and great vortices. We must further conceive of constant fluctuations in the velocity, partly 
also in the direction, of the great ocean currents, not only by reason of the tides and as the effect of the wind, but also because the currents are subject to a sort of pulsation, the nature and origin of which are as yet unknown. There is an interplay of many different forces, producing an extremely variegated picture ; the sea in motion is a far more complex thing than has hitherto been supposed. Physical oceanography is confronted with a host of new problems, the solution of which will be a matter of the highest interest. It was to attack a few of these general problems that the physical and chemical investigations of the "Michael Sars" Atlantic Expedition were undertaken.

We shall now consider the investigations made during the "Michael Sars" Atlantic Expedition into the physical conditions in the Straits of Gibraltar. At the current-measurement station (Station 18) on the 29th and 3oth April we obtained a series of observations from different depths throughout one complete tideperiod. Some of the results are represented in the accompanying three figures. Fig. I 94 shows the direction and velocity of the movement at different depths on the 3 oth April : (I) at Io metres (about 5 fathoms), (2) at 46 metres ( 25 fathoms), (3) at 9 I metres (50 fathoms), (4) at $\mathrm{I}_{3}$ metres ( 100 fathoms), and (5) at 274 metres ( 150 fathoms). The arrows are drawn in the true directions; the velocities are seen by the scale. The current ro metres below the surface (I) had a westerly set on the 3oth April between 2 and 4 A.M., afterwards-until 4 P.M. at least-running without interruption eastwards (between southeast and north-east), that is into the Mediterranean. The velocities were at times very considerable, being greatest about 9 A.M., when we measured velocities up to i $8 \mathrm{~cm}$. per second, corresponding to 2.3 knots per hour; velocities of about I metre per second, or 2 knots per hour, were found during the whole time from 7 to I I A.M. Later in the day the current slowed down; at noon it was only $40 \mathrm{~cm}$. per second (0.8 knot per hour), increasing a little later; at 4.30 P.M. it was $70 \mathrm{~cm}$. per second ( 1.4 knot per hour); then the observations were broken off, but it was ascertained that the velocity was decidedly on the increase. The current thus ran into the Mediterranean with no very fixed set, the uncertainty of direction being partly due to the formation of vortices on the sides of the strait. Early in the morning the current set from the Mediterranean into the Atlantic, as mentioned above; the velocity at 2 A.s. was $47 \mathrm{~cm}$. per second ( 0.9 knot per hour), but it was then 

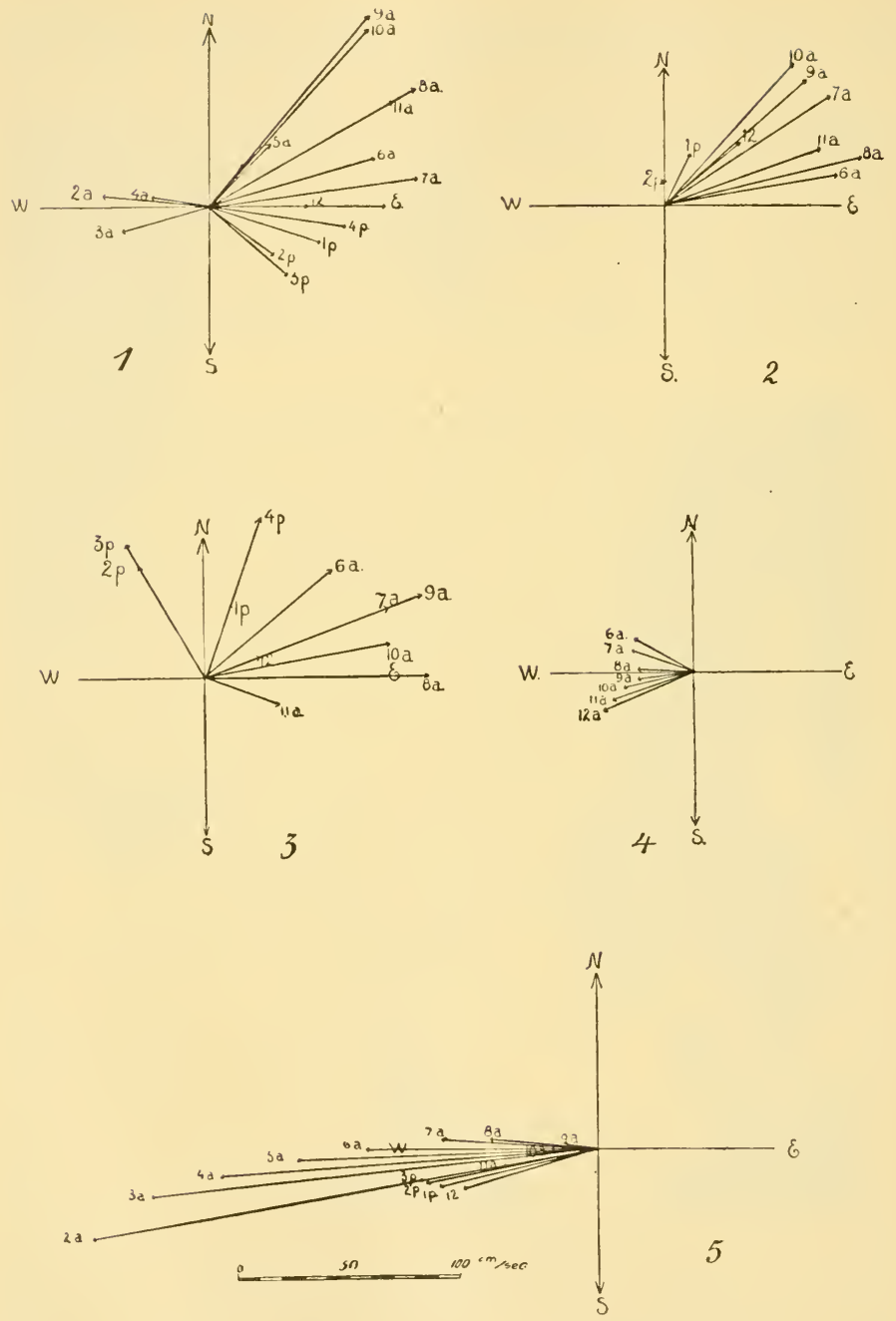

Fig. 194.-The CurreNts iN The Straits of Gibraltar on the 3OTH APRIL I9IO AT DIFFERENT DEPTHS.

$\mathbf{1}$ at ro metres, 2 at +6 metres, 3 at 9 I metres, 4 at 183 metres, and $\mathbf{5}$ at 274 metres. 
decreasing. These periodic changes, between a strong current running east and a much weaker one running west, are caused by the tides, which are strong enough to reverse the current. The tide-period being nearly twelve and a half hours, one might expect the turning of the current about 2 in the afternoon; at this time it was, however, still setting east, though with comparatively small velocity. It was thus only once in the day that the current at Io metres ran out of the Mediterranean; in other words, there was a difference between the two tide-periods in the same day. It is probably connected with the so-called "daily difference" of the tide, well known in many places, which manifests itself by each alternate high-water being conspicuously greater than the intervening one. We must, however, bear in mind that these results, of course, only apply to the particular day on which the observations were made, and we must therefore beware of drawing general conclusions until observations during a longer period and at different times of the year are available.

On the preceding afternoon (29th April) we obtained from the life-boat some measurements of the velocity of the current at a depth of 5 metres. At 5.I 5 P.M. the velocity was I I $3 \mathrm{~cm}$. per second ( 2.2 knots per hour), and was then on the increase, being more than $50 \mathrm{~cm}$. per second (nearly 3 knots per hour) at 6 P.M., and the current then set eastwards. This corresponds to the increasing velocity eastwards at a depth of ro metres half a day and a whole day afterwards. Some observations in the deeper strata were also made from the life-boat about 6 P.M. on the 29th April, the velocity at 25 metres being I $24 \mathrm{~cm}$. per second ( 2.4 knots per hour), and at 50 metres $138 \mathrm{~cm}$. per second ( 2.7 knots per hour); at both depths the current set in a north-north-easterly direction. Unluckily the observations were then interrupted for many hours by the breaking of the anchorcables, otherwise we should have had continuous observations during two whole tide-periods.

On the 3 oth April we obtained some series of measurements from the steamer down to the bottom in about 200 fathoms of water. The current often ran so fast that the wire with the apparatus was brought into a slanting position, and the first messenger was not sent down for some minutes to allow time for adjustment. This rendered the determination of depth somewhat uncertain; the depths quoted refer to the length of wire out, and may sometimes exceed the actual depth, but it was useless to apply corrections, as we did not know the lie of the line in the water. Fig. 194, 2, shows the current at 46 
metres ( 25 fathoms) below the surface between 6 A.M. and 2.20 P.M. In the forenoon the current ran east in the same manner as at a depth of 10 metres; about 8 A.M. the velocity was more than $90 \mathrm{~cm}$. per second (I.8 knot per hour); about II A.M. it was slackening considerably, and at 2.20 P.M. it was merely $9 \mathrm{~cm}$. per second ( 0.2 knot per hour); the current then set to the north. The variations in velocity correspond to those found at 10 metres.

Similar results (Fig. I 94, 3) were obtained at 91 metres (50 fathoms), where the current ran into the Mediterranean in the forenoon with velocities attaining $105 \mathrm{~cm}$. per second $(2$ knots per hour); but between 2 and 3 P.M. it turned to the north-west, that is, mainly towards the Atlantic and contrary to the current at 10 metres.

Fig. I 94, 4, shows the results obtained by sending down the current-meter with ${ }^{8} 83$ metres ( 100 fathoms) of wire. The observations were made between 6.40 A.M. and II.26 A.M., and all this time the current ran out from the Mediterranean in the direction opposite to that of the higher layers, the greatest measured velocity being rather more than $40 \mathrm{~cm}$. per second (o.8 knot per hour). The transition from the current running into the Mediterranean to that running out must have been somewhere above Ioo fathoms.

The observations with the apparatus out with 274 metres ( 150 fathoms) of wire are particularly interesting (see Fig. $194,5)$. They were made from 2.1 5 A.M. to 3.30 P.M., and the current all that time ran west, from the Mediterranean into the Atlantic. At 2.I 5 A.M. the enormous velocity of $227 \mathrm{~cm}$. per second ( 4.4 knots per hour) was observed; at this time the current at Io metres had also a westerly set. Then the velocity decreased; at 8.49 A.M.- - half a tide-period later-a velocity of only $17.5 \mathrm{~cm}$. per second (rather more than 0.3 knot per hour) was measured; at this time the current in the opposite direction at Io metres ran its fastest. Later on, the deep current increased in velocity, running at 3.27 P.M.-after another halftide period $-83 \mathrm{~cm}$. per second ( $1.6 \mathrm{knot}$ per hour). There was a similar difference between two successive tides at 274 metres and at Io metres. These observations gave this important result: that when the surface current ran fastest to the east the under current setting west was at its slowest, and vice versa.

At I 2.22 P.M. one of the current-meters was sent down with 366 metres (200 fathoms) of wire, but after working for ten and a 
half minutes it was hauled up in a wrecked condition. The wings were battered and bent, and the compass was gone; it was clear that the apparatus had been bumping against the stones on the bottom. The propeller had made 280 revolutions, implying a velocity of I I $\mathrm{cm}$. per second ( 0.2 knot per hour), so that the water had moved along the bottom at that rate at least, probably faster, as the propeller must have revolved too slowly after being injured. This separate measurement gives the interesting result that there may be an appreciable current even along the bottom.

Now, in what relation do these currents stand to high and low water? The tide-tables show that at Cadiz and Algeciras high water and low water on 3 oth April 1910 occurred at the following hours :

\begin{tabular}{|c|c|c|c|}
\hline & & High Water. & Low Water. \\
\hline $\begin{array}{l}\text { Cadiz } \\
\text { Algeciras }\end{array}$ & . & $\begin{array}{l}\text { 4.5 I A.M., 5.I } 6 \text { P.M. } \\
\text { 5. I } 5 \text { A.M., 5.40 P.M. }\end{array}$ & $\begin{array}{l}\text { I I.O4 A.M. } \\
\text { I I. } 28 \text { A.M. }\end{array}$ \\
\hline
\end{tabular}

In the straits high water may with sufficient accuracy be referred to about 5 A.M., low water to a little after II, and the next high water to about 5.30 P.M. It follows that the water ran fastest into the Mediterranean about four hours after high water, i.e. at falling tide, and that it ran fastest out from the Mediterranean three or four hours after low water, that is, with a rising tide.

In Figs. 195 and 196 the current-conditions between the surface and the bottom are shown, in the first for the 3 oth April at 9 A.M., when the current into the Mediterranean was running at its maximum, and in the second the mean for the movements at 2 A.M. and at 3 P.M., when the current out of the Mediterranean attained its greatest velocity. The velocities at the different depths have been calculated with regard to the longitudinal direction of the strait, the varying directions of the current having been taken into account ; the actual velocities are shown in Fig. 194. The two diagrams give a good picture of the relation between the upper and the lower current in the middle of the straits, the former about four hours after high water, the latter three or four hours after low water. It is seen that the boundary between the two currents lay at a depth of about I 60 metres when the inflow into the Mediterranean was greatest, and 
that it approached the surface when the inflow was least,

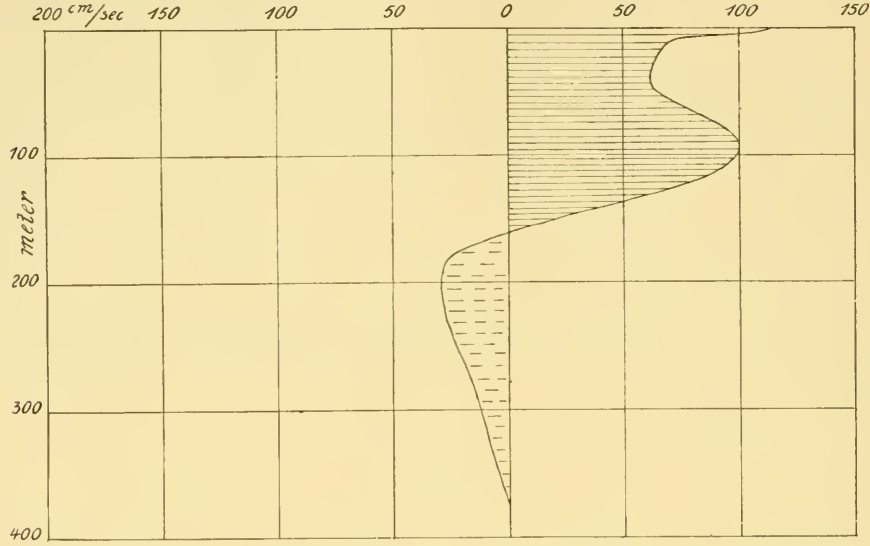

Fig. 195.- The Motions in THE Different layers in the Straits of Gibraltar (CALCULATED FOR THE LONGITUDINAL AXIS OF THE STRAITS) WHEN THE CURRENT was setting into the Mediter Ranean at its Strongest (30th April igio).

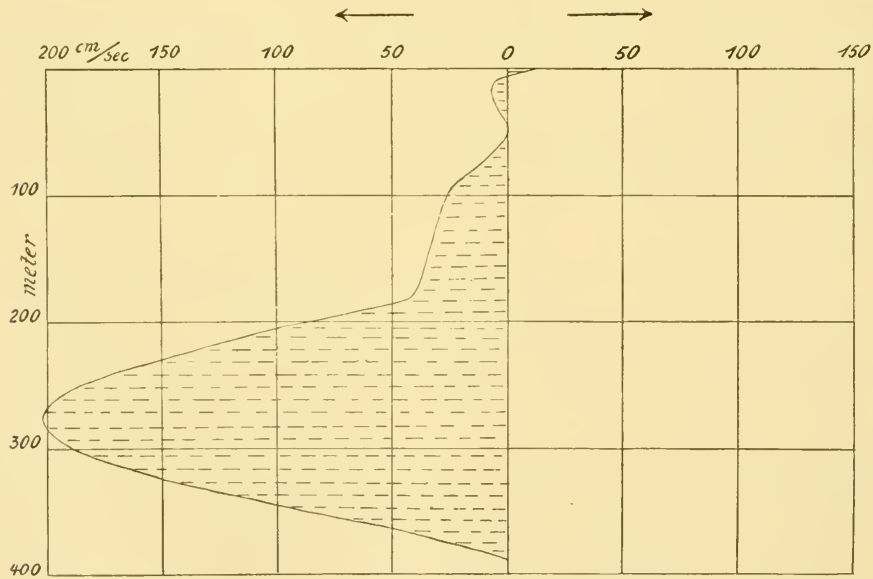

Fig. 196. - The Currents along the longitudinal axis of the Straits of GibRALTAR ON THE 3OTH OF APRIL I9IO, WHEN THE CURRENT SET STRONGLY TOWARDS THE ATLANTIC.

moving IOO-150 metres up or down in the course of half a tide-period. 
Together with the current-measurements four series of Temperatures water-samples and temperatures were taken; the results are in salinities given in the following table:of Gibraltar.

\begin{tabular}{|c|c|c|c|c|c|c|c|c|}
\hline \multirow{2}{*}{$\begin{array}{r}\text { Depth. } \\
\text { Metres. } \\
\quad 0\end{array}$} & \multicolumn{2}{|c|}{$\begin{array}{l}\text { Station I8 A. } \\
29 \text { IV. II } \frac{1}{2} \text { A. M. - } \\
\text { I } 2 \frac{1}{2} \text { P.MI. }\end{array}$} & \multicolumn{2}{|c|}{$\begin{array}{l}\text { Station I } 8 \text { B. } \\
29 \text { IV. } 2-2 \frac{1}{2} \text { P. M. }\end{array}$} & \multicolumn{2}{|c|}{$\begin{array}{l}\text { Station I8 C. } \\
29 \text { IV. I I-I } 2 \text { P.M. }\end{array}$} & \multicolumn{2}{|c|}{$\begin{array}{l}\text { Station I8 D. } \\
\text { 30 IV. } 9 \frac{1}{2}-10^{\frac{1}{2}} \mathrm{~A} \cdot \mathrm{M} .\end{array}$} \\
\hline & $\begin{array}{l}\text { Temp. } \\
\text { I } 7.0\end{array}$ & $\begin{array}{r}\text { Salinity. } \\
36.12\end{array}$ & $\begin{array}{l}\text { Temp. } \\
16.6\end{array}$ & $\begin{array}{c}\text { Salinity. } \\
36.14\end{array}$ & $\begin{array}{l}\text { Temp. } \\
\text { I } 6.6\end{array}$ & $\begin{array}{r}\text { Salinity. } \\
36.02\end{array}$ & $\begin{array}{c}\text { Temp. } \\
\text { I } 7.4\end{array}$ & Salinity. \\
\hline 25 & I 5.16 & 36.19 & I 4.89 & ... & I 5.6 & $\ldots$ & 16. 18 & $\begin{array}{l}30.11 \\
\ldots\end{array}$ \\
\hline 50 & I 3.29 & 37.80 & I 3.35 & $\ldots$ & I 5.09 & 36.20 & I 5.39 & $\ldots$ \\
\hline 100 & 12.92 & 38.30 & $12.9^{2}$ & $3^{8.33}$ & 14.38 & 36.28 & 14.09 & $\ldots$ \\
\hline 200 & I $2.9 \mathrm{I}$ & 38.39 & .. & ... & I 3.11 & 37.97 & I 2.94 & $3^{8 .} 3^{6}$ \\
\hline 300 & I 2.87 & $3^{8.39}$ & $\ldots$ & $\ldots$ & I 2.89 & $3^{8.39}$ & $\ldots$ & ... \\
\hline
\end{tabular}

Here also we see considerable variations from time to time at the different depths, variations corresponding to a difference

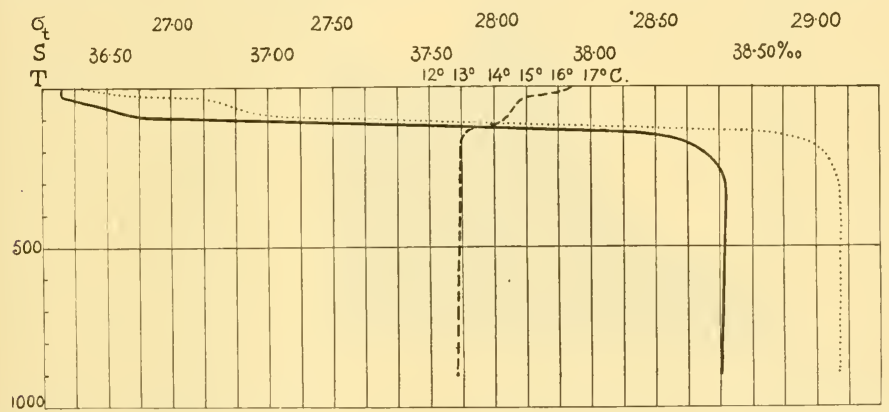

Fig. I97.-Temperature (broken i.ine), Salinity (continuous line), and Density (DotTed line) at Station 19, in the Mediterranean (2nd May 19io).

of level between the layers of I00-I 50 metres. On the 29th April, about 2 P.M., the current running in must have been feeble and that running out must have been strong, judging from the later current-measurements, and the salt Mediterranean under current extended up towards the surface, whereas on the 3oth April, between 9.30 and 10.30 A.M., the upper current was very strong and the under current from the Mediterranean very feeble in comparison, and the salt water from the Mediterranean lay about Ioo metres deeper. The vertical distribution of salinity and temperature is seen to accord with the currents.

Two days after these observations in the Straits of 
Observations in the Mediterranean.
Observations in Spanish Bay.

Gibraltar, the "Michael Sars" entered the Mediterranean, and took observations at Station I9, the hydrographical conditions being shown in Fig. 197. The surface temperature varied from $16^{\circ}$ to $17^{\circ} \mathrm{C}$., and the salinity was nearly 36.4 per thousand. The temperature decreased and the salinity increased downwards, until we struck the Mediterranean deep water at a depth of about 160 metres; from this point downwards we found exactly the same temperatures and salinities as in the undercurrent in the straits. This was on the 2 nd May, between IO A.M. and I P.M. ; the observations in the uppermost 300 metres were made between IO.3O and II.3O A.M. Judging from the previous

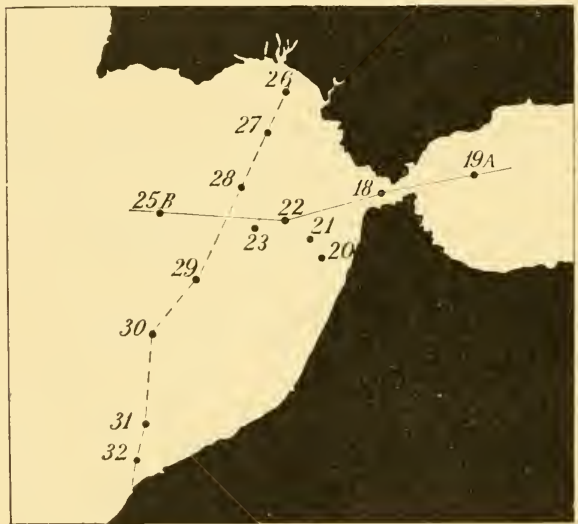

Fig. I98. - "Michael. Sars" Stations in the Spanish Bay between Spain and Morocco in MaY igio. The lines indicate the positions of the two sections represented in the two following figures.

tions in the position of the boundary eastward of the straits corresponding to straits, only considerably smaller, because the current-velocities naturally would be much smaller where the basin was broad.

A few days later a number of observations were taken in the Spanish Bay westward of the straits. The positions of the stations are indicated in Fig. I 98 , and the salinities and temperatures are shown in the two sections: Fig. I99, in an east and west direction, and Fig. 200, in a north and south direction. In the east to west section the salt Mediterranean water with a salinity exceeding 38 per thousand is seen stretching out through the Straits of Gibraltar, its salinity, however, soon decreasing 
to little more than 36 per thousand. Agreat mixing process must be going on here, as might be expected with the mighty submarine current rolling its saline waters into the strata occupying

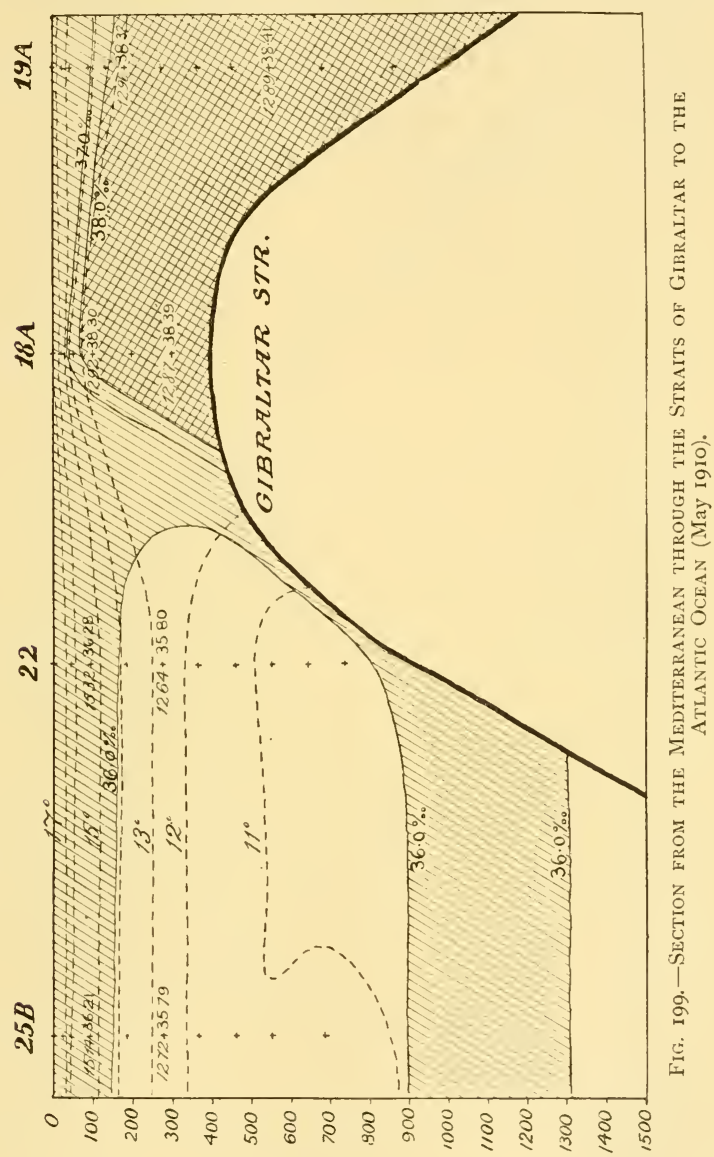

the Spanish Bay. By admixture with the somewhat colder and considerably less saline water, the temperature is slightly, and the salinity greatly, reduced; thereby the density also decreases, becoming lower than that of the deepest layers of the Atlantic region, although higher than that of the surface layers. This 


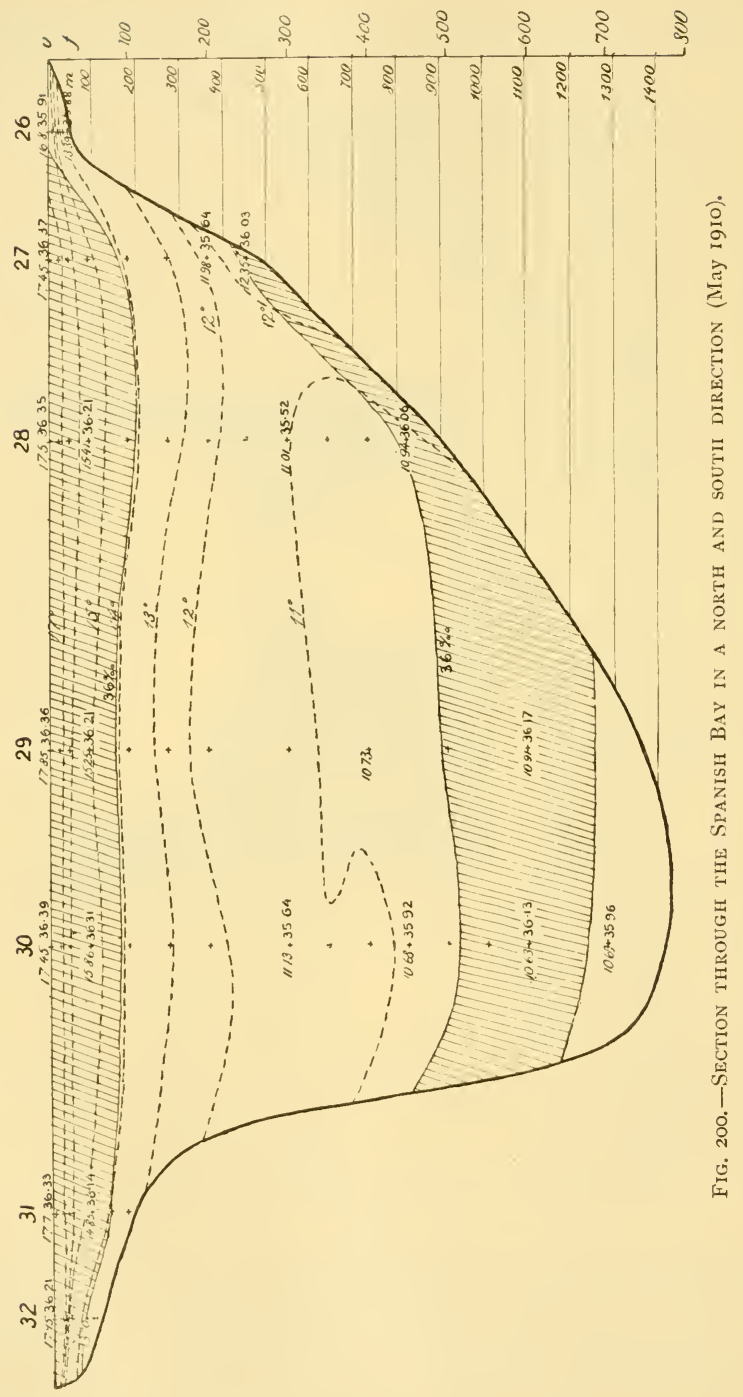


mixed water enters like a wedge between the other watermasses at a depth of about 1000 metres, as clearly shown in the two sections. In this part of the Atlantic Ocean the salinity and temperature first decrease for some hundred metres below the surface; then both increase a little through the influence of the outflow from the Mediterranean, below which they again decrease. The admixture of water from the Mediterranean can be widely traced over the eastern part of the North Atlantic, as already pointed out by Buchanan and Buchan. It is also evident from our observations at a number of stations, for instance at Station I 7 , off the coast of Portugal, as shown in Fig. 20I. In the map showing the physical conditions at the depth of 500 fathoms (given in Fig. 202), we can trace it by the comparatively high salinities and temperatures reaching north towards Ireland and west towards the Azores. This ad mixture is far more in evidence along the coasts of Europe than along those of Africa; this signifies a drift

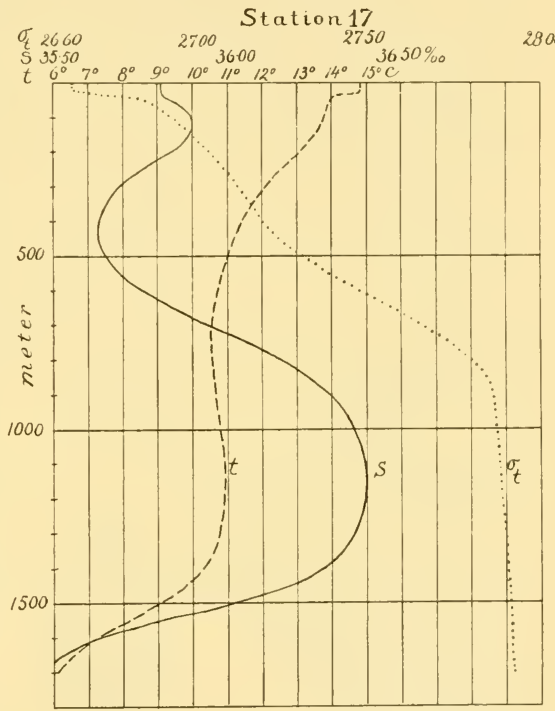
towards the north, Fig. 20i.-Salinity, Temperature, and Density at which might be ex-

Outflow of Mediterranean water into the North Atlantic. pected as an effect of the earth's rotation and the consequent deflection to the right. It appears, however, that some of this mixed water is carried far to the south-west by the great currents running between Madeira and the Azores.

This wedge of mixed water from the Mediterranean is not met with near the surface nor in the greater depths. Thus it is not seen in the map (Fig. 203) showing the physical conditions at a depth of 200 fathoms (366 metres). At this level the saltest water (with a salinity above 36 per thousand) is found in the south-western part of the North Atlantic (excluding the fresher 
American coast-water). Farther north the salinity decreases, being a little more than 35.5 per thousand off the south-western coasts of Europe, and between 35.0 and 35.5 per thousand farther

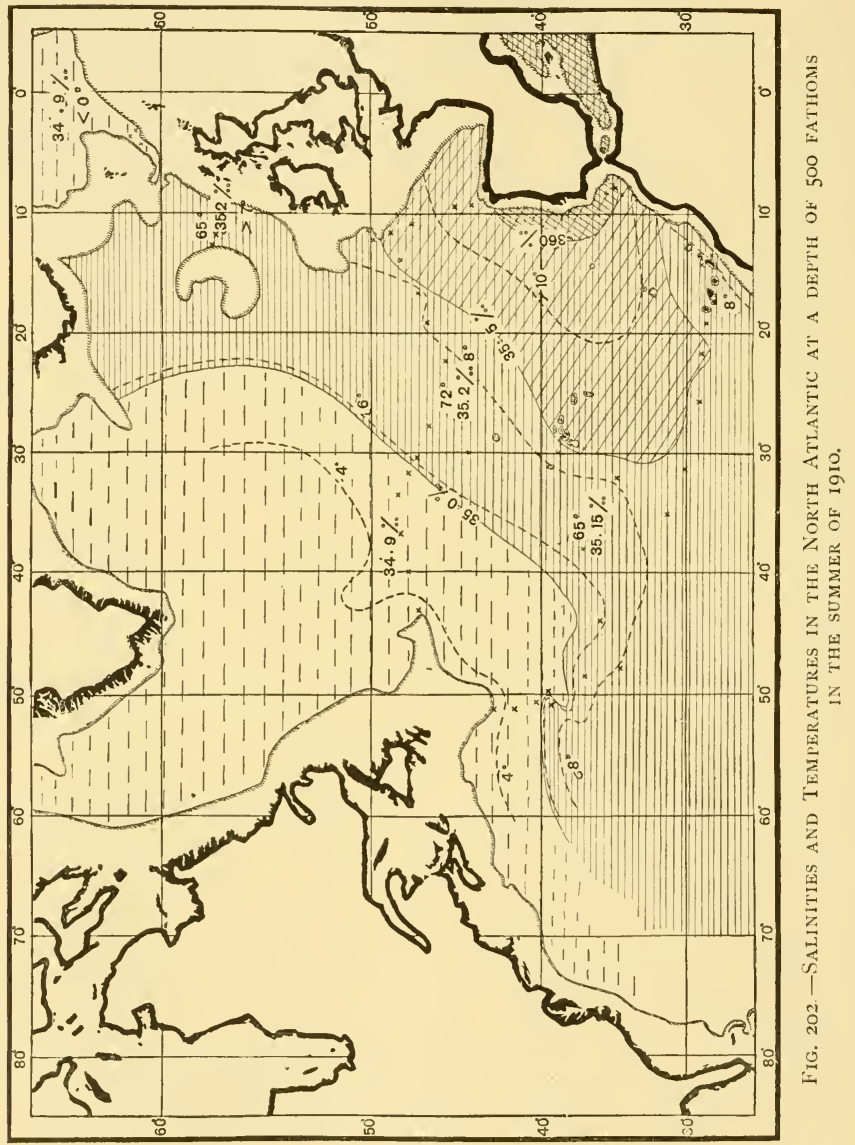

north off the British Isles towards the Faroe Islands and Iceland. In the northern part of the ocean the saltest and warmest water is found on the European side, the Gulf Stream making its influence felt there, whereas the less salt and much colder watermasses south of Greenland are derived from the polar currents. 
In this map (200 fathoms) the lines south and east of the Alternating Newfoundland Banks have a peculiar form. The warm and currents off $\begin{gathered}\text { Newfound. } \\ \text {. The }\end{gathered}$

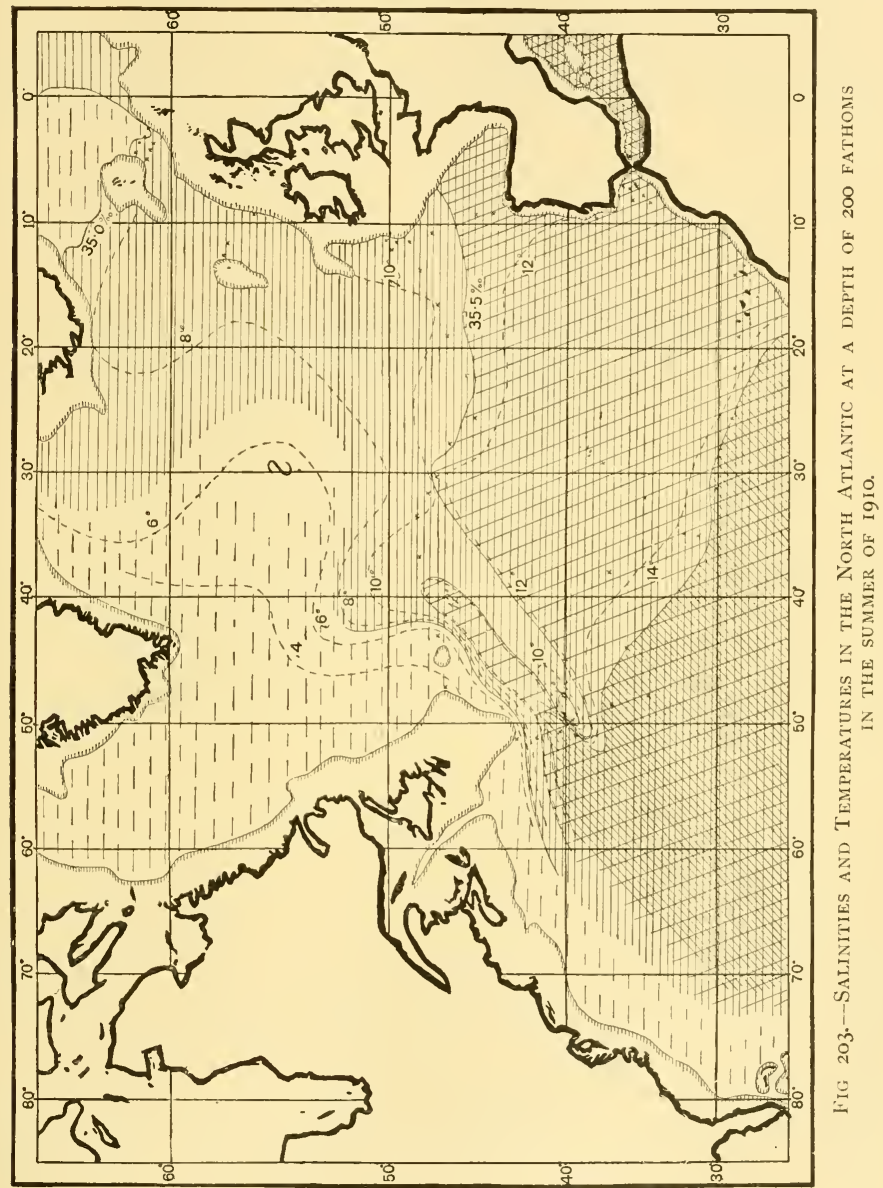
land Bank.

salt water-masses appear to be cleft in two by a colder wedge from the north-east. This indicates a current towards the south-west, forcing its way between the other water-masses flowing in the opposite direction. Now, it is quite possible 
that the lines in the map are wrongly drawn, because had there been many more stations the lines might have formed a number of vortices, like those mentioned above, p. $28_{2}$. However that may be, it is a fact that we fell in with a current running south-west, in the midst of the water-masses following the direction of the Gulf Stream towards the north-east, and this singular circumstance may be dealt with in greater detail.

The section shown in Fig. 204 stretches from the Sargasso Sea along the track of the "Michael Sars" northwards to the

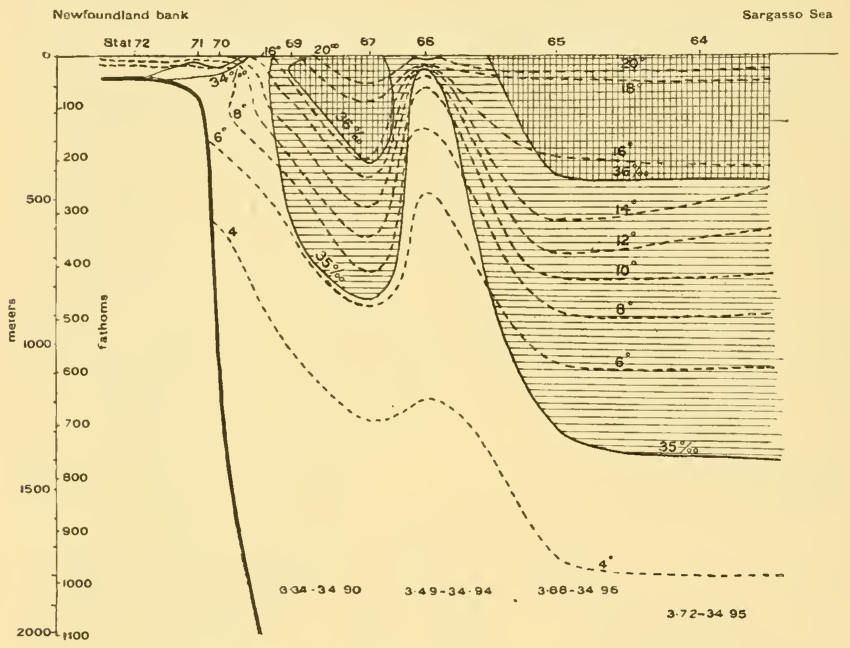

Fig. 204.-Section fron the Sargasso Sea to the Newfoundland Bank.

Newfoundland Bank. At Stations 64 and 65 the conditions were uniform, resembling those found during the cruise from

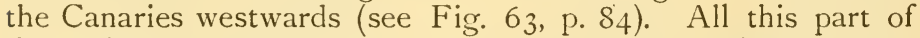
the Atlantic in and about the Sargasso Sea belongs to an oceanographically homogeneous region, but at Station 66 we suddenly met with very different conditions, for it was much colder in all the layers above the deep water, and the salinities were much lower. On proceeding farther north we again found, at Station 67, the same warm and salt water-masses as farther south at Stations 64 and 65 . There was a decided difference also as regards the pelagic flora and fauna, which had a more northern facies at Station 66 than at Stations 
65 and 67. Now, when we consider the position of the water-layers and the effect of the earth's rotation, as treated above (p. 276), we come to the following conclusion: the current in the upper water-layers sets towards the north-east between Stations 65 and 66, another current runs towards the south-west between Stations 66 and 67 , then a current runs to the north-east again towards Station 70.

As we were working at Station 67 on the afternoon of the $27_{\text {th }}$ June, a gale arose, increasing in the course of the night to a hurricane from the south-west, veering later on to the west. There was a rough sea with choppy waves, as is usual with the wind blowing against the current. We kept the ship's head to the wind all night, and it was as much as we could do under heavy steam pressure to stem the storm without drifting off. Next morning the wind fell somewhat; it was fresh from the west when we occupied Station 68. When the captain got an observation, it proved that we had been carried southwards about fifty nautical miles from Station 67 to Station 68. This agrees excellently with our conclusions from the distribution of temperature and salinity, and it is established beyond doubt that in this place there was a strong current running towards the south-west. The west wind caused the ship to drift more to the south than the course of the current. Peake and Murray ${ }^{1}$ and Schott tell us that a current running south-west has been met with before in the same region; thus, the cable-steamer "Podbielski," in May I902, drifted 53

1 " The climate of the British Isles being influenced to such a large extent by the warm water of the Gulf Stream, the movements of this great body of water, the course of its main current, and the manner in which this spreads itself over a very large portion of the North Atlantic, should be a subject of special interest to the inhabitants of these islands. Among those who have not carefully studied the observations that have been made on this subject, a general impression obtains that after leaving the American coast the Gulf Stream consists of a body of warm water moving steadily across the North Atlantic in the direction of the Irish coast. An increasing number of observations tend more and more to show that this is not the case; the movement of this great mass of water is more probably somewhat in the form of bands of current which curve and recurve on one another, forming swirls of large area whose strength and direction change almost daily. A glance at the current charts shows how the Gulf Stream in its passage across the Atlantic spreads itself out at the surface like a fan, and forms what is known as the Gulf Stream drift.

"It will also be noticed that on the line of observation given herewith, an easterly current was met with considerably farther to the westward than would have been expected from the Admiralty current charts; this, however, merely exemplifies the variations which occur in the course of even the main body of the stream at the surface, the course as shown on the Admiralty current charts being its average direction.

"In the appended list of observations the total 'sets' are given, and these are again corrected for the pressure of the wind and the force of the sea, leaving a 'set' due to current only. The correction for wind and sea is necessarily only an approximation, but the result approaches more nearly to the current effect than would have been the case had no correction been attempted. The direction of the current as observed between the Azores and North America is shown on the accompanying map by arrows" (Peake and Murray, "On the Results of a DeepSea Sounding Expedition in the North Atlantic during the Summer of I 899," extra publication of the Roy. Geog. Soc. London, I901, pp. 13-14). 
miles to the south-west in the course of twenty-four hours in lat. $40^{\circ} \mathrm{N}$. and long. $55^{\circ} \mathrm{W}$. It would be interesting to know whether these conditions are constant in this region, as it might then be of importance for navigation, or whether there may be certain irregularities, perhaps one or more progressing vortices.

As a matter of fact, the general current was here split into two branches. Whether it proceeds as two separate currents or not is difficult to judge from our investigations, as we had too few stations in the neighbourhood, and there are no previous observations. Our section from Newfoundland to the Bay of Biscay (Fig. 99, p. I I 5) has a suggestion of a similar division at Station 85 , but it is too slight to base any conclusions upon. It is, however, known that farther south there occur "bands" of water with comparatively low temperatures in the surface-layers of the Gulf Stream. But we are on many points deficient in our knowledge of this most important ocean current, among other things also with regard to the yearly variations to which it is subject.

Influence of the Gulf stream on the climate of Europe.
It is a well-known fact that the climatic conditions of northern Europe are influenced by that branch of the Gulf Stream which flows northwards along the shores of the British Isles into the Norwegian Sea. In places with such a maritime climate as that of the Faroe Islands this influence is especially felt. Martin Knudsen has examined some meteorological observations from the Faroe Islands, and has found (see Fig. 205) a conspicuous difference between the temperature of the air when the wind blew from the Gulf Stream region in the south and west, and when it blew from the north, over the Arctic East Iceland current. The difference was greatest in winter (as much as $6 \frac{1}{2}^{\circ}$ C.) and least in summer (smallest difference $I_{2} \frac{1}{2}$ C.). Pettersson at an early period entered on the study of questions regarding oceanic influence on the climate of Scandinavia, and his work on this subject has been more conducive than anything else to the establishment of the international investigations of North European waters. 
Figs. 206 and 207 show some of his results. At that time (in the nineties) no systematic investigations of the Norwegian Sea through any length of time had been carried on, so he could only study the surface-temperatures noted at three Norwegian lighthouses.

In Fig. 206 we see the variations in the surface-temperature off the west coast of Norway (indicated by the thick line) and in the air-temperature at Orebro in Sweden (indicated by the thin line), both for January during the years I874 to I892. The vertical scale indicates the deviation from the mean temperature, which for the coast-water is $5.3^{\circ} \mathrm{C}$. and for the air $3.4^{\circ} \mathrm{C}$. On the whole the curves agree well, a high temperature in the

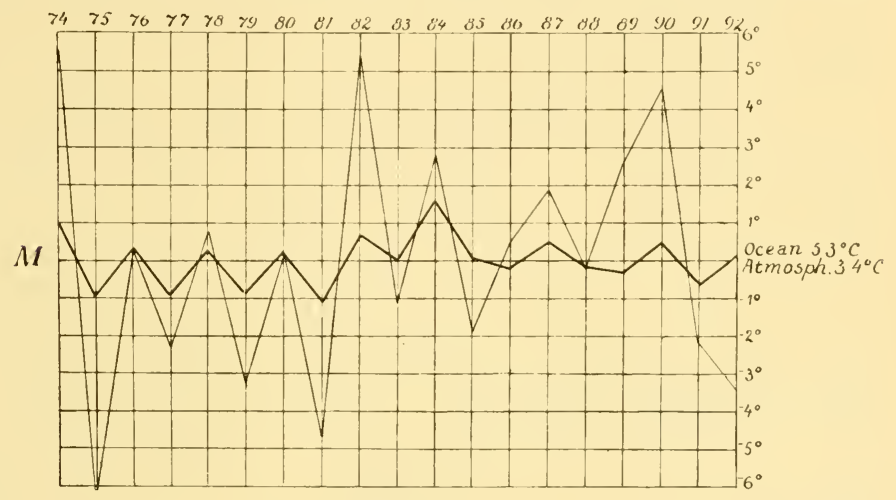

FIG. 206.

The thick line shows the variations in January of the surface temperature off the west coast of Norway from year to year; the thin line the variations of the air-temperature at Örebro (Sweden).

surface-water corresponding to a high temperature in the air. Pettersson further pointed out that a certain deviation from the normal temperature of the air, as a rule, lasts for a length of time; a cold period, for instance, often lasts for weeks, or even months. Now, there are many relations on the land which are influenced by the deviations of the air-temperature from the normal, among other things, the duration of the snowcovering, the time of blossoming of many plants, the time for beginning field-labour in spring. Pettersson found the variations in some of these particulars to agree with the variations in the temperature of the air and of the surface-water off the west coast of Norway some time before. Fig. 207 shows an example of this agreement ; the lower curve gives the variations 
in the temperature of the sea-surface off the Norwegian lighthouses for the month of February, while the upper curve shows the variations of the date at which the coltsfoot (Tussilago farfara) began to blossom in central Sweden (Upsala). This plant begins to blossom, on the average, about the gth April, the exact date varying in different years from the I 8 th March to the 28th April. The two curves agree in many points; when the water off the lighthouses was relatively warm in February the flowering commenced early, and when it was cold the blossoming was late.

Pettersson had at his disposal only observations from the water in the immediate vicinity of these coast stations, but since

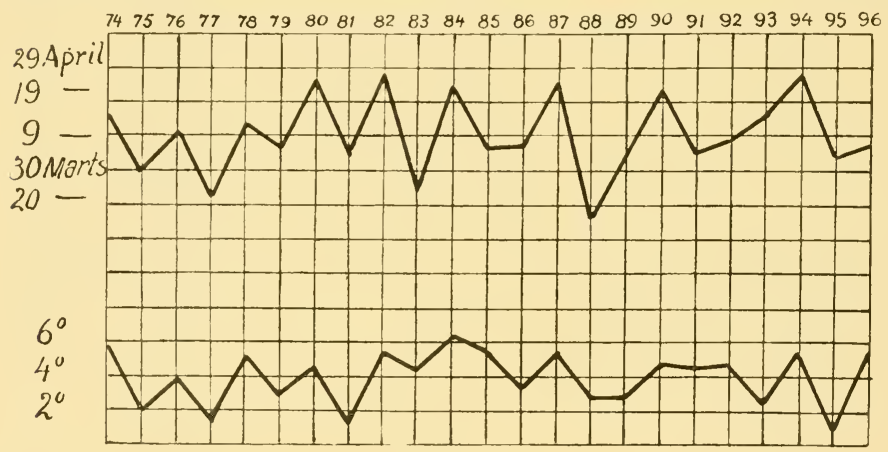

FIG. 207.

The upper curve shows the time of blossoming of Tussilago farfara at Upsala during a series of years. The lower curve shows the surface-temperature of the sea off the west coast of Norway, in the month of February of the same years.

regular investigations were started in the Norwegian Sea in I 900, we have excellent series of observations during a succession of years, not only in the coast-water, but also in that branch of the Gulf Stream which flows into the Norwegian Sea. Nansen and the writer have found, by going through all the observations made in the years 1900 to I905, that there are great variations in the temperature-conditions of this Atlantic current, and that these variations are apparently followed by corresponding variations in many other conditions; for example, the temperature of the air, the year's harvest, the growth of the trees, and various circumstances touching the appearance of great shoals of fish. One or two instances may be referred to here.

During the Norwegian investigations a section was run 
from the mouth of the Sognefjord westwards, in the middle of May, every year from I9OI to 1905. One of these series is figured on p. 240. Nansen and the writer have calculated the mean temperatures in the Atlantic water of this section, both for the surface and for the deeper water. The variations in the surface-temperature are represented in curve I., Fig. 208, curve II. showing the variations in the growth of the pine in eastern Norway during the following year. The low surface-temperature in May 1902 corresponded to the small growth of the pine in the succeeding year, 1903, and the high temperatures in the surface of the Gulf Stream in May 1905 corresponded to a great addition to the height of the pine trees in the year 1906. This is explicable by the fact that the annual growth of the pine is not determined by the meteorological conditions of the same year, but by those of the year before, when the bud was formed, the growth mainly depending on the formation of the bud. Continued investigations will prove whether the agreement strongly suggested by the figure is really a general rule, in which case it may be possible, on the basis of investigations in the Norwegian Sea, to predict

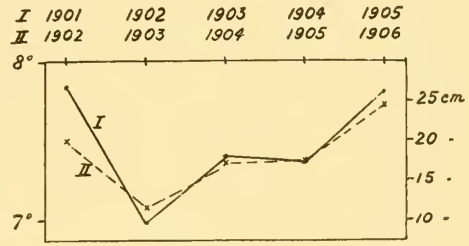

FIG. 20S.

1., nsean temperature of the surface of the "Gult Stream" in the Norwegian Sea (Sognefjord section, May); 11., mean growth of the pine in eastern Norway. with a high degree of probability how much the Norwegian pine will grow in the following year.

By calculating the mean temperature of the Atlantic watermasses below the surface in the Sognefjord section, and multiplying the ascertained value by the area of the transverse section of these water-masses, an expression is obtained for the amount of heat in the northern branch of the "Gulf Stream." This has been done from the observations made during the May cruises, and the results are exhibited in curves I. and II. in Fig. 209; the two curves are obtained by two different methods of calculation which need not be discussed here. The lower curve shows the variations in the mean temperature of the air in Norway during the winter months from the Ist November to the 3 oth April. The coincidence is striking; when, for instance, the amount of heat in the Gulf Stream was great in the month of May, the air-temperature in Norway was high in the following winter. This holds good throughout six years, 
CHAP.

but, of course, that is too short a period from which to draw definite conclusions. Anyhow, these preliminary results point to possibilities of no little importance, and we may in the future be able to predict, months beforehand, whether the coming winter will be warmer or colder than the normal. Many similar relations could be pointed out between the conditions in the sea and facts of interest bearing upon our daily life, but the above examples give an indication of the problems to be faced in modern oceanography.

The Atlantic current flowing northwards over the Norwegian

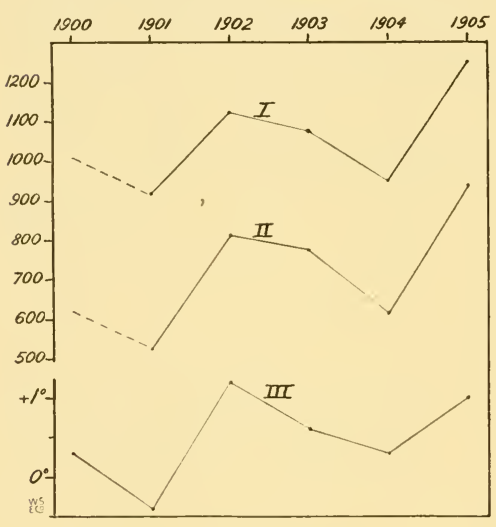

FIG. 209.

I. and II., the annual variations in the amount of heat in the "Gulf Stream" (Sognefjord section, May); III., variations in the air-temperature of Norway (November to April). Sea, which in our waters is also called the Gulf Stream, is thus subject to considerable variations in temperature and total amount of heat. This current is, however, a mixture of water from the Atlantic proper with water from the northern currents penetrating into the Norwegian Sea, north of the Faroe Islands. and the character of the "Gulf Stream" will depend on the conditions of mixture, and on the individual temperature of each of these currents, factors of which we know little. It is highly probable that the

Gulf Stream of the Atlantic also shows annual variations, and, though they may not be of much importance in their effect on the small branch in the Norwegian Sea, they may prove to be of great climatological significance for the countries on both sides of the Atlantic Ocean; a thorough study of this current in the immediate future is therefore looked forward to with great expectations. That there are large annual variations in the caloric conditions of the huge water-masses of the North Atlantic was suggested by the observations of the "Challenger" nearly forty years ago, and has been confirmed during the recent cruise of the "Michael Sars," these two vessels having made investigations in the 
same oceanographical region. In july 19I0 observations were Comparison of made by the "Michael Sars" at Stations 60 to 65 in the vicinity "Challenger" of the "Challenger" Station 65 of June 1873 . Now, the temper- Sars" atures of the great depths beyond 1000 fathoms prove to be temperatureidentical in these two years, showing that the thermometers worked properly, but in the upper layers it was much colder in I910 than it was thirty-seven years before, the difference in

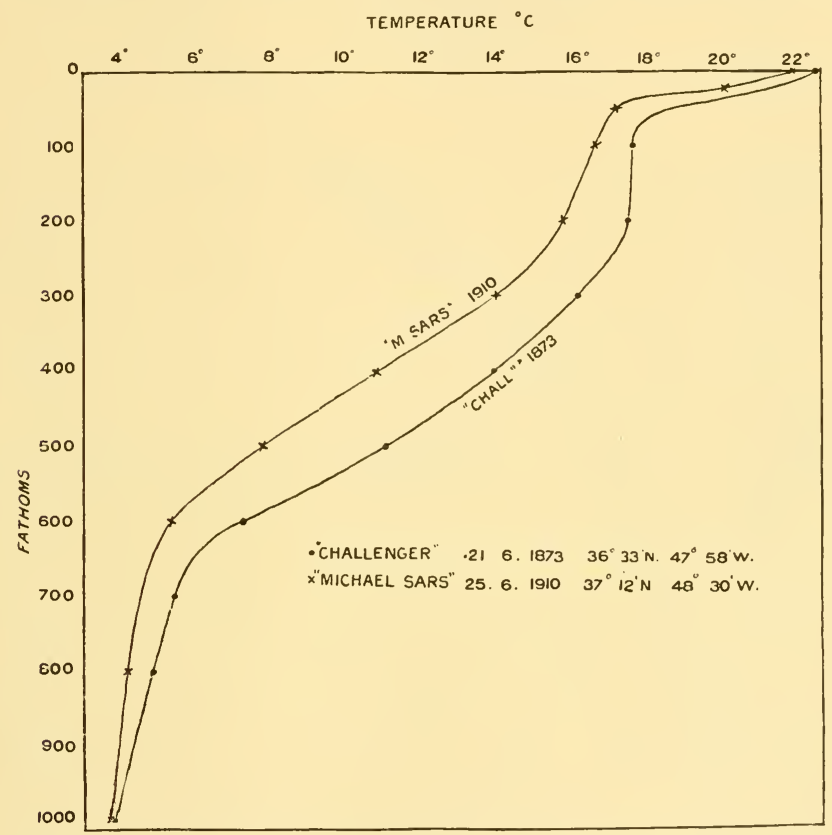

Fig. 210.-Comparison of the Temperatures taken by the "Challenger" iN I873 AND BY THE "Michael Sars" in 1910.

some cases amounting to about $5^{\circ} \mathrm{C}$. at a depth of $700-800$ metres (400 fathoms). Fig. 210 shows the temperature-observations at the "Challenger" Station 65 and the "Michael Sars" Station 65 , between the surface and a depth of 1000 fathoms.

Observations were taken at the "Michael Sars" Station 5 I in June I9IO, in the vicinity of the "Challenger" Station 354 in May I876. Fig. 2 I I shows the conditions at these two stations, which varied only to a slight extent; at certain depths 
it was a little colder in 1876 than in I9IO, at other depths a little warmer, but no general difference appears between the two series of temperatures - one series taken thirty-four years after the other. There have probably been many variations in the course of these years of which we have no knowledge. In this

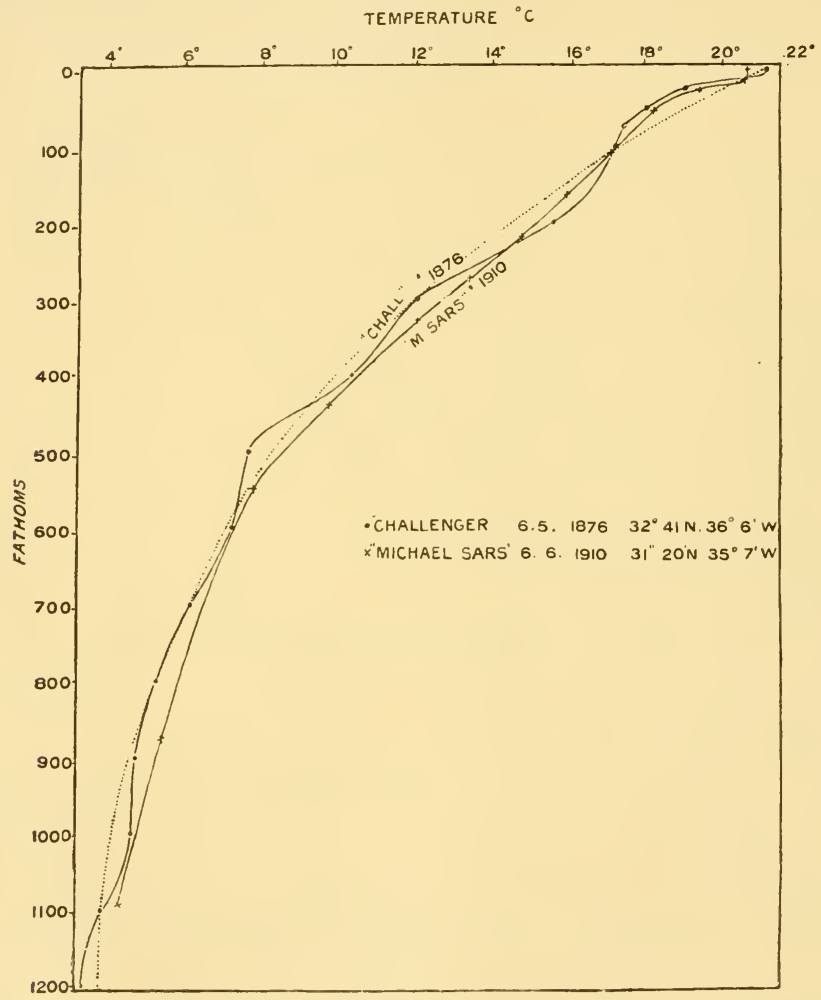

Fig. 2 I I -Comparison of the Temperatures taken by the "Challenger" iN 1876 AND by THE "Michael SaRs" in 1910.

and in many other respects the Atlantic Ocean calls for further and more detailed investigation; as we said at the beginning of this chapter, very much more work will have to be done before we shall be able to solve the many interesting and important problems relating to the great ocean waters.

B. H.-H. 


\section{CHAPTER VI}

\section{PELAGIC PLANT LIFE}

Not many years have elapsed since the scientific world became aware that the sea contains plants in abundance floating on and Historical beneath its surface, and that they build up the organic substances upon which marine animals depend. In the open sea the plants are too minute to be detected without the microscope; so that, until this instrument came to be regularly employed by biologists, it was impossible to know anything about them.

The first to use the microscope for studying unicellular organisms in the sea was the celebrated Danish zoologist, O. F. Müller, who, in 1777 , described one of the most important $\mathrm{O}$. F. Müller. plants of our northern waters, namely, Ceratium tripos. He was succeeded by the microscopist Ehrenberg, who laid the Ehrenberg. foundation of our knowledge regarding the multiplicity of forms, their wide distribution, and their significance in the economy of nature; and also discovered the coverings of diatoms together with coccoliths and the skeletons of various unicellular animals (radiolaria, foraminifera) in deposits on the sea-bottom and in geological strata from previous ages. Ehrenberg aroused interest by pointing out the wonderful structure of these coverings, and improvements in the microscope have resulted in fresh wonders being disclosed, which have induced quite a number of capable amateurs to take up the study of diatoms.

Classification of these algæ dates from about the middle of the nineteenth century. It is based on the shape and structure of the cell-wall, less attention having been given to the living contents and to the biology. The pelagic forms have as a rule thinner coverings, and a more indistinct structure, than the robust species nearer the coast, and have therefore been less studied. However, occasional samples have now and then been collected from the surface with nets, and researches have been carried out by Bailey. J. W. Bailey in the waters off Kamchatka, by Brightwell along Brightwell. 
Lauder.

Cleve.

Wallich.

Nitsch.

Claparède.

Lachmann.

Stein.

Bergh.

\section{John Murray.}

the shores of England, by Lauder at Hong-Kong, and by Cleve in the North Polar Sea and at Java. A regular gold mine in the way of rare pelagic forms was found by Wallich in the intestinal canals of salpæ, and this source has subsequently been utilised for procuring forms that our apparatus could not capture.

Pelagic algæ which have no skeletons of durable mineral constituents, such as silicic acid or lime, were in those days neglected. A few, no doubt, of the larger peridineæ were described by Nitsch, Ehrenberg, Bailey, Claparède, and Lachmann; but there was very little progress made, and it was not till $\mathrm{I} 883$ that T. R. von Stein published his first comprehensive monograph, a great deal of the material for which had been taken from the stomachs of salpæ. R. S. Bergh had already issued, two years previously, a text-book on the organisation of these algæ.

Since I870 important expeditions have been undertaken, one object of which was to study the pelagic organisms systematically. The "Challenger" Expedition, in particular, collected quantities of material from all the seas of the world; though attention was still chiefly directed to those forms whose coverings are met with in deposits on the sea-bottom, that is to say, diatoms with their silicious coverings, and the remarkable little organisms forming the microscopic calcareous bodies which Ehrenberg had already designated coccoliths and rhabdoliths. Murray pointed out that coccospheres and rhabdospheres, as they were termed, are really self-existent organisms in the surface-layers. He could obtain them by allowing a glass of sea-water to stand for a few hours, so that they sank to the bottom and attached themselves to threads placed there for purposes of experiment; and he also found numbers of them in the stomach-contents of salpæ, of which they often formed an essential part. It was possible, too, by noting the occurrence of their coverings in the bottom-samples, to obtain definite information regarding their geographical distribution. $\mathrm{He}$ observed that, while they are abundant in all tropical and subtropical waters in the open ocean, they are not found in arctic and antarctic waters having a temperature below $45^{\circ} \mathrm{F}$., nor are they to be found in the deposits of the polar oceans. Murray further ascertained that diatoms are irregular in their occurrence, and that they are more numerous in coastal areas than out in the ocean. Unfortunately Castracane, when examining the diatoms collected by the expedition, was unable to find any conformity in the distribution of the different species. 
The other expeditions that were sent out about the same time as the "Challenger" carried out their investigations on similar lines. G. O. Sars, who was a member of the Norwegian G. O. Sars. North Atlantic Expedition in $1876-1878$, made a study on board ship of the luxuriant plant life near the ice-limit, and remarked, like CErsted before him, that plants are really the basis Ersted. upon which the nutriment of animals is founded. It was not, however, till twenty years afterwards that an examination was made of the algx in the comparatively small number of samples then collected.

Soon after i 880 Hensen commenced a physiological study Hensen. of the sea, and essayed principaily to estimate its production of nutritive substances at different seasons. As a result the plants came more into notice than they had previously done; and it is significant that Hensen found it necessary to introduce the new name of "plankton " to designate generally all pelagic organisms, "Plankton." both plants and animals, regarded as one universal community. The term "plankton" is now used for all floating organisms which are passively carried along by currents, while "nekton " "Nekton." - a term introduced by Haeckel-is used to designate all pelagic animals which are able to swim against currents. During Hensen's Plankton Expedition in 1889 Schütt made schitt. the first investigations regarding the general biology of the plankton-algæ. His ingenious descriptions and admirable drawings explained the different ways in which the algæ adapt themselves to their floating existence.

An endeavour was made by Hensen to find a method of Quantitative calculating the quantity of pelagic organisms occurring in different localities. He constructed nets to be drawn up for certain distances through the water, that were supposed to filter the whole column of liquid through which they passed, and to retain all the organisms existing therein. The total amount of these organisms was then measured by determining the volume, and a most careful enumeration was made of the number of individuals belonging to each species. The nets were drawn vertically through the whole zone where plant plankton is abundant, that is to say, from a depth of 200 metres to the surface ; and Hensen attempted to utilise the results for measuring the production of life in a column of water whose superficial area is one square metre. He tried at the same time to solve important problems, such as the rate of augmentation of algx, or what proportion of individuals disappears owing either to consumption by other organisms or unfavourable conditions of existence. 
Hensen's work must not be disparaged because his aspirations have been more difficult to realise than he at first imagined. The difficulties are far from insurmountable, while Hensen himself will be always looked upon as one of the founders of the science of marine physiology.

In the biology of the sea we have also to consider the geographical distribution of the different species and their dependence upon ocean currents. The Swedish scientists, Aurivillius. Cleve and Aurivillius, brought these two questions into special prominence, though no doubt they had been previously considered by others. But with the hydrographical investigations Pettersson. of Otto Pettersson and others the whole subject assumed a new aspect. Thanks to improved methods they succeeded in following the movements of the water-layers, by determining their salinity, temperature, and other hydrographical characteristics; and from this time forward the plankton was also enlisted as a supplemental means of characterising watermasses of different origin. Cleve with his marvellous power of distinguishing forms was able in a short space of time to determine numbers of species, animals as well as plants, and it is to him we owe the foundation of our knowledge regarding the distribution of plankton-algæ.

Since the international marine investigations were commenced

International investigations.

Lohmann.

G. Murray.

Blackman. Ostenfeld. about ten years ago, researches have been carried out in the Northern Atlantic, North Sea, and Baltic; and specialists from the different countries of North Europe have gradually extended our knowledge, as far as northern species are concerned.

Simultaneously great improvements have taken place in our methods of studying plankton. Lohmann has made it clear that the catches in the silk nets originally used incompletely represented the flora of the sea, owing to the fact that whole series of the most diminutive organisms slip through the meshes of even the finest straining-cloth. He devised methods for catching them by means of the filter and the centrifuge, and could thus estimate their numbers in a given quantity of sea-water. Coccolithophoridæ, which the "Challenger" Expedition claimed to have discovered, but which Hensen refused to recognise as selfexistent plankton organisms, because he did not capture them himself, were now investigated, and Lohmann was able to declare confidently that they really are algæ, furnished with brown pigment granules, the physiological equivalent of chlorophyl, thus confirming the earlier discoveries of Sir John Murray, George Murray, Blackman, and Ostenfeld. Lohmann 
has further, by his quantitative investigations of the variations in the plankton of Kiel Bay and off Syracuse, taught us the value of exact studies of this description.

Our future investigations will have to be conducted on three main lines :-

(I) In the first place, much study must be devoted to the biology, in the restricted sense of the word, of the alga. We will have to learn how the forms adapt themselves to their conditions of life, and in particular to their floating existence. Here, however, a great advance should most certainly be made, now that $W$. Ostwald has shown us a new factor affecting their Ostwald. floating power, namely, the varying viscosity of sea-water, and since the instructive writings of Wesenberg-Lund have directed our attention to the seasonal modifications which the species adopt to suit variations in viscosity.

(2) In the second place, the distribution of the species throughout the seas of the world requires further investigation at different seasons, and this must be founded on a careful characterisation of the different species. In recent years the peridinex, after a long period of neglect, have received due attention at the hands of Ostenfeld, Ove Paulsen, Pavillard, Jörgensen, Broch, and Kofoid. A great deal, however, still remains to be accomplished.

(3) In the third place, we will have to deal with the laws of production in the sea. This great physiological question calls for observations on a very comprehensive scale, if we are to be in a position to discuss the interesting theories put forward by Brandt, Nathansohn, and Puitter. A brief discussion of their theories will be found at the end of this chapter.

During the Atlantic Expedition of the "Michael Sars" we were able to make observations on all these three aspects of the subject; and in what follows I shall endeavour to summarise our results, and to consider, while doing so, the attitude at present taken up by the scientific world with regard to these three lines of investigation.

Most of the ocean plants exist in countless myriads of minute individuals, though they are invisible to the naked eye. Still, small as they are, they are in a way highly organised, and their organisation is in strict accordance with the particular conditions of life. On land a higher plant consists of a community of separate cells, each of which has a special function to perform in the service of the whole. It establishes an under- 
ground system of roots to collect moisture and nourishment from the soil, and its leaves are raised aloft on slender stems to derive benefit from the rays of light and build up organic substance out of carbonic acid and water. Ocean plants have no such point d'appui; they find their nourishment dissolved in sea-water and distributed uniformly all around them, and they get most benefit from the sunlight when they are regularly spread throughout the whole bulk of the water in the photic zone. Their diffusion is also their best defence against their enemies, for, while animals have no great difficulty in finding and consuming the larger plants, these creatures, scattered everywhere like dust amidst the immeasurable water-masses, are not so easily available. The majority of the floating plants pass their lives as single cells, though they are frequently far more highly organised than the single cells that go to form a higher plant.

As pelagic algæ have generally a greater density than the seawater in which they live, they would sink out of range of the rays of light, and perish, if it were not for the fact that they are kept from descending either by their own exertions or by

Suspension organs.

Diatoms. suspension organs which act as a parachute. The most noticeable features in their organisation are their different forms of structure, which are directly connected with the floating existence they lead. In what follows I shall describe the most important types, belonging to a limited number of classes, most of which have variously shaped pigment granules or chromatophores, consisting of brown colouring matter instead of green chlorophyl. Comprised in their number are diatoms, peridineæ, and brown flagellates, amongst which last we also include calcareous flagellates or coccolithophoridæ. In addition there are a few pelagic representatives of the green and blue-green algæ, which I will discuss separately.

A diatom can be distinguished from other algæ by its silicated cell-wall. This is composed of two quite similar halves, or valves as they are called, that are united to one another like the top and bottom of a pill-box (see Fig. 212). Inside the valves the protoplasm lines the wall like a thin sort of bladder, while the nucleus is frequently in the very centre surrounded by a denser mass of protoplasm connected to the bladder by bridges or strings. The rest of the cavity is full of a clear cell-fluid. The pigment granules, which are organs of nourishment, enable the diatom to collect rays of light and build 
up organic substance out of carbonic acid. They usually lie in regular order along the cell-wall (Fig. 2 I3,a); but if the light becomes too strong for them, they are able to huddle more closely together, either in the middle of the cell or
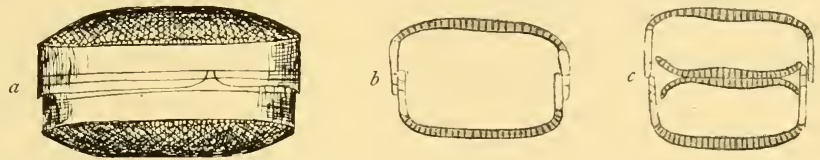

Fig. 212.-Cell-Wall of a Diatom (Coscinodiscus subbulliens) $\frac{3000}{1}$. $a$, External view ; $b$, vertical section ; $c$, section in cell-division.

at some point where they can mutually protect each other from the harmful effects of the rays (Fig. 2 I $3, b$ and $c$ ). This has been demonstrated by Schimper. The assimilation of carbonic acid schimper. produces a fat oil, which may form into comparatively large drops.
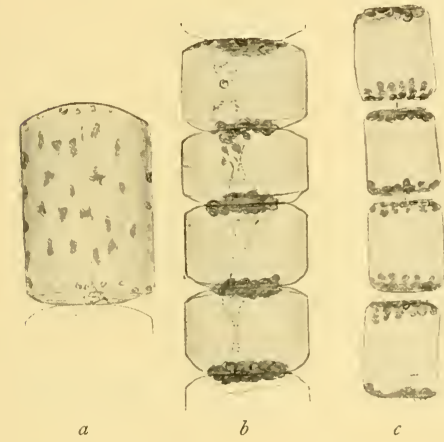

FIG. 213 .

Cells are produced by Cell division. division. The nucleus and protoplasm divide into two parts, the valves are pushed a little apart, and two new valves develop within the old ones. Thus each of the daughter-cells gets one of the valves from the mother-cell and a new valve that joins on to it (see Fig. 2 I 2, c). When once the valves have acquired their shape they seem incapable of expanding, so that the cell generations will gradually become contracted in the plane in which division takes place. It follows that the cavity of the cell will also be diminished, though at the same time $a, b$, Lauderia annulata. $a$, Cell with the pigment granules (chromatophores) in normal position, collected early in the morning; $b$, chain from the surface of the sea, 3 P.M. . chromatophores congregated at the ends of the cells; $c$, Defonula schroderi in the same condition. All $+1+0$.

the perpendicular axis of the plane of division is frequently slightly prolonged. Algæ can, however, regenerate their original size, by throwing off their old valves, growing into a larger bladder with a thin expansible skin, and forming within it new valves that are two or three times as large as the old ones. This is the so-called auxospore development (see Fig. 2 I4).

Diatoms occur in quantities over the whole world in both 
Distribution of diatoms. Littoralforms. Littoral diatoms are apt to have a comparatively thick and extremely silicated cell-wall with the characteristic patterns, ribs, and pores, that have made them such an attractive object of study to amateur scientists. Bilateral symmetry prevails, especially amongst forms that are capable of motion, which are as a rule pointed at the ends like the bows of a boat. Diatoms of
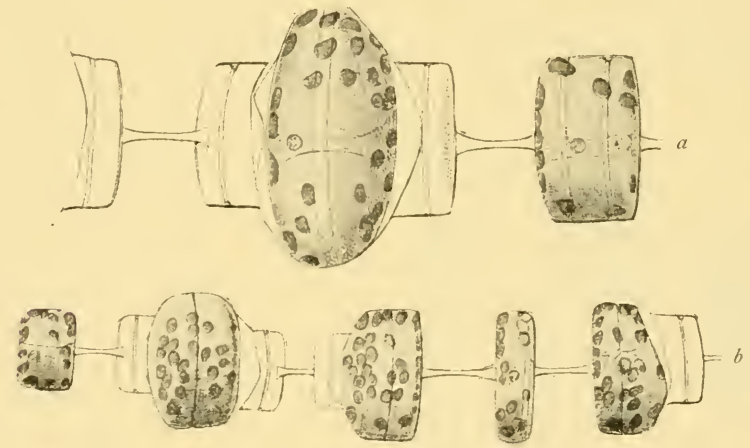

FIG. 2I4.-AUXOSPORE-FORMATION OF THALASSIOSIRA GRAVIDA.

$a$, Showing in the centre a newly-formed auxospore, the old cell-walls still lying outside $\left(\frac{600}{1} \theta\right) ; b$. showing on the left a cell before auxospore-formation, succeeded by an auxospore during its first cell-division, the chain of five cells having originated from an auxospore $\left(\frac{\$ 00}{1}\right)$.

this kind have a highly organised locomotion apparatus, which is differently constructed in the different genera, such as Navicula and Nitzschia. Attached forms show more variation. Symmetry with them depends upon the mode of attachment. Licmophora and Gomphonema are fastened at one end to a gelatine-like stalk, and their cells are wedge-shaped, narrow at the bottom and widening out towards the top. Others, like Epithemia, are convex on the one side and straight on the other, the straight side being the one by which they are attached. And there are others again that consist of more or less highly organised and often ramifying colonies, composed of series of cells, or sheaths of mucilage, within which the cells are able to move past one another. 
Pelagic forms usually have thinner cell-walls, and the I characteristic ornamentations on their silicated valves are not so prominent, though in their case too a high magnifying power will nearly always render them visible. The families that are endowed with locomotion organs are very scantily represented, and even amongst the few that are thus favoured, several species make use of them for quite a different purpose, employing them as organs to secrete mucilage and thus keep the cells united in chains. Most of the pelagic diatoms belong to families that lack organs of locomotion, though by way of compensation various types have highly developed suspension organs, which increase their superficies and consequently their friction against the surrounding water-masses. It is possible, too, that these alga are able to reduce excess weight by evolving specifically lighter matter, such as fat, within the cells or air-bladders outside them, but this has not yet been properly investigated.

The suspension organs, however, have been most carefully studied, especially by Schiitt, who was one of the members of Schuitt. Hensen's Plankton Expedition in I889, and the different cellforms, with their numerous contrivances for maintaining a floating existence, may be grouped under four heads :-

(I) The Bladder Type.-In these the cell is comparatively large, Four types of while the cell-wall and protoplasm are merely thin membranes round a suspension big inner cavity which is filled with a cell-fluid of about the same specific gravity as sea-water. Among diatoms the best instances of this type are species of the genus Coscinodiscus, whose structure resembles cylindrical boxes, sometimes fairly flat-shaped, and sometimes more elongated and rounded at the top and bottom. In most forms the cellwall is quite thin, though it is strengthened by means of a fine meshwork of more or less regular hexagons. One of the biggest, Coscinodiscus rex (Ethmodiscus rex, Antelminellia gigas), is over a millimetre in diameter, and is quite a common form in the warmer parts of the Atlantic (see Fig. 2I 5). A series of species with stouter structure, and more distinct ornamentations on the cell-wall, occur especially in the deeper water-layers, at about the lowermost limit of plant-life (IOO to 200 metres), and belong to a characteristic twilight-flora, of whose existence Schimper became aware during the "Valdivia" Expedition.

(2) The Ribbon Type.-The surface is enlarged owing to the cell being flattened down into a plane, which is often bent or twisted to a certain extent. Diatoms of this type (see Fig. 216) are scarce. We have, along the coasts especially, a few species with flat cells, which are associated in ribbon-shaped colonies, such as Fragilaria and Climacodium. The cell-walls of these species are extremely thin, and not of a particularly distinct structure.

(3) The Hair Type.-The cells are very much prolonged in one direction, or else they are united in narrow, elongated colonies. Diatoms 
Distribution of diatoms.

furnish many varieties of this type. Sometimes the length axis is situated in the division-plane of the cells, as, for instance, in Thalassiothrix longissima, one of the characteristic forms in colder seas; at other times division takes place across the elongated cell, as in the genus Rhizosolenia, of which there are many species (see Fig. 217). Hair-shaped cells of this kind create a great deal of friction when horizontal, but would sink rapidly when perpendicular, if it were not for the fact that they are either slightly curved, or else their terminal faces are sloping; so that

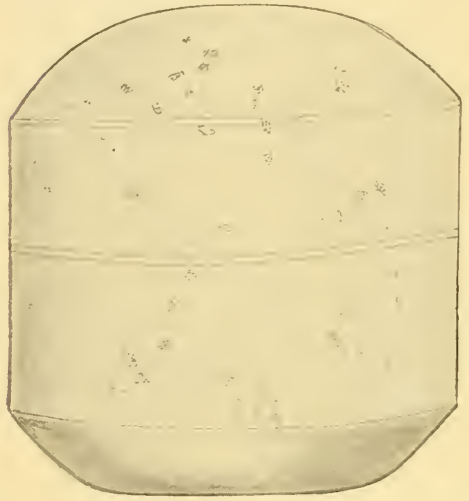

FIG. 215.-COSCINODISCUS REX $\left(\frac{60}{1}\right)$.
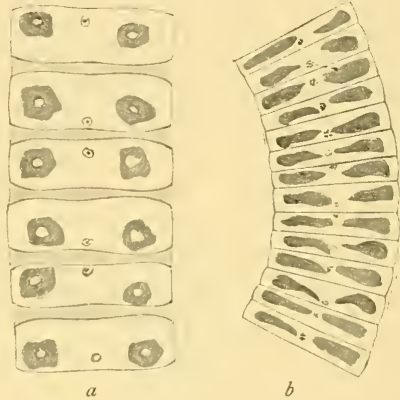

Fig. 2i6. - Pelagic Diaioms of the RIBBON-TYPE $\left(\frac{50}{1}^{\circ}\right)$.

$a$, Chain of Navicula vanhöfeni, the cells connected by a band of mucilage; $b$, part of a chain of Fragilaria oceanica.

the resistance of the water soon restores them to an almost horizontal position, and they sink slowly in long spiral sweeps.

(4) The Branching Type.-The surface of the cell is enlarged by various kinds of hair-shaped or lamelliform outgrowths. To this type belongs the genus Chatoceras with its numerous species (see Fig. 218).

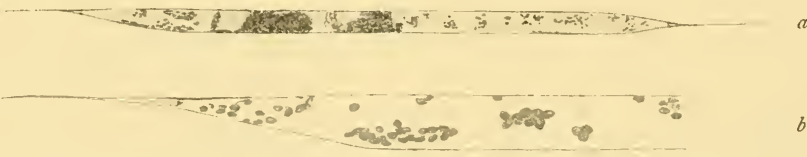

Fig, 217.-PELAgic Diatom of THE haIK-TyPe, RhIZOSOLENIA HEBETATA-SEMISPINA. $a$, Entire cell $\left(\frac{200}{1}\right) ; b$, end of a cell $\left(\frac{500}{1}\right)$.

Every cell has four long setiform outgrowths, and the cells are besides nearly always associated in chains, so that these setæ radiate in every direction. When the chain is straight and stiff it is frequently furnished with special terminal setæ, which are stiffer than the others, and act as a sort of steering apparatus.

In addition to the actual outgrowths from the cell many diatoms can secrete long filaments of mucilage from special 
secretion pores. These filaments act as an effective suspension-apparatus (see Fig. 219). During unfavourable conditions

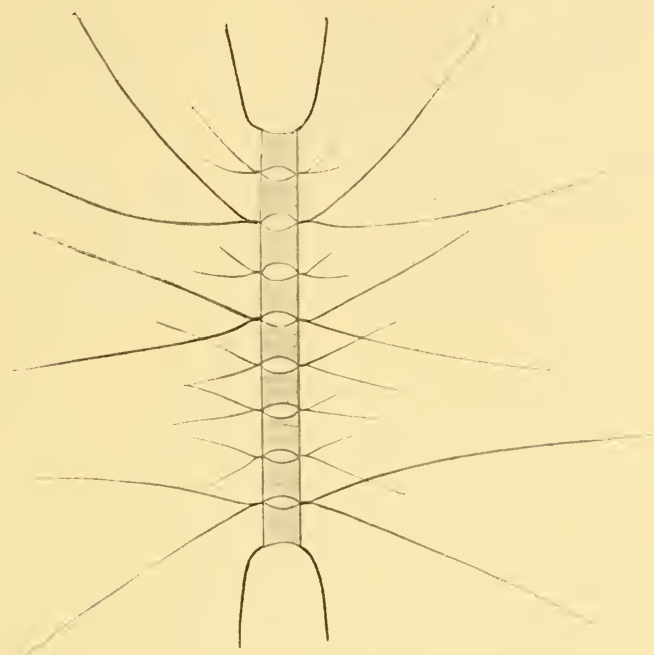

Fig. 218.-Chain OF CHATOCERAS DECIPIENS $\left(1 \frac{60}{1}\right)$.

of existence, especially when there are considerable changes in the salinity, sufficient mucilage is secreted to form a protecting

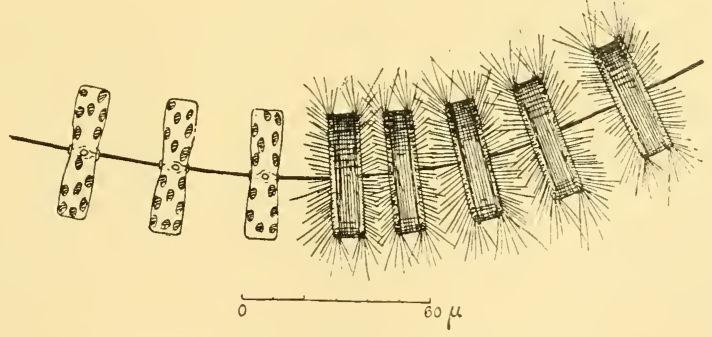

FIG. 219.-ChaIN OF THALASSIOSIRA GRAVIDA $\left({ }^{+0} 0^{\circ}\right)$.

Showing on the right five cells with filaments of mucilage. (Mangin.)

sheath round the cells. This I have myself observed in the case of species of Thalassiosira on the Norwegian coasts.

Adjustment of their organisms to the conditions of their 
floating existence affects the whole structure of these alga, though it is not always carried out to the same degree in the different genera and species. If we examine into their distribution we shall find that no particular region is distinguished by specially well-equipped species. Genera with the greatest numbers of species have their representatives in both the warmest and the coldest areas of the sea, and no essential difference in the development of their suspension-apparatus is to be found between the species of Chatoceras and Rhizosolenia which live near the confines of the polar sea, and their relatives in the tropics. The greatest abundance of forms is to be met with in coastal waters, where, too, the majority of the species have their home. I shall return later on to the special biology of these coast-forms.

Many species of diatoms show variations indicating that within certain limits the algæ can adapt their floating power to the demands made on them. Their tendency to sink increases with a rise of temperature, and decreases with an increase of salinity. It is not alone the specific gravity (density) of sea-water that is here the determining factor; no doubt we must bear specific gravity in mind also, but its variations are comparatively small. Ostwald has shown that the internal friction or viscosity of sea-water is the most important consideration, and this diminishes with an increase of temperature. Other things being equal, sea-water at $25^{\circ} \mathrm{C}$. offers only half the resistance that it would at freezing-point. Salinity, on the other hand, is of less account. A rise of I per cent in the salinity will produce no more than an increase of 2 to 3 per cent in the internal friction, and as salinity in the open sea is subject to what are after all quite inconsiderable variations, it follows that it is really temperature which indirectly affects the development of the suspension-organs. In areas of the sea where there is a big difference in temperature between summer and winter, we find a number of species with distinct summer and winter forms, that have sometimes even been supposed to belong to totally different species. And the same variation occurs also in species with a wide distribution, the warm-water types corresponding to the summer forms, and the cold-water types to the winter ones. The summer forms have usually thinner cell-walls, and a more slender structure; their excess weight appears to be reduced, though at the same time their surface is comparatively larger. As, however, diatoms vary greatly in their dimensions throughout their life-cycle, 
their cells diminishing by being divided and increasing again owing to the formation of auxospores (see Fig. 220), it is

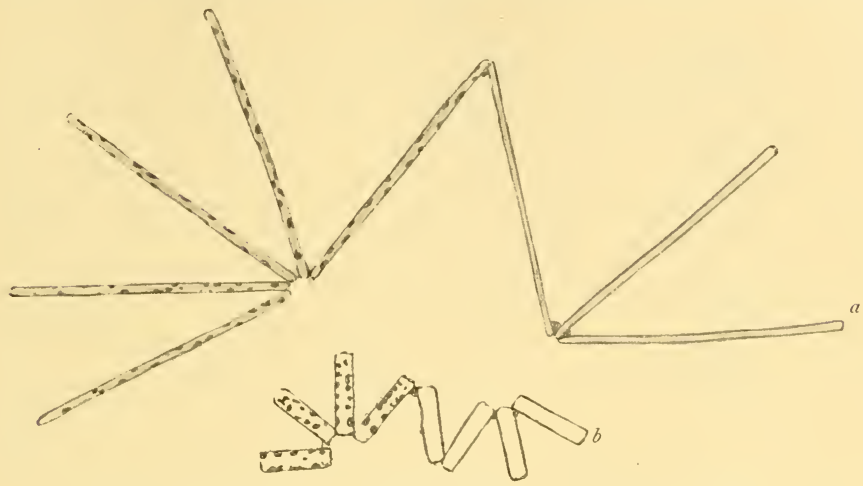

Fig, 220.-COLONIES OF THALASSIOTHRIX NITZSCHIOIDES $\left(\frac{800}{1}\right)$.

$a$, With long cells shortly after auxospore formation ; $b$, with shorter and thicker cells.

difficult to show in the case of many species to what extent variations are due to adaptation and regulation of their floating power, though in the case of some chain-forming species it is

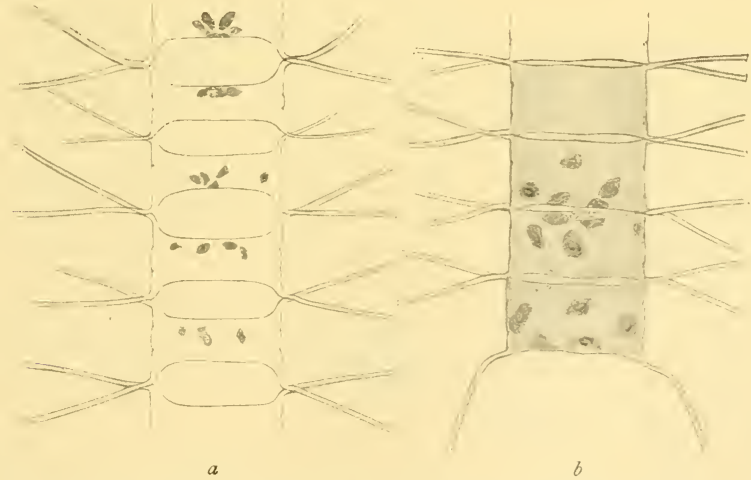

FIG. 221.-PARTS OF TWO CHAINS OF CHATOCERAS DECIPIENS $\left(\frac{40}{1}\right)$. $a$, From the Atlantic off the coast of Spain, April I9 Io ; $b$, from Christiania-Fjord, March I 9 I I

evident enough. Chatoceras decipiens, one of the commonest species in the northern Atlantic, consists of straight chains of flattened, almost rectangular cells, every one of which is 
furnished with four long setæ. Each of these setæ is attached at the root to its fellow from the neighbouring cell, the result being the formation of the chain. The terminal faces of the cells are otherwise separate, so that there are openings between them. In the winter and spring Chatoceras decipiens is furnished with thick cell-walls and stout setæ, and the interstices between the cells are quite inconsiderable (see Fig. $22 \mathrm{I}, b$ ); but in summer the walls are thin and the setæ extremely fine, and the openings in the chain between the cells then become large, round or oval gaps, which are almost as big as the cells themselves (see Fig. $22 \mathrm{I}, a)$. Corresponding variations occur in other species of Chatoceras, and in other diatoms, such as Biddulphia aurita. Along the arctic coasts, for instance, Biddulphia has a rather gross structure, and is almost cylindrical, with short conical projections at the corners, but off the south of Norway it has a comparatively much larger surface, and the corners develop into long, slender outgrowths.

We find a variation of a different nature in the case of

FIG. 222.-CELL OF RHIZOSOLENIA HEBETATA-SEMISPINA ( $\frac{300}{1} \%$.

One end of the cell belongs to the typical arctic hebetata (on the right), the other to the Atlantic form semispina.

Dimorphism. Rhizosolenia hebetata. It occurs in two perfectly distinct forms, that were formerly regarded as good species. The first, which belongs to arctic waters, is thick-walled and gross, and is the true $R$. hebetata. The second, $R$. semispina, has thinner walls and is proportionately longer, and it is furnished with a long hair-like point at each end. Its distribution extends over practically the whole Atlantic, though it is chiefly to be found in the neighbourhood of the cold currents. These two "species" can originate from one another reciprocally as the result of one cell-division. During the course of transition a cell may be hebetata at the one end and semispina at the other (see Fig. 222). Dimorphism of this kind is known, moreover, in the case of other species.

Still, in the open sea conditions of existence are comparatively uniform compared with what we find in coastal waters, where the temperature and salinity vary considerably. Most of the diatoms which belong particularly to the coastal waters have a special adaptation, the so-called resting-spores, which must be regarded as a means of protection against such altered conditions. The contents of the cell can shrink into a denser 
mass in the middle, and become enwrapped in a new thick wall of characteristic shape within the old cell-wall, which is discarded as soon as the resting-spore is completely developed (see Fig. 223). The spores have now acquired an increased specific weight, as compared with their original cell, and sink down into deep water, where they may be found months after they have disappeared from the surface-layers. The majority of them, however, rest on the bottom in shallow coastal waters, until conditions of existence again occur which induce them to make a fresh start.

The germination of the restingspores has not yet been described, though Hensen states that Lohmann has observed the first stages on several occasions. It will be a great advantage when we can follow their development-history through all its stages, and study the conditions of existence that lead to germination. Resting-spores are unknown in the true oceanic species ; but, as already stated, they are found in most of the species belonging to coastal seas. not aware of them till quite a short

FIG. 223.- CHAIN OF CHATOCERAS CONSTRICTUM, WITH THREE RESTING - SPORES AND ONE NORMAL CELL (THE END-CELL OF THE CHAIN) $\left(\frac{4}{1} \frac{0}{6}\right)$.

In some cases we were time ago. It is only recently that they have been discovered in Leptocylindrus danicus (see Fig. 224), in which the cylindrical cells are broken across in the process of spore-forma-

tion, so that the spores FIG. 224.-LEPTOCYLINDRL'S DANICUS, WITH RESTINGSPORE $\left(\frac{1000}{1}\right)$. are liberated, and in Chatoceras pseudocrinitum, in which the resting-spores originate in auxospores.

So far as we are able to ascertain, the auxospores of pelagic diatoms are always formed without any sexual act. There is, however, another kind of organ, the so-called microspores, Microspores. 
Bergon. which, according to Bergon's investigations; would seem to be Karsten. zoospores, and which Karsten assumes to be sexual cells. Karsten has observed the formation of microspores in an antarctic diatom, Corethron valdivice (see Fig. 225), and in the same microscopic preparations found amalgamations of small cells resembling microspores. We cannot yet, however, consider this conclusively settled. We do not know the life-history of the numerous small spores after they have emerged from the mother-cell. We can only hope that the centrifuge will enable us to study the most diminutive and sensitive cells immediately after capture, and that we shall thus succeed in solving this problem in the biology of diatoms.

Peridiner.

Peridineæ are mobile algæ furnished with two cilia. Several species can produce brilliant phosphorescence. Their cells are highly organised, with a distinct difference between the anterior and
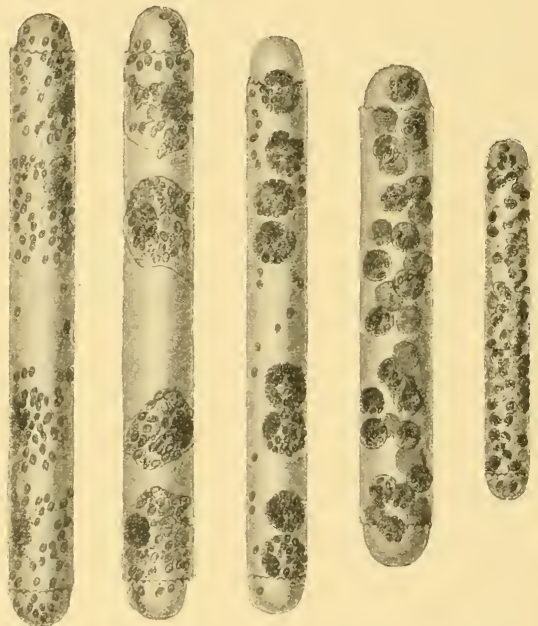

FIG, 225.-MICROSPORE-FORMATION OF CORETHRON VALDIVIA IN DIFFERENT DEVELOPMENT STAGES $\left(\frac{332}{1}\right)$.

Ripe microspores in the cell to the right. (Karsten.)

posterior ends, and between the dorsal and ventral faces. The cell-wall is built up entirely of organised matter, which dissolves soon after the death of the cell. Peridineæ are therefore not noticeable in the deposits of the ocean-bottom, which is one of the reasons why, until quite recently, they were but slightly and imperfectly known. A number of laminæ, characteristic in shape and position, compose the cell-wall. On the posterior side there is a characteristic furrow, with a pore for one of the cilia, which can be withdrawn spirally into a sheath (see Fig. 226). The ventral furrow is often protected by curtain-membranes. Another furrow encircles the cell, and 
is known as the ring-furrow. It is guarded by projecting borders on the anterior and posterior sides, called ring-borders. It is in this furrow that the second cilium lies and vibrates.

These principal organs appear in a great variety of shapes. The genus Ceratium has the anterior end drawn out into a long ceratium. horn, which is open at the top; its posterior end has also nearly always two horn-like projections, which in most species bend in a forward direction. The species of Ceratium are well supplied with brown pigment granules, and they occur in the upper water-layers, where they constitute an essential part of the plant life. The horns must be regarded as suspension-organs, even though the mobility of the cell makes an adaptation of this kind less indispensable. We frequently find them, especially in the species of tropical seas, transformed into very consummate suspension organs. Sometimes they are decidedly long and hair-shaped, sometimes flattened, and in a few species actually terminate in radiating branches. Kofoid has Kofoid. shown that the species of Ceratium can regulate their floating power, and that when, owing to the movement of the water masses, they enter colder or

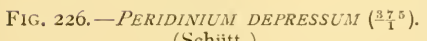
(Schitt.)

warmer layers of water, they can shed portions of their horns or prolong them at will (see Fig. 227). They have also still another mode of improving their floating power. The cell wall grows in thickness during the whole life of the algæ, and simultaneously ribs and pores are constantly developing; but as soon as the cell gets too heavy, one or even several laminæ peel off from the cell armour, and new extremely thin plates take their place.

The species of Ceratium are also formed by division, and with them, too, the daughter-cells each retain half of the membrane of the mother-cell, the other half being new. This does not, however, take place within the cell-wall of the mothercell, and there is therefore no gradual diminution in the bulk of the individual. Sometimes the cells hang together in chains, 
and it is then quite evident that the direction and shape of the horns may vary considerably from one generation to another.

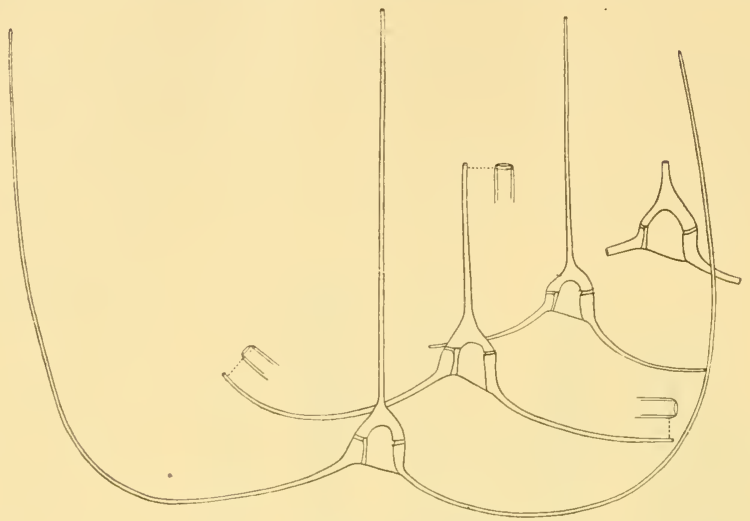

FIG, 227.-CERATIUM TRICHOCEROS.

Showing progressive and proportionate reduction of the horns in autotomy $\left(\frac{165}{1}\right)$. (Kofoid.)

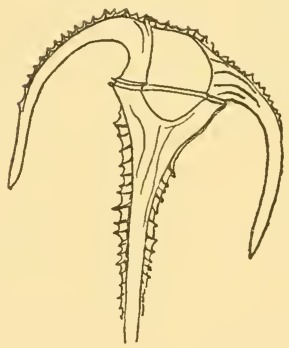

I.

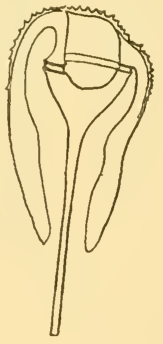

2.

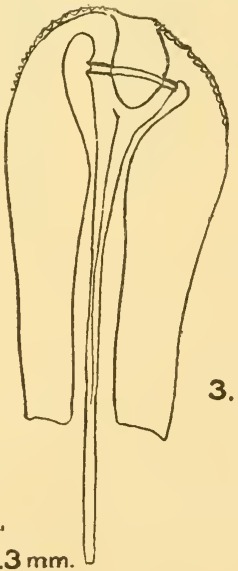

FIG, 228.-CERATIUM PLATYCORNE.

I, Forma compressa; 2, 3, forma normalis.

In other cases, where the cells separate immediately after division, it is more difficult to tell which variations are due to hereditary dissimilarities and which are the result of direct 
adaptations from one generation to the other. Still, now and then even this, too, is possible. I found during the Atlantic expedition of the "Michael Sars" that the subtropical Ceratium platycorne, both of the posterior horns of which are developed ordinarily into flat wing-like suspension-organs, changed gradually into a form with cylindrical horns belonging to the Gulf Stream in the Norwegian Sea, that I had myself previously described under the name of Ceratium compressum (see Fig. 228).

Discontinuous variations have been found as well as continuous ones in the species of Ceratium. Lohmann has Lohmann. shown that the ordinary Baltic form, C. tripos, can set up an intermediate generation of a totally different type, much smaller and with short, straight horns, corresponding to the forms described under the name of $C$. lineatum. Kofoid has met with similar variations in American species (see Fig. 229). The signification of these development forms has not yet been discovered. Jörgen- Jörgensen. sen, who has recently published a monograph on the genus, is inclined to regard them as degenerate forms that have been produced under abnormal conditions of existence. It seems to

FIG. 229.

CHAIN OF CERATILM TRIPOS. Only one cell (IV.) shows the characbelonging to the type of Ceratium californiense $\left(\frac{27 \%}{1}\right)$. (Kofoid.) ter of the type, the others (I.-III.) me, however, more probable that these small, extremely mobile, cells are normal formations, which have a definite function to perform in the imperfectly known
the species of Ceratium. It is still development-cycle of the species of Ceratium. It is still questionable whether peridineæ propagate sexually, even though Zederbauer claims to have discovered sexual propagation in the Zederbauer. ordinary fresh-water form (Ceratium hirundinella). But, $a$ priori, it is quite possible that the above described intermediate generation may be a sex-generation. Just as little as these "mutations" do we understand the significance of the gemmation which Apstein has lately described in Ceratium Apstein. tripos, nor do we know what conditions of existence cause gemmation instead of normal cell-division.

Another important genus with many species, Peridinium, Peridinium. 
differs in various ways from Ceratium, though systematically it is not far removed from it. The cells, however, lack the brown pigment-granules (at any rate, this is so in the case of marine species), and the contents are pale yellow or pink. It is improbable that it can assimilate carbonic acid, and it must therefore somehow or other obtain organic matter for its nourishment. Unfortunately nothing is known regarding its mode of nourishment. These forms do not live so close to the surface as the species of Ceratium, but all observations made hitherto indicate that they belong exclusively to parts of the sea to which light penetrates, where they exist along with the other algæ. Their cells are much grosser than

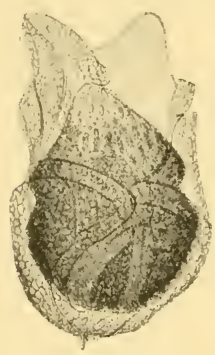

FIG, 230.

GONYAULAX POLYGRAMMA. The cell-contents form a zoospore, shed out from the bursting cell-wall $\left(\frac{6}{1}_{1}^{0}\right)$. (Schütt.) those of the species of Ceratium, and the projections corresponding to the horns of Ceratium are short or entirely wanting. The membrane-curtains along the furrows are only slightly developed, and the cell itself is much more globular. The species of Peridinium, and some other genera (Gonyaulax, Goniodoma), have thus at best only imperfect suspension-organs, but the mobility of the cells makes up for this deficiency. The way they are formed, too, is different from what we notice in Ceratium. There is no proper celldivision, but the cell changes its contents to one, two, or four naked spores, which are shed out from their original covering (see Fig. 230). Each spore afterwards gradually evolves a new cell-wall for itself, within which it develops as the wall expands, and bands, due to accession of growth, intervene between the laminæ composing the structure. This has been demonstrated by Broch. The genus Peridinium includes a large number of species distributed throughout all the seas of the world, but the systematic arrangement of the species is extremely difficult, and has not so far been sufficiently investigated. A large amount of material has, however, been brought home by our expedition, and it is to be hoped that we shall now be able to ascertain the characteristics to which we can ascribe chief systematic importance. A good beginning, at all events, has been made by Kofoid and Broch.

The family Dinophysidæ possesses the most remarkable suspension-organs of all the peridineæ. In northern waters its representatives are limited to a number of species all 
resembling one another and all belonging to the same genus, namely, Dinophysis. The commonest of these, $D$. acuta (see Dinophysis. Fig. 23I), has a small tongue-shaped mobile cell without particularly well-defined suspension-organs. Its ring-furrow and protecting borders are situated at the forepart of the cell, and its sides are flattened to such an extent that the ventral furrow is on quite a sharp edge, where it is guarded by two membrane-curtains. The cell is formed by division, which takes place perpendicularly to the ring-furrow. Within the cell are several brown chromatophores, showing that Dinophysis is one of the peridineæ that assimilates carbonic acid.

In warmer waters this funda-

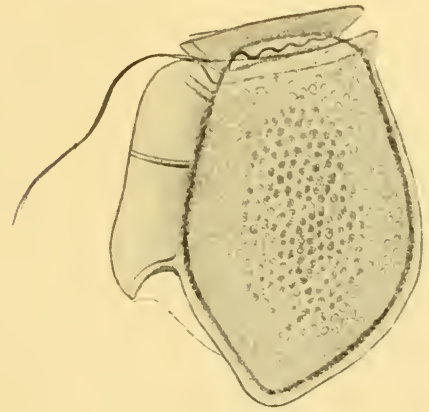

FIG. 23I.-DINOPHYSIS ACUTA.

From the west coast of Norway $\left(\frac{600}{1}\right)$. (Jörgensen.)

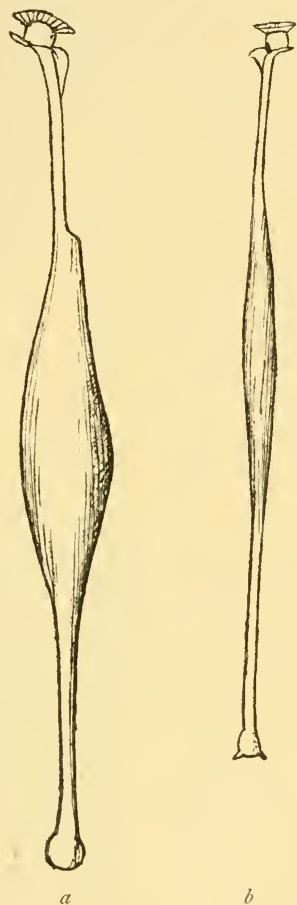

FIG. 232. a, Amphisolenia globosa ; b. Amphisolenia tenella, n.sp. $\left(\frac{600}{1}\right)$.

mental type shows strange variations. Amphisolenia (see Fig. Amphisolenia. 232 ) has its whole cell drawn out to a hair, the ring-furrow is situated right in front on a little head, and the ventral furrow is on a narrow neck with slightly developed membrane-curtains like a kind of collar. The cell widens out slightly like a spindle in the middle, and posteriorly ends in a globular knob by way of balance, or in two or three ramifications. Triposolenia (see Triposolenia. Fig. 233) has a similar anterior structure, but the middle part is 
more expanded, and the two bent legs which issue from it do not lie in quite the same plane, with the result that in sinking the cell describes very long sweeps. Besides these we get other genera, where the suspension-organs are not formed by the ornithocercus. cell itself, but by the membrane-curtains. In Ornithocercus splendidus the ring-borders are transformed into an unmistakable parachute, stiffened by a network of ribs (see Fig. $234, a$ ), and in some species, such as $O$. steinii and 0 . quadratus, the membrane-curtains are ventrally or posteriorly most highly developed (see Fig. 234, b). The majority of these more differentiated forms are without chromatophores, but some of them by way of compensation are in almost constant symbiosis with small brown naked cells that are probably immobile stages of brown flagellates. In Ornithocercus magnificus, for instance, we find these naked cells in the space between the ring-borders, where they are well protected against harm (see Fig. 235); and in a series of species of the remarkable Histioneis. tropical genus Histioneis this home of theirs is expanded posteriorly into a cavity which may be of considerable dimensions as compared with the cell. In Citharistes. Citharistes the cavity takes up

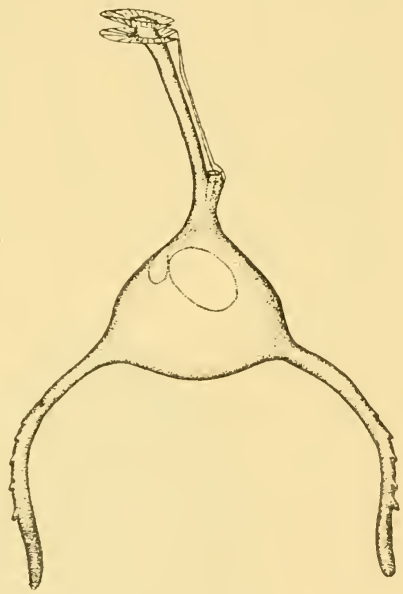
the whole of what should be the central portion of the cell, and the cell-membranes are merely the outer skin like the shell of a guitar (see Fig. 236).

A remarkable subdivision of the peridineæ is the genus Pyrocystis, which Sir John Murray discovered during the "Challenger" Expedition. Pyrocy'stis noctiluca (see Fig. 237) has large globular cells with a thin layer of protoplasm along the cell-wall, a denser mass round the nucleus, and brown pigment granules. Murray stated that the genus was abundant in all tropical and subtropical waters, where the temperature exceeds $68^{\circ} \mathrm{F}$., and where the salinity at the surface is not lowered by the presence of coast or river water. The cells have no organs of motion, but belong to the most brilliantly phos- 
phorescent of the algæ; biologically they are of the "bladdertype." Other species are elongated (see Fig. 238), straight, or crescent-shaped. Within their cells they form big zoo-
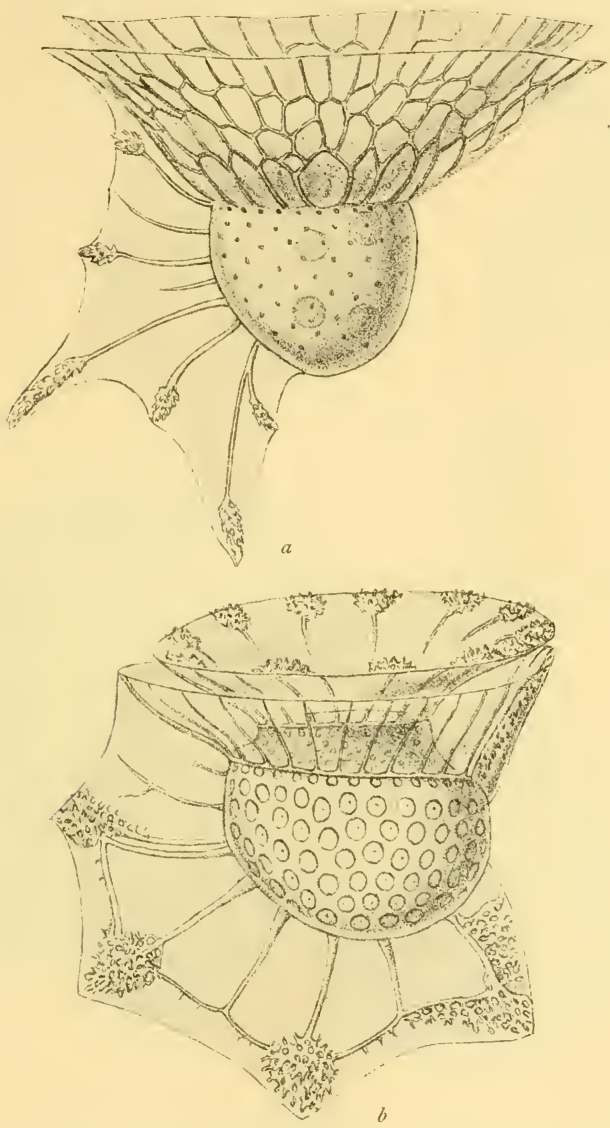

FIG. 234.

$a$, Ornithocercus splendidus $\left(\frac{310}{1}\right) ; b$, Ornithocercus steinii $\left(\frac{500}{1}\right) . \quad$ (G. Murray and Whitting.)

spores, built up exactly like the peridinex type with a ringfurrow and two cilia, for which reason the species of Pyrocystis are included among the peridineæ, though their fully-developed cells are really of a quite different type. 
Besides these highly-organised forms, which I have given as instances, the peridinex include many with a far more simple structure. There are, especially in the samples collected by

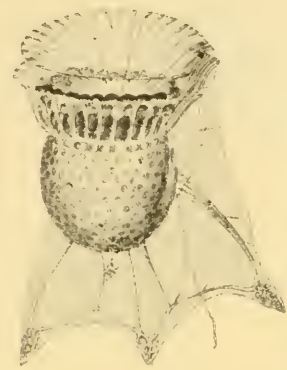

FJG. 235 .

ORNITHOCERCUS MAGNIFICL'S. With brown flagellate cells in the space between the ring-borders $\left(\frac{480}{1}\right)$. (Schütt.) means of the centrifuge, numerous series of small forms, both coloured and colourless, and often with very poorly developed cell-walls. These, too, have already got or will shortly be given names, although many of them are probably nothing more than developmentstages of the larger forms. We can recognise the whole series by their characteristic ring-furrow, so that we are seldom left in doubt as to the classification of even the simplest types. Still a good deal remains to be done before we can claim a thorough acquaintance with their development-history and systematic arrangement.

Coccolithophoridæ.

The third series of pelagic algæ consists of brown flagellates, the chief place amongst which is occupied by calcareous flagellates or coccolithophoridæe (see Fig. 239). Their cells are

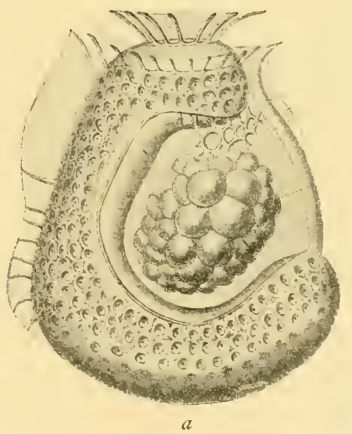

FIG. 236

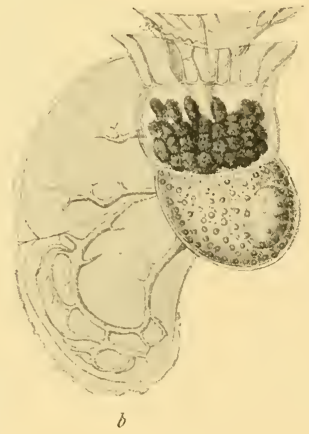

a, Citharistes apsteini $\left(\frac{788}{1}\right) ; b$, Histioneis gubernans $\left(\frac{675}{1}\right)$, both with cells of brown flagellates in special chambers. (Schütt.)

generally nearly globular, with one or two cilia and one or two brown chromatophores, and they are protected by remarkable shields of lime which unite into a complete defensive covering, though sometimes with a big opening in front. The cell does not 
always occupy the whole internal space, but lies sometimes, as it were, at the bottom of a hollow hemisphere or up at the mouth-opening in a conical sac. The shields of lime can be dissolved by the weakest acids, and the cell then remains as an insignificant mass with undefined boundaries. Still, these shields are very characteristic, and have been found in such enormous quantities in the deposits on the ocean-bottom that they aroused the attention of scientists long before the algx themselves were known. The commonest forms (Coccolithophora, Pontosphera) have an almost globular lime-covering, and are therefore without special suspension-organs, though their surface is big in proportion to their bulk, if we consider their extraordinarily minute dimensions ( 5 to $20 \mu$

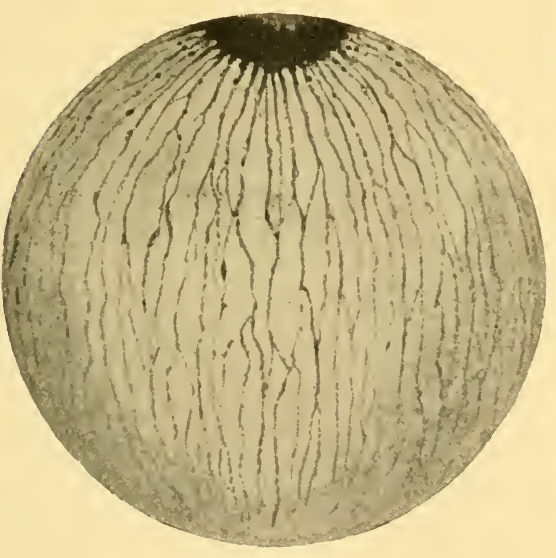

Fig. 237.-Pyrocystis NoctiLUCA. (From Chun.)
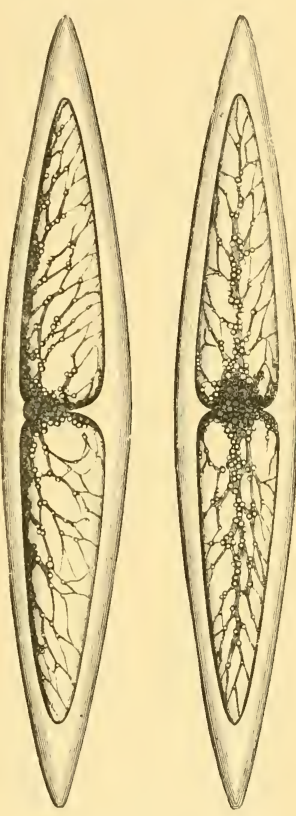

FIG. 238. PIROCISTIS FL'SIFOR.MIS $\left(\frac{100}{1}\right)$. (From "Challenger" Narrative.)

in diameter). But in forms like Rhabdosphara the calcareous shields have each a more or less large spike in the middle. In Discosphara we find trumpet-shaped spines, in Scyphosphara barrel-shaped outgrowths, and during the "Michael Sars" Expedition I succeeded in discovering even stranger forms. Ophiaster has a tuft of slightly spiral flexible calcareous filaments. Michaclsarsia carries in the front of its cell a sort of parachute or pappus of hollow jointed calcareous tubes arranged in a 
wreath. Calciosolenia murayi resembles, to some extent, the shape and structure of Rhizosolenia, as the shiclds of lime are not rounded like those of most other species, but rhomboid and spirally bent, so that between them they form a cylindrical tube, pointed at either end, and furnished at the extremities with one or two fine calcareous setæ.

Notwithstanding their small dimensions these microscopic

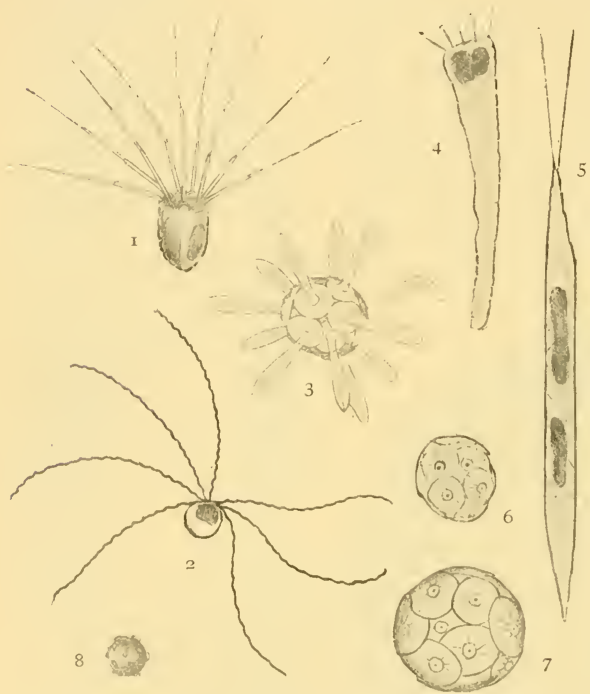

Fig. 239.-Different Types OF Coccolithophoride. $\left(\frac{1000}{1}\right)$.

I, Michaelsarsia elegans; 2, Ophiaster formosus; 3, Rhabdosphara claviger; 4 , Syracosphara prolongata; 5 , Calciosolenia murrayi; 6, 7, Coccolithophora leptopora; 8, Pontosphara huxleyi. calcareous algæ occupy a very important place in the economy of the sea, and their shields of lime, which may be met with in geological deposits dating from as far back as the Cambrian period, show that they have retained their shape practically unaltered through immeasurable ages. They are almost entirely oceanic, and mostly belong to the warmer seas. In coastal waters, where the salinity is lower, they are scarcer, but the commonest species, the little Pontosphara huxleyi, has been found even in the Baltic, and there were such immense quantities of it in the inner parts of the Christiania fjord during the hot summer of I9 I I 5 to 6 million cells per litre) that the calcareous cells with their strong refraction gave the sea quite a milky appearance.

The naked flagellates in the sea are still only imperfectly flagellates. known, though, no doubt, the part they play is quite a considerable one. In coastal waters they occur sometimes in such abundance that we have actually been able, even with our present defective methods, to discover and describe a number of species. In the open sea we are best acquainted with the passive and 
usually almost globular development-stages that live in symbiosis with various animals, and, in particular, with radiolaria. Of these radiolaria, which would seem from Brandt's investigations Brandt. to derive special benefit from the assimilation-products of algæ, we occasionally get the colony-forming species and Acanthometridx in such myriads among the surface-layers, that they contribute a very large proportion of the organic substance produced. I have previously stated that the brown algæ also regularly associate with a whole series of Dinophysidæ. Another family of brown flagellates includes the species of Phceocystis, which form large colonies visible to the naked eye, and enveloped in a loose slime (see Fig. 240). In cold waters these have actually

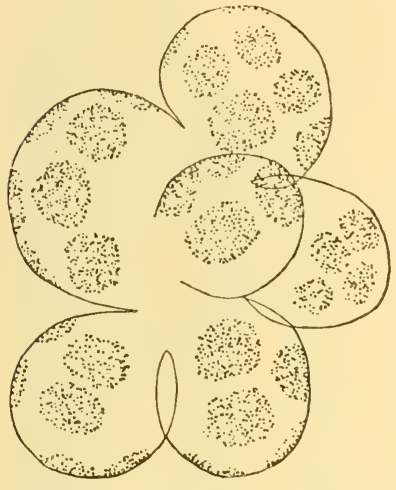

FIG. 240.-PHAOCYSTIS POUCHETI. (Lagerheim.) been known to occur in sufficient numbers to stop up the meshes of silk nets, and render them ineffective in working. ${ }^{1}$

It is the brown algæe that, properly speaking, characterise the plant-world of the sea. Still there are two other important series, the cyanophycex and the chlorophyceæ, which preponderate in fresh water, and are, no doubt, represented in salt water also, though by only a few species.

The Cyanophyceæ are chiefly cyanophycex. to be met with in warmer seas, if we except the brackish water forms that may be found along the coasts of North Europe in the height of the summer. The genus Trichodesminm appears as clusters of threads, composed of brownish-yellow or red cells, which are either parallel to one another, or twisted together, or matted and tangled, and radiating in all directions. Wille, who described these forms wille. collected by the German Plankton Expedition in I889, showed that all the types may belong to the same species, Trichodesmium thiebaulti, under different development-forms. The clusters may be seen sometimes when they collect near the surface in calm weather, and resemble yellowish-brown snowflakes. Like the different kinds of fresh-water forms, they can raise themselves in the water by means of vacuoles that, according to Klebahn, contain air. When abundant they sometimes Klebahn

\footnotetext{
1 See Summary of Results Chall. Exp., p. 499, I895.
}

Trichodesminm. 
cover the surface in one unbroken layer, a phenomenon which Cirsted. Ersted observed in I849, and which led him even then to look upon microscopic plants as the basis of production in the sea. Besides the species of Trichodesminm we have another Katagnymene. genus, Katagnymene, with spiral series of cells in sheaths of slime. Mention must also be made of Richelia. the remarkable little alga, Richelia intracellularis, described by Johs.

Schmidt. Schmidt, which lives in cells belonging to various species of Rhizosolenia (see Fig. 24I). These diatoms appear to have no difficulty in accommodating their guest, which apparently reproduces itself within the cell, and is thus transferred to new generations of the hospitable plant. The riddle is, how did it originally manage to get in? Most likely this happened at a stage when the Rhizosolenia had not yet developed the silicated cell-wall of the hermetically sealed chamber with which we are acquainted.

The green colour which predominates in plants on land is practically only to be found at sea in the globular Halosphara. Halosphara viridis (see Fig. 241). Schmitz.

This has been described by Schmitz from Naples, where the people call it "punti verdi," that is to say, green spots. It is or may be lighter than sea-water, so that it floats quite close to the surface. On the other hand, Hensen's expedition found it at profound depths, even at Iooo metres, away down near the limit of the pene-

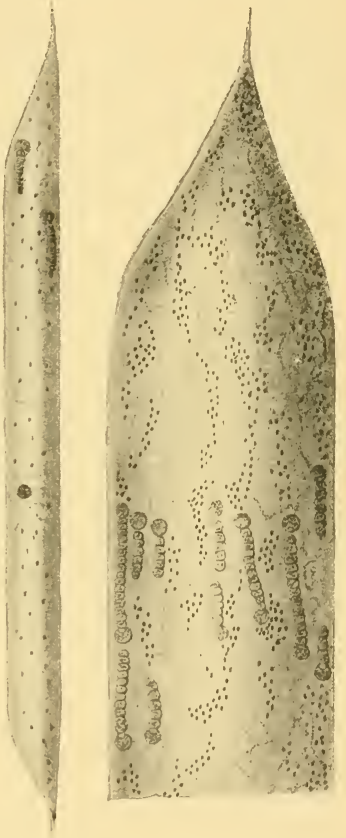

Fig. 24I.-Chains of Richelia INTRACELLULARIS WITHIN THE CELLS OF RHIZOSOLENIA STILIFORMIS. (Karsten.)

tration of sunlight, but if this denotes anything in its lifehistory, it must be at any rate in a state of resting. Halosphara is reproduced by zoospores, though we do not know how they proceed to form the small globular cells that little by little grow up to the normal size. The cell-wall is so firm and thick that its outer part is burst at last in the course of growth and discarded, and the inner elastic parts are thus Cleve. enabled to expand. Cleve has also observed thick-walled 
resting-cells. Halosphara occurs over the whole Atlantic Ocean, and follows the Gulf Stream to its farthest ramifications in the north near the coasts of Norway and Spitzbergen. In the North Sea there are quantities, especially in the winter, and they form their zoospores in May, and thereby commence their new generation.

Just as Halosphera differs from all the rest of the pelagic algæ in having a pure green colour, so, too, it has its own special mode of reproduction. The other forms, whose developmenthistory we know, are reproduced by division, and this goes on incessantly, the rate of increase depending upon different conditions of existence. Halosphara does not undergo division, but continues to grow for a comparatively lengthy period, and

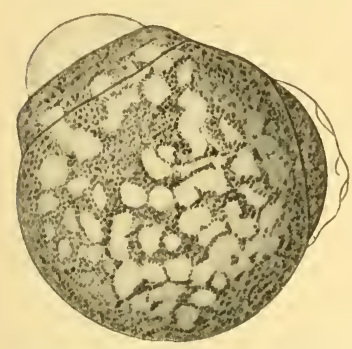

FIG. 242.-HALOSPHERA VIRIDIS, THROWING OFF ITS OLD CELLWALL $\left(\frac{7^{0}}{1}\right)$. then finally transforms all its contents, as has just been stated, into a great number of zoospores.

In addition to Halosphara viridis there are one or two similar species that have been described, but they do not call for any particular discussion.

In the foregoing I have sketched the most important types of pelagic algæ and their biology, but the picture would not be complete if I omitted to describe the drifting species of sea- Floating seaweed. These do not really belong weeds.

to the open sea. They grow along the coasts in the littoral zone, and their gas - filled bladders assist them in maintaining their position whatever be the state of the tide. The violence of the waves finally tears them loose, and then these same gas-bladders keep them for a long time floating on the surface. These patches of-seaweed are to be met with in every coastal sea, the chief kinds along the coasts of North Europe being Fucus vesiculosus and Ascophyllum nodosum, and in the Mediterranean species of Cystosira. They may also drift right out into oceanic waters, and in the Sargasso Sea we have an immense eddy where the patches of weed often collect in enormous quantities. The prevailing weed is Sargassum bacciferum, but one frequently gets patches of Ascophyllum nodosum as well, the whole being derived from the coasts of Central America. The Sargasso weed is easily recognisable, owing to its 
berry-like bladders on special small side branches (see Fig. 243).

One cannot help being struck by the fact that the drifting Sargasso weeds are destitute of the ordinary organs of reproduction. This seems to be invariably the case with attached algæ that have been torn loose from their support. They continue to grow vegetatively, but are deprived of all power of forming new reproduction organs, until they can attach themselves afresh. The same holds good, too, with those strange

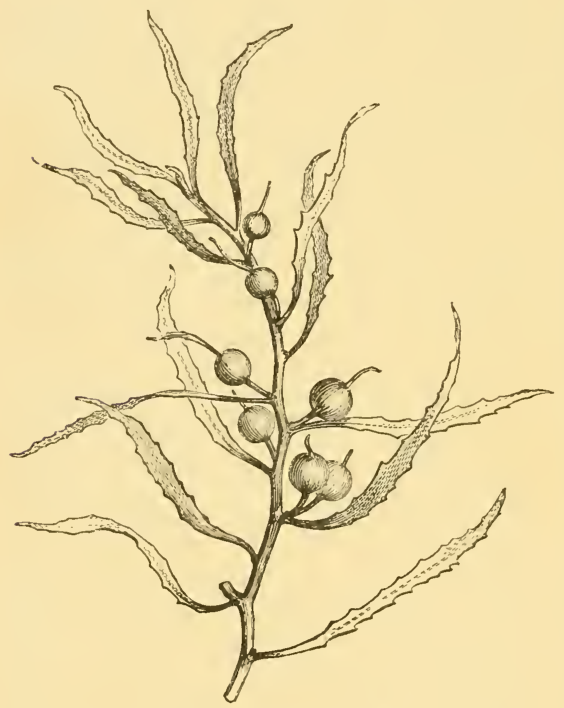

Fig. 243.-BRANCH OF SARGASSU.II BACCIFERUM. (From Kerner.) broken-off masses of alga that one finds drifting about along the bottom in bays, the constant movement of the water-masses preventing them from attaching themselves to the soft mud or sand.

The Sargasso weed continues to grow as it drifts, but the gas-bladders are not formed in the same proportion as on the ordinary branches, the result being that one finds newly detached patches close up to the surface, whereas the older patches with a greater specific weight have sunk lower down. These last have, moreover, thinner branches and a lighter olive-brown colour. Finally, the power of floating ceases altogether, and the patches sink into deep water and perish. Their disappearance is, however, quite imperceptible, since fresh patches of weed are constantly arriving from the coast.

It is quite usual to find smaller algæe fastened to the Sargasso weed, and there is, besides, a characteristic animal-life amidst its branches, but none of these organisms properly belong to the ocean, notwithstanding their being found there so invariably. 
This is true also of the attached algx, which develop upon driftwood, vessels, and other large objects. They show that germs of littoral organisms abound in the open sea, and are far more numerous than our random samples would seem to indicate. In May rgo4, when cruising in the Norwegian Sea, in lat. $67^{\circ} \mathrm{N}$., where the bottlenose whales are annually shot, we came across some wadding from a whaler's gun drifting in the sea, the lower side of which was thickly overgrown with attached forms of littoral diatoms.

Castracane, after examining the first big collection of pelagic Geographical diatoms from all the seas of the world made by the "Challenger" Expedition, came to the conclusion that there was no essential algx. difference between the flora of the different areas. In this, no doubt, he was right to a certain extent, since many species are very widely distributed; still a closer study has shown us that there are definite marine areas and conditions of existence in which they develop in vast numbers, whereas in other localities they occur perhaps in such small quantities that only their skeletons in the bottom-samples furnish evidence that they have actually been present. Besides, we often find that species with a wide distribution have different forms in the different areas, though we have not yet the means of deciding whether these forms diverge from the main type by virtue of hereditary characteristics, or whether they merge into one another through constant modifications. But in any case these forms are characteristic of the flora of a given locality, and any one who examines plankton-samples will become aware that it is nearly always possible to determine the area from which they have come. During the German Plankton Expedition under Hensen in I889, Schütt convinced himself that the different schuitt. currents had their characteristic flora, and he was at a loss to understand how it is that local boundaries of distribution can continue, seeing that the currents are ever carrying off the microscopic plant-life from one part of the ocean to another, and it might consequently be expected that all differences would be obliterated.

Schütt has also given a good description of the character of the plant-life in different parts of the Atlantic, but the honour of being the first to systematically investigate the distribution of all the different species, and the influence exerted upon them by ocean currents, must be assigned to the Swedish biologist Cleve. Cleve. A chemist by profession, he had for many years made a 
special study of diatoms before he commenced co-operating about O. Pettersson 1890 with the well-known hydrographers, Otto Pettersson
and G. Ekman. and Gustaf Ekman. They commenced their labours in the Skagerrack, that remarkable little sea where so many different water-masses meet and pass each other ; and it very soon became clear that different currents might each possess synchronously its own particular flora, and therefore there was the possibility of ascertaining where the water-masses came from, by determining their flora. ${ }^{1}$ All that was requisite was to know the distribution of the different species in contiguous parts of the sea. The investigations were accordingly extended, and samples were collected by ordinary steamers in the North Sea, the Norwegian Sea, and the Northern Atlantic, in addition to the collections that were gradually formed chiefly through the efforts of Swedish, Norwegian, and Scottish scientific expeditions. Cleve also studied the annual changes in the plankton, and had weekly collections made at selected stations on the Swedish coast. The scope of his investigations was further enlarged, for his unique knowledge of forms enabled him to determine, not merely all pelagic plants, but also little by little, a whole series of animal-families which proved no less useful than the algæ as "guiding forms" to determine the character and origin of the plankton.

Planktontypes.

Cleve believed that he could distinguish a series of planktontypes characteristic of defined marine areas. Particular species were therefore assigned by him to one or other of these main types. But whereas outside the Skagerrack each of the planktontypes had its own characteristic distribution, within this sea the same types were found to predominate, each in its own characteristic season. From February to April there were the same species that we have learnt to connect with the coasts of Greenland and Spitzbergen in the Polar Sea, and from May to June there was a plankton resembling that of the Western Baltic. During the course of summer and autumn there were, first of all, species like those belonging to the southern part of the North Sea, and afterwards Atlantic and more northerly forms. Cleve was led to conclude that these changes in the Skagerrack were due to the fact that it is supplied during the course of the year

1 " While passing through the Japan Stream the tow-net observations indicated water from two different sources. When in the colder streams there were very many more small diatoms, Noctiluca, and Hydromeduse than in the warmer streams, where the same pelagic animals that were obtained all the way from the Admiralty Islands prevailed. Many similar instances occurred during the cruise, where the approach to land or the presence of shore water was indicated by the contents of the tow-nets" (Narrative of the Cruise, Chall. Exp., vol. i. p. 750, 1885; see also Summary of Results Chall. Exp., pp. 893 and 895, I895). 
in regular rotation with water-masses from the marine areas to which these plankton-types belong.

Subsequent investigations have shown that Cleve's view, which he endeavoured to apply even more widely, was preconceived. His eagerness to discover how far the distribution of particular species depended on sea currents, made him apt to forget that algæ are living organisms which are incessantly in process of formation. Accordingly, when the conditions of existence in the flowing water-masses gradually alter, it is the new conditions of existence that decide the character of the flora, since the species best qualified to endure them will very soon get the upper hand over the others. When, therefore, in a sea like the Skagerrack we find northern and southern forms alternating during the course of the year, we are not compelled to assume that the flora is being periodically recruited from different areas. The periodic alterations in the conditions of existence, and particularly in temperature and sunlight, which in our latitudes follow the course of the seasons, sufficiently explain why at one time northerly species predominate and thrive in low temperatures, and why southern forms succeed them and benefit by the warmth which they find necessary for their proper development. Of course it is absolutely essential that germs should be present ready to develop whenever the conditions of existence become favourable. A certain proportion of these, no doubt, may be introduced by currents from elsewhere, but there is nothing to prevent them from remaining in a particular area, even though the water-masses are in constant motion. Recent hydrographical researches have shown us that eddies are far more common than was at one time believed. Even in areas where huge masses of water are constantly streaming in one direction, which one might naturally suppose would carry away with them all germs belonging to a local flora, these eddies act as a retaining factor, preventing any complete replacement till germs sufficient to maintain the local flora have been transferred to the supplanting water-masses. In coastal seas, moreover, many of the species are able to evolve resting bottom-stages, which lie waiting to reproduce the local flora, as soon as the conditions of existence are congenial.

Still Cleve's investigations have been of great value, and his plankton-types provide us with a biological division of species which is yet in the main quite serviceable. All that we have to say by way of qualification is that Cleve looked upon his types as representing communities of species limited 
to definite marine areas, whereas in reality the areas of distribution of the different species encroach so upon each other, that a division of this kind is hardly practicable. This is true, not merely of the altering flora of ocean-currents, but also of the attached flora along the coasts and on land. Unless the areas are exceedingly remote from one another, the forms common to the areas usually exceed those peculiar to each area. Cleve's types, on the contrary, have no species in common, and therefore do not record the species in any definite area, but merely group them in accordance with their conditions of existence. If we adopt his principles we can certainly obtain a biological division of the species that is satisfactory in the main; but when we come to details it will, in some cases, be difficult to decide whether a species is to be assigned to this or to that type.

Biogeographically, the pelagic algæ may be divided, firstly according to the latitudes in which they are distributed, which is generally tantamount to saying according to their need of warmth and light, and secondly according to their occurrence along the coasts or in the open sea. This latter classification gives us the most distinct boundaries, and we will therefore consider it first. There is a whole series of species which unmistakably belong to coastal waters, and occur there in myriads at definite seasons of the year. Out in the ocean we do not find them, except when salinities or other physical properties indicate that they must have drifted from the coast. Haeckel. These have been termed neritic on the suggestion of Haeckel. Opposed to them are the oceanic species, which belong to the ocean and float over profound depths, from which occasionally they are swept by the currents into coastal seas and there usually perish.

It is possible to imagine various reasons why the neritic species keep in the vicinity of the coasts. Some may derive benefit from the low or fluctuating salinities, which enable them to outstrip the more easily affected forms. Others, perhaps, require the abundant supply of nourishment from the land in order to grow and multiply as fast as such organisms should do. There may be other species, again, whose developmenthistory makes it necessary for them to remain on the bottom at one stage of their existence, like the hydroid medusæ and all pelagic young-stages of littoral animals. Most of the neritic algæ have a bottom-stage, in so far as they form resting-spores 
that sink to the bottom in the shallow coastal seas, where they Restingrest until conditions of development become favourable again. spores. This has been observed by many naturalists since Schütt first noticed in the Western Baltic that a species which begins to form resting-spores disappears shortly afterwards from the surface-layers. He showed, too, that the resting-spores sink down to the bottom, and, although their germination has not been carefully studied, we may be sure, all the same, that it does take place; further, when we subsequently find the same species once more in abundance, we have every reason for surmising that the resting-spores on the bottom were the principal source from which these forms have been derived.

Ability to form resting-spores must be of the utmost importance for the existence of the species in coastal waters. The chief difference between coastal seas and the ocean, so far as hydrographical conditions are concerned, lies in the extreme and rapid changes in such fundamental conditions of existence as salinity and temperature in coastal waters. Resting-spores, therefore, must be the means by which many species continue in coastal seas, notwithstanding the fact that there conditions of existence are only favourable for a limited portion of the year. The arctic diatoms, for instance, which are sometimes to be found in the plankton of the Skagerrack, are very easily affected by a rise in temperature, but their development takes place during the winter months from February to April, when the temperature is at its minimum. In the summer they are not to be seen, but their resting-spores are then most probably on the bottom. In the same way a whole series of warmth-loving species pass through the winter as resting-spores, and are to be found along our shores only in the warmest months of summer and autumn.

The neritic species may often be met with a long way Neritic out at sea, still continuing to increase, though they are diatoms in the seldom in any great quantity. One of the few instances that I know of, where we regularly find an immense production of neritic diatoms in the open sea, is in the Gulf Stream north of Shetland and the Faroe Islands during May. I made this discovery as long ago as I 895 , and it has often been confirmed since then during the international investigations. When the snows begin to melt in the spring, the surface-layers of water are carried far away out from the land, and the neritic algæ are taken with them. I shall presently show that it just happens to be in the spring that conditions of nourishment favourable 
CHAP.

to an abundant plant-life exist in the Northern Atlantic, and the somewhat exacting neritic species benefit accordingly. This explanation, at any rate, seems to me the most reasonable one.

Another well-known instance is in the Polar Seas during the summer. Close to the melting polar ice, where it meets the warmer water-masses, a rich flora of neritic diatoms sometimes develops, while littoral species form a brown layer over the floes and broken lumps floating between them. Blessing, who took part in Nansen's expedition during I893I 896, has given a good description of this latter phenomenon. We must look upon the Polar Seas as coastal waters in the biological sense. They have the extreme variations of temperature and salinity, and probably also the abundant supply of nourishment, that we would expect to find in a coastal sea. The resting-spores are enclosed in the ice, as I was able to show after examining the material collected by Nansen.

In the warmer parts of the Atlantic there are neritic diatoms nearly everywhere, but never in any great quantity, except where rivers enter the sea in the tropical regions. As a rule, too, they are smaller and weaker in structure than those we meet with in coastal waters under similar conditions of temperature. The cell-walls are very often only slightly silicated, and the form itself is so indistinct that it is difficult to distinguish species, which in their properly developed condition have unmistakable characters. It is not easy to tell whether this degeneration is merely a sign of insufficient nourishment, or whether other causes are also responsible. Certainly in one case want of nourishment is not entirely to blame. Out in the water-masses of the Atlantic to the south of Iceland we get a community of neritic diatoms that occur especially in the spring and autumn. Most of them are species of Chatoceras. The prevailing forms have been long ago determined, and are undoubtedly $C$. schittii and $C$. laciniosum. Still they are so dwarfed in structure, and so much the reverse of typical, that one might very well say that they were separate species (see Fig. 244). During this last expedition of ours we succeeded in finding this diatom-flora again, though in smaller quantities, in the Gulf Stream off the east coast of North America, so that it is practically certain that the neritic diatoms of the Atlantic south of Iceland are derived from the American coastal sea. As they are borne passively northwards towards 
the shores of Iceland, they commence to develop at a great rate, with the result that the plankton in those parts frequently yields abundant though monotonously uniform samples of these degenerate forms. The altered conditions of existence, which obviously must have supervened, have thus resulted in an extensive production of algæ, though without investing them with their normal robust appearance. The strings of cells are of much smaller diameter than usual, so that the formation of auxospores cannot have taken place at the stage that is usual elsewhere. Wesenberg-Lund has told us that pelagic

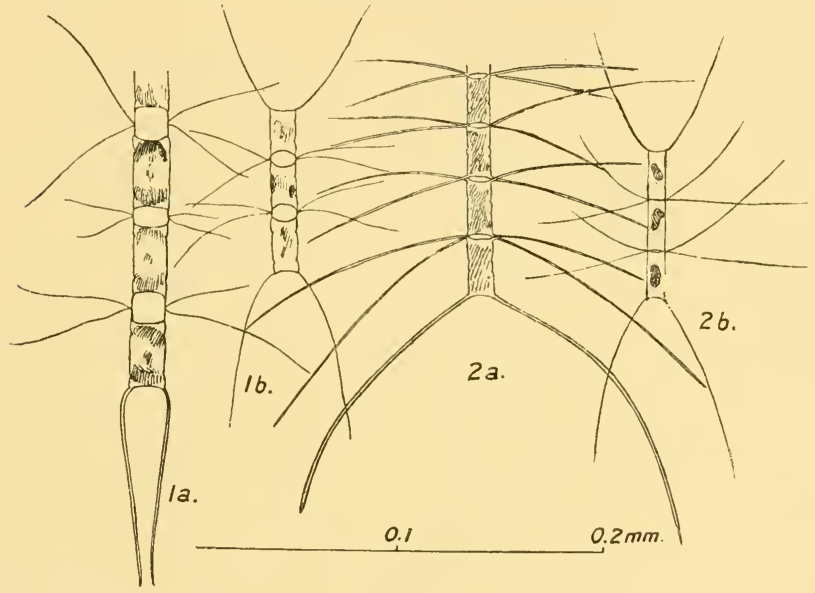

FIG. 244 .

I $a$, Chatoceras laciniosum: $\mathbf{1} b$, forma pelagica ; $2 a, C$. schiittii : $2 b$, forma oceanica.

fresh-water diatoms, such as Asterionella gracillima and Fragilaria crotonensis, keep on reducing their dimensions in the Danish lakes for months, sometimes even for over a year, and then suddenly return to their maximum measurements, and that this is undoubtedly due to the formation of auxospores. All are not, however, affected alike by such a change, and the species occur thereafter in two different sizes, making it necessary to express the measurements of their cell-dimensions by means of divergent curves. This goes on uninterruptedly, moreover, and the smallest forms diminish and seem to degenerate more and more, until in WesenbergLund's opinion they lose all power of regaining their normal 
dimensions and of reproducing their kind. The degenerate forms of neritic diatoms met with in the open sea appear to me to lack the stimulus which in some unknown manner leads to the formation of auxospores; consequently their ultimate extinction is only a matter of time, even though they may continue reproduction through a whole succession of generations. This is, of course, merely an unsupported surmise, for the few random investigations we have hitherto made do not afford sufficient material to settle questions of this nature at all definitely; but my idea is that the hypothetical views of an author are of more value than the enumeration of solitary facts that have no apparent connection.

Resting-spores in the open sea.

When the neritic diatoms evolve resting-spores out in the open sea, which occurrence we have been able to observe on more than one occasion, it might be supposed that the spores would be destroyed after sinking down to profound depths. This is not, however, necessarily always the case, since they appear to sink slowly, and remain within the region of light for weeks if not for months. The spores after leaving their cells are so minute that they are rarely caught in silk nets, so that little has been done as yet to throw light upon this question. But now that we have adopted the centrifugemethod it is possible to collect them, and we discovered numbers of resting-spores of species of Chatoceras in our centrifugesamples from the Atlantic. In a litre of sea-water from Station 87 (lat. $46^{\circ} 48^{\prime}$ N., long. $27^{\circ} 46^{\prime}$ W.), from a depth of 100 metres, I secured altogether i 60 resting-spores belonging to three different species of Chatoceras, though the forms themselves were not present at that time in a vegetative state either in the surface-layers or deeper down. Most probably what we got were representatives from the last remnants of the diatommasses that throng the surface-layers there during the spring.

Distribution.

Neritic species include a very large number of diatomsa class by far the most characteristic in coastal seas. In the majority of these neritic diatoms we have now been able to prove the existence of resting-spores. The peridinex, on the other hand, are mainly oceanic, especially the species of Ceratium. One of the best-known neritic peridineæ is the comparatively low species Prorocentrum micans; but there are probably, too, whole series of small forms, as yet imperfectly known, which prefer the neighbourhood of the coasts. The coccolithophoridx, again, are undoubtedly oceanic, whereas most of the naked flagellates are most 'likely domiciled in 
shallower waters. Halosphara is oceanic, and so also are the species of Trichodesmium; but there are several blue-green species that are brackish-water forms, and they must of course be accounted neritic (Anabena baltica, Nodularia spumigena, Aphanizomenon flos-aqua).

Several of the neritic alga practically only occur locally. Detonula cystifera, for instance, appears in the Limfjord in Denmark and along the south coast of Norway, while Lithodesmium undulatum. Coscinodiscus granii, Navicula membranacea, and Streptotheca thamensis belong to the English Channel and to the southern portion of the North Sea. I could mention additional examples, but the greater number of them are far more widely distributed. It has been found possible to allocate all the species along the coasts of the Northern Atlantic to three comprehensive main groups, namely, the arctic, temperate, and tropical. This is perhaps rather an arbitrary arrangement, as these groups encroach to a very great extent upon one another; so that we get northern forms a long way south in the winter, and in the autumn the southern forms extend northwards. Further researches, too, might result in a stricter classification, while it is known that there are species which, biologically speaking, unite the groups, and might with equal reason be assigned to the one or to the other.

(I) Arctic neritic species are mainly those which Cleve termed Sira- Arctic neritic plankton, and consist principally of diatoms. The characteristic forms species. are the species of Thalassiosira from which this name was derived. They are composed of long strings of short cylindrical cells united by a central thread of slime. Thalassiosira hyalina has its southernmost limit off the north of Norway, while T. gravida and T. nordenskioldii occur in winter as far south as Central Europe. A series of species belonging to the genera Fragilaria, Achnantes, Navicula and Amphiprora are also distinctly arctic forms, and are characterised by having their cells bound together like ribbons. These include Fragilaria oceanica, F. islandica and F. cylindrus, Achnantes teniata, Navicula septentrionalis, $N$. vanhöffenii and $N$. granii, and Amphiprora hyperborea. The usually predominant genus Chatoceras is only represented by two purely arctic species, namely, Chatoceras furcellatum and C. mitra. We must likewise add the well-known Biddulphia aurita. Besides these diatoms, there are the peridinean Gonyaulax triacantha, and the brown flagellate Pheocystis poucheti, with its naked cells in large slimy round or lobate colonies.

(2) Temperate neritic species are even more numerous. The warmth-
ing species fall under Cleve's designation of Didymus-plankton, with Temperate neritic species. loving species fall under Cleve's designation of Didymust it is, however, a better arrangement, perhaps, to associate with them a series of other species with a slightly more northerly character, that cannot be really 
called arctic. Here, too, diatoms predominate, and Chatoceras takes first place. The commonest forms include :-

(a) Northerly : Chatoceras teres, $C$. constrictum, C. diadema, C. debile, C. crinitum, C. pseudocrinitum, C. scolopendra, C. sociale, C. simile, Rhizosolenia setigera, Thalassiosira decipiens, Coscinosira polychorda, Leptocylindrus danicus.

(b) Southerly: Chatoceras weissflogii, C. contortum, C. didymum, C. laciniosum, C. schiittii, C. curvisetum, C. cinctum, C. anastomosans, C. radians, Lauderia annulata, Cerataulina bergonii, Biddulphia mobiliensis and B. regia, Eucampia zodiacus, Ditylum brightwellii, Guinardia flaccida, Asterionella japonica, the peridinean Prorocentrum micans, and the brown flagellate Phacocystis globosa.

Tropical neritic species.

Neritic diatoms in the Antarctic.

(3) Tropical neritic species have had far less study devoted to them; still we may denote by this term a whole series of species that have their northernmost limit on the coasts of the Mediterranean. Of these we may mention :-

Chatoceras furca, C. diversum, C. femur, Hemiaulus hauckii and H. heibergii, Detonula schröderi, Asterionella notata, Rhizosolenia cylindrus.

The neritic flora off the coasts of the Atlantic in the southern hemisphere has also been comparatively little studied as yet. Still we are justified in saying that the neritic diatoms of the antarctic, from the ice barrier northwards, differ in the main from species belonging to the northern hemisphere. The difference indeed is so great, that hardly a single species is common to both arctic and antarctic waters. The investigations of Cleve, Karsten, and Van Heurck show that the following neritic diatoms may be considered characteristic of the antarctic:-Chatoceras radiculum, Molleria antarctica, Eucampia balaustium, Fragilaria antarctica, Thalassiosira antarctica, and probably several others whose biology is as yet only slightly known.

Oceanic species.

Oceanic plankton algæ are much more widely distributed than neritic algæe, and it would almost seem from our material that each species may be met with in all the seas of the world, wherever there are favourable conditions of existence. The diatoms are apt to occur irregularly. Sometimes we find enormous quantities of them, and at other times they may be so scarce that it is difficult to detect them. The peridineæ are more evenly distributed, and this is true especially of the species of Ceratium, which are fairly abundant and hardly ever absent from oceanic-samples, unless perhaps in arctic waters. They may well be used as guiding forms to express the character of the plankton. It is possible that the different 
species and varieties of the genera Peridinium and Gonyaulax might be employed with equal advantage, but they are more difficult to determine, and so little studied as yet that the determinations of Hensen and Karsten are unserviceable. Owing to so little being known about their distribution, I have decided to ignore them for the present.

The oceanic species may also be divided into three main groups :-

(I) Arctic forms, corresponding to Cleve's Tricho-plankton and Chæto-plankton. Most of them occur also in antarctic waters.

Diatoms : Thalassiothrix longissima, Coscinodiscus subbulliens, Chatoceras criophilum, C. boreale, C. convolutum, C. atlanticum, C. decipiens, Rhizosolenia hebetata (semispina), Nitzschia seriata.

Peridineæ : Ceratium arcticum, C. longipes, Dinophysis granulata.

(2) Temperate-Atlantic forms, corresponding to Cleve's Styli-plankton Temperate and Tripos-plankton. The latter of these two designations comprises a small community of species, which are less exacting as regards salinity, and are therefore produced in quantities along the coasts of North Europe.

Diatoms: Rhizosolenia styliformis, $R$. acuminata, $R$. alata, Coscinodiscus radiatus, $C$. centralis, $C$. stellaris, Chatoceras densum, $C$. dichata, Corethron criophilum, Dactyliosolen antarcticus, Thalassiosira subtilis, Coscinosira astrupi, Asteromphalus heptactis, Bacteriastrum delicatulum, B. elongatum.

Peridineæ: Ceratium tripos, C. bucephalum, C. azoricum, C. macroceros, C. intermedium, C. lamellicome, C. reticulatum, C. fusus, C. furca, C. lineatum, Dinophysis acuta, D. hastata, D. homunculus.

Coccolithophoridæ: Coccolithophora pelagica, Pontosphara huxleyi.

Chlorophyceæ: Halosphara viridis.

(3) Tropical-Atlantic forms, corresponding to Cleve's Desmo-plankton, Tropical and comprising a series of species, especially peridineæ and coccolitho- oceanic phoridæ. Cleve's guiding form is the blue-green alga Trichodesmium thiebaultii. The following are some of the commonest :-

Diatoms : Coscinodiscus rex, Planktoniella sol, Gossleriella tropica (see Fig. 245), Rhizosolenia castracanei, Chetoceras coarctatum, Asterolampra marylandica, A. rotula.

Peridineæ: species of Ceratium of all groups (pralongum, cephalotum, gravidum, candelabrum, pennatum, extensum, palmatum, massiliense, carriense, and several others), species of Oxytoxum and Podolampas, Ceratocorys horrida, species of Phalacroma, Dinophysis schüttii and D. uracantha, species of Amphisolenia and Triposolenia, Ornithocercus magnificus, O. quadratus, O. steinii and O. splendidus, Pyrocystis noctiluca and $P$. fusiformis.

Coccolithophoridæ: Coccolithophora leptopora, species of Syracosphera, Calciosolenia murrayi, Michaelsarsia elegans, and many others.

The boundaries of the areas populated by these communities of species are as variable as the limits of distribution for the 
Flora of west coast of Norway.

species themselves. Our investigations at different seasons, both in coastal waters and in the North Atlantic, have shown us that the flora of each locality is constantly changing. One species succeeds another as month follows month, and different societies predominate in the same locality at different seasons.

Along the west coast of Norway, for instance, we find a flora during the winter, from December to February, scanty in numbers, but consisting of many species, and mainly composed of true Atlantic forms (Styli-plankton), which reach their northernmost limits in the dark months of the year. About March or April the temperature attains its minimum, and great quantities
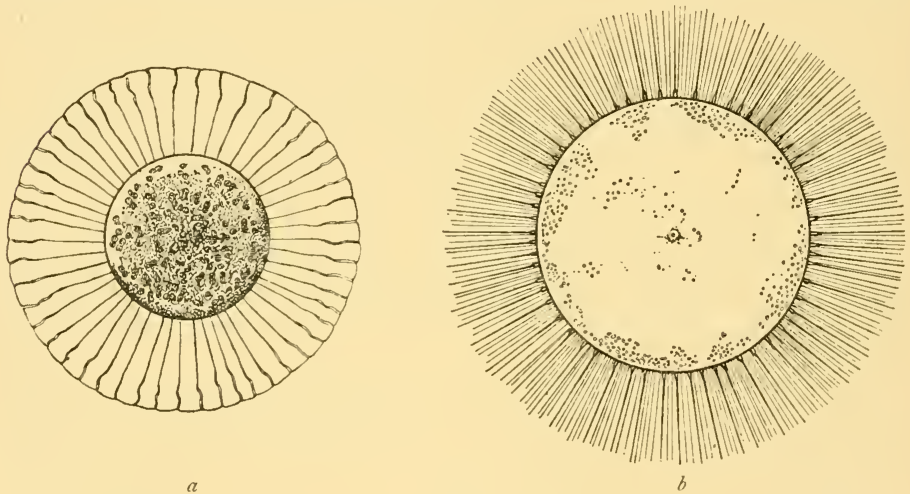

FiG. 245 .

$a$, Planktoniella sol, and $b$, Gossleriella tropica, from the Atlantic. (Schütt.)

of diatoms are then produced, which are mainly arctic. Sometimes these are almost entirely neritic, and sometimes there is a considerable addition of oceanic species. As often as not it is the species of Thalassiosira and Coscinodiscus which first appear, and then comes Chatoccras, $C$. debile being usually the form found on the west coast, $C$. constrictum preferring the Skagerrack. In May the predominant form is generally Leptocylindrus danicus. We next get a period in June when the prevailing forms are oceanic, Ceratium longipes at that time attaining its maximum development and characterising the flora. In August the warmth-loving peridinea begin to be more and more numerous, Ceratium fusus, $C$. furca, and C. tripos being then much in evidence, and continuing to increase until October. Finally, in November we get a comparatively 
large amount of southern neritic species (Didymus-plankton), made up to a great extent of forms of distinctly foreign origin. As the dark months of winter approach, however, their numbers rapidly decline.

In the open sea, too, our investigations appear to indicate Flora of the that the southern forms reach farthest north in the autumn, say about November, while during the months of spring, from April to May, northern forms extend very far south. We have not as yet made investigations at different seasons in the tropical parts of the Atlantic ; consequently we cannot say whether there is an annual cycle of plant-development in a region where the conditions of existence seem to vary so little. It would be an excellent thing if researches of this nature could be undertaken.

Supposing that the ocean-currents do exercise a direct Oceaninfluence upon the character of the plankton in the tropics, it is fair to imagine that it must be in the direction of periodicity. Lohmann has put forward the suggestion that the changes in pelagic animal life near the coasts of South Europe are connected with a cyclic movement of the water-masses. When these reach their northernmost point the conditions of existence will affect the organisms, so that the water-masses that pass through this region in the winter are likely to have a different fauna from that of the water passing through in summer. Elsewhere it is very difficult to tell what changes in the plankton are due to the direct influence of ocean-currents, and what changes are the result of altered conditions of existence partly due to ocean-currents and partly to other causes. It has often been observed, not only by Cleve and Hensen, but also during previous researches made by the "Michael Sars" and during the "Challenger" and "Valdivia " Expeditions, that the plankton changes its character the moment one passes the boundary between two currents. Thus an examination of the plankton may serve as a check on purely hydrographical investigations, which aim at ascertaining the boundaries of currents by means of observations of their temperatures and salinities. Perhaps the best guiding forms are the species of Ceratium, and strangely enough it is very often the species that systematically are the nearest related, which replace each other as we pass from one area to another. Many of them are so closely related that it is only for the sake of convenience that we regard them as distinct species, and there is always the possibility that they may be able to pass directly from one form into the other, even if we cannot actually prove 
that they do so. There is a series of closely related species, for instance, grouped round Ceratium macroceros. Ceratium arcticum is the farthest outpost in the direction of the polar sea, and shows the greatest variation. Its three horns are extremely divergent; the centre one, which points forward, is slightly bent, and so also are the other two. Near the southern limit of the species there are more and more instances, in a series of transition forms, where the two posterior horns bend forward, till we get to Ceratium longipes, the characteristic form of the Norwegian Sea and North Sea during the first half

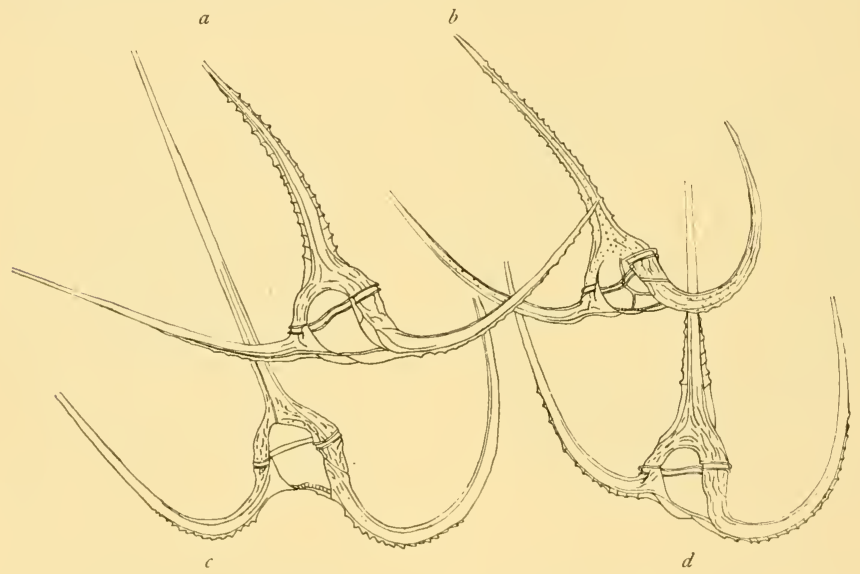

Fig. 246. - SPeCies of CERATIUM Belonging to THE tYPE OF C. MACROCEROS, NORTHERN SPECIES.

a, C. arcticum; b, C. longipes; c, C. macroceros; $d$, C. intermedium (1 $\left.\frac{187}{1}\right)$. (Jörgensen.)

of summer. In this case, the posterior horns are bent quite forward, so that their extremities are parallel with the frontal horn. In the Gulf Stream we get $C$. intermedium, which has a straight frontal horn, like the other members of this type, and all three of its horns are much longer and more slender than those of the two northern species. At the eastern limit, where fresh water from the Baltic and the coasts of North Europe reduces the salinity, and where, too, the high summer temperatures diminish the viscosity of the surface-layers, there is a species with an even better suspension-apparatus, namely $C$. macroceros (see Fig. 246). Its frontal horn is particularly long and thin, and the posterior horns first bend a little backwards, and then 
sweep round to the front, sometimes in a direction parallel to the frontal horn, and sometimes with a moderate amount of divergence. We have already mentioned that $C$. arcticum and $C$. longipes belong to the Tricho-plankton and that $C$. intermedium and $C$. macroceros are Styli-plankton. We have finally a whole series of variations belonging to the tropical Desmoplankton, namely $C$. vultur, C. pavillardii, $C$. trichoceros, and $C$. tenue, which we reproduce from Jörgensen's excellent monograph (see Fig. 247), and many others. They illustrate the different tendencies to variation. In similar fashion there are series of variations which group themselves round the other main types of the genus.

Guiding forms like these are of very great assistance in defining the boundaries of adjacent currents which have a different biological character. But we need to exercise the utmost care in drawing conclusions as to

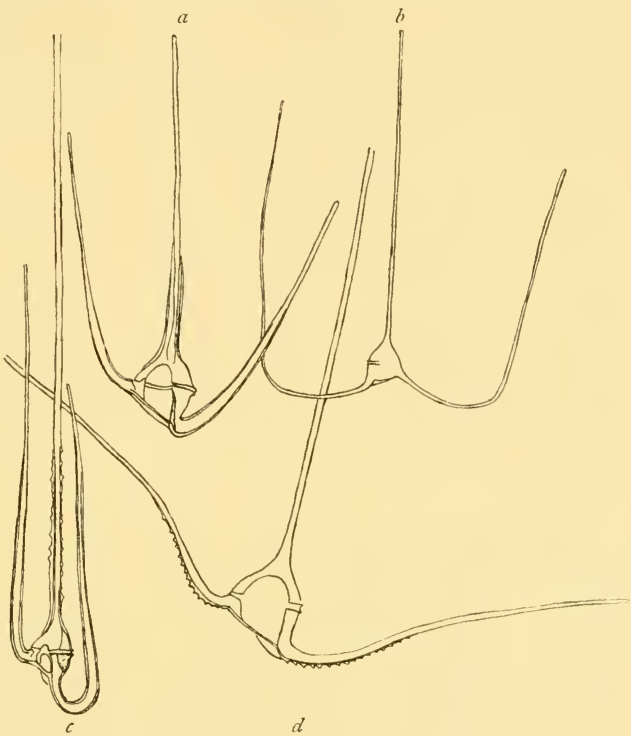

Fig. 247.-Species of CERAtiUn Belonging to the type OF C. MACROCEROS, TROPICAL SPECIES.

$a, C$. pavillardii $\left(\frac{94}{1}\right) ; b, C$. trichoceros $\left(\frac{94}{1}\right) ; c, C$. vultur, var. japonica $\left(\frac{94}{1}\right) ; d, C$. tenue, var. buceros $\left(\frac{210}{1}\right)$. (Jörgensen.) the origin of ocean-currents from the composition of their pelagic flora, and it must not by any means be taken for granted that areas where the same species occur are necessarily united by a continuous stream connection. We have repeatedly made discoveries which go to indicate that most plankton-species of any consequence are to be found scattered about here and there outside their proper domain, so that these stray individuals might easily originate an abundant flora whenever conditions of existence became favourable. 
Cleve, who looked upon the dispersal of organisms by currents as the chief factor in affecting the character of the plankton, was at first of opinion that he could fix the north-western boundaries of the Gulf Stream by noting the distribution of Rhizosolenia styliformis, the guiding form in his Styli-plankton. But he, too, found that its area of distribution extends northwards in the course of spring and summer, and that the swarms of Rhizosolenia actually outdistanced the speed of the current. The wider distribution of the algæ was evidently, therefore, due not alone to the increased volume of the current, but also to a rapid propagation produced by summer warmth outside the influence of the current, the algæ apparently having been already present in this area in small quantities.

Bipolarity of oceanic diatoms.

I may further instance the close agreement between oceanic species in arctic and antarctic waters. Thalassiothrix longissima and Rhizosolenia semispina (hebetata) are the two most characteristic forms among algæ along both the polar boundaries of the Atlantic, though they have also been found in small quantities at various localities in the tropics. I personally came across them on several occasions during the "Michael Sars" Expedition, and it requires, in my opinion, no special theories to account for this "bipolarity." There is quite sufficient connection between the two oceans to enable a few germs which are exceptionally tenacious of life to pass from the one to the other, and this would amply explain the agreement. Characteristically enough there is no similar agreement between arctic and antarctic waters when we come to the neritic forms, and this is probably because they are less adapted to travel over such immense distances. It may be, too, that their tendency to evolve resting-spores is an obstacle to long passive wanderings.

As a means of determining the direction and velocity of currents pelagic algæ will be found of very little use. Their continued existence during the progress of the current must always depend upon their persistence in reproduction, and this again is dependent upon conditions of existence and competition with other species. It is not mere coincidence that the microscopic flora of the warm Atlantic extends farthest north during the dark winter months, when no other species are much inclined to develop, and there is therefore no competition of any consequence, the character of the flora consequently remaining for a long time unaltered. Large animals, such as medusæ and salpæ, or the larvæ of bottom-animals like Phoronis, will be found far better indicators of the currents. Ostenfeld 
has, however, encountered one solitary case where plankton algæ could be employed for this purpose. Biddulphia sinensis (Fig. 248), a neritic diatom from the coasts of the Indian Ocean, was met with in the North Sea for the first time in 1903, to begin with in the southern parts, and then gradually farther and farther north, until at last it was discovered on the west coast of Norway at Bergen. Its travelling rate corresponds to the values which have been otherwise obtained for the velocities of the current along the coasts of Denmark and Norway. Latterly, it has found a fixed distribution-centre in the north-eastern corner of the North Sea, whence it extends still farther northwards every

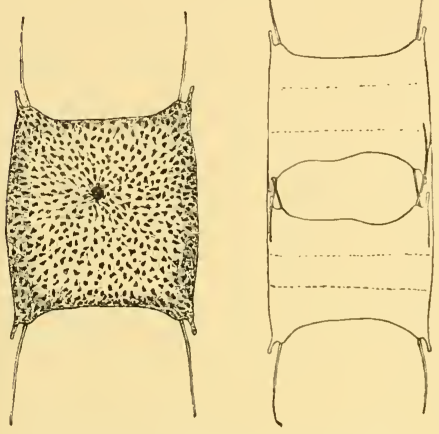

FIG. 248.-BIDDULPHIA SINENSIS $\left(\frac{11}{1}^{\circ}\right)$. (Ostenfeld.) autumn. The velocity of the current could hardly be determined from the observations of these last few years, as there is always the possibility that this diatom has more than one centre of distribution, but its annual wanderings clearly indicate the direction of the current.

A large quantity of plankton algæ has been collected during the "Michael Sars" Expedi- " tion along the whole route, and will contribute valuable information regarding the distribution of the different species. We have been particularly successful in our study of the coccolithophoridx, owing to the improved methods we were able to adopt. I shall deal separately with their distribution in what follows, and at the same time give some particulars of their quantitative occurrence. Part of the material is still incompletely examined. The difficult species of Peridinium in particular, and of a few other genera, will require a separate monograph for their special treatment; we have secured immense numbers of these forms. In other respects our observations practically confirm the views regarding the distribution of species that we owe chiefly to Cleve.

I shall now give a preliminary description of the character of the plankton along our route, founded upon an examination of 
material from representative stations, and upon observations of the living organisms on board ship.

The coast

banks of

North Europe.

(Stations I-IO, 9th-2oth

April.)

All our first stations about the middle of April, with the exception of Stations I and 5, that were close in to land and had a less abundant flora, had an extremely plentiful diatom-plankton, such as we only get in the waters of North Europe during the spring. Our experiments with the closingnet, which, thanks to the fine calm weather, were made with the utmost exactitude at Stations 3 and Io, showed that by far the larger number were to be found between the surface and a depth of 100 metres, though even at a depth of 100 to I 50 metres there were still quite considerable quantities. The character of the flora was mainly northern, especially in the case of the oceanic species. Among the principal forms we got Rhizosolenia hebetata forma semispina and Nitzschia seriata. Neritic diatoms were also numerous, and some had restingspores. They are of a distinctly southern character compared with the species which occur, for instance, along the coasts of the North Sea ; further, they belong to a local flora, which does not seem to have any direct connection with the North Sea. On the whole, these neritic diatoms are so small in their dimensions that they show signs of an "oceanic degeneration."

Besides them, there was an addition of subtropical species, especially in the deeper layers, and especially at the southernmost stations, Nos. 9 and ro, consisting of both diatoms and peridineæ, not in any great quantity, but still occurring regularly. These are the northernmost outposts of the Desmoplankton, including such species as Planktoniella sol, Ceratium gibberum, Dinophysis schiittii, and D. uracantha. ${ }^{1}$

The coast banks of South Europe and North Africa. (Stations 114I, 2 Ist April 22nd May.)

Throughout the stretch of sea along the coasts of South Europe and North Africa our investigations were carried on comparatively close to the coast, and the plankton was generally found to be poor both in quality and quantity as soon as we stood at all far out from the land. It was then composed

${ }^{1}$ As representing this area, I here give a list of species from Station 7, depth 0-20 metres :-

Oceanic diatoms: Chatoceras decipiens, C. densum, C. convolutum, C. peruvianum, C. atlanticum, C. dichata, Coscinodiscus centralis, C. marginatus, Enodia cuneiformis, Thalassiosira subtilis, Asteromphalus heptactis, Rhizosolenia alata, $R$. semispina, $R$. stolterfothii, $R$. shrubsolei, $R$. acuminata, $R$. amputata, Dactyliosolen antarcticus, Nitzschia seriata, Thalassiothrix longissina.

Neritic diatoms: Chatoceras diadema, C. schüttii, C. contortum, C. coronatum, C. scolopendra, Bacteriastrum varians, Eucampia zodiacus, Thalassiothrix nitzschioides, Cerataulina bergonii, Dactyliosolen tenuis, Thalassiosira decipiens, T. excentrica, T. nordenskioldii.

Peridinex: Ceratium tripos forma atlantica, C. lamellicorne forma compressa, C. azoricum, C. furca, C. arietinum, and several others.

Coccolithophoridre: Distephanus speculum, Coccolithophora pelagica. 
of oceanic species, that we subsequently met with in the central parts of the ocean, though there was not more than a mere selection of the very commonest forms. It was here that we first became aware of the immense contrast between the scanty plant life and the teeming animal life. Sir John Murray and I examined the stomach contents of the salpa abounding in the Strait of Gibraltar, and could see that they lived almost entirely on small forms like coccolithophoridæ and tiny peridineæ, which were too diminutive for our silk nets to capture. Radiolaria, however, both Acanthometridæ and colony-forming species, in symbiosis with brown flagellates, were present sometimes in such quantities that their assimilation of carbonic acid played no small part in proportion to that of the scanty plant plankton. Close in to the shore, on the other hand, there was abundance of plankton, and we got quantities of neritic diatoms off Lisbon, in the Strait of Gibraltar, and at several places on the coast of Morocco down to Cape Bojador. Different species predominated in the different samples, but Lauderia annulata was the commonest form everywhere.

No one accustomed to the plankton algæ of northern waters, with their numerous dark-brown chromatophores, could fail to be struck by the fact that the species never had more than a few small chromatophores, and thus had a pale appearance. In the diatoms the strong light frequently had the effect of making the chromatophores group themselves in the centre of the cell, or in Lauderia anmulata at the terminal faces where the cells in the chain touch each other. This was invariably the case in plankton near the surface, though deeper down the position of the chromatophores might be normal. ${ }^{1}$

On this cruise we made acquaintance with the tropical Atlantic plankton in all its abundance. For a northerner it was most fascinating to study the many strange forms, especially of peridinea. Every fresh batch disclosed species that were new or rare, or else remarkable stages of development. The

1 The following list is from a sample pumped up from the surface, off the south coast of Portugal, on 24th April I9ro:-

Diatoms: Lauderia annulata (the prevailing form, found with auxospores), Thalassiosira subtilis, T. gravida, Stephanopyxis turris, Paralia sulcata, Coscinodiscus concinnus, Leptocylindrus danicus, Rhizosolenia alata, $R$. shrubsolei, $R$. styliformis, $R$. stolterfothii, $R$. delicatula, $R$. robusta, Chatoceras densum, C. schiuttii, $C$. didymun, C. curvisetum, C. decipiens, C.lorenzianum, C. diversum, Eucampia zodiacus, Hemiaulus hauckii, Biddulphia mobiliensis, Bacteriastrum varians, Nitzschia seriata.

Peridineæ: Ceratium lineatum, C. macroceros, C. fusus, C. furca, C. candelabrum, species of Peridinium, Gonyaulax spinifera, Diplopsalis lenticula, Dinophysis acuminata, D. rotundata, D. acuta; Coccolithophora pelagica. 
multitude of species was surprising, though none of them was very numerously represented. Every day one might sit and examine some unique microscopical form, which might be lost only too easily, and consequently had to be drawn there and then. And whereas in the north there are large quantities of every species, so that it is easy to investigate them in all their stages of development and variation, this multiplicity of forms in the tropics renders it incomparably harder to find out what stages of development belong to the same species, or how the boundaries between the different species are to be fixed.

The various stations did not differ much from one another, if we except Station 59, near Fayal in the Azores, where there were numbers of neritic diatoms, and Station 66, close to the Newfoundland Bank, where there was an addition of arctic forms. On the whole, the multiplicity of species increased as we went westwards. Possibly considerable differences may be revealed when the material has been completely treated, but all the species occur too sparsely in these samples to justify one in drawing conclusions from negative results. ${ }^{1}$

The Tropical Atlantic flora much resembles the plankton flora of the Indian Ocean observed by Karsten. In the Pacific there would seem, according to Kofoid, to be an even greater multiplicity of species, but I found several of the new species obtained by him during the "Albatross" Expedition, and it is probable that more and more of these rare Pacific species will gradually be found within Atlantic waters also.

In conclusion, it should be stated that, as far as quantity is concerned, the smallest plankton organisms, Lohmann's Nanno-plankton, play a far more important rôle than the whole of the other species caught in our silk nets, which will be subsequently discussed in their proper order.

1 To show the character of the flora I append a list of species found at Station 64 , lat. $34^{\circ}$ $44^{\prime} \mathrm{N}$., long. $47^{\circ} 52^{\prime} \mathrm{W}$., in a closing-net sample from a depth of 200 metres to the surface :Diatoms : Coscinodiscus rex, C. lineatus, Euodia cuneiformis, Planktoniella sol, Gossleriella tropica, Thalassiosira subtilis, Asterolampra marylandica, Rhizosolenia castracanei, R. acuminata, R. styliformis, Bacteriastrum elongatum, Hemiaulus sp., Chatoceras dichata, C. tetrastichon, C. peruvianum, C. coarctatum, C. furca.

Peridineæ: Ceratium pentagonum, C. teres, C. candelabrum, C. gravidum, C. fusus, C. extensum, C. pennatum, C. gibberum, C. buceros, C. platycome, C. azoricum, C. tcnue, C. pavillardi, C. karsteni, C. declinatum, C. gracile, C. arietinum, C. macroceros, C. massiliense, $C$. arcuatum, C. carriense, $C$. reticulatum, $C$. trichoceros, $C$. palmatum, $C$. limulus, $C$. pulchellum, species of Peridinium, Diplopsalis lenticula, Blepharocysta splendor maris, Ceratocory's horrida, Goniodoma polyedricum, G. fimbriatum, Gonyaulax polygramma, G. joliffei, G. pacifica, G. fragilis, G. mitra, Protoceratium reticulatum, Podolampas elegans, P. palmipes, P. bipes, Oxytoxum scolopax, $O$. reticulatum, $O$. cristatum, $O$. milneri, $O$. tesselatum, Dinophysis uracantha, D. schiittii, D. schröderi, Phalacroma argus, $P$. doryphorum, $P$. cuneus, $P$. rudgei, Amphisolenia palmata, and another new species, Ornithocercus quadratus, $O$. magnificus, $O$. steinii, $O$. splendidus, Pyrocystis lunula, P. noctiluca, Hexasterias problematica.

Cyanophycer: Trichodesmium thiebaulti. 
The plankton of the cold water on the Newfoundland Bank The Newwas very poor in species, Ceratium arcticum and Peridinium foundland parallelum being the commonest forms. There were, besides, (Stations 7oa few diatoms, such as Chatoceras atlanticum, C. criophilum, ${ }_{-10 t h}^{79}$ July.) and Rhizosolenia semispina, all well-known species in the Norwegian Sea. In the harbour of St. John's, on the other hand, we found the plankton quite abundant, consisting of northern forms, both neritic and oceanic: the species of Chatoceras (decipiens, debile) predominated.

Our northern section across the Atlantic contributed largely The northern to our knowledge of the distribution of species, since it showed

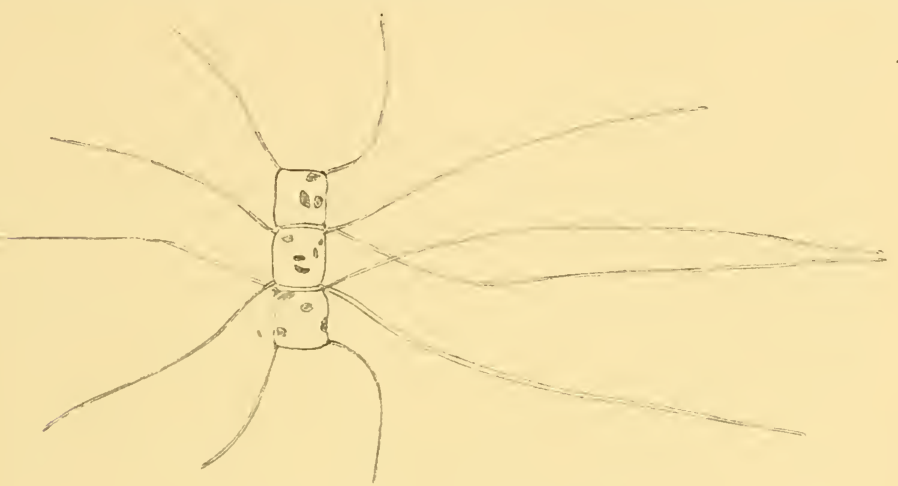
Atlantic section. (Stations $8 \mathrm{I}$ 92 , I2th-24th July.)

FIG. 249. - CHATOCERAS PERPUSILLUM $\left(\frac{600}{1}\right)$.

us that a great many tropical forms are still to be found in lat. $45^{-} 50^{\circ} \mathrm{N}$. These particular waters had been very little studied previously, and it was extremely interesting to follow all this Atlantic flora on its passive journey northwards. On the whole, its character remains unchanged, though of course the number of species becomes considerably reduced. During the first half of the section, on the western side of the mid-Atlantic ridge, there were a few small degenerate neritic diatoms belonging to the species which occur in the Atlantic water-masses south of Iceland: namely Chatoceras schiittii, C. laciniosum, and others. It seems unquestionable that they are derived from the American coast, and follow the current as far as Iceland. At Station 85 I also came across a remarkable little Chatoceras, that Cleve found in 1897 in the Skagerrack and named Chatoceras perpusillum 
(Fig. 249), which had not been met with subsequently. The whole structure of this diatom shows that it, too, is most probably a neritic form, and it must therefore have a wider distribution than was commonly supposed. ${ }^{1}$

As we neared the coast banks of Europe we found the number of species growing distinctly less, though on the other hand the quantity of the plankton increased.

Law of production of organic substance in the sea.

Hensen.

Hensen's net. consisted of extremely fine straining-cloth, with meshes 0.04 to $0.05 \mathrm{~mm}$. in diameter. He made the mouth of his net small in proportion to the filtering silk surface, to ensure as far as possible the immediate filtering of all water that came in through the opening, his object in this being to ascertain approximately how much water was filtered, when the net was drawn through the sea for a calculated distance. Experiments showed that in

1 As illustrating a haul on this section I append a list of the species found in the closing net at Station 8I (lat. $48^{\circ} 2^{\prime} \mathrm{N}$., long. $39^{\circ} 55^{\prime} \mathrm{W}$.), from a depth of 50 metres to the surface :-

Diatoms: Coscinodiscus excentricus, Euodia cuneiformis, Planktoniella sol, Coscinosira astrupi, Thalassiosira subtilis, Corethron criophilum, Rhizosolenia styliformis, $R$. shrubsolei, $R$. fragillima, $R$. alata, R. semispina, Bacteriastrum delicatulum, B. elongatum, Chatoceras atlanticum, C. boreale, C. mediterraneum, C. peruvianum, C. criophilum, C. decipiens, C. contortum, C. schüttii, C. curvisetum, C. laciniosum, C. furcellatum (a resting-spore), Thalassiothrix longissima, T. nitzschioides, Nitzschia seriata.

Peridinez: Ceratium lineatum, C. candelabmem, C. pentagonum, C. gravidum, C. fusus, C. pennatum, C. tripos, C. azoricum, C. gibbenum, C. platycorne, C. arcticum, C. intermedium, C. macroceros, Protoceratium reticulatum, Peridinium oceanicum, $P$. depressum, $P$. divergens, P.conicum, P.ovatum, P. tristylum, and some others, Diplopsalis lenticula, Pyrophacus horologium, Goniodoma polyedricum, Gonyaulax polygramma, Podolampas elegans, P. palmipes, Oxytoxum scolopax, O. diploconus, Ptychodiscus carinatus, Dinophysis acuta, D. schüttii, D. rotundata.

Flagellates: Phaocystis poucheti.

Silicoflagellates : Dictyocha fibula.

Chlorophyceæ: Halosphara viridis.

Cyanophyceæ: Trichodesmium thiebaulti. 
practise his net could not filter the whole of the water which ought to pass through; it was possible, however, to work out a coefficient for each size of net, namely a fraction indicating what proportion of the total quantity of water had actually been filtered. Hensen trusted chiefly to vertical hauls, since he was anxious to know definitely the exact distance through which the net had passed. He lowered his apparatus open, but with a heavy weight attached, so that it went down end-first and therefore caught nothing until hauling in began. Initial investigations aimed at ascertaining the total quantity of plankton in the photic zone, and accordingly the net was drawn in one haul from a depth of 200 metres right up to the surface, or from the bottom to the surface in water shallower than 200 metres, the idea being to find out the quantity of plankton in a column of water of known depth I metre square.

It is not, however, sufficient merely to compare the total quantity of plankton present in different localities; it may be just as important to know what there is at different depths, not only because we have to consider the effect of light, let us say, upon plant production, but because there may be layers of water, such as we find especially in coastal areas, totally distinct in hydrographical characters, and with different conditions of existence. Hensen made vertical hauls from different depths, and had recourse to subtraction when estimating the plankton of the deeper layers, but since that time closing-nets have been introduced, and we are able now to get samples from any layer Petersen's we wish to study. C. G. Joh. Petersen constructed a closingapparatus to go with Hensen's vertical net, and Nansen also designed a vertical closing net which was invariably used by the Nansen's "Michael Sars," and found to be handy and reliable. Provided only the bag be long enough in proportion to the opening, it will act successfully from a quantitative point of view, though we did not employ it much for this purpose, as we had better methods of our own for estimating quantity. Otto Pettersson obtained his estimates of quantity by attaching silk nets to a large current-meter, which recorded the velocity of the current, and thus indirectly supplied approximate figures denoting the amount of water filtered. A series of very interesting determinations, from samples secured in this way, has been described by Broch.

The net-method was found unreliable as time went on. In the first place, it does not fairly represent the total quantity of plankton, since many of the smaller forms pass altogether, or to 
Filtering method.

Lohmann's pump method.

a very great extent, through the meshes; and, secondly, the meshes become gradually clogged with the slimy little algx, or animals, so that the coefficient of filtration does not remain constant. Even during the course of a single haul we occasionally noticed that everything worked well to begin with, but that the cloth became more and more stopped up, until at last filtration ceased entirely. In other words, it is sometimes impossible to tell how much water has been filtered, and consequently the catch is practically valueless from a quantitative point of view.

An endeavour was made to overcome this last difficulty by filtering a quantity of water, previously measured, either through silk nets, or through an even less porous filter-material, such as taffeta, or hardened filter-paper, or sand, an additional advantage being that by this means the very smallest organisms could be retained. Water-samples were secured by water-bottles or by pumps. Lohmann, who did much to perfect the pump-method, was not only able to get his water-samples from any depth desired, but could obtain samples representing a column of water from the surface down to a specified level. The pump was made to work in connection with a long, flexible hose, the mouth of which was lowered as far down as considered necessary, and then drawn gradually up towards the surface as pumping proceeded. The pumped-up water thus represented proportionally the whole distance through which the hose passed before reaching the surface. These samples were afterwards filtered by Lohmann, and the results compared with catches obtained by vertical hauls with the silk nets.

The methods of capture had thus been greatly improved, and it was possible to obtain the smallest organisms, but for practical reasons it was necessary to limit the quantity of water filtered on each occasion. This forced us to turn our attention to the second question, namely the regularity with which Distribution of organisms are distributed in the sea. Fortunately, the pelagic plants extremely regular.

researches of Hensen and his assistants, as well as those of
Lohmann and myself, have all gone to show that the distribution of the pelagic plants, at any rate, is extremely regular. The samples from adjacent localities with similar life-conditions have yielded very concordant results. I do not consider it any exception to this statement that in tropical waters dense masses of Trichodesmium sometimes collect as water-bloom in certain areas and not in others, or that diatoms near the edge of the polar ice occur in more or less local swarms, for I consider it more than probable that these irregularities 
arise because the conditions of existence vary in closely adjoining areas. Lohmann has found that at certain seasons IO to I 5 c.c. of sea-water amply suffice to give a representative sample of the total plankton, but it is evident that only the commonest organisms floating in the sea in any locality do occur so densely and regularly that we can be sure of securing them, or even of catching enough for ascertaining their comparative frequency, in a water-sample consisting of only a few litres of water or less. The more scattered or mobile the individuals are, the larger masses of water must we examine to get a knowledge of the quantity present in any locality.

It follows, therefore, that we must abandon all thought of a universal method. Fine silk nets give us complete collections of the larger Ceratia and diatoms, but are of no use for the smallest species, for which we are obliged to have recourse to more delicate methods of filtration, and to the centrifuge. The larger forms, too, will be found in our silk nets in sufficient quantities, if they are at all abundant, but where they are scarcer than, say, fifty specimens to the litre, the centrifuge cannot be depended on. Besides amongst these larger organisms some species are so scanty that even a vertical haul with the big net yields insufficient material, so we have been compelled to adopt the special methods described in this volume.

Various methods have been employed for estimating the quantity of plankton on the basis of catches made. We can allow the whole sample to sink to the bottom of a measuring glass, and appraise its volume, or we can weigh it while the organisms are saturated with water or spirit, or we can weigh the dry substance. Such determinations of volume and weight give us our first rough idea of the variations in the quantity of plankton, but there are many sources of error which it is unnecessary to discuss here. The worst fault is that measurements of this kind group into a whole the most diverse values, such as plants and animals, producers and consumers, one-celled organisms that are constantly reproducing themselves, and multicellular animals with a longer duration of life, or, again, organisms with slow and others with rapid metabolism. If we want to know a little about the conditions of development of organisms, we must have a method of investigation that allows us to trace the growth and retrogradation of each of the different species by itself, and counting then becomes the only method possible, as Hensen has continually asserted. Counting is a Counting method that requires much time, and also absolute accuracy in

No universal method of estimating quantity of plankton.
Determinations of volume and weight. 
determining the species whose development we desire to trace; consequently most of those who endeavour to work at these interesting questions will be forced to confine themselves to definite problems, and content themselves with tracing the growth of a limited number of species. No doubt a man like Lohmann may be able to know all the species within certain limits, and may actually calculate by counting what each of them contributes to the total plankton volume, but speaking generally a "universal method" that will give us the total quantity of all the plants and animals of the sea in curves and tables is unattainable.

Quantitative investigations on board the "Michael Sars."

During the "Michael Sars" Expedition our quantitative investigations yielded really remarkable results. Lohmann had succeeded by means of a centrifuge in determining the quantity of plankton in quite small samples of Baltic water, and we felt confident, therefore, that this excellent method ought also to prove serviceable in the

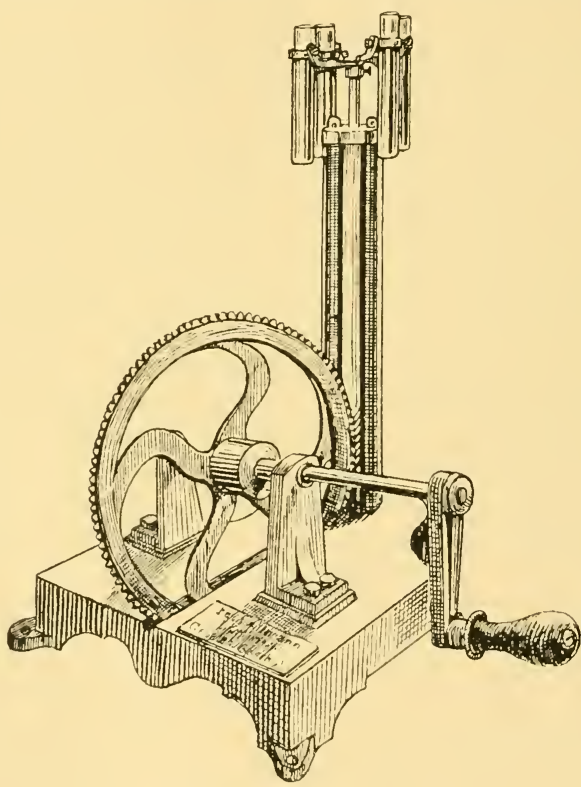

Fig. 250.-Lohmann's HAND-CEnTRIfUge.

open sea. We very soon found, however, that the algæ there Centrifuge. were too scarce for our little hand-centrifuge (Fig. 250) to be of much utility; there was so little to be found at the bottom of the centrifuge glasses (Fig. 251) that we obtained a hopelessly inadequate idea of the plant life, whereas in the stomachs of salpæ we might, perhaps, get a quite abundant flora of small forms. Fortunately, we had taken with us a big centrifuge to be worked by steam (see Fig. 9I, p. I05), and in its six glasses we could centrifuge at one time as much 
as I 200 c.c. of sea-water. It made 700 to 800 revolutions per minute, and after eight minutes the plants were all collected at the bottom of the glasses. Our next proceeding was to pour away the clear water, and after rinsing the deposit, to put it in a smaller glass with a tapering

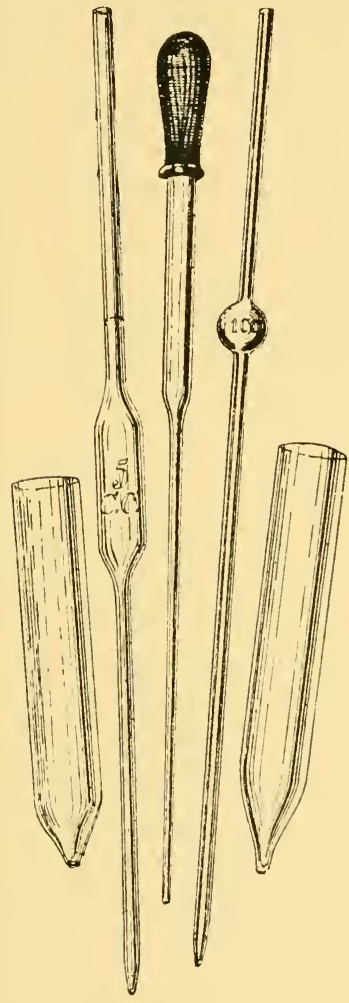

Fig. 25i. - Centrifuge Glasses AND PIPETTES FOR USE WITH LOHMANN'S HAND-CENTRIFUGE. bottom, where it was subjected to the action of a small hand-centrifuge. In this way we collected all the contents of, say, 300 c.c. of sea-water in one drop, which we examined in a counting chamber beneath the microscope, and noted carefully each single organism. As a rule we had to centrifuge the whole 300 c.c., but, if the plankton was very abundant, I 50 c.c. or even IOO c.c. might suffice. Examination with the microscope is always more difficult when the organisms in the counting chamber lie close together.

These investigations were carried Smallest out all the way from the Canaries to organisms the Newfoundland, and thence to the in the open Irish coast banks, and resulted in our discovering that the smallest organisms which pass right through the silk nets are far more abundant than the others in the open sea, while the larger diatoms and peridineæ would appear to be so scanty that the total of all their species together only amounts to about ten per litre. Despite this fact, however, we found in the samples taken with our nets that there were at least fifty species of these larger forms at every station, so that as far as species go the flora is exceedingly rich.

We were also able in this way to determine the occurrence Amount of of algæ at different depths. Samples from the surface, and plant life at from $20,50,75$, and 100 metres were taken regularly, and different we also examined samples now and then from still greater depths. We found, invariably, however, that the plant life 
below roo metres was extremely scanty. The maximum in the ocean nearly always lay at about 50 metres, which is what Lohmann also found in the case of the Mediterranean coccolithophorida. At the surface there was less than down in the 20 to 50 metres zone, though the plankton nearly always approached its maximum value as soon as we reached a depth of 10 to 20 metres. At 75 metres the quantity diminished to about half of that found at 50 metres, and at Ioo metres it had dwindled to at most a fifth. These were the values on our southern section. On the northern crossing the quantity of plankton fell away even more rapidly as we went deeper down ; at Station 92, where there was a slight admixture of coastwater near the surface, and the lighter surface layer was separated from the pure Atlantic water somewhere between 25 and 40 metres, there were upwards of 250,000 plant cells per litre in the surface layer; whereas at 50 metres the plankton was less abundant than at any of our previous stations, and only amounted to 22 I 3 cells per litre.

Schimper's observations in the Antarctic.

Number of individual plant-cells at 50 and 75 metres at Station 64 .
These results quite bear out the most valuable investigations so far made regarding the vertical distribution of algx in the ocean, namely Schimper's observations in the Antarctic during the "Valdivia" Expedition. He found that the entire production was practically limited to the uppermost 200 metres, that the bulk was to be found above roo metres, and that the maximum lay between 20 and 80 metres, or to be more precise, between 40 and 60 metres. We were able to confirm this, after comparing the volume of the samples taken with nets on those few occasions when there was a sufficiently large quantity of plankton at our stations to make such volume-measurements of any real value. There was, however, a different vertical distribution everywhere along the coasts where diatoms abounded, for then the exuberant plant production was limited to the surface layer, which was mixed with fresh water from the land.

As illustrating our investigations at a station in the warmest part of the Atlantic, I give particulars of what I found at Station 64 (lat. $34^{\circ} 44^{\prime}$ N., long. $47^{\circ} 52^{\prime}$ W.) in water-samples from 50 metres ( 150 c.c.) and 75 metres ( 300 c.c.). The figures denote the number of individuals per litre. 
Coccolithophoridæ :-

Pontosphera huxleyi, Lohm.

Cells per litre.

Syracosphara echinata, n.sp.

spinosa, Lohm. . . . $\quad$ I 93

,

ampulla, n.sp.

$50 \mathrm{~m}$.

$75 \mathrm{~m}$.

,

lavis, n.sp.

93

blastula, nop.

I 73

287

123

93

33

$+7$

40

"

blastula, n.sp.

...

83

"

pulchra, Lohm.

160

3

"robusta, Lohm. . . . 80

Calyptrosphara oblonga, Lohm. . . 593

Coccolithophora leptopora, Murr. and Blackm.

, pelagica, Wallich

100

, zeallichii, Lohm.

67

370

7

, lineata, n.sp.

$\cdots$

Rhabdosphara styliger, Lohm.

...

Discosphara tubifer, Murr. and Blackm. .

Scyphosphara apsteini, Lohm.

‥ 23

Calciosolenia murrayi, n.sp.

Ophiaster formosus, n.sp.

$\ldots$

Undetermined coccolithophoridæe $^{\mathrm{I}}$. . $\quad 887$

Total coccolith

Pterosperma disculus, n.sp.

$\overline{3007}$

\section{Pterosperma
Pterosperm
Peridineæ :-}

Protodinium.

$\cdots$

20

Amphidinium gracile

I 853

1007

Oxytoxum scolopax.

Dinophysis, sp.

$$
\text { hjorti, n.sp. }
$$

Exuvialla, sp.

Other peridineæ

Total peridineæ

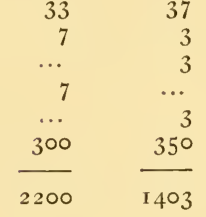

Diatoms :-

Nitzschia seriata

" sp. . . . . . . . . $\quad 7$

Rhizosolenia calcar avis . . . . $\quad$ I4

Thalassiothrix frauenfeldi

Silicoflagellates :-

Dictyocha fibula

Other plant-cells

Total plant-cells

\begin{tabular}{rr}
3 \\
7 & 33 \\
4 & 43 \\
& 7 \\
3 & 93 \\
7 & 377 \\
\hline 8 & 3708
\end{tabular}

I have previously given a list from this station of the species found in a vertical haul with the silk net. The number of

1 Mainly young stages, which could not be determined with certainty; to a great extent they belong no doubt to Coccolithophora leptopora. 
Plankton less abundant in the open sea than in coastal waters.

Plankton less abundant in tropical than in temperate seas.

Van 't Hoff. Metabolism more rapid in warm water than in cold water. species is very considerable, yet the total quantity of individuals is surprisingly small compared with what we might find, for instance, off the coasts of Europe. In the Skagerrack one often gets plant-cells in tens of thousands or even hundreds of thousands in every litre of sea-water from the upper layer, and, what is more, they are much larger and more nutritive than the stunted forms which make up the bulk of this ocean plankton.

It cannot be denied that our investigations are as yet too incomplete to justify us in framing laws for plant production in the ocean. Still the great expeditions which have made researches in the open sea have given us a general conception of the conditions prevailing over wide stretches of water at certain seasons; on the other hand, careful investigations of the variations in the plankton throughout the year have been carried out at a number of coast stations, while our international researches have resulted in a great deal of material being collected at all seasons from the North Sea and adjoining areas. Though these investigations have not all been devoted to studying quantity, they have nevertheless enabled us to form some idea of the annual variations.

One thing at any rate we may learn even from this incomplete material. The development of the plankton is much more irregular than it would be if merely such simple factors as warmth and light controlled production. It is not in the warmest waters that the greatest amount of organic substance is to be found. On the contrary we get larger masses of plants in temperate seas than we have ever yet come across in tropical or subtropical areas, ${ }^{1}$ at any rate so far as the open ocean is concerned. Even when we come as far north as the coast of Norway we find that it is not in the hottest months of summer that the plankton attains its maximum, but in the early part of the spring or the end of autumn. Now it is certainly true that the quantity of vegetable matter present at any given moment is no direct measure of production. According to the law of Van 't Hoff, metabolism always takes place quicker ceteris paribus at a high temperature than at a low temperature, and a plant-cell in the tropics may perhaps produce more organic matter than a similar cell would do in the North Sea in the same space of time. The small tropical plants may

1 The "Challenger" met with diatoms in the Arafura Sea in as great abundance as in the Antarctic regions, but neritic in character (see lists of species in Summary of Results, Chall. Exp., pp. 515 and 733). 
pass more rapidly through their life-cycle, and their numbers may be more drawn upon by the abundant animal life; consequently considerable additions to their apparent total may be necessary, if we wish to estimate properly the importance of plant life in the tropics, as compared with that in higher latitudes. We must remember, moreover, when dealing with observations made in coastal waters all the year round, that the different species have a natural periodicity that may be connected with unknown internal factors in their cycle of life, as well as with the influence of currents which at one time carry the surface-layers away from the coast and at another time towards it. All the same there are many irregularities which cannot be explained as being solely the result of the actual physical conditions of existence. Besides light and warmth we might perhaps be apt to think of salinity, which, in the course of its variations, influences both the density and the osmotic tension of the sea-water. Though we are aware that a low or greatly varying salinity is injurious to many pelagic organisms, there are others which thrive remarkably well and multiply exceedingly under such conditions, as for instance the diatom Skeletonema costatum and the peridinean Ceratium tripos forma subsalsa. Results, in fact, are often the reverse of what one might expect. The flora of brackish-water bays, which is poor in species, may develop into even greater masses than we find synchronously in the open sea, where no osmotic changes have disturbed the vital activity of the numerous species belonging to the community of oceanic algx.

We cannot get away from the view, which was first con- Brandt. fidently put forward by Brandt, that certain indispensable nutritive substances occur so sparsely that, according to Liebig's Liebig's minimum law, they act as factors which limit production. Liebig found that the growth of plants on land depends on the amount of the requisite nutritive substances present, the determining substance being the one of which at any moment there is least in proportion to the needs of the plant. As long as a particular nutritive substance occurs "in minimum," plant production will be proportionate to the available quantities of it, even though there be a superabundance of all other essentials.

If this law is made to include all necessary conditions of life, it will be found to apply universally to all organisms both on land and in the sea, in which case that condition of existence, whether it be physical or chemical, which occurs " in minimum," will be the factor of limitation. We must remember, however, that produc- 
tion at a given moment need not necessarily be proportionate to the conditions of existence prevailing. There may be aftereffects of a previous set of conditions. Indeed it is possible to point to places totally destitute of vegetation, owing to former unfavourable circumstances having destroyed all germs, while new germs have not yet found their way there. Still this is the only reservation we need to make, when asserting the universality of this natural law.

The necessary nutritive substances which are most likely to occur "in minimum" in the sea are nitrogen, phosphoric acid, and, in the case of diatoms, silicic acid; all others occur even to superfluity. Brandt in his works on metabolism in the sea discusses at some length the importance of nitrogen, phosphoric acid, and silicic acid, and his assistants at Kiel have carried out a number of tests to ascertain the extent to which these substances are present in sea-water. Not only the nitrogenous compounds (organic compounds, ammonia, and nitrates), but also phosphoric acid and silicic acid, occur in extremely minute quantities, so that it is particularly difficult to get accurate values representing them. We have therefore, unfortunately, no proper conception as yet of the way in which these substances vary in different parts of the sea. According to Raben's latest investigations the total quantity of combined nitrogen (ammonia, nitrates, and nitrites) in true North Sea water varies between $0.110 \mathrm{mg}$. and $0.314 \mathrm{mg}$. per litre, of which 0.047 to $0.124 \mathrm{mg}$. is saline ammonia, the whole being reckoned as free nitrogen. Even if we assume that the quantity of nitrogen in the Atlantic is considerably less, these values are high compared with the quantity of nitrogen to be found combined in the cells of the plankton-algæ. It seems, therefore, hardly possible that the nitrogenous compounds are entirely consumed by the algæ. It is, however, quite conceivable that the variations in the total quantity of nitrogen, or in the quality of such compounds as are easiest to absorb, may hasten or retard the augmentation of the algx. The same is the case with silicic acid, which Raben found to vary between $0.30 \mathrm{mg}$. and $1.03 \mathrm{mg}$. per litre in thirty samples from the North Sea. The quantity of phosphoric acid, according to Raben's investigations, is as a rule below I mg. per litre, though it slightly exceeds the quantity of nitrogen.

Brandt starts by discussing the occurrence of nitrogenous compounds in the sea. He calculates that large quantities of combined nitrogen are carried out from the land by the 
rivers, as organic nitrogenous compounds, ammoniacal salts, and nitrates. The result would be a constant increase, until at last the sea became poisoned, were it not that it is continually being absorbed by living organisms, or else being restored in some form or other to the atmosphere. We now know that there is very little combined nitrogen in the sea, so that it must evidently be used up as fast as it arrives. The consumers of nitrogen are first and foremost the seaweeds growing along the coasts, and the floating algæ of the open sea, but besides them there are also bacteria, which exist in all sea-water, as shown by Fischer. Their competition with the algæ for the nitro- Fischer. genous compounds is not of any great consequence, so long as they do not interfere with the circulation of nitrogen otherwise than by disintegrating organic compounds so as to form ammonia, or by binding ammonia and nitrates in their cells as albumen.

From the bacteria-life of the soil, however, we are acquainted with another kind of nitrogenous metamorphosis produced by Nitrifying and denitrifying bacteria. There are nitrifying species which oxidise ammonia into nitrites and nitrates, without requiring organic substance to enable them to live; there are further whole series of other species which can reduce nitrites and nitrates, and give off nitrogen in a free state. Their action drives out of the natural circulation larger or smaller quantities of this valuable nutritive substance, scarce enough already, which all plants generally utilise to the uttermost. How great the loss is, as compared with the metamorphosis in other respects, and under what conditions it takes place, are questions that require our most careful attention before considering anything else.

Baur, and others after him, succeeded in finding several Baur. kinds of these denitrifying bacteria in the sea, where they appeared to be widely distributed. It was found, too, that they produced free nitrogen with greater rapidity when the temperature was high $\left(20^{\circ}\right.$ to $30^{\circ} \mathrm{C}$.) than when it was low. Brandt, accordingly, put forward the hypothesis, that to the activity of these bacteria is due the fact that the abundance of plant life does not increase as we approach the tropics, but on the contrary very often decreases. This theory has now for some years been considered the only explanation of the irregular distribution of the plankton, but recent researches have shown that it is untenable.

The denitrifying bacteria require organic substance for their existence. If they are to give off free nitrogen, they must have 
nitrates or nitrites, though denitrification is as little a vital necessity for them as alcoholic fermentation is for the fermentation fungi. Feeding them with sugar and ammoniacal salts will result in their multiplying to an unlimited number of generations, without exhibiting their power of denitrification. They can attack nitrates whenever met with, utilise their oxygen, and give off nitrogen, but denitrification is not of any particular importance, provided the bacteria find sufficient free oxygen in their surroundings. It is only when this fails that they attack nitrates to any great extent. Given the requisite quantity of oxygen they will enter the regular circulation, and no nitrogen worth mentioning will be produced even where denitrifying bacteria are living and multiplying.

This is the case at any rate in the soil, where denitrification is of no importance, unless nitrates are brought into contact with considerable quantities of easily disintegrated organic substance. In the sea the quantity of organic substance is generally so small that a cubic centimetre of salt-water from the open sea rarely contains more than 50 to 100 living bacteria cells, while the nitrogenous compounds occur for the most part as ammonia or inorganic compounds, and not as nitrates or nitrites. It is more than likely that nitrates are not formed to any great extent in sea-water. Nitrifying bacteria are met with occasionally in the mud along the coasts, but they have not been proved to exist in the open sea ; in any case they have not the same importance there that they possess on land, where numbers of them are present in every single gram of cultivated earth. So it is probable that the small quantities of nitrates and nitrites in the sea-water are brought either from the land, or in a minor degree from the atmosphere as the result of electrical discharges. Most of the combined nitrogen of the sea occurs as organic compounds or as saline ammonia, neither of which can be reduced by denitrification. Supposing then that denitrification does play any noticeable part, it will only be in more or less enclosed bays and fjords, where there is a comparatively large amount of organic substance, a plentiful supply of nitrates from land, and so little circulation that there may be a lack of oxygen. In the open sea it is negligible.

Nathansohn. We must look for other conditions to explain the apparent irregularities in the distribution of the plankton. Nathansohn was the first to notice that vertical currents are bound to exercise considerable influence. If it be true that one or 
several of the necessary nutritive substances may be present in such small quantities as to act as factors that limit the development of the vegetation, then the more or less considerable exchange taking place between the illumined surface-layers and the vast water-masses of the deep is certain to produce a great effect. All the forms of animal life inhabiting the sea below 200 metres live solely upon organic substances which are due to plants in the surface layers; that is to say, they either feed directly upon the plant-cells which sink downwards, or upon the inanimate remains or excrements of the animals living up above, or else upon other animals which, in their younger stages, have inhabited the surface-layers and fed on the plants they found there. A large proportion of the produce of the surface-layers must thus be continually descending into the deep sea, and these nutritive substances are therefore withdrawn from their regular circulation in the photic zone. Down in deep water, no doubt, the destructive metabolism of animals will set free these nutritive substances, so that eventually carbonic acid and ammonia will be produced; still these gases can only regain the photic zone by very slow degrees if diffusion is their sole means of conveyance. If, however, whole masses of water are brought up from the deep sea to the surface, the nutritive substances contained in them will once more enter into circulation, and cause an abundant plant life to develop. Nathansohn has pointed out that marine areas where such ascending currents occur, and where the surfacelayers are replaced by water from the deeper layers, are well known to be extremely prolific, not merely in plankton, but also in larger organisms. In anticyclonic systems like that of the Sargasso Sea, on the other hand, where, conformably to the laws of ocean-currents, the water-masses cannot ascend from the deep sea, but where the surface-layers sink downwards, the plankton is much less plentiful than in any other similar area where investigations have been made. Our researches in the Atlantic during the summer of 19 Io have done a great deal to settle this question. I shall first of all, however, refer to a series of investigations which bring quite another light to bear upon the question, and show what difficulties we have to face.

In 1907 Professor Nathansohn and I commenced to study the Christiania fjord, and subsequently I continued these investigations alone. My previous observations had taught me that the pelagic algæ in this fjord attain their maximum between

Ascending currents. 
March and May, and that they occur in rather smaller quantities from June to August. From September to October there is again a maximum, but from then onwards they decrease rapidly and reach their minimum between December and January. It is not surprising that the plankton is scanty during the dark period of the year, but the unmistakable secondary minimum in the summer months must be due to some special cause, which it should be possible to discover by studying carefully the whole year round the variations in quantity and the fluctuations in the outward conditions of existence. It struck me that the factors at work might be analogous to those which cause the differences in production met with in different regions of the great oceans.

Method of estimating the quantity of plankton.

To ascertain the quantity of plankton present we employed the method introduced by Sedgwick and Rafter for drinkingwater tests in North America, which has been described by Whipple. A litre of water is filtered through a fine grade of sand, and the algæ that collect on its surface are rinsed off. To the rinsed-off water containing the algæ, filtered water is added until the whole comes to exactly io c.c. We then transfer I c.c. of this with a pipette to a counting-chamber $5 \mathrm{~cm}$. long, $2 \mathrm{~cm}$. broad, and I $\mathrm{mm}$. high, which exactly holds it. For examination we use a microscope which magnifies to 40 or 50 times the natural size. A thorough knowledge of the species is requisite to enable us to enumerate them correctly. When counting species represented by many individuals we require a micrometer, with a larger or smaller number of millimetre squares marked off by lines, placed in the eyepiece of the microscope.

We soon found that our task was more difficult than we had at first imagined. The quantity of plankton fluctuated greatly in the course of short periods of time, yet the variations could not be ascribed directly to conditions of existence, since these remained fairly constant. The temperature in the surfacelayers rose steadily during March to May from $\mathrm{I} .5^{\circ} \mathrm{C}$. to $6.3^{\circ} \mathrm{C}$., the quantity of chlorine was about $\mathrm{I} 6$ per thousand, and according to Nathansohn the quantity of free ammonia in filtered samples of sea-water was between 0.0I75 $\mathrm{mg}$. and 0.03 I mg. per litre, and of ammonia in organic combined form between 0. I05 $\mathrm{mg}$. and $0.217 \mathrm{mg}$. per litre. Of nitrates and nitrites he only found infinitesimal quantities up to $0.009 \mathrm{mg}$., set down as ammonia. Chatoceras constrictum, one of the commonest diatoms in the spring plankton of the Christiania fjord, furnished the following 
figures, denoting the number of living cells in every litre of surface-water near Dröbak :-

\begin{tabular}{|c|c|c|c|c|c|c|c|c|c|c|}
\hline 1907. & $27 / \mathrm{HI}$. & '30/111. & $2 / \mathrm{N}$ & $9 / \mathrm{rv}$ & I5/1v. & $20 / \mathrm{IV}$. & $4 / x$ & $6 / v$ & I/VI. & I9/VI. \\
\hline $\begin{array}{l}\text { Chatoceras } \\
\text { constrictum }\end{array}$ & $20,8_{5} \mathrm{O}$ & 45,850 & $12,75^{\circ}$ & 59,730 & 760 & 44,425 & 192,500 & 95,480 & I 280 & 0 \\
\hline
\end{tabular}

A quite satisfactory explanation presented itself, however, for the variations turned out to be closely connected with the direction of the winds and currents. The outflowing current in the surface-layers might reduce the quantity of plankton to a mere fraction of the normal amount in the course of a day or two, while the inflowing current might perhaps double the quantity in a few hours. The current exerts so great an influence because the abundant plant life is limited to a thin surface-layer which is sharply differentiated both in salinity and temperature from the water-masses below. On 28th March I907, for instance, the temperature from the surface down to 20 metres was $2.6^{\circ}-3.6^{\circ} \mathrm{C}$, and the quantity of chlorine worked out at I6.74-I7.62 per thousand; from 40 metres down to the bottom at 80 metres the temperature was $6.2^{\circ} \mathrm{C}$., and the quantity of chlorine was I 8.73 per thousand. The outflowing current carries the surface-layers with their algæ out of the fjord, and the infertile deep water may be sucked up to perhaps 5 metres below the surface. The inflowing current, on the other hand, heaps up the fertile surface-waters. We found, on examining the plankton at different depths, that the bulk of the plants was limited to a very thin surface layer, say 5 metres in depth, after the current had set outwards, whereas subsequent to the inflow of the current they were as abundant down to 30 or 35 metres as at the surface.

At a place like this it was difficult to trace any regular connection between the local conditions of existence and the development of plankton-algr, in view of the fact that currents caused variations of even greater extent than those actually due to conditions of existence. We had therefore to conduct our investigations on other lines. Supposing it were possible to determine the rate of growth of the alga we should get a better measure of production, and probably also of the influence due to vital conditions, than variations in the total amount could give us. The number of individuals at any given moment depends not merely upon the rate at which production has 
taken place, but also upon how many have perished or been carried away; and the causes bringing about diminution, which we may perhaps term factors of loss, may vary without being in any way directly connected with the conditions of existence of the plankton. There is one genus, at any rate, whose rate of augmentation can be approximately determined. The species of Ceratium only divide their cells at night, so that if we make our investigations early in the morning we can tell which cells have been divided during the night and which remain entire. In a sample of surface-water on I oth September I 907 we found 300 whole cells and $16 \mathrm{r}$ half cells of Ceratium tripos, the latter consisting of 79 anterior parts and 82 posterior parts. The number of cells, then, had in twenty-four hours increased from $300+\frac{\mathrm{I} 6 \mathrm{I}}{2}=380.5$ on 9 th September to $300+16 \mathrm{I}=46 \mathrm{I}$ on $\mathrm{I}$ oth September. The addition is accordingly $\frac{\mathrm{I} 6 \mathrm{I}}{2}=80.5$ individuals, and the percentage of the total amount on 9 th September works out at $\frac{100 \times 80.5}{380.5}=21.2$ per cent.

This was the plan we adopted for calculating the augmentation of the species of Ceratium at Dröbak during the whole of their vegetation period in 1907 , and we also recorded the average number per litre at different depths during the whole year. ${ }^{1}$ The following tables show our chief results :-

1 Similar investigations in the case of Ceratium tripos were carefully carried out during 1908-1909 by Apstein in the Baltic. The values he obtained for percentages of augmentation on the whole accord as nearly with mine as might be expected. 


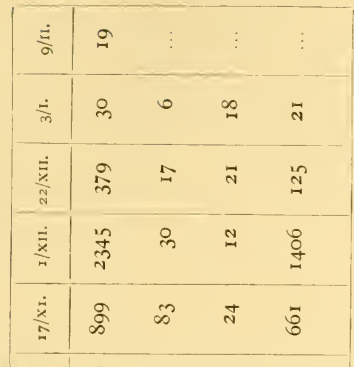

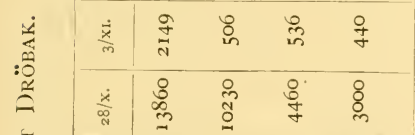

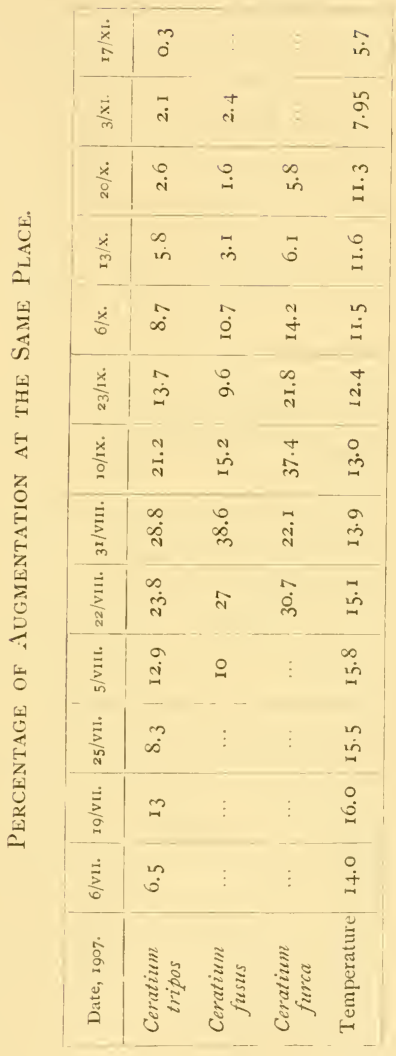

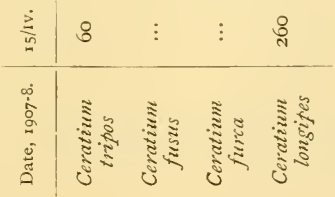


The figures in the tables clearly indicate that, though the rate of increase is highest in August, the number of cells of Ceratium in the fjord makes no great advance before October. Throughout the whole summer the number continues at about the same level, in spite of a comparatively rapid production. This affords a further indication that in the Christiania fjord variations in the current and other factors of loss exert a greater influence than the variations in the conditions of existence which affect rate of increase.

The fact that we find in the Christiania fjord, and assuredly also in many other places along the coasts of North Europe, that the plankton is less abundant in the summer months than in spring, does not necessarily imply any unfavourable change in the conditions of existence due to summer. It may be caused by the melting of the snow in spring, and by the river water all through the summer driving the surface-water and its plantlife away from the coast, so that the production near land barely replaces the loss. In the autumn it would seem as if the prevalent sea-winds heap the surface-layers together along the coast, and thereby accumulate large quantities of plankton.

What effect these movements of the surface-water have upon the occurrence of the plankton we are as yet unable to say definitely, but they must be taken into consideration. We were obliged, therefore, to abandon our original intention, which was to ascertain the importance of such conditions of existence as dissolved nutritive substances, and particularly nitrogenous compounds.

Cultivation experiments.

I made a series of cultivation experiments, however, under conditions of existence resembling the natural conditions as nearly as possible. Stoppered glass bottles holding two and a half litres were kept just floating at the surface, by being filled with about two litres of sea-water; the amount of plankton present was carefully checked in advance, and then one bottle was left in its original state, while in the other two small quantities of chloride of ammonium or calcium nitrate were placed. After an interval of 3 or 4 days the plankton in all the bottles was once more examined, and it was generally found that most of the species had augmented best when nitrogenous nutriment had been added. The addition had naturally to be made with the utmost care, since anything over $0.5 \mathrm{mg}$. per litre generally had a poisonous effect. The following table shows the result of one of these experiments :- 
Number of Cells per Litre.

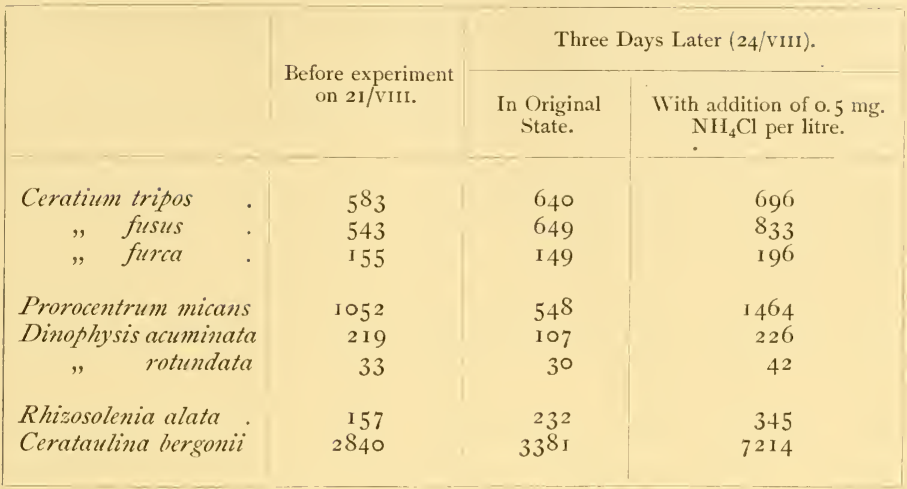

Experiments with pure cultures of different plankton- Allen and diatoms, made by Allen and Nelson at Plymouth, show that they do not thrive without a regular supply of nitrogenous compounds. The plan of working which they adopted may also be employed with advantage when we wish to ascertain what concentration of dissolved nitrogenous compounds induces the plankton-algæ to augment most rapidly. This is the first thing to find out if we desire to know whether a want of dissolved nutritive substances is the limiting factor of production. It is quite possible that augmentation diminishes from lack of nitrogen long before the total amount of this essential has been fully consumed; yet augmentation must not fall below a certain minimum if the species is to hold its own, because of the larger or smaller number of individuals that are constantly perishing. Questions like these can only be settled by experiment, so that the cultivation method of Allen and Nelson is bound to be of great assistance to us eventually. But in the meantime our comparative investigations over large areas of the sea are also of considerable value.

I have already stated that plant life in the Christiania fjord Plankton was limited to a very thin surface-layer, which, owing to its lesser density, was differentiated from the deeper infertile water-masses, and this was practically the case along all the coasts where plankton-algx were plentiful. Out in the open sea, on the other hand, where there are not such extends deeper, but marked differences in salinity, temperature, and density be- 
tween the surface water and the deep water, the pelagic algæ extended deeper; at 50 metres, for instance, the quantity was still near the maximum, and even as deep as 100 metres or more the number was considerable. This, at any rate, was what we found in the case of the diatoms that abounded at our first stations off the Irish coast-banks and in the Bay of Biscay, and this too was what Schimper discovered in the Antarctic. It is also a regular rule that plankton is far more plentiful along the coasts than in the open sea, and, judging from investigations hitherto made, the proportion between what is produced in a typical coastal area and what is developed in typical oceanic water-masses would be more accurately expressed by $100:$ I than by $2: \mathrm{I}$. For this the best explanation which I can give is that the open sea generally suffers from a want of one or more nutritive substances required by the plants, for though these are brought down to the sea in comparatively large quantities by the rivers, they are almost entirely consumed by the plant life of the coastal areas.

This is why the abundant plant life of the coastal seas is confined to the surface-layers, since the water-masses lying below remain separated, and consequently cut off from the plentiful supply of nutritive substances which regulate the augmentation of plants. But out in the open sea there is another important source of nutriment to be taken into account. Nathansohn has pointed out that pelagic animals are constantly taking nutritive matter down into deep water, and that for the time being it is accordingly withdrawn from the plants, even though the metabolism of the animals and the action of bacteria liberate it once more in inorganic form. These nutritive substances may rise to the surface-layers again by diffusion, but the process will require a long time. They may also accompany the ascending water-masses where off-shore winds bring about up-welling, in cyclonic current systems, and where the surface-layers, becoming chilled, sink and make room for warmer layers from below. Wherever vertical circulation takes place, and it is assisted in its action by storms and waves, the temperature and salinity will be extremely uniform from the surface down to a depth where the watermasses have such a high salinity that their greater density sets a limit to circulation. Conversely uniformity in temperature and salinity may be taken as a sign that vertical circulation has just taken place. This was the condition of affairs at our stations to the south-west of Ireland (see Fig. 252), where we 
found abundance of plankton in April ı 9 Io, algæ being present in large quantities as deep down as they have been known to occur, that is to say as far down as sufficient light penetrates. We can appreciate the difference between these conditions and the conditions in coastal areas like the Christiania fjord, if we remember that the nutritive substances in the first case may rise up from the deep water, while in the second they are derived from the surface through the admixture of fresh water.

Vertical circulation is regulated by differences in temperature at the surface, due to summer and winter, which are sufficient to in-

crease the density of the upper layers till it equals the density lower down, and if circulation is to have any effect in the open sea, the surface-layers must be able to sink to a depth of at least 200 to 300 metres. The greater the difference in temperature between summer and winter, the more effective will vertical circulation generally be.

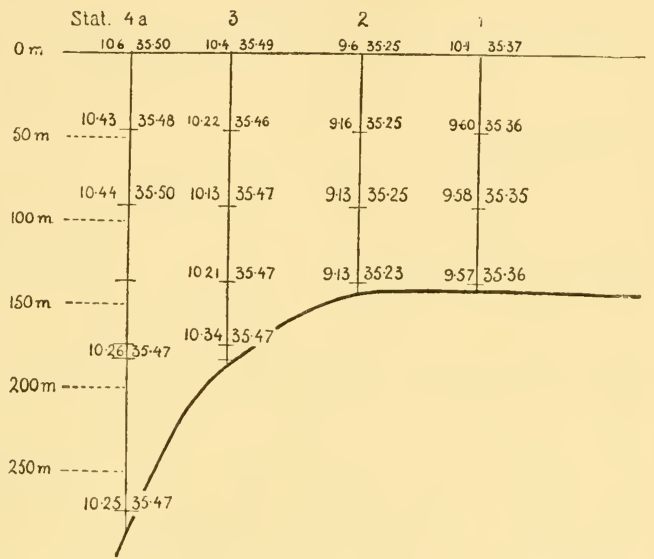

Assuming, then, that our view is correct, namely that plant production in the sea is mainly regulated by the amount of dissolved nutritive substances, we must expect to find plankton produced in abundance in coastal areas to which large rivers convey nourishment from the land, and in oceanic areas where vertical circulation takes place on a large scale, or where ascending currents bring up the deeper water-masses. Where vertical circulation is the controlling influence, the greatest profusion will be at seasons when the temperature of the surface reaches its minimum; that is to say, generally in winter, or in higher latitudes in the early months of spring. It would be possible to test the truth of this theory if we could 
carry out systematic quantitative plankton investigations all through the winter, in combination with hydrographical researches, in parts of the Atlantic like the sea round the Azores, where the plankton is known to be scanty during the summer, but where during the course of winter vertical circulation might be expected to create different conditions of existence.

Whipple.

In this connection it should be mentioned that the influence of vertical circulation upon the production of plankton-algæ in fresh water has long been known to biologists. It has been pointed out by Whipple, who showed that the maxima of diatoms in particular coincide with the seasons when vertical circulation takes place, namely autumn and spring. And in the sea, too, it seems that diatoms, with their power of rapid augmentation, are the first to respond to improved conditions of nourishment.

Which of the essential nutritive substances are the chief limiting factors in the sea, it is impossible to say as yet. Probably, however, nitrogen is the most important, and next to it, perhaps, more especially in the case of diatoms, we may put silicic acid. Brandt and Nathansohn have both discussed the occurrence of these substances, but we need further and more conclusive information than what we now possess. Nathansohn has likewise considered the possibility of carbonic acid occurring "in minimum." This seems paradoxical, of course, since there are comparatively large quantities of it in sea-water. Still the greater part is combined in the form of carbonates, and only a very small portion is set free by dissociation at any given moment, so as to become available for the plants. How much there is in this form will depend on the alkalinity of the sea-water and on the temperature. When the free carbonic acid is used up by the plants, fresh quantities will gradually be absorbed from the atmosphere, though this may take place so slowly that there need not necessarily be any equilibrium between the carbonic acid tension in the atmosphere and at the surface of the sea. It is accordingly quite conceivable that the shortage may for a time be considerable enough to stop the algæ from assimilating carbonic acid. When the temperature is high the quantity of free carbonic acid in the sea-water will ceteris paribus be less than when it is low, and this also may help to explain the relatively poor production in warm seas. Variations in the tension of carbonic acid, however, have not as yet been sufficiently studied.

The organic substances built up by pelagic algæ unquestion- 
ably form the chief basis, and in the open sea practically the sole basis, of nutriment for all the pelagic animal life, as well as, through their pelagic forms, for the fauna of the sea-bottom. It is not, however, quite so certain that all the different algæ are equally useful as food to the animals which live on plant stuffs. Brandt's chemical studies of plankton organisms have distinctly shown that nutritive value does not necessarily correspond to volume. Diatoms, with their long silicated setæ, or with big bladder-shaped cells that merely enclose a thin layer of protoplasm along the inner side of the wall, have little nutritive value compared to the majority of the peridineæ, in which most of the cell-chambers are full of protoplasm. The dry substance of diatoms, according to Brandt's analyses of plankton samples, chiefly Chatoceras, contains io to I I.5 per cent albumen, 2.5 per cent fatty matter, 2 I.5 per cent carbohydrates, and as much as 64.5 to 66 per cent ash, 50 to 58.5 per cent of this last being silicic acid. A nother sample, largely consisting of Ceratium tripos, had a totally different composition, the dry substance containing I 3 per cent albumen, I. 3 to 1.5 per cent fatty matter, 80.5 to 80.7 per cent carbohydrates (half of which was chitin), and not more than 5 per cent ash.

We are still without systematic studies of the nutriment of plankton animals, and consequently do not know for certain whether some families of plants are preferred to others. The contents of the intestinal canals of salpa make it evident that Food of Salpa. these animals at any rate collect all the different small organisms to be found in their neighbourhood. In warmer waters the greater part of their stomach-contents consists of coccolithophoridæ and other tiny forms, but we find besides representatives of all the plankton-algæ. Small peridineæ, for instance, like Gonyaulax polygramma, are seldom wanting. In fact, Stein, the well-known specialist on protozoa, who had no plankton-catches to aid him in his researches, got the best part of his material from the stomachs of salpæ, and was thus able to write his valuable initiatory monograph on peridineæ. And this, too, was the plan adopted at first for studying diatoms, so that our knowledge of pelagic genera like Asteromphalus and Asterolampra is largely due to the examination of the stomachs of salpæ. During the cruise I invariably examined the stomach-contents of salpæ, and obtained thereby plenty of small forms, coccolithophoridxe especially, for comparison with the material in the centrifuge samples. As we approached the coast of Europe, however, the contents took on another character, for at Station 
97 most of the forms were diatoms, and to a great extent consisted of Rhizosolenia alata. Generally speaking we discovered that salpæ do not trouble to make any selection. Lohmann's

Food of

Appendicu-

laria.

Food of Copepods.

Proportion of plants and animals in the plankton. studies of Appendicularia have shown us that these animals get their nutriment by means of a filter apparatus, which allows only the minutest organisms, coccolithophoridx in particular, and small peridinex, to enter the digestive canal.

The chief consumers of plants in the sea are undoubtedly copepods. Their conditions of nutriment, however, have so far been principally studied by means of their excrements, which sink down in the shape of small elongated lumps, and are often brought up in numbers by the silk nets. Still, in these excrementa all the softer components have been digested, and the shells that can be identified do not necessarily always belong to species which are an indispensable part of their nutriment. Undoubtedly the calcareous shields of coccolithophoridæ occur too frequently for their presence to be ascribed to chance, indicating, moreover, that the digestive juices of copepods cannot have an acid reaction. In addition we very often meet with more or less bent and distorted coverings of peridineæ, and in northern waters the excrements contain stiffer forms like the little Dinophysis gramulata in a practically unchanged condition. In localities where diatoms predominate, the excrements consist largely of bent and broken bits of species like Rhizosolenia semispina and $R$. alata. Even if Hensen's view be right that diatoms supply far less nutriment comparatively than the other classes of plants in the plankton, it is at any rate quite certain that the animals do feed on them, and especially when they are plentiful. In the Norwegian Sea I have several times observed that where diatoms abounded there might perhaps be only a few copepods and other plankton animals; still the copepods were there, and in large numbers too, just below the diatom zone, and their excrements consisted to a great extent of the silicious coverings of diatoms.

Hensen noticed that the plants in the sea are often so scanty that it is hard to understand how all the animals get enough nourishment, and this is even more difficult to comprehend when we consider that the plants have directly or indirectly to support every single animal from the surface right down to the bottom. In many cases, perhaps, the plants may be more abundant than a cursory examination would seem to indicate; and the most diminutive forms, which are still practically unknown to us, undoubtedly exist in sufficiently 
large numbers to play a momentous part in the general economy. Still careful study distinctly reveals the fact that the plants of the sea are in striking disproportion to the animals. The most reliable results so far obtained are those due to Lohmann's researches in Kiel Bay. He studied the quantities of all the plankton organisms for a whole year with great thoroughness, and calculated the volume of the various groups in the plankton of the different water-masses at all seasons. To us his most interesting discovery is that the plants on an average made up $5^{6}$ per cent and the animals 44 per cent of the total plankton. In the winter months the plants were easily outnumbered by the animals, and from December to February they formed scarcely a third of the total plankton. In the summer, on the other hand, they predominated, and made up sometimes even as much as three-quarters of the whole. Plants which are reproduced by division must necessarily decrease rapidly whenever vigorous augmentation ceases, if animals are constantly consuming numbers of them.

The life-cycle of animals, with its growth-period in youth and propagation in maturity, is more complicated than that of plants, and gives them a better chance of withstanding unfavourable conditions of existence. A lower temperature necessarily reduces their intensity of breathing, and thus diminishes their consumption of nourishment, and it may be also that they can go without feeding for a comparatively long time, during which they live upon reserve matter that they have accumulated at more favourable seasons. Damas made some interesting studies of the life-cycle of the larger copepods, and found that propagation may require a higher temperature than what is necessary for conserving vital energy, and that therefore these forms can delay their propagation until the conditions of existence become more favourable, so that the young animals may have the rich nutriment required for their growth. Calanus finmarchicus, the commonest large copepod of the Norwegian Sea, abounds wherever the temperature is over $2^{\circ} \mathrm{C}$., in both its half-grown and full-grown stages, but propagation does not begin till the temperature rises to $4^{\circ} \mathrm{C}$., either owing to warmer water-masses arriving from the south, or to heating at the surface from the atmosphere.

Lohmann has endeavoured to calculate the relation between Relation the augmentation of the algæ and their consumption by animals throughout the year in Kiel Bay. He assumes that there is a and consumpdaily accession of 30 per cent to the volume of the algæ, and tion of algæ. 
that this can be consumed by the animals without harm to the plant aggregate. He further assumes that copepods and other multicellular animals require per day a quantity of nutriment equal to a tenth of their own volume, whereas protozoa need half their own volume. In view of what I have previously stated regarding the variations in the rate of production of Ceratium, I have no hesitation in declaring that the augmentation of the algæ varies within wide limits, and the same is undoubtedly also the case with the nutriment-requirements of the animals. Still I am quite ready to concede that Lohmann's assumptions may apply to the average conditions. The following table compiled by him, and showing values in cubic millimetres of plankton per soo litres of sea-water, will doubtless be of interest:-

\begin{tabular}{|c|c|c|c|}
\hline & $\begin{array}{l}\text { Daily Augmentation } \\
\text { of Producers } \\
\text { available for Nutriment. }\end{array}$ & $\begin{array}{c}\text { Daily } \\
\text { Nutriment-requirement } \\
\text { of Animals. }\end{array}$ & $\begin{array}{c}\text { Surplus } \\
\text { or } \\
\text { Deficiency. }\end{array}$ \\
\hline August & 35 & 6 & +29 \\
\hline September & 27 & 8 & +19 \\
\hline October & I 4 & $5 \cdot 5$ & +8.5 \\
\hline November & 9 & $4 \cdot 5$ & +4.5 \\
\hline I)ecember & $3 \cdot 5$ & 2.5 & +1.0 \\
\hline January & 3 & I. 8 & +1.2 \\
\hline February & I & I. 8 & -0.8 \\
\hline March & 3 & 2.4 & +0.6 \\
\hline April . & I3 & 2.0 & $+\mathrm{II}$ \\
\hline May . & 14 & $5 \cdot 5$ & +8.5 \\
\hline June . & 20 & 4.0 & +16 \\
\hline July . & 17 & $4 \cdot 5$ & $+\mathrm{I} 2.5$ \\
\hline August & I 6 & $4 \cdot 3$ & $+\mathrm{II} .7$ \\
\hline
\end{tabular}

According to this table the surplus plant substance is not large, and in February there was actually a deficiency. It is possible, too, that Lohmann's assumptions are on the optimistic side, and that he has put the production-capacity of the plants too high, and the nutriment requirements of the animals too low.

Organic matter in sea-water.

Pütter, after studying the quantities of oxygen consumed by different marine animals, both benthonic and pelagic, considers that the augmentation of the plant aggregate by no means suffices as nutriment for the animals. If his view is correct, there must, of course, be other sources of nutriment, both to replace the loss of organic substance which the animals incur by 
breathing, and also to supply building material for their growth and propagation. Puitter has endeavoured to find out whether Puitter. organic matter dissolved in the sea-water does not provide this. He investigated its amount, and got surprisingly high values. Improved methods have enabled Raben to check his experiments; in water from Kiel there were 10.9 to I 3.9 milligrams, or on an average 1 2.25 milligrams, of organic combined carbon per litre of sea-water, and at a station in the Baltic 3 milligrams. These are really high values, if we compare them with the quantities of organic substance we are able to point to in the form of living organisms. Lohmann's studies show that the total amount of the organic combined carbon in the plankton at Laboe in Kiel Bay varied during the year between $12.7 \mathrm{mg}$. and $189.8 \mathrm{mg}$. per I ooo litres of sea-water. According to Raben's investigations at a place close by, the mean value of organic combined carbon in dissolved form is I $2,250 \mathrm{mg}$. per Iooo litres, or in other words about sixty times as much.

Too little is known, unfortunately, about the occurrence of organic matter, and there are many difficulties to be overcome before we can look for conclusive results. Perhaps the most discouraging thing is that even the best filters allow a good many organisms to pass through them. The water-samples to be examined ought possibly to be freed from all suspended insoluble matter by means of the centrifuge, but even this method will not always give entirely satisfactory results, since some of the algæ (cyanophyceæ, Halosphara) are lighter than sea-water, while the nimbler animals will swim up from the bottom before one can separate the clear water from the deposit. Pütter's hypothesis, however, certainly deserves to be further tested. If it be really true that in the salt-water of the open sea there is organic substance in sufficient quantities to be compared with what is combined in plants and animals, then this substance must be due to the production of plants. We will accordingly be forced to conclude that the pelagic algæ distribute to their surroundings through their surface comparatively large quantities of organic substance, and that their production is thus in actual fact much more considerable than we are led to believe, when we merely measure what they store up in their cells during growth and augmentation. Even if it seems strange biologically that they should evince such want of economy in regard to valuable nutritive matter, it would be unwise to reject the hypothesis, and the best plan is to await the results of continued investigations. Some 
biologists favour the theory and others oppose it; some of them have published the results of special studies, particularly of the nutrition-processes of animals, all of which have been of service to the cause of science, though they have not succeeded in deciding this question.

Lohmann and C. G. J. Petersen have maintained that organic detritus may be of intrinsic importance for the nutriment of animals, as well as plants, and they have demonstrated that organic detritus from the land is present in fairly large quantities in waters like the Baltic or off the coasts of Denmark. We have reason, therefore, to expect extremely interesting results from the work of the Danish biologists on organic detritus in the water and in the deposits at the bottom of the sea. But out in the open sea this detritus is only met with in inconsiderable quantities, as our centrifuge-samples showed us on board the " Michael Sars." I do not, of course, include inanimate organic substances, such as excrements or the empty chitin-coverings of copepods, which form a part of the circulation of nutritive substances through the pelagic organisms. Organic fragments, not actually derived from pelagic organisms, either do not occur at all in the open sea, or, if they do, are not worth taking into consideration.

H. H. G. 


\section{CHAPTER VII}

FISHES FROM THE SEA-BOTTOM

Zoologists on both sides of the Atlantic have long been engaged in collecting facts regarding the occurrence of fishes and other organisms which inhabit the Northern Atlantic and adjacent waters. In recent times special expeditions have offered opportunities of collecting according to definite plans, and the American expeditions in the "Blake" and the "Albatross," and the European ones in the "Challenger," in the "Travailleur," the "Talisman," and the "Princesse Alice" have added essentially to our knowledge. As a consequence a very large amount of material has been accumulated, but as yet this material has not been utilised for the purpose of drawing up a general account of the distribution of the different animal-communities.

Any attempt to review our knowledge, or to summarise the voluminous literature on this subject, would extend this book beyond all reasonable limits, and I shall therefore restrict myself to certain important and characteristic main lines in the distribution of Atlantic fishes and other animals, relying principally on the captures made during the cruises of the "Michael Sars." The material gathered during these cruises is so large that a representative view may now be obtained, and while confining myself to our own observations I hope to give some information of real value. My aim, then, will be to describe the geographical distribution of the fishes, as this group has been made the special object of our researches; other groups of animals will be mentioned only in order to illustrate the surroundings and the animal-communities associated with the different fishes.

In dealing with animal geography one must always presuppose a knowledge of a vast number of animal forms. The animals inhabiting the depths of the sea are strange to all but 
a few specialists, and are known only by Latin names, of which most zoologists even are ignorant. Nevertheless these names must be used if the reader desires to penetrate into the general laws which govern the distribution of animals in the ocean. In order to overcome this difficulty I commence this chapter with systematic lists recording the different species of fishes, and the details of their capture, accompanied by outline drawings of the most important species. By means of these lists the reader may easily obtain information as to what group in the system a certain fish belongs, and further details will be found in the literature of the subject. ${ }^{1}$

Bottom-fishes collected by the "Michael Sars."

During the many cruises of the "Michael Sars" probably all the species of fish which live in the Norwegian Sea and the North Sea have been captured, but only the commonest species will be treated of here. Nearly all the fish caught during the Atlantic cruise in I9 Io will, however, be mentioned, or at all events as many as the present state of the work will permit.

The following list includes all the forms captured by us in the Atlantic which, according to our experience, must be considered as living mainly along the bottom.

\section{List of Fishes caught by the "Michael Sars" along the Sea-Bottom in the North Atlantic}

This list includes 138 different species belonging to almost all the most important groups of bottom-fishes. Thirty-two species belong to the order Plagiostomi, fishes with a cartilaginous skeleton, and 106 to the order Teleostei, fishes with an ossified skeleton.

The Elasmobranchir.-Our list includes of the order Plagiostomi the two sub-orders, Selachii (sharks) and Batoidei, with the family Raiidæ (rays), besides the order Holocephali with the Chimæridæ.

Seventeen species are sharks (Selachii), including the large Atlantic Notidanus, the small but numerous Scylliidæ, which also go into the Norwegian Sea. Of the large group of the Spinacidæ, Acanthias vulgaris is caught by the nets of the fishermen in the North Sea ; it follows the herring shoals, and is therefore called dog-fish by the fishermen.

The two genera Centrophorus and Spinax include deep-sea fishes living on the slope. Centrophorus is confined to the Atlantic only, and so is Centroscyllium; Spinax niger is caught in the Norwegian fjords also. Two teeth of extinct species of sharks, Carcharodon and Oxyrhina, were

${ }^{1}$ See, for instance, A. C. L. G. Giinther, An Introduction to the Study of Fishes, chap. xxi., Edinburgh, 1880; Francis Day, The Fishes of Great Britain, Edinburgh, 1880-84; Boulenger and Bridge, Fishes, in the Cambridge Natural History, 1904. The lists are arranged according to the system proposed by Boulenger. 
found in deep water by the "Michael Sars," similar to those found in such great numbers by the "Challenger" in the Pacific.

Twelve species are rays (Raiidæ). Raia microocellata and $R$. miraletus are true Atlantic species, caught by the "Michael Sars" only south of the Canaries. The other species are caught also in the Norwegian Sea.

Of the family Chimæridæ, Chimara monstrosa is recorded from the Norwegian Sea, from the extreme north of Norway, from the whole of the Atlantic down to the Cape of Good Hope, from Sumatra and Japan. C. mirabilis was discovered by the "Michael Sars" in 1902, south of the Faroe Islands, in deep water. Hariotta raleighana, in appearance a most remarkable deep-sea fish, was previously known from the Atlantic slope off the United States.

The Teleostei are represented in our list by no less than eight sub-orders.

The Malacopterygii include salmon-like fishes; two species of the genus Argentina live near the continental edge or the deepest part of the coast-banks of the Norwegian Sea and the Atlantic. The family Alepocephalidæ includes true deep-sea fishes, black in colour, known from the greatest depths of the ocean, but not recorded from the Norwegian Sea. They are salmon-like in form, and attain the dimensions of a small salmon.

The Apodes, or eel-like fishes, include a great number of deep-sea fishes belonging to the family Synaphobranchidæ. Synaphobranchus pinnatus is known from all the oceans of the world, and was caught in deep water by the "Michael Sars" at many stations. The family Murænidæ includes shore-fishes; the splendid Murena helena was caught off the African coast.

The Haplomi and the Heteromi include true deep-sea fishes, the genera being Bathysaurus, Bathypterois, the new genus Bathymicrops, Halosauropsis, and Notacanthus. None of them are known from the Norwegian Sea, but some have a world-wide distribution, and have been caught at the very greatest depths where trawlings have been taken.

The Catosteomi and Percesoces are only represented by one species each ; both coast-fishes. Centriscus scolopax is a brightly-coloured little coast-fish with a pipette-like rostrum.

The Anacanthini are represented in our list by no less than 36 different species, I9 of Macruridæ, and I7 of Gadidæ. These two families are very nearly related. The Macruridxe include the most important and numerous bottom-fishes on the continental slopes and over the abysmal areas of the ocean. The Gadidxe are the most numerous and economically the most important food-fishes in northern and subtropical waters. The Macruridæ have representatives which live in very deep water only, others which are confined to certain geographical areas of the slope, and so on ; these will be treated in greater detail later. Of the Gadidæ the genus Gadus has a number of species (for instance, the cod, the haddock, the whiting, the pollack, the saithe) which are characteristic of different parts of northern waters, while the genus Merluccius is the most important food-fish on subtropical coast-banks. The genera Molva (ling) and Brosmius (tusk) inhabit the deepest parts 
of the coast-banks, and the genera Mora, Lepidion, and Halargyreus the uppermost part of the continental slope.

The Acanthopterygii.-Fifty-one species belong to this very important and large group of highly developed fishes, most of which are true coastbank fishes, only a few of them being known from the uppermost part of the slope.

Most of these fishes, the Serranidæ, Sciænidæ, Pristipomatidæ, Sparidæ, Mullidæ, Caproidæ, Labridæ, Scorpænidæ, Triglidæ, Trachinidx, Uranoscopidæ, and Callionymidæ, are brightly-coloured fishes, with hard ossified scales and spines of moderate size, living in shallow water, or deeper, on the coast-banks, with a maximum distribution in warm subtropical waters. The northern limit of their distribution differs for different species, several extending even to the southern warmer parts of the bays and fjords of Scandinavia; other families, e.g. Cottidæ and Blenniidæ, have representatives in the Arctic (Triglops, Lumpenus). None of these families have, however, any economical importance in the Norwegian Sea or North Sea.

The family Pleuronectidæ, or flounders, includes very important food-fishes. The plaice, flounder, sole, dab, megrim, halibut, all belong to this family. Hippoglossus, Pleuronectes, and Zeugopterus are northern genera; Solea is the most important genus in the Atlantic, Solea vulgaris being of importance also in the southern parts of the North Sea.

The Scombriformes, to which belong the genera Trachurus or Caranx, Scomber, Thynnus, are mostly pelagic, but are also caught very near to the shore. The mackerel, the tunny, the horse-mackerel are all economic species of great importance.

\title{
Class--PISCES
}

\section{Sub-Class-ELASMOBRANCHII}

Order-PLAGIOSTOMI

\author{
Sub-Order-SELACHII
}

Notidanide

Notidanus griseus, Cuv. (six-gilled shark), 1902, Faroe-Shetland channel (Fig. 253).

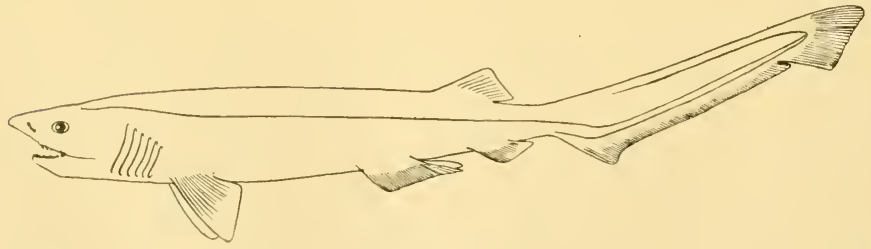

F1G. 253.

Notidanus griseus, Cuv. (After Bonaparte.) 


\section{SCYLLIIDE}

Scyllium canicula, Cuv. (rough hound), I910, Stations 3, 14, 20, 39.

Pristiurus melanostomus, Bonap. (black-mouthed dogfish), I902, Faroe-Shetland channel; 1910, Stations I, 21.

Pristiunus murimus, Coll., 1902, Faroe-Shetland channel, i roo to I300 metres.

\section{CarchariIDE}

Mustelus vulgaris, Müll. and Henle (smooth hound). I9ıо, Station I3.

\section{LAMNIDE}

Carcharodon, fossil tooth, I9Io, Station 48 (see Fig. 254).

Oxyrhina, fossil tooth, 1910, Station 48 .

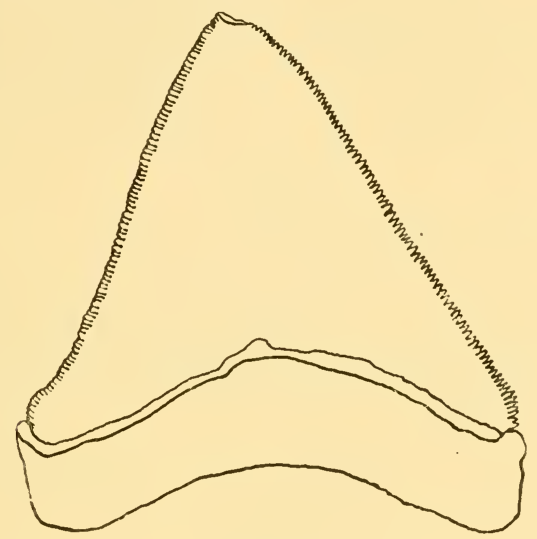

FIG. 254 .

Carcharodon megalodon, Fossil Tooth. Station 48. (After Zittel.) This figure shows a Carcharodon tooth from Tertiary deposits; those dredged from the deep-sea deposits have never the base preserved (see Fig. 126, p. 156).

\section{SPINACIDE}

Centrina salviani, Risso, I910, Station 13.

Acanthias vulgaris, Risso (dog-fish), 1902, Faroe Bank, 390 metres; FaroeShetland channel ; 1910, Stations 1, 3, 20, 39 (see Fig. 255).

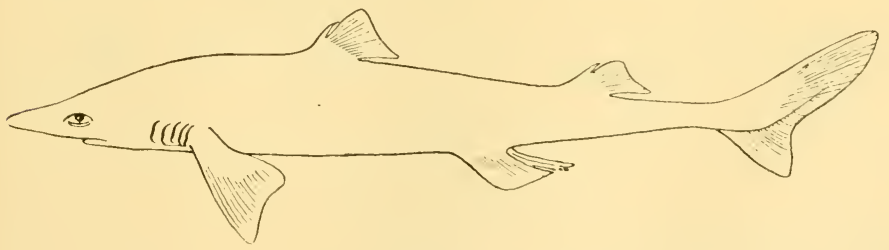

FIG. 255 .

Acanthias vulgaris, Risso. (After Smitt.) 
Centrophorus crepidater, Boc. and Cap., r 902, Faroe Bank, 750 metres.

Centrophorus squamosus, Gmel., 1902, Faroe Bank, 390 to $75^{\circ}$ metres (see Fig $256)$.

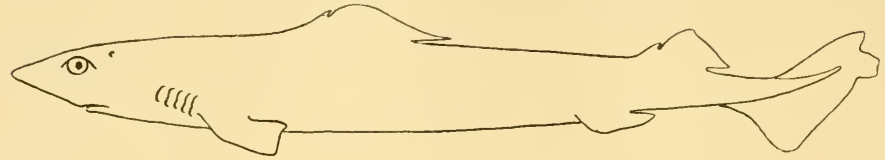

FIG. 256.

Centrophorus squamosus, Gmel. (After Jensen.)

Centrophorus calceus, Lowe, 1902, Faroe Bank, 750 metres.

Centrophorus coelolepis, Boc. and Cap., 1902, Faroe Bank, 750 metres.

Spinax niger, Bonap., 1902, Faroe Bank, 426 metres; 1910, Station 21.

Spinax (Etmopterus) princeps, Coll., 1902, Faroe-Shetland channel and Faroe Bank.

Centroscyllium fabricii (Reinh.), 1902, Faroe-Shetland channel and Faroe Bank.

RHINIDE

Rhina squatina, Duméril, r9ro, Station 39.

\section{Sub-Order-BATOIDEI}

RAIIDE

Raia clavata, L. (thornback ray), r 902, Faroe Bank, 130 metres; I910, Stations I, 3, I3, I 4, 20, 39 (see Fig. 257).

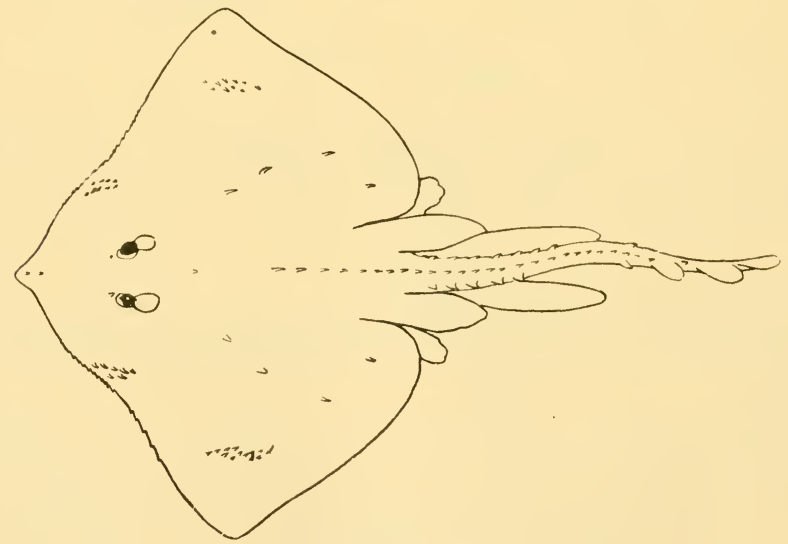

FIG. 257 .

Raia clavata, L. (After Smitt.)

Raia punctata, Risso, r9ro, Stations $37,38,39$.

Raia microocellata, Montagu, 1910, Station 37 . 
Raia alba, Lacép., 1910, Station 37.

Raia miraletus, L., I910, Station 39.

Raia fylla, Ltk., I910, Stations 25, 95.

Raia circularis, Couch, I910, Stations 3, I3, 39 (see Fig. 258).

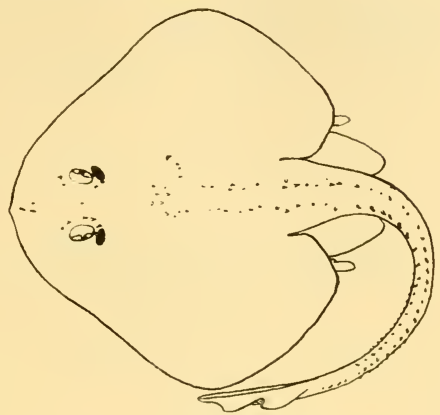

FIG. 25 .

Raia circularis, Couch. (After Smitt.)

Raia batis, L. (skate), I902, Faroe Bank, I 30 metres; Faroe-Shetland channel.

Raia vomer, Fries, I902, Faroe Bank, 750 metres ; I9 Io, Station 3.

Raia nidrosiensis, Coll., I 910 , Station 4.

Raia fullonica, L., I902, Faroe Bank, 390 metres; I910, Station 2 I.

\section{MYLIOBATID $Æ$}

Myliobatis aquila, Cuv. (whip-ray), I9 1о, Station 36.

\section{Order-HOLOCEPHALI}

CHIMÆRIDE

Chimera monstrosa, L., I902, Faroe Bank, 435 metres; I9Io, Station 2 I.

- Chimara mirabilis, Coll., I902, Faroe-Shetland channel; 1910, Station 4 (see Fig. 259).

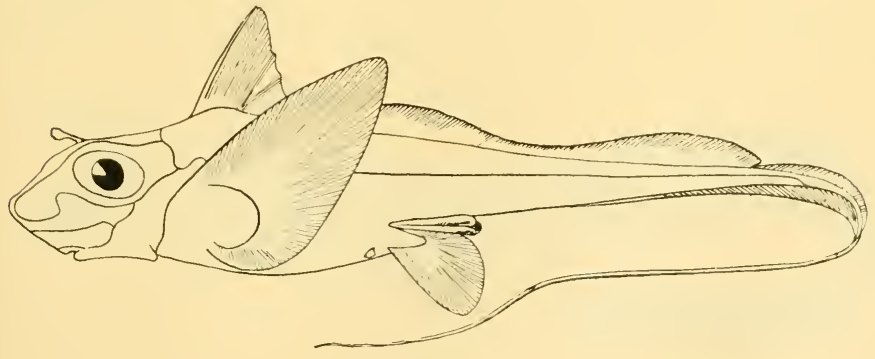

Fig. 259.

Chimera mirabilis, Coll. Nat. size, $76 \mathrm{~cm}$. 
Hariotta raleighana, G. and B., I910, Stations 35, 101 (see Fig. 260).

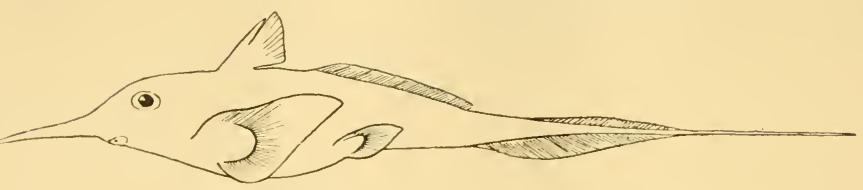

FIG. 260.

Hariotta raleighana, G. and B. (After Goode and Bean.)

\section{Sub-Class-TELEOSTOMI \\ Order-TELEOSTEI \\ Sub-Order-MALACOPTERYGII}

SALMONIDE

Argentina silus, Nilss., 1910, Station 39 (see Fig. 261). Argentina sphyrana, L., I910, Stations I, 3.

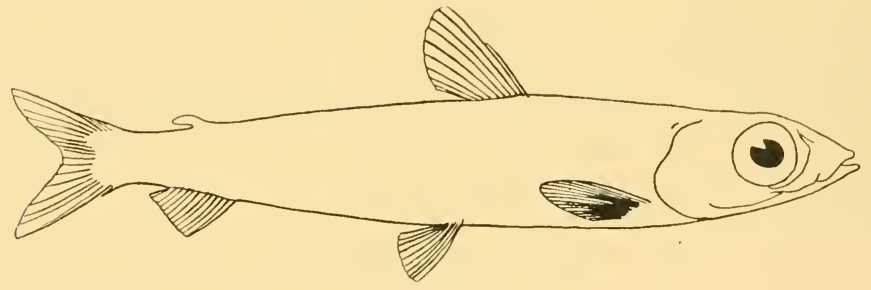

FIG. 26I.

Argentina silus, Nilss. (After Smitt.)

\section{ALEPOCEPHALIDE}

Alepocephalus giardi, Koehl., I902, Faroe-Shetland channel; Faroe Bank, $75^{\circ}$ to 840 metres (see Fig. 262).

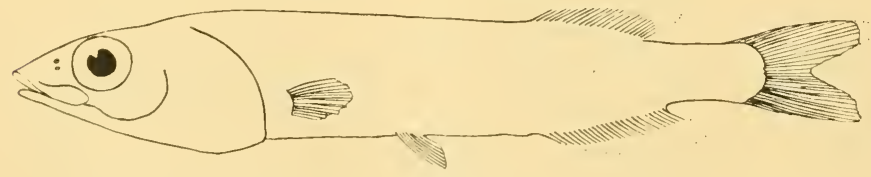

FIG. 262.

Alepocephalus giardi, Koehl. (After Collett.)

Bathytroctes rostratus, Günth., I 9 I0, Stations 29, 56.

Conocara macroptera, Vaill. (G. and B.), r 910 , Station 25 (see Fig. 263). 


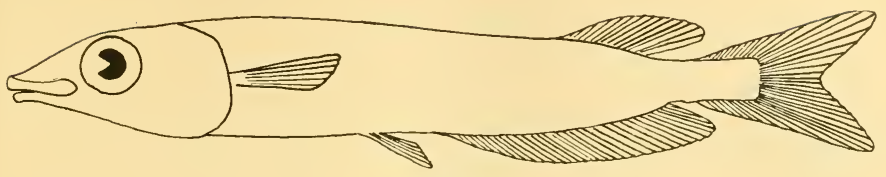

Fig. 263.

Conocara macroptera, Vaill. Nat. size, $20 \mathrm{~cm}$.

\section{Sub-Order-APODES}

SYNAPHOBRANCHIDE

Synaphobranchus pinnatus, Gron., I902, Faroe-Shetland channel; Faroe Bank, $75^{\circ}$ metres ; I910, Stations 4, 24, 4I, 53, 88, 95, Iо I (see Fig. 264). Histiobranchus sp., I910, Station 88.

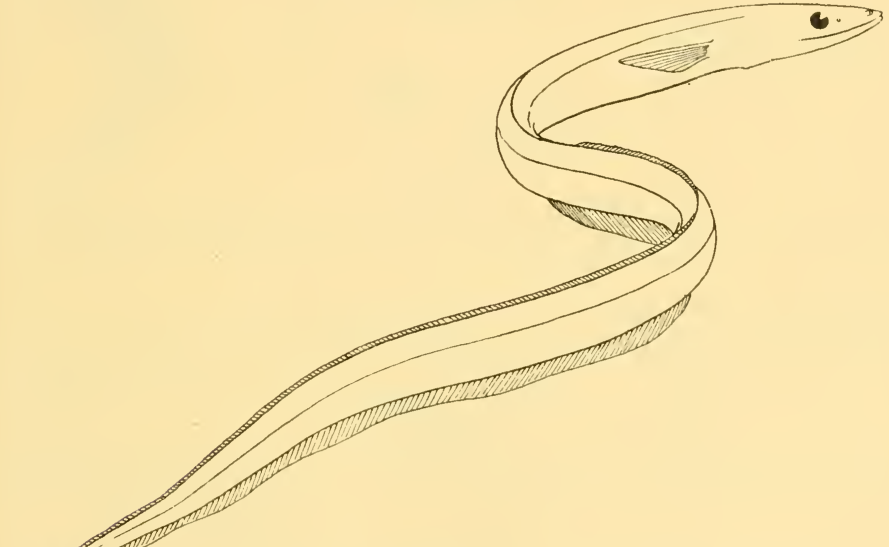

FiG. 264.

Synaphobranchus pinnatus, Gronov. Nat. size, $31 \mathrm{~cm}$.

MURÆNIDE

Murcna helena, L., 1910, Station 38 (see Fig. 265).

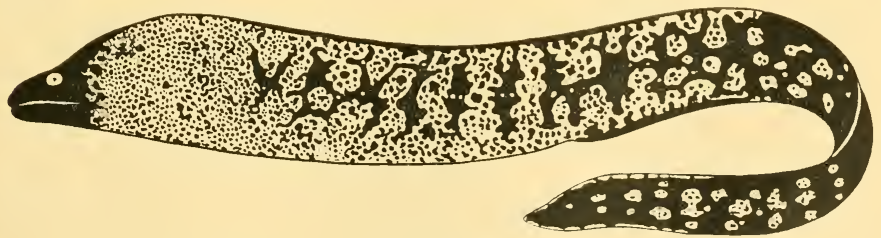

FIG. 265.

Murana helena, L. Nat. size, $102 \mathrm{~cm}$. 


\section{Sub-Order-HAPLOMI}

\section{SCOPELIDE}

Bathysaurus ferox, Günth., 1910, Stations 25, 35, 53, 95 (see Fig. I03, a). Bathypterois longipes, Günth., I910, Station 53.

Bathypterois dubius, Vaill., 1910, Stations 23, 41 (see Fig. 266).

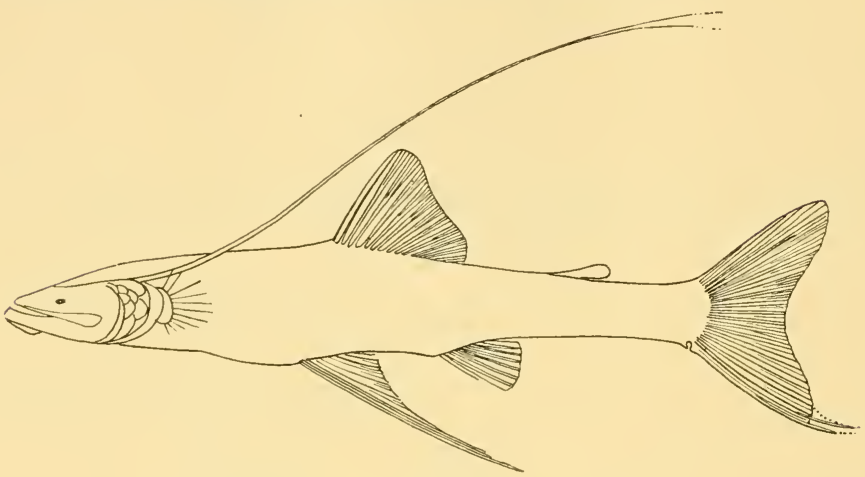

FIG. 266.

Bathypterois dubius, Vaill. Nat. size, $17 \mathrm{~cm}$.

Benthosaurus grallator, G. and B., I910, Station 53 .

Bathymicrops regis, n.g., n.sp., I9I0, Station 48 (see Fig. 305).

\section{Sub-Order-HETEROMI}

\section{HALOSAURIDE}

Halosauropsis macrochir, Günth. (Coll.), ig10, Stations 35, 53, 88, 95 (see Fig. $103, b)$.

\section{NOTACANTHIDE}

Notacanthus bonapartii, Risso, 1902, Faroe-Shetland channel; Faroe Bank, 840 metres (see Fig. 267).

Polyacanthonotus sp., 1910, Stations 53, 95.

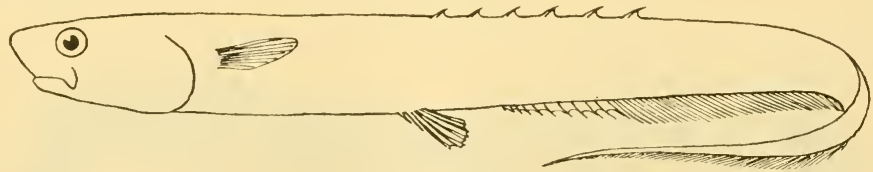

Fig. 267.

Notacanthus bonapartii, Risso. (After Goode and Bean.)

\section{Sub-Order-CATOSTEOMI}

Centriscide

Centriscus scolopax, L., I910, Station 39 (see Fig. 268). 


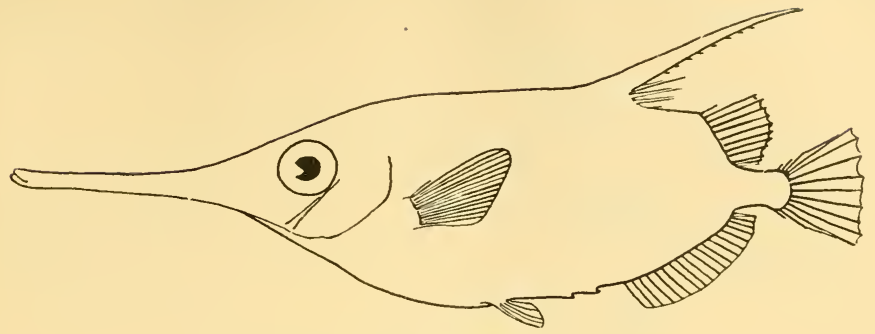

FIG. 268.

Centriscus scolopax, L. Nat. size, $16 \mathrm{~cm}$.

\section{Sub-Order-PERCESOCES}

ATHERINIDE

Atherina presbyter, Cuv. and Val., i9io, Station $3^{6 .}$

\section{Sub-Order-ANACANTHINI}

MACRURIDE

Trachyrhynchus trachyrhynchus, Günth., I910, Stations 4, 23.

Trachyrhynchus murrayi, Günth., 1902, Faroe-Shetland channel; Faroe Bank, 840 metres (see Fig. 269).

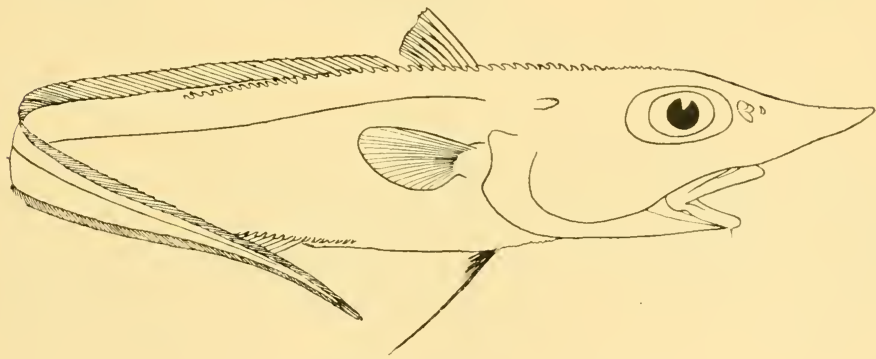

FIG. 269.

Trachyrhynchus murrayi, Günth. (After Günther.)

Macrurus (Colorhynchus) talismani, Collett, 1902, Faroe-Shetland channel: I910, Stations 4, 24, 4I.

Macrurus (Colorhynchus) colorhynchus, Risso and Bonap., I910, Station 2 I.

Macrurus sclerorhynchus, Val., I910, Stations 25, 41, 88, 95, 101.

Macrurus aqualis, Günth., I902, Faroe Bank, 750 metres; 1910, Stations 4, 23,

$25,35,4$ I (see Fig. 270).

Macrurus zaniophorus, Vaill., i910, Stations 4, 4I.

Macrurus gïntheri, Vaill., 1902, Faroe-Shetland channel.

Macrurus (Coryphanoides) rupestris, Gunn, I902, Faroe-Shetland channel ;

Faroe Bank, 750 to 840 metres. 


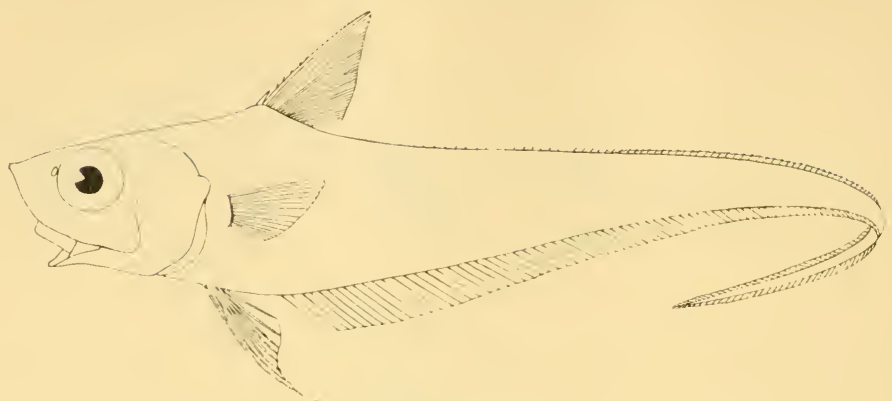

FIG. 270.

Macrurus aqualis, Günth. Nat. size, $23 \mathrm{~cm}$.

Macrurus (Coryphanoides) asperrimus, Vaill., I9 Io, Station 4I.

Macrurus (Cetonurus) globiceps, Vaill., r 910, Station 4r (see Fig. 271).

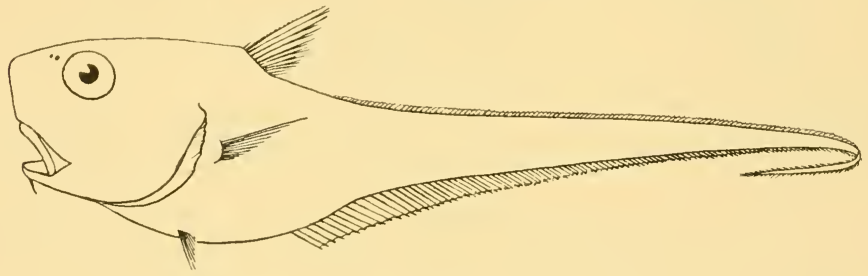

FIG. 27 I.

Macrurus (Cetonurus) globiceps, Vaill. (After Vaillant.)

Macrurus (Chalinura) brevibarbis, G. and B., I910, Station 10.

Macrurus (Chalinura) murrayi, Günth., 1910, Stations 25, 95.

Macrurus (Chatimura) simulus, G. and B., i9 10, Station 53.

Macrurus (Malacocephalus) levis, Lowe, r910, Station 2 I.

Macrurus (Nematomurus) armatus, Hect., igı, Stations io, 35, 53, 88 (see Fig. 272).

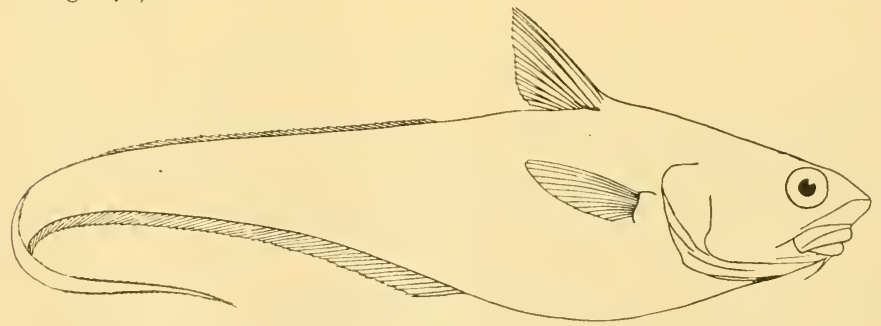

FIG. 272.

Macrurus (Nematonurus) armatus, Hect. (After Günther.) 
Bathygadus longifilis, G. and B., I910, Stations 23, 24, 4I (see Fig. 273).

Bathygadus melanobranchus, Vaill., 1910, Stations 2.3, 4 1.

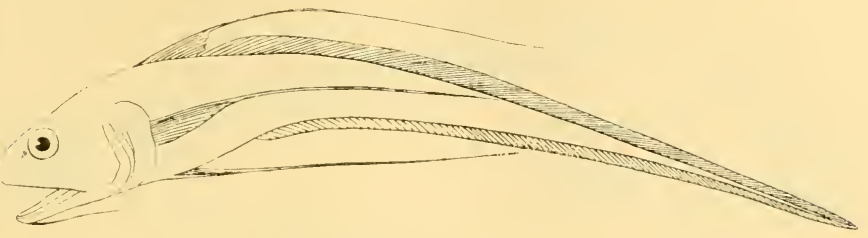

FIG. 273 .

Bathygadus longifilis, G. and B. (After Brauer.)

\section{GADIDE}

Gadus callarias, L. (cod), r 9 Iо, Rockall (see Fig. 274).

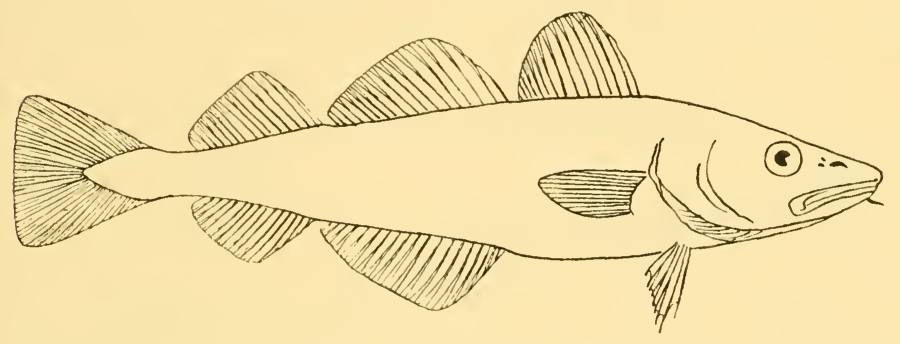

F1G. 274.

Gadus callarias, L. (After Snitt.)

Gadus aglefinus, L. (haddock), I902, Faroe Bank, I30 metres; I910, Station 3. Gadus merlangus, L. (whiting), I910, Station I4.

Gadus luscus, L. (bib), I910, Station I4.

Gadus esmarki, Nilss., I910, Station I.

Gadus poutassou, Risso, I9 I0, Stations I, 3 .

Gadiculus argenteus, Guichenot, 1910, Stations 3, 21, 96.

Merluccius vulgaris, Flem. (hake), 1910, Stations I, 3, I4, 20, 21, 36, 39 (see Fig. 275).

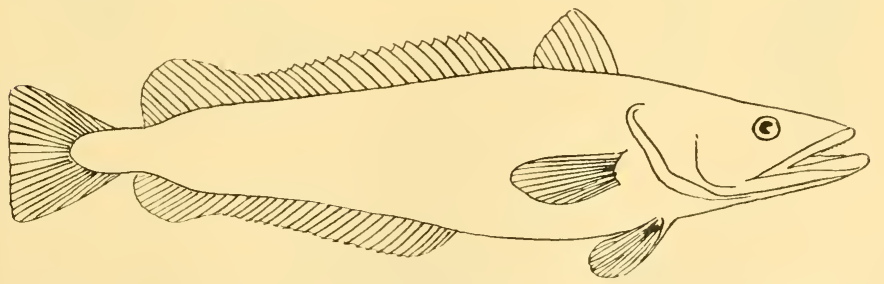

FIG. 275.

Merluccius vulgaris, Flem. (After Smitt.) 
Phycis blennioides, Brünn, I910, Stations I, 3, 21 (see Fig. 276).

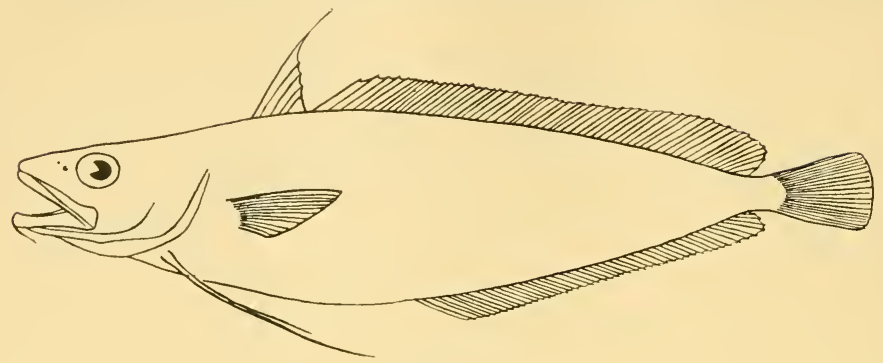

Fig. 276.

Phycis blennioides, Brünn. (After Smitt.)

Molva molva, L. (ling), I902, Faroe-Shetland channel; Faroe Bank, $35^{\circ}$ to 440 metres (see Fig. 277).

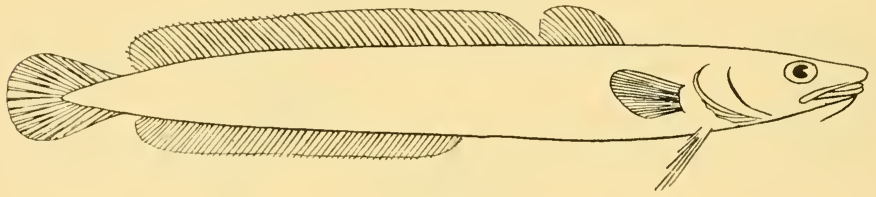

FIG. 277 .

Molva molva, L. (After Smitt.)

Molva byrbelange, Walb., I902, Faroe Bank, 840 metres.

Molva elongata, Risso, I9 Iо, Station 2 I.

Brosmius brosme, Ascan (tusk), 1902, Faroe-Shetland channel; Faroe Bank, 550 to 440 metres.

Mora mora, Risso, 1902, Faroe Bank, $75^{\circ}$ metres; ig10, Stations 4, 23, 4I (see

Fig. 278).

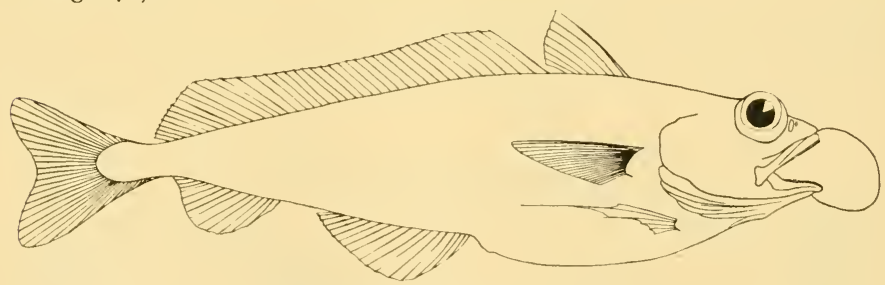

FIG. 278 .

Mora mora, Risso. Nat. size, $45 \mathrm{~cm}$.

Antimora viola, G. and B., I9ro, Stations 4, 95, гог (see Fig. 279).

Lepidion eques, Günth., I902, Faroe-Shetland channel ; Faroe Bank, 750 metres ; I910, Station 4 (see Fig. 280). 
Halargyreus affinis, Coll., 1902, Faroe-Shetland channel; Faroe Bank, $75^{\circ}$ metres (see Fig. 28I).

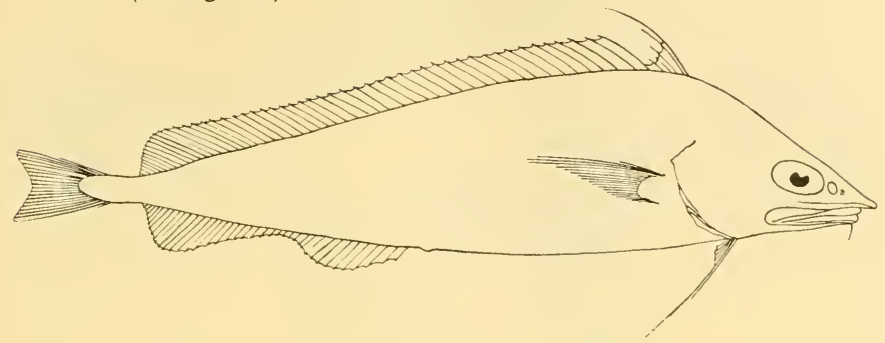

FIG. 279.

Antimora viola, G. and B. (After Günther.)

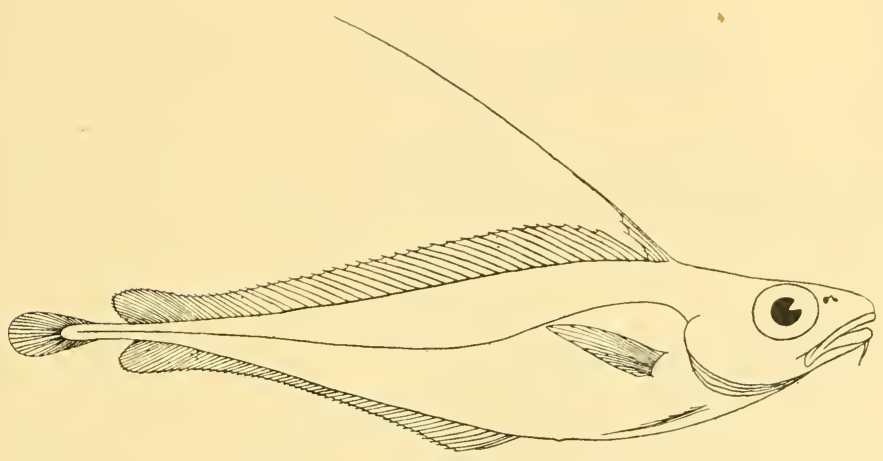

FIG. 280 .

Lepidion eques, Günth. (After Günther.)

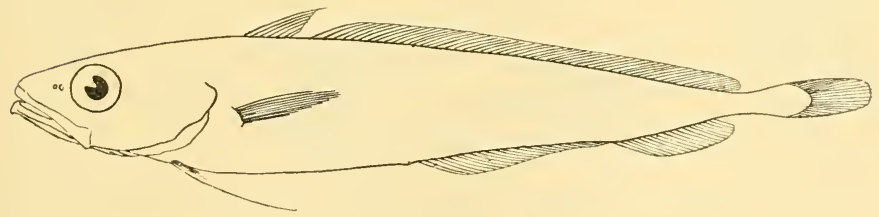

Fig. 28I.

Halargyreus affinis, Coll. (After Collett.)

\section{Sub-Order-ACANTHOPTERYGII}

Division-PERCIFORMES

\section{BERYCIDÆ}

Hoplostethus mediterraneum, Cuv. and Val., I9ro, Stations 4, 2 I (see Fig. 282). 


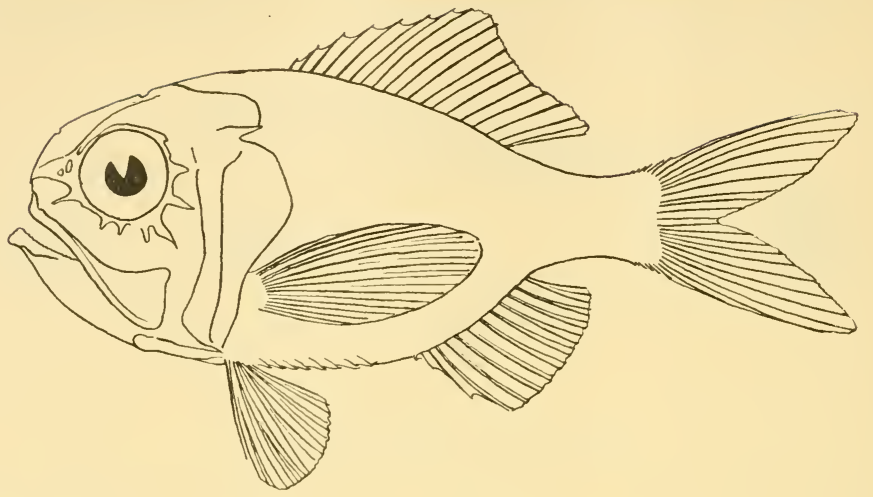

FIG. 282.

Hoplostethus mediterraneum, Cuv, and Val. (After Goode and Bean.

\section{ACROPOMATID}

Efigonus telescopus, Risso, 1902, Faroe Bank, 750 metres.

\section{SERRANIDE}

Serranus cabrilla, Cuv. and Val., r910, Station 37 (see Fig. 283).

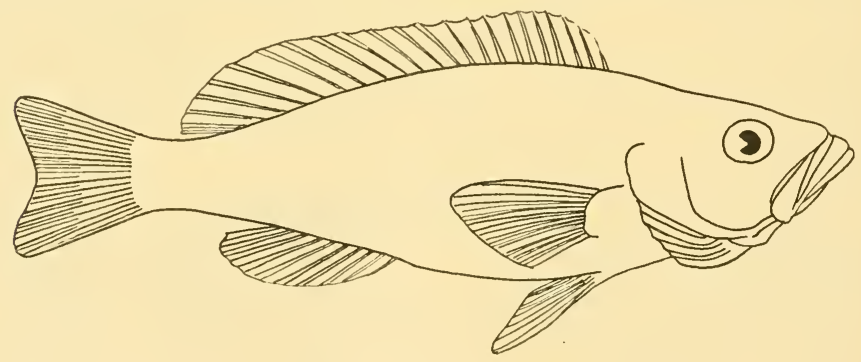

Fig. $28_{3}$.

Serranus cabrilla, Cuv, and Val. Nat. size, $21 \mathrm{~cm}$.

\section{SCIÆNIDA}

Sciana aquila, Risso, 1910, Station 36 (see Fig. 284).

Umbrina ronchus, Val., i910, Station 36 . 


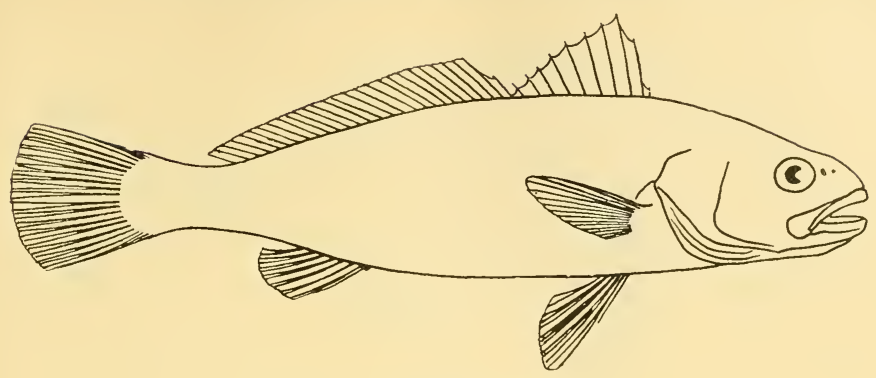

FIG. 284 .

Scicena aquila, Risso. (After Smitt.)

\section{PRISTIPOMATID}

Pristipoma bennettii, Lowe, I9ro, Station $3^{6 .}$

Diagramma mediterraneum, Guichenot, I910, Canary Islands.

\section{SPARIDE (Sea-Breams)}

Dentex vulgaris, Cuv. and Val., 1910, Canary Islands (see Fig. 285).

Dentex macrophthalmus, Cuv. and Val., 1910, Stations 20, 38,39 .

Dentex maroccanus, Cuv. and Val., I910, Stations 20, 37 (see Fig. 48, $a$ ).

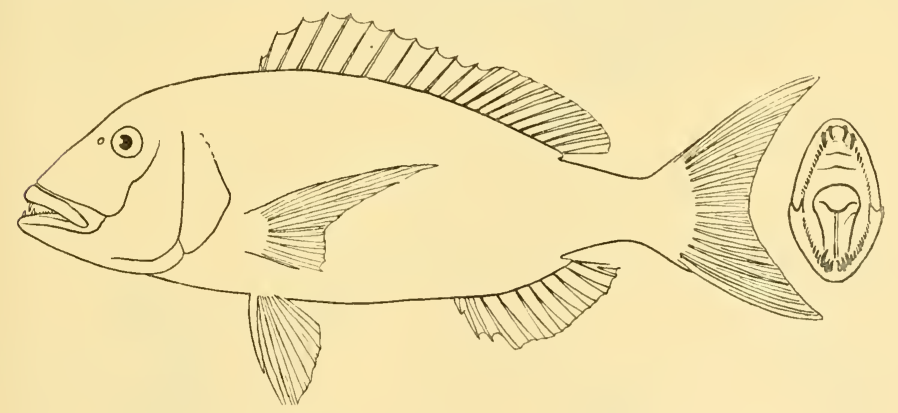

FIG. 285.

Dentex z'ulgaris, Cuv. and Val. (After Cuvier and Valenciemes.) (The teeth, after Day.)

Cantharus lineatus, Montagu (White), I9ro, Canary Islands, Station 37.

Box vulgaris, Cuv. and Val,, 1910, Station $3^{6 .}$

Sargus rondeletii, Cuv. and Val., igro, Canary Islands.

Sargus annularis, Cuv. and Val., I 910, Station $3^{6}$ (see Fig. 286).

Chrysophrys aurata, Cuv. and Val., I910, Canary Islands.

Pagrus vulgaris, Cuv. and Val., I9ro, Canary Islands, Stations 38, 39 (see Fig. 287).

Pagellus centrodontus, Cuv. and Val., I910, Stations I3, 20 (see Fig. 288).

Pagellus acarne, Cuv. and Val., I9ro, Station 20. 


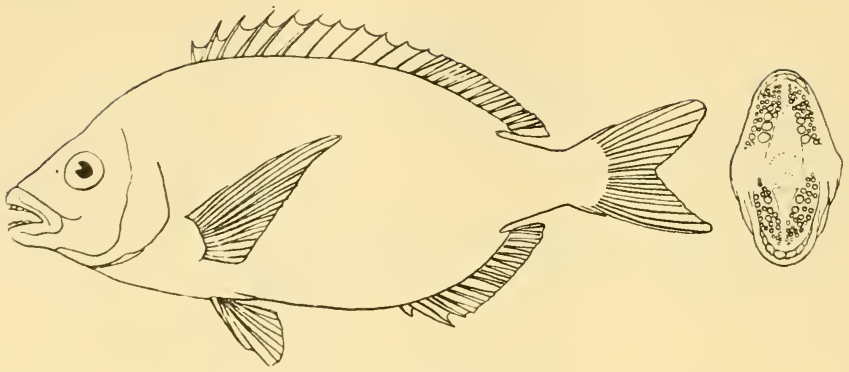

Fig. 286.

Sargus annularis, Cuv. and Val. (After Cuvier and Valenciennes.)

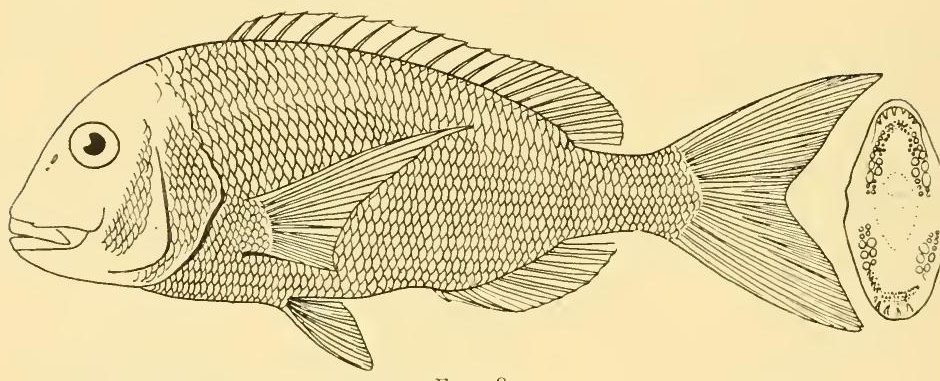

FIG. 287 .

Pagrus vulgaris, Cuv. and Val. Nat. size, $50 \mathrm{~cm}$.

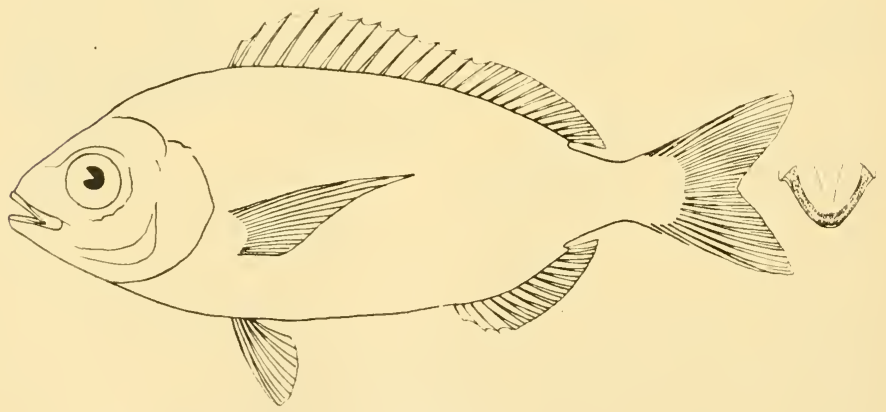

FIG, 288.

Pagellus centrodontus, Cuv. and Val. (After Smitt.)

\section{MULLIDÆ}

Mullus surmuletus, L. (red mullet), г910, Stations 20, 37, 39 (see Fig. 289). 


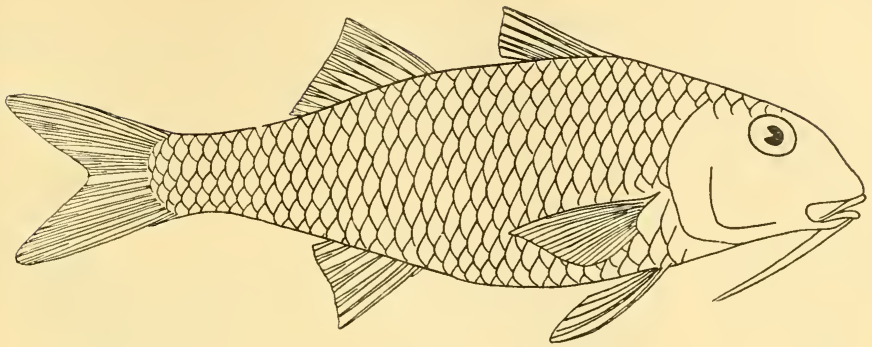

FIG. 289 .

Mullus surmuletus, L. Nat. size, $29 \mathrm{~cm}$.

\section{Caproide}

Capros aper, Lacép., I910, Stations I, 3, 20, 39 (see Fig. 290).

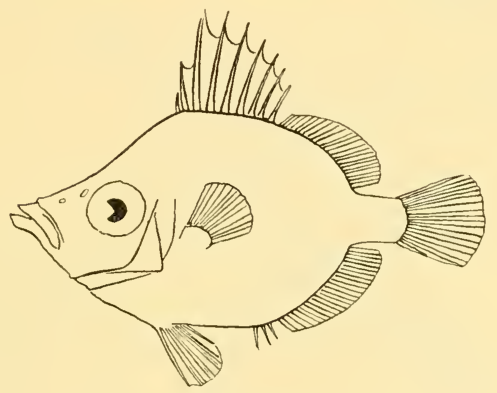

FIG. 290.

Capros aper, Lacép. Nat. size, $9 \cdot 3 \mathrm{~cm}$.

LABRIDÆ

Coris julis, L., 19ro, Station 37 (see Fig. 291).

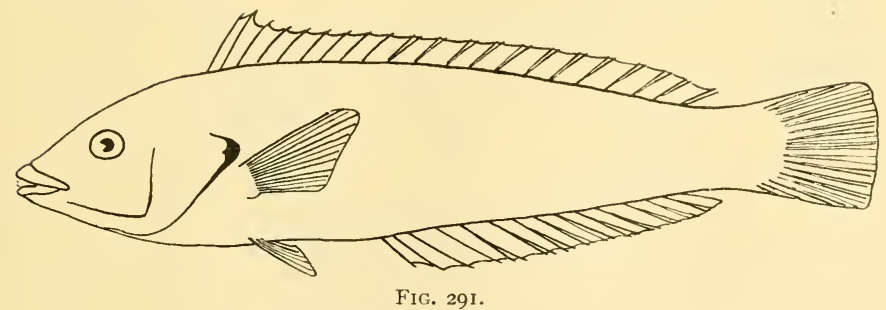

Coris julis, L. Nat. size, $18 \mathrm{~cm}$. 


\section{Division-SCOMBRIFORMES \\ Carangide}

Caranx trachurus, L. (horse-mackerel), 1910, Stations I, 3, I4, 20, 36, 39 (see Fig. 292).

Temnodon saltator, Cuv. and Val., 1910, Station $3^{6 .}$

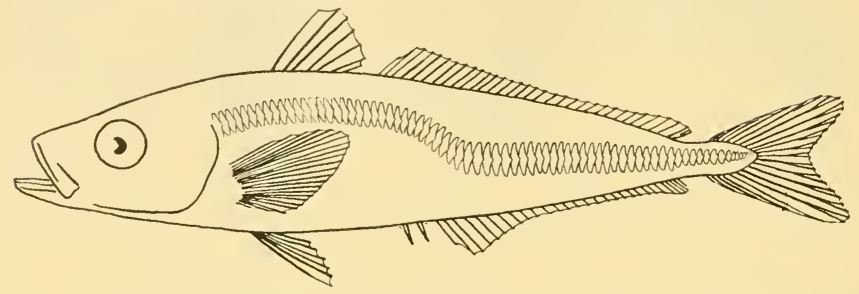

FIG. 292.

Caranx trachurus, L. Nat. size, II cm.
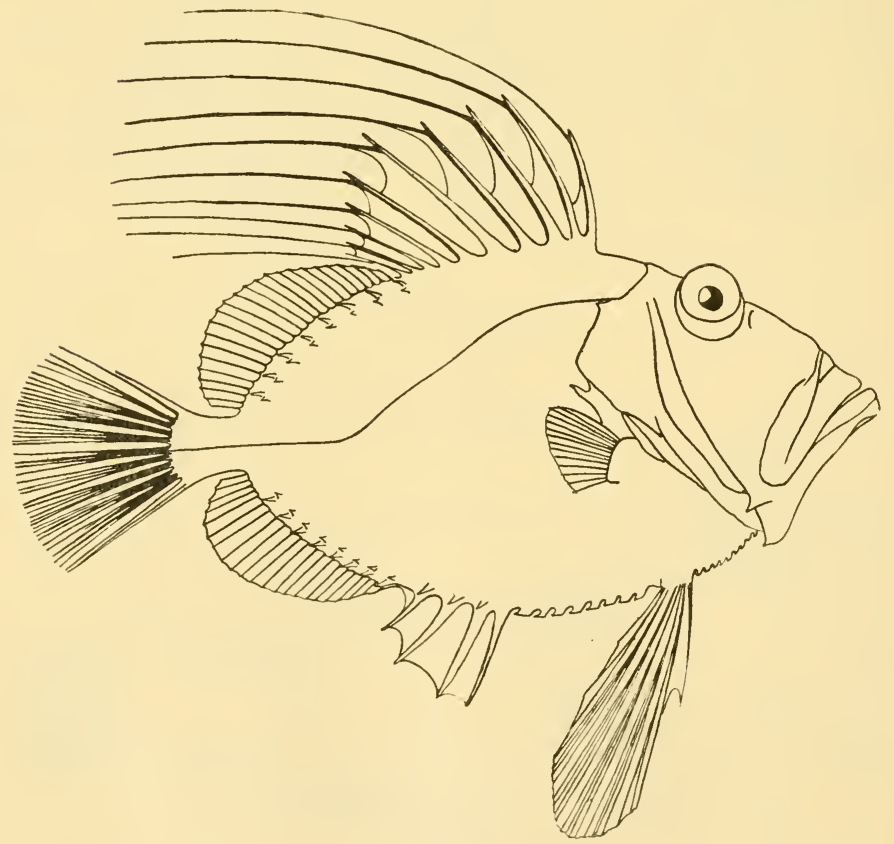

FIG. 293.

Zeus faber, L. Nat. size, $26 \mathrm{~cm}$. 


\section{TRICHIURIDE}

Lepidopus caudatus, Euphr., I910, Station 43 (Gomera).

\section{Division -ZEORHOMBI}

\section{ZEID\&}

Zeus faber, L. (dory), I910, Stations I, 20 (see Fig. 293).

\section{Pleuronectidi}

Hippoglossus vulgaris, Flem. (halibut), 1902, Faroe-Shetland channel; Faroe Bank, I 30 to 450 metres (see Fig. 294).

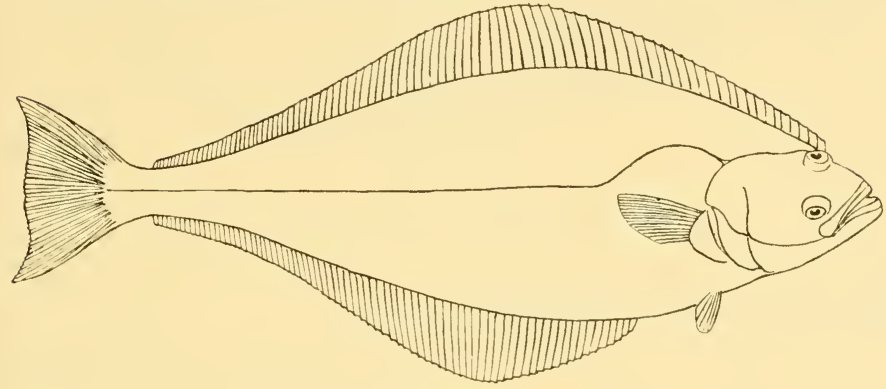

FIG. 294.

Hippoglossus vulgaris, Flem. (After Smitt.)

Pleuronectes limanda, L., I902, Faroe Bank, I 30 metres.

Arnoglossus laterna, Walb., I910, Station 3.

Arnoglossus lophotes, Günth., 1910, Stations 3, 37, $3^{8 .}$

Arnoglossus grohmanni, Bonap., i910, Station 38.

Zeugopterus megastoma, Donov. (megrim), I902, Faroe Bank, I30 metres; i9ic.

Stations I, 3, 96 (see Fig. 295).

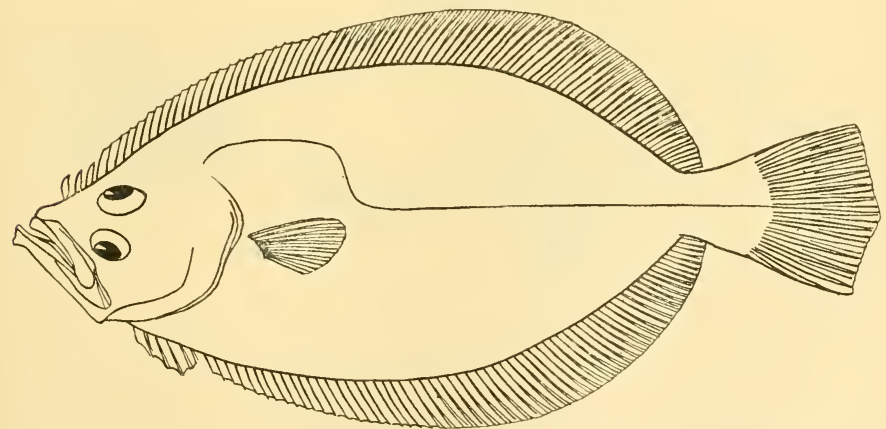

FIG. 295 .

Zeugopterus megastoma, Donov. (After Smitt.) 
Zeugopterus boscii, Risso, I9I0, Station 21.

Solea vulgaris, Quensel (common sole), I910, Stations 20, 38 (see Fig. 296).

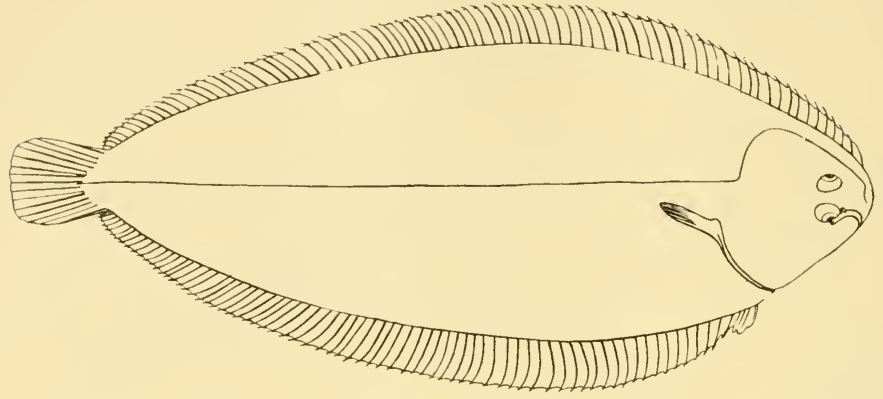

FIG. 296.

Solea vulgaris, Quensel. (After Cunningham.)

Solea lutea, Bonap., I910, Stations 36, 38.

Solea variegata, Flem., I910, Station 3.

\section{Division-SCLEROPAREI}

SCORPANIDE

Sebastes dactylopterus, Nilss., I 9 Iо, Station 2 I (see Fig. 297).

Scorpana scrofa, L., I910, Stations 37, 38 (see Fig. 298).

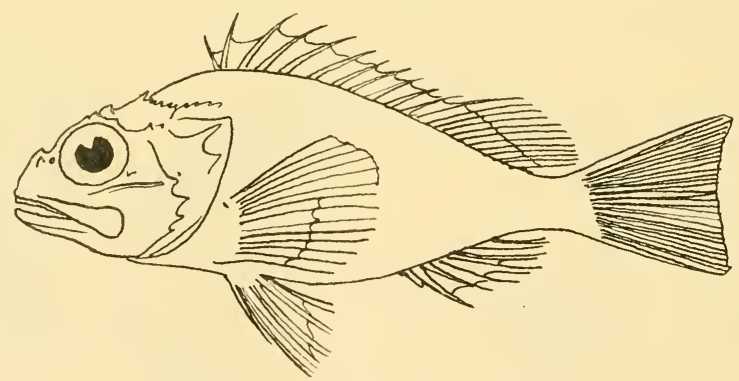

FIG. 297.

Sebastes dactylopterus, Nilss. (After Moreau.)

Scorpana ustulata, Lowe, I910, Stations 37, 39.

Scorpena cristulata, G. and B., I910, Station 4. 


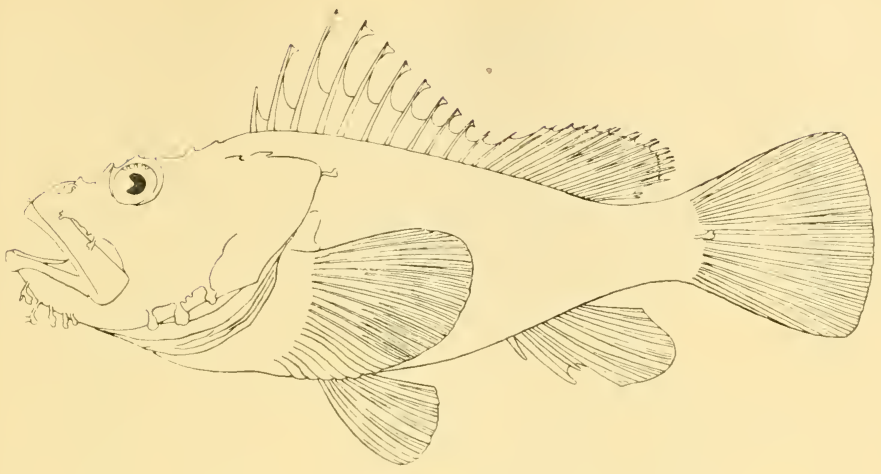

FIG. 298.

Scorpana scrofa, L. Nat. size, $48 \mathrm{~cm}$.

TRIGLIDÆ (Gurnards)

Trigla pini, Bl., I910, Stations 3, 20.

Trigla hirundo, Bl., I910, Station 20.

Trigla gumardus, L., I910, Stations I, 3.

Trigla cuculus, Bl., 1910, Station 20.

Trigla lyra, L., I910, Stations 3, 20 (see Fig. 299).

Trigla obscura, L., I9 9 o, Station 38.

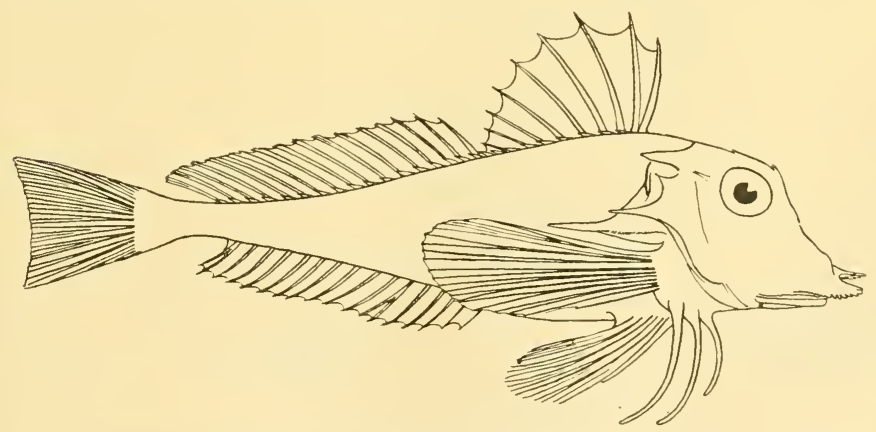

FIG. 299.

Trigla lyra, L. (After Day.)

Lepidotrigla aspera, Cuv. and Val. (Günth.), I9ı, Stations 20, 39.

Peristedion cataphractum, Cuv, and Val., I910, Stations 20, 39 (see Fig. 300). 


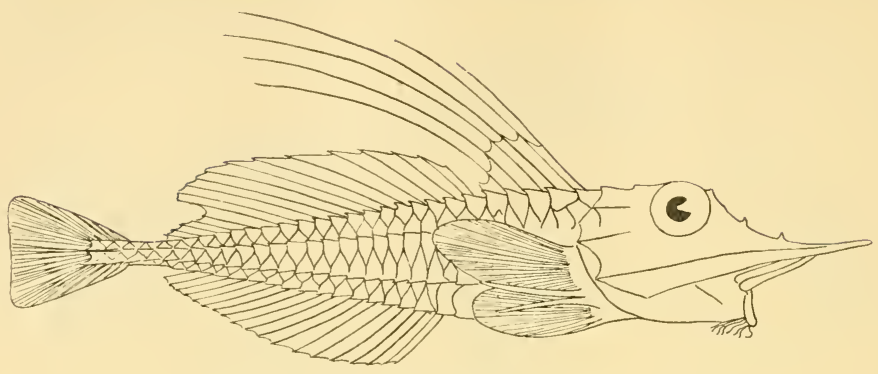

FIG. 300 .

Peristedion cataphractum, Cuv. and Val. Nat. size, $30 \mathrm{~cm}$.

Division-JUGULARES

TrachinidÆ (Weevers)

Trachinus draco, L., I9 Iо, Station 38.

Trachinus vipera, Cuv. and Val., I910, Station 14 (see Fig. 301).

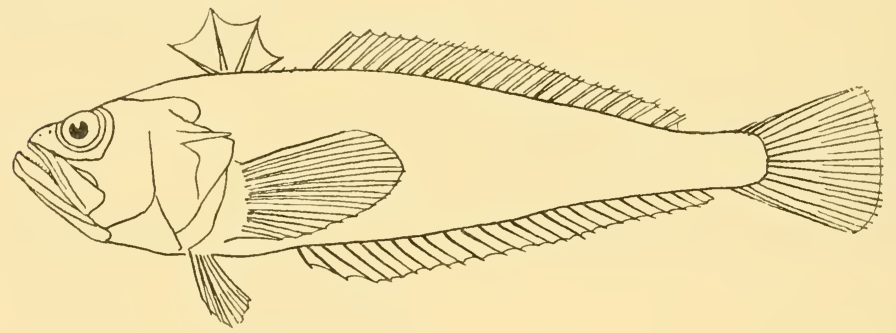

Fig. 30I.

Trachinus vipera, Cuv. and Val. (After Cuvier.)

URANOSCOPIDE

Uranoscopus scaber, L., I9ro, Station 37.

Callionymide

Callionymus maculatus, Bonap., I910, Station 3.

\section{ZOARCIDE}

Lycodes terra nova, Coll. (?), 1910, Station 70 (see Fig. 302).

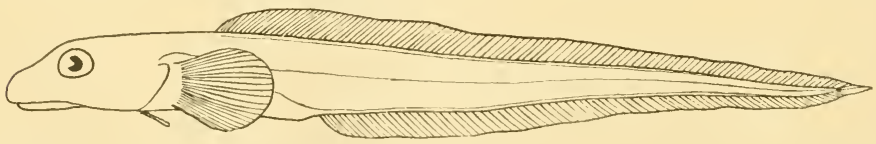

FIG. 302.

Lycodes terre nove, Coll. (?) Nat. size, I I cm. 


\section{Sub-Order-PEDICULATI}

LOPHIDE

Lophius piscatorius, L., I910, Station 3 (see Fig. 303).

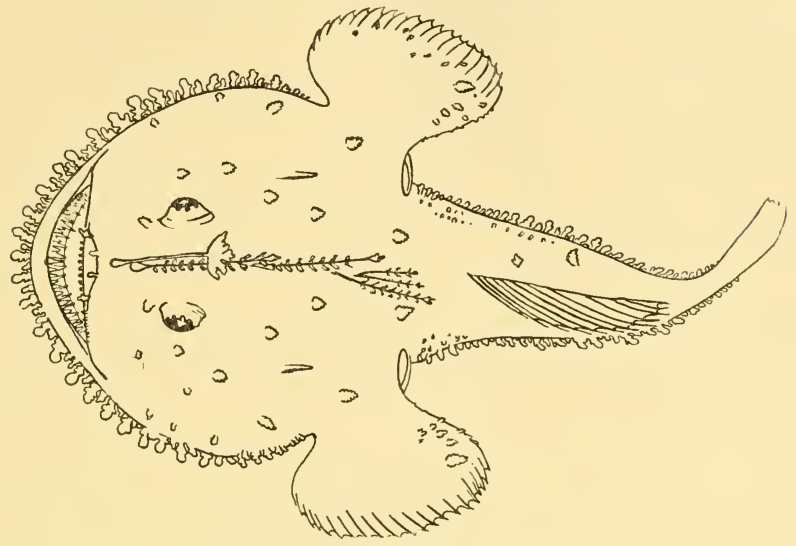

FIG. 303 .

Lophius piscatorius, L. (After Smitt.)

Malthide

Dibranchus hystrix, Garm., I910, Station 70.

\section{Sub-Order-PLECTOGNATHI}

TETRODONTIDE

Tetrodon spengleri, Bl., I910, Station 37 (see Fig. 304).

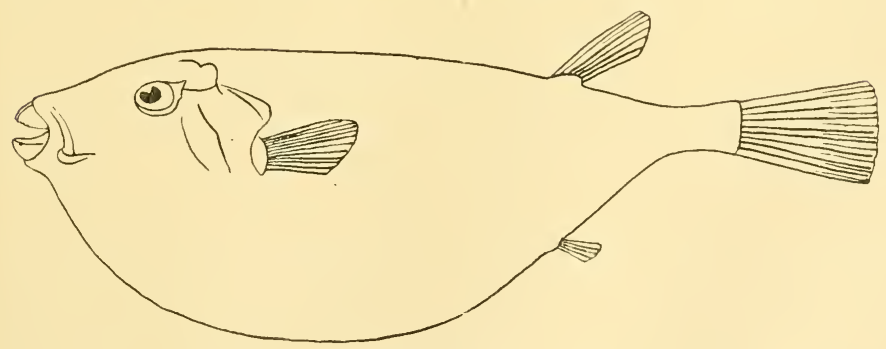

FIG. 304.

Tetrodon spengleri, Bl. (After Valenciennes.) 


\section{The Geographical Distribution of Bottom-Fishes in the North Atlantic}

\section{The Fishes of the Abyssal Plain ${ }^{1}$}

In Chapter IV. the areas of the ocean-floor at different depths are given, the percentages being as follows :-

Areas shallower than I00 fathoms $=7.0 \%$

" between 100 and $500 \quad, \quad=5.6 \%$ or $1.4 \%$ per 100 fathoms.

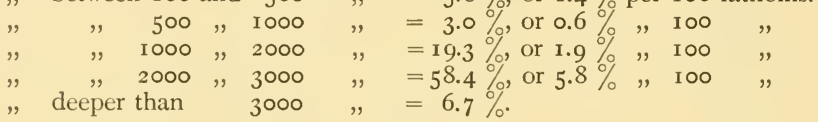

About two-thirds of the sea-floor is thus covered by more than 2000 fathoms (or 3600 metres) of water, forming an abyssal plain $90 \frac{1}{2}$ millions of square English miles in extent, or nearly half the surface of the earth.

What organisms inhabit this abyssal plain? When studying the literature of deep-sea expeditions, we must remember that all the hauls hitherto made in the abyssal area have been effected by means of trawls or dredges, which function not only while being towed along the bottom, but also while being lowered and raised, filtering the immense column of water from bottom

Difficulty in recognising what animals brought up in the trawl really lived at the bottom. to surface. Therefore only organisms like worms, molluscs, holothurians, starfishes, corals, and all sessile forms may safely be considered as having been captured at the bottom. In the case of crustaceans and fishes, however, it may be doubted whether they were really caught at the bottom or in intermediate waters. Lists recording the catches of deep-sea expeditions at great depths cannot therefore be accepted as representing the animal-life on the ocean-floor, for in such lists we often find forms which are now known to live quite close to the surface. Although we have now a much more precise idea of the vertical distribution of pelagic fishes than was previously possible, some surprising facts are occasionally brought to light. Thus, as mentioned in Chapter III., the "Michael Sars" at Station 48, between the Canaries and the Azores, brought up an Alepoceplualus in the large trawl towed at the bottom in 5000 metres, just as these fishes have been captured by most deep-sea expeditions; on the trawl-rope a small tow-net was fixed in

1 The mean sphere level, which lies at a depth of about 1700 fathoms, has hitherto been regarded as the depth at which the abyssal plain of the ocean commences, but it will be seen that Dr. Hjort places this depth at 2000 fathoms, - J. M. 
such a way that it was towed about Iooo metres above the bottom, and in this net an Alepocephalus was also captured.

Such facts warn us against hasty conclusions. Many fishes may, like the fishes in the Norwegian Sea (Gadidæ, Sebastes), occur in midwater above considerable depths as well as on the coastal banks and the continental slopes. A single record of a species from intermediate waters does not necessarily entitle us to consider the species as entirely pelagic. As in most biological questions, we have to judge from the available evidence, and, in dealing with the captures of fishes by deepsea expeditions ${ }^{1}$ in depths exceeding 2000 fathoms (3600 metres), I have endeavoured to eliminate all those species which are apparently pelagic, having been frequently captured at intermediate depths. In this way I have attempted to ascertain Fishes from. how many species and individuals have really been captured on the bottom in the bottom of the abyssal plain of the oceans, and the result is 2000 fathoms. given in the following table, which comprises 35 individuals belonging to 2 I species in all :-

1 The excellent lists given by Brauer in his Report on the Deep-Sea Fishes of the "Valdivia" Expedition, the list by Vaillant in his Report of the French deep-sea expeditions, Garman's Report of the "Albatross" expeditions, Goode and Bean's Oceanic Ichthyology', and Murray's splendid Summary of the "Challenger" Expedition, have greatly facilitated this task. 
Botton-Fish taken at Depths exceeding 2000 Fathoms (3600 metres).

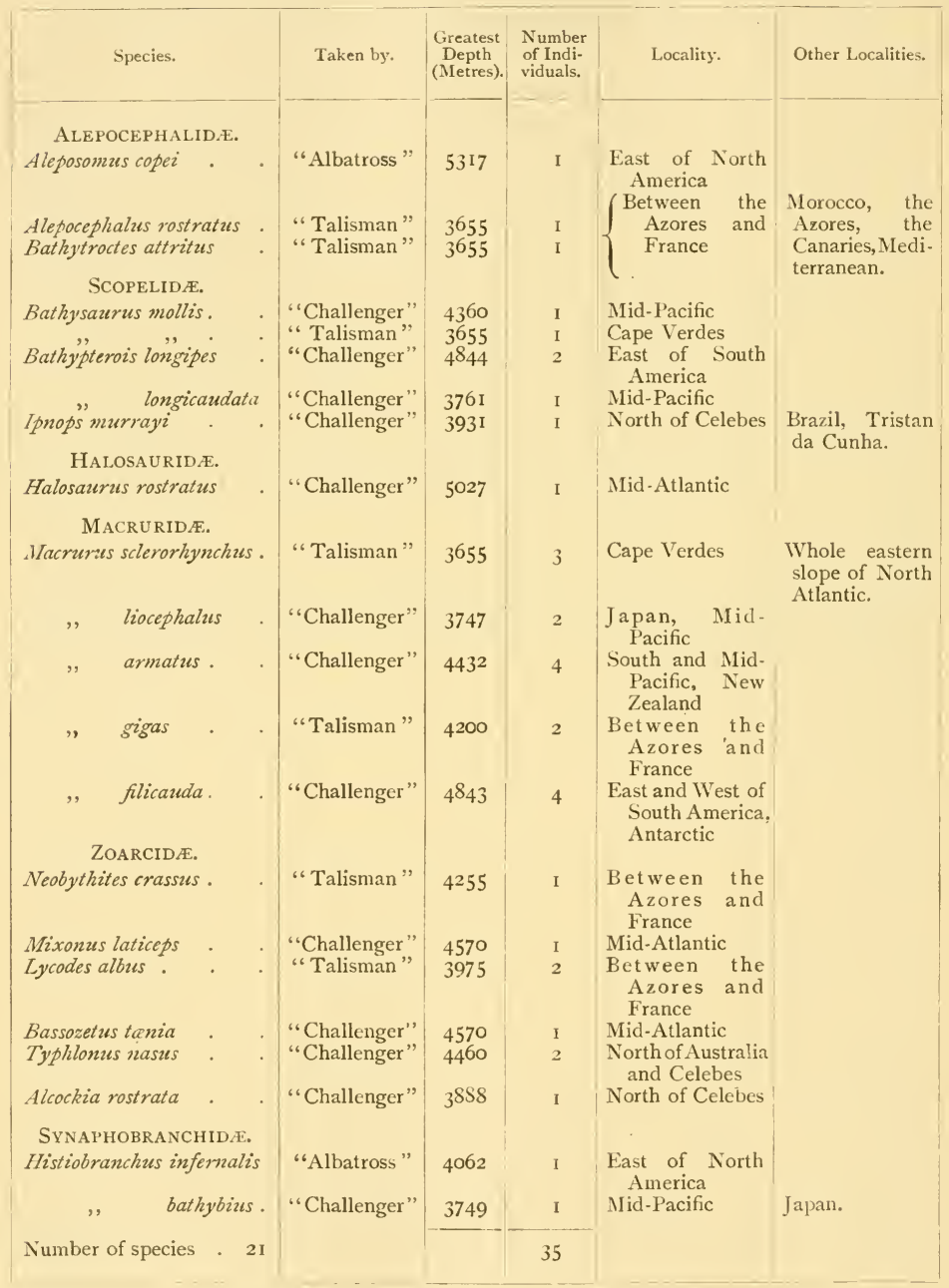

It is doubtful whether ail these came from the bottom. Thus the three Alepocephalidæ, the six Scopelidæ, the one 
Halosaurus, and the two Synaphobranchidre may be suspected of pelagic habitat. Less doubt may be entertained about the I 5 Macruridæ and the 8 Zoarcidæ, and the probability is that these (some 20 individuals) constitute the total result of the attempts of all the deep-sea expeditions to capture bottom-fish on the abyssal plain beyond the 2000-fathoms line. Most of these fishes were taken by the "Challenger" in 57 hauls with the dredge or trawl in depths exceeding 2000 fathoms. In these hauls 22 individuals were captured, and the French expeditions caught I I bottom-fish in eight hauls, giving an average of I fish to two hauls.

The 35 individual fishes enumerated belong to 2 I species, I 5 genera, and 6 families. On the average not even two individuals of each species have been captured. The genus Macrums preponderates, I 5 of the 35 individuals belonging to this genus, and of deep-sea fishes the Macruridæ may most safely be regarded as bottom-dwellers. The impression of scantiness conveyed by these facts, only one or two individuals of each species of fish being known from the immense area of the abyssal plain, agrees with the scarcity of the lower orders in the same barren region. A perusal of the "Challenger" Reports astonishes us by the fact that large numbers of species of lower animals are known only from a single locality, and often from one solitary specimen.

These facts suggest that the bottom-fishes of the abyssal region are very local in their occurrence, but, considering the small number of individuals recorded, it seems risky to come to that conclusion, as the want of material for comparison tends to weaken our power of discriminating between the species. In certain problems of geographical distribution, the question may be vital whether two individual fishes caught in widely separated parts of the world are to be referred to one species or not. The systematic study of these deep-sea species leaves a strong impression that many of them differ very slightly from one another. Thus, for instance, my collaborator, Mr. E. Koefoed, and myself have not been able to convince ourselves that there is any specific difference between the two species, Macrurus armatus and $M$. gigas, mentioned in the above table, and this circumstance alone leads to far-reaching conclusions, $M$. armatus having been caught in the Pacific and $M$. gigas in the North Atlantic (see Fig. 308).

The collections of the "Michael Sars" throw much new light on these questions. In the following table I give the

Wide distribution of deep-sea forms.
Scantiness of animal life at great depths. 
distribution of the most important forms taken in the abyssal plain and the bordering intermediate zone. The localities of special importance are the Southern Ocean for Halosauropsis macrochir, and the Pacific for Macrurus armatus.

\begin{tabular}{|c|c|c|}
\hline \multirow{2}{*}{ Species. } & \multicolumn{2}{|r|}{ Localities where Captured. } \\
\hline & $\begin{array}{c}\text { By the "Michael } \\
\text { Sars." }\end{array}$ & By other Expeditions. \\
\hline 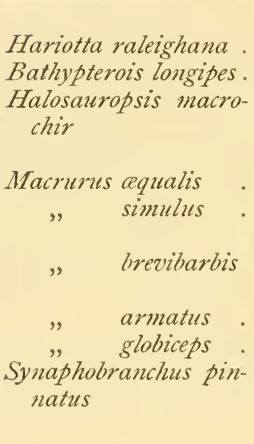 & $\begin{array}{c}25,35,4 \mathrm{I} \\
53,88 \\
\text { I0, } 88 \\
\text { I0, } 35,53,88 \\
4 \mathrm{I}, 88 \\
24,4 \mathrm{I}, 53,88 \\
95, \text { IOI }\end{array}$ & $\begin{array}{l}\text { Off the east coast of North America. } \\
\text { Off the east coast of South America. } \\
\text { Between South Africa and Kerguelen, } \\
\text { off east coast of North America, } \\
\text { Gibraltar, Morocco, the Azores. } \\
\text { From Faroe Islands to Cape Verdes. } \\
\text { Off the east coast of North America, } \\
\text { Denmark Straits. } \\
\text { Off the east coast of North America, } \\
\text { Denmark Straits. } \\
\text { Pacific. } \\
\text { Bay of Biscay to the Azores. } \\
\text { Japan, Philippines, Arabian Sea, off } \\
\text { east coast of North America, Faroe } \\
\text { Islands to Cape Verdes, off Brazil. }\end{array}$ \\
\hline
\end{tabular}

Besides these we caught at Station 48 an Alepocephalus and the new form Bathymicrops regis (see Fig. 305), which may both be pelagic.

Excepting the Hariotta, which has only been taken at somewhat lesser depths (Station 35, 2603 metres), all these species

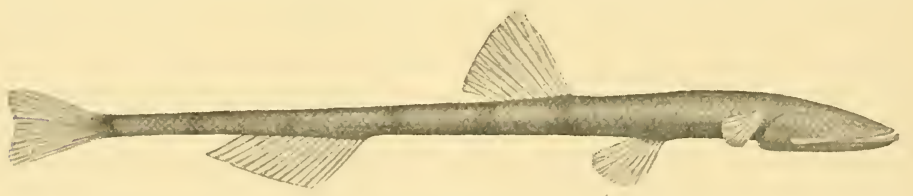

FIG. 305.

Bathymicrops regis, n.g., n.sp. Nat, size, $1 \mathrm{I} \mathrm{cm}$.

belong to the genera recorded by previous expeditions from the abyssal plain. Of the nine species, three (Halosauropsis macrochir, Macrumes armatus, and Synaphobranchus pinnatus) have previously been taken in other oceans. Of special interest is the fact that $M$. armatus has been found in so many new 
localities, and this species is now known to have the widest distribution on the abyssal plain, and on this only. Another

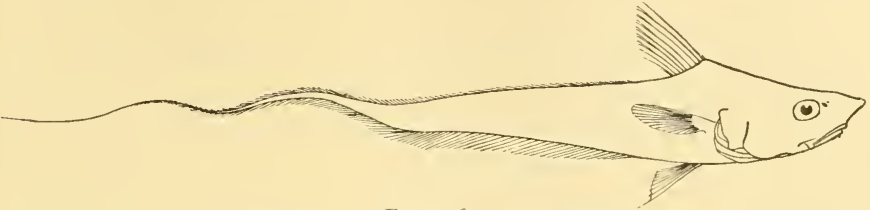

FIG. 306.

Macrurus (Lionurus) filicauda, Günth. (After Günther.)

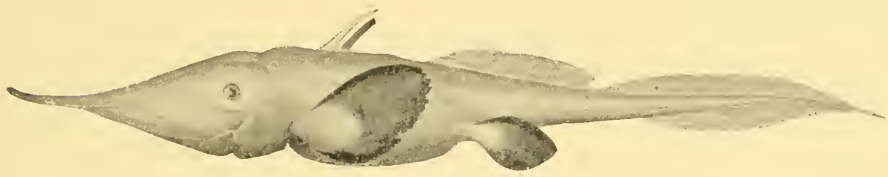

FIG. 307 .

Hariotta raleighana, G. and B. Nat. size, $30 \mathrm{~cm}$.

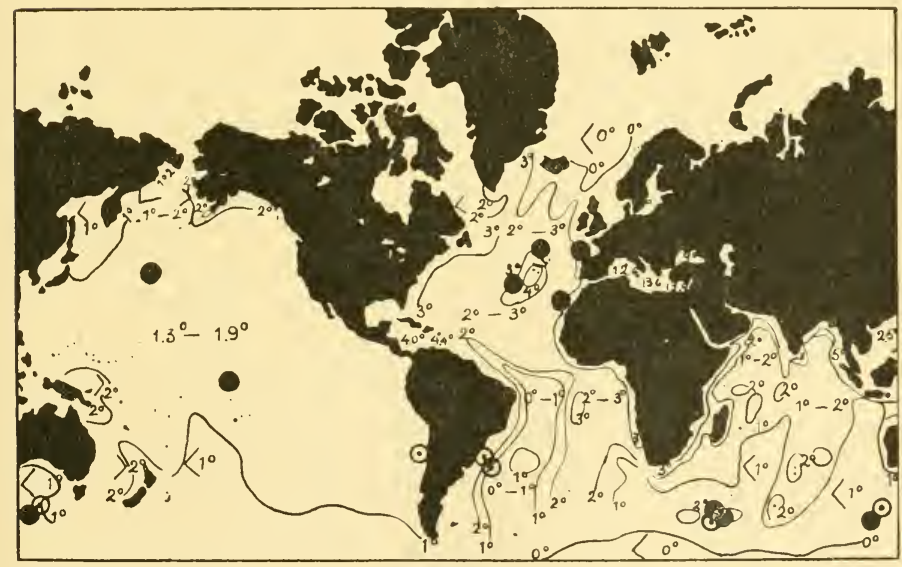

FIG. 308.

Chart showing the localities where Macrurus armatus $\odot$ and 1 . filicauda $\odot$ have been taken. Temperatures in Centigrade.

species, $M$. filicauda, also shares this wide distribution (see Fig. 306, and Chart, Fig. 308).

Highly interesting also is the fact that no less than four of these deep-sea forms, viz. Hariotta raleighana (see Fig. 307), 
Species found on both sides of the North

Atlantic.

Abyssal forms have a considerable vertical distribution.

Bathypterois longipes, Macrurus simulus, and Macrurus brevibar$b i s$, are now known from both sides of the Atlantic. The three last-mentioned species were also caught near the Azores, and we must therefore conclude that their habitat stretches right across the Atlantic. Macrumus aqualis was previously known only from the eastern side, Macrumus globiceps also from the Azores, and during the cruise of the "Michael Sars" it was taken a little north of the latter locality (Station 88). If the above table is compared with the list of "Michael Sars" stations, it will be noticed that these fishes from the abyssal region have a considerable vertical distribution, occurring also on the continental slopes.

Sir John Murray has, in his excellent "Summary," given lists recording all the different animals captured at each of the "Challenger" stations, and in a final chapter he endeavours to lay down some of the most important laws governing the distribution of animals in the ocean. At twenty-five stations where the depth exceeded 2500 fathoms the "Challenger" took with dredge and trawl 600 individual animals of all kinds ; this gives 24 individuals per haul. Now, firstly, many of these were pelagic (most of the crustaceans and some of the fishes), and secondly, many of them were very small (hydroids, bryozoa). "Challenger" As examples I give a list of the bottom-forms (protozoa hauls in the deep water of the North Atlantic. excluded) obtained at some of the "Challenger" stations between the Canaries and the West Indies.

Station 5. Depth, 2740 fathoms. Three living mussels (Leda, Limopsis, Arca), and some dead shells.

" I3. Depth, I900 fathoms. Some bryozoa and brachiopods ( io Terebratula).

14. Depth, i950 fathoms. Some bryozoa.

" 16. Depth, 2435 fathoms. Sharks' teeth (Oxyrhina, Lamna), valves of Scalpellum, 2 mussels (Arca).

"20. Depth, 2975 fathoms. Dredge came up half full of clay, containing half a dozen tubes of serpulids, some of these with the worms living.

" 6r. Depth, 2850 fathoms. Trawl captured some ophiuridæe (Ophioglypha), 2 holothurians, 7 Scalpellum.

" 63. Depth, $275^{\circ}$ fathoms. Trawl captured some fragments of worms, 3 Scalpellum, I fish (Halosaurus rostratus).

This list is representative of most deep-sea hauls, and their uniform poverty is only broken by rare exceptions, as in a noteworthy haul taken by the "Challenger" in the Pacific, between Japan and Hawaii, at Station 244, in 2900 fathoms, which gave :- 
I sponge, I antipatharian, 6 actinians, 2 corals, I hydroid colony, 2 crinoids, 3 starfish, I sea-urchin, 5 holothurians, many worms, 7 or 8 mussels, and a brachiopod.

This is, as far as I have been able to ascertain, the richest haul in depths exceeding 2000 fathoms on record, but nevertheless the impression created by the results of the many deepsea hauls of the "Challenger" is that animal life is poorly developed in the abyssal region.

During the cruise of the "Michael Sars" I therefore considered it an interesting object to ascertain if our large otter trawl could catch more, and possibly larger, animals on the abyssal plain. As stated in Chapter III., technical success attended our attempts at great depths, and the catches were certainly somewhat larger than those previously taken in the North Atlantic, but nevertheless they were very poor, as shown by the following list :-

Station 10. Bay of Biscay, ${ }_{2567}$ fathoms (4700 metres). Trawl dragged for five hours gave: Some sponges, 3 actinians, some holothurians (Elpidia), 2 starfish (Frugella, Dorigona), a few worms, ascidians, and bryozoa, I gasteropod, and 2 fishes, presumably bottom-fish: Macrurus armatus (Hector), I individual $70 \mathrm{~cm}$. in length, and M. brevibarbis (G. and B.), I individual $25 \mathrm{~cm}$. in length.

Same Station. Duration of haul, $3^{\frac{1}{2}}$ hours. Cod-end full of ooze, and in the meshes 3 ophiurids (Ophiopleura, Ophioglypha, Ophiocten?); washing the ooze produced 4 actinians (one of them growing on a hermit crab), I holothurian (Elpidia), worms in clay tubes, and some gasteropods.

Station 48. Between the Canaries and the Azores, over 5000 metres. Duration of haul, $4 \frac{1}{2}$ hours. Trawl contained a large quantity of ooze, the washing of which produced : 30 pieces of pumice-stone, I shell of Argonauta, I ear-bone of a whale, 2 sharks' teeth (Carcharodon and Oxyrhina), ro large shells of pteropods (Cavolinia), I umbellularian (Umbellula gïntheri), I sertularian, 2 holothurians (Latmogone violacea, Elpidia sp.). Besides these there were 3 pelagic fishes (Malacosteus indicus, Argyropelecus sp., and a Leptocephalus), and 3 fishes which may be surmised to have lived at the bottom (Alepocephalus, a new genus related to Ipnops: Bathymicrops regis, see Fig. 305 , and a specimen not yet determined).

These hauls of the "Michael Sars" thus entirely confirm the idea of the poverty of the abyssal plain, a confirmation especially valuable on account of the size of the trawl employed and the technical success attending its use in great depths. The proof afforded by these results of the " Michael Sars," like that from all other expeditions, suffers from the inherent weakness attached to all negative proofs. The barrenness of the abyssal plain may be only apparent, owing to imperfections in 
the methods of capture, the technical difficulties of operating dredges and trawls at great depths being of considerable moment, but I do not attach great importance to this, because the same appliances, when used in deep water on the continental slope, gave large catches.

If we fix the boundary of the abyssal plain at the 2000-

Hauls in depths of I 500 to 2000 fathoms. fathoms line, we may consider the area between the 2000and I500-fathoms lines as an intermediate zone between the abyssal plain and the continental slope. In this zone the "Challenger" made 25 hauls with trawls and dredges, with the result that three times as many fishes per haul, and twice as many invertebrates, were captured as on the abyssal plain. The "Michael Sars" made 3 hauls with the trawl in such depths, which, compared with our results from the abyssal plain, are very interesting, and invite inspection of their details :-

Station 35. South of the Canaries, 1424 fathoms (2603 metres). Trawl dragged two hours. Result of haul: Many silicious sponges (including Hyalonema), hundreds of holothurians, large prawns (Benthesicymus, n.sp.), I 8 bottom-fish (9 Macrurids, I Bathysaurus, 2 Halosauropsis, 5 Alepocephalus, I Hariotta).

" 53. South of the Azores, I430 to I 570 fathoms (26I5 to 2865 metres). Trawl dragged three or four hours. Result of haul : 2 large and many small sponges, 3 mussels, 5 cirripeds (Scalpellum), 30 large prawns (Aristeopsis), 15 hermit crabs, 5 Pentacheles, I large white decapod (Munidopsis, n.sp.), 500 holothurians, 39 bottom-fishes, ( 7 Macrurus, 5 Halosauropsis, 2 Benthosaurus, 2 Bathysaurus, 2 Bathypterois, 6 Alepocephalus, 5 Synaphobranchus).

" 88. North of the Azores, I 700 fathoms (3120 metres). Result of haul : a great number of holothurians, sea-urchins, starfish, ophiurids, some crustaceans (Polycheles, Munidopsis, Parapagurus), 2 I bottomfishes ( 7 Macrurus, I Bathysaurus, 3 Histiobranchus).

These hauls plainly show that the appliances of the "Michael Sars" were excellently suited for the capture of bottom organisms, fish as well as invertebrates. Indeed in one single haul (Station 53) we caught nearly as many individual bottom-fishes as the "Challenger" captured in its twenty-five hauls in depths between I 500 and 2000 fathoms. I think we are justified in concluding that the vast difference between our captures on the abyssal plain and these three hauls in 2600 to 3200 metres represents an actual difference in the abundance of animal life in the two regions. The fauna of the abyssal plain must be very poor compared with the more abundant life met with, at all events in the Atlantic, in depths of about 3000 metres and less, where the fauna is infinitely richer in number of species as well as in number of individuals. Perhaps the most striking contrast is 
obtained when we consider the enormous difference in the number of animals brought up by the trawl from the two regions in question.

\section{The Fishes of the Continental Slopes}

The angle of the slopes rising from the abyssal plain towards the coast varies in different parts of the globe, being in some places steeper than in others. The percentages of the ocean-floor given on P. I 32 show that the steepest angle occurs between 500 and 1000 fathoms, while the slope between 1000 and 2000 fathoms is much steeper than in the upper 100 fathoms. Between the shore-line and the roo-fathoms line the angle of the slope is low, and this area is regarded as a special region, generally termed the coast-plateau, or the continental shelf or platform (see Fig. I44, p. I 98). The fishermen's term for this section of the sea-bottom is "the banks," and the narrow intermediate belt between the coast-plateau and the continental slope is by the fishermen termed "the edge."

One of the objects of the "Michael Sars" Expedition was to make a number of trawlings on the continental slopes of the Atlantic in different latitudes, in order to study the fish-fauna at different depths and under varying conditions. We succeeded in making quite a number of good hauls, and, taken together with the captures of other expeditions (especially those of the French deep-sea expeditions), they give a good representation "Michael Sars " hauls on the continental slope. of the different fish-faunas. Our stations along the slope may be divided into three groups :-

I. West of Great Britain (including some hauls from localities south of the Faroe Islands in the year 1902).

2. Spanish Bay, west of Morocco.

3. South of the Canaries.

First of all, we will consider the number of fishes caught in these hauls at different depths, as recorded in the following table, and next we will investigate the vertical and horizontal distribution of the species :- 


\begin{tabular}{|c|c|c|c|c|c|c|c|c|}
\hline \multicolumn{3}{|c|}{ West of Great Britain. } & \multicolumn{3}{|c|}{$\begin{array}{l}\text { Spanish Bay, west of } \\
\text { Morocco. }\end{array}$} & \multicolumn{3}{|c|}{ South of the Canaries. } \\
\hline Station. & $\begin{array}{c}\text { Depth } \\
\text { (metres). }\end{array}$ & $\begin{array}{c}\begin{array}{c}\text { Number } \\
\text { of }\end{array} \\
\text { Fishes. }\end{array}$ & Station. & $\begin{array}{c}\text { Depth } \\
\text { (metres). }\end{array}$ & $\begin{array}{c}\text { Number } \\
\text { of } \\
\text { Fishes. }\end{array}$ & Station. & $\begin{array}{c}\text { Depth } \\
\text { (metres). }\end{array}$ & $\begin{array}{c}\text { Number } \\
\text { of } \\
\text { Fishes. }\end{array}$ \\
\hline I & 146 & 308 & 20 & $14 \mathrm{I}$ & I6I & $\cdots$ & $\cdots$ & $\cdots$ \\
\hline 3 & 184 & $33^{2}$ & $\cdots$ & $\cdots$ & $\ldots$ & $\ldots$ & $\ldots$ & $\ldots$ \\
\hline Faroe slope & $83 I$ & 300 & $2 \mathrm{I}$ & 535 & I 17 & 39 & 280 & about 300 \\
\hline 4 & 923 & 332 & $\cdots$ & $\cdots$ & $\cdots$ & $\cdots$ & $\cdots$ & ... \\
\hline Faroe slope & 1060 & 76 & $\ldots$ & $\ldots$ & $\cdots$ & $\cdots$ & $\cdots$ & $\cdots$ \\
\hline, & 1073 & I 27 & 23 & I 2 I 5 & 77 & $4 I$ & I 365 & about 80 \\
\hline 95 & I 797 & 82 & 24 & I 615 & $3^{2}$ & $\ldots$ & $\ldots$ & ... \\
\hline IOI & 1853 & 90 & 25 & 2055 & 29 & 35 & 2603 & I 8 \\
\hline
\end{tabular}

The French deep-sea expeditions made in all Io6 hauls at different depths down to 5000 metres, mostly in the same part of the Atlantic examined by the "Michael Sars," the fishing results being very interesting :-

\begin{tabular}{|c|c|c|c|c|c|c|c|c|c|}
\hline 4 & between & & nd & 100 & es gave & 224 & es, & $5^{6}$ & haul. \\
\hline 9 & , & 100 &, & 200 & , & 323 & $"$ & 36 &, \\
\hline 6 & , & 200 & " & 500 & , & I 275 & " & $2 \mathrm{I} 2$ & ," \\
\hline 28 & " & 500 & , & 1000 & " & 1044 & , & 37 & , \\
\hline 29 & " & 1000 & " & 2000 & ", & 905 & , & 31 & $"$ \\
\hline 20 & ", & 2000 & " & 2900 & ", & I I 5 & , & 6 & " \\
\hline 4 & $"$ & 2995 & $"$ & 4000 & $"$ & $6 I$ & ", & 15 & , \\
\hline 6 & " & 4000 & " & 5000 & " & 10 & " & 2 & " \\
\hline
\end{tabular}

Number of fishes at various depths.

Both these tables show clearly that the number of bottomfish decreases from land towards the abyssal plain. This decrease is, however, far from uniform. Even down to 500 fathoms the "Michael Sars" obtained just as many fishes as on the bank, viz. about 300 fishes in one haul, and these were not small. At the same time the trawl was also crammed with other animals. In depths greater than 500 or 600 fathoms we no longer obtained anything like that number, but even down to I 000 fathoms (i 853 metres) we still got as many as 90 fishes in one haul. Beyond Iooo fathoms fishes seem rapidly to decrease in number, for neither the "Michael Sars" nor the French expeditions got more than a score, or exceptionally nearly two score of fishes in depths exceeding 1000 fathoms. The richest haul of fishes known from a great depth is one taken by the "Michael Sars" at Station 53, in 2865 metres, viz. 39 fishes, of which some were large. 
If we now consider what species of fish we obtain in our trawlings along the continental slopes, we immediately recognise different strata, each characterised by its peculiar fish-community. It will be of interest to define the extent of these communities by means of the species found most abundantly at different depths, though there are no sharp limits between them, as it is difficult to find even two kinds of fish (or other animals) having in every respect the same distribution. It is thus obvious that on the borders of the different communities recognised by us, we shall find species belonging to neighbouring communities.

We have already mentioned that the "Michael Sars" caught some of the abyssal species along the continental slopes, and the French deep-sea expeditions also gathered similar information. We may then first consider the bathymetrical range of some of these peculiar bottom-fish living at the greatest depths :-

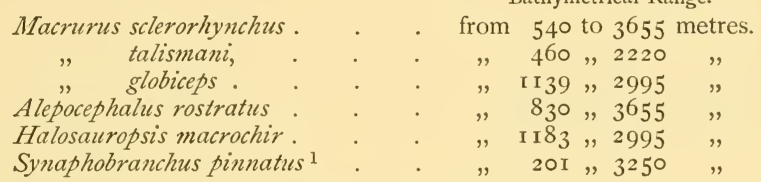

We see here a group of species which may occur in very deep water as well as along the continental slope; the upper limit seems to be about 800 or 900 metres (about 450 fathoms), although stray individuals have been caught in somewhat shallower water.

The main body of the fishes peculiar to the continental slopes consists, however, of other species, which have not been captured in the abyssal plain, though they have a wide distribution, like the denizens of the abyssal plain, and resemble them also in shape. Such are the following :-

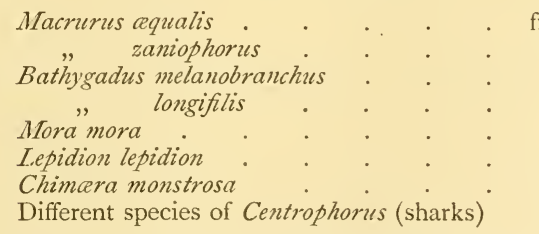

Bathymetrical Range. from 460 to 1319 metres.

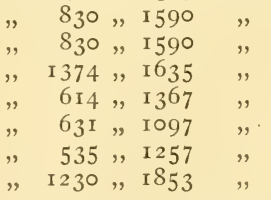

1 The fact that this form has been taken within such wide limits must, in my opinion, give rise to the suspicion that it may really be caught in midwater; perhaps it never actually occurs in the abyssal area. 
These appear to be representatives of the fauna peculiar to the steepest part of the slope, from 700 to I 500 metres (400 to 800 fathoms).

The "Michael Sars" captured on the Atlantic slope, in depths between 800 and 2600 metres, over I 200 fishes, the relative abundance of the different forms being as follows :569 fishes, or about 47 per cent, belonged to Macruridæ.

\begin{tabular}{|c|c|c|c|c|c|}
\hline 393 & $"$ & 33 & ", & $"$ & $\begin{array}{l}\text { Gadidæ (Mora, Antimora, Lepidion, } \\
\text { Halargyreus). }\end{array}$ \\
\hline 66 & ", & 6 & , & , & Alepocephalidæ. \\
\hline 4 & $"$ & 4 & $"$ & $"$ & $\begin{array}{l}\text { Sharks (Centrophorus, } \\
\text { Etmopterus). }\end{array}$ \\
\hline
\end{tabular}

The remaining io per cent consisted of fish represented by only a few individuals (Notacanthus, rays, and others).

In about 400 to 500 fathoms (700 to 900 metres) we meet with forms having their lower limit in this region, which live in greatest abundance at 200 to 300 fathoms. As instances may be mentioned :-

Sebastes dactylopterus

Motella macrophthalma

Hoplostethus mediterraneum

\section{Bathymetrical Range.} from 75 to 975 metres.

$\begin{array}{lrr}, & 146, & 987\end{array}$,

In about 300 to 350 fathoms ( 550 to 650 metres) we meet with real representatives of the fauna of the coast banks. The following are some of these species, found in deep water by the French expeditions, with their bathymetrical range :-

Brauer on the distribution of the Macruridæ.
Bathymetrical Range.

Merluccius mulgaris (hake)
Gadiculus argenteus
Zeugopterus megastoma
Dentex macrophthalmus.

Merluccius vulgaris (hake) Zeugopterus megastoma

In these depths we thus find in the same hauls representatives of two entirely different faunas, and we must therefore consider this region as an intermediate belt.

Before attempting to describe the fauna of the coast banks, I wish to discuss some questions of general importance arising from the examination of animal life on the continental slopes.

In his report on the deep-sea fishes of the "Valdivia" Expedition, Brauer gives a very able and interesting review of the general laws governing the geographical distribution of these fish, particularly the Macruridæ. While the genus Macrurus is found in all the oceans, he considers most of the species to be local. Of 16 species of Macruridæ he has so far 
only found one ( $M$. parallelus) which is common to the Indian, Atlantic, and Pacific Oceans. All the r9 species taken at the Sandwich Islands are known only from that locality. Some species, like $M$. armatus and $M$. filicauda, have a wide distribution, but these are exceptions from the rule. Thus, in his opinion, there are no species common to both sides of the Atlantic. The only exceptions then known ( $M$. simulus, $M$. goodei, $M$. berglax, and $M$. mpestris) are explained by him as being due to these species following the cold Labrador current from their normal habitat, the eastern side of the ocean.

Brauer attempts to explain the peculiar distribution of the Macruridæ. He considers that the Macruridæ have originated from coast-fishes, and only commenced to migrate towards the abyssal region after a great variety of coast-forms had been developed. "The fact," he observes, "that only a few species have penetrated into the abyssal plain, while the main body of the species still remains on the slope, tends to show that in most cases the migration towards the abyssal plain is still going on, that it is very slow, and that it has not yet reached the borders of the abyss; or else it indicates that the abyssal plain tends to limit further distribution, acting as an almost insurmountable obstacle."

We have seen that all the deep-sea expeditions, prior to the "Michael Sars," captured only 35 individual "bottom-fishes," and that these belonged to twenty-one species. Our present knowledge must therefore be very imperfect. We have not yet learnt to fish to perfection at 2000 or 3000 fathoms, and we have as yet made too few fishing experiments at such depths. The short cruise of the "Michael Sars" in the Atlantic has essentially altered Brauer's ideas of the distribution of deep-sea fishes, and it appears desirable to give the interesting question raised by him a fresh trial, in view of the large amount of information which we now possess regarding the migrations of many fishes. When, for instance, we find the cod of the Norwegian Sea at one season spawning near the coasts of Norway, at another season migrating to Spitzbergen, or to the slopes of the coast-plateau, we must conclude that fishes may undertake horizontal as well as vertical migrations of enormous extent in a short space of time. Seeing that Macrurus sclerorhynchus has the enormous bathymetrical range of from 540 to 3655 metres, we can hardly suppose that the distribution of deep-sea fishes down the slope and on the abyssal plain could have been prevented by "lack of time." We have 
every reason to believe that the physical conditions in these depths have been essentially the same at least for thousands of years.

We possess, of course, no information as to the time required for the distribution of a species into oceanic depths. In shallow waters we know quite well that new physical conditions may permit a species to migrate into new areas and to multiply enormously in a short space of time (as an instance may be mentioned the immigration of cod into the Liimfjord after the North Sea broke through at Thyboroen). At all events it seems reasonable, first of all, to look for factors in operation at the present day, the influence of which may be investigated, before we fall back on the hypothetical conditions prevailing in a previous geological period.

In his "Challenger" Summary, Sir John Murray has attempted an explanation of the quantitative distribution of organisms in different depths, which not only throws much light on these important geographical questions, but also possesses the great advantage of containing in itself a whole programme

Murray on the " mud. line" and mud-eating animals. of future research. He found that many deep-sea animals-the hydroids, for example-had developed special apparatus for catching the minute shells and particles of food that fall from the surface waters, and the holothurians and other echinodermsthe most abundant of deep-sea animals-had their intestines always crammed with the surface layers of the deposit on which they were captured, either Blue mud, Diatom ooze, Globigerina ooze, Pteropod ooze, or Red clay.

We have seen in Chapter IV. that marine deposits may be separated into two main groups: terrigenous deposits and pelagic deposits, the former occurring in deep and shallow water around all continents and islands within an average distance of one hundred or two hundred miles from the coast, and the latter occurring in the deeper water towards the central parts of the great ocean basins.

It is a well-known fact that the detrital matter which is carried into the sea by rivers is rapidly deposited on meeting salt water, but in shallow water, where currents and wave-action produce their maximum effect, these fine detrital matters are not allowed to settle on the bottom, but are moved along till they reach the lower limit of wave-action. In enclosed seas this may be at a depth of only a few fathoms, but along coasts facing the great oceans the waves are so long and so high that to a depth of several hundred fathoms minute particles of sand may be dis- 
turbed, as, for instance, off the north of Scotland. Murray has termed the limit of wave-action the mud-line, and the average depth in the open ocean at which mud commences to be laid down he places at about ioo fathoms.

Beyond the mud-line the physical conditions become more and more uniform, and for a few hundred fathoms below this limit animal life is exceedingly abundant. This region, according to Murray, is the "great feeding ground" of the ocean, especially around continental shores; the organic particles from the continents and from the shallow waters there slowly come to rest on the bottom and supply food to the wealth of crustaceous forms which are captured in such situations (Calanus, Euchata, Pasiphaa, Crangon, Calocaris, Pandalus, Hippolyte, Pagurus, Amphipoda, Isopoda, and Mysida).

The surface layers of the organic deposits which are Decreasing situated in moderate depths towards the central parts of the ocean basins (Diatom ooze, Globigerina ooze, Pteropod ooze), yield an abundance of food for benthonic animals, but all investigations go to show that where the organic oozes pass with increasing depth into Red clay, the quantity of food for bottom-living animals rapidly diminishes, and the number of animals captured on Red clay bottoms likewise diminishes very greatly. The poorest hauls during the whole of the "Challenger" Expedition were those taken in the stretches through the central Pacific from Japan to Valparaiso, and Alexander Agassiz's investigations on board the "Albatross" gave similar results. He calls the central South Pacific a "barren region."

This short statement will make it obvious, that the conditions of life offered to organisms may vary greatly in different depths. Murray's theory on the importance of the deposits to the distribution of animal life is of special value, because it opens up to science the possibility of finding certain definable reasons for the differences observed in the specific composition, and in the abundance, of animal life from place to place.

This study has, however, been somewhat neglected as far as the oceans are concerned. Most of the deep-sea expeditions have been so absorbed in faunistic research, that the problems of the economy of the ocean have been very little attended to, and the strong interest taken in theoretical plankton-research peculiar to recent times has drawn attention away from the bottom-life of the ocean and the importance of the deposits as food for the bottom fauna, but Lohmann and C. G. J. Petersen have recently turned attention again to Murray's point of view. 
Petersen on organic matter in the uppermost layer of deposits.

During his plankton work in the Liimfjord, Petersen arrived at the conclusion that the plankton played a very unimportant part in the food of bottom-animals (as, for instance, the oyster). He commenced therefore to study the finely granular mass found in the gut of the bottom animals. He discovered that the uppermost layer of mud on the fjord bottom, 2 or $3 \mathrm{~mm}$. in thickness, consisted of detritus containing minute remains of organisms, mainly of decayed plants from the littoral region, and that only this upper layer of the mud has any nutritive value, the deeper blue-black layer not occurring in the gut of the bottom animals. Starting from these researches, Petersen studied the organic (nutritive) constituents of the mud, especially of the upper layer, and investigated the abundance of bottom-animals over different kinds of deposits. For this purpose he constructed an apparatus (see Chapter X.) for cutting away from the sea-bottom a square foot of its surface. When this large "bottom sample" is sifted the animals contained in the mud can be counted, and by comparing the quantities of mud-eating animals thus found per square foot of bottom, the yielding power of different areas may be estimated, much on the same principle as the productive value of agricultural land is estimated.

The "Michael Sars" had, during the Atlantic cruise, some of Petersen's apparatus on board, but owing to difficulties in using them in deep water, we did not succeed in obtaining material of any value, a fact all the more regrettable, as there is no doubt that Petersen's method gives far more exact results as regards the quantities of certain animals living on the bottom in shallow water than hauls with dredges and trawls. Nevertheless, the material at hand may be used to illustrate the question. The most stringent quantitative science is in the first stages of a new study satisfied to dispense with the demand for absolute exactness, and contents itself with relative values-in other words, with a comparison between different localities.

"Challenger" hauls on different deposits.

Sir John Murray long ago attempted to compare the number of animals taken in the dredge or trawl on different deposits, based on the results of the "Challenger" Expedition, and I reproduce some of his figures from the second volume of the "Challenger" Summary :- 


\begin{tabular}{|c|c|c|c|c|c|}
\hline & & & & \multicolumn{2}{|c|}{ Specimens per Haul. } \\
\hline & & & & Trawlings. & Dredgings. \\
\hline \multicolumn{6}{|l|}{ On Red Clay- } \\
\hline In the Atlantic & . & . & . & 40.0 & 4.2 \\
\hline , Pacific . & . & . & . & 20.3 & ... \\
\hline , Southern Ocean & . & . & . & 50.0 & I 3.3 \\
\hline \multicolumn{6}{|l|}{ On Globigerina Ooze- } \\
\hline In the Atlantic & . & . & . & $2 \mathrm{I} . \mathrm{I}$ & $5 \cdot 2$ \\
\hline,$\quad$ Pacific & . & . & . & 56.5 & 7.0 \\
\hline "Southern Ocean & . & . & . & 96.7 & $5 \cdot 0$ \\
\hline \multicolumn{6}{|l|}{ On Terrigenous Deposits- } \\
\hline In the Atlantic & . & . & . & 108.5 & $55 \cdot 3$ \\
\hline , Pacific . & . & . & . & 71.4 & 59.0 \\
\hline Magellan Strait & . & . & . & 100.0 & $\ldots$ \\
\hline Southern Ocean & . & . & . & $\ldots$ & 93.0 \\
\hline
\end{tabular}

These figures plainly show that animal life was found most abundantly on terrigenous deposits, though the Globigerina ooze was also, especially in the Southern Ocean, very rich in organisms.

At the two deepest stations of the "Michael Sars" (Station IO, 4700 metres, and Station 48, over 5000 metres) the trawl was dragged for hours along the bottom, and brought up great quantities of ooze, which on being sifted yielded only a few holothurians (one individual at Station ro and two at Station 48). Of other mud-eating animals we found none at Station 48; and at Station Io, in two hauls, a gasteropod, two ophiurids, and a few worms.

These hauls are comparable with those made by the "Challenger" between the Canaries and the West Indies (see p. 4I8), in depths between 2000 and 3000 fathoms.

Different conditions are encountered on the slopes in shallower water, the slopes of both continents and submarine ridges. From the "Michael Sars" journal the following results of trawlings on the continental slope west of the British Islands may be quoted :thecontinenta
slope to the "Michael Sars" trawlings on numbers of invertebrates, mainly echinoderms, ophiurids and starfish being Britain. especially abundant.

Station 95, I 797 metres (981 fathoms). Besides 82 fishes, 300 holothurians, 800 ophiurids, starfish, Phormosoma, etc. 
CHAP.

Station 4, 923 metres ( 547 fathoms). Besides 332 fishes, quantities of starfish, sea-urchins (Brissopsis, Phormosoma), etc.

South of the Faroe Islands, 831 metres ( 460 fathoms). Besides 300 fishes, large numbers of invertebrates.

Abundant fauna on Globigerina ooze on and beyond the continental slope.
In Chapter IV. Sir John Murray has stated that the bottomsamples collected during the cruise of the "Michael Sars" show that Globigerina ooze approaches nearer to the coasts of the British Islands than was previously supposed, having been found at Station 4, 547 fathoms; Station 93, 688 fathoms; Station 95, 981 fathoms; Station 98, 742 fathoms; and Station 100, 835 fathoms.

While the fishes of the continental shelf all live on terrigenous deposits, like Blue mud, the "Michael ${ }_{1}$ Sars" results prove that in the eastern Atlantic, at any rate, most of the fauna of the continental slope live on Globigerina ooze. Circumstances may be quite different on other slopes, as, for instance, the Atlantic slope off the United States, or off Newfoundland, where terrigenous deposits seem to have a much wider distribution. But the very important question of the limits between the terrigenous and the pelagic deposits requires further careful study by means of series of hauls with the trawl and series of samples of the deposits from shallow water down the slope to the abyssal plain.

The results given above show in any case that. the Globigerina ooze in depths of 550 to 1000 fathoms may be a rich ground for animal life, since we got such good hauls at the stations quoted, and this is corroborated by the hauls taken on this type of deposit in deeper water, far from continental land, as at Stations 53 and 88 .

At Station 53, south of the Azores, 26I 5 to 2865 metres ( 430 to I 570 fathoms), the trawl captured in one haul, besides 39 fishes, about 500 holothurians, and abundance of different crustaceans, actinians, etc.

At Station 88, in 3 I 20 metres (about I 700 fathoms), the trawl brought up a wealth of animals, especially sea-urchins, starfish, ophiurids, holothurians, etc.

We thus see that it is not terrigenous deposits alone which harbour an abundant bottom fauna; in fact, on true pelagic deposits, like Globigerina ooze, we may have the conditions necessary for abundant life. The percentage of carbonate of lime gives no indication of the suitability of the conditions for animal life, for the terrigenous deposits with abundant fauna, as well as the barren Red clay, both contain very little calcium carbonate. The important item is the organic substance con- 
tained in the deposits, which fertilises the surface layers of the Importance Blue mud as well as of the Globigerina ooze.

of organic matter in the

Petersen has shown that only the uppermost layer of the deposits. mud contains organic detritus, but the quantity of organic substance deposited is not always the most important factor. Where the water is in motion at the bottom, a fine cloud of organic matter is swept along, and in such localities the mudeaters thrive in great quantities. The fishermen have for a long time profited by this fact, for they do not seek those places (as in pits and channels on the bottom) where mud is laid down, but choose rather the spots where the bottom is covered with coarser particles, and where the finest mud cannot settle. In these places the fish find most food, and the fishermen most fish.

Perhaps conditions like these prevail on the eastern Atlantic slope, as, according to the current-measurements of the "Michael Sars," considerable currents extend down to great depths. All such conditions call for further examination, especially in the open ocean, and it may be affirmed that studies of this kind will be essential for an understanding of the quantity of life along the bottom.

Returning to the question of the geographical distribution of different species of fish, we may now examine some of the conditions which influence that distribution, according to the present state of our knowledge.

We have seen that the species Macrumus armatus is known from the abyssal plain in the Pacific as well as in the Antarctic and Atlantic Oceans. The chart (Fig. 308) indicates the localities of capture and also the temperature, and shows at a glance that, notwithstanding the immense geographical range of this species, it is taken only where the range of temperature is very small ( $\mathrm{I}^{\circ}$ to $3^{\circ} \mathrm{C}$.). The species is not local; it is not limited by distance, but by certain physical conditions, which in this case prevail over an immense geographical area.

Temperatures in abyssal depths are, as we have seen in Chapter $V$., on the whole very uniform. It is therefore interesting to note that it is especially the abyssal forms that are known from wide areas; thus, for instance, Macmurus filicauda, known from the Pacific and Antarctic, has a bathymetrical range from 25 I 5 to 4843 metres. Macmums parallelus, known from New Zealand, Japan, Ceylon, South-west Africa, ranges down to I 300 metres. Halosauropsis macrochir, known from the Southern
Influence of bottomcurrents on the distribution of fish.
Distribution of different species of fish. 
Ocean, between South Africa and Kerguelen, and from the "Michael Sars" Stations 35, 53, 88, and 95, was taken down to 2995 metres.

As regards the North Atlantic in particular, the distribution of the deep-sea fauna and the hydrographical conditions show in many instances a marked and interesting correspondence. The rule just discussed holds good also in this ocean : the deepest living forms have a wide distribution. Thus three forms (Macmurus brevibarbis, M. simulus, and Hariotta raleighana), previously known from the American side of the Atlantic, were found by us on the eastern side, as well as on the ridge in MidAtlantic. These forms were only taken at the deepest stations.

In Fig. 99, p. I I 5, a section is given from Newfoundland to Ireland, showing the vertical distribution of salinities and temperatures, and we see from this that on the eastern side of the Atlantic high temperatures go far deeper than on the western side, where the isotherms take an upward turn along the slope. In intermediate depths, for instance between 500 and 800 fathoms, it is therefore much colder on the western side, while at depths of 1000 to 2000 fathoms similar temperature conditions prevail on both sides. Special interest thus attaches to the fact that representatives of the deepest living forms were found on both sides of the ocean, while the faunæ of the slopes in 500 to 800 fathoms are, on the whole, distinct. From this latter rule exceptions may be noted, some forms being also at these depths common to both sides, like Antimora viola, found first on the eastern side by the "Michael Sars," Macmums rupestris, and $M$. calorhynchus; these forms, however, appear to be allied to the fauna of the coast banks, and they can hardly be counted among the forms characteristic of the intermediate depths on the slopes.

Among the Macruridæ the following species may perhaps be considered as characteristic of the two sides of the North Atlantic :-

Western Side.
Macrurus carminatus.
", bairdii.
" $\quad$ goodei.
"

Fishes from the slopes of the eastern Atlantic.
Eastern Side.

Macrurus zaniophorus.

, equalis.

" sclerorhynchus.

Bathygadus melanobranchus. longifilis.

We will here only discuss the fauna of the eastern side, where trawlings as well as hydrographical investigations were made by the "Michael Sars." The most important fish caught 
are recorded in the following table, arranged according to the three series of trawlings taken: (I) west of the British Isles, (2) west of Morocco, and (3) south of the Canaries:-

\begin{tabular}{|c|c|c|}
\hline West of the British Isles. & West of Morocco. & South of the Canaries. \\
\hline 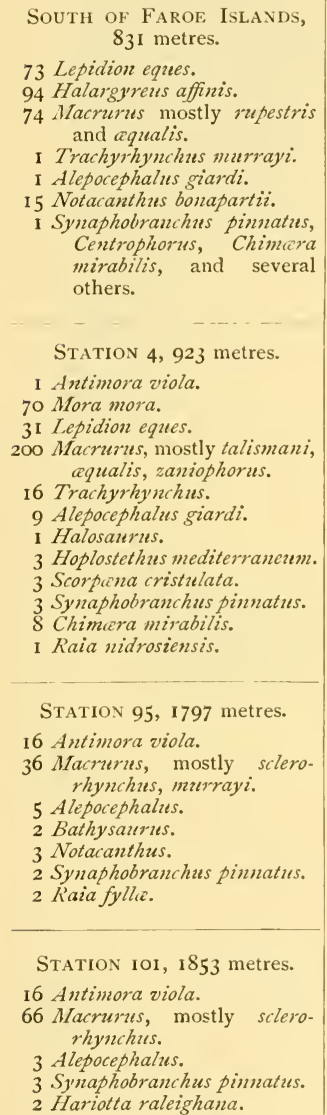 & 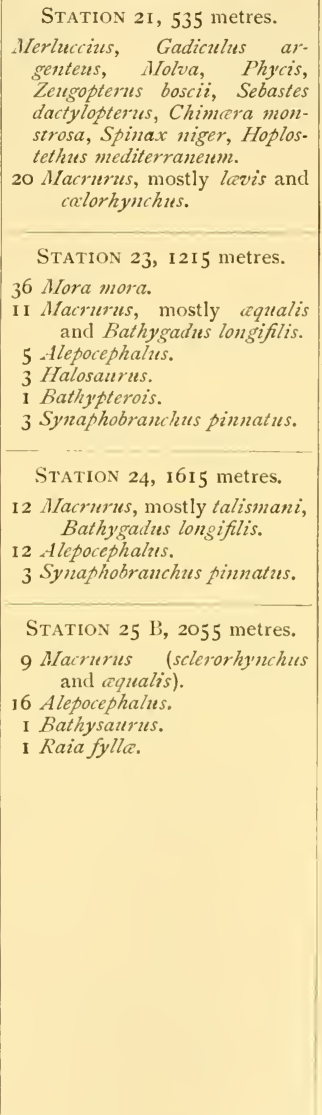 & 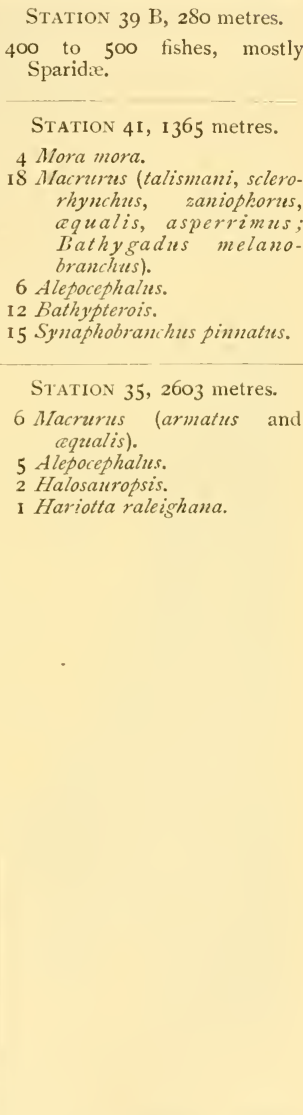 \\
\hline
\end{tabular}

From this list we see that the fish fauna of the slope is very uniform all the way from the Faroe Islands to south of the Canaries; no less than six species are common to the northern 
and southern series. The hydrographical conditions prevailing along the east side of the Atlantic at these depths are well seen in the chart for 500 fathoms (see Fig. 202, p. 296), which shows that the temperature at 500 fathoms to the south of the Faroe Islands is above $7.0^{\circ} \mathrm{C}$, and south of the Canaries, $8.0^{\circ} \mathrm{C}$. Only outside of the Mediterranean do we find a higher temperature. On the western side of the Atlantic the temperature at the same depth is only $4.0^{\circ} \mathrm{C}$. These facts seem to me to throw much new light on the geographical distribution of the deep-sea fauna.

Fishes of the Norwegian Sea.

The conditions in the deep basin of the Norwegian Sea, which has been described in Chapter IV., are no less interesting. In the little chart (Fig. 309) the contour-lines for 600 and 2000 metres are shown. The 2000 metres isobath encloses the abyssal plain of the Norwegian Sea, the central parts of which are covered by 3000 and 3500 metres of water. The area between the 2000 and the 600 metres isobaths shows the region of the slopes, which are steep all the way from Spitzbergen to the Wyville Thomson Ridge, a deep channel (the FaroeShetland channel) running from the deep basin right down to the ridge. The hydrographical conditions in the Norwegian Sea are indicated in the vertical section (Fig. 3IO), which runs through the points $a, b, c$, from the east coast of Greenland across Jan Mayen to Vesteraalen in Norway. In this section the "Atlantic water," with a salinity above 35 per thousand, is shaded, and is seen to be limited to the eastern side, the depth of the layer not exceeding 600 to 700 metres (or 350 to 400 fathoms). All the water to the west, and beneath this "Atlantic water," is quite cold, most of it below O C., the abyssal plain itself being covered by water having a temperature below $-\mathrm{I}^{\circ} \mathrm{C}$.

Abyssal fauna of the Norwegian Sea.
The fauna of this cold deep basin has been extensively studied during the Norwegian expeditions on board the "Vöringen" and the "Michael Sars," during the Danish expeditions on board the "Ingolf" and the "Thor," and also by Swedish and French expeditions (Duke of Orleans, etc.). On the chart (Fig. 309) small circles denote localities where Norwegian expeditions have employed dredges or trawls, the captures everywhere being remarkably poor in species.

The abyssal plain and the slopes of the Norwegian Sea do not show a single species in common with the Atlantic. While in the Atlantic the genus Macrurus plays an important part in 
the fauna of the abyssal area, not one species of this genus has been found in the cold water of the Norwegian Sea, where the genus Lycodes (of the family Zoarcidæ) predominates. But Lycodes is not limited to the Norwegian Sea, being represented in

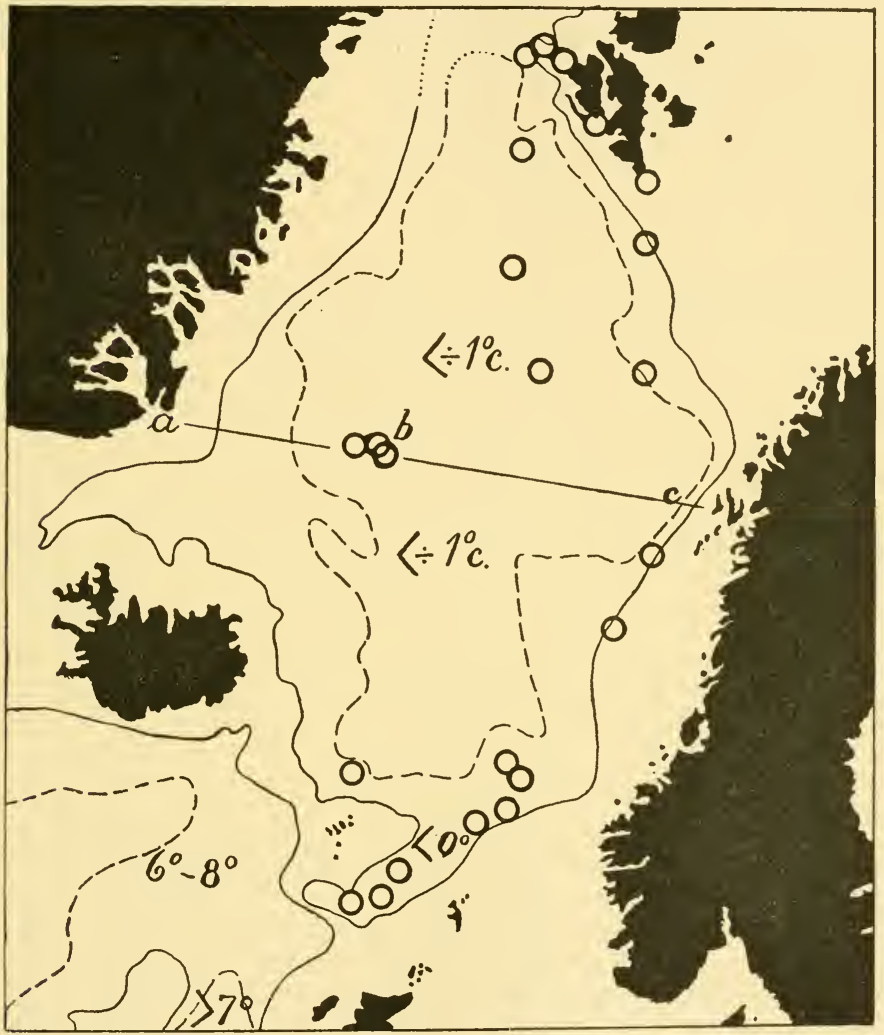

Fig. 309. -The Norwegian Sea.

Continuous line $=600$ metres.

Broken line $=2000$ metres.

Section through $a, b, c$, shown in Fig. 310 .

the abyssal depths as well as on the slopes of the Atlantic, though no species has been found common to the Atlantic and the Norwegian Sea. To the Danish scientist Adolf Jensen we owe our knowledge regarding this interesting biological fact. 
The principal "cold-water" fish of the deep Norwegian Sea belong to the following species :-

ZoARcidæ-Lycodes murcena, L. flagellicauda, L. frigidus, L. pallidus, L. similis, L. eudipleurostictus, L. seminudus.

OPHIDIDE-Rhodichthys regina.

LIPARIDE-Careproctus reinhardi, Paraliparis bathybii.

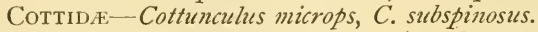

SHARKS-Somiosus microcephalus (the Greenland shark).

RAYS-Raia hyperborea.

Excepting the Greenland shark these species have been
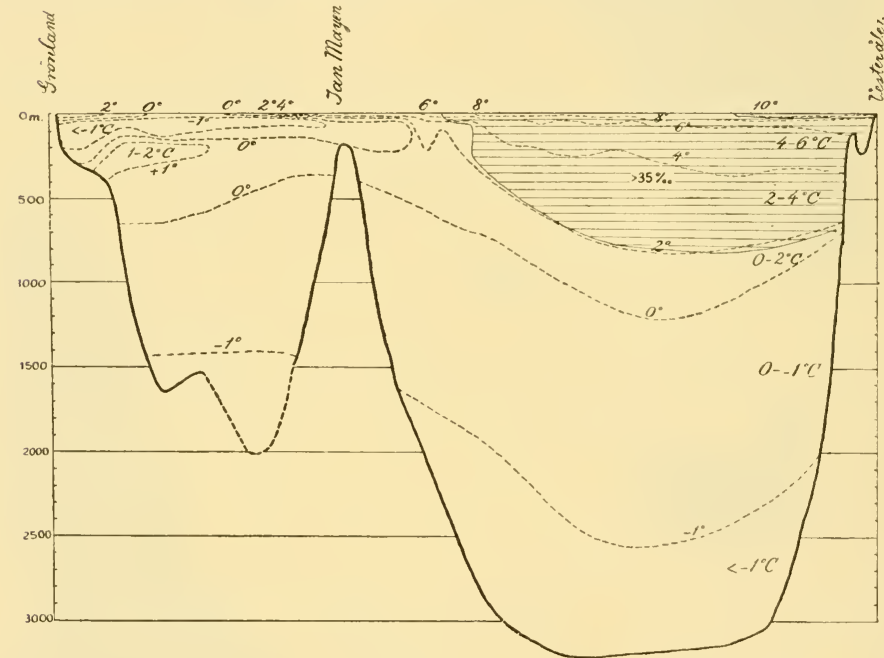

Fig. 310.-Section across the Norwegian Sea from Greenland to Norivay in Position SHown in Fig. 309. (Drawn by Helland-Hansen.)

taken in cold water only, below $\mathrm{O}^{\circ} \mathrm{C}$., and mostly in small numbers, though occasionally they are more numerous.

Thus a haul made by the "Michael Sars" to the north of the Faroe Islands, in 975 fathoms, with a trawl similar to the one used in the Atlantic, gave in two hours: 34 Paraliparis bathybii, I Rhodichthys regina, and I 7 Lycodes. East of Iceland, in 467 fathoms, where the temperature was $-0.6^{\circ}$ C., the Danish research steamer "Thor," on a line of 225 hooks, obtained 4 Raia hyperborea, I Greenland shark, and 20 black halibuts (Hippoglossus hippoglossoides); the latter two species are not, however, exclusively cold-water fish. 
Previously all these fishes of the Norwegian Sea were generally believed to live only along the bottom, but, as mentioned in Chapter III., the "Michael Sars" in May I9I I obtained in a pelagic haul in the cold layers of the Norwegian Sea a specimen of Paraliparis bathybii. In the cold water layer there are thus fishes which at least occasionally occur in midwater.

On the coast banks off Greenland, Jan Mayen, and the Arctic most northerly coasts of Spitzbergen dwells a genuine Arctic fauna. Of these shallow cold-water species the following are most important: Icelus hamatus, Triglops pingelii, Lumpenus maculatus, L. medius, and L. lampetriformis, besides Gadus saida (the polar cod).

On the east and south side of the Norwegian Sea, from Spitzbergen along the coast of Norway and the North Sea banks, and also at Iceland, the cold water does not occur on the slopes in depths less than 600 or 700 metres, and the change from the cold water to "Atlantic water" is very marked. The deep-sea fauna and the fauna of the coast banks are for this reason much more sharply separated than in the Atlantic. At most seasons the limit is determined by the vertical distribution of the Atlantic water, and this limit may oscillate according to changes in the current, though this point has not yet been thoroughly examined.

The fishing experiments of the "Michael Sars" have sometimes in a very striking way shown how sharp the limit is between the two faunæ. In June 1902, for instance, a long line of I 200 fathoms was shot on the northern slope of the North Sea bank towards the deep water, one end of the line being in 2 I 7 fathoms, where the temperature was $6^{\circ} \mathrm{C}$., and the other end in 300 fathoms, where the temperature was $-0.2^{\circ} \mathrm{C}$. In the cold water we obtained cold-water fish (Raia hyperborea), while near the upper end of the line (in warmer water) the fish belonged to the coast bank species (Sebastes, Macmurus fabricii). Raia hyperborea has been taken from North Spitzbergen down to the slope of the North Sea plateau; Macrumus fabricii is known from the Bay of Biscay, from the ocean off the east coast of North America, and from other localities.

\section{The Fishes of the Coast-Banks}

The "Michael Sars" has now had the opportunity of investigating the coast-banks from Spitsbergen to a little south 
of the Canaries, a stretch of more than 40 degrees, or 2400 miles. A survey of the animal life on this long stretch of sea-floor is very interesting. As the temperature gradually falls toward the north the fauna changes. Some species are hardy, and are distributed over a greater part of the area; others can only live under more uniform conditions, and therefore have a more limited area of distribution.

Zoological oceanography has long recognised this, and zoological literature contains much information regarding the distribution of animals within our area of investigation. I will mention only one example, for which purpose I choose the G. O. Sars on excellent survey of the mollusca of Arctic Norway by G. O. the Mollusca of Norway.

Sars, recording the geographical distribution of 174 species of lamellibranchs and 366 species of gasteropods.

Of the 174 lamellibranchs no less than 128 or 74 per cent were known also from Great Britain ; I 9 or 70 per cent from the Mediterranean, and 56 or 32 per cent from boreal North America.

Of 366 gasteropods found in Norway, 225 or 62 per cent were also known from Great Britain ; 133 or 36 per cent from the Mediterranean, and 77 or 23 per cent from the coasts of boreal North America. A great many species of molluscs have been taken in the Mediterranean as well as in Norway, and quite a number of forms are common to the faunæ of Norway and of North America.

Examining the conditions in various parts of the coast of Norway, we see that the Mediterranean species rapidly decrease in number as we go north from western Norway, for instance, from the latitude of Bergen towards the North Cape. While II 9 lamellibranchs and I 33 gasteropods are common to the Mediterranean and Southern Norway, Northern Norway and the Mediterranean have only 49 lamellibranchs ( 28 per cent) and 35 gasteropods (10 per cent) in common. Also south of the Mediterranean we find a similar decrease in the number of species common to both areas; thus only 5 species of lamellibranchs and 4 species of gasteropods are common to Madeira and Northern Norway.

A thorough understanding of the distribution of different animals, or of the different animal-communities, is, however, not obtainable by means of records of this kind, for it makes a world of difference whether a few specimens of a species have been found in a certain locality or whether it lives there in great quantities. A complete knowledge of the distribution of 
a species would be based on material containing information as to how many individuals of the species live in different sections of the area, and a complete knowledge of an animalcommunity would be to have information as to the exact relative occurrence of the animals.

In regard to no species, however, does our present knowledge comply with this ideal demand. As regards the fishes we have

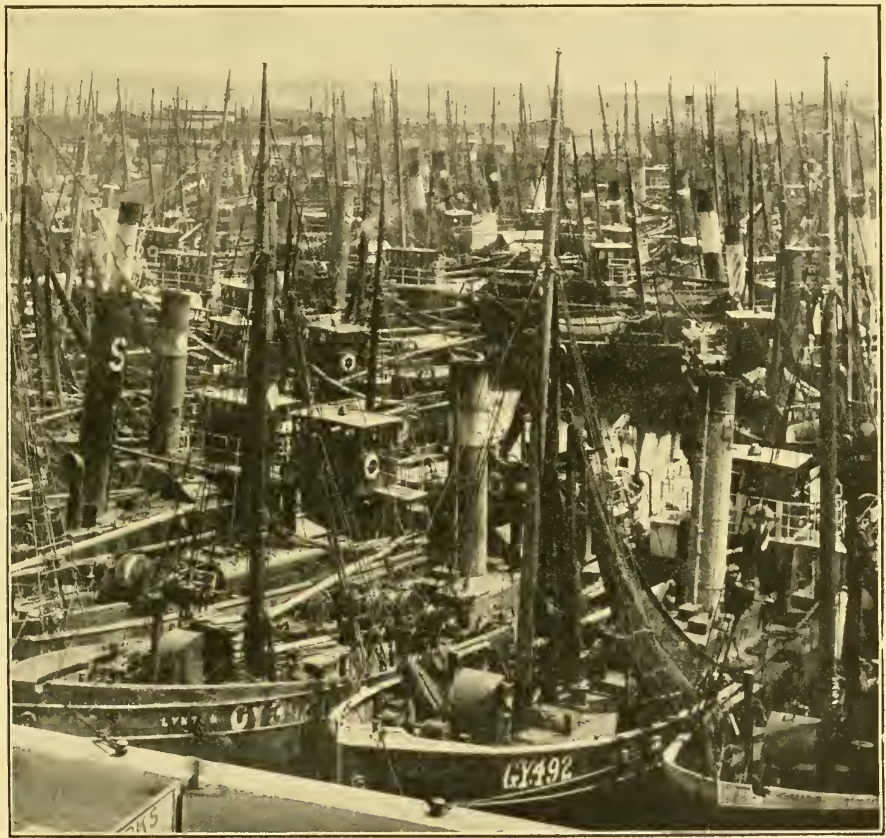

Fig, 3it.-Steali-Trawlers laid up in Grimsby during Engineers' Lock-out.

most information on the species of economic importance, for in recent years many fishing experiments have been made with the object of ascertaining what quantities of fish occur in different waters. In co-operation with the International Council for the Fishery study of the sea, the fishery statistics of several countries have statistics. also been so far improved, that the quantities of fish landed are now separated in regard to species and areas where caught. The quantities landed are certainly not on the whole repre- 
sentative of the quantities living in the sea. For instance, it is clear that the intensity of fishing is not only determined by the abundance of fish, the prices and the distances to fish markets being (among others) very important points. But notwithstanding these drawbacks, we possess at the present time hardly any better means of judging of the abundance of fish in different areas than the information regarding the capture of edible fish contained in the fishery statistics of recent years. An enormous fleet of modern fishing steamers (see Fig. 3 II) is now distributed from Cape Kanin, at the mouth of the White Sea, down to Morocco, that is to say, over the area investigated by the "Michael Sars."

From the statistics published by Dr. Kyle of the International Bureau for the Study of the Sea, we have compiled two tables recording the capture of bottom-fish in 1906. One (Table A) shows the catch of each species in each fishing area expressed in percentages of the quantity of the species landed from all areas; the other (Table B) shows the catch of each species expressed in percentages of the aggregate quantity landed from each area. The tables deal with nearly a million tons of fish of all kinds from all waters, the quantities varying greatly in different areas. First of all is the North Sea with nearly 400,000 tons, or nearly 40 per cent of the total quantity ; then comes the coast of Norway, north of Stat, with 28 per cent, Iceland with 18 per cent, the Faroe Islands with 4 per cent, the region north-west of the British Isles with 5 per cent, the Bay of Biscay, Portugal, and Morocco with less than $\frac{1}{2}$ per cent each. Among the different bottom-fish the cod plays the most important part with no less than 44 per cent, next comes the haddock with 25 per cent, plaice with $6 \frac{1}{2}$ per cent, saithe with $3 \frac{1}{2}$ per cent, ling 3 per cent, and hake with a little above 2 per cent, of the total quantity.

Considering now the abundance of each species in each of the nine areas recognised by the fishery statistics, we first observe that most of the species have their maximum abundance in the North Sea. This applies principally to the haddock, the whiting, the species of Bothus, the plaice, the lemon sole, and the dab. The intensity of the fishing in the North Sea is, of course, to some extent responsible for this. But nevertheless we find several exceptions. Thus the Norway haddock (Sebastes), the cod, the saithe, and the tusk are taken in the greatest quantities off the coast of Norway, the halibut at Iceland. On the other hand, we find in regard to dog-fish, 


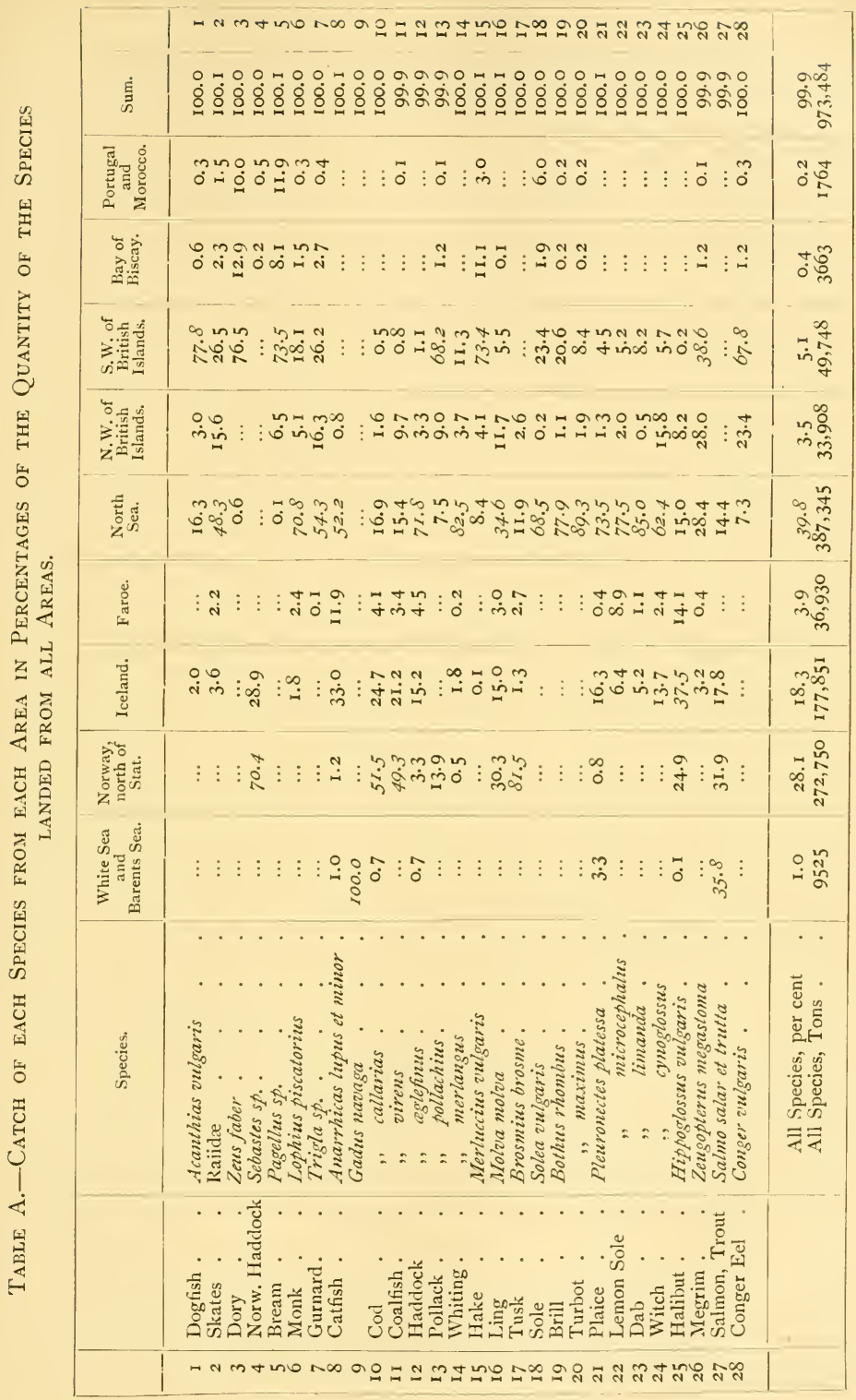




\begin{tabular}{|c|c|c|}
\hline & 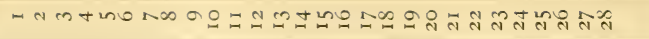 & \\
\hline 至 & 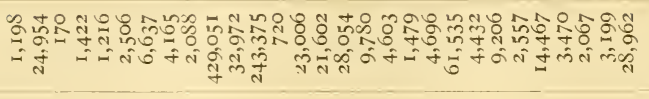 & $\begin{array}{l}\text { एँ } \\
\text { ก̂ } \\
\hat{\sigma}\end{array}$ \\
\hline 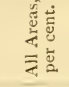 & 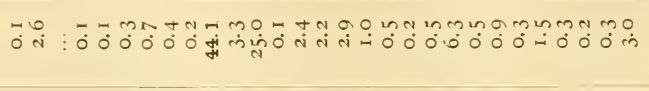 & $\stackrel{\circ}{\circ}$ \\
\hline 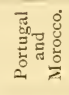 & 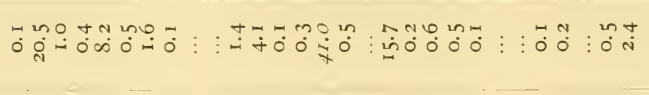 & $\stackrel{2}{8}$ \\
\hline 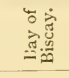 & 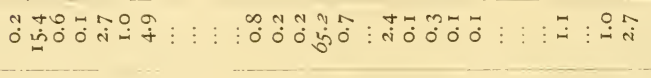 & $\dot{\alpha}$ \\
\hline 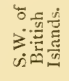 & 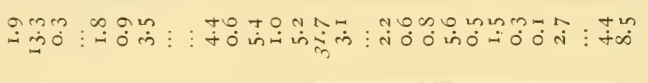 & $\stackrel{0}{\circ}$ \\
\hline 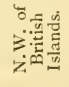 & 范 & $\stackrel{\circ}{8}$ \\
\hline 壱岙 & $\ddot{\circ}$ m & $\stackrel{\infty}{\alpha}$ \\
\hline ڤ్ّ & 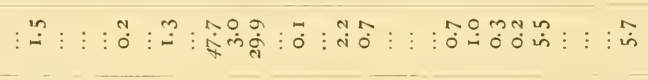 & $\stackrel{\circ}{\circ}$ \\
\hline 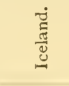 & $\begin{array}{l}\text { ? } \\
0\end{array}$ & $\stackrel{\circ}{\circ}$ \\
\hline 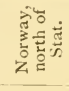 & $\vdots \vdots$ कें० & $\dot{\Omega}$ \\
\hline 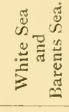 & 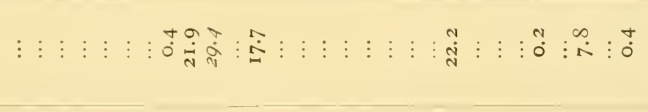 & $\stackrel{\circ}{\circ}$ \\
\hline 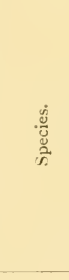 & 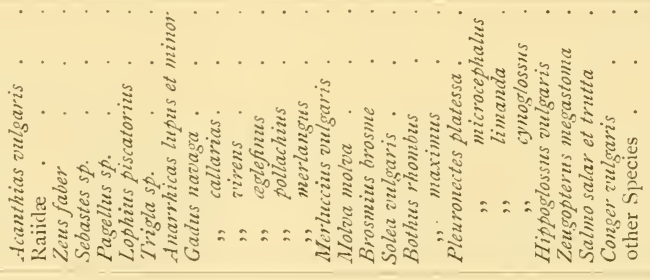 & \\
\hline & 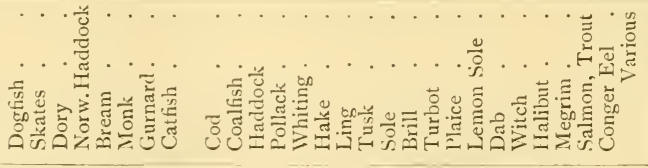 & \\
\hline & 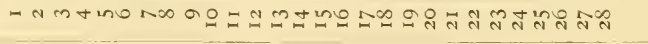 & \\
\hline
\end{tabular}


bream (Pagellus), pollack, hake, megrim (Zeugopterus), and conger-eel, that the greatest quantities are taken south-west of the British Isles in the Atlantic.

We can thus distinguish northern species which are mainly Northern and taken north of the North Sea and in the North Sea, and southern species, which are chiefly derived from the Atlantic, notwithstanding the fact that comparatively little fishing is carried on in this area. The percentages of each species in the aggregate quantities landed from each area confirm these facts.

In the area between the mouth of the White Sea and the west coast of the British Isles we find the cod constituting at least 20 per cent of all the fish caught, on the coast of Norway even 8 I per cent, at Iceland 60 per cent, and at the Faroe Islands 48 per cent. South-west of the British Isles the quantity of cod dwindles to $4 \frac{1}{2}$ per cent, and farther south it disappears. The haddock also constitutes a large proportion of the quantities landed from the area between the White Sea and the northwest of the British Isles (excepting off Norway, where the bottom is unsuitable for haddock-fishing); in the North Sea even 45 per cent of all the fish caught are haddock. The quantities of this fish also dwindle and finally disappear south-west of the British Isles. The same applies to plaice, halibut, ling, and tusk.

The percentages of southern fish, on the other hand, increase west of the British Isles. The hake (Merluccius) practically does not occur north of the North Sea, where it constitutes only about $\frac{1}{2}$ per cent of the total quantity; south-west of the British Isles it reaches 32 per cent, in the Bay of Biscay even 65 per cent, and all the way southward it constitutes at least 30 per cent of the total quantity. Similar conditions apply to the pollack, sole, sea-bream (Pagellus), the monk or angler, the gurnards, and others.

On the coast banks of the western side of the Atlantic we Northern and meet with similar groups of northern and southern forms, the change between these groups occurring about the New England states. We give some instances of quantities of fish species in the western Atlantic. landed in the New England states, the middle Atlantic states, and the south Atlantic states, taken from the fishery statistics for the year I 906, the figures signifying tons :- 
Influence of temperature conditions on distribution of fishes.

\begin{tabular}{|c|c|c|c|c|c|}
\hline & & & Northern States. & Middle States. & Southern States. \\
\hline Cod . & . & . & 40,000 & $\mathrm{I}, 400$ & $\ldots$ \\
\hline Haddock & . & . & 21,000 & 200 & $\ldots$ \\
\hline Saithe. & . & . & 7,900 & 50 & $\ldots$ \\
\hline Flounder & . & . & 2,150 & $\mathrm{I}, 400$ & $35^{\circ}$ \\
\hline Halibut & . & . & 5,500 & ... & $\ldots$ \\
\hline Hake . & . & . & I 5,000 & 200 & $\ldots$ \\
\hline Mullet . & . & . & ... & 150 & 18,500 \\
\hline Sciænidæ & . & . & 3,300 & I I , 400 & 4,300 \\
\hline Sparidae & . & . & 30 & ... & 6,100 \\
\hline
\end{tabular}

The northern forms-cod, haddock, saithe, flounder, and halibut-disappear along the coast of the southern states, as does also the hake. On the other hand mullet, Sciænidæe, and Sparidæ, i.e. the southern forms, increase as we go south, just as they do on the eastern side from the Bay of Biscay towards the coast of Morocco.

If, with these facts in mind, we look at the chart (Fig. 312) recording the temperature at a depth of 100 metres (about 50 fathoms), we shall be astonished at the fact that the distribution of different species curiously coincides with certain temperatures. The southern limit of northern boreal species everywhere coincides with the isotherm for $10^{\circ} \mathrm{C}$. On the west side this isotherm just reaches the border between the northern and middle states of North America, while on the east side, on the coast of Ireland, this isotherm just separates the two areas termed respectively areas north-west and south-west of the British Islands.

The areas of the northern species correspond on both sides of the ocean to the area between $2^{\circ}$ and $10^{\circ} \mathrm{C}$., the maximum frequency of the species occurring between $6^{\circ}$ and $8^{\circ} \mathrm{C}$. These latter temperatures are found on the Newfoundland banks, on the southern and western banks of Iceland, in the North Sea, and along the entire coast of Norway. The uniformity of the fauna peculiar to all these localities compares well with the uniform conditions of temperature. South of the $10^{\circ}$ isotherm we have on both sides of the ocean belts with temperatures between $10^{\circ}$ and $18^{\circ} \mathrm{C}$.; that on the west side ranges from Cape Cod to Florida, and that on the east side from Iceland to south of the Canaries.

A peculiar feature is that all the isotherms on the west side are quite close together, the water layers being squeezed 
between the oceanic sub-tropical waters from the south and the arctic Labrador current from the north. All changes in temperature are therefore on the western side very sharp. On the eastern side the layers are spread out fan-wise, and as a consequence we may at a depth of Ioo metres find the same temperature prevailing from north to south over wide areas, as,

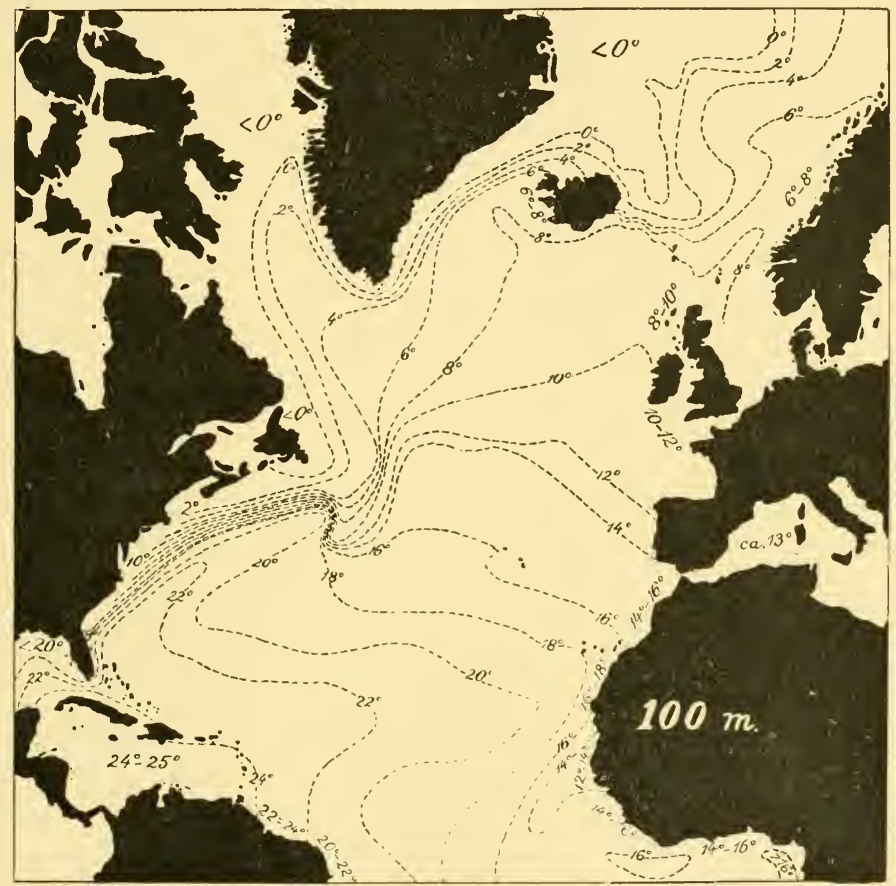

Fig. 312.-Distribution of Temperature in the North Atlantic at a Depth of 100 METREs. (Drawn by Helland-Hansen.)

for instance, along the coast of Norway from the North Sea to the North Cape.

We may now discuss the distribution of the southern and northern species.

Comparing the percentages of the different species noted in The southern the quantities landed from different geographical areas (see species. 
Table B), we observe that northern (boreal) forms decrease enormously to the west of the British Isles. We may say that there is a sharp southern limit to the distribution of these species west of the Channel; the cod, saithe, tusk, and halibut here quite cease to play any part in the captures.

The northern limit for the southern forms is essentially different. Of the species recorded in the systematic list of bottom-fish captured by the "Michael Sars" in the Atlantic, $6_{3}$ species were previously known from the Mediterranean, and are found there in abundance. Of these only a few are genuine southern forms; ro species have their northern limit on the coast of France, 19 on the coasts of the British Isles, and 23 occur in varying numbers even on the coasts of Scandinavia. As we shall show in Chapter $\mathrm{X}$., this wide range of certain species is probably due to the fact that the water-layers in the North Atlantic run north, and transport especially the young stages of certain southern species, which may as a consequence pass their youth very far from the localities where they were born. This is why the boreal fish-fauna is more or less mixed up with southern forms, especially in the southern part of the boreal region, for instance in the southern North Sea, in the areas west of the British Isles, in the Kattegat, and along the coast of the Skagerrack, in which localities high summer temperatures prevail in the upper layers.

To the south-west of the British Isles, from the Bay of Biscay towards Morocco, we enter the real area of the southern fauna. This is shown by the table containing the fishery statistics, as well as by the record of the captures made by the "Michael Sars"

Fishes taken by the " Michael Sars "dcwn to 300 fathoms. in the Atlantic. In the following list the captures made during the cruise down to about 500 metres, or 300 fathoms, are recorded and arranged in three groups: (1) West of the British Isles, (2) West of Morocco, and (3) South of the Canaries. 


West of British Isles.
OFF FARoE IsLANDs,
130 metres (trawl and long-line).
2 Gadus aglefintus.
12 Hippoglossus z'ulgaris.
6 Pleuronectes limanda.
I Zeugopterus megastoma.
I Raia clavata.
9 Raia batis.

Stition I, 146 metres.

2 Gadus esmarkii.

2 , poutassout.

2 Phycis blennioides.

20 Merluccius a'ulgaris.

4 Zeugopterus megastoma.

I84 Caranx trachurus.

I Zeus faber.

52 Capros aper.

I8 Trigla gurnardus.

5 Argentina sphyrüna.

20 Acanthias vulgaris.

I Pristiurus melanostomus.

7 Raia clavata.

Station 3, I 84 metres.

I Gadus ceglefinus.

8 ," poutassout.

40 Gadiculus argenteus.

5 Merluccius vulgaris.

I Phycis blennioides.

I 70 Zeusopterus megastoma.

2 Arnoglossus laterna.

2 ", lophotes.

3 Solea variegata.

2 Caranx trachurus.

2 Capros aper.

I2 Trigla gurnardus.

29 ,, lyra.

I ,, pini.

5 Callionymus maculatus.

4 Lophius piscatorius.

4 Argentina sphyrana.

8 Acanthias vulgaris.

5 Scyllium canicula.

25 Raia clavuta.

I ,, vomer.

I , circularis.

OfF Faroe Islands, 442 metres (long-line).

8 Molva molva.

40 Brosmius brosme.

2 Hippoglossus vulgaris.

2 Chimcera monstrosa.

40 Pristiurus melanostomus.

I Spinax niger.

3 Centrophorus squamosus.
West of Morocco.

Off the Coast of Portugal, StATIONS I 3-14, 70-80 metres, (trawl and line).

8 Gadus merlangus.

36 ,, luscus.

22 Merluccius vulgaris.

I Pagellus centrodontus.

1 Caranx trachurus.

3 Trachinus vipera.

I Mustelus vulgaris.

I Scyllium canicula.

I Centrina salviani.

I Raia clavata.

I Raia circularis.

Station 20, 14 I metres.

52 Merluccius vulgaris.

I Solea vuigaris.

7 Pagellus centrodontus.

I ,, acarne.

3 Dentex maroccanus.

5 ,, macrophthalmus.

I I Mullus surmuletus.

8 Caranx trachurus.

4 Zeus faber.

30 Capros aper.

I Trigla hirundo.

16 ,, lyra.

3 ," cuculus.

2 ," pini.

20 Lepidotrigla aspera.

I Peristedion cataphractum.

4 Acanthias vulgaris.

6 Scyllium canicula.

I Raia clavata.

Station 2I, 535 metres.

I4 Gadiculus argenteus.

8 Merluccius vinlgaris.

I2 Phy'is blennioides.

I Molva elongata.

9 Malacocephalus levis.

9 Calorhynchus calorhynchus.

2 Macrurunger.

6 Zeugopterus loscii.

10 Sebastes dactylopterus.

30 Hoplostethus mediterraneum.

2 Chimera monstrosa.

I I Pristiurus melanostomus.

2 Spinax niger.

I Raia fullonica.
South of Canary Islands.

Station 36, io metres.

5 Merluccius vulgaris.

I Solea lutea.

Many Sargus annularis.

Many Pristipoma bennettii.

2 Sciena aquila.

2 Umbrina ronchus.

2 Box vulgaris.

32 Atherina.

77 Caranx trachurus.

I Temmodon saltator.

73 Clupea pilchardus.

I, alosa.

26 Engraulis encrasicholus.

1 Myliobatis aquila.

Station 37, 39 metres.

I Arnoglossus lophotes.

I Dentex maroccanus.

2 Cantharus lineatus.

3 Serranus cabrilla.

I Coris julis.

I Mullus surmuletus.

2 Scorpana scrofa.

2 ," ustulata.

I Uranoscopus scaber.

2 Tetrodon spengleri.

2 Raia punctata.

2 , microocellata.

I, alba.

Station 38, 77 metres.

2 Solea vulgaris.

2 , lutea.

2 Arnoglossus lophotes.

I ,, grohmanni.

I Pagrus vulgaris.

I Dentex macrophthalmus.

2 Trigla obscura.

I Scorpana scrofa.

I Trachinus draco.

I Lophius piscatorius.

I Murana helena.

2 Raia punctata.

Station 39 B, 280 metres.

Io Herluccius vulgaris.

I Pagrus vilgaris.

250 Dentex macrophthalmus.

I Mullus surmuletus.

2 Caranx trachurus.

I Capros aper.

Many Centriscus scolopax.

I Trigla lyra.

Many Lepidotrigla aspera.

I Peristedion cataphractum.

I Scorpena ustulata.

5 Argentina silus.

5 Acanthias vulgaris.

I Scyllium canicula.

2 Rhina squatina.

20 Raia miraletus.

I ,, clavata.

4 ," punctata.

I , circularis. 
In the lists from the stations west of the British Isles we find the northern forms : haddock, halibut, and tusk, but also forms which never occur in the Norwegian Sea or the North Sea, such as Capros aper and Centrophorus squamosus. The hake (Merluccius), the gurnard (Trigla), and southern flatfish (Amoglossus lophotes, $A$. laterna) also occur.

To the west of Morocco the hake and the southern cod (Gadus luscus), besides a few whiting, are the only representatives of the cod family. Here we find no less than five species of gurnards in one haul, mullets (Mullus surmuletus), and Sparidæe (Pagellus centrodontus, Dentex maroccanus, and D. macrophthalmus). In the deep haul in 535 metres we observe the southern ling (Molva elongata), Sebastes dactylopterus, and different Macruridæe, along with Merluccius (hake), and Gadiculus argenteus.

To the south of the Canaries the acanthopterygian fish decidedly predominate. We find Sparidæe (Dentex, Pagrus, Sargus, Box, Serranus, Scorpana, Mullus, Trachimus, Trigla). There are also soles (Solea, Arnoglossus), hake, and anglers. In shallow water we also meet with the young of different herrings, such as pilchards, Clupea alosa, and anchovy.

Thus the three series of hauls show the changes encountered in the fauna, from the mingled community of boreal and southern forms west of the British Isles to the entirely southern fauna on the west coast of Africa.

These records also serve to illustrate the catches of fishing vessels on the European and African banks of the Atlantic. As is well known, the trawling industry was developed in the North Sea. When it was carried farther south along the Bay of Biscay, along the coast of Portugal, and along the coast of Morocco, the hake and the sole were first and foremost the main objects of capture. These two species are still of first importance to the trawlers. From Table B, page 442, we learn that in the Bay of Biscay the hake constitutes 65 per cent, and farther south 36 per cent, of all the fish caught. The valuable sole constitutes no less than 16 per cent of the weight of all the fish caught in the most southerly areas. The rays play an important part (in the Bay of Biscay I 5 per cent, farther south 2 I per cent), but also the acanthopterygians (Pagellus, Mullus, Dentex, etc.) are of great importance. I have obtained some information on their catches off the Moroccan coast-banks from trawlers, who tell me that the hake constitutes two-thirds of the catch. The acanthopterygians very often make up one-fourth, 
and farther south, near the Canaries, off Agadir, they may even amount to two-thirds of the total catch. Soles are also numerous. South of the Canaries we saw during our cruise (see Chapter III.) a considerable handline fishery for acanthopterygian fish (Dentex, Diagramma, etc.) carried out on hard stony and gravelly bottom. The trawl cannot be worked there, where the acanthopterygians were present in enormous shoals, outnumbering all other species. We had there a fauna entirely different from the boreal fauna, lacking all the northern forms.

All the way from western Ireland to the coast banks of Depth limit Morocco, fishing is carried on down to deep water, at least to 300 fathoms ( 500 to 600 metres). West of Ireland the trawlers in April capture two kinds of ling (Molva molva and M. clongata), hake and breams (Pagellus), down to 300 fathoms, and west of Morocco they get large hake down to 200 or 300 fathoms. Fishing thus goes on as deep as the fauna of the coast banks extends.

As we have seen already, the Macruridx peculiar to the fauna of the slopes, commence at about 500 or 600 metres. Will this fauna of the slopes, particularly the Macruridæ, Mora, etc., ever be the object of a fishing industry? This question is important, and the possibility of such an industry cannot a priori be denied. If we consider that the "Michael Sars" in one haul, with a comparatively small trawl, at Station 4 took over 300 fishes, some of which, as for instance the Mora, seemed just as fit for the market as the tusk, it does not seem improbable that improved technical appliances may render fishing profitable even down to 500 fathoms and more.

It is very interesting to note, as shown in the following table, that the temperature in 300 fathoms (the limit of the coast fish) is $10^{\circ}$ C.- a temperature which we have previously referred to as marking the southern limit of the northern forms to the west of Ireland, where the southern forms commenced to increase in abundance :-

\begin{tabular}{|c|c|c|}
\hline Depths in Fathoms. & $\begin{array}{c}\text { Station 43, } \\
\text { South of the Canaries. }\end{array}$ & $\begin{array}{c}\text { Station 93, } \\
\text { West of Ireland. }\end{array}$ \\
\hline 50 & I $6.8^{\circ}$ & $10.8^{\circ}$ \\
100 & I $5.7^{\circ}$ & $10.4^{\circ}$ \\
200 & I $3.1^{\circ}$ & $10.3^{\circ}$ \\
250 & $11.7^{\circ}$ & $10.2^{\circ}$ \\
300 & $\ldots$. & $10.0^{\circ}$ \\
350 & $9.5^{\circ}$ & $\ldots .2^{\circ}$ \\
400 & $\ldots$ & $9.2^{\circ}$ \\
\hline
\end{tabular}


Vertically as well as horizontally the fauna termed by me the southern one appears to exist within the same limits of temperature. The different species appear to be at liberty to move within these limits and to be independent of depth. Thus there are many observations showing that the southern species occur in deeper water on the Atlantic slope than they do in the North Sea. This is easy to understand, because in the North Sea only the shallow upper layers are affected by high summer temperatures. Nevertheless the records of such species from deeper water available from the results of the "Michael Sars" and other expeditions are quite surprising. Thus the French deep-sea expeditions found :-

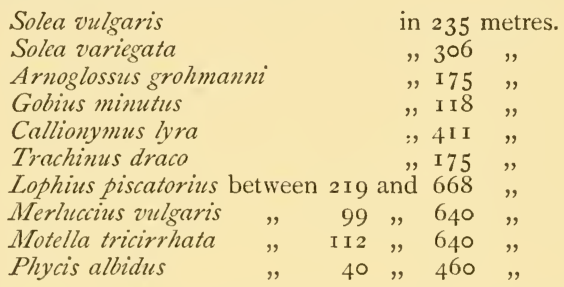

These instances are quite sufficient to show that in the southern part of our area the fishes tend to migrate vertically within considerable bathymetrical ranges. Evidently temperature here plays a dominant part, and perhaps also other factors come into play, above all the deeper penetration of light in southern waters.

The Northern (boreal) Species.
We have previously seen that the northern species in North European waters range from the Barents Sea in the north to west of the British Isles in the south. But within this wide area we meet with many variations in detail, even though the fish fauna of the whole area in a broad sense may be said to be homogeneous. Thus some species belong mainly to the most northerly part of the area, while others are taken in quantities worth mentioning only in the far south of the region. The abundance of a species does not alone depend on latitude or conditions of temperature, but the extent of the area of bottom suitable to the species is also of great importance.

An analysis of this question cannot, however, be restricted to a search for the geographical limits of the species. As regards the northern forms, information as to their bathymetrical distribution is very important. The English fishery statistics 
flounder, and dab-are the most characteristic, but young stages of cod, rays, and dog-fish (Acanthias) also occur plentifully.

In medium depths, from 40 to 100 metres ( 25 to 50 fathoms), the gadidæ-haddock, large cod, pollack, and whiting-predominate, but we also meet with flat-fish, turbot, lemon sole (Pleuronectes microcephalus), and young halibut, and with some southern forms : hake, gurnards, anglers, and conger eels.

Below roo metres (50 fathoms) we meet with the saithe, ling, tusk (see Fig. 313), large hake, besides witch, megrim, and large halibut.

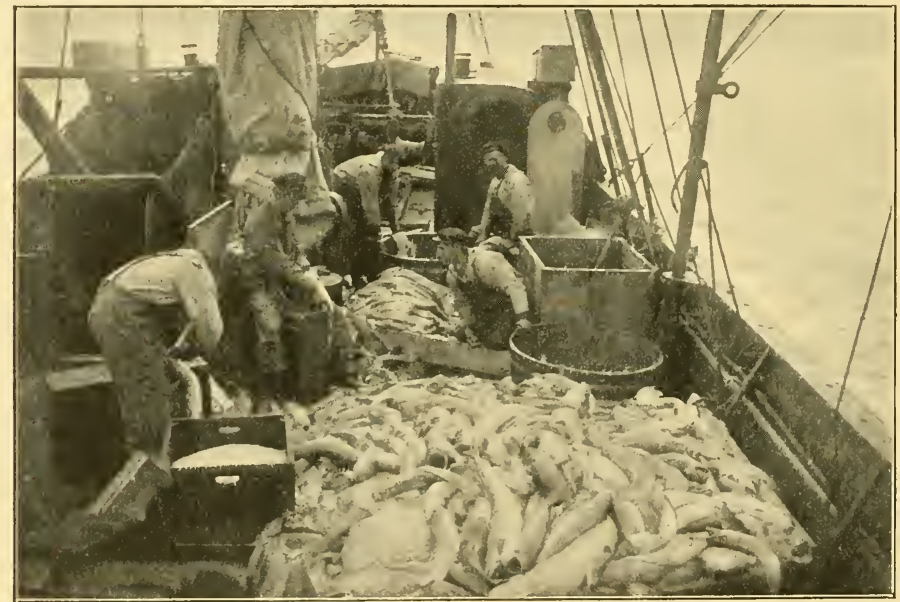

Fig. 313.-The "Michael Sars" fishing Ling and Tusk in the deep part of THE NORTH SEA.

Different physical conditions accompany these characteristic differences in the distribution of the fish; for instance, the depths from o to 40 metres are the ones mainly influenced by summer temperatures; on the shallow coast banks and on the Dogger Bank the temperature at the bottom rises to at least I $2^{\circ} \mathrm{C}$. in the summer season. The sole may thus find here temperatures similar to those off the Atlantic coast of Europe, though in somewhat shallower water. Below 40 metres the summer temperature is not much higher than the temperature during winter, viz. between $6^{\circ}$ and $7^{\circ} \mathrm{C}$.

The species inhabiting the deeper areas of the plateau extend out towards the deep basin of the Norwegian Sea until 
the cold bottom water with a temperature below $\mathrm{o}^{\circ} \mathrm{C}$. is reached, where they are gradually replaced by the cold water fauna previously described.

The same laws which regulate the distribution of different species in the North Sea apply also in the main to other boreal waters where these species live. Scientific fishing experiments, and above all the mass of information gathered from the fishing industry, have in recent years vastly contributed to our knowledge on these points. If on the basis of this knowledge we want to compare the actual conditions in different boreal waters, we must compare areas of corresponding depth. In this way we may possibly form an idea as to the part played by the extent of the sea-bottom, and by physical conditions, in regard to the distribution of our northern species. Some examples may illustrate this point.

In the North Sea the shallow banks in depths less than 40 metres cover large areas, while off the coast of Norway there are hardly any such banks, the coast sloping steeply into greater depths. Shallow banks occur off the south and west coast of Iceland, and far north and east in the Barents Sea, as well as round Cape Kanin. Of the fish inhabiting the shallow areas of the North Sea, only the plaice and the cod occur in great quantities on these northern banks of Iceland and Cape Kanin. Sole, brill, and other flat-fish might also find suitable conditions of depth here, but the temperature is too low. Off the coast of Norway none of these flat-fish, neither the plaice nor the sole, occur abundantly. Thus we plainly see the important parts played by depth as well as by temperature in respect of the occurrence of various species.

While the haddock in the North Sea constitutes nearly half of the total weight of bottom-fish landed, the same species constitutes only 3 per cent off the coast of Norway. This is not because Norway is too far to the north, nor because the temperature of the water is too low, since at Iceland and in the Barents Sea, where conditions are similar, haddock amounts to 20 per cent of the catch, but because off the coast of Norway there are no great areas of suitable depth and with the soft bottom preferred by the haddock. On the contrary we here meet with great areas of "cod-bottom" (sand, stones, shingle, or rocks overgrown with kelp), and therefore the cod makes up over 80 per cent of all the bottom-fish taken off northern Norway.

Thus the extent of the area, and the captures made therein, 
CHAP,

Food-fishes taken in different parts of the North Atlantic.

are closely correlated. If we know the area where a vessel fishes, we can predict the nature of the catch, and on the other hand we may judge of the extent and nature of the area from a knowledge of the fish caught in that area. This fact may be illustrated by the following table giving the quantities of important food-fish in millions of kilograms landed from different areas of the North Atlantic :-

\begin{tabular}{|c|c|c|c|c|c|c|}
\hline & & Cod. & Haddock. & Plaice. & Halibut. & Hake. \\
\hline White Sea, Barents Sea. & $\cdot$ & $\begin{array}{r}3 \\
22\end{array}$ & $\begin{array}{l}2 \\
8\end{array}$ & ${ }^{2}$ & $\cdots_{3}$ & o \\
\hline Iceland . . & . & 106 & 37 & $10^{2}$ & $5 \frac{1}{2}$ & ० \\
\hline Faroe Islands & & I 8 & I I & $\frac{1}{4}$ & 2 & ० \\
\hline North Sea . & - & 73 & I 74 & 45 & 2 & 2 \\
\hline Atlantic coast of Europe & . & 9 & I I & $3 \frac{1}{2}$ & I & 20 \\
\hline Total & . & 430 & 243 & 88 & $\mathrm{I}_{4}$ & 22 \\
\hline
\end{tabular}

According to this table the North Sea proves to be the richest of all in plaice and haddock, just as it includes the greatest area of shallow sandbanks and flats with muddy bottom. The sea of Norway is richest in cod, just as it represents the greatest stretch of rocky coast with temperatures between $6^{\circ}$ and $8^{\circ} \mathrm{C}$.

Boreal fishes on the slope of the Norwegian Sea.

Below 100 metres (50 fathoms) and down to 300 fathoms, we find on the northern slope of the North Sea plateau the following species to be the most important: saithe, ling, tusk, and halibut (see Fig. 3I 4). During the summer we also find the cod in such depths, especially to the north of Lofoten, and on the slopes from the Faroe Islands to Lofoten. A little higher up on the bank these species are mingled with large hake, witch (Pleuronectes cynoglossus), and megrim (Zeugopterus megastoma). Lower down on the slope below 200 metres we find Norway haddock (Scbastes), blue ling, black halibut (Hippoglossus hippoglossoides), Macmums fabricii, Argentina silus, and Greenland sharks. This latter group of species has been found during the Norwegian fishery investigations along the "edge" of the continental platform all the way from Spitzbergen and Bear Island along the coasts of Norway, the North Sea plateau, the Faroe Islands, and along the Faroe-Iceland ridge.

If we follow the 600 metres line in the chart (Fig. 309) from Spitsbergen and round the southern part of the Norwegian Sea 
to Iceland, we shall at the same time trace the limit between the cold-water fauna of the deep basin and the boreal fauna of the slope of the coast plateau. Within this boreal region we may discern different areas of distribution. The ling, for instance, is caught off the coast of Norway in abundance as far north as Lofoten; north of Lofoten, between the Faroe Islands and Iceland, and at Iceland, the ling is only poorly represented,
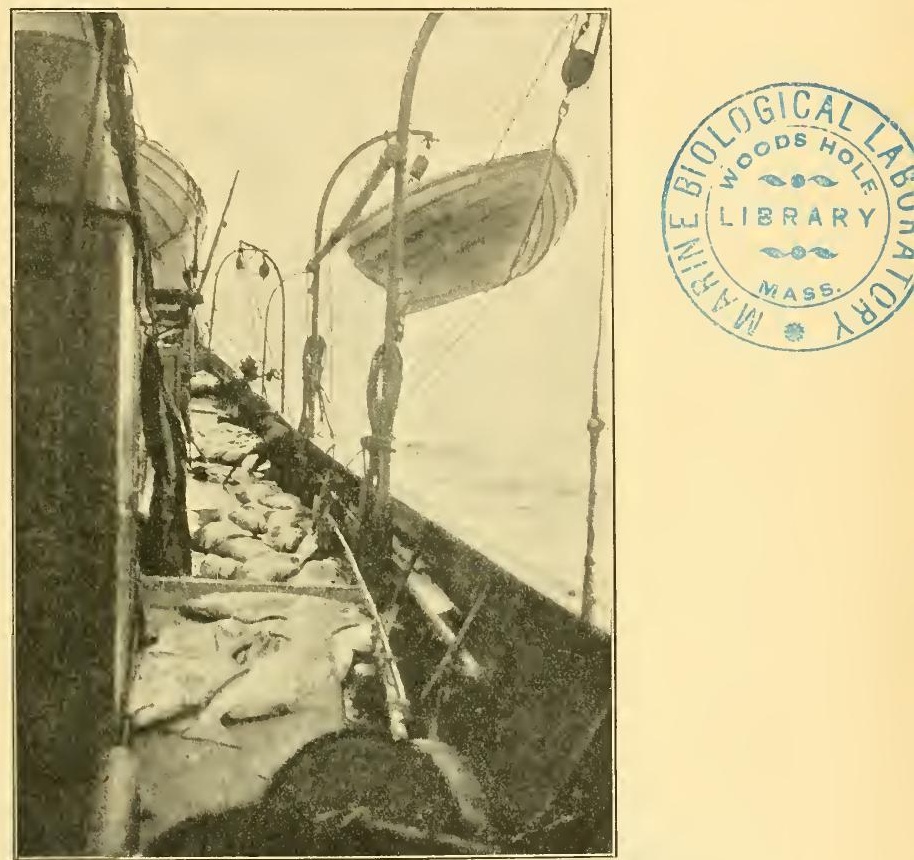

Fig. 314.-The "Michaei. Sars" fishing Halibut on the Slope.

while the cod there plays an important part in the "edge" fishery during the summer. Large halibut, from 50 to I 50 kilos in weight, on the other hand, occur on the slope from west of Bear Island, round the North Sea plateau, the Faroe Islands, and on to Iceland. The Norway haddock has a similar distribution to that of the large halibut.

The fauna of the eastern and southern slopes of the Norwegian Sea thus proves to be very uniform for a distance of 
I 200 or 1500 miles, in accordance with the uniformity of the physical conditions. As we have previously seen, uniform physical conditions of a different character are met with along the slopes of the Atlantic from the Wyville Thomson Ridge down to south of the Canaries, the forms peculiar to this region being entirely different to those inhabiting the slopes of the Norwegian Sea,

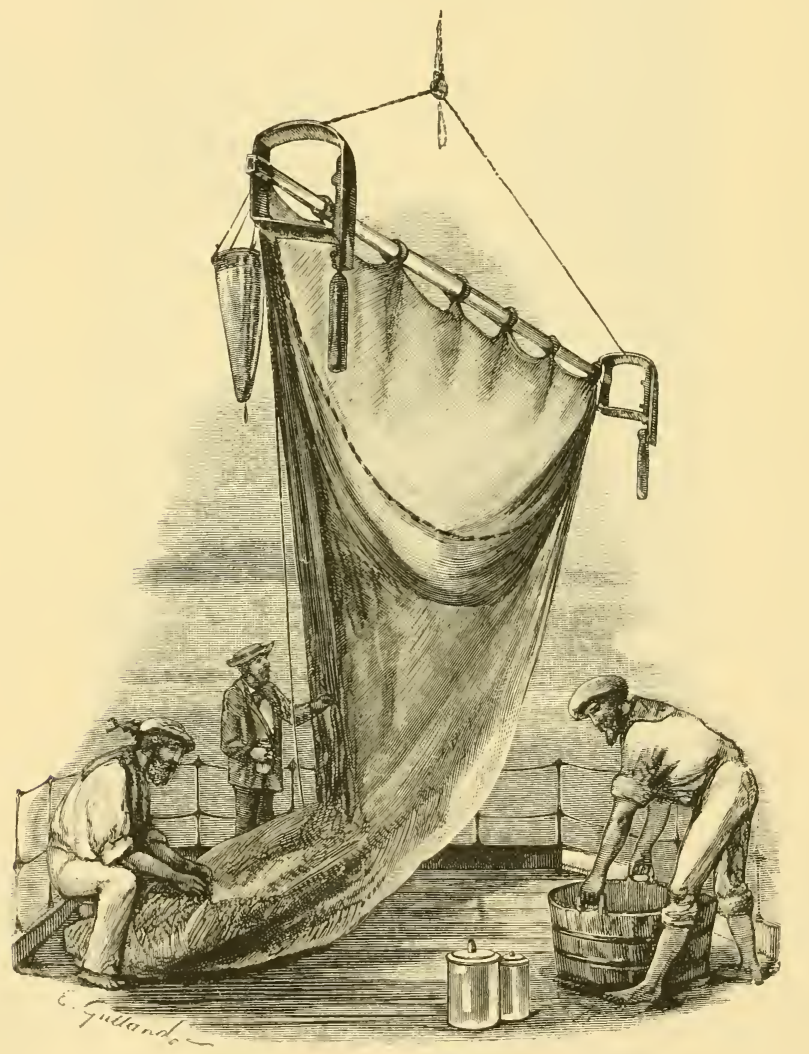




\section{CHAPTER VIII}

INVERTEBRATE BOTTOM FAUNA OF THE NORWEGIAN SEA AND NORTH ATLANTIC

ThE topography of the Norwegian Sea has been briefly noticed in Chapter IV. and the hydrography in Chapter V.

The distribution of forms in the Norwegian Sea agrees with the hydrographical conditions, and we can distinguish two great regions, the boreal and the arctic, each of which has its own appropriate fauna. All those parts of the ocean-floor Boreal region covered by Gulf Stream water or by coast-water make up the ${ }_{\text {Norwegian }}^{\text {for }}$ boreal region, while the arctic region is covered by water with Sea. polar characteristics. The temperature and salinity in boreal areas vary greatly in the different water-layers, and are much affected by the seasons. What chiefly distinguishes the boreal region from the arctic region is the higher temperature, which never falls below o $\mathrm{C}$., and over large areas never sinks below $6^{\circ} \mathrm{C}$. The uppermost water-layer may form an exception, for the temperature may occasionally at the very surface and for a comparatively short time fall below o $\mathrm{C}$. High summer temperatures are characteristic of the upper water-layers, and exercise a considerable effect upon the fauna. The boreal region of the Norwegian Sea includes the North Sea with the Skagerrack and Kattegat, the Norwegian coast plateau as far as the North Cape, the coast plateau of the Faroe Islands, and the south and west coasts of Iceland.

In the arctic region the temperature and salinity are much Arctic region more uniform than in the boreal region: the temperature is ${ }_{N}^{\text {of the }}$ (orian usually below $0^{\circ}$ C., though in summer the actual surface may Sea. show higher temperatures under the influence of the sun, but the sun's heat does not penetrate so deeply as in the boreal region; the salinity varies greatly at the surface, but at the depth of a few metres it is rarely less than 30 per thousand. The arctic region comprises the coast plateaus of Greenland 
north of Denmark Strait, Spitsbergen, Franz-Josef Land, Novaya Zemlya, the coast between the White Sea and the Kara Sea, as well as the plateau of Jan Mayen and the deep central basin of the Norwegian Sea.

In addition to these purely boreal and purely arctic areas Boreo-arctic region of the Norwegian Sea. there are transitional areas, designated boreo-arctic, which may be found wherever boreal and arctic water-masses meet Such areas occupy more or less extensive tracts, and exercise a distinct influence upon the distribution of the fauna. The temperature is not so high as in the boreal region, except perhaps at the surface, varying between $0^{\circ} \mathrm{C}$. and $3^{\circ}$ or $4 \mathrm{C}$., though in the shallower parts a far higher temperature is found in summer, due to the heat of the sun, and as a result there are certain boreal littoral forms that occur also in the boreoarctic region.

The following are boreo-arctic areas: the south-western portion of the Barents Sea, from the East Finmark and Murman coasts to the White Sea, where a branch of the Gulf Stream, flowing eastwards, is gradually blended with arctic water; the north and east coasts of Iceland, where branches of the Gulf Stream unite with the East Iceland Polar Stream ${ }^{1}$; the IcelandFaroe ridge, where the East Iceland Polar Stream meets the Gulf Stream ; the Wyville Thomson Ridge, over which the Gulf Stream passes into the Norwegian Sea, where a mixture of the two waters undoubtedly takes place, but this boreo-arctic area is of small importance compared to the others; and the continental slope on the eastern side of the Norwegian Sea, where there is a narrow area of mixture between Atlantic water and arctic water, resulting in temperatures slightly higher than o C. A weak branch of the Gulf Stream flows along the west coast of Spitsbergen, giving rise to a very limited boreoarctic belt, though, generally speaking, the west side of Spitsbergen must be considered purely arctic. The shallower parts of the coastal waters, as well as the inner portions of the fjords, from Lofoten to the North Cape, are boreo-arctic.

North

The topographical conditions in the North Atlantic are Atlantic. much like those of the Norwegian Sea, but the hydrographical conditions are dissimilar. On the eastern side the coast banks of both Europe and North-West Africa are bathed by much warmer water than those of corresponding parts of the Nor-

1 I ought to state, however, that owing to the influence of the East Iceland Polar Stream the north-eastern coast must perhaps be considered a purely arctic area. 
wegian Sea, and the littoral fauna naturally accords with its surroundings. This is true also of the archibenthal area (that is to say, the steep continental slopes) and the abyssal region. The temperature at 1000 metres may be as high as $6^{\circ}$ or $8^{\circ} \mathrm{C}$., and $2^{\circ}$ or $3^{\circ} \mathrm{C}$. at still greater depths. Here, again, the fauna conforms to its surroundings. In addition to the vast central abyssal plain, the boreal region of the Atlantic includes the coast plateaus off Europe and North-West Africa, and the southern slopes of the ridges extending from the Shetlands to Greenland, that is to say, practically the whole of the eastern portion of the Atlantic. Arctic currents, on the contrary, prevail in the western portion of the Atlantic, and cause hydrographical, and therefore faunal, dissimilarities at different parts of the coast. In the coastal areas south of Cape Cod (about lat. $42^{\circ}$ N.) we find Gulf Stream water and a characteristic warm-water fauna; but north of Cape Cod we meet with an icy polar current descending from higher latitudes, so that the stretch of coast from Cape Cod to the north of Newfoundland must be looked upon as boreo-arctic. More genuinely arctic conditions prevail off the coasts of Labrador and Greenland.

\section{Boreal Region of tile Norwegian Sea}

The boreal coastal area may be divided into three vertical The coastal zones, distinguished by different physical, topographical, and biological conditions. The uppermost is the littoral zone, which extends from the shore down to a depth of 30 or 40 metresthat is to say, almost as far down as there are sea-weeds. The physical and topographical conditions characterising the littoral zone are: periodic changes in temperature and salinity (the temperature of the water being directly affected by that of the air), strong light, and a great variety in the materials at the bottom, such as loose stones, solid rock, sand with or without coarse or fine fragments of different kinds of shells, mud, and "mixed mud" - that is to say, sand, mud, and stones all mixed together. Here we find the whole vegetation collected, consisting of fucoids, green and red algre, Laminaria, and Zostera, all of which, as a rule, form big interdependent communities that are very often arranged in belts.

The lower limit of the sublittoral zone on the west coast of the Scandinavian peninsula may be put at about i50 metres. It differs from the preceding in being without vegetation, as well as in having more uniformity in the bottom-

Thea of the boreal region of the Norwegian Sea. 
deposits, higher and more constant salinities, and less pronounced differences in temperature. The bottom consists either of solid rock or sandy clay, or else of a rather coarse mixture of shells and sand, which is often found on the slopes of rocky portions in particular, together with large stones and pebbles. On the other hand, we do not get the fine mixture of shells and sand which is so characteristic of the littoral zone out among the skerries. The lower limit of this zone practically coincides with the lower limit of the coastal water, the salinity of which is lower than that of the Atlantic water lying beneath it. ${ }^{1}$ The temperature does not vary more than a few degrees in the different seasons, being lowest during the summer in the deeper portions, but it is, for part of the year at any rate, higher than that of the Atlantic water.

Below the sublittoral zone we come to another zone, distinguished by more uniform and more constant topographical and physical conditions, which we may call the continental deep-sea zone (ranging from I 50 to 1000 metres or more). The bottom consists mainly of rock or a fine mud, which may perhaps be mixed with a little sand in the uppermost portions. In its upper parts, near the borders of the sublittoral zone, temperatures and salinities vary to a slight extent, but in the deeper parts both are constant, the salinity being 35 per thousand or a little over, and the temperature between $6^{\circ}$ and $7^{\circ} \mathrm{C}$. all the year round.

We propose to discuss the coastal area of the boreal region under three headings: (I) the islands of the Norwegian west coast, where the littoral zone alone is represented; (2) the fjords, where all the zones are represented; and (3) other northern boreal areas.

Littoral zone of Norwegian islands.
(I) Islands of the Norwegian West Coast ("Skjargaard").We may divide the littoral zone among the islands of the Norwegian west coast into different areas. There is first a low-tide area, subject to changes of tide, and accordingly dry for certain portions of the twenty-four hours. Here we can distinguish three "facies" with different bottom-conditions, namely (I) rocky, either bare rock or very scantily overgrown; $(2)$ a fucoid belt; and (3) sand. Each of these has, as a rule, several forms peculiar to it, though unquestionably a good many species of the littoral fauna are common to all. The dissimilarity in the com-

1 It must, however, be stated that the limits between the coastal water and Atlantic water vary with the seasons. 
position of the fauna of the different "facies " depends to a great extent on the structure of the animal-forms, inasmuch as some forms must have a vegetable or hard solid foundation, while others require loose material. Littoral gasteropods, as a rule, require a solid foundation, and they are therefore generally absent from the sandy bottom ; but there are certain burrowing forms which can only live where the bottom is incoherent. Other forms, again, like the crab, are able to live on nearly every kind of bottom.

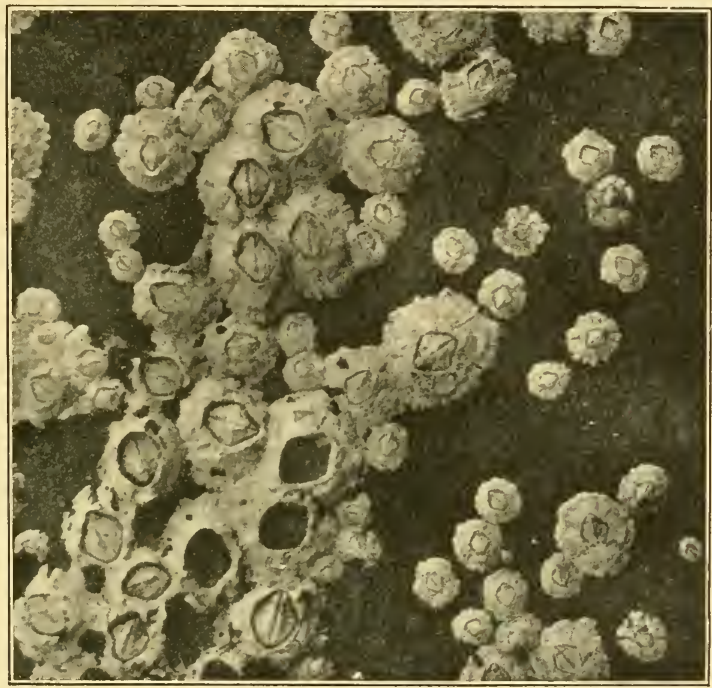

FIG. 315 .

Balanus halanoides, L.

Below the low-tide area, with its fucus vegetation, we find on hard bottom a Laminaria belt beginning immediately below the fucoid belt, and always covered by water. ${ }^{1}$ We find also a Zostera belt, hard bottom, and sandy bottom.

On the bare or scantily overgrown rocks near high-water Low-tide mark we find a white belt of barnacles (Balanus balanoides, see area. Fig. 315); when examined at high tide we notice these little creatures extending and contracting their lash-like limbs to set

1 Only at very low ebb-tides and in certain places do we find certain species of Laminaria also laid bare. 
the water in more rapid motion, and so bring nourishment to their mouths inside their shells, but when exposed at ebb-tide the

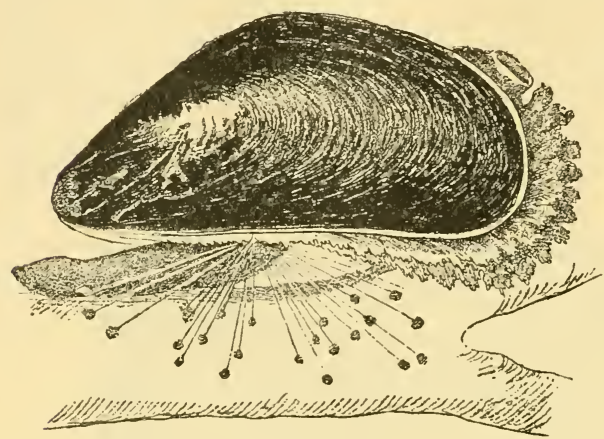

FIG. 316.

Mytilus edulis, L. shells are closed and the animals remain concealed within them. Immediately below the barnaclebelt we frequently find a belt consisting of dense masses of mussels (Mytilus edulis, see Fig. 316 ), though the individuals in such localities never attain any considerable size. On the rocks we find everywhere four species of gasteropods, which are very characteristic of this area, namely, the limpet (Patella vulgata, see Fig. 3I7), two periwinkles (Littorina

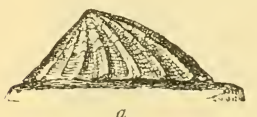

FIG. 3I7.

Patella vulgata, L. $a$. From the side; $b$. from beneath.

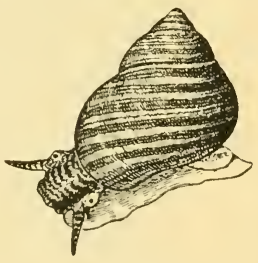

FIG. 318. Littorina littorea, L.

littorea, see Fig. 318, and L. rudis), and the purple snail

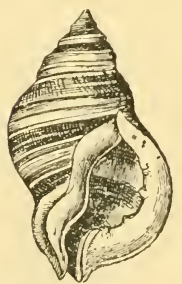

FIG. 3 I9.

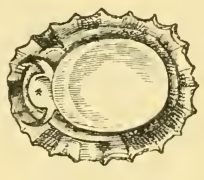

b

(Purpura lapillus, see Fig. 319), this last being often plentiful in the barnacle-belt, where it feeds on these crustaceans. These forms live chiefly on the naked rock, but, except the limpets, also often on the algæ in the tidal area. But when the belt of fucoids is exposed at ebbtide, especially in sheltered places where a good current runs, we see that the alga, the species of Fucus in particular, have their special fauna, consisting chiefly of attached forms. Purpura lapillus, L. The majority of them are hydroids, the com- . monest species being Dynamena pumila (see Fig. 320), 
Laomedea flexuosa, and Clava squamata (see Fig. $32 \mathrm{I}$ ). There are several bryozoans ${ }^{1}$ here too, and the fucoids are often densely thronged by small white spiral-shaped tube-worms (Spirorbis). Amongst the unattached forms associated with the algæ I may mention: Littorina obtusata, which keeps mostly to little bays sheltered from the action of the waves; $L$. littorea, which is very common; and our smallest shelled snail Skenea planorbis, which is met with in favoured spots under stones and upon algæ of different species.

More local in their occurrence,

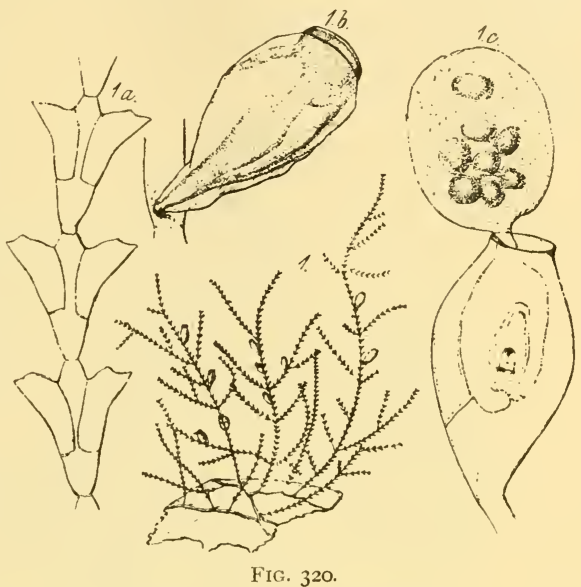

Dynamena pumila, L. (After Hincks.)

though generally numerous where found, are certain species of Actinix-the red Actinia equina (see Fig. 322), the yellow or brownish Metridium dianthus (see Fig. 323), and Urticina crassicomis being the commonest forms. The first of these is generally found in quiet bays where the shore is covered with large stones and pebbles, the individuals being sometimes attached to these and sometimes to cracks in the rock. As this species produces its young fully developed, and the newly-born actiniæ are able to attach themselves easily, it is frequently met with in fairly large colonies.

FIG. 32I.

Clava squamata, Müll. (After Hincks.)

Another remarkable mode of propagation, namely schizogony, is to be seen in Metridium dianthus in its younger stages. From the foot-disc of the animal small pieces unwind and form new organs, such as new tentacles, new mouth, etc. In this way colonies are formed, which may be widely distributed over the rock or the roots of the laminaria.

\footnotetext{
${ }^{1}$ Chiefly Alcyonidium hirsutum, Flustrella hispida, Bowerbankia imbricata.
} 
The fully developed individuals of Metridium are usually found in places where there is a strong current.

Off the coasts of Scandinavia the sandy bottom of the low-tide area is not so extensive as along other coasts of the North Sea, but it is interesting to note that the fauna inhabiting this region is much the same everywhere, and that burrowing forms predominate. There is first the sandgaper (Mya

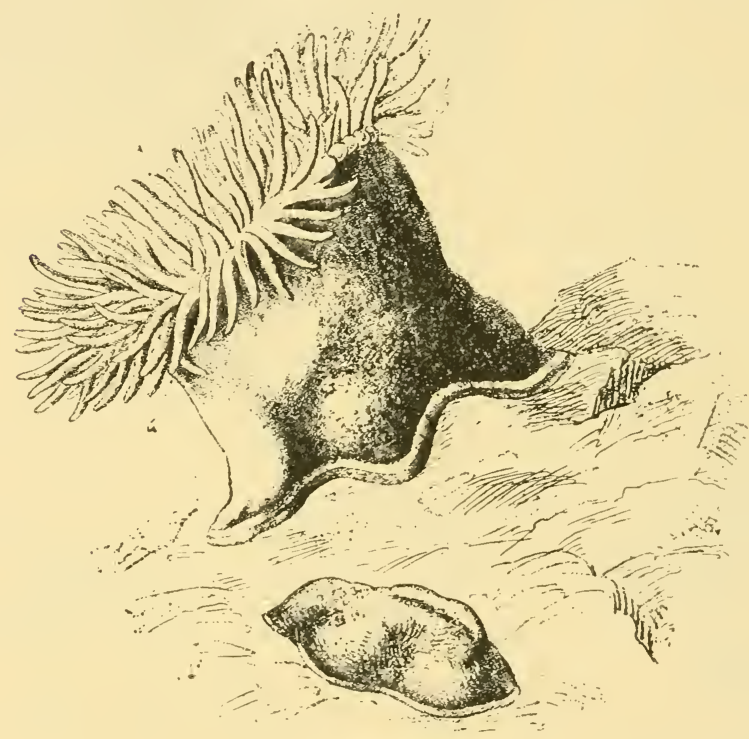

FIG. 322 .

Actinia equina, L.

arenaria), and then the cockle (Cardium edule, see Fig. 324), and also different species of Tapes, though these are not so universally distributed. The lugworm (Arenicola piscatom, see Fig. 325) is another burrowing form, and its presence can easily be detected by little heaps of string-like excrements.

In addition to these forms, which are adapted for life in the low-tide area at those parts of the coast where the ebb-tide recedes a long way, we also get the common shore crab (Carcinus monas), often to be found under fucus that has been left exposed. This is the case also with the common starfish (Asterias ubens), and occasionally, too, with the common 
sea-urchin (Echinus esculentus), the hermit crab' (Pagums bernhardus), and a few other forms. Their occurrence is, however, really due to their being surprised by the receding of the tide, and they are not, strictly speaking, adapted to a life in this area.

There are some forms characteristic of the low-tide area

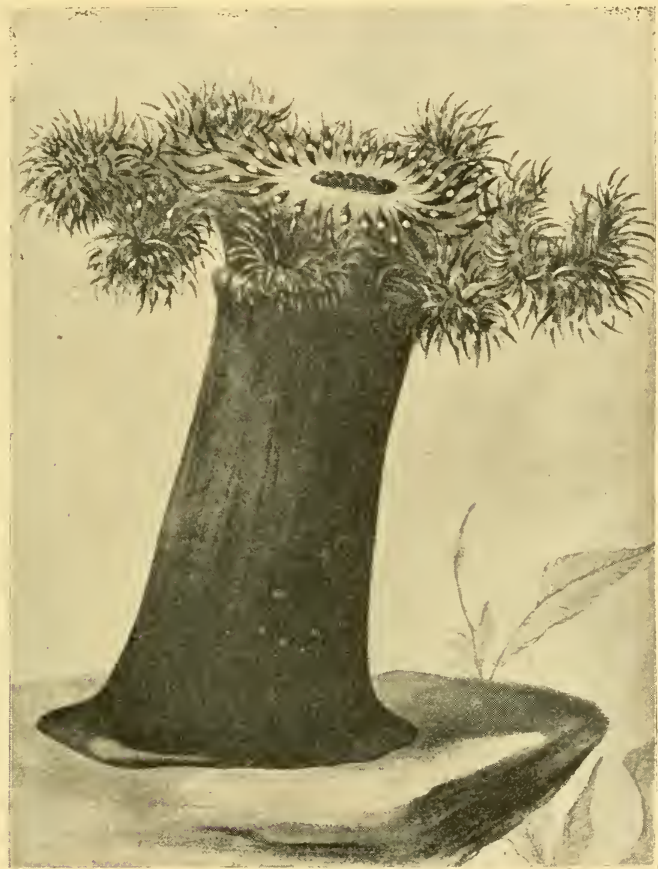

FIG. 323

Metridium dianthus, Ell. (After Andres.)

which cannot be regarded as belonging solely to any particular facies. Perhaps the commonest are the sandhoppers (Gammarids), which have a wonderful knack of hiding themselves quickly in holes and cracks, when the stone or other object, under which hundreds may be sheltering, is removed. One of the most abundant is Orchestia littorea, which, although a true marine form, is able to exist for a long time out of the water. I have found quantities of them during summer living 
perfectly happily with true land-animals, such as centipedes and woodlice, in places that were very rarely covered by the sea, so that they had to depend upon the slight moisture retained beneath the stones; individuals found living under these conditions on being

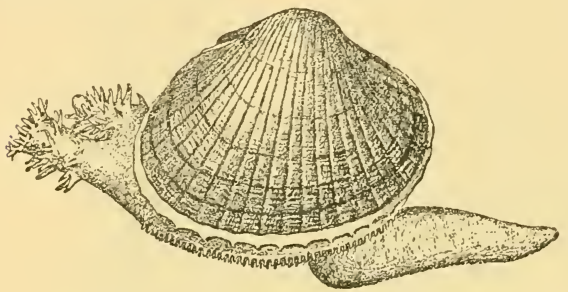

FIG. 324 .

Cardium edule, L.

transferred directly to sea-water showed not the least sign of being inconvenienced by the sudden change. Another equally common sandhopper (Gammarus locusta, see Fig.

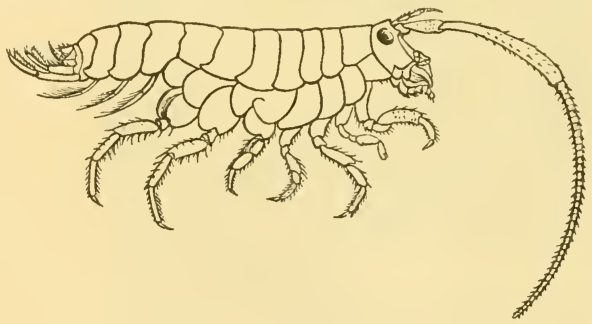

FIG. 326.

Gammarus locusta, L. (After Bate and Westwood.)

326 ) is also a littoral form, but it never quits the sea for any length of time.

Unexposed area.

Laminaria belt.
In the unexposed portion of the littoral zone of the skerries we may distinguish four "facies": (I) Laminaria belt, (2) Zostera belt, (3) hard bottom, and (4) sand.

The Laminaria belt begins immediately below the fucoids, and along the west coast of

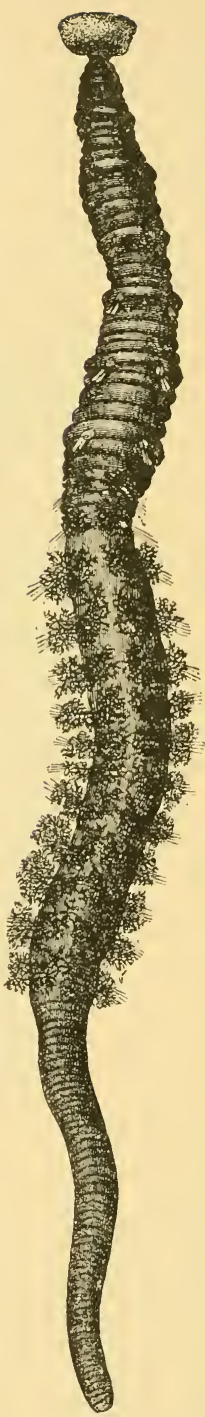

Fig. 325 .

Arenicola piscatorum, L. 
Norway there are three common species : Laminaria lyperborea, $L$. digitata, and $L$. saccharina. The first of these occurs in great thickets in open bays or places where the play of the waves is felt, whereas the other two grow in more sheltered localities. The fauna varies accordingly. On the stalks of Laminaria hyperborea we get numbers of attached forms, chiefly hydroids, bryozoans, synascidians (see Fig. 327), and

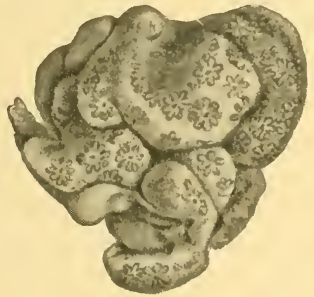

FIG. 327

Synascidian: Polycyclus fuscus, Huitfeldt Kaas. calcareous sponges. Halichondria panicea, one of the few siliceous sponges of the littoral zone, also

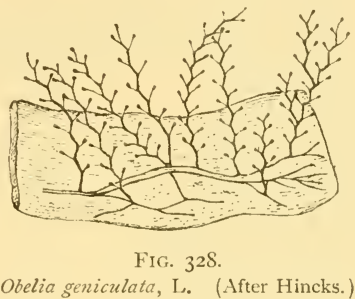

frequently forms a thick covering over long pieces of the stalks. On the blades of the laminaria two forms are very common, namely the bryozoan Membranipora membranacea, which makes a white covering over large portions, and the little hydroid Obelia geniculata (see Fig. 328). An unattached form, the gasteropod belonging to the Patellid family (Nacella pellucida), is very conspicuous, owing to its handsome blue striped shell, and lives exclusively on the laminaria.

Besides the attached forms,

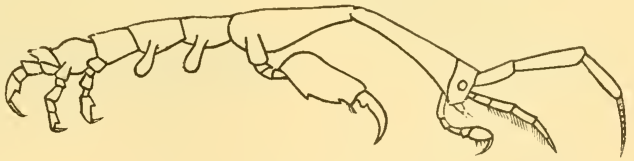

FIG. 329.

Caprella linearis, L.

that often completely cover the lower parts of the laminaria, there are unattached species in great abundance existing upon or among them. The best way of observing them is to shake a thickly overgrown laminaria stalk, placed in a large glass of sea-water, when we may perceive swarms of amphipods, worms, ${ }^{1}$ tiny mussels and snails, little starfishes, and other creatures. The most noticeable of the amphipods are the elongated and strangely built caprellids, of which Caprella linearis (see Fig. 329) 
is the commonest. With their prehensile claws they climb about among the hydroids and red algæ, hooking themselves on by their hind limbs, swaying to and fro for a time, and then catching hold of another branch with their front claws and climbing farther. In fairly sheltered localities we often get among the branches of the hydroids and algre little tubeshaped dwellings constructed out of various materials and inhabited by different species of amphipods, ${ }^{1}$ and here, too, we meet with some kinds of pycnogonids. ${ }^{2}$ Beautifully coloured

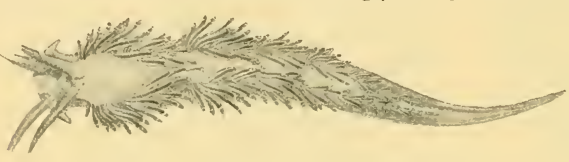

FIG. 330 .

Eolis rufobranchialis, Johnst. (After Alder and Hancock.) nudibranchs (usually species of Eolis, and especially Aolis rufobranchialis, see Fig. 330) crawl slowly about and feed like the pycnogonids upon the hydroids; certain kinds of nudibranchs (especially some species of Doris, see Fig. 33 I, Polycera, etc.) occur chiefly in the winter. Animal groups that are very numerously represented in the algæ-vegetation of the littoral zone, though they must be very carefully searched for, are rhabdocolous turbellaria and several species of Halacarids. There are, in addition, quantities of the young of Mytilus, asterids, etc. Among the "roots" of the laminaria we frequently get Nereis, Ophiopholis aculeata, and borer mussels (Saxicava).

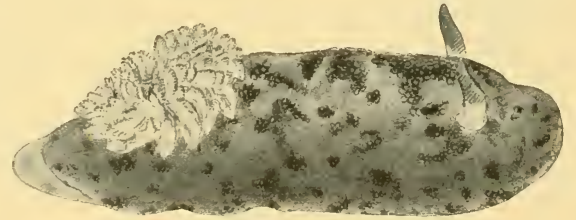

FIG. 33I.

Doris tuberculata, Cuv. (After Alder and Hancock.)

borea, which prefers the most exposed situations, where there are waves or strong currents, as well as hard bottom to which to attach itself, we find the eelgrass (Zostera marina) in enclosed sheltered localities (pools, estuaries, etc.) and upon soft muddy bottom. The fauna of the eelgrass is not nearly so rich in species as that of the laminaria, still there are several characteristic forms living mainly, and perhaps exclusively, in its vicinity. There is, for instance, a small whitish semi-trans-

1 Especially species of the family Podoceridx, characterised by the extremely hairy antenne.

${ }^{2}$ Nymphon brevirostre, Phoxichilidium femoratum, Phoxichilus spinosus, etc. 
parent snail (Rissoa), which may often be found in enormous quantities; often also there are great numbers of another snail (Akera bullata), and in the mud, even where there is no zostera vegetation, we frequently find species of Philine. A species of attached ascidian (Ciona intestinalis, see Fig. 332), which, however, is also found on laminaria, especially when growing in sheltered or rather deep places, is one of the most prominent animal forms of the eelgrass. Hydroids and synascidians are also occasionally met with. Swimming amongst the blades of the eelgrass we further find various crustaceans, of which two species of prawns (Pandalus anmulicomis and Palcmon) are the most noticeable. They are not limited to the eelgrass, however, but occur also in places where zostera does not grow. The list of forms to be found here is far from exhausted, for I have mentioned only some of the chief ones. The zostera belt is not of so much importance along the Atlantic and North Sea coasts of Scandinavia, as it covers a very limited area in comparison with the other subdivisions of the littoral zone, and it is negligible indeed, when compared with the immense tracts in the Kattegat which are literally overgrown with this plant.

Such in general is a picture of the fauna to be found in the algx and zostera vegetation of the strand-belt; though it must be understood that when speaking of this fauna as associated with the plants I do not imply that these animal-forms can exist only upon them. This is only exceptionally the case. The relationship between them depends on the fact that, as a rule, the alga afford an excellent foundation for the attached forms, which find favourable conditions of nourishment wherever the algxe flourish. For we must remember that these attached forms are obliged to obtain their nourishment from such organisms as chance to come within their reach, and since currents and waves furnish the necessary assistance, we 
generally find the most abundant animal life among the algæ in localities where wave-action is most effective. Most of the non-attached forms are in no way directly dependent upon the algæ-vegetation.

It will be evident that attachment to fucus and laminaria is not biologically essential, if we bear in mind that the same animal forms which attach themselves to these plants occur also on rocks and stones. The vegetation merely increases the area available for the attached forms. Nor is any particular plant essential for any particular species of animal. No doubt

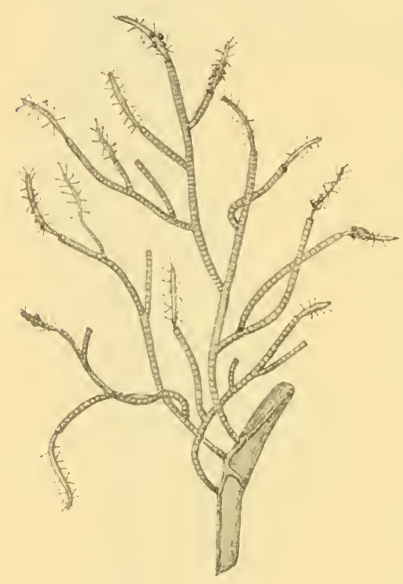

FIG. 333

Coryne pusilla, Gaertn. (After Hincks.) on the Norwegian west coast Laomedea flexuosa and Clava squamata nearly always attach themselves to Ascophyllum, while Obelia geniculata and some others prefer laminaria, but this is chiefly owing to the tides. On the Skagerrack coasts, where tides are inconsiderable and irregular, we find even in the fucus belt forms like Coryne (see Fig. 333), Tubularia, and Obelia geniculata, though on the west coast of Norway they grow only among the laminaria and at a lower depth. These forms cannot stand exposure for any length of time, and they are therefore not to be found in places where the ebb regularly goes back a long way. The forms met with in the tidal area cannot, however, be in any way dependent upon the ebb-tide for their existence, seeing that they occur numerously also on the coasts of the Skagerrack, where tides are scarcely felt. Instances of this are furnished by Clava, Campamularia flexuosa, and Dynamena pumila, but the fact that these forms are able to withstand exposure for considerable periods of time makes it possible for them to occupy a far more extensive area than would otherwise be the case.

So far as the structure of their organs is concerned, the unattached forms in the algx-fauna are particularly well equipped for gripping, climbing, or creeping about among the hydroids and the red bushy algæ that usually grow in quantities upon the laminaria. The crustaceans (caprellids and amphipods) 
have extremely bent legs and claws, the naked snails have their flexible foot-discs and the planarians their rhabdites, so that these creatures furnish excellent examples of adaptability to external conditions. A bodily structure of this kind is necessary for these forms, or when exposed to the action of the waves or currents they would run the risk of being torn from the objects to which they cling.

The marine alga are known to be rather particular about the localities they select. Some species grow high up on the

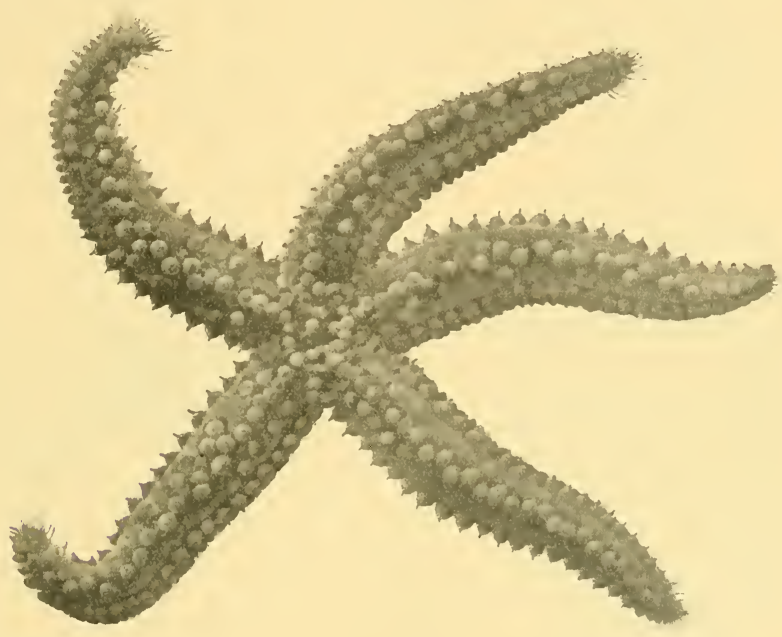

FIG. 334 .

Asterias glacialis, L. (After Ludwig.)

rocks so as to be covered only at high tide, while others choose the lowest limit of ebb-tide; some prefer sunlight, while others thrive only away from it ; some grow best amidst the waves and breakers, while others need sheltered places. This is, to some extent, true also of the animal forms of the upper littoral zone, many of which prefer the open parts of the coast, while others live in sheltered localities, and others again where the currents are strong. The three bryozoans Alcyonidium, Flustrella, and Bowerbankia, for instance, seem to prefer shelter and a good current, whereas Membranipora pilosa flourishes best in the laminaria belt, in exposed places where Laminaria hyperborea 
CHAP.

grows. Littorina littorea and L. obtusata again are found in greatest abundance wherever there is shelter, while Nacella pellucida generally lives on the blades of Laminaria hyperborea. In the sheltered haunts of Laminaria saccharina and $L$. digitata, particularly on the first named, we find the brittle-star Ophiothrix fragilis, while the localities with $L$. hyperborea have evidently no attractions for it ; the blades of $L$. saccharina, too, are much patronised by the bryozoan Aetea. Asterias glacialis (see Fig. 334) also prefers sheltered localities. Why there should be these apparently capricious affections is as yet unknown, but it may be that in undisturbed waters there are higher temperatures during the summer, and that consequently various influences are brought to bear upon the organisms at one stage or another of their lives.

Hard bottom in the unexposed portion of the littoral zone.

The most typical localities of this kind are met with as a rule in sounds amongst the skerries, where there is a more or less strong current, which carries away the finer particles of mud that would otherwise settle, and leaves only large fragments of shells and similar debris. On the hard bottom there are usually numbers of both attached and unattached forms, chiefly consisting of bryozoans, hydroids, especially the

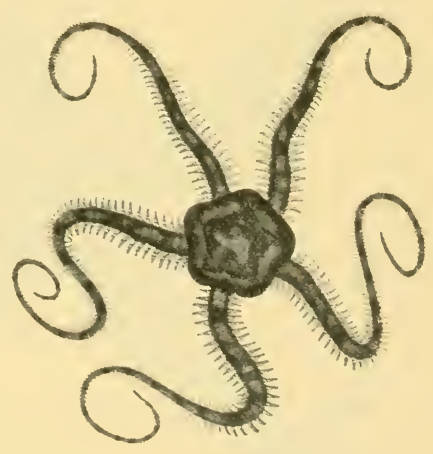

FIG, 335 .

Ophiopholis aculeata, L. genus Tubularia, and ascidians. The coral Alcyonium digitatum too is often plentiful, ${ }^{1}$ generally attached to large empty mussel shells or stones. The empty mussel shells are also patronised by big colonies of the serpulid Pomatoceros triqueter, which however is just as much at home on the rocks up to the very shore. There are, besides, Anomia ephippium, Chiton cinerens, Tectura virginea, Buccinum undatum, and several others, some sedentary, and others, like the chitons and Tectura, able to move about from one place to another; as well as Mytzlus modiolus, though this mussel is far more plentiful inside the fjords, and Gonactinia prolifera.

1 This form may even be found up to low-tide mark, where there are strong currents, as for instance in narrow shallow sounds. 
Several echinoderms occur numerously wherever there are currents. There are quantities of the brittle-stars: Ophiopholis aculeata (see Fig. 335), Ophiocoma nigra, and Ophiura albida. Two species of sea-urchins that live on the hard bottom in the littoral zone are very common among the skerries on the west coast of Norway, namely Echimus esculcntus and Strongylocentrotus dröbachiensis. On the other hand, Echimus acutus and Parechime miliaris ${ }^{1}$ have a different local distribution, to which I shall allude later. All four species may be found up to low tide mark. This is true also of the big darkbrown holothurian Cucumaria frondosa (see Fig. 336), large numbers of which live on the hard bottom among the skerries, and in the outer parts of the fjords, especially where there is a strong current. They fasten themselves to the rock by means of their suckers, and often have their tentacles stretched out in order to capture pelagic organisms, which are afterwards licked off, the animal sticking one tentacle at a time into its mouth.

Together with the above forms we find a mussel, Lima hians, which is very characteristic of these localities. It is of interest biologically, because it lives within a nest constructed with the assistance of its byssus out of bits of empty mollusc shells, fragments of echinids or serpulids, and similar materials; in fact, no loose substances appear to come amiss.

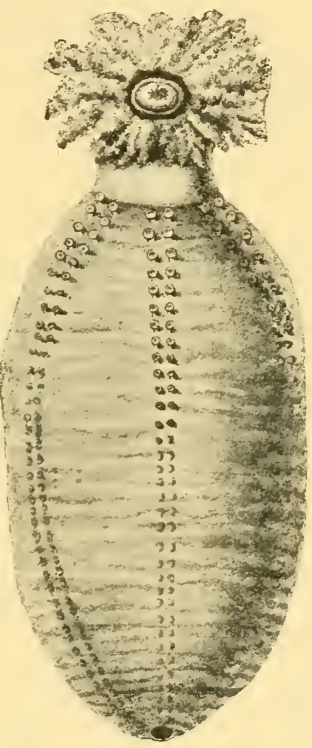

FIG. 336 .

Cucumaria frondosa, Gun.

Two starfishes are always present, namely Asterias mbens and A. milleri. There are other species as well, of course, such as worms and serpulids, but they cannot be called particularly characteristic.

Here, too, the lobster (Homarus vulgaris) is equally at home, and may be met with under rocks and stones, occasionally venturing on to sandy bottom. It is distributed throughout the whole littoral zone from a depth of about one metre downwards, a certain proportion of individuals migrating vertically, descend-

\footnotetext{
1 In a few localities all these species may be found together.
} 
ing to greater depths in winter. The spawning females usually repair to shallow places in the summer, the higher temperatures being better suited to the development of the eggs and larvæ.

Several of the strange mask crabs (Hyas, see Fig. 337, Stenorhynchus, Inachus) also inhabit the littoral zone, chiefly where the bottom is overgrown with algæ, bryozoans, and hydroids, being rarely met with upon sandy bottom. They are supplied with small hooks on the carapace and extremities, by which they attach to themselves the algx or animal-colonies around them. These crabs are extremely sluggish and inactive, and they derive an advantage from this remarkable habit, since they are difficult todistinguish from their surroundings, and consequently they can conceal themselves from their prey as well as from their enemies.

Sandy bottom in the unexposed littoral zone.

The bottom here chiefly consists of what has been called shellsand, made up entirely of shell-

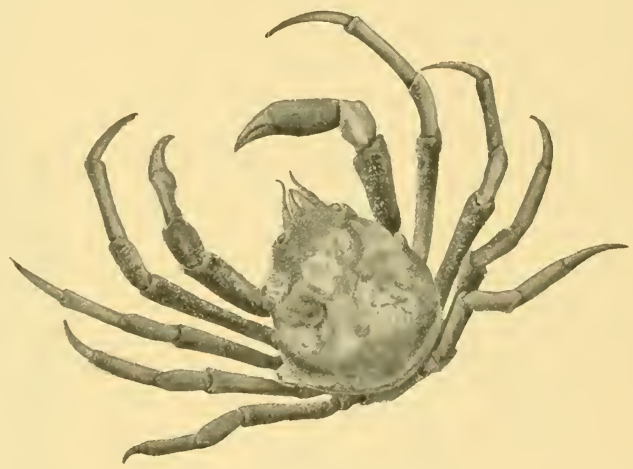

FIG. 337.

Hyas araneus, $\mathrm{L}$.

fragments of molluscs, echinoderms, balanids and other creatures; it is usual to make a distinction between the coarse and the fine shell-sand. This detritus is practically only met with in the littoral zone of the skerries, and is undoubtedly due to the action of the waves and breakers. Burrowing forms, for the most part mussels, spatangids, clypeastrids, and worms, predominate. The lancelet (Amphioxus) also makes this its principal home. The loose formation is burrowed into quite easily, and a lancelet can work its way down in the course of a few seconds. ${ }^{1}$ We must also include the sand-eels (Ammodytes) amongst the vertebrate forms that burrow in this sandy bottom, though they are somewhat local in their occurrence.

This form burrows in a curving direction beneath the surface of the sand, finally protruding its head very slightly a short distance from where it went in, and remaining stationary in this position. 
Several families of burrowing mussels inhabit the shell-sand, the most important being Veneridæ, Tellinidæ, Astartidæ, Cardiidæ, and Solenidæ. The most characteristic species are Venus casina, V. fasciata, Timoclea ovata, the species of Tellina and Psammobia, Nicania banksi, Solen ensis and Cardium fasciatum. The common cockle, Cardium edule, on the other hand, never occurs here. Solen ensis is generally so deeply embedded that an ordinary dredge brings up merely fragments instead of the whole animal. The small species of Lunatia belonging to the gasteropod family Naticidx, and particularly Lunatia intermedia, also burrow some distance down, as they feed on little mussels, boring through their thin shells to get at the animals within. Antalis entalis is often common here.

Spatangids are represented by Echinocardium flavescens (see Fig. 338 ), the commonest of all, Spatangus purpureus, and Echinocyamus pusillus, the last named being the only clypeastrid in northern seas. Except perhaps Spatangus purpureus, they are not confined to the shell-sand of the skerries, but may be found also in the clay of the sublittoral zone. All of them burrow deeply. Another deep-burrowing form is Astropecten irregularis, which

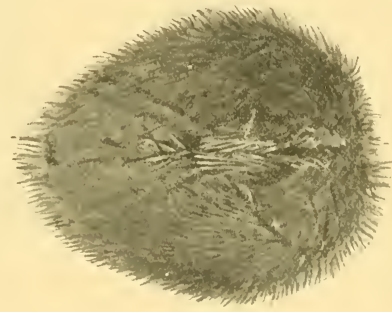

FIG. 338 .

Echinocardium flavescens, O. F. Müll. also lives in the clay bottom of both the skerries and fjords. This creature has conical legs (without suckers) particularly well adapted for digging, though they compel it to procure its food in a different way from Asterias rubens, which preys on large mussels by placing its foot-suckers on their shells and pulling the valves apart till the muscles relax and the shell is opened, whereas Astropecten swallows whole little worms, mussels, the young of Echinocardium, and other small animals.

The worms are chiefly those belonging to the genera Glycera and Nephthys, and the family Ophelidæ (Ophelia limacina and Travisia forbesi). They live down in the sand, where they make long passages that are kept open by having the walls lined with a film of slime.

All these animals are variously equipped for living buried in the sand, which naturally forms a splendid protection against their enemies. The burrowing mussels are provided with two more or less elongated movable siphons, the openings of which 
are always raised above the level of the sea-floor, the one being for supplying food and water, and the other for voiding excrements. The Spatangids get their nourishment down in the sand by means of their remarkably shaped mouth-feet, and through the rapid vibrations of the spines, some of which are specially adapted for the purpose, they keep the water circulating in the holes where they lie, and so obtain oxygen for breathing. Astropecten has a row of small spines along its arms, which vibrate in similar fashion, and cause a circulation of water round its body. The tubes of the worms are almost invariably directly connected by an opening with the level of the sea-floor.

Among the higher crustaceans inhabiting the sandy bottom

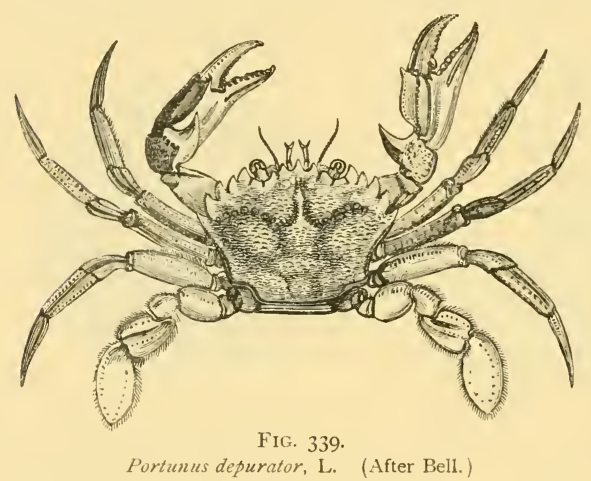
we get one or two species of swimming crabs (Portumus, see Fig. 339). They harmonise in colour with the variations in the colour of the bottom, and are thus enabled to escape notice when motionless. Their name is derived from the terminal joint of the fifth pair of swimmerets, which is expanded and paddleshaped, so that they are able to swim upwards. During the cruises of the "Michael Sars" in the North Sea one of these swimming crabs (Portumus depurator) was found hanging in the drift-net, and numbers of young crabs of the same species were captured in the plankton net. These forms must, nevertheless, be regarded as genuine bottom animals; I have observed that they can even burrow down into the sand for a short time, but never remain there long.

One of the most characteristic forms of the littoral zone is the common edible crab, Cancer pagums, which is not so particular as the lobster regarding the nature of the bottom, being as much at home on sand as on rocks. Cancer pagumus goes farther up the fjords than the lobster does, but they both are undoubtedly littoral animals, occasionally found close up to low-tide mark, and occurring exceptionally below the lower limit of the littoral zone. 
(2) The Fjords.-We have seen that the fauna of the Littoral zone. littoral zone among the skerries, especially in the tidal area and laminaria belt, is abundant both in species and individuals. There is a diminution, however, as we penetrate farther into the fjords. In the tidal area of the inner fjords, and at greater depths also, we miss the limpet and the purple snail, while the hydroids to be found on the fucus in the skerries become less and less abundant, until even Dynamena pumila disappears. This change in the fauna is mainly due to the decrease in salinity, since the surface of the inner fjords, for a great part of the year at any rate, is occupied by a layer of less saline water in which these forms cannot thrive. Far up the fjords, however, in the tidal area, we get the barnacle, the mussel Mytilus, and the black periwinkle, which seem to be less affected by a difference in salinity, though even they require a certain percentage of salt, since they disappear, for instance, from the tidal area in the more enclosed parts of the fjords, where, owing to the great accession of fresh water, the salinity is particularly low. The mussel and black periwinkle, it is true, may sometimes occur even here also, but only in fairly deep water. We also find the horse mussel in the fjords. The great thickets of Laminaria hyperborea, which are so characteristic of the skerries, are absent from the inner fjords, and so are most of the forms associated with them. In their place, however, we get Laminaria digitata and $L$. saccharina, but in comparatively small quantities.

The difference between the inner fjords and the skerries is not so marked when we descend to greater depths, since a good many forms are equally at home in both. Some of the littoral fauna, like the lancelet, appear to avoid the fjords altogether. ${ }^{2}$ Two forms, which rarely ascend far up the fjords of West Norway, are the lobster and the common edible crab; but the common shore crab (Carcinus manas) penetrates to their inmost recesses. The big black sea-slug (Cucumaria frondosa) is another form which abounds among the skerries and in the outer parts of the fjords, but very exceptionally penetrates far in. No doubt their absence is due to the feeble currents, or the greater or less accessions of fresh water prevailing in the fjords-local conditions that are bound to affect the distribution of the fauna.

The distribution of the two sea-urchins Echinus esculentus

\footnotetext{
${ }^{1}$ It is interesting to note that Dynamena pumila is also found in the estuary of the Elbe as far up as Cuxhaven.

2 The reason for this may perhaps be that the lancelet requires pure sand or shell-sand to live in, while the bottom of the fjords generally consists of mud.
} 
and Echinus acutus (forma flemingi) is curious. The former is very common out among the skerries, while $E$. acutus confines itself to a few localities, but on ascending the fjords $E$. esculentus becomes scarcer, and descends to greater depths, whereas $E$. acutus occurs in the greatest abundance. A similar distribution characterises the sea-urchins Parechimus miliaris and Strongylocentrotus dröbachiensis, which much resemble one another in outward appearance, and are both exceedingly plentiful in their different localities. Strongylocentrotus lives in the more open estuaries and bays of the skerries, whereas Parechimus miliaris keeps to sheltered waters, and especially to pools. For instance, in a pool south of Bergen (the Inderœe Poll) I found Parechinus miliaris literally in thousands, but there was not a single specimen of Strongylocentrotus; in the neighbourhood of Bergen again I collected from another pool of a rather less typical character, sixty-three specimens of Parechimus, and only three specimens of Strongylocentrotus. This difference has not been explained, though most probably the cause is to be found in the difference in temperature. Pools contain water of a much higher temperature than the sea outside, and most likely Parechimus miliaris requires for its reproduction warmer water than Strongylocentrotus. It is interesting to note that, according to Petersen, there is the same diversity between these two forms in the Kattegat.

The foregoing is not meant to be even an approximately complete account of the forms inhabiting the skerries and the fjords, my sole object having been to show that the dissimilarity in physical conditions (temperature, salinity, etc.) and in the nature of the bottom, between the skerries and the inner parts of the fjords, determines the difference in their biological conditions.

Those areas of the littoral zone which have been called Pools. pools, or "polls" (see p. 225), are salt water basins connected with the sea outside by a shallow channel. The pools vary in depth, the deepest not exceeding 30 metres. One feature which they all have in common is that their channels to the sea are far shallower than their basins. The surface is always covered by a layer of more or less fresh water derived from the land, having a lower temperature than the salt-water layer underneath. About $\mathrm{I} \frac{1}{2}$ or 2 metres below the surface the temperature in some summers may rise to $30^{\circ} \mathrm{C}$. or even more, while that of the surface-layer does not rise above $18^{\circ}$ or $20^{\circ} \mathrm{C}$., 
though the conditions vary in different years. Below 2 metres the summer temperature decreases as we approach the bottom, but late in autumn and in winter the temperature is highest at the bottom.

In the intermediate warm salt water layers we get a fauna abounding in individuals that form a distinctive feature of the pools. There is, first of all, the oyster, Ostrea edulis, which finds its principal home here, and there are also quantities of Pecten opercularis attached to the rocks all round. The ascidian fauna is represented by several species, which are all exceedingly plentiful, the commonest being Ascidia mentula, Ascidiella aspersa, Ciona intestinalis, and Clavellina lepadiformis. The most abundant of the bryozoans is Aetea, while a species of Bougainvillia appears to be the commonest hydroid. The principal sea-anemones are Metridium dianthus, Urticina crassicornis, and a species of Sagartia. Parechimus miliaris is the only echinoid, but it occurs in great numbers. Ostrea, Pecten, and Parechinus indicate the decidedly southern character of the fauna, and it may not be out of place to mention that among the plankton forms we get a copepod (Paracartia grani) belonging to a genus not met with again till we reach the west coast of Africa.

In addition to the forms having a southern distribution and of southern origin, however, we find eurythermal and euryhaline forms. Asterias rubens, Carcinus moenas, and Mytilus edulis are nearly always present, the last named in particular being in great abundance, frequently attached to the lines stretched across the oyster-pools for carrying the bundles of twigs or the baskets to which the oyster spat attaches itself. Mingled with this assemblage of mussels, ascidians, etc., we get enormous quantities of smaller animal forms, the crustacean family Tanaidæ being invariably represented.

Among the forms described as characteristic of the littoral Vertical zone, there are very few that do not occur in all its depths, that is to say, only a few forms are restricted to the actual strandbelt. These few, however, include most of the forms that characterise the tidal area. ${ }^{2}$ No doubt even these may occasionally be met with at a depth of a few fathoms, but

1 In enclosed places, though not actually in pools, Corella farallelogramma is also common.

2 For instance, Patella vulgata, Purpura lapillus, Littorina littorea, L. rudis, and L. obtusata ; besides Balanus balanoides, Mytilus edulis, Orchestia littorea, Campanularia flexuosa, Clava squamata, Actinia equina, Alcyonidium hirsutum; and among the burrowing species M/ya arenaria, Cardium edule, and Arenicola piscatorum. 
the tidal area is their proper home. On the other hand, those forms which have been described as passing their lives in the vicinity of low-water mark are not limited to this situation, but may be met with throughout the whole littoral zone, sometimes on sand, sometimes on rock, and sometimes impartially on either hard or soft bottom. Furthermore, on the coasts of Norway the majority of the forms which characterise the littoral zone either never, or only to an inconsiderable extent, pass below its lower limit, though there are some that go down to perhaps about 100 metres, and a very few that descend to greater depths. But forms which on the Norwegian west coast are exclusively littoral, may be met with in deeper water in other northern areas, as I shall show later on.

The sublittoral zone.
It would hardly be possible in a short account like this to give even an approximately complete description of the fauna along the coasts in the sublittoral zone, seeing that this is the abode of most coastal species living below the littoral zone. As a rule, the soft bottom is of a different character from that in the deepest parts of the fjords. Instead of viscous gray clay or mud, a coarser clay, more sandy in character, covers the floor in the medium depths of the sublittoral zone, which in the case of the fjords is near the sides or on submarine banks. Where there are plateaus sloping gradually down from the sides we also get rocks and stones and bits of shells, and there is thus accommodation for forms that naturally live on hard bottom. We often get, for instance, quantities of brachiopods and bryozoans, as well as a certain number of hydroids, ascidians, etc. Generally speaking, the character of the bottom here is more favourable to animal life than in the deep water, for while the mud harbours chiefly burrowing mussels, for instance, the medium depths accommodate, in addition, a large number of creeping snails.

A good many forms which occur in the continental deepsea zone ascend to the sublittoral, and some even as high as the littoral ${ }^{1}$ zone. Still for most of them we may put the upper limit of distribution at 100 to 200 metres. Probably, however, their vertical distribution is affected to some extent by the variations in the vertical distribution of the Atlantic water, which may be higher or lower according to the different seasons

${ }^{1}$ For instance, Pagurus pubescens, Ophiopholis aculeata, and Terebellides strömi. 
of the year. ${ }^{1}$ Other sublittoral species again are plentiful everywhere throughout the whole sublittoral zone, but rarely descend below its lower limit, so that we find at a depth of 100 to 200 metres a mixed fauna, consisting partly of forms that have here reached their upper or lower limit of vertical distribution, and partly of forms which find here the most favourable conditions of life. The sublittoral zone accordingly ranks first in number of species.

The continental deep-sea zone for all practical purposes The coincides with the deeper parts of the fjords, whereas out among continental the skerries, with their comparatively shallow water, we either do not find it at all or else meet with it merely in very limited areas. A feature of the fjords is their very great depth, usually increasing as we proceed inwards, and in their deepest parts, so far as the nature of the bottom and the physical character of the water are concerned, we get what are practically Atlantic conditions.

In the fjords the greatest depth is met with along the middle and in the innermost portions, and may be put on an average at 400 to 800 metres. $^{2}$ The sides of the fjords descend in some places practically perpendicularly into deep water, in other places forming more or less extensive submarine plateaus and terraces. At various depths, especially in the seaward portions, there are cross ridges, which frequently consist of hard bottom. The material covering the floor in deep water is almost invariably a soft, viscous, grayish clay or mud. It is the animal life existing upon and in this mud which I shall now describe.

The mud-fauna of the deeper parts of the fjords resembles the sand-fauna in the littoral zone, inasmuch as it consists mainly of burrowing forms, or at any rate of forms which to some extent burrow into the mud to obtain their nourishment. When we sift the mud brought up by the trawl or dredge, we obtain a number of curious little bodies (round, star-shaped, rod-like, conical, etc.), composed of sand or particles of mud. These creatures are rhizopods (foraminifera). By putting out extremely fine thread-like prolongations of their protoplasm through one or more openings in their covering, they attract to themselves small organic particles in the mud which furnish

1 Thus Helland-Hansen has fixed the summer limit along the coasts at 75 metres, and the winter limit at 150 metres.

${ }^{2}$ In some fjords, such as the Sogne and Hardanger fjords, the depth is in places 1000 metres or more. 
CHAP.

them with nourishment-an operation that under favourable circumstances can actually be observed. ${ }^{1}$ Of larger forms, the numbers of which render them characteristic of these depths, two sea-slugs deserve mention: a red one (Stichopus tremulus, see Fig. 340), and a gray one (Mesothuria intestinalis). They belong, however, to a division different from the sea-slugs found in the littoral zone, the distinction consisting inter alia in a different structure of the tentacles.

Other characteristic forms are: the brittle star Amphiura norvegica, the sea-slugs Cucumaria hispida and Bathyplotes tizardi. Of higher crustaceans we have the genus Munida, with the two species $M$. rugosa and $M$. tenuimana, of which the latter in particular is to be met with in the deepest parts of the fjords, and the prawn Pontophilus norvegicus. The mussels come next to the rhizopods in number of species, the forms

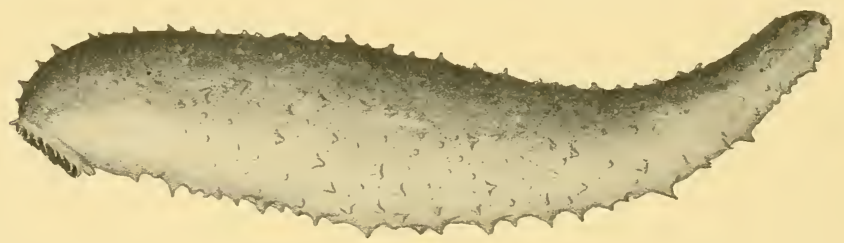

FIG. 340.

Stichopus tremulus, Gunn. Reduced. (After O. F. Müller.)

most frequently found being Malletia obtusa, Portlandia lucida, P. tenuis, and $P$. frigida, Abra longicallis and A. nitida, Kelliella miliaris, Axinus flexuosus and $A$. ferruginosus, Nucula tumidula, and the species of Neara. Scaphopods include three characteristic forms, namely Antalis striolata, Siphonentalis tetragona, and Cadulus subfusiformis, which last becomes more abundant as the depth increases. Worms are represented by the families Maldanidæ and Terebellidæ, of which latter Terebellides strömi is very common, and there are also Lumbrinereis fragilis, Nephthy's, Aricia, etc.

The cœelenterates are represented on the mud of the deeper parts of the fjords by the group of pennatulids or sea-pens, a kind of unattached coral animal. The commonest forms are Kophobelemnon stelliferum (see Fig. 341) and Funiculina quadrangularis, though they are not so regularly or abundantly distributed as the two sea-slugs already referred to, which are found practically everywhere. Two species of sea-anemones (Actinostola callosa and Bolocera tuedice) ${ }^{2}$ are also universally distributed,

1 The following are a few forms which are characteristic owing to their numbers and size: the globular Saccammina spherica, the rod-like ramifying Rhabdammina abyssorum, and the starshaped Astrorhiza arenaria, the test of which consists of particles of sand, the rod-like nonramifying Bathysiphon filiformis, etc. In addition there are other large forms of which I may mention the species of Cristellaria, the shells of which are calcareous and consist of several cells.

2 Both these forms are found in the deep parts of the fjords, but I am not certain whether they live on the mud or on the patches of harder bottom which occur here and there. 
and so is the sponge Thenea muricata (see Fig. 342), which adheres to the mud by means of long outgrowths, and the worm-like gephyrean Sipunculus priapuloides.

Thus the majority of the mud-fauna in the deep parts of the fjords, owing to the nature of the bottom, consists of unattached animal forms, most of the sponges, corals, hydroids, ${ }^{1}$ bryozoans, ascidians (including the unattached molgulids), and brachiopods being absent ; in other words, the nature of the bottom gives the fauna its character. Still even here it is possible for certain attached forms to occur normally, and very often abundantly. There are frequently great quantities of the little mussel (Arca pectunculoides), which fastens itself by its byssus-filaments sometimes to the larger foraminifera, sometimes to slag from steamers, or any other hard substances which it happens to come across in the mud. There are also numbers of the white semi-transparent Pecten abyssorum, which occurs, according to Sars, also in the deepest parts of the Christiania fjord, where it attaches itself to rotten bits of sea-weed.

I shall now turn to the faunal conditions in the fjords where there is hard rocky bottom, i.e. the more or less steep sides of the fjords and the submarine ridges or eminences. These latter are sometimes isolated raised portions of the floor surrounded on all sides by softer bottom, and sometimes spurs running out from the walls of the fjord. The slopes of the ridges and eminences are frequently covered with coarse sand and stones, as are also the sides of the fjords where not too steep. In many cases, however, the walls go down so steeply that no loose deposits occur till we reach a depth of several hundred metres.

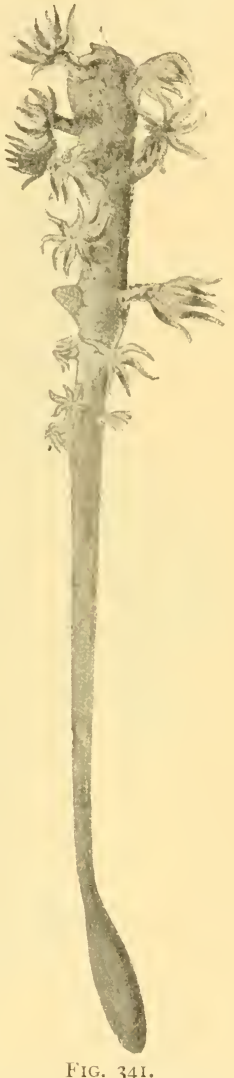

Kophobelemnon stelliferum, O. F. Mull. (After Asbjörnsen.)

The fauna here is quite different from that on the muddy bottom, consisting mostly of attached forms of various groups,

I Only a little form (Perigonimus abyssi) is common here, attached to mussel shells, especially those of Nucula tumidula. 
CHAP:

especially sponges, cœlenterates, bryozoans, brachiopods, and tube-worms, with a few unattached forms, of which the crustaceans are the most important. Most of the species of attached forms belong to the sponges, colenterates, and bryozoans, though the brachiopods and tube-worms exceed the others in number of individuals. The sponges are nearly

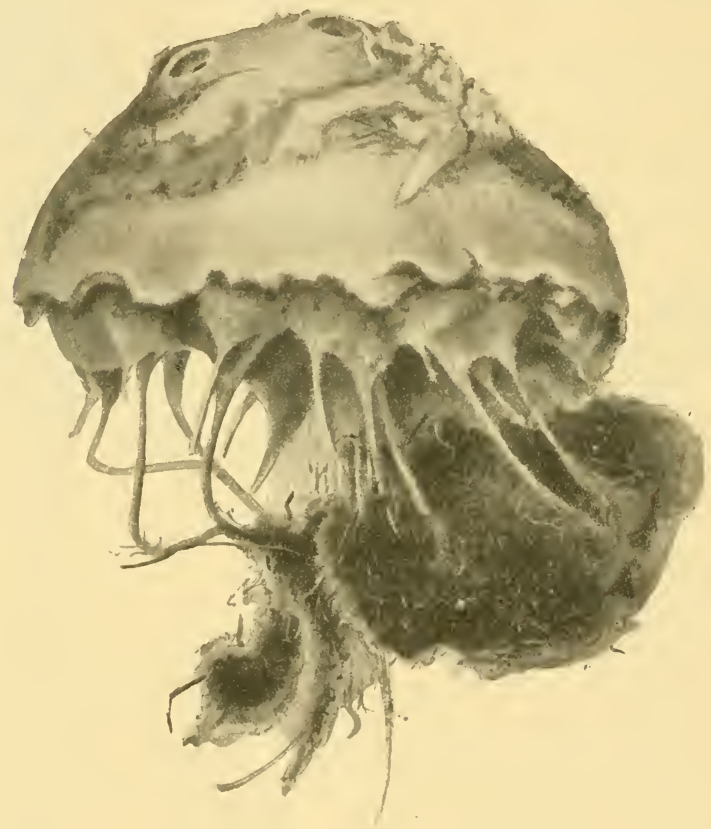

FIG. 342 .

Thenea muricata, Bowerbank.

all silicious, whereas in the littoral zone they are chiefly calcareous. The principal coelenterates are attached coral animals, especially gorgonians, ${ }^{1}$ alcyonarians, and hydroids. We commonly get, for instance, one or two species of alcyonaria of the genus Paraspongodes, the larger specimens of which resemble cauliflowers; in the same way we find Alcyonium

1 Paramuricea placomus, Primnoa lepadifera. In the same localities we also find two seaanemones (Phellia abyssicola and Bolocera tuedia), of which the latter also occurs on muddy bottom in the deep parts of the fjords (see p. 482 ). 
digitatum, belonging to the same group, upon hard bottom in the littoral zone. We must also include anong the alcyonaria the sea-tree, Paragorgia arborea (see Fig. 343), which is taller than a man and has many branches. Of true corals we may mention Lophohelia prolifera and Amphihelia ramea, though the coral fauna is not regularly distributed over the hard bottom, but is more or less local; still there are often numbers of individuals where hard bottom does occur. Several species of hydroids, such as Lafoea dumosa, Sertularella gayi, etc., are very common; and of the bryozoans, Retepora beaniana, easily recognisable owing to its trellis-like structure, is both widely distributed and plentiful. So, too, are the brachiopods, Terebratulina caputserpentis and Wraldheimia cranium, and the two tube-worms, Placostegus tridentatus, the tube of which divides into three tooth-like processes, and Serpula vermicularis (see Fig. 344). Both these worms, it may be added, have calcareous tubes, in contradistinction to the tube-worms of the mud

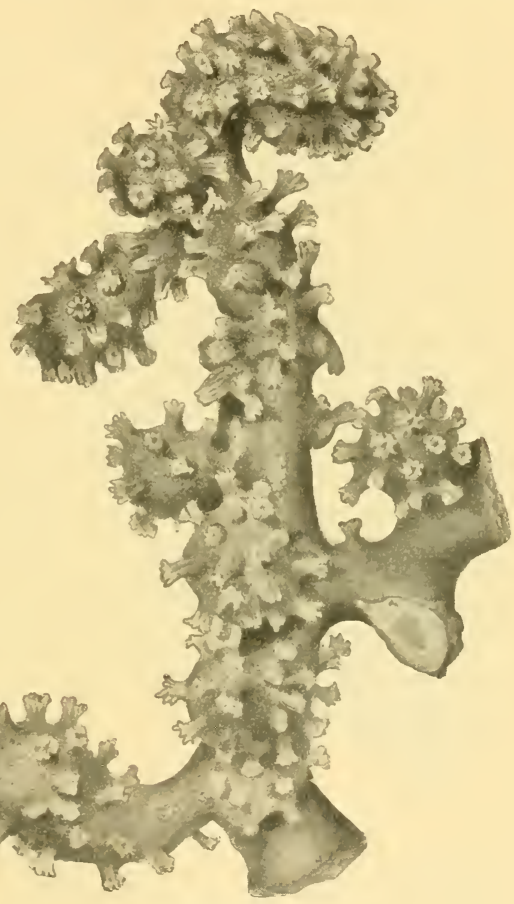

FIG. 343 .

Branch of Paragorgia arborea, L. which inhabit tubes of mud or sand. There is, besides, a species of barnacle (Verruca strömi) on the stones, which is frequently nearly as abundant as Balamus balanoides in the tidal area.

It would take too long to give a full description of the unattached fauna associated with the hard bottom. I will therefore merely point out that some free forms occur only upon the attached forms, and seem accordingly to be dependent 
upon them. The most noticeable of these is medusa's head (Gorgonocephalus linckii, see Fig. 345), a brittle-star with extremely branching arms that lives upon the larger gorgonians and sea-trees. A crustacean, Galathodes tridentatus, appears also to be intimately connected with the corals, and large quantities are occasionally found upon them. As for the remaining higher forms of crustaceans the fauna consists chiefly

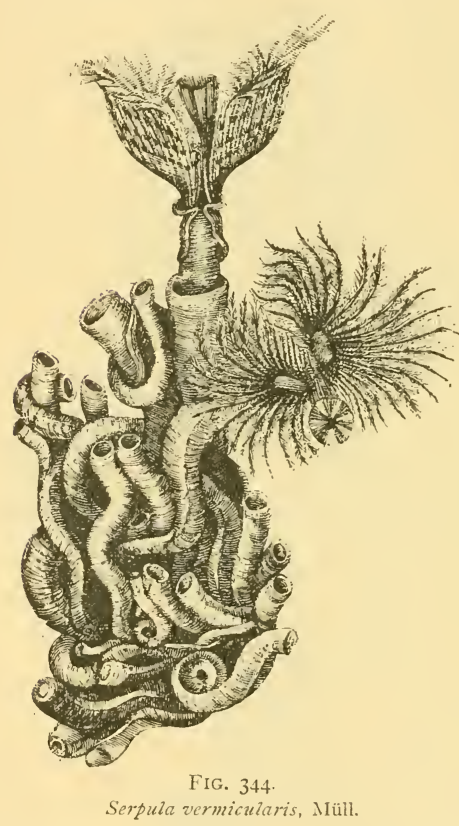
of prawns, though they are different from the ones in the littoral zone, ${ }^{1}$ but other groups are not entirely wanting. ${ }^{2}$

The large mussel, Lima excavata, is extremely characteristic of the rocky bottom, attaching itself by means of its fine silky byssus-filaments. We may further mention a sea-slug (Psolus squamatus, see Fig. 346), easily recognisable owing to its abruptly truncated disc with suctorial feet, by which it adheres to stones, shells, etc. ; a crinoid (Antedon petasus) occurring locally, though often in abundance, especially where there are sponges; several star-fishes, Pentagonaster granularis, Porania pulvillus, Hippasterias phrygiana (plana), which last seems to prefer places where the hard bottom is covered with coarse sand ; a brittle - star (Ophiopholis aculeata); molluscs, as, for instance, species of Pecten; ascidians, particularly of the family

Styelidæ; sea-spiders (Nymphon strömi), etc. At considerable depths there is also the remarkable starfish Brisinga endecacnemos. Some of these are exclusively deep-sea forms, and rarely leave the deeper parts of this zone. Munida tenuimana, Bathyplotes tizardi, Brisinga endecacnemos, and Lima excavata do not occur in depths less than 300 or 400 metres.

Littoral zone.

(3) Other Northern Boreal Coastal Areas. - There are several areas where the littoral zone has been but little studied,

1 Pandahus propinquus, P. brezirostris, Hippolyte polaris, and II. securifrons.

2 Thus a hermit-crab (Pagurus pubescens), which occurs, too, in the littoral zone, is quite common, and so are Munida migosa, which also inhabits soft bottom, and the stone-crab (Lithodes maja). 
and the information received from Iceland and the Faroe Islands is not as yet sufficiently comprehensive to enable one to speak with confidence regarding the composition of the littoral fauna there. In Iceland, however, if we may judge from our knowledge of the hydroid fauna in the boreal coast areas, the conditions are very similar to those on the Scandinavian coasts, and the same is true also of the North Sea coasts of Britain.

If we compare the North Sea coasts with the Skagerrack coasts of Scandinavia we find many points of resemblance, the littoral fauna for the most part living under similar natural conditions in both areas. The tides of the Skagerrack, however, are inconsiderable and irregular, and in consequence forms, which on the North Sea coasts belong to the low-tide area, can undoubtedly live here in shallow water and on thesamekind of bottom, but they are not left regularly exposed by the ebb. A good instance of this may be seen in the case of the hydroids Clava squa-

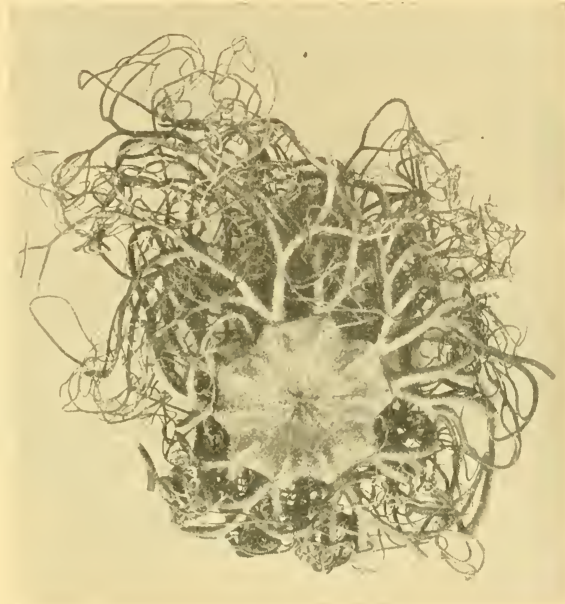

FiG. 345 .

Gorgonocephalus linckii, M. and T., var. Reduced.

mata and Laomedea flexuosa, which are quite common on the fucoids in spite of the fact that the ebb-tide only on rare occasions leaves them exposed. On the other hand, certain species, which are not met with in the low-tide area of the North Sea, and consequently do not patronise the fucus there, attach themselves to these algæ on the Skagerrack coasts. It is evident from this that it is not the actual foundation but the natural conditions and the ability to adapt themselves to these conditions which determine the distribution of the animals in the strand-belt.

Although the littoral faunas of these two coastal areas bear a very strong resemblance to each other, there are yet 
some differences between them. Thus several forms that abound on the west coast of Norway are absent from the Skagerrack coast, if we may judge from my observations at Risör in Norway compared with the researches of Théel at Kristineberg in Bohuslän. ${ }^{1}$ For instance, Cucumaria frondosa, a littoral echinoderm common on the North Sea coast, has not been met with in the Skagerrack, and Ophiocoma migra is very rarely found in the latter area. Echimus acutus occurs in enormous quantities on the North Sea coast, but is extremely

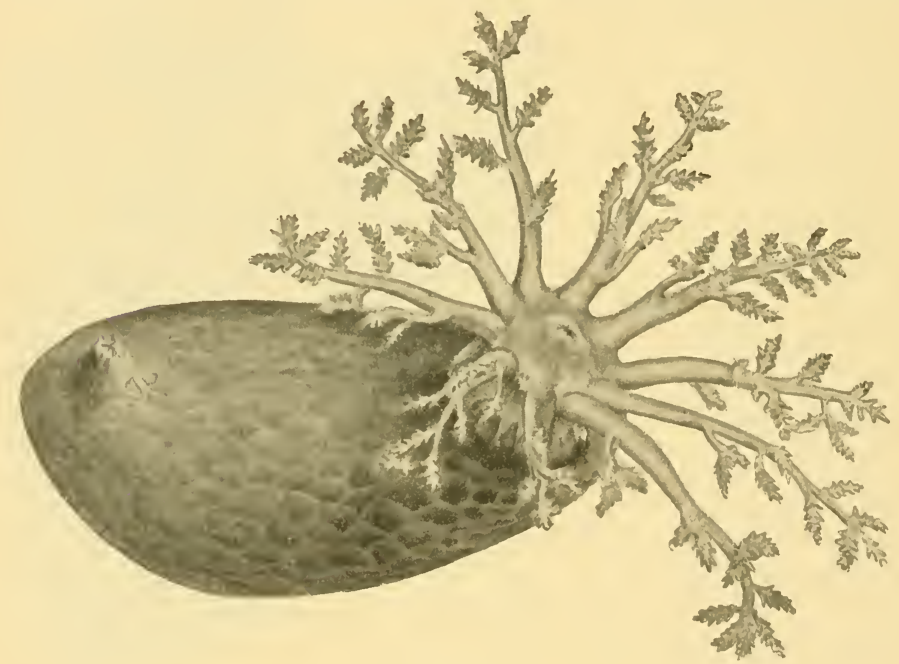

FIG. 346 .

Psolus squamatus, Koren.

rare on the Skagerrack coast, while the mussel, Lima hians, has not been met with on the Bohuslän coast of Sweden, though in certain localities of the Norwegian west coast it is one of the most characteristic forms of the littoral fauna. On the other hand, the Skagerrack coast is the home of certain littoral forms which occur but rarely on the coast of the North Sea. Thus on the west coast of Norway Echinocardium cordatum is seldom found, and then only in a few special localities, whereas in Bohuslän it seems to be one of the

1 Théel, "Om utvecklingen af Sveriges zoologiska hafsstation Kristineberg och om djurlifvet i angränsande haf och fjordar," Arkiv. f. Zoologie, Bd. iv., 1907. 
commonest forms. Ophiura ciliaris, too, is far more plentiful in the Skagerrack, and the gasteropod, Nassa reticulata, occurs in quantities in the littoral zone of the Skagerrack, but is comparatively rare on the North Sea coast.

I have noticed also a difference between the fauna which patronises Laminaria hyperborea and the fauna associated with the two other species of Laminaria. It is only the first named with its stiff thick stalks which is densely crowded with attached forms, whereas the comparatively thin pliant stalks of the other two are either entirely neglected or only made use of to an inconsiderable extent, with the result that there are nearly always far more individuals in the L. hyperborea belt than in either of the other two laminaria communities.

I have already stated that the natural conditions prevailing on the different coasts affect the character of the fauna much more in the littoral zone than at greater depths. Where, for instance, there is nothing in the way of foundation for attached forms, we must expect to find a fauna more suited to another kind of environment. Thus on many North Sea coasts, where the long shallow shores consist merely of sand, like the "vader" of Schleswig and Holland, upon which the waves do not break with any violence, there are immense stretches where practically the sole inhabitants are the lug-worm (Arenicola), a tunnelling amphipod (Corophium grossipes), and one or two other forms. In such sandy stretches the fauna differs entirely from that found along rocky coasts, and only occasionally do we get attached forms where piles, stone quays, or other suitable foundations happen to occur. The animal life differs again on the sandy Danish coasts, which are unprotected by a line of outer islands, and are therefore exposed to the full force of the breakers, where the constant disturbance produced by the waves upon the sandy bottom is distinctly unfavourable to plant and animal life ; consequently the upper littoral zone on such coasts rarely harbours many forms. On the other hand, at slightly greater depths, and in fjords or similar enclosed areas, we get the conditions requisite for the development of Zostera vegetation with its special fauna. We may see how much the topography of the bottom affects the development of animal life by studying the conditions on the Kattegat coast of Denmark ; wherever reefs, overgrown by algæ, occur amidst the eelgrass, we may be certain of finding a fauna consisting of chitons, snails, bryozoans, and hydroid polyps.

The littoral fauna in the southern portion of the North Sea 
comprises quite a number of shallow-water forms that are otherwise foreign to northern regions-Mediterranean immigrants which make occasional visits or have effected a permanent lodgment in comparatively limited tracts. Some of them I shall refer to later on, when dealing with the shallower portions of the North Sea. Their presence may be ascribed to hydrographical conditions, and in no way depends upon the topography of the bottom. To some extent the English Channel acts as a boundary between two littoral faunal areas, a fairly large number of Mediterranean forms living in the Channel but not venturing into the North Sea; while on the other hand several northern forms do not enter the Channel, these last being especially forms of Arctic origin. Many or probably most of the species are common to both areas, since the majority of the boreal species of the North Sea were originally immigrants from southern waters.

The sublittoral zone.

So far as the coasts of the boreal region are concerned the sublittoral zone does not vary much, though certain species from the continental deep-sea zone, which ascend to the sublittoral zone along the North Sea and Atlantic coasts of Scandinavia, are absent from large portions of the Skagerrack and Kattegat as well as from other coasts of the North Sea. They would seem to be forms whose distribution follows the Gulf Stream, and are therefore found mainly along the eastern coasts of the North Sea and Atlantic. They include the holothurian Psolus squamatus, the asterid Pentagonaster granularis, the gephyrean Bonellia viridis, the brachiopod Waldheimia cranium, and some mussels. Munida rugosa, which is one of the most characteristic decapods belonging to the sublittoral and deep-sea zones is, according to Théel, seldom met with on the Bohuslän coast of Sweden ; the true corals and gorgonids of the deep-sea fauna, which elsewhere patronise the sublittoral zone, are much restricted in their distribution throughout the Skagerrack and wide tracts of the North Sea, and seem to be absent from the fjords of the Bohuslän coast. Certain forms, which along the coasts are chiefly sublittoral in their distribution, occur sometimes quite commonly in one area, whereas in another area they may be scarce or even entirely absent. For instance, on the Swedish and Norwegian coasts of the Skagerrack the spatangid Brissopsis lyrifera is generally met with in the sublittoral zone, but on the west or North Sea coast of Norway it is comparatively rare. The converse is the case with the 
spatangid Schizaster fragilis, which is plentiful in the North Sea, but not found in the Skagerrack. ${ }^{1}$

We propose now to discuss the fauna of the continental plateaus within the boreal region, dealing firstly with depths less than 100 metres, ${ }^{2}$ and secondly with depths greater than 100 metres.

I. Continental Plateaus covered by less than 100 Metres of The southern Water.-In the portion of the North Sea to the south of and central the Dogger Bank, where the waters are shallow and the North Sea. summer temperature is high, there are southern forms unknown farther north, though this exclusively southern element in the fauna is very inconsiderable compared with the remaining boreal forms, some of which are more abundantly developed than in more northerly latitudes. During the cruise of the "Nichael Sars" in I904, I was able to carry out investigations with the dredge at a series of stations from the Danish coast to Scotland, in lat. $56^{\circ}$ to $58^{\circ} \mathrm{N}$. in depths between I4 and 100 metres, an area not previously systematically examined.

The floor of the North Sea is for the most part covered with soft materials (sand, sandy mud, and clay), with areas of stony bottom in places, though even here the rocks and stones are nearly always mixed with softer materials. In some localities the soft materials contain masses of empty shells, which are invaluable to the animal life, acting as a foundation for the hydroids, bryozoans, and other attached forms. This mixed bottom supports a greater variety of forms than the soft bottom, offering suitable conditions to unattached forms, whether they burrow or not, as well as to attached forms.

The abundance of echinoderms characterises to a great extent the fauna of the North Sea. Among the star-fishes Asterias mbens occurs at all depths and upon every kind of bottom, though it seems less partial to soft clay bottom at considerable depths. Astropecten irregularis is met with everywhere, and the sea-mice Echinocardium and Spatangus purpureus ${ }^{3}$ are equally common. Ophiura ciliaris (see Fig. 347) may be described as the brittle-star of the North Sea, for we found well-developed specimens every where on mixed bottom down to a depth of about IOO metres, and at temperatures varying from $7^{\circ}$ to $\mathrm{I} 2^{\circ} \mathrm{C}$., but

1 The continental deep-sea zone not being represented, or only in very limited tracts, in the coastal areas of the Skagerrack, Kattegat, western and southern North Sea, a good many forms characteristic of that zone are absent here.

2 As the type for this area we take the southern and central parts of the North Sea, those parts being the best explored.

3 In a trawling at 96 metres we found 500 specimens of the last named. 
CHAP.

not on soft clay bottom; all the individuals from stations in the open North Sea at considerable depths were very much lighter in colour and much larger than those taken along the Norwegian and British coasts. A good idea of the enormous quantities in which this form sometimes occurs was afforded by a haul with the dredge off Aberdeen, in 25 metres of water (temperature I0.26 C.), where they must have literally covered the bottom, and the same remark applies to the west coast of Jutland. In some localities we met with numbers of Brissopsis lyrifera, which prefers as a rule clay bottom in deep water at a tem-

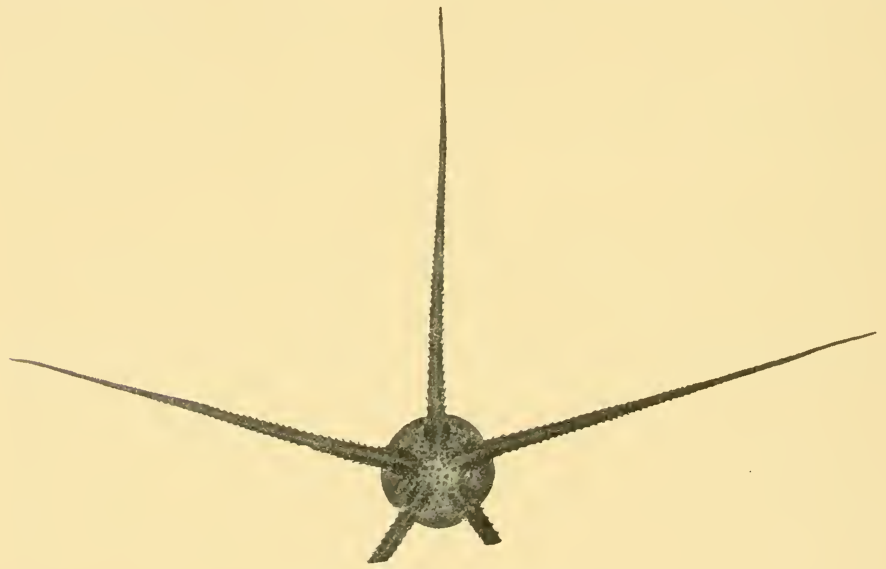

Fig. 347.

Ophiura ciliaris, L. Reduced.

perature of $6^{\circ}$ or $8^{\circ} \mathrm{C}$., though occasionally specimens may be found on sand. Everywhere, throughout the whole area examined, there were the two brittle-stars Ophiopholis aculeata and Ophiothrix fragilis, as well as the starfish Luidia sarsi, which are numerous here and there, but cannot be called characteristic forms. More local, though plentiful in places, were sea-slugs (Cucumaria elongata), which were met with at two stations, together with Brissopsis, on muddy bottom in about 50 metres, at a temperature of approximately $8^{\circ} \mathrm{C} .^{1}$

1 Of other echinoderms found at a few stations, in smaller quantities, I may mention Ophiura albida (only at one or two stations in the neighbourhood of the Danish coast and one station off Aberdeen in 25 metres) and $O$. sarsi, Amphiura filiformis (chiajei?), Ophiocten sericeum (many young-stages in young-fish trawl east of Aberdeen in 62 metres, temperature $8.4^{\circ} \mathrm{C}$., and also from the Norwegian depression), Asterias miilleri, Solaster papposus (only from the edge of the 
Special mention must be made of specimens of our common sea-urchin Echinus esculentus from two stations in the North Sea : two specimens from 77 metres, temperature $7.1^{\circ} \mathrm{C}$., and eight specimens from 96 metres, temperature 6.1 $5^{\circ} \mathrm{C}$. The species generally varies very little, and individuals from our littoral zone scarcely differ at all. Normally the shell is high and of a reddish colour, while the spines are violet. The ten specimens from the North Sea, however, all differed from the typical form, having a flattened shape and varying considerably in colour. The shell itself shows variations from the typical red hue to a chocolate brown, and the spines assume every intermediate shade from the most beautiful vermilion (like what we find in $E$. elegans) to pure green. Many specimens have in consequence an outward resemblance to Strongylocentrotus or Echinus miliaris. Mortensen has described from the North Sea (40 fathoms) two specimens of flattened shape with unusually long bright red spines (like those of E. elegans). Norman tells of a variety from deep water near the Shetlands that had very fine spines and an exceptionally high shell, and Sars has described a similar variety from the Great Edge.

These facts appear to justify the conclusion that, whereas in shallow water and along the coasts the species is of a fairly constant type as regards both shape and colour, it has a marked tendency to variation at greater depths, although the normal, or almost normal, form is to be found also in deeper water, as on the Faroe banks. The deeper portions of the North Sea in particular appear to produce very striking variations.

Of shell-bearing snails there are two forms which characterise the area investigated, namely Neptunea antiqua and Sipho gracilis, both species being met with everywhere from Denmark to the Scottish coast, and sometimes in great numbers. ${ }^{1}$ Judging by our investigations Neptunea extends into shallower water than Sipho, though both species exist plentifully side by side at considerable depths. One biological peculiarity worth recording was that every individual of Sipho in the haul referred to had a sea-anemone (Chondractinia digitata) on its shell, and at other stations, too, they were found living together in symbiosis. These sea-anemones were likewise found on the

\footnotetext{
Norwegian depression, from the Danish coast, and east of Aberdeen in 62 metres), Echinaster sanguinolentus, Strongylocentrotus dröbachiensis (only from the Danish coast, one specimen with Stylifer turtoni on its shell), Echinus esculentus var., Echinocyamus pusillus (only east of Aberdeen in 62 metres), Cucumaria lactea.

1 We secured izo specimens of Neptunea and 375 of Sipho at one haul from a depth of 96 metres (temperature $6.15^{\circ} \mathrm{C}$.).
} 
shells of Neptumea, and on several specimens of this large snail two other large actinians (Urticina crassicomis and Metridium dianthus) had attached themselves. Our common whelk (Buccimum undatum, see Fig. 348) occurred over the whole area down to a depth of Ioo metres, as a rule along with the two snails referred to, though never in such great abundance. ${ }^{1}$

Nudibranchs yielded, with one or two exceptions, only a very few specimens, and this was particularly the case with Tritonia, Doris, and Doto. At certain stations, however, remarkably enough from muddy bottom where there were no hydroids, the young-fish trawl brought up quantities of

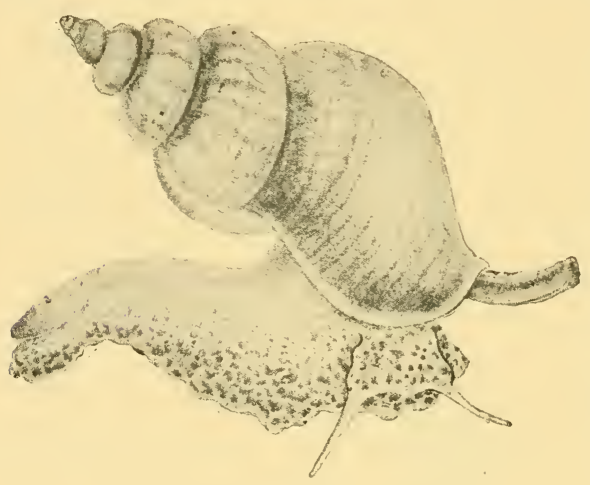

FIG. 348 .

Buccinum undatum, L. Eolis, which had most probably located themselves upon Virgularia and Alcyonium, although their usual home is among hydroids. Chetoderma, a worm-like form belonging to the molluscs, was represented by only a few specimens (depth 47 to 80 metres, temperature $7^{\circ}$ to $8^{\circ}$ C.) ; cuttle-fishes by some specimens of Loligo forbesi at one station (depth 38 metres, temperature $10^{\circ}$ C.), and a little Sepiola from 94 metres. The almost complete absence of species of Chiton,

1 Of more or less regularly distributed mollusc-forms we may further mention: Peclen opercularis (large), Mytilus modiolus (from a depth of 96 metres about 70 specimens were taken, averaging 11 or $12 \mathrm{~cm}$. in length and often with Urticina attached), Modiolaria nigra, Cardium echinatum, Cyprina islandica, Venus gallina, Mactra elliptica (very numerous off the coast of Jutland, 14 metres, temperature $12.5^{\circ}$ C.), Solen ensis, Cultellus pellucidus, Aporrhais pes-pelecani, Antalis entalis. At some stations we came across Nucula tenuis, Leda minuta, Kellia suborbicularis, Corbula gibba, Dosinia lincta, Cylichna cylindracea, all on mud in about 50 metres and at a temperature of $8^{\circ} \mathrm{C}$. Astarte sulcata was extremely numerous at one station (depth 86 metres, temperature $8.4^{\circ}$ C.), but otherwise very scattered. Also Nicania banksi, Pectunculus slycimeris, Mactra stultorum, Psammobia ferröensis, Panopiea norvegica (large specimen, $80 \mathrm{~mm}$. long, $55 \mathrm{~mm}$. high), Saxicava arctica, Pholas crispata (in pieces of timber on the bottom, depth 32 metres, temperature $10.9^{\circ}$ C.), Abra sp., Montacuta (on Spatangzes), Philine sp., Velutina levigata, Lunatia intermedia (in enormous quantities at Jammer Bay off the coast of Jutland, I4 metres, together with Mactra elliptica, on which latter, judging from the many shells with holes bored in them, it feeds), Lunatia montagui, Natica catena (strings of eggs were found in large quantities on the north slope of the Dogger Bank, though the animal itself was rarely captured1), Boreofusus berniciensis, Scalaria trevelyana, Volutopsis norvegica (only at one station, depth 96 metres, temperature $6.15^{\circ} \mathrm{C}$., though in fairly large quantities-about 30 specimens). 
notwithstanding the apparently suitable bottom of stones and shells, is very remarkable, a few specimens of Lepidopleurns (Chiton) cinereus at one station (57 metres, temperature $7.9^{\circ} \mathrm{C}$.) being all that we met with.

The bottom of the North Sea abounds, as already stated, in empty shells, particularly of mussels. The commonest forms are Cardium echinatum, Cyprina islandica, Venus gallina, Dosinia lincta, Mactra, Psammobia ferröensis, Solen, etc., all of which were likewise taken alive. Lucina borealis, on the other hand, though shells were met with here and there at a depth of $3^{8}$ to $9^{S}$ metres, sometimes even in fairly large quantities, was not captured alive out in the North Sea by us, and the "Pomerania" Expedition obtained only empty shells on the Dogger Bank; it is not included by Heincke amongst the molluscs of Heligoland, but we do find it along the coasts of Britain and in the Skagerrack. Empty shells of Mya truncata forma typica were also found in two localities, one at a depth of I 4 metres off the north-west coast of Jutland, and the other midway between Jutland and Scotland at a depth of 68 metres.

The higher crustacean fauna is comparatively poor in species, most of them being restricted in distribution and few in numbers. The hermit crabs Pagurus bernhardus and $P$. pubescens are exceptions, as they are pretty generally distributed over the whole area, though only the first named is met with in shallow water, at or below 40 metres; at greater depths both species occur, as in some other areas of the North Sea. Of crabs Hyas coarctatus is common in both deep and shallow water, whereas Portunus depurator (or holsatus?) and $P$. pusillus are more limited in their distribution, and occur mainly in the lesser depths. Other forms are more local, though frequently met with in considerable numbers, like the little Porcellana longicomis; as a contribution to its biology I may mention that we found large numbers at two stations (depth 32 metres and 42 metres, temperature $10.9^{\circ} \mathrm{C}$. and $8.7^{\circ} \mathrm{C}$.), where in one case it had crept into the holes made by the borer-mussel (Pholas crispata) in sunken pieces of timber and in the other it occupied cavities in the large clotted lumps of sand constituting the colonies of the tube-worm Sabellaria alveolata. At greater depths it was absent, Porcellana being to a great extent a littoral form. ${ }^{1}$

1 We also found two other crabs in shallow water west of Jutland ( 32 metres) : the ordinary edible crab (Cancer pagurus) and Hyas araneus. Single specimens of two species of Ebalea 
The stone crab (Lithodes maja, see Fig. 349) was met with only in the deeper parts where the temperature was lower ( 77 metres and 96 metres, temperature $7.1^{\circ} \mathrm{C}$. and $6.15^{\circ} \mathrm{C}$.), as in the deep parts of the Norwegian fjords. The whole central portion of the North Sea proved remarkably poor in shrimps (caridids) though the few species present were frequently in considerable numbers. ${ }^{1}$

The ordinary wide-meshed appliances (trawls and dredges) undoubtedly give a good idea of the larger bottom-forms composing the fauna, but are less satisfactory when the fauna consists mainly of small crustaceans, for which we found the young-fish trawl extremely useful, as by its means we secured

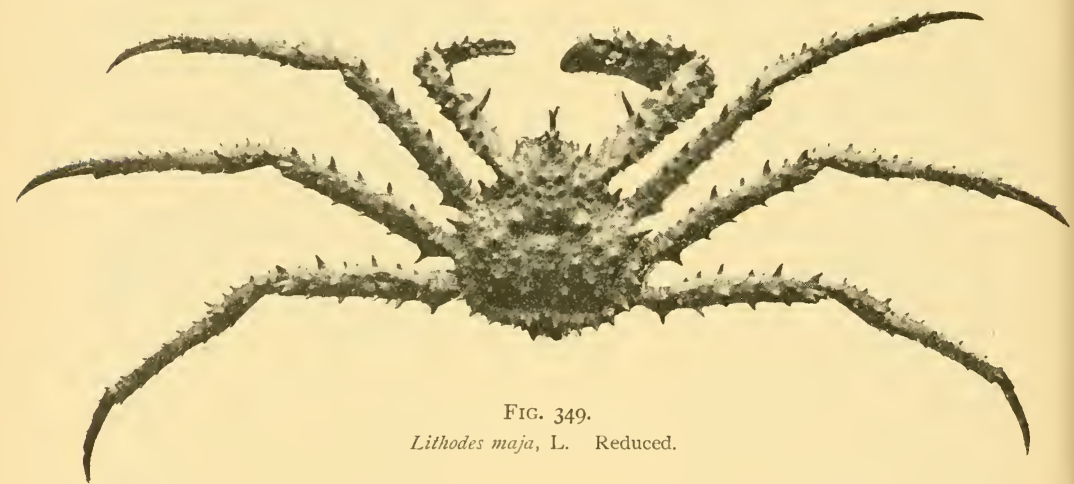

the large numbers of young crangonids already referred to, besides quantities of lower forms of crustaceans, especially amphipods, cumaceans, etc., and larvæ of higher crustaceans, particularly hermit crabs. Even these, however, occur locally,

(E. cranchi and $E$. tuberosa) were obtained at depths from 47 metres to 86 metres, with temperatures of 8 to $8.4^{\circ} \mathrm{C}$. We also obtained specimens of the crabs Inachus dorsettensis and Stenorhynchus rostratus, and a single specimen of Atelecyclus septemdentatus was taken in the neighbourhood of the Scottish coast in 62 metres at a temperature of $8.4 \mathrm{C}$. At one station on the coast of Jutland ( 32 metres, temperature $10.9^{\circ}$ C.) the crab Corystes cassivelanus was common, but it was quite absent in the central portions. Galathea dispersa and $G$. intermedia were got at some stations.

1 We found, for instance, numerous specimens of a little crangonid (Cheraphilus nanus) at a depth of 78 metres, temperature $7^{\circ} \mathrm{C}$., a number of individuals belonging to a form related to the common shrimp, Crangon allmanni, and Pandalus annulicornis. At a station near the Scottish coast, that is to say in the western portion of the North Sea, at a depth of 86 metres, temperature $8.4^{\circ} \mathrm{C}$., we found in addition to small specimens of the two last-mentioned forms, of which Crangon was in myriads, several specimens of another shrimp (Hippolyte securifrons), which is also met with on the eastern side, but not at corresponding depths in the central portion. 
being extremely numerous in certain localities and absent in others; no doubt the currents at the bottom are responsible for this, seeing that the depth and temperature are in themselves entirely favourable. These enormous quantities of small crustaceans must have an appreciable influence upon the shoals of fishes, and in particular upon the young fishes, and this I have been able to confirm by direct observation. On the northern slope of the Dogger Bank we captured a number of young whitings and flounders with the trawl at a depth of 38 metres (temperature $10^{\circ} \mathrm{C}$.), and their stomachs at first sight seemed to contain only sand, but closer investigation revealed small amphipods (sand-hoppers) which thus formed their principal nourishment, the sand being swallowed simultaneously with them; the stomachs of the larger fishes generally contained hermit crabs and swimming crabs (Portunus). The caprellids seemed to be especially associated with a bottom overgrown with hydroids, and were found only exceptionally where hydroids were absent. ${ }^{1}$

The central portion of the North Sea is poorly supplied with pycnogonids (sea-spiders), there being only one widely distributed form (Pycnogonum littorale), and it was only found in deep water ( 80 to 100 metres) at low temperatures $\left(6^{\circ}-7^{\circ}\right.$ C. $)$, where I sometimes found it, as described by Sars, clinging to large sea-anemones (Urticina crassicornis and Metridium dianthus), into the skin of which it bores its proboscis for sucking; a solitary specimen of Nymphon strömi was the only other pycnogonid found in deep water.

The ascidians (sea-squirts) are also poorly represented; the monascidians (simple sea-squirts) were not very conspicuous anywhere in the area examined, but we got large and well-developed specimens of Ciona intestinalis in about 80 metres (tempera-

1 The commonest is Caprella linearis (it seems difficult to discover any invariable difference between this species and $C$. septentrionalis), but stray specimens occur of Proto pedata, mainly found along the edge of the Norwegian depression, at a depth of about 100 metres, and one individual of Protella phasma was captured at 77 metres, temperature $7.33^{\circ} \mathrm{C}$. 
ture about $7^{\circ}$ C.), whereas along the Norwegian coasts it is chiefly found in quite shallow water, where it attains its fullest development. Ascidiella virginea and Styela loveni were fairly widely distributed. A large globular compound ascidian (Macroclimum pomum, see Fig. 350), although very local, was at times very plentiful.

The attached fauna, which, properly speaking, includes the sea-squirts, is mainly represented by three groups: sponges, hydroids, and bryozoans, the two last forming occasionally regular little forests. On the northern slope of the Dogger Bank (depth 38 metres, temperature $10^{\circ} \mathrm{C}$.) there were considerable quantities of large bush-like colonies of two species of bryozoans (Flustra securifrons, see Fig. 35 I, and Alcyonidium

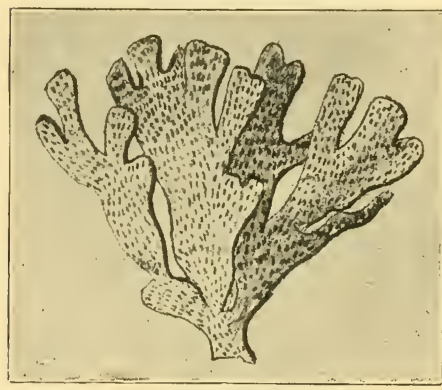

FIG. 351 .

Flustra securifrons, Pallas. gelatinosum), which, with Flustra foliacea, are the most characteristic of the North Sea bryozoans; they vary in relative abundance, but on the Great Fisher Bank Flustra foliacea appears to be the predominant form. Small bryozoans, sometimes occurring in large quantities, are found growing on the bigger species or on other substances.

Hydroids are distributed over the whole area examined wherever the bottom is suitable, especially where it is covered with empty shells or stones. They sometimes form "communities," but are as a rule scattered about here and there. Tubularia larynx is occasionally met with in enormous quantities, and there are sometimes "communities" of Thujaria thuja (see Fig. 352), Hydrallmannia falcata, Campanularia longissima, and C. verticillata. The species of Dicoryne and Hydractinia are very often found on shells inhabited by hermit crabs. ${ }^{1}$ The hydroids in the central portion of the North Sea differ to a certain extent from those found in the northern portion or on the other plateaus. Thujaria and Hydrallmannia are, however, common to both areas.

Among colenterates there are really only two forms, if we

\footnotetext{
1 Dicoryne conferta, Hydractinia echinata; other species commonly found in the North Sea are Campanularia johnstoni, Plumularia pinnata, Lafoea dumosa.
} 


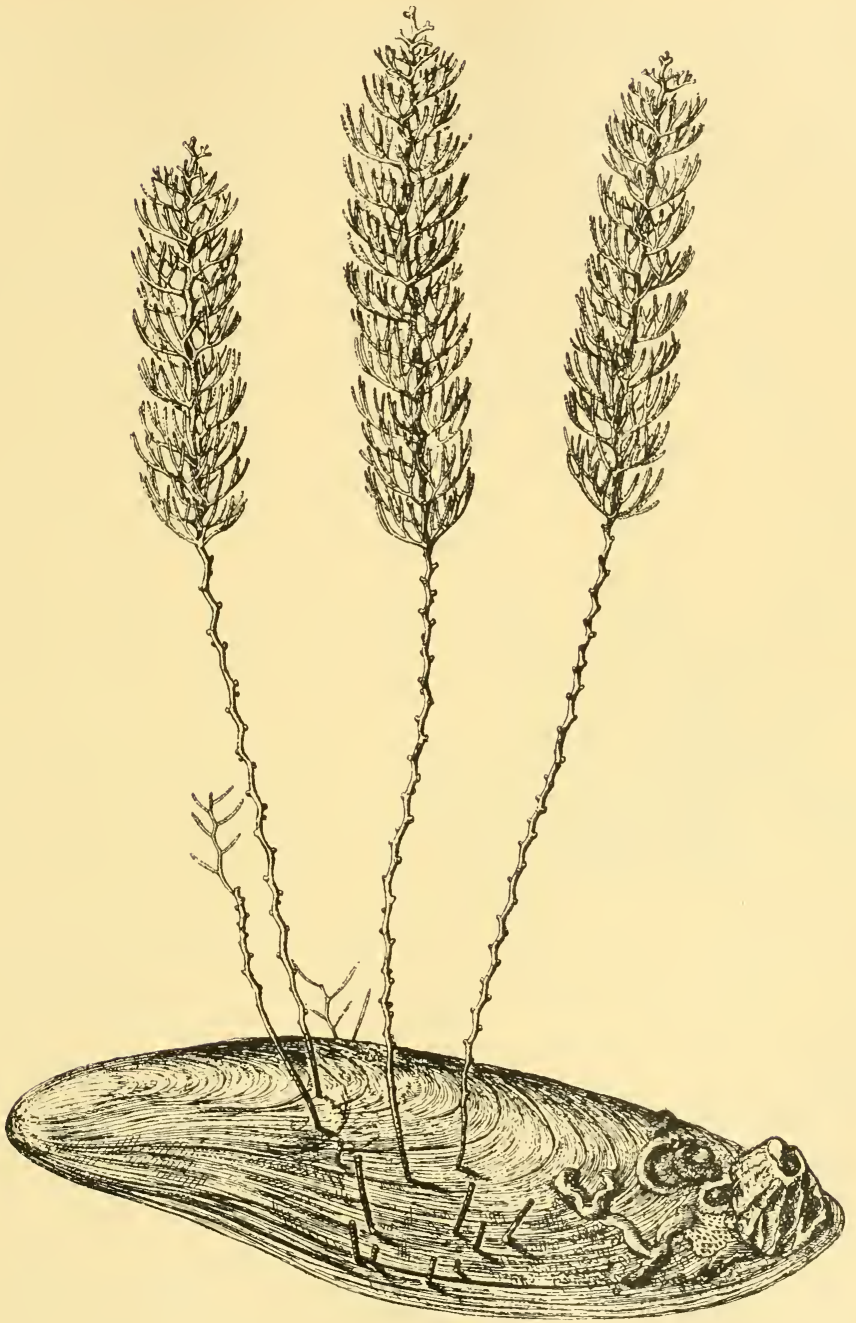

FIG. 352.

Thujaria thuja, L. (After Hincks.) 
except the sea-anemones already referred to, ${ }^{1}$ which are universally distributed over the central portion of the North Sea, namely dead-men's fingers (Alcyonium digitatum) and the sea-pen Virgularia mirabilis. The former generally consists of irregularly shaped ramifying masses attached by the base to other substances, but in the area examined by the "Michael Sars" during 1904, in depths between $3^{8}$ and 96 metres, temperature $10^{\circ}$ to $6.15^{\circ} \mathrm{C}$., there was an interesting variation in its relation to its foundation. An annelid (Sabella pavonia), commonly met with here, inhabits an upright muddy tube attached at the lower end. The whole length of this tube was covered by the dead-men's fingers, which in some instances grew out from the lower end of the tube into the usual irregularly ramifying masses. This symbiosis was no fortuitous occurrence, but was invariable throughout the whole of the central portion of the North Sea where these two forms are everywhere to be found. ${ }^{2}$ On the coasts of Scotland and Jutland, on the other hand, Alcyonium occurred in its ordinary form. The common Virgularia mirabilis, found at depths of 50 to 100 metres, with a temperature of $7^{\circ}-8^{\circ} \mathrm{C}$., was the only sea-pen met with in the area examined, but we obtained a fairly large number of individuals.

Sponges constitute a group of attached forms abounding in individuals, though remarkably poor in species; they cannot be said to be regularly distributed, but are more or less local. On the north side of the Great Fisher Bank in particular we got enormous quantities of a ramifying whitish form (Halichondria panicea var. bibula). ${ }^{3}$ The different variations of Ficulina (Suberites) ficus are, however, the most prevalent. The commonest of these variations, where the sponge grows round shells and gives shelter to the hermit crab Pagums pubescens, are comparatively scarce in the central portion of the North Sea, and we came across them at only one or two stations, but in the more northern parts of the North Sea plateau they were plentiful. Another variety, attached to empty shells of the sea-tooth (Antalis entalis) which as a rule shelter the gephyrean Phascolosoma strombi, was abundant at

1 Urticina crassicornis, Metridium dianthus, chiefly found on large shells of Mytilus modiolus and Neptunea, Bolocera tuedie and Chondractinia digitata on shells of Neptunea and Sipho; at one or two stations (depth about 100 metres, temperature slightly over $6^{\circ} \mathrm{C}$.) we got Zoanthus.

2 Several of these overgrown tubes were empty, which looks as if the worm benefited least by the symbiosis.

3 Thanks to information kindly sent me by Professor Plate, Berlin, I can add H. panicea forma typica as being common on the Great Fisher Bank; this form was also abundant on the northern slope of the Dogger Bank. 
several stations, for instance on the northern slope of the Dogger Bank ( 38 metres) and north-west of the Great Fisher Bank (77 metres).

The little tube-worm Filigrana implexa, whose slender white irregular tubes are associated in trellis-work colonies, was met with over a large portion of the area examined, but only in the deeper parts. Another common form is Thelepus circimnatus, whose sinuous, parchment-like tube, covered with fragments of shells, grains of sand, etc., is attached to foreign substances such as empty mussel - shells, Flustra, etc. The annelid Aphrodite aculeata is characteristic of the North Sea, but is as a rule limited to the deeper parts with soft or "mixed" bottom, though nowhere found in any great quantity. I have already stated that Sabella pavonia is common, ${ }^{1}$ and, speaking generally, we may say that as far as worms are concerned the central portion of the North Sea does not differ typically from the boreal portion of the Norwegian Sea.

One peculiarity of the deeper parts of the central North Sea is that on soft bottom there is an absence of the foraminifera so plenti-

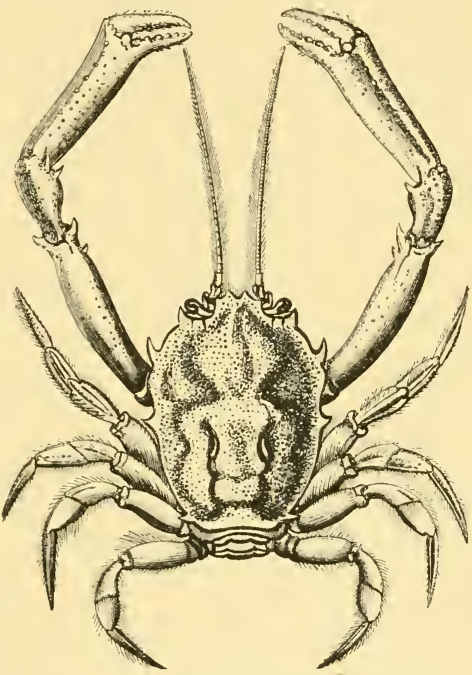

FIG. 353 .

Corystescassivelanus, Mont. o Reduced. (After Bell.) ful in the Norwegian fjords; this I can assert after examining very minutely the contents of the fine sieves through which the bottom-material was passed.

It has been mentioned that in the southernmost portion of the North Sea, off the coasts of Belgium, Holland, and southeastern England, there are many forms of southern origin, which are absent in more northerly latitudes; some of them, however, find their way farther north than the others, though all keep to shallow waters with high temperatures. This is, for

1 On deep soft bottom we found representatives of the Maldanidæe, as well as Eumenia crassa, Trophonia glauca, Lumbrinereis, and Nephthys, which we also find on the coasts. 
instance, the case with the crab Corystes cassivelanus (see Fig. 353), the mussel Mactra stultorum, the shelled snail Natica catena, and the tube-worm Sabellaria alveolata, all of which were found west of Jutland to the north of lat. $56^{\circ} \mathrm{N}$. The last mentioned was met with at only one station (depth 4 I metres, temperature $8.7^{\circ}$ C.), but in large quantities and big colonies; while the other three were taken in shallow water (less than 40 metres) with the highest temperatures observed during the cruise $\left(10^{\circ}\right.$ to $12{ }^{\circ} \mathrm{C}$.). The characteristic ribbon-like egg-clusters of Natica were found as far out as the northern slopes of the Dogger Bank, where the animal itself had been previously captured. According to Professor Plate both Natica catena and Mactra stultorum occur on the Great Fisher Bank, which shows that these forms do sometimes leave the coast region. On the other hand, Corystes seems exclusively to follow the coasts of Britain and Denmark, since we did not capture it with our trawl on the Dogger Bank, though depths and temperatures appeared to be favourable, and it has not been recorded at any great distance from the coast. These forms are found along the shores of Britain, and penetrate into the northern part of the Kattegat, but, if we except Mactra stultorum, they do not reach the coast of southern Norway.

Our knowledge regarding the faunal character of the North Sea may be briefly recapitulated as follows: In the southernmost portion, at depths down to 40 or 50 metres, where the water-layers in summer attain a temperature of $\mathrm{I} 3^{\circ}-\mathrm{I} 5^{\circ} \mathrm{C}$., but in winter are cooled down to $4^{\circ}$ or $5^{\circ} \mathrm{C}$., the fauna consists partly of northern elements capable of adapting themselves to variations of temperature, and partly of a special southern contingent that has wandered in through the English Channel and requires high temperatures for at any rate part of the year. Most of these latter forms are limited to the southernmost portion, though a few follow the coasts towards the north, penetrating on the east side even to the Skagerrack, and on the west side to the coasts of Northumberland or perhaps still farther, but avoiding the deeper parts of the central area. The northernmost portion of the plateau, where the depths exceed Ioo metres, but where, notwithstanding, the waters are warmer than in the central parts, is characterised in similar fashion, as we shall presently show, partly by special southern deep-water forms that have wandered in past Shetland and only very rarely get as far as the coast of Norway or the Skagerrack, and partly by forms which may either have arrived originally from the 
south, or else are true natives, nowadays at any rate widely distributed throughout the northern seas. Most of the forms met with in the central portion are also to be found along the coasts, but numbers of forms frequenting the coasts, especially shallow-water forms, do not inhabit the plateaus.

We have not at present sufficient information to describe in detail other plateaus in depths less than Ioo metres. The "Michael Sars" occupied two stations in 50 to 100 metres, off south-eastern and south-western Norway, where the fauna did not appear to differ from that in the outer part of the fjords and in the island belt. Certain forms (for instance Balanoglossus, taken off Risör on the south-east coast) have, however, not been taken in the western fjords nor in the central North Sea, but they have been recorded from the west coast of Sweden (Bohuslän). At the localities mentioned we were able to observe the remarkable fact that certain forms (for instance Echinus esculentus, Asterias rubens, Ophiothrix fragilis) occur in comparatively deep water, while in the fjords and island belts they generally occur in the littoral zone only.

The investigations of C. G. J. Petersen in the Skagerrack show, as far as we can judge from his short statements, a marked similarity to the conditions prevailing in the North Sea. At present it is impossible to enter into a detailed account, and we can only state that along with the similarity there are certain discrepancies: thus, for instance, the pennatulid Pennatula phosphorea has not been captured by the "Michael Sars" in the central North Sea, but it is frequent on the Norwegian North Sea plateau and in the Kattegat.

2. Continental Plateaus covered by more than Ioo Metres of Water. - The different lands bounding the Norwegian Sea and North Sea form the emerged portions of larger or smaller submarine plateaus. The bottom on these plateaus varies considerably, though, generally speaking, it may be described as a mixture of stones and rock together with fine or coarse sand; only exceptionally, and in the deeper portions, is it composed of mud. The character of the bottom renders investigations extremely difficult, and the fauna is therefore not so well known as that of the fjords. Where the bottom is covered with softer material the fauna resembles that of the fjords. This is particularly the case in the Norwegian depression or gut, Norwegian running parallel to the Norwegian coast from the latitude of depression. Stat to the Skagerrack. The depth in the middle averages 
approximately 300 or 400 metres, till we come to the inner portion of the Skagerrack where it increases to about 700 metres. The bottom consists of soft mud throughout, except for a long narrow strip of stones and rock that penetrates its north-eastern portion. On the one side the depression is bounded by the Norwegian coast-plateau, which is here only a few miles wide, and on the other side by the plateaus of the North Sea and Skagerrack.

During the cruise of the "Michael Sars" in I 902 investigations were made with the trawl and dredge in its northern portion, the principal forms found being as follows :-

Echinoderms : Stichopus tremulus (in quantities), Bathyplotes tizardi, ${ }^{1}$ Cucumaria hispida, Myriotrochus vitreus, Amphiura norvegica, Ophioscolex glacialis, Ophiura sarsi, Asteronyx loveni (on Funiculina), Schizaster fragilis, Brissopsis lyrifera, Spatangus raschi, Psilaster andromeda, Pontaster tenuispinus.

Crustaceans: Pontophilus norvegicus, Pandalus bonnieri.

Ascidians: Ascidia obliqua.

Molluscs: Abra longicallis, Malletia obtusa, Portlandia lucida, Aximus flexuosus, Pecten septemradiatus, Sipho islandicus, Scaphander punctostriatus, Antalis agilis, Siphonentalis tetragona, Cadulus subfusiformis. ${ }^{2}$

Worms: Lumbrinereis fragilis, Latmonice filicornis, Aricia sp., Terebellides strönit.

Gephyreans: Sipunculus priapuloides.

Colenterates: Bolocera tuedice, Actinostola callosa, Kophobelemnon stelliferum, Funiculina quadrangularis, Ulocyathus arcticus.

Sponges: Thenea muricata.

Also the foraminifera Astrorhiza and Rhabdammina, though these are not numerous.

These animal forms make it tolerably certain that the fauna in the Norwegian depression is practically identical with the Atlantic fauna in the boreal region of the Scandinavian peninsula, and closely resembles the fauna of the western fjords of Norway. Petersen's researches have revealed similar conditions in the deepest portion of the Skagerrack. But along with the fjord forms, which exceed the others in numbers, there is a fauna in the Norwegian depression composed of forms seldom or never occurring among the skerries and in the fjords, but having their home on the plateaus of the open sea."

1 On the other hand, Mesolhuria intestinalis has not been found by the "Michael Sars" nor by other Norwegian and Danish Expeditions.

2 This species was found by the Norwegian North Atlantic Expedition.

3 To this fauna I assign the following forms:-Echinoderms: Spatangus raschi, Pontaster tenuispinus; Molluscs: Sipho islandicus, Antalis agilis; Crustaceans: Pandalus bonnieri; Colenterates : Ulocyathus (Flabellum) arclicus. 
In the depression these are all common enough to be regarded as an essential part of the fauna. Spatangus raschi, for instance, appears never to approach the coasts or to enter the fjords, but keeps to the deeper parts of the plateaus where it takes the place of Spatangus purpureus; it has also been found by the "Michael Sars" on the continental slopes south of the Faroe Islands. Pontaster tenuispinus only exceptionally enters the fjords of West Norway to the south of Stat, though it is found now and then in the Trondhjem fjord, and during the cruise of the "Michael Sars" in 1902 it was found at the mouth of the Sulenfjord near Aalesund. ${ }^{1}$ Antalis agilis and Pandalus bonnieri are only met with occasionally in the fjords, ${ }^{2}$ and Ulocyathus arcticus belongs to the forms which do not enter our more southerly enclosed fjords, but may be met with in the more open northern fjords as far as the North Cape; it has also been found, according to Norman, on the Shetland plateau.

All or most of the forms enumerated as belonging to both the fjords and the plateaus, as well as those which chiefly or exclusively belong to the plateaus, may be met with as far north as Lofoten, and probably extend to the North Cape. The Norwegian North Atlantic Expedition came across many of the forms that inhabit the Norwegian depression and fjords in deep muddy hollows on the plateau north of Stat, and some of the forms occur on muddy bottom upon the outer slopes of the continental edge wherever the temperature is above $0^{\circ} \mathrm{C}$.

One peculiarity of the Norwegian depression still remains to be mentioned, namely that a deep trench extends along the northeastern side to about the latitude of the Sogne fjord, approximately 400 metres deep, where experiments with lines revealed a true hard-bottom fauna of corals (Paragorgia, Primnoa) and sponges; the "Michael Sars" found this to be the case in several places in the trench. ${ }^{3}$ It is strange that this deeper portion is not full of mud like the adjoining shallower parts, since usually we find a reversed state of things, hard bottom rising up out of the

1 Pontaster tenuispinus is found in two variations of colour, namely a rather pale form of weak structure, which belongs exclusively to the warm area, and a deep-red form much more stoutly built, which as a rule seems to belong to cold areas, though reddish individuals of weak structure occur also in warmer waters.

${ }^{2}$ A good many individuals of Pandalus bonnieri, which used to be regarded as rare, have lately been found in the Norwegian depression and in the fjords north of Stat. It is of interest to state that the Danish research vessel "Thor" has found large quantities off South Iceland. It has also been discovered in the fjords near Bergen during certain years in varying quantities.

${ }_{3}^{3}$ Large well-developed colonies of Lophohelia prolifera were found on the plateau near Stat, together with other forms that are characteristic of such localities. 
surrounding mud, and we can only conclude that the bottom here must be scoured by the action of currents.

Some very interesting discoveries were made by the "Michael Sars" in I 904 in a southern part of the depression between lat. $58^{\circ}$ and $59^{\circ} \mathrm{N}$, at a depth of 292 metres, the temperature being $5.83^{\circ} \mathrm{C}$., where the young-fish trawl brought up a quantity of amphipods, cumacea, Euchata norvegica, etc. Among these forms there were two that were particularly noticeable, namely Epimeria loricata, of which there were many specimens, full-grown as well as young, and Acanthozone cuspidata, of which there was one young specimen. Both these species were hitherto only known to exist in more northern latitudes, the former not having been met with to the south of the Malangen fjord, and the latter not south of the Trondhjem fjord, where several other arctic forms have their southern limit. ${ }^{1}$

The faunal conditions on hard bottom and on sand at the upper part of the Norwegian depression, from about Ioo metres down to considerable depths, are very like those in the Norwegian fjords, but differ in many respects from those of the central parts of the North Sea. The sponges resemble those taken on hard bottom in the deep parts of the fjords. Among the hydroids there was Sertularella gayi, a form that is absent from the central portion of the North Sea, but is one of the commonest deep-water hydroids of the fjords. Crangon allmanni and Pandalus annulicornis again were represented only by young individuals in the central portion, whereas at the edge of the depression our appliances brought up numbers of full-grown specimens. Other forms that we failed to find in the central area, but which occurred on the edge of the Norwegian depression, were: Hippasterias plana, Solaster endeca and S. papposus, Antedon sp., Psolus squamatus, Nymphon strömi (of which we secured only one solitary specimen in the central portion, in spite of repeated trawlings and dredgings, though quite common on the edge of the depression), Crania anomala (common), Porella (characteristic of hard bottom in the fjords), as well as one or two other bryozoans, Scaphanderpunctostriatus,

1 The following are a few of the other forms taken at the same time, showing that the boreal fjord and plateau forms occurred together; several of them are met with in the arctic region, and may perhaps be of arctic origin:-Amphipods: Epimeria cornigera, Pardalisca abyssi (in quantities), Lilljeborgia fissicornis, Rhachotropis (two or three species). Cumacea : Eudorella emarginata, Campylaspis verrucosa and $C$. horrida, Hemilamprops cristata. Isopods: Apseudes spinosus, Munnopsis typica, Rocinela dammoniensis. Decapod crustaceans: Pontophilus norvegicus, Pandalus bonnieri, Hippolyte polaris, Bythocaris simplicirostris, Caridion gordoni. Molluscs: Rossia sp., Torrellia vestita, Portlandia tenuis, Pecten hoskynsi, Cardium minimum. Echinoderms : Ophioscolex glacialis, Antedon tenella. Worms : Filigrana implexa (in quantities). 
etc. It must, however, be clearly borne in mind that there were many forms common to both areas,- - partly those which belong to the entire boreal region, and partly those which are exclusively or nearly always found on the plateaus.

As already stated, the bottom on the plateaus rarely, and as a rule only in deep hollows, consists of soft mud, being for the most part coarse or fine sand, sandy mud, stones, and rocks. The stony bottom usually predominates near the outer limits of the plateaus, or continental edge. Investigations by Rasch in I 844 and by Sars in 187 I made it clear that large round stones and pebbles are to be met with on the Great Edge to the west of Aalesund at a depth of about 200 metres, and the "Michael Sars" also found round stones and pebbles there, as well as on

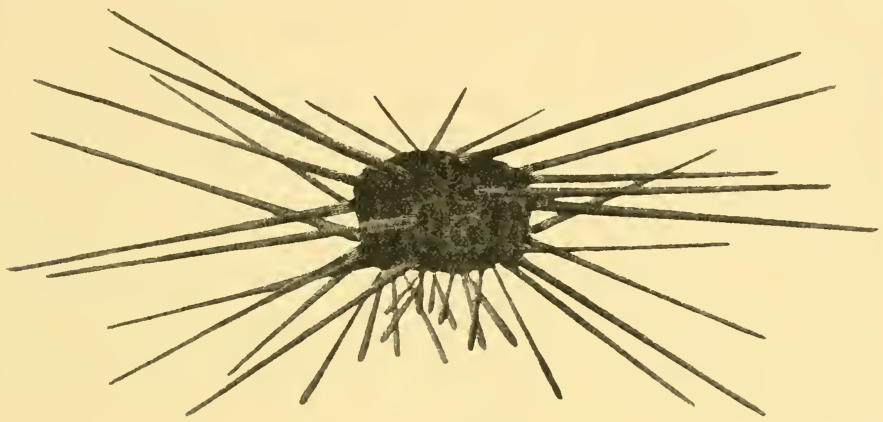

FIG. 354.

Dorocidaris papillata, Leske. Reduced. (After Düben and Koren.)

the rather less sharply defined edge of the Faroe plateau; in the latter locality the dredge brought up from a depth of about 400 metres a mass of loose round stones.

The character of the fauna on the edges of the boreal plateaus, judging from what we have found on the Faroe and the Norwegian plateaus, is fairly uniform. Owing to the nature of the bottom we meet with attached forms, particularly sponges (for instance Oceanapia robusta), hydroids, corals, brachiopods, and bryozoans, together with a number of unattached forms, of which the echinoderms are the most characteristic. Among brachiopods we get Crania anomala, Terebratulina caputserpentis, Waldheimia cranium, and $W$. septata, the last of which inhabits the plateaus of the open sea and never or only exceptionally enters the fjords. The same is the case with several echinoderms : Dorocidaris papillata (see Fig. 354), 
for instance, easily recognisable owing to its long thick spines, is one of the most characteristic forms of the plateaus and especially of the edges, but hitherto not found within the fjords; a characteristic brittle-star, Gorgonocephalus lamarcki, is also a plateau form, represented within the fjords by Gorgonocephalus linckii. One species of Echinus (E. acutus forma norvegicus) is often found in quantities, and far exceeds the fjord form in size. There are also the following brittle-stars, some of which are found in large quantities: Ophiacantha abyssicola and $O$. bidentata, Ophiactis abyssicola, all three of which are pure coast forms that do not go far up the fjords, ${ }^{1}$ Ophiopholis aculeata, Ophiura sarsi, Ophioscolex glacialis, and $O$. purpurea, which are commonly found on the edges and are also fjord forms. During a cruise of the "Michael Sars" in I 902, the lines on the Faroe Edge yielded a large number of molluscs (Sipho glaber, or a very similar form), which attached themselves to the bait, but they seem to occur in such abundance only in a few localities. The tubeworm Placostegus tridentatus is frequently found attached to the stones, and a deepwater barnacle (Verruca strömi) also, both of them being characteristic of the rocky bottom in the deep parts of the fjords; and on the spines of Dorocidaris there is now and then a Scalpellum. There are large quantities of the little mussel Anomia, which is also commonly found in the fjords. Corals, too, are found locally on the edges just as much as in the fjords, and the species are the same. ${ }^{2}$

The spaces between the stones are filled with sandy mud, so that the forms accustomed to soft bottom may be found there. How many of the characteristic species occur on the edges cannot be stated with certainty, but probably many, if not most, of the forms belonging to the soft bottom of the plateaus inhabit the edges also, though not in such great abundance. $^{3}$

My reason for mentioning the fauna of the plateau-edges separately is, not that the forms constitute a separate faunal

1 This is true of the Norwegian fjords south of Stat, though these species, like several others, have been found in the Trondhjem fjord.

2 The dredge brought up branches of Primnoa, Paragorgia, Paraspongodes, Lophohelia, and Amphihelia; also Sertularella gayi, Allopora, sponges, masses of Ophiacantha bidentata, Ophiacantha abyssicola, Ophioscolex purpurea, Ophiactis abyssicola, Gorgonocephalus. Deepsea individuals of Echinus esculentus were found both by Sars and by the "Michael Sars" in 1906, though as a rule they differed in shape from those found in the middle of the North Sea.

${ }^{3}$ Of the forms found by G. O. Sars, by the Norwegian North Atlantic Expedition, and by the "Michael Sars" on the Great Edge and its northerly continuation, as well as by the "Michael Sars" on the Faroe Edge, we may mention Stichopus tremulus, Spatangzis raschi, Echinocyamus pusillus, Schizaster fragilis, Astarte sulcata, Poromya granulata, Limopsis minuta, Onuphis, Nephthys, and other annelids, eic. ; all these forms belong to soft bottom. 
region,-though, probably owing to the influence of currents, forms like Dorocidaris and Waldheimia septata seem to find their most favourable conditions of existence there, and consequently are extremely abundant,-but because the plateauedges are the limits of distribution between the fauna inhabiting the plateaus and the totally distinct fauna of the deep central basin of the Norwegian Sea known as the "cold area." To avoid misunderstanding I may repeat that on the steep slope below the actual edge, and down to a depth of 600 or 800 metres, that is to say, to a depth where the temperature does not fall below $\mathrm{O}^{\circ} \mathrm{C}$., forms belonging to the boreal fauna may be met with. Still these slopes are as a rule so precipitous in comparison with the wide plateaus that, topographically, one is almost entitled to look upon the edges as a boundary region. The bottom of the slopes below the edge itself seems to consist nearly everywhere of soft mud dotted over with large-sized stones, thus providing a home for both mud-bottom forms and hard-bottom forms.

I have stated that we are still only imperfectly acquainted with the fauna on the bottom of sand and stones upon the plateaus, as only a few systematic investigations have been undertaken here and there. But we know enough to conclude that from a zoo-geographical point of view it is similar to that of the muddy bottom, consisting partly of forms that are common to both the plateaus and the fjords, and partly of forms peculiar to the plateaus which do not enter the fjords. The latter, however, like the corresponding forms of the muddy bottom, are comparatively few. This is confirmed by some dredgings made by the "Michael Sars" in 1906, when researches were carried out on several parts of the Norwegian plateau.

Without attempting a full description of the lower animalforms on the plateaus, we may refer to a few of the principal ones. Several hauls by the "Michael Sars" with the trawl in 1902 and 1906 showed an abundance of animal life in the northern portion of the North Sea Plateau, on hard sandy bottom (probably mixed with small stones) at depths of 150 to 200 metres, belonging to both fjord forms as well as plateau forms :-

There were numbers of Spatangus (especially S. raschi in the greater depths), Echinus acutus forma norvegicus, and Dorocidaris papillata, forms characteristic of the edges, also considerable quantities of Asterias rubens, Porania pulvillus, Goniaster borealis (?), Echinaster sanguinolentus, Pontaster tenuispinus, Stichaster roseus, Hippasterias phrygiana (plana), 
Ophiopholis aculeata, Ophiothrix fragilis, Nephrops norvegicus, Pagurus bernhardus and P. lavis, Rossia macrosoma, Pecten septemradiatus and $P$. opercularis, Occanapia robusta, Ficulina ficus (with Pagurus pubescens) as well as many other sponges. Occasionally we got Sipho islandicus, Natica sp., Neptunea antiqua (with Chondractinia digitata), Bolocera tuedia, Halipteris christi, Atelecyclus septemdentatus, Inachus dorynchus, Portunus tuberculatus, Galathea nexa, Pagurus meticulosus, Onuphis tubicola, Nereis sp., Stichopus tremulus, Brissopsis lyrifera, Luidia ciliaris,

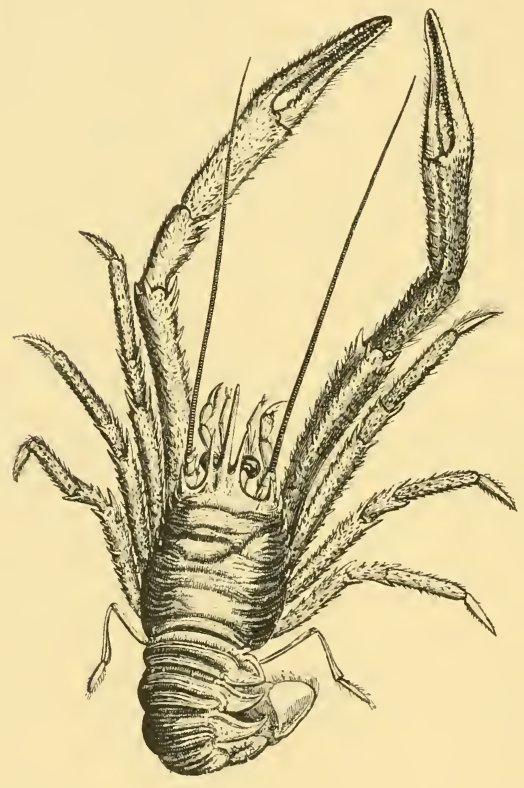

FIG. 355.

Munida rugosa, Fabr. Reduced. Ophiura ciliaris, Ascidia venosa, etc.

This list shows that several forms found in the Norwegian depression and on the deep muddy bottom occur here also. Two crustaceans (Hyas coarctatus and Munida rugosa, see Fig. 355) should be noticed in particular, as they inhabit the plateau in large numbers, and seem to furnish an important supply of food to the larger kinds of fish; they were both also taken by the trawl in 200 metres on the Norwegian coast-bank off Stat. In addition we secured a couple of starfishes (Pontaster temuispinus and Astropecten irregularis), while brachiopods, bryozoans, chitons, etc., were attached to the stones. Among the amphipods we noticed species of the genus Hoplonyx, immense numbers of which sometimes collect on dead fish or baited lines.

British investigators have made the plateau round the Shetland islands, to a depth of about 200 metres, one of the most familiar. ${ }^{1}$ Most of the Shetland forms are identical with those occurring in the Norwegian boreal region, but we do 
not find there many of the forms that on the west coast of Norway are chiefly distributed in the great depths of the fjord; ${ }^{1}$ there are also certain forms living in deep water at the Shetlands having a southern distribution, Atlantic or Mediterranean forms which find their northern limit there. These differences may to some extent be due to the warm Atlantic water which flows over the Shetland plateau; thus the "Michael Sars" found a temperature of $9.12^{\circ} \mathrm{C}$. on the western edge at a depth of 300 metres, and captured with a line a southern shark (Hexanchus griseus), frequently taken by British fishermen, which has never been caught farther north in the Norwegian Sea. It is interesting to remark that some of the forms, though no doubt only stray individuals, make their way eastwards along the northern portion of the North Sea plateau as far as the edge of the Norwegian depression, beyond which, however, they never pass, like the crab Portumus tuberculatus ${ }^{2}$ and the starfish Luidia ciliaris, which were captured on the northern slope of the Viking Bank. Others penetrate even into the Norwegian fjords, like the hermit crab Pagurus meticulosus (tricarinatus), and the crab Atelecyclus septemdentatus, small individuals of which were captured on several occasions in the Bergen fjord. Some of the southern forms occurring off the Shetlands wander down along the east coast of Scotland and England, though without spreading farther eastwards, and we find the same faunal agreements and dissimilarities between the east coast of Britain and the west coast of Norway as in the case of the Shetlands.

Certain parts of the plateaus, at a depth of 100 to I 50 metres, seem to be favourite abodes of the hydroids, which form regular forests on the bottom, and are plentifully represented by both species and individuals. Just as with the hydroid fauna in the laminaria tracts, so here, too, an assemblage of other animal groups, especially lower crustaceans and naked molluscs, live upon and among these hydroids. ${ }^{3}$

The hydroids appear to occupy comparatively large tracts of the plateaus, though not regularly distributed over their

1 For instance, Stichopus tremulus, Bathyplotes tizardi, Amphiura norvegica, Pandalus propinquus, Munida tenuimana.

2 A specimen of this species was also taken on the deeper part of the slope, in 275 metres, with a temperature of $7.94^{\circ} \mathrm{C}$.

${ }^{3}$ Characteristic and common forms of hydroids were: Thujaria thuja, easily recognisable owing to its verticillate branches, Hydrallmannia falcata, Diphasia abietina and D. fallax, Sertularella tricuspidata, Lafoea sp., Campanularia volubilis. Among the lower crustaceans it is especially the caprellids (Eginella spinosa) and the arcturids (Astacilla longicomis and Arcturus sp.) which climb about among the hydroids by means of their specially adapted feet. Eolids too creep about here in great numbers. 


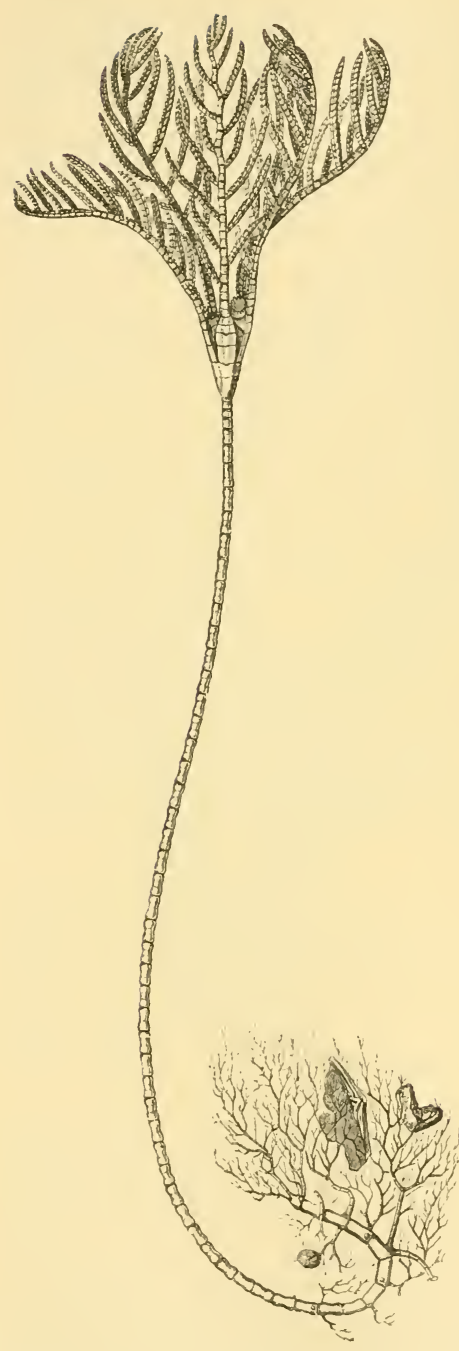

FIG. 356.

Rhizocrinus lofotensis, G. O. Sars. Magnified. (After Wyville Thomson.) whole extent. They thrive well apparently on sandy bottom, wherever it is covered with fragments of shells, to which they may attach themselves, and this is even better seen in the central portion of the North Sea. The "Nichael Sars" found hydroid-bottom, of the kind described, on the northern portion of the North Sea plateau, on the Faroe plateau east and west of those islands and on the large bank to the south of them, on the Iceland-Faroe ridge, and on the south - eastern Iceland plateau.

A number of species belonging to different groups, which among the skerries and in the western fjords of Norway are littoral forms, or at any rate only occasionally descend below the lower limit of the littoral zone, occur at greater depths out on the plateaus, where they are sometimes very plentiful.

During the cruise of the "Michael Sars" we found on the eastern Faroe plateau, at a depth of IIO metres, on sandy shellstrewn bottom: Cucumaria frondosa, Strongylocentrotus dröbachiensis, Pandalus annulicornis, Pagurus bernhardus, Asterias rubens, Mytilus modiolus, Buccinum undatum, Alcyonium digitatum, and on the Faroe Bank, south-west of the Faroe Islands, at about 125 metres, Echinus esculentus and Ophiura albida. On the banks around the Faroes beyond the Ioo-metres line there 
were: Spatangus purpureus, Echinocardium, Echinaster sanguinolentus, Luidia sarsi, Hippasterias plana, Ophiopholis aculeata, Ophiothrix fragilis, Scaphander, Hyas coarctatus, Pagurus pubescens, Inachus dorhynchus, Stenorhynchus longirostris, the annelids Thelepus circinnatus and Leodice norvegica (both very common), etc. Some of these are mainly littoral forms on our coasts. Inachus dorhynchus and Stenorhynchus longirostris seem to have a more westerly distribution than the rest, the former being very rarely, and the latter never, found near the Scandinavian coasts, though two other species (Inachus dorsettensis and Stenorhynchus rostratus) do occur there; these four forms are all met with on the North Sea coasts of Great Britain. From the deep part of the plateaus we may mention the comparatively rare Rhizocrinus lofotensis (see Fig. 356), which is fixed in the mud by root-like off-shoots.

One locality examined by the "Michael Sars" in 1902 is entitled to special notice, viz. the extensive Faroe Bank to the south-west of the Faroes, where the bottom at a depth of 100 to 300 metres is peculiar, being quite covered with an enormous quantity of empty shells of different mussels, ${ }^{1}$ with a few living specimens among them. ${ }^{2}$ The empty shells were pure white, and it was interesting to see how this white colour affected the other bottom-animals, fishes as well as invertebrates. A couple of species of Raia, for instance, had large white spots, and a flounder (Pleuronectes limanda) had assumed the light colour of the bottom ; Ophiura albida, which on our coasts and elsewhere is of a blackish-brown colour, was here perfectly white, and the spines of Echimus esculentus were far lighter in colour than usual. Astacilla longicornis, which climbed about among the hydroids, had on the other hand assumed their green hue.

The geological significance of these shell-covered banks (there are several round the Faroe islands, and fossil shells are also found on the Norwegian coast-banks) has been discussed at considerable length by Professor Brögger. ${ }^{3}$ They are generally believed, like the Norwegian coast-banks and the plateaus round the Shetlands, etc., to have stood at a higher level during the glacial and inter-glacial periods, forming part of the littoral region of the sea-floor, and to have since subsided. The fossil remains of animals that along our coasts nowadays appear to be able to live, or at any rate to thrive, only in shallower waters are taken as proof of subsidence, it being assumed that with the subsidence of the bottom this shallow-water fauna became extinct.

\footnotetext{
1 Pectunculus glycimeris, Venus casina, Tellina crassa, Arca tetragona, Tapes edulis.

2 Pectunculus glycimeris, Venus casina, Tellina crassa, Mactra elliptica, Psammobia tellinella, and Dosinia.

3 "Om de senglaciale og postglaciale nivaaforandringer i Kristianiafeltet (Molluskfaunaen)," Norges geol. Undersögelse, No. 31, pp. 106, etc., Kristiania, I900-1901.
} 
That there must have been considerable alterations in the physical conditions of the sea on these banks appears evident from the large decayed shells of an arctic form, Pecten islandicus, and the remains of other arctic molluscs. The enormous quantities of empty shells of more southern forms may indicate that special forces have been at work, resulting in the destruction of these animals in vast numbers. But, on the other hand, I consider it too hasty an assumption from a biological point of view to maintain that, because these forms are in other localities solely or mainly littoral forms, their extinction must have been due to subsidence of the ocean-floor. As already mentioned, the "Michael Sars" dredged from the bank large living specimens of several of the species represented by empty shells in such abundance, showing that there is still a possibility of finding the necessary conditions of existence there. And there were also some characteristic littoral forms, like Echinus esculentus, Ophiura albida and Alcyonium digitatum, of which the first named was in too great abundance to have been merely the result of chance.

The occurrence of these forms may perhaps be explained by the high temperature $\left(9.33^{\circ} \mathrm{C}\right.$.) at these depths in the middle of August 1902-a temperature differing very slightly from that prevailing at the same season along the Norwegian coast in the shallower depths principally inhabited by these forms-for temperature and salinity more than depth regulate distribution. An extinct fauna of forms like these at a spot somewhere out on the plateaus does not necessarily imply subsidence of the bottom, but more likely physical changes in the sea-water. Oysters and many other forms are examples of this. A further instance may be cited from the North Sea cruise of the "Michael Sars" in I904. At Jammer Bay, on the north-west coast of Jutland, at a depth of I 4 metres, the dredge brought up great quantities of Mactra elliptica, Lunatia intermedia, Ophiura ciliaris, Echinocardium, etc., along with a very large number of empty shells belonging to the mussel Venus gallina, of which only two living specimens were found. It would be absurd to assert in this case that mortality was due to changes of level, as this form is found elsewhere in quantities at such depths, but the numbers of empty shells point to an encroachment of unfavourable conditions. Another factor must be kept in view, namely bottom-currents, that may possibly, under certain circumstances, accumulate bottom-material such as piles of empty shells at particular localities, which would not 
necessarily indicate mortality from extraordinary circumstances, but merely an accumulation, from a considerable area, of individuals whose deaths were due to natural causes. Although certain indications along the coasts of our own and other lands would appear to justify us in regarding currents as a means of conveyance, we know far too little about the matter to be able to discuss it with any profit. ${ }^{1}$

In my remarks regarding the edge of the Norwegian depression I endeavoured to show that the fauna of this part of the North Sea differs from that in its more central parts (see p. 506); for this difference, however, the depth, nature of the

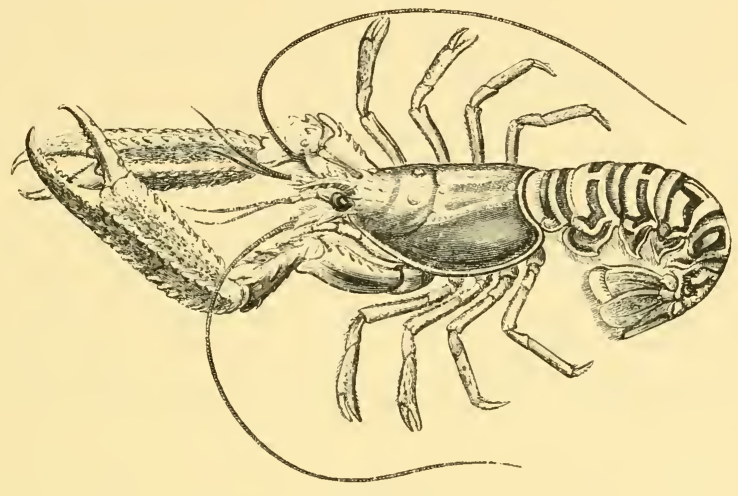

FiG. 357 .

Nephrops norvegicus, L. Reduced. (After Bell.)

bottom, and temperature cannot be held solely responsible. This difference holds good also for the continental plateau beyond the roo metres curve. The "Michael Sars" captured in I 10 to I 50 metres: the crustaceans Nephrops norvegicus (see Fig. 357), Geryon tridens, Sabinea sarsi, Pontophilus spinosus, Pandalus brevirostris, Hippolyte pusiola, Caridion gordoni; the pycnogonids Nymphon strömi and $N$. mixtum; the echinoderms Hippasterias plana (according to Plate rarely found on the Great Fisher Bank), Solaster endeca, Pteraster militaris (two small specimens), Ophiocten sericeum (quantities of young specimens); the snail Scaphander punctostriatus, etc. None of these forms (except one individual of $N y m p h o n$ strömi) were met with in the central portion of the North Sea. Three of them in particular

1 Compare Heincke, "Die Mollusken Helgolands," Wissensch. Meeresuntersuch. Komm. f. Untersuchung Deutsch. Meere, Neue Folge, Bd. I, pp. I40 et seq. 
(Nephrops norvegicus, Nymphon strömi, and Hippasterias plana) furnish unmistakable evidence of the dissimilarity of these areas, for they are widely distributed over the North Sea, occurring even on the coasts of Great Britain in depths both greater and less than Ioo metres, and if they existed in the central portion of the North Sea, where we frequently towed our big trawls, they could hardly have avoided capture. Then why should a considerable part of the central area of the North Sea be closed to a number of forms more or less widely distributed elsewhere? We must, I think, conclude that in this central area there are special hydrographical conditions which exclude these forms and their larvæ. As a matter of fact, Helland-Hansen has shown that in the deeper layers there is a circular current of Atlantic water in the North Sea, a branch of the Gulf Stream following the east coast of Scotland, turning north-east just before reaching the Dogger Bank, and afterwards sweeping northwards on reaching the edge of the Norwegian depression. As a result, the periphery of the central portion of the North Sea is bathed by water of much the same composition as the warmer water of the Atlantic, enclosing an area covered by more stagnant and on the whole colder water, having a fauna of its own. ${ }^{1}$ Repeated investigations will be necessary to ascertain whether this faunal dissimilarity observed in the summer of 1904 is permanent or not.

\section{Arctic and Boreo-Arctic Regions of the Norwegian Sea}

When we speak of an arctic and a boreal fauna it must be clearly understood that there is not always a distinct line of demarcation between the two, either in regard to topographical boundaries or to forms. There are undoubted intermediate areas, where boreal and arctic forms meet, and many forms are as much boreal as arctic, being impartially distributed over either region, and able to thrive amidst very different natural conditions. It is interesting to note, however, that the same species sometimes occurs in two distinct varieties, usually connected by transition forms, and that the varieties conform to the region in which they occur, a fact indicative in all probability of the influence of physical conditions upon organisms.

A circumstance that has especially attracted the attention of arctic investigators is that some animal forms are apt to

${ }^{1}$ I must add that the entire northern part of the North Sea plateau is also covered by Atlantic water. 
flourish in some localities in such immense quantities as to displace all others, a phenomenon that may certainly be seen also now and then in the boreal region, though not to such a marked extent. Even when several species occur together the specimens appear to be more numerous than is the case in the boreal region. On one occasion in the Barents Sea the "Michael Sars" brought up in a single trawling over a ton of big sponges (Geodea), and near Jan Mayen at another time more than a barrelful of Pecten grönlandicus. The prawns again are sometimes in myriads, and Sars relates that during the Norwegian North Atlantic Expedition the trawl came up positively full of the feather star, Antedon eschrichti. One reason for such enormous quantities of individuals is that many of the arctic animals produce their young fully developed, without any free pelagic stage, so that in all probability a large proportion continue to live where they were born. ${ }^{1}$ Currents, the nature of the bottom, and conditions of nourishment must also be taken into account. ${ }^{2}$

Nowhere perhaps do we find such a marked contrast between the boreal and arctic faunas as when we pass from one of the boreal coast plateaus out into the cold area of the Norwegian Sea. If we trawl on the plateaus, where the temperature does not sink below $6^{\circ}$ or 7 C., we find a boreal fauna consisting to a great extent of forms which have migrated into the Norwegian Sea from southern latitudes. As soon, however, as we come to the slope of the deep basin (the cold area), at a depth of say 600 to 800 metres, $^{3}$ where the temperature falls below $0^{\circ} \mathrm{C}$., the exclusively arctic element begins to predominate, and we meet with species that are almost entirely foreign to the banks and coasts of the boreal region.

There is the remarkable Umbellula encrinus (see Fig. 358), a form belonging to the pennatulids, that may grow several metres high, with large rosette-like polyps at the upper end of the stalk. Of star-fishes we have the beautiful purple Pontaster

Direct

development. 
tenuispinus, also found on the plateaus and in the Norwegian depression, the whitish-yellow Bathybiaster vexillifer (see Fig. 359 , which in the cold area takes the place of Psilaster andromeda,

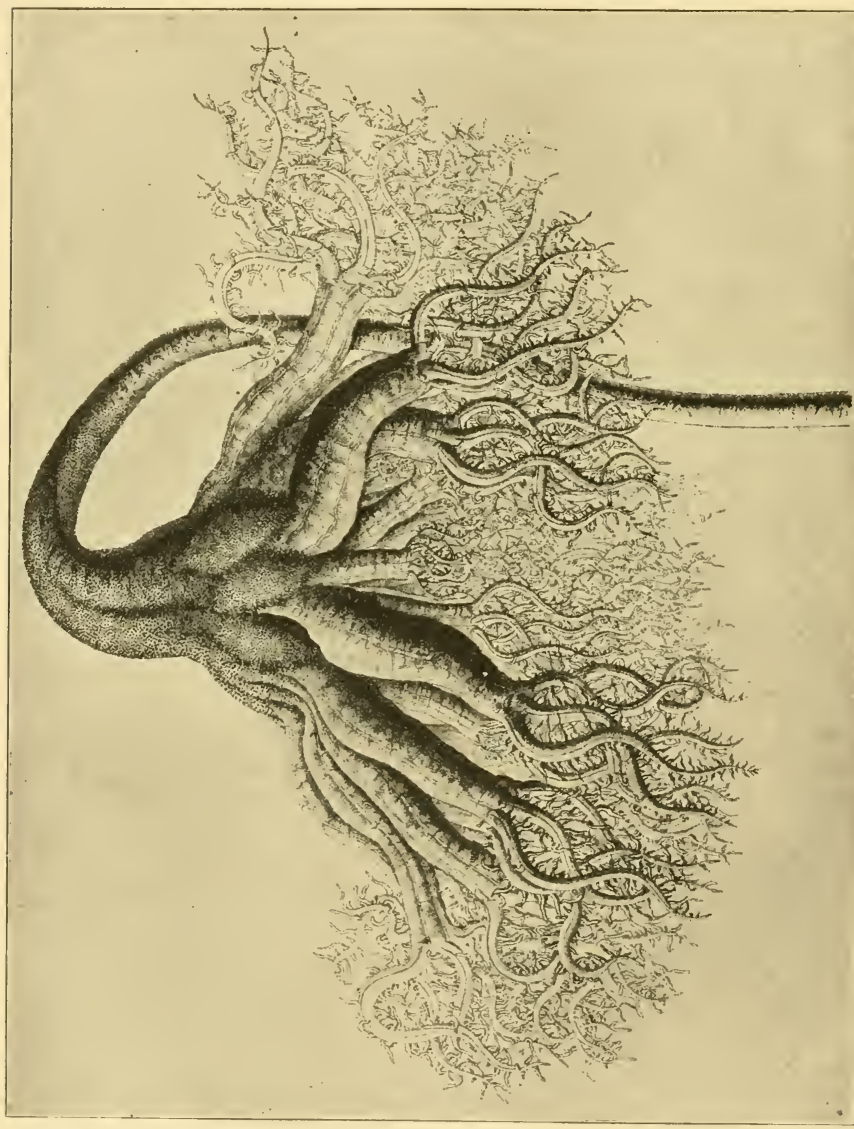

its relative of the plateaus and coasts), and in smaller quantities the semi-transparent Hymenaster pellucidus (see Fig. 360). Among brittle-stars the big light-coloured Ophiopleura borealis and the smaller gray Ophiocten sericeum (also found along the coasts, though in a slightly different variety) are in greatest 
abundance. The sea-slugs Stichopus tremulus and Mesothuria intestinalis so characteristic of the deep parts of our fjords, are entirely absent, but instead of these forms with foot-suckers we have a footless genus Trochostoma (see Fig. 36r). The sea-mice are represented by Pourtalesia (see Fig. 362), a very remarkable genus that in some respects resembles forms long extinct, but Spatangus, Echinocardium and Brissopsis (character-

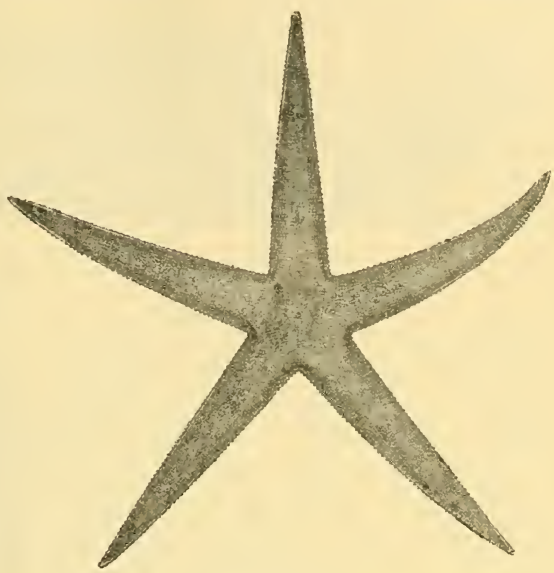

FIG. 359. istic of our fjords and Bathybiaster vexillifer, Wy. Thoms. Reduced. (After Bell.) coast-banks), and the ordinary sea-urchins are no longer to be

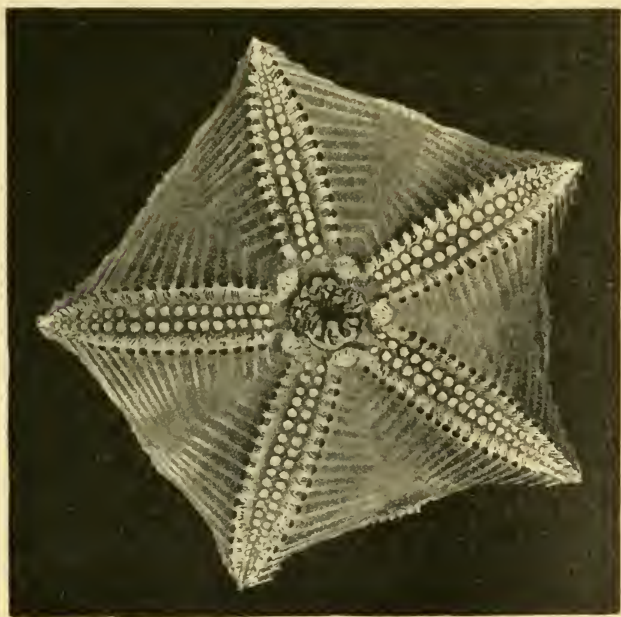

FIG. 360.

Hymenaster pellucidus, Wy. Thoms. "Michael Sars," 1900. found. Huge sealilies or featherstars (Antedon eschrichti, see Fig. $36_{3}$, and $A$. pro(ixa), and quantities of the medusa's head (Gorgonocephalus eucnemis), are attached most likely either to $U m$ bellula or to the numerous sponges, Cladorhiza sp., whose hard central axis and tree-like ramifying shape make it so conspicuous, some of which sometimes form regular thickets along the bottom. There are gigantic representatives of the 
pycnogonids or sea-spiders, Colossendeis proboscidea in particular

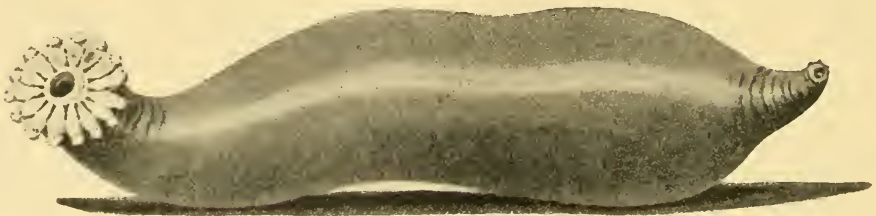

FIG. 36I.

Trochostoma boreale, M. Sars. Reduced. (After Danielssen and Koren.)

being immense, though Nymphon robustum (see Fig. 364 ) is the most numerous and characteristic species of the cold area, and is easily recognisable by its semicircular prehensile organs, resembling fingers which incline towards one another. The higher crustaceans consist entirely of shrimplike forms, such as Sclerocrangon

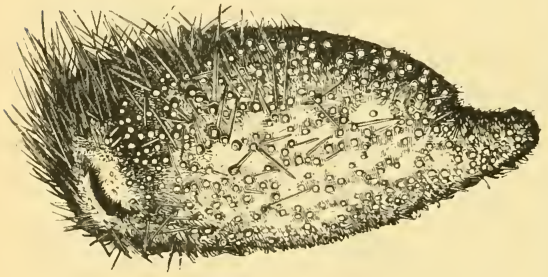

FiG. 362.

Pourtalesia jeffreysi, Wy. Thoms. (After Wyville Thomson.)

ferox (see Fig. 365), Bythocaris, and Hymenodora glacialis (the last of which is also found pelagic in the deeper water-layers), whereas crabs are very poorly represented in the arctic areas. On the other hand, the lower crustaceans, especially isopods and amphipods, occupy a very prominent position among the fauna of the Norwegian Sea deep basin, as there are numbers

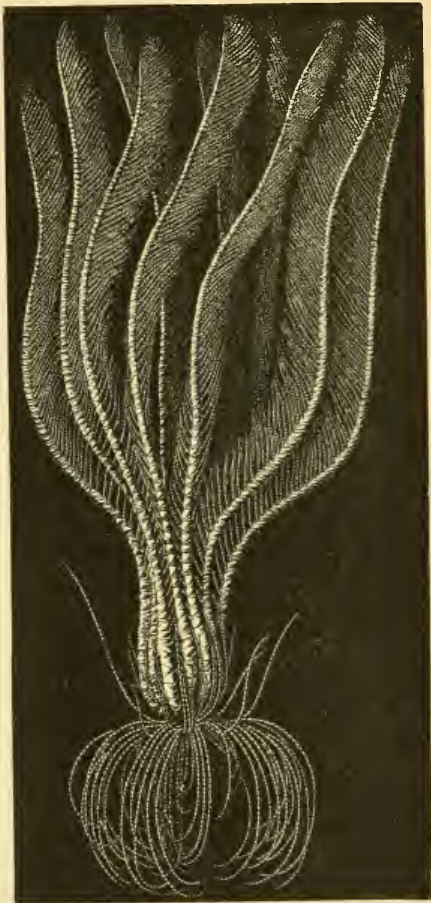

F1G. 363 .

Antedon eschrichti, J. Müller. Reduccd. (After Stuxberg.) of species, and several attain to considerable size. One of the 
most characteristic of the amphipods is Amathillopsis spinigera (see Fig. 366), which has an extremely spinose body. ${ }^{1}$ The cold area, moreover, like the plateaus and coasts, has its caprellids climbing about among the sponges and hydroids, the most numerous and common being Caprella spinosissima, whose body is covered with dense strong spines. Among isopods we get the remarkable Eurycope gigantea belonging to a group with very long legs that easily drop off; it has a relation not nearly

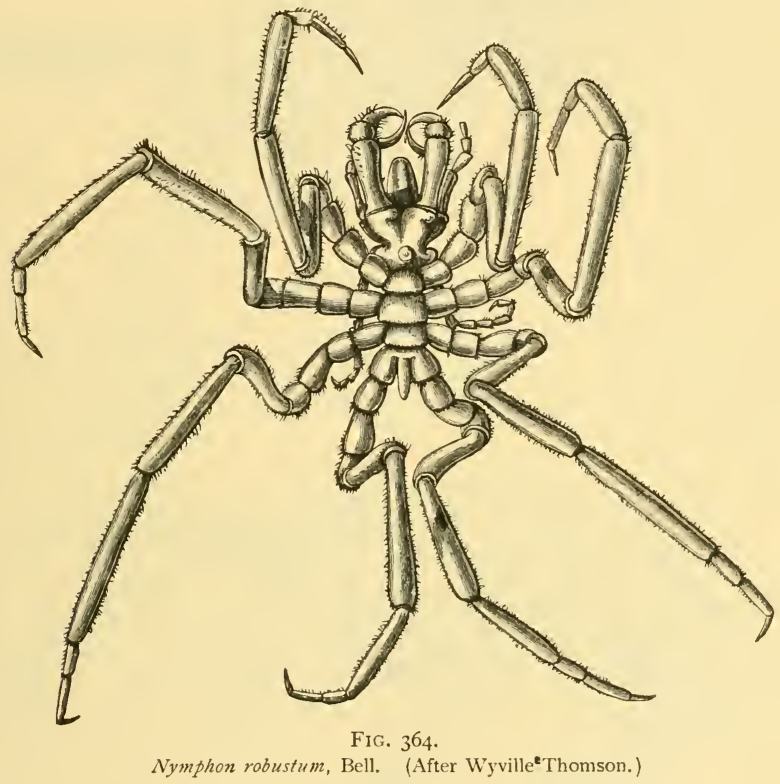

so big (Munnopsis typica) in the greater depths of the boreal region and widely distributed throughout the arctic seas. The isopod fauna is further represented, often in considerable quantities, by the genera Arcturus ( $A$. baffini, see Fig. ${ }_{367)}$ and Astacilla (A. granulata).

A sea-anemone, Allantactis parasitica, is another of the most characteristic forms, attaching itself to the shells of snails belonging to the species of Sipho and Neptunea.

1 Other amphipods conspicuous owing to their size are Stegocephalus inflatus, the extremely thick forepart of whose body makes it easily recognisable, Cleippides quadricuspis, with long spines along the dorsal portion of its posterior segments, Anonyx sp., etc. 
CHAP.

Hydroids are little in evidence; the vast thickets of these animals found on the plateaus are absent. ${ }^{1}$ Alcyonaria are chiefly represented by the genus Paraspongodes, with its cauliflower-like colonies, numbers of which also flourish in

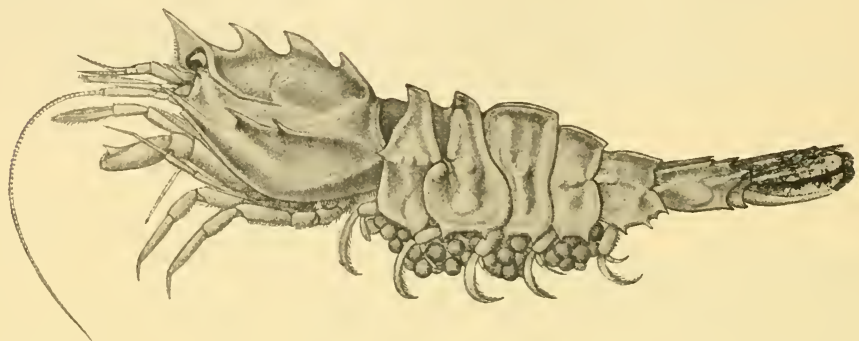

FIG. 365 .

Sclerocrangon ferox, G. O. Sars. (After G. O. Sars.)

warmer waters; apparently the same species occur in both areas, the most widely distributed being $P$. fruticosa.

The commonest molluscs are shelled snails of the genera

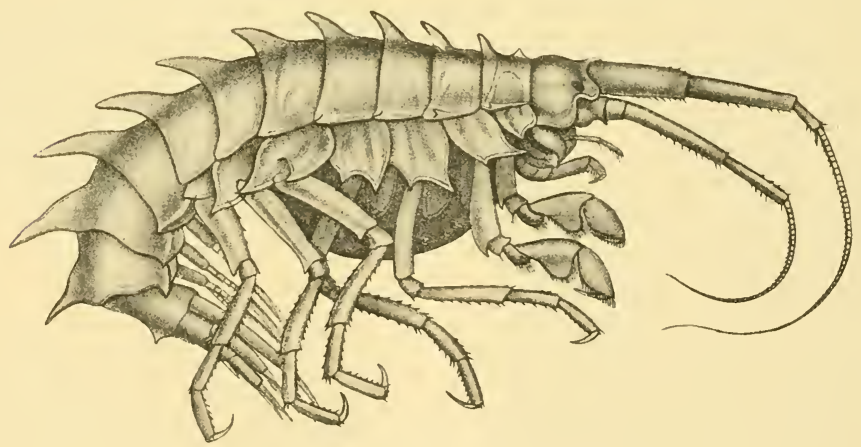

FIG. 366.

Amathillopsis spinigera, Heller. Slightly magnified. (After G. O. Sars.)

Neptunea and Sipho. There are cuttlefishes of the genus Octopus, though never in any great quantity, and another very remarkable form is the rare Cirroteuthis milleri, one of the eight-armed group, whose members differ from the other in

1 The most characteristic representatives of this group, belonging to the family Myriothelidie (genus Lampra), are rare. 
having fins; its arms are united to each other throughout their whole length by a skin attachment. The sea-tooth (scaphopod), Siphonodentalium vitreum, is also a very widely distributed form.

In the Norwegian Sea deep basin beyond 2000 metres the conditions seem as a rule to be less favourable for the development of an animal-life abounding in species, as already alluded to by Sars in his report on the first cruise of the Norwegian North Atlantic Expedition. The bottom at these great depths

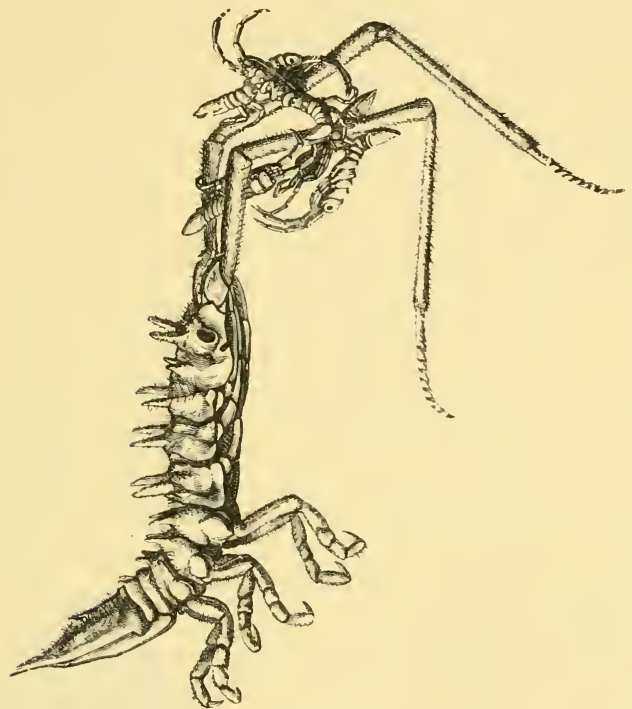

FIG. 367.

Arcturus bafini, Sab. With young. (After Wyville Thomson.) consists of Globigerina (or Biloculina) ooze, offering no foundation for attached forms. Only a few species are limited to these profound depths, as the majority occur also in the shallower areas of the Arctic region, or are met with on the slopes of the Norwegian Sea deep basin.

One of the most characteristic deep-sea forms is a sea-lily, Bathycrimes carpenteri, that attaches itself to the soft bottom by means of the root-like ramifications issuing from its stalk (this form has a near relation, Rhizocrinus lofotensis, which occurs in the deeper parts of the boreal region). Another characteristic echinoderm is a sea-slug, Kolga hyalina, which is never found in depths less than 2000 metres. Elpidia glacialis (see Fig. 368), too, must be considered a characteristic sea-slug of the Norwegian Sea deep basin, though it may from time to time be met with in the north at lesser depths. These two holothurians belong to a remarkable group, with few though very large feet arranged in rows on either side; they 
occur occasionally in immense quantities. Crustaceans are represented by a characteristic deep-sea form, namely the isopod Glyptonotus megalurus, nearly related to a form that occurs in the arctic region in shallower waters; pycnogonids by

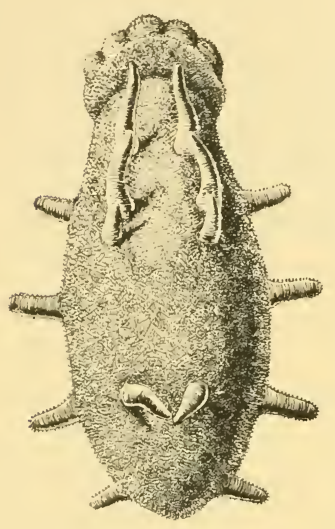

FIG. 368 .

Elpidia glacialis, Théel. Magnified. (After Stuxberg.) Ascorhynchus abyssi; and molluscs by Pecten frigidus (see Fig. 369), Neptunea mohni, Natica bathybi, etc. There are also some deep-sea sponges, prominent amongst which are the Hexactinellids; although not regularly distributed over the Norwegian Sea, they are found in great quantities to the north of Spitsbergen at a depth of 1000 metres, where they and another group (Tetraxonia) constitute the most characteristic portion of the fauna. Outgrowths on their under sides enable them to hold fast to the soft bottom, which is littered with silicious spicules from dead sponges. ${ }^{1} \quad$ Römer and Schaudinn have doubted whether the deep-sea fauna of those northern latitudes is to be considered zoo-geographically as a part of the fauna of the Norwegian Sea deep basin, or whether it belongs to a separate faunal area, the deep polar basin ; deepsea sponges have, however, been subsequently found in quantities farther south (lat. $72^{\prime} 23^{\prime} \mathrm{N}$., long. I $30^{\prime}$ W.) at a depth of 2000 metres. $^{2}$

The forms limited exclusively to the abyssal region, or at any rate only very exceptionally occurring in shallower waters, are not the only ones which characterise the Norwegian Sea deep basin, for we find regularly also a number of other forms met with on the slopes in the cold area. ${ }^{3}$

Just as the Norwegian Sea deep basin has its own (even though rather few) character-

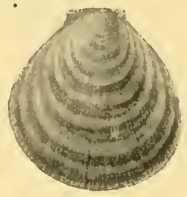

FIG. 369 .

Pecten frigidus, Jensen. "Michael Sars," I 900. istic forms, which do not ascend to the arctic plateaus but constitute a typical deep-sea fauna, so, too, the plateaus have a

1 Römer and Schaudinn, op. cit. p. 49.

2 Kolthoff, Till Spetsbergen och nordöstra Grönland, I9oo, pp. 212-213.

3 The "Michael Sars" found at about 2000 metres the echinoderms: Bathybiaster vexillifer, Ophiocten sericeum, and Pourtalesia; the mollusc: Siphonodentalium vitreum; the crustaceans: Bythocaris leucopis and Hymenodora glacialis; the pycnogonid: Nymphon robustum; the worm : Lumbrinereis, etc. The tube-worm, Myriochele, with its fine sand-tube, belongs to the forms which occur in quantities in the depths of the Norwegian Sea. 
series of species that do not descend to the profound depths. These latter may be designated arctic shallow-water forms, or, Arctic to use a different zoo-geographical description, arctic continental forms, though it is as well to remember that the depth on the shallow-water forms. plateaus averages about 400 metres. As in the case of the boreal plateaus, so here, too, we can distinguish between forms that keep entirely to less depths and those which chiefly inhabit the deeper portions. The bottom conditions of the plateaus are quite different from those that prevail in the abyssal region, since hard bottom is to be found as well as soft, whereas the floor of the deep basin consists almost entirely of soft materials; consequently the plateaus have a far greater abundance of attached animal forms.

Currents, owing to the increased abundance of nourishment they bring with them, are likewise responsible for the greater profusion of attached forms on the arctic plateaus. To what extent they affect the distribution of animal-life may be seen by comparing the fauna of the west and east coasts of Spitsbergen. Römer and Schaudinn, who made careful researches in 1898 , found that on the western side non-attached forms, especially echinoderms, were most in evidence, while on the eastern side, where strong currents flow through the sounds, attached forms predominated. Of this latter area Römer and Schaudinn write as follows: "Most of the rocks and large stones are covered with barnacles, while monascidians and synascidians form populous colonies on the bottom. Sponges, which are scarce on the western side, are represented by numerous species, and alcyonids inhabit the deeper channels. The shallower rocky localities accommodate large congregations of actiniæ. The animals, however, which, so to speak, hall-mark the fauna, and are developed in almost fabulous fashion, are hydroids and bryozoa. So dense are the thickets formed in some places by these organisms that the heavy dredge failed to reach the bottom, and merely brought up animals instead of bottom-material." Amongst these attached forms, moreover, there is, just as in the boreal region, a rich fauna of nonattached forms like worms, crustaceans, and molluscs. Römer and Schaudinn drew attention to the fact that the worms, crustaceans, and molluscs, in particular, did not show such a striking difference in their distribution around Spitsbergen as other groups, but were, on the contrary, fairly equally distributed between east and west. Nor are echinoderms absent on the eastern side, where in fact there are actually more species than 
on the west, but in regard to individuals they are very much exceeded by the attached forms.

A great difference between the arctic region in high latitudes, where the Gulf Stream has lost its warming influence, and the boreal region, is to be found in the littoral, or more correctly in the strand, zones. The luxurious growth of fucus and laminaria which covers the rocks along the coasts in the boreal region, both above and below low-water mark, is wanting in depths less than about 6 metres. This is due to the ice blocking up the shore for a great part of the year and preventing the development of animal and plant life. The strand zones in high arctic latitudes accordingly exhibit nothing but naked rock, in contradistinction to the rocks of the boreal region, where we find numbers of attached animal-forms right up to high-water mark. As soon, however, as we descend below the limit of the baneful effects of the ice, we meet with a profusion of both plants and animals, sometimes even in greater abundance than in the boreal region.

Arctic littoral forms.

Though we are thus unable to speak of an actual strandfauna in high arctic latitudes, we can distinguish, to a certain extent, between the littoral, or rather sub-littoral, and the deeper non-littoral forms. The former, however, appear to be comparatively few in number, taking 40 metres as the lower limit as we did in the boreal region, while on the other hand most of the non-littoral forms reach nearly up to or actually pass the littoral limit. Generally speaking, the limits between a littoral and non-littoral zone seem to be less clearly defined in the arctic than in the boreal region. ${ }^{1}$ The reason for this is obvious enough, if we remember that temperature largely controls distribution. In high arctic latitudes the difference in temperature between deep and shallow waters is inconsiderable compared with that at corresponding depths in boreal areas. As a result the forms find favourable conditions of existence, so far as temperature is concerned, at very different depths, and the vertical distribution of most of the arctic forms is far more extensive than that of boreal forms. A few instances may be cited: Hymenaster pellucidus in the Norwegian Sea deep basin is found even below 2000 metres, while on the east side of Spitsbergen it occurs at 27 metres; Antedon eschrichti may be met with in the cold area of the Norwegian Sea at very considerable depths, whereas at Spitsbergen it flourishes in

${ }^{1}$ Cf. Stuxberg, "Evertebratfaunan i Sibiriens ishaf," Vega.exped. vetenskap. iakttagelser, Bd. i. pp. 730 , etc. 
18 metres of water, and the same is the case with Ophiocten sericeum; Nymphon robustum, which even at depths of 2000 metres is the most characteristic pycnogonid of the Norwegian Sea deep basin, can actually thrive at a depth of 6 metres in the arctic littoral zone; Gorgonocephalus eucnemis occurs in the Norwegian Sea deep basin and yet finds itself at home in the arctic littoral zone. Many similar examples could be adduced, but special works on the different groups, indicating the depths at which the various forms have been found, furnish the clearest evidence. The character of the water in different arctic areas must also be taken into consideration. Species which almost invariably live in water at a temperature below $0^{\circ} \mathrm{C}$. will not be met with in shallow depths except where truly polar water predominates; thus on the west coast of Spitsbergen there are echinoderms found only in deep water, which on the east side occur very much nearer the surface, owing to the fact that on the west side the Gulf Stream makes its influence felt to a considerable depth, while on the east coast the water is everywhere polar. I shall return to the influence of warm currents upon animal life in arctic tracts.

It must not be supposed, however, that the vertical distribution in arctic tracts is entirely devoid of system. No doubt there are a great many forms with a far more extensive distribution than would be possible in the boreal region, still the arctic plateaus shelter numerous forms that do not descend into the Norwegian Sea deep basin, and apparently therefore are unable to thrive in such deep water. In their case it is evidently not temperature but other factors that regulate distribution, and besides it is actually possible to point to a purely littoral arctic fauna, although its representatives are far from numerous.

Hard bottom as well as soft are to be found in the deeper parts of the arctic plateaus; where the bottom is of mud it differs from the brownish Globigerina (or Biloculina) ooze of the Norwegian Sea deep basin, being of a grayish colour like what we find in the Norwegian fjords and on the boreal coast banks; in the Barents Sea, however, we get greenish-gray mud. The arctic mud, like the boreal, contains many foraminifera, though the species differ to a certain extent. ${ }^{1}$ We may divide the species composing the arctic fauna into

1 The species named by Kiær (Norwegian North Atlantic Expedition, Thalamophora, p. 12) as characteristic of the gray mud in northern arctic areas are : Astrorhiza crassatina, Lagena apiculata, Pulvinulina karsteni, Globigerina pachyderma. Biloculina lavis, Globigerina bulloides and $G$. pachyderma, Haplophragmium latidorsatum, Truncatulina wüllerstorf, Rotalina orbicularis, and Lagena apiculata are common in the Globigerina (or Biloculina) ooze of the Norwegian Sea deep basin; some of them belong also to boreal areas. 
Purely arctic forms.

three categories. The first category may be termed purely arctic, occurring in water having a low temperature all the year round. ${ }^{1}$ Allowing for slight variations it is safe to assert that the majority of them require a temperature considerably below what prevails in the deeper parts of the boreal region $\left(6^{\circ}\right.$ to $7^{\circ}$ C. $)$, though a few coast and shallow-water forms are able to exist at higher temperatures for a short portion of the year ; this is particularly the case with those arctic forms that come as far south as the Lofoten, Murman, and Finmark coasts. Still even within the purely arctic areas we find faunal differences that are due to temperature. Some forms are never, or very rarely, found in water having a temperature above $0^{\circ} \mathrm{C}$., others appear to thrive impartially throughout the whole arctic region in whatever temperatures prevail, while others again

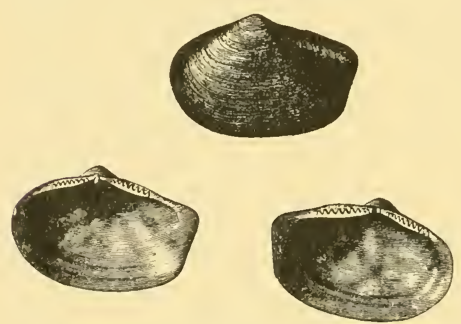

FIG. 370.

Yoldia arctica, Gray. (After Stuxberg.) avoid the coldest water and keep as much as possible to temperatures slightly above $\mathrm{O}^{\circ} \mathrm{C}$.

As regards horizontal distribution within the arctic region we may assume that most of the species are widespread, even if they have not yet been met with everywhere, for we are still only imperfectly acquainted with the fauna over a large portion of the arctic plateaus, especially that off East Greenland. Some species, however, will undoubtedly prove to be more or less local, judging from what we have found in the boreal region.

A few of the larger forms that characterise the arctic coasts and plateaus are given in the following list : ${ }^{2}$ -

Molluscs: Margarita cinerea, Onchidiopsis glacialis, Natica clausa, Amauropsis islandica (rarely found on the Norwegian west coast), Neptunea despecta, Sipho curtus, S. turgidulus, S. kröyeri, S. glaber, Buccinum glaciale, B. hydrophanum, B. grönlandicum, and a few other species of Buccinum, species of Bela, Siphonodentalium vitreum, Nucula tenuis var. expansa, Yoldia hyperborea, Y. (Portlandia) arctica (see Fig. 37o) and $Y$. limatula, Arca glacialis, Pecten grönlandicus, $P$. islandicus, Astarte (Nicania) banksi var., $A$. borealis, and $A$. crebricostata, Axinopsis orbiculata, Aximus gouldi, Tellina calcarea (rarely found alive on the Norwegian west coast, though extremely abundant in the arctic region),

1 There are a few exceptions, for instance, Pecten islandicus, Ctenodiscus crispatus, Onchidiopsis glacialis, which are more boreo-arctic than arctic (see p. 534).

3 In this list I deal only with the molluscs, echinoderms, crustaceans, and ascidians. 
and a few other species of Tellina, Venus fuctuosa, Cardium ciliatum, C. grönlandicum, Thracia truncata (rarely found in the boreal region), Pandora glacialis. Brachiopods: Rhynchonella psittacea (see Fig. 37I), Terebratulina spitsbergensis. Echinoderms : Asterias lincki, A. panopla, A. grönlandica, A. hyperborea, Stichaster albulus, Ctenodiscus crispatus, Ophiopleura borealis, Ophiura nodosa, Amphiura sundevalli, Opliiopus arcticus, Gorgonocephalus eucnemis and G. agassizi, Antedon eschrichti, A. prolixa, Cucumaria minuta, C. glacialis, Eupyrgus scaber, Trochostoma boreale, Ankyroderma jeffreysi, Chirodota lavis, Myriotrochus rinki. Decapod crustaceans: Sclerocrangon ferox, S. boreas, Sabinea septencarinata, Hippolyte turgida and H. spinus, Bythocaris payeri, Idotea entomon. Two species of pycnogonids, $N y m p h o n$ robustum and $N$. lirtipes, are very abundant in the arctic region; the former is largely a deep-sea form, which descends far

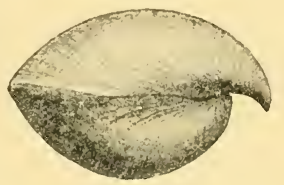

FIG. 37 I.

Rhynchonella psittacea, Chemn. (After G. O. Sars.) down into the cold area of the Norwegian Sea deep basin, whereas $N$. hirtipes belongs more to the banks and plateaus. Both species were trawled by the "Michael Sars" on the Jan Mayen plateau, showing that they may be abundant in shallow waters also. The largest pycnogonid of the Norwegian Sea is Colossendeis proboscidea, found both on the slopes of the deep basin and on the banks. There are also several other species of $N^{\top} y m p h o n$, such as $N$. elegans,

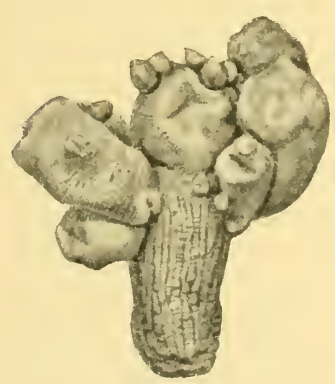

FIG. 372 .

Dendrodoa aggregata, Rathke. Nat, size.

$N$. macronyx, and $N$. gracilipes, which are common arctic forms. The hydroids have comparatively few purely arctic species, though the magnificent large Tubularia regalis is one that deserves special notice; in congenial localities like the Bear Island shoal and the banks of Jan Mayen it forms regular thickets on the bottom. Among ascidians Dendrodoa (Styela) aggregata (see Fig. 372) is a very characteristic arctic form, and is often found in little colonies composed of a number of cohering individuals. Another characteristic though rarer species is Chelyosoma macleyanum, easily recognisable owing to its extremely flattened shape and the squares into which its surface is divided. Ciona intestinalis, one of our commonest boreal forms, occurs in the arctic tracts as a distinct variety (longissima). The compound ascidians are represented by several species, amongst which the tuberous Synoicum incrustatum, whose surface is encrusted all over with grains of sand, may be easily recognised. Other forms are Molgula retortiformis, Amaroucium mutabile (tuberous and of a reddish-violet colour), and Sarcobotrylloides aureum.

The second category of forms in the arctic region is made Arctic-boreal up of those which are at the same time extensively distributed forms. 
over the boreal parts of the Norwegian Sea, and are thus just as much boreal as purely arctic; I append a short list :-

Molluscs: Lepeta ceca, Margarita grönlandica and $M$. helicina, Lunatia grönlandica, Littorina rudis, Cylichna alba, Leda pernula, Modiolaria lavigata and M. nigra, Astarte (Nicania) banksi with varieties, Astarte compressa, L. (=elliptica, Br.), Mya truncata (chiefly arctic, whereas M. arenaria is the typical boreal form), Saxicava arctica, Pecten hoskynsi, Portlandia frigida. Echinoderms: Strongylocentrotus dröbachiensis, Pontaster tenuispinus, Echinaster (Cribrella) sanguinolentus, Solaster papposus (occurs as a rule in the arctic region as a distinct variety, S. affinis), Pteraster militaris, Opliura sarsi and O. robusta, Ophiocten sericeum, Ophiopholis aculeata, Ophiacantha bidentata, Ophioscolex glacialis, Cucumaria frondosa, Psolus phantapus. Decapod crustaceans: Pandalus borealis, Hippolyte gaimardi, and H. polaris, Pagurus pubescens, Hyas araneus and H. coarctatus. Isopods: Munnopsis typica. Pycnogonids: Nymphon grossipes (and a few other species of Nymphon). Ascidians: Pelonaia corrugata, Styela rustica and S. Loveni, Styelopsis grossularia, and Ascidia prunum. Worms: a number of species of Harmothö, Lumbrinereis fragilis, Onuphis conchylega, Nereis pelagica, Arenicola piscatorum (marina), Owenia assimilis, Nicolea zostericola, Thelepus circinnatus, and Terebellides strömi.

These forms are very interesting biologically, as they show to how great an extent the same species is able to adapt itself to different natural conditions. Many of them ${ }^{1}$ are quite common in the littoral zone of the boreal region, where during a large portion of the year the temperatures are comparatively high, and yet they are also to be found in arctic tracts, where temperatures are all the year round below $\mathrm{O}^{3} \mathrm{C}$., or at any rate not more than a few degrees above $0^{\circ} \mathrm{C}$. during a very short period. Others, again, are more consistent, as they inhabit only the greater depths of the boreal region, where throughout the whole year the temperature is fairly uniform and comparatively low (though never sinking below $6^{\circ}$ or $7 \mathrm{C}$.), whereas in the arctic region they exist in shallow water; thus on the Norwegian west coast we find the mussel Portlandia frigida, the brittle-star Ophiacantha bidentata, and the prawn Hippolyte polaris (see Fig. 373) only as a rule beyond 100 metres, whereas in high arctic latitudes they may be met with at a depth of about IO metres. The species included in this second category do not all by any means show the same distribution throughout the arctic region; some forms occur every-

\footnotetext{
1 Margarita grönlandica and $M$. helicina, which both occur in the boreal laminaria belt, Saxicava arctica, Strongylocentrotus dröbachiensis, Echinaster sanguinolentus, Ophiopholis aculeata, Cucumaria frondosa, Hippolytegaimardi, Pagurus pubescens, Hyas, Styela rustica, Nereis pelagica, Arenicola, Nicolea, etc.
} 
where in both the arctic and the boreal regions, while others are generally limited within the arctic region to water having temperatures just about or above $0^{\circ} \mathrm{C}$. These last are intermediate forms between this and the following category, and include, for instance, the prawn Pandalus borealis.

A third category of species composing the arctic fauna consists of boreal forms that are able to enter the arctic region owing to the warmth introduced by various branches of the distribution. Gulf Stream, which counteracts the chilling effects of the icy coastal and polar currents. On the coasts of East Finmark and on the Murman coast these are particularly in evidence. These boreo-arctic intermediate areas occupy that portion of the Norwegian Sea where the waters of the Gulf Stream and polar currents intermingle, or where the shallow coast waters

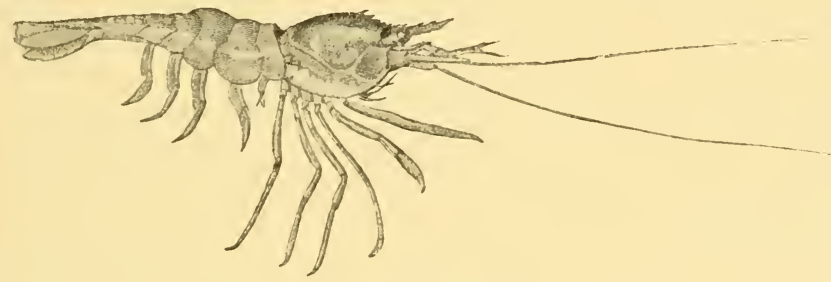

FIG. 373 .

Hippolyte polaris, Sab. Reduced. (After Parry.)

acquire a high summer temperature in consequence of the comparatively milder climate produced by the proximity of the Gulf Stream.

This boreo-arctic area contains certain forms of truly arctic origin, less sensitive in regard to temperatures above $0^{\circ} \mathrm{C}$., and attaining here the extreme limits of their advance in a boreal direction. It also contains genuine boreal species, which may range as far south as the Mediterranean, and have their northern limit within this area.

Along the north-west coast of Norway from Lofoten to the Boreo-arctic North Cape (West Finmark) the character of the fauna is very complicated, owing to the diversified hydrographical conditions, especially in the deeper places of the coastal area compared with those in the inner basins of the fjords. Many of these north-western fjords are open to the ocean for part of their length, so that their seaward portions may fairly be regarded 
as inlets, while their landward portions are cut off by submarine barriers which are often comparatively shallow. As a consequence the warm water of the Gulf Stream flows along the bottom of the fjords till it reaches the barriers, but is unable to penetrate into the inner basins, which are therefore greatly affected by climate, their water-masses at comparatively shallow depths being stagnant and at a low temperature. We find accordingly an arctic fauna predominating in the inner basins, while the boreal forms met with on the coast and in the seaward portions of the fjords in corresponding depths are for the most part absent. ${ }^{1} \quad$ Still there are arctic forms in these latitudes along the coast in the shallow waters of the littoral (and sublittoral) zones, where climatic conditions occasion low temperatures for at any rate part of the year. The fauna at greater depths along the coast, on the other hand, is purely boreal owing to the influence of the Gulf Stream. We are accordingly justified in regarding Lofoten as the southern limit of the boreo-arctic area, so far as the coast tracts are concerned, even though the boreal element preponderates there, and similarly we are entitled to call the inner basins of the fjords boreo-arctic, although in their case it is the arctic element that predominates. $^{2}$

The coastal areas and fjords east of the North Cape (East Finmark) are altogether boreo-arctic. The fjords here are open arms of the sea, in which there is no distinction between the fauna of the outer and of the inner portions, and, owing to the intermingling of Gulf Stream and polar waters, the purely boreal character of the fauna predominating in West Finmark is absent even in the deeper parts. Moreover, the farther east we go and away from the influence of the Gulf Stream the more do these conditions assert themselves, the fauna becoming gradually more and more purely arctic. A comparison between this area and large parts of one of the best-known areas in high arctic latitudes, namely Spitsbergen, shows how perfectly justified we are in calling it boreo-arctic, for we find a fauna on the Murman coast which, in addition to purely arctic species, includes littoral ${ }^{3}$

G. O. Sars, "Some Remarks on the Character of the Marine Fauna along the Northern Coasts of Norway," Tromsö Museums Aarshefter II., 1879, p. 60; Nordgaard, Hydrographical and Biological Investigations in Norwegian Fjords, Bergen, 1905.

2 It must be distinctly stated, however, that this fauna is made up mainly of forms which, although undoubtedly of arctic origin, are distributed over both the boreal and arctic regions; whereas the purely arctic forms are comparatively few. These fjord areas are entitled to be characterised as boreo-arctic owing to the presence of a small number of purely boreal forms with boreo-arctic distribution otherwise.

3 Purpura lapillus, Littorina littorea, Nacella pellucida, Mytilus edulis, Tellina baltica, Asterias rubens, Balanus balanoides, Crangon vulgaris, Dynamena pumila. 
and deeper-living ${ }^{1}$ boreal forms that are never met with at Spitsbergen.

Another boreo-arctic area lies in the south-western portion of the Norwegian Sea on the ridge connecting Iceland and the Faroes. The crest of the Wyville Thomson Ridge between the Faroes and Shetland has not been examined by the "Michael Sars," but undoubtedly it may be included. On the broad ridge between the Faroes and Iceland we took up several stations in I 902 , at a depth of 450 to 480 metres, the temperature varying between $3.12^{\circ} \mathrm{C}$. and $3.98^{\circ} \mathrm{C}$. ; the greatest depth on the top of this ridge is about 500 metres. Here we came across the same mixed fauna already described as characteristic of the northeastern boreo-arctic area, the "Michael Sars" securing distinct arctic forms, ${ }^{2}$ together with boreal forms ${ }^{3}$ which penetrate into the boreo-arctic portion of the Barents Sea. If we remember that the polar and Atlantic currents meet about the middle of the Iceland-Faroe ridge, it will be easy to understand the boreo-arctic character of the bottom fauna. It is remarkable that such distinctly cold-water forms as Hymenaster and Nymphon robustum were found in water with a temperature of $3^{\circ}$ or $4^{\circ} \mathrm{C}$; no doubt the individuals were few (only one specimen of $N y m p h o n$ robustum, for instance, being taken), still their occurrence seems to show that the bottom-water on the ridge has not always the high temperatures we recorded-the temperatures must often be considerably lower, perhaps even below $0^{\circ} \mathrm{C}$. at times. ${ }^{4} \quad$ Boreal deep-water forms are furthered in their advance occasionally by warm currents, and yet they can endure low and varying temperatures; the converse probably holds good with various purely arctic forms, which owe their distribution to the cold arctic water, but can endure the higher temperatures when that is displaced by Gulf Stream water. In spite of this Hymenaster and $N y m p h o n$ robustum are just as much arctic forms as Hippasterias, Pentagonaster, and Pontophilus are boreal forms.

1 Antalis entalis, Schisaster fragilis, Hippasterias plana, Pentagonaster granularis, Verruca strömi, Hippolyte securifrons, Crangon allmanni, Nephrops norvegicus (?), Pontophilus norvegicus, Munida rugosa, and several others. The hydroids, on the other hand, are very widely distributed, as most of the species met with in these tracts are commonly distributed throughout the boreal region; some species of hydroids seem able to adapt themselves to all temperatures (eurythermal forms).

2 Hymenaster pellucidus, Solaster squamatus, Antedon eschrichti, Rhachotropis aculeata, Epimeria loricata, Nymphon robustum, Lampra purpurea.

3 Hippasterias plana, Pentagonaster granularis, Schizaster fragilis, Antedon tenella, Gorgonocephalus lincki and G. lamarcki, Pontophilus norvegicus, Sabinea sarsi, and amongst hydroids Thujaria thuja and Hydrallmannia falcata, although not in any great quantities.

"The Danish "Ingolf" Expedition recorded a temperature of +0.5 C. at about 5 IO metres. 
I have already stated that the north and east coasts of Iceland are boreo-arctic areas. Even as far south as lat. $64^{\circ} \mathrm{I} 7^{\prime} \mathrm{N}$. and long. I $4^{\circ} 44^{\prime} \mathrm{W}$., that is to say, quite close in to the coast, the "Michael Sars" found purely arctic forms at a depth of 75 metres, namely, the prawn Sclerocrangon boreas and the ascidian Molgula retortiformis, together with forms that are either widely distributed throughout both regions, or are boreal with a boreo-arctic distribution. ${ }^{1}$ Here again, therefore, the character of the fauna was evidence of the meeting of the

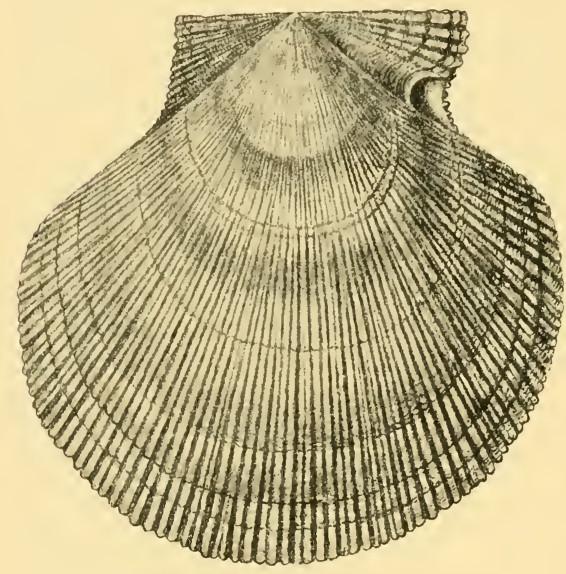

FIG. 374.
Pecten islandicus, L. Reduced. (After G. O. Sars.) two great currents, the East I celand Polar Stream and the At lantic Stream.

Before leaving the arctic fauna I have still to mention a few characteristic forms, which penetrate for a short distance into the boreal region along the coast of Norway. The starfish Ctenodiscus crispatus is found as far south as Christiansund, where it occurs in enormous quantities; and another starfish, Leptoptychaster arcticus, ${ }^{2}$ has its southern limit in the Trondhjem fjord. A very characteristic arctic species of mussel, Pecten islandicus (see Fig. 374), is very numerous and of large size in the Trondhjem fjord, and may be met with even farther south, while the same fjord is the southern limit for the molluscs Onchidiopsis glacialis, Dendronotus velifer, and a few others. We have thus another instance of the difficulty in fixing definite boundaries for the different regions. The Trondhjem fjord shelters too many forms which

${ }^{1}$ I append the names of a few forms:-Ascidians: Ascidia obliqua, Pelonaia corrugata, Macroclinum pomum (numerous), Distoma crystallinum. Crustaceans: Hyas coarctatus, Pagurus, Pandalus annulicomis, Hippolyte polaris, Crangon allmanni, Arcturus sp. Echinoderms: Asterias rubens, Echinaster sanguinolentus. Pycnogonids: Pycnogonum littorale, Nymphon mixtum, N. hirtipes. Cœelenterates: Metridium dianthus, Corymorpha glacialis, Tubularia indivisa (common), Hydrallmannia falcata, and a few other hydroids. Also some sponges and worms.

${ }^{2}$ The peculiarity about this form is that it lives mainly in boreo-arctic areas, and is thus neither purely arctic nor purely boreal. 
do not enter the boreo-arctic area to be designated an intermediate area. Possibly both Ctenodiscus crispatus and Leptoptychaster arcticus live chiefly in isolated basins, where the temperature for part of the year sinks lower than in the other parts of the fjord, though I do not know that this has actually been confirmed.

Occasionally too we find in far more southern areas a few forms that must be considered purely arctic, although they are quite acclimatised and plentiful. They are survivals (relicts), and date from the glacial age when the northern seas were inhabited by an arctic fauna. The milder climate which succeeded the glacial period brought about the

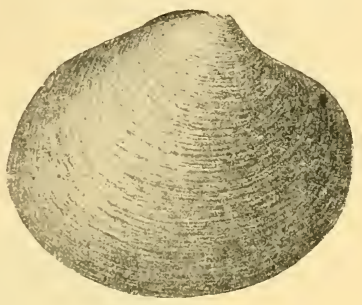

FIG. 375 .

Tridonta borealis, Chemn. (After G. O. Sars.) elimination of all those species that are now purely arctic, and such forms are at present practically limited to arctic tracts. Only a few were able to adapt themselves to the altered con-

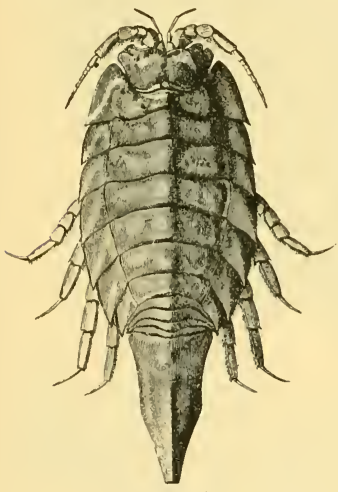

FIG. 376 . ditions, ${ }^{1}$ and are to be found to this day in isolated areas, located outside the range of this chapter, though owing to the interest attached to them, they may be briefly alluded to.

There is, for instance, the mussel Astarte (Tridonta) borealis (see Fig. 375), large quantities of which are found in the arctic tracts from Lofoten northwards. In the south we do not find it till we come to Öresund, The Belts, and the Western Baltic, where it is very plentiful. In the intervening waters it is merely a stray guest, having been found once or twice in the neighbourhood of Bergen. The survival forms include also a few crusIdotea entomon, L. (After Stuxberg.) taceans, for instance, the isopod Idotea entomon (see Fig. $376)$, some worms, and a sea scorpion (Cottus quadricomis), which are mostly to be found in the Baltic, and in a few lakes of North Europe that were connected with the sea in the glacial age.

1 On the other hand there are, as already stated, a number of forms from the glacial age which became thoroughly acclimatised, and, in contradistinction to the relict-forms, are widely distributed throughout both regions. 


\section{Deep-Water Fauna of the North Atlantic}

It is easy to see how much the configuration of the bottom, and the hydrographical conditions associated with it, affect the distribution of animal-forms, if we compare the fauna of the Norwegian Sea north of the submarine Iceland-Faroe Shetland and Iceland-Greenland ridges, with the fauna of the Atlantic Ocean to the south of these ridges. Thanks to the painstaking researches of the Danish "Ingolf" Expedition, and the subsequent investigations of the "Michael Sars" in

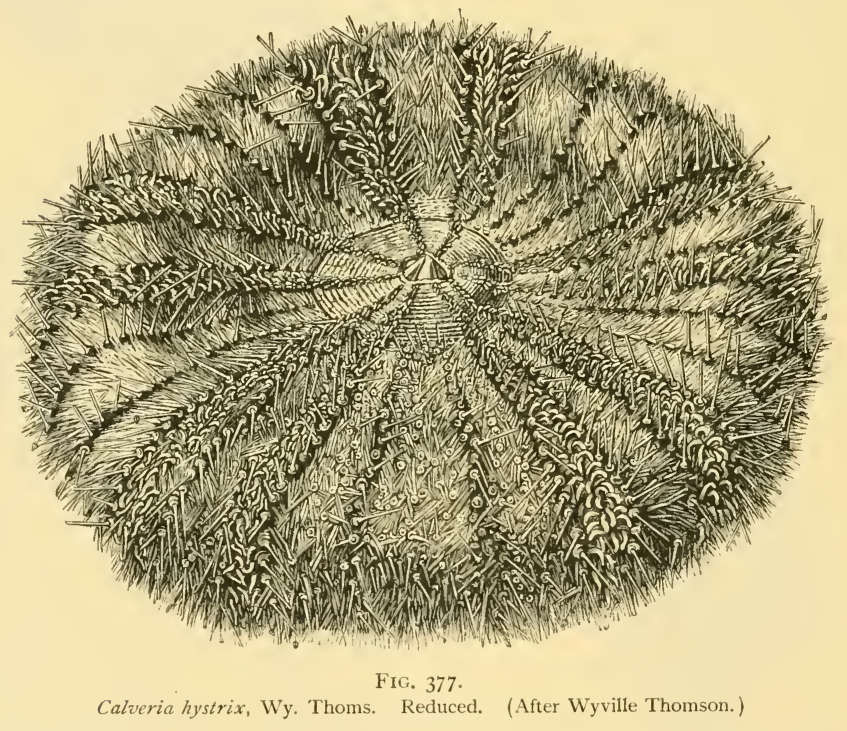

I902, we are now acquainted with the principal characteristics of both. The chief hydrographical differences in these two marine areas are due to the intervening ridges, covered on an average by 550 to 600 metres of water, which prevent the icy bottom water of the Norwegian sea from entering the Atlantic, and conversely the warm Atlantic water from flowing over the floor of the Norwegian Sea. ${ }^{1} \quad$ Two temperature-readings are sufficient to make this clear: in 1902 the "Michael Sars" found a temperature of $-0.4 \mathrm{I}^{\circ} \mathrm{C}$. in the Faroe-Shetland channel at

${ }^{1}$ On the other hand, the Atlantic and Polar currents meet, as already stated, over the Iceland-Faroe ridge. 
a depth of I 100 metres, while at a similar depth hardly a
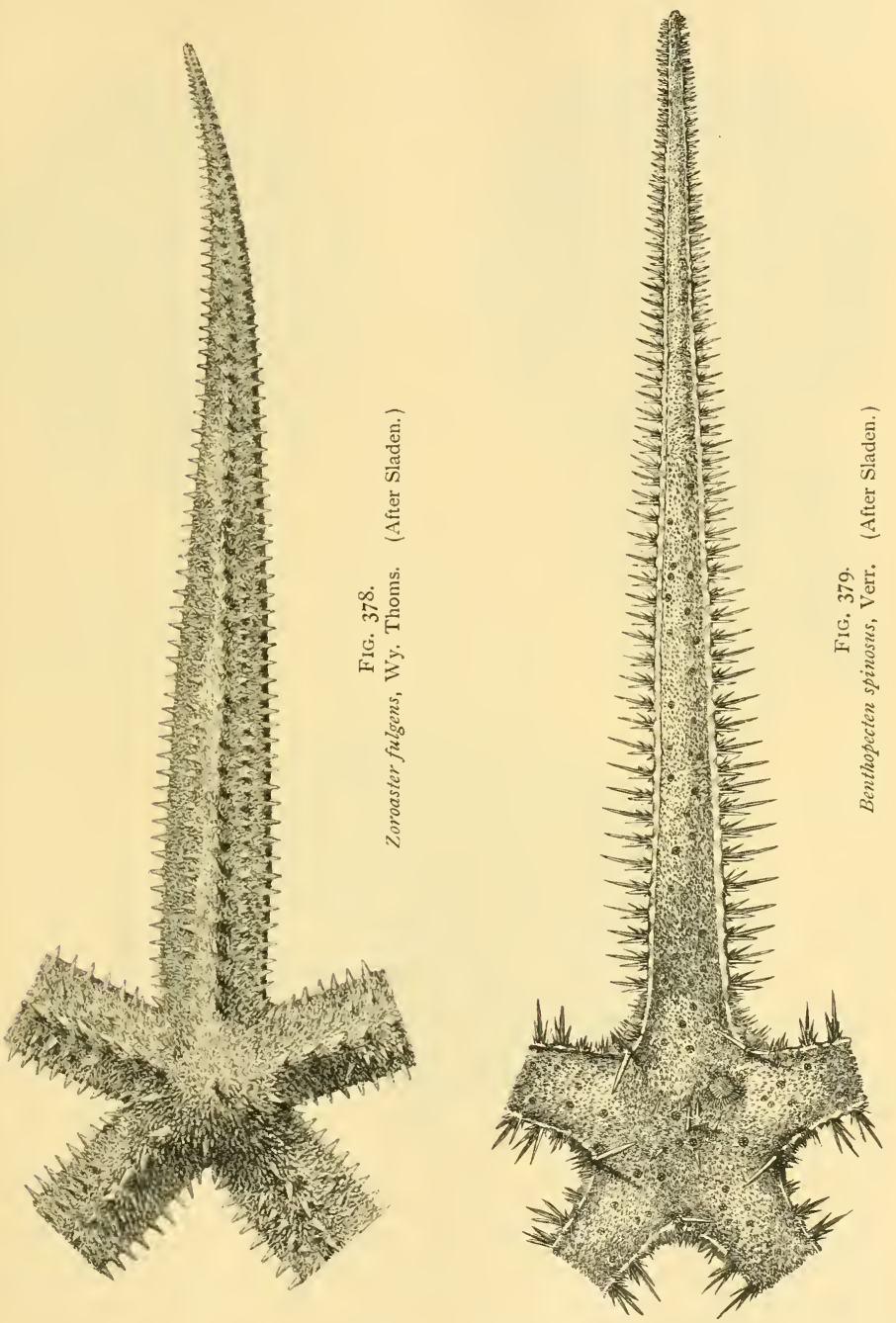

degree farther south the temperature was as high as $+8.07^{\circ} \mathrm{C}$. 
Such great temperature differences produce a corresponding dissimilarity in the fauna (see pp. I 3 and 66I). We have trawled in the cold Norwegian Sea deep basin and captured more or less familiar arctic forms, and then only a few hours steam farther south we have trawled again on the southern slope of the Wyville Thomson Ridge, and taken forms, fishes as well as inverte-

Archibenthal fauna of the North Atlantic.

brates, which one would expect to find in quite southern areas.

Among the deep-water forms of the Atlantic that are present in large quantities on the southern slopes of the ridges and plateaus we have first some species of sea-urchins belonging to the remarkable family of the Echinothuridæ (see Fig. 377). ${ }^{1}$ They differ from all other sea-urchins in the structure of their shells, for, instead of having continuous plates of lime, their plates

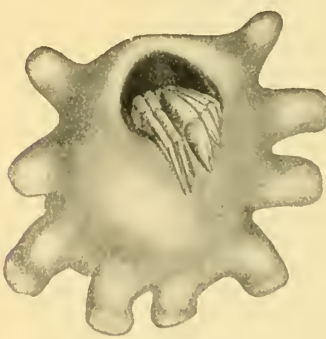

FIG. 380 .

Epizoanthus paguriphilus, in symbiosis with Parapagurus pilosimanus. Reduced. " Michael Sars," r9o2, 750 metres. are connected by non-calcareous attachments of skin, so that their shells are flexible and more or less like leather. One species of holothurian, Latmogone violacea, is very abundant. It belongs to the same division as the forms Elpidia and Kolga, which are so plentiful in the Norwegian Sea. The "Michael Sars" also found large numbers of the starfish Zoroaster fulgens (see Fig. 378).

The following are a few other forms met with on the southern slopes of the ridges :-

Regular sea-urchins: Echinus alexandri and E. affinis, Porocidaris purpurata. Irregular sea-urchins: Urechinus naresianus, Pourtalesia wandeli, Echinosigra phiale, Hemiaster expergitus. Starfishes: Bathybiaster robustus (a species which outwardly resembles $B$. vexillifer of the Norwegian Sea, though the structure of its skeleton is different), ${ }^{2}$ Plutonaster bifrons, Benthopecten spinosus (see Fig. 379), Pentagonaster perrieri, Solaster abyssicola. Ophiurids: Ophiopleura aurantiaca, Ophiomusium lymani, Amphiura denticulata. Coelenterates: Epizoanthus paguriphilus (in symbiosis with Parapagurus pilosimanus, see Fig. 380), the pennatulids Anthoptilum murrayi and Umbellula lindahli, the true corals Stephanotrochus diadema (see Fig. 381) and Flabellum sp. (see Fig. 382), the horn-corals Acanthogorgia armata and Strophogorgia challengeri. Decapod crustaceans: Lispognathus thomsoni, Scyramathia carpenteri, Geryon affinis, Cymonomus normani, Neolithodes grimaldi, Parapagurus pilosimanus, Munida microphthalma, Munidopsis curvirostra, Uroptychus rubro-vittatus, Polycheles sculptus and

1 The species occurring here include Phormosoma placenta, Calveria (Asthenosoma) hystrix, and Sperosoma grimaldii.

2 According to J. A. Grieg, Conservator of the Bergen Museum. 
P. nanus, Nephropsis atlantica. Molluscs: Dentalium caudani and others. Sponges: Pheronema carpenteri (see Fig. 383).
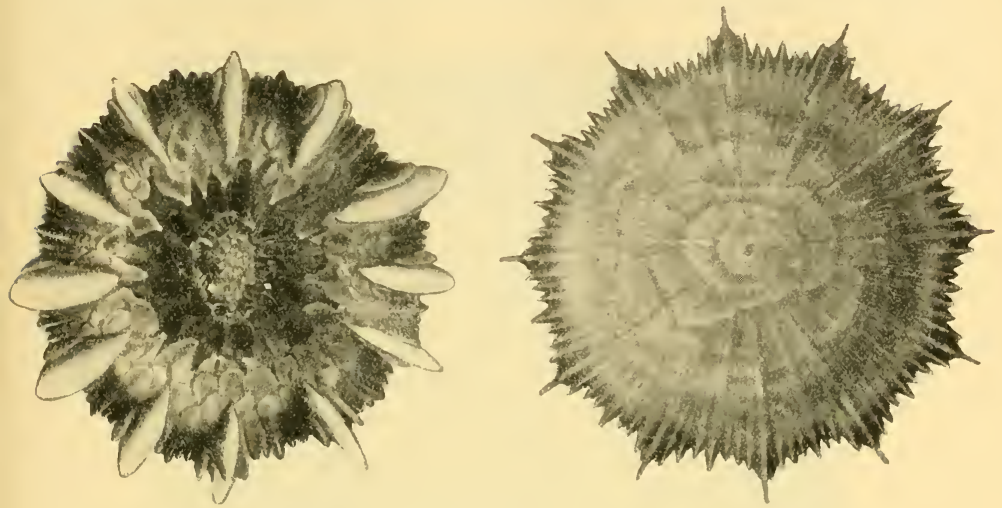

Fig. 381 .

Stephanotrochus diadema, Moseley. "Michael Sars," 1902, 750 metres.

This list is very far from complete, but it shows what a number of forms there are which do not belong to the Norwegian Sea.

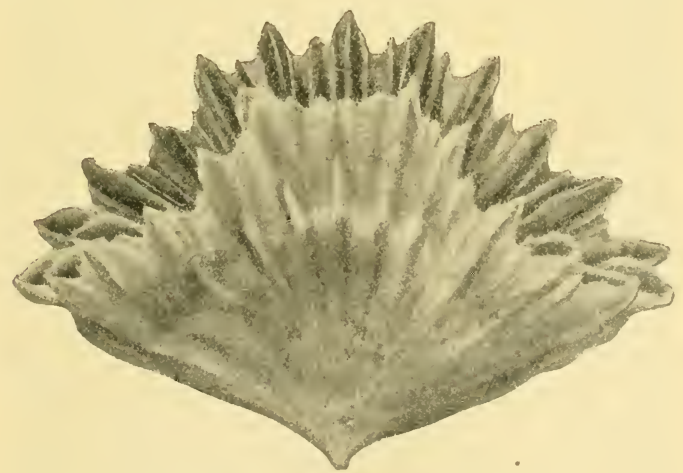

FIG. 382 .

Flabellum sp. " Michael Sars," I9I0, Station Ior, 1853 metres.

Besides these specifically Atlantic forms, the fauna on the southern slope of the ridges and plateaus comprises others familiar to us from the boreal region of the Norwegian Sea, and from the North Sea, where they occur either on the plateaus or in the deeper parts of the fjords, including :- 
Sea-slugs: Stichopus tremulus, Bathyplotes tizardi, and Cucumaria hispida. Starfishes: Psilaster andromeda, Astrogonium pareli, Pteraster multipes, Peltaster nidarosiensis, Brisinga coronata and B. endecacnemos.

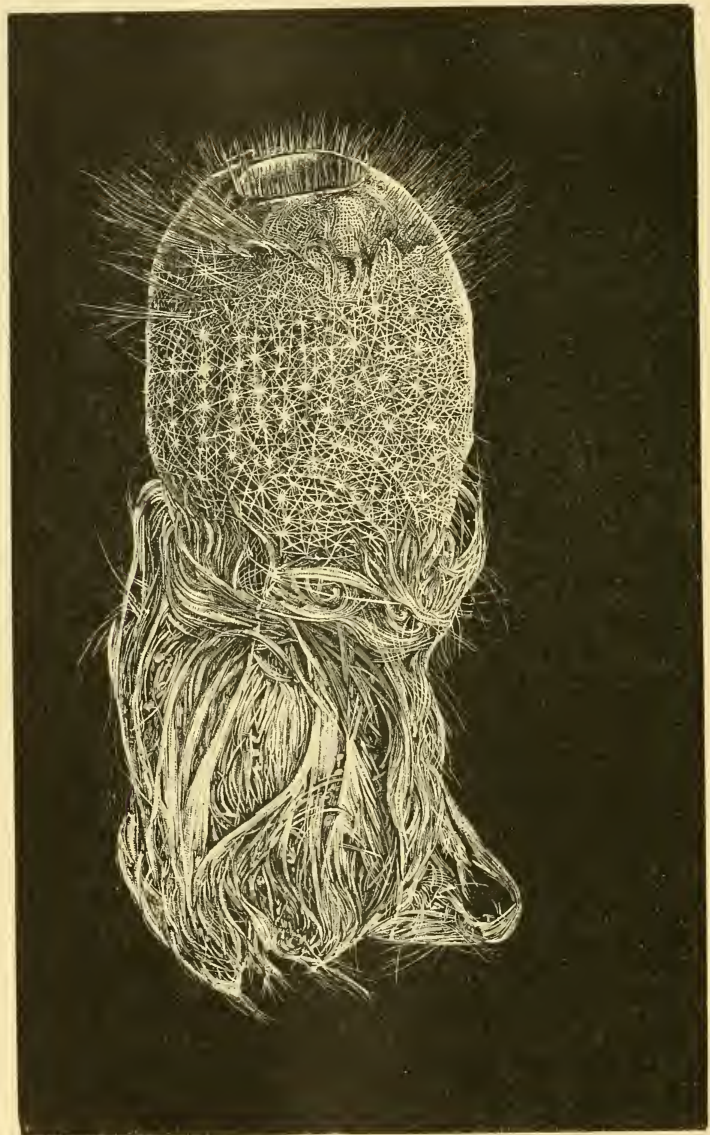

Fig. 383 .

Pheronema carpenteri, Wy. Thoms. Reduced. (After Wyville Thomson.)

Brittle-stars: Ophiacantha abyssicola, Ophiactis abyssicola, Ophiocten sericeum, Asteronyx loveni (on Funiculina quadrangularis), Gorgonocephalus lincki. Sea-mice: Spatangus raschi, Schizaster fragilis. Sealily : Rhizocrinus lofotensis. Crustaceans: Munida tenuimana, Pasiphaa 
tarda, Pontophilus norvegicus, Pagurus pubescens, Calocaris macandrea, Geryon tridens. Worms: Aphrodite aculeata, Latmonice filicornis, Lumbrinereis fragilis. Brachiopod: Waldheimia septata (in large quantities).

This list also might easily be extended. We see, therefore, that the fauna in the continental (archibenthal) deep - sea area of the Northern Atlantic consists partly of species peculiar to it, and partly of others that regularly belong to the continental deep-sea fauna of the Norwegian Sea. Two questions arise: How is the Atlantic archibenthal (and abyssal) fauna distributed outside the Nor-

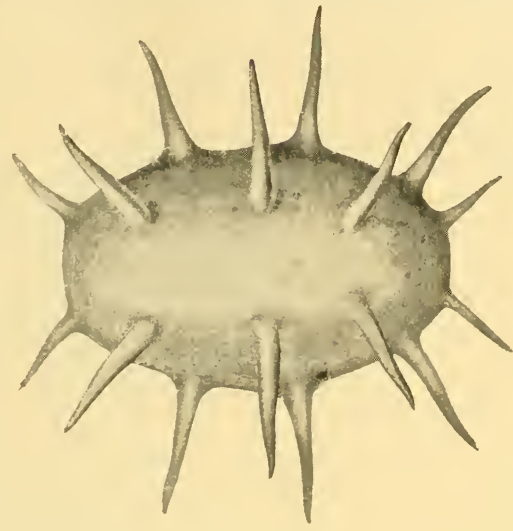

FIG. 384 .

Deima fastosum, Théel. "Michael Sars," I9 10, Station 48. wegian Sea? Is there any real resemblance between this fauna

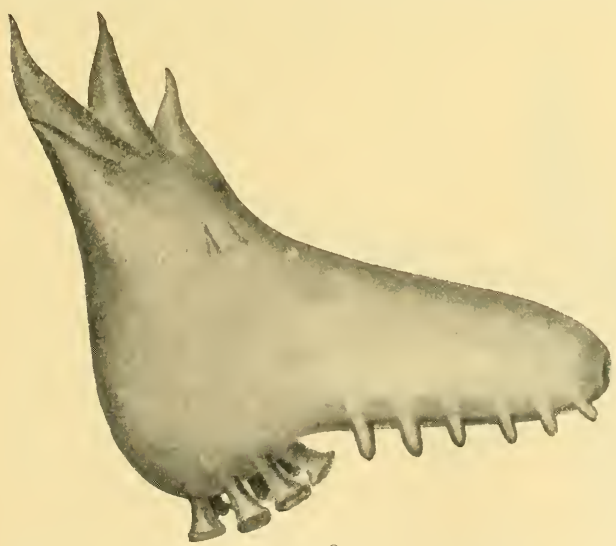

FiG. 385 .

Peniagone wyvillii, Théel. " Michael Sars," 1910, Station 53 , 2615 to 2865 metres. and its counterpart in the cold area of the Norwegian Sea?

There seem to Limits of the be some reasons for archibenthal fixing the lower limit of the archibenthal fauna at about 2000 metres, and the upper limit at about 800 or I 000 metres. The charts of the area south of the ridges published by the Danish "Ingolf" Expedition show that beyond 2000 metres the slope of the bottom becomes less steep downwards to the vast abyssal plain whose upper limit may be put some- 
CHAP.

where between 2000 and 3000 metres; the temperature at the same time falls to about $2 \frac{1}{2}^{\circ} \mathrm{C}$., which prevails everywhere in

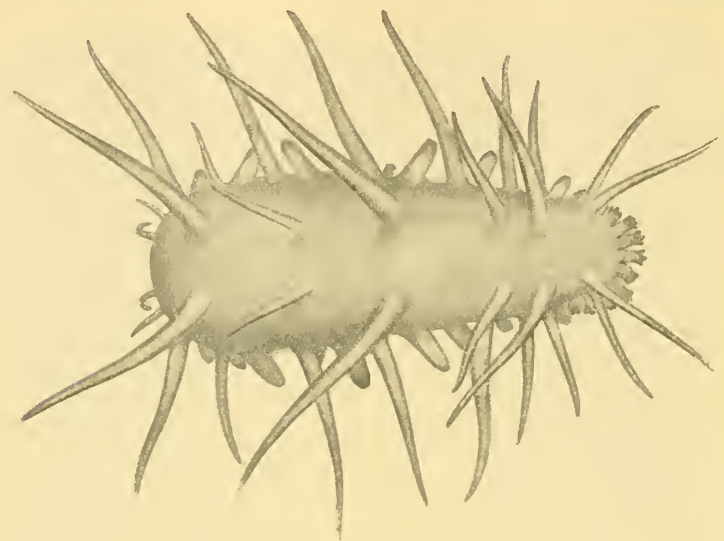

FIG. 386 .

Oneirophanta sp. " "Michael Sars," I910, Station 10, 4700 metres.

the abyssal tracts of the Atlantic and other non-arctic waters. The upper limit certainly presents greater difficulties, but I

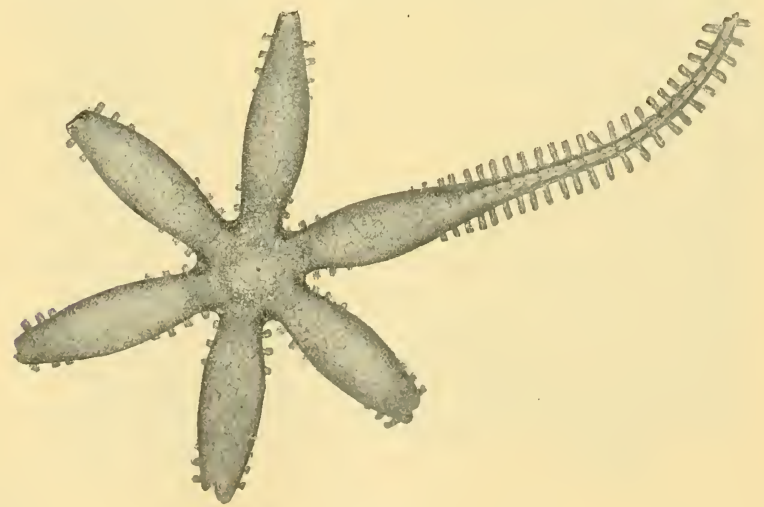

FIG. 387 .

Freyella sexradiata, Perrier. " Michael Sars," I9ro, Station ro, 4700 metres.

believe that a great many of the forms which characterise the archibenthal belt do not as a rule extend into depths less than 
800 metres, though it is quite possible that certain forms may be met with at 600 metres. We have not yet acquired sufficient knowledge of the factors regulating vertical distribution to be able to divide the different parts of the Atlantic into vertical zones, and a division of this kind will, I fancy, always be more or less a matter of personal opinion. Besides, it is undeniable that forms which properly belong to the abyssal fauna may find their way to the lower parts of the archibenthal zone, and that

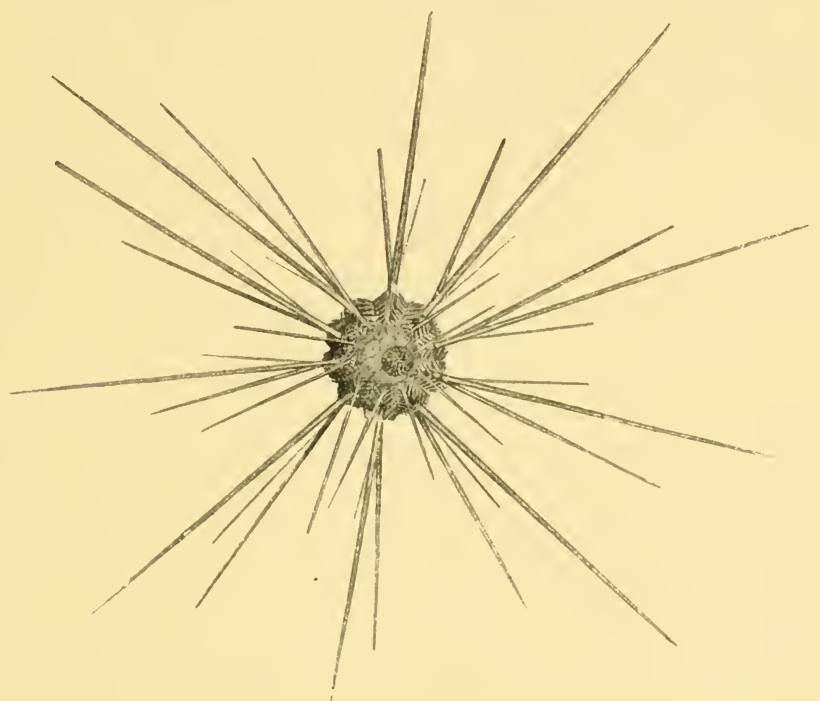

FIG. 388 .

Salenia hastigera, Agassiz. Reduced. "'Michael Sars," I910, Station 88, 3 I 20 metres.

archibenthal forms may go down into the abyssal region, while, given favourable conditions, certain littoral and sub-littoral forms may descend below the upper limits of the archibenthal belt. In any case there is no clearly defined boundary between archibenthal and abyssal areas.

Real abyssal forms are, for instance, the following: Deima Abyssal forms. fastosum (see Fig. 384), Peniagone wyvillii (see Fig. 385), Oneirophanta sp. (see Fig. 386), Freyella sexradiata (see Fig. 387), and Salenia hastigera (see Fig. 388), the last mentioned being found, however, also in the archibenthal zone.

I have already stated, with regard to the horizontal dis- 
CHAP.

Archibenthal abyssal fauna of the North Atlantic.

tribution of the Atlantic deep-sea ${ }^{1}$ fauna, that some of the forms occur likewise in the deeper parts of the boreal areas of the Norwegian Sea. This, however, refers only to a small proportion, since the majority consist of specifically Atlantic forms which do not cross the boundaries of the Norwegian Sea. As to the distribution of this specifically Atlantic fauna opinions differ. One very prevalent view is that, throughout the North Atlantic at any rate, temperatures, salinities, and other external physical conditions are extremely uniform, and that consequently the various forms have a correspondingly extensive distribution. Certain facts seem to me to contradict this, for instance, in such well-known groups as the echinoderms and decapod crustaceans, of which there are numbers of species. Mortensen's work on the North Atlantic echinids, and Koehler's description of the material collected by the Prince of Monaco. show that the West African coastal seas shelter 28 species of echinids, and that immediately to the south of the ridges 2 I species of the same group have been trawled by the "Ingolf" and "Michael Sars." In all these two areas yielded $39^{2}$ species, but not more than Io of them are common to both.

We find much the same position of affairs when we compare the deep-sea fauna of the European or African Atlantic side with its counterpart on the West Atlantic (American) side. ${ }^{3} \quad$ Merely taking the echinids, which may be regarded as specifically belonging to the archibenthal-abyssal fauna on both sides, there are altogether 74 species, but only 24 of them are common to both areas. The other groups of echinoderms have not yet been so carefully studied, but we know enough to show that in their case, too, a similar difference exists between these archibenthal-abyssal areas of the Northern Atlantic.

If we take decapod crustaceans the result is still the same. The northernmost portion of the European Atlantic area immediately south of the ridges has been examined by Danish and Norwegian expeditions at many stations, and I 5 archibenthal-abyssal species of Brachyura and Anomura have been discovered at depths of 1000 to 2000 metres, while the researches of the Prince of Monaco, and the "Travailleur " and "Talisman" Expeditions, have resulted in 40 species being found at the same depths in West African Atlantic waters;

1 I wish to make it clear that in what follows no distinction will be made between the archibenthal and abyssal faunas, unless expressly stated, but would merely remark that the bulk of the species belong to the archibenthal zone.

${ }_{2}^{2}$ I have omitted one or two species that have a very extensive bathymetrical distribution, inasmuch as they occur also in the littoral and sub-littoral zones of the coastal areas.

${ }^{3}$ No account has here been taken of pelagic deep-water forms. 
there are altogether 45 species in the two areas, Io of which are common to both. A comparison between the West Atlantic (American) and the East Atlantic (European-African) deep-sea crustaceans shows an equally small number of common forms.

These instances show that, in spite of temperatures and salinities appearing identical in widely separated localities, it is possible to distinguish between the faunal communities of the deeper tracts of the ocean, and we perceive accordingly that temperature and salinity are not the only factors which regulate the distribution of species. Unquestionably there are other physical conditions which are of considerable importance, and it must further be remembered that biological factors, such as competition between species, exert a decided influence. ${ }^{1}$

Murray showed in 1895 that the results of the "Challenger" Expedition afforded no confirmation of the opinion that a universal deep-sea fauna was spread all over the floor of the ocean; he compares the catches at six deep-water stations scattered over the Atlantic, Pacific, and Southern Oceans, the total number of species recorded being 290, but not a single species was common to the six stations. ${ }^{2}$ At the same time we must remember that whole groups of forms, showing common characteristics in bodily structure, and belonging to types quite distinct from the littoral ones, belong either entirely or principally to the deep sea. These types are as a rule very extensively distributed, even if their species and genera may be limited to more circumscribed areas. Among fishes, for instance, we have the Macrurus-type, which is to be found in all the greater depths of the oceans of the world, although particular species have a comparatively limited distribution. The big group of holothurians known as Elasipoda is a particular type, separated in all essentials from the littoral and sub-littoral forms of holothurians. They belong almost entirely to the archibenthal and abyssal tracts of the different oceans, and are often abundant enough to give a distinct character to the deep-sea fauna. The same is true also of the Echinothuridæ, though in their case there are littoral and sub-littoral species; some species, however, have a comparatively limited distribution. Among crinoids we find survivals from remote ages of the earth, namely, the stalked genera (Rhizocrimus, Bathycrinus, Pentacrinus, etc.), as typical inhabitants of widely

3 I must, however, point out that in all probability some faunal groups show a greater uniformity in widely separated localities than others.

2 See Summary of Results Chall. Exp., p. $143^{8}$. 
separated areas of the deep sea. And so, too, we could mention deep-water types of particular structure in the case of most of the invertebrate classes.

Now as these types are distributed over a large portion of the great oceans, and occur there sufficiently generally to give the deep-sea fauna its character, it is fair to assert that this fauna is more uniform than the fauna of the littoral and sub-littoral zones. As is well known, we get great differences in the physical conditions of the different areas of both littoral and sub-littoral zones, consequently we find there greater variations of the fauna than in the deep sea, where physical conditions are uniform, or, in other words, there are more coastal faunal areas than there are deep-sea faunal areas.

We may briefly characterise the deep-sea fauna as follows: It is largely composed of groups of forms, which morphologically differ in many essentials from the types of the littoral fauna. These groups are distributed over very extensive tracts of the deep sea, but the different species (genera, families) within the groups may be limited to more circumscribed areas. It is evident, therefore, that we can distinguish between the various faunal areas of the deep sea, though we may not yet be able to fix their boundaries. ${ }^{1}$

Deep-sea fauna of the North Atlantic compared with that of the Norwegian Sea.

The second question is how far the deep-sea fauna of the Atlantic resembles that of the Norwegian Sea, or in other words whether the Atlantic area with its higher bottomtemperatures shares many species with the "cold area" of the Norwegian Sea. As indicated on p. I3, Murray in 1886 summarised the results obtained in the Faroe Channel by the "Lightning," "Porcupine," "Knight Errant," and "Triton " Expeditions, and showed that of 385 species recorded from the "warm" and "cold" areas, only 48 species (or I $2 \frac{1}{2}$ per cent) were common to both areas. ${ }^{2}$

The Lycods are especially characteristic of the cold area of the Norwegian Sea, whereas the Macrurids are typical of the deeper parts of the Atlantic, and Jungersen has drawn attention to the abundant horn-corals and joint-corals (Gorgonids and Isids) as well as the "star-corals" (Oculina, Amphihelia) and other corals of the Atlantic deep water, none of which occur in the Norwegian Sea deep basin.

The finding of such differences in the general character of

\footnotetext{
${ }^{1}$ In regard to the boundaries, however, the cold area of the Norwegian Sea forms an exception, and the same may possibly be true of the Antarctic deep sea (Chun, Aus der Tiefe des Weltmeeres; Mortensen, Echinoidea of the "Ingolf" Expedition).

2 See also Murray and Tizard, Proc. Roy. Soc. Edin., vol. xi. p. 638, 1882.
} 
the two faunas led to a closer examination of certain forms which had formerly been looked upon as common to both areas, and as a result the Danish zoologist Jensen came to the conclusion that not a single species of Lycodes belonging to the cold area occurs in either the Atlantic or the boreal parts of the Norwegian Sea. He further succeeded in showing that one of the most characteristic mussels of the cold area, formerly designated Pecten fragilis and included as such among the fauna of the Northern Atlantic, is in reality a form peculiar to the cold area of the Norwegian Sea, and he has accordingly named it Pecten frigidus. Other naturalists have made similar discoveries in the case of a number of other forms. Thus, the irregular sea-urchin of the Norwegian Sea, Pourtalesia jeffreysi, is quite distinct from the Atlantic forms of the same genus. The characteristic starfish of the Norwegian Sea, Bathybiaster vexillifer, was formerly said to be distributed throughout the Atlantic, but it is now known to be different from the Atlantic form, which is Bathybiaster robustus. Another starfish, Pontaster tenuispinus, is represented by different varieties in the two areas, and the same is true of the ophiurid Ophiocten sericeum. The one characteristic pennatulid of the Norwegian Sea, Umbellula encrimus, is not found outside that sea, though there is a species closely related to it in the Atlantic, namely, Umbellula lindahli. Further evidence of the difference in the two areas is supplied by a pycnogonid belonging to the genus Colossendeis. A form in the Norwegian Sea deep basin, Colossendeis angusta, is said to occur also in the Northern Atlantic, but if we compare Atlantic and Norwegian Sea specimens we immediately recognise considerable differences in their structure, the latter being much more robust and furnished with shorter legs and claws. Any one seeing the two forms side by side would be able to tell the respective areas from which they came, though it may be difficult to find sufficient dissimilarities to designate them separate species.

These are merely a few instances. It must be admitted that nothing like a complete comparison of the species has yet been made, but we know enough to justify us in looking upon the cold area of the Norwegian Sea as a distinct deep-sea faunal Cold area of the Norwegian Sea an arcticabyssal area. region, which with Mortensen and Jungersen we may term the arctic abyssal. ${ }^{1}$ No doubt, this arctic-abyssal region owes its

1 In my description of the fauna in the cold area on pp. 517-524, I have made a distinction between the continental slopes and the abyssal region below 2000 metres, but no such distinction has been made here, for in instituting a comparison between the fauna of the cold area and the fauna of the Atlantic, I have included everything below 800 metres. 
distinctive character chiefly to the low temperature of its bottom water, and to its isolated position due to the submarine ridges, which are responsible for the low temperature.

Formerly homogeneous fauna in the deep water of the

Norwegian Sea and North Atlantic.
Origin of the present-day fauna of the Norwegian Sea.
Though the cold area of the Norwegian Sea must be regarded on these grounds as a separate faunal region, it undoubtedly had formerly more direct connection with the deep water of the Atlantic. The many closely allied species in both areas point to a common origin. Most probably the fauna was at one time homogeneous in both areas, and the bottom water of the Norwegian Sea had then the same temperature as we . find in the Atlantic nowadays. When physical conditions changed in the Norwegian Sea, either owing to the formation of the submarine ridges or from other causes, the fauna responded in two ways. Some of the warm water forms, including a number of present Atlantic forms, died out, while others were able to adapt themselves to the altered physical conditions and survived. Their adaptation, however, led to morphological alterations in the species, and in some cases these alterations were considerable enough to produce distinct species differing from the primitive Atlantic forms. Naturally, the isolation brought about by the submarine ridges had much to do with the development and establishment of their characteristics. In fact, it seems like an experiment carried out by nature herself on a large scale, and shows that external conditions can probably alter the bodily structure of a species, and consequently give rise to the formation of new species and varieties.

To understand properly the composition of the fauna in the Norwegian Sea at the present time we must go back to the Glacial Age, when uniform arctic conditions prevailed, and the fauna was everywhere arctic. This is confirmed by the marine deposits of the Glacial Age, containing exclusively arctic animal forms, met with in what are now boreal areas. When subsequently the ice melted, and the climate became milder, southern forms were able to immigrate, gradually distributing themselves throughout the boreal (and boreo-arctic) waters.

The question as to what happened to the arctic fauna of the Glacial Age admits of a thoroughly satisfactory answer. In areas which at the present day are arctic, we still find arctic species, but in boreal areas the changes have been great. Some of the arctic forms which formerly inhabited what are now boreal areas have gradually died out from failure to adapt themselves to the new conditions; their remains may 
be seen in glacial deposits, though they no longer live in the neighbourhood. Considerable numbers of the arctic species have succeeded in adapting themselves to the altered conditions, and constitute at the present day a regular portion of the boreal fauna, being at the same time distributed throughout the arctic region; these are the arctic-boreal forms.

The present-day fauna of the Norwegian Sea thus consists of two elements of different origin: (I) an endemic arctic element, and (2) a southern element derived from the littoral, sub-littoral, and the deeper parts of the Atlantic and Mediterranean. Thus we may divide the present-day fauna into groups, as follows :-

(I) One group consists of two categories of endemic arctic forms, viz. the purely arctic species, and the arctic-boreal species widely distributed throughout both arctic and boreal waters. Both categories existed everywhere in the Norwegian Sea throughout the Glacial Age, but only species of the last-named category have since been able to adapt themselves to the boreal areas. These species, therefore, in contradistinction to the remaining boreal forms, are of genuine arctic descent ; that is to say, when a species occurs normally in both arctic and boreal areas, it is as a rule arctic in its origin.

The purely arctic species are not generally limited to the arctic region of the Norwegian Sea, but are usually widely distributed over the other arctic seas as well. Very frequently they inhabit all the areas round the pole (European, Asiatic, and American), and are in that case designated circumpolar species. The arctic-boreal species have precisely the same arctic distribution, but within the boreal region their southern boundaries have strict limitations; the bulk of them on the European side never leave the Norwegian Sea, being absent from the coast banks south of the British Islands and deeper parts of the Atlantic, ${ }^{1}$ owing to the physical differences of the sea-water. A great many of the arctic-boreal forms, in boreal areas at any rate, inhabit the littoral or sub-littoral zone along the coasts and in the North Sea, and it is precisely in these zones to the south of the English Channel that the hydrographical conditions (and especially the temperature) differ

1 There are, however, a few exceptions to this rule in the case of archibenthal and abyssal forms, some arctic-boreal deep-water species being distributed throughout the northern Atlantic as far as the Azores, including among others the echinoderms Cribrella sangzinolenta, Pontaster tenuispinus var., and Ophiacantha bidentata. An explanation may perhaps be found in the fact that the temperatures in the deeper boreal areas of the Norwegian Sea and Atlantic are fairly alike and uniform. 
CHAP.

most from those of the Norwegian Sea. It seems, then, that the arctic-boreal species have not been able to adapt themselves to such conditions, or in other words that their power of adaptation is limited.

Outside the Norwegian Sea the species of this group have another area of distribution on the western side of the Atlantic, north of Cape Cod. The cold polar current sweeps down over the shallow parts of the American coast, and produces conditions that vary from arctic to boreo-arctic. As a result we find there arctic species, such as normally occur in the boreo-arctic areas of the Norwegian Sea and similar waters, and also the majority of the arctic-boreal species of the Norwegian Sea, a few of the latter being found as well a little to the south of Cape Cod, where conditions are more boreal.

(2) The second group consists of the boreal species, that is to say, those species which are limited to boreal areas within the Norwegian Sea, and those which are able to penetrate as well into boreo-arctic areas, though not into arctic tracts. Most of them are widely distributed over the northern Atlantic, either in its littoral and sub-littoral or in its deeper zones. We find their southern limit accordingly in the Mediterranean or at the Azores and the Canary Islands, while the deep-sea forms also go a long way south on the American side. Very few of the shallow-water forms, however, which extend southwards along the coasts of Europe are to be met with on the American side of the Atlantic, either because they cannot pass across the profound depths separating the two continents, or because they are debarred from advancing over the shallow northern parts of the Atlantic by the arctic conditions prevailing there. No satisfactory explanation can, therefore, be given for the presence of the very few boreal shallow-water forms which are common to both sides.

I have already stated that most of the species of this group have migrated into the Norwegian Sea in post-glacial times, and their present distribution is evidence of this ; but there are some species nowadays confined on the eastern side to the boreal and boreo-arctic areas of the Norwegian Sea, and on the western side occurring to the north, and in some cases also a little to the south, of Cape Cod. As to their origin it is difficult to form an opinion, but most probably a number of them have been developed from arctic species after the ice-period came to an end, and have adapted themselves to their boreal 
environment without any considerable changes in their bodily structure, as for example the decapod crustaceans Hippolyte securifrons (boreal)-Hippolyte spimus (arctic), Sabinea sarsi (boreal)-Sabinea septemcarinata (arctic). These forms are so alike that I cannot help thinking they must have had some phylogenetic connection in a geologically not very remote past. Other forms of the same category have no near relations in the arctic region, and cannot, therefore, be of arctic origin. That these species lived in the Norwegian Sea in late glacial times, when more boreo-arctic conditions prevailed, seems evident from their normal distribution nowadays in boreo-arctic areas, but it is impossible to decide whether they migrated into the Norwegian Sea from the American or the European side, or are derived possibly from southern species which have become morphologically so altered in their new home that the specific differences are unmistakable.

There are other species in the Norwegian Sea which, so far as is known, are strictly confined to the boreal and boreoarctic areas, extending neither southwards nor to the coasts of North America in the west. They are, however, not very numerous. Like the forms just mentioned they could not have lived in the Norwegian Sea during the Glacial Age, and have probably originated there in post-glacial times, through development from southern immigrants that have been morphologically altered by adaptation to their environment. Several of them are closely allied to species known outside the Norwegian Sea. In some cases there would seem to have been a variation from the immigrated species, and we find inhabiting the Norwegian Sea both the primitive form and its descendant, like the crustaceans Pagumis chiroacanthus (a purely boreal endemic species)_Pagumus lavis (immigrated primitive form), Cheraphilus (purely boreal endemic)-Crangon or Pontophilus (immigrated primitive form), Virbins fasciger (purely boreal endemic) - Virbius varians (immigrated primitive form). We may take it for granted, in view of what we know nowadays regarding the larger invertebrate forms, that the majority of these species have not a widespread distribution either southwards or westwards, and this might give grounds for believing that they had immigrated in their present form.

I have already mentioned that the littoral and sub-littoral faunas differ greatly in different areas of the Atlantic, and we find similar differences when we compare the Atlantic and

Distributional areas. 
Norwegian Sea. Certainly, many species are common to both, but there are far more peculiar species, the difference becoming more pronounced the farther south we go. The British Isles and the English Channel, the shallow-water fauna of which has been thoroughly studied, may be taken as the boundary where the northern and southern forms meet, both categories having reached their respective southern and northern limits of distribution. Along the British coasts and the Channel we get, accordingly, a kind of coalition territory, which has often been considered a separate faunal "province," and has actually been termed Lusitanian, though in my opinion without sufficient justification. The shallow-water faunas of Iceland and the Faroe Islands are so little known that it is impossible to say whether they are coalition territories or not. We must remember that it is much more difficult for shallowwater forms to find access to insulated areas like these, cut off as they are by profound depths and special conditions of temperature, than to the British coasts.

It is now admitted that faunal resemblances and dissimilarities between different marine areas are chiefly due to the physical conditions of the sea-water, but we must not regard them as the sole factors that regulate distribution. Two marine areas may have similar physical conditions and yet differ greatly faunistically. The Northern Pacific and Northern Atlantic have in many cases similar hydrographical conditions, but their faunas are on the whole quite distinct. There are other factors at work, and isolation probably does more than anything else to cause faunal differences. Two areas may be isolated from each other owing to the topographical character of the bottom, or because the physical properties of the water prevent any faunal connection, and consequently their faunas develop in different directions. Temperature is another of the chief physical conditions affecting distribution, and this explains why the British coasts, the Mediterranean, the Azores, and the Canary Islands, not to mention tropical coastal areas, shelter many forms which do not occur in the Norwegian Sea, although there do not seem to be any obstacles of a topographical character in the long connected coast of western and northern Europe.

We often see the limit of the arctic fauna in the Norwegian Sea put at about lat. $67^{\circ} \mathrm{N}$., it being apparently forgotten that, owing to the hydrographical conditions, a large arctic area (part of the arctic-abyssal) extends as far south as lat. $60^{\circ} \mathrm{N}$., 
while a purely boreal area (the deeper parts of the plateaus) extends to lat. 7 I $^{\circ} \mathrm{N}$. How little latitude affects faunal marine areas is evident when we compare the conditions on either side of the northern Atlantic, for on the American side the southern limit of the arctic shallow-water area lies about lat. $42^{\circ} \mathrm{N}$., whereas on the European side it lies about lat. $67^{\circ} \mathrm{N}$.

It has already been mentioned that intervening areas of a different hydrographical character can always prevent connection between two marine areas. The northernmost parts of the Pacific and Atlantic are arctic, and so also is the sea between them lying to the north of America. As a result the arctic faunas of the two areas have an uninterrupted connection and resemble each other. It is otherwise with the temperate parts of these oceans, for their boreal forms are isolated by the arctic tracts which intervene, though they share a few boreal species like Crangon vulgaris, as well as some others that are too closely allied for any one to doubt that they have formerly been identical. This probably arises from hydrographical changes in what are now arctic areas, which caused an isolation of specimens belonging to the same species in both areas, for there are indications that higher temperatures prevailed during post-glacial times in the coast-waters of some of these arctic tracts, and we may assume that the boreal species now occurring normally in boreoarctic areas could exist then in what have since become purely arctic waters, and that by way of the shores of Canada and Alaska they had uninterrupted connection from ocean to ocean. When subsequently arctic conditions set in, the individuals of these boreal boreo-arctic species were compelled to retire southwards either to the Atlantic or to the Pacific, and all connection between them ceased. There is, of course, the possibility that these species lived as long ago as the tertiary age-in which case their present distribution can be easily explained-for tertiary fossils make it perfectly certain that a warm climate existed at that time in these latitudes.

The theory of a warmer post-glacial period is based upon the sub-fossil boreal molluscs found in certain arctic areas, like those from the south-west coast of Greenland described by Adolf Jensen, comprising shells of present-day boreal species no longer found there (Anomia eplippium, Cyprina islandica, Zirphae crispata). In the Gulf of St. Lawrence, too, where conditions are nowadays arctic or boreo-arctic, we get quantities of empty mussel-shells belonging to undoubtedly southern forms. In the purely arctic waters of Spitsbergen there are sub-fossil

Warm climate in post-glacial period. 
shells of Mytilus edulis, Littorina littorea, and Cyprina islandica, all boreal forms requiring a higher temperature and not living there now. Again, in northern boreal areas there are subfossil deposits of molluscs which require greater warmth than generally prevails in the boreal region (Tapes decussatus in Denmark, Isocardia cor in Norway, etc.), and it is held in some quarters that they could only have existed there when the temperature of the sea was higher.

Without criticising this theory, I should like to point out that we ought not always to take these finds of sub-fossil shells, belonging to species no longer inhabiting the adjoining seas, as evidence that great hydrographical changes have necessarily taken place in these areas. Tapes decussatus, for instance, which is now quite extinct along the coast of Denmark, is still ta be found at various places along the west coast of Norway, from Bergen down to the south coast, but only in restricted localities where there are special natural conditions, that is to say, in shallow, well-sheltered, sandy bays, dry at low water, but affording full access to the salt water of the sea. These bays differ greatly from the "pools," which have a layer of fresh water at the surface and a muddy bottom smelling unpleasantly of sulphuretted hydrogen, but one feature they do possess in common, namely, that the sun raises their temperature considerably above the normal, so much so, in fact, that I have sometimes recorded $23^{\circ}$ or $24^{\circ} \mathrm{C}$. in the shallow water of these "Tapes bays" during the summer. Beyond question this high summer temperature, in combination with favourable bottom-conditions and the salt water, enables Tapes decussatus to thrive, and, what is still more important, to reproduce itself. It is not difficult to imagine that these rather limited localities may have been silted up, or cut off from the inflowing of salt water in some way or other, thus giving rise to sub-fossil deposits of Tapes shells. Nevertheless, in the case of boreal forms found fossil or sub-fossil in arctic areas, it seems to me that the warmer seawater theory is the only reasonable one, since there is nothing to indicate that other important factors have been instrumental in their extinction.

Effect of changes of temperature upon animal life.
It is important to ascertain how changes of temperature affect a species, whether they influence chiefly the development and growth of the young stages or the full-grown animals through other physiological processes. This question has not been deeply studied, though we have acquired sufficient knowledge to enable us to draw one or two conclusions. We know, for 
instance, that a high temperature is required for the development of the oyster larva, and that along the Scandinavian coast it is only in the so-called pools that reproduction on any large scale takes place. Most probably the same is the case with many other inhabitants of the pools. The eggs and larvæ of the lobster are only developed during the warmest part of the year, though the female often carries spawn in winter, and it has been found by experiment that a fall of a few degrees in temperature is sufficient to retard the development of the larvæ several weeks. We can understand, therefore, why these forms do not live in arctic or boreo-arctic areas. Even though the fertile eggs or larvæ of boreal forms do not demand a higher temperature for their development, additional warmth may nevertheless be absolutely essential for the production and development of the ova within the mother's body. This, again, limits the distribution of many forms. The converse naturally holds good, and the development and other physiological processes of forms living exclusively in arctic waters can only take place at a low temperature.

We have already seen that many species are common to both boreal and purely arctic areas, and we must ascribe their widespread distribution to their power of adapting themselves to very different temperatures. Most likely we are dealing here with physiologically distinct species, even though the differences do not appear in corresponding morphological alterations in bodily structure. Not that differences of this latter kind are by any means excluded, as I have previously shown how a species may vary morphologically in certain directions, according as it occurs in arctic or boreal tracts. Future researches regarding the time when reproduction begins in these widespread forms in the respective areas will possibly show that the temperature at which development takes place varies a good deal less than the temperature prevailing in the different areas seems to indicate. For forms which live in boreal deep water, where the temperature is comparatively low all the year round, the difference is in any case not particularly great, and if it should prove that the widespread shallowwater forms develop during the winter in boreal areas, the difference there again is relatively small. Now we find that two of our typical littoral animals, the sea-slug Cucumaria frondosa and the starfish Echinaster (Cribrella) sanguinolentus, both of which inhabit arctic tracts, deposit their eggs in boreal waters early in March when the upper water-layers have a low 
temperature. Experiments have taught us that the eggs of Cucumaria, which float near the surface, are so much affected by the surface-temperature of the coast-water in summer, that they are destroyed before a single larva is hatched, and it follows that the existence of this form in the littoral zone of the boreal region depends upon its period of reproduction being in the coldest months of the year; this is probably true also of Echinaster. Again, in the case of another arctic-boreal species, Hippolyte gaimardi, which along the west coast of Norway lives only in the littoral zone, the eggs develop during the cold months of the year, and the young are hatched in April. On the other hand, the lobster and the oyster, which are typical boreal forms inhabiting the littoral zone, have their period of reproduction in the months between June and August. ${ }^{1}$ It must be admitted, however, that too few researches have been made upon which to base any general conclusions, and that the conditions in arctic tracts are quite unknown. ${ }^{2}$

Eurythermal forms.

Little is known as yet regarding the power of withstanding variations of temperature in different species, though most of the littoral animals, which are eurythermal and exposed to extreme variations, are astonishingly hardy. The Swedish zoologist Aurivillius has found, from observations made on the coast of Bohuslän in Sweden, that the barnacle (Balanus balanoides), the periwinkle (Littorina littorea), the sandgaper $(M y a)$, the cockle (Cardium), and the lugworm (Arenicola) are able to endure for a considerable period a temperature below freezing point, and that the barnacle after being quite a long time in the ice had actually got vigorous young. ${ }^{3}$ Other littoral forms can protect themselves by descending into deeper water or by burrowing downwards into the mud. Still we cannot expect every species to be equally hardy, and wholesale destruction sometimes takes place under specially unfavourable circumstances, as, for instance, when the ice lasts too long or when the bottom freezes to too great a depth. That many of our littoral animals are able to live in boreo-arctic areas at a

1 The German naturalists Samter and Weltner have published an interesting account of several arctic survival forms in North German lakes, illustrating their mode of life and reproduction. One crustacean, Mysis relicta, lives during the summer in the depths of cold lakes, and migrates landwards during autumn and winter, reproduction chiefly taking place at a temperature of $3^{\circ} \mathrm{C}$. With another crustacean survival-form, Pontoporeia affinis, also, reproduction takes place in winter at temperatures varying between $0^{\circ}$ and $7^{\circ} \mathrm{C}$.

2 It will be interesting to find out whether the boreal forms which penetrate into boreo-arctic areas with high temperatures for a short portion of the year have a short period of reproduction there, seeing that farther south their reproduction is known to extend over several months.

${ }^{3}$ Aurivillius, "Littoralfaunans förhillande vid tiden för hafvets isläggning," öfvers. Kgl. Vet. Akad. Förhandl., 1895. 
low temperature depends upon their finding the conditions necessary for reproduction, namely, higher temperatures during a portion of the year.

With regard to vertical distribution, it should be noted Stenothermal that the deeper a species lives the more uniform is the temperature to which it is exposed (stenothermal forms). This is true especially of the boreal areas, whereas in arctic tracts there is, as a rule, less difference between the temperatures in deep and in shallow water. It is not so much the depth as the temperature which regulates the distribution of animals. Another factor affecting distribution is salinity. Many forms, particularly the littoral ones, can stand a considerable variation of salinity (euryhaline species), while others are limited to water varying little in salinity (stenohaline species); the former includes those littoral forms which are as much at home among the skerries as far up the fjords or even in the mouths of the rivers, while the latter are only to be found off the coast or at considerable depths.

I have already tried to make it clear that no arrangement of vertical faunal zones applies to the whole of the Norwegian Sea. Forms which near the coast inhabit the littoral zone may be met with, normally apparently, out on the plateaus, in the sub-littoral zone, or perhaps in the deep-sea zone. Thus in the northern portion of the North Sea the trawl brought up from a depth of I80 to I90 metres Ophiothrix fragilis and large specimens of Eupagurus bernhardus-forms which are distinctly littoral along the Norwegian coast, and on the Faroe plateau we found these and a number of others at I Io metres. When we compare the North Atlantic with the Norwegian Sea we find still more striking differences, some of the species belonging to the Norwegian Sea occurring at far greater depths in the Atlantic. Now if we remember that the physical conditions in the medium in which a species lives are largely responsible for its vertical distribution, we may assume that in the littoral zone of the coastal waters and in the deeper parts of the Norwegian Sea and Atlantic there are at any rate certain identical conditions-temperature is most decidedly not one of them-which permit these species to live impartially in these areas. If it were merely a question of adaptation to quite different conditions, we might expect them to adapt themselves also to the deeper water-layers along the coasts.

Light is unquestionably one of the principal factors affecting Effect of light. vertical distribution. During the Atlantic Expedition of the 
"Michael Sars" in Igio tests were made at various depths, and it was found that the light was far stronger south of the Azores than in the northernmost portion of the Atlantic at corresponding depths. But whether light is in itself sufficient to explain the different vertical distribution of a species in different marine areas, or whether there are other contributing factors, are matters yet to be decided. So far the question has not been sufficiently studied.

Effect of currents.

The animals of the ocean-floor owe their distribution mainly to the agency of currents, since these serve to transport their pelagic larvæ, and perhaps also carry along full-grown bottomforms like the amphipods and most of the prawns, which creep almost as much as they swim. It is through transportation of larva that the Norwegian Sea acquired most of its southern forms, and to this day these forms are still being disseminated in similar fashion throughout its component parts. We must bear in mind that most bottom-animals are attached, or, if we except a few crustaceans, very limited in their locomotion, and that consequently distribution by direct migration is all but impossible. The distribution of larvæ is subject to physical laws, and is dependent on the occurrence of the adult animals, and on the hydrographical conditions that prevail. Larvæ of arctic forms which inhabit only polar areas will, as a rule, only be transported by polar currents, so that the bottom they will reach, when their development is completed, will lie within the arctic region. In the same way the species belonging to Gulf Stream areas will be retained in boreal waters.

In addition to the two main currents of the Norwegian Sea there are several others consisting of blended layers, such as mixtures of the Gulf Stream, polar water, coast water, North Sea water, and bank water in various combinations. Probably every one of these plays its own particular part in distributing the larvæ, and consequently the bottom-animals, but we do not yet know to what extent. It seems absolutely certain, in view of what we have learnt regarding pelagic animals, that the larvæ in an area bordering on two currents may be swept away by one or the other, and so conveyed to a strange area. This, I fancy, explains why a coast-form like our common sea-urchin, Echinus esculentus, may be exceptionally met with in deep water out in the North Sea and Atlantic, where it succeeds in existing as a somewhat different variety. The occurrence of the arctic amphipods, Epimeria loricata and Acanthozone 
cuspidata, far south in the Norwegian depression, is probably also due to the same cause, as they have most likely been carried there by one of these blended currents and have managed to adapt themselves to more boreal conditions. That larvæ may be transported in quantities to areas where they are unable to develop was proved during the autumn of 1903 , when the fjords near Bergen were found to be full of Actinotrochae (larvæ of Phoronis, a form related to the bryozoans, which occurs in the south parts of the North Sea and other southern waters), but in the following year repeated dredgings failed to reveal a single full-grown animal either there or anywhere else on the coast of Norway.

Currents also carry nourishment to the bottom-animals and sweep away the finer particles of mud and other soft substances, leaving, in sounds especially, nothing but the bare rock, or perhaps a slight covering of coarse sand and shells. This enables attached forms to thrive, since the current prevents their being buried, and at the same time supplies them with the nourishment they require.

It is strange that a few boreal forms are peculiar to the plateaus and do not enter the fjords, for the fjords and plateaus have most of their forms in common. Whether it is due to the fact that these peculiar forms develop at a time when the Atlantic water, in which they probably live during both their larval and full-grown stages, does not penetrate into the fjords, or whether the physical conditions of the fjords are in some way uncongenial, is unknown. Similarly we are unable to explain why a number of boreal forms, which are widely distributed elsewhere, avoid the North Sea and Skagerrack, or why some plateau-forms enter fjords north of Stat, like the Trondhjem fjord, but are absent from fjords farther south.

Distribution is of course very much affected by the character Effect of of the sea-floor, since whole groups of animals are limited by their bottomstructure or mode of living to some particular kind of bottom. No doubt there are forms which appear to be equally at home everywhere, but there are others again which are extremely exacting in their requirements. This is especially the case with burrowing forms, like the lancelet and numbers of mussels and worms, and as a result we find, when conditions are favourable, that extensive stretches of the bottom are occupied by one or more of these. Some forms like sponges and corals, belonging to groups most of whose members are attached and therefore confined to rocky bottom, have developed special organs in the 
way of root-like outgrowths, by means of which they adhere to soft bottom and can accordingly reside there normally. Plant-growths have much to do with the distribution of bottomanimals, providing foundations for attached forms; some few species appear to be associated solely with one particular kind of plant, whether it be eelgrass or laminaria or some other congenial alga.

A. A.

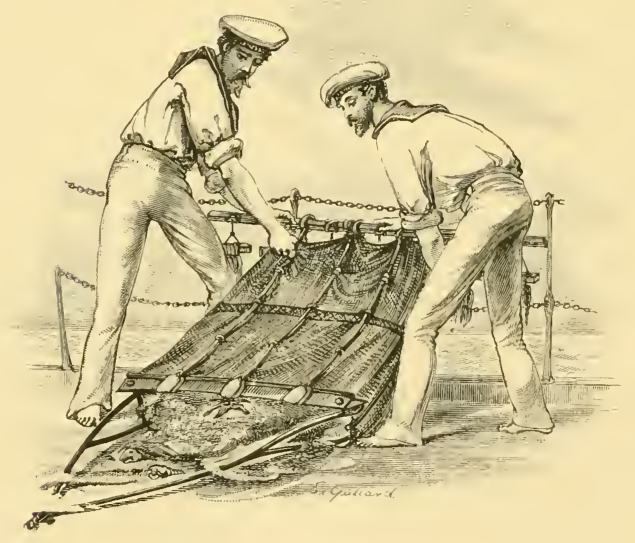




\section{CHAPTER IX}

PELAGIC ANIMAL LIFE

In the "Challenger" Summary, Sir John Murray writes as follows: "The tow-net experiments carried out on board the "Challenger" during several years in all parts of the world led me to the conviction that these intermediate regions were inhabited, although with a much less abundant fauna than the waters near the bottom or those near the surface of the ocean. Thousands of hauls of the tow-nets were taken in the surface and subsurface waters, and the contents were daily submitted to microscopic examination; the forms present in these waters became quite familiar to the naturalists. When, however, the tow-nets were sent down to deep water, and dragged in depths as nearly as possible of 500 , 1000 , and 2000 fathoms, organisms - such as the Tuscaroridæ among the Radiolaria-were nearly always observed in the gatherings in addition to the usual surface organisms. Organisms from these intermediate layers of water appear to have a much wider horizontal distribution than the surface fauna or flora. These oft-repeated experiments produced a strong belief that all the intermediate zones of depth were inhabited. I am not aware that the Tuscaroridx have ever been taken in the surface or sub-surface waters. It is probable that the animals in the intermediate zones of depth obtain their food by the capture of the dead organisms continually falling from surface to bottom. It is well known that the deposits at the bottom are in most regions chiefly made up of the dead shells and skeletons of surface organisms." 1

During the cruise of the Italian ship "Vettor Pisani," Captain G. Palumbo constructed a closing-net with which Lieutenant Gaëtano Chierchia collected animals from accurately determined depths. At the zoological station at Naples this work was continued by Eugen von Petersen and Professor Carl Chun.

1 Summary of Results Chall. Exp., p. 1455, I895. 
When Chun in 1898 fitted out the "Valdivia" Expedition, special arrangements were made for the purpose of obtaining an accurate knowledge of the animal life in "mid-water." Hundreds of hauls with closing-nets and with other large nets were taken at various depths, the material procured proving that the main conclusions drawn from the "Challenger" Expedition were quite correct. Even in hauls between 5000 and 4000 metres living crustaceans as well as larvæ of the same animals were captured-a sufficient proof that these organisms not only live but also breed at these depths.

The conception of a "pelagic" mode of life, originally associated with the animal-life of the ocean-surface, thus gradually proved to hold true for life in mid-water also, and to apply to floating or drifting organisms as well as free-swimming animals. The main characteristic of pelagic life is its independence of the bottom. The term "bottom-animals" is applied not only to the animals fixed to or creeping along the bottom, but also to those animals which, like certain crustaceans and bottom-fishes, swim and feed along the bottom. But it is impossible to draw a perfectly sharp limit between these migrating bottom-dwellers and some of the deep-living pelagic animals, which have been called "bathypelagic." In accordance with the varying conditions in deep and shallow water and in different parts of the ocean, the pelagic aninals have been subdivided into groups: thus Ernst Haeckel ${ }^{1}$ introduced the idea of "Holopelagic" (wholly pelagic) to distinguish those forms leading an entirely pelagic life from those forms having a bottom-stage like the Hydromedusæ, which he called "Meropelagic" (partly pelagic); he further distinguished those forms found only in coastal waters by the term "Neritic" from those found only in the open sea, which he called "Oceanic."

As in all geographical comparisons of animals we may divide the pelagic organisms into tropical, subtropical, boreal, arctic, and antarctic forms. It has also been proposed to arrange the pelagic fauna in certain bathymetrical zones, distinguishing between those forms living in profuse light, or in the region of twilight, or in the dark abyssal waters, but such distinctions are arbitrary, because our knowledge of the bathymetrical distribution of animals is limited, because the laws of distribution are imperfectly understood (for instance, the effects of light), and because the bathymetrical

1 Ernst Haeckel, Plankton-Studien, Jena, I8go. Haeckel used the words "holoplanktonic" and "meroplanktonic," but I prefer "holopelagic" and "meropelagic," as the word "plankton" is not so clearly defined, and is used in different ways (see Chapter X). 
occurrence of certain species is subject to great variation in different regions. We shall, therefore, dispense with the many Latin and Greek terms employed to define such groups of pelagic organisms, and simply use the term "bathypelagic" to denote those animals that live deep in the intermediate layers. Hensen proposed the term "plankton" to denote every kind of organism floating or drifting in the water, either shallow or deep, "dead or living," and Haeckel applied it so as to include all pelagic animal and plant life as a whole, in contrast to bottom-life as a whole, which he terms " benthos."

In this chapter I propose to consider only the different species or communities of pelagic animals, not the pelagic life as a whole. Pelagic forms occur in all classes of the animal kingdom from the unicellular Protozoa to the fishes; to mention them all would be to write a text-book on zoology. The chief aim of this book is however to give some of the general and special results of the cruises of the "Michael Sars." A discussion of the results relating to pelagic animals (as with the bottomfish) calls for some information about the principal forms, so I commence with a short review of pelagic animals. ${ }^{1}$ In the absence of descriptions of the animals, the illustrations will give the reader an idea of some of the forms referred to. Their geographical distribution, as known from previous expeditions, is briefly indicated, and in a later section I shall deal with the distribution of the most important animals in their communities in the different areas of the North Atlantic and the Norwegian Sea.

\section{Short Review of Pelagic Animals}

Among unicellular animals the Foraminifera and the Radiolaria may be given prominence. Being exceedingly rich in species, as well as individuals, they play an enormous part in the economy of the ocean, and their shells constitute an essential portion of the deposits on the ocean-floor.

The pelagic foraminifera have shells of carbonate of lime, usually Foraminifera. divided into several chambers communicating with each other, allowing the protoplasm to penetrate the whole shell, which is perforated by innumerable small apertures (foramina), through which the finest threads of the protoplasm (the pseudopodia) may pass. In Chapter IV. p. I72, a list is given of all the species known to be pelagic, and certain important forms are figured. The list embraces eight genera and twenty-six species, fourteen of which belong to the genus Globigerina, also represented by an enormous number of individuals. During the

1 A very useful review of the results of modern (especially German) investigations is given in Steuer's Planktonkunde (Leipzig and Berlin, I9IO), with extensive lists of literature. 
cruise of the "Challenger" Sir John Murray captured them from a boat in calm weather floating at the surface of the ocean, where they were just visible to the naked eye. On the ocean-floor in moderate depths in tropical and sub-tropical regions the dead shells occur in such enormous numbers that the deposit is called Globigerina ooze. The species and individuals decrease in number as we go north or south from the tropics, and in the Norwegian Sea only one species, viz. Globigerina bulloides (see Fig. II8, p. I 50), occurs in any abundance either at the surface or in the bottom deposits. ${ }^{1}$

Radiolaria. The Radiolaria occur in a profusion of species. The cell possesses a central capsule containing the nucleus or nuclei and an outer layer of protoplasm capable of throwing out very thin threads (pseudopodia). The skeleton is developed in various ways and facilitates the discrimination of an enormous number of sharply separated forms (see Figs. I IO to 117 in Chapter IV.). In his report on the "Challenger" Radiolaria, Haeckel described no less than 20 orders, 85 families, 739 genera, and 4318 species, taken partly from the deposits and partly in the townettings; in one single bottom sample from 4475 fathoms in the Pacific 338 species were found. The Radiolaria are wholly pelagic, and occur in all oceans where the salinity is not too low (as it is in the Baltic), over deep water as well as over shallow water, attaining their maximum development in the Pacific.

In order to discuss their distribution we may mention some of the typical groups :-

The Acantharia are mostly spherical ; the perforations of the central capsule are regular. The skeleton consists of acanthin, a peculiar elastic. organic substance, in the form of twenty needles radiating from the centre of the sphere. The majority of the species occur in tropical waters and in the upper layers of the ocean. They are divided into two groups, Acanthometra and Acanthophracta.

In a vertical haul in the Atlantic Popofsky ${ }^{2}$ found no less than 75 species of Acanthometra alone, and a haul in the Indian Ocean procured a similar number. North and south from the equator the number of species decreases, the majority living between lat. $40^{\circ} \mathrm{N}$. and $40^{\circ} \mathrm{S}$. The different regions of this warm belt have many species in common. According to Popofsky the total number of known species is I79, of which only I 8 have been found in the Atlantic to the north of lat. $50^{\circ} \mathrm{N}$., and 10 of these are known only as casual or seasonal visitors. The commonest forms in northern waters are Acanthochiasma fusiforme, Acanthometron pellucidum (Fig. 389), Acanthonidium echinoides (Fig. 390), Phyllostaurus quadrifolius, Acanthostaurus nordgaardi (Fig. 39I).

It is generally supposed that the temperature limits the bathymetrical distribution of the Acantharia, just as it is known to limit their horizontal occurrence. In the Atlantic the German Plankton Expedition found the deepest living species at a temperature of $9.4^{\circ} \mathrm{C}$. In the Mediterranean, where high temperatures occur deeper, they have been

1 See Murray, "On the Distribution of the Pelagic Foraminifera at the Surface and on the Floor of the Ocean," Natural Science, vol. xi. p. 17, 1897.

2 Popofsky, "Acanthometriden," Ergeb. Plankton-Expedition, Bd. iii., 1904; "Die nordischen Acantharien," Nordisches Plankton, No. xvi. 
taken down to a depth of 1200 metres. In northern waters several species have been taken just at that time of the year when the temperature is highest.

The Aulacanthidæ, the Challengeridæ, the Tuscaroridæ, and the Medusettidæ have silicious skeletons and prefer mainly cold water.

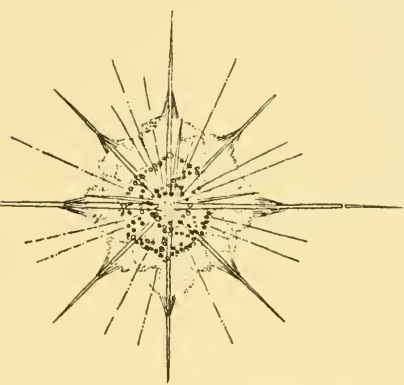

FIG. 389 .

Acanthometron pellucidum, J. Müller. (After Hertwig, from Steuer.)

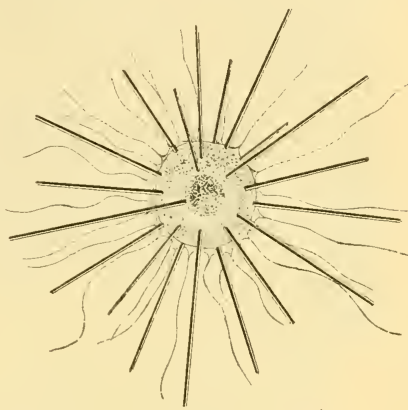

FIG. 390.

Acanthonidium echinoides, Claparède and Lachmann. (From Popofsky.)

The Aulacanthidæ are spherical, the skeleton consisting of numerous isolated hollow needles, some of which radiate from the centre while other smaller ones are arranged along the surface of the sphere. The great majority of the Aulacanthidæ have been found in the north-western corner of the Atlantic (the Irminger. Sea and Davis Straits), and also south of the Cape Verdes, but several species are very widely distributed, for instance Aulographis pandora (Fig. 392) taken in the Mediterranean, Indian Ocean, Pacific, and also in the Atlantic north and south of the Equator. This species occurs between 400 and 1000 metres, and is considered specially characteristic of these depths. One of the best-known species, Aulacantha scolymantha (see Fig. 393), is found, like several other radiolarians, in

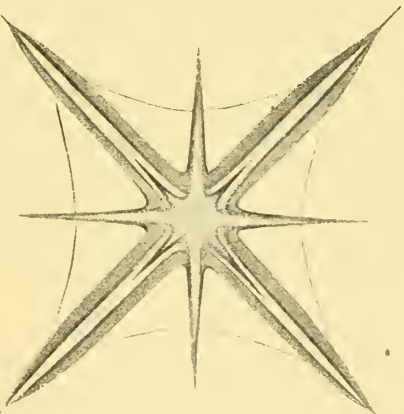

FIG. 39I.

Acanthostaurus nordgaardi, Jörgensen $(\stackrel{ \pm 0}{1} 0)$ (From Jörgensen.) two races distinguished by their difference in size. One is a pygmy 0.6 to $1.8 \mathrm{~mm}$. in diameter, the other a giant about 3 millimetres in diameter. At Naples, and during the cruise of the "Valdivia," Haecker ${ }^{1}$ studied the bathymetrical ${ }^{1}$ V. Haecker, "Tiefsee-Radiolarien," Wiss. Ergeb. "Valdivia" Expedition, Bd. xiv. (Jena, I908). 
distribution of these forms, and found the small one (var. typica) occurring in all depths, the large one (var. bathybia) in depths between 400

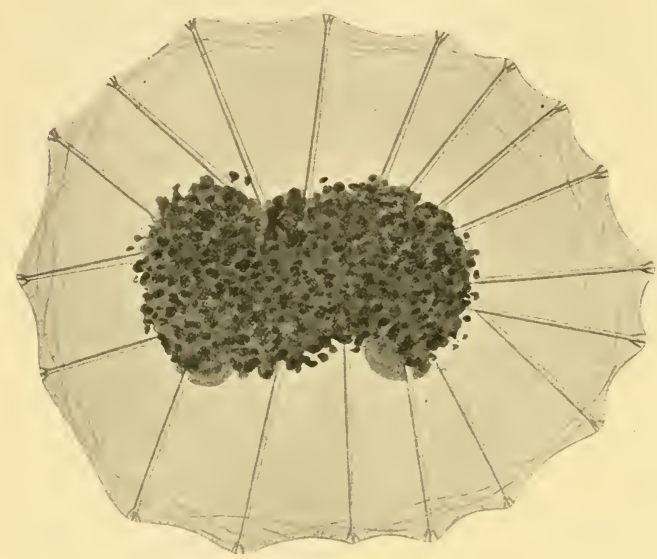

FIG. 392.

Aulographis pandora, Haeckel (about ${ }^{2}{ }^{0}$ ). (From Haecker.)

and 1000 metres; the giant form occurs very rarely in Norwegian fjords.

The Challengeridæ have an egg or lentil-shaped silicious shell of most delicate structure, the aperture being provided with a collar or tubeshaped moulding (see Fig. 394). They occur in all oceans, but sometimes their distribution is very peculiar, for some species live only in abyssal depths under the equator, others at

both poles, others only in Antarctic waters; some species live in the surface waters, others between 50 and 400 metres, others between 400 and IO0O metres, others again between 1500 and 5000 metres. From Haecker's report on the Radiolaria of the "Valdivia" Expedition we reproduce some of these species. Protocystis (Challengeria) tridens (Figs. 394, 2 and 3) occurs in the northern and southern cold zones, having been taken as far north as Spitsbergen, in the Norwegian fjords, the Skagerrack, round Greenland, in the Labrador current, and also in Antarctic waters by the "Valdivia"; in Norwegian waters it has been taken in deep water

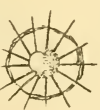

$a$

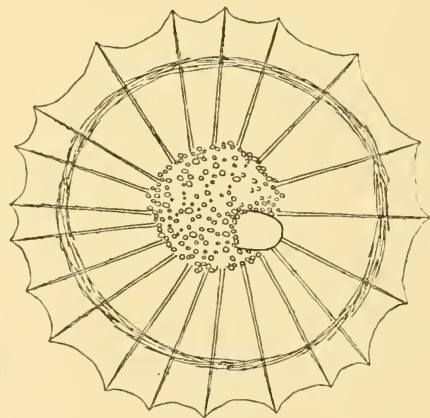

$b$

FIG. 393.

Aulacantha scolymantha, Haeckel. $a$, var. typica; $b$, var. bathybia, deep-sea form. (After Haecker, from Steuer.)

up to 50 metres below the surface. P. swirei (Fig. 394, 1) has been taken only in the Antarctic from the surface down to a depth of 4000 and 5000 metres. P. thomsoni (Fig. 394, 4) belongs to a group of 
large forms, of which the species $P$. naresi is the largest. These forms have been taken in abundance only at the greatest depths, as is the case with the giant race of Aulacantha scolymantha. Among Norwegian Sea forms we may mention Protocystis bicornis and P. harstoni, Challengeria xiphodon, and Porospathis holostoma, the three latter being found in the Atlantic as well. $P$. holostoma has been taken at great depths in the Norwegian Sea and in the Sargasso Sea.

The Tuscaroridæ are genuine deep-sea forms, having a bottle-shaped shell provided with large strong spikes arranged in rings around the main axis (see Fig. 395). In hauls with closing nets they have never been taken in less than 400 metres of water; some species, for instance Tuscaretta tubulosa, occur in all oceans.

Remarkable deep - sea forms, as well as certain small surface forms, belong to the Medusettidæ. Medusetta arcifera has been taken in the Norwegian fjords.

On the basis of his study of the Radiolarians of the "Valdivia" Expedition, Haecker distinguishes the following bathymetrical regions :layer.

(I) An upper Acanthometra-

(2) A Challengeria-layer ( 50 to 400 metres).

(3) A Pandora - layer (from Aulographis pandora, 400 to 1000 metres), in which the Tuscaroridæ are also found.

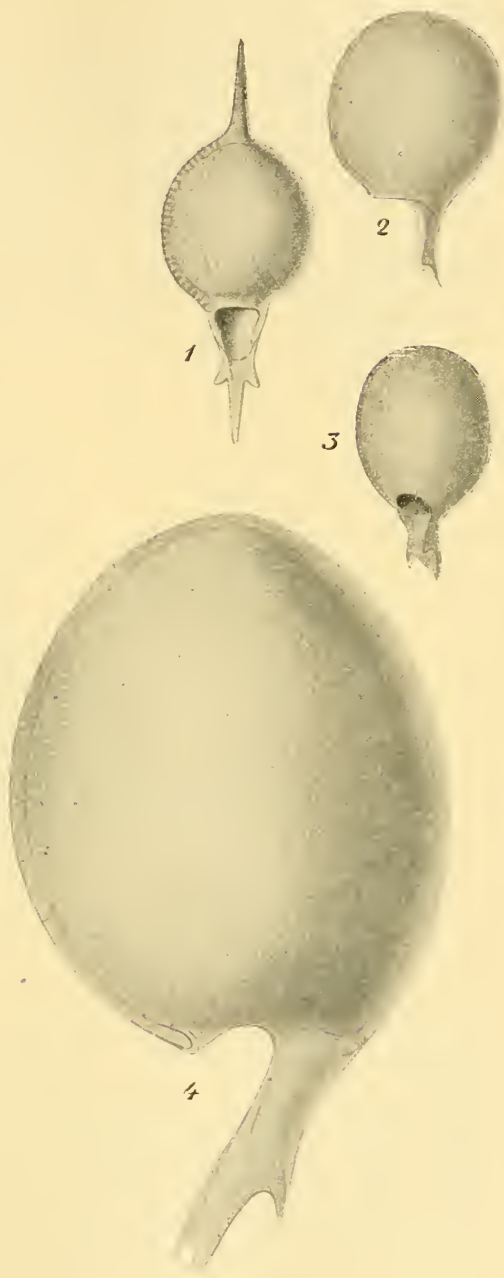

FIG. 394.

Challengeridæ $\left(\frac{210}{1}\right) . \quad$ I, Protocystis swirei, John Murray; 2 and 3, Protocystis tridens, Haeckel; 4, Protocystis thomsoni, John Murray. (From Haecker.) 
(4) An abyssal layer ( 1500 to 5000 metres), in which the large Challengeridæ (Protocystis naresi, P. thomsoni) are found.

The multicellular animals are all represented among the pelagic forms, from the medusæ to the fishes.

Commencing with the Coelenterates we may mention the Medusæ, the Siphonophores, the Ctenophores, and the larval Actiniæ.

Medusæ. The Medusæ are generally bell-shaped or globular, with a more or less transparent jelly-like body. On the edge of the bell some forms have a band-shaped fold or moulding ("craspedon"), and accordingly the medusæ are divided into two main groups: Craspedota with a craspedon, and Acraspeda without a craspedon.

The Craspedota comprise four groups: Anthomedusæ, Leptomedusæ,

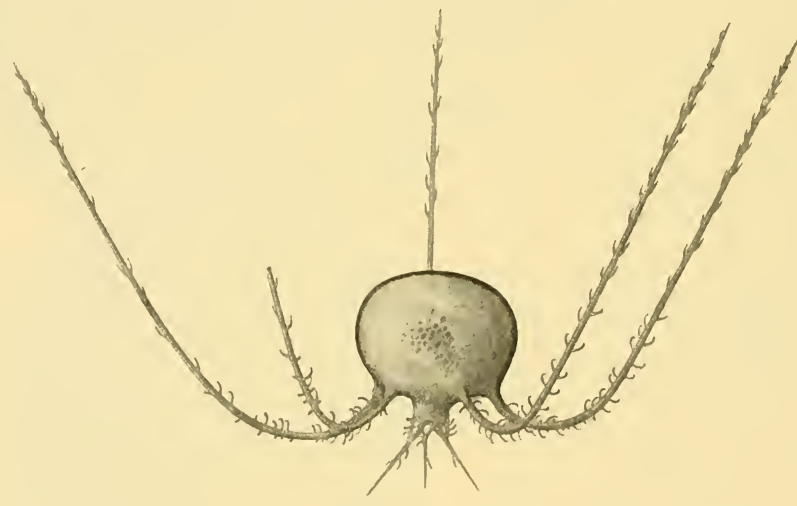

FIG. 395 .

Tuscaretta globosa (Borgert), subsp. chuni, Haecker (about $\underset{1}{20}$ ). (From Haecker.)

Trachymedusæ, and Narcomedusæ, of which the first two are meropelagic and the last two holopelagic. The meropelagic forms pass through an "alternation of generations," i.e. the eggs produced by the medusæ develop into larvæ which attach themselves to the bottom and grow into hydroid polyps or zoophytes; by "budding" the zoophytes produce small medusæ, which lead a swimming pelagic life and produce eggs. Fig. 396 shows a colony of hydroids with different stages of medusæ developing, and Fig. 397 shows one of the medusæ just after leaving the colony. The Craspedota are therefore termed hydroid medusæ or hydromedusæ, although they include two groups with no alternation of generation and no bottom stages, which are supposed to be descended from neritic forms. The hydromedusæ having an alternation of generations are represented by a vast number of species in the surface waters off all coasts where the temperature is not too low. They do not occur far from land nor in deep water. Their pelagic life 
is short and they die unless they reach the bottom within a certain limited time.

Damas and Koefoed ${ }^{1}$ mention as the most important forms in Scandinavian waters the following species: Sarsia tubulosa, S. eximia, Euphysa aurata, Corymorpha nutans, Hybocodon prolifer, Bougainvillia superciliaris var., Dysmorphosa octopunctata, Tiara pileata, Limneandra norvegica, Melicertidium octocostatum, different species of Obelia and

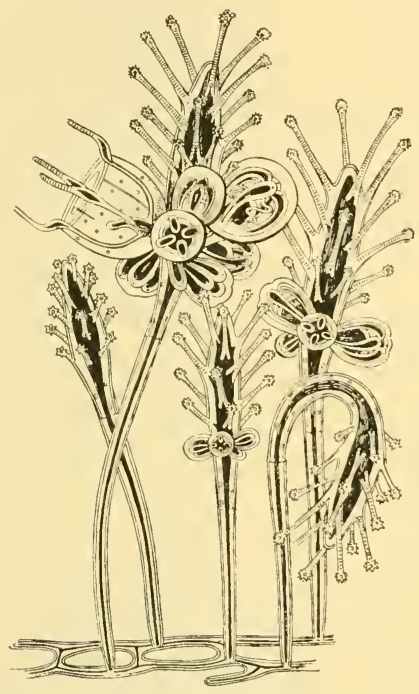

FIG. 396.

Hydroid colony of Syncoryne pulchella.

(From Allman.)

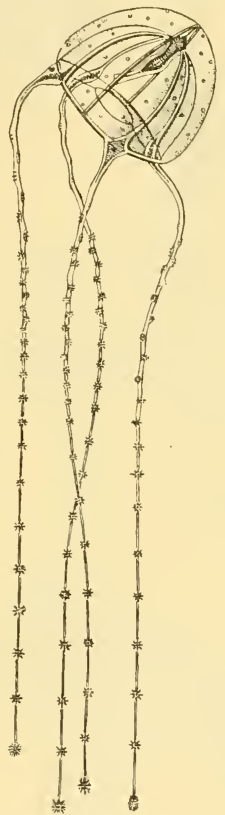

FIG. 397.

Medusa, just after leaving colony.

Phialidium, Mitrocomella fulva, Tiaropsis multicirrata, and Lutonia socialis. From the Arctic plateau between Spitsbergen and Bear Island they mention Sarsia flammea, Codonium princeps, Catablema campanula, Hippocrene superciliaris (see Fig. 398). These forms do not play any part in the fauna of the open ocean.

The Trachymedusæ have a direct development without a hydroid or bottom stage. In northern waters we meet with only one species in such numbers, and so frequently, that it may be considered truly northern

1 Damas et Koefoed, "Le Plancton de la Mer de Groenland," Duc d'Orleans' Croisière océanographique (Bruxelles, 1905). 


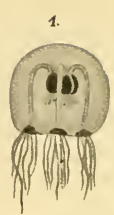

3.

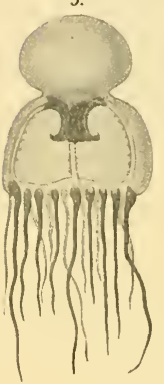

FIG. 398.

Arctic Medusæ : I, Hippocrene superciliaris, Ag. ; 2, Codonium princeps, Haeckel; 3, Catablema campanula, Haeckel. (From Vanhöffen.)

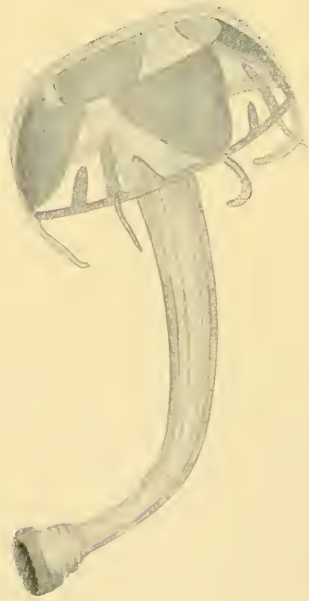

FIG. 400.

Liriope tetraphylla, Chamisso and Eysenhardt (about $\underset{1}{ })$. (From Vanhöffen.)

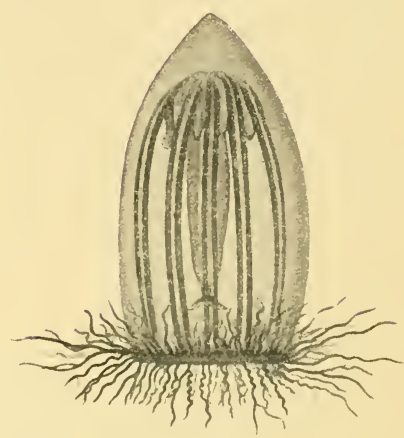

FIG. 399.

Aglantha digitalis, O. Fabr. $\left(\frac{2}{1}\right)$. (From Vanhöffen.)

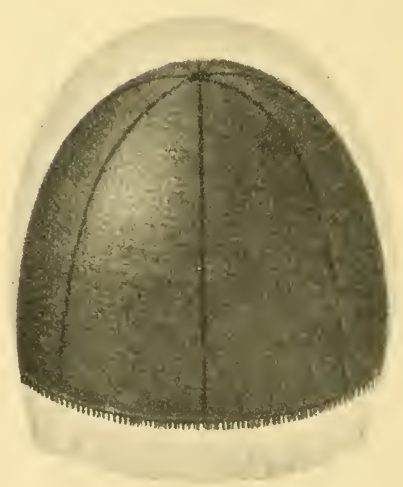

F1G. 401.

Crossota brunnea, Vanhöffen (6). (From Vanhöffen.) 
(boreal), viz. Aglantha digitalis (see Fig. 399), which sometimes plays an important part in the pelagic life of the Norwegian Sea; in the North Sea Hensen fell in with a shoal of these medusæ which he estimated at $23 \frac{1}{2}$ billions of individuals. As mentioned by Haeckel, it is characteristic of this form that it suddenly appears in enormous quantities for some days and then suddenly disappears for some months.

As rare visitors in the north may be mentioned, Pantachogon haeckelii, Pectyllis arctica, and Crossota norvegica. ${ }^{1}$ Other species are strictly limited to the warm zone of the ocean, which may be said to

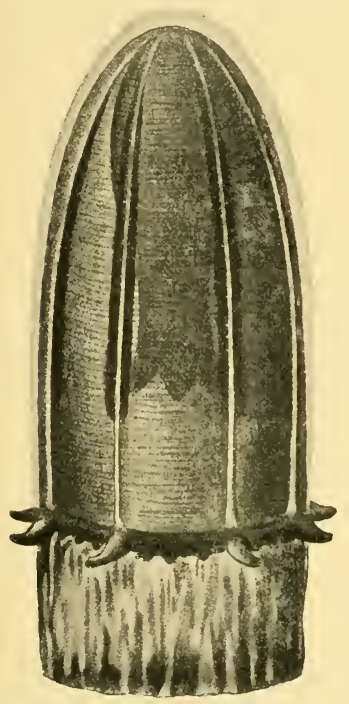

FIG. 402.

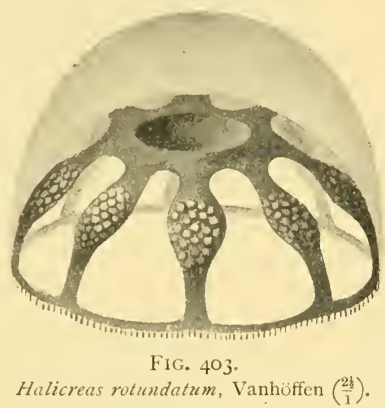

(From Vanhöffen.)

Agliscra ignea, Vanhöffen $\left(\frac{5}{1}\right)$.

(From Vanhöffen.)

reach the 40 th or 5 oth degree of latitude, where we find some small forms living entirely in the upper layers of the Atlantic and Indian Oceans, as for instance Rhopalonema velatum, Aglaura hemistoma, and Liriope tetraphylla (Fig. 400); they are devoid of colour or only faintly tinted, some of them being only a few millimetres in diameter. Others are genuine deep-sea forms, found only below 600 or 1000 metres. Crossota brunnea (Fig. 40I) is dark brownish, Agliscra ignea (Fig. 402) is a flaring red, and Halicreas rotundatum (Fig. 403) is distinguished by bright red markings.

The Narcomedusæ are oceanic forms, including some small colourless surface forms and strongly tinted (brown) deep-sea forms.

1 This species was taken by me in a deep haul in the Norwegian Sea, and Vanhöffen placed it very near to the tropical species Crossota brunnea, see Wiss. Ergeb. "Valdivia" Expedition, Bd. 3, 1902 : and "Die Fauna und Flora Grönlands," Grünland Expedition (Berlin, I 897). 
The Acraspeda include the common jelly-fish, and excepting the genus Pelagia they all go through an alternation of generations. The free-swimming medusæ produce eggs, the larvæ fixing themselves to the bottom and developing a zoophyte differing from the hydroid-zoophyte in that it produces only one kind of bud; the division is transverse, the medusæ not being'produced, as in the hydroida, by evagination (Fig. 404).

In northern waters, for instance on the coast banks and in the fjords of Scandinavia, the brown stinging jelly-fish Cyanea capillata and the transparent jelly-fish Aurelia aurita are the most important species ; in the southern part of the North Sea we find the blue Cyanea lamarckiana, which annually drifts up to the Skagerrack and the west coast of Norway. Distantly related to these is Rhizostoma octopus, which is similarly dis-

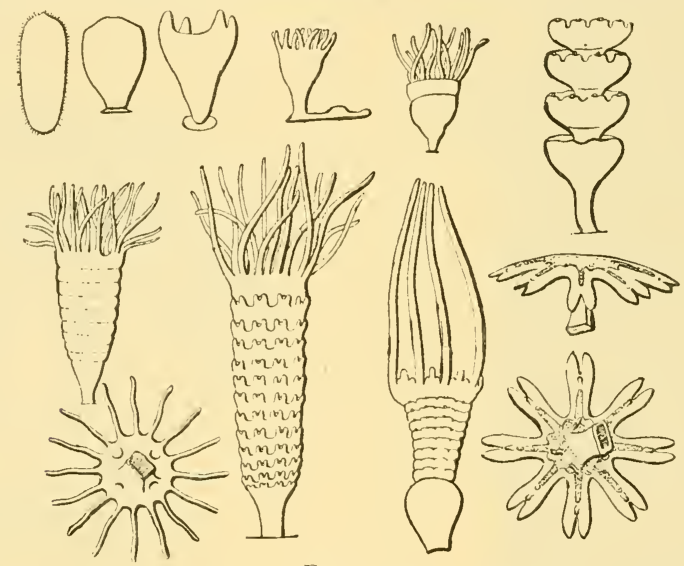

FIG. 404.

Development of Aurelia aurita from the ovum. The upper series shows the development of the larva (planula) into Scyphostoma; the lower series shows stages in the formation of small medusæ by division. (After Hatschek, from Hertwig.)

tributed and occurs in Scandinavian waters as a visitor. The oceanic genus Pelagia, as already indicated, has a direct development, and is thus holopelagic (see Fig. 405). Of certain smaller groups resembling the Trachymedusæ, I may mention the genera Atolla, Periphylla (Fig. 406), and Nausithoë, which are wholly oceanic forms widely distributed mainly in deep water.

During the cruises of the "Michael Sars" the distribution of medusæ in the Norwegian Sea and in Norwegian coast waters has for years been investigated, and Damas, who is working up the material, has found 64 species, of which I 4 are new to science; some are shallow-water forms, and others belong to the deep fauna of the fjords. In 1900 I noted the occurrence of Cyanea capillata all over the warm part of the Norwegian Sea, and later on the drift of this form from the coasts has been traced, as also the drift of Cyanea lamarckiana from the North Sea to the west coast of Norway (see Chapter X.). 
During the Atlantic cruise in 1910 a large collection of medusæ was obtained, of which only the Acraspeda have been determined by Broch, who records the following forms from the stations specified:-

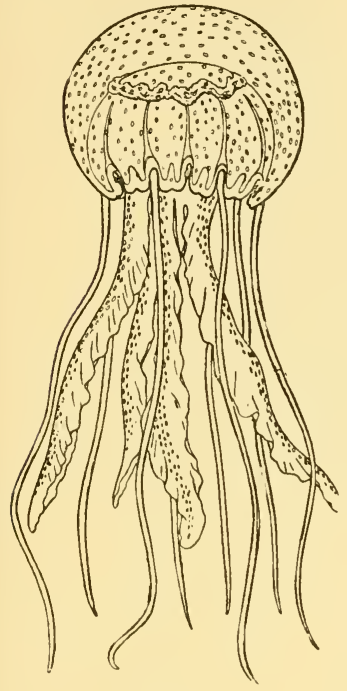

FIG. 405.

Pelagia perla, Slabber.

(After McAndrew and Forbes, from Steuer.)

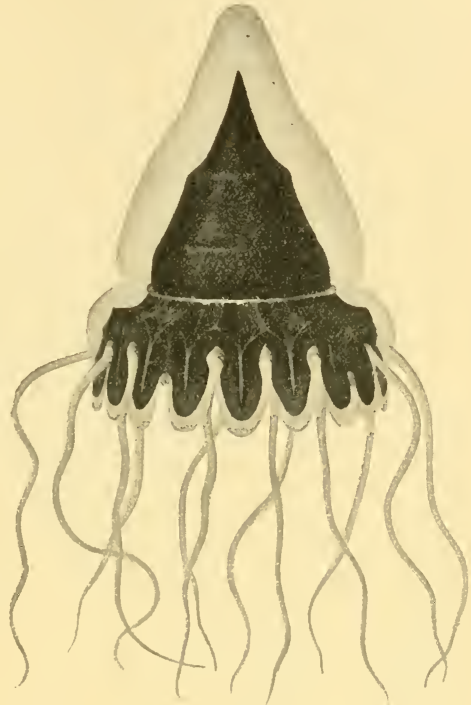

FIG. 406.

Periphylla hyacinthina, Steenstrup. About nat. size. (From Vanhöffen.)

Periphylla hyacinthina, Steenstrup, Stations Io, I9, 34, 42, 45, 51, 52, 53, $5^{6}, 58,62,64,66,67,70,80,81,82,84,88,92,94,98$, IOI.

P. regina, Haeckel, Stations I 9, 49, 56, 62, 63, 64, 84, 92.

Nausithoë atlantica, n. sp., Stations 56, 9o, $9^{2}$.

" globifera, n. sp., Stations 10, 88, 90, 98, го г.

Atolla zeyvillei, Haeckel, Station 62.

" bairdii, Fewkes, Stations 10, 23, 25, 29, 35, 42, 45, 49, $5 \mathrm{I}, 53,56,62,64,66,67,70,80,81,82,84,87,88,90$, 92, 94, 98, гог.

Pelagia perla, Slabber, Stations 10, 25, 51, 52, 56, 81, 82, 84 , $86,87,88,90,92,94$.

Chrysaora mediterranea, Peron et Lesueur, Algeciras.

Poralia sp. (rufescens?), Station 85. Aurelia solida, Browne, Station 56.

This list shows that Periphylla hyacinthina and

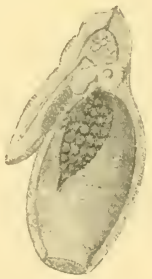

FIG. 407.

Diphyes arctica, Chun $\left(\frac{5}{1}\right)$. (From Vanhöffen.) Atolla bairdii are so widely distributed in the North Atlantic that they may be said to occur everywhere; they are, as we shall see later, both 
CHAP.

deep-living forms. Among surface forms only Pelagia perla was taken abundantly, and its distribution was peculiar, the species being most numerous along the line of stations crossing the Azores in a north and south direction, coinciding with the submarine ridge on which these islands are situated (see Map III.).

Siphono-

The Siphonophores are phoræ.

an interesting group, sometimes referred to the hydromedusæ, but entirely independent. They are oceanic, and have no bottom-stage, their development being a direct one. This class of animals is exceedingly rich in species, and we can only mention some North Atlantic forms.

Only three species are wholly indigenous to northern waters: Diphyes arctica (Fig. 407), peculiar to the Gulf Stream north of lat. $59^{\circ}$ or $60^{\circ} \mathrm{N}$., extending to Spitsbergen in lat. $8 \mathrm{I}^{\circ} \mathrm{N}$., and Galeolaria biloba and Cupulita cara, which are less common. In the Atlantic we find a wealth of both deep-sea and pelagic forms, some of the latter being known as visitors in the North Sea and the Norwegian Sea, a few having being found on the west coast of Norway and described by Michael Sars as long ago as the 'thirties, like Agalmopsis

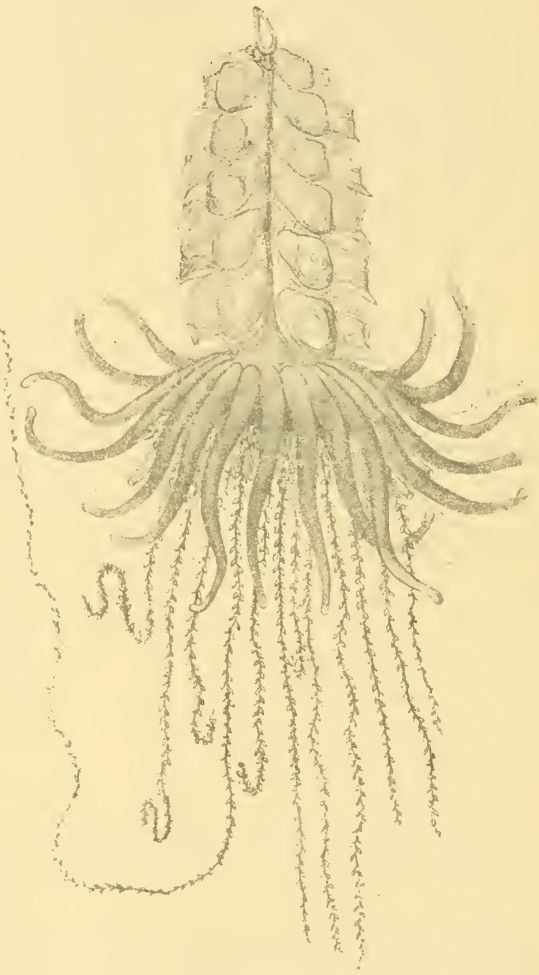

FIG. 408 .

Physophora hydrostatica, Forskal. About half nat. size. (From M. Sars.)

elegans and Physophora hydrostatica (Fig. 408); in the Sognefjord Haeckel also found Circalia stephanomma. These forms have numerous swimming bells and long tentacles, and are interesting as immigrants from the Atlantic into the North Sea and the Norwegian Sea. Among forms peculiar to the warm surface layers we may mention the "Portuguese man-o'-war," Physalia arethusa (Fig. 409), and the "By the wind sailor," Velella spirans (Fig. 4IO), which belong to the regions south of the 4oth degree, but have occasionally been found as visitors on the shores of the British Islands. 
Together with these forms we often find Cestus veneris, one of the Ctenophore. Ctenophores, a class including many pelagic forms, both surface and deep sea. Four species of Ctenophores have been observed in the arctic region: Mertensia ovun, Pleurobrachia pileus, Bolina infundibulum, and Beroë cucumis. After studying the collections of the "Belgica" and the "Michael Sars," Damas and Koefoed state that Pleurobrachia pileus

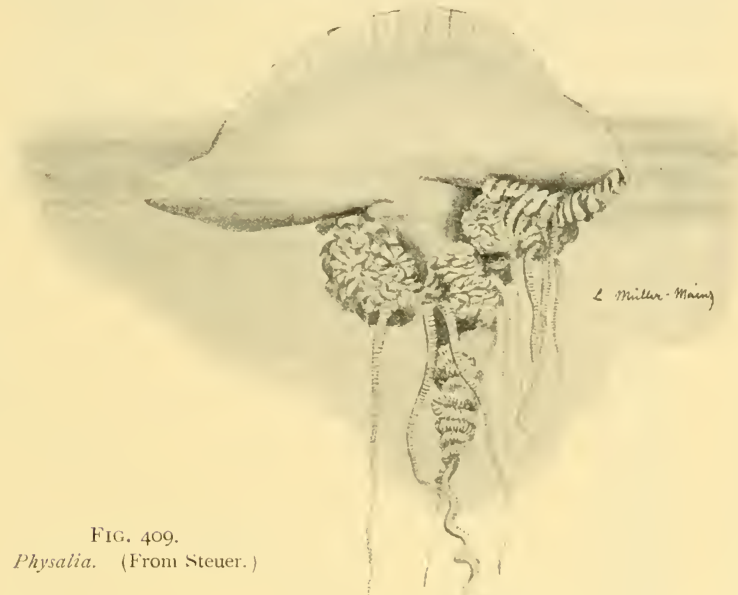

is a coast form occurring from the channel infundibulum and Beroë cucumis have a occur in deeper water, for instance, in the fjords; Mertensia ovum is an arctic form, wegian fjords.

Pelagic larvæ are encountered among if all the higher groups of Pelagic larvæe. animals either holopelagic or merothe fishes. Among the higher organised rule seems to be that the mature stages eggs and larvæ are pelagic, whereas stages are generally pelagic. Pelagic, stages are found in the echinoderms by etc.), annelida, bryozoa, and in various 5 crustaceans from the sessile cirripeds to the lobsters and crabs; snails and mussels also have pelagic young.

In spring especially the coast-waters teem with the larvæ of all these animals, the larval forms very often differ from the adult, and an enormous amount of work has been devoted by zoologists to the description of all these forms. Some of these larvæ seek the bottom after a lapse of only a few days, but many species lead a long pelagic life and during this period go through metamorphoses, among the most 
remarkable being the larvæ of starfishes, ophiuridæ, and sea-urchins. In the larvæ of the ophiuridæ (see Fig. 4II) the skeleton consists of rigid

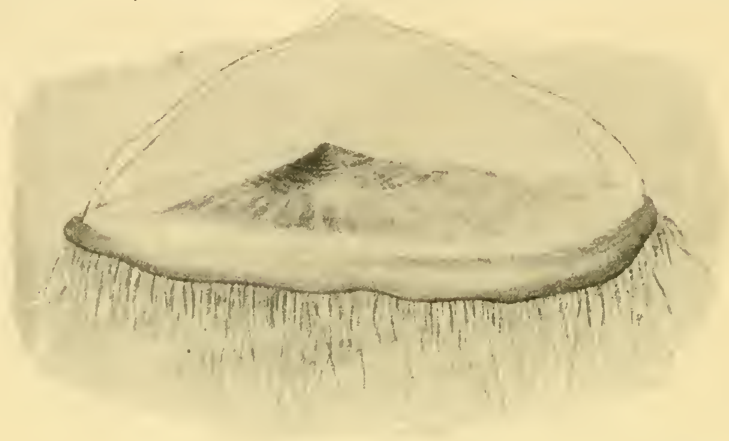

Fig. 410 .

Velella spirans, Esch. (From Steuer.)

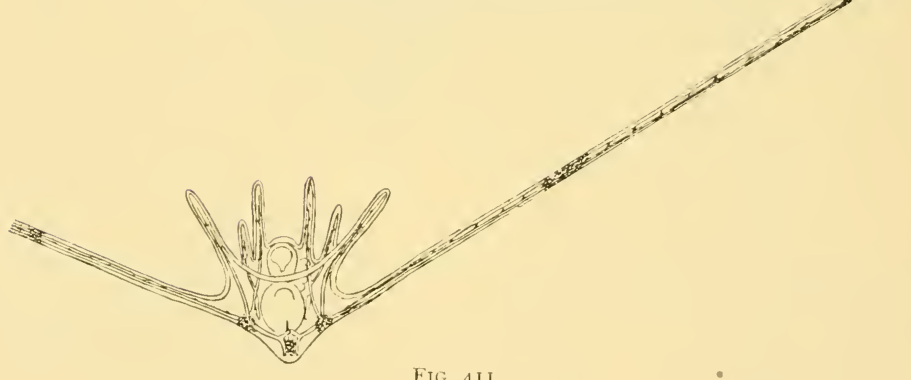

FIG. 4 II.

Larva of Ophiothrix fragilis, O. F. Müller (about $\frac{300}{1}$ ). (From Mortensen.)

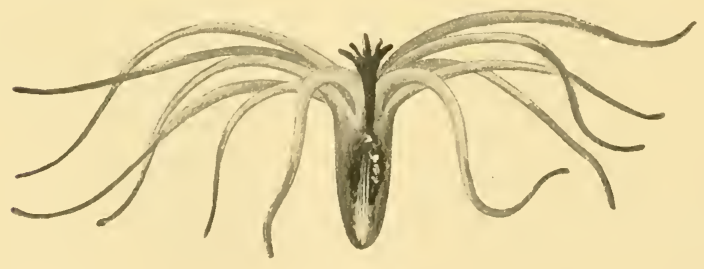

FIG, 412.

Arachnactis albida, M. Sars. Nat. size. (From Sars.)

rays of carbonate of lime, with a belt of cells provided with whip-like hairs, by the aid of which they swim ; these larvæ go through wonderful metamorphoses before finally attaining the adult form. 
The larval Actiniæ are biologically of great interest, especially Actiniaria. Arachnactis albida, first described by Michael Sars (Fig. 4I 2). The northeastern corner of the Atlantic is its main area of distribution, principally between the Hebrides and the Faroe Islands, but at certain seasons it is carried into the North Sea and the Skagerrack, and to the west coast of Norway, where Sars found it (see Fig. 480).

A description of the larvæ peculiar to the different groups would lead us too far, but in order to prepare the reader for the next chapter some of the forms have been mentioned.

The Worms are comparatively rare among the pelagic forms. Of Vermes. the lowest worms (platyhelminthes) the pelagic Nemertines are of interest. Nearly all Nemertines live along the bottom, but a pelagic genus (Pelagonemertes) was described by Moseley in the "Challenger" Reports. Subsequently several species have been described, all represented by isolated specimens. These remarkable forms are red or orange coloured, and their digestive tract is extremely ramified. According to Brinkmann, who is examining our material, most of the previously known species, as well as some new species, have been taken during our Atlantic cruise, and prove that several species hitherto regarded as distinct are really identical : thus Nectonemertes grimaldi, $N$. lobata, and $N$. pelagica are all identical with $N$. mirabilis. The genus Nectonemertes with $N$. mirabilis, and also the genus Hyalonemertes with $H$. atlantica, were established by Verrill. The two forms (see Fig. 4I3) differ, as shown by later investigations, only in one single character, $N$. mirabilis having two long appendages on the head, which are lacking in $H$. atlantica. The abundant material collected by the "Michael Sars" has enabled Brinkmann to show that all the individuals of $N$. mirabilis are

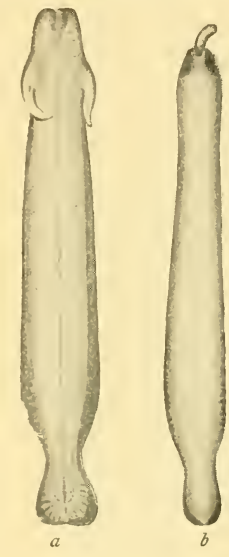

FIG. 413.

Nectonemertes mirabilis, Verrill. Slightly enlarged. $a$, male ; $b$, female. males, while all the individuals of $H$. atlantica are females, and he concludes that both belong to the same species, the difference between them being only a sexual one.

Very interesting were some gigantic specimens belonging to this group secured during the cruise. One form, Dinonemertes investigatoris (see Fig. 4I4), was $20.5 \mathrm{~cm}$. long, and when living was of a bright red tint and nearly transparent, all the ramifications of the digestive tract being plainly visible. As we shall see when reviewing the captures of the "Michael Sars," all these Nemertines are deep-sea forms with a very characteristic vertical distribution. Several of the species are very widely distributed, Nectonemertes mirabilis, for instance, being known from Davis Straits, from the Pacific off California, and all through the Atlantic ; Dinonemertes investigatoris is known from the Atlantic as well as from the Indian Ocean.

The most abundant group of pelagic worms as regards number of 
individuals is the Sagittidæ or Chætognaths, which, along with copepoda, salpæ, pteropoda, and radiolaria, everywhere constitute the bulk of the small pelagic organisms captured by our fine-meshed tow-nets. They are perfectly transparent, of slender build, and swift of motion. On the head are some bristle-like gripping appliances, and an elastic film-like rim, reminding one

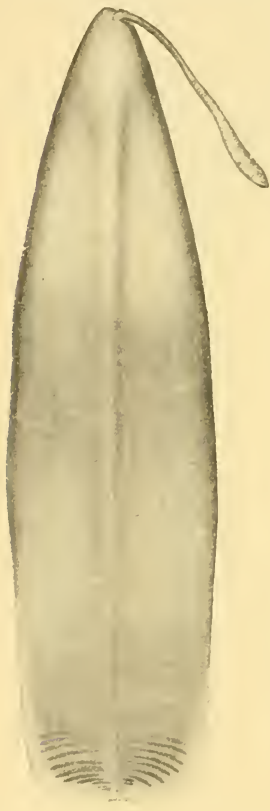

FIG. 4 I4.

Dinonemertes investigatoris, Laidlaw. Half nat. size. of the fin of a fish, runs along the body and the "tail" (see Fig.4I 5).

The Sagittidæ comprise only a few genera, the most prolific in species being the genus Sagitta, which is represented in all oceans; some of the species are very widely distributed, such as Sagitta hexaptera, S. serratodentata, S. bipunctata. In northern waters Krohnia hamata, Sagitta arctica, and Sagitta gigantea are characteristic forms, the last mentioned having been taken by the "Michael Sars" in deep hauls in the Norwegian Sea, while Sagitta inflata is a form peculiar to warm waters. All these species are perfectly transparent, but during the Atlantic cruise we found specimens of a bright red colour, precisely like that of the pelagic Nemertines, belonging to Sagitta macrocephala and Eukrohnia fozoleri; they were very abundant, and occurred, like the Nemertines, only in deep hauls.

The very numerous families of higher worms, especially the Annelida, contribute very little to the pelagic fauna of the ocean.

Among the best known is the genus Tomopteris, which has many beautiful surface forms, some of these (like $T$. septentrionalis) being boreal, some belonging to warm waters. In his narrative of the cruise of the "Valdivia," Chun tells us that nearly every haul from deep water in the Antarctic brought up beautiful specimens of Tomopteris, as long as the finger, transparent, and with rosetinted feet (parapodia). Individuals belonging to the genus Tomopteris were taken in several of the deep hauls and also in the surface hauls of the "Michael Sars," but the material has not yet been worked up.

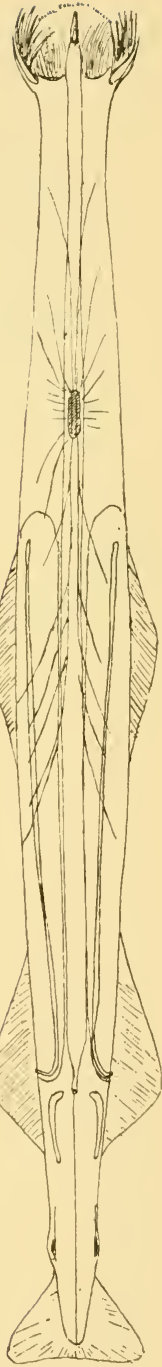

FIG. 415 .

Sagitta hexaptera, d'Or̉. ( $\left.\begin{array}{l}* \\ 1\end{array}\right)$. (From Hertwig.) 
No class of multicellular animals in the ocean is represented by any- Crustacea. thing like such countless forms and individuals as that of the Crustaceans ; in the life of the ocean they play, according to Haeckel, a part corresponding to that of the insects in the land fauna. The Entomostraca include the most important groups, first the Copepoda, then the Ostracoda, and the Cladocera. Among the larger Crustacea, the Schizopoda, the Amphipoda, and the Decapoda are also very important, but in abundance and specific variation they can never be compared to the groups of smaller crustaceans.

The Copepoda, as a rule, attain only a few millimetres in length, and Copepoda. are adapted to feed on the small plants of the oceanic flora in the upper layers of all oceans. It may safely be asserted that they are the chief consumers of these minute plants, and in turn serve as food for larger animals.

Giesbrecht ${ }^{1}$ discusses the geographical distribution of 299 species of Copepoda, and divides the area of their distribution into three regions: (I) a warm region between $47^{\circ} \mathrm{N}$. and $44^{\circ}$ S., (2) a northern region, and (3) a southern region. The warm region comprises all the oceans, the warm-water species throughout the world being more alike than the species of warm and cold regions in the same ocean. Of the 299 species, no less than 254 belong exclusively to the warm region; there are besides

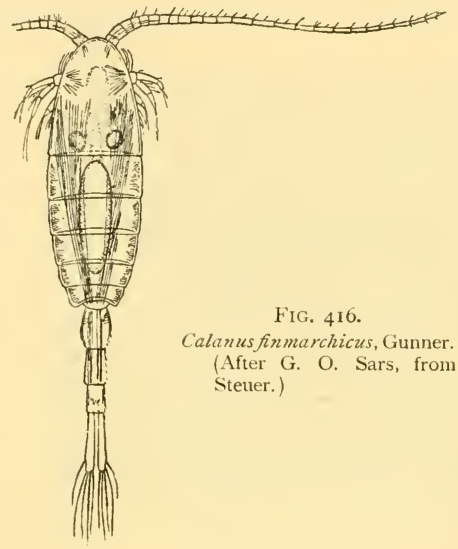
a few widespread forms and others peculiar to the northern or southern region. About 85 per cent of the species belong to the warm region, 5 per cent to the northern, and 2 per cent to the southern region.

As characteristic of the warm region Giesbrecht mentions the following genera: Augaptilus, Calocalanus, Copilia, Euchirella, Hemicalanus, Monops, Pleuromma, Pontella, Pontellina, Sapphirina. Peculiar to the northern area are: Acartia bifilosa, Calanus hyperboreus, C. cristatus, Centropages hamatus, Euchata norvegica, Pseudocalanus elongatus, and perhaps Temora longicornis. Some forms are common to the warm region and one of the cold regions, such as Anomalocera patersoni and Centropages typicus, while Calanus finmarchicus and Oithona similis occur in all the three regions.

The warm and cold water forms differ in structure, the body, legs, and antennæ of the warm water forms being generally provided with wonderful feather or fan-shaped attachments, which greatly enlarge the

${ }^{1}$ Giesbrecht, "Systematik und Faunistik d. pelag. Copepoden," Fauna und Flora des Golfes von Neapel, Bd. I9, IS92. 
surface of the animals and facilitate their floating, while in northern waters the species are devoid of such appendages. It is thus interesting to compare the widespread species Calanus finmarchicus (Fig. 416), which occurs in greatest abundance in boreal areas, with the tropical Augaptilus filigerus (Fig. 4I7), which has elaborate appendages, reminding one of peacocks' feathers. We find the same difference between Oithona plumifera and Oithona similis, and between Euchata marina and Eucheta norvegica (Fig. 4I8). We find in these cases a perfect analogy with what Gran has described among the peridineæ in Chapter VI.; for instance, Ceratium platycorne (see Fig. 228 , p. 324) in warm water en-

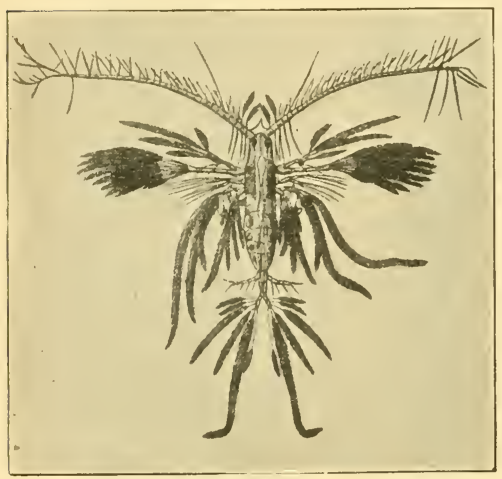

FIG. 417.

Augaptilus filigerus, Claus.

(After Zacharias, from Steuer.)

larges its surface, while in cold water the horns are much more slender, the lower specific gravity caused by the higher temperature rendering floating appliances necessary for both animals and plants (see also Chapter X.).

The Copepoda occur in all depths, and some authors have attempted to define certain bathymetrical regions, each with its own characteristic forms, but the observations available are insufficient to enable us to form definite ideas on the subject; much new light will' doubtless be thrown on the matter when the reports of the "Valdivia" and "Michael Sars" Expeditions come to be published. The discussion as to whether the surface forms of cold regions are found in the deep water of warm regions is interesting.

The "Valdivia" Expedition captured Euchirella venusta and Calanus finmarchicus in a haul with a closing net between 1600 and 1850 metres 
in subtropical seas where the surface temperature is very high, and Dahl mentions this latter form as living in deep water in the Sargasso Sea.

Numerous investigations on the Copepoda of the Norwegian Sea have in recent years been made by the "Michael Sars," the material having been worked up mainly by Damas, whose results will be mentioned in the sequel. From the Atlantic cruise of I9Io the "Michael Sars" also brought home a large collection of Copepoda captured both in horizontal hauls and in closing nets, and this material is at present being described by Nordgaard and Lysholm, but their results are not yet ready for discussion. G. O. Sars has, however, been good enough to determine the Copepoda for me in a few selected samples, and these determinations are so interesting that I give in the following table the number of species found at various depths :-

Number of Species of Crustaceans, chiefly Copepoda, taken in Closing Nets at the Stations specified

\begin{tabular}{|c|c|c|c|c|c|}
\hline Depth of the Hauls. & $\begin{array}{c}\text { Station } \\
50 .\end{array}$ & $\begin{array}{c}\text { Station } \\
63 .\end{array}$ & $\begin{array}{c}\text { Station } \\
8 \text { o. }\end{array}$ & $\begin{array}{c}\text { Station } \\
92 .\end{array}$ & $\begin{array}{l}\text { Station } \\
\text { I I } 3 .\end{array}$ \\
\hline o to 200 or 300 metres & 22 & 25 & I 6 & I 8 & $2 \mathrm{I}$ \\
\hline 200 or 300 to 500 metres & 22 & 32 & 27 & 12 & I 8 \\
\hline 500 to 1000 metres & $5 \mathrm{I}$ & 27 & 34 & 33 & I I \\
\hline
\end{tabular}

The most northerly station (I I 3 ) is relatively poor in species, especially in the deep cold layers, the richest station being the most southerly one (50), and remarkably enough the richest sample is the deepest one in 500 to 1000 metres, which contained twice as many species as the surface sample.

The Ostracoda are considered by Haeckel to be the most important Ostracoda. group of Crustacea next to the Copepoda, being represented by a great number of species. The "Challenger" collected $22 \mathrm{I}$ species, of which 52 were taken in depths greater than 500 fathoms, I9 beyond 1500 fathoms, and 8 beyond 20,00 fathoms. Many ostracoda possess the power of emitting intense phosphorescent light, and Haeckel narrates how on his voyages to Ceylon he saw the entire sea like a continuously twinkling ocean of light as far as the eye could reach; the microscope proved most of these luminous animals to be ostracoda, with some medusæ, salpæ, and worms.

Some of the surface ostracoda are very widely distributed, like Conchacia elegans, which occurs all the way from the Norwegian Sea to the Antarctic. In northern waters we may find also $C$. borealis and $C$. obtusata. In Antarctic waters we find $C$. antipoda, closely resembling C. obtusata of the north. As abyssal forms we may note the large individuals (attaining $\mathrm{I} \mathrm{cm}$. in length) of the genus Gigantocypris (see Fig. 4I9), recorded by the "Valdivia" from the Indian Ocean and from the Atlantic between lat. $14^{\circ} \mathrm{N}$. and $42^{\circ} \mathrm{S}$., previousily 
known from the Pacific. ${ }^{1}$ The "Michael Sars" took this genus in deep water at several stations in the North Atlantic.

The Cirripedia are the only group of crustaceans which in the adult stage abandon the pelagic life of youth and become sessile, fixing themselves to the bottom like many other invertebrates. Some are fixed to the rocks of the littoral region (the balani), or to pumice stones and nodules from the great depths of the ocean, while others are attached to whales and turtles, or (like the Lepadidæ) to floating objects carried along by currents. One species (Lepas fascicularis) forms considerable floating clusters composed of several individuals. A peculiar group (for example, Sacculina from the tail of decapod crustacea) is entirely

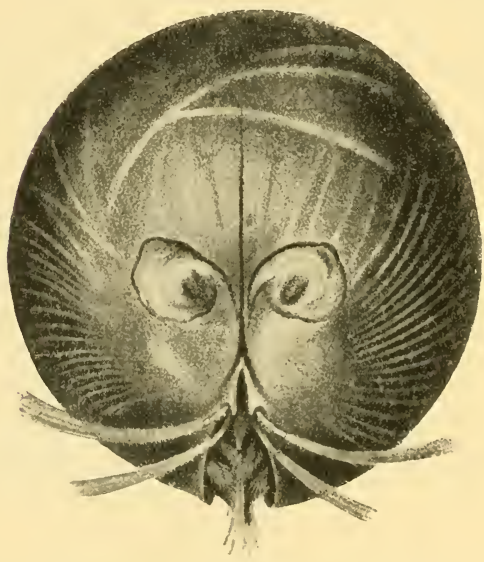

F1G. 419.

Gigantocypris agassizii, G. W. Müller ( $\left(\begin{array}{l}3 \\ 1\end{array}\right)$.

(From Müller.) parasitic and transformed to such a degree that the crustaceous nature of the animal is hardly recognisable.

The Cirripedia from the Atlantic cruise of the "Michael Sars" have been examined by P. P. C. Hoek, who found the following species of the genus Lepas:-

Lepas anatifera (see Chapter III., p. I 00 , Fig. 87 ), taken at Station 6 I (on a floating $\log$ ), and off St. John's.

Lepas anserifera, Station 67 (on Sargasso weed), Station 69 (on a small $\log$ ).

Lepas pectinata, Stations 10, 25, 3I, $69,86,91$ and 92 (fixed to birds' feathers, cork, fucus, pumicestone, and to L. fascicularis).

Lepas hilli, Station 56 (on a turtle). Lepas fascicularis, Stations 2 5, 91, 92.

All these species are known from other oceans, especially the Pacific, and are principally warm-water forms. Of other Cirripedia the following species were captured :-

Pacilasma carinatum, Station 53 (on the bottom).

Conchoderma virgatum, Station 56 (on a turtle).

Scalpellum velutimum, Stations 24 and 53 (on the bottom).

, dicheloplax, Station ro (on the bottom).

" atlanticum, Station 23 (on the bottom).

Schizopoda. G. O. Sars described 57 species of Schizopoda from the "Challenger" Expedition, ${ }^{2}$ of which 32 were taken only at the surface, 6 between 32 and 300 fathoms, 4 between 300 and 1000 fathoms, II between 1000 and 2000 fathoms, and 4 beyond 2000 fathoms. Most of these were 
represented by few specimens, though widely distributed. Hardly any of the "Challenger" species described by G. O. Sars are found in the Norwegian Sea.

The Schizopoda play a great part in northern waters, where the numerous species occur in enormous numbers, sometimes near the bottom and sometimes near the surface ; the fishermen term them "Kril." They

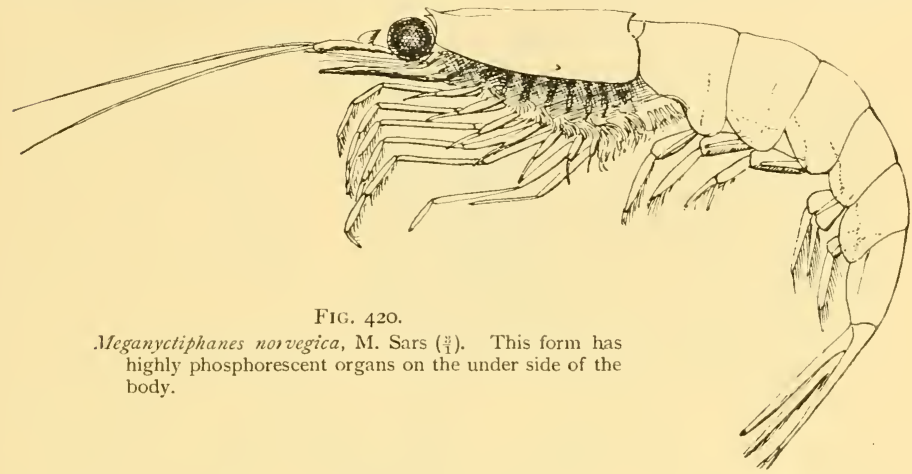

are mostly colourless, transparent, with large red spots around the mouth, and have generally the appearance of small prawns with black stalked eyes. The most important species are Meganyctiphanes norvegica (Fig. 420) and Thysanoèssa longicaudata. The closing-net samples determined by Sars included some Schizopoda,

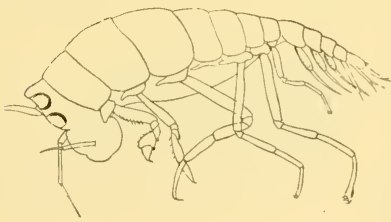

FIG. 421 .

Scypholanceola agassizii, Woltereck. (From Woltereck.)

Amphipoda, and Isopoda (see list, pp. $654-655)$.

The great majority of the species of Amphipoda. Amphipoda inhabit the warm oceans, where they occur mostly in the upper 400 metres of water. Woltereck has described some very remarkable deepwater forms belonging to the genera Lanceola and Scypholanceola (Fig. 42I). The members of the latter genus have light-reflecting eyes, the retina of which is entirely transformed and provided with peculiar cornet-shaped reflectors. They were previously considered rare, but according to Woltereck, who is describing our material, they were taken in great quantities during the cruise of the "Michael Sars." Another deep-sea form is the large transparent Cystosoma with splendid red eyes, which was taken in both our southern and northern sections in depths exceeding 500 metres (Fig. 422). One of the most striking types is the genus Phronima, of the family Hyperidæ. Most of the Hyperidæ make themselves a house of the empty mantle of a Salpa or Doliolum, and lay their eggs in the 
barrel-shaped abode (see Fig. 423). Phronima was taken in great quantities in the surface waters during our southern and northern sections across the Atlantic.

In the Norwegian Sea two forms are very important: Parathemisto oblivia (Fig. 424), which lives in the open sea, frequently even in very cold water, and also in the Norwegian fjords; and Euthemisto libellula, which sometimes attains a length of $4 \frac{1}{2} \mathrm{~cm}$., and lives in the icy waters of the

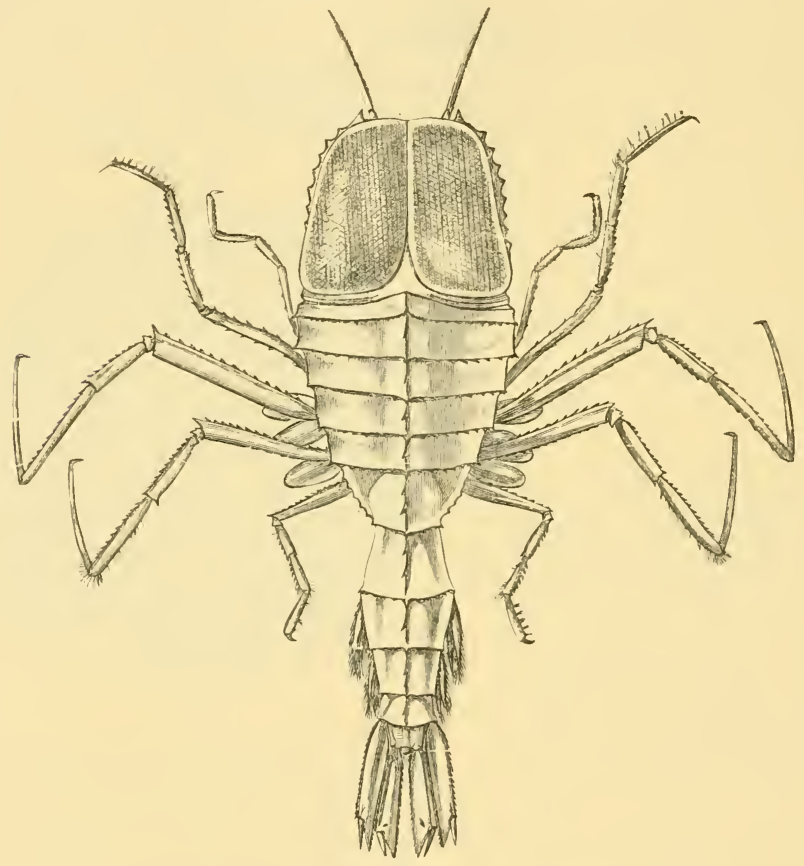

F1G. 422.

Cystosoma neptuni, Guérin-Ménéville. (After Wyville Thomson.)

Polar Sea. Both these forms were taken also in the Atlantic, but only in boreal areas (see list, pp. 654-655). A form which lives at great depths in the Norwegian Sea is Cyclocaris guilelmi, taken by the Prince of Monaco off the Lofotens and described by Gran.

Isopoda.

While capturing turtles at Station 56 we observed a great number of deep-blue Isopoda belonging to the species Idotea metallica.

Decapoda. The Decapoda include nearly all the large types of crustaceans, like prawns, lobsters, crayfish, crabs, etc. The first deep-sea expeditions captured a considerable number of decapod crustaceans in the trawls at 
great depths, and they were consequently supposed to be bottom-dwellers. Subsequently the Prince of Monaco, and later the "Valdivia," took in pelagic tow-nets a number of forms belonging chiefly to the family Sergestidæ, and to the genera Acanthephyra, Notostomus, and Eryoneicus, all of which were thus proved to lead a pelagic life. The "Valdivia" took Sergestes in a haul with a closing net from 5000 to 4000 metres, and Chun states in his narrative of the cruise that whenever the vertical nets reached deep water this genus never failed to appear in the hauls.

During the Atlantic cruise of the "Michael Sars" we obtained large red prawns in such abundance (several litres per haul) as to prove that these animals play a more important part in pelagic life than was previously supposed. Our catches are also of special interest, be-

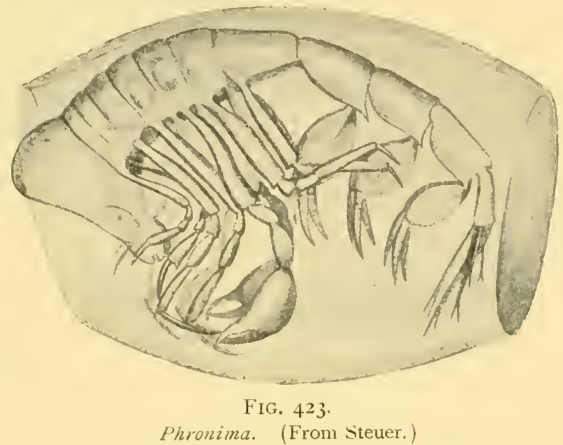
cause their study has thrown new light upon the vertical distribution of the different species. We may here mention some of the most important forms recorded by Oscar Sund, who is describing this group.

Of pelagic decapoda more than forty species were taken during our expedition, but the great bulk is made up of about a dozen species, each of which has a wide geographical range, being regularly caught at all

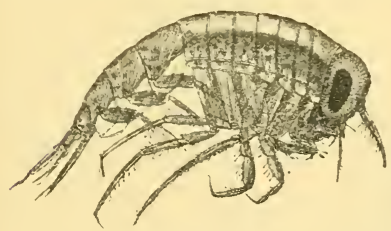

FIG. 424 .

Parathemisto oblizia, Kröyer ( $\left(\begin{array}{l}4 \\ 1\end{array}\right)$. (From Sars.) stations over vast areas. Most of these common species, which will be dealt with later on, present peculiarities in their biology and distribution.

Most of the pelagic decapoda belong to the more primitive divisions of the group, viz. Sergestidæ, Peneidæ, Pasiphæidæ, and Hoplophoridæ, but a truly pelagic Pandalid (Plesionika nana, n. sp.) was taken at most of the stations from Spain to Newfoundland.

The genus Acanthephyra of the Hoplophoridæ (see Plate III. Chapter X.) includes large red prawn-like forms, of which no less than eight different species were taken. On the section between Newfoundland and Ireland the two species $A$. purpurea and A. multispina were in special abundance.

Before the cruise of the "Michael Sars" only fifteen individuals belonging to the genus Notostomus, representing no less than thirteen species, had been recorded. We procured nineteen individuals in the North Atlantic belonging to five species, of which four are new to 
science. One of these new species is represented by a specimen $17 \mathrm{~cm}$. long (see Fig. 425) - one of the largest pelagic prawn ever taken. Notostomus was taken only in the deepest hauls, which only extended down to 1500 or 2000 metres; perhaps hauls in still deeper water might have

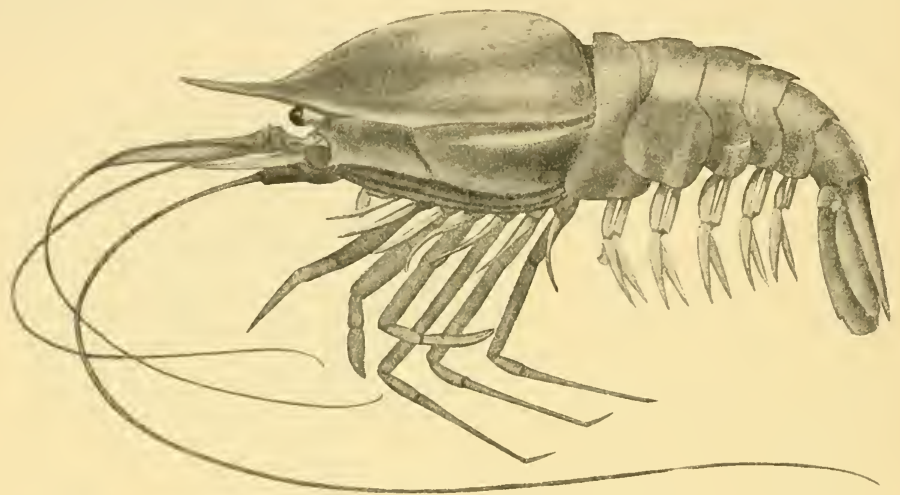

FIG. 425 .

Notostomus, n. sp. Nat. size, $17 \mathrm{~cm}$.

yielded more of them. Still larger are the bottom-living Peneidæ, of which a whole tubful were taken south of the Canaries in our trawl

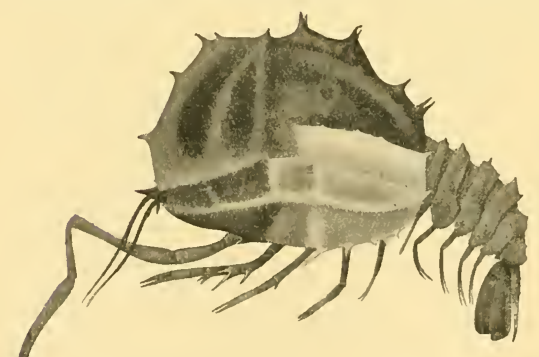

FiG. 426.

Eryoneicus cacus, Spence Bate. (From Faxon.) (Station 4I, 2605 metres), some of them 30 to $40 \mathrm{~cm}$. long, with feelers 4 or 5 feet long.

One of the most remarkable genera is Eryoneicus, of which twelve species are known, easily recognisable by their inflated balloon-like bodies (see Fig. 426). They are allied to Pentacheles, Polycheles (Fig. 427), etc., and Sund, after examining the twenty-four specimens collected by the "Michael Sars," expects to beable to show that they are really the larvæ of these abyssal bottom-living decapoda. Thus, what might be regarded as a new species of Eryoneicus is in reality a larval stage of a previously known decapod, Polycheles sculptus.

During the first cruise of the "Michael Sars" in the Norwegian Sea I succeeded in capturing the two species Pasiphaa princeps and Hymenodora glacialis (Fig. 428) in deep hauls. Pasiphaa probably lives sometimes on the bottom, sometimes in midwater, and is common in Norwegian 
fjords along with numerous species of Pandalus, "the deep-water prawns,"

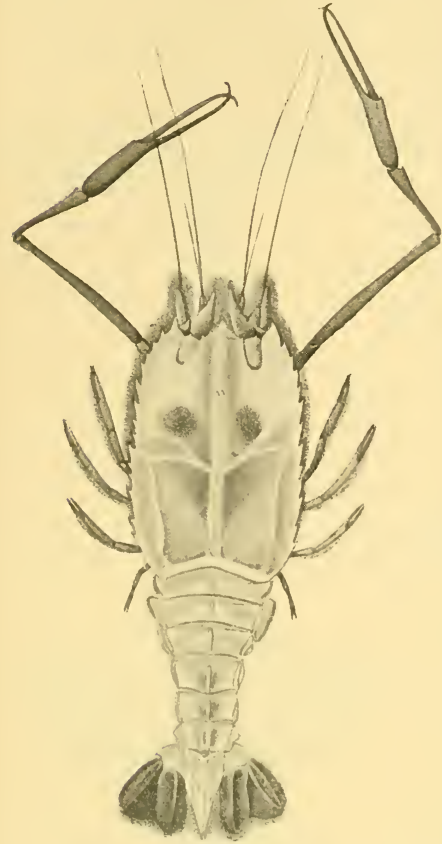

FIG. 427 . which are now the object of important fisheries. Hymenodora is known even from the ice-region, and was met with by Scoresby during his arctic voyages. ${ }^{\mathrm{I}}$

Though the Mollusca are widely distributed and represented by a vast number of different forms on the ocean-floor, the pelagic forms are comparatively few, but as regards abundance of individuals few groups of pelagic animals can compare with the winged snails or Pteropoda, which are divided into two groups: Thecosomata (or shelled pteropods) and Gymnosomata (or Pteropoda. naked pteropods).

The Thecosomata are important on account of the part they play both in the plankton and in the bottom-deposits (see Chapter IV.). They include the family Limacinidæ having a spiral shell, of which the well-known Limacina helicina occurs in immense quantities in the Arctic (the seas around Spitsbergen and Greenland), while Limacina balea, the "Flueaat" of Norwegian fishermen, is a boreal species, and Limacina retroversa (Fig. 429) is a Polycheles sculptus pacificus, Fax. (From Faxon.) more southern form occurring also in
the Norwegian Sea. The shell is about the size of a pin's head, and can

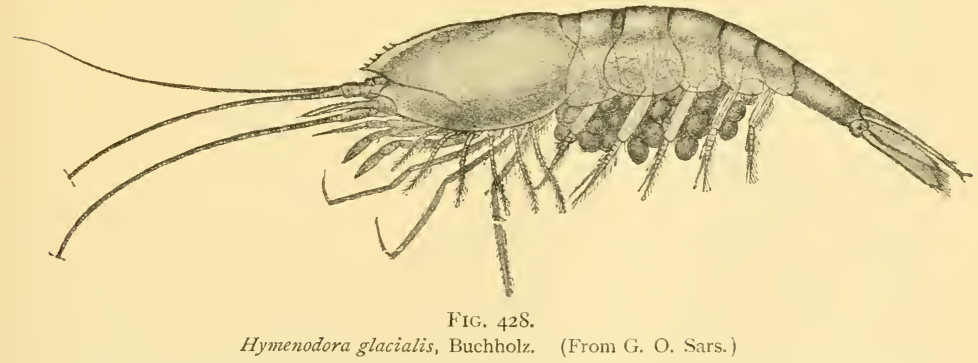

1 In the pelagic life of the ocean the Insecta are represented only by several species of Hemiptera (Halobates and Halobatodes), which are found skimming over the surface in the tropical regions. 
barely be seen in the sea with the naked eye. The two last-mentioned forms are found in warm currents on the coast of Norway, and their presence is feared by the fishermen, because they very often spoil the herring which feed on them; the shells are very slowly digested and the stomach-contents putrify when the herrings are salted, and then the whole herring decomposes. Among the many warmwater species Limacina bulimoides is characteristic. The Cavolinidæ include numerous forms with cornet-shaped shells. Clio pyramidata (Fig. 430) and Diacria trispinosa are very important forms, occurring in vast numbers, and their shells are very numerous in the deposits. Creseis

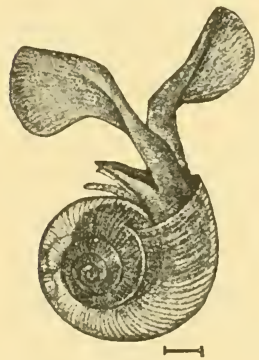

FIG. 429.

Limacina retroversa, Fleming. (From Sars.)

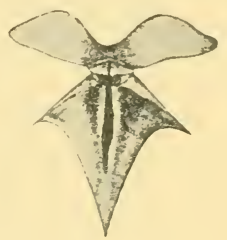

FIG. 430.

Clio pyramidata, L.

(From Boas.)

acicula (Fig. 43I) and Cavolinia gibbosa (Fig. 432) are characteristic forms.

The "whale's food," Clione limacina (Fig. 433), is specially abundant in northern waters, and is better known than most of the Gymnosomata. It is 3 or $4 \mathrm{~cm}$. long, perfectly transparent, with red shadings and black stomach. In the Polar Sea it may be seen swimming among the ice-floes, but it occurs also in the Norwegian Sea, in the Norwegian fjords, and in the Atlantic south of Iceland.

The majority of the pteropoda (both species and individuals) are restricted to

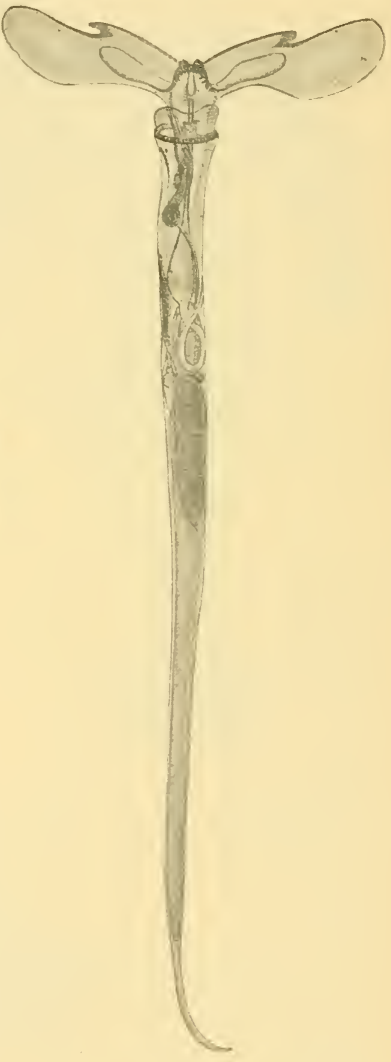

FIG. 43I.

Creseis acicula, Rang. (From Meisenheimer.)

warm water: in the Atlantic the northern limit for the warmwater forms may be roughly drawn from the Bay of Biscay to New York, and the southern limit from Brazil to the Cape. This area is the real home of Clio pyramidata, C. cuspidata, Creseis acicula, the Cavolinidæ, the Cymbulidæ, Pneumoderma violaceum, Limacina inflata, L. lesueuri, L. bulimoides. As with the radiolaria and copepoda, many 
of these warm-water species of pteropoda are also known from the Indian and Pacific Oceans, where their geographical distribution is similar to that in the Atlantic. North of lat. 45 or $46^{\circ} \mathrm{N}$. we meet with only a few of the warmwater forms, Creseis acicula and Clio cuspidata having been taken in isolated specimens up to $60^{\circ} \mathrm{N}$. Typical denizens of this region are Clio pyramidata and Diacria trispinosa, which appear to be as numerous as under the equator. The northern forms Limacina helicina and L. balea, as well as Clione limacina, also occur in the northern part of the Atlantic. In the Antarctic we find species which are very similar to the northern ones.

Meisenheimer, ${ }^{1}$ who reported on the pteropoda of the "Valdivia" Expedition, is of opinion that the horizontal and vertical distribution of the pteropoda depends mainly on the temperature. Most of the species require a high temperature, and for this reason the majority live in the surface layers.

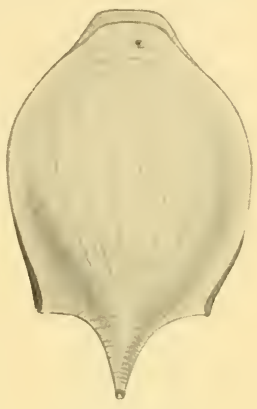

FIG, 432.

Cavolinia gibbosa, Rang. (From Meisenheimer.) Only exceptionally do they occur as deep as Iooo metres, and this is specially the case in the Mediterranean, where high temperatures prevail

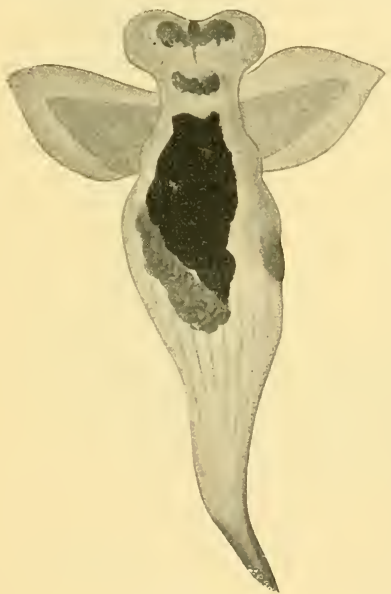

FIG. 433 . to very considerable depths. During our Atlantic cruise we found some real deep-sea forms : Peraclis diversa, Limacina helicoides, and Clio falcata, which occurred only between 500 and 1500 metres.

During the Atlantic cruise of the "Michael Sars" pteropoda were taken in thousands, and this material has been examined by Bonnevie, who records the following species :-

The Thecosomata include:-Limacinidæ: Limacina balea, $L$. retroversa, $L$. bulimoides, L. inflata, L. lesueuri, L. helicina, L. helicoides, Peraclis reticulata, P. triacantha, P. diversa, and Procymbulia sp. Cavolinidæ: Clio pyramidata, C. cuspidata, C. falcata, Creseis acicula, Styliola subula, Hyalocylix striata, Cuvierina columnella, Diacria trispinosa, D. quadridentata, Cavolinia inflexa, C. gibbosa, C. longirostris, C. tridentata, C. uncinata. Cymbulidæ: Cymbulia Clione limacina, Phipps. (From|Vanhöffen.) peronï.

The Gymnosomata comprise, besides Pneumodermopsis macrochira and Clione limacina, several new species not yet described.

Of other Mollusca I may mention the beautiful surface forms:

1 Meisenheimer, Wiss. Ergeb. "Valdivia" Expedition, Bd. 9, 1905. 
Ianthina, Carinaria (see Fig. 122, p. I54), Pterotrachea (see Fig. 123, p. I54), and Glaucus, which were taken in abundance in the southern section of our Atlantic cruise.

Of the large group of Cephalopoda (squids and cuttle-fishes) previous expeditions obtained very few in their small tow-nets, those captured being generally taken in the bottom trawls, and it was uncertain whether they lived at the bottom, or in intermediate depths, or near the surface. It has long been recognised, however, that many Cephalopoda are true pelagic animals, and in the sixties of last century Japetus Steenstrup applied the term "Decapodes pelagici" to the group CEgopsidæ. The Prince of Monaco not only captured Cephalopods in his pelagic trawls, but also obtained them from the stomachs of whales which he shot, his material being reported on by Joubin. ${ }^{1}$ During the "Valdivia" Expedition the large vertical nets captured a wealth of new forms belonging especially to small types, and Chun in his narrative draws attention to the remarkable Cranchiidæ and the little Spirula. Chun has recently published the first part of his report on the "Valdivia" collections of Cephalopoda, dealing with the CEgopsidæ. ${ }^{2}$

It was a special pleasure to me that Chun undertook to describe the Cephalopoda obtained during our Atlantic cruise, and his report, which has just been completed, is available for this preliminary record of the results. His determinations are given in the list on pp. 595-597, and comprise 43 species in all, 3 or 4 of which are new to science, besides some larval forms, the identity of which is uncertain.

The Cephalopoda are generally divided into two groups according to the number of tentacles, those with ten arms or tentacles being termed Decapoda, and those with eight tentacles Octopoda; the Decapoda are subdivided into CEgopsidæ and Myopsidæ.

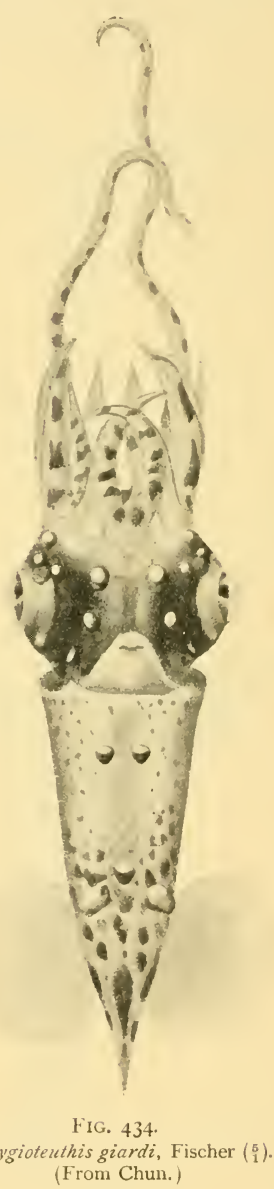

Pterygioteuthis giardi, Fischer ( $\left.\begin{array}{l}5 \\ 1\end{array}\right)$. The Myopsidæ and all the Octopoda have a membrane covering the eye, but in the CEgopsidæ this is perforated.

'Joubin, "Céphalopodes provenant des campagnes de la Princesse-Alice," Campagnes scientifiques du Prince de Monaco, Fasc. xvii., 1900.

2 Chun, Wiss. Ergeb. "Valdivia" Expedition, Bd. 18, 1910. 
Most pelagic squids belong to the Egopsidæ, which present a wealth of forms ranging from minute fantastically shaped deep-sea species to the giant squids.

The Enoploteuthidæ obtained by us are small forms previously known from the Atlantic and Indian Oceans. The general occurrence of Pterygioteuthis giardi (see Fig. 434) seems to justify the conclusion that it is a very common pelagic species, inhabiting the open ocean far from land; it is provided with light-organs. The larvæ belonging to this

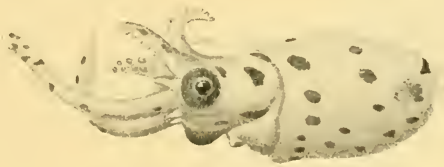

FIG. 435 .

Larva of Enoploteuthidx $\left(\begin{array}{c}10 \\ 1\end{array}\right)$. (From Chun.)

family are very abundant in the North Atlantic (see Fig. 435).

Of the family Onychoteuthidæ many undetermined larvæ have been taken by the "Michael Sars," which are of great interest as proving the occurrence of this group; a larval form taken by the "Valdivia" is shown in Fig. 436. Onychoteuthis banksii occurs from the Mediterranean to the Kattegat and Skagerrack and along the entire coast of Norway. Octopodoteuthis sicula

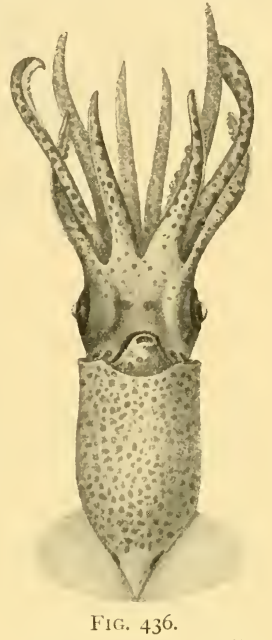

Young of Teleoteuthis caribea, Les. $\left(\frac{3}{1}\right)$. (From Chun.) and Calliteuthis reversa are minute forms, the former known from the north-eastern part of the Atlantic, while the latter is widely distributed in the surface waters of the Indian and Pacific Oceans, and has

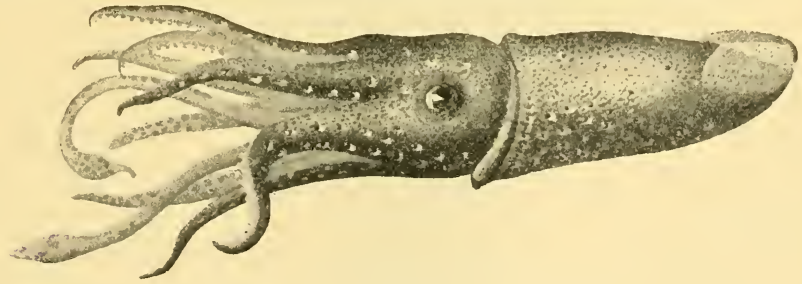

FIG. 437 .

Calliteuthis reversa, Verrill $\left(\frac{2}{1}\right)$. (From Chun.)

light-organs (see Fig. 437). Ctenopteryx siculus, Brachioteuthis riisei, and the three species of Doratopsis are small and live presumably in the upper water-layers. Doratopsis exophthalmica (Fig. 438) is noticeable on account of its remarkable eyes (see Fig. 439).

The families Ommatostrephidæ, Gonatidæ, and Chiroteuthidæ 
include mostly large forms, belonging to a biological group of squids (comprising the family of giant squids, Architeuthidx), the members of which are among the pirates of the ocean, and in their turn fall a prey to the large squid-hunting whales. Illex illecebrosus and Ommatostrephes todarus are northern forms, of great importance on the banks of Newfoundland, and along the coasts of Iceland and Norway, as Gonatus fabricii (see Fig. 98, p. I13) is the squid of the "bottle-nose grounds" in the Norwegian Sea. Todaropsis eblane and Ommatostrephes sagittatus extend nearly as far north as the southern borders of the Norwegian Sea.

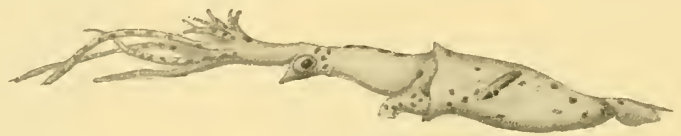

FIG. 438 .

Doratopsis exophthalmica, Chun $\left(\frac{3}{1}\right)$. (From Chun.)

Mastigoteuthis, Grimalditeuthis, and Chiroteuthis are large squids, some of which were captured by the Prince of Monaco around the Azores, Madeira, and Canaries. Grimalditeuthis richardi described by Joubin, proves to be identical with $G$. bonplandi (see Fig. 440) taken by the "Michael Sars." A new species is described by Chun under the name of Mastigoteuthis hjorti. We succeeded in catching adults as well as larvæ of the Ommatostrephidæ and Gonatidæ; Chun has described the interesting larva of Ommatostrephes (see Fig. 44I), taken in the southern

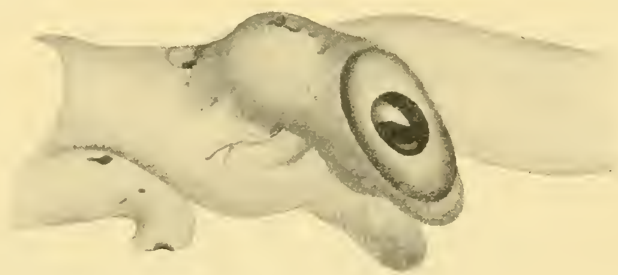

FIG. 439 .

Head of Doratopsis lippula, Chun.

section of our Atlantic cruise, in which the two long tentacles are united into a tube.

In the Cranchiidæ we have an entirely different group of wonderful deep-sea forms, which probably undertake extensive vertical migrations ; some of these, for instance Corynomma speculator, Toxenma belone (Fig. 442), and Bathothauma lyromma (Fig. 443), were taken in the Indian Ocean by the "Valdivia."

Among the Myopsidæ I mention first the interesting form Spirula australis (see Fig. 60, p. 8I), of which only three specimens had previously been taken: one in the Pacific by the "Challenger," one off North America by the "Blake," and one in the Indian Ocean by the 


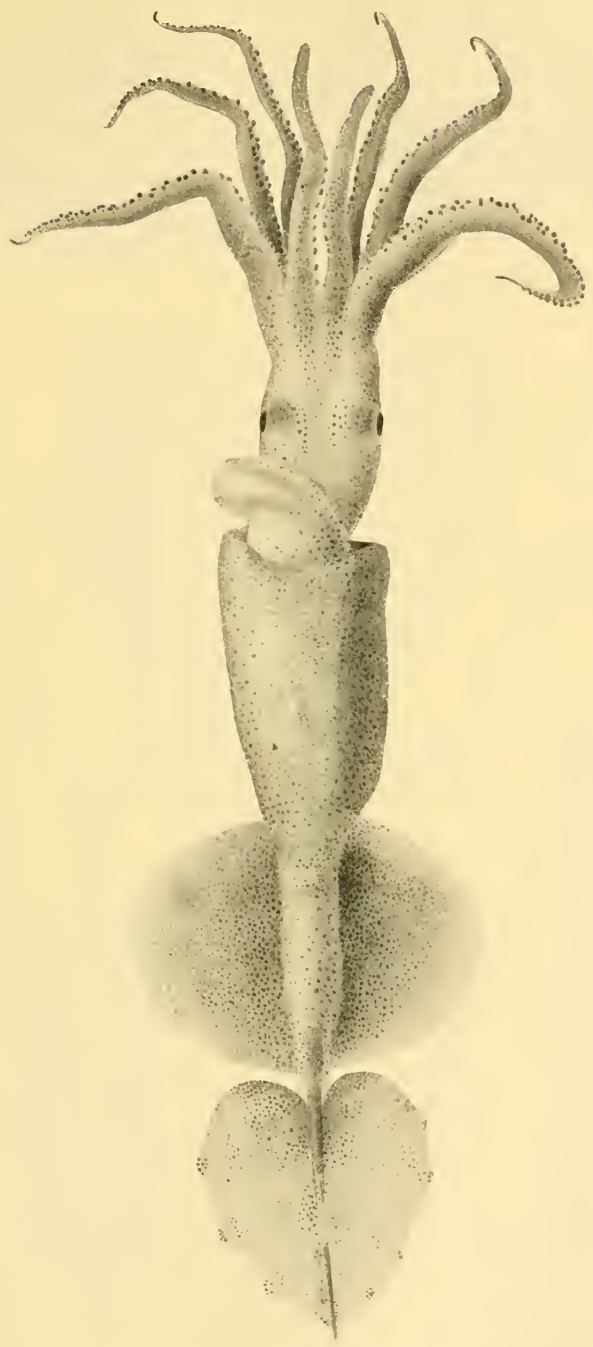

FIG. 440 .

Grimalditeuthis bonplandi, Vérany. Half nat. size. (From Joubin.) 
"Valdivia." The "Michael Sars" captured no less than seven specimens,

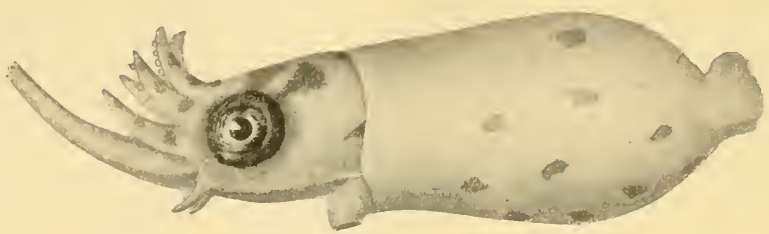

FIG. 44 I.

Larva of Ommatostrephes ( $\left.\frac{10}{1}\right)$. (From Chun.)

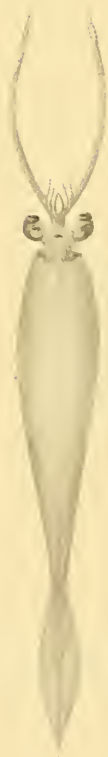

FIG. 442.

Toxeuma belone, Chun. About nat. size. (From Chun.)

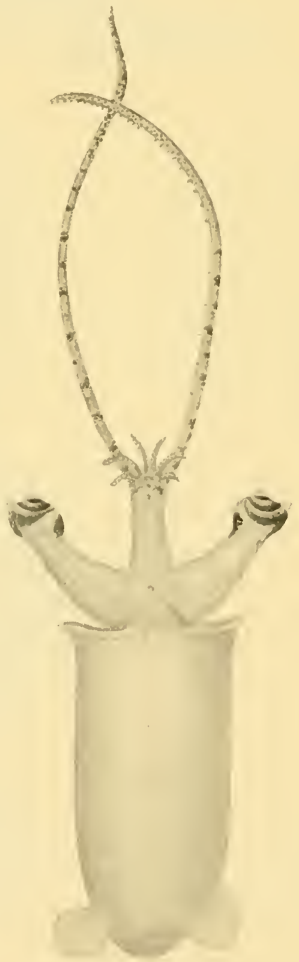

FIG. 443 .

Bathothauma lyromma, Chun. Two-thirds nat. size. (From Chum.)

in different interesting stages of development, around the Canaries and 
on the track to the Azores. In all probability this form is bathypelagic. Of other Myopsidæ the genera Sepiola, Rossia, Loligo, and Sepia have been captured only in trawls along the bottom. The same remark applies to the genera Octopus and Cirroteuthis, belonging to the Octopoda. A large new species, named by Chun Octopus (Polypus) lothei, was taken in the trawl south of the Canaries in 2600 metres of water. Interesting pelagic forms of Octopoda were also met with ; for instance: Tremoctopus, Eledonella, Bolitena, Opisthoteuthis, Vampyroteuthis, and Cirrothauma. The two last mentioned are probably the most interesting. Vampyroteuthis infernalis, a fantastic deep-sea form, had previously been taken by the

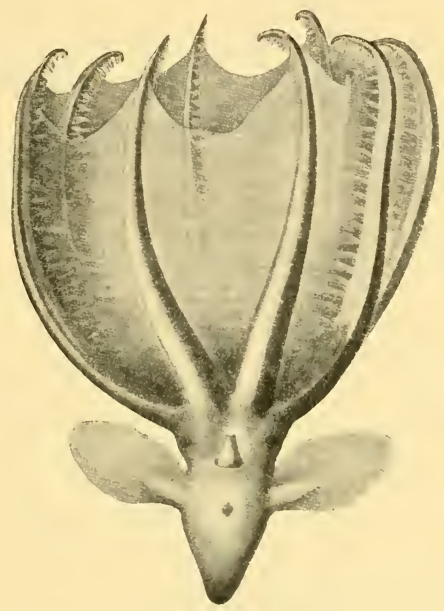

FIG. 444 .

Cirrothauma murrayi, Chun. About half nat. size. (From Chun.)

"Valdivia." Cirrothauma murrayi (Fig. 444) is a new species taken at great depths in our northern section. It is as fragile as a Ctenophore, and of a jelly-like consistency, its structure being exceedingly interesting and unlike that of any previously known squid. It is, besides, the only blind squid known, and has therefore been exhaustively treated by Chun in his report on our material.

\section{CEPHALOPODA DECAPODA}

\section{A. GEGOPSID}

\section{ENOPLOTEUTHIDE}

Abraliopsis morisii, Vérany, Station 23.

Pterygioteuthis giardi, Fisch., Stations I $_{5}, 29,35,45,49,51,52,53,54,56,62$, $64,67,8 \mathrm{I}, 87$.

Larvæ of Enoploteuthidæ, Stations 45, 47, 48, 5 I , 53, 56, 58, 62, 67, 81, 82, 84 . 


\section{ONYCHOTEUTHID正}

Larvæ of Egopsidæ, mostly Onychoteuthidæ, Stations 10, 29, 32, 49, 5 1, 52, 57 , $64,82,88$.

\section{VERANYIDF}

Octopodoteuthis sicula, Rüppell, Station 90.

\section{HistioteuthiDE}

Calliteuthis reversa, Verrill, Stations 42, 49, 5I, 52, 58, 62, 70, 80, 81, 82, 84, 92.

\section{OMMATOSTREPHIDE}

Illex illecebrosus, Les., Stations 3.3, 39, Newfoundland Bank.

Todaropsis eblance, Bal., Station 33.

Ommatostrephes sagittatus, Lam., Station i I 5 .

Larvæ of Ommatostrephidæ (Rhynchotenthis), Stations 48, 56, 67 .

\section{Gonatid}

Gonatus fabricii, Lichtenst., Stations 70, 80, 81, 94.

\section{BATHYTEUTHIDE}

Ctenopteryx sicums, Rüppell and Vérany, Stations $56,88$.

TRACHELOTEUTH1DE

Brachioteuthis riisei, Steenstrup, Stations 45, 51, 52, 53, 62, 64, 67, 84, 88 .

\section{Chiroteuthid}

Mastigoteuthis flammea, Chun, Stations 29, 64.

Larvæ probably of the preceding, Stations 35, 5 I, 53, 84.

Mastigoteuthis grimaldii, Fisch. (Joubin), Stations 64, 67, 81, 82 .

Mastigoteuthis hjorti, 11.sp., Stations 52, 62, 63 (?).

Grimalditeuthis bonplandi, Vérany, Station 53.

Doratopsis vermicularis, Vérany, Station 64.

Doratopsis lippula, Chun, Station $5 \mathrm{I}$.

Doratopsis exophthalmica, Chun, Station 90.

Young stages probably of the preceding, Stations 53, 88, 94.

Young stages of the genus Doratopsis, Stations 23, 53, 56, 58, 8 I, 90.

\section{Cranchilde}

Cranchia scabra, Leach, Stations 5 I, 52.

Leachia cyclura, Les., Stations 23, 64 .

Desmoteuthis pellucida, Chun, Stations го, 45, 67, 98, гог.

Corynomma speculator, Chun, Stations 5 I, 64 .

Teuthonenia megalops, Prosch., Stations ro, 45, 5i , 58, 63, 64 .

Toxeuma belone, Chun, Stations 498, 51, 53, 67.

Galiteuthis suhmii, Hoyle, Station 64 .

Bathothauma lyromma, Chun. 


\section{B. MYOPSID在}

\section{SPIRULIDÆ}

Spirula australis, Lam., Stations 34, 35, 42, 44, 45 .

SEPIOLID

Heteroteuthis dispar, Rüppell, Stations 42, 56, 58 .

Sepiola rondelettii, d'Orbigny, Stations 39, 96.

Rossia caroli, Joubin, Station 70.

\section{LOLIGINIDE}

Loligo media, L., Stations I 4, 20.

Loligo forliesi, Steenstr., Station 39.

SEPHDE

Sepia d Orbignyi, Férussac, Station 33.

Sepia officinalis, L., Station 37.

\section{CEPHALOPODA OCTOPODA}

\section{PHILONEXIDE}

Tremoctopus atlanticus, d'Orbigny, Stations 51, 53, 62 . Argonauta sp., Stations 45, 49B.

Larvæ, either of Tremoctopus or Argonauta, Stations 95, 98, гог.

POLYPODIDE

Octopus (Polypus), n.sp., Station 58 .

Octopus (Polvpus) lothei, n.sp., Station 41.

\section{BOLITANIDE}

Eledonella pygmaa, Verrill, Stations 45, 53, 62.

Bolitena diaphana, Hoyle, Stations 35, 53, 56, 64, 92.

\section{Cirroteuthide}

Opisthotenthis agassizii, Verrill, Station 4.

Cirroteuthis umbellata, Fischer, Stations 25, 5.3, 70.

Vampyroteuthis infernalis, Chun, Stations $5 \mathrm{I}, 57$.

Cirrothauma murraji, n.sp., Station 82 .

The Tunicata have been so termed from the gelatinous mantle or tunic Tunicata. surrounding their body, which is composed of a peculiar substance, " tunicin," supposed to be closely related to cellulose. All Tunicata have pelagic larvæ, which have long attracted the interest of zoologists, because their central nervous system (medullar tube), sense organs, and axial skeleton present a striking likeness to the lower vertebrates or to the early embryonal stages of the vertebrates. Among the Tunicata there is a large group, the Ascidians, which at the close of larval 
life fix themselves to the bottom and become sessile, like the Hydro-

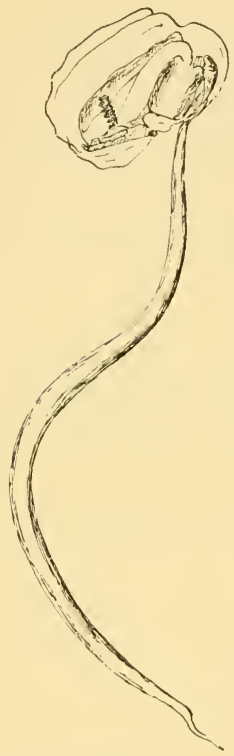

FI(s. 445 .

Oikopleura labradoriensis, Lohm (about $\frac{10}{1}$ ).

(From Lohmann.) medusæ, forming colonies by budding. They are thus meropelagic, whereas all other Tunicata are holopelagic and perfectly independent of the bottom. These latter are the only ones to be dealt with here, viz. Appendicularians, Salpæ, and the genera Doliolum and Pyrosoma.

The Appendicularia resemble greatly the larvæ of Ascidians, and present a remarkable likeness to early vertebrate types. As a rule they are transparent and perfectly devoid of colour. Their body (see Fig. 445) is clumsy in shape and contains all the organs of nutrition and propagation, with a long elastic tail which serves solely the purpose of locomotion. Lohmann has studied the biology of this group, ${ }^{2}$ and his results will be referred to later. The Appendicularians live mostly in the upper 200 metres of the ocean, though in tropical waters they occur deeper; in fact in the Sargasso Sea the German Plankton Expedition found more of them below than above 200 metres. As with most surface forms the species are most abundant in warm waters, like Appendicularia sicula, Fritillaria venusta, and Oikopleura parva, while Oikopleura vanlioffeni and $O$. labradoriensis are northern forms.

The Salpæ are free-swimming, barrel-shaped, transparent animals, well-known to all sea-faring people (Fig. 446). They are often seen crowding the surface-waters of the ocean in countless numbers. Among investigations of recent years we may cite the report on the "Valdivia" collection by Apstein. ${ }^{2}$ In hauls with closing nets the "Valdivia" found the majority of Salpæ in depths less than 200 metres.

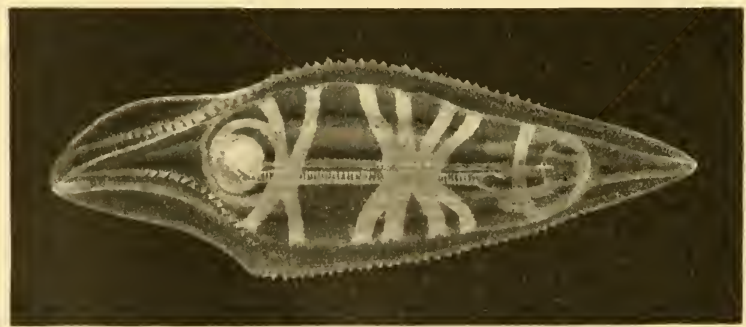

FIG. 446.

Salpa fusiformis forma aspera, Cham. Nat. size.

1 Lohmann, Ergeb. Plankton-Expedition, Bd. 2, I896.

2. Apstein, Wiss. Ergeb. "Valdivia" Expedition, Bd. 12, 1906. 
Only exceptionally, and chiefly in the Antarctic, forms were found between 1500 and 1000 metres that in warm waters live at the surface. The Salpæ are individually most abundant in warm water, and in the Atlantic we do not find a single species which is peculiar to the area north of lat. $45^{\circ} \mathrm{N}$. Apstein tells us that three species have been found in the northern region, viz. Salpa fusiformis, S. mucronata, and S. zonaria, but they really belong to warm waters and have been carried north by currents (see Fig. 447). The genus Cyclosalpa comprises typical warm-water forms.

The genus Doliolum is also, according to Neumann's ${ }^{1}$ treatise on the "Valdivia" collection, chiefly a warm-water form exceedingly sensitive to changes of temperature. Doliolum krolmi, D. tritonis,

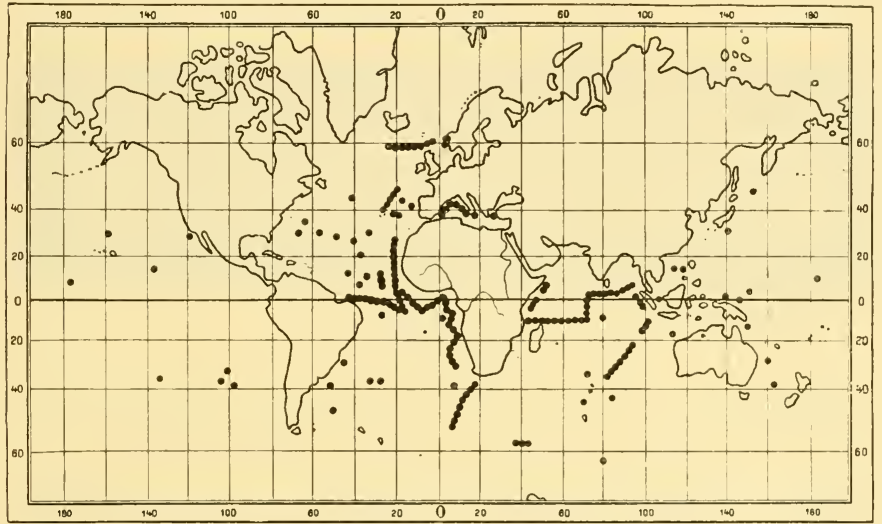

Fig. 447.-DistribUtion OF SALPA FUSIFORMIS.

(From Apstein.)

D. miilleri, and D. gegenbauri are the species which go farthest north in the Atlantic.

The genus Pyrosoma (Fig. 448) has from the earliest days of oceanography attracted the interest of man, to a great extent on account of the strong phosphorescent light emitted, the name meaning "fire-animal." The individuals are aggregated into cylindrical colonies, which may attain an enormous size (several yards long). Some occur in the surface-waters, some in deep water.

In the narrative of the "Challenger" cruise, Sir John Murray, describing the voyage from the Bermudas to the Azores, writes as follows :- "On the 25th (of June) a very large colony of a new species of Pyrosoma was captured in the trawl. The cylinder was 4 feet 2 inches in length and $\mathrm{I} O$ inches in diameter, closed at one end, and as in the

\footnotetext{
1 Neumann, Wiss. Ergeb. Valdivia-Expedition, Bd. 12, 1906.
} 
smaller forms, the colony was spotted with red, the red spots being the visceral nuclei of the several animals. The specimen was kept in a tub of water till after dark, when it gave off brilliant phosphorescent light on being disturbed. The officers amused themselves by writing their names along this living cylinder with one finger, the track of which remained as a bright line of light for some seconds. Salpæ were the commonest animals in the surface waters; there were several kinds, and many long bands of them in the chain form were taken in the surface nets. Brilliant phosphorescence was observed at night during calm weather." 1 During the Atlantic cruise of the "Michael Sars" great quantities of Salpæ, Doliolum and Pyrosoma, were captured. The collections have been examined by Bjerkan, to whom I am indebted for the following list, which shows that many of the species are widely distributed in the North Atlantic. Excluding the Appendicularia, which have not yet been

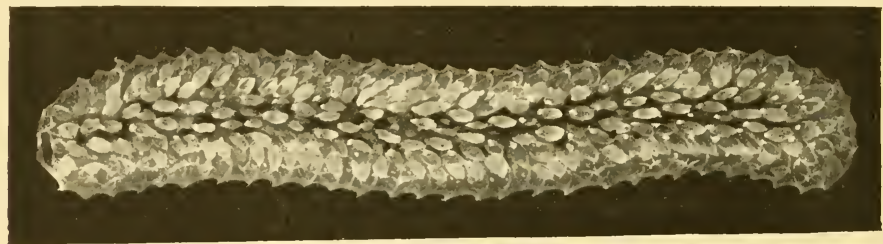

FIG. 448.

Pyrosoma spinosum, Herdman. Nat. size.

investigated, seventeen species were taken during the cruise, of which seven were taken to the north as well as to the south of the Azores.

Cyclosalpa pinnata, Forsk., Stations $56,57,5^{8}, 59,86,88$.

Cyclosalpa floridana, Apstein, Stations 22, 25, 29.

Salpa maxima, Forsk., Stations 29, 33, 34, 35, 42, 43, 52, 56, 62, 66, 86, 88.

Salpa fusiformis, Cuv., Stations 10, I 9, 31, 39, 5 I, 52, 53, 56, 58, 67, 81, 82, 84 .

$86,87,88,90,92,94,97,98$, 100, 101, 102.

Salpa fusiformis forma aspera, Cham., ${ }^{2}$ Stations 10, 15, 19, 24, 25, 29, 32, 5 I, $58,62,67,84,87,88,90,92$.

Salpa amboinensis, Apstein, Stations $19,23,49,56,58$.

Salpa mucronata, Forsk., Stations $32,43,44,45,50,56,57,58,59,67,8_{3}, 8_{7}$.

Salpa confoderata, Forsk., Stations 3I, 40, 42, 43, 5I , 69, 8I, 84, 86, 88.

Salpa zonaria, Pall., Stations 1o, I5, 22, 23, 25, 29, 42, 43, 56, 62, 66, 67, 71, So,

8 I, 82, 84, 88, 97, 102 .

Salpa tilesii, Cuv., Station 10.

Salpa henseni, Traustedt, Stations ${ }_{5}^{6},{ }_{5}^{8}$.

Doliolum tritonis, Herdman, Stations 88, 90, 92, 94, 98, 100, гог.

Doliolum sp., Stations 23, 25, 29, 32, 34, 44, 48, 49, 56, 67, 84 .

Pyrosoma spinosum, Herdman, Stations 10, 39, 51, 62, 64, 67, 81, 84, 87, 88, 90.

Pyrosoma giganteum, Lesueur, Stations 29, 48, 87, 88.

Pyrosoma atlanticum, Péron, Stations 42, 47, 56, $5^{8}$.

Pyrosoma, n.sp., Stations 49, 56, 88.

1 Narrative Chall. Exp., vol. i. p. 170, 1885.

2 Previously forma echinata (Herdman). 
As indicated in Chapter VII., zoologists have until lately been un- Fishes. able to decide what species of fishes live along the bottom, and what species belong to the intermediate and surface waters. In recent years our knowledge has greatly increased. The "Valdivia" Expedition took no less than I5 I species in pelagic fishing appliances. ${ }^{1}$ Many of these have raised considerable interest on account of their curious shapes, especially the so-called "deep-sea fishes," which were supposed to live in the great depths of the ocean.

During the cruise of the "Michael Sars" probably about I0,000 specimens of pelagic fishes were taken, exclusive of the many larvæ and young stages. This abundant material has not yet been worked up, and complete lists, even of the adult fishes, are not available. Of the Scopelidæe (including the genus Myctophum), the genus Melamphä̈s and different Stomiatidæ, only a limited number of species have been dealt with, many of the species being new, while the larvæ and young fish have as yet only been divided into certain groups. Nevertheless, the following list is of interest, as it indicates a great advance

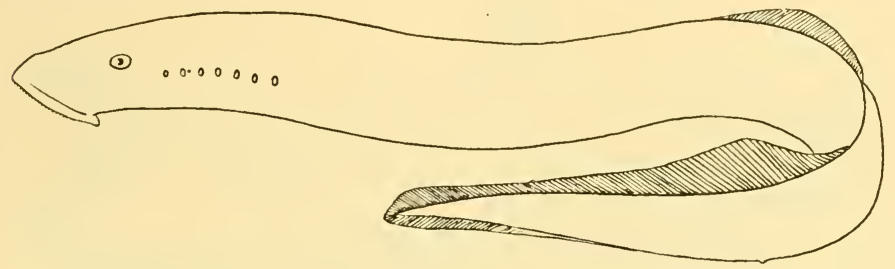

FIG. 449.

Petromyzon marinus, L. (From Goode and Bean.)

in our knowledge of the fishes of the North Atlantic; though the collections of the "Michael Sars" are deficient as regards the coastal and northern waters of the Atlantic, much information has been gained regarding the pelagic fishes of the Norwegian Sea and the North Sea.

The present list records 95 species, all, except one specimen of the lamprey, Petromyzon marimus (see Fig. 449), taken on the banks of Newfoundland, belonging to the Teleostei, or bony fishes.

The sub-order Malacopterygii comprises many of the most important forms from coastal waters as well as from the ocean.

The Clupeidæ (or herrings) are economically the most important of all pelagic fishes, and belong wholly or chiefly to the coast waters (neritic). In southern waters (Bay of Biscay, off the coasts of Spain, Portugal, and Africa) the principal species are the anchovy (Engraulis encrasicholus, see Fig. 450), Clupea alosa, and the sardine or pilchard (Clupea pilchardus, see Fig. 45I), while in northern waters the herring (Clupea harengus) and the sprat (Clupea sprattus) predominate.

The Salmonidæ have many pelagic representatives. The lightcoloured salmon and sea-trout are generally considered to be pelagic when away from the rivers and the coasts. The list of bottom-fish in 
Chapter VII. includes the deep-sea genera Argentina and Alepocephalus, and it is somewhat surprising to find the small curious forms of the pelagic genus Opisthoproctus referred to the same family; but there are

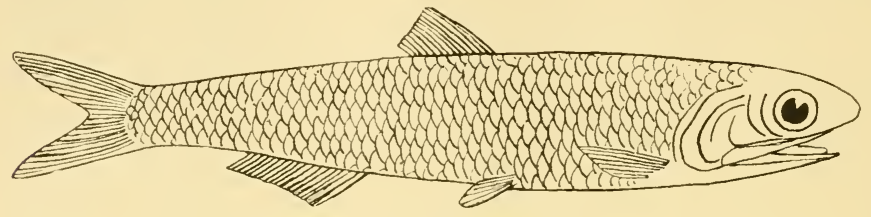

FIG. 450 .

Engraulis encrasicholus, Cuv. (From Day.)

really certain features connecting it with Alepocephalus. The Opisthoproctidæ are small fishes, only a few centimetres long, laterally com-

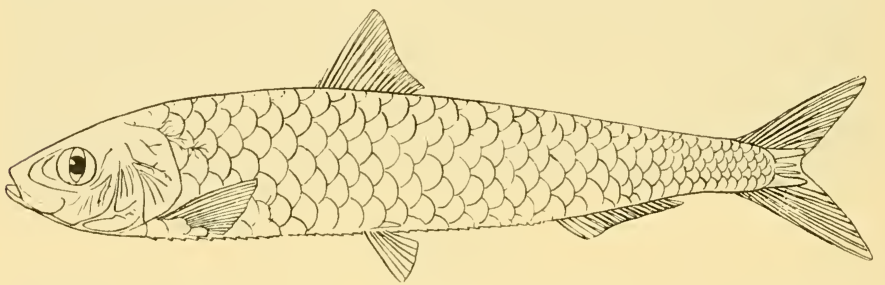

FIG. 451 .

Clupea pilchardus, Walb. (From Smitt.)

pressed, with large thin scales, telescopic eyes, a remarkable flattening of the belly, forming a peculiar sole, and with a small adipose fin as in all

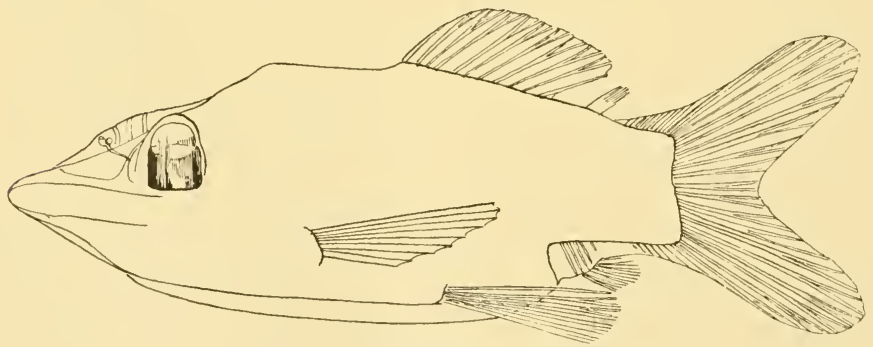

FIG. 452 .

Opisthoproctus grimaldii, Zugmayer. Nat. size, $2 \mathrm{~cm}$.

other Salmonida. One species, Opisthoproctus soleatus, was taken previous to our cruise in the Atlantic, and the other species (O.grimaldii, see Fig. 452) was taken subsequently near Gibraltar. 
The families Stomiatidæ and Sternoptychidæ present many points of resemblance, and comprise many fishes which were previously looked upon as genuine deep-sea forms. They vary greatly in shape, some being long and slender, others short and laterally compressed, and the

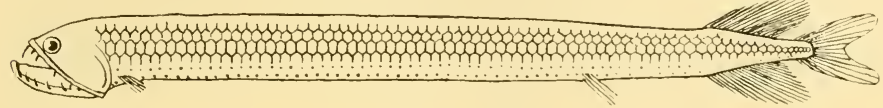

FIG. 453 .

Stomias boa, Risso. Nat. size, $16 \mathrm{~cm}$.

mouth is large with a great number of teeth. Both families are characterised by abundant light-organs, the only difference between them lying in the fact that the Sternoptychidx have only one kind of

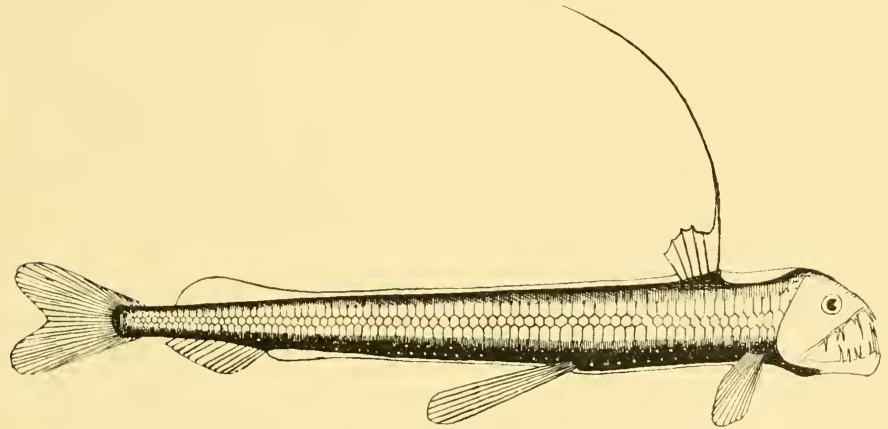

FIG. 454

Chauliodus sloanei, Bl. and Schn. Nat. size, $6 \mathrm{~cm}$.

light-organ, while the Stomiatidæ have below or behind the "eye large and powerful light-organs, very often coloured, quite different in structure from the small ones on the body.

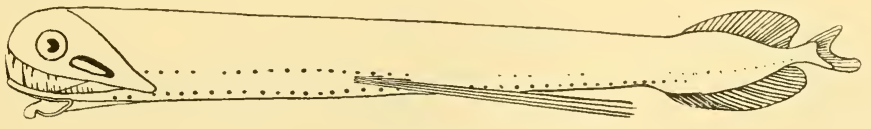

FIG. 455 .

Photostomias guernei, Coll. Nat, size, $17 \mathrm{~cm}$

The Stomiatidæe occurring most commonly in the Atlantic are Stomias boa (see Fig. 453) and Chauliodus sloanei (see Fig. 454), both taken in the tow-nets of the "Michael Sars" at nearly all oceanic stations. They both occur in all oceans, and some of the rarer forms, like Macrostomias longibarbatus, Malacosteus indicus, and Astronesthes niger, are also known from other oceans. An interesting species, 
CHAP.

Photostomias guemei, is shown in Fig. 455. The list includes several new forms, which have not yet been described, showing that the Stomiatidx are more abundant in the Atlantic than was previously supposed.

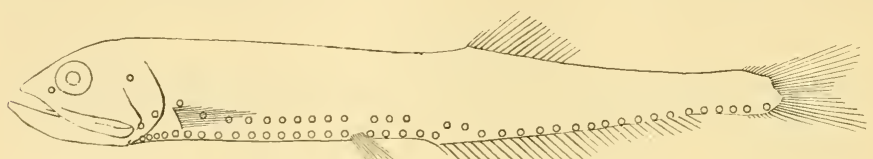

FIG. 456 .

Gonostoma denudatum, Rafin. Nat. size, $3.5 \mathrm{~cm}$.

The Sternoptychidx occur in vast numbers, some of the forms being among the most abundant of all pelagic fishes in the ocean, like

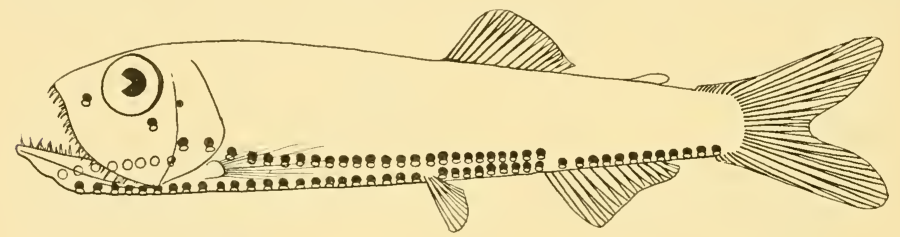

FIG. 457 .

I inciguerria lucetia, Garm. Nat. size, $3.9 \mathrm{~cm}$.

the genus Cyclothone; in the North Atlantic the two species C. microdon and $C$. signata (see Plate I. Chapter X.) are specially abundant. Nearly

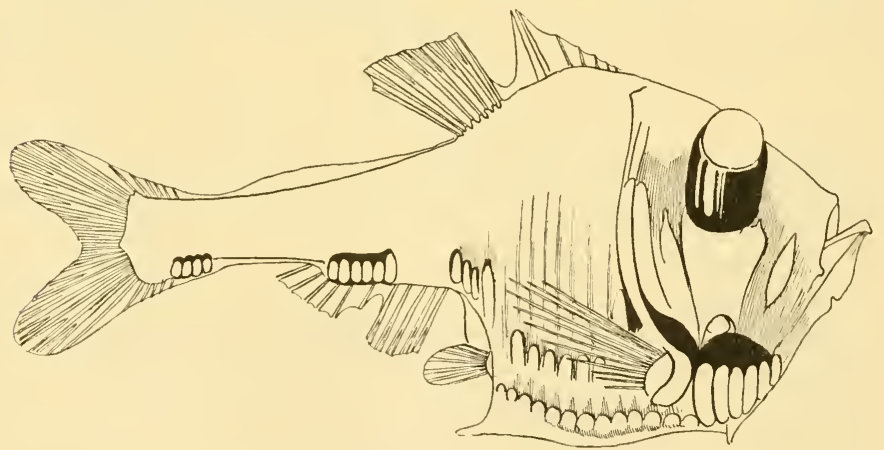

FIG. 45 S.

Argyropelecus hemigymnus, Cocco. Nat. size, $3.5 \mathrm{~cm}$.

allied to Cyclothone is the genus Gonostoma, the species Gonostoma grande and $G$. rhodadenia ${ }^{1}$ being biologically very interesting (see Plate II.

1 On Plate II. this species is named G. elongatum. 
Chapter X.). Gonostoma denudatum is shown in Fig. 456. The genera Vinciguerria (see Fig. 457), Ichthyococcus, and Valenciennellus resemble each other considerably, and have large and numerous light-organs; their geographical distribution is very wide. Very peculiar are the compressed silvery forms of the genera Argyropelecus (see Fig. 458) and Sternoptyx, which have highly-developed light-organs. Most of them occur in all oceans, the species in the list having been taken at many stations in the North Atlantic, while some of them are also known from the Norwegian Sea.

The sub-order Apodes includes the eel-like fishes devoid of ventral

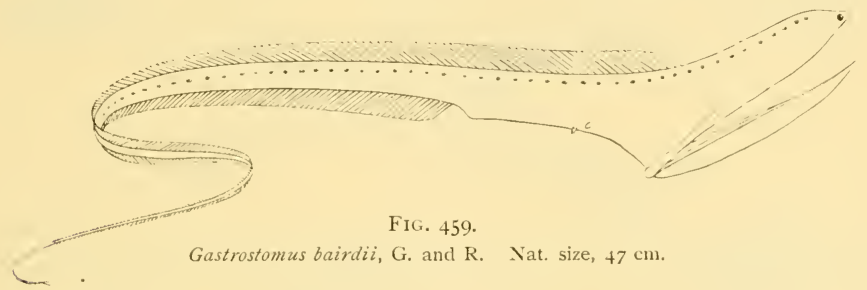

fins. From coastal waters the eel, the conger, and the Murænidæ are best known. In deep waters the Synaphobranchidx, included in the list of bottom-fishes, are very important; some of them are perhaps deep-living pelagic fish, but our knowledge on this point is still imperfect. The three species of the Nemichthyidæ and the two species of the Saccopharyngidæ are undoubtedly pelagic forms. Gastrostomus bairdii is shown in Fig. 459. Serrivomer sector was taken at numerous stations, one specimen of the large and remarkable Nemichthys

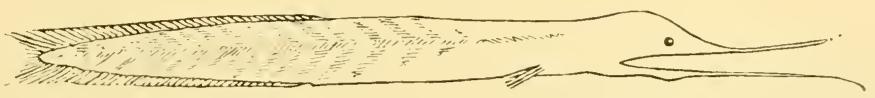

Fig. 460.

Cyema atrum, Günth. Nat. size, II. $5 \mathrm{~cm}$.

scolopaceus was captured south of the Azores, and the peculiar Cyema atrum (see Fig. 460) was taken at three stations in the southern part of our track. To this sub-order belong the larval forms termed Leptocephali, which are all larvæ of Anguillidæ, Murænidæ, Nemichthyidæ, Synaphobranchidæ, and Saccopharyngidæ.

The sub-order Haplomi includes the Scopelidæ, one genus of which, Myctophum, is represented by numerous species (Brauer mentions more than seventy); these play a greater part in the surface fauna of the ocean than all other pelagic fishes. Our list records only those species determined up to the present time, and there are doubtless many more. Of greatest interest to us are Myctophum glaciale, $M$. punctatum, which 
(together with $M$. elongatum) are known from the Norwegian Sea, but most of the species belonging to this genus are warm-water forms. $M$. rafinesquei is shown in Fig. 46r. Several genera belonging to the Scopelidx are recorded in the list of bottom-fishes, Bathysaums,

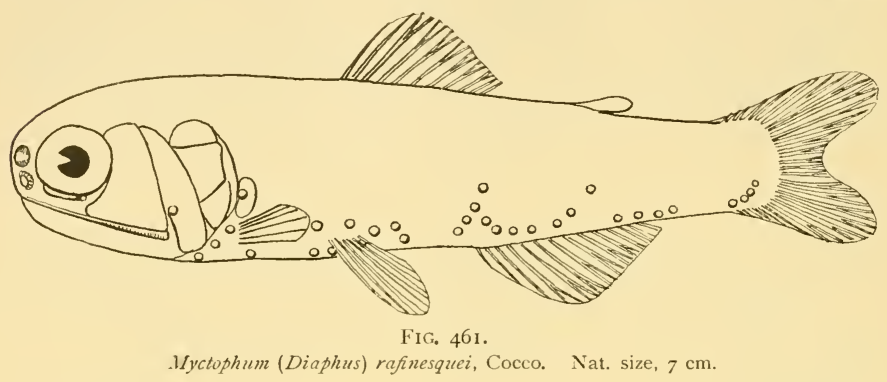

Bathypterois, etc., which will probably prove to be bathypelagic forms, but the present state of our knowledge renders this merely a conjecture. Of interest is the remarkable form Omosudis lowei taken on a long line between the Canaries and the Azores (Station 49 ; see Fig. 462). This sub-order

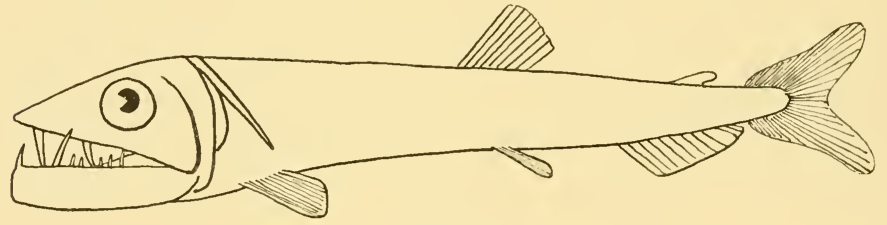

FIG. 462.

Omosudis lowei, Günth. Nat, size, $15 \mathrm{~cm}$.

includes the Cetomimidæ, one genus of which was previously known and one was discovered by us; both genera contain blind forms (see Chapter X.).

The sub-order Catosteomi contains the Syngnathidæ, the needle-fish

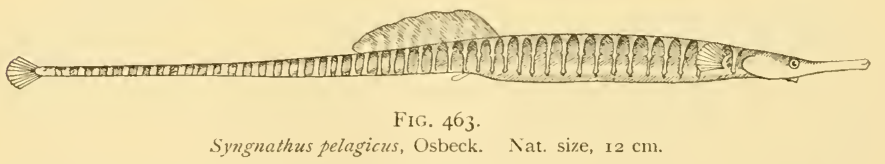

and the pipe-fish. The pipe-fishes (Siphonostoma typhle and Syngnathus acus) are common along the coasts of Northern Europe. Of the needleshaped species, Syngnathus pelagicus (see Fig. 463) is a typical Sargasso form (see Plate V. Chapter X.), while Nerophis cequoreus lives mainly in the north-eastern part of the Atlantic, where it occurs in all the hauls 
with surface tow-nets. The beautiful little Hippocampus (see Fig. 7I, p. 89) was taken between the Canaries and the Azores.

The sub-order Percesoces contains several important and interesting surface-fish. To the family Scombresocidæ belong the gar-pike (Belone), the genus Scombresox, and the flying-fish of the genus Exocoetus. Scombresox saurus attains a length of $50 \mathrm{~cm}$., and resembles the garpike, but does not approach so near the coasts, nor does it extend so far north; it is known from the Atlantic coasts of North America, Northern Europe and Africa. Day records a capture of 100,000 individuals in one haul off the British shores. Only very young specimens were taken by the "Michael Sars" (see Chapter X.), but these are very interesting, because they prove that the species occurs pelagically right across the Atlantic. Flying-fishes were constantly observed on our southern

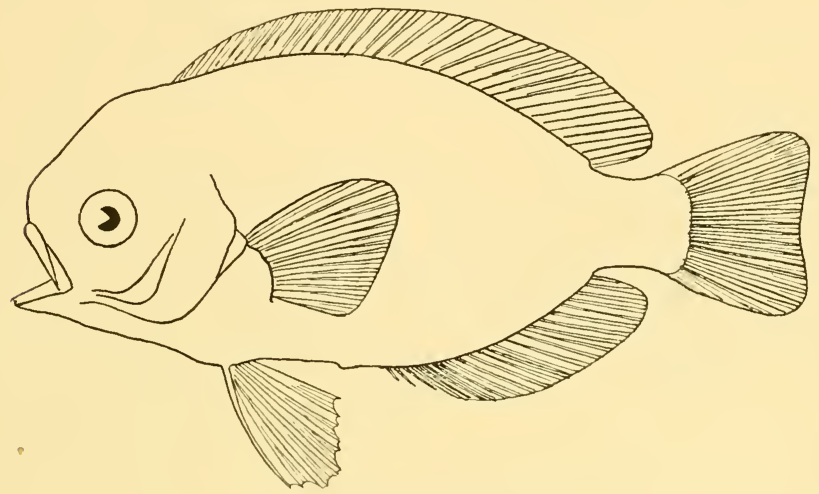

FIG. 464 .

Lirus maculatus, Günth. Nat. size, $9.5 \mathrm{~cm}$.

track, and some of the specimens which flew on board have been referred to Exocoetus spilopus. Between 40 and 50 species of this genus are known from tropical and sub-tropical waters. Very interesting are our captures of minute young flying-fish (see Chapter X.). The only fish belonging to the sub-order Percesoces from great depths is Chiasmodus niger (see Fig. 514, p. 721), taken by the "Michael Sars" in the Sargasso Sea. It was previously known from the eastern and western sides of the Atlantic, and from the Indian Ocean. The fish has very powerful teeth, and can swallow a fish much larger than itself, the digestive tract being marvellously tensile (see Chapter X.). Lirus maculatus (see Fig. 464) and L. ovalis belong to the family Stromateidæ. Along with Acanthopterygians, like Polyprion americamus, these fishes gather around wreckage and other floating objects. They live in tropical or sub-tropical surface waters, and biologically resemble the large lumpfish or sun-fish. All the forms mentioned were captured from a boat, either with a hoop-net or, in the case of Mola rotunda, with a harpoon. 
The sub-order Acanthopterygii does not play the important part

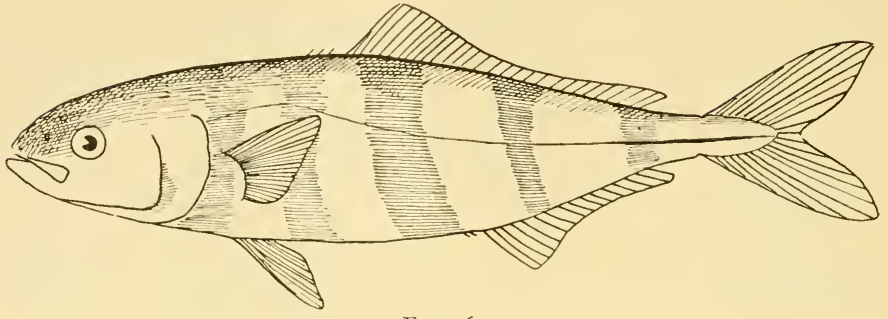

FIG. 465 .

Naucrates ductor, L.

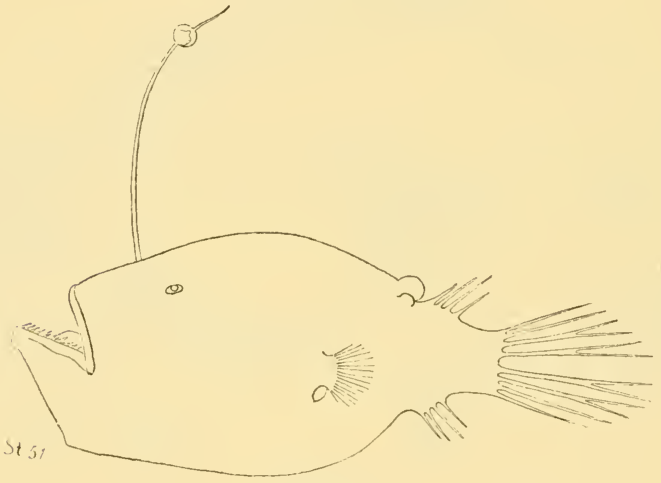

FIf. 466.

Ceratias couesi, Gill. Nat, size, $3 \mathrm{~cm}$.

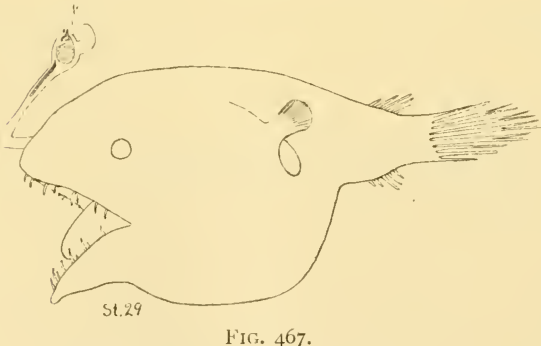

Oneirodes, n.sp. No. 2. Nat. size, $3 \mathrm{~cm}$.

among the oceanic pelagic fish that it does among the bottom-fishes (see Chapter VII.). One group, however, is very important, viz. the Scombri- 
(see Figs. 466-469). They are small, generally black, forms, with a mouth of gigantic size provided with powerful teeth. They have attracted special attention from the nasal tentacle carrying at its end a peculiar

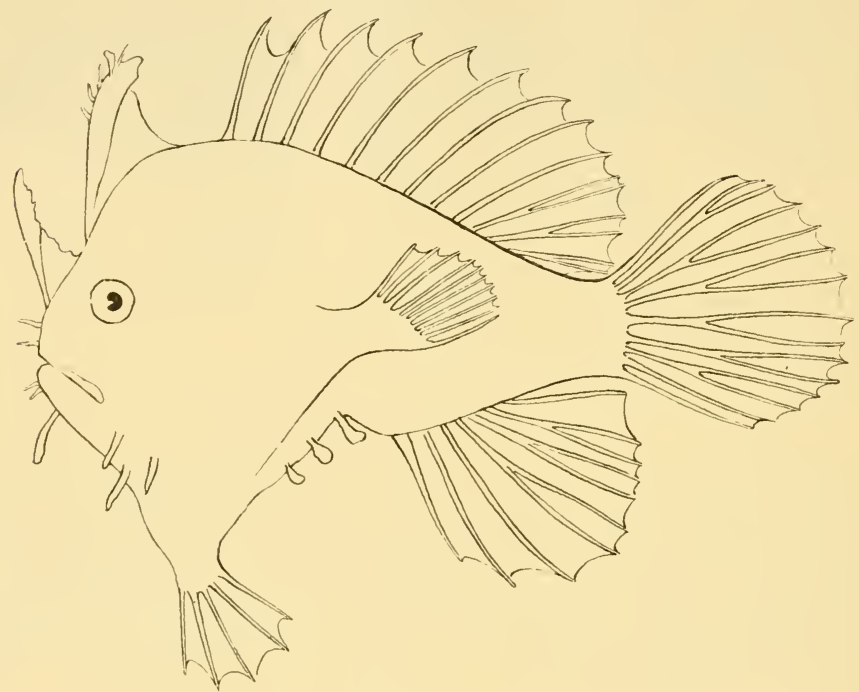

FIG. 47 I.

Antennarius marmoratus, Günth. Nat. size, $3.3 \mathrm{~cm}$.

lantern-like light-organ. Of the eight species of Ceratiidæ taken during our cruise, no less than five are supposed to be new to science; one species (Melanocetus krechi) is represented by a single specimen

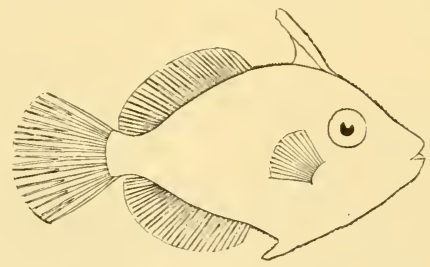

FIG. 472

1Yonacanthus. Nat. size, $2 \mathrm{~cm}$.

from the Indian Ocean. Such facts show that our knowledge of the fauna of the ocean still leaves much to be desired. Remarkable small forms of the genus Aceratias (see Fig. 470) also belong to this sub-order. One of these was previously known from the Indian Ocean only; the 
other was taken off the Congo. Antennarius marmoratus (see Fig. 47I) presents in its shape some likeness to the Ceratiidæ and to Lophius, but is in fact a small surface form peculiar to the Sargasso Sea (see Plate V. Chapter X.), where the genus Monacanthus, belonging to the sub-order Plectognathi (see Fig. 472 and Plate V.), also occurs.

\section{PELAGIC FISHES}

Taken by the "Michael Sars" in igio in the Atlantic NORTH OF LAT. $26^{\circ} \mathrm{N}$.

\section{Class-CYCLOSTOMATA}

\section{Order-PETROMYZONTES}

Petronyzontid Æ

Petromyzon marinus, I., I910 (see Fig. 449).

\section{Class - PISCES}

\section{Sub-Class-TELEOSTOIMI}

\section{Order-TELEOSTEI}

\section{Sub-Order-MALACOPTERYGII}

\section{Clupe1D}

Engraulis encrasicholus, Cuv., I910, Station $3^{6}$ (see Fig. 450).

Clupea alosa, L., r9 9 o, Station $3^{6 .}$

Clupea pilchardus, Walb., r9ro, Station 36 (see Fig. 45 I).

\section{SALMONIDE}

Opisthoproctus soleatus, Vaill., I910, Stations 49, 52, 64 (see Fig. 72, p. 89). Opisthoproctus grimaldii, Zugmayer, 1910, Stations 23, 49 (see Fig. 452).

\section{STOMIATIDE}

We give here Brauer's ${ }^{1}$ classification of the Stomiatidæe and Sternoptychidæe. Stomias boa, Risso, 1902, Faroe-Shetland Channel; r9ro, Stations 10, r9, 29, $34,42,51,53,56,62,63,64,67,80,82,84,87,88,90,92,94,98$, го I (see Fig. 453).

Chauliodus sloanei, Bl. and Schn., I91о, Stations 1о, 25, 29, 34, 35, 42, 45, 49, $50,51,52,53,56,62,63,64,80,81,82,84,88,90$ (see Fig. 454).

Photostomias guernei, Coll., I 910 , Stations 34, 45, 49, 51, 53, 58, 8 I, 82 (see Fig. 455).

Eustomias obscurus, Vaill., I910, Station 29. 
Eustomias, n.sp., I9ro, Stations 45, 8 I.

Macrostomias longibarbatıs, A. Br., I 910 , Stations 23, 52.

Melanostomias, n.sp., I91o, Stations 49, 87.

Dactylostomias, n.sp., I910, Stations 42, 45, 49, 51, 52, 53, 56, 58, 62 .

Echiostoma (species undetermined), I9ro, Station 62 .

Idiacanthus ferox; Günth., I910, Stations 34, 42, 45, 49, 51, 53 (see Fig. 67, b, p. 86).

Malacosteus indicus, Günth., r9 10, Station 48.

Malacosteus niger, Ayres, 1910, Station 5 I.

Malacosteus choristodactylus, Vaill., I910, Stations 45, 51, 58.

Astronesthes niger, Rich., I910, Stations 51, 52, 53, 64, 67 (see Fig. 80, p. 93).

Astronesthes (species undetermined), I910, Stations 42, 87, 88 .

\section{STERNOPTYCHIDE}

Gonostoma rhodadenia, Gilb., I910, Stations 49, 51, 52, 53, 58, 101.

Gonostoma grande, Coll., i 910 , Stations 45, 53, 56, 62, 64, 81, 88, 92, 94, 98.

Gonostoma denudatum, Rafin., I910, Stations 58, 62 (see Fig. 456).

Cyclothone signata, Garm., I910, Stations 10, 22, 25, 27, 28, 34, 35, 40, 42, 45, $47,48,49,50,51,52,53,56,62,63,66,67,80,81,82,88,90,92,94$, го I. Cyclothone signata alba, A. Br., I910, Stations 34, 52, 56, 62, 64, 66, 67, 81, 92, Iог.

Cyclothone livida, A. Br., I910, Stations 34, 35.

Cyclothone microdon, Günth., I910, Stations 10, 19, 25, 27, 29, 34, 35, 42, 45,

$47,48,49,50,51,52,53,56,62,63,64,67,80,81,82,90,92,94$, 101 .

Cyclothone microdon pallida, A. Br., I910, Stations 28, 35, 56, 63, 81, 98, го .

Cyclothone acclinidens, Garm., I910, Stations 51, 67.

Vinciguerria lucetia, Garm., I 910, Stations 20, 29, 34, 39, 42, 45, 50, 5 I, 52, 53, $56,62,64,69,81,88$ (see Fig. 457).

Ichthyococcus ovatus, Cocco, 1910 , Stations $23,5^{8 .}$

Valenciennellus tripunctulatus, Esm., I9 10, Stations 23, 29, 34, 35, 42, 45, 48, 5 I, $52,53.56,5^{8}, 62$.

Argyropelecus affinis, Garm., I9 10, Stations 34, 45, 48.

Argyropelecus hemigymmus, Cocco, I910, Stations Io, I5, 19, 23, 29, 34, 35, 42,

$45,49,5 \mathrm{I}, 52,53,56,5^{8}, 62,64,66,67,88,92,9^{8}$ (see Fig. $45^{8}$ ).

Argyropelecus olfersi, Cuv., I910, Stations 10, 23, 56, 58, 88, 92.

Argyropelecus aculeatus, Cuv. and Val., r9io, Stations 23, 29, 34, 42, 52, 53, 58, $62,67$.

Sternoptyx diaphana, Herm., I910, Stations 23, 29, 34, 45, 48, 49, 5 I, 52, 53, $56,62,66,67,81,82$.

\section{Sub-Order-APODES}

\section{NemichthYide}

Serrivomer sector, Garm., 1910, Stations 45, 49, 51, 52, 56, 64, 67.

Nemichthys scolopaceus, Richards, I910, Stations 5 I, 58.

Cyema atrum, Günth., I910, Stations 45, 53, 62 (see Fig. 460).

\section{SACCOPHARYNGIDAE}

Gastrostomus bairdii, Gill and Ryd., r9го, Stations 35, 53, 62, 64, 67, 80, 8 I (see Fig. 459).

New genus, I9io, Station 53 (see Fig. $83, b$, p. 97). 


\section{Sub-Order-HAPLOMI}

\section{SCOPELIDE}

Omosudis lowei, Günth., I910, Station 49 (see Fig. 462).

Myctophum (Myctophum) rissoi, Cocco, I910, Stations 29, 56.

Myctophum (Myctophum) glaciale, Reinh., i 902, Faroe-Shetland Channel, Faroe Bank; I910, Stations 10, I5, 19, 70, 80, 82, 90, 102.

Myctophum (Myctophum) benoiti, Cocco, 1910, Station 28.

Myctophum (Myctophum) benoiti hygomi, Lütk., I910, Stations 29, 49.

Myctoplum (Myctophum) punctatum, Rafin., I9 10, Stations 25, 29, 53, 80, 92.

Myctophum (Myctophum) affine, Lütk., i910, Stations 52, 53 .

Myctophum (Myctophum) humboldti, Risso, I910, Stations 20, 53.

Myctophum (Myctophum) coccoi, Cocco, I9 Iо, Stations 20, 25, 29, 53, 56, 58, 62, 64.

Myctophum (Myctophum) cherocephalum, Fowl., i9 10, Stations 50, 53.

Myctophum (Diaphus) gemellari, Cocco, I 9 10, Stations 49, 53, 56.

Iyctophum (Diaphus) rafinesquei, Cocco, I910, Stations 62, 84 (see Fig. 46r).

Myctophum (Lampanyctus) maderense, Lowe, I910, Station 34.

Myctophum (Lampanyctus) warmingi, Lütk., I910, Station 5 I.

Nyctophum (Lampanyctus) micropterum, A. Br., I910, Stations 51, 62.

Myctophum (Lampanyctus) gemmifer, G. and B., I910, Station 58.

\section{Cetominde}

Cetomimus storeri, G. and B., I910, Station 35 (see Fig. 497, p. 681).

New genus, 19ro, Station 64 (see Fig. 498, p. 682).

\section{Sub-Order-CATOSTEOMI}

\section{SyNGNATHIDÆ}

Syngnatluus pelagicus, Osbeck, I910, Sargasso Sea, Stations 51, 53, 64 (see Fig. 463 ).

Nerophis aquoreus, L., I 9 го, Stations 10, 56, 58, 84, 86, 87, 88, 90, 92, 94, 98. Hippocampus ramulosus, Leach, i910, Station 48 (see Fig. 7 1, p. 89).

\section{Sub-Order-PERCESOCES}

\section{SCOMBRESOCIDE}

Scombresox saurus, Walb., I910, Stations $25,27,37,46,47,48,49,50,5$ I, 52, $56,64,66,90$.

Exocoetus spilopus, Val., I910 (see Fig. 61, p. 82).

\section{Chiasmodontide}

Chiasmodus niger, Johns., I910, Station 52 (see Fig. 514, p. 721 ).

\section{Stromateide}

Lirus medusoplagus, Cocco, I910, Stations 23, 25.

Lirus maculatus, Günth., I9I0, Station 49 (see Fig. 464).

Lirus ovalis, Cuv. and Val., r910, Stations 49, 56 .

Linus perciformis, Mitchell, I910, Station 6 I. 


\section{Sub-Order-ACANTHOPTERYGII}

Division-PERCIFORMES

BERYCIDE

Melamphaës mizocepis, Günth., I910, Stations 67, 80, 81, 82, 92.

Melamphaës, n.sp., I9 10, Stations 5 I, 67.

Cyphosid

Cyphosus boscii, Lacép., I910, Station 6 I.

SERRAN1DE

Polyprion americanus, Bl. and Schn., i910, Station 56.

\section{CAProIDE}

Capros aper, Lacép., I 9 Iо, Stations I, 3, 20, 39, 56, 58.

\section{Division-SCOMBRIFORMES}

\section{Carangide}

Caranx trachurus, L., I9 Iо, Stations I, 3, I 4, 20, 36, 39, 49, 52, 56, $5^{8}$ (see Fig. 86, p. 98).

Temnodon saltator, Cuv. and Val., i910, Station 36.

Seriola, sp.juv., I9 1о, Station 66.

Naucrates ductor, L., i 9 ro, Station 49 (see Fig. 465).

TRICHIURIDE

Lepidopus caudatus, Euphras., r9ı, Station 43.

Division-ZEORHOMBI

ZEIDÆ

Zeus faber, L., i 9 го, Stations I, 20.

Division-SCLEROPAREI

SCORPENIDE

Sebastes dactylopterus, de la R., I910, Station 2 I.

\section{Sub-Order - PEDICULATI}

\section{Ceratidde}

Ceratias conesi, Gill., I 9 10, Station 5 I (see Fig. 466).

Ceratias, n.sp., I9Io, Station 42 (see Fig. 59, p. 8I).

Oneirodes, n.sp. No. I, 1910, Stations 64, 81, 84 (see Fig. 90, p. 104).

Oneirodes, n.sp..No. 2, I910, Station 29 (see Fig. 467).

Oneirodes, n.sp. No. 3, r 9 10, Station 53 (see Fig. 468).

Oneirodes megaceros, Holt and Byrne, or n.sp. No. 4, r9ro, Stations 52, 62 (see Fig 8I, p. 95).

Melanocetus johnsoni, Günth., I 9 го, Station 53 (see Fig. 469).

Melanocetus krechi, A. Br., I9 10, Stations 45, 53 . 
ACeratilde

Aceratias mollis, A. Br., I910, Stations 45, 49, 51, 64.

Aceratias macrorhimus indicus, A. Br., I910, Stations 45, 49, 51, 56, 67 (see Fig. 470).

\section{ANTEnNARIIDE}

Antennarius marmoratus, Günth., 1910, Stations 64, 66, 67 (see Fig. 471).

\section{Sub-Order-PLECTOGNATHI}

Division-SCLERODERMI

BALISTID瓜

Wonacunthus sp., I910, Station 67 (see Fig. 472).

Division-GYMNODONTES

TETRODONTID E

Tetrodon spengleri, Bl., I91о, Station 37.

MOLIDE

Nola rotunda, Cuv., i910, Station 87 (see Fig. 102, p. I19).

\section{Distribution of Pelagic Animals}

The foregoing remarks and lists show that our knowledge of the distribution of pelagic animals in the ocean is now considerable, especially as regards small forms, which are easily captured in closing nets, and whose habitat may therefore be localized with accuracy. As to larger organisms the difficulties increase in proportion to their size. Thus only five of the I $5 \mathrm{I}$ pelagic species of fishes taken during the "Valdivia" Expedition were captured in closing nets, but the bathymetrical distribution of certain species was approximately determined by lowering large vertical nets to different depths and comparing the catches. By studying the material thus obtained, Brauer ${ }^{1}$ succeeded in ascertaining the bathymetrical distribution, or at least the upper limit, of several common species.

In Chapter II. I have described our methods of capturing pelagic animals by means of large closing nets and by simultaneously towing eight or ten nets at different depths, and in Chapter III. I have given particulars of some of the catches thus secured. My object in this chapter is to show in some detail the knowledge now available as to the vertical and horizontal distribution of pelagic animals and animal-communities 
in the waters examined by the "Michael Sars," viz. the North Atlantic and the Norwegian Sea.

To commence with, it will be advisable to consider the details of our fishing methods. The method of simultaneously towing many appliances at different depths cannot be supposed to give such exact results as hauls with closing nets, because the townets function not only while being towed along, but are also liable to do so while being lowered and raised. To counteract the errors arising in this way we generally towed our nets all night long, or for lengthened periods sometimes extending to twelve hours. The distance thus covered in towing the nets was infinitely greater than the distance traversed by the nets in being lowered and raised, and the sources of error were presumably proportionally diminished.

In order to judge of the results obtained in this way we may examine the catches of individuals belonging to a definite species at all depths and at all stations. Of the well-known species Argyropelecus hemigymmus we took during our cruise a total of 286 individuals, at the various depths indicated in the following table :-

Vertical distribution of Argyropelecus.
Surface

At a depth of 50 metres

$\begin{array}{lrl}, & \text { I00 } & , \\ , & \text { I } 50 & , \\ , & 300 & , \\ , & 500 & , \\ , & 750 & , \\ , & \text { 1000 } & , \\ , & \text { I } 250 & , \\ , & \text { I500 } & , \\ , & 2000 & ,\end{array}$

$\circ$ individuals.

$\begin{aligned} 0 & , \\ 0 & , \\ 62 & , \\ 55 & , \\ 48 & , \\ 0 & , \\ 6 & , \\ 0 & , \\ \text { I I } & , \\ 4 & ,\end{aligned}$

The bulk occurred at depths between 150 and 500 metres; no individuals were caught above 150 metres, and only about 7 per cent were taken at depths lower than 500 metres. If we assume, then, that these 7 per cent were captured during the process of hauling in the appliances, and that none of them live at depths below 500 metres, we will have an idea of the accuracy of our method.

We see, further, that by far the greater number were caught at a depth of 300 metres, where we generally had out a $\frac{3}{4}$-metre silk net, whereas at 150 metres and at 500 metres the appliance used was, as a rule, a young-fish trawl, that would have had a far greater capacity for catching these fishes. It seems, accordingly, that a preponderating majority of the individuals of this species 
are very strictly limited to an intermediate layer situated at a depth of about 300 metres. A closer investigation showed that the individuals captured at a depth of 150 metres were all caught at night. This may be due either to an upward nocturnal wandering or to chance, though on this question the small amount of our material makes it unsafe to hazard an opinion; in subsequent investigations, however, it will be worth while taking this fact into consideration. Among the individuals captured at 500 metres there must, at any rate, be a few that were taken in the process of hauling in the youngfish trawl through the intermediate layer above, though the majority probably lived at that depth - a deduction supported by the fact that far fewer specimens were found in the young-fish trawl towed at 1000 metres, which may have been captured while hauling in.

This instance is a good illustration of our method with its advantages and deficiencies. Clearly the method is trustworthy only in cases where many specimens have been caught. At the same time, it is the only effective method of capture known at present, and it is therefore interesting to inspect the results obtained.

The distribution of different animal-communities in the ocean rarely coincides with what seem to be natural distributional areas. The fact is that the occurrence of animals is largely influenced by such conditions as depth and temperature. In Chapter VII. we have seen that the limit between the southern and the northern bottom-fishes did not coincide with the border-line between the Atlantic Ocean and the Norwegian Sea, but ran from Ireland or the Channel to Iceland, and thence to the coast of the United States. In the case of pelagic animals we may also distinguish between southern or Atlantic communities and northern communities, the borderline between these two communities very nearly coinciding with the line separating the corresponding communities of bottom-fish.

\section{A. The Atrantic Pelagic Communities}

There is a striking difference between the pelagic faunas of the open ocean and of the coast banks. In the open sea we find different pelagic communities according to the different conditions presented at various depths, and by way of introduction it may be useful to inspect the aggregate catches of a 
CHAP.

Fishes taken at different depths at Station 53 .

definite group of pelagic animals taken at a genuine oceanic station far from land in deep water. I have for this purpose prepared the following list recording all the fishes taken at Station 53, to the south of the Azores, during the night of the 8 th -9 th of July, but I regret being unable in the case of the young fish to indicate the species, which would have added greatly to the interest of the list :-

\section{Pelagic Fishes, Station 53}

Surface, TOW-NET: Scopelidæ: Myctophum coccoi, M. punctatum, M. chorocephalum, M. affine, M. humboldti, etc.; Stomiatidæ: Stomias boa, I 3 Astronesthes niger.

50 METRES, TOW-NET: Great numbers of larvæ and young fish, some with telescopic eyes, 4 small larvæ of the common eel (Leptocephalus brevirostris, $4.8-5.7 \mathrm{~cm}$. long); many Scopelidre: I 2 Stomias boa, Chauliodus sloanei, 3 Dactylostomias n.sp. No. I, Idiacanthus ferox.

Ioo METRES, TOW-NET: Scopelidæ: Myctophum (Diaphus) gemellari, 3 Stomias boa, Vinciguerria lucetia, Argyropelecus.

I 50 Metres, YOUNG-FISH TRAwL: A few fish-larvæ, 2 Leptocephalus n.sp., some Argyropelecus, 2 Stomias boa, Photostomias guernei, Gonostoma rhodadenia, new genus of Saccopharyngidæ.

300 METREs, YOUNG-Fish TRAWL: Young fish with telescopic eyes; Scopelidæ (Myctophum coccoi, etc.); 5 Cyclothone signata, Cyilothone microdon, Io Vinciguerria lucetia, I 3 Valenciennellus tripunctulatus, if Argyropelecus hemigymmus, Argiropelecus aculeatus, Sternoptyx diaphana (young fish from $8.5 \mathrm{~cm}$. in length).

550 METRES, TOW-NET: I4 Cyclothone signata, 7 Cyclothone microdon, I 4 Chauliodus sloanei, 3 Sternoptyx diaphana.

800 METRES, yOUNG-FISH TRAWL: 22 Cyclothone signata, I 2 I Cyclothone microdon, Gonostoma rhodadenia, Gonostoma grande, Stomias boa, 2 Vinciguerria lucetia, 2 Idiacanthus ferox, Astronesthes niger, 4 Gastrostomus bairdii.

I 300 METRES, LARGE NET: Leptocephalus, I6 Cyclothone signata, 357 Cyclothone microdon, 7 Gonostoma grande, Photostomias guernei, 5 Chauliodus sloanei, 2 İiacanthus ferox, Cyema atrum, 3 Gastrostomus bairdii, Melanocetus johnsoni, Melanocetus krechi, Oneirodes n.sp. No. 3, 3 Aceratias macrorhinus indicus.

These catches may be classified into three main regions:( I) a region extending downwards from about 500 metres, characterised by the occurrence of $C_{y}$ clothone and various black or dark coloured fishes, and of many peculiar invertebrates, red prawns being prominent; (2) a region ranging between I 50 and 500 metres, characterised by a peculiar community of silvery or grayish fishes, belonging to the families Sternoptychidæ and Stomiatidx; and (3) the surface region comprising the upper I 50 metres, characterised by transparent or blue coloured animals and juvenile forms, especially the members of the large family Scopelidæ. 
In describing the pelagic communities of the open Atlantic it is therefore natural to treat each of these three regions separately, and to consider the pelagic communities of the coast banks as a fourth biological region.

Bathypelagic Communities in Depths greater than 500 Metres.-The most abundant fishes in this region are two Sternoptychidae of the genus Cyclothone, viz. C. signata and C. microdon.

Of these two species we caught altogether over 7500 Vertical individuals, which were all measured and arranged according to their length and the instrument in which they were captured, so as to obtain information regarding the occurrence of the different sizes at different depths. Fig. 473 shows, in the case of both species, the results of the catches made between Newfoundland and Ireland.

Cyclothone microdon was found during the cruise of the "Michael Sars" in the North Atlantic at every station where an appliance was towed in depths below 500 metres. Above 500 metres it was met with only occasionally, and at a depth of 300 metres we came across only one individual. In depths from 500 metres down to 1500 metres its quantitative occurrence appears to be fairly uniform.

In our northern as well as in our southern section we found approximately the same number of individuals in each of the three young-fish trawls which we towed simultaneously at depths of 500 metres, I000 metres, and I 500 metres. At depths below 1500 metres we made only a few hauls, though, on the other hand, we carried out some vertical hauls, which allow of a comparison between the quantity met with above and below ${ }_{5} 50$ metres. At Station 63 (in the northernmost portion of the Sargasso Sea) we secured ten individuals in a haul from a depth of 4500 metres up to I 500 metres, and twenty-seven individuals in a haul from 1350 metres up to 450 metres. Accordingly, seeing that the first haul was made through a distance more than three times as great as the second, we get the result that there were nine times more individuals in the intermediate layer from 1350 metres up to 450 metres than below I 500 metres. A more complete analysis of the different depths from 1500 metres down to the bottom of the sea (about 5000 metres) would have been very desirable, but unfortunately we were unable to spare time for it. It may be that there is a layer at the lowest depths where there are no individuals, and I, for my part at any rate, cannot 

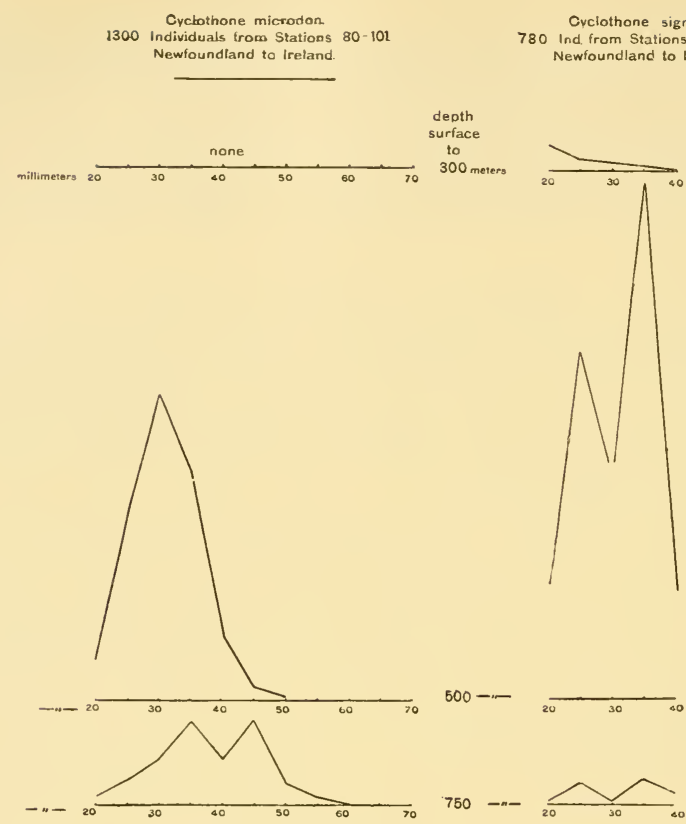

780 Ind from Stations 80-101 Newfoundland to Ireland.
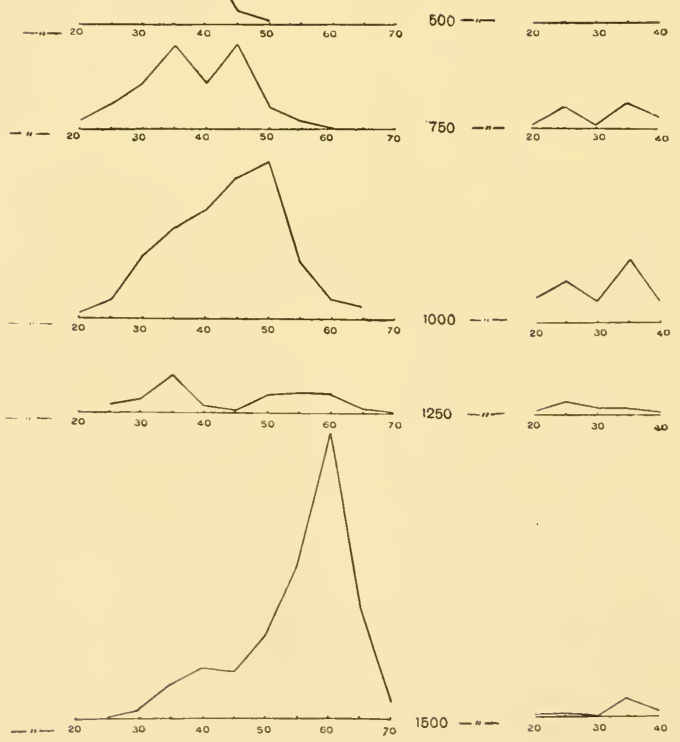

FIG. 473 . 
help believing that the profoundest deep is far more poorly supplied than the intermediate layer.

If we next examine the size-distribution at the different depths, we shall see that it is perfectly clear that the smaller sizes are met with much higher up than the larger ones, which latter are mainly to be found at a depth of 1500 metres. In the northern section we find that at a depth of 500 metres the greatest number of individuals were $30 \mathrm{~mm}$. in length,

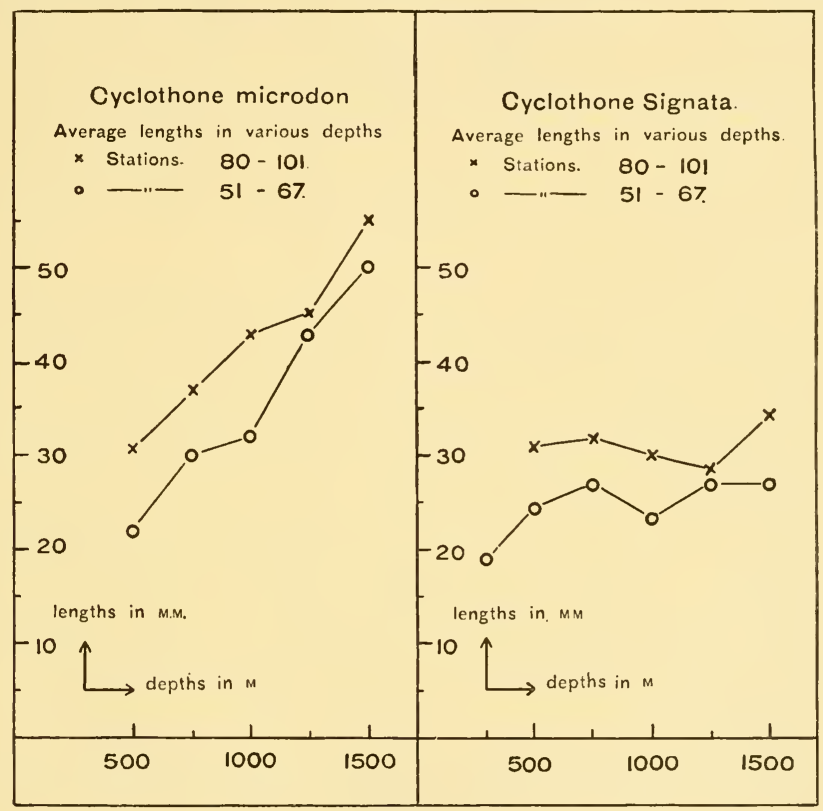

FIG. 474.

whereas at I 500 metres the majority attained $60 \mathrm{~mm}$. At a depth of 500 metres we came across only two that were over $50 \mathrm{~mm}$. in length. The smaller and younger individuals of a length of $20-30 \mathrm{~mm}$. live, accordingly, to a preponderating extent, rooo metres higher up in the water-layers than the majority of the largest and oldest individuals.

Another remarkable fact which strikes us when we study our catches is that the average size of the individuals is much less in the southern than in the northern section at the same 
depth, as shown by the graph (Fig. 474). We see, for instance, that in the southern section, if we want to get individuals of an average size of $30 \mathrm{~mm}$., we must fish 250 metres farther down than we would in the northern section.

The vertical distribution of Cyclothone signata is very different from that of $C$. microdon. We have captured many individuals at a depth of 300 metres, at any rate, in our southern section. The bulk, however, were found at a depth of 500 metres. In the hauls made at greater depths, the quantity diminished so rapidly that we may assume that a large portion of the fishes were caught during the process of hauling in, and that there is only a comparatively thin layer below 500 metres in which they live. In a vertical haul from a depth of 4500 metres to 1500 metres we caught no individuals of this species, but, on the other hand, we secured three individuals in a haul from 1350 metres to 450 metres.

Cyclothone signata is, accordingly, found in an intermediate layer with a maximum in the number of individuals at about 500 metres. In the case of this species, too, we note that the younger individuals are mainly to be found high up in the water (notice particularly the southern stations), and that the same size is to be found deeper in the southern section than in the northern (see Figs. 473 and 474).

We have a remarkable parallel to the vertical distribution distribution of of these two species of fish in the case of the species of
Acanthephyra. red prawns. These latter, along with the black fishes, form a populous and characteristic "community." We have come across no fewer than about forty species of pelagic prawns, of which we shall here refer only to Acanthephyra multispina and A. purpurea.

Acanthephyra multispina shared with Cyclothone microdon the peculiarity that the largest and oldest individuals were found in the nets towed at the greatest depths, say, at IOOO-I 500 metres (see Fig. 475). At depths between 500 and 750 metres we met with medium-sized specimens, and in the upper layers, from 50 to I 50 metres, we found the larvæ. These larvæ were taken in quantities, whereas formerly only a single individual collected by the Prince of Monaco, described by Coutière as Hoplocaricyphus similis, but now identified as a larva of Acanthephyra multispina, was known.

Acanthephyra purpurea resembles Cyclothone signata, in that its distribution is chiefly confined to an intermediate layer between 500 and 750 metres in depth. Our appliances 
captured so few individuals at greater depths that we may safely assume that even these were caught during the process of hauling in. A vertical haul at Station $6_{3}$, from a depth of 4500 to 1500 metres, yielded five individuals of $A$. multispina, but none of $A$. purpurea; while another haul from 1350 to 450 metres gave us two $A$. multispina and thirty-three A. purpurea. The larva of the latter occur in the higher layers of water, just as is the case with $A$. multispina.

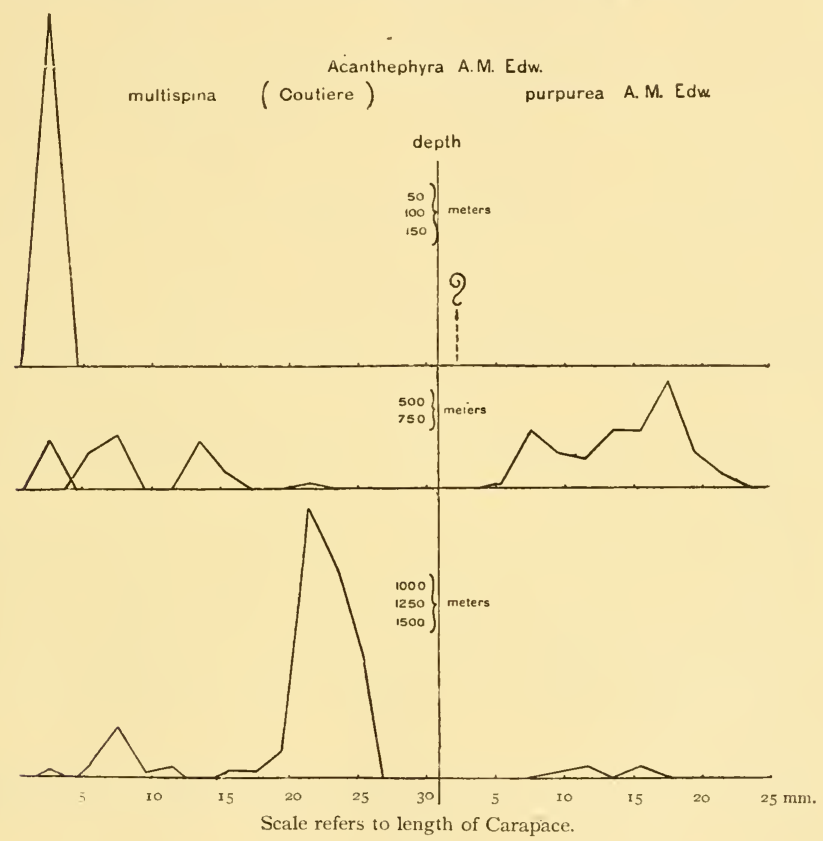

FIG. 475 .

What has just been said illustrates the conditions on the northern section from Newfoundland to Ireland, and if we examine the material from the stations farthest south in the Sargasso Sea, we are confronted with exactly the same difference that we encountered in the case of the species of Cyclothone, namely, that the same forms descend to greater depths in the south than they do in the north; the larger individuals of Acanthephyra purpurea, for instance, occur at depths 
between 500 and 750 metres in the northern section, whereas in the south they were seldom captured by the net towed at 500 metres, though present in large numbers at a depth of 1000 metres.

Bathypelagic region.

The results of these investigations clearly show that the dark-coloured fish, the deep-red prawns, and other organisms are limited to the deep parts of the ocean beyond 500 metres. This bathypelagic region may, however, be subdivided into various layers. We thus recognise a layer varying according to geographical position between 500 and 800 metres containing the light-coloured species of $C y c l o t h o n e$ and the bright-red prawn with orange-coloured eggs (Acanthephyra purpurea). The layer from 800 or 1000 metres downwards may require to be still further subdivided, for certain forms like the larger Acanthephyra with red eggs (A. multispina). Notostomus and several fishes and squids have been taken only in the deepest hauls at 1500 or 2000 metres, but we must point out that the deeper parts of the Atlantic were not investigated by us, our efforts being devoted mainly to the upper layers between I 500 metres and the surface. We shall, therefore, consider the layers below 500 metres as a whole, referring to some characteristic forms from this bathypelagic region, examining their horizontal and vertical distribution, and discussing the laws which seem to govern their occurrence.

We have seen that Haecker, in dealing with the vertical distribution of the Radiolaria, recognised a Pandora region from 400 to 1000 metres, and an abyssal region from I 500 to 5000 metres; and this division coincides very well with the two regions characterised, respectively, by the occurrence of Cyclothone signata and $C$. microdon and by the two species of prawns.

Among the medusæ a similar correlation is found, Periphylla hyacinthina being most abundant at 500 metres, and Atolla bairdi at 1000 metres.

No nemertines were taken in depths less than 700 or 800 metres, and the fifteen specimens belonging to the genus Planctoncmertes, taken at five separate stations, were taken beyond 1500 metres.

The ostracod Gigantocypris was taken at eleven stations, but only one individual occurred at 500 metres, the remainder occurring in deeper water. Pyrosoma spinosum was always taken beyond 750 metres, most of the specimens coming from I 500 metres. 
Three species of pteropoda (Peraclis diversa, Limacina helicoides and Clio falcata) live below 500 metres, but according to Bonnevie, the first of these seems to avoid the cold bottom water, while the second species seems to prefer this water and the third seems indifferent. All three forms are dark-coloured, and their structure differs from that of the surface forms, being of a more archaic type.

All the large groups of squids include bathypelagic species, of which the following may be mentioned :-

Egopsidæ: Calliteuthis reversa, Mastigoteuthis flammea, M. grimaldi and M. hjorti, Grimalditeuthis bonplandi, Toxeuma belone.

Myopsidæ: larvæ of Spirula.

Octopoda: Eledonella pygmae, Vampyroteuthis infernalis, Cirrothauma murrayi.

Many peculiar species of fish were found at and beyond 750 metres, for instance: Malacostcus indicus and $M$. niger, Gastrostomus bairdii, Cyema atrum, Gonostoma grande, Melamphaës mizolepis, Cetomimus storeri and a closely allied new genus. Of eight species of Ceratiidæ seven have been taken only beyond 500 metres. Aceratias macrorhinus indicus may also be mentioned.

Proceeding to consider the horizontal or geographical dis- Horizontal tribution of these forms, we commence with the most abundant species of fish, Cyclothone signata and C. microdon. The chart distribution of Cyclothone. (Fig. 476) shows the localities where these species have been taken previous to and during the "Michael Sars" Expedition, and it is seen that the records are so numerous that these fishes may be said to occur all over the area examined, wherever a fishing appliance was lowered to a depth of 500 metres. They are found everywhere, from the Wyville Thomson Ridge in the north to beyond the Azores in the south, and from the slopes of Africa and Europe to the slopes of America; but the distribution of the two species is not identical. Cyclothone microdon has been captured by previous expeditions ${ }^{1}$ on both sides of Greenland, in Davis Straits, in Denmark Straits, and also south of Iceland, whereas C. signata is unknown in these localities; and outside the Atlantic C. microdon occurs in the Pacific, in the Indian Ocean, and in the Antarctic south of lat. $50^{\circ} \mathrm{S}$., whereas $C$. signata is much more restricted in its southern distribution, having been taken at only one locality to the south of lat. $40^{\circ} \mathrm{S}$.

The peculiar vertical and horizontal distribution of the two

1 This information is derived from a chart in Brauer's paper on the deep-sea fishes of the "Valdivia" Expedition. 
forms in question seems explicable when compared with the distribution of temperature. In Chapter VII. we noted that the temperature along the ocean-floor is very uniform, and consequently the abyssal bottom-fish, like Macrums amatus and $M$. filicauda, have a very wide distribution. 'Throughout the abyssal region of the Pacific, Atlantic, and Indian Oceans the temperature varies only between $\mathrm{I}^{\circ}$ and $3^{\circ} \mathrm{C}$., and only far south in the Antarctic do we meet with temperatures below o C. The water-layer from 5000 or 6000 metres up to I 500

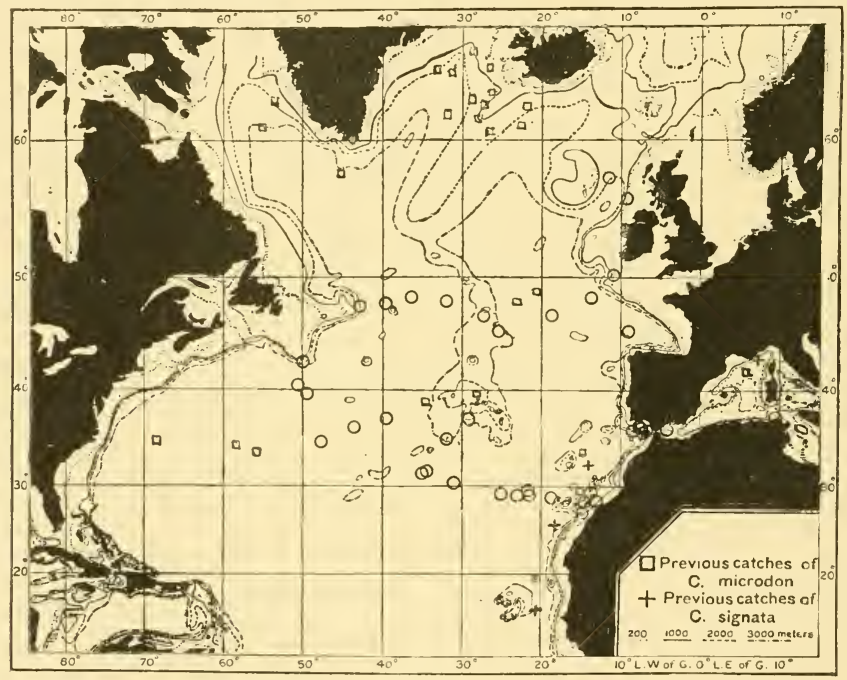

orclothone Signata and microdon caught by "Michael Sars"

FIG. 476 .

metres is practically homogeneous as to temperature, and if it were possible for a fish to swim so far, keeping constantly at a depth of 1500 metres, it might travel from India to Australia, then westwards past the Cape, and northwards through the Atlantic as near to Iceland as the depth would permit, encountering all the way no greater variations in temperature than from 3 to $5^{\circ} \mathrm{C}$. Even at a depth of Iooo metres conditions are very uniform, for only in the Indian and North Atlantic Oceans do the temperatures rise to $7^{\circ}$ or $8^{\circ} \mathrm{C}$., 
neglecting the somewhat higher temperatures found off the entrances to the Red Sea and the Mediterranean, but the temperatures at 1000 metres usually vary only from $4^{\circ}$ to $6^{\circ} \mathrm{C}$. The habitat of Cyclothone microdon is below 1000 metres, the temperatures generally varying between $3^{\circ}$ and $6^{\circ} \mathrm{C}$., and the wide range of this species must evidently be directly connected with the wide areas occupied by these temperatures. On the other hand, the area of distribution of C. signata at about 500 metres shows great differences in temperature in different parts of the ocean. In the Indian and Atlantic Oceans, where C. signata is found, temperatures at this depth are generally above $10^{\circ} \mathrm{C}$., sometimes even above $15^{\circ} \mathrm{C}$. In the sea between Newfoundland and Iceland, as well as south of lat. $40^{\circ} \mathrm{S}$., temperatures are below $5^{\circ} \mathrm{C}$., and in these localities C. signata is absent.

These facts, especially the conditions touching the wide distribution of the bathypelagic $C$. microdon, assume more general importance considering that we found many bathypelagic species in the North Atlantic, which have been taken in the deep water of other oceans. As instances of such forms I may mention the widely distributed medusæ Atolla and Periphylla, which were taken by us in the Northern Atlantic at nearly all the localities and depths where $C$. microdon and $C$. signata were taken. The genus Gigantocypris, taken at three stations in our southern and at six stations in our northern section, had previously been captured by the "Valdivia" in the Indian Ocean. Three species of squids, taken by us in deep hauls in the North Atlantic, were caught by the "Valdivia" in the Indian Ocean, viz. Calliteuthis reversa, Mastigoteuthis flammea, Toxeuma belone. Bathypelagic fishes common to both these oceans are: Malacosteus indicus, Cyema atrum, Melamphaës mizolepis, Cetomimus storeri, Melanocetus krechi, Ceratias conesi, besides Aceratias macrorhinus indicus. These squids and fishes are, however, represented by very few specimens, in some cases only one from each ocean. The fact that we caught several new species of the family Ceratiidæ, as well as such interesting forms as Gastrostomus bairdii and Gonostoma grande, proves that a great field of research is still open to systematic zoologists. The chart (Fig. 477) shows the distribution of Gonostoma grande.

All the forms mentioned live, as far as we know, always in deep water, except perhaps the early stages, which in some cases occur closer to the surface, but certain cold-water

Bathypelagic forms. 
species found in depths below 500 or 1000 metres may in other localities nearer the polar regions reach the surface.

During the Atlantic cruise of the "Michael Sars " numerous arctic or northern forms were found in deep water in company with the genuine or permanent deep-sea animals, especially in our northern section from Newfoundland to Ireland. We succeeded in proving the continuous occurrence of such forms from the cold water-layers off the Banks of Newfoundland down to great depths, just as these cold water-layers have

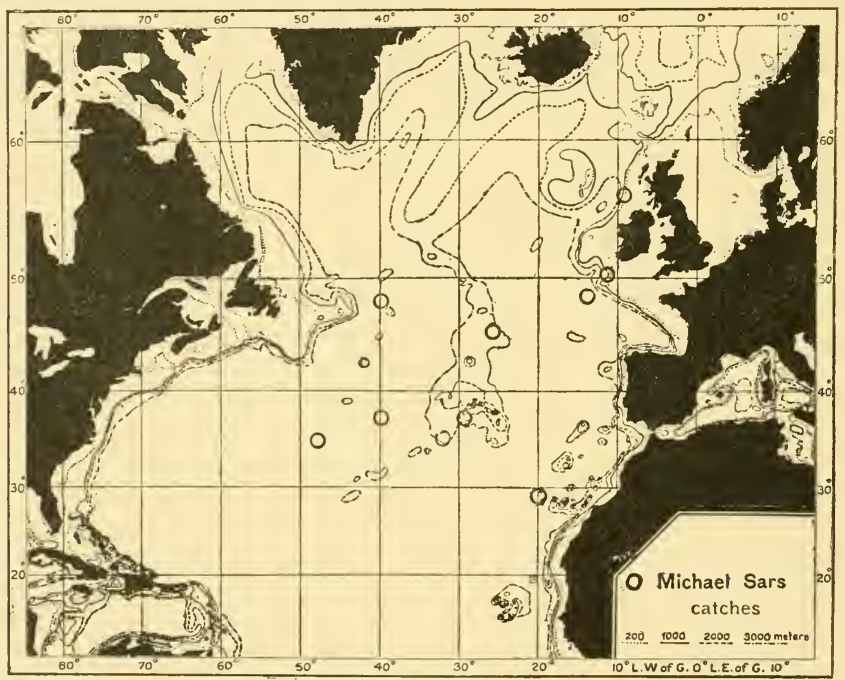

Gonostoma grande

FIG. 477 .

proved to be directly connected with the deep layers of the ocean (see pp. 658-659).

Pelagic Communities in Depths between I50 and 500 Metres.-At the upper limit of the bathypelagic region in about 500 metres certain fish, entirely different from the bathypelagic species, make their appearance along with Cyclothone signata. These fish are as a rule laterally compressed, with a mirror-like silvery skin; when coloured, the back is generally blackish brown, and the resplendent mirrorlike sides of the body blue or violet. The eyes are large, 
very often telescopic, and the body is provided with a number
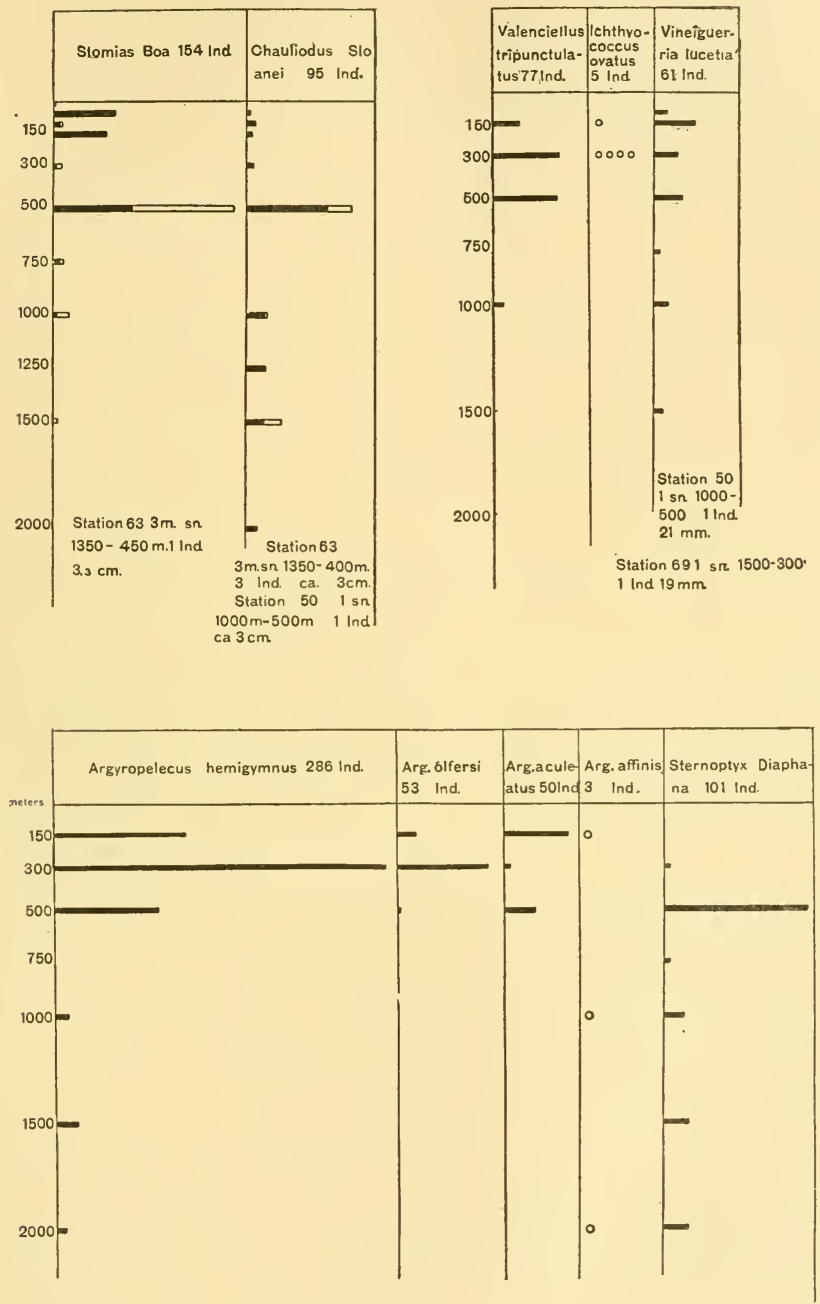

FIG. 478 .

of light-organs varying in size. These forms have their lower 
limit at about 500 metres, where they are found together with the upper representatives of the bathypelagic fauna, just as on the continental slopes the Macrurid bottom-fauna is mingled with the deepest living species belonging to the coast banks. Fig. 478 shows the vertical distribution of certain of these pelagic fishes, and we see that Stemoptyx diaphana, Stomias boa, and Chauliodus sloanei were taken most abundantly at 500 metres, while the species of the genera Argyropelecus, Valenciennellus, and Vinciguerria were mostly taken at 300 metres; the upper limit for all these species seems to be about I 50 metres below the surface. As regards the geographical distribution of these species, we find that, excepting Stomias boa, they occur in the Indian Ocean to the north of lat. $40^{\circ} \mathrm{S}$., and in the Atlantic between lat. $44^{\circ} \mathrm{N}$. and $40^{\circ} \mathrm{S}$., though Argyropelecus olfersi, $A$. aculeatus, and $A$. hemigymmus have been found on the coasts of Norway, and Stomias boa has been taken in the Faroe-Shetland channel during one of our cruises in the "Michael Sars."

During our Atlantic cruise in 1910, Argyropelecus affinis and $A$. aculeatus, Valenciennellus tripunctulatus, Ichthyococcus ovatus, and Serrivomer sector were only taken at our southern stations, and did not appear at any of the stations between Newfoundland and Ireland, while Argyropelecus hemigymmus, Stemoptyx diaphana, Stomias boa, and Chauliodus sloanei were caught both at northern and southern stations, but only Stomias boa occurred in numbers of any consequence at the northern stations. Thus, of 286 specimens of Argyropelecus hemigymmus taken during the cruise only I 7 were captured on our northern track; of IOI specimens of Sternoptyx diaphand only 2 were taken north of the Azores; of 95 specimens of Chanliodus sloanei only ro were taken north of the Azores. On the other hand, out of our total of 154 specimens of Stomias boa 9 I were taken on the northern track, and this species appears to be the only abundant one north of lat. $45^{\circ} \mathrm{N}$.

The temperature throughout the region occupied by these fishes, between lat. $40^{\circ} \mathrm{S}$. and $45^{\circ} \mathrm{N}$., and between 500 and 150 metres, exceeds $10^{\circ} \mathrm{C}$. We found the distribution of the fishes of the Atlantic coast banks to be limited by this temperature in a northerly direction as well as vertically. A limit of this kind can only be roughly fixed, and is subject to variations, but the isotherm of $10^{\circ} \mathrm{C}$. seems on the whole to coincide with the localities where the organisms in question occur in numbers of importance. Within the region great 
variations apparently occur, for at a depth of 200 metres the temperature exceeds $17^{\circ} \mathrm{C}$. in the Sargasso Sea, in the Mexican Gulf it is above $20^{\circ} \mathrm{C}$., in the Indian Ocean it varies between $13^{\circ}$ and $20^{\circ} \mathrm{C}$, while in the southern Atlantic it is only a little above $10^{\circ}$ or $12^{\circ} \mathrm{C}$. The fauna living at this depth is thus subject to temperatures varying between $10^{\circ}$ and $20^{\circ} \mathrm{C}$., corresponding with what we found in the case of the fishes of the Atlantic coast banks from south of the Canaries to the south-western coast of Britain.

All the silvery fishes of the region between 150 and 500 metres are small, and the same remark applies to all the other organisms of the community. They consist almost exclusively of small crustaceans (copepoda, ostracoda, amphipoda), sagittidæ, pteropoda, and small medusæ. Besides these we commence to find the larvæ of squids and fishes, which, however, become more numerous in the layer above I 50 metres.

Pelagic Communities in Depths less than 150 Metres.-In reviewing the pelagic oceanic forms I mentioned that they belong mainly to the warm belt on both sides of the equator between lat. $40^{\circ} \mathrm{N}$. and $40^{\circ} \mathrm{S}$., where both species and individuals are most numerous. Foraminifera, radiolaria (acantharia), copepoda, medusæ, siphonophora, pteropoda, and salpæ all occur in abundance, and the number of species rapidly decreases as soon as we leave tropical waters. This is also the case with the typical and most abundant surface fishes, the scopelidæ, which occur in numerous tropical and subtropical forms, while only a few species are found in the northern part of the North Atlantic.

The beautiful siphonophores Physalia and Velella were first Distribution seen by us during our short visit to the Mediterranean and in the Spanish Bay. On the way from the Canaries to the Azores and thence westward to Station 64 they were frequently seen, sometimes accompanied by Agalmopsis and Cestus veneris, besides various surface mollusca. On the other hand, none of these forms were observed on our northern track between Newfoundland and Ireland.

The shelled pteropods (Thecosomata) are vertically limited to a comparatively thin layer, extending in our northern section Distribution down to only 50 or Ioo metres, and in the southern section to 250 metres, four-fifths of all the individuals taken occurring within these limits. No less than 3500 individuals comprising 22 species were preserved by us, and of these only about 500 specimens comprising I 6 species came from the northern section. 
Distribution of Salpidæ.

Distribution of Cephalopoda.

Distribution of Scopelids.

In the southern section, again, the majority were taken in the western half towards the Sargasso Sea, west of the longitude of the Azores, where these forms occurred in great abundance.

The distribution of salpæ is somewhat different. Certain forms occur only in the south, for instance, Cyclosalpa floridana, Salpa amboinensis, and $S$. henseni; but the majority were taken to the north and south of the Azores, for example, Cyclosalpa pinnata and Salpa maxima. The medusa Pelagia perla is similarly distributed. All these surface animals occur in this central region of the North Atlantic in such countless numbers as to be immediately noticeable, and it struck me at the time that this peculiar distribution north and south of the Azores might be correlated with the submarine ridge on which these islands are situated. The currents are probably influenced by the configuration of the bottom, and the distribution of the pelagic organisms, even in the surface waters, may possibly be thereby affected, as we have often observed during previous cruises of the "Michael Sars" in the Norwegian Sea. A third group of salpæ, viz. Salpa fusiformis, S. mucronata, S. confoderata, and $S$. zonaria, while certainly most abundant north and south of the Azores, occurred frequently in other localities, especially in our northern section. Salpa fusiformis was doubtless the principal form among these, and was the only one observed.at all the stations to the south-west of Ireland, between Rockall and the west coast of Scotland, and towards the FaroeShetland channel. Fig. 479 illustrates the distribution of Salpa zonaria, which was found abundantly in the northern part of the Atlantic.

Most of the squids taken at the surface occurred south of the Azores, especially larval forms, and included larvæ of Onychoteuthidæ, Octopodoteuthis sicula, Cranchiidæ (Cranchia scabra, Teuthowenia megalops, Galiteuthis suhmii), Heteroteuthis dispar, Tremoctopus atlanticus, and Argonauta. Certain northern forms like Gonatus may be supposed to be wholly boreal.

Among oceanic surface fish the Scopelidæ are probably most abundant. They were taken in thousands, but only a few have as yet been determined. Of these, Myctophum rissoi, $M$. benoiti, $M$. affine, $M$. humboldti, $M$. coccoi, $M$. choerocephahm, $M$. gemellari, $M$. maderense, $M$. warmingi, $M$. micropterm, and $M$. gemmifer were taken only in the south ; while $M$. glaciale, $M$. punctatum, and $M$. rafinesquei were also taken in our northern section. The Scopelidæe were usually accompanied by numerous young fish, of which I may mention 
the fry of the horse mackerel, the young of Scombresox saurus (a near relation of the gar-pike), and of the flying fish (Exocoetus). These forms were with one exception observed only in our southern section.

A peculiar group of fishes are the Sargasso fish, which live Sargasso on or around the Sargasso weed. We found Antennarius marmoratus, Syngnathus pelagicus, Hippocampus ramulosus, and Monacanthus, together with a peculiar Sargasso fauna, including small crabs (Planes minutus) and small prawns of several kinds

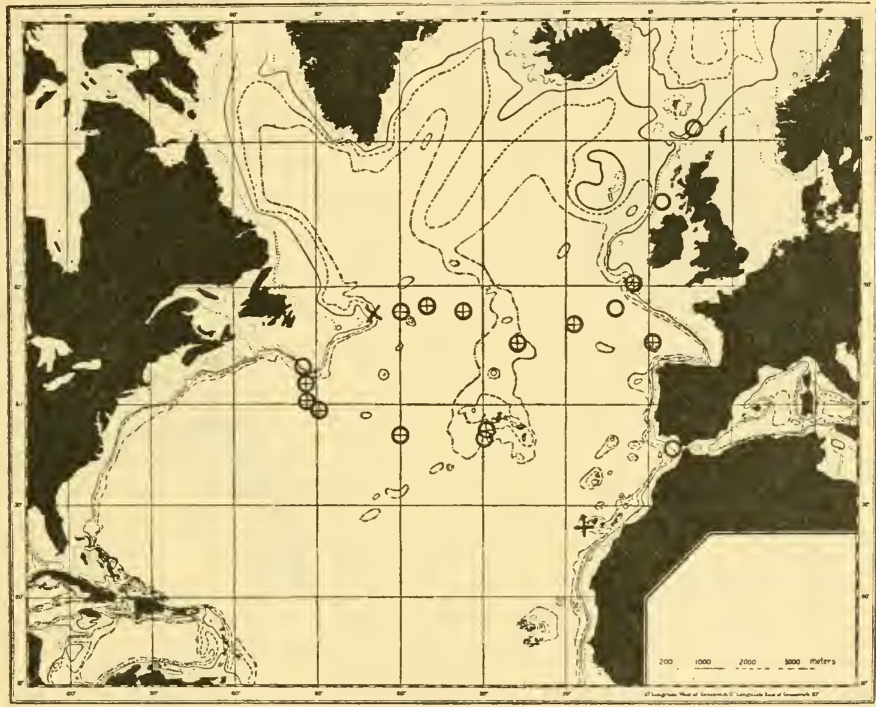

Fig. 479.-DISTRIBUTION OF SALPA ZONARIA.

(see Plates V. and VI., Chapter X.). But besides the Sargasso fish various remarkable forms occur in the surface waters of the ocean, such as the "wreck-fish," Lirus medusophagus and L. ovalis, Polyprion americanus, and the pilot fish (Naucrates ductor), taken by us to the south of the Azores, where salpæ and large medusæ were present in such numbers, as well as the enormous sunfish (Mola), harpooned due north of the Azores.

A community nearly as peculiar as the Sargasso fauna exists in the north-eastern corner of the area investigated by us, extending from the Azores to Ireland and thence to Rockall 
Transitional area between the Atlantic and the Norwegian Sea. and the Faroe-Shetland channel. Johs. Schmidt first drew attention to this community. Salpa fusiformis, the larval actinia Arachnactis albida (the distribution of which is shown in Fig. 480), the barnacles Lepas pectinata and L. fascicularis, young stages of the thread-like fish Fierasfer, Nerophis aquoreus, larvæ of the common eel and scopelidæ (Myctophum glaciale and $M$. punctatum) occur here in great numbers. Excepting the salpæe, the barnacles and the leptocephali, which also occur in the warm Atlantic, all these forms live in what may be

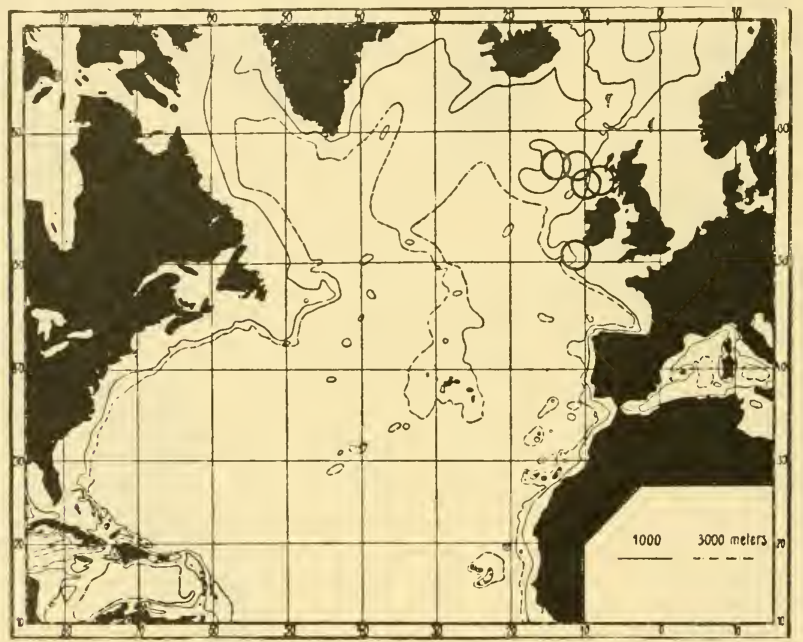

Fig. 4SO.-Distribution OF ARACHN.ACTIS ALBIDA.

called a transitional area between the Atlantic and the Norwegian Sea.

The conditions of temperature in this bathymetrical region are shown in Figs. I59, p. 227 , and I60, p. 228 (surface temperature for February and August), and in Fig. 312, p. 445 (temperature at 100 metres). Comparing these charts with the current chart in Chapter X., we obtain a good impression of the currents of the North Atlantic. The warm Gulf Stream, originating in the Gulf of Mexico, follows the east coast of the United States towards the Banks of Newfoundland, where it divides into several branches. A northern branch appears to run towards Davis Strait, partly as an undercurrent. An eastern branch runs towards the Azores and, spreading out like a fan, 
merges finally into the Canary stream and the enormous whirlpool of the Sargasso Sea. A North European branch, after reaching the British Isles, continues to the Norwegian Sea and the North Sea. We may consequently distinguish various surface regions in the North Atlantic: (1) the genuine Gulf Stream; (2) the eastern Azores current; (3) the Canary current; (4) the Sargasso Sea; $(5)$ the North European Gulf Stream.

The last mentioned, which we crossed on our northern track, receives a certain admixture of cold water from the Labrador current, besides many animals from northern waters. It appears from these considerations that the limit to the genuine warm-water forms of the Atlantic follows a line parallel to the axis of the true Gulf Stream water, the faunas to the north and south of this line differing to some extent.

Pelagic Communities on the Coast Banks of the Atlantic.The chief aim of our cruise was to examine the pelagic life of the open ocean, and our catches on the coast banks were therefore casual. On the coast of Africa, at Cape Bojador, quite close to the shore we caught the young of the anchovy (Engraulis encrasicholus), Clupea alosa, the sardine (Clupea pilchardus), the horse mackerel (Caranx trachums), and Scombresox saurus. Together with the mackerel, the bonito, the tunny, and the gar-pike, these fish are the most important pelagic species on the coast banks. To these may be added the great sharks: the blue shark (Carcharias glaucus), probably the species most commonly captured by sea-faring people; the hammer-head (Zygana malleus), which the trawlers get among the hake on the coast of Morocco; and several others.

As far as we know, these fishes belong mainly to the coast waters; at all events the herring, mackerel, tunny, and garpike spawn in the coast waters or their vicinity. On the other hand, we found on our cruise the eggs and young of Scombresox so far from land that they may safely be said to spawn in the open ocean, as is probably the case with Caranx. Many of these fishes are probably widespread in the ocean, even if they do appear in the coast waters.

When journeying some years ago on the west coast of Fishery in the France I was informed that a peculiar bonito and tunny fishery had recently originated in the Atlantic, carried out with deck cutters which went as far as 150 miles off the coast of France, the voyages lasting eight to twelve days. The fishing commences in July and continues all the autumn, and is a kind 
of harling, like the mackerel fishery in the North Sea. It is carried on only during the day, some of the fish weighing over thirty pounds. This is the only fishery I know of in the open ocean over deep water and away from the coast banks, and the species captured visit the coast banks, at all events, some time during the year.

Among pelagic fishes, however, the sardine is the most important to the fisheries on the Atlantic coast banks, and it is captured in the same area as the Atlantic bottom fish, i.e. from the Channel along the coasts of Spain and Portugal and Africa. The sardine, the bonito, and the tunny are here probably the only Atlantic pelagic species of economic importance.

\section{B. The Northern Pelagic Communities}

In the ocean we find no sharply defined border between the animal-communities belonging respectively to the tropics and the polar seas; on the contrary, there are numerous transitions between the extreme conditions of life peculiar to the tropics and the polar regions. It is therefore difficult to classify the communities, and this difficulty is intensified by the fact that most records note merely the occurrence or non-occurrence of certain organisms and not their quantitative occurrence-a vital point in discussing questions of distribution. If I attempt to separate the genuine Atlantic from the northern pelagic animalcommunities, it is because I feel that in this way we shall actually gain a better conception of their main features. I believe that a division of this kind will coincide generally with the limit drawn between the areas of distribution peculiar to the southern and northern bottom fish on the Atlantic coast banks, viz. the isotherm of $10^{\circ} \mathrm{C}$. at 100 metres, running from the Channel, south of Ireland, skirting the south coast of Iceland, and thence to the United States.

Among northern communities it is impossible to separate oceanic and coastal communities so sharply as among Atlantic communities, probably because northern communities are chiefly restricted to comparatively small areas, and the substances carried from the land vary in quantity and quality, giving rise to corresponding variations in the food supply. Neither is the vertical distribution so easily defined as in the Atlantic, certain species having a very different vertical distribution in different areas.

It is extremely important for a true conception of the 
communities of northern waters to distinguish between the various types of areas of distribution. In accordance with all previous descriptions of the animal life of northern waters, we may recognise three typical faunas, viz. (I) the arctic, (2) the boreal, and (3) the temperate Atlantic.

The arctic communities include those forms which are propagated and attain their maximum abundance in waters belonging to the ice-covered area at temperatures below $2^{\circ} \cdot \mathrm{C}$.

The temperate Atlantic communities comprise those forms which occur mainly in the warm layers of the Atlantic, and only at certain seasons or in small quantities occur in the north. Most of these forms are entirely oceanic.

The boreal communities include those forms having their maximum frequency in waters at temperatures between $4^{\circ}$ and $8^{\circ} \mathrm{C}$. It is the boreal region which specially interests us, but the nature of boreal communities can only be fully grasped when we know the "strange elements"-the Atlantic and arctic "visitors."

The boreal region includes several areas, each limited by natural borders, one of which lies between the west coast of Britain and South Iceland, extending to the Faroe-Shetland channel, the upper layers being occupied by the North European branch of the Gulf Stream. Another area is the Norwegian Sea, separated from the first-mentioned by the submarine ridges between Shetland and Faroe and Iceland; a third area is found round Greenland, Davis Straits, and the Newfoundland banks.

We will discuss the Norwegian Sea first, because this area has been most thoroughly investigated.

The Norwegian Sea.-The borders of the ice may be con- Arctic animal sidered as indicating roughly the limits of distribution of pelagic arctic communities. It is therefore interesting to examine the ice-limits as shown by the charts published by the Danish Meteorological Institute. Fig. 48I represents some of these ice-limits for different months of the years I902, I903, and I906, showing considerable variations from season to season and from year to year. Vast areas of the Barents Sea and White Sea are closed in winter and open in summer, as also the sea off Spitsbergen, and the Greenland Sea between Jan Mayen and Greenland. The Polar Sea north of Spitsbergen is in certain years ice-covered all the year round, but sometimes a 


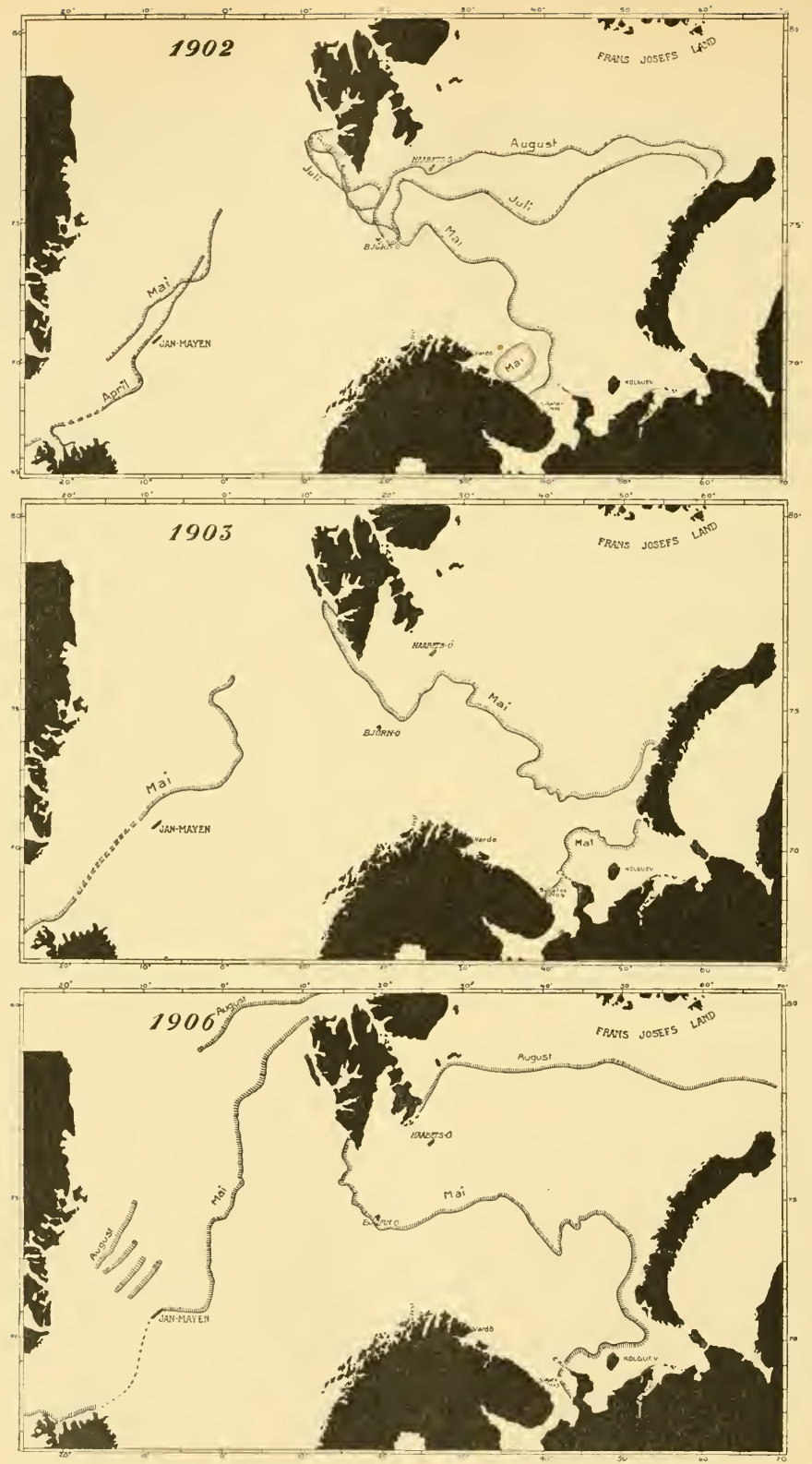

Fig, 48I.-ICE boundaries frov the Charts of the Danish Meteorological Office. 
bay of open water runs for an unknown distance towards the north.

The vertical distribution of the cold water in the Norwegian Sea along a line from Greenland past Jan Mayen to Vesteraalen is shown in Fig. 310, p. 436, which indicates that the great body of water in the Norwegian Sea has a temperature below $2^{\circ} \mathrm{C}$., and that warm water is found only in the eastern part of the sea towards Norway to a depth of 500 or 600 metres.

The investigations of the "Michael Sars" have been limited mainly to the area covered by this warm water, but a thorough investigation of the arctic Greenland Sea has been made by the Duke of Orleans in his expeditions on board the "Belgica," in which Koefoed took part, and had the opportunity of making collections with the same appliances as were employed on board the "Michael Sars." The "Belgica" and "Michael Sars" material has been dealt with jointly by Koefoed and Damas, upon whose treatise ${ }^{1}$ I have drawn for information about some of the most important arctic forms.

Damas and Koefoed divide the Copepoda of the Greenland Sea into several biological groups: (I) forms which live mainly in the surface waters, such as Calamus fimmarchicus and $C$. hyperboreus, Pseudocalanus elongatus and $P$. gracilis, Oncea conifera and $O$. notopus, Oithona similis; (2) forms living mostly in mid-water, but occasionally appearing at the surface, a typical form being Euchata norvegica; (3) mid-water forms which never occur at the surface, especially Euchata glacialis; and (4) deep-sea forms, like Euchceta barbata, Chividiella macrodactyla, and others.

At the surface the commonest form is Calanus hyperboreus, one of the largest of copepods, attaining a length of $9 \mathrm{~mm}$. Calanus hyperboreus. At the ice it is found 5 to ro metres below the surface in enormous numbers. Thus in July a few hauls with closing nets in lat. $75^{\circ} 55^{\prime} \mathrm{N}$. long. $9^{\circ} \mathrm{W}$., depth I 275 metres, gave :-

In a haul from Io to o metres, I000 specimens.

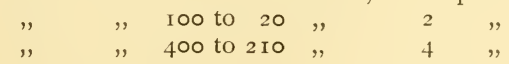

It is mainly an arctic form, and occurs in the Polar basin, in the Greenland Sea, and in the colder parts of the Norwegian Sea. Its propagation takes place principally in the shallow parts of the Greenland Sea, on the coast banks and not where the water is deep, whence the young are carried out into deeper water by currents. The wealth of animal life in the Arctic is 
largely due to the enormous abundance of this species, which constitutes the food of the arctic whales.

Vertical distribution of Copepoda in the Norwegian Sea.

In the boreal parts of the Norwegian Sea most of the arctic species occur in the deeper layers in accordance with the hydrographical conditions, as shown by the following abstract from a table given by Damas and Koefoed :-

\begin{tabular}{|c|c|c|c|c|c|c|}
\hline & & $\begin{array}{c}\text { o- } 50 \\
\text { metres. }\end{array}$ & $\begin{array}{l}50-100 \\
\text { metres. }\end{array}$ & $\begin{array}{l}100-200 \\
\text { metres. }\end{array}$ & $\begin{array}{l}200-500 \\
\text { metres. }\end{array}$ & $\begin{array}{l}500-1000 \\
\text { metres. }\end{array}$ \\
\hline Calanus finmarchicus & . & $x$ & $x$ & $\times$ & $\times$ & $\times$ \\
\hline Calanus hyperboreus. & . & & & $x$ & $x$ & $x$ \\
\hline Pseudocalanus elongatus & . & $\times$ & $\times$ & $\times$ & $x$ & $x$ \\
\hline Microcalanus pusillus & . & & & & & $x$ \\
\hline Euchata norvegica . & . & & & $\times$ & $x$ & $x$ \\
\hline Eucheta glacialis & . & & & & & $x$ \\
\hline Chiridius armatus. & . & & & $x$ & $\times$ & $\times$ \\
\hline Chiridius obtusifrons. & . & & & & $x$ & $x$ \\
\hline Amallophora magna. & . & & & & & $\times$ \\
\hline Oncae conifera. & . & & & & $\times$ & $x$ \\
\hline Oithona plumifera & . & & $x$ & & $x$ & $x$ \\
\hline Oithona similis. & . & $\times$ & $x$ & $x$ & $\times$ & $x$ \\
\hline
\end{tabular}

According to this table a peculiar bathypelagic fauna appears to exist in the Norwegian Sea, whether the surface layers be warm or cold. We find, however, many transitions between the typically arctic and the typically boreal forms, and the most intimate knowledge of their distribution and life-history is necessary to enable us fully to characterise the various species.

Among the pteropoda Limacina helicina is typically arctic ; it spawns on the coast banks of Greenland at a temperature of $0^{\circ} \mathrm{C}$., and between the ice-floes, the young being gradually distributed into deeper water.

As already indicated, there are certain medusæ which must be considered as arctic coast forms (see Fig. 398, p. 570), such as Hippocrene superciliaris, Codonium princeps, Catablema campanula. Of oceanic medusæ Aglantha digitalis is found in the upper layers, and Crossota norvegica in the deepest layers of the Norwegian Sea, both being characteristic forms.

The siphonophore Diphyes arctica, the sagittidæ Krohnia hamata, Sagitta gigantea and S. arctica, the ostracod Conchocia borealis, the schizopoda Meganyctiphanes norvegica, Boreophausia inermis and Thysanoëssa longicandata, the amphipoda Euthemisto 
libellula and Parathemisto oblivia, the prawns Hymenodora glacialis and Pasiphaa princeps are partly arctic, partly boreoarctic, and partly boreal in their occurrence, but in the present state of our knowledge it is impossible to define sharply the general laws of their distribution. In the year I 900 I made a number of closing-net hauls in the Norwegian Sea, which showed that there was a peculiar pelagic fauna in the deep cold layer below the Gulf Stream, including the following large forms: Cyclocaris guilelmi, Hymenodora glacialis, Pasiphaa princeps, and large Sagittæ (S. gigantea).

Of holopelagic fish there is not a single arctic species. The coast fishes of Greenland, Spitsbergen, and other Arctic shores may certainly be captured in the surface waters above the coast-banks, but their life-cycle is not wholly pelagic. In regard to one species only, Gadus saida (the polar cod), there may be some doubt, for it lives everywhere along the ice independent of depth, but it seems most feasible to classify it among the Arctic shore-fishes. In the case of this fish the ice apparently replaces the shore, a condition peculiar to many other arctic forms.

Highly important is the Capelan or Caplin (Mallotus villosus), which lives in the Arctic or in the extreme north of the boreal area, where it appears at all events once a year to deposit its spawn on the coast banks. We may thus term it a meropelagic fish of "boreo-arctic" character.

The black Paraliparis bathybii has been taken by the "Michael Sars" in mid-water in the Norwegian Sea, but whether this species is mainly a bathypelagic or a bottom fish cannot be decided from the available records.

It has long been known that Atlantic species sometimes Atlantic appear in the coast waters of Norway, and Nordgaard ${ }^{1}$ has ${ }_{\text {communities. }}^{\text {animal }}$ published an interesting review of historical details of this kind. Thus in I82 I salpæ were observed by a certain Norwegian priest, and between the 'twenties and 'forties of last century when Michael Sars was engaged in his pioneer work on the west coast of Norway, he found many Atlantic forms, like Salpa mucronata and S. fusiformis, well known by the fishermen and termed "Silderaek," a portent of successful herring fishery. Sars described from the west coast of Norway some new species of Siphonophores and a larval Actinian having their main distribution in the Atlantic, such as Galeolaria

\footnotetext{
1 Kigl. Videnskapers selskaps skrifter, Trondhjem, 1910.
} 
biloba and G. truncata, Agalmopsis elegans, Physophora hydrostatica (borealis), and Arachnactis albida. Since then many records of Atlantic forms occurring on the coast of Norway have been published, and Collett ${ }^{1}$ has collected many such records referring to fishes. Similar information has been gathered in Sweden, Denmark, and Germany. I give here some of these records, without any claim to completeness.

Of Foraminifera, the majority of which are oceanic forms, Globigerina bulloides is always found in the Gulf Stream off the coast of Norway.

Surface Radiolarians (Acantharia), and also Atlantic deepsea species of the same group, sometimes occur, for instance, Challengeridæ, Medusettidæ, and Arachnosphæridæ. Jörgensen has greatly contributed to our knowledge on this group of animals. In the Skagerrack, Atlantic Radiolarians have also been found by Aurivillius.

As prominent among Atlantic Medusæ taken in the Norwegian Sea and fjords we may mention Atolla bairdi and Periphylla hyacinthina. In May I9I I investigated the Sognefjord, having a depth of 1000 to 1200 metres, towing simultaneously a number of pelagic fishing appliances at various depths, and captured more than 1000 Periphylla hyacinthina of all sizes; they occurred at all depths below 75 metres, IoO large and 300 small individuals being taken at 750 metres. Of southern jelly-fish Cyanea lamarcki and Rhizostoma octopus have been taken on the Norwegian coast; the former is a coast form and probably came from the southern North Sea. Among the Siphonophores Physophora hydrostatica is most abundant, but the other forms recorded by Michael Sars also occur. $^{2}$ Damas has drawn attention to the importance of this immigration.

Arachnactis albida is frequently found and is a characteristic Atlantic species.

Nordgaard has recorded Atlantic Copepoda from Lofoten (Pleuromma robusta), and the barnacle, Lepas fascicularis, has frequently been found. The southern pteropod Clio pyramidata also occurs. Salpa fusiformis and S. mucronata occur on the coast of Norway, having been recorded by many observers from the south-west coast to Trondhjem fjord (Nordgaard).

Regarding the squids some interesting information is on record. Steenstrup collected information about colossal squids

1 Collett, Meddelelser om Norges Fiske (Kristiania, 1902-1905).

2 See Damas in Report on Norwegian Fishery and Marine Investigations, vol. ii. No. 1, I909. 
from the Northern Atlantic stranded on various North European coasts, which he described as Architeuthis dux. The stranding of such giant squids is recorded from Nordland (where Collett heard of a specimen 12 feet long) and from Trondhjem. In my opinion it is an open question whether certain smaller squids do not passively invade the Norwegian coasts in enormous quantities from the Atlantic. During the cruises of the "Michael Sars" in the Norwegian Sea we never found the larvæ of the abundant Gonatus fabricii, but on our Atlantic cruise we caught them between Newfoundland and Ireland.

Our knowledge is, however, most exhaustive on the subject of the Fishes, and from Collett I have compiled the following list of Atlantic species found in Norwegian waters with their relative frequency:-

\section{SCOMBRIDE (MACKERELS)}

Auxis thazardus, 2 specimens.

Thynnus thynmus (the tunny), annually.

Euthynnus alliteratus, 3 specimens.

Sarda sarda, almost annually.

\section{Stromateide}

Centrolophus pompilus, 2 specimens.

\section{ZEIDE}

Zeus faber (John Dory), about I6 specimens, between Christiania and Bergen.

LAMPRIDE

Lampris guttatus, anmually one or more specimens.

BRAMIIDÆ

Brama raii, I specimen.

Pterycombus brama, I4 specimens.

Trichiurus lepturus, I specimen.

TRICHIURIDE

XIPHIIDE

Xiphias gladius (the swordfish), 30 or 40 specimens during the last twenty years, Christiania fjord to Finmark.

\section{TRACHYPTERID}

Trachypterus arcticus, annually one or more specimens stranded. Regalecus glesne, I 2 specimens during sixty years.

\section{STERNOPTYCHIDE}

Argyropelecus olfersi, about 20 specimens observed as far as Finmark. Argyropelecus aculeatus, I specimen.

Argyropelecus hemigymmus, I specimen in Finmark. 
CHAP.

\section{SCOPELIDE}

Myctophum glaciale, 4 or 5 specimens in one hundred years.

Myctophum elongatum, shoals observed during certain periods in the Trondhjem fjord.

SCOMBRESOCIDÆ

Scombresox saurus (skipper or saury pike), found now and again as far as Finmark. Exocoetus volitans (flying-fish), I specimen, Christiania fjord.

\section{Clupeide}

Clupea pilchardus (sardine), since $\mathrm{r} 87$ I no specimen on record.

Clupea alosa, 30 specimens.

Clupea finta, io specimens recorded.

Engraulis encrasicholus (anchovy), insignificant numbers.

SyNGNATHIDE

Nerophis aquoreus, sporadic, as far as Tromsö.

MOLIDE

Mola mola (sunfish), stranded now and again; in Christiania fjord 20 specimens since the 'seventies.

Besides these several southern sharks have been found, for instance, the blue shark (Carcharias glaucus), which, however, is rare. Petromyzon marinus, which we took in the surface waters off the banks of Newfoundland, has been found up to Finmark.

These carefully gathered records show that many Atlantic fishes occur in the Norwegian seas only as very rare visitors, and seldom in great quantities. That these fishes are scarce is shown by the fact that in all the hauls made by the "Michael Sars" in the Norwegian Sea only Myctophum glaciale and Nerophis were observed. On the other hand interesting information as to the occurrence of Atlantic invertebrates has been gathered.

This list of Atlantic fish from the Norwegian Sea is of general interest because none of the species recorded are known to live in the deep region of the Atlantic below 500 metres, but are forms belonging either to the surface layers, or silvery forms from the "intermediate" layers about 300 metres. The Sternoptychidæ and the Trachypteridæ belong to the latter, while the others are typical surface forms. Not a single Cyclothone has as yet been captured in the Norwegian Sea.

In the Norwegian Sea the boreal region is essentially communities. limited by the presence of arctic water, which in the Greenland 
Sea in the west, at Spitsbergen in the north, and in deep water, even close to the banks of Norway and the North Sea, excludes all boreal species (see Fig. 310, p. 436).

In the boreal area, as thus limited, we find not a single species of fish, perhaps not even a single animal-form, which may be said to be entirely oceanic. ${ }^{1}$ The only oceanic community in the Norwegian Sea would perhaps be the arctic deepsea fauna. Among the boreal species, however, we find several gradations between the purely oceanic and the purely coast forms of life.

Of all invertebrates the minute crustacean Calanus calanus fimmarchicus is undoubtedly the most important in the boreal finmarchicus. community. If during spring or summer a hoop-net is towed along the surface in the warm part of the Norwegian Sea off the coast banks, a practically uniform catch is obtained, consisting almost exclusively of this species, indicating a "monotonous" pelagic life, as Haeckel calls it. G. O. Sars, in his reports on the "Vöringen" Expedition, drew attention to this fact and to the wealth of life peculiar to the open ocean, and this monotonous fauna has recently been investigated by Gran and Damas during the cruises of the "Michael Sars." Calanus finmarchicus occurs both above the coast banks and in the fjords, but in these localities its preponderance is less pronounced than in the open sea.

In the coast waters we notice many pelagic forms belong- Coast water ing to various groups, along with many larval forms of bottom animals, thus introducing a strange variety into the pelagic life. Want of space prevents a full discussion of this animal community, and in regard to the various groups I refer the reader to my preceding review. Besides Calanus finmarchicus there are many other Copepoda, especially the genera Centropages, Temora, Acartia, Anomalocera, and Euchata. Of Schizopoda Thysanoëssa, Meganyctiphanes, Mysis, and of Decapoda Pasiphcea and Pandalus, occur. Vast numbers of Medusæ are found at the surface and in the deep water of the fjords, in the Norwegian depression or gut, and in the Skagerrack. Two species of jellyfish, the brown stinging jelly-fish Cyanea capillata, and the transparent Aurelia aurita, are frequent. Of Pteropoda we meet with Clione limacina, Limacina retroversa, and L. balea. The most important squid is Ommatostrephes todarus. Of fish the following species may be noted: mackerel (Scomber scomber), sprat (Clupea sprattus), herring (Clupea harengus), salmon

1 According to Damas even Calanus finmarchicus is to some extent dependent on the configuration of the bottom (in the spawning time). 
(Salmo salar), sea trout (Salmo trutta), capelan (Mallotus villosus).

In the southernmost part of our boreal region certain Atlantic pelagic forms are found in such numbers that they may be considered as belonging to the boreal area, though in the main they are Atlantic; so far the occurrence of these species resembles that of certain bottom fish, like the sole, the turbot, and the brill. The principal forms are: the horse mackerel (Caranx trachurus), Clupea alosa, and the anchovy (Engraulis encrasicholus).

Certain bottom fishes are often found in mid-water, such as the sharks which pursue the herring shoals, the common dog-fish (Acanthias vulgaris), the herring-shark (Lamna cormubica) and the large Selache maxima. Many fishes of the cod family lead a partly pelagic life, especially the saithe, and sometimes also the cod, haddock, and others. A specially remarkable type is the Norway haddock (Sebastes marinus). The pelagic eggs, larvæ, and young of economically important fishes, chiefly the cod and flounder families (Gadidæ and Pleuronectidæ) form another very important section of the pelagic communities.

When in the year I900 I commenced my investigations with the newly built "Michael Sars," one of my main objects was to find out to what extent the fishes of the coast banks occurred in the deep mid-water of the Norwegian Sea. A large amount of information regarding this question has been accumulated, and we may now classify these animals in four groups:-

I. Larvæ and young organisms which have been carried out by currents, mainly of jelly-fish and cod, saithe and haddock.

2. Adult coast fish which have migrated; they spawn on the coast banks, but not over the deep water of the Norwegian Sea, the species observed being herring, cod, haddock, and saithe; also the squid, Ommatostrephes todarus.

3. Adult forms which spawn and occur in all stages of development in the coast waters, and also spawn over the deep Norwegian Sea; the only species of this kind observed is the Norway haddock (Sebastes marinus).

4. Atlantic animals : besides those previously mentioned we have also found the squids, Gonatus fabricii and Architeuthis dux, and the "Atlantic" whales, the "Bottle-nose" (Hyperoodon diodon) and the cachalot (Physeter macrocephahis).

Of these groups I will discuss the three last, leaving the first to be dealt with in the next chapter.

On the chart (Fig. 482) I have denoted all the localities 
from which we possess definite information as to the occurrence The herring. of herrings, gadids, and Sebastes over deep water. Most of the

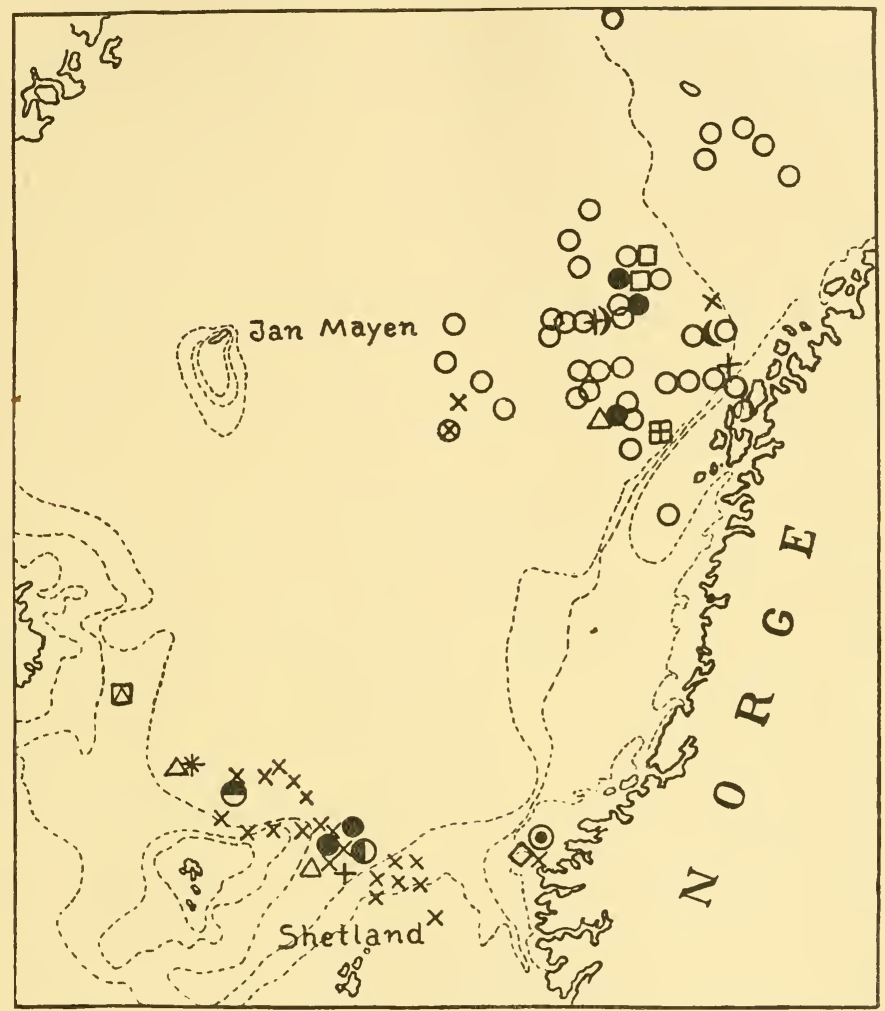

Fig. 482.-Animals CaUght over great Depths in the Norwegian Sea. The isobaths represent depths of 100,200 , and 500 fathoms.
O Sebastes.
(C) Cyclopterus.
D Haddock.
- Cephalopoda.
$\times$ Herrings.
Anarrhicas
(D) Lamna.
- Acanthias.
+ Cod.
$\triangle$ Gadus virens.
C Greenland shark.
A Mackerel.

herrings occur from the northern slope of the North Sea towards Iceland. Only in two places elsewhere, between the Lofotens and Jan Mayen, did we succeed in capturing herrings, and 
though the individuals are few they are very interesting because the localities are no less than 240 miles distant from any shore. As the herring spawns on the bottom comparatively near the shore, and the young are consequently born there, these captures illustrate the actual migrations. Several of the records obtained near the slopes of the coast banks of the North Sea, the Faroe Islands, and Iceland are specially interesting, because the fishermen always report that herrings occur in the stomachs of ling and cod captured on the slopes of the banks in summer. It will be an interesting object for future research to ascertain if herrings may be captured along the bottom on the slopes. This might be possible now that the trawl has proved a fit appliance for the capture of herrings along the bottom, and if successful would confirm the hypothesis of Sir John Murray that this part of the sea bottom, the "mud-line," is a feeding ground for these fishes.

The Gadidæ (cod, haddock, and saithe) have been taken in the surface waters over the deep parts of the Norwegian Sea far from the coast banks, but not in great numbers. The species most numerously represented in these parts seems to

The Norway haddock.

Ommato. strephes todarus. be the Norway haddock (Sebastes marinus). As will be noticed from the chart it has been taken in many localities, and these have been added to by recent investigations. Sebastes occurred mostly at depths of 100 to 200 metres, and we captured them by means of floating long lines, as shown in Fig. 74, p. 90, in numbers bordering on the abundance necessary for commercial fishing. Thus on one occasion we captured 65 fishes on 600 hooks with salted bait. Two young specimens of this fish were captured during the "Vöringen" Expedition, and during our cruises we have found the fry in thousands all over the Norwegian Sea - a fact pointing to the existence and propagation of a large stock of Sebastes in these intermediate layers.

Among the squids Ommatostrephes todams plays the most important part in the animal community of the Norwegian Sea. In his book on the Mollusca of Northern Norway, G. O. Sars, referring to this form, says: "It is the commonest squid on our coasts, and among the fishermen is generally termed 'Akker,' 'sprut,' etc. They generally appear in enormous shoals, coming from the open ocean in pursuit of the herring shoals on which they gorge themselves greedily. In pursuing the herring they often run up on the beach in their excitement, and long sandy beaches are sometimes said to be covered with the carcases of stranded squids. At Lofoten they have been 
fished and salted in barrels for bait in the cod-fisheries, being usually captured at dusk or during the night by the aid of minute grapnels, several large hooks tied around a cylindrical piece of lead, baited with a herring and lowered to a suitable depth. The species is known outside Norway from the Skagerrack, the Faroe Islands, and Iceland, as well as from the west coast of France and the Mediterranean."

While fishing on the slopes of the coast banks one often finds this squid in the stomachs of cod, and repeatedly I have had occasion to make most interesting notes as to the occurrence of this species in the open sea far from land. One night we were hauling long lines on the Faroe slope, working with an electric lamp hanging over the side in order to see the line, when like lightning flashes one squid after another shot towards the light; on the same occasion the beaks of these animals were found in the stomachs of the captured fish. In October 1902 we were one night steaming outside the slopes of the coast banks of Norway, and for many miles we could see the squids moving in the surface waters like luminous bubbles, resembling large milky white electric lamps being constantly lit and extinguished; with a hand-line we captured several specimens. The existence of such numbers of squids in the open sea must undoubtedly be considered a very important item in the fauna.

Squids occur very abundantly also in the western part of the Norwegian Sea, where the small "bottle-nose" whale is captured by whalers during spring and summer. I have tried The "bottleto obtain reliable information as to where this whaling goes on, and on the basis of this information I have prepared a chart (Fig. 483 ); each dot signifies a place where several whales have been observed or shot. The chart brings out the peculiar fact that all the localities are situated on the western side of the Gulf Stream water in the Norwegian Sea, i.e. in the transition belt between the Arctic and Atlantic currents. We gather from this chart that in April and May the "bottle-nose" is widely distributed over this part of the Norwegian Sea ; in July the whaling ceases, and in September the inhabitants of the Faroe Islands get their last "bottle-nose." These whales are never, or only on extremely rare occasions, observed or shot on the coast banks, and thus they do not enter the Barents Sea, but, according to an experienced whaler, they follow the 8oo-fathoms line.

I have succeeded in obtaining information as to the stomachcontents of the "bottle-nose"; these consist mainly of the 
Gonatus fabricii. remains of squids, not Ommatostrephes todarus, but Gonatus fabricii, which must consequently occur in great numbers in

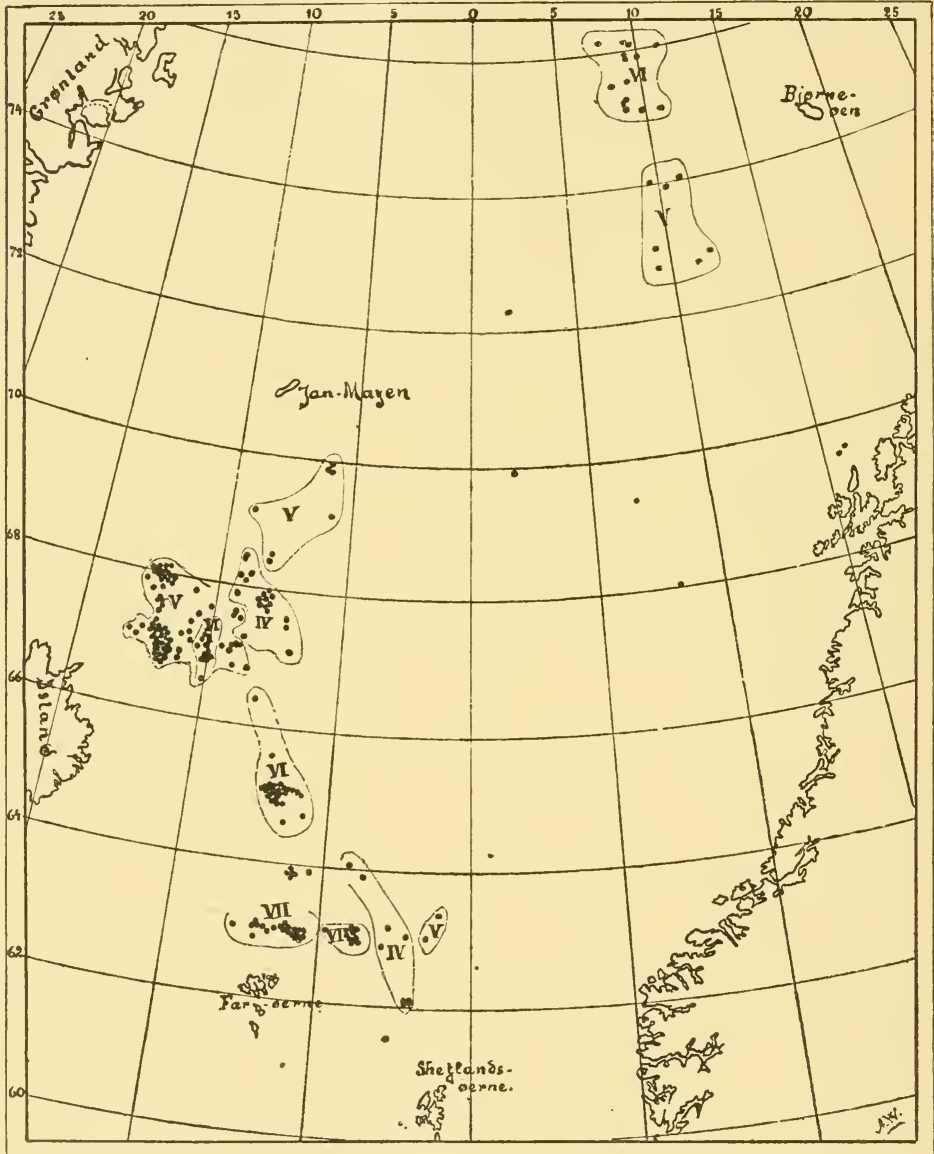

Fig. 483.-Distribution of "Bottle-Nose" IVHALE (HYPEROODON DiOdov) IN THE Norwegian SEA.

IV.-V1I. indicate the months April-July.

the western part of the Norwegian Sea; farther south, in the vicinity of the Faroe Islands, herrings are also found in the stomachs. As previously mentioned, numerous larvæ of Gonatus 
fabricii were taken on our Atlantic cruise between Newfoundland and Ireland (at Stations 70, 80, 8I, and 94, covering a wide expanse of ocean); such larvæ have never been taken by us in the Norwegian Sea. As a working hypothesis we may suppose that in spring and summer Gonatus migrates into the Norwegian Sea from the Atlantic, just as the "bottle-nose" is universally believed to do.

The same remark probably applies to the interesting giant squid, Architeuthis dux, a specimen of which (see Fig. 484) was Architeuthis. found floating at the surface to the north of the Faroe Islands during a cruise with the "Michael Sars" in 1902. This specimen was not large, but in 1903 in Iceland I had the opportunity of making an interesting observation, showing the gigantic dimensions of these squids. On the I 5 th of August the "Michael Sars" arrived in Mofjord on the east coast of Iceland, and visited the local whaling station. On the shore were two freshly caught whales, one a north-caper, the other

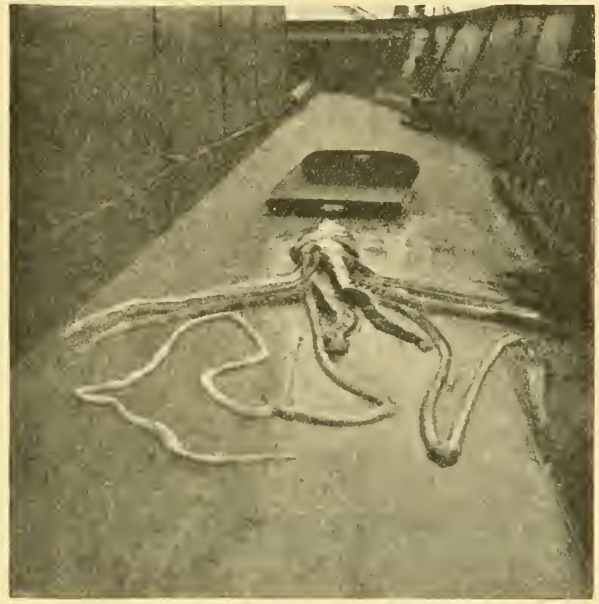

FIG. 484.-ARCHITEUTHIS, FOUND DEAD NORTH OF THE FAROE ISLANDS.

a cachalot. Inspecting the cachalot I saw around its enormous jaws several long parallel stripes (see Fig. 485), consisting, as closer scrutiny revealed, of great numbers of circular scars or wounds about $27 \mathrm{~mm}$. in diameter; Fig. 486 shows a piece of the skin with these scars. It occurred to me that these scars must have been left by the suckers of a giant squid, and following up this idea I found in the whale's mouth a piece of a squid-tentacle $17 \mathrm{~cm}$. in maximum diameter. In the stomach of the whale many squid-beaks of various sizes were found, the largest measuring $9 \mathrm{~cm}$. in length, besides some fish bones, and the men who had shot the whale told me that in its death-flurry it disgorged the arm of a squid" 6 metres 
long. Similar observations have been recorded from the Azores by the Prince of Monaco.

The Boreal Area outside the Norwegian Sea.-The northern North Atlantic has previously been investigated by Danish expeditions on board the "Ingolf," "Thor," and "Tjalfe" in the waters of western Europe, Iceland, and Greenland, by a German expedition on the west coast of Greenland and by British expeditions west of Britain, while Hensen's Plankton Expedition also crossed this area. On the other hand, the

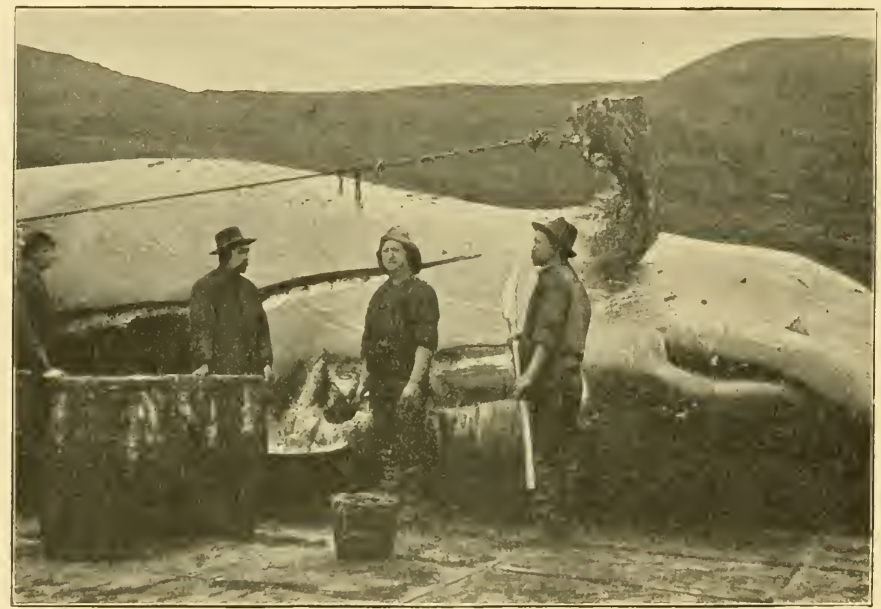

Fig. 485.-CACHALOT WITH LONG STRIPES FROM STRUGGLE WITH ARCHITEUTHIS.

exceedingly interesting waters between Davis Strait and the United States have been very little examined.

The results of all these expeditions prove the northern North Atlantic to contain the same pelagic animals as the Norwegian Sea. According to the various bodies of water, however, the animal life varies in composition in different parts of the ocean. Thus to the west of Britain pelagic life is temperate Atlantic, mingled to some extent with boreal forms; to the south of Iceland the boreal forms predominate, though the Atlantic admixture is very important; in Davis Strait the character of the fauna is mainly Arctic, though some boreal forms still appear (the capelan, for instance, seems very characteristic). Proceeding from Labrador to the Northern States the purely 
Arctic, the boreal, and the subtropical Atlantic forms are met with in succession, their distribution changing according to seasons and local conditions; the boreal waters are here squeezed between bodies of Arctic and Atlantic water, and the transitions between the different bodies of water and between the different animal-communities are very sudden.

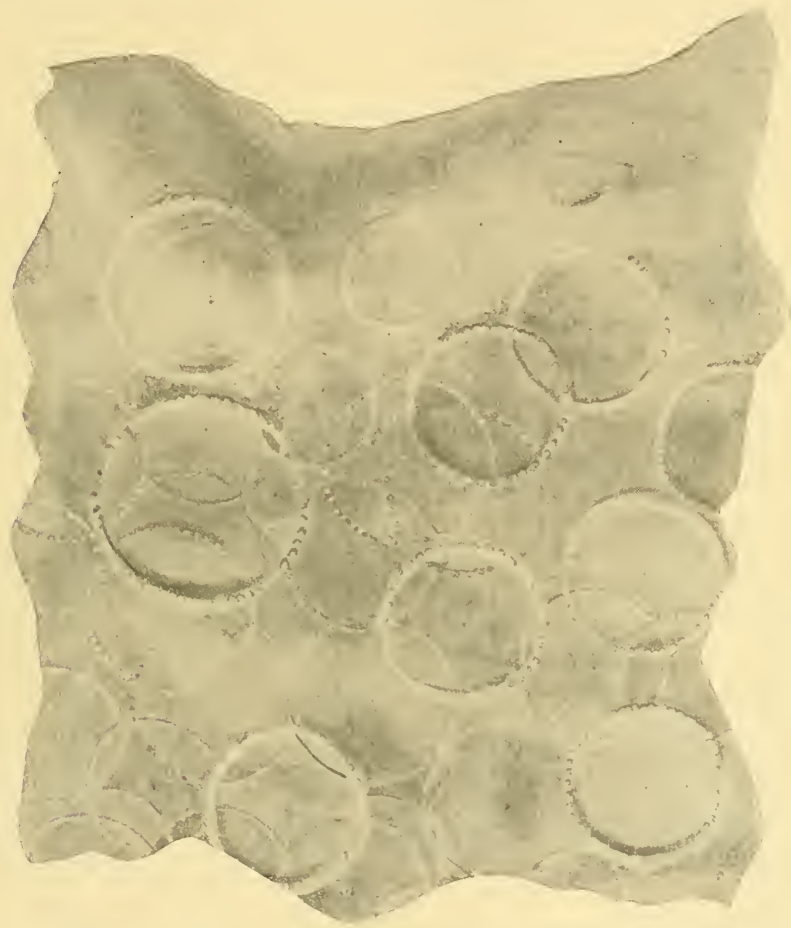

Fig. 486-Skin of Cachalot With Marks from Struggle with ARchiteuthis. Nat. size.

The tow-nettings made by the "Michael Sars" in I910 between the Sargasso Sea and Newfoundland and thence,to Ireland are particularly interesting, because they comprisé Arctic, boreal, and Atlantic forms mingled together in the same oceanic area, and afford a rare opportunity for observing to what extent the distribution of different forms depends jon certain physical conditions. 
G. O. Sars' list of Crustacea referred to ON PP. 656-7.

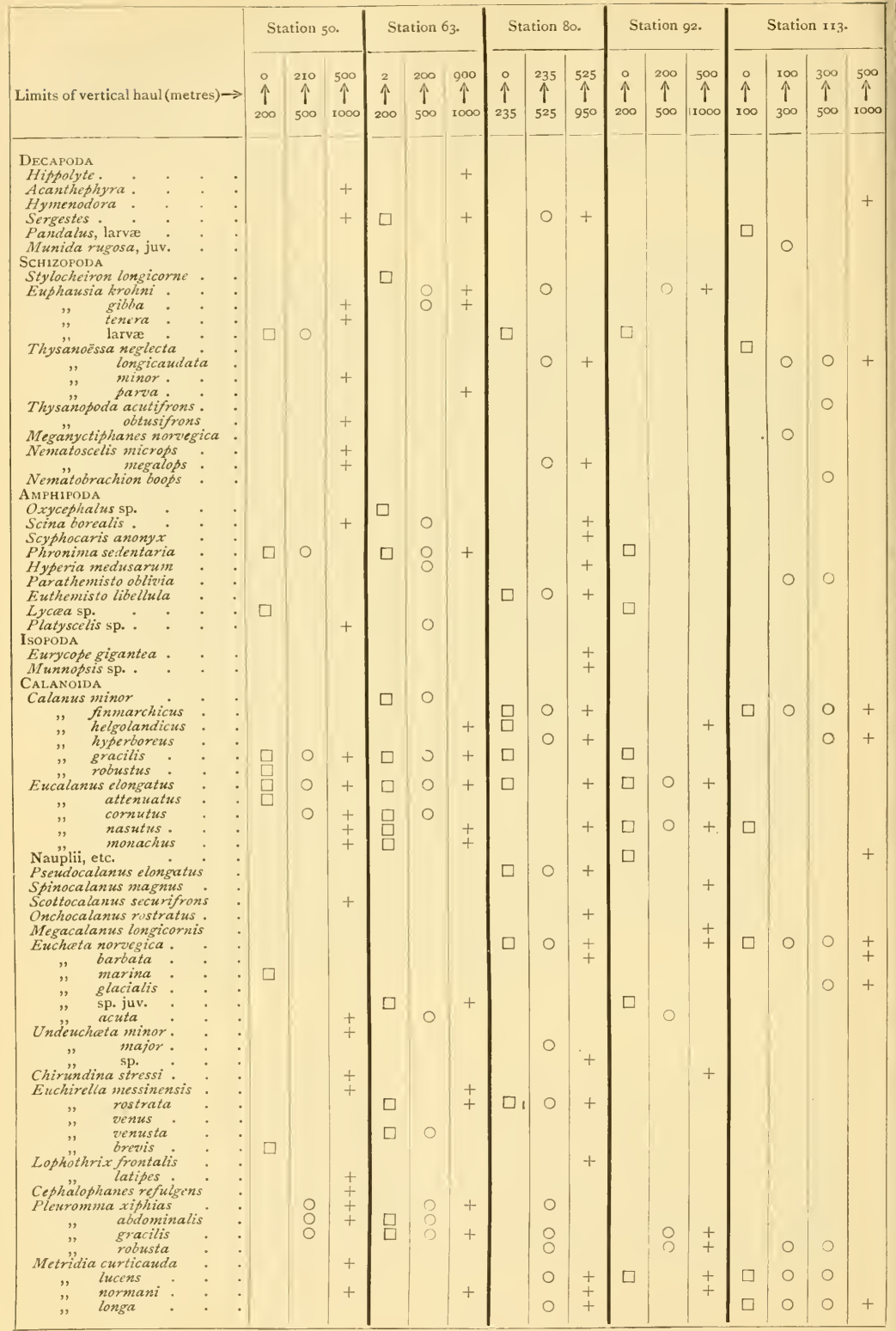


G. O. Sars' list of Crustacea (continued).

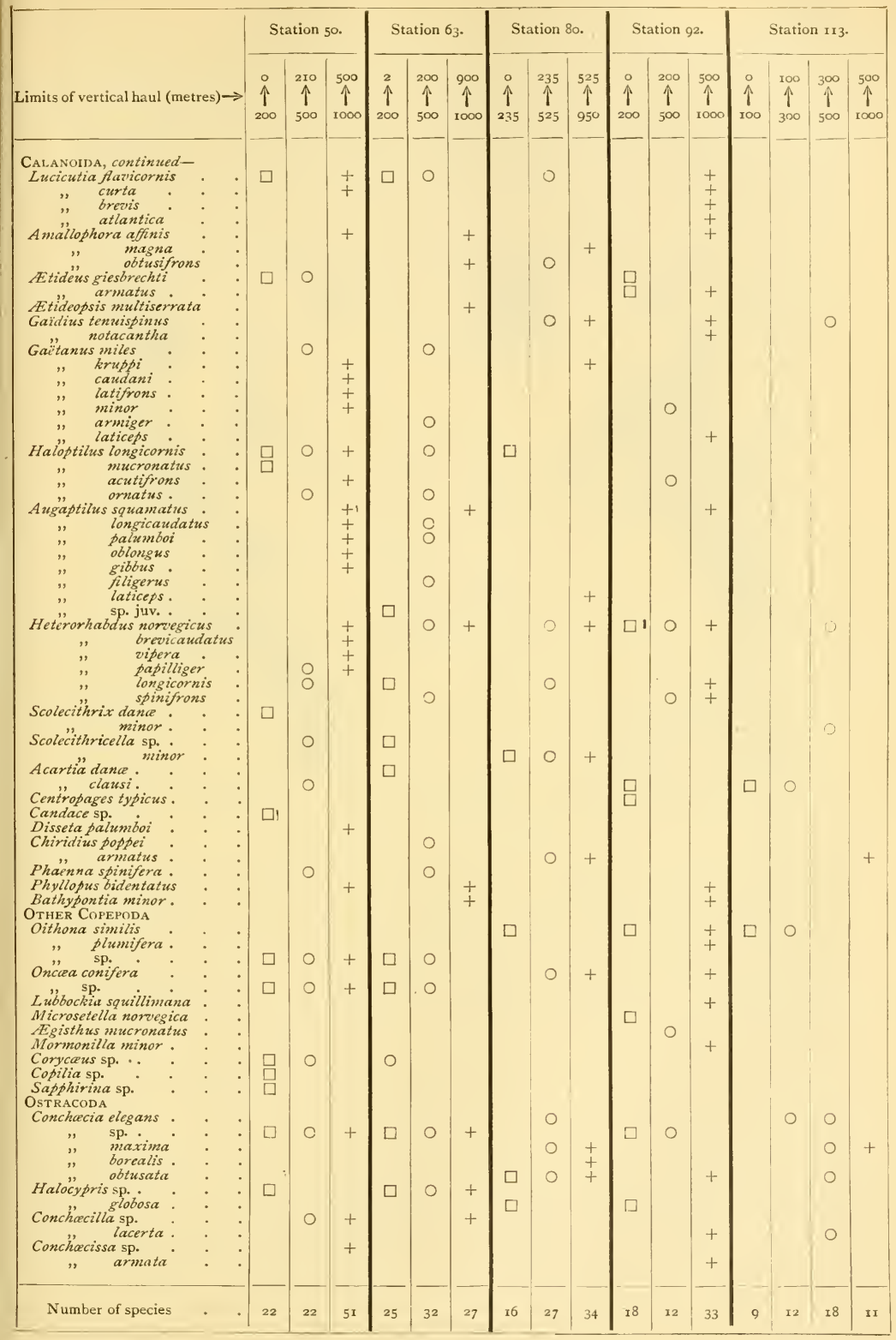


Our collections of minute crustaceans, especially Copepoda, are very extensive, but their examination will take a long time. In order to give some information about the distribution of these interesting forms, I asked G. O. Sars to determine the species contained in some of our closing-net hauls, and selected samples from certain stations (see Fig. 487), which I believed to be specially characteristic, viz. two stations in the Sargasso

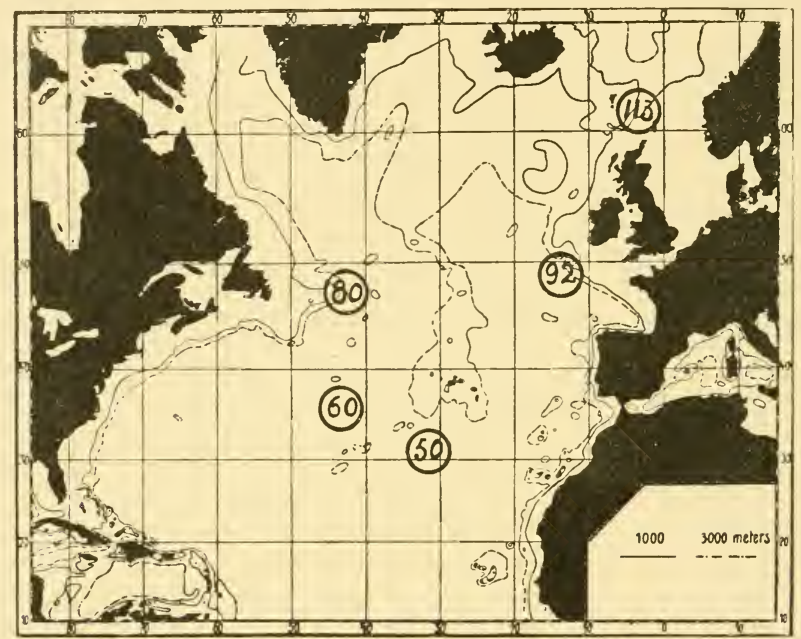

Fig. 487.-Positions of Stations from which lists of Crustacea have been DRAWN UP. [Station 60 should be 63.]

Sea $(50,63)$, one station off the Newfoundland banks (80), one station off Ireland (92), and one station in the Norwegian Sea north of the Wyville Thomson Ridge ( I I 3 ). Before referring to Sars' determinations (see list, pp. 654-5) I may indicate the temperatures at the various depths where the nets were towed:-

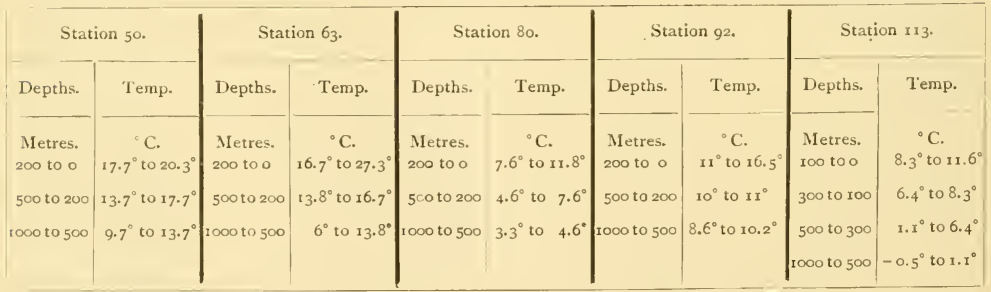


From a study of the list on pp. $654-5$ we note the following points :-

(I) A certain number of genuine warm-water forms occur only in the upper hauls (200 to o metres) in the southern stations (50 and 63), such as: Eucalanus attenuatus, Euchata marina, Euchirella brevis, Haloptilus mucronatus, Scolecithrix dance, Acartia dance, Candace, Copilia, Sapphivina.

(2) Some Atlantic deep-sea forms do not occur at the surface either in the Sargasso Sea or along our northern track; they do not enter the Norwegian Sea and are consequently distributed like the Atlantic bathypelagic fauna. Such are: Amallophora affinis, Augaptilus squamatus, Phyllopus bidentatus, Bathypontia minor.

(3) Some forms have a large vertical range in warm waters, like Calanus gracilis and Pleuromma gracilis.

(4) Other forms have a large vertical range in the southern as well as in the northern stations, like Eucalamus elongatus (see Stations 50, 63, 80, and 92).

(5) A peculiar group is composed of forms having at the boreal stations a large vertical range, but occurring at the warm southern stations only in deep water such as: Calanus fumarchicus (Stations 8o and II 3 at all depths); Euchata norvegica (Stations 80 and I I 3 at all depths, Station 92 only between 1000 and 500 metres, also, according to Nordgaard, Station 64, in I 250 metres, Station 62 in 1000 metres) ; Metridia longa (Stations 8o and I I 3 in all hauls); Pseudocalanus elongatus (Station 80 at all depths); Scolecithricella minor (Station 8o at all depths); Hetcrorhabdus norvegicus (Station 92 at all depths, and in deep water at Stations 50, 63, 80 and I I 3). All these forms occur in the Greenland Sea, where they also have a large vertical distribution (Damas and Koefoed).

(6) Certain forms recorded only from the deep hauls at Stations 80 and II 3 , where the temperature is lowest, such as Euchata barbata, E. glacialis, Calamis hyperboreus, Amallophora magna. None of these occur in deep water at Stations 50 and 63, but, according to Nordgaard, Calamus hyperboreus and Euchata barbata have both been taken at Station 62 in the Sargasso Sea in a horizontal haul at 1000 metres in great numbers, $6_{5}$ specimens of Calanus hyperboreus being counted in a small part of the sample. These forms belong to the Arctic region in the Norwegian Sea, where according to Damas and Koefoed they are also deep-sea forms, except the surface species Calanus hyperboreus. 
The general results may be summarised as follows :-

In the northern North Atlantic we find Atlantic, boreal, and Arctic forms. On our track from Newfoundland to Ireland we met chiefly Atlantic species at the surface (see Station 92, 0-200 metres). In deeper water we find certain Atlantic deep-sea species which nowhere in the ocean reach the surface, mingled with boreal species. At Station 80, situated in an area where the cold waters of the Labrador current communicate directly with the deep bottom layers, the boreal forms occur at all depths (Group 5), as they do in the Norwegian Sea; but to the east of Station 8o, where the warm layers are thicker, we meet only the boreal forms in the deeper water, and in the

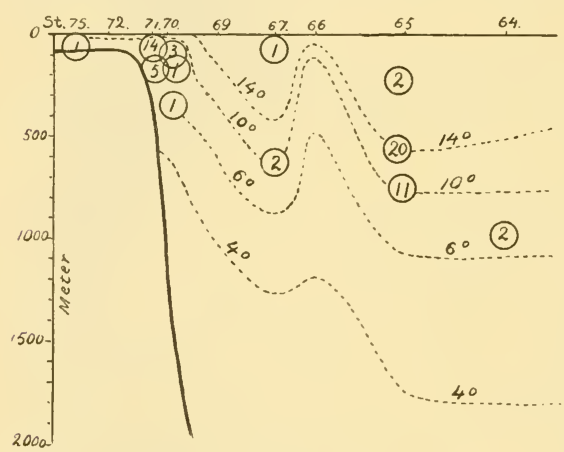

Fig. 488.-VERTICAL DistribUtion OF CLIONE LIMACINA between Newfoundland and the Sargasso Sea. The encircled figures denote the number of individuals captured.
Sargasso Sea at depths of IO00 metres. Thus Euchata norvegica was taken at all depths at Stations 80 and I 13 ; at Station 92 only from 1000 to 500 metres, and at Station 62 only at 1000 metres.

The genuine Arctic forms (Group 6) occur in waters with temperatures below 5 or $6^{\circ} \mathrm{C}$., thus Calames hyperborcus was taken on the Newfoundland banks at the surface, at Station 80 only below 200 metres, and at Station 62 at 1000 metres.

As shown in Chapter III., this conformity appeared even during the cruise, and was obvious not only in regard to these small crustaceans, but for quite a number of other boreal and Arctic animals as well (see pp. Io6-108 and 117-1 I8). The most important boreal and Arctic forms encountered between Newfoundland and Ireland, besides the Copepoda previously mentioned, were: the medusa Aglantha, the Ctenophores Beroë, Pleurobrachia, and Mertensia, the worms Sagitta arctica and Krohnia hamata, and the pteropods Limacina helicina and Clione limacina.

During our voyage from the Sargasso Sea to Newfoundland and thence to Ireland, Clione limacina was, according to 
Bonnevie, taken at the depths indicated by circles in Figs. 488 and 489. At Newfoundland it lived at the surface, but all the way from Newfoundland to Ireland it was taken only below 750 metres. Its occurrence in only 50 metres on the coast banks off Ireland is remarkable and important, showing that this form occurs in shallow water, both on the eastern and western sides of the North Atlantic, in cold and in warm water.

This distribution seems to be shared by Aglantha digitalis,

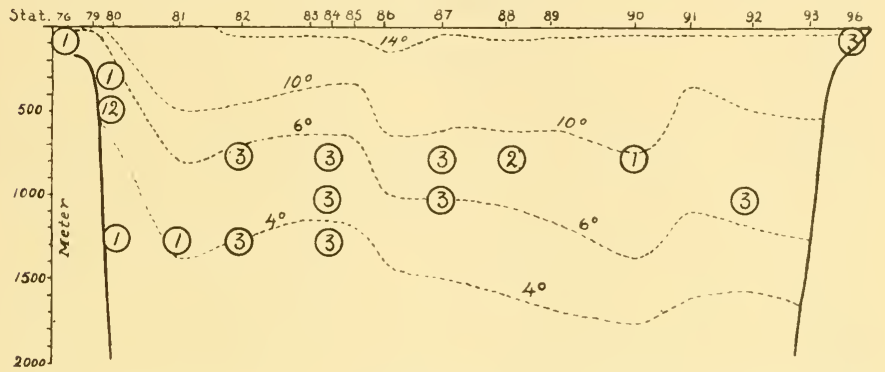

Fig. 489. - Vertical distribution of CLIONE LIMACINA Between Newfoundland AND IRELAND.

The encircled figures denote the number of individuals captured.

which was taken on the Newfoundland banks at the surface, at Station 80 in vertical hauls from 950 to 525 metres, at all the deep stations farther east (for instance Station 92) at 1000 metres, but close to the slope of the coast banks of Ireland it was taken only 100 metres beneath the surface.

In the deep water of our northern section our pelagic fishing appliances at, for instance, Iooo metres gave bathypelagic Atlantic forms like Cyclothone microdon, Atolla bairdi, Gigantocypris, Pelagonemertes, Pyrosoma, Acanthephyra, besides boreal forms like Euchata norvegica, Aglantha digitalis, and Clione limacina. 


\section{CHAPTER X}

GENERAL BIOLOGY

Aвout the beginning of the nineteenth century many distinguished men of science seem independently to have developed the idea that the structure of animals and their occurrence in various localities are determined by external conditions.

Lamarck in his Philosophie zoologique (I809) writes as follows: "The external conditions always and strongly exert their influence on all living beings. This influence is, however, difficult to ascertain, because its effects only appear, and may be recognised, after a very long time."

Goethe's zoological works all testify to his strong belief that "all living beings possess the faculty of adapting themselves to the manifold conditions presented by external influences, without, however, resigning a certain hard-earned and decided independence." In his Skeletons of Rodents he says that "the difference of forms is a consequence of their necessary dependence on the outer world." In his introduction to comparative anatomy he attempts to show the various influences exerted by certain climatic conditions, by water, and by air upon the shape of animals, which become altered on passing from one group of conditions to another. This again explains the fact that "no organism intended to live is conceivable without a perfect organisation." Goethe was full of such ideas, but felt the danger of following them up. and of "losing oneself in the infinite" (Principles of Zoological Philosophy).

Kant's view is still clearer as regards the idea of adaptations to surroundings. He endeavoured to show that all biological investigations had to take for granted that living beings are fitly organised in relation to their natural surroundings. But no definite human idea of the fitness of adaptations is of any value as knowledge. No more does any human idea necessarily correspond to the reality occurring in nature. The idea is only 
valuable as stimulating the investigator to seek realities. And reality, in the scientific sense, means a definite positive mechanism, existing in the organism itself or in the surrounding medium. The object of investigation is to understand these mechanisms; the leading idea may often prove an empty fancy beyond the world of realities.

In the second half of last century the investigations on the history of the development of animals disclosed many organs (for instance, rudimentary organs), the function of which in the life of the organism could not be understood. According to the Darwinian idea the development of species consisted in innumerable minute changes. These changes were conceived as being due to "chance," which to a certain extent seemed to contradict the idea of "fit adaptations."

The historical way of explaining the structure or occurrence of organisms is, however, at present not considered contradictory to the ideas of adaptation. Even Lamarck, as mentioned above, thought that a species must exist for a very long time before the effects of the influence of surroundings appear or disappear.

As to the origin of variation it is now more and more recognised that a comprehension is only to be gained by studying the reaction of organisms against the influence of surroundings. One may endeavour to ascertain these reactions by experiment, by observing the changes taking place in the organisms when subjected to altered conditions. In nature we may also observe how the shape of individuals alters in various surroundings, and how similar shapes reappear in similar environments.

In recent times we note an increasing tendency to observe animals in their natural surroundings, and during frequent expeditions the influence of this tendency has been predominant. In recent literature we may find many investigations and many opinions, which remind us of the interest attached to these problems about a hundred years ago.

In the history of oceanic research nothing has possibly contributed so much to the awakening of this interest as the discovery of entirely different animal-communities living. on either side of the Wyville Thomson Ridge (see Fig. Io6, p. I 24). Atlantic forms occur to the south and Arctic forms to the north of the ridge, corresponding to the very different thermal conditions on either side. ${ }^{1}$

1 See Murray and Tizard, "Exploration of the Faroe Channel, during the summer of 1880 , in H. M.'s hired ship 'Knight Errant," "Proc. Roy. Soc. Edin., vol. x. p. 638, r882 ; Tizard, "Remarks on the soundings and temperatures obtained in the Faroe Channel during the summer 
Another series of investigations in this field were those of C. G. J. Petersen, regarding the distribution of mollusca in the Kattegat. In The Cruises of the "Hauch," Petersen ${ }^{1}$ has employed the only empirical method of investigating the distribution of animals, viz. to analyse the distribution of species in relation to various external conditions, as for instance, high or low salinity, high or low temperature, great changes in temperature or salinity, etc. It proved possible in the Kattegat to define areas of distribution of certain species, coinciding with areas where characteristic physical conditions prevailed.

Similar methods have been employed by Chun for the study of pelagic organisms. An important branch of this science has the object of studying the changes occurring in the physical conditions of the ocean, and the influence of these changes on the occurrence or abundance of organisms. By means of a continually increasing co-operation between hydrography and biology, both equally necessary in the study of such problems, oceanography has made great progress, especially during the international investigations in the study of the sea.

The additions which during the cruises of the "Michael Sars " it has been possible to make to these branches of science consist mainly of information regarding the vertical and horizontal distribution of animals, accompanied by physical observations of various kinds. These. biological and physical investigations place us in a position to test certain ideas regarding the adaptations of animals, and thus acquire knowledge on certain important mechanisms of life.

The following review of some of our principal results can by no means claim to be complete. The literature referred to, the various fields of biology discussed, and even the selection made from the material collected by our recent expedition, have all been limited for the purpose of this review. Still I hope to indicate some new contributions to science, and at the same time to convey some idea of the general methods and aims of biological oceanic research.

\section{Colours of Marine Animals}

From time immemorial seafaring men have possessed a certain amount of knowledge as to the colours of marine animals.

of 1882 (H.M.S. "Triton ')," Proc. Roy. Soc. Lond., vol. xxxv. p. 202, $188_{3}$; Murray, "The physical and biological conditions of the seas and estuaries about North Britain," Proc. Phil. Soc. Glasgon, vol. xvii. p. 306, 1886.

i Petersen, Det videnskabelige Udbytte af Kanonbaaden "Hauchs" togter, Kjöbenhavn, 1893. 
Sailors know well the sky-blue colours peculiar to the tropical surface forms. Herring-fishermen also know that the blackishbrown back of the herring is almost invisible from above, and only when occupying a slanting position or making a sudden turn does the herring become visible, its mirror-like sides emitting a silvery flash. The deep-sea fishermen are equally acquainted with the dark, black, brown, violet, or red colours peculiar to deep-sea animals. No scientist can claim the discovery of these phenomena, which are as well known as the colours of the ocean itself.

When considering the peculiar colours of marine animals, and their variation in different surroundings, many naturalists concluded that the colouring was due to their attempts to adapt themselves to the colours of their surroundings, in order to make themselves invisible or to protect themselves against enemies, just as is supposed to be the case with the land fauna.

This idea requires confirmation by acquiring more exact knowledge as to the conditions of light and the colours of animals from similar depths. Our knowledge regarding the penetration of light in the ocean has been as deficient as our knowledge of the vertical distribution of the animals, and the whole subject has thus been a matter of suppositions and ideas rather than of actual knowledge.

During the Atlantic cruise of the "Michael Sars" we investigated the intensity of light at different depths and also the colours of the animals. The results obtained by the photometer at a few stations in the Sargasso Sea are referred to on pp. 251-2. On a sunny day when the water was perfectly clear and transparent, light-rays of all colours, but very few red rays, were observed at a depth of 100 metres. At 500 metres the light acted strongly on the photographic plates, especially the blue rays, but the green rays were absent; even at Iooo metres the influence of the sunlight could be traced on the plates, but at 1700 metres no influence was noticeable.

As we have seen in Chapter IX. the different water-layers in the Sargasso Sea contain animals of very different colouring, certain general features in the colouring being easily recognisable in certain regions. In the hauls from 500 to 750 metres and deeper we found only black fishes and red crustaceans (prawns). At 300 metres we found the laterally compressed Sternoptychidæe with silvery sides and brownish backs. In the upper layers we met with transparent young fish, for instance leptocephali, or silvery Scopelidxe and blue flying-fish.

Penetration of light.
Animals of the Sargasso Sea. 
Plates I.-VI. show certain forms found in the Sargasso Sea, representing a small selection from the numerous coloured drawings by Rasmussen. Plate I. shows the black Cyclothone microdon from deep water and the light coloured C. signata, which has its lower limit just at the upper limit of the black fish. Other black fish and some red prawns from depths beyond 500 metres are represented in Plates II. and III. The black and red colours are easily seen in strong sunlight. The theory of protective colours must therefore assume that these colours only appear in dark surroundings. In this connection it is very interesting to note that the upper limit to the occurrence of these black and red deep-water animals, which according to latitude varies between 500 and 750 metres, is also the limit within which most of the sun's rays are absorbed, and it is important also to note that the red rays belong to that part of the spectrum which is most rapidly absorbed by the water.

In connection with the question of the colouring of these bathypelagic forms we may refer to some observations made during the cruise regarding the vertical migrations of such dark-coloured forms, as shown in Fig. 490. Three species, Gastrostomus bairdii, Cyema atrum, and Gonostoma grande have been taken only at 750 metres or deeper, while two species,

Vertical migration of animals. Gonostoma rhodadenia ${ }^{1}$ and Photostomias guemei, have been taken also at lesser depths, even at i 50 metres. I have already mentioned several instances (see p. 93) where forms like Astronesthes and Idiacanthus have been taken at the surface, but only at night. In the case of Photostomias and Gonostoma rhodadenia I have denoted the night-captures with a dark disc, while a ring denotes day-captures. These catches seem explicable only by supposing vertical migrations to take place, and as these occur in the darker part of the twenty-four hours they probably coincide so precisely with the disappearance and reappearance of daylight that the dark colouring may be of no danger to the animals in their nightly migrations towards the surface of the sea.

The occurrence of dark colours thus coincides with the region where the intensity of the sunlight is greatly diminished. Another circumstance seems to confirm this, viz. that in different waters the upper limit to the black fish and the red crustaceans seems to coincide with the same low intensity of light.

1 The specimens which in Fig. 490 are referred to Gonostoma elongatum have, on closer investigation, proved to be the closely allied Gonostoma rhodadenia. 


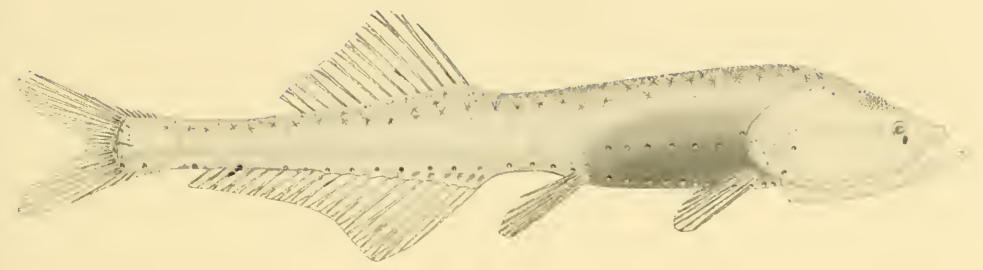

$2.7 \mathrm{~cm}$.

CYCLOTHONE SIGNATA.

CYCLOTHONE MICRODON. 



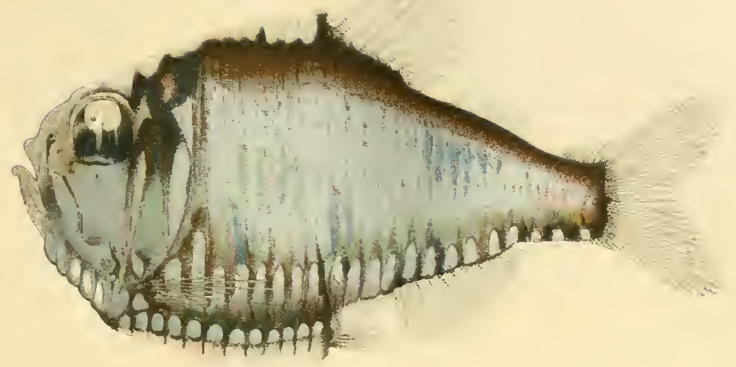

AFIGYFOPELECTTS AFFIIIE, GARM

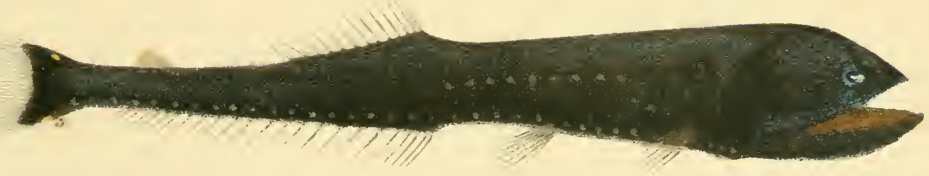

JINOSTLINA GRANDE, COLLETI

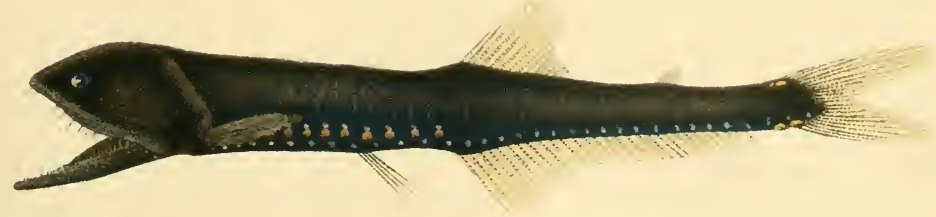

FUNOSIOMA ELONGATUM, GTHR 



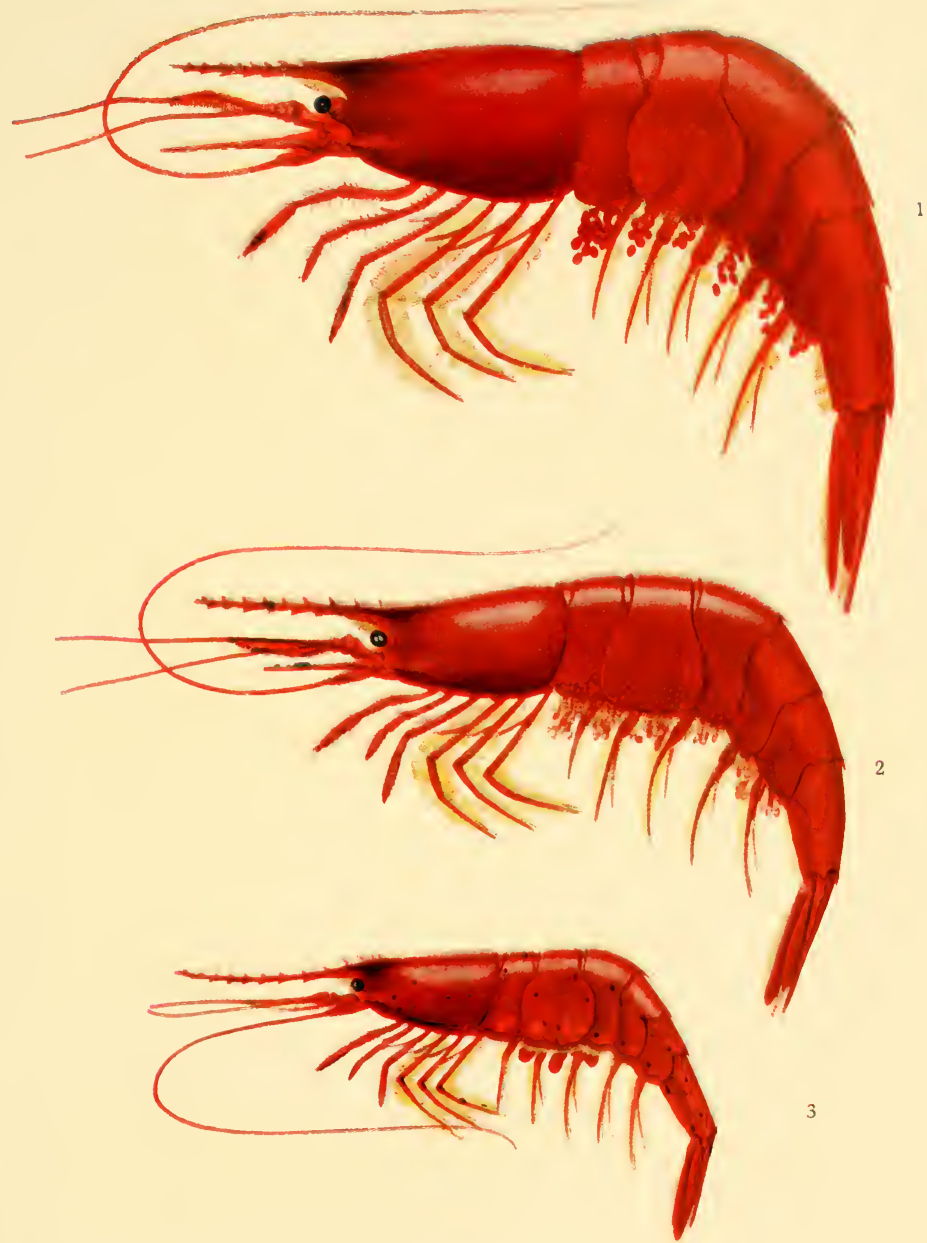

1. Acanthephyra multispina (Coutière), Sund

2. Acanthephyra purpurea, A. M.-Edwards

3. Systellaspis debilis, A. M.-Edwards 

We have seen that the upper limit for Cyclothone microdon and the red crustaceans, in the northern section from Newfoundland to Ireland, or about lat. $50^{\circ} \mathrm{N}$., was approximately 500 metres below the surface, and we have also noticed that the limit of depth for the same forms at the southernmost stations, or about lat. $33^{\circ} \mathrm{N}$., was some $200-300$ metres deeper. In the Norwegian Sea I have previously investigated the intermediate

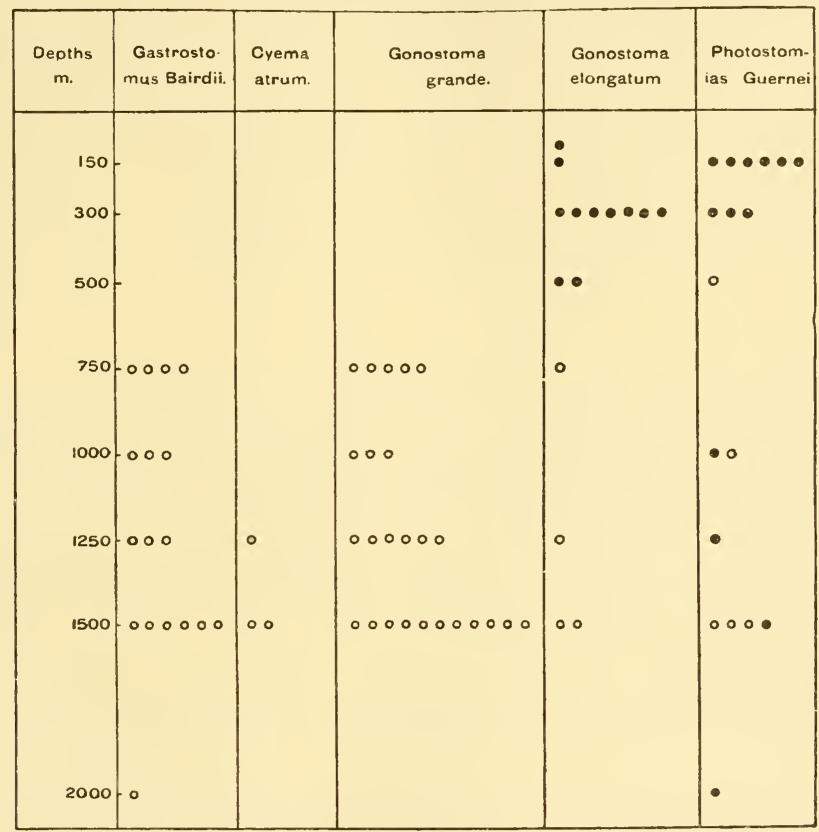

Fig. 490.-Viertical distribution of black-coloured Pelagic Fishes.

pelagic fauna, and found pelagic red prawns as well as the darkred fish, Sebastes norvegicus, at depths of about 200 metres below the surface. Sebastes was taken, for instance, with floating long lines in considerable quantities on a course from Jan Mayen to Lofoten-that is to say, in about lat. $67^{\circ} \mathrm{N}$., - at a depth of 200 metres, and it was found, though in decreasing quantities, in even less depths. Along the Norwegian coast, in the fjords and sounds, we have a particularly rich fauna of red crustaceans (especially Pandalus borealis), occupying depths 
whose upper limit in the north, at any rate, may be put at above IOO metres. ${ }^{1}$ Now, if we calculate the depth to which the rays of the sun penetrate, after passing through the same distance in the water, assuming always that the rays are direct and that the rate of absorption is the same, we find that the rays will have passed through the same distance to reach a depth of 500 metres in lat. $50^{\circ} \mathrm{N}$., that they will pass through to reach 650 metres in lat. $33^{\circ} \mathrm{N}$., or 300 metres in lat. $67^{\circ} \mathrm{N}$.

The transparency of the water, however, varies greatly in different regions. If we take the results of previous observations during different expeditions, we may set down the visible depth in the open sea as being roughly 50 metres in lat. $33^{\circ} \mathrm{N}$., 40 metres in lat. $50^{\circ} \mathrm{N}$., and 25 metres in the Norwegian Sea in lat. $67^{\circ} \mathrm{N}$. Taking this into consideration, we find that there will be the same intensity from the rectilinear rays-

In lat. $33^{\circ} \mathrm{N}$. at about 800 metres.

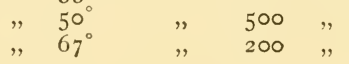

The red and black animal forms, therefore, as has been found in the investigations I have just described, have an upper limit in the different waters which corresponds everywhere with the same intensity of light.

Very interesting also is the fact that certain dark bathy-

Increase of pigmentation with increase of depth. pelagic forms appear as varieties differing in the intensity of their colours. Broch from his study of the "Michael Sars" collections thus recognises four varieties of the deep-sea medusa Atolla bairdi: ( I) stomach alone containing pigment; (2) peripheral muscular belt also pigmented; (3) the brown pigment distributed also on the lower side of the bell, while gonads are

1 Sir John Murray reports that in Upper Loch Fyne, in Loch Etive, and in some other sealochs of the west coast of Scotland, which are cut off from the ocean by submerged barriers, red prawns and other red crustaceans are very numerous in depths of 50 to 70 fathoms (about 270 to 3 IO metres); for example Nyctiphanes (Meganyctiphanes norvegica), both adult and young, can always be captured in these lochs by dragging nets one or two fathoms above the bottom. This species possesses ten phosphorescent organs : one pair in the eye peduncle, two pairs on the under side of the thorax, and the remaining four in the median line of the abdominal segments. Sir John believes that these organs are used as a kind of "bull's eye lantern," and enable the Nyctiphanes to see and pick up the minute particles of organic matter which are settling on the bottom-deposits. Many specirnens of this species were kept in aquaria for a considerable period, and were observed to light up and shut off their phosphorescent organs at will. The surface layers of water in these Scottish lochs are much less saline than the deeper layers, and contain much suspended matter, so that the penetration of iight is much obstructed. Besides Nyctiphanes other red or red and transparent crustaceans are always to be captured in the deeper water-layers of the Scottish sea-lochs, such as Calanus finmarchicus, Euchata norvegica, Conchacia elegans, Boreophausia raschii, Pandalus annulicornis, Pasiphrea sivado, Crangon allmani, Hyppolyte securifrons, etc. (see Murray, Scot. Geogr. Mag., vol. iv. pp. 353-6, I888; Comptes rendus des Séances du 3me Congrès international de Zoologie, Leyde, IS95, p. 107). 
still visible; and (4) gonads also concealed by pigment when viewed from above.

For each of these varieties Broch has recorded the vertical distribution observed, as represented in the following table, the figures denoting the number of specimens found in each layer :-

\begin{tabular}{|c|c|c|c|c|c|}
\hline \multicolumn{2}{|c|}{ Depth. } & No. I. & No. 2 . & No. 3 . & No. 4 \\
\hline \multirow{2}{*}{\multicolumn{2}{|c|}{$\begin{array}{l}\text { Surface } \\
\text { Ioo metres }\end{array}$}} & $\ldots$ & $\ldots$ & $\ldots$ & $\ldots$ \\
\hline & & $\ldots$ & $\ldots$ & $\ldots$ & $\ldots$ \\
\hline $25^{\circ}$ & $"$ & I & $\ldots$ & $\ldots$ & $\ldots$ \\
\hline 500 & ", & 17 & 4 & $\ldots$ & $\ldots$ \\
\hline $75^{\circ}$ & ", & I & 17 & I 4 & 7 \\
\hline 1000 & ", & 5 & 33 & I9 & 3 \\
\hline $125^{\circ}$ & ", & $\ldots$ & I & 2 & 4 \\
\hline 1500 & , & I & 9 & 6 & 4 \\
\hline 2000 & $"$ & $\ldots$ & $\ldots$ & $\ldots$ & I \\
\hline
\end{tabular}

Even if the difference between Nos. 2, 3, and 4 is not strongly marked, the increase in dark pigment following the increase in depth is still very perceptible.

Another instance of this is afforded by the following table, showing the vertical distribution of eleven species of pelagic decapod crustacea, according to the results of Sund's examination of the "Michael Sars" decapoda :- 


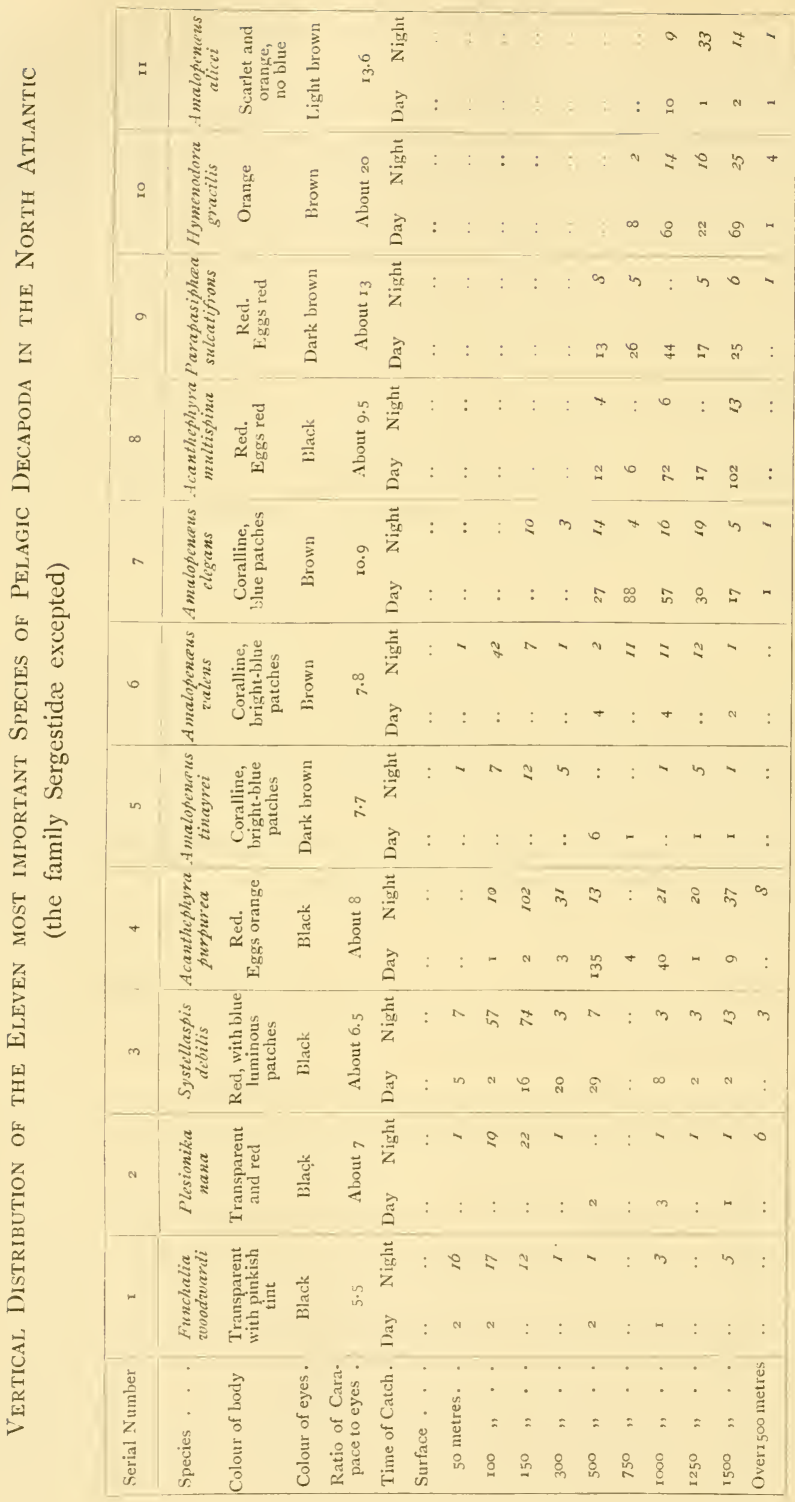


The close correspondence between the development of pigment and the vertical distribution is very striking. Nos. 1 and 2 live above 150 metres, and are nearly transparent. Nos. 3 to 7 are distinguished by deep red colours with blue patches, and were taken above 500 metres during the night, but in the daytime have their maximum distribution at 500 metres or deeper. Nos. 8 to I I have no blue pigment, but only red and yellow colours, and live deeper than 500 metres, not having been taken in less depths even at night.

As indicated in Chapter IX. the deep layers contain a great Dark-coloured variety of animals, and in all these groups we repeatedly find the same dark colours. In the medusæ Atolla, Periphylla, Crossota we find dark-brown colours or, as in Agliscra and others, red colouring. Among the Sagittidæ we meet red colours (Sagitta macrocephala, Eukrohnia fowleri). All the crustaceans are red (Eucheta, Cyclocaris, Gigantocypris, Schizopoda, Decapoda); in the Pteropoda the colours are dark violet (Peraclis diversa, Limacina helicoides, Clio falcata). The squids are red, the fishes black or blackish violet.

In the Atlantic gray, mirror-like, and silvery colours are characteristic of the fishes between I 50 and 500 metres. The silvery sheen is very often iridescent with dark green, violet, and blue tinges (see Argyropelecus affinis in Plate II.). The backs of these animals are brown or black. These colours correspond to those of the herring in boreal waters, and as previously mentioned they have been well known and recognized as protective colours. From above the fish are not easily seen because from this point of view the ocean looks dark or black. On the other hand, the light rays from above are reflected by the mirror-like sides of the body. From a position below the fish an eye would have great difficulty in distinguishing the outlines of the fish because of the rays coming directly from the source of light. This can only be understood when examining the fish in a living condition, for preserved fishes lose their silvery sheen very soon, generally turning black, and losing their original appearance. Most Scopelidæ have generally been represented as black, but many of them are really quite silvery (see Fig. 49I, which, however, is not very good, because the silvery sheen does not come out well in this kind of reproduction).

These remarks apply not only to the animals of this intermediate layer, but to many surface forms having a similar arrangement of colour. During our Atlantic cruise this was deeper layers.

Silvery and light-coloured animals in the shallower layers. 
especially conspicuous in the case of the minute young of Scombresox living at the very surface, the sides of which are mirror-like, while the back is not black, but intensely blue. This seems to correspond well to the fact that the uppermost layers of the ocean, viewed from above, appear blue. A similar arrangement of colour is met with in boreal waters, for instance Colourings of in the colouring of the surface fish, the mackerel. The colours animals really adaptations to environment. seem so intimately adapted to certain conditions, and the advantages they offer for the purpose of eluding observation are so obvious, that we can hardly avoid the conclusion that these colours must be considered as the result of adaptation to surroundings.

In the surface layers most animals are colourless. The eel larvæ (leptocephali) are specially interesting, being indeed so

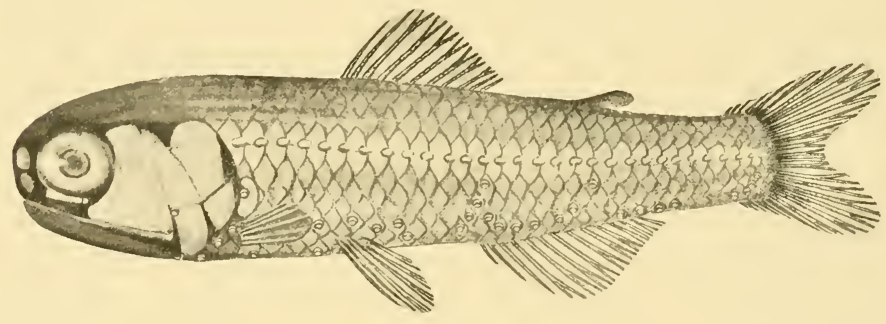

FIG. 49 I.

Myctophum (Diaphus) rafinesquei, Cocco. Nat. size, $7 \mathrm{~cm}$.

transparent that when sorting them out of the living material captured, one can only see their small black eyes; even their blood is transparent and perfectly devoid of hæmoglobin.

The surface fishes are so well known that I may merely refer the reader to Plates IV. and $V$. One group containing sea-blue forms is represented by the flying-fish. The pilot-fish are also blue, but with some darker transverse bars. Is this because biologically it approaches another group of surface-forms, which live in the immediate vicinity of drifting or floating objects? To this group belong the wreck-fish (Lirus, Polyprion). WV captured such fishes swimming around a log covered with barnacles, and the similarity between the colours of the fish and those of the $\log$ and its inhabitants was marvellous. The most intimate adaptations to life among drifting objects are met with among the animals of the Sargasso Sea (see Plates 

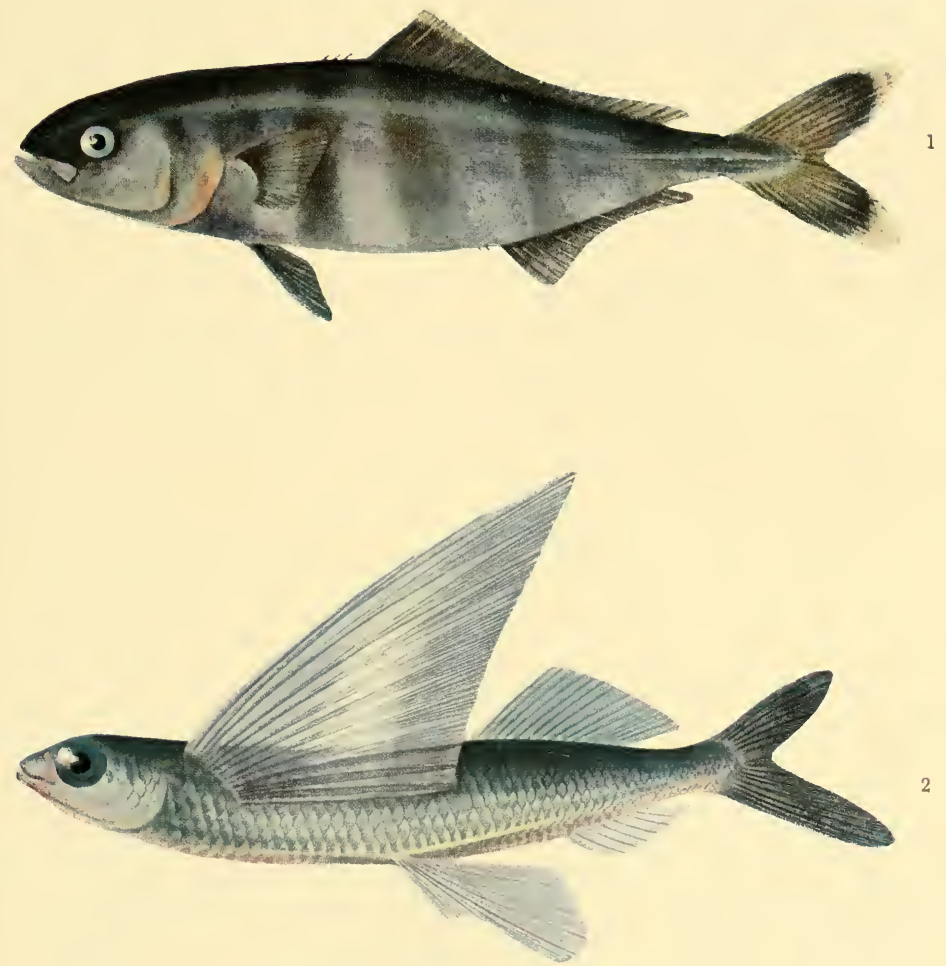

1. Naucrates ductor, L.

2. Exocoetus spilopus, Val. 


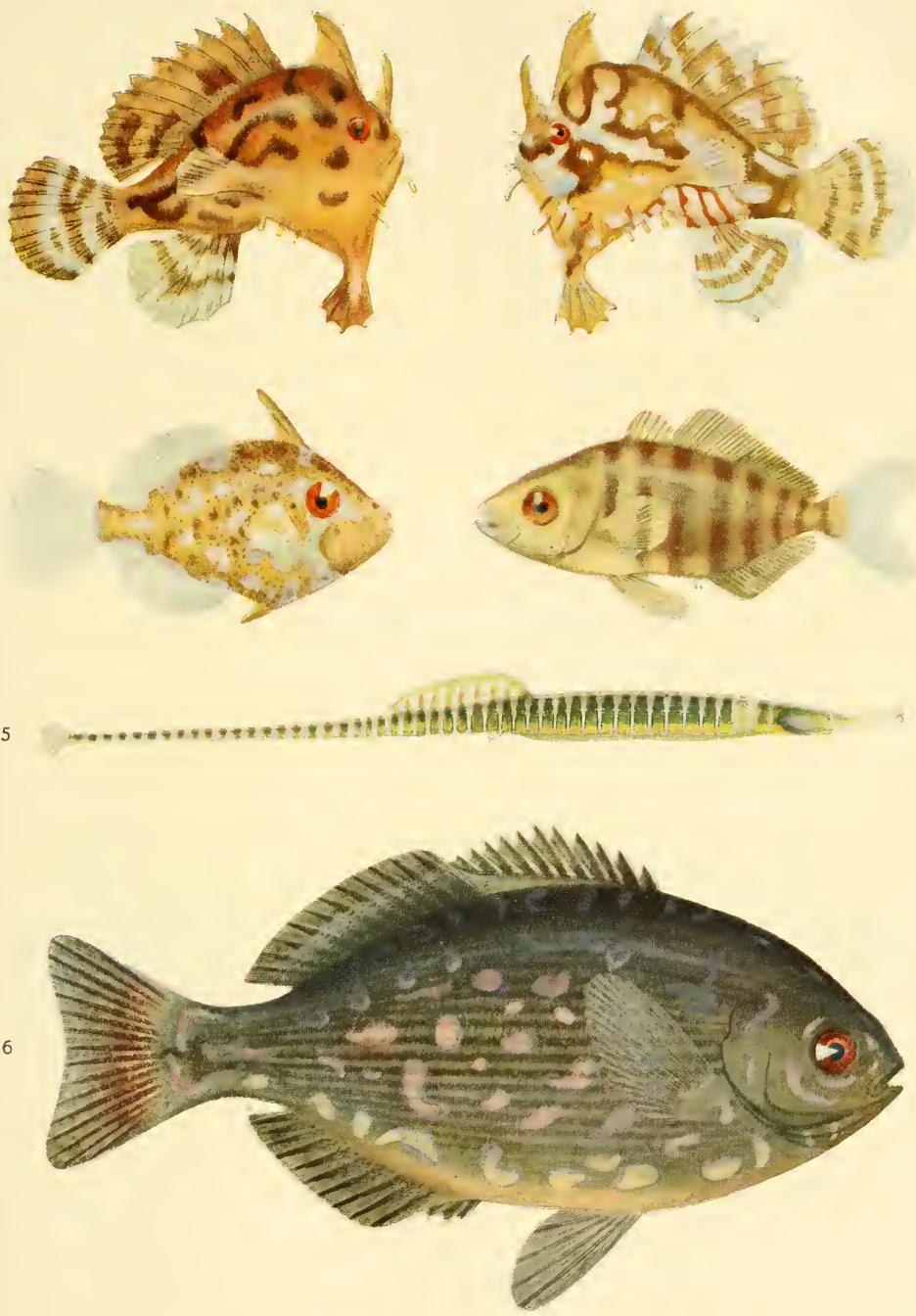

1. Antennarius marmoratus, Günth.

2.

3. Monacanthus, juv.
4. Seriola, juv.

5. Syngnathus pelagicus, Osbeck.

6. Cyphosus boscii, Lacep. 


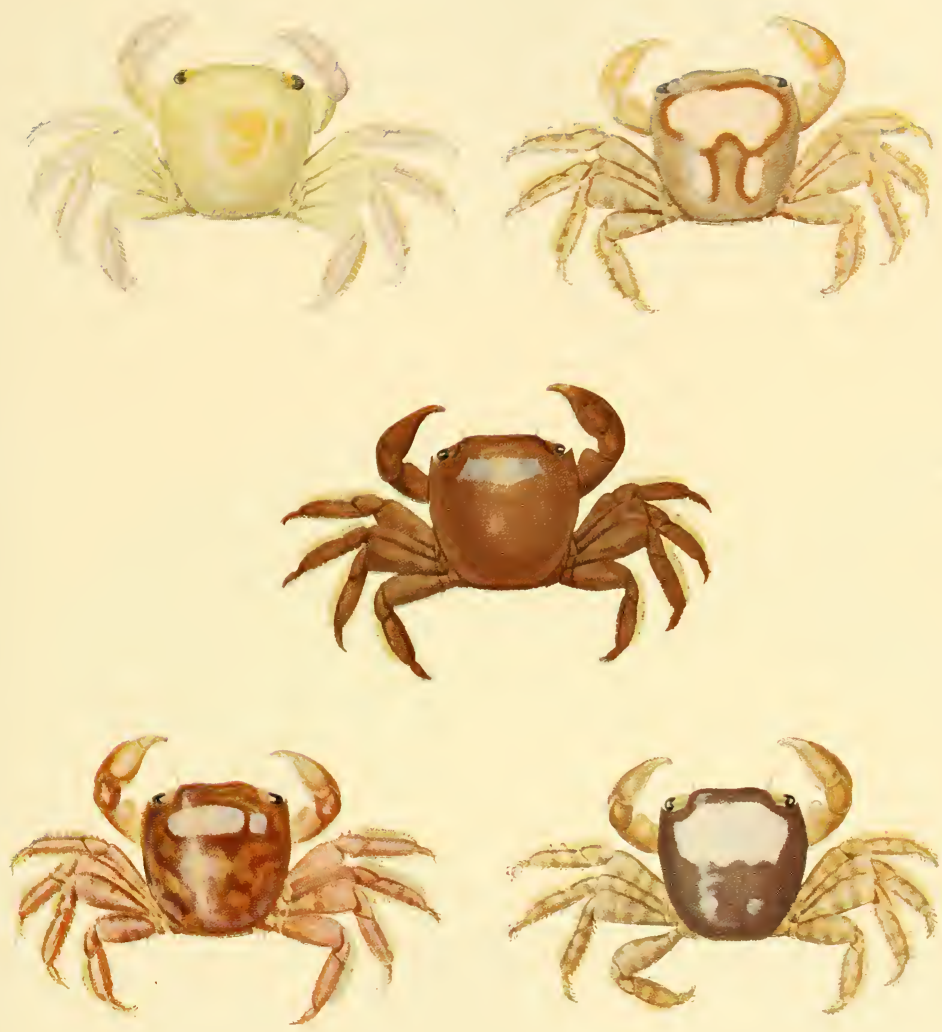

Planes minutus (L.) 


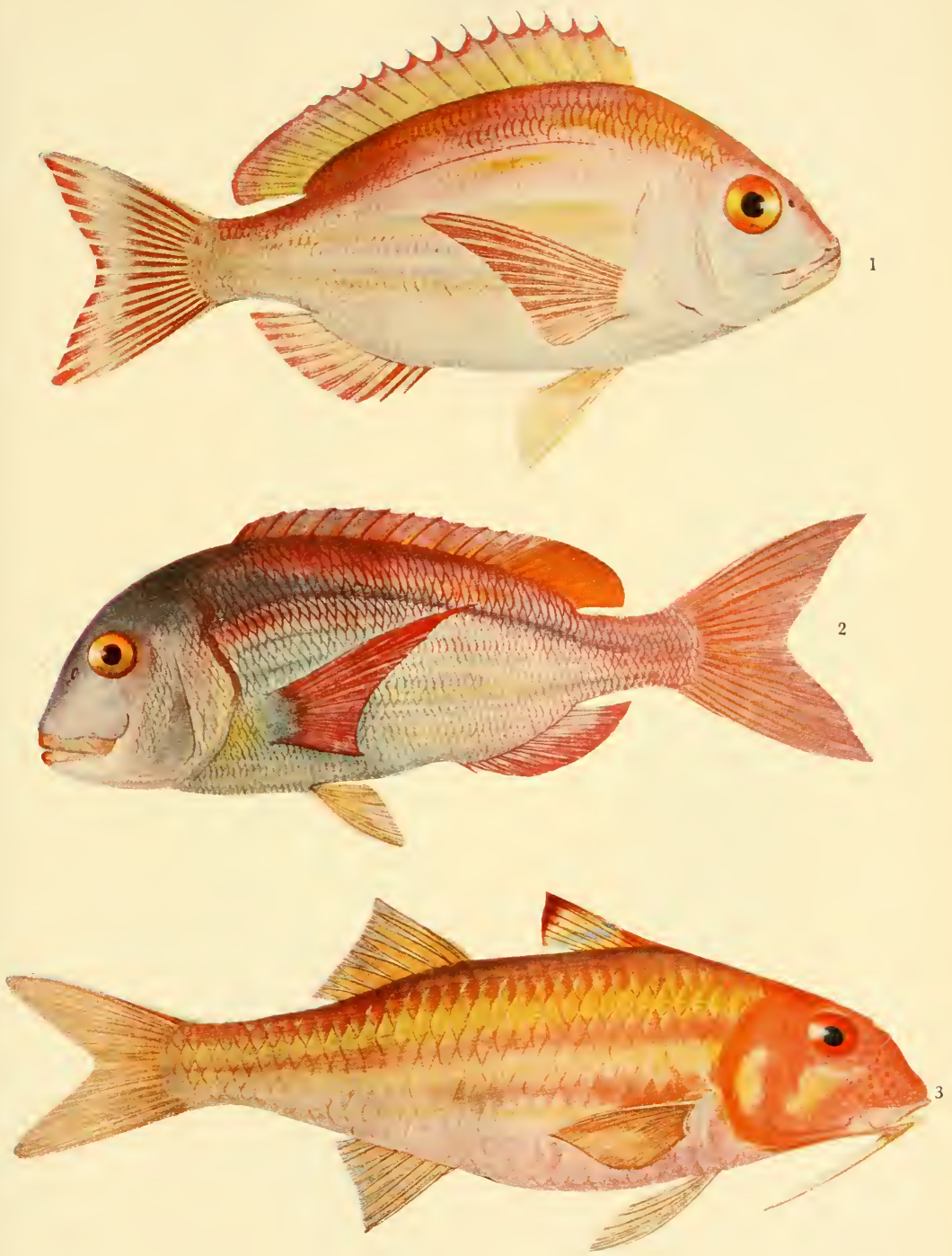

1. Dentex maroccanus, Cuv. \& Val.

2. Pagrus vulgaris, Cuv. \& Val.

3. Mullus surmuletus, L. 



\section{$\Xi$ \\ $\frac{5}{2}$}
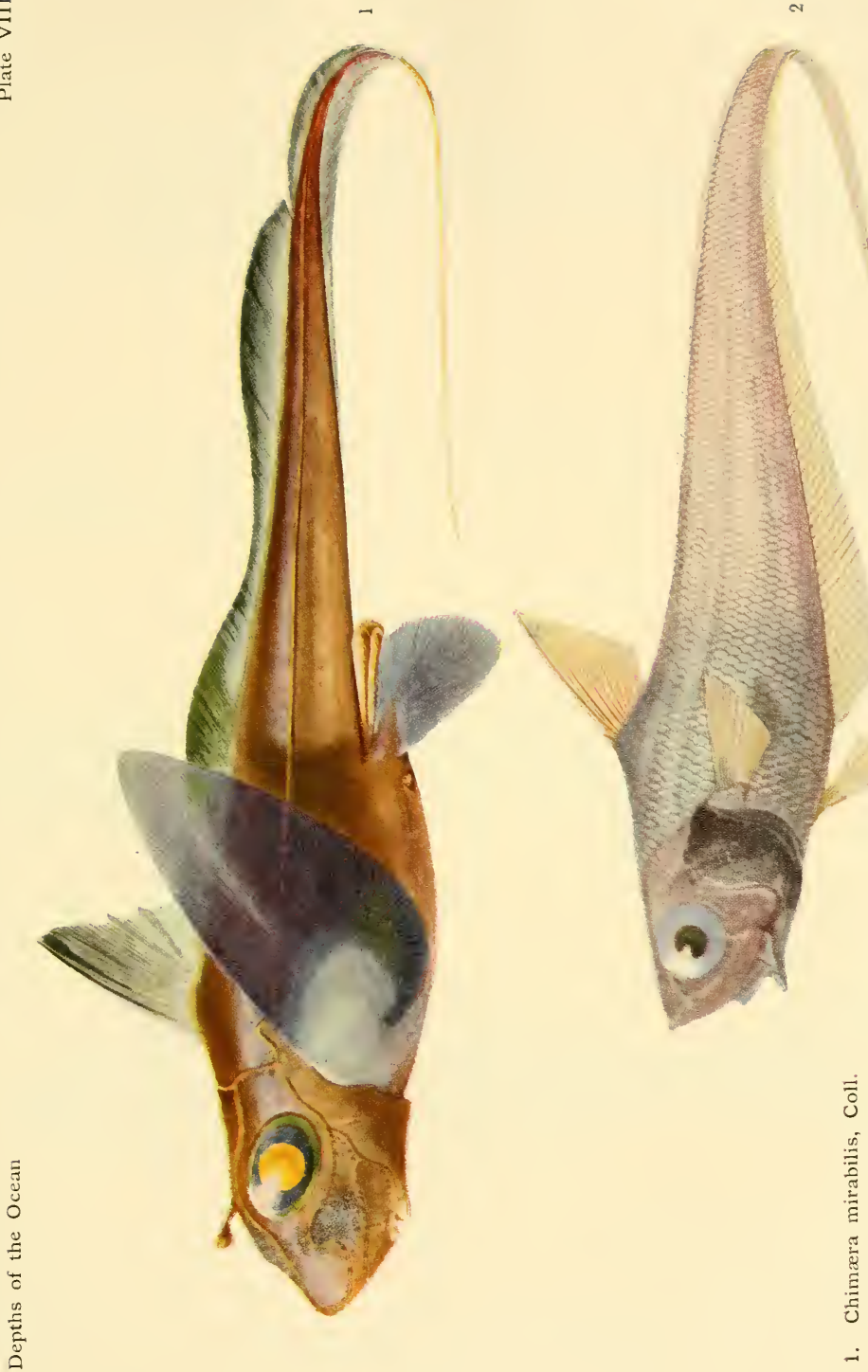

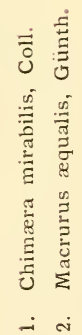



Depths of the Ocean

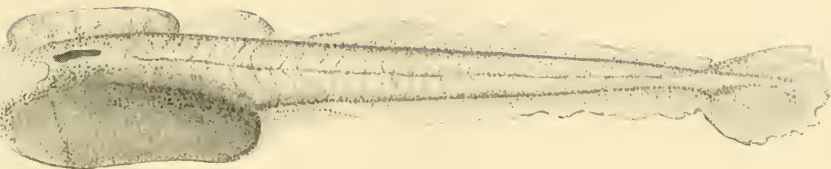

$0.9 \mathrm{~cm}$

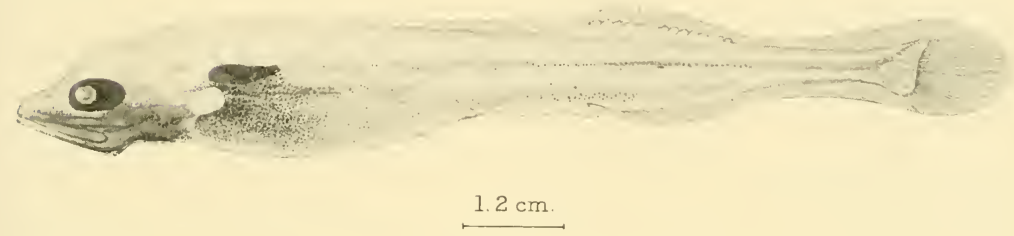

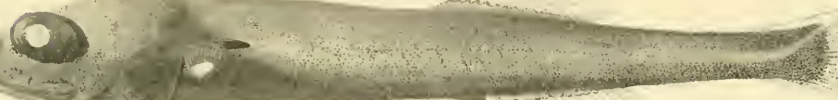

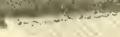

\section{$1.6 \mathrm{~cm}$.}

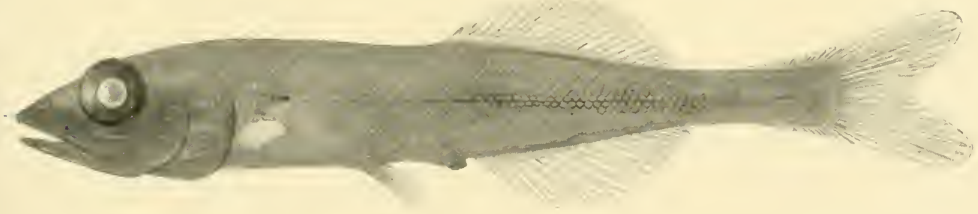

$5.2 \mathrm{~cm}$. 

V. and VI.). The small fishes (Antemarius marmoratus, Monacanthus, Seriola, Syngnathus pelagicus), the crabs (Planes mimutus), the prawns (Latreutes ensiferus and Palcemon natator), and also the naked snails, in fact all the animals of the Sargasso Sea, seem in regard to colours, shape (see for instance the remarkable prehensile organs of the pectoral fins of Antennarius), and size, to be intimately adapted to life among the drifting tufts of the Sargasso weed. The idea of the utility of these adaptations is here unavoidable. The occurrence of blue fins appeals to me as most striking, and this feature is specially noticeable in Hippocampus (the sea-horse). The specimen captured by us (see Fig. 7I, p. 89) was reddish-brown, only the fins, which have to be freely moved in the blue water, being deep blue. Plate VI. shows five different specimens of the crab Planes minutus, exhibiting all the varieties of colouring presented by the Sargasso weed. This species ought to be a splendid object for experiments in order to test the possible effects of variation in the colour of the surroundings; Antennarius might possibly also be employed for this purpose, but on an expedition like ours the idea of performing such experiments had to be abandoned.

What I have said here refers mainly to the Sargasso Sea, which was examined by us in regard to the light-conditions at different depths, as well as the vertical distribution and the colouring of the animals. As to the animals of the coastal waters and those of the bottom of the ocean I have much less to say. In coastal waters the light-conditions are undoubtedly very different from those in the open ocean. The large amounts of suspended substances reduce the transparency of the water and prevent the light rays penetrating so far as they do in the clear tropical or subtropical ocean. Hermann Fol's interesting experiments at Nice have already been referred to (see p. 252); he went down in a diving dress as far as 30 metres, at which depth red animals appeared black.

Are the red, yellow, and blue colours of the coast-fish (as shown on Plate VII.) to be explained as protective colours? Are they adaptations to the red of certain algx and other colours of the sea-bottom, like the gaudy paintings of the coral-reef fishes? Or are they to be considered like those adaptations which Darwin has ascribed to sexual selection?

Still more difficult is it to frame any idea as to the laws of colour in the abyssal region. Plate VIII. shows two bottom fishes from deep water, just on the limit where the traces of 
sunlight disappear, viz. Chimara mirabilis and Macrurusequalis. Brown, blue, and violet are the principal colours of the abyssal fishes; very often the pupil of the eye is yellow, as in Chimcra. But has any eye at all the power of perceiving colours in the abyssal region? Is any other light present there than the light produced by the animals themselves?

In what has been said above I have compared the conditions of light and the colours of animals at various depths, and in every case we have had to acknowledge that there is some connection between the colours of the fauna and the light-intensity in the surrounding water. On the other hand it is in many cases difficult to show that the colours are actually protective colours, and many scientists have relinquished the idea that the colours are protective. The indisputable connection between light-intensity and peculiarities of colouring has been explained as resulting from a purely physiological process of assimilation. An interesting attempt in this

Pigmentation a physiological process. direction has been made by Doflein, ${ }^{1}$ who says : "In normal life certain gland-shaped organs in the higher decapod crustacea form pigments. The formation of these pigments is influenced by light. Feeble light is sufficient for the formation of red pigment. Under the influence of light and of still unknown processes of assimilation, the red pigment may be transformed into yellow or even into white pigment. Very little is known of the nature of the yellow and white colour substances, which may perhaps arise from a union of the pigment and other constituents of the body of the crustacean, for instance, the lime salts. The blue pigment is derived from the red under the influence of light, and dissolving passes into the tissues where it becomes colourless and disappears, evidently through the chemical processes into which it enters. The destruction of blue pigment occurs also under the influence of light, this substance thus being of a temporary nature, visible only when produced in great quantities, but under other conditions destroyed as soon as formed. This would explain the presence of red pigment in crustaceans living in deep water, and the lack of pigment in many pelagic crustacea, as well as the blue colours of oceanic forms. In the surface layers of the ocean the formation and destruction of pigment, under the influence of light, are in equilibrium. Small quantities of pigment indeed prove to be present in nearly transparent forms, but in the

1 F. Doflein, "Lebensgewohnheiten und Anpassungen bei Decapoden Krebsen," Festschrift fïr Richard Hertwig, Bd. iii., Jena, I9Io. 
blue oceanic species, living in the intense light of the surface, the formation of blue pigment is so vigorous that it exceeds the destruction. Light is thus a very important agent in all these processes, bearing on the formation and transformation of pigment in the bodies of crustaceans, but it is not the only one. Other powers may equally influence the conditions of pigmentation. Experiments thus prove that when subjected to low temperatures blue colour developed in the animals; this was in my opinion due to the prevention of the destruction of the blue pigment in the tissues, thus causing an accumulation of this pigment."

I have quoted Doflein's theory because it opens up very interesting questions for future experimental research, though it hardly explains all the colour adaptations presented by the oceanic animals, for instance the mirror-like forms with dark backs and silvery sides, from intermediate layers, nor does it explain the profuse variation in the Sargasso animals and their peculiar conformity with the various colour-shades of the ocean and of the Sargasso weed. I fail to see any necessity for controversy over the two theories, one claiming the colours as due to adaptation serving the purpose of protection, the other explaining them as being due to peculiar processes of assimilation. Perhaps the latter theory alone may in many cases be sufficient, but may it not possibly signify the very mechanism by the aid of which the organisms adapt themselves in order to obtain protection?

A more perfect understanding can only be obtained from an increased knowledge as to the habitats of animals, as to the physical conditions there, and as to their life-history generally. The influence of various physical factors on the animals may be studied by experiment, and several interesting experiments have already been made. Gamble and Keeble, for instance, have proved the variations in colour of Hippolyte varians to correspond to variations in the colours of the surroundings. But the significance of such influences in the life of the animals can in my opinion only be understood by studying the life of the animals in nature.

\section{LighT-ORGANS}

That many organisms possess the power of emitting light Phosphorhas been known from earliest times. The Norwegian fishermen distinguish two kinds of phosphorescence: "dead phosphorescence" and "fish phosphorescence." The "dead 
phosphorescence" resembles the stars in a clear sky, myriads of minute nearly invisible points emitting a scintillating light, now increasing, now decreasing, in intensity. The "fish-phosphorescence" appears like great dull bubbles of light which suddenly flare up, as if a dull electric lamp had been turned on and then extinguished, and is produced by large animals, fishes or squids, rushing through the water, sometimes, by the impetus of their movements, causing all the minute phosphorescent organisms to flare up intensely in response to the irritation produced. That the "dead phosphorescence" is also caused by living organisms has been recognised since time immemorial by fishermen and others who haul ropes or nets through the water at night. Very often small phosphorescent creatures, especially minute crustaceans, are captured and furnish proof that the light is not emitted by the water itself. But scientific men have not always recognised this, for Franklin believed that the phosphorescence of the sea was due to electric sparks caused by friction among the salts of sea-water. According to Steuer, the abbot Dicquemare is supposed to have filtered the sea-water and in this way proved that the water emitted no light. Later on microscopic examination of the minute organisms of the sea has finally proved that the emission of light is inseparable from living substance, and that it is restricted to certain organs built for the sole purpose of this peculiar function of life.

The power of emitting light is found in most groups of marine animals and plants, beginning with the bacteria. Among plants the peridineans and the remarkable ball-shaped flagellates, Noctiluca miliaris and Pyrocystis noctiluca, are noted for their power of emitting light. In animals this power is always attributed to certain structures, which may be said to represent all conceivable forms of glandular development, from simple epithelial membranes to more or less complicated tubular or lobular glands. These organs secrete a slimy luminous substance. As a rule a layer of black pigment is arranged around the gland; acting as a reflector. Very often the light is projected through a transparent lensshaped organ. The light-organs thus very often resemble minute eyes, and were previously supposed to perform the function of perceiving instead of emitting light. As we reach the more highly organised groups in the animal kingdom the structure of light-organs exhibits an increasing complexity. In minute crustaceans (see Fig. 492) we very often find only a 
single row of luminous cells in the usual epithelium, and a lens formed by the cuticula or chitinous layer of the epidermis. In squids and fishes the organs are very complicated, as we shall presently see.

The object of the "Michael Sars" Expedition being mainly the investigation of the distribution of animals, the examination of the collections has necessarily been limited to the determination of the species, and my contributions to this fascinating section of the science of marine life will largely consist in discussing the distribution of animals possessing light-organs, which occur in salt water only, for no luminous animals are known from fresh water and no phosphorescence occurs there.

Glandular, clearly defined, and localised light-organs are found mainly in pelagic animals. Among bottom animals from the coast banks luminosity is exceedingly rare, but on the other hand, many bottom animals have been brought up from the abyssal region in a luminous condition, and have continued to emit light when placed in dark surroundings on board (see Fig. 70, p. 88, representing a luminous umbellularian). No special luminous structure has been found in these cases, the luminosity being attached to the surface epithelium. As regards fishes, Günther has drawn attention to the fact that many deep-sea forms secrete a large amount of slime. The heads of

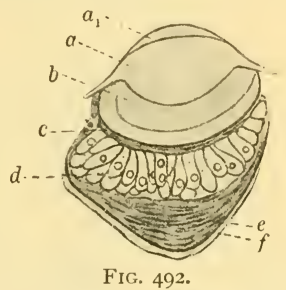

Light-organ of Sergestes challengeri, $\mathrm{H} . \quad a$, lens of the chitinous cuticle; $b$, inner lens ; $d$, glandular cells ; $e$, reflector; $f$, cover. (After Hansen, from Steuer.) many deep-sea Macruridæ exhibit certain pits and channels, which produce great quantities of slime. This slime is supposed to be luminous, and to perform the function of ordinary glandular light-organs, which last are found only in a few fishes supposed to live along the bottom, for instance, sharks (Spinacidæ, Spinax niger), and even in these they occur only as isolated organs, not in such numbers as in the genuine luminous fishes.

Among the pelagic fishes of the coast banks no species is known to possess light-organs; neither the herrings nor the mackerels have any representatives with light-organs. As shown in Chapter IX. there is not a single independent pelagic fish-species in the northern boreal waters, and as a consequence no boreal pelagic fish-species possesses light-organs. ${ }^{1}$ A minute examination of the lower forms has never been made, and at

${ }^{1}$ I regard the Scopelidæ in the Norwegian Sea as visitors, and not as true boreal forms. 
present it is probably impossible to lay down any rules relating to them.

If we take into account the exceptions here mentioned, we arrive at the result that in the higher groups, viz. squids and fishes, special light-organs are known mainly in oceanic forms

Luminous fishes. belonging to warm areas.

Among the fishes the luminous forms are mostly found in the families Stomiatidx, Sternoptychidæ, Scopelidæ, and Ceratiidæ.
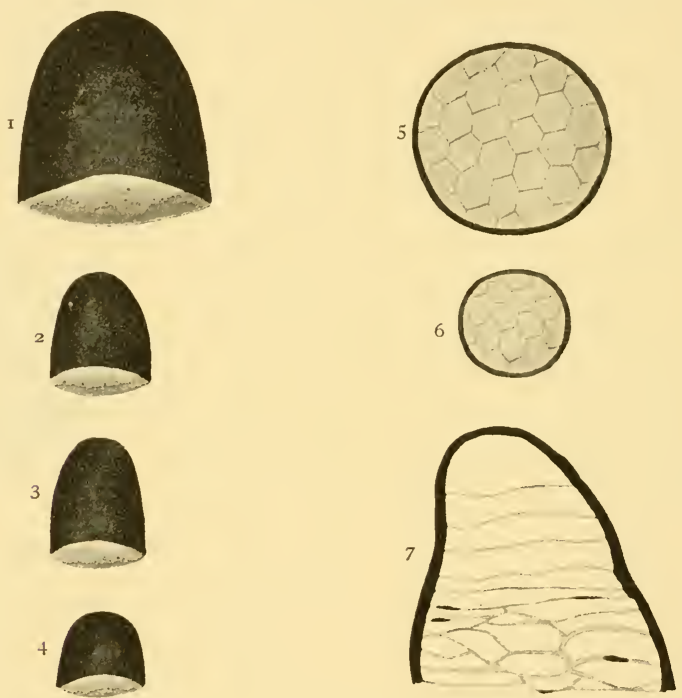

FIG, 493

I. The largest photophore from the ventral series between the pectoral and the ventral of Cyclothone signata, Garm., and C. signata alba, A. Br.

2. The largest photophore from the ventral series between the pectoral and the ventral of Cyclothone microdon, Günth., and $C$. microdon pallida, A. Br.

3. The largest photophore from the ventral series between the pectoral and the ventral of Cyclothone livida, A. Br.

4. The largest photophore from the ventral series between the pectoral and the ventral of Cyclothone acclinidens, Garm.

5. The largest photophore from the ventral series between the isthmus and the ventral of Cyclothone signata, Garm.

6. The smallest photophore from the ventral series between the isthmus and the ventral of $C y c l o t h o n e$ signata, Garm.

7. Reflector cells of a photophore from the ventral series of Cyclothone microdon pallida, A. Br.

(After Brauer.)

After carefully examining the specimens belonging to these groups captured by the "Valdivia," Brauer pointed out that a certain regularity in the arrangement of the light-organs seems 
to correspond with different depths, and that the light-organs are not peculiar to the deepest and darkest water-layers. Previously this belief was generally adopted because the light-organs were looked upon as a means of illuminating the dark abyssal region. Brauer indicates that of the six species of Cyclothone five are black and live in deep water, while one species (C. signata) is grey, lives in much shallower water, and has by far the largest light-organs (see Fig. 493, showing the small lightorgans of the dark forms and the large ones of $C$. signata). Of the Scopelidx, the surface forms of the genus Myctophum (s.s.) possess the largest light-organs, while the sub-genus Lampanyctus, taken in closing-net hauls by the "Valdivia" between 800 and 600 metres, has very small light-organs.

If now we consider the captures of the "Michael Sars," and the vertical distribution of the fishes previously described, we see that our experience confirms Brauer's views. Cyclothone microdon with small light-organs was found much deeper than $C$. signata (see Plate I., showing these two forms, the difference between their lightorgans being easily observed). Of special interest is Fig. 490, showing the vertical distribution of five black fish-species, two of which (Gastrostomus bairdii ${ }^{1}$ and Cyema atrum) have no light-organs;

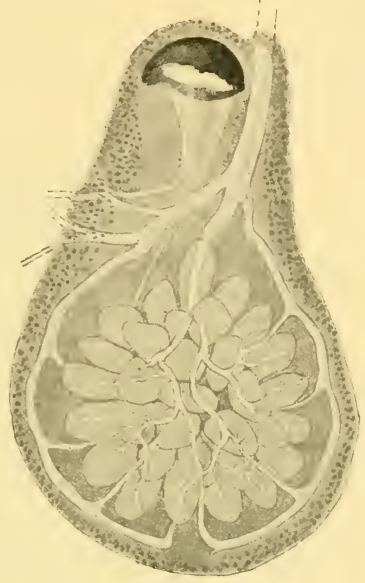

FIG. 494.

Gonostoma rhodadenia, Gilb. Photophore from upper lateral series $\left(\frac{5,5}{1}\right)$. Gonostoma grande has very small light-organs, while those of Gonostoma rhodadenia and Photostomias guernei are large (see Plate II., showing the two species of Gonostoma, Fig. 67, a, p. 86, representing Photostomias guemei, and Fig. 494, showing a light-organ of Gonostoma rhodadenia magnified). Besides these we found in our deepest hauls many forms without lightorgans, for instance, species belonging to the genera Aceratias, Melamphaës, Cetomimus.

Light-organs are, therefore, specially characteristic of fishes belonging to the upper 500 metres in warm oceanic waters.

1 On the tip of the tail this species is provided with an organ, the function of which is unknown; it has been regarded as a light-organ, but this does not alter our view. 
Our contribution to the knowledge of this subject consists mainly in determining the vertical distribution of the silvery

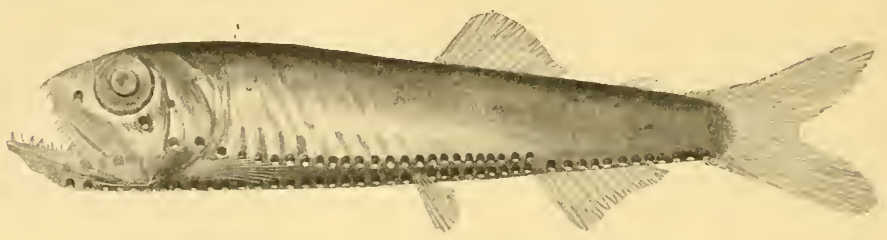

FIG. 495 .

I inciguerria lucetia, Garm. Nat. size, $4 \mathrm{~cm}$.

luminous Sternoptychidæe and Stomiatidæ more exactly than had previously been done (see Fig. 478 , p. 629 , showing the vertical

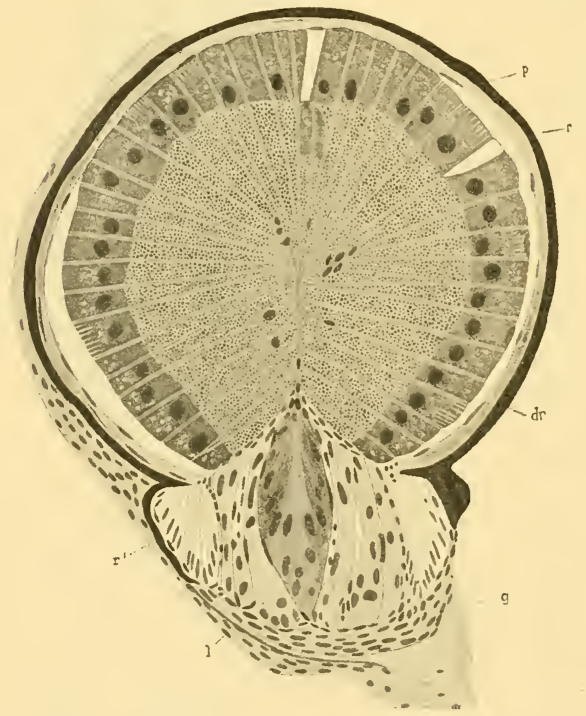

FIG. 496.

Light-organ of Vinciguerria lucetia, Garm., from ventral series of body (about $\frac{300}{1}$ ). $d r$, glandular cells; $l$, lens; $r$, reflector ; p. black pigment. (From Brauer.) Fig. 434, p. 590). These forms are entirely pelagic. The Octopoda, being bottom animals, possess no light-organs. In the large group of squids light-organs have also been found in of the most peculiar luminous fishes). Fig. 495 represents one of these, Vinciguerria lucetia with its numerous powerful light-organs, the structure of which, according to Brauer, is shown in Fig. 496, where we see the black pigment behind the reflector, the gland, and the lens (see also Fig. 493,7 , which shows a section through the light-organ in $\mathrm{Cyclo-}$ thone).

Splendid lightorgans have also been discovered in squids, and Chun has described them in many species (see

distribution of some $\sqrt{2}+x^{2}$ 
species which live in intermediate depths, and are now and again, like the Scopelidx, captured at the surface (see p. 649).

The function and importance of the light-organs in the life Function of of animals have been subjects of controversy in the world of light-organs. science. The production of light has been explained as a simple consequence of metabolism, and it has been supposed that the light itself serves no purpose. Comparisons have been drawn between the accumulation of mucous substance and the mucous secretion of the light-organs, and it has been pointed out that these organs occur particularly in pelagic animals, which in order to float in the water are supposed to need the mucus for the purpose of reducing their specific gravity. Brandt, who has studied the adaptations of animals to pelagic life, is perhaps right in supposing that metabolic factors have played a part in the history of the development of light-organs, but a closer scrutiny of the structure of these organs, and particularly the discovery of reflectors and lenses, seem to place it beyond doubt that the light-organs serve the function of projecting light in definite directions. This is the function for which the higher animals use their light-organs, but for what purpose do they project light? Is it in order to illuminate the surrounding water, to avoid foes, or to recognise their own kind? These questions are not easy to answer with any certainty. At all events the answers would probably tend to show that the many different kinds of light-organs serve different purposes. For instance, the large light-organs carried on the tentacles of the Ceratiidx are probably used for other purposes than the smaller organs found in Vinciguerria on the side of the body.

Brauer has examined the position of light-organs in relation to body segments in different species, and has found them to be arranged in exactly the same manner in all individuals belonging to the same species, and consequently the number and position of the light-organs are specific characters. He advocates the idea that in the ocean the light-organs replace the specific colour-markings of terrestrial animals.

Is it possible to explain the peculiar geographical distribution of luminous animals, for instance, fishes? The fact that lightorgans are found only in marine animals has been explained by supposing the salt to be necessary for the production of light. Experiments have shown that luminous bacteria develop and emit light only when sodium chloride or calcium chloride is present. As regards those organisms which secrete a slime 
that only becomes luminous on the surface of the animal, the phosphorescence seems to present an analogy or likeness to certain chemical reactions, for instance, the slow oxidising of organic compounds (grape sugar, etheric oils), which are accompanied by a feeble emission of light. In higher specialized organs chemical processes of a more complex nature probably take place. From the structure of the organs we may be induced to believe that the development of the organ must have depended on the fact that its function was intended to be seen by an eye. The light emission must evidently be of vital importance to the life of the animal and to the maintenance of the species. The discussion of these questions must therefore be postponed until we have mentioned the eyes of the different animals.

\section{EYES}

Nothing has appeared more hopeless in biological oceanography than the attempt to explain the connection between the development of the eyes and the intensity of light at different

Variation in the size of the eyes. depths in the ocean. In a trawling from abyssal depths in the ocean we may find fishes with large eyes along with others with very small eyes or totally blind. Nowhere would a more perfect uniformity be expected than in the dark and quiet depths of the ocean. Brauer, who has given a valuable contribution to our knowledge of the eyes of deep-sea fishes, remarks in his treatise on the fish collections of the "Valdivia" Expedition: "If the surroundings really acted directly on the organisms, and were the only agents which could produce alterations, their influence would be much more uniform and general. Instead of this we find the greatest variation. Thus we find the eyes now altered or permutated, now highly differentiated even in closely related forms."

The conditions, however, where these different forms live, are not so uniform as was supposed, or rather, these forms do not really live under the same conditions. First of all it made a great difference when we learnt that certain fishes were bottom dwellers and others pelagic in their habits.

Most, if not all, bottom dwellers from abyssal depths have large eyes, very often larger than those of bottom fish living in the strong light of the coast banks. Perhaps there is a maximum in the development of eyes in bottom fish at a certain depth followed by a decrease in size as we proceed still deeper. But even the deepest living forms, which must be supposed to 
migrate all over the abyssal plain of the oceans, have very large eyes, the diameter of the eyes in Macmus armatus, for instance (see p. 4I7, and Fig. 272, p. 398), being equal to onefifth of the length of its large head.

As regards pelagic fishes we must remember that light penetrates to far greater depths than was previously supposed, for, as already stated, in the Sargasso Sea photographic plates were strongly acted upon by light at 500 metres, and at 1000 metres traces of light were clearly perceptible, so that at least certain components of the sunlight penetrate to that depth.

If we now review the size of the eyes of the fishes in relation to their vertical distribution, we notice a strange change just about the bathypelagic limit often referred to in this book, viz. 500 to 750 metres, varying according to latitude.

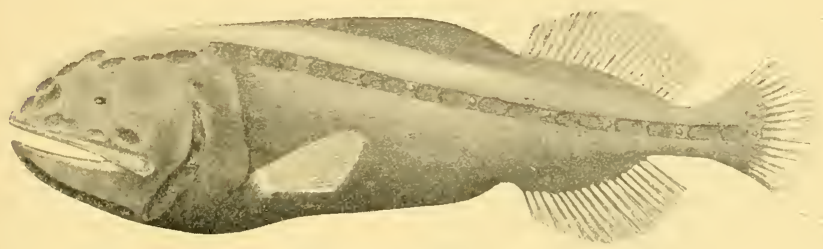

FIG. 497.

Cetomimus storeri, G. and B. Nat. size, $12 \mathrm{~cm}$.

In the fish taken between I 50 and 500 metres the diameter of the eye compared to the length of the head is, according to Brauer, as follows :-

\begin{tabular}{lcc|lcc} 
Stomias & about I $: 4$ & Argyropelecus about & I $: 2$ \\
Chauliodus &, & I $: 4$ & Sternoptyx &, & I $: 2$ \\
Ichthyococcus &, & I $: 2.6$ & Opisthoproctus &, & I $: 4$ \\
Vinciguerria &, & I $: 3$ & & &
\end{tabular}

If we consider Cyclothone and other fish which live deeper than 500 metres we find the following relations :-

$$
\begin{gathered}
\text { Cyclothone signata I : I } 2 \text { (see Plate I.) } \\
, \quad \text { microdon I : I } 2 \text { (see Plate I.) } \\
, \quad \text { obscura I : I } 5 \text { or } 20,
\end{gathered}
$$

and if we inspect the figures representing Gastrostomus bairdii (Fig. 83, a, p. 97), Cyema atrum (Fig. 69, p. 87), and Gonostoma (Plate II.), we obtain a still stronger impression of the small size of the eyes. Finally our deepest pelagic hauls contained blind forms which have never been taken in the upper layers; I reproduce two of these blind fishes (Figs. 497 and 498), of 
which Cetomimus storeri has been taken before, while the other form will probably have to be referred to a new genus. It is

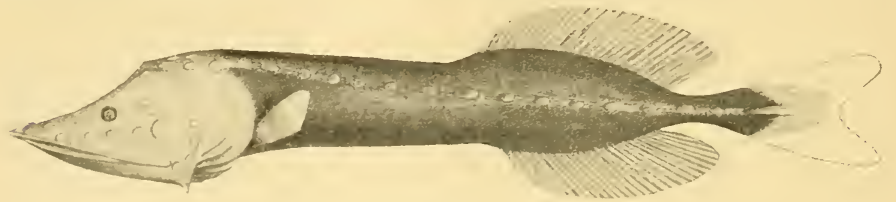

FIG. 498.

New blind fish, resembling Cetomimus, from Station 6 . Nat. size, $6 \mathrm{~cm}$.

also interesting in this connection to note that the only blind squid known was taken during our cruise at Station 82 in 1500 metres. Chun has called it Cirrothauma murrayi and has shown that its eyes are entirely concealed below the skin (see Fig. 499).

There is consequently no doubt that as far as fishes are concerned, there is in the ocean a limit between an upper region down to 500 metres, where the pelagic fishes have large and welldeveloped eyes, and a lower region where imperfect organs of vision are typical. The only exception to this rule I can think of is that a few fishes, mainly belonging to the genus

FIG. 499.

Rudimentary eye of Cirrothauma murrayi. (From Chun.)

Melamphaës and having large eyes, were taken in our deepest hauls beyond Iooo metres. Brauer remarks that in $M$. mizolepis he has found great variation in the relation of the diameter of the eye to the length of the head (from 
I $: 5.2$ to $I: 7$ ), and he imagines this to be due to differences in age. In the other species of this genus at all events the relation is usually $1: 7$ or 8 . Further investigations are necessary to explain these relations.

Malacosteus also has a relatively large eye, but in this genus as well as in other Stomiatida we must suppose that important vertical migrations occur. Thus we see from the table (Fig. 490) that Photostomias guernei has been captured at night in comparatively shallow water, and its eyes are considerably larger than those of the fishes which constantly live at great depths (see Fig. 67, $a$, p. 86).

The pelagic decapod crustacea show a similar correspondence between the development of eyes and vertical distribution (see table, p. 668). In the two species living above i 50 metres the ratio of carapace to eye is $5-7$, and in the five species with a maximum distribution about 500 metres the ratio is $6-I I$, while in the four species living below 500 and mostly beyond I 000 metres the ratio is 9-20.

Although in fact many cases as yet seem inexplicable, there seems to be reason for supposing that the efficiency of the eyes decreases with the decreasing intensity of light as we descend into deep water. That we cannot fully explain all cases seems to be a natural consequence of the fact that our knowledge of the vertical distribution of pelagic fishes is still imperfect, being based mainly on the closing-net hauls of the "Valdivia " and the long horizontal hauls of the "Michael Sars," and both these expeditions were of very short duration. Further investigations will probably furnish many interesting details as to differences within the regions recognised by us, for we are aware that various kinds of eyes occur in the region above 500 metres, such as stalked eyes, telescopic eyes, as well as eyes built on the principles of the common type of fish eye.

Stalked eyes seem to be peculiar to larval stages, Stalked eyes. and in certain cases are known to develop into normal eyes even during the larval stage (Lo Bianco). They seem to occur only in the uppermost layers, where all transparent fish larva live. Considering the insufficiency of our knowledge of the development of pelagic fishes, I do not venture to guess to what species our stalk-eyed larvæ belong.

Telescopic eyes are found only in fishes from depths less than Telescopic 500 metres. We have observed them in Argyropelecus, in a eyes. new genus closely related to Dysomma (see Fig. 540, p. 746), in Opisthoproctus, and also in leptocephali. Fig. 500 represents 
an Argyropelecus seen from above, and we see that the eyes point upwards, which is probably the case in most fishes possessing telescopic eyes, even if exceptions occur.

Two interesting facts go to explain this peculiar adaptation. Firstly, these telescopic eyes occur only in fishes which are very bad swimmers, fishes which practically only float in the water-layers. Secondly, the light-measurements in the Sargasso Sea showed that the light-rays acted more strongly on the top plate than on the side plates; for fishes possessing small swimming capacity the telescopic eyes seem to be most perfectly adapted to receive the faint rays of light which penetrate to these dusky depths.

Among eyes built on the general principle the difference in size first commands attention when the vertical penetration of light and the vertical distribution of each species come to be investigated. As regards the upper layers, an interesting subject will also be found in the detailed study of the anatomy of different eyes. In the retina of the human eye two special kinds of sensory cells are known to occur, viz. "rods" and

Anatomy of the eyes. "cones." These cells occur also in the eyes of fish from the surface layers. From Brauer's investigations we know that in all deep-sea fishes, as well as in silvery fishes from about 300 metres, only the "rods" are found in the retina of the eye. According to an old maxim of Max Schultze, nocturnal animals possess only

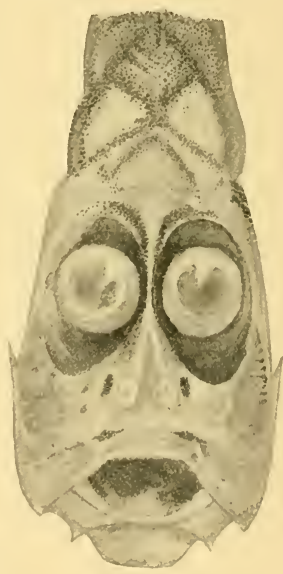

FIG. 500 .

Argyropelecus hemigymnus, Cocco. Head seen from above, enlarged. "rods" while diurnal animals have both "rods" and "cones." It has therefore been generally believed that the "rods" alone possess the faculty of observing light-intensity, light and shade, while only the "cones" perceive colours, quality of light.

Further, an interesting difference has been found in the colour-substance or pigment of the retina by day and by night. Brauer has also found that these conditions in the eyes of deepsea fishes signify that their eyes are constantly adapted to nocturnal conditions. The deep-sea fishes are "nocturnal animals" and "day-blind." But the gradual development of these peculiarities from the surface to the bottom, from the 
larval stages living at the surface to the adult fishes of the deep sea, presents a vast field for future research and opens up a vista of possibilities, which may explain the adaptation to special surroundings peculiar to each species.

Investigations in the deep regions below 500 metres should evidently, first of all, attack the questions whether a regular decrease in the size of the eye occurs with increasing depth, and whether the number of blind species and blind individuals is not far greater than is generally supposed. Our pelagic hauls only exceptionally went below I500 metres, but nevertheless we found in the deepest hauls no less than three species of blind fishes, of which two were new to science, besides one blind squid. In the deep oceans, where the depth exceeds 5000 or 6000 metres, we might perhaps expect interesting discoveries if large and efficient appliances were towed after the vessel with 5000 or 6000 metres of wire out.

But if it be the case that the size of the eyes in pelagic fishes decreases vertically with the decreasing intensity of light, how can we explain the fact that the bottom-fishes, like Macrurus armatus, living in abyssal depths possess large and apparently well-developed eyes? In order to explain this, the possible existence of a source of light other than sunlight has been sought for, but nothing has so far been discovered beyond the light produced by the organisms themselves. We shall therefore have to consider at the same time the power of emitting and the power of perceiving light possessed by the animals, so that we must take their light-organs as well as their eyes into account.

From what has been said we see that a remarkable coincidence exists between the development of light-organs and eyes in pelagic fishes. The Scopelidæ, Sternoptychidæ, and Stomiatidæ, which live above 500 metres, possess welldeveloped light-organs and eyes, while from 500 metres downwards light-organs and eyes both decrease in size.

Along the sea-bottom, however, the fishes possess only eyes and no special light-organs. We have previously seen that the invertebrates are luminous even in abyssal depths, and at Abyssal bottom fishes have eyes but present the large eyes of the bottom fishes cannot be explained otherwise than by supposing that the light emitted by the invertebrate bottom animals is so strong that objects on the bottom may be seen by the eyes of fishes. As regards most of the bathypelagic fishes we may, on the other hand, suppose that they have little use for eyes, because pelagic life in great depths is scanty, and not so definitely localized as on the sea-bottom. 
These are the explanations offered at present, but they open up new questions. How is it possible, for instance, for the bathypelagic fishes to find their food in the dark, sparsely populated, water-layers? Clearly we can advance no farther in this field without more knowledge gathered from new and extensive investigations. Even with our present knowledge, and accepting the explanations given as perfectly correct, many questions arise in regard to details. I will mention one very interesting instance.

During the "Challenger" Pelagic fishes living near the bottom. Expedition some specimens were captured of a certain blind fish (Ipnops murrayi), which was taken in the trawl only at great depths, between 3000 and 4000 metres. As already mentioned, the "Michael Sars" also captured a small blind fish, apparently a near ally of Ipnops, which we have called Bathymicrops regis (see Fig. 305, p. 416). Ipnops and Bathymicrops both belong to the family Scopelidx, and among allied forms we find a remarkable series in respect to the development of the eyes. This series has been represented in Fig. 50I, $a$ to $e$ :-

$a$ represents the head of
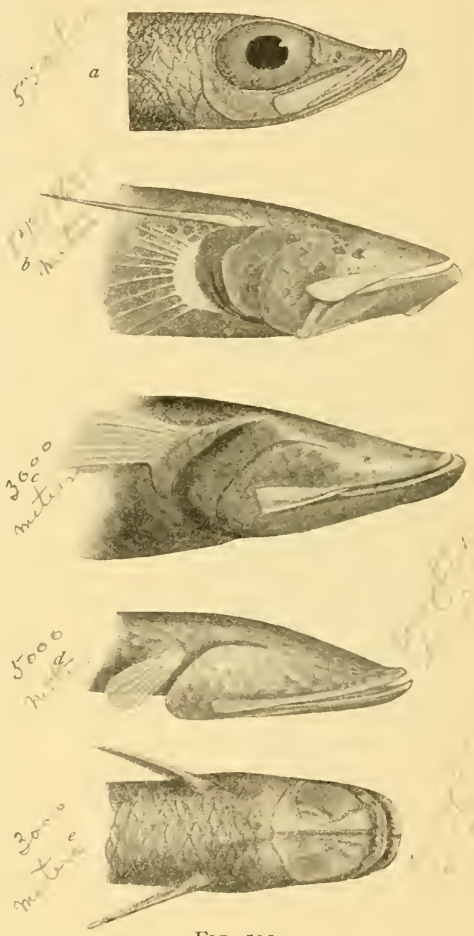

Fig. 50I.

Development of Eves in SCOpelids. Chlorophthalmus productus, Gthr., taken at Fiji in 575 metres.

$b$ represents the head of Bathypterois dubius, Vaill., taken by the "Talisman" at the Canaries, and by the "Michael Sars" at Station 4 I between 843 and 1635 metres.

$c$ shows the head of Benthosaurus grallator, G. and B., taken off America, and by the "Michael Sars" at Station 53 in about 3000 metres.

$d$ shows the head of Bathymicrops regis, n.g., n.sp., taken by the "Michael Sars" in about 5000 metres. 
e represents the head of Ipnops murrayi, Gthr., taken by the "Challenger" in about 3000 metres.

a shows a "normal" eye like the eyes of bottom-fishes on the slopes of the coast banks; $b$ and $c$ exhibit very small eyes; finally, $d$ and $e$ are perfectly blind. In Bathymicrops the whole head is covered with scales, including the eyes, which are only faintly visible through the covering as minute black dots. In Ipnops the head is covered with filmy bony plates, and eyes are entirely absent. A peculiar organ, which has been regarded as a light-organ, is situated below the plates, and supposing this interpretation to be correct it is the only light-organ known in these forms. ${ }^{1}$

How is this series of remarkable forms to be arranged conformably to the biological classification of the fishes according to their light-organs attempted above? They have all been taken only in the trawl, but are they really bottom fish? Why then (if we may be allowed the expression) do they not all possess large eyes, like other bottom fish living at similar depths? On the other hand, we must admit that they all differ from pelagic fishes in appearance. Most bathypelagic fishes are black, and their scale covering is but poorly developed.

As a "working hypothesis" I would suggest that these fishes belong to the deepest water-layers near the ocean-floor, and for this reason they unite qualities characteristic of both bottom fishes and pelagic fishes. The fact that they belong to the family Scopelidx seems to strengthen this view, as this family comprises such a wealth of pelagic forms. Several of these fishes, as for instance Benthosaumes grallator (Fig. 502), are also provided with long filaments or whiplike appendages indicating pelagic habits; to the south of the Azores we took some splendid specimens, in which these appendages, really transformed fin-rays, were intact, as seen in the figure.

Another problem attaches to the remarkable fact, previously Pelagic fishes mentioned, that light-organs are lacking in all pelagic fishes of the coast waters and also of the boreal area. Neither are they found in the fishes of tropical coast waters, where the temperature waters and of the boreal area. cannot be supposed to prevent their development, nor do they occur in those of the Norwegian Sea, where the depth is sufficient

1 Sir John Murray and Professor Moseley at first described these organs as modified eyes, without lens or vitreous humour, and with only rods arranged in hexagonal bundles in the retina. Later Moseley stated they were certainly not eyes, but phosphorescent organs (see Manchester Science Lectures, Dec. I8, I877, p. 132; Narr. Chall. Exp., vol. i. p. 239, I885; Zool Thrlt Exp., Part LVII. Appendix A, I887). 
to enable us to find all degrees of light-intensity, at all events during summer. Paraliparis bathybii, | the large black bathypelagic fish found by us in the Norwegian Sea (see Fig. I07, p. I 27 ), possesses well-developed eyes, although it lives in deep water and undoubtedly in surroundings just as devoid of daylight as does Cyclothone microdon. The same remark applies to Rhodichthys regina.

Is it the rich phosphorescent pel-

agic fauna peculiar to the coast waters i and the boreal area which renders w light-organs useless and eyes useful to the fishes of these regions? Is it the case that the peculiar light-organs and the wonderful eyes can develop only in warm oceanic waters of low specific gravity? Are all these features only special adaptations to special and definite conditions, like the splendid colours of animals in tropical lands? Are the small light-organs and the minute organs of vision peculiar to the deep, dark, and cold oceanic waters only rudimentary organs, which are no longer of vital importance to the fishes? Are they to be considered as evidence that these fishes are descended from ancestors living under entirely different conditions in lesser depths?

\section{Floating and Organs of Floating}

If organisms did not possess the power of floating, thus preventing them from sinking into deep water, the ocean would become a lifeless desert, because in the surface layers of the ocean live the minute plants which form the source of nourishment for all animals in the various depths of the ocean.

In order to understand the faculty of floating possessed by 
various organisms, we must first of all become acquainted with the external conditions governing floating and sinking; mainly owing to the investigations of Chun and Ostwald our knowledge on this point has increased greatly in recent years. ${ }^{1}$

First and foremost among these conditions is the specific specific gravity of ocean water. If an organism has the same specific gravity of gravity as the sea-water it floats, because, according to the law of Archimedes, it displaces a volume of water equal to its own weight. When the specific gravity of the organism is greater than that of the water it has a surplus gravity and may possibly sink. If nothing counteracts its sinking, the velocity will be proportionate to the value of the surplus gravity (equal to the specific gravity of the organism minus the specific gravity of the water).

Experience shows, however, that all objects of the same viscosity of specific gravity do not sink with equal velocity. Fine sand particles float much longer in water than large pebbles, although they have the same specific gravity. This is due to a property more or less peculiar to all liquids, called the viscosity or the internal friction of the liquid, but in a liquid with a definite viscosity objects sink with varying velocity, which depends on what has been termed the surface resistance of bodies.

An object has a great surface resistance, and sinks slowly, when its surface is large compared with its volume, and when its surface presents a large area at right angles to the direction of the sinking.

Surplus gravity and surface resistance are the two properties in sinking bodies which determine the velocity of their sinking. The greater their surplus gravity and the smaller their surface resistance the greater is the velocity of their sinking. High specific gravity and great viscosity of the water counteract the sinking and require lower specific gravity and less surface resistance on the part of the organisms in order to keep them floating.

We will first consider the two "external conditions," the specific gravity and the viscosity of the water, and then discuss the faculty of regulating the surplus gravity and surface resistance possessed by the organisms, enabling them to adapt themselves to their surroundings. The importance of the two elements, specific gravity and viscosity, anywhere in the ocean

${ }^{1}$ See, for instance, Chun's Reisebericht (loc, cit.); W. Ostwald, "Theoretische Planktonstudien," Zoologische Jahrbiicher, Abtg. Systematik, etc., Bd. I8, Jena 1903 ; "Zur Lehre vom Plankton," Naturwissenschaftliche Wochenschrift, N.F., Bd. 2, Jena, I903. 
depends first of all on the salinity and temperature, but the influence of salinity and temperature is essentially different in regard to specific gravity and to viscosity. This fact is easily seen from the following table, compiled from Knudsen's tables for specific gravity and from Ostwald's measurements for viscosity :-

\begin{tabular}{|c|c|c|c|c|}
\hline \multirow{2}{*}{$\begin{array}{c}\text { Temperature } \\
\text { C. }\end{array}$} & \multicolumn{2}{|c|}{ Viscosity. } & \multicolumn{2}{|c|}{ Specific Gravity. } \\
\hline & $30 \%$ Salinity. & $35 \%$ Salinity. & $30 \%$ Salinity. & $35 \%$ Salinity. \\
\hline $0^{\circ}$ & 102 & 103 & 24 . I I & 28.13 \\
\hline $5^{\circ}$ & 87 & 88 & 23.75 & $27 \cdot 70$ \\
\hline $10^{\circ}$ & 75 & $7^{6}$ & 23.09 & 26.98 \\
\hline $15^{\circ}$ & 66 & 66 & 22.16 & 26.00 \\
\hline $20^{\circ}$ & $5^{8}$ & 59 & 20.99 & $24 \cdot 79$ \\
\hline $25^{\circ}$ & $5^{2}$ & 53 & $19.6 \mathrm{I}$ & 23.37 \\
\hline $30^{\circ}$ & 47 & 47 & 18.02 & 21.76 \\
\hline
\end{tabular}

We see from this table that within the common limits of salinity, 30 to 35 per thousand, the salinity influences viscosity very little ; in other words, viscosity is almost entirely dependent on temperature. If the viscosity of pure water at $\mathrm{O} C$. is placed at 100 , ordinary sea-water at $0^{\circ} \mathrm{C}$. has a viscosity of $\mathrm{IO}_{2}-\mathrm{IO}_{3}$; at $10^{\circ} \mathrm{C}$. it has decreased by one-fourth, and at $25^{\circ} \mathrm{C}$. by onehalf. Sea-water at $25^{\circ} \mathrm{C}$. is only half as viscous as the same water at $0^{\circ} \mathrm{C}$., that is, the same body sinks twice as rapidly at $25^{\circ}$ as at $0^{\circ} \mathrm{C}$. Variations in salinity alone, it will be observed, influence the specific gravity as well as variations of temperature. In the ocean specific gravity and viscosity therefore do not run parallel, but they run in the same direction. Thus a body, which can maintain its specific gravity independent of changes in temperature and salinity, will have its velocity of sinking increased with falling specific gravity and viscosity of the sea-water, and its floating faculty will be augmented when viscosity as well as specific gravity increase.

Temperature, and especially salinity, influence the floating pressure. faculty of living bodies, through changes in osmotic pressure. If the salinity of a cell is higher than that of the surrounding water, the cell will, if not surrounded by an impermeable membrane, give off salt and absorb water. The volume of the cell will then increase, but although the cell actually increases in weight, its specific gravity will decrease. In 
salter water, on the other hand, such a cell will give off water; its volume will decrease, and it will attain a higher specific gravity. These alterations will, however, react on the surface resistance of the cell and influence its relations to the viscosity of the water, as we shall subsequently see.

These three elements - specific gravity, viscosity, and osmotic pressure-constitute the external conditions governing the faculty of floating at different depths. Ostwald has in various ways attempted to explain many of the peculiar features of pelagic organisms. He cites instances from interesting experiments made by Chun, Verworn, and Brandt, showing how organisms decrease in size and volume with increasing salinity, when sea-water evaporates in open vessels. The animals sink when the sea-water is diluted with fresh water, and rise towards the surface when the salinity increases. After some time the difference in osmotic pressure becomes adjusted, so long as the difference between the cell and its surroundings has not been too great. These ideas due mainly to Chun and Ostwald have, during recent years, largely stimulated the scientific world to study the influence upon organisms of variations in the external conditions.

All groups of pelagic plants and animals are now known Floating to have a wonderful power of adaptability pertaining to their faculty of floating in surroundings of varying specific gravity, viscosity, and osmotic pressure. As regards the pelagic plants, Gran has in Chapter VI. mentioned some important and characteristic instances of the alterations in shape to which certain plants are subject in various waters. When dealing with the various groups of pelagic animals I mentioned a few instances of the differences in the general characters of the animals as to shape, size, and appearance in warm and cold waters.

The various means adopted by different organisms in order to increase their faculty of floating may perhaps be classified as follows :-

(I) Certain organisms seek to diminish their specific gravity by secreting and depositing specifically light substances in their cells. A very important part is here played by the fats and oils, which are also of enormous importance as a reserve food for the animals in question. From the radiolarians to the whales, the fats are of great significance to pelagic life. In the crustaceans, for instance the northern Calanus fimmarchicus, in fish eggs, which frequently possess oil-globules, in fishes and in pelagic mammalia, the fats are specially important. 
Absorption of water.

Air-bladders. All the forms living in the surface waters of the sea, which

Numerous forms absorb water to such an extent that their water-contents may amount to 90 per cent of the whole organism, as in the medusæ, ctenophores, and many fish eggs. In fish eggs chemical analysis shows how the amount of water decreases during development, and how this decrease continues as the larvæ seek deeper water and finally settle on the bottom. Salpæ and Pyrosomidæ with large soft integuments also contain a high percentage of water. have developed special floating devices in the shape of airbladders or bells, may also-at all events in order to avoid a too formal classification-be ranged into this group. These remarkable devices are specially noticeable in the wonderful group of the siphonophores. The air-filled lungs of whales and seals and the air-bladders found in most fishes are also instrumental in diminishing the specific gravity of these animals.

(2) A reduction of the specific gravity of the kind mentioned above must necessarily reduce or abolish the surplus gravity, which tends to make the animals sink. But even if a surplus gravity is present they will float, if they can offer a sufficient amount of surface resistance, which may be effected either actively by swimming, or passively as a consequence of the shape of the body.

In order to understand the various and complicated adaptations within this field, we should have to compare the various types of shape found in pelagic animals. I will at present limit myself to pointing out the main laws as laid down by Ostwald and Chun. In considering surface resistance two points are essential : (I) the size of the organism, and (2) the shape of the organism.

If we take two bodies, for instance two balls, consisting of the same substance but with different diameters, and let them sink in the same fluid, the larger one, that is, the ball in which the relation between surface and volume is smallest, will sink the faster; thus the smaller the body the slower will it sink. Ostwald terms the relation between surface and volume the "specific surface," and gives the above-mentioned fact in the following words: "small bodies sink slower than similar large bodies which have the same surplus gravity, because their specific surface is greater."

Next it is important to take into account the diameter of organisms transverse to the direction in which they sink. A thin plate sinks much faster in a vertical than in a horizontal 
position. Ostwald terms this relation the "size of projection," Size of and has asserted that the velocity of sinking decreases in projection. proportion to the increase in the size of projection. ${ }^{1}$

These two principles of "specific surface" and "size of projection" have in a most wonderful manner been employed by organisms for the purpose of developing their faculty of floating. First of all, in organisms which cannot lower their specific gravity by depositing fats or absorbing water, we find a dominant tendency to develop minute forms in specifically light waters. In this connection we may note that small radiolarians are found in shallow water, and large ones much deeper, as

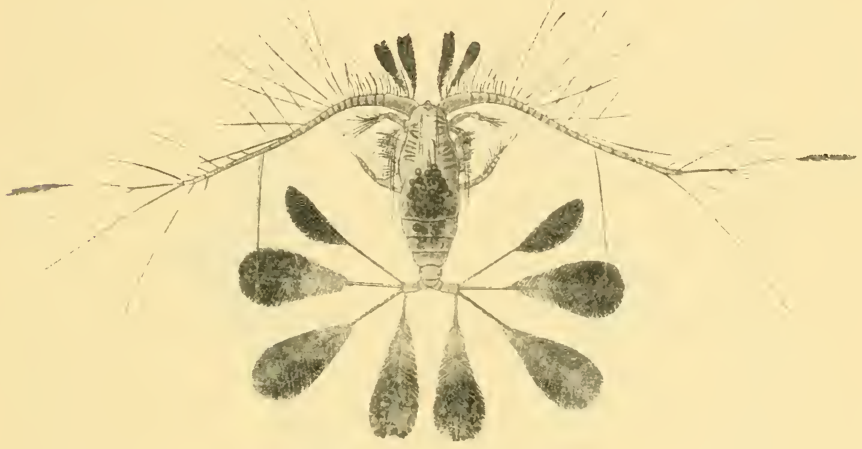

FIG. 503 .

Calocalanus pavo, Dana. $q$ (about $\left.\frac{20}{1}\right)$. (From Giesbrecht.)

mentioned in Chapter IX., and in Chapter VI. Gran refers to the minute coccolithophoridæe of the light oceanic surface-layers. A large "size of projection" is found in countless numbers of crustaceans, especially in warm oceanic waters. The copepoda, for instance, show magnificent devices for enlarging their surface, developing feather, plate, or rod-shaped appendages (see Fig. 503). The surface resistance of these appendages depends on their position in the vertical line, and thus they serve the purpose of vertical locomotion as well.

Ostwald next points out the necessity of studying in nature

1 Since this was written Sandström has published a paper, "Hydrometrische Versuche," Meddelanden frän hydrografiska by'ran, Stockholm, 1912, showing that the velocity of sinking is not exactly proportional to the size of projection, other circumstances, which are not yet clearly understood, also influencing the process. 
the specific gravity and viscosity of different waters, and comparing them with the distribution and structure of the animals. In this way I shall presently attempt to compare various areas of the waters investigated by the "Michael Sars." For this purpose Mr. Einar Lea has, on the basis of the observations made by Dr. Helland-Hansen on our cruise, worked out the three sections representing temperature, specific

Temperature, specific gravity, and viscosity along section from the Sargasso Sea to the Norwegian Sea.

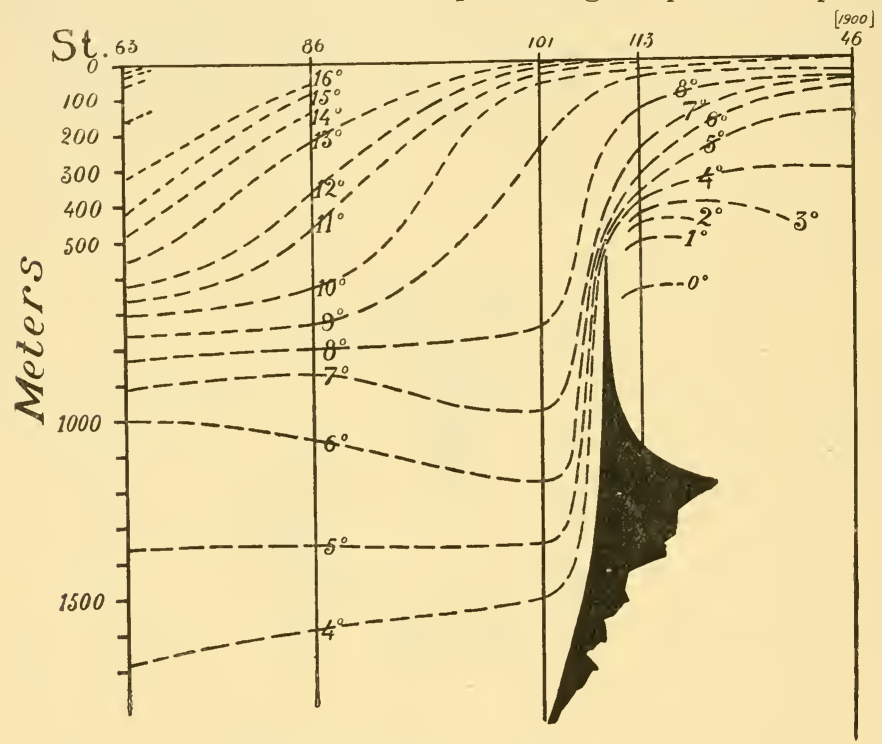

Fig. 504.-Distribution of Temperature from the Sargasso Sea (Station 63)

To Lofoten (NoRwegian SEA).
Depth in metres; temperature Centigrade.

To Lofoten (Norwegian SEA).
Depth in metres; temperature Centigrade.

gravity, and viscosity from the Norwegian Sea, west of Lofoten, to the Sargasso Sea (see Figs. 504, 505, and 506).

As to these sections, I wish to remark that they must not be considered as representing the direct continuity of the watermasses from the Sargasso Sea to the Norwegian Sea. The currents do not run directly between the two terminal stations, and perhaps it would be more correct to represent each of the stations separately without connecting the curves. With this reservation in mind, however, it should prove very instructive to compare the conditions as shown in the sections.

We see from the little chart (Fig. 62, p. 83) that Station 63 
is situated in the Sargasso Sea, Station 86 on our northern track, Station IOI to the south of, and Station I I 3 to the north of, the Wyville Thomson Ridge, while Station 46 from the year I 900 is west of the Lofotens.

Figs. 504 and 505 show that just on the verge between the two seas, between Stations IOI and I I3, a marked drop occurs in the temperature and specific gravity. In the Norwegian Sea (Station 46 of I 900 ) a specific gravity of 1.0278 is

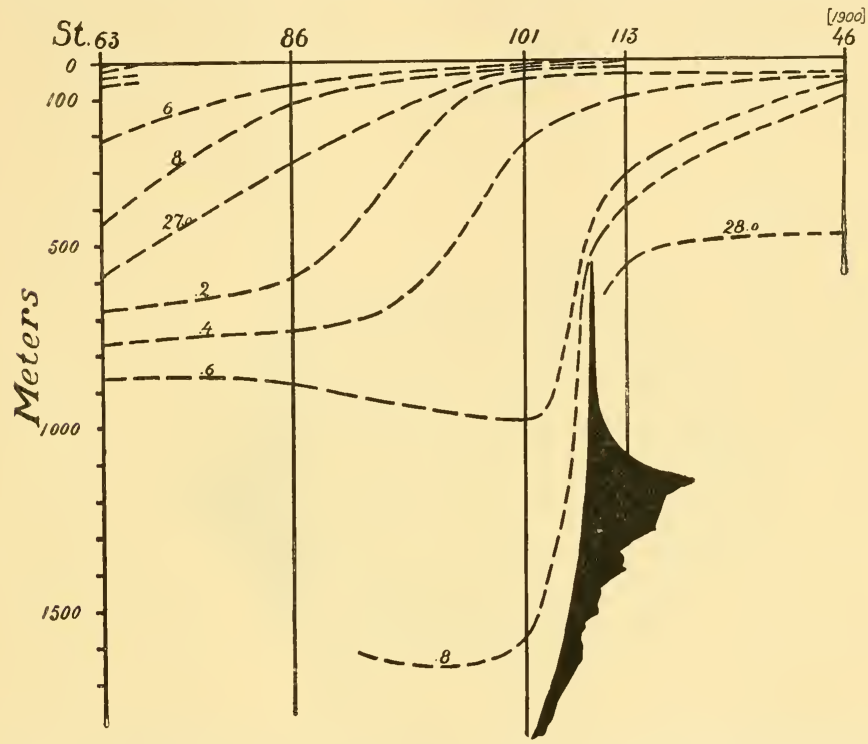

Fig. 505.-Distribution of Specific Gravity from the Sargasso Sea (Station 63) TO LOFOTEN (NORWEGIAN SEA).

$28=\mathrm{I} .028$.

found only at roo metres, and towards the Wyville Thomson Ridge even at I 500 metres. A specific gravity of 1.028 does not occur in the Atlantic at all at the depths here treated of, while the entire deep layer in the Norwegian Sea is of a specific gravity even higher than I.028. In the Atlantic the curves all fall away towards deep water and as we approach the tropics. In the Sargasso Sea we find the same specific gravity at 600 or 800 metres as occurs in the Norwegian Sea at 50 metres. The densely gathered curves at the surface denote water of low specific gravity. 
The viscosity exhibits, as shown in Fig. 506, a similar course. We find a much greater viscosity in the waters of the Norwegian Sea than in those of the Atlantic. The conditions of viscosity at a depth of 50 metres in the Norwegian Sea correspond to the conditions at about 800 metres in the Atlantic, where at the surface we meet water-layers of small viscosity: " thin water."

If now we compare the distribution of animal life, as

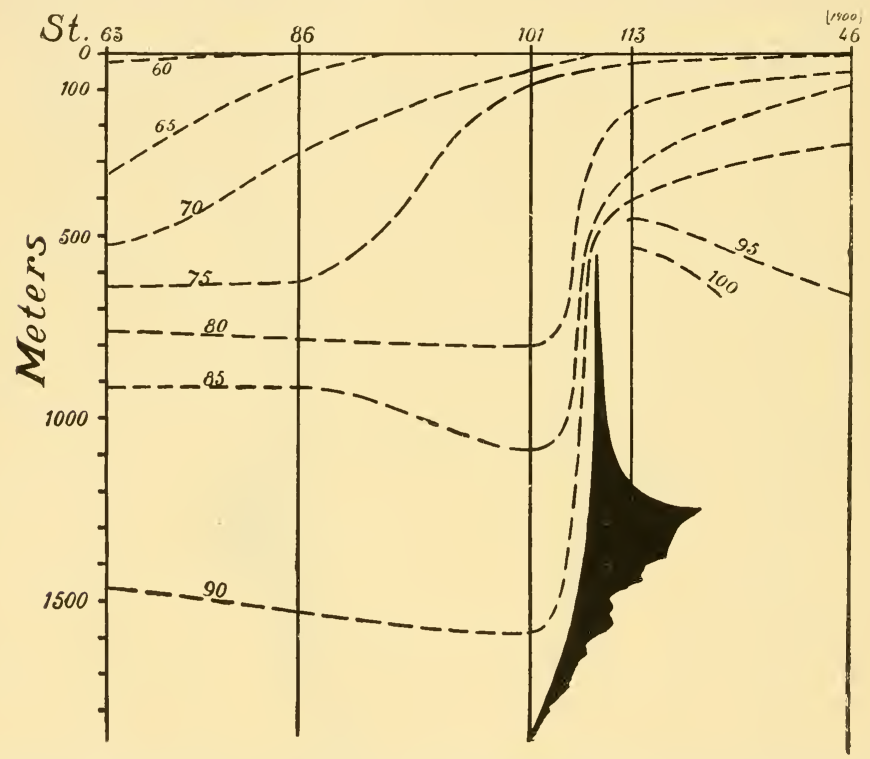

Fig. 506.-Distribution of Viscosity (see text) Fron the Sargasso SEa (Station 63) to Lofoten (NORWEGIAN SEA).

$\mathrm{IOO}=$ the viscosity of distilled water at $\mathrm{O}^{\circ} \mathrm{C}$.

described in Chapter IX., with these facts, we may clearly understand many of the peculiarities of distribution.

Warm-water oceanic life.
From the distribution of specific gravity and viscosity it follows that in light, thin, and warm oceanic waters only those animals are found which have lowered their specific gravity by the aid of light substances (fats, water), or have increased their surface resistance by reducing their size or by developing special organs for floating. To the first type belong the Siphonophores (Physalia, Physophora, Agalmopsis, and many others), besides Medusæ, Salpæ, Doliolum, Pyrosoma, and 
large fishes which, like the sunfish, have a layer of blubber round their body, and may be seen floating at the surface, the dorsal fin above the water (see Fig. 507).

The organs of floating have previously been described and

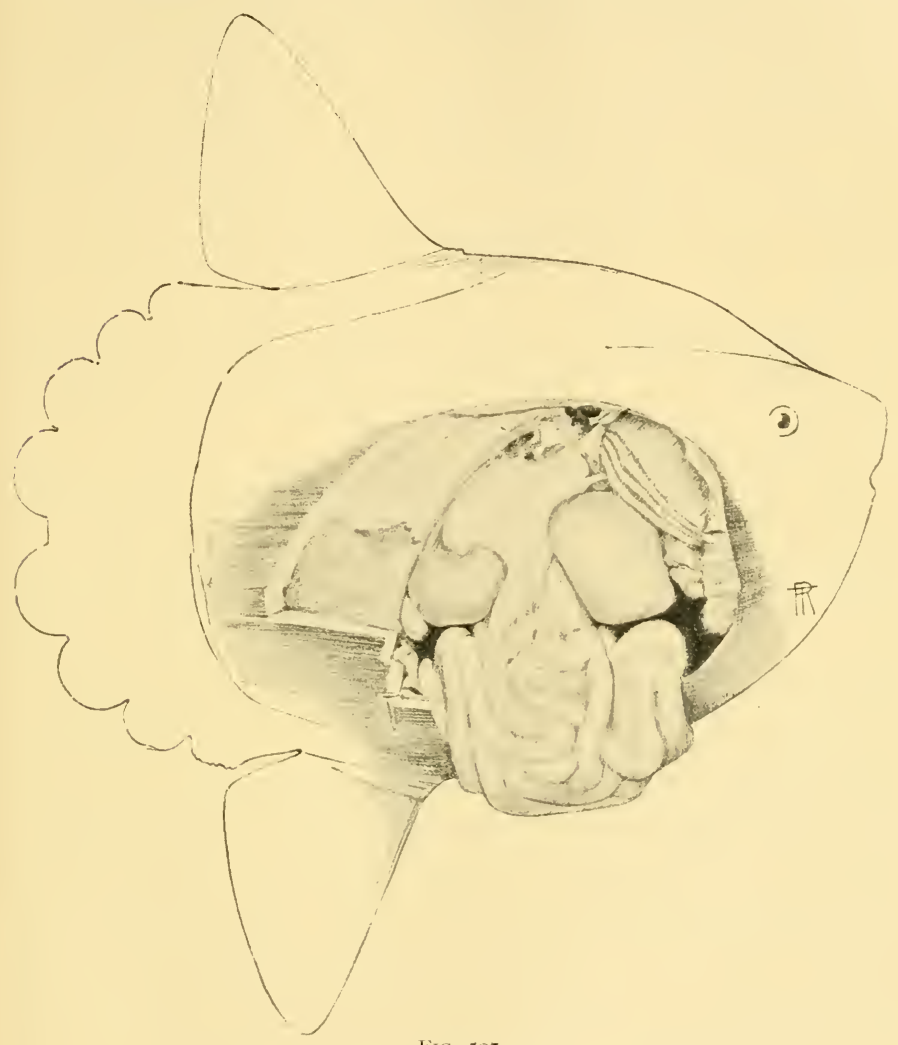

FIG. 507 .

Mola rotunda, to show the thick fat covering under the skin.

figured (see the Copepoda in Figs. 416-418, and the radiolaria and foraminifera with siliceous and calcareous spines and filiform pseudopodia, pp. 146-1 53).

Of special interest to us, however, is the oceanic fauna, the members of which are remarkable for their small size, and in this fauna the fishes especially appeal to us. The whole fauna 
of typical surface fish (Scopelidx, young fish), besides the silvery fishes of the intermediate layer, the Sternoptychidæ and the Stomiatidx found mainly between I 50 and 500 metres, live just in the specifically light and thin water-layers (see Fig. 526, representing an adult Argyropelecus hemigymnus, only 34 millimetres long, but with almost ripe ovaries). Excepting the long ribbon-like Trachypteridæ, Regalecus glesne, etc., these minute fishes are, as far as we know, the principal if not the only ones peculiar to these light water-layers. In the surface-layers it is possible to recognise three distinct types: (I) the minute Scopelidx; (2) the larger oily fish like the sunfish; and (3) the species which live near solid floating objects, such as the Sargasso fish.

One meets exceedingly few large fish in the ocean belonging to the good swimmers, for instance, mackerels, pilot fish, swordfish, and sharks. Little is really known about the distribution of all these, but several of them spend at least some part of their lives in coast waters.

Boreal

A comparison of the fauna of the Norwegian Sea and that of pelagic life. the Atlantic is very interesting. We have seen in Chapter IX. that numerous fishes which live mainly in the Atlantic have been found in the Norwegian Sea as very rare visitors. From the notes of Professor Collett, covering many decades, I have given a list (see p. 643) recording the frequency of the occurrence of these Atlantic forms. The most remarkable feature is the fact that most of them have been found at the very surface, or have drifted ashore and have been found stranded on the beach. Among these fishes there are several species, for instance those belonging to the genus Argyropelecus, which live at 300 metres in the Atlantic and have not been captured at these depths in the Norwegian Sea. Figs. 504-506 show that the lines of temperature, specific gravity, and viscosity situated in 300 to 500 metres in the Sargasso Sea rise up to the very surface as we approach the Norwegian Sea. In this direction the Gulf Stream runs, at all events in the northern part of the section.

The facts pertaining to the occurrence of boreal species in the Atlantic are just the reverse. In Chapter IX. we have learnt that on our track from Newfoundland to Ireland we found boreal species, Clione limacina, Aglantha, Calanus, Euchata, and several others, at depths between 750 and rooo metres, while in the Sargasso Sea we took Calanus hyperboreus and Euchata at 1000 metres. At these depths we find the same specific 
gravity and viscosity as in the Norwegian Sea, and also the same temperatures. These boreal species are essentially larger than the warm-water forms belonging to the Atlantic surfacelayers, and have far smaller organs of floating. This applies equally to the genuine deep-sea forms of the Atlantic in whose company the boreal forms are found (see, for instance, what I have previously said about the radiolarians, the trachymedusæ, and the crustaceans). A parallel is also found in fishes and squids, of which some larger forms commence to appear in the deeper layers, their size apparently increasing as we descend towards the bottom (compare the measurements of Cyclothone signata and C. microdon, Fig. 473, p. 620, and the two figures representing ripe Cyclothone, Figs. 527 and 528). The bathypelagic Gastrostomis bairdii, one of our deepest-living pelagic fishes, was found to attain a length, including its long tail, of $75 \mathrm{~cm}$. In these regions we also find large prawns, which appear to increase in size with increase of depth (Acanthephyra, Notostomus). The squids seem to be arranged in two groups, a number of small forms living in the upper layers and the larger species living in deeper water. Although our captures from a systematic point of view may be characterised as exceedingly rich, they are not satisfactory for a study of the vertical size-distribution of squids.

The peculiar agreement between size, form, and distribu- Coast waters. tion of species and the occurrence of a certain specific gravity and viscosity of the water seems entirely absent in coast waters, where the specific gravity of the water is lower than in the ocean, because the inflow of fresh water from continental rivers lowers the salinity. The viscosity, mainly dependent on temperature, should, as a rule, be similar to that of the open ocean outside. One would therefore expect to find, for instance on the coast banks of Africa, similar oceanic forms, or the same faunistic characters on the whole, as in the Atlantic Ocean. On the contrary, we find that the fauna as well as the flora have entirely different features. For unicellular plants as well as for animals, the rule holds good that all forms are much larger than those in the open ocean. Among plants the minute coccolithophorida are replaced by peridinex; instead of the minute oceanic scopelidæe we meet with pelagic herrings and mackerels, animals of quite another size and character.

As to the northern part of the Atlantic we perceive that several boreal forms (among others Clione limacina), which in 
the open ocean are found from 750 to 1000 metres, ascend not only to the coast banks of Ireland, where the water is warm and the specific gravity low, but also to the coast banks of Newfoundland (see Fig. 489, p. 659, showing the vertical distribution of Clione on our northern track).

How is this remarkable distribution to be explained? First of all it shows that our conclusions as to the distribution of animals must be drawn with great caution. Except the single occurrence of Clione to the west of Ireland, all the captures agree as to temperature, specific gravity, and viscosity, both in deep water as well as on the Newfoundland banks. We require further information regarding the physical and biological conditions in order to understand the difference between the coast banks and the ocean. The biological conditions, especially the great difference between the food supply on the coast banks and in the ocean, will be discussed after touching upon certain physical conditions.

As previously mentioned, Ostwald has pointed out the influence exercised by salinity on the size of organisms; in surroundings of low salinity certain organisms absorb water and increase in volume, while in high salinities they diminish in volume. To what degree this fact may entail a difference between the size of organisms belonging to the salt oceanic waters and the size of organisms in the fresher coast waters, can only be decided by future investigations. Possibly the richer nourishment offered by coast waters affords the organisms a better chance to store up fatty substances (Clione as well as Noctiluca store up fat), which increase the power of floating. Finally, we may raise a question which seems to be worthy of future investigation. Is the viscosity of the water influenced by the number of organisms suspended in it? That this may be so is conceivable when we think of china ink, for instance, which is more or less viscous according to the amount of substance dissolved in the water. Investigations as to the actual facts occurring in nature have not yet been made. Those who have observed the extent to which coast water may be filled with suspended substances, detritus as well as living organisms, may perhaps find this question worth consideration.

\section{Migrations}

We have considered how far and in what manner the appearance, shape, size, and also the several organs of different 
organisms may be supposed to have been adapted to certain external conditions prevailing in the water-layers which surround them. But these water-layers are not stationary, and the conditions in a certain water-layer may change in many different ways from time to time. These changes alter the habitat of the animals and cause active or passive migrations. The study of these migrations is specially interesting as showing the influence of physical conditions acting upon the animals.

From time immemorial it has been known that many Daily vertical animals ascend at night to the surface of the ocean. Fishermen have during ages turned this knowledge to advantage in setting their drift-nets at night at the surface of the sea to capture the herring. Recently it has proved possible to trawl successfully for herring along the sea-bottom, but only during the daytime. All sailors can tell us that at night great numbers of animals gather in the surface waters, which are never seen there in the daytime. An interesting instance of this was mentioned in Chapter IX. While fishing with long-lines on the Faroe banks our lines were set for cod along the bottom in about 200 fathoms; the lines were hauled at night, and the stomachs of the cod contained squids, which had been eaten during the day, while at night numerous squids were seen at the surface darting into the glare of our electric lamp hanging over the side. Most fishermen have had similar experiences.

A certain amount of information has also been gathered as to the vertical migrations of minute pelagic organisms moving towards the surface at night. Chun especially has investigated the extent of these migrations, and found that the majority of small pelagic organisms migrate generally within a vertical range of 30 to 50 metres. Steuer draws attention to the fact that vertical migrations very rarely involve all the pelagic forms of a locality; at all events they do not migrate in the same manner, for there are many transitions between forms which only retreat vertically during a few hours in the daytime, and forms which rise only during the darkest nocturnal hours. If the forms were large enough to be seen in the water, we should "by day as well as by night be able to observe a continuous rise and fall of organisms. Only during the day we should see a larger congregation in deeper water, and at night at the surface."

Some instances of the difference plainly observable in our catches by day and by night have already been mentioned 
(see p. 95). Specially striking were the fishes Astronesthes and Idiacanthus occurring at the surface only at night. It was also very interesting to note the remarkable coincidence between the vertical migrations of the fishes and the development of their light-organs. Fig. 490 shows the vertical occurrence of five black fishes, each mark denoting the capture of one individual ; in the case of Gonostoma rhodadenia and Photostomias guernei, a black dot denotes a specimen captured at night, while a ringshaped dot denotes a specimen taken during the day. In Gastrostomus, Cyema, and Gonostoma grande only slightly developed light-organs, if any, are met with. In Gonostoma rhodadenia and Photostomias guernei particularly large lightorgans are present (see Fig. 494 and Plate II.). Specially interesting is a comparison of the two species of Gonostoma, the light-organs along the side of the body in $G$. rhodadenia having a length of $2.5 \mathrm{~mm}$., while in $G$. grande they are only $0.5 \mathrm{~mm}$. long. Evidently we have here a type of deep-sea fishes, living in deep water, but with the power of migrating towards the surface. These forms have retained their welldeveloped light-organs, which in other black fishes of the deep sea must be considered as extremely reduced, perhaps even quite rudimentary, organs. A perfect analogy is found in the decapod crustacea. The deepest living species (see table on p. 668, Nos. 8-II) have no light-organs and make no vertical migrations. Light-organs, or organs which are believed to produce light, are found only in species living between I 50 and 500 metres with a maximum distribution at about 500 metres. These species have been found much higher up in the water during the night than during the day, as is brought out quite clearly by the table.

During our southern cruise we might have had a good opportunity of making an exact study of vertical migrations by the aid of precise closing-net hauls, but time did not permit, though our isolated observations are very interesting, for instance those made at Station 48. While towing our big trawl all day at this station, we were continually taking hauls with surface tow-nets, the catches during the day consisting only of the common surface forms: Ianthina, Pterotrachea, fish eggs, pteropoda, radiolaria, etc.; but between 6 and 7 P.M. the nets suddenly captured a mass of small red copepoda, which during the day had been taken at about 70 metres. At Station 53, during the day, we captured only radiolarians at the surface; at 30 metres there were a few copepoda, no young 
fish or scopelidæ, while at 60 metres there were several copepoda, and no scopelidæ. In the same place, during the night, we obtained at the surface a rich collection of copepoda, numerous scopelidæ, and thirteen black fishes (Astronesthes niger). These instances furnish conclusive proof of vertical migrations of considerable extent.

Ostwald, after studying the variations in the viscosity of the water from time to time, has made an attempt to explain the vertical migrations as due entirely to physical laws. During the twenty-four hours certain changes occur in the temperature of the ocean surface, and the viscosity of the water is, as we have seen, largely dependent on temperature. According to Buchan, the mean diurnal fluctuation of the surface temperature, as shown by the "Challenger" observations, was in mid North Atlantic $0.8^{\circ}$ Fahr., in mid South Atlantic also $0.8^{\circ} \mathrm{F}$., in mid North Pacific $1.0^{\circ} \mathrm{F}$., and in mid South Pacific $0.9^{\circ} \mathrm{F}$.; near the equator both in the Atlantic and Pacific the diurnal range is only $0.7^{\circ} \mathrm{F}$. The mean daily range deduced from the whole of the "Challenger" observations during the three years and a half is $0.8^{\circ} \mathrm{F}^{1}$

According to Krummel ${ }^{2}$ the daily range of temperature occurring in the surface waters of the open ocean amounts to about $0.5^{\circ} \mathrm{C}$. ; in the North Atlantic $0.59^{\circ} \mathrm{C}$. Although several investigators, like Aimé and Hensen, tackled the problem we have very little knowledge regarding the daily changes at different depths. From Krümmel I give the following differences found by Aimé between evening and morning at different depths in the Mediterranean :-

\begin{tabular}{|c|c|c|c|}
\hline \multirow{2}{*}{$\begin{array}{l}\text { Depth. } \\
\text { Metres. }\end{array}$} & \multicolumn{2}{|c|}{ Temperature. } & \multirow{2}{*}{ Difference. } \\
\hline & Evening. & Morning. & \\
\hline$\circ$ & $\mathrm{I}_{5 . \mathrm{I}^{\circ} \mathrm{C} .}$ & $14.6^{\circ} \mathrm{C}$. & 0.5 \\
\hline 2 & $\mathrm{I} 5 . \mathrm{I}^{\circ} \mathrm{C}$. & $14.6^{\circ} \mathrm{C}$. & 0.5 \\
\hline 4 & $\mathrm{I} 5.0^{\circ} \mathrm{C}$. & $\mathrm{I} 4.5^{\circ} \mathrm{C}$. & 0.5 \\
\hline 6 & $14.8^{\circ} \mathrm{C}$. & $\mathrm{I} 4.5^{\circ} \mathrm{C}$. & 0.3 \\
\hline Io & $14.6^{\circ} \mathrm{C}$. & $\mathrm{I} 4.4^{\circ} \mathrm{C}$. & 0.2 \\
\hline I 4 & $\mathrm{I} 4.4^{\circ} \mathrm{C}$. & $14.3^{\circ} \mathrm{C}$. & O. I \\
\hline I 8 & $\mathrm{I} 4.3^{\circ} \mathrm{C}$. & $14.3^{\circ} \mathrm{C}$. & 0.0 \\
\hline 22 & $\mathrm{I} 4.3^{\circ} \mathrm{C}$. & $14.2^{\circ} \mathrm{C}$. & O. I \\
\hline
\end{tabular}

1 Phys. Chem. Chall. Exp., Part v. p. 6, 1889.

${ }^{2}$ Otto Krümmel, Handbuch der Ozeanographie, Bd. 1, Leipzig, 1907. 
From this it does not seem that such migrations as those mentioned above are due to changes in temperature and viscosity alone. We must, for the present, suppose that the animals have the power of actively altering their level in the water-layers. Ostwald's observations on the viscosity of seawater, and on the floating capacity of organisms, should render these questions easier of solution, and their further investigation should form a very interesting object for future expeditions.

Effect of currents on the distribution of animals.

The currents of the ocean exert a very strong influence on the distribution of many animals. All seafaring men and the inhabitants of all shores have known for ages that drifting objects are carried very far by the currents of the sea, and that "rare" and strange animals are stranded on the coasts. Along the entire coast of Norway, even up to the Barentz Sea, drifting objects and stranded fish are found, which really belong to the distant warm Atlantic. Numerous accounts of the passive migrations of animals through currents are to be found in literature, many of them valuable notwithstanding the fact that these conditions have only exceptionally been made the subject of systematic investigation.

Looking at the current-chart (Fig. 508), we see that the central part of the North Atlantic, south of a line drawn from the Bay of Biscay to the northern United States, forms a separate current-system. The branch of the Gulf Stream flowing north-east towards the coasts of northern Europe receives an admixture of cold water from the Labrador current, and also large volumes of water, as well as numerous organisms, from the main body of the Gulf Stream. Entering the Norwegian Sea this branch of the Gulf Stream runs through the Faroe-Shetland Channel, sending off one branch to the North Sea and another branch along the coast of Norway right up to the Barentz Sea. This current system enables us to understand many of the laws governing the distribution of pelagic forms as referred to in Chapter IX. Thus the warmwater fauna of the North Atlantic belongs mainly to the central current system; isolated specimens belonging to this fauna not only occur in the north European Gulf Stream, but are found in the Norwegian Sea, and on the northernmost coasts of Norway (see the discussion of the distribution of pelagic fishes in depths between 150 and 500 metres in the Atlantic, and the occurrence of Atlantic fishes in the Norwegian Sea, p. 644). The distribution of the animals of the coast banks 
is peculiar in so far that southern species of molluscs, for instance, occur as isolated specimens even far north in the Norwegian Sea, while northern species have a sharp southern limit (see Chapter VII.). Vast numbers of small pelagic organisms are introduced into the Norwegian Sea from the Atlantic.

As the water-masses of a current are carried along, the

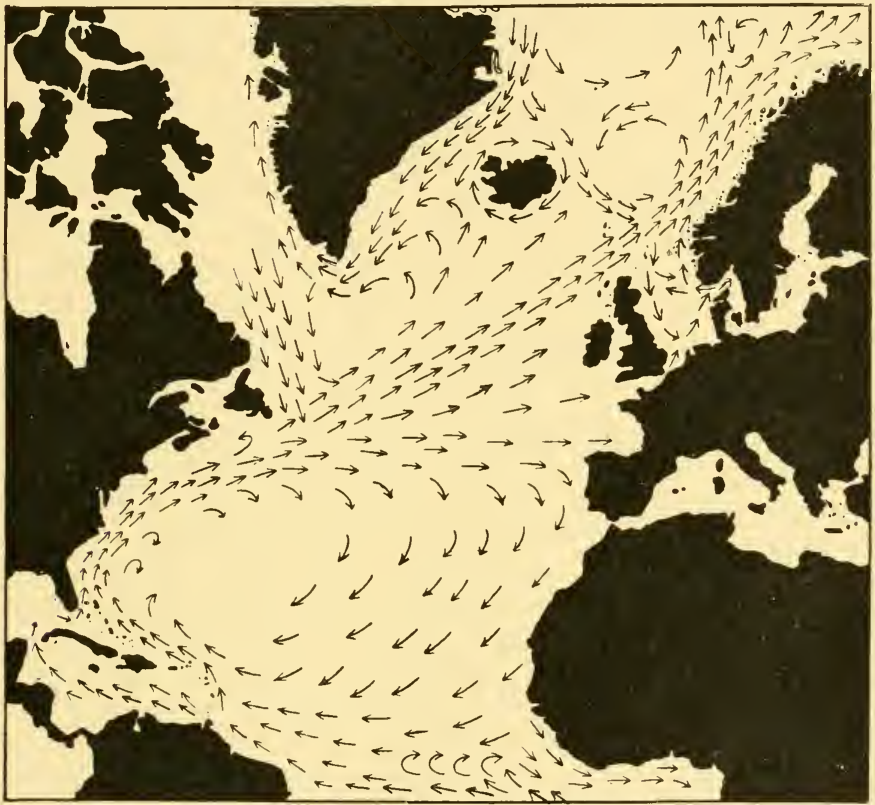

Fig. 508.-Currents of the North Atlantic. (From Schott's "Valdivia" Report and Helland-Hansen and Nansen's memoir on The Norwegian Sea.)

conditions of existence for certain animals change, and as a consequence the fauna gradually changes in character. This change of fauna from place to place in the same expanse of water has always presented interesting problems in oceanic research. Sir John Murray writes upon this point as follows : "Where cold and warm currents meet at the surface of the Effect of large ocean, there is a rise of temperature for the animals of the cold current, and a fall of temperature for the animals of the warm range of current, which results in a plentiful destruction of organisms. in the surface 
The tow-net collections during the 'Challenger' expedition gave frequent illustrations of this fact by the dead animals collected in such positions off the coast of North America, off the Cape of Good Hope, in the North Pacific, and elsewhere. Dr. O. Fischer records a remarkably large number of bacteria on the borders of such meeting currents. This destruction of life is not limited to minute pelagic organisms, but occasionally affects animals which live at the bottom of the sea. Some remarkable instances of this kind have been observed between depths of 50 and 100 fathoms off the eastern coast of the United States.

"Lieutenant-Commander Tanner, commanding the United States Fish Commission steamer 'Albatross,' reports that 'on the morning of July 20 , I 884 , in lat. $37^{\prime} 47^{\prime} \mathrm{N}$., long. $74^{\prime}$ I $5^{\prime} \mathrm{WW}$., near the roo-fathom line, we passed numerous dead octopods floating on the surface. This unusual sight attracted immediate notice and no little surprise among those who knew their habits, as it was not suspected at first that they were dead. We lowered a boat and picked up three or four specimens, which we were unable to identify, but in general appearance they resembled Alloposus mollis (Verrill) of unusually large size. These dead cephalopods were seen frequently on the $100-$ fathom line and outside of it, from the position given above to the meridian of Montauk Point, a distance of 180 miles. They were less numerous, however, as we went to the northward and eastward. Several dead squid were seen also, and two specimens were picked up with a scoop-net.'

"A still more remarkable instance of this kind is furnished in the well-known case of the destruction of the tile-fish (Lopholatilus chamcleonticeps) in the same locality in the spring of 1882. In the months of March and April I882, vessels arriving at Philadelphia, New York, and Boston reported having passed large numbers of dead or dying fish scattered over an area of many miles, and from descriptions and the occasional specimens brought in, it was evident that the great majority of these were tile-fish. Naturally, these fish were not evenly distributed over all the area in which they were seen, some observers reporting them as scattering, and others as at times so numerous that there would be as many as fifty on the space of a rod square. As one account after another came in, it became apparent that a vast destruction of fish had taken place, for vessels reported having sailed for forty, fifty, and sixty miles through floating fish; and in one case, the schooner 
'Navarino' sailed for about I 50 miles through waters dotted Destructive as far as the eye could reach with dying fishes. Computations effect of largé range of made by Captain J. W. Collins seem to indicate that an area temperature. of from 5000 to 7500 square statute miles was so thickly covered with dead or dying fish that their numbers must have exceeded the enormous number of one billion. Since there were no signs of any disease, and no parasites found on the fish brought in for examination, their death could not have been brought about by either of these causes; and many conjectures were made as to the reason of this wholesale destruction of deep-water fishes, such as would ordinarily be unaffected by conditions prevailing at the surface, submarine volcanoes, heat, cold, and poisonous gases being variously brought forward to account for the loss of life. Professor Verrill has noted the occurrence of a strip of water having a temperature of $48^{\circ}$ to $50^{\circ}$ Fahr., lying on the border of the Gulf Stream slope, sandwiched between the Arctic current on the one hand and the cold depths of the sea on the other. During i 880 and I88 I Professor Verrill dredged along the Gulf Stream slope, obtaining in this warm belt, as he terms it, many species of invertebrates characteristic of more southern localities. In I 882 the same species were scarce or totally absent from places where they had previously been abundant; and this, taken in connection with the occurrence of heavy northerly gales and the presence of much inshore ice at the north, leaves little doubt that some unusual lowering of temperature in the warm belt brought immediate death to many of its inhabitants. This is the more probable, as it is a well-known fact that sudden increase of cold will bring many fish to the surface in a benumbed or dying condition."

From the Barents Sea we know many instances of a similar destruction of animals on a large scale. The case of the boreoarctic fish, the capelan (Mallotus villosus), is specially striking, millions of this fish having occasionally been found drifting dead at the surface. In the Barents Sea very sudden changes of temperature occur, and it is natural to conclude that the death of the fish is caused thereby. The greatest destruction of this kind probably occurs among the young stages, eggs and larvæ of fishes. As we shall see later, these young stages may be removed by currents very far from the places where they are capable of developing, and in all probability they are also liable to

1 Sir John Murray, "On the Annual Range of Temperature in the Surface Waters of the Ocean," Geogr. Journ. vol. xii. pp. 128-130; i 898 . 
Mixing of Gulf Stream and boreal waters.
Annual changes in velocity of currents.

encounter catastrophes which sweep them off in enormous numbers. I come to this conclusion because our investigations on the age-composition of various fish-species have proved the frequency of the different year classes to be so variable (see section on age and growth).

As the Gulf Stream flows northwards its waters are gradually cooled, partly because they give off heat to the cold air, and partly because of the admixture of cold water. With the cooling the southern forms disappear, and their place is taken by entirely different boreal species; very little is known about the actual stages of this change.

During the cruise of the "Michael Sars" from the west coast of Scotland to Rockall, and north to beyond the Wyville Thomson Ridge we found vast numbers of Salpæ (S. fusiformis), the great majority of which were wholly degenerated. Bjerkan, who is examining our collection of Salpx, informs me that the mantle and the muscular system of the specimens were generally in a very ragged condition, in many cases only the intestine being distinctly recognisable. Here then, on the border between the Atlantic and the Norwegian Sea, it appears that certain forms die in large numbers, while others degenerate. Gran refers to the degeneration of certain coast diatoms found drifting far out at sea (see p. 342).

When organisms cannot within a certain time regain conditions necessary for them, or to which they can adapt themselves, they invariably die sooner or later. The isolated specimens of such fishes as Argyropelecus found in the northernmost parts of the Atlantic undoubtedly represent a few survivors of the change.

The boreal fauna which in northern waters replaces the genuine Atlantic forms also belongs to a great current-cycle. If we look at the current charts (Fig. I93, p. 284 and Fig. 508), we observe that the Gulf Stream receives admixtures from boreal and boreo-arctic currents, which consequently carry boreal organisms. As we have previously seen, we meet with a wealth of boreal forms in deep water even in the Sargasso Sea, and probably much farther south, living below the warm-water fauna of the surface.

The velocity of ocean currents is subject to many varieties of periodical and non-periodical changes (see pp. 284-5). The annual changes are of peculiar interest, and are very noticeable in northern waters, though also important in the Atlantic. If we compare the two charts (Figs. I 59, p. 227, and r6o, p. 228) 
we see that the surface temperatures of the North Atlantic change very considerably from February to August. In February the isotherm of $5^{\circ} \mathrm{C}$. follows approximately the 4 oth degree of latitude, while in August it reaches the north-western corner of Iceland, north of the 5oth degree. The isotherm of $10^{\circ} \mathrm{C}$. has in February a course approximating to that of the I 5 isotherm in August, when the isotherm of $10^{\circ}$ runs far north in the Norwegian Sea, where the seasonal difference is

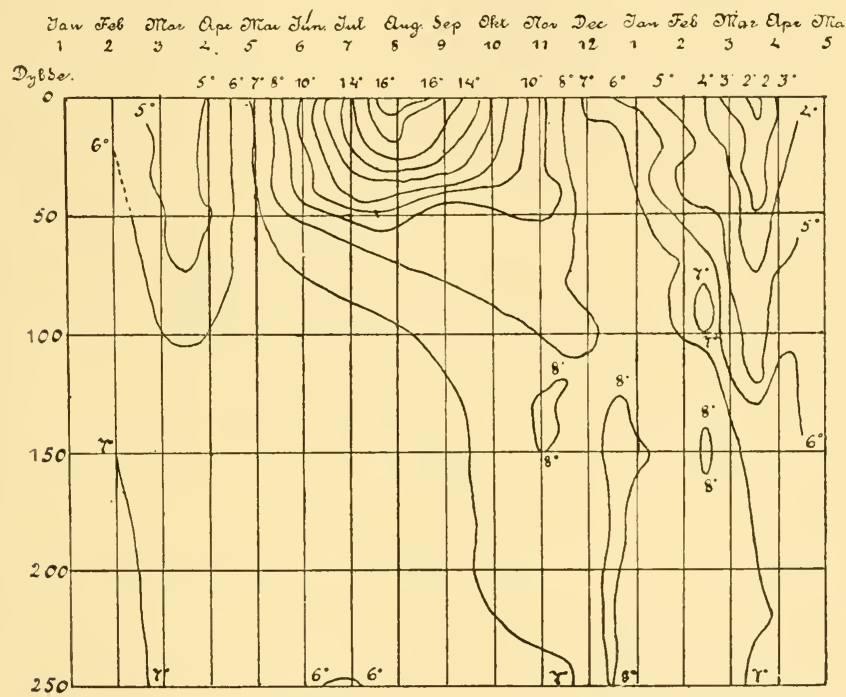

Fig. 509.-VARIATION OF TEMPERATURE ACCORDING TO DEPTH DURING DIFFERENT Seasons, off the Norwegian West Coast.

still more pronounced. Fig. 509 shows the vertical distribution of temperature during approximately fifteen months, as observed by me in the 'nineties of last century while making repeated investigations in one locality off the west coast of Norway. We perceive that during the summer months warm temperatures occur in the upper 50 metres, temperatures which during winter we can find in the Atlantic only south of the 4 oth degree of latitude (see Fig. I59, p. 227). During autumn high temperatures $\left(8^{\circ} \mathrm{C}\right.$.) pass down through the water column, so that towards the close of the year the warmest water is found at 250 metres. At the same time the surface-layers cool 
rapidly and the lower temperatures gradually descend towards deep water during early spring and summer. Great changes in specific gravity, viscosity, and light-intensity accompany these changes in temperature; in the very magnitude of these changes we must look for the essential difference between the tropical and subtropical conditions on the one hand, and the arctic-boreal conditions on the other.

The greatest interest attaches to the fact that the immigration of Atlantic forms into the Norwegian Sea occurs at the season when the conditions in the latter are most similar to those of the Atlantic. The international investigations have contributed to our knowledge on this immigration.

Distribution of Salpa.

Schmidt, ${ }^{1}$ for instance, in the Danish investigation-steamer " Thor," had the opportunity of studying the immigration of Salpæ from the Atlantic into the Norwegian Sea, and writes as follows :-

"The organisms concerned were the distinctly Atlantic Salpæ (especially Salpa fusiformis), which are so characteristic and which

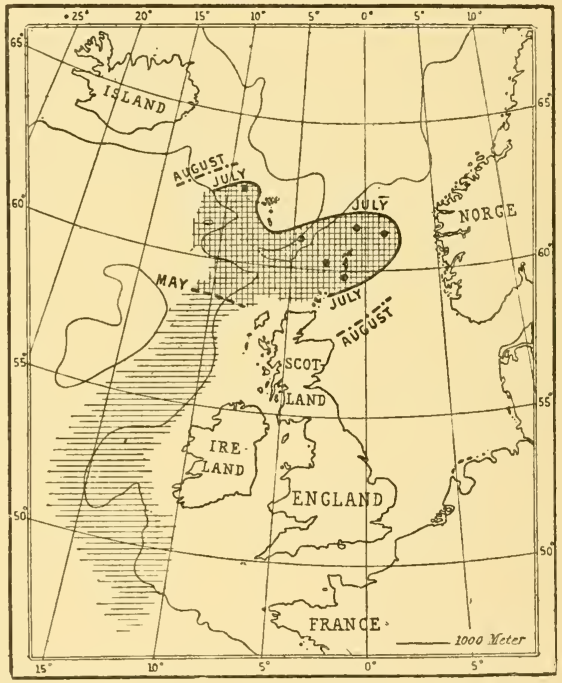

Fig. 5IO.-DRIFT OF SALPE (SALPA FUSIFORAIIS) IN Ig05. (From Schmidt.)

were taken often in hundredweights in each haul of our pelagic apparatus in the Atlantic beyond the 1000-metres line. The year 1905, during which we several times crossed the North Sea, made two cruises to and from Iceland and the Faroes, following approximately the rooo-metres line, then sailed southwards west of the British Isles to the Bay of Biscay, was thus specially well suited to give light on these conditions, as I have endeavoured to delineate on the accompanying Chart [reproduced in Fig. 5IO]. The shaded lines

\footnotetext{
1 Johs. Schmidt, "The Distribution of the Pelagic Fry and the Spawning Regions of the Gadoids," etc., Rapports et procès verbaux du Conseil International, vol. x., Copenhagen, I9og.
} 
(single or double) on this Chart represent the regions where the Salpx occurred. As will be seen, up to the end of May the Salpæ were limited to the Atlantic, where the northern boundary was found on the voyage of the 'Thor' southwards to lie to the west of the Hebrides, and absolutely none were found in the Norwegian Sea or North Sea. Towards the end of July the conditions had quite changed, a fact of which I was able to convince myself on a cruise from Scotland to Bergen and from Bergen to the Shetlands, the Faroes, and Iceland. From the chart, on which the places where we found the Salpx are marked by black spots, we see how the northern boundary has moved to the east and north. Thus a large tongue of the Salpæ had pushed its way north of the British Isles in a northeasterly direction, far towards the Norwegian coast, and in a northerly direction we see now that the Salpæ reached as far as north-west of the Faroes. And it was not a matter of small quantities. Thus at our station (Station I 2 I, I 905) north of the Shetlands we took many hundred litres per half-hour haul; and in the quiet, calm weather we could see under the clear surface how the water was quite thick with the Salpæ which occurred here and, it is to be remarked, over small depths (less than 200 metres), along with other distinctly Atlantic oceanic forms, in almost as large quantities as we had found them anywhere, even in the Atlantic over deep water where they really belong. At the end of August, when the 'Thor' was coming southwards from Iceland, the northern boundary had moved somewhat, yet not very much. We see also that the south-eastern boundary in the North Sea had spread out farther, corresponding to a greater development of the large tongue in July."

Similar experience has also been gained during the Norwegian investigations. Thus in the survey of the "Michael Sars" investigations on pelagic organisms in the years I900I908, Damas writes as follows:

"In the middle of the summer the invasion of oceanic forms from the Atlantic commences in the Faroe-Shetland channel. There we find an imposing array of species that are entirely absent from the Norwegian Sea, and that certainly do not belong to the fauna appropriate to that sea-basin. Among the most characteristic we may name: Lepas fascicularis, Physophora borealis, Cupulita sarsi, Solmaris corona, Salpa fusiformis, S. runcinata, and S. irregularis, Arachnactis albida, Clio pyramidata and C. uncinata. These forms do not enter en bloc, and the water-masses which convey them do not seem to have 
a homogeneous composition. Their approach is heralded by an immense swarm of Lepas fascicularis, which at the beginning of May and June float passively on the surface of the northern portion of the North Sea. Arachnactis albida follows soon afterwards, as does also Physophora borealis. The salpæ and doliolids, which with Cupulita sarsi, constitute the bulk, generally make themselves visible in July, August, and September."

We know that these warm surface forms approach the coast of western Norway, and as far north, for instance, as the Trondhjem fjord. ${ }^{1}$ Even within the Norwegian Sea such seasonal migrations occur, the warm water layers from the eastern part spreading out over the deeper areas during summer.

The foregoing remarks refer only to the passive migrations or drift of pelagic forms with the currents of the sea. Fishermen have, however, long recognised the vast active migrations of the powerful swimmers, especially fishes, generally supposed to be undertaken in order to reach definite localities. The first to submit these migrations to scientific investigation was probably G. O. Sars. As to the herring fisheries on the coasts of Norway he was struck with the fact that while herrings of all sizes are captured along the entire coast from the Skagerrack to the Barents Sea, spawning herrings are only caught in large quantities on a definite restricted portion of the coast, viz., from Stavanger to Romsdal (the Norwegian North-Sea coast), and he concluded that the herrings must necessarily migrate to these places to spawn, enormous spawning-migrations entering as a necessary link in the life-history of the herring.

Numerous instances of such migrations are known from the fishing industries, on the coast of Norway principally in the case of herring and cod, and in Iceland of cod and plaice. I refer the reader to my description of the migrations of the capelan (Mallotus villosus) in the Finmark Sea ${ }^{2}$ (Barents Sea). This small boreo-arctic fish spawns in spring on the coast banks of Finmark, and during summer it migrates far north into the Barents Sea towards the ice-limit. In March I90I, when many miles off the Finmark coast and over deep water, I could observe and fish the capelan, the shoals being followed by millions of auks, fulmars, kittiwakes, and gulls, the stomachs of which contained capelan. 
The exact experimental proofs as to migrations obtained during recent years from the marking of fish are also of great value. Marking experiments on marine fishes were started in the 'nineties of last century by C. G. J. Petersen, during his studies of the life-history of the plaice. During the international investigations they have been carried out on a large scale, especially by Heincke, Garstang, Trybom, and Schmidt, the investigations by the last named on the migrations of cod and plaice at Iceland having perhaps yielded the clearest results. The Iceland plaice

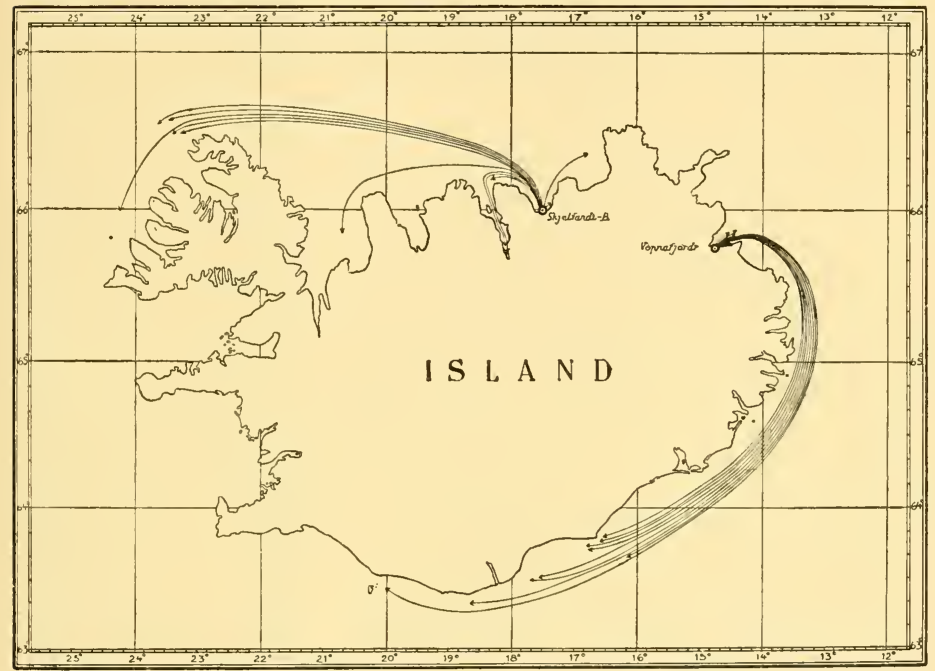

Fig. 5it.-Schmidt's Marking Experiments showing the Migrations of Plaice in ICELANDiC WATERS. (From Schmidt.)

spawn during spring south and west of the island, but at other times they migrate to the north and east coasts. Schmidt marked a number of plaice in Skjalfandi Bay on the north coast, and a number in Våpnafjord on the east coast (see chart, Fig. 5 I I). He got a great many of these back from the west and south coasts, where they were taken in the spawning season. From the North Sea interesting results from marking experiments are also available, but the fishes do not appear to migrate to such an extent as in Icelandic waters.

While investigating the fisheries and the whaling in northern Norway, I was successful in obtaining similar conclusive 
evidence as to the migration of whales. With the aid of Captain Sörensen I obtained the two harpoons or bomblances which in the years 1888 and 1898 were found in the bodies of blue whales (Balcnoptera musculus) killed in the Barents Sea (see Fig. 512). Such harpoons were never used there, being employed only by the whalers of the Atlantic, for instance, off the coast of North America, and they bear the stamp of the American patent-holder, testifying to their American origin. They must, therefore, be considered as proving enormous migrations on the part of the whales in which they were found.

G. O. Sars attempted to show that some migrations were undertaken in order to obtain food, and others for the purpose of reproduction, and he thus distinguishes between feeding-migrations and spawning-migrations. When the capelan gather in millions on the coast banks of Finmark, when countless numbers of cod approach the banks of Lofoten, and when the herrings flock to western Norway, they migrate to spawn. The fat-herring collecting off the coast of Nordland, and the cod gathering around the shoals of capelan in the Barents Sea, are examples of feedingmigrations. Such were the ideas of Sars. A more detailed discussion could only be given by reviewing the whole natural history of each species.

An attempt at explaining a vast migration of fishes by means of mechanical laws has recently been made by

Fiffect of submarine waves.
Otto Pettersson. ${ }^{1} \quad$ Each year during late autumn large numbers of herrings gather off the island belt at Bohuslän

1 Otto Pettersson, Studien ïber die Bewegungen des Tiefenwassers und ihren Einfuss auf die WVanderungen der Heringe, Fischerbote, 1911.
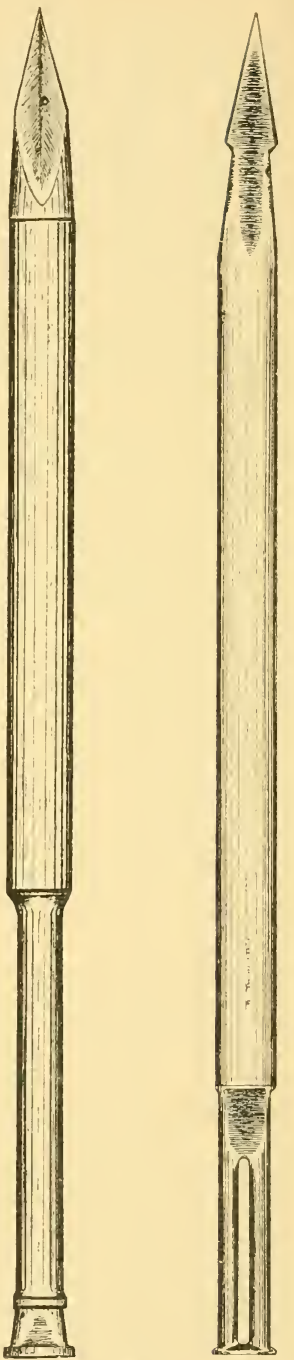

FIG. 5I 2.-AMERICAN" "BOMBLANCES" TAKEN IN BLEE Whales in NortherN NORWAY, FINMARK, ISSS AND 1898 . 
(on the west coast of Sweden), and are captured in the deep channel of the Kattegat, or in the fjords of Bohuslän. Pettersson discovered that the regular occurrence of these herrings in several cases coincided with certain large submarine waves which he could register in the Gullmar fjord, and he sets up the hypothesis that there is a certain connection between these two phenomena. Fig. 5 I 3 shows curves denoting different salinities in the Gullmar fjord in November and December I9Io, and it is seen that the deep salt layers rose several times during November, like huge waves, up towards the surface. Extensive investigations off the coast in the Kattegat proved the occurrence of similar deep-sea waves

\section{Bornö.}

Nov

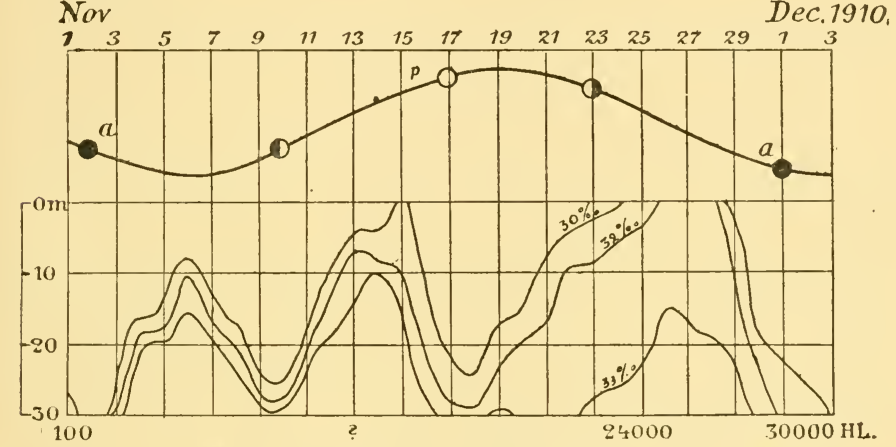

Fig. 5I3.-Submarine Waves in the Gulluiar Fjord in November and

Decenber ílo. (From Pettersson.)

in the latter locality. These waves, according to Pettersson, carried the water of the Jutland coast banks (bank-water with a salinity of 32 to 34 per thousand) like a torrent into the Kattegat and its fjords, forcing the fresh surface water out. The herring shoals dwelling on the Jutland coast banks were literally, Pettersson says, sucked into the fjords of the Swedish west coast as by an enormous vacuum pump. This inflow, Pettersson points out, takes place periodically and coincides with the phases of the moon (see Fig. 5I3). One wave, on the 15 th of November, occurred at full moon, when the moon was nearest to the earth (perigee), another wave on the 28 th of November occurred at new moon, when the moon was farthest from the earth (apogee). Coinciding with the last wave the herring shoals appeared, and between the $23 \mathrm{rd}$ and 24 th of November 24,000 barrels of herring were taken. 
Pettersson's observations made by the aid of his ingenious self-registering appliances are of very great interest, but it must be pointed out that the relations between the phases of the moon and the waves are not very well marked. Further, it is well known that similar oscillations in the water-layers of the Scottish lochs are produced by the varying winds that blow over the surface. ${ }^{1}$

Nordgaard has compiled an account recording the months of the year when southern Atlantic fish-species are stranded on the coasts of Norway, and has found that such strandings generally occur from January to May. On this subject he remarks: "It is hardly accidental that so many specimens of these pelagic deep-sea fishes arrive on the coast during the first months of the year, during the time of the cod fisheries (when the shoals of cod appear in order to spawn). It is obvious that during this season especially the deeper layers move towards the land, probably as a compensation current in deep water caused by the off-shore winds forcing the surface layers out to sea." If we look at Fig. 509, showing the annual changes of temperature in the sea off western Norway, we shall see that towards the new year and during spring a marked drop in temperature occurs in the surface layers. We must take it for granted that the organisms consequently tend to move towards the surface, the specific gravity and viscosity of the water increasing enormously compared with the conditions in warmer seasons.

These conditions and their influence upon animal life are to a great extent mere guess-work, but they open up a vast field for future oceanic research.

\section{Nutrition}

Sir John Murray divides marine deposits (see p. I6I) into two main groups: (I) Terrigenous deposits formed in deep and shallow water close to the land masses; and (2) Pelagic deposits formed in deep water remote from land.

Corresponding to this division we may define the nourishment of marine animal life as derived from two main sources: (I) Organic detritus carried into the sea from land or formed by disintegration of the plants of the coast belt and the animals living upon them; and (2) Pelagic plants.

As a third source, Pütter has suggested the organic com-

1 See Murray, Scott. Geogr. Mag., vol. iv. p. 345, I888, and vol. xiii. p. I, 1897 . 
pounds dissolved in sea-water, which must be formed, however, when all is told, either by dissolution of the detritus or as excreta from living organisms.

It has long been recognised that the dust-like detritus plays Organic an important part in the nourishment of certain bottom-animals detritus. (see Chapter VII. and the reference to Murray's "mud-line"). Investigations on the food of the oyster by Redeke and American investigators have proved that detritus forms the main contents of its stomach and intestines. Zoologists know that great numbers of bottom forms (holothurians, worms, and many others) are "mud-eaters," which live by passing the soft mud of the sea-bottom through their digestive tract. Lohmann and Rauschenplatt have lately shown that detritus also plays an important part in the nourishment of pelagic forms. Our ideas on this subject have recently been advanced by the systematic investigations of C. G. J. Petersen. ${ }^{1}$

In the Limfjord Petersen studied how detritus was formed by the disintegration of the dead plants along the coast, how it was found suspended in the water, and finally settled on the bottom as a soft layer 2 or 3 millimetres in thickness. In every respect this fine mud was similar to that found in the digestive tract of mussels and other animals. Petersen has proved this phenomenon to be of general importance in all the waters examined by him, and it will be necessary to examine the conditions in various areas of the sea in a very extensive way before we can arrive at a more perfect knowledge as to the nutrition of animals. In the open ocean conditions are still practically unexplored, and I will here only draw attention to some points worthy of examination in the future.

How far out to sea is the organic detritus carried? During our Atlantic cruise Gran was continually looking for detritus, centrifuging water-samples for this purpose, but as he tells us in Chapter VI. only insignificant quantities were found in the open ocean. If we may draw conclusions from bottom-deposits like Blue mud, there are vast differences in various areas of the ocean. In Chapters IV. and VII. we have seen that the terrigenous deposits on the eastern side of the Atlantic are limited to the African and European coast banks, while on the western side they extend far into the ocean beyond the coast banks of America (see Map IV.). These facts may obviously be explained as being due to currents (see current-chart, Fig. 508), which on the western side 
run off-shore and on the eastern side run towards the land. The distribution of the Sargasso weed also furnishes evidence, for, wherever found it has actually been derived from the shore, and, as we know, the Sargasso weed covers a vast area of the western part of the Atlantic. Even the Sargasso weed must become detritus. Hensen has shown that the tufts of this weed gradually become overgrown with heavy bryozoa, which causes them to sink, and then they are gradually disintegrated, being transformed into detritus while sinking, and furnishing nourishment for the animals in deep water. During the cruise of the "Michael Sars" the deep waters of the western part of the ocean proved to contain a far more abundant animal life than the corresponding depths in the eastern part. We have seen from Chapter IX. that by far the greater number of the Pteropoda collected, about 3500 or 4000 specimens, were taken in the south-western portion of our track, that is in the Sargasso Sea, and the same remark applies to the pelagic fishes, for instance Cyclothone microdon. In giving some figures in support of this, I wish to point out that these figures must only be looked upon as relative values, and are therefore only suited for a comparison between different localities.

I choose for comparison two stations east of the Sargasso Sea, between the Canaries and the Azores (Stations 42 and 49), and two stations in the Sargasso Sea (Stations 62 and 64), and indicate the number of specimens taken at corresponding depths with the same fishing gear:

\begin{tabular}{|l|c|c|c|c|}
\hline & \multicolumn{2}{|c|}{ East of the Sargasso Sea. } & \multicolumn{2}{|c|}{ In the Sargasso Sea. } \\
\hline Station 42. & Station 49. & Station 62. & Station 64. \\
\hline $\begin{array}{l}\text { Young - fish trawl, } \\
\text { I000 metres } \\
\text { Large tow-net, I500 } \\
\text { metres . }\end{array}$ & 6 & 8 & 90 & 448 \\
\hline
\end{tabular}

In northern boreal waters, like the Norwegian Sea, the water-layers of the coast banks cover nearly the whole of the deep area; we know this because many of the animals which are born on the coast banks are found to have drifted out into the waters above the deep area. Are also the detritus and dissolved substances carried so far from the shore? How far is the abundant life peculiar to boreal waters due to supplies 
of nutriment derived from the shore? These questions must be left to future research.

In Chapter VI. Gran has described the vertical distribution Pelagic of pelagic plants. In the open Atlantic he found that the plants. great majority of the plants occur in depths between 10 and 50 metres; at 75 metres the numbers decrease to about one-half, and at 100 metres to one-tenth, of the numbers found in the upper layers. The whole of the animal life in the oceans, 5000 or 6000 metres deep, thus mainly depends on the pelagic plants suspended in the uppermost 100 metres of water. The animals frequenting this upper layer feed partly on plants, partly on other animals, while in deeper water only animal food is available, besides the dead plants and animals sinking from the surface. Nutrition in the upper "plant"-region must therefore be different from that in the deeper layers.

Many animals of the plant-region are typical plant-eaters, and their bodies are organised for this purpose. This is especially the case as regards appendicularians and salpæ, the foremost part of their digestive tract, the so-called branchial sac, being provided with a grating of the finest and most delicate structure, retaining even the most minute plants (the cocco-lithophoridx). Many of these minute plant-forms were indeed first discovered by examining the stomach-contents of salpæ (Stein, Sir John Murray, Lohmann), and during the Atlantic cruise of the "Michael Sars" Gran also collected salpæ in order to secure material for comparison with our tow-net captures of minute plants. The colenterates (medusæ, ctenophores, siphonophores) are well adapted to capture minute plants by the aid of their tentacles, and so are the unicellular animals (foraminifera and radiolaria) by the aid of their long thin plasm threads (pseudopodia). The most important of all plant-eaters are, however, the small crustaceans, particularly copepoda, which seem specially adapted for feeding on the microplankton of the ocean. Gran has examined the excrements of copepoda, which sink through the water in the shape of minute sausage-like lumps, and are very often taken in considerable quantities in the silk nets. All the soft parts have been digested, but the shells of the plants eaten, the calcareous shells of the coccolithophoridæ, the armour of peridinex and the silicious shells of diatoms, can be identified. In the Norwegian Sea Gran observed that the copepoda were present in enormous numbers just below the layers containing a wealth of diatom plant-life, but nevertheless the excrements of these copepoda consisted of the frustules of the diatoms. The 
food of copepoda in deep water has not yet, as far as I know, been made the subject of systematic investigation, although this point is essential to a more complete understanding of marine biology. Nordgaard, who is describing the copepoda from our Atlantic cruise, has at my request been kind enough to examine the stomachs of a large number of copepoda from our deepest hauls in the Sargasso Sea, but has not been able to find anything morphologically definable in their stomach-contents. Do these copepoda there feed on detritus formed by the dead and

Importance of minute crustacea as food-animals. disintegrating organisms falling from the surface of the ocean?

Along with other small animals (foraminifera, radiolaria, sagittidæ), the copepoda and other crustacea form the main food-supply for the majority of the somewhat larger oceanic animals. Thus the stomach-contents of the pteropods Clio falcata and Limacina helicoides taken at depths between 500 and 1500 metres consisted of foraminifera and radiolaria. In the stomachs of large prawns, Acanthephyra purpurea and A. multispina taken below 500 metres, Sund found the remains of copepoda, sagittidæ, and fragments of minute fishes (Cyclothone). Koefoed has examined numerous stomachs of $C y c l o t h o n e$ without finding any contents, but their guts contained organic remains, mainly the jaws of minute crustaceans. The stomach of the fish Gonostoma grande from deep water was found to contain a mysid (Eucopia australis), and in Gonostoma rhodadenia were found five euphausidæ (Nematoscelis, Stylocheiron, Euphausia, Thysanopoda), seven sagittæ, five copepoda (Euchata, Eucalanus), and some lumps consisting of radiolaria.

Many of the pelagic fishes are extremely voracious. Repeatedly other fishes have been found in their stomachs of a size nearly equal to that of the devourer. Thus a small Astronesthes niger had a scopelid in its stomach, and a Chauliodus had eaten a Stomias boa. The record for voracity is held by the remarkable Chiasmodus niger (of which we took three specimens in the Atlantic), which is known to swallow fishes several times its own size. Fig. 5 I 4 shows a specimen with only slightly extended abdomen; Fig. 5 I 5 shows a specimen that has swallowed a fish much larger than itself, and most strangely one of the same species.

Abundance of minute crustacea in various areas and depths.
Generally speaking, the very minute animals, especially the minute crustacea, play an exceedingly important part as nourishment for other and larger animals. These minute crustaceans are constantly taken in the fine silk tow-nets, and in nets with a somewhat larger mesh they constitute the bulk 
of the catches. If we compare such catches at different depths and in different waters, we generally get a fair idea of the relative amount of nourishment present, and it may be of interest to examine some catches of this kind from the Atlantic and the

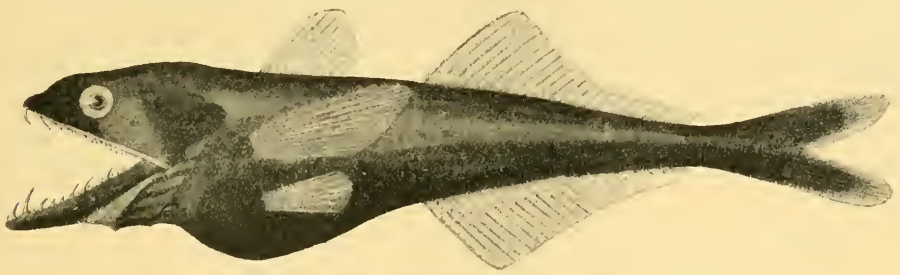

FIG. 5 I4.

Chiasmodus niger, Johns. Nat, size, $9.5 \mathrm{~cm}$. From Station 52 .

Norwegian Sea, where the "Michael Sars" employed the same silk hoop-nets, I metre in diameter, with $\frac{1}{4}$ millimetre mesh. To commence with, we will consider the same hauls from the

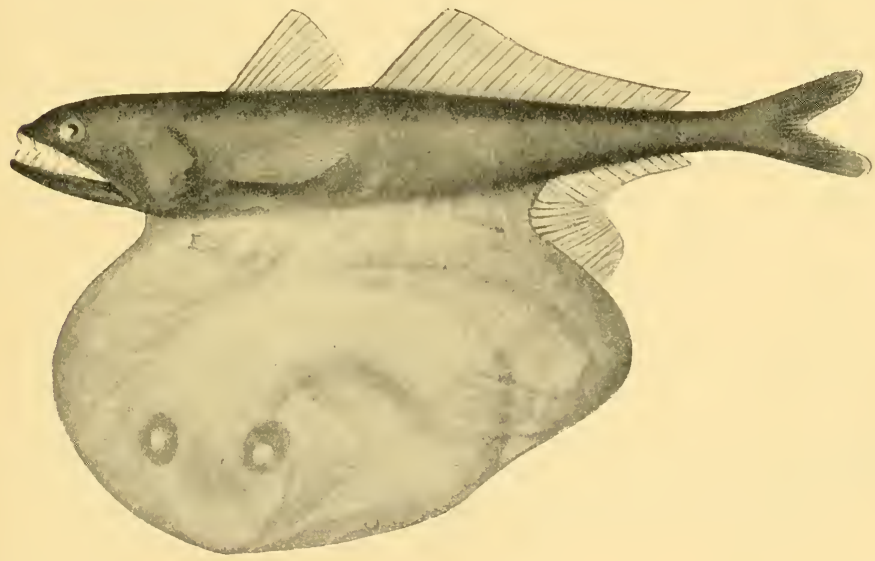

FIG. 5I5.

Chiasmodus niger, Johns. This specimen had swallowed a larger specimen of the same species. Nat. size, $5.7 \mathrm{~cm}$. From Station 56 .

Atlantic which in Chapter IX. we have discussed from a systematic point of view, noting the volume of small pelagic animals captured, compared with the temperature, specific gravity, and viscosity of the water at corresponding depths. 
During the first cruise of the "Michael Sars" in the Norwegian Sea in I900 I was convinced that in deep water a great quantity of food would accumulate wherever a rise in the specific gravity occurs, and where, consequently, all sinking bodies either stop or have their sinking velocity reduced, forming as it were a "bottom" in mid-water. In my report on the cruise ${ }^{1}$ I mentioned the matter, and the following observations appear to confirm this hypothesis.

In the Sargasso Sea series of hauls with closing-nets were taken at Stations 50 and $6_{3}$, the net employed at Station 50

St 63 .

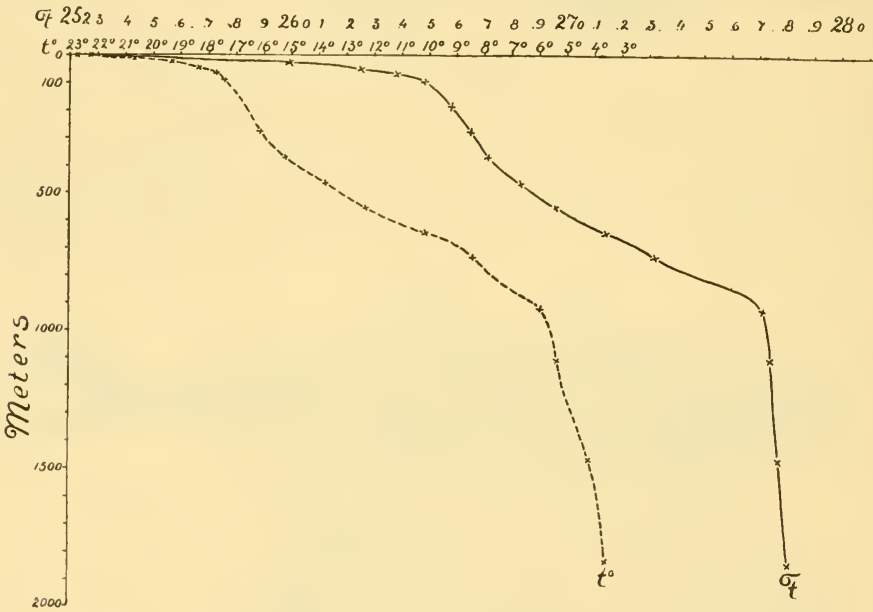

Fig. 5i6.-Curves of Temperature $\left(t^{\circ}\right)$ and Specific Gravity $\left(\sigma_{t}\right)$, Station 63. (Sargasso Sea.)

being I metre in diameter, and at Station 6.3 half a metre in diameter, made of very fine silk. At Station 50 hauls from 200 to 0 metres gave 3 c.c., containing 22 species of Crustaceans.

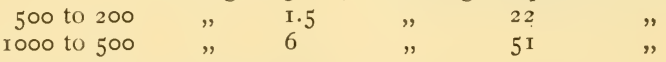

At Station 63 hauls from

$$
\begin{aligned}
& \text { I00 to o metres gave } 1.6 \text { c.c. } \\
& 200 \text { to } 100 \quad, \quad 0.5 " \\
& 500 \text { to } 200 \quad, \quad 1.6 "
\end{aligned}
$$

1 Ijort, Die erste Nordmeerfahrt des norwegischen Fischereidampfers "Michael Sars," Igoo, Petermann's Mitteilungen, Bd. 47, I90I. 
These figures show a minimum below IOO metres, and a maximum between 500 and 1000 metres. Comparing this with the curves for specific gravity at these two stations (Figs. 516 and $5 \mathrm{I} 7$ ), we notice a pronounced rise in specific gravity in the upper 100 metres (the plant region), followed by a very slow rise and then a rapid rise towards 1000 metres, beyond which the specific gravity becomes very uniform. The temperature, which greatly influences the viscosity, falls gradually, corresponding to the rise in specific gravity, and in consequence the viscosity increases towards deep water.

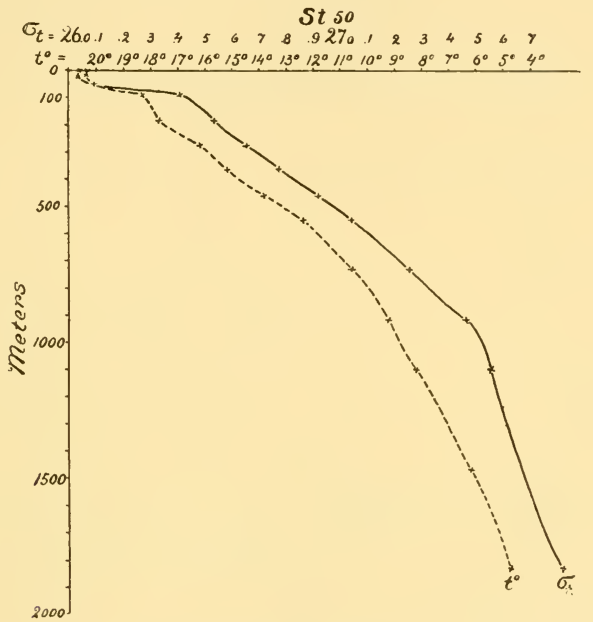

Fig. 517. - Curves of Temperature $\left(t^{\circ}\right)$ and Specific Gravity $\left(\sigma_{t}\right)$, Station 50. (South of the Azores.)

Off the banks of Newfoundland we took the following series at Station 80:

$$
\begin{aligned}
& 235 \text { to } \circ \text { metres gave } 5 \text { c.c. containing I } 6 \text { species of Crustaceans. } \\
& \begin{array}{lllll}
525 \text { to } 235 & , & 45 & , & 27 \\
950 \text { to } 525 & , & 28 & , & 34 .
\end{array}
\end{aligned}
$$

The curve of specific gravity here (see Fig. $5 \mathrm{I} 8$ ) is essentially different from those in the Sargasso Sea, for a rapid rise occurs down to about 500 metres, beyond which the specific gravity becomes practically uniform, and at this station no minimum quantity of organisms is noticeable between 500 and 200 metres, but on the contrary a considerable rise. 
CHAP.

The abundant plankton peculiar to boreal waters in summer (August) apparently accumulates in those layers where the highest specific gravity occurs, the volume thence decreasing in the deep uniform layers below 500 metres. A series of hauls taken close to the Wyville Thomson Ridge in the southern part of the Norwegian Sea at Station I I 3 gave the following results :-

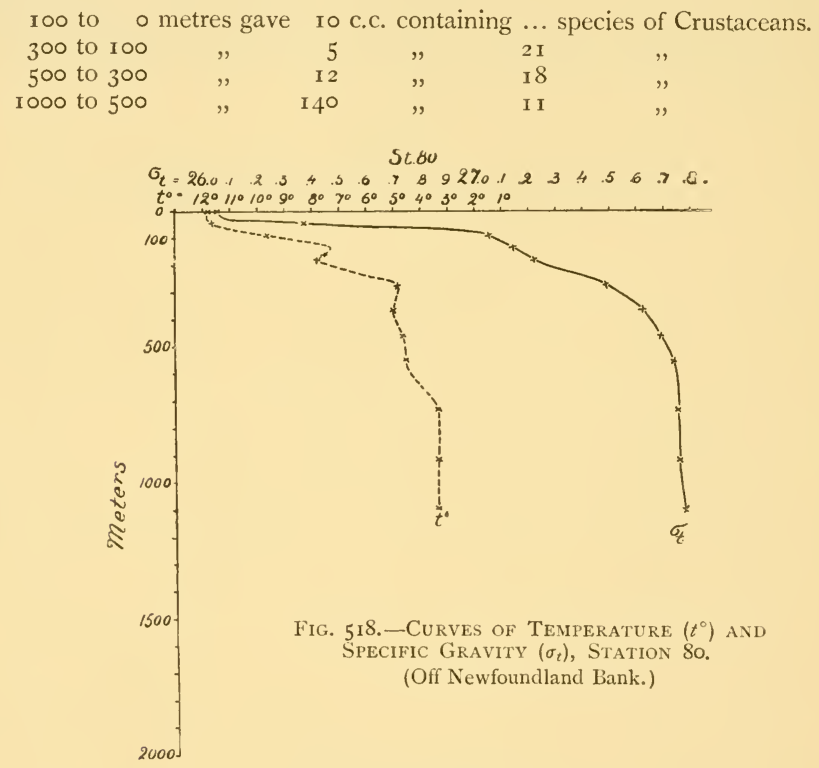

The curve for specific gravity shows here (see Fig. 519) a rapid rise down to 100 metres, then a slow rise down to about 300 metres, and finally a rapid rise down to about 600 or 700 metres. A pronounced minimum in the volume of crustacea occurs between 300 and 100 metres, and an enormous increase is found between 1000 and 500 metres, where the volume is fifty times larger than the volume in the surface layers of the Sargasso Sea.

In my opinion these facts prove the correctness of the hypothesis that minute pelagic crustacea (and consequently nourishment suitable for larger organisms) tend to accumulate at those depths where a pronounced rise in the specific gravity 
and viscosity occurs. Especially convincing is the fact that although this rise occurs at very different depths in the three localities mentioned, the increase in the volume of small organisms captured in the nets in every case coincides with the rise in the specific gravity.

An important point for our conception of the animal life of the Atlantic is that the greatest volume of pelagic crustacea has never been found in the upper IOO or 200 metres, where the production of minute plants takes place; the great majority of small pelagic crustacea live everywhere in the deeper intermediate layers. The examples cited above show further that the volume of organisms captured differs greatly in corresponding depths at the different stations, being strikingly small in the Sargasso Sea compared with the boreal waters off Newfoundland and the southern part of the Norwegian Sea.

All these investigations indicate the quantity of organisms present only at the moment of examination. We cannot, from our results, conclude that similar conditions always prevail, nor that the aggregate quantities of food-animals which live and

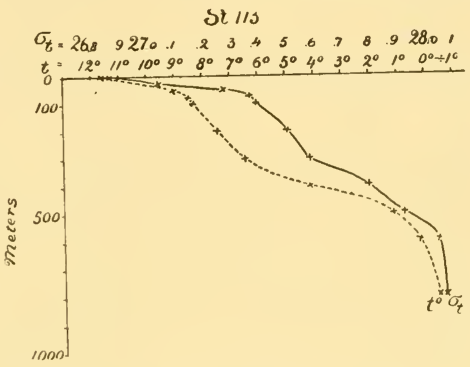
die during the year are proportionate to the quantities found at a given moment in the different localities. The quantity of food-animals changes first according to seasons and second according to the intensity of production, but very little is known about these two important factors. Only in restricted areas of the coastal waters have attempts been made to investigate these questions systematically at different seasons, and at present we can only compare the conditions found in different localities. Such comparisons have led us to recognise a vast difference between boreal and subtropical conditions, which we may with advantage consider separately.

The boreal waters are mainly characterised by great seasonal Seasonal changes. We have previously noted the great seasonal changes in temperature principally in the surface layers where pelagic plants are produced. A no less important part is played by the changes in light intensity from summer to winter changes in the abundance of minute crustacea. 
and from winter to summer. Any one who has examined the quantity of organisms obtainable in silk nets at different seasons in boreal waters will know the magnitude of these changes. I may cite some of my own results from the coast waters of Norway.

During my winter cruises in the sea between northern Norway and Spitzbergen and 240 miles west of Tromsö, the sea was everywhere found to be so poor in organisms from the surface down to $\mathrm{I}$ oo fathoms that we had to drag our nets for $\mathbf{I} \frac{1}{2}$ or 2 hours before we perceived any organisms at all on the silk cloth of the nets. In February I made a haul in the Westfjord (Lofoten) with an 8-feet hoop-net from 200 metres to the surface, and caught only 380 specimens of Calanus finmarchicus, although perhaps 1000 tons of water were filtered by the net. On the Ioth of April a haul was made on the bank off Tromsö (Svendsgrund), with the same net and from Io0 metres to the surface, when 2356 specimens of Calanus were taken. Another haul yielded I6,420 specimens of Calamus, and a third about one litre of Calanus. This obvious increase in their numbers continued during spring, and on the Ist of June in the Altenfjord a Io-minutes' haul with a I-metre net at the surface yielded so many individuals of Calanus, that their weight, after squeezing off the water, amounted to 0.8 kilogram, - a weight corresponding to at least two millions of individuals. In July some hauls with the 8-feet net were made in the Norwegian Sea, generally from 200 metres to the surface, and as a rule 200 or 250 c.c. of Calanus were taken, mainly consisting of Calanus finmarchicus. These hauls indicate the characteristic features of the occurrence of minute crustaceans in boreal waters: the poverty of winter, the abundance of summer.

Gran and Damas have continued these investigations during the cruises of the "Michael Sars," at the same time taking up the study of the life-history of Calanus finmarchicus. Gran arrived at the conclusion, now confirmed by more recent investigations, that the life-cycle of this species is annual. During winter only adult animals are met with. They breed in spring, and the young pass through five larval stages; in the sixth stage they assume the shape of the adults. From a detailed study of the material collected in the nets Damas attempted to draw a chart showing the spawning places, arriving at the conclusion that spawning does not take place to any important extent in the fjords, nor on the coast banks, but principally above the 
continental slopes of the Norwegian Sea. From these localities the young stages spread over the whole sea, including the coast banks and the fjords of Norway. During summer only young individuals are met with, immediately recognizable by the presence of large oil-globules. These minute calani constitute the main nourishment upon which more or less directly the animal life of the Norwegian Sea depends. Even the enormous whalebone whales feed on calani. During the last months of the year the number of calani decreases enormously, and in winter only a few adult individuals remain.

In Chapter VI. Gran gives an account of Lohmann's attempts at calculating the relation between the increment in pelagic plants and the consumption of plants by animals in the fjords at Kiel during the course of a year. According to Lohmann's calculations the volume of plants increases daily by 30 per cent, which increase may be used up by animals without endangering the existence of the plant-stock. Copepoda and other multicellular animals are supposed to need a daily supply of food equivalent to about one-tenth of their own weight. Starting from these assumptions Lohmann attempts to calculate the relation between production and consumption in the course of the year, and arrives at the conclusion that there is generally a surplus of plants except in the winter. For details I refer to the table on p. 384 , recording the daily increment of various food producers during the year, which varies greatly from summer to winter, the relation amounting sometimes to $35: \mathrm{I}$.

In tropical and subtropical waters no seasonal changes of Conditions in this kind appear to take place. At least all the tow-nettings tropical taken in the tropics by various expeditions have always yielded remarkably uniform catches in the upper layers, which are the ones most thoroughly examined, these catches being very small compared with similar catches during summer in boreal waters. As instances of this I may mention that the closing-nets of the "Michael Sars" when hauled from 200 metres to the surface in the Sargasso Sea yielded on the average 3 c.c. of plankton, while in the Norwegian Sea from 85 to 225 c.c. were obtained in numerous similar hauls. ${ }^{1}$ Similar results were obtained during the German Plankton Expedition.

It is, however, at present impossible to form any idea whether the volumes thus obtained really tell us anything whatever about the annual production. First of all in boreal waters we have to deal with the enormous seasonal changes. Secondly,

\footnotetext{
1 Damas and Koefoed, loc. cit.
} 
we know nothing whatever about the "daily increment" in the producing organisms of the open ocean, and therefore the futility of every attempt at comparison is evident. The small volume of plants and animals peculiar to the upper strata of the warm regions of the ocean cannot, in consequence, justify the conclusion that the production is small. The abundance of animals found in the deeper layers of the open ocean seems to indicate rapid production associated with rapid consumption in the upper plant region of the sea.

Although it is as yet quite impossible to form an opinion on the absolute magnitude of the production in certain regions, it has been supposed that the relative amount of nutriment contained in various waters might be compared. As mentioned by Gran on pp. 367-38 I, botanists are of opinion that in the open ocean, far from land, certain of the nutritive substances essential to plant life, especially nitrogen, are present in very small quantities (the minimum of Liebig), and consequently the plants cannot develop as profusely as they otherwise would do. Pelagic plant life draws its principal supply of dissolved or undissolved nitrogen either from the coasts (see remarks on detritus), or from localities where cold and warm currents meet. In these latter localities the conditions may suddenly become favourable for the development of life, just as development in boreal waters begins in spring, when the rays of the sun raise the temperature of the surface water. The organic substances contained in the cold waters become transformed into inorganic salts through the action of bacteria, and these salts are used by the microscopic plants to build up new protoplasm. Murray and Irvine ${ }^{1}$ first drew attention to the importance of this process in the ocean, which plays a great part wherever large sheets of cold and warm water are mixed. ${ }^{2}$

The boreal waters should, accordingly, present favourable conditions for developing an abundant animal life during the warm season, the coast waters carrying detritus spread out over the whole oceanic area, while arctic currents mix with the warm Atlantic Gulf Stream, for instance in the Barentz Sea, north and east of Iceland, and off the coast banks of Labrador and Newfoundland.

\footnotetext{
1 "On Coral Reefs and other Carbonate of Lime Formations in Modern Seas," Proc. Roy. Soc. Edin., vol. xvii., I8go.

2 Similar ideas have been expressed by Nansen, "The Oceanography of the North Polar Basin," Norzuegian North Polar Expedition, Christiania, 1902.
} 


\section{Propagation}

During autumn and the last months of the year thermal conditions alter greatly in boreal waters, high temperatures retreating from the surface down to 200 or 300 metres (see Fig. 509). At the same time the sexual organs develop in most boreal food fishes: the cod family, the herrings, the flat-fishes and others, and during the three or four first months of the

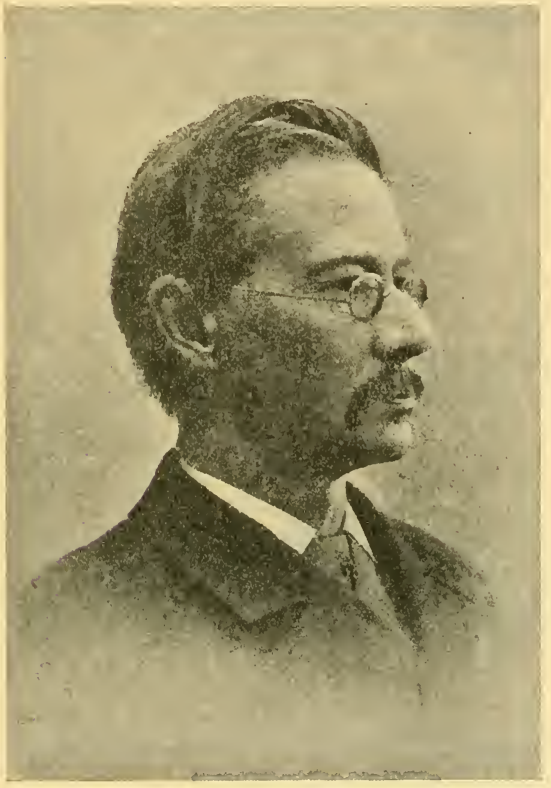

G. O. SARS. year they spawn. Most of these edible fishes possess large ovaries containing enormous numbers of eggs, the cod, for instance, having apparently on the average no less than five million eggs.

Late in the 'sixties of Developlast century, G. O. Sars mental stages commenced his investigations on the famous cod fisheries in the Lofoten Islands. $\mathrm{He}$ found that the eggs of the cod were pelagic, floating in the surface layers of the sea, and he carefully studied the development of these eggs, making a number of excellent drawings, which I regret to say have never been published. These original drawings foreshadow much of the knowledge gained in recent years on the early development of the cod, and I consider it interesting to reproduce some of them illustrating certain stages. The characters distinguishing these stages are just as law-bound as those of the adult individuals. One stage (see Fig. 520) is characterised by dark transverse bars of black pigment, which subsequently dissolve into fine longitudinal bands, following the dorsal and ventral side of the body, a fine stripe running along the lateral line. Later on the 


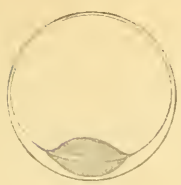

1

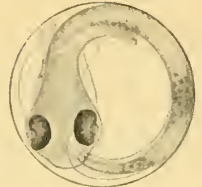

2

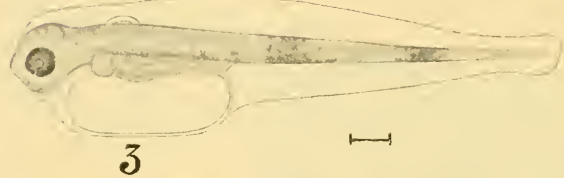

$5 \mathrm{~mm}$.
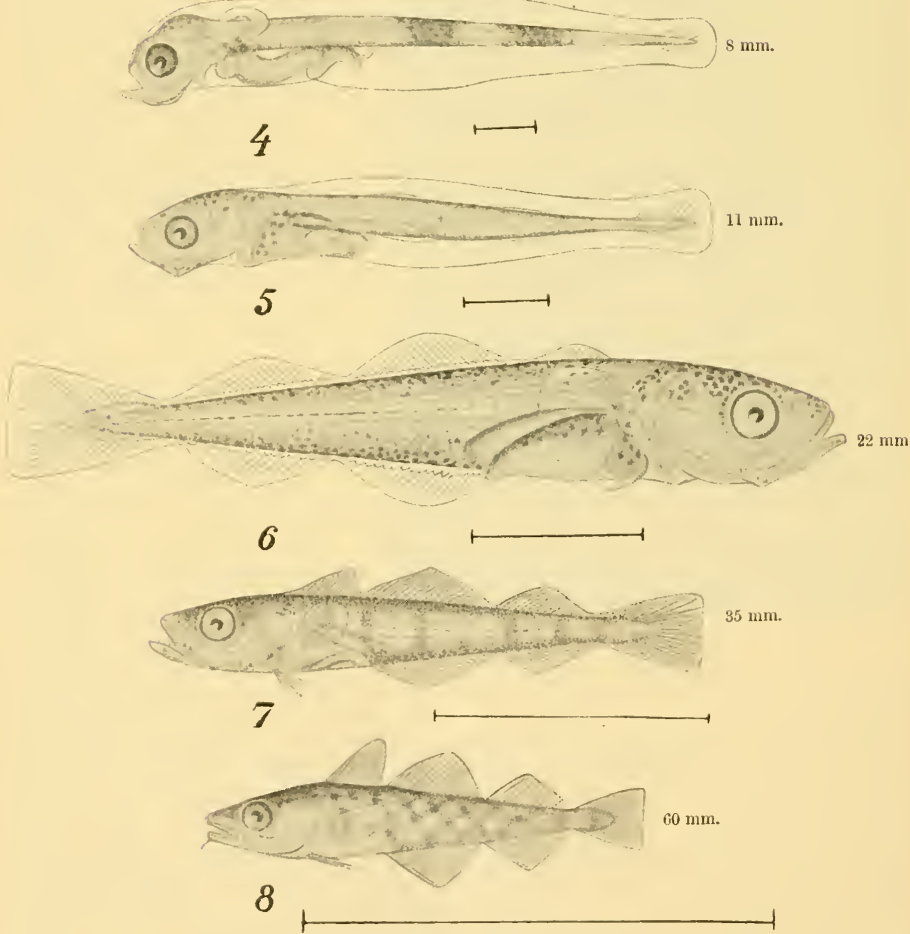

FIG. 520 .

Development of the cod (Gadus callarias) from the egg to the young-fish stage. (From drawings by G. O. Sars.) 
pigment is arranged in a chequered colour pattern, resembling the squares of a chess-board. So regular and characteristic are these stages that, once knowing them, we can separate a young cod from every other young fish, and define its stage of development or even its age.

Since Sars discovered the eggs of the cod to be pelagic, a great many other species have been found to possess floating eggs and larvæ, for example all the cod-species and flat-fishes, the sprat, the mackerel, and many others. A voluminous literature recording the investigations has accumulated, Agassiz,
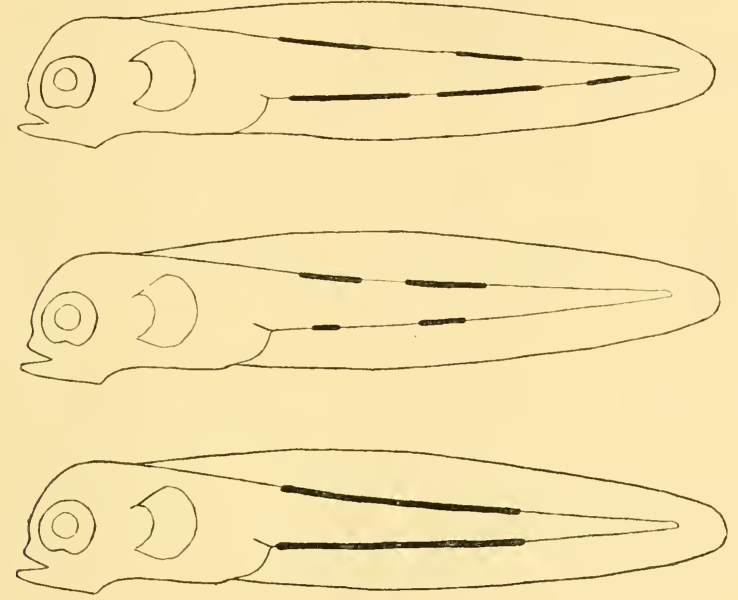

FIG. 52 I.

Diagrammatic figures to show the arrangement of the postanal pigment in the earliest stages of Gadus callarias, G. virens, G. pollachius. (After Schmidt.)

Ehrenbaum, Heincke, Hensen, Holt, M'Intosh, Masterman, Petersen, and Schmidt having made valuable contributions to our knowledge of the eggs and larvæ of various fishes. ${ }^{1}$ From Schmidt ${ }^{2}$ I reproduce some outline drawings (see Fig. 52 I) of the pigment arrangement in a corresponding larval stage of three closely related cod-species, viz. Gadus callarias, G. virens, and $G$. pollachius (the cod, saithe, and pollack). Although these larva closely resemble each other, the arrangement of the pigment is different.

1 Ehrenbaum gives an excellent summary in "Eier und Larven von Fischen," Nord. Plankton, Lfg. 4, 1905, Lfg. 10, 1909.

2 Schmidt, loc, cit. 
This power of distinguishing the different species in early stages has been of great advantage to oceanography. By securing the eggs and larvæ floating in the surface waters, we can decide what species spawn in a definite area. We capture in our silk nets a profusion of different eggs and larvæ, and can with certain limitations separate them as belonging to various species, just as we assort the catches of adult fishes Spawning from a haul with the trawl. The spawning area of a species
areas. can thus be determined by merely taking numerous tow-nettings, and ascertaining the presence or absence of the eggs belonging to the species in question.

To catch the adult spawners is very often difficult, and takes a long time. The floating eggs can, on the other hand, be taken with the greatest ease, and the simple appliance of the tow-net furnishes an excellent means of ascertaining where the fishes spawn, for most species remain some time underneath the recently spawned eggs. In April I90I. I followed up this reasoning on the coast banks off northern Norway, and succeeded in finding enormous shoals of cod on certain banks, where no fishing was carried on, and where, as a consequence of our discovery, millions of cod were afterwards taken. ${ }^{1}$

Stimulated by this experience I advised the International Council for the Study of the Sea to effect a systematic survey of the spawning areas of the cod family. My proposals were adopted, and an enormous amount of material relating to the natural history of the cod family was accumulated, thanks to the exertions of those on board the Danish, Belgian, English, Scottish, Dutch, Norwegian, Swedish, and German investigation steamers.

The Danish steamer "Thor," under the leadership of Schmidt, investigated certain parts of the Atlantic and the waters round Iceland. The Norwegian steamer "Michael Sars" examined the Norwegian Sea and the northern portion of the North Sea, while the steamers of the other countries worked mainly in the North Sea. The results obtained through this organisation of the work proved that even closely related species presented certain peculiarities as regards the situation and extent of their spawning places, ${ }^{2}$ as shown in the following table :-

1 Fiskeri og Hvalfangst $i$ det nordlige Norge, Bergen, 1902.

2 "Rapport sur les travaux de la commission A dans la période 1902-1907," Rapports et Procès verbaux du Conseil international, vol. x. Copenhague, I909. 
I. Spawning in the Atlantic, in the North Sea, and in the Norwegian SEA.

A. On coast banks in depths less than 100 metres.

Gadus merlangus, Optimum 20 to 60 metres.

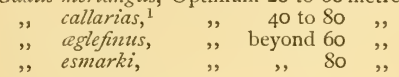

B. On the slopes of the coast banks.

Molva molva, Optimum 60 to 200 metres.

Gadus virens, , , 100 to 200 ,,

C. On the edge of the coast banks.

Brosmius brosme, Optimum 100 to 500 metres.
II. SPAiving ENtiRely, or almost ENTIRELY, IN THE ATLANTIC.

A. On coast banks beyond 100 metres.

$$
\begin{aligned}
& \text { Gadus luscus. } \\
& \text {," minutus. } \\
& \text {, pollachius. }
\end{aligned}
$$

B. On the slopes towards the edge.

Merluccius vulgaris, Opt. 100 to 200 metres.

C. On the edge of the coast banks.

Gadiculus argenteus, ${ }^{1}$ )

Gadus poutassou,

Optimum from

Molva byrkelange, ${ }^{1}$

, elongata
200 to 1000 metres.

From the point of view of general biology it is interesting to note from this table that species, which in shape and general anatomy are very similar, present such pronounced differences as to their habitat during this most important process of life (see the chart, Fig. 522, showing the spawning area of the three ling species).

C. G. J. Petersen ${ }^{2}$ was one of the first to draw attention effect of to the influence exerted by currents on pelagic eggs. After currents on his investigations in the Lesser Belt (Faenoe Sund) he sums up as follows: "It is one of the facts that have astonished me most during these researches that the fry of pelagic eggs, which were sometimes found in such huge numbers in Faenoe Sund, was not hatched there, or at any rate was only to be found there quite exceptionally. This condition did not only apply to the cod, but indeed to all species which possess floating eggs, in contrast to the fishes which deposit their eggs on the bottom." It has proved very important to investigate the drift of pelagic eggs, and this study has yielded important results regarding the different species. The drift of the eggs depends on physical as well as biological conditions. The direction and velocity of the currents, the temperature, the duration of the hatching and development, the actual duration of the pelagic life which varies in different species, all these are important points. Finally, the specific gravity of the eggs and larve is of great importance in determining the depth at which they float. From my investigations on the distribution of cod eggs, larvæ, and pelagic fry in

1 Also spawn in the Norwegian fjords.

2 Report of the Danish Biol. Station, 1893. 
northern Norway I reproduce Fig. 523, in which the different curves denote:-

I. The outer limit of pelagic cod eggs during the spring of $190 \mathrm{I}$.

II. minute larvæ and young, June-July, I90I.

III. large pelagic fry, August 1900.

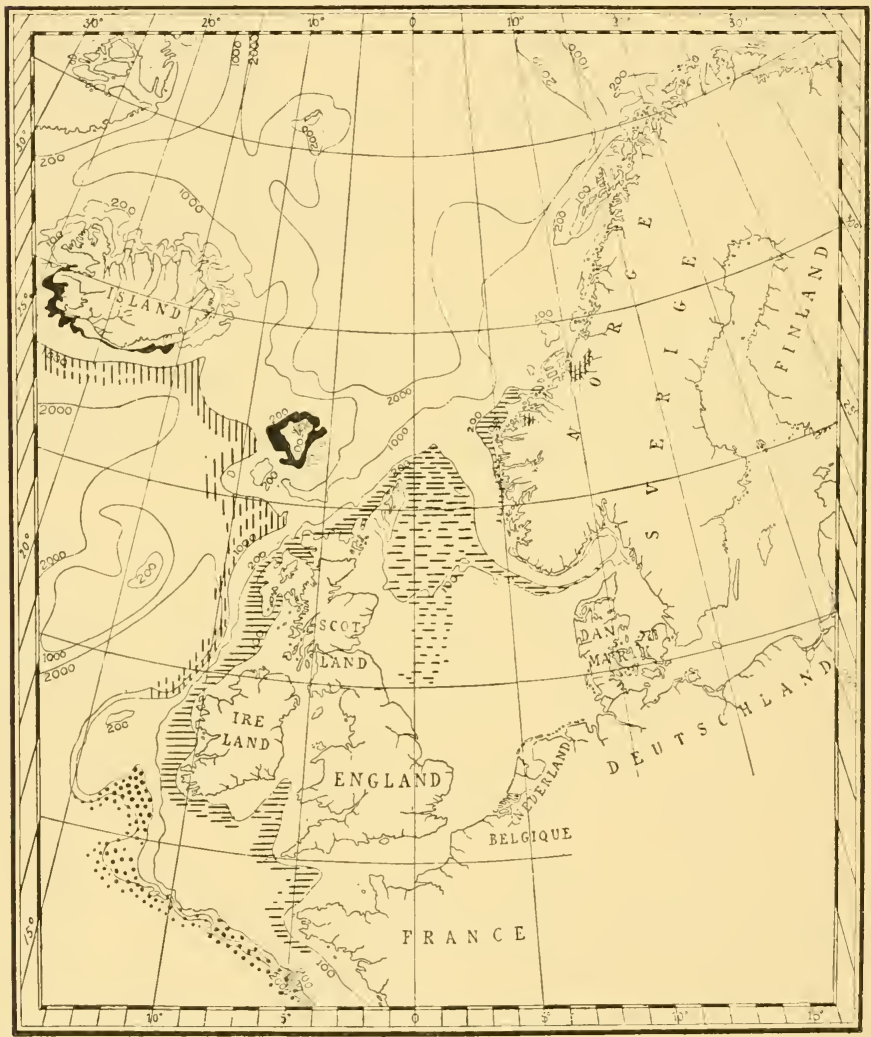

Fig. 522.- Spawning Regions of the three Species of the genus Molva. Vertical lines, .llolva byrkelange; horizontal lines and black portions, .1\%. molva; dots, M. elongata.

(From International Reports, vol. x.)

In northern Norway there is plainly a movement along the coast and away from land. During development the minute fish are carried hundreds of miles away from the spawning places. 
The direction of the movement will, of course, depend on the currents, and on other conditions peculiar to various localities. In the district of Romsdal Damas made some excellent investigations on board the "Michael Sars," and ascertained that spawning took place almost exclusively on the coast banks, that in the fjords being quite insignificant (see Fig. 524). The young fry, however, were later found in vast quantities in the fjords, having been carried in by currents. Schmidt has

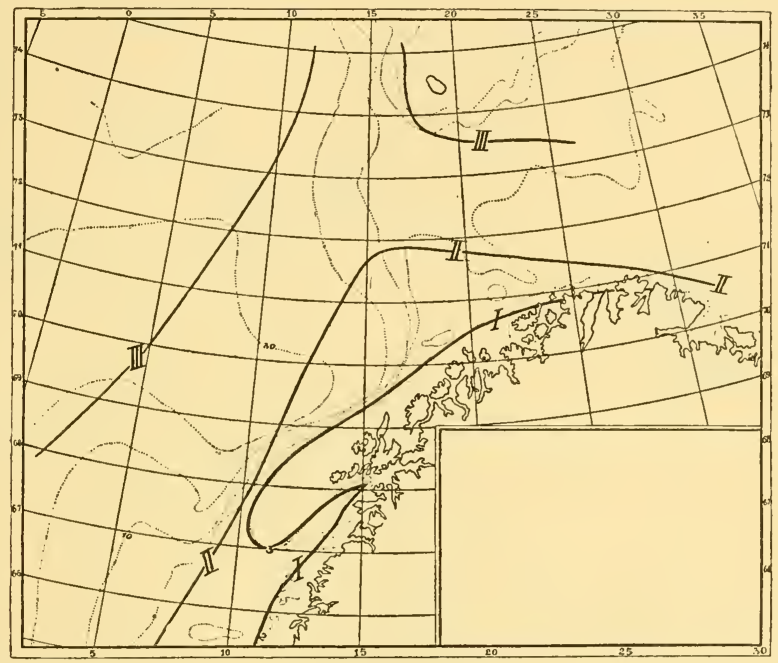

Fig. 523.-Distribution of Pelagic Eggs and Young-Fish of the Con at DIFFERENT SEASONS.

I. Outer limit of pelagic eggs in the spawning time, January to April Igor.

II. Outer limit of pelagic young-fish, June to July rgor.

III. Outer limit of pelagic young-fish, August to September Igoo.

given an account of the spawning of different cod-species off Iceland, the occurrence of pelagic eggs and their subsequent fate (see Fig. 525). Most cod species and flat-fishes spawn on the south and south-west coasts of Iceland, the northern and north-eastern sides of the island being encircled by cold waters during winter and spring. The freshly spawned eggs drift from the south to the west coast, and farther to the north and east coasts, the current running in this direction. The duration of the pelagic stage is, however, different in different species of the cod family; their spawning seasons also differ. As a con- 
sequence the distribution of the first bottom-stages is different, for instance, in cod and saithe, as shown in Fig. 525. The young saithe, having a comparatively short pelagic life, occur mainly on the south and west coasts, and only to a small extent on the north and east coasts. The eggs and fry of the cod are pelagic for a longer period, and consequently the majority of them drift round to the north and east coasts.

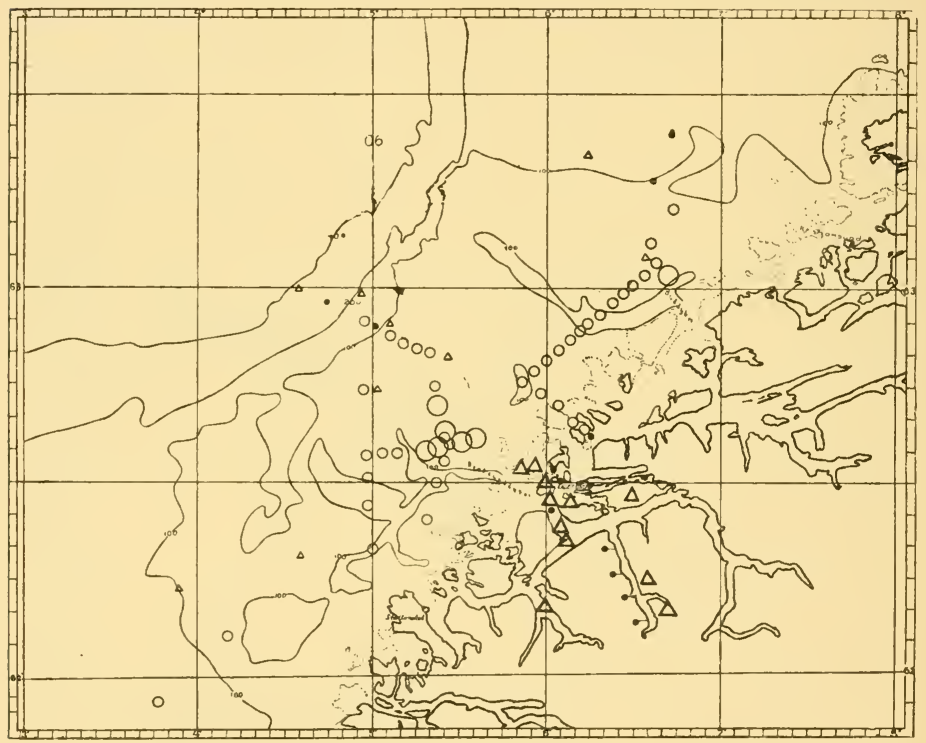

Fig. 524.-Distribution of Eggs and Larva of Gadoids in the Romsdal District.

Dots denote that less than 500 eggs were taken; small circles, that 500 to 10,000 eggs were taken; large circles, that 10,000 to 100, 000 eggs were taken (March to April I906)-all in hauls of five minutes' duration. Small triangles denote that less than roo pelagic fry were taken, large triangles, that roo to ro, ooo pelagic fry were taken per hour in May to June $\mathbf{1 9 0 6 .}$ (From Damas' investigations with the "Michael Sars.")

When currents run off-shore, the direction of the current and the extent of the influence of the coast-water in the open ocean can be ascertained by studying the distribution of organisms born on the coast banks. As we have seen, this study is also very important for our ideas as to the amount of nutriment carried from the land to the open ocean. Fish fry are actually such current indicators, and in the Norwegian Sea they are accompanied by stinging medusæ (Cyanea capillata), 
which have also a bottom stage on the coast banks. In August 1900 their distribution was identical with that of the pelagic cod fry, and was limited by curve III. in chart, Fig. 523. Similar instances might be quoted in profusion, especially from recent Danish and Norwegian investigations. Of special interest is the great number of observations of larvæ and young fish drifting from the Atlantic coast banks off the west coast of Scotland into the North Sea and the Norwegian Sea (compare the drift of Salpæ).

We will now proceed to review our knowledge as to the

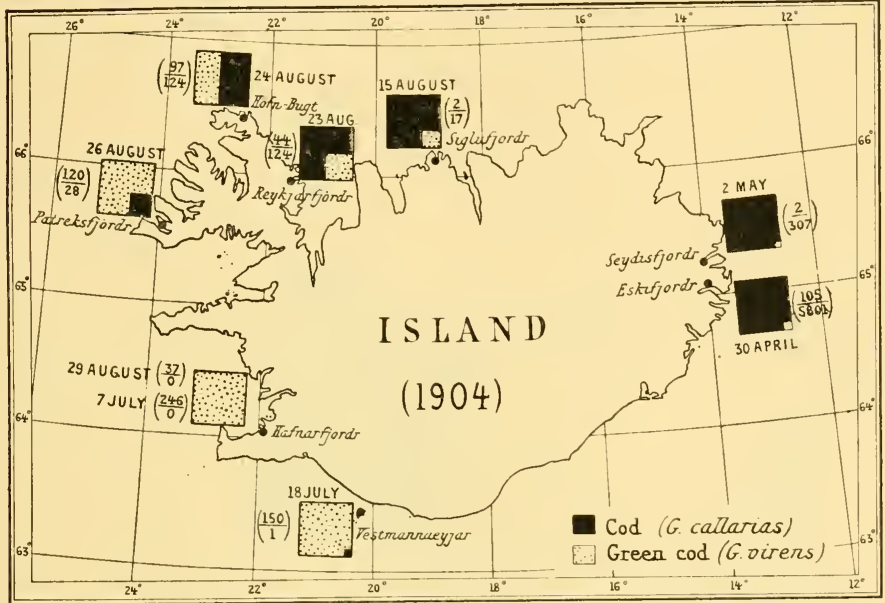

Fig. 525.-Relative numbers of the Earliest Bottom-Stages of Gadus ViRENS

AND G. Callarias around ICEland in THE Summer of 1904. (From Schmidt.)

conditions of the Atlantic, referring, for want of space, mainly to our own investigations.

It is not an easy matter to examine the reproduction of animals in the open ocean. Very few studies have, therefore, been made on the development of the oceanic fishes, and little is known as to their characters in early stages. Valuable information has been gathered and drawings have been made, especially by Günther and by Danish naturalists, Lütken and others, but complete series, showing the development of the species, are only available for a very limited number of species. Every expedition must, therefore, in the present state of our knowledge, make a laborious systematic study of the collections 
brought home. As regards our own expedition we have as yet been able to accomplish only a small part of this work, and at present I am unable to pass a definite opinion on our material as a whole, nor to say what this material does not contain.

Spawning seasons.

Do our collections of fish eggs and fry from the Atlantic indicate any definite spawning seasons in the Atlantic, as there are in the Norwegian Sea? It is generally known that in the tropics many animals propagate at all times of the year. Thus Carl Semper writes as follows: "During my stay in the Philippines nothing struck me as being more peculiar than the

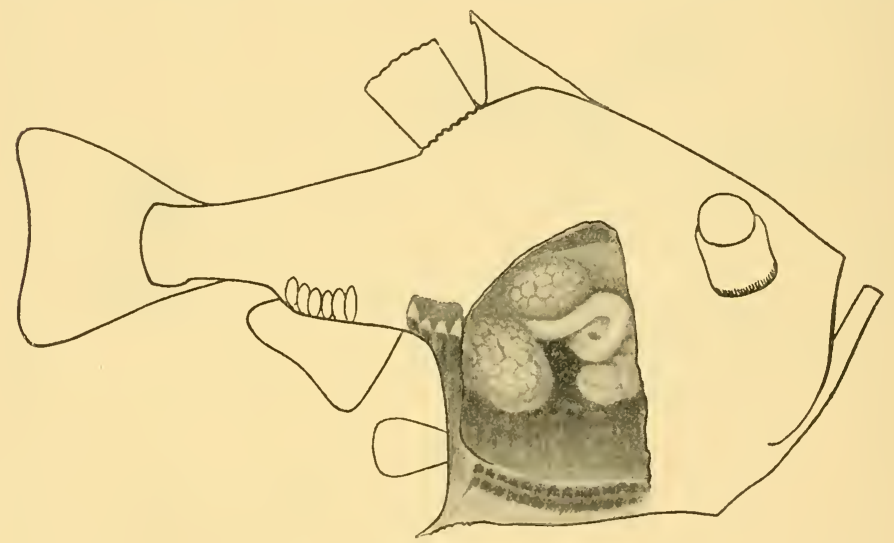

Fig. 526.

Argyropelecus hemigymnus, Cocco. Nat. size, $3.4 \mathrm{~cm}$.

evident lack of periodicity in the life of the animals, peculiar even to insects, land mollusca, and other terrestrial animals. I could always find eggs, larvæ, and adult individuals of a species at the same time, during winter as well as in summer." It is quite evident that a short voyage in a steamer, passing over enormous stretches of ocean in the course of a few days, offers no opportunity of studying the conditions of propagation all the year round. I can only point out how desirable it is that the Atlantic should be examined at all seasons of the year, for only by this means can the conditions be fully understood.

Although we could effect no reliable quantitative analysis, it struck me on our cruise that the number of fish larva and fry 
seemed far to exceed that of the pelagic fish eggs; this also appears to have been the case with the catches of the German Plankton Expedition, but these catches were very small. The scarcity of fish eggs and the abundance of pelagic fish fry might appear to indicate a continuous production of rapidly hatching eggs, the larval and post-larval stages being of much longer duration, but a study of the ovaries of the adult fishes does not favour this supposition. In Cyclothone, for instance, the eggs seem to be equally developed in every portion of the ovary, and to ripen throughout the entire length of the ovary at the same time. During our cruise the ovaries were found to be ripest at Stations 53 and 64 on the southern section.

Any observer previously acquainted only with the spawning of large boreal fishes must be strongly impressed by the appearance of the minute, sexually mature, oceanic fishes. Figs. 526 to 529 represent some ripe fish of genuine oceanic types and their ovaries. In the laterally compressed Argyropelecus hemigymmus (Fig. 526), the ovaries, containing only a few hundred eggs, lie wholly or partly above one another, and the full-grown individual, the ovaries of which approach ripeness, is only $3.4 \mathrm{~cm}$. long. Cyclothone signata (Fig. 527) becomes sexually mature when 3 or $3.5 \mathrm{~cm}$. in length, the aggregate number of eggs contained in both ovaries being about IOOO. Cyclothone microdon (Fig. 528), on the whole a larger species, becomes mature when about $6 \mathrm{~cm}$. in length, the ovaries containing a total of about 10,000 eggs. A specimen of Photostomias guernei $10.8 \mathrm{~cm}$. in length had, according to Collett, about 400 eggs in each ovary. Gonostoma grande had, according to Collett, 2798 eggs. On the other

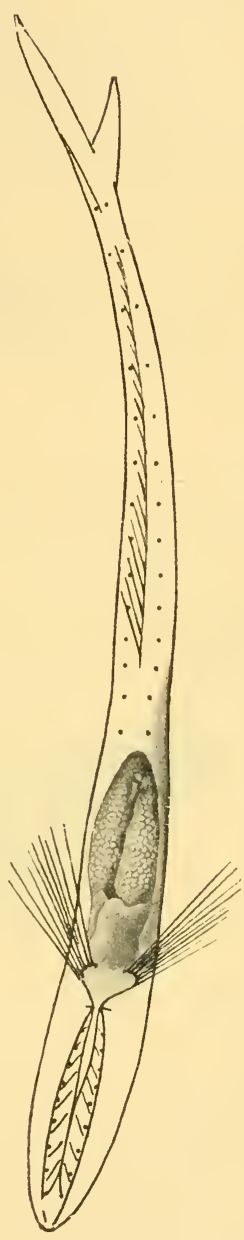

Fig. 527 .

Cyclothone signata, Garm.

Nat. size, $3.5 \mathrm{~cm}$. hand, the larger pelagic fishes from deep water, like Gastrostomus bairdii (see Fig. 529), have many eggs, but they 
are very small (according to Gill and Ryder $0.7 \mathrm{~mm}$. in diameter).

An important question is: Where does the spawning take place? I do not believe in any general vertical spawning migration among deep-sea pelagic animals, even if the eggs develop in the upper strata of the ocean; the eggs themselves must rise to the surface. If this were not so, we

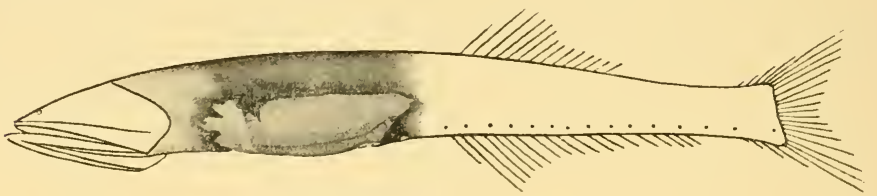

FIG. 528 .

Cyclothone microdon, Günth. Nat. size, $6.3 \mathrm{~cm}$.

should undoubtedly have taken, in the upper layers, many more of the pelagic fishes peculiar to deep water, whereas we took them with ripe eggs in deep water. The eggs captured and examined by us vary greatly in size and Size of fish appearance; Fig. 530 shows the relative size of some of eggs. them. A is a small egg a little more than $\frac{1}{3} \mathrm{~mm}$. in

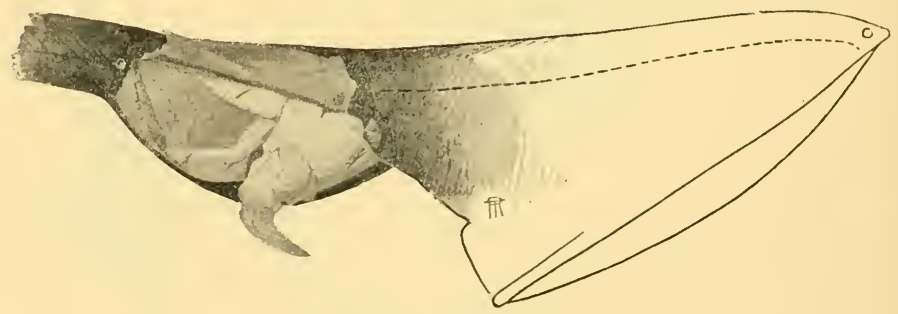

FIG. 529 .

Gastrostomus bairdii, Gill and Ryder. Nat. size, $76 \mathrm{~cm}$.

diameter, taken between the Canaries and the Azores; B and $\mathrm{C}$ are nearly ripe eggs from Cyclothone signata and C. microdon (0.46 and $0.56 \mathrm{~mm}$. in diameter); D is the egg of Gastrostomus bairdii. It is interesting to compare these with the cod egg $(E)$, especially when we consider the number of eggs produced by this fish. Cyclothone signata, the eggs of which are perhaps only one-tenth of the volume of the cod eggs, has only Ioco eggs compared with the five million eggs of the cod. 
This great contrast in the conditions of propagation is obviously a very characteristic feature. At this point, however, we encounter the same difficulty met with in discussing the reproduction of the minute plants and food animals of the ocean, for we are ignorant as to how often these small fishes reproduce their kind during the year.

Figs. 53I and 532 represent the eggs of Scombresox and Trachypterus, and show that oceanic eggs are not all small. The large egg of Trachypterus $(2.8 \mathrm{~mm}$. in diameter) was captured at Station 52, south of the Azores, and plainly shows that the large and remarkable Trachypteridæ propagate in
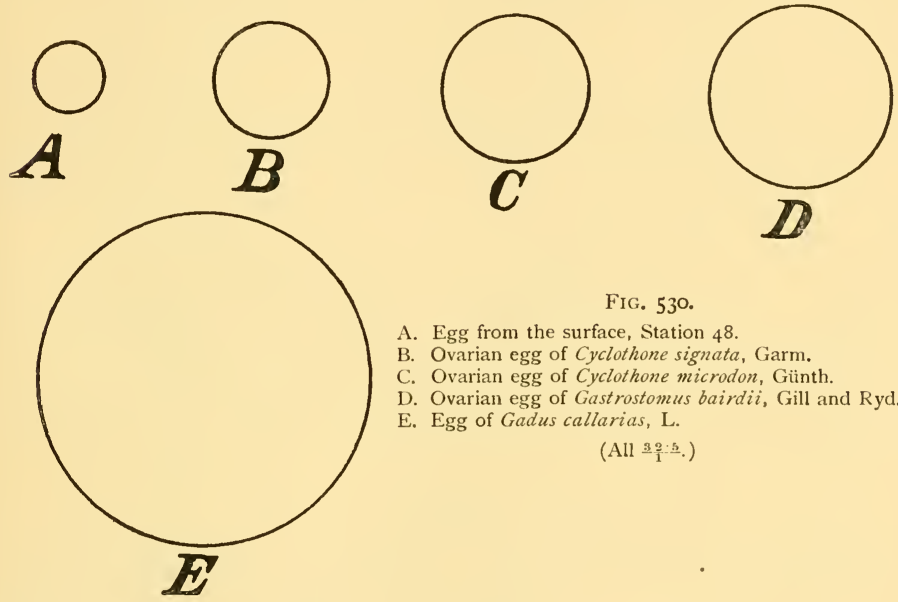

FIG. 530.

A. Egg from the surface, Station 48.

B. Ovarian egg of Cyclothone signata, Garm.

C. Ovarian egg of Cyclothone microdon, Günth.

D. Ovarian egg of Gastrostomus bairdii, Gill and Ryd.

E. Egg of Gadus callarias, L.

(All $\frac{32 \cdot 5}{1} \cdot$.)

entirely oceanic conditions. Judging from their appearance they probably live at similar depths as Argyropelecus and the Stomiatidæ.

During the whole of our Atlantic cruise we constantly captured young fish, in fact many thousands in all. According tribution of $\begin{gathered}\text { young fish. } \\ \text {. }\end{gathered}$ to their vertical distribution these young fish may be divided into two groups. Fig. 533 shows that the majority of the 3604 young fishes examined were taken in the uppermost 150 metres of the sea. Most of the young fishes taken in appliances used in deeper water have, in all probability, been taken while hauling in the gear, and nearly all the peculiar large leptocephali have also been taken in the upper layer. But there is a certain group of young fishes which show a maximum frequency about 
300 metres, mainly those of the genus Argyropelecus, the adults

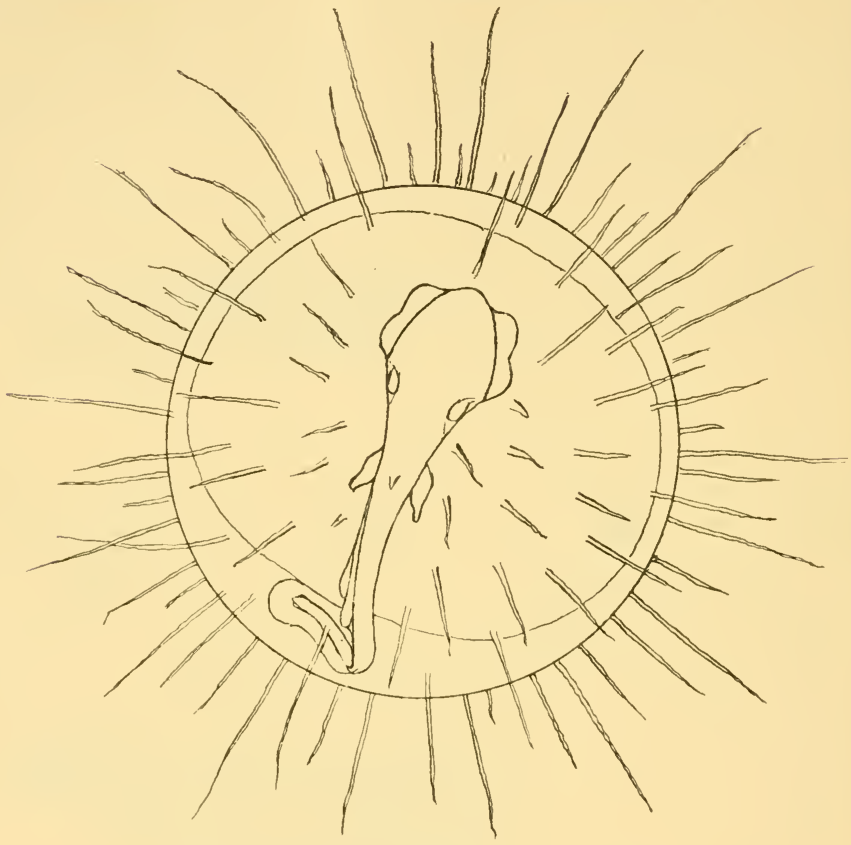

FIG. 53I.

Egg of Scombresocid. Diameter, 2.2 mm. Station 64 .

of which live at these depths. A third group containing larvæ

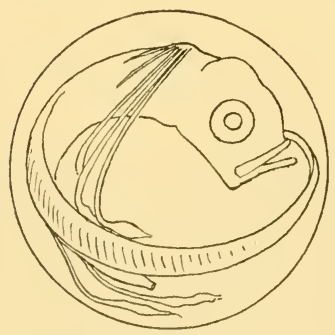

FIG. 532.

Egg of Trachypterus.

Diameter, $2.8 \mathrm{~mm}$. Station 52 .

and young of Alepocephalidæ has only been taken below 500 metres. We see from Fig. 474 , p. $62 \mathrm{r}$, that even the small stages of Cyclothone are found at 300 and 500 metres.

It is interesting to note that the young stages of pelagic fishes are subject to the same laws regarding the development of colouring and lightorgans as the adults. In the uppermost 150 metres the young are quite transparent, and many of them possess light-organs in very early stages. Early stages of Argyropelecus (see Fig. 534) develop the silvery 
sheen peculiar to the adults, and the young Alepocephalidx (see Plate IX.) have the black pigment peculiar to the fish-
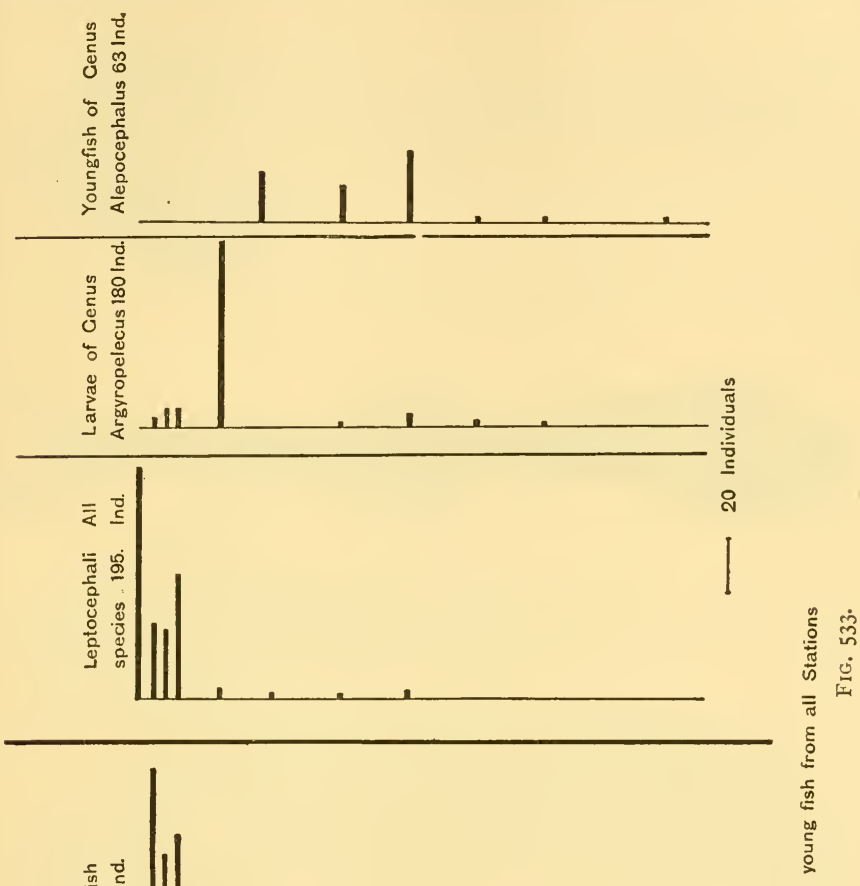

fauna of deep water. The genus Gonostoma is in this respect specially interesting, for the young of the deepest living species, 
Gonostoma grande (see Chapter IX. and Plate II.), occur in deep water, and even when only 3 or 4 centimetres long are of

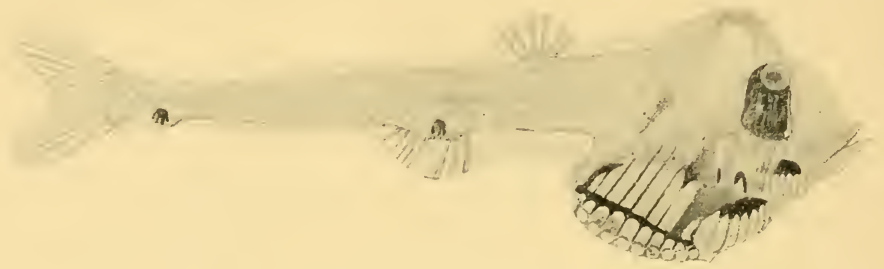

FIG. 534 .

Argyropelecus, sp. juv. Nat. size, $0.8 \mathrm{~cm}$.

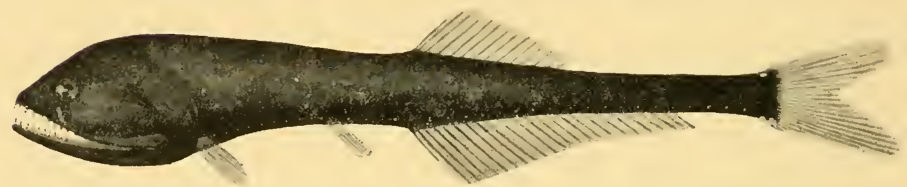

FIG. 535 .

Gonostoma grande, Collett. Nat. size, $3.7 \mathrm{~cm}$.

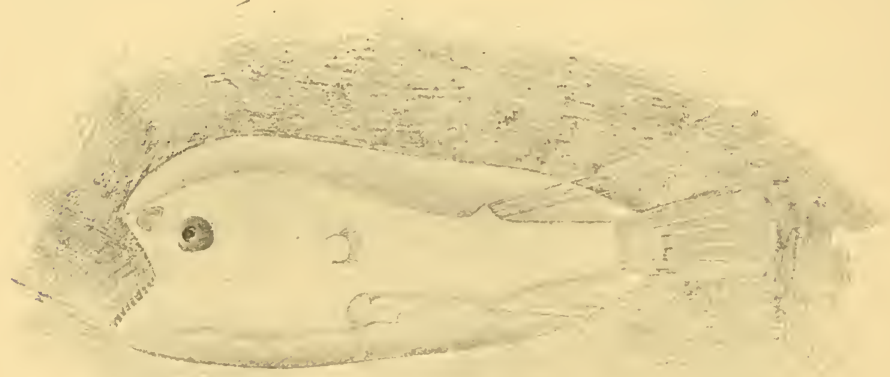

Fig. 536.

Aceratias macrorhinus indicus, A. Br., juv. Nat. size, $1.8 \mathrm{~cm}$.

a deep black colour (see Fig. 535), while the young of Gonostoma demdatum are colourless and live in the surface waters. Fig. 536 represents the young of the dark species, Accratias 
macrorhinus indicus, $1.8 \mathrm{~cm}$. long. So few of these were captured that I cannot attempt to define their vertical distribution.

These instances suffice to show that in the ocean the vertical distribution of young stages varies greatly in different species. Certain forms pass the whole of their life-cycle in deep water beyond 500 metres; others live in deep water only in the adult stage, or at least spend their early life in the upper water-layers ; others, again, pass the whole of their life in certain clearly defined intermediate layers; while others live in the surface waters all their lives. All these groups are holopelagic forms, but we meet with a group of genuine deep-sea fishes,

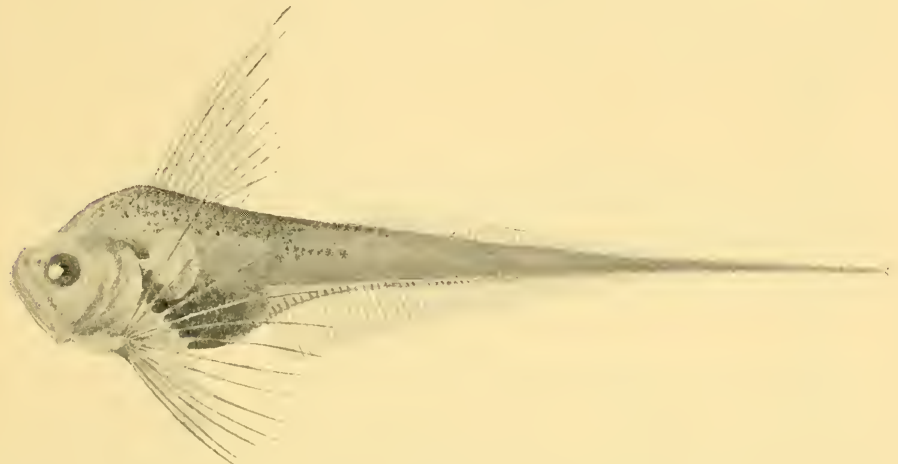

FIG. 537.

Young of Macrurus. Nat. size, $4.6 \mathrm{~cm}$. Station Ior.

which in the adult stage live along the ocean-floor, while the eggs and fry occur in the water above, at depths varying in different species. These forms remind us of the fishes of the coast banks, from which they have probably been derived. Of special interest is the fact that we found the pelagic young of Macruridæ (see Fig. 537) south of the Azores and at Station IOI, between Rockall and the west coast of Scotland, though we have been unable to determine the species.

The majority of the young fish collected by us belong to the biological group of transparent surface forms, but some of the minute stages may have escaped our notice or may have been damaged beyond recognition by the coarse cloth employed in some of our gear. The various forms contained in our collections have yet to be systematically examined, so 
that I can here only with great reserve say something about my preliminary impressions. It seems as if most of the specimens belong to the family Scopelidx, which is repre-

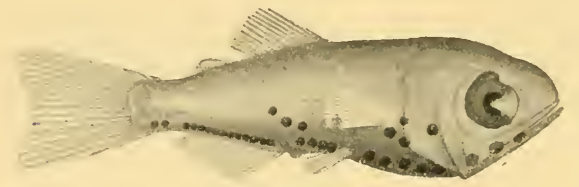

FIG. 538 .

Myctophum rissoi, Cocco. Nat. size, I1. $5 \mathrm{~mm}$. sented in great numbers. Even young stages develop lightorgans (see Fig. 538), the arrangement and numbers of which, according to Brauer, are so regular that specific distinctions may be based upon them. Secondly, there are many interesting and peculiar forms, stalk-eyed larvæ (see Fig. 539) of

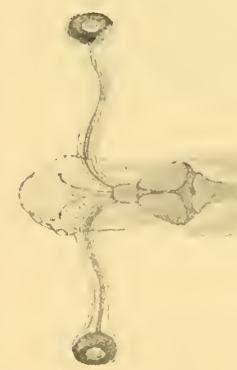

FIG. 539 .

stalk-eyed fish larva. Nat. size, $0.9 \mathrm{~cm}$.

various species being present. We have also excellent series of perfectly transparent forms with large telescopic eyes (see

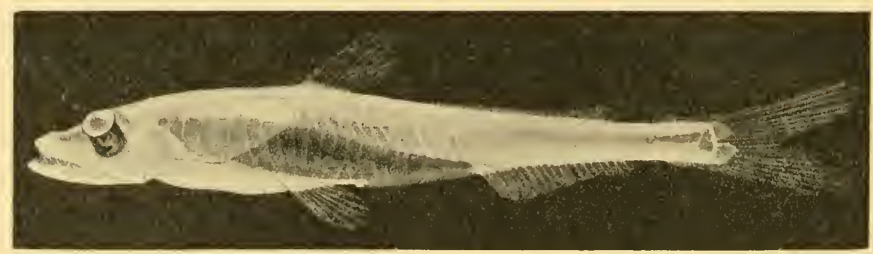

FIG. 540.

New fish, resembling Dysomma. Nat. size, $8.5 \mathrm{~cm}$.

Fig. 540, representing one of a series of stages belonging to a near ally of the genus Dysomma).

I was very anxious during our cruise to see if the pelagic appliances would yield any widely distributed young fish 
belonging to the large edible types of pelagic fishes known Geographical from the coast banks, such as the mackerel, but our preliminary distribution examination has not revealed many of these. At Station 42 one young individual belonging to the genus Scomber was taken, but this station is not far from the Canaries. The only young belonging to larger fishes of any economic importance taken by us in great numbers were those of the Saury pike (Scombresox saurus; see Fig. 54I) and of the horse mackerel (Caranx trachurus). The young of both these forms have obviously a wide distribution, occurring abundantly in the open ocean even at the greatest possible distance from the coast; the eggs of Scombresox saurus were taken in the Sargasso Sea.

The list of pelagic fishes in Chapter IX. shows that the majority were taken on our southern track, which agrees with the results of previous expeditions. Liitken says in his Spolia

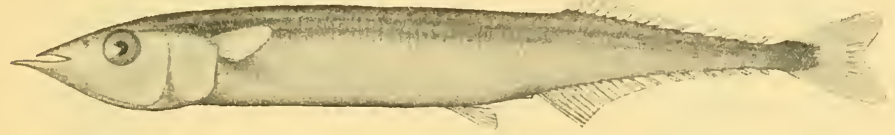

FIG. 54I.

Scombresox saurus, Walb. Nat. size, $6.2 \mathrm{~cm}$.

Atlantica that the young of Scombresox were the most numerous fishes in his collections from the open Atlantic, having been obtained from no less than ninety different localities situated in two belts between latitudes I I or $12^{\circ}$ and $40^{\circ}$ on both sides of the equator. They are typical surface forms, distinguished by a dark-blue colour on the back, while the sides are silvery and mirror-like. They pass through a typical metamorphosis, like the young of the gar-pike, the long jaws appearing only at a more advanced age (see Fig. 542, reproduced from Lütken). Related to Scombresox is the genus Exocoetus, which includes the typical flying fishes; I have indicated in Chapter III. that the young of these flying fishes (see Fig. 543) were taken by us at several localities in various stages. Scombresox, Caranx, and Exocoetus were thus the most important young fish belonging to large surface forms taken in our Atlantic cruise. In the chart (Fig. 544) I have indicated the quantities of young fish captured by us in various localities, though these quantities have in my opinion no other value than showing that great numbers of larva may be captured during summer in the open ocean as 
well as near the coast banks. Our methods of capture were not designed for the purpose of obtaining detailed information

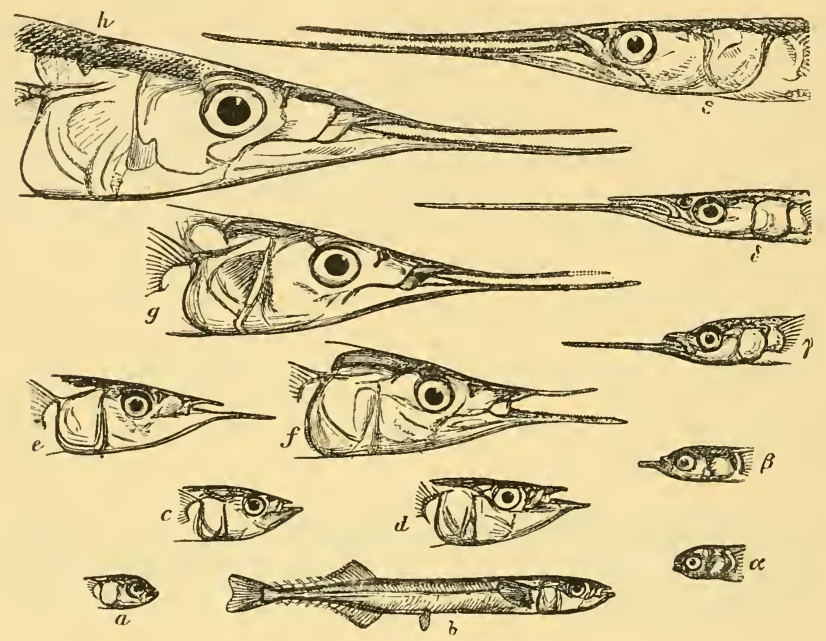

FIG. 542 .

$a-h$, heads of Scombresox saurus in different stages of development ; $b$, a young fish. The younger stages somewhat enlarged, the older somewhat reduced in size. $a-\epsilon$, heads of Belone vulgaris. (From Lütken.)

as to the quantities occurring in different areas of the ocean ; but in the present state of our knowledge it is very interesting

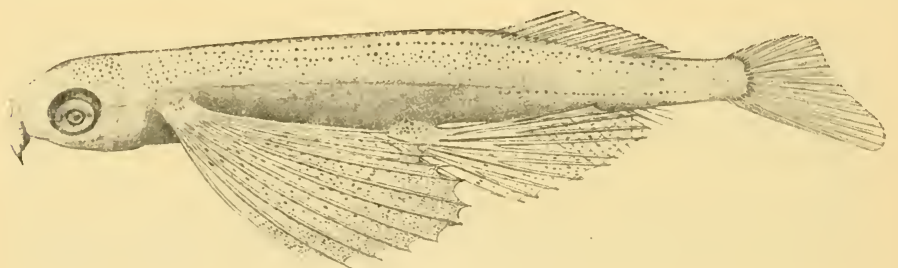

FIG. 543.

Young flying fish (Exocoetus). Nat. size, $2 \mathrm{~cm}$.

to note that such large numbers of larvæ and young fish really occur all over the ocean.

Eel-larvæ

(leptocephali).
I will here restrict myself to giving some information as to an isolated group, viz. the larvæ of the eel-like fishes (lepto- 
cephali). We see from Fig. 533 that about 200 individuals of this group were taken by us, belonging to some 20 species, and I have represented in Chapter III. some of the most peculiar new forms. Like most Atlantic fish-larvæ these forms are difficult to classify, because our knowledge of the different developmental stages is deficient, and also because these larvæ pass through a remarkable metamorphosis before assuming the ultimate shape of the adult. In a number of cases we are therefore quite ignorant as to what larval forms develop into

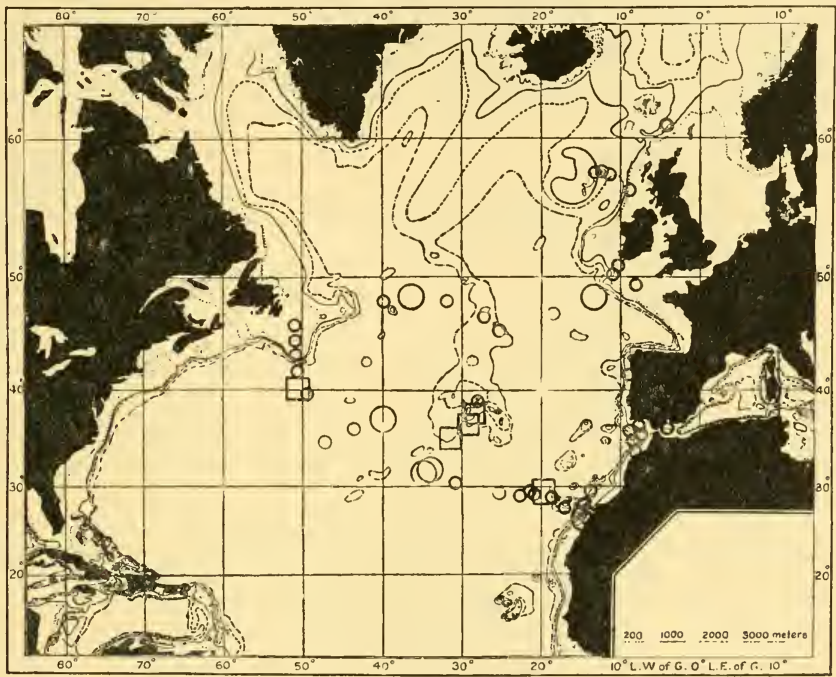

$0<100$

O $100-250 \square>250$ Youngfish

Fig. 544.-Distribution of Young Fisir.

the various known species belonging to the group of Apodes. Our material is being examined by Einar Lea, and will probably help to clear up some of the difficulties mentioned above. The stages belonging to Gastrostomus bairdii (repeatedly mentioned in Chapters III. and IX.; see Fig. 83, $a$, p. 97) form a very interesting series, the stages $a$ and $b$ (see Fig. 545) obviously being the transition stages between leptocephalus and adult; figure a plainly exhibits characters peculiar to the leptocephalus as well as to the adult, and evidently forms a more advanced stage of the transition. Another interesting transition stage in leptocephali is exhibited by the form repre- 
sented in Fig. 546, taken at Station 53 in I 300 metres. The head has been much transformed, but the body still retains much of the leptocephalous character, while on the ventral side pigment has been developed.

Fig. 547 shows the number of leptocephali of every description taken during our cruise, and we see that the majority were taken south of a line from Newfoundland past the Azores to
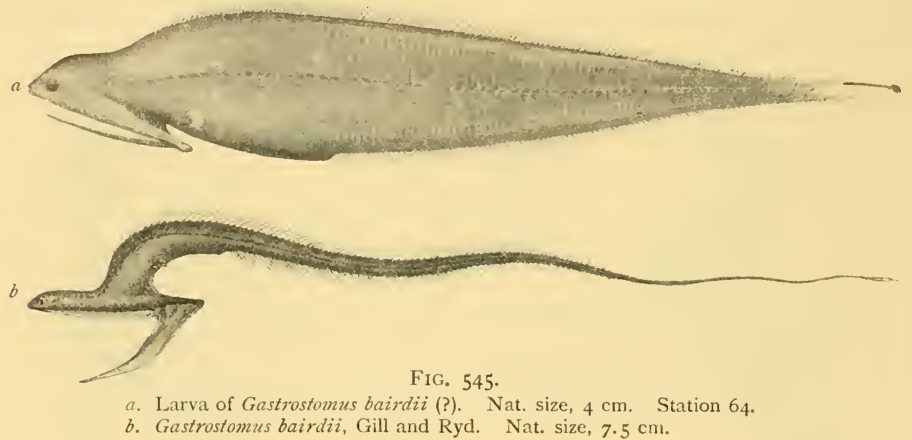

North Africa. The ones taken north of this line belong, according to Lea, to the following species :-

Leptocephalus brevirostris, the larva of the common eel.

Leptocephalus Congri vulgaris, the larva of the conger eel.

Leptocephalus Synaphobranchi pinnati, the larva of Synaphobranchus pinnatus.

Leptocephalus amphioxus, larva of an unknown species.

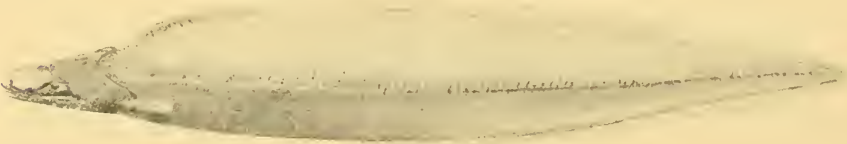

FIG. 546.

Transition-stage from leptocephalus to "young fish." Station 53, 1300 metres.

Only one specimen of the last mentioned was taken at Station 8 I off Newfoundland, so that we may say that the three first mentioned are the only ones observed north of the line indicated. The majority of individuals as well as of species were thus taken south of the Azores.

The interest attached to this peculiar distribution of the leptocephali is greatly increased when we examine their dis- 
tribution according to size and consequently according to age. We then find that the earliest stages of all the leptocephali

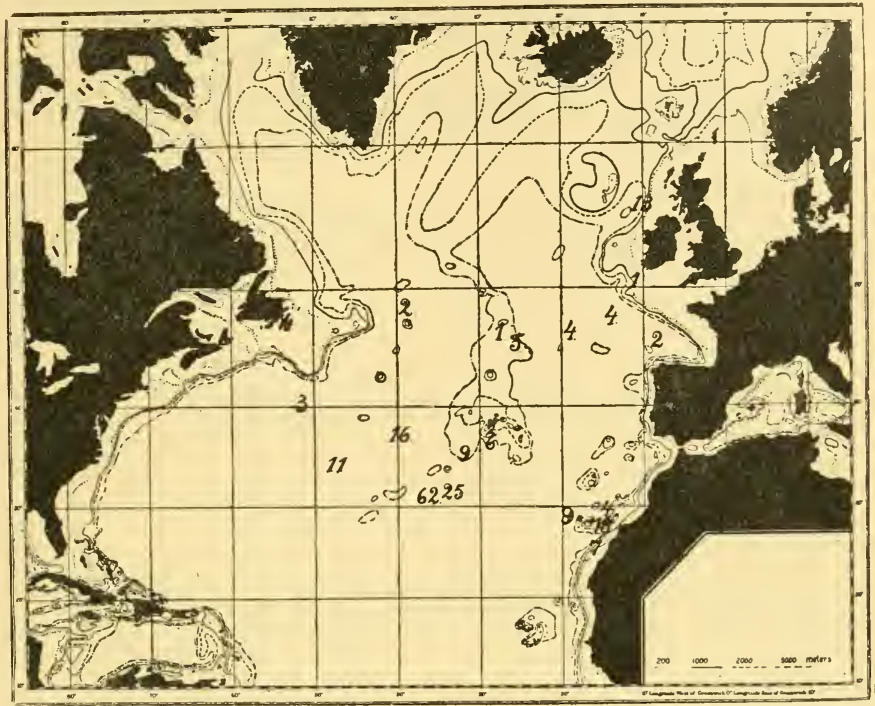

Fig. 547- Number of Leptocephali of ALL SPECies CaUght at Each Station.

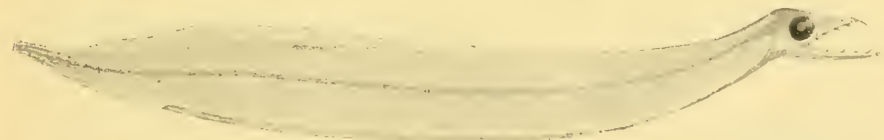

FIG. 54 S.

Young Leptocephalid, only 1.7 cm. long. Station 64 .

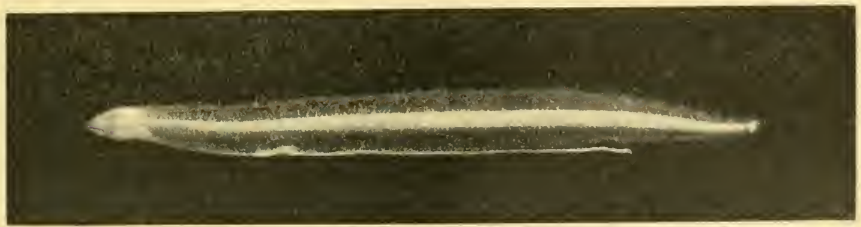

FIG. 549.

Leptocephalus Synaphobranchi pinnati. Nat. size, about $5 \mathrm{~cm}$. Station 62 .

captured were also taken in our southern section, south of the Azores. As mentioned in Chapter III. we took, in the Sargasso Sea at Station 64, very small leptocephali between I and $2 \mathrm{~cm}$. 
long (see Fig. 548). In this locality we also captured small

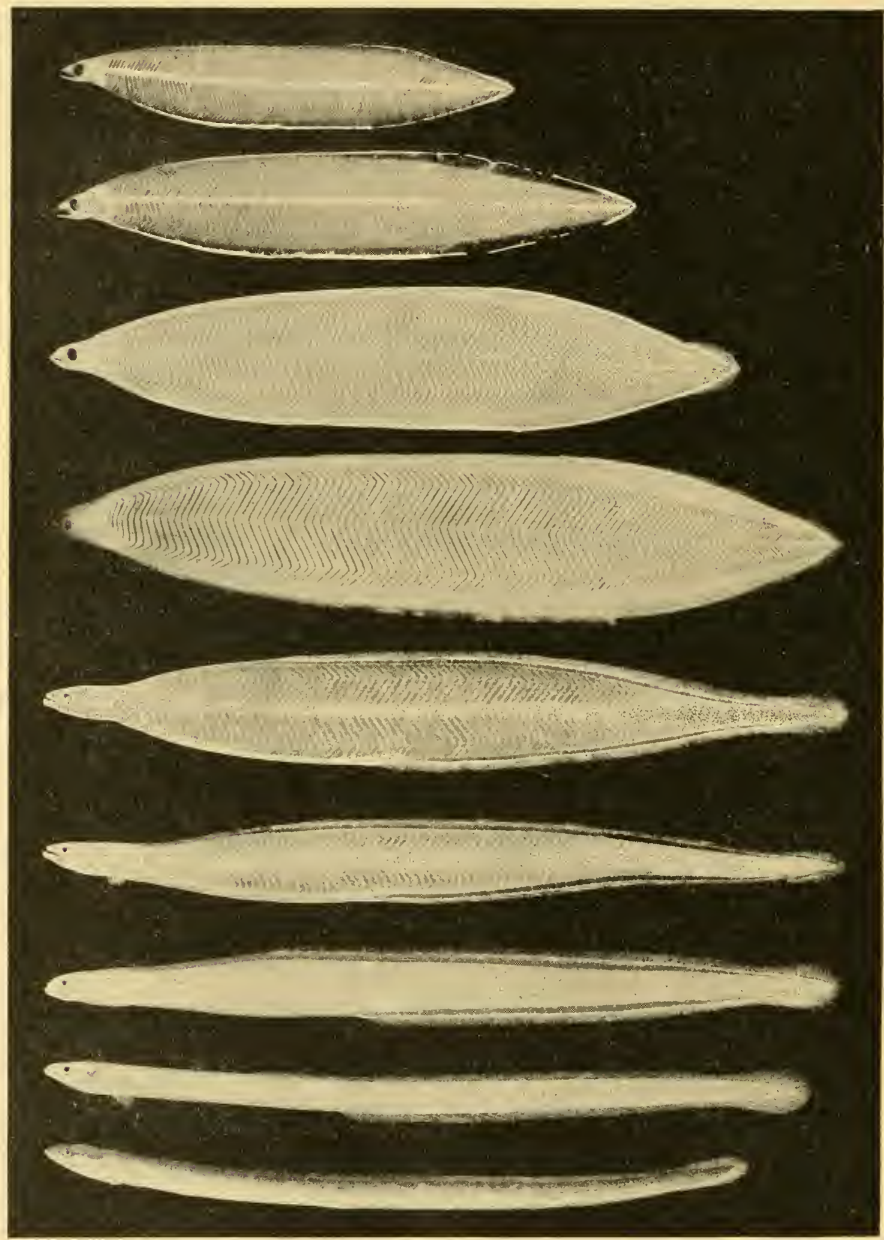

FIG. 550 .

Stages of development of the common eel (Anguilla vulgaris, L.). $\quad\left(\frac{1.4}{1}.\right)$

(The five lower figures from Schmidt.)

stages of leptocephali belonging to the common eel and to Synaphobranchus pinnatus (see Fig. 549). North of the line from 
Newfoundland to the Azores and Morocco only essentially larger (and older) stages of these species were taken, as shown in the case of the larvæ of the common eel (Leptocephalus brevirostris). It has long remained a mystery where the common eel spawns. Larve of the No sexually mature individual has ever been found among the millions of eels annually captured in the waters of Europe, nor have the eggs or minute larvæ ever been found. The autumnal migration of the eel has, however, been known for ages. During this migration the eels leave the rivers, lakes, and closed waters of the sea and make for open water, and certain naturalists, like C. G. J. Petersen, concluded that the eel was actually an oceanic deep-sea species. This idea seemed all the more obvious as the Italian scientist Grassi had, in the Mediterranean, proved Leptocephalus brevirostris to be the larva of the eel. A marked advance in the solution of this mysterious problem was made when Johs. Schmidt ${ }^{1}$ succeeded in capturing quantities of leptocephali along the Atlantic slope of the coast banks of western Europe. Schmidt here found the fully developed larvæ, mostly exceeding $6 \mathrm{~cm}$. in length, and all the transition stages before the leptocephalibecome "glass eels" or elvers, which in spring invade

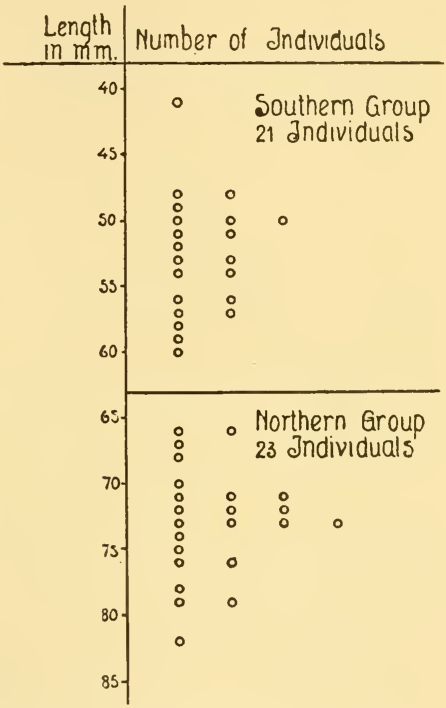
all the coasts of northern Europe, where they are well known.

During our cruise we found essentially smaller stages, ${ }^{2}$ down to $4 \mathrm{~cm}$. long, and we have thus been able to trace the series shown in Fig. 550. In this figure the five lower stages are taken from Schmidt's excellent account, the upper four stages having been drawn from specimens captured by the "Michael Sars," all magnified I.4 time. The three upper figures

1 See Schmidt, "Contributions to the Life-History of the Eel," Rapports et Procis-verbaux dut Conseil international, vol. v., I906.

"See Hjort, "Eel-larvæ from the Central North Atlantic," Nature, vol. lxxxv. p. I04, I9ro. 
represent stages prior to the fully grown leptocephalus, the five lower figures representing stages of the "metamorphosis." Without entering into the voluminous literature of the subject, we may state that we found a certain regularity as regards the geographical distribution of the various stages. Measuring the forty-four specimens taken by the " Michael Sars," and arranging them according to size (see Fig. 55I), we see that they may be divided into two groups, one ranging from $4 \mathrm{I}$ to $60 \mathrm{~mm}$., and

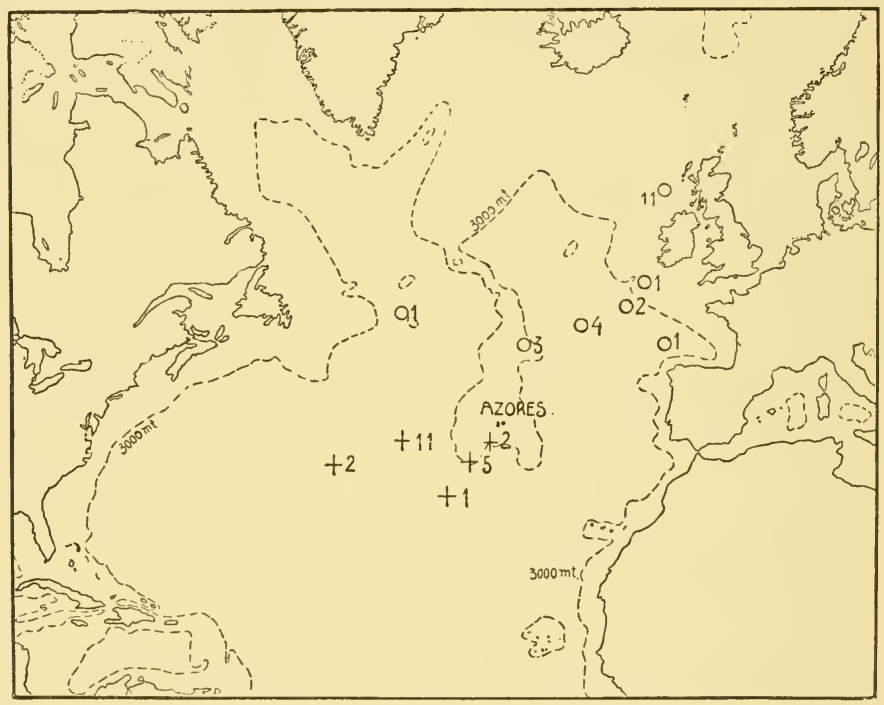

Fig. 552.-Number of Larve of the Common Eel CaUght during the Expedition. full grown larvæ; + smaller larvæ.

the other exceeding $60 \mathrm{~mm}$., in length. All the individuals of the former group were taken south of the Azores as denoted by crosses in Fig. 552, while all the specimens longer than 60 mm., i.e. the full-grown leptocephali, were taken north of the Azores as denoted by circles.

I presume that this peculiar distribution can only be explained by supposing that the eel spawns south of the Azores, and that the eggs and larvæ pass through their early stages there, being later carried into the northern North Atlantic and towards the coasts of northern Europe by the Gulf Stream. If this be correct, the majority of the young eels found in Europe 
have been carried there by the currents from distant spawning grounds, just as the herrings are carried to the coasts of northern Norway from distant spawning grounds on the North Sea coast, or as the young cod of northern Iceland have drifted from the south coast of that island. This result is in itself of great importance, contributing to our knowledge of the mysterious life-history of the eel, especially when viewed together with similar facts pertaining to other leptocephali (conger, Synaphobranchus), and to forms like Argyropelecus, Scopelidx, etc., which were far more numerous on our southern than on our northern track. Just as all the tropical and warm water forms, from foraminifera and copepoda to fishes, occur mainly south of the 4oth degree, so also is the spawning of warm water fishes limited to this same area. I therefore believe that the eel probably belongs to this "intermediate" group, of which one is reminded by the large eyes and the silvery sheen of migrating "ripe" eels (compare, for instance, Serrivomer).

I am inclined to explain the fact that we did not obtain many of the remarkable larvæ and young fish collected by other expeditions from the surface of the ocean, as recorded for instance by Lütken in his Spolia Atlantica, by supposing that we did not go far enough south. Lütken states that his small young swordfish were all captured in tropical localities, and in regard to the mackerel he quotes Captain Andrea thus: "The Bonito is the oceanic fish which I have most frequently seen and captured; it is seen everywhere in the North and South Atlantic between the tropics, increasing in abundance as one approaches the equator. In the Indian Ocean I have not seen it south of lat. $26^{\circ} \mathrm{S}$. nor east of long. $70^{\circ} \mathrm{E}$. In the Java Sea, the China Sea, the Yellow Sea, and the Japan Sea I have never observed it."

In this place I have limited my remarks to the fishes alone, but similar results would probably appear in most animal groups if their vertical and horizontal distribution were studied; this must be reserved for the future, when the material collected by the expedition has been examined in detail.

\section{Age And Growth}

It has long been recognised that there is a certain correlation between the size and the age of animals belonging to the same species, and that a definite increment in size takes place within 
a certain law-bound space of time, which varies in different species. These facts form the basis of an important branch of marine research, which possibly more than any other will help us to understand the life conditions of animals. The foundation of this branch of science is mainly due to C. G. J. Petersen ${ }^{1}$ and $\mathrm{H}$. Heincke.

Fish measurements.
In his first investigations Petersen aimed at defining the age of the fish-species occurring in a restricted area, and for this purpose he selected a small Danish fjord, the Holbaek fjord, where he attempted to capture all sizes of the various fishes, and measured the length of each one; he then tabulated these lengthmeasurements for each species in order to study the frequency of the various sizes. Fig. 553 shows the results of his measurements of the common viviparous blenny (Zoarces viviparus). The scale is in Danish inches, and each dot denotes a specimen measured; males and females were measured separately, where the sexes could

be distinguished. I quote Petersen's description of this graphic representation: "If we now consider the females, we undeniably find remarkably few of a length between 8 and ro inches; also there is a marked gap between the largest of the fry and the smallest females. Something similar is seen though less plainly in the males. The latter are, however, too few to let the gaps appear quite plainly. Alternating with these gaps certain sizes occur as it were in heaps, where many fish have almost the same length. The blennies may, to put it shortly, I892.

${ }^{1}$ C. G. J. Petersen, Beretning fra den danske biologiske Station, No. I, 1890, Kjöbenhavn, 
be classified in three groups: (1) the large ones, (2) an intermediate group, and (3) the small ones or fry, and when fishing we will very seldom be uncertain as to which group we may refer the fishes captured. It is impossible to apply the rule to both sexes, but the males seem on the average to be somewhat smaller than the females, and also less numerous. Among the larger sizes of the blennies, the longest ones seem to be sparingly represented. Notwithstanding all my exertions in various localities, I have never been able at this time of the year (summer) to find blennies of less length than the ones recorded under the head of fry, that is, about 3 to 4 inches. As the fry, when born, are actually $I \frac{1}{2}$ inch long, I cannot doubt that the group of small blennies, which at this time of the year differ so considerably in size from the large ones, really are the fry of the year, which during the last six months have grown to this size, that is, have added a couple of inches to their length. It appears equally natural to consider the intermediate group of blennies, between 6 and 8

오 $14^{\prime \prime}$

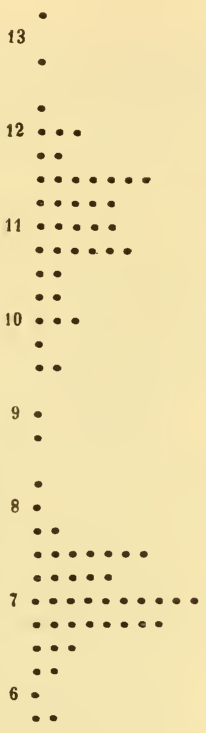

$$
5
$$
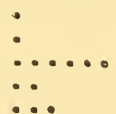

3

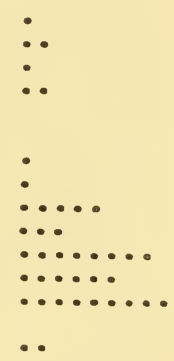

inches, as the fry of the previous year. The direct consequence is that all the large blennies between Io and I 2 inches are of an age exceeding one year and a half by one year at 
least, and as only very few individuals grow to a large size, this group must be considered as 'full-grown' blennies. In other words, it takes the blennies $2 \frac{1}{2}$ to 3 years to become 'full-grown."'

This account contains the foundation of this branch of science and a programme for further investigations, which have been employed in many recent researches, and will in

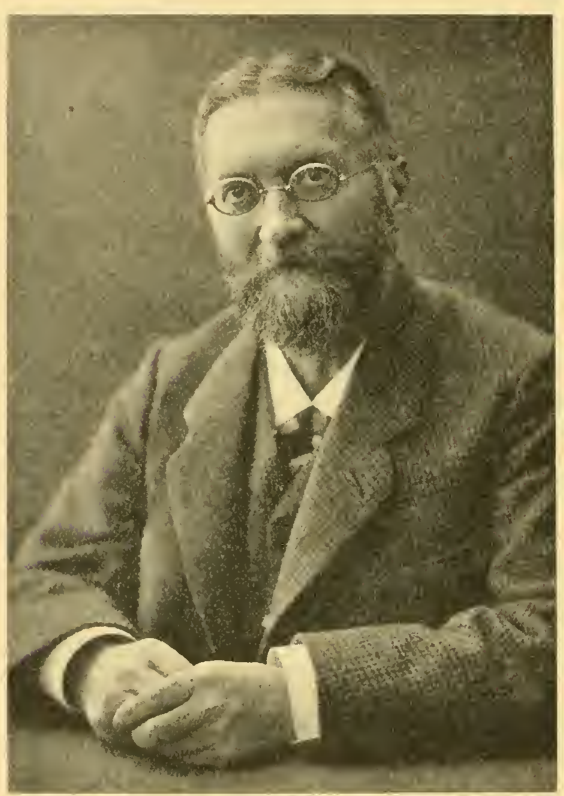

H. HEINCKE. future be employed along with more modern methods.

Another important series of investigations was inaugurated by Heincke, who endeavoured to employ the methods of anthropology by recording various dimensions of the organisms in order to characterise variations in growth peculiar to a species in different areas of the sea. Heincke measured the length and height of body, length of head, etc., in a great number of herrings from various marine areas, and he found the relations between these dimensions to be so characteristic that he supposed the herring to be subdivided into various races, each constituting a peculiar type of growth.

These two methods are, however, useful only as long as one can operate with great numbers of measurements according to the principles of the statistical method, and it proved in many cases impossible to determine the age and the type of growth of each individual by these methods. As regards the study of age alone this proved a great obstacle, especially in regard to the older animals. It was therefore very important to find a method which would give the age of each individual and define its particular type of growth. 
It has been discovered that in various boreal fishes the seasonal changes in their growth leave certain traces in all the osseous structures, such as vertebræ, gill-covers, otoliths, and scales, a difference being plainly seen between the parts formed during rapid growth (in summer), and the parts formed during feeble growth (in winter). In this way visible rings or zones are formed in the structures mentioned, varying according to summer and winter, thus enabling us to count the number of winters and summers passed by the fish in question, and to ascertain its growth in various phases of life. This was first discovered by Hoffbauer in the scales of the carp (1 899), and has also been observed to hold good in the case of the otoliths of the plaice (Reibisch), and of the scales of gadoids (Stuart Thomson), while Heincke and others have proved various bones to be good indicators of growth. A voluminous literature $^{1}$ has accumulated as the result of these methods, which assumed greater importance when in I904, upon the recommendation of Heincke, the international fishery investigators adopted them and applied them to many special and general problems. In recent years during the fishery investigations of several countries the growth and age of various commercial species have been subjected to analysis.

In Norwegian fishery work the scales have mostly been employed for age assessments, and in this way a number of species belonging to the cod family have been treated by Damas, while Sund has studied the age of the sprat, Broch, Dahl, and Lea the age and growth of the herring, and Dahl of the salmon and trout. ${ }^{2}$

Fig. 554 represents a series of scales of saithe, ranging from I 7 to $67 \mathrm{~cm}$. in length, taken on the west coast of Norway. They have been represented in proportion to the size of the

1 See Knut Dahl, "The Assessment of Age and Growth in Fish," Internationale Revue der ges. Hydrobiologie u. Hydrographie, Bd. II., I909, containing review of literature.

2 Désiré Damas, "Contribution à la biologie des Gadides," Rapp. et Proc.verb. de la com. perm. pour l'expl. de la mer, vol. x., Copenhague, I909.

Hjalmar Broch, "Norwegische Heringsuntersuchungen während der Jahre 1904-1906," Bergens Mus. Aarbog, 1908, No. I.

Oscar Sund, "Undersökelser over Brislingen i Norske farvand," Aarsberetning vedk. Norges Fiskerier I9Io, Bergen, I9II.

Knut Dahl, "The Scales of the Herring," Report on Norwegian Fishery and Marine Investigations, vol. ii. No. 6, Bergen, 1907 ; "Age and Growth of Salmon and Trout in Norway," Salmon and Trout Association, London, I9r I.

Johan Hjort, "Report on Herring Investigations until Jan. 1910," Publications de Circonstance, No. 53, Copenhague, 1910.

Johan Hjort and Einar Lea, "Some Results of the International Herring Investigations, 1907-1911," Publ. de Circonstance, No. 61, 1911; "Einige Resultate der internationalen Heringsuntersuchungen," Mitteilungen des Deutschen Seefischerei-Vereins, No. I, I9I2.

Einar Lea, "On the Methods used in the Herring Investigations," Publ. de Circonstance, No. 53, I9IO; "A Study on the Growth of Herrings," Publ. de Circonstance, No. 6I, I9II. 
fish, and we therefore easily see how the number of annual rings increases proportionately with the growth of the fish. By counting the winter-rings we can ascertain how many winters each fish has lived, and by examining a great number

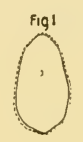

$17 \mathrm{~cm}$
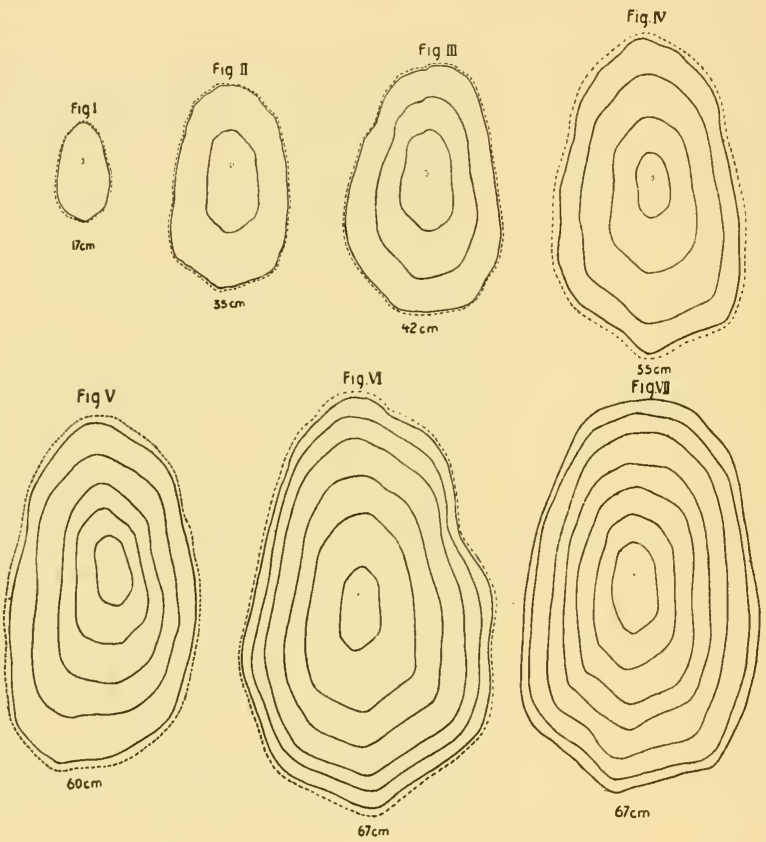

Fig $10 \mathrm{~m}$

Bergen April 1907

Gadus virens

Fignvu Bredsund Juli 1907

fig vi Haugsholmen Mars 1907

FIG. 554.

Scales of saithe (Gadus virens) of different sizes (size of the fish noted below each scale). (From Damas.)

of individuals from a definite catch we may ascertain the number of individuals belonging to each annual class. In this way we may obtain an idea of the age-composition of the catch. The next step is to examine a large number of catches, and to form an estimate regarding the age-composition of the 
fish-stock. Fig. 555 represents an analysis of the age-composition of a catch of saithe; it is of course not representative of

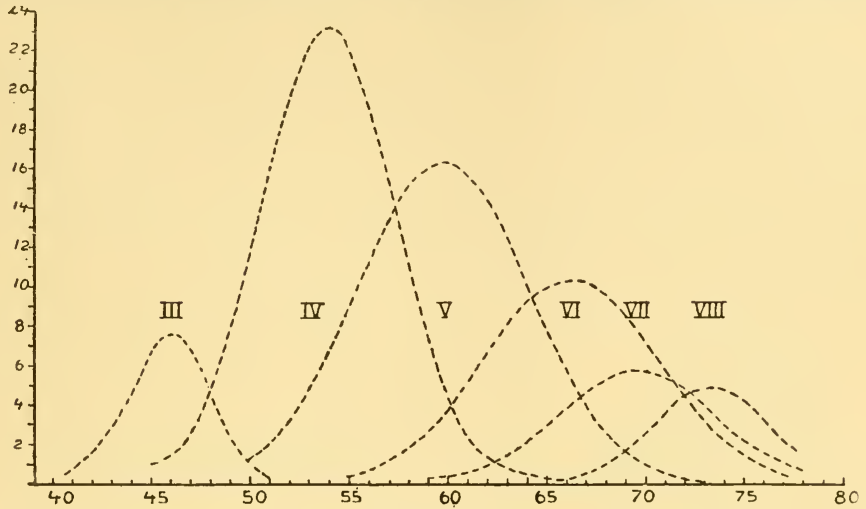

FIG. 555 .

Age distribution of the saithe (Gadus virens) from an examination by Danias of the scales of 654 fishes caught in Söndmör (Norway) in July 1907. The age-groups that were poorly represented have been left out.

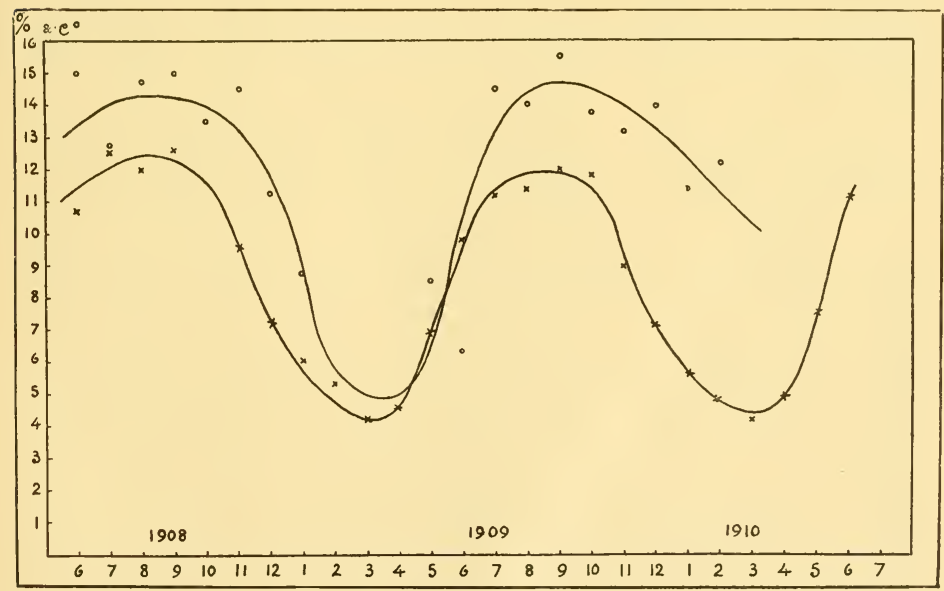

FIG. 556 .

Percentage of fat in sprats caught off the Norwegian west coast in different months.

$x$ Average temperature of the surface of the sea, off Bergen, in each month of the year. (From Sund.)

the saithe-stock, but might perhaps have been so in regard to the special shoal of saithe from which it was taken. 
Growth dependent on external conditions.

Some of the general results obtained by these investigations are of great interest; for instance, the growth of fishes has proved to be largely dependent on the temperature. Some chemical investigations corroborate this. Fig. 556 shows the fat-contents of the sprat as determined by H. Bull, compared by Sund with the surface temperature of the sea off western Norway in various seasons of the year. The fat-contents of the sprat increase during summer, when there is a rise in temperature, while both decrease towards the end of the year; it follows from this that the growth of the fish must be influenced by the prevailing temperatures in different waters.

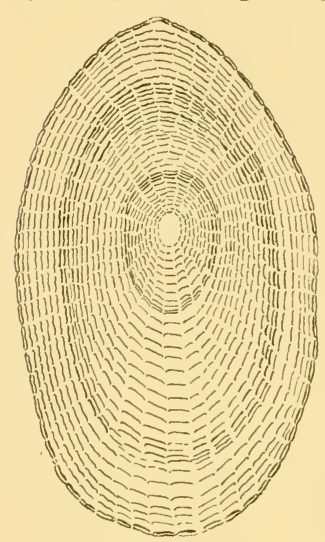

FIG. 557 .

Scale of Gadus callarias, L. Nat. size of fish, $55 \mathrm{~cm}$. Station 72 .

The investigations on the scales of fishes have now given us numerous facts confirming and elucidating this. Thus Damas says that the age of first maturity in the cod undoubtedly varies greatly according to local conditions. Generally the growth of cod-species may be said to decrease, and the age of first maturity to increase, the farther north we go. Thus on the Skagerrack coast a saithe may be $30 \mathrm{~cm}$. long at the end of its first year, while a saithe of corresponding age in northern Norway is not, as a rule, more than $10 \mathrm{~cm}$. in length. In northern waters, therefore, the winter-rings in the scales are much more marked than in more southern waters, for instance, in the North Sea. The duration of the warm season also differs in different waters, and the time when it sets in varies in different localities as well as at different depths (see Fig. 509, which shows that at 200 or 300 metres the highest temperatures do not occur in the summer, but late in the autumn). An examination of cod scales from the Barents Sea proved that in August summer growth had not yet commenced in that area, where the winter season is of very long duration, while the summer is short. It is interesting to compare this with certain observations which we had the opportunity of making during our Atlantic cruise on the banks of Newfoundland, where, as mentioned on pp. Iog-I I4, the cod spawn in July. We here observed cod with large ripe ovaries and found the recently hatched larvæ at the surface. The scales of these 
cod (see Fig. 557) plainly show winter-growth along their edges, that is to say, vigorous summer-growth had not yet set in, and as a matter of fact the temperatures were low (between 2 and 4 C., see Station 72, Fig. 95, p. I 10) just where the cod were taken.

These variations of growth put their stamp on the fish, the shape of which depends on its growth-history. And in waters, like those off the Norwegian coast, subject to great variation and extending south and north through so many degrees of latitude, an infinite variety in growth-types appear as a natural consequence. Some of these types may perhaps, through generations, be subjected to the accumulating influence of surroundings, thus possibly giving rise to races. Other and minor variations in growth may perhaps be considered as
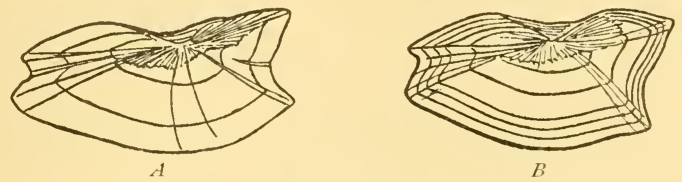

FIG. $55^{8}$.

Interoperculum of plaice (Pleuronectes platessa). A, $\delta 21 \mathrm{~cm}$. long, North Sea, three years old; $B, \varsubsetneqq 21 \mathrm{~cm}$. long, Baltic Sea, six years old. (From Heincke.)

temporary or individual variations due to surroundings only, and not subject to the laws of heredity.

The way in which individuals vary according to surroundings might profitably be studied by experiments in transplantation and marking of various types. Heincke ${ }^{1}$ has made some very interesting investigations on the growth of the plaice, and found that in waters so widely different as the North Sea and the Baltic the growth of the plaice varied greatly. Fig. $55^{8}$ shows the gill covers of two plaice of the same size, both 2 I $\mathrm{cm}$. long; the North Sea plaice is only 3 years old, while the Baltic plaice is no less than 6 years old. Similar distinct types of growth have been discovered in the herring during the international investigations, Dahl having first drawn attention to the existence of such types; Lea continued these investigations with a large amount of material, and claims that among others two growth-types may be recognised, one belonging to the north-eastern part of the North Sea (the Norwegian west coast), and the other to the Kattegat (see Fig. 559).

${ }^{1}$ Die Beteiligung Deutschlands an der internationalen Meeresforschung, IV. V. Jahresbericht, Berlin, 1908. 
Both the scales represented belong to herrings six winters old and represent true averages of growth, which has obviously been very different in the two types.

While studying the growth of Gadidae, Damas conceived the idea that by examining the growth-history of single individuals, as depicted in their scales, one should be able to determine the localities, or at least the conditions, in which the individuals had grown up, in other words that this study should afford a key to the migrations of the fishes; thus he considers it probable that a certain saithe captured on the west coast of Norway may be recognised as having spent its infancy on the north coast of Norway. Similar ideas have
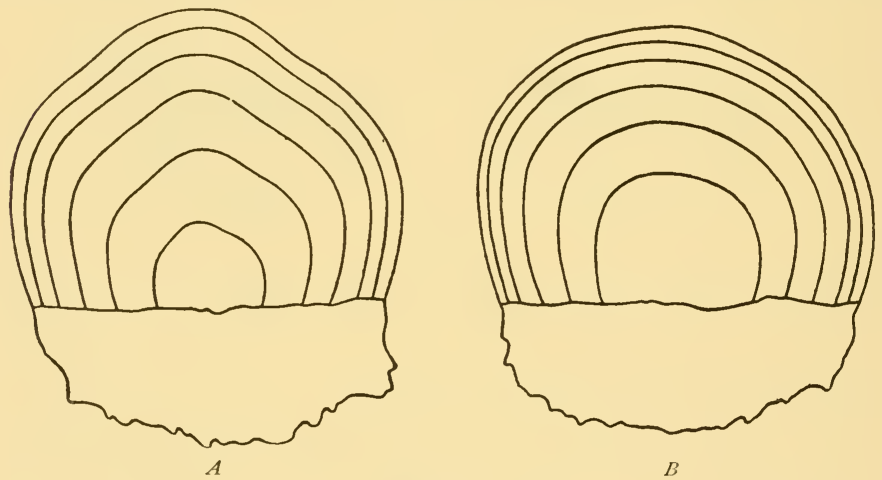

FIG. 559 .

Diagram of herring scales of average growth. $A$, from the north-eastern part of the North Sea ; $B$, from the Kattegat.

been expressed by Lea after studying the scales of herring. He discovered that among the fat-herrings of northern Norway the ones born in 1904 could be seen to have had an exceedingly poor growth during their third year, the summer-belt in the scales being strikingly small in that year (see Fig. 560). This peculiar feature was in that year limited to a certain part of the coast. The individuals thus "marked" were, however, in subsequent years when increasing in age found to have a much wider distribution, extending to the west coast of Norway and other localities. He considers this as significant of migration, and even attempts to calculate the percentage of the herrings taken on the west coast that had spent their infancy in northern Norway. 
The study of numerous samples taken from the fish-stock Age-comof a certain area may aim at ascertaining the age-com-position of position of that stock, and from the results the position of that stock, and from the results the follow- fishes. ing main points in the natural history of the fish may be elucidated: (I) the age at which maturity occurs; (2) the
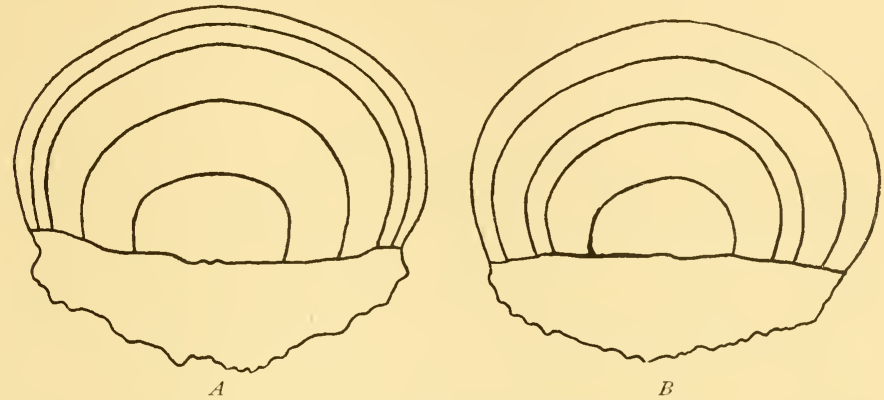

FIG. 560.

Two scales of five-year-old herrings. $\quad A$, growth under normal conditions ; $B$, abnormal growth in the third zone.

duration of life; and (3) the variations in the age-composition and magnitude of the fish-stock.

Studies of this kind have shown us that various species
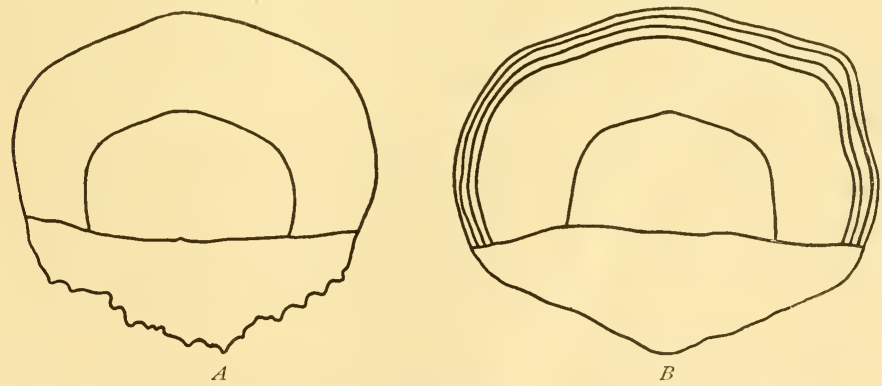

FIG. 56I.

Scales of $A$, herring (Clupea harengus) ; $B$, sprat (Clupea sprattus). Both fishes $16 \mathrm{~cm}$. long.

are distinct even in this respect. Nothing shows this more clearly than a comparison between the two closely related species : the sprat and the herring. Fig. 56 I represents scales of a herring and of a sprat, both $16 \mathrm{~cm}$. long, the herring being only $\mathbf{I} \frac{1}{2}$ year old and the sprat 4 years. The 
age-composition of spawning shoals in the two species appears from the following examples:

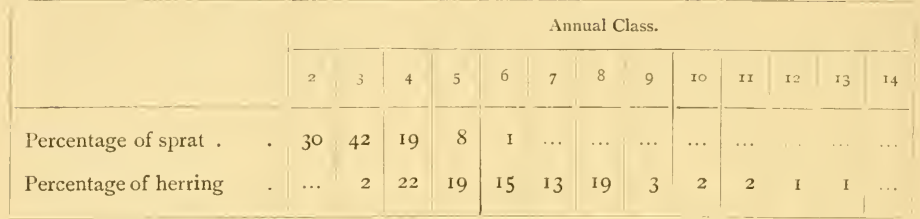

Sund found that the majority of sprats spawn when two to four years old, while Dahl found that the herrings spawn from the $3^{\text {rd }}$ to the 14 th year, the majority between four and eight years old. This difference is fundamental in the life-history of the two species. The life-cycle of the sprat is rapid, indicating a rapid renewal, while the herring lives much longer, spawns for a great number of years, and spawning commences two years later than in the sprat. The herring is a typically boreal fish, its southern limit to the south-west of Britain conforming to that of all the boreal bottom-fishes (see Chapter VII.). Herrings live, at least sometimes, at considerable depths, depositing their eggs on the bottom of the coast banks during winter and spring, now in shallow, now in deeper water.

The sprat is distributed far south in the Atlantic, occurring, according to Day, round the Iberian Peninsula. It is a surface fish occurring in boreal waters mainly where high summer temperatures prevail; it spawns during summer, the eggs being pelagic.

From the study of the age of fishes I was induced to hope that the variations in the magnitude of the fish-stock might be estimated, and my collaborators have made very extensive investigations with most important results. This applies to the cod family as well as to the sprat and the herring. I will here only review some of our results from the herring investigations.

For a number of years samples for age-analysis have been collected during the various herring fisheries on the coast of Norway, the analysis of which has proved that the age-composition of immature herrings, as well as the shoals of spawning herrings, vary considerably from year to year. These variations are mainly due to the fact that certain annual classes are exceedingly prolific, while others are very poorly represented. The following table records the results of an analysis of 
samples representing immature fat-herrings from northern Norway in the years 1907-1910, ${ }^{\mathrm{I}}$ the frequency of each annual class being given in percentages of the total sample for each year:

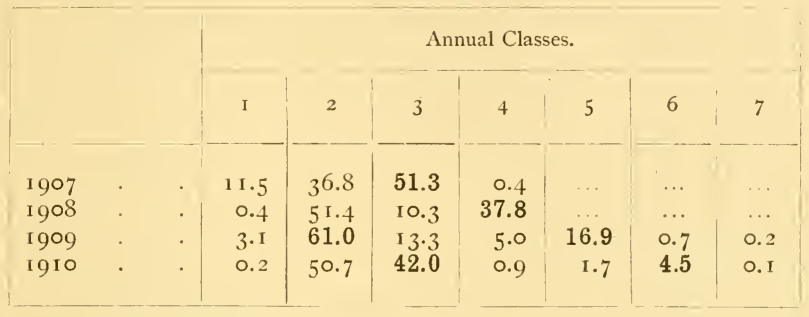

This table shows that the fat-herrings in 1907 consisted mainly of fish two and three years old, in 1908 they were mainly two and four years old, and in I9ro again the majority were two and three years old. This apparent irregularity has an enhanced interest when we remember that the herrings, which in 1907 were three years old, in 1908 were four years old, and so on. The annual classes born in 1904 and in 1907 are printed in heavy type, and the table shows a decided regularity in the abundance of certain annual classes. The same regularity appeared when older herrings were studied. When four years old the fat-herrings begin to "migrate" away from the shoals of immature herrings, and mingle with the "spring-herring" shoals (the spawners). In such spawning shoals from western Norway the year class born in 1904 proved to have the occurrence shown in the following table in percentages of the total sample analysed each year, comprising sixteen annual classes :-

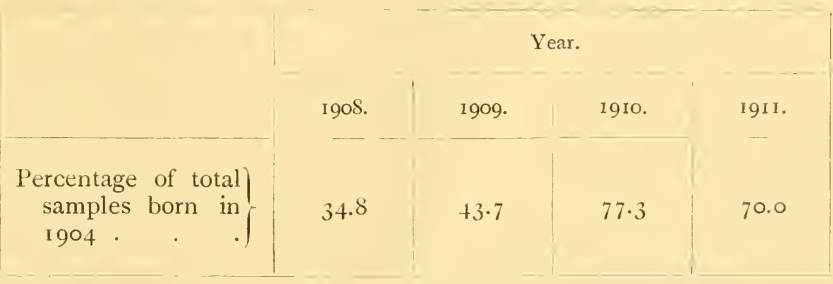

Among the great number of annual classes composing the 1 J. Hjort and E. Lea, "Some Results of the International Herring Investigations, I907-
I9I I," Publ. de Circonstance, No. 61, Copenhague, 191 I. 
herring stock, one single annual class may thus be enormously prolific, the individuals exceeding in number those of all other annual classes taken together.

These facts naturally lead to the following conclusions touching questions of interest to general biology as well as to practical fisheries. The age-composition of a fish-stock varies exceedingly; there are good and bad years, producing annual classes rich or poor in individuals. Favourable and unfavourable conditions must thus vary in nature, and seem to affect specially the earlier phases in the life of the fish, inasmuch as we perceive that in advanced years the numerical preponderance of an annual class is equally perceptible for a number of years.

The variations caused by the influence of one year will therefore not always perceptibly influence the number of individuals of the total stock, and in practical fishery its influence will as a rule only be felt some years later, when the annual class in question plays an important part in the catches of fishermen. If favourable years have occurred just before or after the birth of the class in question its influence may perhaps not be felt at all. All this of course applies only to species with many annual classes of spawners, for where few annual classes spawn (or perhaps only one) conditions will be different.

The influence of one year may, however, appear in the quality of the whole stock, for instance in the fat-contents (see Fig. 556 representing the growth of the sprat).

Wherever there is a good opportunity of obtaining representative samples showing the age-composition of a fish-stock, it should be possible to predict the composition of that stock for the following years. We may thus, for instance, count upon the possibility of annual classes containing a marked abundance of young individuals reappearing, after the lapse of a definite time, as equally abundant shoals of older and more valuable fish.

The results here mentioned have been obtained through laborious investigations occupying many years, involving the study of the fishes at all seasons, in order to prove that the various growth-rings of the scales really correspond to seasonal changes.

Growth of fishes in the ocean.

As far as I know, no systematic investigations as to growth have ever been made in the open ocean, but I may point out that in tropical waters and at all depths in the ocean the same biological problems, which we have just described from boreal waters, present themselves for study and solution. In this connection I consider it interesting to cite some instances from 
$42 \mathrm{~cm}$. long, taken at Station $4 \mathrm{I}$ in 1365 metres. We see here a great number of rings, perhaps twenty in all, but these rings

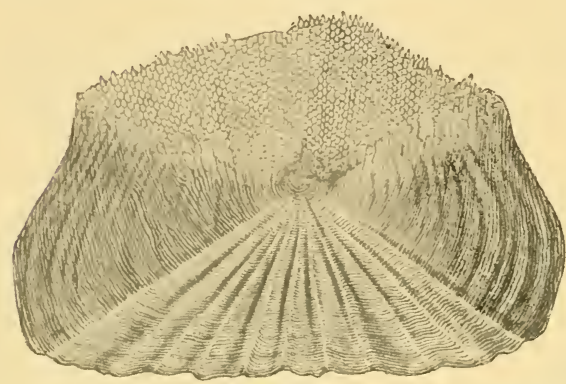

Fig. 564 .

Scale of Cantharus lineatus, Montagu (White). Length of fish, $42 \mathrm{~cm}$. are in many respects essentially different from the annual rings in the scales of boreal fish. In the latter the central rings are as a rule very large, the subsequent rings becoming narrower as the fish grows older. If the rings in the scale of Bathygadus signify periods of growth, these would seem to be of a peculiar character.

Fig. 564 is the scale of a fish $42 \mathrm{~cm}$. in length from the coast banks of Africa, Cantharus lineatus, taken in shallow water at a high temperature. This scale also shows rings which are very distinct, especially towards the periphery of the scale.

In Fig. 565 I have represented a scale from a surface fish, Polyprion americanus, $49 \mathrm{~cm}$. in length, taken in the surface waters at Station 56.

In the scales of all these fishes, taken under such various conditions, we observe peculiarities of structure, resembling the

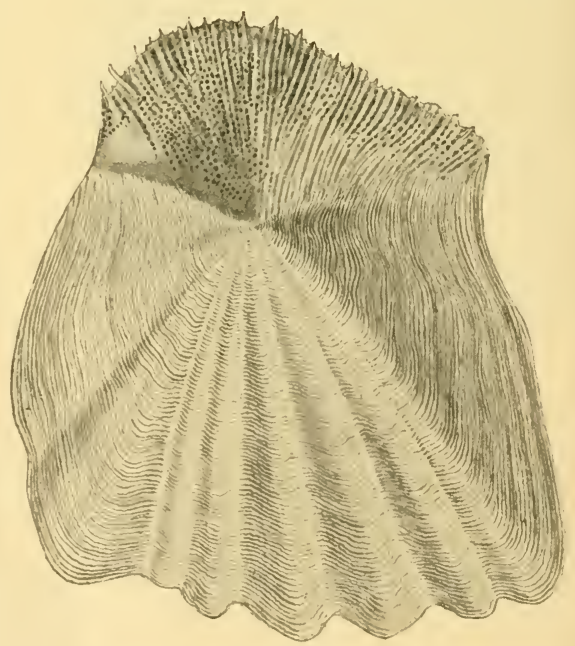

FIG. 565 .

Scale of Polyprion americanus, Bl. and Schn. Length of fish, $49 \mathrm{~cm}$. rings produced by the periodicity of growth in the scales of fish from boreal waters. There seems thus to be every reason for subjecting the growth of the scales and other organs of 
warm-water and oceanic fish-species to a closer investigation, and for studying them at various seasons. As a means of control and comparison, measurements on a large scale, according to Petersen's method, would be very important. Although our material is very abundant, it is insufficient for the purpose of distinguishing various size-groups among the fishes. That such groups occur among the deep-sea fishes is plainly indicated by our measurements of Cyclothone (see Fig. 473, p. 620), which show a binodal curve for individuals of Cyclothone signata from 500 metres, and a multinodal curve in the case of $C$. microdon. At 500 metres the average size is about $35 \mathrm{~mm}$., and at I 500 metres about $60 \mathrm{~mm}$. Perhaps there is another group in depths between the two mentioned. Regarding the meaning of the nodes in these curves I must confess myself ignorant.

From the coast banks of Africa we have a series of measurements of Dentex macrophthalmus, which for the sizes between I 7 and $24 \mathrm{~cm}$. show a very regular size-distribution of the fish captured.

Future investigations of the fish-fauna of the coast banks may lead to good results by starting from the study of such forms as occur also in the North Sea, for instance the hake (Merluccius vulgaris). Their growth might then be subjected to a comparative study on a long stretch of coast through many degrees of latitude and under exceedingly various conditions. The same method might also beapplied in the case of the southern pelagic clupeidx: the sprat, the pilchard, and the anchovy.

\section{Abundance of Marine Animals}

On dry land we can, to a large extent, examine the yield of the soil, weighing and measuring the crops, and keep count of animals of economic importance. As regards the yield of the sea our experience is merely of a relative kind. From generation to generation a certain amount of knowledge has been accumulated as to the quantities of various fish that have been captured, but the number of animals actually living in the sea is unknown.

Many scientists have undoubtedly often had to acknowledge that biology would be raised to an essentially higher level, if it were possible to arrive at absolute figures denoting the numbers of individuals inhabiting the sea, instead of merely the relative figures which are now obtained through the study and comparison of various catches. 
Quantitative estimations of organisms in the ocean.

A first attempt in this direction was made by Sir John Murray during the cruise of the "Challenger," by calculating the amount of calcium carbonate in the form of living organisms per square mile of the ocean by 100 fathoms in depth.

No one has devoted more time and thought to this problem than $\mathrm{V}$. Hensen, who has been indefatigable in his endeavours to devise methods for an absolute determination of the quantities of organisms contained in the ocean, his avowed intention being to ascertain the quantities of "primitive food for marine animals." 1 From theoretical considerations he concluded that the primitive food of marine animals necessarily consisted of the microscopic plants living in the surface waters of the ocean, and that the effect of currents would be to distribute these minute plants quite regularly and uniformly. He held the idea that a hoop-net hauled vertically from bottom to surface would filter a column of water with a diameter very nearly corresponding to the diameter of the net, and that in this way it was possible to calculate the catch per square metre of surface. The volume of the catch might be measured, and the number of individuals belonging to all the species might be counted. Definite figures might thus be obtained representing the abundance of each species per square metre of surface, and the area of the water being known, the aggregate quantities might be calculated. In order to count all the micro-organisms he invented a method based on the principle employed in physiology for the purpose of counting blood corpuscles, viz. to dilute a sample of known volume with a known volume of liquid in which the organisms become evenly distributed. With a specially devised instrument a small sample (say I c.c.) is taken out and its contents counted.

This method has added greatly to the practical working of biological ocean research, and will undoubtedly increase in importance in future. Like all other means of research it must be employed with judgment, and the special nature of the investigations must decide whether it may be applied and at what stage with advantage. The application of the method has led to much discussion, the enthusiastic advocates of the method considering it imperative that it should be used in all "truly scientific" investigations on the micro-organisms of the ocean, while its opponents have looked upon it as a means of

1 V. Hensen, "Über die Bestimmung des Planktons," V. Bericht der Commission sur wiss. Untersuchung der deutschen Meere in Kiel, $18 S_{7}$. 
investigation to be applied, like all other means, according to circumstances.

Hensen invented his method for the purpose of investigating the floating or suspended life in the sea, which he termed "plankton." This plankton is, however, very difficult to define, for among the profusion of organisms, ranging from the minutest plants, the coccolithophorida, to large crustaceans and fishes, there is an enormous variety in size, in activity, and consequently in the faculty of avoiding the appliances of capture. In many investigations, therefore, the word plankton may be taken to signify practically "the catch made in the hoop-net constructed by Hensen, when new and in perfect working order." But does this selection among the organisms of the sea correspond to an arrangement peculiar to the organisms in nature? All our experience shows that the catching power of the Hensen net is restricted, firstly, because, as shown in Chapter VI., an important group of plants (the coccolithophoridx) may pass through the meshes of even the finest silk nets, and secondly, because the selection of animals actually taken is very limited, consisting of unicellular animals, minute crustaceans, sagittidæ, etc., while the large crustaceans, schizopoda, decapoda, and even small fish-fry, mostly avoid the net. This limited power of capture alone is apt to affect our ideas of marine life in a perfectly arbitrary manner; but another objection to the universal application of the Hensen method arises from the fact that in large areas the conditions do not correspond to the theoretical conditions on which the method is based, for in theory the distribution of the organisms is regarded as something like the even distribution of the molecules of a gas encased in a box or aquarium.

In I 885 Hensen made an expedition in the "Holsatia" and in I 889 another in the "National," during which vertical hauls were made with his nets in shallow water from bottom to surface, and in the ocean mostly from 200 metres to the surface. The volumes of organisms taken during these cruises have been represented graphically in Fig. 566, reproduced from Steuer's text-book. In this figure the track of the cruise has been used as horizontal axis, and lines have been drawn vertically (as ordinates) to show the relative volumes taken per square metre of surface. These volumes are very great in the Irminger Sea and in the North Sea (amounting to i66.9 c.c.), and very small in the Sargasso Sea as well as in 
the open ocean on the whole. In all or most of these samples the numbers of individuals have been counted after the return of the expedition, - a laborious and painstaking piece of work,

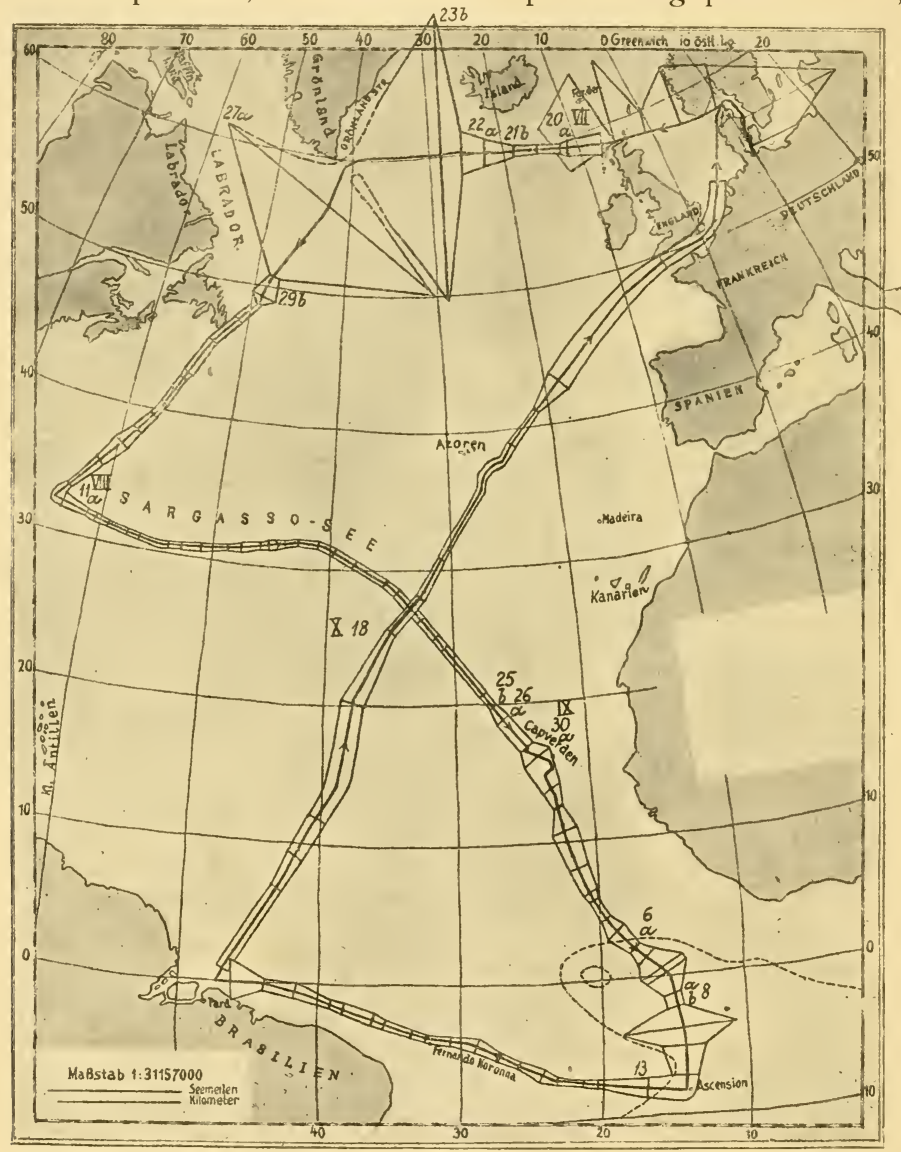

Fig. 566. - Volumes of "Plankton" in the Atlantic and in the North Sea, ACCORDING TO THE INVESTIGATIONS OF THE "HOLSATIA" IN I885 AND THE "NATIONAL". IN I889. (AfterlHensen, from Steuer.)

which has added greatly to our knowledge of marine biology. In Chapter IX. I have had occasion to refer to many important facts for which we are indebted to these expeditions, but I 
doubt whether the method of work adopted has resulted in a correct idea of the quantities of organisms which these hoopnets can capture per square metre of surface, and whether this method recommends itself for adoption in the present state of our knowledge.

It is evident that the quantity of organisms present at any given moment does not afford any gauge as to the "primitive food" contained in the ocean. The quantity of such food depends on the intensity of reproduction, which is entirely unknown, from coccolithophoridæ to fishes. For this reason the volumes of plankton shown in Fig. 566 convey no idea of the actual production of the ocean, a fact of which Hensen was fully aware. The abundance in boreal waters only lasts a short time, and during that time production is probably not by any means so rapid as in the warm ocean. While the Hensen nets thus capture only an arbitrary selection of organisms, the depths from which the nets were hauled were also chosen in an arbitrary manner. Hensen ${ }^{1}$ himself says, when describing the copepoda: "The figures show that the copepoda usually live still deeper than 200 metres, their density being, however, insignificant." The results seem to have given rise to some doubt in his mind as to the latter opinion.

In Chapter IX., and when speaking of nutrition, I have mentioned some of the investigations made on board the "Michael Sars" regarding the capture of minute crustaceans in closing-net hauls from various depths. The catches have been classified in regard to number of species as well as to volume, and the characteristic feature was that the greatest number of species and the greatest volumes of these crustaceans did not occur in the upper water-layers, but at certain intermediate depths. In the Sargasso Sea the greatest volumes were captured between 1000 and 500 metres, off Newfoundland between 500 and 200 metres, and in the Norwegian Sea (Station I I3) between I000 and 500 metres. In the Sargasso Sea a greater number of species (5I) was found in the deep hauls between 1000 and 500 metres than in the "surface" hauls between 200 metres and the surface (22). Certain species occurred at all depths, others only in the deepest hauls. Our horizontal hauls showed that besides these minute forms taken by the closing-nets there is a prolific community of large crustaceans, prawns, etc., in deep water, where many litres could be taken in each haul, while higher up

1 "Das Leben im Ozean," Erg. d. Plankton-Expedition, Bd. v., Kiel, Igrr. 
these animals are absent, and the volume is obviously at a minimum.

We may therefore assert that the small nets actually capture a purely accidental selection of the animals present, and that the use of the nets only above 200 metres gives a merely casual selection, which is by no means a characteristic gauge as to the quantity of organisms living beneath a square metre of surface even at the moment.

Is the idea of a certain quantity per square metre of surface on the whole of any value whatever as regards the ocean? We may speak about the quantities produced per hectare or per square metre of soil, and we may also classify the production of a pond; but is there in the ocean any connection whatever between the different layers of a column of water 5000 or 6000 metres deep by I metre square in regard to the vertical exchange of nutritive substances? Is it not probable that this exchange takes place in an oblique direction and at various angles at different depths? At the surface of the North Atlantic the Gulf Stream in many places runs with great velocity, but how deep this current extends, or, to put it more correctly, at what depths it runs in the same direction and with the same velocity, is indeed as yet almost unknown. Below this current there are perhaps in places powerful reaction currents, running in opposite or other directions, probably with a considerable vertical range (see current measurements described in Chapter V.), and these would have to be passed through before reaching depths where the water layers move very slowly or not at all. Bodies sinking from the productive plant-stratum at the surface must, therefore, be supposed to be carried far away in a horizontal direction before reaching deep water. The nutriment of the deep layers of any locality is thus not derived from a point situated exactly above it, but has probably come from some very distant point, and the fact that boreal forms are found in deep water below the warm waters of the south may be a corroborative proof of this.

()ualitative investigations must precede quantitative estimations.

Notwithstanding my admiration for Hensen's methods, I have always held that before these methods can be applied in nature we must make a qualitative investigation, to be followed by an investigation as to the relative quantities of the organisms present, in order to define the selection which must be made if we wish to determine the absolute quantities. To define the quantity of something perfectly casual is indeed of little 
importance, but to determine the exact quantity of something clearly defined, as, for instance, the number of individuals of certain definite species living in a sharply limited water-layer, is of the highest interest.

When planning the Atlantic cruise of the "Michael Sars " I considered it our first duty to investigate in a qualitative way what organisms live at the various depths. For this purpose we made many determinations of quantity (see Chapter IX.), for instance, in order to illustrate the abundance of certain species in each of the appliances towed at different depths. This method made no pretence of giving absolute figures, but it gave us certain ideas regarding the relative quantities of organisms living at different depths, and the figures obtained by counting the fishes in our trawlings are of a similar kind. My opinion is that these estimates represent the natural conditions better than the ideas regarding animal life in the Atlantic gained by the German Plankton Expedition; this ocean, being inhabited by organisms at all depths, is very far from being as poor as shown by the nettings of the Plankton Expedition. At the surface reproduction must be exceedingly rapid, or else it would be perfectly inconceivable that so many animals could live in the deeper water, unless, indeed, their nourishment were derived from distant localities, a question that future investigations must answer. Further, the peculiar difference between the quantities of organisms occurring in the deep water of boreal and of warm oceanic waters will have to be more closely studied. In the ocean we find first a minimum just below the surface, then a pronounced maximum, with probably a minimum again in the deeper waters (see Chapter IX. on capture of Cyclothone in closing-nets at Station 63). I suggest as a working hypothesis that this is due to the peculiar distribution of specific gravity and viscosity, which is quite different in boreal and in warm oceanic waters.

When speaking of floating, I mentioned how the distribution of temperature, and consequently of specific gravity and viscosity, affected the geographical distribution of species, and in Chapter IX. I drew a limit between boreal and warm-water forms, which on the whole, horizontally and vertically, coincided with the isotherm of $10^{\circ} \mathrm{C}$. In thus employing temperature alone as a means of dividing animal-communities my idea has only been to consider the temperature as an indicator of certain climatic conditions on which animal life is dependent. From this point of view let us inspect a section of the Atlantic along 
the 3 oth meridian west (Fig. 567). We see that the waterlayer limited by the isotherm of $\mathrm{IO}^{\circ} \mathrm{C}$. is relatively thin in proportion to the depth of the ocean. The genuine warmwater layers with temperatures exceeding $15^{\circ} \mathrm{C}$. reach only to $30^{\circ}$ south and north, and are only 200 to 300 metres thick. The whole layer above IO $^{\circ} \mathrm{C}$. has a thickness varying between 300 and 700 metres (or between $\frac{1}{20}$ and $\frac{1}{9}$ of the depth of the ocean). Now it was only a part of this small layer which was examined by Hensen's expeditions, and consequently the results must necessarily be incomplete.

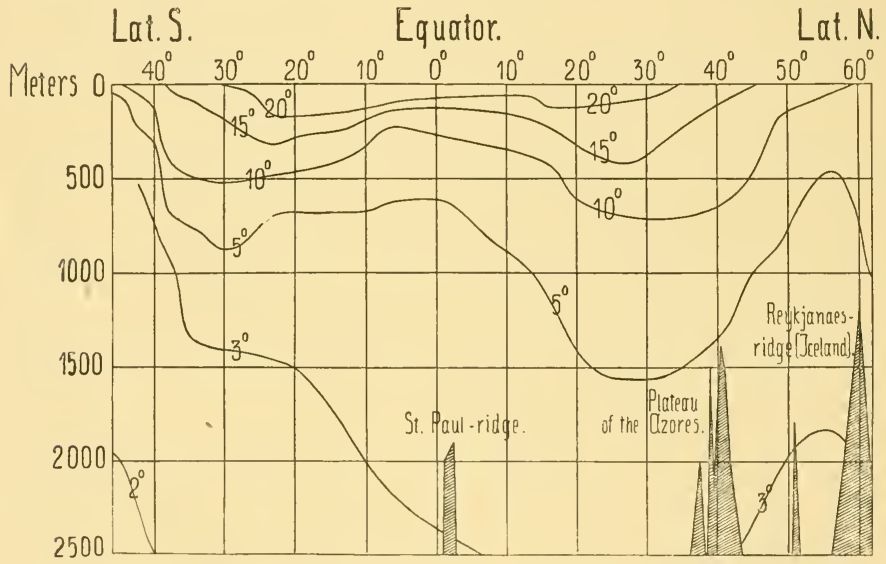

Fig. 567.-Distribution of Temperature in the Atlantic along the thirtieth Meridian of West Longitude. (From Schott.)

Distribution of whales.

In order to understand the abundance of animal life in various parts and at various depths of the Atlantic, it is very useful to review our knowledge of the distribution of whales in that ocean. I agree with Eschricht in dividing the whales into different biological groups according to the food on which they live. One group feeds on "plankton," another on both plankton and fishes, and a third group on squids.

Genuine "plankton whales" are the arctic "right" whale (the Greenland whale, Balana mysticetus, see Fig. 568), and the boreal blue whale (Balcnoptera musculus, Fig. 569). By the aid of their enormous tongues they press the water out of their mouths between the whalebone lamellæ, thus filtering the water and retaining the minute organisms (see Fig. 570). 
Another group of whalebone whales, the fin-whale (Balcenoptera physalus), the humpback whale (Megaptera boops,

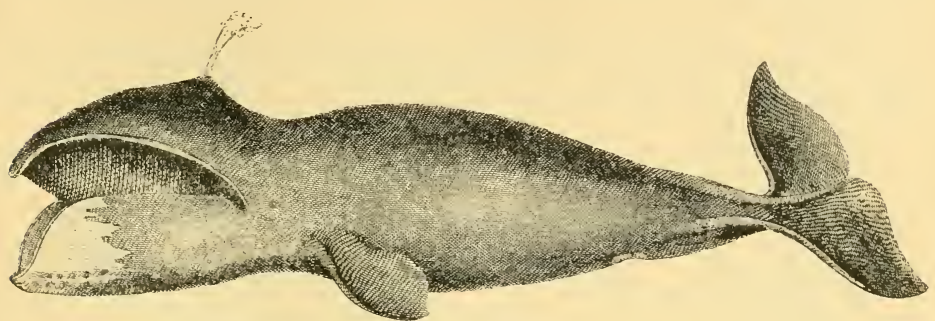

FIG. 568 .

Greenland whale (Balcena mysticetus). (From Scoresby.)

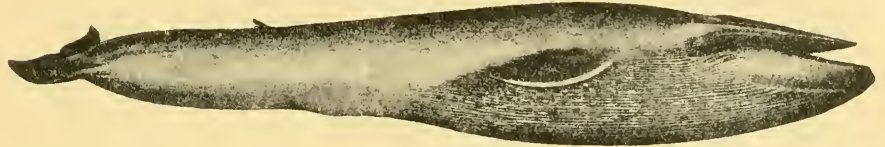

FIG. 569 .

The blue fin-whale (Balcenoptera musculus). (From G. O. Sars.)

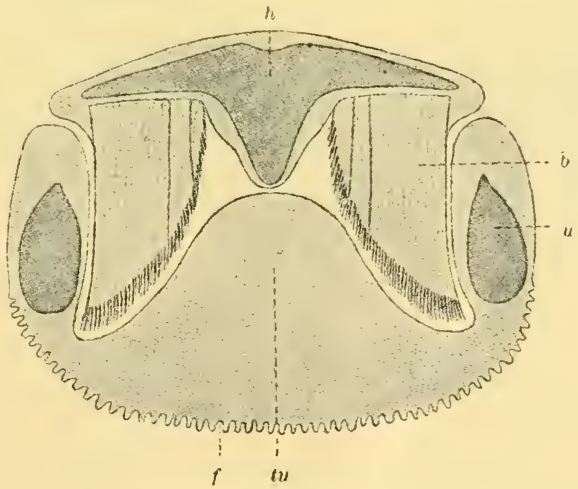

FIG. 570 .

Cross-section of head of a fin-whale (Balcenoptera). (From Boas.) $h$, Head; $u$, lower-jaw ; $b$, whalebone ; $t u$, tongue; $f$, furrows of the skin.

Fig. 571), and the "saithe" whale (Balcnoptera borealis) feed on plankton as well as on pelagic fishes, mainly capelan and herrings, which also constitute the main food of the small toothwhales of the porpoise description. 
The cachalot or sperm-whale (Physeter macrocephalus, Fig. 572) and the bottle-nose (Hyperoodon diodon) feed mainly on squids. ${ }^{1}$

Howard Clark ${ }^{2}$ has published an interesting chart recording the various whaling areas, in which he has separated areas fished in 1887 from areas previously fished but then abandoned. The whales fished in various areas are denoted by letters :-

B. = Greenland whale.

R. = Other Right whales (Balæna).

$\mathrm{F} .=$ Fin-whales (Balænoptera).

H. = Humpback whales (Megaptera).

S. = Cachalots or Sperm-whales.

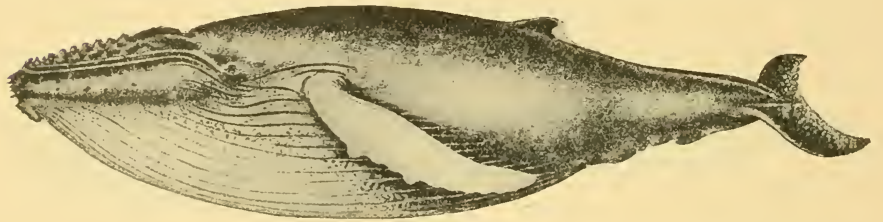

FIG. 57 I.

The Humpback (Megaptera boops). (From G. O. Sars.)

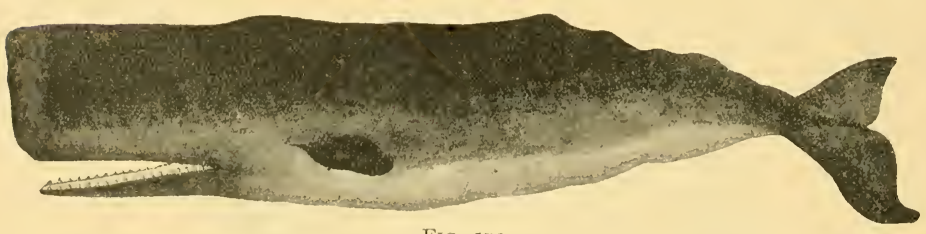

FIG. 572 .

Cachalot or Sperm-whale (Physeter macrocephalus). (From drawing in the Bergen Museum.)

The Chart (Fig. 573) gives his records from the Atlantic, and at the same time the temperature at 100 metres has been entered, from Fig. 3I 2, p. 445, and from Schott's report on the "Valdivia" Expedition. The dense hatching shows areas where whales were fished in 1887 , the open hatching areas then abandoned. In northern boreal waters, north of the isotherm of $10 \mathrm{C}$., only or mainly the Greenland whale, fin-whales, and humpbacks are found, the right whale of the North Atlantic (north-caper or Biscayan whale, Balcna biscayensis, Fig. 574) being a rare visitor. In antarctic waters, where the thermal

2 The Fisheries and Fishery Industries of the United States, Section V., Washington, I887. 
conditions correspond to those of boreal waters, right whales predominate; in recent years, however, large numbers of fin-

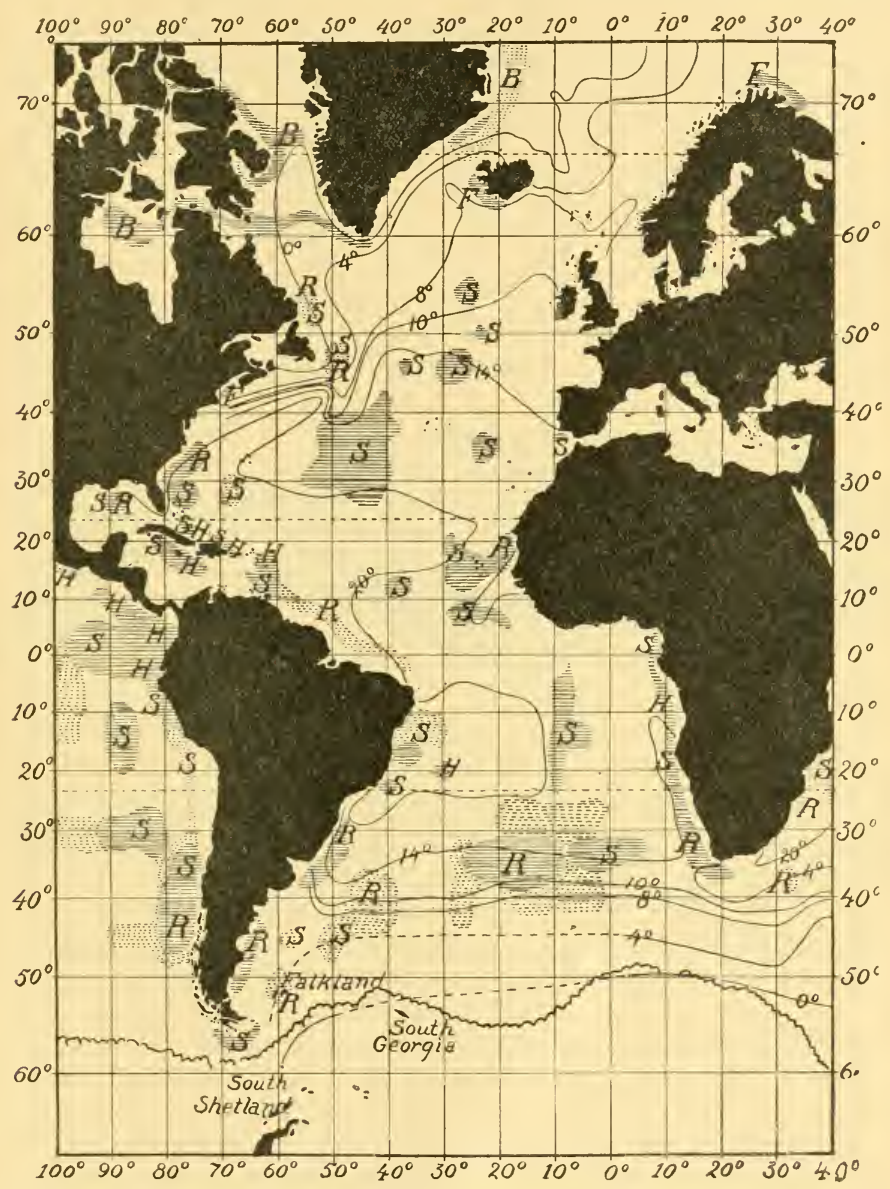

Fig. 573.-Distribution of Whales, and Temperature at iOo metres (see text).

whales and humpbacks have also been found there. In coast waters right whales and humpbacks predominate. In the open ocean between the parallels of $10^{\circ}$ north and south, 
the cachalot is the principal, if not the only, large species which has been the object of man's exertions in these parts.

The distribution of whales, here roughly outlined, seems to agree very well with what I have previously stated in regard to the distribution of pelagic animals. In boreal, and probably also in antarctic, waters the abundance of minute pelagic animals (plankton) in the upper layers is particularly characteristic of certain seasons of the year, and for this reason the whalebone whales have their habitat in these waters. In coast waters the plankton is equally rich in many places, along with quantities of small pelagic fishes, herrings, sprats, pilchards, etc., which are the food sought by humpback whales. Whether the various right whales, like Balcua biscayensis, in

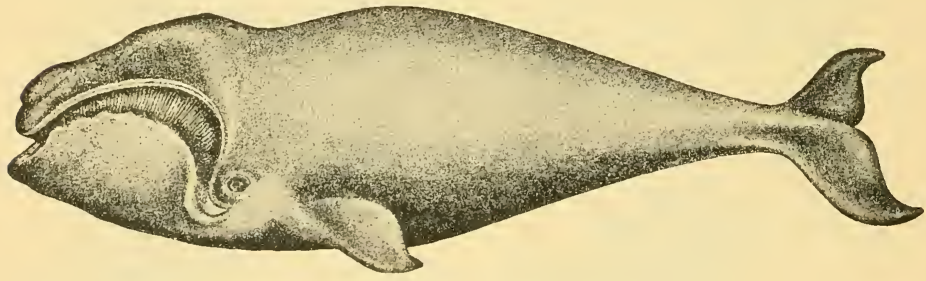

FIG. 574 .

Balena biscayensis. (From Guldberg.)

southern waters eat the small herring species besides the plankton is unknown to me; in boreal waters I am only aware that plankton has been found in their stomachs.

In the open ocean the plankton is scarce in the upper layers, but the deeper layers contain multitudes of large crustaceans and squids, and here only squid-hunting whales like the cachalot are found in numbers. Enormous diving power is peculiar to the cachalot and its ally, the bottle-nose. One of our most experienced bottle-nose whalers has told me how the whale "sounds" when struck by the harpoon, very often diving straight down, taking out as much as 400 fathoms of line in a perfectly vertical direction. It is very interesting to note that on our Atlantic cruise we found many proofs of the existence of quantities of squid in vast areas of the open ocean, partly belonging to the same species as the Prince of Monaco found in the stomachs of sperm-whales. The occurrence of these whales, and the importance of the sperm-whaling carried on in the open 
oceans, seem to indicate that the oceans are not quite so poor as Hensen's results would imply. But the nature, reproduction, and vertical distribution of the "plankton" differ entirely in the warm part of the ocean and in boreal waters. The only thing we can do at present is to compare these two classes of conditions, and to compare the groups of phenomena regarding adaptation found in the ocean.

Generally speaking, I think our experience justifies the opinion that the scientific investigation of an ocean must commence with observations of a qualitative kind. A chemist, intent upon the investigation of a complex chemical compound, sets to work in the same way, first endeavouring to make out the nature of the single components of the compound, and in many cases he will find it practicable to make preliminary, merely relative, estimates as to the quantity of each component present before entering into an absolute quantitative analysis.

Hensen himself has shown how to make a definite selection in the case of the complex "plankton "-problem by taking up for quantitative investigation the occurrence of one single organism, viz. the pelagic egg of the plaice. In this Pelagic case, of course, an infinitely more clearly defined and sharply limited problem presented itself, and Hensen endeavoured to solve it for certain areas of the North Sea and the Baltic, developing the very interesting idea that the number of spawning plaice might be arrived at by studying the number of pelagic eggs within a restricted area, and ascertaining the number of eggs spawned by the average female plaice. While studying the cod eggs of the Norwegian Sea I have very often had occasion to consider the same problem, but I have never ventured to attempt its solution. Even in this case I considered it necessary, first of all, to make qualitative investigations, commencing with a detailed study of the areas where the eggs of each species occur.

The Norwegian waters are peculiar in varying greatly in depth: in the course of a few miles one may find depths ranging from a few to a couple of hundred fathoms; they are very instructive although, compared with the North Sea or the Baltic, they exhibit extreme conditions.

Another point to be considered is the fact that eggs, as soon as spawned, are carried away by currents, the distance which they travel depending on various local conditions. The influence of these currents must, therefore, be ascertained, as the eggs cannot be considered as stationary. 
A third and important point is that all the individuals of a species do not spawn at the same time. Hensen himself thinks that each fish spawns several times within a short period, and besides the spawning season of each species varies from place to place. At a definite moment it is thus impossible to find all the eggs in the earliest stage, for as a matter of fact in the Norwegian coast waters the same haul includes eggs in various stages as well as larvæ and more advanced young. As regards Norwegian waters it is therefore, as far as I can see, at present impossible to realise Hensen's idea of counting the fishes of the sea, or to cope with the problem of calculating the stock arising from the developed larvæ.

Artificial fishhatching.

Quantitative investigations on the seafloor.

It is well known that in many countries a considerable amount of work has been devoted to so-called artificial fishhatching, which consists in keeping the eggs until the minute larvæ have escaped. Hopes have been entertained of increasing the fish-supply by means of this hatching, the idea having prevailed that these larvæ had a better chance of growing up than the eggs. But when these minute larva are placed in the sea, where there are already great numbers of them, they disappear from view in a few minutes, and their subsequent fate is entirely unknown. All calculations as to how many of them grow up must be based on unknown and uncontrollable factors, and become all the more doubtful considering there is now ample proof that the abundance of different annual classes varies enormously in nature.

Quantitative investigations of an entirely different kind have in recent years been started by C. G. J. Petersen, ${ }^{1}$ who constructed a bottom-sampler, or kind of gripper (see Fig. 575), which, like a dredging apparatus, brought up a large sample from the surface of the sea-floor. The bottom-sampler is intended to cut out a sample of one square foot from the bottom, which is passed through sieves, the sand and mud being sifted off, leaving the animals to be classified, measured, counted, weighed, and finally submitted to chemical analysis. These investigations on the abundance of bottom animals are simpler than those dealing with the pelagic organisms, which move so freely in a horizontal as well as in a vertical direction.

Petersen has also attempted to solve the problem of the quantity of fishes by experiment. ${ }^{2} \quad$ He captured great numbers

1 Report of the Danish Biol. Station, No. xx., I9I I.

2 "The Labelling of Fish in the Sea," Fishery Report for the Years $1888-1889$, and Report from the Danish Biol. Station, No. iv., 1893. 
of plaice, marked them, and let them go again. He then kept account of the percentage of marked plaice subsequently recaptured, and comparing this percentage with the total catch according to the fishery statistics he hoped to arrive

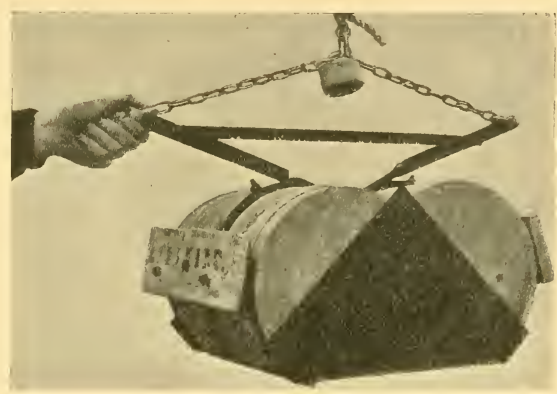

Fig. 575.-C. G. J. Petersen's Bottom-Collector.

approximately at the proportion between the number of plaice caught by the fishermen and those living in definite regions. In restricted areas, where immigration and emigration are insignificant, his interesting experiments have yielded very good results, providing probably the only accurate knowledge at present available regarding the abundance of fishes in the sea.

J. H. 



\section{INDEX OF PROPER NAMES}

Agassiz, Alexander, 1 2, 17, 18, 30, 33, 138, 731

Agassiz, Louis, IO

Aimé, G., 4, 216, 221, 703

Alberti, L. B., 2

Allen, E. J., 377

Anderson, W. S., 178

Andrea, A. F., 755

Andrusoff, Nicolaus, I 5

Appellöf, Adolf, vii

Apstein, Carl, 325, 374, 598, 599

Audouin, J. V., 7

Aurivillius, C. W. S., $310,556,642$

Bache, A. D., 8

Bailey, J. W., 8, 9, 307, 308

Balfour, A. F., I4I

Bartholomew, J. G., I 3 I

Baur, E., 369

Belknap, G. E., I I, 27

Bergh, R. S., 308

Bergon, P., 322

Berryman, Lieut., 9

Bjerkan, Paul, vii, 600, 708

Bjerknes, Vilhelm, 26I

Blackman, — 310

Blagden, Charles, 3

Blessing, H. G., 342

Bocage, Barboza du, Io

Bodländer, G., 177,178

Böggild, O. B., I9I

Bonnevie, Kristine, vii, 589, 625, 658

Boulenger, G. A., 388

Brandt, Karl, 31 1, 333, 367, 368, 369, 3So, $381,679,691$

Braver, August, 413, 424, 425, 601, 605, 6 i 1,6 I $5,625,676,677,678,679,680$, $681,682,684,746$

Bravais, A., 4

Brennecke, Wilhelm, 256

Bridge, T. W., 388

Brightwell, Thomas, 307

Brinkmann, August, vii, 577

Broch, Hjalmar, vii, 3II, 326, 359, 573, $666,667,759$

Brooke, J. W., 8, I30

Bruce, W. S., I8, 135
Buache, Philippe, 3

Buchan, Alexander, 72, 295, 703

Buchanan, J. Y., 13, 19, 183, 192, 230, 232, $236,246,267,295$

Bull, Henrik, 762

Bunsen, R. W., 253

Carpenter, W. B., 7, I0, 67

Caspari, W. A., viii

Castracane, Francesco, 308, 337

Charcot, Jean, 18

Chierchia, Gaëtano, 56I

Chrystal, George, 16, 132, 278

Chumley, James, viii

Chun, Cari, viii, $16,35,546,561,562,585$, $590,592,595,662,678,682,689,691$, 692,701

Claparède, Edouard, 308

Clark, Howard, 780

Clarke, F. IV., IS6

Cleve, P. T., 308, 310, 334, 337, 338, 339, $340,345,346,347,349,352,353,357$

Cohen, E., 178

Collet, L. W., I 89

Collett, Robert, 642, 643, 698, 739

Collins, J. W., 707

Cook, James, 3, 4

Cosa, Juan de la, 2

Coutière, H., 622

Cruquius, $\longrightarrow, 3$

Cusanus, Nicolaus, 2

Dahl, Knut, 581, 759, 763, 766

Dalrymple, Alexander, 3

Damas, Désiré, $383,569,572,575,581$, $639,640,642,645,658,711,726,727$, $735,759,761,762,764$

Dana, J. D., 5

Darwin, Charles, 661, 67 I

Davy, — 3

Day, Francis, 388, 607, 766

Dayman, Joseph, 9

Dicquemare, Abbot, 674

Dittmar, W., 175, 235

Doflein, F. J. T., 672,673

Dohrn, Anton, I8, 20

Donati, V., 3 
Dons, Carl, viii

Drygalski, Erich von, I7

d'Urville, T. S. C. Dumont, 4

Ehrenbaum, Ernst, 731

Ehrenberg, C. G., 307, 308

Ekman, F. L., 232

Ekman, Gustav, 15, 338

Ekman, V. W., 67, 234, 246, 263, 274, 275

Ellis, Henry, 215

Eschricht, D. F., 778

Fischer, Alfred, 369

Fischer, Otto, 706

Flint, J. MI., I7, 165

Fol, Hermann, 248, 250, $67 \mathrm{I}$

Forbes, Edward, 6, 7

Forch, Carl, 274

Forchammer, J. G., 178

Forel, F. A., 278

Forster, J. G. A., 3

Forster, J. R., 3

Fox, C. J. J., 253

Franklin, Benjamin, 3, 213,214, 674

Franklin, John, 7

Fulton, T. W., 261, 262

Gamble, F. W., 673

Garstang, Walter, 7 I 3

Giesbrecht, Wilhelm, 579

Gill, Theodore, 740

Glas, George, 77

Goethe, J. W. von, 660

Goodsir, Harry, 7

Gran, H. H., v, vi, 60, 65, 103, 105, II 7 , $225,645,691,693,708,717,719,726$, 727,728

Grassi, G. B., 753

Grieg, J. A., vii, 538

Günther, A. C. L. G., 5, 91, 388, 675, 737

Haeckel, Ernst, 20, 108, 309, 340, 562, 563, $564,57 \mathrm{I}, 574,58 \mathrm{I}, 645$

Haecker, Valentin, $565,566,567,624$

Halley, Edmund, 3

Heincke, Friedrich, 495, 515, $713,731,756$, $758,759,763$

Helland-Hansen, Björn, v, vii, 67, 93, 249, $283,303,481,516,694$

IIensen, Victor, 15, 37, 309, 310, 315, 321 , $334,337,347,349,358,360,382$, $563,571,652,703,718,731,772$, $773,775,776,778,783,784$

Heurck, H. van, 346

Hjort, Johan, viii, 412, 712, 722, 759, 767

Hoek, P. P. C., viii, $5^{8} 3$

Hoff bauer, C., 759

Holt, E. W. L., 73 I

Hooke, Robert, 2

I looker, J. D., 5, 6

Horne, John, 199, 202, 208
Hulett, —, I79

Huxley, T. H., 9

Irvine, Robert, I7 8, I $82, I \delta_{3}$, I 84, I 92 , 728

Irvine, William, 3

Iversen, Thor, v, 53, 6I

Jeffreys, J. Gwyn, I I

Jenkin, If. C. Fleeming, 9

Jensen, Adolf, 435, 547

Johnson, J. Y., 5

Joly, John, I60, I87

Jörgensen, Eugen, 31 I , 325, 350, 351, 642

Joubin, Louis, 590,592

Judd, J. W., I 84

Jungersen, H. F. E., 546, 547

Kant, Immanuel, 660

Karsten, Gustav, 322, 346, 347, $35^{6}$

Keeble, —, 673

Kelvin, Lord (Wm. Thomson), 12, 27, 29, $43,219,220,226,233$

Kiær, Hans, 527

Kircher, Athanasius, 3

Klebahn, H., 333

Knudsen, Martin, 237, 239, 246, 255, 300, 690

Koefoed, Einar, v, vii, 54, 88, 4 I 5, 569, 575 , $639,640,657,720,727$

Koehler, René, 544

Kofoid, C. A., 311, 323, 325, 326, 356

Kolthoff, Gustaf, 524

Kotzebue, O. von, 4

Krogh, August, 253, $25^{\mathrm{S}}$

Krümmel, Otto, 224, 260, 703

Krusenstern, A. J. von, 4

Kyle, H. M., 440

Lachmann, Johannes, 308

Lamarck, J. B. de, 660, 66 I

Lambert, J. H., I3 1

Lauder, H. S., 308

Lea, Einar, vii, $695,749,763,764,767$

Lebedinzeff, Arsenius, 15

Lee, G. W., I 89,759

Lee, S. P., 9

Lenz, H. F. E., 4

Liebig, Just us von, 367,728

Lo Bianco, Salvatore, 683

Lohmann, Hans, 310, 321, 325, 349, 356, $360,361,362,363,364,382,38_{3}$, $384,385,386,427,598,717,727$

Lovèn, S. L., 7

Lowe, R. T., 5

Lucas, F. R., 29, 30, 39, 40, I 70

Luksch, Jos., 249

Liitken, C. F., 737, 747, 755

Lysholm, —, $5 \mathrm{SI}_{\mathrm{I}}$

MacAndrew, R., 8

M'Clintock, Leopold, 9 


\section{INDEX OF PROPER NAMES}

M'Intosh, W. C., 73I

Magellan, Ferdinand, 2

Makaroff, S., 15

Marsigli, _- 3

Martins, C. F., 4

Masterman, A. T., 73I

Maury, M. F., 4, 8, 195, 213

Meisenheimer, Johannes, 589

Mercator, Gerard, 2

Mill, H. R., I 3

Milne-Edwards, Henry, 7

Mohn, H., 26I

Monaco, Prince of, I3, 90, 252, 544, 585, $590,592,622,652,782$

Mortensen, Theodor, 493, 544, 546, 547

Moseley, H. N., 577, 687

Mulgrave, Lord, 3

Müller, G. IV., 582

Miiller, Johannes, 7

Müller, O. F., 3, 307

Murray, George, 3 Io

Murray, James, is

Murray, John, v, vi, vii, viii, 7, I3, I 5, I6, $17,57,106,108,130,132,133,134$, I 43, I61, I70, I78, I82, I 83, I 84, I92, $225,229,299,308,310,355,4$ I 3, 4 I 8 , $426,427,428,430,517,545,546,56$ I, $564,599,648,661,662,666,687,705$, $707,716,717,719,728,772$

Nansen, Fridtjof, I 5, I Io, 209, 21 9, 220, 232, $259,274,283,302,303,342,359,728$

Nares, G. S., 67

Nathansohn, Alexander, 311, 370, 371, 372, 378,380

Natterer, Konrad, I 5

Nelson, E. W., 377

Neumann, Günther, 599

Nitsch, Roman, 308

Nordenskjöld, Otto, 17

Nordgaard, Ole, viii, 229, 532, 581, 642, $657,712,716,720$

Norman, A. M., 493

Cirsted, A. S., 309, 334

Orleans, Duke of, 434, 639

Ostenfeld, C. H., 255, 310, 31 1, 352, 353

Ostwald, Wolfgang, 31 I, 3 I 8, 689, 690, 69 I, $692,693,700,703,704$

Palumbo, G., 56 I

Parry, W. E., 4

Paulsen, Ove, 3I I

Pavillard, Jules, 3 I I

Peach, B. N., I99, 202, 208

Peake, R. E., 19, I69, I70, 299

Péron, F., 4

Petersen, C. G. J., 36, 43, 359, 386, 427, $428,431,503,504,662,713,717,731$, $733,753,756,771,784,785$

Petersen, Eugen von, $35,249,56$ ז
Pettersson, Otto, 15, 20, $219,232,253,300$, $301,302,310,338,359,714,715,716$

Philippi, Emil, 174

Phipps, Captain, 4

Plate, Ludwig, 500, 515

Popofsky, A., 564

Pourtalès, L. F. de, 9, Io

Puehler, Christoff, 2

Pullar, F. P., 16

Pullar, Laurence, 16, 225

Pullen, Captain, 4, 9

Piitter, August, 31 I, 384-386

Raben, E., I 84, I $85,368,385$

Rafter, G. W., 372

Raken, M., ${ }^{7} 78$

Rasch, Halvor, 507

Rasmussen, Thorolv, vii, 664

Rattray, John, I 3

Rauschenplatt, E., 7 I 7

Redeke, H. C., 7 I 7

Regnard, Paul, 252

Reibisch, Johannes, 759

Renard, A. F., 134, 143, I61, 192

Rennell, James, 5

Richter, C., 2 I 7

Risso, J. A., 5

Römer, Fritz, 517, 524, 525

Romme, - 5

Ross, J. C., 4, 5, 6

Ross, John, 4, 5

Ryder, J. A., 740

Sabine, Edward, 4

Samter, - 556

Sandström, J. IV., 274, 693

Sarasin, Edouard, 248

Sars, G. O., viii, 8, 225, 309, 438, 493, $507,508,517,523,532,581,582$, $583,645,648,654,655,656,712,714$, 729,731

Sars, Michael, 6, 7, 574

Saussure, H. B. de, 4, 2 I 5

Schaudinn, Fritz, 517, 524, 525

Schimper, A. F. W., 313, 315, 364, 378

Schloesing, T., 177

Schmelck, Ludwig, I9 I

Schmidt, Johs., 67, 72, 334, 634, 710, 713, 73I, 735, 753

Schmitz, Fr., 334

Schott, Gerhard, 299, 780

Schultze, M. S., 684

Schiitt, Fr., 309, 31 5, 337, 348

Scoresby, William, 4,5 , I I

Scott, R. F., I 7

Sedgwick,,- 372

Semper, Carl, $73^{8}$

Shackleton, E. H., I8

Sigsbee, C. D., 27, 29, 30, 31, 32, 33

Smith, B. Leigh, I I

Sörensen, Gerhard, 7 I 4 
Spratt, T. A. B., 7

Steenstrup, Japetus, 590, 642

Stein, T. R. von, 308, 381,719

Steuer, Adolf, 563, 674, 701, 773

Stuxberg, Anton, 526

Sund, Oscar, vii, $5^{8} 5,667,720,759,762,766$

Tait, P. G., 246

Tanner, Z. L., 706

Théel, Hjalmar, 4 \$8, 490

Thomson, C. Wyville, 7. Io

Thomson, J. S., 759

Thomson, William (see Kelvin)

Thouars, A. D., 4

Thoulet, I., I 87

Tizard, T. H., 7, I3, 546, 66 I

Torell, Otto, ro

Trybom, Filip, 7 I 3

Turner, William, $7 \mathrm{So}$

Vaillant, A., 4I 3

Van Heurck, H., 346
Vanhöffen, Ernst, 57 I

Van 't Hoff, J. H., I 90,366

Verrill, A. E., 577, 707

Verworn, Max, 691

Waghenaer, L. J., 2

Wallich, G. C., 9, 308

Weber, Max, 17

Wedderburn, E. M., I 6

Wegemann, Georg, 226

Wells, J. C., II

Weltner, Wilhelm, 556

Wesenberg-Lund, C., 3 I I, 343

Whipple, G. C., 372, 380

Wilkes, Charles, 5

Wille, J. N. F., 333

Winkler, L. WV., 253

Wolfenden, R. N., 267

Woltereck, R., viii, $5^{8} 3$

Wright, E. P., IO

Zederbaur, E., 325 


\section{INDEX OF GENERA AND SPECIES}

Abra, 494

longicallis, 482,504

nitida, 482

Abraliopsis morisii, 595

Acanthephyra, IOI, I 1 8, I 26, I27, $58_{5}, 622$ $624,654,659,699$

multispina, $5 S_{5}, 622-624,668,720$

furpurea, $585,622.624,668,720$

Acanthias, 452, 647

vulgaris, $39 \mathrm{I}, 44 \mathrm{I}, 442,447,45 \mathrm{I}, 646$

Acanthochiasma fusiforme, 564

Acanthogorgia armata, $53 \mathrm{~S}$

Acanthometron pellucidum, 564, 565

Aianthonidium echinoides, 564, 565

Acanthostanms nordgaardi, 564,565

Acanthozone cuspidata, 506, 558,589

Acartia, 645

bifilosa, 579

clausi, 655

dane, 655,657

Aceratias, $108,610,677$

macrorhinus indicus, $S_{7}, 90,96,609,615$,

6 I8, 625, 627, 744, 745

mollis, 615

Achnantes, 345

teniata, 345

Actinia equina, 463, 464, 479

Actinostola callosa, 482,504

Aginella spinosx, 5 I I

Aigisthus mucronatus, 655

Eolis, 468, 494

rufobranchialis, 468

Aetea, 472, 479

Aitideus armatus, 655

giesbrechti, 655

dsalnopsis, 631, 697

elegans, 574, 642

Aglantha, I I8, 658, 698

digitalis, 570, 57 I, 640, 659

Aslaura hemistoma, 57 I

Agliscra, 669

ignea, $57 \mathrm{I}$

Akera bullata, 469

Alcockia rostrata, 4 I 4

Alcyonidium, 47 I

gelatinosum, 498

hirsutum, 463, 479
Alcyonium, 494, 500

digitatum, $472,484,500,5$ I 2, 5 I 4

Alepocefhalis, 71, 76, $\mathrm{S}_{1}, \mathrm{~S}_{7}, 89,95,12 \mathrm{I}$, I 27,4 I 2,4 I3, 4 I6, 4 I9. $420,433,602$, 743

giardi, 394, 433

rostratus, 414,423

Aleposomus copei, 414

Allantactis parasitica, 521

Alloposus mollis, 706

Amallophora affinis, 655, 657

magna, 640, 655, 657

obtusifrons, 655

Amalopenaus alicei, 668

elegans, 668

tinayrei, 668

Amaroucium mutabile, 529

Amathillopsis spinigera, 521, 522

Amauropsis islandica, 528

Ammodytes, I I0, 474

Amphidinium gracile, 365

Amplithelia, 508,546 ramea, $4 \mathrm{~S}_{5}$

Amphioxus, 474

Amphiprora, 345 hyperborea, 345

Amphisolenia, 347

globosa, 327

palmata, 356

tenella, 327

Amphinua chiajei, 492

denticulata, $53^{S}$

fliformis, 492

norvegica, 4S2, 504, $5 \mathrm{II}$

sundevalli, 529

Anabcna baltica, 345

Anam-hicas, 647

lupus, 44 I, 442, 45 I

minor, 442

Anguilla vulgaris, 752, 753

Ankyroderma jeffreysi, 529

Anomalocera, 645

patersoni, 579

Anomia, $50 \mathrm{~S}$

ephippium, 472, 553

Anonyx, $52 \mathrm{I}$

Antalis agilis, 504, 505 
Antalis entalis, $475,494,500,533$

striolata, 482

Antedon, 506

eschrichti, 517, 519, 520, 526, 529, 533

petasus, 486

prolixa, 519, 529

tenella, 506, 533

Antelmincllia gigas, 3 I 5

Antennarius, $\mathrm{IO}_{3}, 67 \mathrm{I}$ marmoratus, 610, 611, 615, 633, 671

Anthoptilum murrayi, $53^{8}$

Antimora, 127, 424

riola, I 2 I, 400, 40 I, 432, 433

Aphanizomenon flos-aqui, 345

Aphrodite aculeata, 50I, $54 \mathrm{I}$

Aporrhais pes-pelecani, 494

Appendicularia, $3 \mathrm{~S}_{2}$ sicula, 598

Apscudes spinosus, 506

Arainnactis, 120,126 albida, 576, 577, 634, 642, 711, 712

Arca, 4 is

glacialis, 528

pectunculoides, $4 \mathrm{~S}_{3}$

tetragona, $5 \mathrm{I} 3$

Architenthis, 65 I, 652, 653

dux, 643, 646, 65I

Arcturus, 51 I, 52 I, 534

baffini, $52 \mathrm{I}, 523$

Arenicola, $489,530,556$

marina, 530

piscatomm, 464, 466, 479, 530

Argentina, 389

silus, 394, 447, 455

sphyrena, 394, 447, 449

Argonauta, 419, 597, 632

Argyropelecus, 68, 85, 87, 89, $101, \quad 126$, 127, 419, 605, 616, 6I8, 630, 68I, $68_{3}, 684,698,708,741,742,743,744$, 755

aculeatus, 612, 618, 630, 643

affinis, 612, 629, 630, 669

hemigymnus, $85,612,616,618,629,630$,

$643,684,698,738,739$

olfersi, 612, 629, 630, 643

Aricia, 482,504

Aristeopsis, 420

Arnoglossus, 448

grohmanni, 407, 447, 450

laterna, 407, 447, 448

lophotes, 79, 407, 447, 44S

Ascidia mentula, 479

obliqua, 504, 534

prunum, 530

venosa, 510

Ascidiella aspersa, 479

virginea. 497

Ascophyllwm, 470

nodosum, 335

Ascorhynchus aby'ssi, 524

Astacilla, 521
Astacilla granulata, 521 longicomis, 511 , 513

Astarte banksi, 528,530

borealis, 528,535

compressa, 530

crebricostata, $52 \mathrm{~S}$

clliptica, 530

sulcata, 494, 508

Asterias glacialis, $47 \mathrm{I}, 472$

grönlandica, 529

hyperborea, 529

lincki, 529

mïlleri, 473, 492

panopla, 529

mbens, 464, 473, 475, 479, 491, 503, $509,512,532,534$

Asterionella gracillima, 343

japonica, 346

notata, 346

Asterolampra, $38 \mathrm{I}$

marylandica, 347,356

rotula, 347

Asteromphalus, $3 \mathrm{SI}_{\mathrm{I}}$

heptactis, 347,354

Asteronyx loveni, 504, 540

Asthenosoma hystrix, 538

Astrogonium pareli, 540

Astronesthes, 95, 664, 702

niger, 93, 95, 603, 612, 618, 703, 720

Astropecten, 475,476

irregularis, $475,49 \mathrm{I}, 5 \mathrm{IO}$

Astrorhiza, 504

arenaria, $48_{2}$

crassatina, 527

Atelecyclus septemdentatus, 496, 5 10, 5 I I

Atherina, 447

presbyter, 397

Atlanta cunicula, I73

depressa, 173

fusca, 173

gaudichaudii, 173

sibbosa, 173

helicinoides, 173

inclinata, 173

inflata, 173

involuta, 173

lesuenrii, I73

mediterranea, 173

peronii, 173

primitia, 173

quoyana, 173

rosca, 173

souleyetii, 173

tessellata, 173

turriculata, 173

violacea, 173

Atolla, 86, I01, IO8, I I8, 572, 627, 669

bairdi, 624, 642, 659, 666

ieyvillei, 573

Augaptilus, 578,655

filigerus, 580,655 


\section{INDEX OF GENERA AND SPECIES}

Augaptilus gibinus, 655

laticeps, 655

longicaudatus, 655

oblongus, 655

palumboi, 655

squamatus, 655,657

Aulasantha scolymantha, 565, 566, 567

var. bathyliza, 566

var. typica, 566

Aulographis pandora, 565, 566, 567

Aurelia, $9 \mathrm{~S}$

aurita, 572, 645

solida, 573

Auxis thasardus, 643

Axinopsis orbiculata, $52 \mathrm{~S}$

Axinus ferruginosus, $4 \mathrm{~S} 2$

flexuosus, 482,504

gouldi, $52 \mathrm{~S}$

Bacteriastrum delicatulum, $347,35^{8}$

elongatum, $347,356,35^{S}$

varians, 354,355

Balena biscayensis, $7 \mathrm{So}, 7 \mathrm{~S}_{2}$

mysticetus, 778,779

Balenoptera, 779

borealis, 779

musculus, $714,778,779$

physalus, 779

Balanoglossus, 503

Balanus balanoides, $46 \mathrm{I}, 479,4 S_{5}, 532,556$

Bassozetus tirnia, 4I 4

Bathothauma lyromma, 592, 594, 596

Bathybiaster robustus, 538,547

vexillifer, $51 \mathrm{~s}, 519,524,53 \mathrm{~S}, 547$

Bathylizes, 9

Bathycrinus, 545 carpenteri, 523

Bathygadus, 770

longifilis, 399, 423, 432, 433

melanobranchus, 399, 423, 432, 433, 769

Bathymicrops, 389, 686, 687 regis, 88, 396, 416, 419, 686, 687

Bathyplotes tizardi, 4\$2, 486, 504, 511,540

Bathypontia minor, 655,657

Bathypterois, 389, 420, 433, 606

dubius, 8o, 396, 686

longicaudata, 4 I 4

longipes, 396, 414, 416, 4I 8

Bathysaumes, 76, 95, 120, I $21,389,420$, 433,606

ferox, 121, 396

mollis, 414

Bathysiphon fliformis, 482

Bathytroctes, 394

attritus, $4 \mathrm{I} 4$

Bela, $52 \mathrm{~S}$

Belone, 607 vulgaris, 748

Benthesicymus, 420

Benthopecten spinosus, 537, 538

Benthosaurus, 95, 420
Benthosaums grallator, 396, 686, 687, 688

Beroi, I I 8, 658

cucumis, 575

Biddulphia aurita, 320, 345

mobiliensis, 346, 355

regia, 346

sinensis, 353

Biloculina levis, 527

Blepharocysta splendor maris, 356

Bolina infundibulum, 575

Bolitana, 595

diaphana, 597

Bolocera tuedia, $482,484,500,504,510$

Bonellia viridis, 490

Boreofusus bernicicnsis, 494

Boreophansia inermis, 640 raschii, 666

Bothus, 440 maximus, 441, 442, 451

rhombus, 44I, 442, 45I

Bougainzillia, 479

superciliaris, 569

Bowerbankia, $47 \mathrm{I}$ imbricata, 463

Box $, 77,448$

vulgaris, 403, 447

Brachioteuthis riisei, 59 I, 596

Brama raii, 643

Brisinga coronata, 540

cndecacnemos, 486,540

Brissopsis, 430, 492, 519

lyrifera, 490, 492, 504, 510

Brosmizs, 389

brosme, 400, 44I, 442, 447, 45I, 733

Buccinum, I I 2, $52 \mathrm{~S}$

slaciale, $52 \mathrm{~S}$

grönlandicum, $52 \mathrm{~S}$

hydrophanum, 528

zendatum, 472, 494, 512

Bythocaris, 520

leucopis, 524

payeri, 529

simplicirostris, 506

Cadulus subfusiformis, 482, 504

Calanus, 427, 69\$, 726

cristatus, 579

finmarchicus, I08, I $18,383,579,580,639$,

$640,645,654,657,666,691,698,726$

gracilis, 654,657

helgolandicus, 654

hyperboreuts, $118,579,639,640,654,657$, 658

minor, 654

robustus, 654

Calciosolenia murrayi, 332, 347, 365

Callionymus lyra, $45^{\circ}$

maculatus, 410,449

Callitcuthis reversa, 591, 596, 625, 627

Calocalanus, 579

pavo, 693 
Calocaris, 427 macandrea, $54 \mathrm{I}$

Calveria hystrix, $536,53 \mathrm{~S}$

Calyptrosphera oblonga, 365

Campanularia flexuosa, 470, 479 johnstoni, 498 longissima, 498 verticillata, $49 \mathrm{~S}$ volubilis, 5 I 1

Campylaspis horrida, 506 verrucosa, 506

Cancer, 64 pagumus, 476, 495

Candace, 655,657

Candeina nitida, I 72

Cantharus lineatus, 74, 403, 447, 770

Caprella linearis, 467,497

septentrionalis, 497

spinosissima, 52 I

Capros, 71 aper, $405,447,448,609,6 \mathbf{I}_{4}$

Caran $x, 89,370,635,747$ trachurus, 77, 98, 406, 447, 614, 635, 646,747

Carcharias glaucus, 635,644

Carcharoion, 87, 388, 391, 4 I9 megalodon, I 56, 39 I

Carcinus monas, 464, 477, 479

Cardium, 556 ciliatum, 529 echinatum, 494, 495 edule, 464, 466, 475, 479

fasciatum, 475

grönlandicum, 529

minimum, 506

Careproctus reinhardi, 436

Caridion gordoni, 506, 515

Carinaria, 590

atlantica, 173

cithara, 173

cornucopia, 173

cristata, 172

depressa, $\mathbf{1 7 2}$

fragilis, 172

galea, 172

gaudichaudii, 173

lamarckii, 154,172

punctata, 173

Catablema campanula, 569, 570, 640

Cavolinia, 419

sibbosa, 172, 589

globulosa, I 72

inflexa, 1 72, 201, 589

longirostris, I 72, 589

quadridentata, 172

tridentata, 172,589

trispinosa, 172, 201

uncinata, 172,589

Centrina, 64 salviani, 39I, 447

Centriscus scolopax, 79, 389, 396, 447
Centrolophus pompilus, 643

Centropages, 645

Centropages hamatus, 579 typicus, 579, 655

Centrophoms, 388, 423, 424, 433

calceus, 392

coelolepis, 392

crepidater, 392

squamosus, $392,447,448$

Centroscyllizm fabricii, 392

Cephalophanes refulgens, 654

Cerataulina bergonii, $346,354,377$

Ceratias, 8I, 82, I0I, 609, 6 I 4

conesii, 92, 608, 61 4,627

Ceratium, 323, 325, 326, 344, 346, 349, $374,376,377,384$

arcticum, $347,350,35 \mathrm{r}, 357,35^{\mathrm{S}}$

arcuatum, 356

arietinum, 354, 356

asoricum, $347,354,356,35^{8}$

bucephalum, 347

buceros, 356

candelabmem, $347,355,356,35^{8}$

carriense, 347,356

cephalotum, 347

compressum, 325

declinatum, 356

extensum, 347,356

furca, $347,348,354,355,375,377$

fusus, $347,348,355,356,358,375,377$

gibbenum, $345,356,358$

gracile, 356

gravidum, $347,356,35^{8}$,

hirundinella, 325

intermedium, $347,350,351,35^{8}$

karsteni, 356

lamellicorne, 347,354

limulus, 356

lineatum, $325,347,355,358$

longipes, $347,348,350,35 \mathrm{I}, 357$

macroceros, $347,350,35 \mathrm{I}, 355,356,35^{8}$

massiliense, 347,356

palmatum, 347, $35^{6}$

pavillardii, 351,356

pennatum, $347,35^{6}, 35^{8}$

pentagonmm, $356,35^{8}$

platycorne, $324,325,356,35^{8}, 5^{80}$

prolongum, 347

pulchellum, $35^{6}$

reticulatum, $347,35^{6}$

tenue, $35 \mathrm{I}, 356$

var. buceros, 351

teres, 356

trichoceros, 324, 351, 356

tripos, 307, 325, 347, 348, 354, 367, 374, $375,3 \mathrm{SI}_{\mathrm{I}}$

vultur, $35 \mathrm{I}$

var. japonica, $35 \mathrm{I}$

Ceratocorys, 347

horrida, $35^{6}$

Cestum veneris, $85,89,575,63$ I 
Cetomimus, $104,677,682$

storeri, 6I $3,625,627,68$ I, 682

Chatoceras, 3 r8, 342, 344, 345, 346, 348 , $357,3 \mathrm{~S}_{\mathrm{I}}$

anastomosans, 346

atlanticum, 347, 354, 357, $35 \mathrm{~S}$

boreale, 347,358

cinctum, 346

coarctatum, 347, 356

constrictum, 321, 346, 348, 372, 373

contortum, 346, 354, 358

convolutum, 347,354

coronatum, 354

crinitum, 346

criophilum, $347,357,35 \mathrm{~S}$

curvisetum, 346, 355, $35 \mathrm{~S}$

debile, 346, 348, 357

decipiens, 317, 319, 320, 347, 354, 355, $357,35^{8}$

densum, 347, 354, 355

diadema, 346, 354

dichata, 347, 354, 356

didymum, 345, 346, 355

diversum, 346, 355

femur, 346

furca, 346, 355

furcellatum, 345,358

laciniosum, 342, 343, 346, 357, $35^{\text {S }}$

lorensianum, 355

mediterraneum, $35 \mathrm{~S}$

mitra, 345

perpusillum, 357

peruvianum, 354, 356, $35^{\mathrm{S}}$

pseudocrinitum, 321,346

radians, 346

radiculum, 346

schiittii, 342, $343,346,354,355,357,35^{8}$

scolopendra, 346,354

simile, 346

sociale, 346

teres, 346

tetrastichon, 356

weissflogii, 346

Chatoderma, 494

Challengeria tridens, 566 xiphodon, 567

Chara, 177

Chauliodus, 85, I0 I, 68I, 720

sloanei, $S_{5}, 96,60_{3}, 6$ I, 6 I $8,629,630$

Chelyosoma macleyanum, 529

Cheraphilus, $55 \mathrm{I}$

nanus, 496

Chiasmodus niger, 607, 613, 720,721

Chimara, $71,424,672$ mirabilis, 59, 389, 393, 433, 672

monstrosa, $389,423,447$

Chiridiella macrodactyla, 639

Chiridius armatus, 640, 655

obtusifions, 640

poppei, 655

Chirodota lavis, 529
Chiroteuthis, 592

Chirundina stressi, 654

Chiton, 494

cinereus, 472,495

Chlorophthalmus productus, 686

Chondractinia digitata, 493, 500, 510

Chrysaora mediterranea, 573

Chrysophrys aurata, 74, 403

Cinclopyramis infundibulum, I 49

Ciona intestinalis, 469, 479, 497, 517, 529

longissima, 529

Circalia stephanomma, 574

Cirrotenthis, 595

miilleri, 522

umbellata, 597

Cirrothauma, 595

murrayi, 595, 597, 625, 682

Citharistes, 328

apsteini, 330

Cladorhiza, $5 \mathbf{I 9}$

Clathrocanium regina, $\mathbf{1} 49$

Clava, 470

squamata, $46_{3}, 470,479,4^{8} 7$

Clavellina lepadiformis, 479

Cleippides quadricuspis, $52 \mathbf{I}$

Climacodium, 3 I 5

Clio andrea, 172

australis, 172

balantium, 172

chaptali, I72

cuspidata, I 72, 588,589

falcata, $5 \mathrm{Sg}, 625,669,720$

polita, 172

pyramidata, I I 8, I $72,588,589,642,7$ I I

sulcata, 172

uncinata, 7 I I

(Creseis) acicula, I72, 5SS, 589

chierchice, I 72

conica, 172

virgula, I 72

(Hyalocylix) striata, I72, $5 \mathrm{S9}$

(Styliola) subula, 1 72, $5^{89}$

Clione, $70 \mathrm{I}$

limacina, I07, го8, I 8 , I26, 588, 589 , $645,658,659,698,699$

Clupea alosa, 447,44 S, 6о I, 6 I I , 635, 644, 646 finta, 644

harengus, 601, 645,765

pilchardus, 447, 601, 602, 61 1, 635, 644 sprattus, 601, 645, 765

Coccolithophora, $33 \mathrm{I}$

leptopora, 332, 347, 365

lineata, 365

pelagica, $347,354,365$

wallichii, 365

Codonium princeps, 569, 570, $64^{\circ}$

Colossendeis, 547

angusta, 547

proboscidea, 520, 529

Conchoderma virgatum, $5 \mathrm{~S} 2$

Conchacia, 655 
Conchacia antipoda, 58 I borealis, $58 \mathrm{I}, 640,655$ elegans, $581,655,666$ maxima, 655 obtusata, $58 \mathrm{I}, 655$

Conchacilla, 655 lacerta, 655

Conchacissa, 655 armata, 655

Conger vulgaris, 44I, 442, 45 I

Conocara, 7 I macroptera, 394

Copilia, 579, 655, 657

Corallina, 145

Corbula gibba, 494

Corella parallelogramma, 479

Corethron criophilum, $347,35 \mathrm{~S}$ valdivia, 322

Coris julis, $78,405,447$

Corophium grossipes, 489

Corycaus, 655

Corymorpha glacialis, 534 nutans, 569

Coryne, 470 pusilla, 470

Corynomma speculator, 592, 596

Corystes, 502 cassivelanus, 496, 501, 502

Coscinodiscus, $34 \mathrm{~S}$

centralis, 347,354

concinmus, 355

excentricus, $35 \mathrm{~S}$

granii, 345

lineatus, 355

marginatus, 354

radiatus, 347

rex, I 7, 3 I 5,3 I $6,347,356$

stellaris, 347

subbulliens, 3 I 3,347

Coscinosira estrupi, 347,358

polychorda, 346

Cottunculus microps, 436 subspinosus, 436

Cottus quadricornis, 535

Cranchia scabra, 596, 632

Crangon, 427, 496, 55 I allmanni, 496, 506, 533, 534, 666 vulgaris, 532, 553

Crania anomala, 506, 507

Creseis acicula, 588,589

Cribrella sanguinolenta, 549

Cristellaria, 482

Crossota, 669 brumnea, 570, $57 \mathrm{I}$ norvegica, 57 I, 640

Ctenodiscus crispatus, 528, 529, 534, 535

Ctenopteryx siculus, 591, 596

Cucumaria, $55^{6}$

elongata, 492

frondosa, 473, 477, 488, 512, 530, 555 glacialis, 529
Cucumaria hispida, $4 \mathrm{~S} 2,5 \mathrm{O} 4,540$ lactea, 493

minuta, 529

Cultellus pellucidus, 494

Cupulita cara, 574 sarsi, 7 I I , 7 I 2

Cuviorina columnella, I 72, 589

Cyanea capillata, 572, 645, 736 lamarckiana, 572, 642

Cy'clocaris, 669 guilelmi, 584, $64 \mathrm{I}$

Cyclopterus, 647

Cyclosalpa, 599 floridana, 600, 632

pinnata, 600, 632

Cyclothone, 93, 96, 103, 126, 604, 618, 619, $623,624,625-627,644,677,678,68 \mathrm{I}$, $699,720,739,742,77 \mathrm{I}, 777$

acclinidens, 612,676

lizida, 6 г 2,676

microiton, 86, IOI, I02, I03, I0 8, I I 8 , 1 26, 604, 61 2, 618, 6 19-622, 624, 625$627,659,664,665,676,677,681,688$, $699,718,739,740,74 \mathrm{I}, 77 \mathrm{I}$

microdon pallida, 612,676

obscura, 68 I

sisnata, 85, Iо1, I02, 103 , I08, I I 8,604 , $612,618,619-622,624,625-627,628$, $664,676,677,681,699,739,740,741$, 771

signata alba, 612, 676

Cyema, 702

atrum, 87, 96, 101, 605, 612, 618, 625, $627,664,665,677,68 \mathrm{I}$

Cylichna alba, 530

cylindracea, 494

Cymbalopora (Tretomphalus) bulloides, I 72

Cymbulia peronii, 589

Cymonomus normani, $53 \mathrm{~S}$

Cyphosus hoscii, 6I 4

Cyprina islandica, 494, 495, 553, 554

Cystosira, 335

Cystosoma, $\&_{5}, 8_{9}, 92,5 \delta_{3}$

neptuni, $5 \mathrm{~S}_{4}$

Cythore dictyon, 155

Dactyliosolen antarcticus, 347, 354 tenuis, 354

Dactylostomias, 93, IOI, 6I 2, 6 IS

Deima fastosum, 54 I, 543

Dendrodoa aggregata, 529

Dendronotus velifer, 534

Dentalium caudani, 539

Dentex, 7I, 79, 448, 449

macrophthalmus, 403, 424, 447, 448, 77 I maroccanus, $70,403,447,448$

vulgaris, 74,403

Desmoteuthis pellucida, 596

Detonula cystifera, 345

schraderi, 313,346

Diacria quadridentata, 589 


\section{INDEX OF GENERA AND SPECIES}

Diacria trispinosa, 588, 589

Diagramma, 449 mediterraneum, 74, 403

Dibranchus hystrix, 4 I I

Dicoryne conferta, 498

Dictyocha fibula, 358, 365

Dinonemertes investigatoris, 577,578

Dinophysis, 327,365

acuminata, 355,377

acuta, 327, 347, 355, $35^{8}$

granulata, 347,382

hastata, 347

homunculus, 347

rotundata, $355,358,377$

schröderi, 356

schiittii, 347, 354, 356, 35s

uracantha, 347,354, 356

Diphasia abietina, 5 I I

fallax, 5 I I

Diphyes arctica, 573, 574, 640

Diplopsalis lenticula, $355,356,358$

Discosphara thomsoni, I 45

tubifer, 365

Disseta palumboi, 655

Distephanus speculum, 354

Distoma crystallinum, 534

Ditylum brightwellii, 346

Doliolum, 5 ${ }_{3}, 598,599,600,696$ gegenbauri, 599

krohni, 599

miilleri, 599

tritonis, 599, 600

Doratopsis, 591, 596

exophthalmica, 591, 592, 596

lippula, 592, 596

Dorigona, 419

Doris, 468-494

tubercuiata, 468

Dorocidaris, 508

papillata, 507, 509

Dosinia, 513

lincta, 494, 495

Doto, 494

Drepanopsetta, I 10

Dynamena pumila, 462, 463, 470, 477, 532

Dysmorphosa octopunctata, 569

Dysomma, $68_{3}, 746$

Ebalea cranchi, 495, 496 tuberosa, 495, 496

Echinaster, $55^{6}$ sanguinolentus, 493, 509, 5I3, 530, 534, 555

Echinocardium, 475, 491, 513, 514, 519 cordatum, 488

flavescens, 475

Echinocyamus pusillus, 475, 493, 508

Echinosigra phiale, $53^{8}$

Echinus acutus, $473,478,488$

forma flemingi, 478

forma norvesicus, 508,509
Echinus affinis, 538

alexandri, 538

elegans, 493

esculentus, 465, 473, 478, 493, 503, 508, $512,513,514,558$

miliaris, 493

Echiostoma, 612

Eledonella, 595

pygmcea, 597, 625

Elpidia, 4I9, 538

glacialis, 523, 524

Engraulis encrasicholus, 447, 601, 602, 6 I I, $635,644,646$

Epiganus telescopus, 402

Epimeria cornigera, 506

loricata, 506, $533,55^{\mathrm{S}}$

Epithemia, 314

Epizoanthus paguriphilus, 538

Eryoneicus, $5^{8} 5,5^{86}$

cacus, 586

Ethmodiscus rex, 3 I 5

Etmopterus, 424

Eucalanus, 720

attenuatus, 654,657

cornutus, 654

elongatus, 654, 657

monachus, 654

nasutus, 654

Eucampia balaustium, 346

zodiacus, 346, 354, 355

Euchata, IO7, IIS, 427, 645, 654, 669, 698,720

acuta, 654

barbata, 639, 654, 657

glacialis, 639, 640, 654, 657

marina, $580,654,657$

norvegica, I I $8,505,579,580,639,640$,

$654,657,658,659,666$

Euihirella, 579

brevis, 654,657

messinensis, 654

rostrata, 654

venus, 654

venusta, 580,654

Eucladium, 177

Eucopia australis, 720

Eucoronis challengeri, 146

Eudorella emarginata, 506

Eukrohnia fowleri, 578, 669

Eumenia crassa, 501

Euodia cuneiformis, 354, 355, 358

Eupagurus bernhardus, 557

Euphausia, 654, 720

gibba, 654

krohni, 654

tenera, 654

Euphysa aurata, 569

Eupyrgus scaber, 529

Eurycope gigantea, 521, 654

Eustomias, 612

obscurus, 6 I I 
Euthemisto, 107, 108, I28, 126 libellula, 584, 640-64I, 654

Euthynnus alliteratus, 643

Eutonia socialis, 569

Exocoetus, 607, 633, 747, 748 spilopus, 82, 607, 61 3 volitans, 644

Exuvialla, $3^{65}$

Ficulina ficus, 500, 510

Fierasfer, I 20, 634

Filigrana implexa, 501, 506

Flabellum, 538, 539 arcticus, $5 \mathrm{O} 4$

Flustra foliacea, 498 securifrons, 498

Flustrella, $47 \mathrm{I}$ hispida, 463

Fragilaria, 3 I 5, 345 antarctica, 346 crotonensis, 343 cylindrus, 345 oceanica, 3 I 6, 345

Freyella sexradiata, 542, 543

Fritillaria venusta, 598

Frugella, 4 I9

Fucus, 462, 464, 470, 487, 526 vesiculosus, 335

Finchalia woodwardi, 668

Funiculina, 504 quadrangularis, $482,504,540$

Gadiculus argenteus, 399, 424, 433, 447, 448,733

Gadus, 389 aglefinus, IIO, 399, 44I, 442, 447, 45 I, 733 callarias, 399, 44 I, 442, 45 I, 730, 73I, $733,737,741,762$

esmarkii, 399, 447, 733

luscus, 399, 447, 448, 733

merlangus, 399, 44 I, 442, 447, 45 I, 733 minutus, 733

navaga, 44 I, 442

pollachius, 44I, 442, 45 I, 731, 733

poutassou, 399, 447, 733

saida, 437, $64 \mathbf{I}$

virens, 44 I, 442, 45 I, 647, 73I, 733, 737, $760,76 \mathrm{I}$

Gaëtanus armiger, 655

caudani, 655

kruppi, 655

laticeps, 655

latifrons, 655

miles, 655

minor, 655

Gaïdius notacantha, 655 temuispinus, 655

Galathea dispersa, 496 intermedia, 496 nexa, $5 \mathrm{IO}$
Galathodes tridentatus, 486

Galeolaria biloba, 574, 641-642 truncata, 642

Galiteuthis suhmi, 596, 632

Gammarus locusta, 466

Gastrostomus, 104, I06, 108, 702 bairdii, 76, 96, 97, І І 1, 1 04, I 1 8,605 , $612,618,625,627,664,665,677,681$, $699,739,740,741,749,750$

Geodea, 517

Geryon affinis, 538 tridens, 5 I 5, $54 \mathrm{I}$

Gigantocypris, 90, I01, 581, 624, 627, 659, 669 agassizii, 582

Glaucus, 590 atlanticus, $\mathrm{S}_{5}$

Globigerina, 164, $56_{3}$

equilateralis, 172

bulloides, I 50, I 72, 527, 564, 642

conglobata, 172

cretacea, 172

disitata, 172

dubia, $\mathbf{1} 72$

dutertrei, 172

helicina, 172

inflata, 172

linnaana, I 72

marginata, 172

pachyderma, I72, 527

mubra, 172

sacculifera, 172

Glycera, 475

Glyptonotus megalurus, 524

Gobius minutus, $45^{\circ}$

Gomphonema, 314

Gonactinia prolifera, 472

Gonatus, 632, 651

fabricii, I I 2, I1 $3,592,596,643,646$, 650,651

Goniaster borealis, 509

Goniodoma, 326

fimbriatum, 356

polyedricum, $356,35^{8}$

Gonostoma, 604, 677, 681, 743

denudatum, 604, 605, 612, 744

elongatum, 604, 664, 665

grande, IOI, 604, 612, 6I8, 625, 627, $628,664,665,702,720,739,744$

rhodadenia, 604, 612, 618, 664, 665, 677 , 702,720

Gonyaulax, 326, 347

fragilis, $35^{6}$

joliffei, 356

mitra, 356

pacifica, 356

polygramma, 326, 356, 358, 38 I

spinifera, 355

triacantha, 345

Gorgonocephalus, 508

agassizi, 529 


\section{INDEX OF GENERA AND SPECIES}

Gorgonocephalus eucnemis, 519, 527, 529 lamarcki, 508, 533 linckii, 486, 487, 508, 533, 540

Gossleriella tropica, 347, 348, 356

Grimalditeuthis, 592 bomplandi, 592, 593, 596, 625 richardi, 592

Guinardia flaccida, 346

Halargyreus, 370,424

affinis, 401, 433

Halichondria panicea, 467 forma typica, 500 var. bibula, 500

Halicreas rotundatum, 57 I

Halimeda, I 79

Haliomma wyvillei, 148

Halipteris christi, 510

Halobates, $5^{8} 7$

Halobatodes, 587

Halocypris, 655 slobosa, 655

Haloptilus acutifrons, 655 longicornis, 655 mucronatus, 655, 657 omatus, 655

Halosauropsis, 95, I 2 I, 389, 420, 433 macrochir, I2I, 396, 416, 423, 43I

Halosaums, 76, 4I 5, 433 rostratus, 414,418

Halosphara, 334, 335, 345, 385 viridis, 334, 335, 347, $35^{8}$

Haplophragmium latidorsatum, 527

Harmothö̈, 530

Harriotta, 76, I 27, 4 I6, 420 raleighana, 127, 389, 394, 416, 417, 432, 433

Hastigerina pelagica, I 52, I 53, 172

Hemiaster expergitus, 538

Hemiaulus, 356

hauckii, 346, 355

heibergii, 346

Henticalanus, 579

Hemilamprops cristata, 506

Heterorhabdus brevicaudatus, 655

longicornis, 655

norvegicus, 655,657

papilliger, 655

spinifrons, 655

vipera, 655

Heteroteuthis dispar, 597, 632

Hexanchus griseus, 510

Hexancistra quadricuspis, 147

Hexasterias problematica, 356

Hippasterias, 533 phrygiana, 486, 509

plana, 486, 506, 509, 513, 515, 516, 533

Hippocampus, 89, 607, $67 \mathrm{I}$

ramulosis, $61_{3}, 633$

Hippocrene suferciliaris, 569, 570, 640

Hippoglossus, 370
Hitpoglossus hippoglossoides, 436, 455 vulgaris, $407,44 \mathrm{I}, 442,447,45 \mathrm{I}$

Hippolyte, 427, 654 gaimardi, 530, 556 polaris, 486, 506, 530, 531, 534

pusiola, 515

securifrons, $486,496,533,55$ I, 666

spimss, 529, $55 \mathrm{I}$

turgida, 529

varians, 673

Histiiobranchus, 395, 420

bathybius, 414

infernalis, $4 \mathrm{I} 4$

Histioneis, 328

gubernans, 330

Homarus vulgaris, 473

Hoplocaricyphus similis, 622

Hoplonyx, 5 10

Hoplostethus mediterraneum, 401, 402, 424 , 433,447

Hyalocylix striata, 589

Hyalonema, I0, 420

Hyalonemertes, 577

atlantica, 577

Hyas, 474, 530

araneus, 474, 495, 530

coarctatus, 495, 510, 5I 3, 530, 534

Hybocodon prolifer, 569

Hydractinia echinata, 498

Hydrallmannia, 498

falcata, 498, 5 I I, 533, 534

Hymenaster, 533

pellucidus, 5I8, 519, 526, 533

Hymenodora, 587, 654

glacialis, $127,520,524,586,587,64$ I

gracilis, 668

Hyperia medusarum, 654

Hyperoodon diodon, 646, 650, 780

Hyриum, 177

Ianthina, 85, 88, 173, 590, 702

Icelus hamatus, 437

Ichthyococcus, 605, 68 I ovatus, 612, 629, 630

Idiacanthus, 664, 702 ferox, 86, 87, 612, 618

Idotea entomon, 529, 535 metallica, $5 \mathrm{~S}_{4}$

Illex illecebrosus, 592, 596

Inachus, 474 dorsettensis, 496, 513 dorynchus, 5 IO, 5 I 3

Ipnops, 4I9, 686, 687 murrayi, $87,41_{4}, 686,687$

Isocardia cor, 554

Katagnymene, 334

Kellia suborbicularis, 494

Kelliella miliaris, 482

Kolga, 538

hyalina, 523 
Kophobelemnon stelliferum, 482, 483,504

Krithe producta, 155

Krohnia hamata, 108, 118, 578, 640, 658

Latmogone violacea, 419,538

Latmonice filicornis, 504, $54 \mathrm{I}$

Lafoea, 5 II

dumosa, 485,498

Lagena apiculata, 527

Laminaria, 459, 461, 467, 470, 489, 526, 530,560

disitata, 467, 472, 477

hyperborea, 467, 468, 471, 472, 477, 489

saccharina, 467, 472, 477

Lamna, 4 I 8, 647

comubica, 646

Lampra, 522

purpurea, 533

Lampris guttatus, 643

Lampromitra huxleyi, I47

Lanceola, $5^{8} 3$

Laomedea flexuosa, 463, 470, 487

Latrcutes cnsifernts, 671

Lauderia annulatia, 3 I 3, 346, 355

Leachia cyclura, 596

Leda, 4 is

minuta, 494

pernula, 530

Leodice norvegica, $5^{\mathrm{I}} 3$

Lepas, 582

anatifera, I00, 582

anserifera, $5^{\mathrm{S} 2}$

fasciculuris, $120,582,634,642,7$ I1, 712

hilli, 582

pectinata, 582, 634

Lepeta caeca, 530

Lepidion, 60, 370, 424

eques, 400, 40I, 433

lepidion, 423

Lepidopleurus cinereus, 495

Lepidopus caudatus, 407, 6I4

Lepidotrigla aspera, 409, 447

Leptocephalus, 618

amphioxus, 750

brevirostris, 61 $8,750,753$

Congri vulgaris, So, 8I, 750

Synaphobranchi pinnati, 750, 75 I

Leptocylindrus danicus, 321, 346, 348, 355

Leptoptychaster arcticus, 534, 535

Licmophora, 3 I 4

Licodes albus, 4 I4

Lilljeborgia fissicomis, 506

Lima excavata, 486

hians, 473,488

Limacina, I IS, 164

antarctica, 172

australis, 172

balea, $5^{8} 7,5^{89}, 645$

butimoides, 172, 588, $5^{89}$

helicina, $108,172,587,589,640,65^{8}$
Limacina helicoides, 172, 589, 625, 669, 720 inflata, 1 72, 588, 589

lesueuri, $172,588,5^{89}$

retroversa, 1 72, 587, 588, 589, 645

triacantha, 172

trochiformis, 172

Limneandra norvegica, 569

Limopsis, 4 I 8 minuta, 508

Liriope tetraphylla, 570, 571

Lirus, 670

maculatus, 91, 92, 607, 613

medusophagus, 61 3,633

ovalis, 91, 607,613,633

perciformis, IOI, 6I 3

I.ispognathus thomsoni, 538

Lithodes, 64 maja, 486, 496

Lithodesmium undulatum, 345

Lithoptera darwinii, 148

Lithothamnium, 145

Littorina littorea, 462, 463,472, 479, 532, 554,556

obizesata, $463,472,479$

rudis, 462, 479, 530

Loligo, 595

forbesi, 494, 597

media, 597

Lophizes, 611

piscatorizts, I 08, 4 I I , 442, 447, 450, 45 I ,609

Lophohelia, 58,508

prolifera, 485,505

Lopholatilus chamaleonticeps, 706

Lophothrix frontalis, 654

latipes, 654

Lubbockia squillimana, 655

Lucicutia atlanta, 655

brevis, 655

curta, 655

flavicornis, 655

Lucina borealis, 495

Luidia ciliaris, $51 \mathrm{IO}, 51 \mathrm{I}$

sarsi, $492,5^{1} 3$

Lumbrinereis, 501,524

fragilis, 482, 504, 530, 541

Lumpenus, 370

lampetriformis, 437

maculatus, 437

medius, 437

Lunatia, 475

grönlandica, 530

intermedia, $475,494,514$

montagui, 494

Lyciea, 654

Lycodes, 435, 436, 547

eudipleurostictus, 436

Aagellicauda, 436

frigidus, 436

murana, 436

pallidus, 436

seminudus, 436 
Lycodes similis, 436

terra novie, 410

Macroclinum pomum, 498, 534

Macrostomias longibarbatus, 94, 603, 6 I2

Macmurunger, 447

Macnumus, 60, 62, 7 I, 76, 95, 97, 109, 120, I 2 I, I 26, I 27, 4I 5, 420, 424, 434, 745 equalis, 59, 397, 4I6, 4IS, 423, 432, 433,672

armatus, $68_{5}$

bairdii, 432

berglax, 425

carminatus, 432

fabricii, 437,455

gigas, 4I 4, 4 I 5

goodei, 425,432

giintheri, 397

liocephalus, $4 \mathrm{I} 4$

parallelus, 425, 43 I

sulcatus, 432

zaniophomss, 397, 423, 432, 433

(Cetonurus) globiceps, 398, 4 I 6, 4 I 8, 423

(Chatinura) brevibarbis, 398, 4I6, 4 I 8 , 419,432

murrayi, 398, 433

simulus, 398, 41 6, 4 I 8, 425, 432

(Colorhynchus) calorhynchus, 397, 432, 433 talismani, 397, 423, 433

(Coryphanoides) asperrimus, 398, 433 rupestris, 397, 425, 432, 433

(Lionurus) filicauda, 414, 417, 425, 43 I, 626

(Macrums) sclerorhynchus, 397, 414, 423, $425,432,433$

(Malacocephalus) lavis, 398, 433, 447

(Nematonurus) armatus, 398, 414, 415, 4 I $6,417,419,425,43$ I, 433, 626, 769

Mactra, 495

ellipica, 494, 5 I 3,5 I 4

stultorum, 494, 502

Malacostens, $68_{3}$

choristodactylus, 93, 612

indicus, $87,419,60_{3}, 612,625,627$

niger, 93,625

Malletia obtusa, 482,504

Mallotus villosus, 641, 646, 707, 712

Margarita cinerea, 528

grönlandica, 530

helicina, 530

Mastigoteuthis, 592

flammea, 596, 625, 627

grimaldi, 596, 625

hjorti, 592, 625

Medusetta arcifera, 567

Megacalanus longicornis, 654

Meganyctiphanes, 108,645 norvegica, $58_{3}, 640,654,666$

Megaptera boops, 779, 7 So

Melamphais, 6o1, 609, 614, 677, 682 mizolepis, 609, 614, 625, 627, 682
Melanocetus, 609

johnsoni, 609, 6I4, 6 I 8

krechi, 87, 6I0, 6I4, 6I8, 627

Melanostomias, 6 I 2

Melicertidium octocostatum, 569

Membranipora membranacea, 467

pilosa, 47 I

Merluccius, 3 S9, 433, 443, 448

vulgaris, 69, 399, 42 I, 44I, 442, 447, $450,45 \mathrm{I}, 733,77 \mathrm{I}$

Mertensia, I 8,658

ovum, 575

Mesoplodon, I 57

Mesothuria intestinalis, $4 \mathrm{~S}_{2}, 504,5 \mathrm{I} 9$

Metridia curticauda, 654

longa, 654,657

lucens, 654

normani, 654

Metridium, 464

dianthus, 463, 465, 479, 494, 497, 500, 534

Michaelsarsia, $33^{1}$

elegans, 332, 347

Microcalanus pusillus, 640

Microsetella norvegica, 655

Mitrocomella fulva, 569

Mixonus laticeps, 4 I 4

Modiolaria lavigata, 530

nigra, 494, 530

Molleria antarctica, 346

Mola, 633

mola, 644

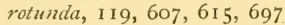

Molgula retorliformis, 529, 534

Molva, 389, 433, 734

byrkelange, 400, 733, 734

elongata, 400, 447, 448, 449, 733, 734

molia, 400, 44 I, 442, 447, 449, 45 I, 733, 734

Monacanthus, 6I o, 6I I, 6I5, 633, 67 I

Monops, 579

Montacuta, 494

Mora, 60, 8I, 370, 424, 449

mora, 59, 400, 423, 433

Mormonilla minor, 655

Motella macrophthalma, 424

tricirrhata, 450

Mullus, 448 surmuletus, 70, 7 I, 404, 405, 447, 448

Munida, 482 microphthalma, $53 \mathrm{~S}$

rugosa, $4^{S_{2}}, 486,490,5$ Io, 533, 654

tenuimana, $4 \mathrm{~S}, 486,540$

Munidopsis, 420 curvirostra, 538

Munnofsis, 654 typica, 506, 521, 530

Auriena helena, 79, 389, 395, 447

Muricua placomus, 252

Mustelus, 64

z'ulgaris, 39 I, 447 
Nya, 556

arenaria, $464,479,530$

truncata, 530 forma typica, 495

Myctophum, 601, 605, 677

(Diaphus) gemellari, 61 $3,618,632,670$ rafinesquei, 606,6 I $_{3}, 632$

(Lampanyctus), 677 elongatum, 606, 644 semmifer, 61 3,632 maderense, 6 I $_{3}, 632$ micropterum, 61 3,632 warmingi, $61_{3}, 632$

(Myctophum) affine, 61 3, 61 8, 632 benoiti, 61 3, 632 hygomi, 6 I $3_{3}$ charocephalum, 6I 3,6 I $_{1}, 632$ coccoi, 95, 61 3,6 18, 632 glaciale, 605, 61 $3,632,634,644$ humboldti, 61 3,6 1 8,632 punctatum, 95, 605, 61 $3,618,632,634$ rissoi, 61 $3,632,746$

Myliobatis aquila, 393, 447

Myriochele, 524

Myriotrochus rinki, 529 vitreas, 504

Mysis, 645 relicta, 556

Mytilus, 468, 477

edulis, 462, 479, 532, 554

modiolus, 472, 494, 500, 51 2

Nacella pellucida, 467, 472, 532

Nassa reticulata, 489

Natica, 502, 510

bathybi, 524

catena, 494, 502

clausa, 528

Naucrates ductor, 91, 608, 609, 614, 633

Nausithoё, 572

atlantica, 573

globifera, 573

Nautilus, 87

Navicula, 3I 4, 345

granii, 345

membranacea, 345

septentrionalis, 345

vanhöffeni, 316, 345

Necera, 482

Nectonemertes grimaldi, 577

lobata, 577

mirabilis, 577

pelagica, 577

Nematobrachion boops, 654

Nematoscelis, 720 microps; 654

Nemichthys scolopaceus, 93, 9\$, 605, 612

Neobythites crassus, 4I 4

Neolithodes grimaldi, $53 \mathrm{~S}$

Nephrops norvegiaus, 510, 515, 516, 533

Nephropsis atlantica, 539
Nephthyss, 475, 482, 501,508

Neptunea, 493, 494, 500, 52I, 522 antiqua, 493, 510, 517

despecta, $52 \mathrm{~S}$

molini, 524

Nereis, 468, 510 pelasica, 530

Nerophis, 120, 6.44 aquoreus, I26, 606, 61 3, 634, 644

Nicania banksi, 475, 495, 528, 530

Nicolea, 467, 530 zostericola, 530

Nitzschia, 314, 365 seriata, $347,354,355,35^{8}, 365$

Noctiluca, $68,33^{8}$ miliaris, 674

Nodularia spumigena, 345

Notacanthus, I2 I, 389, 424, 433 bonapartii, 396, 433

Notidanus, 388 griseus, 370

Notostomus, 585, 586, 624, 699

Nucula tenuis, 494 var. expansa, 528 tumidula, 482,483

Nyctiphanes, 666 (Meganyctiphanes) norvegica, 666

Nymphon, 529, 530

brevirostre, 468

elegans, 529

gracilipes, 529

grossipes, 530

hirtipes, 529, 534

macronyx, 529

mixtum, 515, 534

robustum, 520, 524, 527, 529, 533 strömi, 486, 497, 506, 515, 516

Obelia, 569 geniculata, 467,470

Oceanapia robusta, 507, 5 IO

Octopodotenthis sicula, 591, 596, 632

Octopus, 522, 595

(Polypus), 597 lothei, 595, 597

Oculina, 546

Oikopleura labradoriensis, 598 parva, 598 vanhïffeni, 598

Oithona, 655 plumifera, 5So, 640, 655 similis, 579, 580, 639, 640, 655

Ommatostrephes, 592, 594 sagittatus, 592, 596 todarus, $592,645,646,648,650$ Omosudis lowei, 91, 606, 61 2

Onciea, 655 conifera, 639, 640, 655 notopus, 639

Onchidiopsis slacialis, 52S, 534

Onchocalamis rostratus, 654 
Oneirodes, 94, 95, 104, 608, 609, 6I 4, 6IS megaieros, 94, 614

Oncirophanta, 542,543

Onuphis, $50 \mathrm{~S}$

conchylega, 530

tubicola, 510

Onychotenthis banksi, $59 \mathrm{I}$

Ophelia limacina, 475

Ophiacantha abyssicola, 5oS, 540

bidentata, 508, 530, 549

Ophiactis abyssicola, 508,540

Ophiaster, 331

formosus, 332,365

Opliocoma nigra, 473, 488

Ophiocten, 4 I 9

sericeum, 492, 5 I5, 518, 524, 527, 530, 540,547

Ophioglypha, 418, 4 I9

Ophiomusium lymani, $53 \mathrm{~S}$

Ophiopholis aiuleata, 468, 472, 473, 4So, $486,492,508,5^{1} 3,530$

Ophiopleura, 4 I9

aurantiaca, $53 \mathrm{~S}$

borealis 518,529

Ophiopus arcticus, 529

Ophioscolex glacialis, 504, 506, 50S, 530

purpurea, 508

Ophiothrix fragilis, $472,492,503,510,513$, 557,576

Ophiura, 109

albida, 473, 492, 5 I 2, 5 I 3,5 I 4

ciliaris, $4 \mathrm{~S} 9,491,492,5 \mathrm{IO}, 5 \mathrm{I} 4$

nodosa, 529

robusta, 530

sarsi, 492, 504, 508, 530

opisthoproctus, $104,681,68_{3}$

grimaldii, 90, 602, 6 I I

soleatus, 90, 94, 602, 6I I

Opisthoteuthis, 595

agassizii, 597

Orbulina universa, 151, 172

Orchestia littorea, 465,479

Ornithocercus, 328

magnificus, 328-330, 347, 356

quadratus, $32 \mathrm{~S}, 347,356$

splendidus, 32S, 329, 347, 356

steinii, 329, 347, 356

Ostrea, 479

edulis, 479

Owenia assimilis, 530

Oxycephalus, 654

Oxygyrus kerandrenii, 173

rangii, 173

Oxyrhina, S7, 3SS, 39I, 4IS, 4 I9

trigodon, I 57

Oxytoxum, 347

cristatum, $35^{6}$

diploconus, $35^{\mathrm{S}}$

hjorti, 365

milneri, 356

reticulatum, 356
Oxytoxum scolopax, 356, 358, 365

tessellatum, 356

Pagellus, 7 I, 44 I, 442, 443, 448, 449

acarne, 403, 447

centrodontus, 64, 403, 404, 447, 44S

Pagrus, 79, $44 \mathrm{~S}$ vulgaris, 74, 79, 404, 447

Pagurus, 95, 427, 534

bernizardus, $465,495,510,5 \mathrm{I} 2$

chiroacanthus, 551

lavis, 510,551

meticulosus, $5 \mathrm{IO}, 5 \mathrm{I} \mathrm{I}$

pubescens, 4So, 4S6, 495, 500, 510, 513, $53 \mathrm{O}, 54 \mathrm{I}$

tricarinatus, 5 I I

Palcemon, 469

natator, $67 \mathrm{I}$

Palinurus vulgaris, 64

Pandalus, 427, 5S7, 645, 654

annulicornis, 469, 496, 506, 5 I 2, 534, 666

bonnieri, 504, 505, 506

borealis, 530, 531, 666

brevirostris, 486, 515

propinquus, 486, 511

Pandora glacialis, 529

Panopiea norvegica, 494

Pantachogon haeckelii, 57 I

Paraiartia grani, 479

Paragorgia, 505, 508

arborea, 485

Paralia sulcata, 355

Paraliparis bathybii, I26, I 27, 436, 437, $64 \mathrm{I}, 688$

Paramuricea placomus, 484

Parapagurus, 420

pilosimanus, 538

Parapasiphcea sulcatifrons, 668

Paraspongodes, $484,508,522$

fruticosa, 522

Parathemisto oblivia, $5 S_{4}, 5 S_{5}, 64 \mathrm{I}, 654$

Pardalisca abyssi, 506

Parechinus, 478, 479 miliaris, $473,478,479$

Pasiphcea, I 27, 427, 5S6, 645 princeps, 540-54 I, 586, 64 I sivado, 666

Patella vulgata, 462, 479

Pecten, 479, 486 abyssortm, $48_{3}$

frigidus, 524, 547

grönlandicus, 517,528

hoskynsi, 506, 530

islandicus, 514, 528, 534

opercularis, $479,494,510$

septemradiatus, 504, $5 \mathrm{IO}$

Pectunculus glycimeris, 494, 213

Pectyllis arctica, $57 \mathrm{I}$

Pelagia, I I S, I 19, 572

atlantica, 95

perla, $573,574,632$ 
Pelagonemertes, 577, 659

Pelany's sarda, 609

Pelonaia corrugata, 530, 534

Peltaster nidarosiensis, 540

Peniagone wyvillii, 541, 543

Pennatula phosphorea, 503

Pentacheles, 420, 586

Pentacrinus, 545

Pentagonaster, 533

sranularis, 4\$6, 490, 533

perrieri, 538

Peraclis bispinosa, 172

diversa, 589, 625, 669

reticulata, 172,589

triacantha, 589

Peridinium, 326, 347, 353, 355, 356

conicum, $35^{8}$

depressim, $323,35 \mathrm{~s}$

divergens, $35^{8}$

oceanicum, 358

ovatum, $35^{\mathrm{S}}$

parallelum, 357

tristylum, $35^{\mathrm{S}}$

Perigonimus abyssi, $48_{3}$

Periphylla, 572, 627, 669

liyacinthina, 573, 624, 642

regina, 573

Peristedion cataphractum, 70, 409, 410, 447

Petromyzon marinus, 6o I, 6I I, 644

Phaenna spinifera, 655

Phacocystis, 333

globosa, 346

poucheti, 333, 345, $35^{8}$

Phalacroma, 347

argus, 356

cuneus, 356

doryphorum, 356

magei, 356

Phascolosoma strombi, 500

Phellia abyssicola, $4 \mathrm{~S}_{4}$

Pheronema carpenteri, $539,54^{\circ}$

Phialidium, 569

Philine, 469, 494

Pholas crispata, 494, 495

Phormosoma, 109, 429, 430 placenta, $53^{8}$

Phoronis, 352, 559

Photostomias, 86, 664 guernei, 86, 87,603, 604, 61 1, 618, 664, $665,677,68_{3}, 702,739$

Phoxichilidium femoratum, 468

Phoxichilus spinosus, 468

Phronima, $5^{8_{3}}, 5^{8_{4}}, 5^{s_{5}}$ sedentaria, 654

Phycis, 433

albidus, 450

blennoides, 400,447

Phyllopus bidentatus, 655, 657

Phyllostaurus quadrifolizes, 564

Physalia, 68, 85, S8, 575, 631, 696
Physalia arethusa, 574

Physeter macroichlialus, 646, 780

Physopizora, 696

borealis, 711 , 712

hydrostatica, 574, 642

Pimelepternes boschii, IOI

Placostegus tridentatus, 485,508

Plagusia, 73

Planctonemertes, 624

Planes minutus, 103, 633, 67 I

Planktoniella sol, $347,348,354,356,358$

Platyscelis, 654

Plesionika nana, 585,668

Pleurobrachia, i 8,658

pileus, 575

Pleuromma, 579

abdominalis, 654

sracilis, 654,657

robusta, 642,654

xiphias, 654

Pleuronectes, 390

cynoglossuls, 44I-442, 45 I, 454

flesus, 45I

limanda, 407, 44I, 442, 447, 45 I, $5^{\mathrm{I}} 3$

microcephalus, 441-442, 45I, $45^{2}$

platessa, 441-442, 45I, 763

Plumularia pinnata, 498

Plutonaster bifrons, $53^{8}$

Pneumoderma violaceum, $5^{88}$

Pneumodermopsis macrochira, 589

Podolampas, 347

bipes, 356

elegans, $35^{6}, 35^{8}$

palmipes, $356,35^{8}$

Precilasma carinatum, 582

Polyacanthonotzs, 396

Polybizts, 65

henslowi, 66

Polycera, 468

Polycheles, 420, 586

nanus, 539

sculptus, $538,5^{\$ 6}$

pacificus, 587

Polycyclus fuscus, 467

Polyprion, 670 americants, 98, 607, 614, 633, 770

Pomatoceros triqueter, 472

Pontaster tenuispinus, 504, 505, 509, 510, $5^{1} 7-5$ I $8,530,547,549$

Pontella, 579

Pontellina, 579

Pontophilus, 533, 55 I norvegicus, $4 \mathrm{~S} 2,504,506,533,54 \mathrm{I}$ spinosus, 515

Pontoporeia affinis, $55^{6}$

Pontosphara, $33 \mathrm{I}$

haxleyi, 332, 347, 365

Poralia, 573

rufescens, 573

Porania pulvillus, 486, 509

Porcellana, 495 


\section{INDEX OF GENERA AND SPECIES}

Porcellana longicornis, 495

Porella, 506

Porocidaris purpurata, 538

Poromya granulata, 508

Porospathis holostoma, 567

Portlandia frigida, 482,530

lucida, 482,504

tenuis, $4 \mathrm{~S}_{2}, 506$

Portunus, 476, 497

depurator, 476, 495

holsatus, 495

pusillus, 495

tuberculatus, 510,511

Pourtalesia jeffreysi, 520, 547

wandeli, 538

Priminoa, 505, 508

lepudifera, $4 \mathrm{~S}_{4}$

Pristipoma, 77

bennettii, 403, 447

Pristiurus melanostomus, 391, 447 murinus, $39 \mathrm{I}$

Procymbulia, 5 s9

Prorocentrum micans, 344, 346, 377

Protella pliasma, 497

Proto pedata, 497

Protoceratium reticulat $u m, 356,35^{8}$

Protocystis bicornis, 567

Itarstoni, 567

naresi, 567,568

swirei, 566,567

thomsoni, 566, 567, 568

tridens, 566, 567

Protodinium, 365

Psammobia, 475

ferröensis, 494, 495

tellinella, $5 \mathrm{I} 3$

Pscudocalanus elongatus, 579, 639, 640, 654, 657 sracilis, 639

Psilaster andromeda, 504, 5 I8, 540

Psolus phantapus, 530 squamatus, 486, 488, 490, 506

Pteraster militaris, 515, 530 multipes, 540

Pterosperma disculus, 365

Pterotrachea, $85,88,590,702$ coronata, I 54

Pterycombus brama, 643

Ptery gioteuthis giardi, 590, 591, 595

Ptychodiscus carinatus, $35^{\mathrm{S}}$

Pullenia obliquiloculata, I 72

Pulvinulina canariensis, 172

, crassa, 172

karsteni, 527

menardii, 172

micheliniana, 172

patagonica, I 72

tumida, 172

Purpura lapillus, 462, 479, 532

Pycnogonum littorale, 497, 534

Pyrocystis, 328, 329
Pyrocystis fusiformis, 331, 347

lunula, 356

noctiluca, 328, 331, 347, 356, 674

Pyrophacus horologium, $35^{8}$

Pyrosoma, 598, 599, 600, 659, 696

atlanticum, 600

giganteum, 600

spinosum, 600, 624

Raia, 513

alba, 393, 447

batis, 393, 447

circularis, 64, 393, 447

clavata, 64, 392, 447

fullonica, 393, 447

fylle, 393, 433

hyperborea, 436, 437

microocellata, $389,392,447$

miraletus, $389,393,447$

nidrosiensis, 393, 433

punctata, 393, 447

vomer, 393, 447

Regalecus glesne, 643, 698

Retepora beaniana, 485

Khabdammina, 504

abyssorum, $48_{2}$

Rhabdosphora, $33 \mathrm{I}$

claviger, $145,332,365$

styliger, 365

Rhachotropis, 506

aculeata, 533

Rhina squatina, 392, 447

Rhizocrinus, 545

lofotensis, 512, 513, 523, 540

Rhisosolenia, 316, 3 I8, 332, 334

acuminata, 347, 354, 356

alata, $347,354,355,358,377,3 \mathrm{~S}_{2}$

amputata, 354

caliar avis, 365

castracanei, 347,356

cylindrus, 346

delicatula, 355

fragillima, $35^{8}$

hebctata-scmispina, 316, 320, 347, 352, $354,357,35^{8}, 3^{82}$

robusta, 355

semispina (see $R$. hcbetaza)

setigera, 346

shrubsolei, 345, 355, 358

stolterfothii, 354, 355

styliformis, 334, 347, 352, 355, 356, 358

Rhizostoma octopus, 572,642

Rhodichthys regina, 436,688

Rhopalonema velatum, $57 \mathrm{I}$

Rhynchonella psittacea, 529

Rhyncotenthis, 596

Richelia intracellularis, 334

Rissoa, 469

Rocinela dammonicnsis, 506

Rossia, 506, 595 
Rossia caroli, 597

macrosoma, 5 10

Rotalina orbicularis, 527

Sabella pavonia, 500, 501

Sabellaria alicolata, 495, 502

Sabinea sarsi, 5 I 5, 533, 55 I septencarinata, 529, $55 \mathrm{I}$

Saccammina sphorica, 482

Sacculina, 582

Sagartia, 479

Sagitta, 578

arctica, II $8,578,640,658$

bipunctata, 578

sigantea, 578, 640, 64I

hexaptera, 578

inflata, $57 \mathrm{~S}$

macrocephala, 578,669

serratodentata, $57 \mathrm{~S}$

Salenia hastigera, 543

Salmo salar, 442,646 trutta, 442, 646

Salpa, $38_{1}, 5 s_{3}, 710598$

amboinensis, 600, 632

confaderata, 600, 632

fusiformis, 126, 599, 600, 632, 634, 641, $642,708,710,711$

forma aspersa, 598, 600

forma echinata, 600

henseni, 600, 632

irregularis, 7 I 1

maxima, 600, 632

mucronata, 599, 600, 632, 641, 642

muncinata, 7 I I

tilesii, 600

zonaria, 599, 6oo, 632, 633

Sapplivina, 579, 655, 657

Sarcobotrylloides aureum, 529

Sarda sarda, 643

Sargassum bacciferum, 335, 336

Sargus, 77, 448

annularis, 403, 404, 447

rondelettii, 74,403

Sarsia eximia, 569

flammea, 569

tubulosa, 569

Saxicava, 468

arctica, 494, 530

Scalaria trevelyana, 494

Scalpcllum, 4I8, 420, 508

atlanticum, 582

darwinii, I 59

dicheloplax, 582

velutinum, $5 \mathrm{~S} 2$

Scaphander, 513

punctostriatus, 504, 506, 5 I 5

Schisaster fragilis, 491, 504, 508, 533, 540

Sciena aquila, 402, 403, 447

Scina borealis, 654

Sclerocrangon borcas, 529, 534

ferox, 520, 522, 529
Scolecithricella, 655

minor, 655,657

Scolecithrix danit, 655,657

minor, 655

Scomber, 370, 747

scomber; 609, 645

Scombresox, S9, 94, 607, 635, 670, 741, 747 saumus, 607, 61 $3,633,635,644,747,748$

Scorpana, 79, 448

cristulata, 408, 433

scrofa, $78,408,409,447$

ustulata, $408-447$

Scottocalanus securifrons, 654

Scyllium canicula, 39I, 4.47

Scypliocaris anony'x, 654

Scypholanceola, $5^{8}$ agassizi, $5^{8} 3$

Siyphosphira, 331, 347 apsteini, $3^{6} 5$

Scyramathia carpenteri, 538

Sebastes, IIO, 437, 440, 44 I, 442, 455, 647 , 648,665

dactylopterus, 408, 424, 433, 447, 448, 6 I 4

marinus, 646,648

norregicus, 665

Selache maxima. 646

Sepia, 595

d'orbignyi, 597

officinalis, 597

Sepiola, 494, 595

rondelettii, 597

Sergestes, $5^{85}, 654$

challengeri, 675

Seriola, 614, 671

Serpula vermicularis, 485,486

Serranus, 448 cabrilla, 78, 402, 447

Serrivomer, 85, 93, IOS, 755 sector, 605, 612, 630

Sertularella gayi, $485,506,508$

tricuspidata, $5 \mathrm{I} \mathrm{I}$

Sipho, 493, 500, 521, 522

curtis, $52 \mathrm{~S}$

glaber, 508,528

gracilis, 493,517

islandicus, 504, 510

kröyeri, $52 \mathrm{~S}$

turgidulus, 528

Siphonentalis tetragona, 482, 504

Siphonodentalium vitreum, $523,524.52 \mathrm{~S}$

Siphonostoma typhle, 606

Sipunculus priapuloides, $4 \mathrm{~S}_{3}, 5 \mathrm{O}_{4}$

Skeletonema costatum, 367

Skenea planorbis, 463

Solaster abyssicola, 538

affinis, 530

endeca, 506, 5 I 5

papposus, 492, 506, 530

siuamatus, 533

Solea, $79,370,448$ 


\section{INDEX OF GENERA AND SPECIES}

Solea lutia, 408, 447

vulgaris, 64, 69, 370, 408, 441, 442, 447 , $45 \mathrm{O}, 45 \mathrm{I}$

Solen, 495

ensis, 475, 494

Solmaris corona, 7 I I

Sommiosus microcephalus, 436

Spatang"us, 494, 509, 517, 519 purpureus, 475, 49I, 505, 5I3, 5I 7

raschi, 504, 505, 508, 509, 540

Sperosoma grimaliti, $53 \mathrm{~S}$

Spharoidina dehiscens, 172

Spinax, 388

niger, 388, 392, 433, 447, 675

(Etmopterus) princeps, 392

Spinocalanus magnus, 654

Spirorbis, 463

Spirula, 81, S2, 590, 625

australis, 592, 597

Stauracantha murayana, I47

Stegocephalus inflatus, 52 I

Stenorhynchus, 474

longirostris, $5 \mathrm{I} 3$

rostratus, 496, 513

Stephanopyxis turris, 355

Stephanotrochus diadema, 538, 539

Sternoptyx, 605, 68I diaphana, 612, 618, 629, 630

Stichaster albulus, 529

roseus, 509

Stichopus tremulus, $482,504,508,510,511$, 519,540

Stomias, $8_{5}$, IOI, $68_{\mathrm{I}}$

boa, 603, 6I I, 618, 629, 630, 720

Streptotheca thamensis, 345

Strongylocentrotus, 47 S, 493

dröbachiensis, $473,478,493,512,530$

Strophogorgia challengeri, 538

Styela aggregata, 529

loveni, 498, 530

rustica, 530

Styelopsis grossularia, 530

Stylifer turtoni, 493

Styliola subula, 589

Stylocheiron, 720

longicorne, 654

Suberites ficus, 500

Synaphobranchus, S I, 95, I 20, 420, 755 pinnatus, So, IOI, 3S9, 395, 4 I6, 423,

$433,750,751,752$

Syncoryne pulchella, 569

Syngnathus, 92

acus, 606

pelagicus, 103, 606, 6 I $_{3}, 633,67$ I

Synoicum incmestatum, 529

Syracosphara ampulla, 365

blastula, 365

echinata, 365

lavis, 365

prolongata, 332

pulchra, 365
Syracosphura robusta, 365 spinosa, 365

Systellaspis debitis, 668

Tapes, 464, 554

decussatus, 554

edulis, 513

Tectura, 472

virginca, 472

Teleoteuthis caribua, $59 \mathrm{I}$

Tellina, 475, 529

baltica, 532

calcarea, 528

crassa, $5 \mathrm{I} 3$

Temnodon saltator, $406,447,614$

Temora, 645

longicomis, 579

Terebellides strömi, $4 \mathrm{So}, 4 \mathrm{~S}_{2}, 5 \mathrm{O} 4,53 \mathrm{O}$

Terebratula, 4 is

Terebratulina caput-serpentis, $4 \mathrm{~S}_{5}, 507$ spitsbergensis, 529

Titrodon spengleri, 4 I I, 447, 615

Teuthowenia megalops, 596, 632

Thalassiosira, 345, 348

antarctica, 346

decipiens, 346, 354

excentrica, 354

grazida, 314, 3i 7, 345, 355

hyalina, 345

nordenskioldii, 345,354

subtilis, $347,354,355,356,35^{8}$

Thalassiothrix frauenfeldi, 365

longissima, $316,347,353,354,35^{8}$

nitzschioides, $319,354,35 \mathrm{~S}$

Thalassochely's corticata, 97

Thelepus circinnatus, 5OI, 5I3, 530

Thenea muricata, $4 \mathrm{~S}_{3}, 4 \mathrm{~S}_{4}, 5 \mathrm{O} 4$

Thracia truncata, 529

Thujaria, 498

thuija, 49\&, 499, 5I I, 533

Thymmus, 370

pelamys, 609

thynnus, 609, 643

Thysanoëssa, 645

longicaudata, $5 S_{3}, 640,654$

minor, 654

neslecta, 654

parva, 654

Thysanopoda, 720

aiutifrons, 654

obtusifrons, 654

Tiara pileata, 569

Tiaropsis multicimata, 569

Timoclea ovata, 475

Todaropsis eblance, 592, 596

Tomopteris, $57 \mathrm{~S}$ septentrionalis, 578

Torrellia vestita, 506

Toxenma belone, 592, 594, 596, 625, 627

Trachinus, 448

draco, $410,447,45^{\circ}$ 


\section{8}

\section{DEPTHS OF THE OCEAN}

Trachinus vipera, 410,447

Trachurus, 390

Trachypterus, 94, 741, 742 arcticus, 643

Trachyrhynchus, 81, 433 murrayi, 397, 433 trachyrhynchus, 397

Travisia forbesi, 475

Tremoctopus, 595, 597 atlanticus, 597, 632

Trichodesmium, 333, 334, 345, 360 thicbaulti, $333,347,356,35^{8}$

Trichostoma, 177

Trichizurus lepturus, 643

Tridonta borealis, 535

Trigla, 71, 79, 44I, 442, 448, 45 I cuculus, 409, 447 surnardus, 409, 447 hirundo, 409, 447 lyra, 409, 447 obscura, 409, 447 fini, 409, 447

Triglops, 370 pingelii, 437

Triposolenia, 327, 328, 347 bicornis, 328

Tritonia, 494

Trochostoma, 519 boreale, 520, 529

Troplionia glauca, 501

Truncatulina wïllerstorfi, 527

Tubularia, 470, 472 indivisa, 534 laryinx, 498 regalis, 529

Tuscaretta globosa subsp. chuni, 568 tubulosa, 567

Tussilago farfara, 302

Typhlonus nasus, 414

Ulocyathus arcticus, 504, 505

Umbellula, $\$_{7}, 519$ encrinus, 5I 7, 5I 8, 547 gïntheri, 87, 88, 419 lindahli, 538, 547

Umbrina ronchus, 402, 447

Underechata major, 654 minor, 654

Uranoscopus scaber, $4 \mathrm{IO}, 447$

Urechinus naresianus, $53 \mathrm{~S}$

Uroptychus rubro-vittatus, 538

Urticina, 494 crassicomis, $463,479,494,497,500$

Valenciennellus, 605, 630 tripunctulatus, 612, 61 8, 629, 630

Vampyroteuthis, 595 infernalis, 595, 597, 625

Velella, 68, 85,63 I spirans, 574,576

Velutina lavigata, 494

Venus casina, 475, 513 fasciata, 475

fluctuosa, 529 gallina, 494, 495, 5 I 4

I'erruca strömi, $485,508,533$

I inciguerria, 605, 630, 679, 68 I lucetia, 604, 612, 618, 629, 678

Tirbius fasciger, $55 \mathrm{I}$ varians, $55 \mathrm{I}$

Virgularia, 494 mirabilis, 500

Volutopsis norvegica, 494

Waldheimia cranium, 4S5, 490, 507 septati, 507, 508, $54 \mathrm{I}$

Xiphias gladius, 643

Yoldia hyperborea, 528

limatula, 528

(Portlandia) arctica, 528

Zeugopterus, 370, 443

boscii, $408,433,447$

megastoma, 407, 424, 44 I, 442, 447, 45 I, 454

Zeus faber, 406, 407, 441, 442, 447, 609, 6 I 4,643

Ziphius cavirostris, 157

Zirphata crispata, 553

Zoanthus, 500

Zoarces viviparus, 756, 757

Zoroaster fulgens, 537, $53 \mathrm{~S}$

Zostera, 459

marina, 468

Zygina malleus, 635 


\section{GENERAL INDEX}

Abundance of marine animals, 77 I -785

Abyssal fauna of the Norwegian Sea, $434-437$, $547-548$

forms of the Atlantic, 543

plain, boundary of, 420

plain, fishes of, 4I 2-42 I

Acantharia, 564, 631, 642

Acanthin, 567

Acanthometra, 564

Acanthometridie, $333,355,564,567$

Acanthophracta, 564

Acanthopterygii, 390, 40I-4IO, 448-449, $607-608,609,6$ I 4

Accumulators, 24, 26, 27, 29, 3 I

Aceratiidæx, 6 I 5

Acraspeda, 568, 572, 573

Acropomatidx, 402

Actiniaria, $63,95,419,430,463,494$, 525,577

larval, 634,64 I

Actinotrochæ, 559

Eolids, 5 II

African coast fisheries, 74

Age and growth of fishes, 755-771

Age-composition of the stock of fishes, 765

Agulhas current, 277

"Akker," 648

"Albatross," The, I2, I 7, I 8,92, I 38,387 , 706

Albuminoid matter in deep-sea deposits, I47

Alcyonaria, 9, I 49, 484, 485, 525

Aldrich Deep, I 3 I, I 32, I 40, I 4 I

Alepocephalidx, 7 I, 389, 394-395, 4 I 4, 424, 742,743

Algre, 106, I2.4, I 45, 462, 463, 469, 470, $474,487,489,530,560$

calcareous, I 45, I 46, I 77

green, 459

pelagic, $307-386$

red, $459,468,470$

Alkalinity of sea-water, 176

Alternation of generations, 568

"Amber," The, 19

Ammonia in relation to plant life, 368,369 , 370,372

in sea-water, 177,178
Amphipoda, 85, 89, I07, 467, 468, 470, $489,496,497,506,510,520,521,558$, $579,58_{3}-58_{4}, 631,640,654$

Anacanthini, $389,397-401$

Anchovies, 76, 448, 601, 635, 646, 77 I

Anemones, 479

Angler, $443,448,452$ (see also Monk) eggs of, IOS

"Anglia," The, 20

Anguillidie, 605

Animal life at different depths, $85,95,415$, $557-55^{8}$

remains in marine deposits, 148

Annelida, I 49, 500, 50 I, 508, 575, 578

Anomura, 544

"Antarctic," The, I7

Antarctic continent, area of, I 32 expeditions, $5,6,16,17$, Is regions, 244,245

Antennariidxe, 615

Anthomeduse, 568

Anticyclonic area of North Atlantic, 194

Antipatharia, 87, 4I9

Apatite, 185

Apodes, 389, 395, 605, 6 12

Appendicularians, $382,598,600,719$

Arabs at Cape Bojador, 76

Arachnosphæridæ, 642

Aragonite, I7 7, 179

Archibenthal area, 459

fauna of the North Atlantic, 538-546

Archimedes, law of, 689

Architeuthidæ, 592

"Arctic," The, 9

Arctic alge, neritic, 345 oceanic, 347

Arctic currents, I I 5, 459, 707 expeditions, 7, I O, I I, I 5, 259, 260, 26 I, 274

fauna, I 3,5 I $7-523,528-529$

abyssal, $547-548$

boreal, 529-53 I

littoral, 526-527

shallow-water, $437,525-526$

ice, 207,638

regions, I I , 244, 245, 274, 457

and boreo-arctic regions, 516-535 
Arcturids, 5I I

Areas of the ocean-floor at different depths, 4 I 2

Argus Bank, 178

Ascidians, 62, 103, 419, 469, 472, 479, 483 , $486,497,498,504,517,518,529,530$, $534,597,598$

Astartide, 475

Asterids, I09, 468, 490

Atherinidæe, 397

Atlantic Ocean, area draining into, 194 area of, 134

area of, at different depths, 134,136

continental shelf and slope in, I 34

deepest sounding in, 132

deeps of, 140-143

depths of, I 31 , I 32, I 34-1 36 , I 40-1 42

number of soundings in, ${ }^{1} 31$

shore-slopes of, I 35

submarine banks of, I 35

North, ahyssal area of, 196

area of, 195

anticyclonic area of, 194

archibenthal fauna of, 538,546

continental shelf in, 195

continental slope in, 195 -I 96

deeps of, 196

deep-water fauna of, $536-548$

deposits of, 9, 194, 198-209

depths of, 56, 194, 195

hydrographical conditions of, 295-300, $45^{8-459}$

temperature of, 194, 22 I, 222, 224, 227, 228, 295, 305

Atlantic ridge, I I 8, I 20,135

Attraction of land-masses, effect of, I 30

Auks, 124, 712

Aulacanthidie, 565

Austrian expeditions, I 5

Auxospore development, 314, 314-319, 343, 344

Azores current, eastern, 635

Bacteria, 182, I88, 259, 369, 370, 674, 728 denitrifying, $259,369,370$

nitrifying, $259,369,370$

sulphur-reducing, I82, I 88

Bailey Deep, I 42

Baillie sounding machine, 25, 25

Balanids, 474,582

Balistidæ, 6I 5

Baltic Sea, phosphorus in water of, 185

silica in water of, $\mathrm{I}_{4}$

"Banks," 42 I

"Banquereau," I 12

Barium nodules, I 57 sulphate, 157,190

Barnacle belt, 46 I -462

Barnacles, 100, 200, 207, 477, 508, 525, 556, $634,642,667,668,669,670,672,68_{3}$

Bartlett Deep, I96

Bathometers, 2

Bathymetrical contours first shown on maps, 3 range of deep-sea fishes, 423

Bathypelagic animals, 562, 563, 624-628

Bathyteuthidre, 596

Batoidei, 388, 392-393

Belgian Expeditions, 16

"Belgica," The, I 6, 575, 639

Belknap Deep, $\mathbf{I}_{42}$

Belt of Venus, 89

Benthos of the Faroe Channel, 127

Berycidre, 40 I-402, 6I 4

"Besugo," 74

Biloculina clay, $164,523,527$

Biological laboratories, marine, 20

Biology, general, 66o-785

Bipolarity of occanic diatoms, 352-353

Birds following shoals of capelan, 712

on Rockall, 124

Black Sea, I 5, I 78, I 82,257

Bladder type of suspension organs, 3 I 5 , 329

"Blake," The, 1 2, 27, 30, 31, 387, 592

Blennies, $756,757,758$

Blenniidze, 390

Blind fishes, Io4, 68 I, 682, 685, 686, $68_{7}$ squid, $6 S_{2}$

Blue mud, I60, 161, 162, 167, 168, 171 , I 75, I81, I82, I 87 , I 88 , I9S, 199, 200, 201, 426, 431, 717

Bog manganese ore (see Manganese nodules)

Bolitænidæe, 597

Bomb-lances taken in blue whales, 7 I 4

Bonito, 6o9, 635, 636, 755

Boreal pelagic life, I07, IOS, I I 8 , I 20, I 26 region of the Norwegian Sea, 457, 459-5 I6

Boreo-arctic region of the Norwegian Sea, $45^{8}, 53$ I -535

"Bottle-nose grounds," 592

"Bottom-water" in Mediterranean, 6S

in North Atlantic, 115, I I 7, 220

in Norwegian Sea, I 25

Boulder clay, 205, 208

Boundary-waves, 274, 7 I 5

Brachiopoda, I6o, 4 I 8,4 I $9,480,48_{3}, 48_{4}$, $48_{5}, 490,507,510,529,541$

Brachyura, 544

Bramiidæ, 643

Branching type of suspension organs, 3 I 6

Bream, 64, 44I, 442, 443, 449

Brill, 441, 442, 451, 453, 646

"Britannia," The, 19

British Antarctic Expeditions, 5, I 7, I8 Association Dredging Committee, 6 cable ships, 19

surveying ships, I9

Brittle-stars, $472,473,482,486,491,492$, $508,518,530,540$

Bronzite spherules, I 54, I5S

Brooke Deep, I42

Brooke's sounding apparatus, 8, 9, I 30 
Bryozoa, 9, I49, 4I $8,419,463,467,47$, $472,474,479,480,483,484,485,489$, $49 \mathrm{I}, 498,506,507,510,525,559,575$. 7 IS

"Buccaneer," The, I3, I9

Buchanan Deep, I 42

Buchanan's stopcock water-bottle, 2 jo, 231

"Budding," reproduction by, 568

"Bulldog," The, 9

"Burro," 74, 76

"By-the-wind sailor," 574

Cables, telegraph, 9, I69, I 70

Cachalot, $646,651,652,780,782$

Calanoida, i I $8,654-655,727$

Calcareous deposits, 162 sponges, 467

Calcite, 178 , I 79

Calcium carbonate, I 45, I 59, I73, I74, I75, I 76- I So, I 8 I, I S4, I 86, I 88, I 90, I 93 430

phosphate, I59, I $71,18_{3}$, I $85,190,193$ sulphate, 175, I 76 , I 79

Callionymide, 390, 4 IO

"Cambria," The, 20

Canary current, 635

Capelan, 641, 646, 652, 7 1 2, 7 14, 707, 779

Caprellids, 467-468, 470, 497, 5 I I

Caproida, 390, 61 4

Carangida, 406, 609, 6I 4

Carbon dioxide, $176,177,179$, I 86,188 , $193,253,254,255,256,258,327,355$. 380

Carbonic acid (see Carbon dioxide)

Carchariidae, 39 I

Cardiidæ, 475

Caridids, 496

Carp, 759

Catfish, 44 I, 442, 45 I

Catosteomi, 389, 396-397, 606, 61 3

Cavolinidze, 588

Centrifuge, 50, I05, I I 7, 310, 361, 362, 363, 386

Centriscidæe, 396-397

Cephalopoda, 590-597, 632, 647

Ceratiidx, 609-611, 614, 625, 627, 676, 679

Cetomimidre, 606, 613

Chretognaths (see Sagittidie)

Chreto-plankton, 347

Challenger Deep, I 3 I, I 40, I 43

"Challenger," The, I, 9, ·10, I I, I 2, 23-27, $34,50,72,91,93$, 106, I 30, 140, I43, 2 I I, 2 I 5, 2 I6, 230, 232, 305, 306, 308, $309,310,337,349,366,389,4$ I 3, 4 I 5 , $4 \mathrm{I} 8,419,420,427,428,429,545,56 \mathrm{I}$, $562,564,581,582,592,686,687,703$, 706,772

Challengeridæe, 565, 566, 568, 642

"Chatter-marks," 205

"Chiacarone," 74, 76

Chiasmodontide, 6 I 3
"Chierne," 74

"Chiltern," The, I 9

Chimæridæ, 388, 389, 393-394

Chiroteuthidae, 591, 596

Chitons, $472,489,510$

Chlorine titration for determining salinity, 237,238

Chlorophyceæ, $333,347,35^{8}$

" Chopa," 74

Christiania fjord, pelagic algre of, $371-376$, 377,379

Chromatophores, 312, 355

Chun Deep, 143, 196 nets, 35,36

Circulation, oceanic, I I, 229, 310, 378-3So

Cirripeds, $63,42 \mathrm{O}, 575,5^{\mathrm{S} 2}$

Cirrotenthidæe, 597

Cladocera, 579

"Clan McNeil," The, 20

Clays, deep-sea, I 55, I66, I 85 - I 88

Clinkers dredged by "Michael Sars," 202, 207

Closing nets (see Nets)

Clupeidae, 601, 6I I, 644, 77 I

Clypeastrids, 474,475

Coalfish, 44 I, 442, $45^{\mathrm{I}}$

Coast banks, 55, I 98, 354, 437, 456 plateau, $42 \mathrm{I}, 425$

"Coast-water," 240, 241, 278

Coastal area of the boreal region of the Norwegian Sea, 459-460

Coccolithophoridxe, I06, I I 7, I 73, I 77, 3 I0, $330-332,344,347,353,354,355,364$, $365,381,382,693,699,719,773$, 775

Coccoliths, I46, 307, 308, 332, 382

Coccospheres, I 45, I 46,308

Cockle, 464,556

Cod, 9, 55, I I 2, I I 3, I I 4, I 22, 440, 44 I, $442,443,444,446,448,451,452,453$, $454,456,641,646,647,648,649,7$ I 2 , $714,716,729-732,735,755,762,76_{3}$, 766

Cod-eggs, I Io, I I I, $78_{3}$

Cod-fry, 92, I I , I I I, 734, 735

Cod-larva, $646,731-738$

Colenterates, $482,484,498,504,534,538$, 7 I9

"Colonia," The, 20

Colours of marine animals, $662-673,729$, $731,742,743,744$

Coltsfoot, $3 \mathrm{O} 2$

Compressibility of sea-water, 246

Concretionary substances in deep-sea deposits, I $90-193$

Conduction (see Heat)

Conger-eels, 441, 442, 443, 451, 452, 605, 755

Continental deep-sea zone, $460,4 \mathrm{SI}-486$ edge, I 33, I 98, 42 I, 456, 507-509

products in marine deposits, I $53^{-1} 54$ 
Continental shelf, $56,133,134,136,138$, 195 , I $98,421,430$

slope, $55,133,134,136,138,195,198$, $213,420-437$

Contour lines of depth first used on maps, 3

Convection currents, 226

Copepoda, 88, 107, 108, 382, 384, 479, 578, $579-581,588,631,639-640,642,645$, $655,658,693,697,702,703,719,720$, $727,755,775$

Coprolitic mud, 148

Coral mud, I49, I6I, I62, I66, I 68, ISo, 199,200

reefs, IS I

sand, I 44, I 49, I 62, I 66, I 80

Coral Patch, 195

Corals, 9, 58, 121, $149,419,483,484,485$, $486,490,505,507,508,538,545-559$

Cosmic spherules, I 54, I 58 , I60, I66, I 7 I

Cottidie, 390,436

Crabs, 62, 63, 64, 65, 66, 91, 103, 420, $461,464,474,476,477,486,495,496$, $497,498,500,502,511,520,575,584$, 633,67 I

Cranchiidre, 592, 596

Crangonids, 496

"Craspedon," 568

Craspedota, 568

Crayfish, 584

Crinoids, I 09, 419, 486, 545

"Cruiser," The, 20

Crustacea, 95, I 8 8 , I I 8, I 2 I, I 26, 127,149 , 225,4 I $8,420,430,469,470,476,479$, $482,486,496,497,504,510,511,515$, $520,524,525,528,534,540,545,551$, $556,558,562,575,579,581,582,584$, $631,645,656,65^{8}, 66_{3}, 665,666,669$, $672,673,674,691,699,719,720-727$, $773,775,782$ (see also Decapods)

Ctenophore, 575, 595, 658, 692, 7 I9

Cumacea, 496, 506

Current, Agulhas, 277

Canary, 635

Eastern Azores, 635

East Iceland Polar, 1 24, 300, 534

Labrador, 100, I I 5, I I 8,2 I 3, 244, 260, $635,658,704$

Current-meter, 67, 263-264, 359

observations, I $3,66,67,73,99,264-306$

Currents, oceanic, 5, 66, 67, I1 $3,174,244$, $245,259-306,310,349-352,370-374$, $431,514,517,525,527,531,533,534$, $536,55^{8-559}, 634-635,704-710,717-$ 7 I $8,733.738$

reaction, 776

tidal, I 70, 267-272

Cuttle-fish, 82, 87, 93, I03, I I 9, 494, 522, 590

Cyanophycer, $333-334,35^{6}, 35^{8}, 3^{8} 5$

"Cyclops," The, 4, 9

Cyclostomata, 6 I I

Cyphosidx, 6 I 4
THE OCEAN

Dabs, I 1 O , 441, 442, 451, 452

Dacia Bank, 57, 195, 267

"Dacia," The, 13, I9

Danish Expeditions, 16, 67, 72

" Dart," The, I 9

"Dead-men's fingers," 500

" Dead water," 275

Decapod Cephalopoda, 590 Crustacea, 420, 506, 529, 530, 538, 544, $55^{1}, 579,582,584-587,585,654,702,773$

Deeps, 133, 139-143, 169

Deep-sea deposits (see Deposits)

fauna, $415,536-548$

Denitrification, 369,370

Density observations, I 3, 236, 237, 238, 239, 246

Deposits, marine, 8,9 , I O, I43-I 75, 427-431, $559,560,784$

Depth of the Ocean, I 29-143, I 64

Desmo-plankton, $347,35 \mathrm{I}, 354$

Deutsche Seewarte, 214,227

"Deutschland," The, I 8

Development, direct, 517

Diatom ooze, I7, 146, 161, 162, 165, 168, $169,171,175,183,185,426,427$

Diatoms, $6,60,61,65,106,146,312-322$, $341-344,345,346,347,35^{2}, 353,354$, $355,356,357,358,360,361,363,365$, $366,378,380,381,382,708,719$

Didynus-plankton, 345,349

Dimorphism in diatoms, 320

Dinophysidx, 326, 333

Discontinuity layers, $16,223,280$

"Discovery," The, I 7

Dog-fish, 440, 44 I, 442, 45 I, 452, 646

Doliolids, 712

Dolomite, I 8 I, 205

"Dolphin," The, 9, I 4 I

Dolphin Rise, 56

Dolphins, 65

"Dorado," 74

Dory, 441, 442

Dredging, 3, 5, 6, 10, I I , 24-27, 30-32

Drift-bottles, 261, 262

Drift nets, 45, 55, 90, 9 I of vessels in the ice, 260 of wreckage in the North Atlantic, 260

"Duplex," The, I 9

Dutch Expeditions, I 7 Meteorological Institute, 2 I 5

Earbones of whales, 87, I49, I 56, I 57, I60, I66, I 71, 202, 207, 4I9

Earn, Loch, temperature observations in, I 6 Earth, area of the, 132

Earth's crust, variation in level of the, 131

Earth's rotation, effects of (see Rotation)

Echinoderms, I 20, $121,127,149,158,429$, $473,474,488,491,492,504,506,507$, $515,523,524,525,527,528,529,530$, 544,575 
Echinoidea, 149, 473, 544, 546

Echinothuridze, 545

"Edge" (see Continental edge)

"Edi," The, I 8

Eelgrass, 468, 469, 489, 560

Eel larvæ, So, 81, 94, 96, 97, I0I, 103, 104, 1 20, 1 26, 61 $8,634,670,748-755$

Eels, I 04, 605, 753, 755 conger, 44I, 442, 443, 45 I, 452, 605, 755 sand, 474

Effect of light on distribution of organisms, $224,557,55^{8}$

" Egeria," The, 19

Ekman's reversing water-bottle, 234

Elasipoda, 545

Elasmobranchii, 38S-389, 390-394

"Electra," The, I 9

Electrolytic conductivity of sea-water, 237

Elevation in continental areas, 175

Elvers, 753

Enoploteuthidæ, 59I, 595

" Enterprise," The, I 3

Entomostraca, 579

Etive, Loch, Arctic fauna in, 13

Euphausidæ, 720

Euryhaline forms, 479, 557

Eurythermal forms, 479, 533, 556-557

Everest, Mount, 131, I 33

Extra-terrestrial materials in marine deposits, I 54

Eyes of different animals, 68o-688

"Fantome," The, I9

"Faraday," The, 20, 169

Faroe Islands, 300, 513-5I5

Faroe-Shetland Channel, 7, I I, I3, 55, I 23 , I 25, I 26, I $27,222,243,278-28_{3}$

Feather-stars, $517,519,523,540$

Ferrous sulphide in deep-sea muds, I $8 \mathbf{I}, \mathbf{I} 82$, I $8 S$

Fish-eggs, 84, 92, 94, 103, I08, I IO, I I I, $691,692,702,707,729-741,745,747$, $7 \mathrm{~S}_{4}$

Fish-fry, 97, I I0, I I 1, I I 2, 6I 8,63 I, 707, $736,738,739,740,741-748,749,757$, 773,784

as current indicators, 736

Fish-hatching, artificial, 784

Fish measurements, $756-75 \mathrm{~S}$

otoliths in marine deposits, I49, I 5 I

remains in marine deposits, 149

teeth in marine deposits, 151

Fishery in the open ocean, $635-636$

on African coast, 73

on Newfoundland Bank, I I I - I I 4

investigations, 20

statistics, 439-444

Fishes, African coast, 74, 635

age and growth of, 755-77 I

bottom, $387-456$

pelagic, $601-615$
Fishes, Sargasso Sea, 633

Fishing, depth limit on Atlantic slope, 449

Fjords, 460, 477-486

Flagellates, 106, I I 7, 3 I 2, 330, 332-335, $344,358,674$

Flat-fishes, $448,451,45^{2}, 453,731,735$

Floating and organs of floating, 688-700

Flounders, 97, 444, 45 I, 452, 497, $5^{\text {I } 3,646}$

"Flueaat," $5 \mathrm{~S} 7$

" Flying-Fish," The, I 9, 663, 670

Flying-fish, 82, 94, 103, 106, I08, 607, 633, 747,748

Food of marine animals, 427, 772, 775

Foraminifera, 89, I46, I49, I64, I67, I 7 I, I 72, I 73, 307, 48I, 50I, 504, 527, 563$564,631,642,697,7$ 19, 720, 755

Fossil mollusc shells, 553-554

" Fram," The, I 5, 237, 259, 261, 274

"Français," The, I 8

Freezing-point, 239

French Expeditions, I3, I 8, 68

Frog-fish, 103

Fucoid belt, $461,462,466$

Fucoids, 459, $46_{3}, 487$

Fulmars, 7 I 2

Fyne, Loch, Arctic fauna in, 13 temperature observations in, 229

Gadidre, 399, 4I 3, 424, 452, 646, 647, 648, $736,737,759,764,766$

Gar-pike, 633, 635, 747

Gases in the sea, 253-259

Gasteropods, 62, 63, I I $2,163,164, I 73$, $419,429,438,46 \mathrm{I}, 462,467,475,489$

Gastrostomidæe, 97, 97

"Gauss," The, I 7, 174

"Gazelle," The, I 2

Geoid, the earth as a, 129

Gephyrea, $48_{3}, 490,500,504$

German Expeditions, I 5, I6, I 7, I 8 , I40, $224,260,727,739$

Gettysburg Bank, 267

"Gettysburg," The, 12

Gibraltar Strait, I I, 66, 67, 72, 264, 2S5290, 29I, 293

Glacial period, $535,548,549$

Glaciated stones dredged by "Michael Sars," $203,205,207$

"Glass eels," 753

Glauconite, I47, I 57-158, I 59, I62, I 7 I, I 89 , 190

Globigerina ooze, 63, I49, I6o, I6 I, I62, 163 , 164-165, 166, I67, I 68, I69, I 70, I 7 I, $173,174,175$, I $80,199,200,201,202$, $426,427,429,430,431,523,527,564$

" Goldfinch," The, I9

"Gold-Seeker," The, $27 \mathrm{~S}$

Gonatidx, 591, 592, 596

"Gorgon," The, 9

Gorgonians, 4\$4, 486, 490

"Grappler," The, 20 
Gravitational attraction of land-masses, 130

"Great Northern," The, I9

Greenland Polar current, 244

Green mud, I6I, I62, I67, I69, I7 1, I 89 , I 98

sand, $8,148,162,167,171,189$

Growth of fishes, 755-77 I

Gulf Stream, 3, I00, I07, I I 4, I I 5, I I 7, I I $8,120,122,124,194,207,2$ I 3, 2 I 4 , $223,230,240,242,244,259,261,270$, $276,281,296,298,299,300-306,457$, $458,459,531,532,534,574,634,635$, $641,69 S, 704,707,708,728,776$

Gulf-weed fauna, 91

Gulls, I 24, 7 I 2

Gurnard, 7 I, 79, 44 I, 442, 443, 448, 45 I

Gymnodontes, 6 I 5

Gymnosomata, $587,588,589$

Gypsum (see Calcium sulphate)

Haddock, 440, 44 I, 442, 443, 444, 44 S, 45 I, $452,453,454,455,456,646,647,648$ eggs, I IO, I I I

larvæe, I IO, I I I, 646

Hair type of suspension organs, 315-316

Hake, $64,69,71,77,79,440,44 \mathrm{I}, 442$, $443,444,448,449,45 \mathrm{I}, 452,454$, 635

Halacarids, 468

Halibut, 55, 440, 44 I, 442, 444, 446, 448, $45 \mathrm{I}, 452,454,455,456$

Halosauridæe, 396, 414

Hand-line fishing (see Line-fishing)

"Hansa," The, 260

Haplomi, 389, 396, 605, 61 3

Hardanger fjord, $48 \mathrm{I}$

Harling fishing, 636

Harpoons taken in blue whales, 7 I 4

"Hauch," The, 662

Helland-Hansen's photometer, 93, 94, 249 252

Hemiptera, $5^{87}$

Hemp lines for apparatus, 23-31, 2 I I

"Henry Holmes," The, 20

Hensen's plankton net, $37,45,358,359$

Hermit crabs, $465,486,495,496,497,49 S$, 500

Herrings, $55,448,635,645,646,647-648$, $663,699,712,714,715,716,755$. $758,759,764,765,766,767,768,779$, 782

Heteromi, 389,396

Heteropods, I 63, I 64, I 67, I $72-173$

Hexactinellida, 524

" Hirondelle," The, I4

1 Iistioteuthida, 596

Iljort Deep, I 96

Holbaek fjord, 756

Holocephali, 388, 393-394

Holopelagic forms, 562

IIoloplanktonic forms, 562
IIolothurians, $62,63,76,8_{1}, 87,95,120$, I 2 I , 4 I 8,4 I 9, 420, 429, 430, 473, 490, $523,538,545,575,717$

"Holsatia," The, 773,774

Ilooke's sounding-machine and water-bottle, 2, 209

Hoplophoride, 585

Horse-mackerel, 77, $89,98,609,633.635$, 646,747

Hydrographical Bureau, Washington, 2 I 5

sections, 84, I07, I IO, I I 5, I 24, 240, $277,379,694,695,696$

IIydroid polyps (see Zoophytes)

IIydroids, 9, I03, 4 I $8,419,426,462,467$, $46 \mathrm{~S}, 469,470,472,474,477,479,4 \mathrm{~S}_{3}$, $484,485,487,497,491,494,498,506$, $507,511,512,513,521,522,525,529$. 534,568

Hydromedusie, 338, 562, 568, 574, 598

Hydrometer, 236

Hydrosphere, I 29

Hyperida, $5^{S_{3}}$

Icebergs, I I 5, I I 6, I 54, 205, 207, 208, 259 Ice boundaries, 638

Ice-drift, 207

Iceland Polar current, I24, 300, 534

Indian Ocean, area of, 138,139 continental shelf and slope of, I 37 deepest sounding in, IS, I 32 deeps of, I 39, I40, I4 I, I 42 depths of, I $31,132,138,139,141,142$ number of soundings in, I 31

"Ingolf," The, I6, 434, 533, 536, 54 I, 546, 652

Inorganic materials in marine deposits, I 5 I

Insecta, $587,73^{8}$

"International," The, 20

International Council for the exploration of the sea, v, 20, 300, 310, 439, 440, 732,759

Invertebrate bottom fauna, 457-560

"Investigator," The, I 9

Ionic dissociation of sea-water, 175

Iron in sea-water, I 50, I53, I 54, I 55, I 66, I 75, I86, I87, I88, I89, I90, I91, I92 concretions in marine deposits, I9 I

and manganese nodules (see Manganese nodules)

"Isabelita," The, 76

Islands of the Norwegian West Coast, fauna of, $460-476$

Isopoda, $506,520,52 \mathrm{I}, 524,530,535,583$, 584,654

"Jeanette," The, 259

Jeffrey Deep, I 42

Jelly-fish (sec Medusæe and Siphonophore)

"John Pender," The, I9

Josephine Bank, 57

Jugulares, 4 Io 
Keltie Deep, I96

Kelvin's sounding machine (see Thomson)

Kittiwakes, 712

"Knight Errant," The, I3, 20S, 546, 66 I

"Kril," $58_{3}$

Labrador current, I OO, I I 5, I I 8,2 I 3, 244 , $260,635,658,704$

Labridie, 390

Lakes, survey of Scottish, I6, 225 temperature of, 239

Lamellibranchiata, 95, 207, 438

Laminaria belt, 46I, 466-468, 47 I , 489, 5 I I

Lamnidæ, 391

Lampreys, 60 I

Lampridx, 643

Lancelet, 474, 477, 559

"Languste," 64

Le Blanc's sounding machine, 29

Lemon sole (see Sole)

Lepadide, 582

Leptocephali, 8o, 81, 84, 86, 87, 92, 93, 94, $96,101,103,104,108,118,120,126$, $605,634,66_{3}, 670,68_{3}, 741,743$, $748-755$

Leptomedusie, 568

Libbey Deep, 196

Liebig's minimum law, 367, 728

Life-cycle of animals, $38_{3}$

Light, effect on the distribution of organisms, $224,254,557-55^{8}$

Light-intensity, 248-253, $710-725$

Light-organs of animals, 673-68o, 702, 742

Light-penetration, 93, 94, 248-253, 450, 663, $664,666,68$ I

" Lightning," The, IO, I I, I 2, 546

Limacinidre, 587

Lime (see Calcium carbonate)

Limpets, 462,477

Lines for sending down instruments, 2 I I

Ling, 55, 440, 441, 442, 443, 448, 449, $451,452,454,455$

Ling Bank, current measurements on, 268, 269,272

Liparidie, 436

Littoral deposits, 16 I

zone, $459,460-46 \mathrm{I}, 472-478,486-490$

Lobsters, $473,476,477,555,556,575,584$

Lochs, Scottish, I 3, I6, 225

Loliginidæ, 597

Lophidre, 4 I 1

Low-tide area, 46 I-466

Lucas sounding machine, 29, 30, 39, 40, I 30

Lugworm, 464, 489, 556

Lump-fishes, 607

Lusitanian faunal area, $55^{2}$

Lycodidæ, Io9, 436, 546

Mackerel, 609, 633, 635, 643, 645, 647, $670,698,699,747,755$

eggs and larve, $73 \mathrm{I}$
Macruridie, 389, 397-401, 414, 415, 420, $424,425,432,448,449,545,546,630$, 675,745

Magnesium carbonate, I7S, I79, I80-ISI, I S6, 193

phosphate, 193

sulphate, I 75, I 76

" Magnet," The, 20

Makaroff Deep, I 96

Malacopterygii, 394-395, 601, 6I I-612

Maldanidæ, 482 , 501

Malthida, 4 I I

Manganese in marine deposits, I 50, 153,155 , 166, I 68, 17 1, I86, 187, 190, 191, 192 nodules, $155,157,159,160,166,168$, I 7 I, I 88, IS9, I90, I 9 I- 192

" Marathon," The, 19

Marine biological laboratories, 20 deposits (see Deposits)

Mask crabs, 474

Mean sphere level, 4 I 2

Mediterranean, 7, I I, I 3, I 5, 68, 7 I, 72, I I $5,178,194,220,239,248,249,252$, $292,293,295$

" Medusa," The, I 3

Meduse, 86, 92, 95, 9S, IO I, I I 8 , I 19, 352, $568-574,581,624,627,631,632,633$, $640,642,645,658,666,669,692,696$, 719,736

larvae, 646

"Medusa Head," 486, 519

Medusettidie, $565,567,642$

Megrim, 79, 44I, 442, 443, 45 I, 452, 454

Meropelagic forms, 562

Meroplanktonic forms, 562

Messengers, 21 7, 219, 234, 235

Metabolism, $177,366,37 \mathrm{~S}$

Meteoric spherules, I 55

Meteorological Institute, De Bilt, 2 I 5

Office, London, 2 I 4

Metre-wheel for sounding, 2 I I

"Nichael Sars," The, 20, 22, 30, 37, 38 , $45,46,47,48,49,52,53,55,56-128$, 305,306

deposit-samples, 199-2O2

Microspores, $321-322$

Mid-Atlantic ridge, I I 8, I 20, I 35, 632

Migrations of animals, $700-716,764,767$

Mill Deep, I96

Miller-Casella thermometer, 4, 215,216

Minerals in marine deposits, 15 I - I 54

"Minia," The, I9

Minimum law, Liebig's, 367,728

" Mirror," The, 20

Molgulids, $48_{3}$

Molidie, 6 I 5,644

Mollusca, 8, 9, S8, 91, I03, I 2 I, 146, I 49, I67, I 7 I, $438,473,474,486,494,495$, $504,506,508,5$ I I, 51 4, 522, 524, 525, $528,530,534,539,553,554,587,5 \mathrm{Sg}$, $631,662,738$ 
Monaco Deep, 196

Monaco, oceanographical museum at, I4 pelagic trawl, 36

Monascidians, 525

Monkfish, 79, 44I, 442, 443, 448, 45 I, $45^{2}$

Moonfish, I 19

"Moraine profonde," 205

Morocco fishery, 69

Moseley Deep, 142, 196

Mud-eaters, 717

"Mud-line," I 33, I 34, 426-427, 648, 7 I 7

Muds, deep-sea, I $S_{5}$ - I 88

Mullet, 7 I, 444, $44^{8}$

Mullide, 390

Murænidæ, 79, 389, 395, 605

Murray Deep, I40

Mussels, 418, 419, 420, 462, 467, 468, 472, $473,474,475,477,479,480,482,483$, $486,488,490,495,5^{\circ}, 5^{\circ} 2,508,5^{1} 3$, 5 I $4,530,534,535,547,553,559,575.7$ I 7

"Mutine," The, I 9

Myliobatidx, 393

Myopsidæ, 590, 592, 595, 597, 625

Myriothelidæ, 522

"Myrmidon," The, I 9

Mysids, 720

Nannoplankton, 356

Nansen's closing net, 35, 359

Nansen thermometer, 233

Naples Zoological Station, 20

Narcomedusæ, 568, 57 I

Nares Deep, I 32, I41, I95, 196

Narratives of "Michael Sars" cruises, 52-128

Naticidæ, 475

"National," The (see "Plankton" Expedition)

Nauplii, 654-655

"Navarino," The, 707

Needle-fish, I03, I 20

Negretti and Zambra thermometer, 4, 2 I 7

Nekton, 309

Nemertines, 86, 577, 578, 624

Nemichthyidæ, 605, 612

"Neritic," 562

Neritic algæ, 344-346

diatoms, 354

peridineæ, 344

plankton algxe, $340-346$

"Nero," The, I6, I 3 I, I 43

Ness, Loch, temperature oscillations in, I6

Nets attached to current-meter, 359

Chun's, 35,36

closing, 58, 59, 6I, IOI, IO2

drift, 45

Hensen's, 37, 45, 35 8,359

"Michael Sars," 46, 47, 48, 49, IOI, 102

Nansen's, 35, 359

Petersen's, 359

Newfoundland Bank, I06, I07, I09, I I0, III-II, I I 5, II 6, II 7,2 I $3,244,245$, 297-300, 357
"Newington," The, 20

Night-hauls by "Michael Sars," 92, 93, 94,95

" Nimrod," The, is

Nitrates, 368, 369, 370, 372

Nitrites, 368, 369, 370, 372

Nitrogen in sea-water, $253,258-259,368$ $370,377,3$ So, 728

Nodules, manganese (see Manganese nodules) phosphatic (see Phosphatic nodules)

" Norge," The, I 24

" Norseman," The, I9

North Atlantic (see Atlantic, North)

North Sea, current observations in, 268, 269

fauna of, 49I-503

phosphorus in water of, $\mathrm{I}_{5}$

silica in water of, 184

Norwegian Depression, 503-507

Expeditions, 10, 12, 15, 309, 504, 505. 517,523

fisheries, $37,55,56$

fjords (see Fjords)

Norwegian Sea, 12, 55, 122, 124, I25, I67, 196-198, 220, 222, 223, 239, 240, 243 , $26 \mathrm{I}, 274,275,276,277,27 \mathrm{~S}, 28 \mathrm{O}, 28 \mathrm{I}$, $28_{2}, 28_{3}, 2 S_{4}, 302,303,304,457,5$ I $6-535$

fauna of, 92, I07, $108,118,120,126,127$, $434-437,5$ I $7-525,546-55$ I, $637-64$ I, 647

Notidanidre, 390,396

Nudibranchs, 468, 494

Nutrition of marine animals, 716.728

Ocean, area of the, 132

"Oceanic," 562 plankton algæ, 346-349

Oceanographical Institute at Paris, I4

Museum at Monaco, I4

Oceanography, physical, 2 10-306

Octopoda, 590, 595, 597,625, 678, 706

(Egopsidæe, 59o, 595-596, 625

Ommatostrephidæe, 59I, 592, 596

Onychoteuthidæe, 591, 596, 632

Ophelidx, 475

Ophidiid, 88

Ophiuridæe, I2I, 4I $8,419,420,429,430$, $436,538,547,576$

Orbulina ooze, 164

Organic matter in marine deposits, $428,430-$ $431,716,7$ 17-7 I9

remains in marine deposits, 145

substances in the sea, $35^{\mathrm{S}-37 \mathrm{O},}{ }_{3} \mathrm{SI},{ }_{3} \mathrm{~S} 5$. $386,717,728$

Origin of the present-day fauna of the Norwegian Sea, $548-55$ I

Osmotic pressure in the cells of animals, 690691

Ostracoda, S9, IOI, I49,579, $5 S_{1-5} S_{2}, 624$, $631,640,655$

Otoliths of fishes in marine deposits, I49, I 5 I of the plaice, 759

Otter board, 42 
Otter trawl, 4I, 42, 63

Ox bone dredged, 202, 207

Oxidizing areas in the ocean, $1 S 7-188$

Oxygen in sea-water, $253.25 \mathrm{~S}$

Oyster "polls," 225, 226, 257-258, 478-48o, 554,555

shells, 202, 207

Oysters, 479-514. 555, 556

Pacific Ocean, area of, $1_{3} 6,1_{37}, 1_{3} 8$ continental shelf and slope in, 136 deepest sounding in, I 7, I 3 I

deeps of, I 39-I 43

depths of, I 3 I, I $32,136-138$, I $40-143$

number of soundings in, $13 \mathrm{I}$

shore-slopes of, I 37

Palagonite in deep-sea deposits, I 53, ISS. IS9

Pandalids, $5_{5}$

Pasiphridxe, 585

Patellids, 467

"Patrick Stewart," The, 20

Pealie Deep, I96

Pediculati, 4 I I, 609, 6 I 4

Pelagic animals, 56I-659

Arctic communities, 637-64 I

Atlantic communities, $617-636$

boreal communities, $637,644^{-t, 56}$

northern communities, 636.659

appliances, 34,45

deposits, I6I, I62.163, I 67, I 7 I, 426, 430,7 I 6

Peneidæ, 585,586

" Penguin," The, 19, 14 I

Pennatulids, I09, $4 \mathrm{~S}_{2}, 5 \mathrm{O} 3,5 \mathrm{I} 7,538,547$

Percesoces, 389, 397, 607, 613

Perciformes, $401-405,614$

Percussion, bulbs of (see "Chatter-marks")

Peridinex, 65, 322-330, 346, 347, 348, 354, $355,35^{6}, 35^{8}, 3^{6} 3,3^{6} 5,3^{8 \mathrm{I},} 3^{82}, 5^{80}$, $674,699,719$

neritic, 344

suspension organs of, 323

Periwinkles, 462, 477,556

Permanence of oceanic and continental areas, IO

Petersen's pelagic young-fish trawl, 36

bottom-collector, 785

Petromyzontes, 6 I I

Petromyzontidæe, 6I I

Pettersson's insulating water-bottle, 232

Pettersson-Nansen water-bottle, 4O, 2 I 5 , $219,220,232,233$

Phillipsite, I 59-I60, I66, I90

Philonexidæ, 597

Phosphates (see Calcium phosphate)

Phosphatic concretions, I59, 162, I 89, I92, 193

Phosphorescence, 68, 86, S8, 94, 329, 673, $674,675,680$

P'hosphoric acid, 368
Photometer, Helland-Hansen's, 93, 94, 249252

Regnard's, 252

Photometric observations, 94, 24S-252

Physical oceanography, $210-306$

Phytoplankton, 60, 61, 94, I 17

Pigmentation (see Colours of marine animals)

Pilchards, 44S, 601, 771,782

Pilot-fishes, 91, 609, 633, 670, 698

Pipe-fishes, 606

Pisces (see Fishes)

Plagiostomi, 388, 390-393

Plaice, 440, 44I, 442, 443, 45I, 453, 454, $712,713,759,76_{3}, 7 S_{5}$

eggs, $7 \mathrm{~S}_{3}$

Planarians, 47 I

Planet Deep, I 43

" Planet," The, IS, I 4 I, I 43

Plankton, I3, 37, 45, 65, I07, I08, 309$3 \mathrm{II}, 33 \mathrm{~S}-34 \mathrm{O}, 357,35^{\mathrm{S}-366}, 37 \mathrm{O}-3 \mathrm{~S}_{3}$, $562-563,772-776,779,7 \delta_{2}, 78_{3}$

algæ, neritic species of, $340-346$ oceanic species of, 346-349

"Plankton" Expedition, I 5, 309, 3 I 5, 333 , $337,564,598,652,773,777$

Plant life, 6o, 94, 254-256, 305-386, 727-728 remains in marine deposits, 145

Plateaus, fauna of continental, 49I-5 I6

Platyhelminthes, 577

Plectognathi, 4 I I, 61 I, 6 I 5

Pleuronectidæ, 390, 407-40S, 646

"Podbielski," The, 299

Podoceridre, 468

"Pola," The, I 5

Polar currents, IIO, 1 I 7 , I I 8, I 24, 244 , $245,276,300,458,531,533,534$

Pollack, 44 I, 442, 443, 45 I, 452, $73 \mathrm{I}$

"Polls" (see Oyster "polls")

Polypodidæe, 597

"Ponmerania," The, 495

Pools (see Oyster " polls")

" Porcupine," The, I I, I 2, 546

" Portuguese man-of-war," 68, 89, 92, 574

Potassium, I 89-190

Potential temperature (sec Temperature)

"Pourquoi Pas?" The, is

Pourtales Bank, I 78

Prawn larve, 622, 623

Prawns, 420, 469, 482, 486, 517, 530, $53 \mathrm{I}$, $534,55^{8}, 5^{8} 3,584,585,586,587,6$ I . $622,624,633,641,66_{3}, 664,665,671$, 699. 720,775

red, 81, 86, 94, IOI, IO2, I04, I I 8

Pressure in the sea, 24, $219,224,245-247$

"Princesse Alice," The, 14, 387

Pristipomatidze, 390, 403

Propagation of marine animals, 729-755

Protozoa, 563

Pteropoda, 72, S7, I07, IIS, 163, I64, I67. I 72, 201, 419, 57 S, 587-590, 625. 631 , $640,642,645,658,669,702,718,720$ 
Pteropod ooze, I49, 160, I6I, I 62, I63-I 64 . $167,168,169,171,173,174,180$, I $99,200,426,427$

Pterospermataceæ, 365

Pulsations in currents, 273

Pumice, I 52-I 53, I 55, I 56, I66, I 69.208, 4 I 9 Pump method of capturing plankton, 65,360 "Punti verdi," 334

Pycnogonids, 109, 468, 497, 515, $519,524$. $527,529,530,534,547$

Pycnometer, 236

Pyrosomida, 692

Qualitative investigations of marine organisms, $776 \cdot 778$

Quantitative estimations of marine organisms, $772-776$

of plankton, 37, 309-310, 358.366, 372 $377,772-776$

with bottom-sampler, $784-78_{5}$

Quartz, I53, I62, I63, 205

Radio-active matter in marine deposits, 62 , I $60,166,170$

Radiolaria, I I 8, I $48.307,355,56 \mathrm{I}, 563$, $564-568,578,588,624,631,642,691$, $693,697,699,702,719,720$

Radiolarian ooze, I7, I49, I60, I61, I62, I 65 - I 66, I 68,169, I 7 I, I 83, I 84, I 85

Raiidæe, $388,389,392,393,424,436,44 \mathrm{I}$. $442,448,45 \mathrm{I}, 452$

"Rambler," The, 19

Rays (see Raiida)

"Recorder," The, I 9

Red clay, I 49, I 54, I 55, I60, I6 I, I62, I63, I $65,166,168,169,17$ I, I 73, I 74, I 75 . I 80,182, I 86,187, I 89, I 9c, I 99, 200 , $426,427,429,430$

Red-fish larve, I IO, I I

Red mud, I61, I62, I67, I69

Reducing areas in the sea, I $87-188$, I 89

Refractivity of water in relation to salinity; 236-237

Regnard's photometer, 252

Resting spores, 320-32 I, 34 I, 342, 344

"Retriever," The, I9

Reykjanes Ridge, 56

Rhabdoliths, 146, 308

Rhabdospheres, I45, I 46, 308

Rhinidre, 392

Rhizopods, $48 \mathrm{I}, 482$

Ribbon type of suspension organs, 3 I 5

Richter's reversing thermometer, 217,2 I8, 220,233 ।

Rockall, 123, 124

Rock fragments in marine deposits, I 55, I 56, I $57,16_{3}, 166,170,17$ I, I 85 - 88,202 209

"Roddam," The, 20

Rotation, effects of the earth's, 274-278, 295, 299
Saccopha1yngida, $104.605,612,618$

Sagittide. 86. IO I, I04, 578, 631, 640, 641, $669,720,773$

"Saifia," 74

Saithe, $440,444,446,452,454,646,64 \delta$. $649,731,736,759,760,761,762,764$ larvie, 646

Salinity of sea-water, $230,236,237,238$, $239 \cdot 245,318$

“Salmon-herrings," 95

Salmonidx, 69, 394, 441, 442, 601, 602, 6 I I, 645,759

Salpidie, 98, I I 8 , I I 9, I 26, 308, 352, 355, $381,382,578,581,598,599,600,631$, $632,633,634,641,692,696,708,7$ I0, 7 I $1,712,719$

Salts of the sea, $230-245$

Sandgapers, 464,556

Sandhoppers, $465,466,497$

Sand-stars, 120

Sardines, $76,601,636$

Sargasso fishes, 633,698

Sargasso Sea, 83, 94-99, 100, 106, I07, I08, I $18,194,222,223,241,242,246,298$, $371,598,619,623.631,632,633,635$, $656,657,658,663-664,670-671,673$, $681,684,694,695,698,708,718,720$, $722,723,724,725,727,747,773,775$ weed, 91, 103, 106, 108, 335-337, 671, 673,718

Saury pike, 747

Scales of fishes as indicators of age and growth, I I $4,759-765$

Scaphopoda, $482,500,523$

"Schizogony," 463

Schizopoda, 579, 582-583, 640, 654, 669. 773

Scianidae, 390, 402-403, 444

Sclerodermi, 6 i 5

Scleroparei, 408-4 IO, 6I 4

Scombresocidre, 607, 61 3,644

eggs of, 103,742

Scombridx, 609, 643

Scombriformes, 390, 406-407, 609, 6I4

Scopelidre, 68, 95, I 26, I 27, 396, 4 I 4, 60 I, $605,606,613,618,631,632,634,644$, $66_{3}, 669,675,676,677,679,685,686$, $687,698,699,703.746,755$

eggs and young of, I 8

Scorpanidxe, 390, 408-409, 6 I 4

"Scotia," The, I 8 , I 9, I 35 , I 70

Scottish lochs, investigations in, 13, 16, 225

Scottish Antarctic Fxpedition, I8

Scyllidæe, 388, $39 \mathrm{I}$

Scyphostoma, 572

Sea-ancmones, $4 \delta 2,484,493,497,500,52$ I

Sea-bream (see Bream)

Sea-horses, 89, 67 I

"Sealark," The, I9

Sea-lilies (see Feather-stars)

Sea-mice, 49I, 517, 519, 540 
Sea-pens, $87,88,482,500$

Sea-scorpion, 535

Sea-slugs, $477,482,486,492,519,523.540$, 555

Sea-spiders, $486,497,520$

Sea-squirts, 497,498

Sea-tooth (see Scaphopoda)

Sea-trees, $48_{5}, 486$

Sea-trout, 646

Sea-urchins, I 20, +1 9, 420, 430, 465,473, $478,493,519,538,547,558,576$

Sea-water, chemical composition of, I 75, I 76 , 235

compressibility of, 246

ionic dissociation of salts in, 195

transparency of, $253,666,67$ I

samples, methods of obtaining, 230 preservation of, 235

Sea-weeds, $145,335-337,369$

Seals, 692

Seiches, I6, 278

Seine Bank, I78, 195

"Seine," The, I9

Seine-net fishing, 76,77

Selachii, 388, 390-392

Sepiidae, 597

Sepiolidxe, 597

Sergestidæ, $5^{85}$

Serpulids, 4 I $8,463,473$

Serranidæe, 390, 402, 614

Sertularians, 87,4 I 9

Shad, 448

Sharks, 64, 424, 436, 455, 635, 644, 646, 647,698

blue, 635,644

Greenland, 647

hammer-head, 635

herring, 646

Sharks' teeth, 87, I 49, I 56, I 57, I60, I 66, I 7 I, 4I8, 4 I9

"Shearwater," The, I I

"Sherard Osborn," The, I 9

Shoals, oceanic, 13

Shore slopes, I 35, I 37, I 39

Shrimps, 496

"Siboga," The, 17

Sideromelan, I 53

Sigsbee Deep, 196

Sigsbee's dredge, 32

method of trawling. 31, 42, 45

sounding machine, 29

trawl, 33, 42

" Silderaek," 64 I

Silica, I 45, I $\delta_{3-1} \delta_{5}$, I 86, I $87,188,368$

Silicates, I 85 , I 87 , I So, I 90

Siliceous deposits, 162

remains in marine deposits, $14 \mathrm{~S}, \mathbf{I} 49$

sponges, 467

Silicic acid (see Silica)

Silicoflagellates, 358,365

"Silvertown," The, I 9
Sinking of air-filled capsule, 247

of solid body, 247

Siphonophora, 98, 574, 631, 640, 641, 642, $692,696,7$ I9

Sira-plankton, 345

Six's thermometer, 4, 2 I 5

"Size of projection," 693

Skate, 64, 79, 44 I, 442, 45 I

" Skjergaard," 227, 460

Snails, $462,467,469,471,477,480,489$, $493,494,502,517,52 \mathrm{I}, 522,575,67 \mathrm{I}$

Sogne fjord. $55,228,240,277,303,4 S_{I}$, 574

Solenidze, 475

Soles, 64, 69, 79, 440, 44I, 442, .443, 448 . $449,451,452,453,646$

Sounding by bathometer, 2

by hand, 2, I 30

by hemp-line, $23,24,25,26,27,28,29$. I 30

by wire, $5,12,27,28,29$, I 30

deepest, I 7, I 3 I

first abysmal, 5

first attempt at deep-sea, 2

Sounding machine, Baillie's, 25, 26

Brooke's, 8, 9, I 30

Hooke's, 2, 209

Le Blanc's, 29

Lucas's, 29, 30, 39, 40, I 30

Sigsbee's, 29

Thomson's, 28

Soundings first shown on maps, 2

Spanish Bay, 57, 65, 68, 69, 72, 292-295

Sparidæe, 69, 390, 403-405, 433, 444, 448

Spatangids, $474,475,476,490,49 \mathrm{I}$

Specific gravity of sea-water, 689, 690, 691, 692, 694, 695, 696, 698, 699, 700, 710 , $716,721,722,723,724,725,777$ (see also Density)

surface, 692, 693

Spheroid of revolution, the earth as a, I 29, I 32

Spinacidae, 388, 391, 675

Spirulidie, 597

Sponges, IO, 72, 95, 419, 420, 483, $48_{4}$, $486,498,500,504,505,506,507,508$. $510,517,519,521,524,525,534,539$. 559

Sponge spicules in marine deposits, I $_{4} 8$, I $_{3}$

Sprat eggs, 73 I

larvae, 73I

Sprats, 91, 601, 645, 759, 761, 762, 765 . $766,771,782$

"Sprungschicht" (see Discontinuity layer)

" Sprut," 648

Squid larvae, $63 \mathrm{I}$

Squids, I I 2, $113,590,591,592,624,625$, $627,632,642,643,645,646,648-649$, $650,651,669,674,675,676,67 \mathrm{~S}, 6 \mathrm{~S}_{2}$, $68_{5}, 699,706,782$

"Stale" water, 257

Stalk-eyed fishes, 86, I03. 108 
Stalk-cyed cuttle-fish, 93 fish-larva, 746

Standing waves, 278,284

Starfish, I 20, 419, 420, 429, 430, 464, 467, 486,49 I, 492, 5 I 0,5 I I, 5 I $7,534,538$, $540,547,555,575.576$

Stenohaline forms, 557

Stenothermal forms, 557

"Stephan," The, I8

Sternoptychidie, 603-605, 611-612,618,619, $643,644,66_{3}, 676,678,685,698$

Stomiatidx, 96, 102, 601, 603-604, 611, 618, $676,678,6 S_{3}, 6 S_{5}, 698,74 \mathrm{I}$

Stones dredged by the "Michael Sars," I 2 I, 1 70, 202-209

Storeggen, current observations on, 269, 270 , 273

"Stork," The, I9

Stratification in marine deposits, I 74, 200, 201

Stromateidæe, 607, 613, 643

Styelidre, 4\$6

Styli-plankton, $347,348,351,35^{2}$

Sub-littoral zone, 459-460, $480-48 \mathrm{I}, 490-49 \mathrm{I}$

Subnarine banks, I 35

waves, 7 1 4-7 16

Subsidence in oceanic areas, I74, I75, 207, 208, 209

Sulim Deep, 195, I 96

Sulphates in marine muds, I 8 I, I 82,1 S8

Sulphides in marine muds, I 75, ISI, I 82, I 88

Sulphur, I 8 I - I 83 , I 88,258

Sulphuretted hydrogen, 257, 554

"Summer-belts" in fish-scales, I 14.764

"Sunda Graben," I 4 I

Sunfishes, 607, 633, 697, 698

Surface resistance, 689-690, 692

Surplus gravity, 689, 692

Suspension organs, 312, 315-320, 323, 327 . $328,35^{\circ}$

Swedish Expeditions, IO, I 5, 17

Swire Deep, 14 I

Swordfish, 698, 755

"Sylvia," The, I9

Symbiosis, 328, 334, 355, 493, 500

Synaphobranchiidæe, I 2 I, I 27. $389,395,4$ I 4 . 4 I 5,605

Synascidians, $467,469,525$

Syngnathidæe, 6o6, 613, 644

"Talisman," The, I 3. 68, 387, 544. 686

Tanaidx, 479

Teeth of fish in marine deposits, I 5 I

Teleostei, 388, 389, 394-4 I I, 601, 6 I I-6 I 5

Teleostomi, 394-4 I I, 6 I 1-6 I 5

Telescopic eyes, 90, 96, 97, 746

Tellinidx, 475

Temperate neritic species of pelagic algie, 345-346

oceanic species of pelagic algre, 347

Temperature conditions as aflecting -animal life, $431-437,444-445,554-556.705-706$
Temperature observations, 3,4, I I, I3, 6 I . $68,70,72,84$, IO3, IO6, IO7, IIO, I I I, I I 3, I I 7, I 25, I 26, 2 I 3-230, 239 , $246,305,306,694,709,722,723,724$. 778

oscillations in lakes, I 6

potential, 22 I, 239

seiche, 16

Terebellidæe, 482

Terraqueous stage of the earth's evolution, I 29

Terrestrial materials in marine deposits, ${ }_{5}$ I

Terrigenous deposits, I6I, I62, I66, I67, I $71,426,429,430,716,717$

Tetraxonia, 524

Tetrodontid $x, 4$ I I, 6 I 5

Thalamophores, 527

Thecosomata, $587,589,631$

Thermocline (see Discontinuity layer)

Thermometers, 3, 4, 24, 2 I 5, 2 16, 2 I 7, 2 19, 244

Miller-Casella, 4, 2 I 5, 2 I 6

Nansen, 233

Negretti and Zambra, 4, 217

Richter, 217,2 IS, 220, 233

Six, 4, 2 I 5

"Thin water," 696

Thomson sounding machine, 28

"Thor," The, 67, 72, 434, 505, 652, 710 , 7 I I, 732

Thoulet Deep, I 96

Tidal currents, 67, 99, I 70, 267-272, 289

Tile-fish, 706

Tizard Deep, 142

" Tjalfe," The, 652

Tow-nets, $34,35,36,37,45,46,47,48$. 49,68

Tracheloteuthidre, 596

Trachinidae, 390,410

Trachymedusie, 568, 569, 572, 699

Trachypterida, 643, 644, 698, 74 I

Transparency of sea-water, $253,666,67$ I

"Travailleur," The, I3, 68, $3 \mathrm{~S}_{7}, 544$

Travertine, 177

Trawling and dredging, 24, 26, 27, 30, 3I, $32,36,41,42,49,62,68,71,87,99$, I 20 , 12 I

Trichiuridae, 407, 6I4, 643

Tricho-plankton, 347

Triglidæe, 390, 409-4 Io

Tripos-plankton, 347

"Triton," The; I 3, 208, 546, 662

Tropical neritic species of pelagic algre, 346 oceanic species of pelagic algre, 347

Trout, 44 I, 442, 759

Tubeworms, 502, 508, 524

Tufa, I 53, I 55, 177

Tunicata, 149, I60, 597-600

Tunicin, 597

Tunnies, 6o9, 635, 636

Turbellaria, rhabdocolous, 468

Turbot, 441, 442, 45 I, 452,646 
Turtles, $65,87,97,98,119,582,584$

Tuscarora Deep, 140

"Tuscarora," The, I I, I2, 27, I4 I

Tuscaroridx, $561,565,567$

Tusk, 55, 440, 44I, 442, 443, 446, 448, $449,45^{\mathrm{I}}, 45^{2}, 454$

Umbellularia, 4 ig

Uniformity of hydrographical conditions and of animal life, $\delta_{3}, \$_{4}$

United States Coast Survey, 8, I0, I 2

Exploring Expedition, 5

Fish Commission, 12

Hydrographic Office, 8

Uranoscopidx, 390, 4 IO

"Vader," 489

Valdivia Deep, 140

"Valdivia," The, I6, 34, 36, 87, 93, 94, 140, I $63, I_{64}, 1_{65}, 3$ I $5,349,364,4$ I $3,424$. $562,565,566,567,57$ I, $580,58_{1}, 585$, $589,590,591,592,594,595,598,599$, $601,605,625,627,676,677,680,683$, 780

Veneride, 475

Veranyidæ, 596

Vermes (see Worms)

Vertical circulation of ocean waters, 229, 37 S, 379,380

oscillations of ocean waters, $275,278,279$ $281,282,715$

migration of organisms, $89,93,95,96,664$

"Vettor Pisani," The, I3, 561

"Viking," The, 20

Viscosity of sea-water, 311, 318, 689, 690, $69 \mathrm{I}, 694,696,698,699,700,703,710$, $716,721,723,725,777$

"Vitiaz," The, I 5

Volcanic ashes, I 51 , I 52 , I 53

glass, $153,155,156,160,169$, I 88

mud, I6I, I62, 167, I69, I7 I, I9S

sand, I $44,162,167,17 \mathrm{I}$

"Volta," The, 20

"Vöringen," The, I 2, 645, 648

Vortex movements, 281-285, 298, 300

Wad (see Manganese nodules)

"Washington," The, I 3

Water-bottle, Bucharian, 230, $23 \mathrm{I}$

Ekman, 234

Hooke, 209

Pettersson, 232

Pettersson-Nansen, 40, 21 5, $219,220,232$, 233

Water-bottles, 4, 21 5, $219,220,230-236$

"Waterwitch," The, I9
Waves, boundary, 274

standing, 278,284

submarine, 7 I 4-7 16

Weevers, 79

Weights used for sounding, 25, 29

"Westmeath," The, 20

Whales, Atlantic, 646 -

Biscayan, 780

bottle-nose, $54,646,649,650,65 \mathrm{I}, 7 \mathrm{So}$, 782

blue, 7 14, 778

caaing, 95

cirripedia attached to, $5_{5} \mathrm{~S}_{2}$

distribution of, $778-783$

earbones of (see Earbones)

fin-, $779,780,78 \mathrm{I}$

floating devices of, 691, 692

Greenland, $778,779,7 \mathrm{So}$

humpback, 779, $78 \mathrm{So}, 7 \mathrm{SI}_{\mathrm{I}}, 7 \mathrm{~S}_{2}$

migrations of, 7 I 4

north-caper, 651,780

plankton, 778

right, $778,7 \mathrm{SO}, 7 \mathrm{SI}_{\mathrm{I}}$

saithe, 779

sperm, $94,780,7 \mathrm{~S}_{2}$

squid-hunting, 592,792

tooth-, 779

whalebone, $727,779,782$

" Whale's food," 107, 588

Wharton Deep, I32, I4I

Whelks, 494

Whiting, 64, 440, 44 I, 442, 448, 45 I, 452, 497

Wind-produced currents, 274

"Winter-rings" in fish-scales, I I 4. 760

Wire for sounding, etc., 5, I $2,27 \cdot 3 \mathrm{I}, \mathrm{I} 3 \mathrm{O}$. 2 II

Witch, 44I, 442, 45I, 452, 454

Worms, 9, 62, 63, 418, 419, 464, 467, 482, $484,485,489,501,502,504,506,508$, $524,525,530,534,541,559,577-579$, 58 I, 658, 7 I 7

Wreck-fish, 98, 633, 670

IVyville Thomson Ridge, I3, I22.127, I70, $207,208,223,243,456,45 \mathrm{~S}, 533,53 \mathrm{~S}$, $625,656,661,695,708,724$

Xiphiidæ, 643

Zeidx, 407, 614, 643

Zeolites, I 59, I60, I7 I, IS8, I90

Zeorhombi, 407-408, 6 I 4

Zoarcidæe, 410, 4I 4, 4 I 5, 435

Zoophytes, $489,568,572$

Zooplankton (see Plankton)

Zoospores, 322, 329, 334, 335

Zostera belt, 46I, 468-472, 489 



\title{
A SELECTION OF WORKS FOR NATURALISTS THE CAMBRIDGE NATURAL HISTORY
}

\author{
ELITED BY
}

S. F. HARMER, Sc.D., F.R.S., and A. E. SHIPLEY, M.A., F.R.S.

In Ten Volumes. Fully Illustrated. Medium Svo. I $7 \mathrm{~s}$. net each.

Library Edition. In Ten Volumes. Half Morocco. Gilt tops.

In sets only. Medium Svo. $£ \&: 8$ s. net.

\section{VOLUME I.}

Protozoa, by Marcus Hartog, M.A., D.Sc.; Porifera (Sponges), by lgerna B. J. Sollas, B.Sc. ; Coelenterata and Ctenophora, by S. J. Hickson, M.A., F.R.S. ; Echinodermata, by E. WV. MacBride, M.A., F.R.S.

VOLUME II.

Flatworms and Mesozoa, by F. W. Gamble, D.Sc. ; Nemertines, by Miss L. Sheldon ; Threadworms and Sagitta, by A. E. Shipley, M.A., F.R.S.; Rotifers, by Marcus Hartog, M.A., D.Sc.; Polychaet Worms, by W. Blaxland Benham, D.Sc., M.A.; Earthworms and Leeches, by F. E. Beddard, M.A., F.R.S. ; Gephyrea and Phoronis, by A. E. Shipley, M.A., F.R.S. ; Polyzoa, by S. F. Harmer, Sc.D., F.R.S.

VOLUME III.

Molluses, by the KEv. A. H. Cooke, M.A. ; Brachiopods (Recent), by A. E. Shipley, M.A., F.R.S. ; Brachiopods (Fossil), by F. R. C. Reed, M.A.

VOLUME IV.

Crustacea, by Geoffrey Silth, M.A., and the late II. F. R. Weluon, M.A.; Trilobites, by HENRY WooDs, M.A.; Introduction to Arachnida and King-Crabs, by A. E. Shipley, M.A., F.R.S. ; Eurypterida, by Henry Woods, M.A. ; Scorpions, Spiders, Mites, Ticks, ete., by Cecil WArburTON, M.A. ; Tardigrada (Water-Bears), by A. E. Shipley, M.A., F.R.S. ; Pentastomida, by A. E. Shipley, M.A., F.R.S. ; Pyenogonida, by D'Arcy W. T'hompson, C.B., M.A.

\section{VOLUME V.}

Peripatus, by Adam Sedgwick, M.A., F.R.S. ; Myriapods, by F. G. Sinclair, M.A. ; Insects, Part I., Introduction, Aptera, Orthoptera, Neuroptera, and a portion of Hymenoptera (Sessiliventres and Parasitica), by David Sharp, M.A., M.B., F.R.S. 


\section{A SELECTION OF WORKS FOR NATURALISTS}

\section{THE CAIVIBRIDGE NATURAL HISTORY-(continued)}

VOLUME VI.

Hymenoptera, continued (Tubulifera and Aculeata), Coleoptera, Strepsiptera, Lepidoptera, Diptera, Aphaniptera, Thysanoptera, Hemiptera, Anoplura, by D.Avid Sharp, M.A., M.B., F.R.S.

\section{VOLUME VII.}

Hemichordata, by S. F. H.RMER, Sc.D., F.R.S.; Ascidians and Amphioxus, by IV. A. Herdian, D.Sc., F.R.S. ; Fishes (Exclusive of the Systematic Account of Toleostei), by T. IV. BRIDGE, Sc.D., F.R.S.; Fishes (Systematic Account of Teleostei), by G. A. Boulenger, F.R.S.

VOLUME VIII.

Amphibia and Reptiles, by Haxs G.adow, M.A., F.R.S.

VOLUME IX.

Birds, by A. H. Evins, M.A.

VOLUME X.

Mammalia, by Frang Evers Beddard, M.A., F.R.S.

THE DEPTHS OF THE SEA. An Account of the Results of the 1)redging Cruises of H.M.S. Lightning and Porcupine: 1868-69-70. By Sir C. Wyville Thouson, LL.D., D.Sc. With Illustrations, Maps, and Plans. Svo. 3is. 6d.

THE GEOGRAPHICAL DISTRIBUTION OF ANIMALS. With a study of the relations of living and extinct faunas as elucidating the past changes of the earth's surface. By Alfred R. WALlace, O.M. lllustrated. Two vols. 8vo. $42 \mathrm{~s}$.

ISLAND LIFE, OR THE PHENOMENA AND CAUSES OF INSULAR FAUNAS AND FLORAS. Including a revision and attempted solution of the problem of geological climates. By ALFRED R. Wallace, O.M. With Illustrations and Maps. Extra Crown 8vo. 7 s. $6 \mathrm{~d}$.

OBSERVATIONS OF A NATURALIST IN THE PACIFIC between 1896 and I 899 . By H. B. Guppy, M.B. Illustrated. 8vo. Vol. I. Vanua Levu, Fiji : Its Physical and Geological Characters. I 5s. net. Vol. II. Plant Dispersal. 2 is, net. 



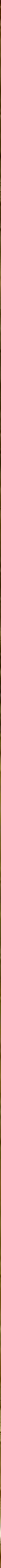

